6hom

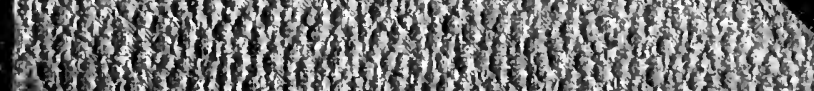

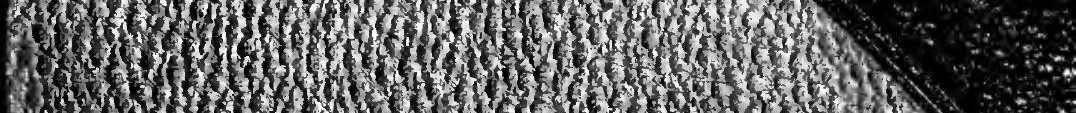

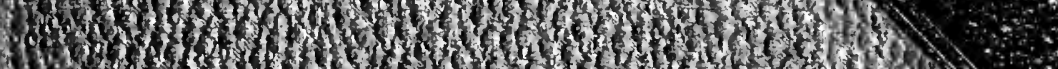

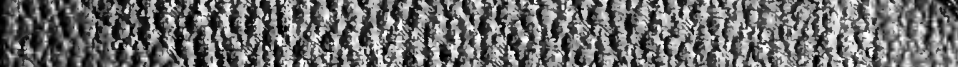

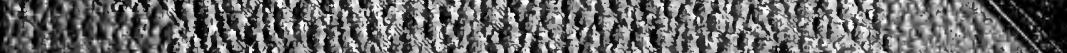

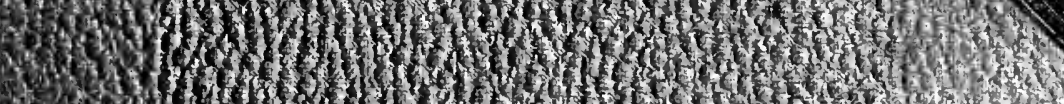

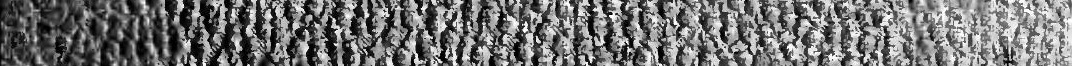

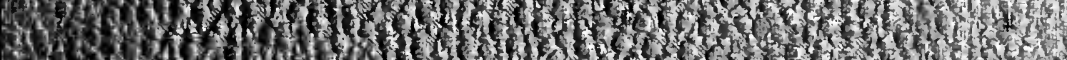

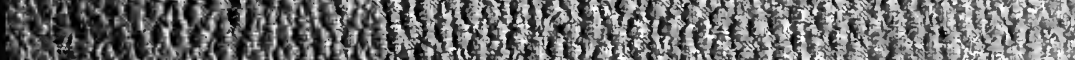

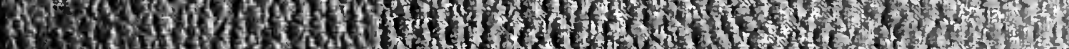
Nis

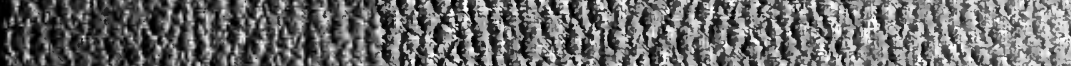

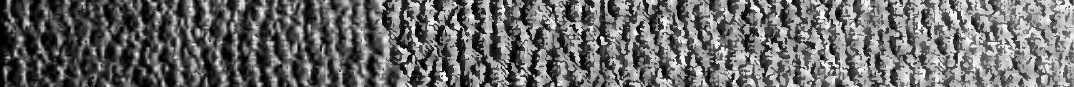

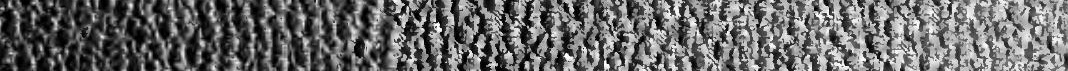

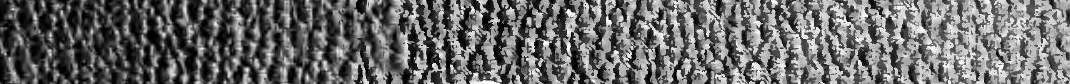

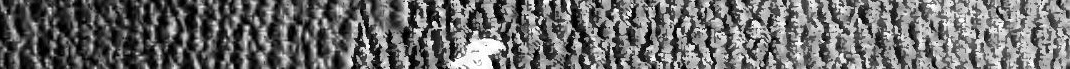
3 3.

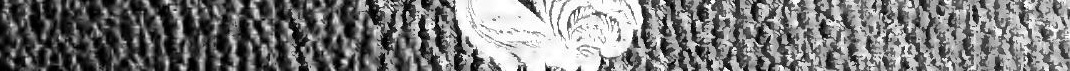

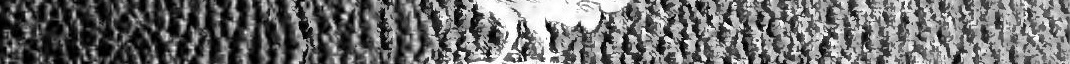
504 . Z2

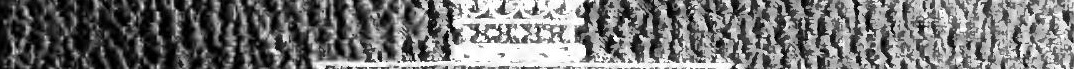

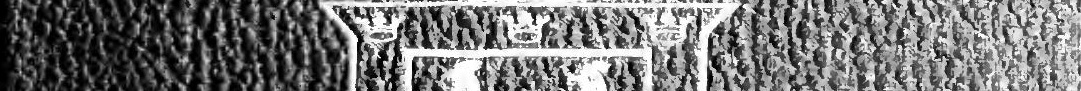

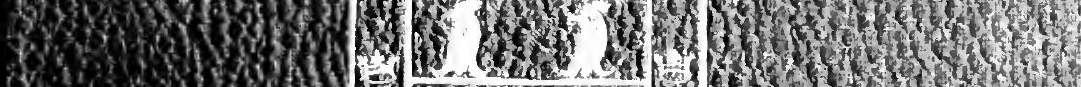

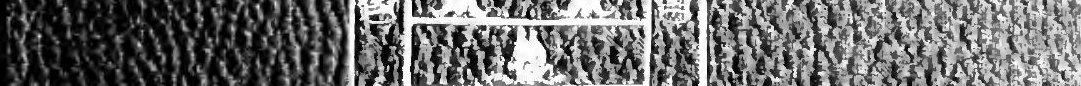

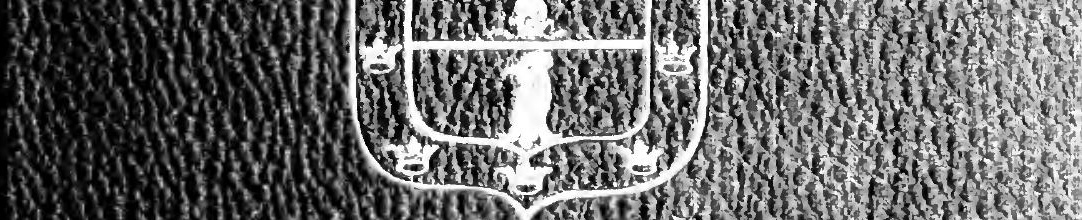

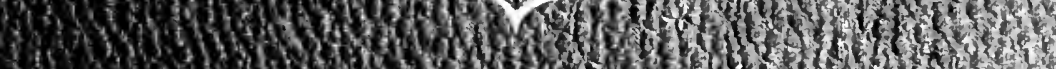
30.

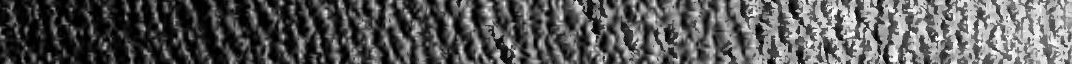

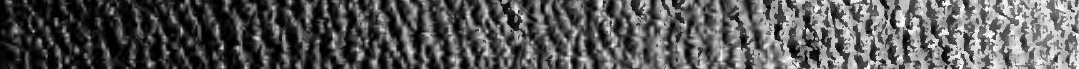
D.630.

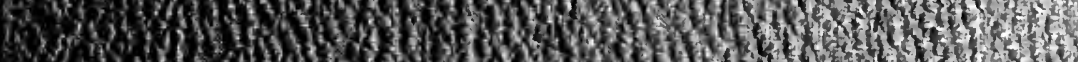

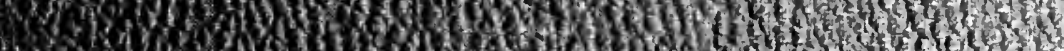

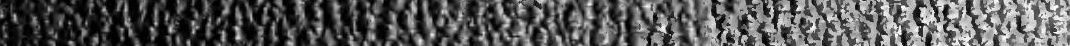

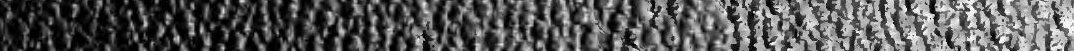
35 s. (7)

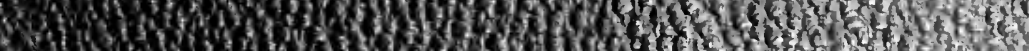

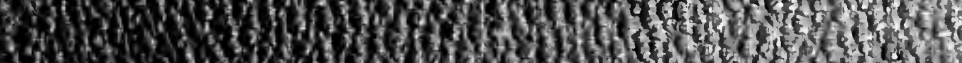

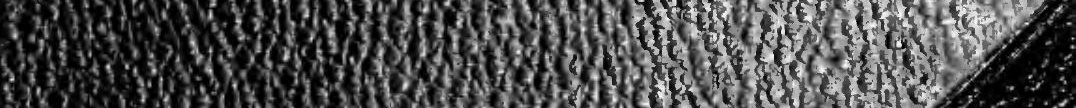

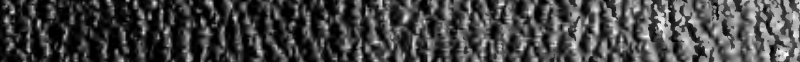

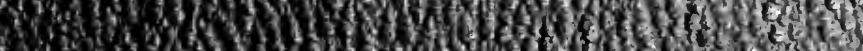

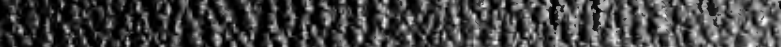

fints. 

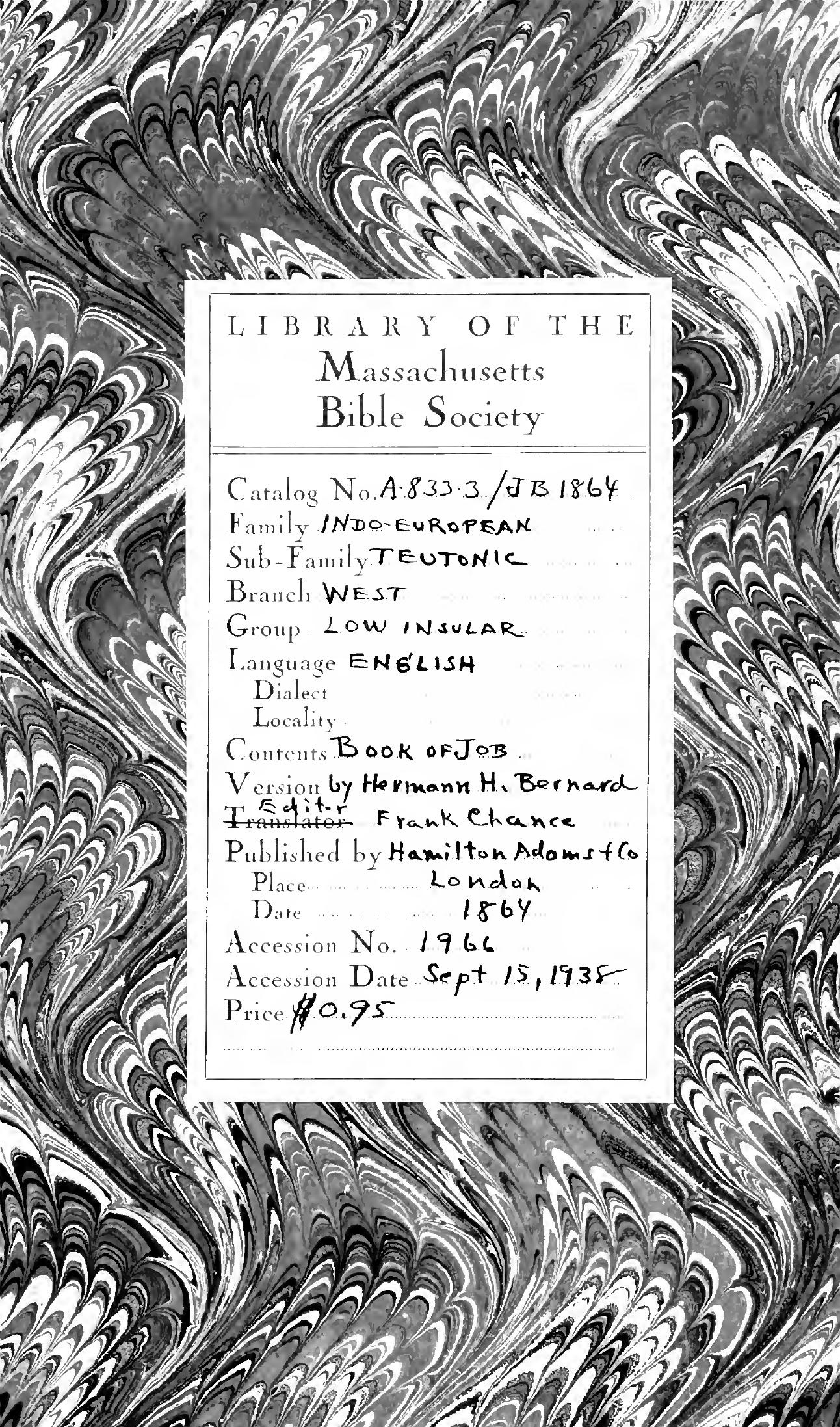
2

$x$ 


$$
\begin{aligned}
& \text { A. } \\
& \text { céas. ál: ams. } \\
& \text { Orex, Dik } \\
& \text { - 系正 } 1878 \text {. }
\end{aligned}
$$






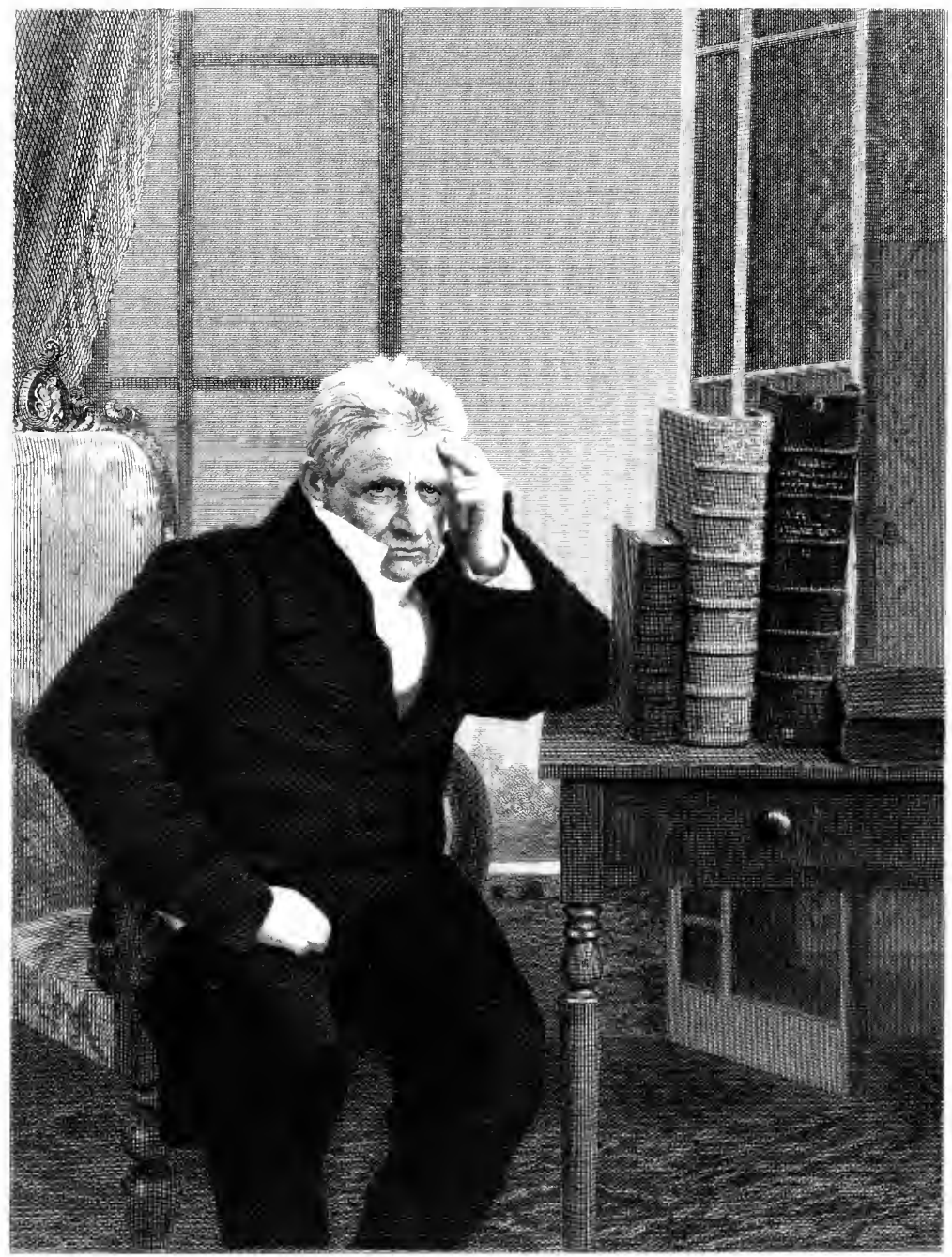

It Lerrard 


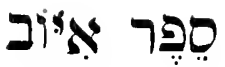

\section{THE BOOK OF JOB,}

AS EXPOUNDED TO HIS CAMBRRIDGE PUPISS,

BY THE LATE

\section{HERMANN HEDWIG BERNARD, PH.D., M.A.,}

FOR SEVEN-AND-TWENTY YEARS HEBREW TEACHER IN THE UNIVERSITY OF CAMBRIDGE;

AUTHOR OF "CREED AND ETHJCS OF THE JEWS, EXHIBITED IN SELECTIONS FROM THE YAD HACHAZAKAH OF MALMONIDES ;"

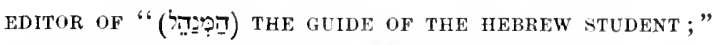

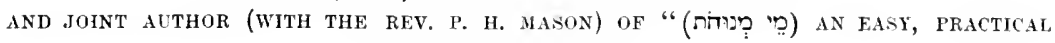

"hebrew Gramiar," Sic.

EUITED, WITH A

\section{Translation and Godoitional ẩ lotes,}

BI

HIS FRIEND AND FORMER PUPIL,

FRANK CHANCE, B.A., M.B.,

LATE TYRWHITT'S UNIVERITY HEBREW SCHOLAR, TRINITY COLLEGE, CAMBRIDGE; FELLOW OF THE ROYAL COLLEGE OF PHYSICIANS;

translator of virchow's "cellular pathologr," etc., etc.

VOLUME I.

(CONTAINING THE WHOLE OF THE ORIGINAL WORK.)

LONI)ON :

HAMILTON, ADAMS, AND CO., 33, PATERNOSTER ROW. 1861. 
ALEX. MACINTOSH, PRINTER, GREAT NEW STREET, LONDON. 


\section{To atlo distliar, \\ ROBERT LUCAS CHANCE, ESQ., \\ OF BIRMINGHAM,}

WHO, IN FULFILMENT OF A PROMISE GENEROUSLY MADE BY HIM

TO DR. BERNARD,

BEARS THE WHOLE EXPENSE OF THE PUBLICATION OF THIS WORK;

AND TO

THOSE AMONG DR. BERNARD'S PUPILS, WHO READ THE BOOK OF JOB WITI HMM,

I DEDICATE THIS THE FIRST VOLUME. 



\section{EDITOR'S PREFACE.}

'To those among Dr. Bernard's pupils, who had, like myself, the good fortune to read the book of Job with him, I feel that no reason need be assigned by me for offering the following pages to their notice-knowing, as I do, how great and universal a desire, nay even longing*, was evinced by them, whilst he was still in the possession of his eyesight, to see his masterly exposition of one of the grandest books of the Bible given to the world, and again, how great and universal was their regret, when, from his becoming blind, they were led to fear that it would descend with its author to the tomb. $†$

* That I may not be accused of exaggeration for using the somewhat strong word, longing, I will here relate a fact. One of Dr. Bernard's pupils-a Fellow of his College-was so struck by his master's interpretation of the Book of Job, that he actually read the Book six times with him, and paid him seven guineas each time. 'This really inordinate appreciation of his labours naturally gratified Dr. Bernard, but it also filled him with alarm; for what, said he to me more than once, can this man's object be, unless he have some idea of publishing a Commentary on Job? And to this alarm, indeed, I think we may fairly ascribe the appearance of the present work, at least in a complete form, for I know that when I went down to Cambridge to help Dr. Bernard, he was filled with dread lest he should be forestalled, and was not tranquillized until he had advertised that he was preparing his Commentary. Now, had he not thus been spurred on, he would very probably have waited, and had he waited but a few months longer, this work would never have been completed. (1863.)

$\dagger$ How nearly these fears were realized may be inferred when $I$ state that the manuseript of this work was not completed before May or June, 1857, and that Dr. Bernard died on the 15th November following. (1863.) 
To those, among his pupils, however, who never read the book of Job with him, as well as to the public generally, I may, perhaps, be allowed to enumerate the advantages that this exposition, which it has fallen to my lot to preserve to the world, possesses over all others that have been published of the book of Job.

They are:-

1. That, according to it, the speakers, one and all, though more especially Job, will be found to remain true to their characters throughout, without deviating for one instant from the principles which at the outset they respectively profess.

2. 'That the speech of Elihu, the son of Barachel, which has been, by so many Commentators, variously characterized as empty, bombastic, laboured, insipid, diffuse and unintelligible, in the mouth of a shallow, conceited, presumptuous and arrogant young man,* is, by the clear and well-defined line of demarcation which Dr. Bernard has drawn between the reasoning of that

* Il n'y eut qu'Eliu, qui étoit le plus jeune et le moins judicieux, qui ne se rendît pas . . . . par un vain étalage de paroles Eliu rend ici raison, \&c. (Calmet sur Chap. xxii. 1.)

Dr. Luther . . . . . . . sahe blos von ilım die üble Seite eines windigen jungen Mensehen, voller Stolz und Einbildung (Michaelis Uebersetzung des Alten Test. 2te Ausgabe, lster Theil, Anmerkungen zu Hiob, Cap. xxxii. S. 136).

In Elihu's Reden welt ein ganz anderer Geist, sie sind sehr breit und ermüden dureh die darin herrschende Redseligkeit (Berthold, Histor. Krit. Einleit. in d. A. u. N. Test., 5ter. 'Th., Erlangen 1815, $\$ 498$, S. 2157).

Elihu tritt . . . i iberklug mit jugendlichem Dünkel auf, und spricht wie ein Orakel. Er perorirt Gemeinplätze, anmaszend, eingebildet und allein weise Er . . . . spielt mit Floskeln, und maeht Tiraden und kettet Bild an BilderAlles ohne Zweek und Ende (Eichhorn, Einleit. in d. A. Test., 3ter Band, S. 562).

$\mathrm{Als}$ ein fremdes späteres Einschiebsel verrathen sich diese Reden durch das Matte, Weitschweifige, Gesuchte, Unklare des Inhalts und Vortrags (De Wette, Lehrbuch der Histor. Krit. Einleit. in die Bibel, 7te Ausg., Berlin, 1852, §287, S. 385).

Nach Cap. xxxii.-xxxiii. V. 8, ist der junge Kümpfer zu deutlich als ein eingebildeter und dabei leerer Schwätzer gezeiehnet._-Wer vermiszt aber nicht alle lähmende Kraft in der breiten und schwulstigen Redseligkeit des . . . . . sich spreizenden diinkelhaften Sprechers, so dasz sein leerer Wortschwall, \&c.! (Umbreit, das Buch IHob, 2te Auflage, Heidelberg, 1832, Einleitung, S. xxvi, Fusznote). 
speaker and the arguments of the other three friends of Job, shown to be, with the exception of the speech of God Himself, the brightest ornament of the work, and well worthy of the tacit approbation of God, as implied by His confining His severe rebukes to Job and his three aged friends.

3. That in it the book of Job (and the same may be said of all the other books of the Old Testament expounded by Dr. Bernard to his pupils), is interpreted by the help of the Hebrew contained in the Bible itself, and not, as is so unfortunately become the fashion of the day, by constant recomse to the Cognate languages (1); so that very few instances indeed will be found in the present work, in which recourse has been had even to the dialect of the Mishnah and Gemara, a dialect, which, in spite of all that is said against it-and all that is so said will be found to proceed from those who can read neither the Mishnah, nor the Gemara-bears the greatest affinity to the Hebrew of the Bible, and may, therefore, be much more fitly and safely referred to for the elucidation of the same, than any other of the Cognate dialects, the more especially as it was spoken by the Hebrews themselves at the time when they had yet their high-priest and their templeservice.

4. That it will be found to contain, not only Dr. Bernard's reasons for the manner in which he translates the book, but also the construction of the more difficult passages, whereby the Hebrew student will derive the more advantage, as there is not, to my knowledge, any work, by which he might learn to construe the Hebrew Bible. Moreover, that scarcely a rerse, or even a word, will be met with, in the interpretation of which Dr. Bernard disagrees with the Authors of the Established Version, without his assigning a reason for his doing so, and justifying his own translation by similar passages in the Bible. Nor will there again any instance be found, in which a transposition of words has been adopted, or an ellipsis supplied, without the support of appropriate passages from the Bible; and, as the ellipses are always supplied in pure Biblical Hebrew, the reader will at once

(1) Fur this note sec p. xr. 
be enabled to see how the poetical parts of this book may be resolved into prose.*

In order that Job might be exhibited true to his character and principles, and not, as is the case with all the Translations and Commentaries that have hitherto been brought before the public, in continual contradiction with himself, often eating, so to say, in the latter part of a chapter, nay sometimes even of a verse, the words he had used in the earlier part, it was absolutely necessary for Dr. Bernard to refuse him any knowledge of an immortal soul and of a future state, until the time when God revealed Himself to him. At this, I know full well, a great outcry will be raised, but what does an outcry prove? Will it confute the arguments, by which Dr. Bernard defends this opinion of his, and of which I will only say here that they stand upon too firm a basis of their own to need any support from me. I will, however, observe that this opinion was long since advocated by an eminent English prelate, $\uparrow$ though he went to the length of classing David and Solomon in this respect with Job, a length, to which Dr. Bernard declines to follow him, as it is his firm belief, that men, who, like those inspired bards, had held, either directly or indirectly, communion with the Deity, must needs have been aware (as Job himself became upon the appearance before him of Jehovah) $\ddagger$ that they were not mere animals, and that their existence would not terminate with their life.

* The reader should bear this last remark in mind, and remember that with Dr. Bernard, "supplying an ellipsis" is equivalent to " turning poetry into prose," for else he will certainly accuse him of constantly violating the laws which regnlate and limit ellipses. When Dr. Bernard says, "so and so for so and so," or "so and so stands for so and so," he by no means always wishes to express that there is an ellipsis in the strict sense of the word; his intention very frequently is rather to EXPAND into intelligible PROsE, concise and perhaps somewhat unintelligible verse. In fact, he often explains in Hebrew what other Commentators are content to explain in their own mother-tongue. He would, however, have done well to use the sign $=$, instead of for or stands for, as he would not then have exposed himself to any misinterpretation. (1863.)

+ Vide Warburton, Div. Leg. Vol. v. p. 31.

$\ddagger$ But see Translation, p. 5ll, note *. (1863.) 
Equally imperative upon him did Dr. Bernard consider it to be, to put from Chap. xxvii. 13 to the end of Chap. xxviii. into the mouth of Zophar the Naamathite, instead of into that of Job, as is done in the original text, and to make other transpositions, which it would take up too much space to specify; and here, again, I think I may safely challenge those who are disposed to protest against such transpositions (2) to upset Dr. Bernard's arguments if they can. At the same time, I will mention here that in the first chapter of Lamentations only do the first letters of the verses (in the original) form the Hebrew alphabet in its regular order, whilst, in the $2 \mathrm{~d}, 3 \mathrm{~d}$, and 4 th chapters, the $د$; instead of coming after the $\boldsymbol{V}$, comes before it-an incontestable proof that there are at least some verses in the Bible which do not occupy the place they should. In the $3 \mathrm{~d}$ chapter, indeed, in which every letter of the alphabet is found at the beginning of three consecutive verses, all the three verses beginning with $\unlhd$ must be transposed and put after those beginning with $\boldsymbol{V}$, in order that the alphabet may be exhibited in its proper order.

With regard to the Hebrew tenses, simple as well as converted, it has been clearly shown in Mason and Bernard's Grammar (Letter li. $\$ 8$ ), that the rules laid down for their employment hold good only in the narrative, and not in the poetical and prophetical parts of the Old T'estament, as the poet and prophet, carried away by their enthusiasm, cannot submit to be fettered by a strict compliance with such rules. The reader will not, therefore, it is hoped, take offence at any apparent violation of them by us, in the translation of the poetical part of our book, for how could we do otherwise than follow our author? In some cases, however, where in the Hebrew the tenses have been used in strict accordance to rule, the exigencies of the English language have prevented us from giving a literal translation; thus, for example, in chaps. ix. 11, xix. 7, the futures 7y and

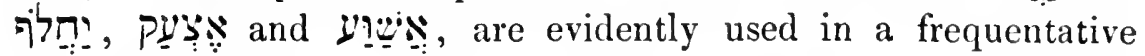
sense, and should therefore, strictly speaking, be respectively rendered, He constantly passes, He constantly goes by, and I re-

(2) For this note see p. xvi. 
peatedly cry, I repeatedly cry aloud; but to whom would not such renderings be tiresome and annoying? and who but a pedant of the first water would venture to be guilty of them? In the narrative parts of the book, however, I have done my best to translate the tenses in accordance with the rules laid down by the first Hebrew grammarians.

Dr. Bernard has always considered it his duty to caution his pupils against bestowing implicit reliance upon those, who comment upon, and translate, the Hebrew Bible, without having proved their fitness for the task they have undertaken, by shewing in what way they write, point, and express their ideas in, Hebrew. The importance, nay, the necessity of such a caution, was never felt by me so fully as it is now that I have, during the progress of this work, thoroughly sifted nearly all that has been said by modern Commentators on the Book of $\boldsymbol{J}_{\mathrm{ob}}$, and found the deficiencies of some of them in Hebrew to be great beyond conception. In saying, however, that I have sifted the productions of these gentlemen, I do not mean to express that their blunders are so few and far between as to require careful examination to detect them; on the contrary, so numerous and so glaring are they in the majority of cases, that the difficulty rather was to discover anything else. Everyone, indeed, who is pretty well acquainted with the rules of Hebrew grammar and syntax, and tolerably well versed in Hebrew composition, must wonder at the extreme presumption displayed by men so ignorant of the language, in daring even to lay their hands upon the Hebrew Bible. Some few of their blunders I have thought it right to expose in the Commentary, but should it be considered that they have been there judged with too great harshness, I would beg of those who are of this opinion, before they give their final verdict in favour of the defendants, once more, and accurately and impartially, to weigh the grossness of the blunders against the harshness of the censure, when, if they should still abide by the conclusion that the blunders are, I will not say justifiable, but in any, even in the slightest degree excusable, I solemnly pledge myself to acknowledge my error, to retract all that $I$ have said upon the subject, and to make every apology. But if, on the 
other hand, it should be allowed to be the fact that blunders have been committed, such as no tyro, who had been under the guidance of a competent tutor for one month, could possibly commit-that Hebrew has been written which no student who had written Hebrew exercises for one week, could possibly write, and that hardly one page can be found in more than one of the Commentaries in which some error of punctuation * does not occur, and that even in words which are merely transcribed from the Hebrew Bible-then I must say I conceive it to be the duty of every one who is aware of these facts, and to whom the Word of God is precious, to raise his voice to give the alarm, and to conjure the Biblical student, not to take, as is too often, unfortunately, done in our day, $\dagger$ for his guides men, whonotwithstanding the pompous display they make of Syriac Coptic, Samaritan, Arabic, Persian, $\ddagger$ and maybe another score or

* This will be found to be strictly and literally true in the case of Rosenmiiller's Commentary (2d Edit., Leipsic, 1824).

† Thus, for example, in a new translation of Job (Conant's), which is now being brought out in America, and of which we have the first two parts, comprising twenty-nine chapters, the names of Schultens, De Wette, Ewald, Schlottmann, \&c., are mentioned often enough, whilst those of Aben-Ezra, Jarchi, Kimchi, Ralbag, Wolfssohn, are altogether proscribed, not the slightest indication being given that the translator had ever even heard of such commentators.

革 So Bouillier says on רעמה (Chap. xxxix. 19): "Nescio quid aliis videatur; at meo saltem judicio operosus ille eruditionis Arabicx apparatus tantum ab illustrando loco abest, ut potius nobilis figure splendorem offuscet atque obliteret." We should like to know what he would have said if he could have seen Dr. Lee's "Book of the Patriarch Job," a work, which, from its author's constantly trespassing against the most vital rules of Hebrew grammar and syntax, and from his giving to pure Hebrew words, by tracing them to Arabic roots, a totally different meaning from that which they have in the other places of the Hebrew Bible, in which they occur, may much more fitly be termed a travesty, than a translation, of Job. The wantonness with which Hebrew grammar is violated, and the commonest Hebrew words are strained and tortured (cf., for example, chap. xii. 2, where he translates the work is executed. Thus, for example, in the very first chapter, verse 3, Job is made to possess five thousand yoke of oxen instead of five hundred, and in the last chapter Eliphaz and his two friends are commanded by God to take not seven bullocks but seven heifers!!! And yet, probably, these two verses will be found by those who are possessed of energy enough to wade through the whole work, and whom even the "men black with cold," spoken of in chap. vi. 16, have not deterred from its perusal, to be among the most tolerable in the whole translation. 
two of Eastern languages (3), with which they try to dazzle the reader-give such conclusive proof that of Hebrew they know nothing, or even less than nothing.*

When Dr. Bernard made the Book of Job his study, his endeavours were exclusively directed towards ascertaining the true train of reasoning pursued therein — with what success it will be, of course, for the reader to determine. Into such questions, therefore, as-to what class of composition the book may be considered to belong; whether the men who are introduced as speakers into it ever existed, and if they did exist, when and where they lived; who the author of the work was, and when, and where, he lived,-Dr. Bernard has forborne to enter, unwilling to hazard an opinion upon subjects, with regard to which, from the want of sufficient data, it must always remain impossible to arrive at any satisfactory conclusion. For my own part, feeling no inclination to undertake a task to which Dr. Bernard has found himself unequal, I content myself with giving, for the satisfaction of the reader, a translation (the first, I believe, that has been made in English) of Ben-Zev's introduction to the Book of Job, which, as coming from the pen of one of the most eminent Hebraists that ever lived, will, I doubt not, be found interesting. With this translation I have thought fit to give the original for the benefit of the Rabbinical student, who, however, will do well, before venturing upon it, to make himself familiar with the passages quoted in the Commentary from Wolfssohn, this Commentator's Rabbinic being far less concise and idiomatic, and therefore much more easy than that of Ben-Zev.

'The plan, which Dr. Bernard adopts in expounding the Hebrew Bible generally, and the Book of Job in particular, to his pupils,

(3) For this note see p. xx.

* I must beg of the reader to consider the severe remarks contained in this paragraph as proceeding rather from Dr. Bernard than myself. In me it would, perhaps, be esteemed presumptuous to pass such severe strictures, however firmly I might be convinced of their truth; in him it could not be esteemed presumptuous by any one, who had had the opportunity of judging of his very remarkable knowledge of Hebrew. (1862.) 
is, in the first instance, after reading and translating a verse, to comment upon it, so as fully to develop all the ideas contained therein, explain its meaning, and point out its connexion with the verses which precede it or follow it, either immediately, or at some distance; then, to dwell upon every word in the verse, which may call for any critical remarks, and shew how its signification bears upon the general drift of the verse; next, in the case of such verses, as, owing to transpositions which have to be made, or ellipses which require to be supplied, seem to offer some difficulty of construction - first, to resolve them into prose, by making such transpositions, or supplying such ellipses, in pure Biblical Hebrew, then to construe them, and shew how, from the meaning of the individual clauses of the verse may be deduced the sense already assigned in the Commentary to the whole verse. This plan, according to which the sense of different passages is given more than once, Dr. Bernard made it a sine quâ non that I should, when developing into a Commentary his interpretation of the Book of Job, pursue in all its particulars, and this he did, urged by the following weighty motives: 1 . Because, in the case of verses in which great brevity of language is combined with great profundity of thought, the sense attributed to them is made more palpable to, and impressed more forcibly upon, the mind of the reader, by his having it laid before him more than once, in different places and in somewhat different words. 2. Because, as a practical Hebrew teacher, he knew that a work, by which the Biblical student might learn to construe the Hebrew Bible with accuracy had never yet appeared, while the want of it was greatly felt. I, of course, was but too happy to adopt a method, by which I knew Dr. Bernard to have produced in the University of Cambridge so many Hebrew scholars, and by which I myself had been benefited so much; but, in doing so, I am fully aware that I have laid myself open to the charge of prolixity, particularly as, with the view of assisting the reader to run over a chapter before reading it accurately with the help of the Commentary, I have appended foot-notes to the 'Translation, in which the explanations given in the Commentary are embodied. To this charge, if made, I should have readily pleaded guilty, but Dr. Bernard insisted upon taking the fault, if fault it be to afford every possible 
assistance to the Biblical student, entirely on his own shoulders.* For any other charges also that may be brought against the Commentary, or foot-notes of the 'Translation, Dr. Bernard requests me to say that he holds himself responsible, $t$ whilst, as far as regards the Translation-it being entirely my own-I, and I alone, am responsible for any fault that may be found with it, as I am also for any misprints, faulty references, \&c., that occur in the whole work, since, in consequence of Dr. Bernard's grievous affliction, upon me alone has devolved the care of consulting the different works made use of, and of revising the proof-sheets. In conclusion I will say, that, whatever advantage or pleasure the reader may derive from the study of this work, to Dr. Bernard, and to Dr. Bernard alone, should his thanks be rendered, as the only claim which I wish, or conceive myself entitled, to make, is to be allowed to say with Job: $\ddagger$

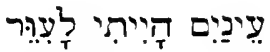

Eyes was I to the blind.

20, Fitzinililam-street, Cambridge, June, 1857.

* It is but right, however, to say that the foot-notes were added to the Translation after we had come to the determination of making a separate volume of it, a determination, to which we were led by the consideration that, in this manner, the Commentary and Translation could be compared together with much greater convenience, than if they together formed a single volume, whilst those who did not wish to enter into the matter deeply would be thus enahled to procure the Translation separately. [I subsequently decided, however, upon including the Commentary and Translation in one volume; but, notwithstanding, I deemed it advantageous to retain the foot-notes. 1862.]

† Dr. Bernard's responsibility is, however, of course mich lessened by his not having lived to conduct the work through the press. (1863.)

† Chap. xxix. 15, first hemistich.

(4) For this note see p. xxii. 
NOTES REFERRED TO IN PP. vir, Ix, xir, xiv.

(1) p. vii. See p. xi and p. xx, note 3. Dr. Pusey, in the Introduction to his Commentary on the Minor Prophets (1860), seems to think that this practice of constantly appealing to the Cognate dialects is on the wane. I cannot say that I have discovered any very evident signs of this, whilst I continually see fresh signs of the practice being still in vogue--but, I trust that Dr. Pusey may be right. At any rate, nobody can liave contributed more to the extinction of this most iliogical and pernicious habit in England than Dr. Bernard, who, during the seven-and-twenty years lue was Hebrew teacher in the University of Cambridge, never lost an opportunity of inveighing against it, and constantly inculcated into his pupils the importance of interpreting Hebrew through Hebrew alone. Now, as he had a great many pupils, and several of them have since become eminent teachers of IIebrew, it is probable that his views upon this point have become, or are becoming, widely disseminated through England. Dr. Pusey's words are : "But the comparison of the Cognate dialects opened for the time an unlimited licence of innovation. Every principle of interpretation, every rule of language, was violated. The Bible was interpreted with a wild recklessness, to which no other book was ever subjected. A subordinate meaning of some half-ınderstood Arabic word was always at hand to remove whatever one misliked. Now, the manifoldness of this reign of misrule has subsided. But interpretations as arbitrary as any which have perished still hold their sway, or from time to time emerge, and any revisal of the Authorized Version of the Old Testament, until the precarious nse of the dialects should be far more settled, would rive us chaff for wheat, introducing an indefinite amount of error into the Word of God." The first part of the last sentence may by some be thought more or less applicable to Dr. Beruard's Commentary-ard I will not contest that he is at times arbitrary, though $I$ think that few of his age, and possessing the same wonderful practical knowledge of Ilebrew, would be less so. For my own part, I will take this opportunity of saying that, whenever I see an interpretation of any passage in Job, which pleases me better than that advanced by Dr. Bernard, or by myself; I shall not fail to adopt it, and to record my adoption of it, if I have the opportunity. There is no really difficult passage in .Job, upon which my mind is so thoroughly made up, that I could not be prevailed upon to alter my opinion. I retain my present views procisionally-until I meet with something better.

Sir G. C. Lewis also, in his "Astronomy of the Ancients" (p. 391), has some very pertinent remarks, though they refer to Coptic and Egyptian, and not to Arabic and Hebrew. He says: "Now when the tradition of a language is lost, but its affinity with a known language is ascertained or presumed, the attempts to restore the signification of words proceed upon the hypothesis that the etymology of the word ean be deteruined by its resemblance, more or less 
close, to a word in the known language, and that the etymology of the word is a certain guide to its meaning. But, although there is a close affinity between etymology and meaning, yet etymology alone cannot be taken as a sure index to meaning. When the signification of a word is ascertained, it is often difficult to determine the etymology.........But, when the process is inverted, and it is proposed to determine the signification of the words of an entire language from etymological guesses, unassisted by any other knowledge, the process is necessarily uncertain and inconclusive, and can be satisfactory only to a person who has already made up his mind to accept some system of interpretation." Sir G. C. Lewis then quotes an example which may be found in Diez, Roman. Wörterb., p. $356, s . v$. troja. If then, even when the tradition of a language is lost, it is neither satisfactory nor safe to guess at the meaning of its words by the help of a cognate language, how much more unsatisfactory and unsafe must it be to make such guesses in the case of a language, in which the traditional meaning of nearly every word has been preserved, as it has been in Hebrew ! Yet Gesenius very frequently rejects the traditional meaning of a Hebrew word, and assigns a new one to it, based upon some "half-understood" root in a language (Arabic), of which we have no reason for supposing that he possessed any intimate knowledge. Besides which, everybody who has consulted an Arabic dictionary is well aware that an Arabic root has frecquently half-a-dozen, or even ten or twelve different meanings, ${ }^{*}$ so that it naturally often happens that one finds something suitable. The very fact, that it is sometimes difficult in Hebrew to obtain good sense, without departing from the traditional meaning of some word in the passage, goes far to prove that the traditional meaning is the correct one-for one never invents a meaning which does not suit the context.

It must not, however, be inferred that, because Dr. Bernard rejected Arabic as a means of interpreting Hebrew, he had no knowledge of Arabic. On the contrary, I believe he had a tolerable knowledge of it, and I have heard him say that he once drew up a list of Arabic and Hebrew roots, which had the same or corresponding letters, and yet differed altogether in meaning. I myself, too, know quite enough of Arabic to be able to find a new meaning for as many Hebrew roots as anybody, even a second Gesenius, would wish to reinterpret. (1862).

(2) p. ix. My own opinion with regard to the alsolute necessity for these transpositions las become somewhat modified since I wrote the above-as will be seen in the Appendix. At the same time I will observe that very few Commentators and critics will be entitled to protest against the transpositions, which Dr. Bernard makes, as impossible, inasmuch as it lappens to be the fashion just now to go much farther, and to ascribe the different books of the Bible to any one, rather than to the writer to whom tradition has so wantonly assigned them. And yet Conant, with truly marvellous inconsistency, designates the transposition in Chap. xxvii., first proposed by Kennicott, and adopted by Dr. Bernard, as " the

- Comp. the roots (wg ح 
slashing criticism of his (Kennicott's) time," whilst Ewald, who declares the whole of Elihu's discourse," and part of God's, to be an interpolation, is not only not blamed by Conant for this merciless proceeding, but is lauded to the skies, his view of the book of Job being styled, "a view well worthy of the great mind from which it emanated." (Introd. p. xvii.) Why, the critics of the last century were but lambs as compared with that tiger Ewald, who rends and tears whatever he lays hold of, and calls this mangling process criticism! And yet one sees why this species of criticism, which he seems to have been one of the first to invent, is becoming popular. Years of study are required before one can acquire a profound knowledge of Hebrew, and if one does at length succeed in mastering the language, a Commentary, which is the result of all this study and which contains merely the interpretations of the difficult passages, and the explanations of the grammatical difficulties, and does not venture into the alluring paths of theory, meets with but few readers, and yet is a very laborious task. Here the road to fame is very toilsome, and the fame ultimately attained is but very small, and does not extend beyond the limits of a very narrow circle. A work on the other hand, which, like some late productions, contains anything paradoxical and startling with regard to the books of the Bible, and confidently affirms that every one of these must be dismembered and assigned to different authors, attracts immediate attention, and is eagerly sought for by the public, ever greedy of excitement and novelty. The author, though, perhaps, but yesterday a teacleer of arithmetic, is at once exalted to the rank of a Biblical critic of the first order, and it is besides straightway inferred that he must be a profound Hebrew scholar (though all the time he is probably only a smatterer) +-for how else could he

* Ewald evidently rejects Elihu's discourse, because it does not accord with his own interpretation of the preceding portion of the book. His argument seems to have been this. I am infallible; whatever view, therefore, I take of Job's character, it must be correct ; any part of the book, therefore, which does not accord with my view, cannot be genuine. Elihu's discourse does not accord with my view of $\mathrm{J}_{\mathrm{ob}}$; therefore, it cannot be genuine.

† Thus, Bishop Colenso, when comparing two corresponding and very nearly identical passages in Ps. lxviii. 2, and Numb. x. 35, asserts most boldly (Part ii, p. 293) that the

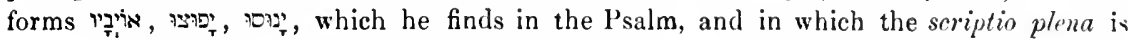
used, are older than the corresponding forms in Numb., viz., Tw, in which the scriptio defectiva is used, and hence he derives an argument in favour of his view, that the Psalm was written before the pass. in Numbers. Now I thought that every one pretending to the least familiarity with Hebrew was aware, that the scriptio defectiva is found chietly in the older books, and that the more molern the Ilebrew, the more common does the srriptio plena become, until at last in Rabbinic the scriptio defectiva (as far at least as Short Cherik (Defective Long Cherik), and Kibbuts (Defective Shurik) are concerned) becomes quite the exception, and, indeed, ' and ' are frequently introduced where they are never found in the Bible. See Gesenius, Lehrgeb. p. 51 ; Ewald, Krit. Gramm. pp. 40-46, and especially, pp. 53, 54, 60-62. 159; and Kalisch, Gramm., Part i., pp. 9, 10. It is very evident that Bishop Colenso has not read much Hebrew, or that, if he has, he has read it very carelessly, for else he could not have failed to note this prevalence of the fuller forms in the later boolis. We see then that the only possible conclusion, which can be drawn from a comparison of the full and defective forms in the two pass. quoted abore, is that the pass. in Numbers is the OLDER-a conclusion, the rery opposite of that which 
possibly determine when there was a difference of style sufficient to justify his inferring a different author-a point upon which but few could pronounce eren in their own native language. Fame is thus at once and cheaply attained, and our author is set down as a man of far greater grasp of intellect than those dull, plodding fellows, who content themselves with facts, and scarcely stir beyond the narrow limits of their' grammar's, their lexicons, and their text. And yet all that is required to command success as a critic of this kind is plenty of imagination uncontrolled by judgment, and plenty of unshrinking dogmatism !

Bishop Colenso draws. But he has not only committed this very gross blunder, ${ }^{*}$ he has also shown himself greatly deficient in soberness of judgnent-for who, let me ask, with but a grain of caution, would go and base an argument of this importance upon such an uncertain foundation as the scriptio plena and defectiva, concerning which Gesenius remarks (op. cit., p. 49) that a great deal depended upon the caprice of the copyists? Dr. Colenso should at least hare compared all the most trustworthy editions and codices. Let the readers, therefore, of Dr. Colenso's criticisms upon the Books of the Old Test. receive with great caution any argument which he bases upon the use of certain Hebrew forms or words, and let them remember that they have to deal with a critic, whose zeal is apt to run away with his judgment!

I would also caution the reader against putting his trust too hastily in Dr. Davidson, a critic of the same class as Bishop Colenso, who looks up to him (Pref. to Part iii., p. xi.) as a profound Hebrew scholar. This profound Hebrew scholar has, however, made a most gross blunder (first pointed out by Mr. Wright, "Journal of Sacred Lit.," for April, 1863, p. 185) in the second vol. of his Introduction to the Old. Test., p. 33s, where he

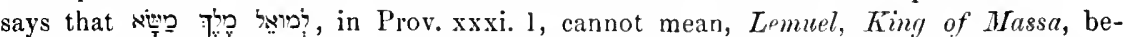

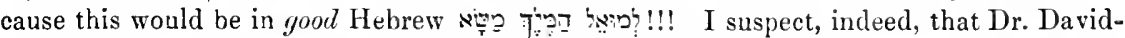

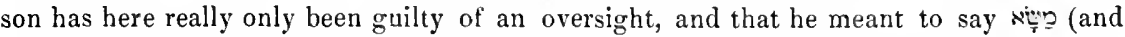
not 7 (p) should have the article prefixed. But, even if this is so, he is still guilty of the most gross carelessness; and that he is careless, I have further evidence, for in the list of errata to his first vol. I find, "Page 373, line 18, reud 7p." Suspecting the mistake, I turn to p. 373 , and there I find Dr.Davidson, therefore, whilst correcting one mistake in his errata, allows his printer to make another, and a very much more palpable one. In every book containing much Hebrew, one expects to find several misprints in the text, and one thinks none the worse of the author for them, but who expects to find a misprint in the corrections of crrata!!!! Surely nobody but an excessively careless person could allow a misprint to escape him in such a place! But, to revert

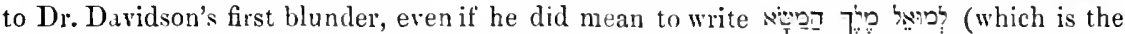
most favourable construction that can be put upon his blunder), he would still be guilty of a mistake, for it is by no means necessary to put the article before the name of the town or country following, and governed by 7 , so that Massa, would, in spite of Dr. Davidson's most dogmatic assertion to the contrary, be most

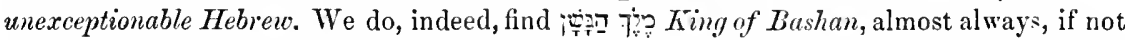
always; but, with regard to other names of towns and countries, the difficulty is realiy, rather to find instances in which the article is prefixed, to surh a degree do examples in which it is omitted crowd in upon one. Comp., for towns,

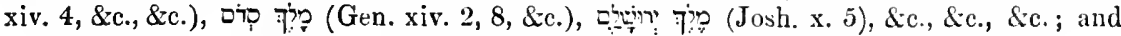

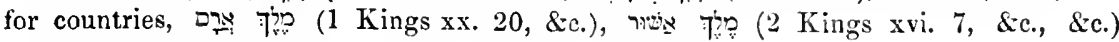

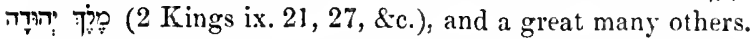

* The grossness of the blunder is of conrse materially increased by Dr. Colensn's so buldy basing an important argument upon it. 
This dogmatism, this would-be intellectual despotism, would really be amusing, if it were not so pernicious. Upon myself, indeed, and no doubt the same is the case with others who, like myself, have become case-hardened, it produces much the same effect as a shower-bath, that is, it takes away my breath for a moment by its very impudence, but then refreshes and exhilarates me ; but many, I fear, are awed and crushed down by it, so as to sacrifice their own judgment. And yet what is this dogmatism, but either credulity or dishonesty? credulity, if the dogmatist places absolute belief in his own intemperate and hasty judgment, or in the fallible judgment of others ; dishonesty, if, by trumpeting abroad the infallibility of arguments, which he himself either does not believe in, or knows to be weak, he hopes to induce others to accept them, and to look up to him as their guide. Now Ewald and Colenso are among the greatest of dogmatists I know, but I class them among the credulous, and not among the dishonest of their kind. I believe them to be sincere, and I think that it is much to be regretted that the marvellously large store of the very deepest faith, which the former places in himself alone, and the latter, both in himself and in those whom he looks up to, rationalists, men of science and the like *, has not been placed where it might do

* This may be called the age of exact scientific inquiry, but to me it seems rather the age of hasty, rash, and dogmatic géneralizations from small (often very small) groups of imperfectly ascertained and incompletely digested facts. The public-such is the advance which it has made in scientific knowledge-is now admitted to the consideration of questions which, not so very long agc, would have been regarded as altogether beyond its pale ; and the natural consequence is, that the so-called scientific theories, which have of late been advanced, have not been prepared with the same care that would have been bestowed upon them, if it had been intended to submit them only to the criticism of men thoroughly competent to deal with them; whilst, by way of compensation, they have been propounded with that highly magisterial and dictatorial tone, which imposes so much upon the public, but which may always be regarded as an infallible sign of zceakness, be it conscious or unconscious. It is the public now, which, in consequence of its immense numerical majority, pronounces the verdict, and so the framer of a new theory, if he can only satisfy the public (no very hard task), can afford to disregard the opinion of his scientific brethren. His chief care must be to make his theory as plausible, interesting, exciting, in short, as sensational, as possible; for, if he can do this, and is an adept at dogmatizing, his success is assured. The art of book-making* has, in fact, been introduced into science, and the result is what might have been predicted-gain, it may be, to the public, but injury to science. Biblical criticism and scientific inquiry, therefore-I mean as practised by those who write for the public-seem at the present time to occupy the same low level. Theories spring up like mushrooms, but, fortunately, they will be, most of them, but little longer-lived. The patience of our forefathers seems to have forsaken us; we write for our contemporaries only, they wrote for posterity also.

It must be observed that I here speak only of the scientific theories of the present day, and by no means of the scientific facts, of which no one can possibly appreciate the importance more highly than I do. But as for the theories-and it is in the theories that Bishop Colenso and others mainly put their trust-they are to the facts much as an elaborately-tooled and richly-gilt cloth binding of Shakespeare is to the contents, both as regards their comparative value and durability.

* By book-making, here, I understand putting books together in such a way, as rather to please the public and sell well, than to satisfy the requirements of really scientific men. 
themselves good, and could do nobody else any harm. But, unfortunately, we cannot place our faith where we like; every one almost seems to have a certain share of it, and if he cannot place it where it is best placed, he will certainly - and that, perhaps, while scoffing at the credulity of others-accord it to mere fancies and speculations, such as the identity of Arabic and Hebrew roots, the origin of man, species, \&c., \&c., the evidence in favour of which is of the most unsubstantial and inconclusive kind, ${ }^{*}$ and which, therefore, however plausible as conjectures, yet, from the very nature of the subjects, never can be exalted into estublished facts, and, consequently, should not, in accordance even with the principles of their originators, be accepted as matters of belief, and yet, notwithstanding, are firmly believed in by them. Ewald frequently disdains to produce any arguments at all; he most coolly states that a thing, of which nobody ever heard before, is so, and he expects his readers to believe it; and by this astounding impudence he but too frequently succeeds in imposing his fancies upon them. Thus in his Krit. Gramm., p. 539, he says of

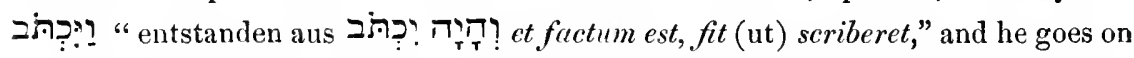
to shew how $\Pi_{T}$ T ? has become shortened into ? followed by a dagesh. He does not offer this as a conjecture ; he says it is so, and he has succeeded in inoculating many with a firm belief in this mere assertion. Thus Nordheimer $\dagger$ (Gr. vol. i., p. 128) speaks of this view, as of a matter of fact, and in a recent number of the Athencum (June 13, 1863, p. 772), I find the following, which no doubt alludes to the same view, "we should also dismiss van conversive, and give the true philosophy of the matter." Kalisch is much more cautious, and (Gr., Parti., § 49) characterizes a view very similar to Ewald's, viz., that 1 conv. is a contraction for

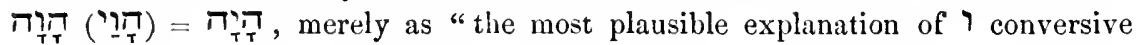
yet proposed." To such language as this last I can have no objection, only let no one convert what is, and ever must remain, a mere conjecture, into a fact! (1863.)

(3) p. xii. The Commentators, who make use of these languages in the interpretation of Hebrew, are no doubt sincere in their highly illogical belief that any Hebrew root, with the traditional meaning of which they are dissatisfied, must $\ddagger$ have the same meaning as a root with corresponding or equivalent letters in one or other of the cognate lang., still this is by no means the only reason which leads them to study these languages; another, and with many I fear, a much more powerful, reason operates with them as an incentive. They are well aware, namely, that,

- It is really a marvel to me how men, who are nuaterialists and consequently believe the human mind to be a mere quality of matter (the brain), yet place in their own minds a faith which would not disgrace the most sincere believer in revealed religion. Which then is the more credulous of the two? I think the so-called sceptic, for he places the same amount of faith where it can do neither himself, nor anybody else, any good.

$\dagger$ Nordheimer, however, is by no means blind to Ewald's faults. The estimate, which he has formed of Ewald's Krit. Gr. (see the Introd. to his Gr., vol.i., pp.xvi, xvii), seems to me perfectly just, and I agree with him both as to the merits and the demerits of this work, though I am sure very little practical Hebrew is to be learned from it.

$\ddagger$ I say must advisedly, for may is a word but very seldom used by these dogmatic gentlemen. 
with the public generally - and even with the learned who are unacquainted witl Oriental languages, or have but a slight knowledge of them-—a man, who gives evidence of an acquaintance with Hebrew, Syriac, Arabic, Coptic, \&c., passes for a better Hebrew scholar than one who knows no Oriental language but Hebrew -and hence they study and quote ${ }^{*}$ these cognate languages. For every word they quote $t$, they know they will get credit for at least a hundred, so who can blame them for quoting? And besides this, they save themselves so much labour. Many years' toil is needed before one can acquire a profound knowledge of Hebrew, but if one will only study a few of the cognate languages, then three or four or more years' less study may be bestowed on Hebrew, and yet a much greater reputation for a knowledge of it be obtained. $\neq$ But some one from among the uninitiated may say, it surely must require three or four or more years to acquire a knowledge of these cognate languages! Well, some years might possibly be required by one, who had never studied any Eastern language, and had never been well grounded in any other, but one who had some knowledge of Hebrew, and had learned one or two other languages accurately, would, I think, in a very few months acquire as much of one of these cognate dialects as would serve his purpose-and, indeed, I think, he might accomplish six of then in one year, if he devoted his whole time to their study. He would not be called upon

* They must quote, else the study remains unknown.

t There is great art, too, in quoting. Just as a man, who has, perhaps, only been snubbed by a nobleman, or told to get out of the way by the nobleman's footman, may, if he be very cunning, succeed in persuading his friends that he is upon intimate terms with this nobleman; so a man, who knows but a few words of Arabic, \&.c., may, by a skilful use of them, convey the impression to his readers that he is familiar with the language.

$\ddagger \mathrm{I}$ find an excellent illustration of $\mathrm{my}$ argument in a so-called Persian Grammar, written by a Mr. Bleeck (London, Quaritch, 1857). Besides the Grammar, this book contains a "new plan for facilitating the study of languages;" and this plan, which is exceedingly simple but impracticable, and, as it seems to me, by no means novel, is illustrated by specimens from fourteen languages, most of them oriental and with very difficult looking Alphabets, whereas one specimen would have sufficed, if Mr. Bleeck's intention had been simply to illustrate his plan. But Mr. Bleeck evidently cared very little about his plan, and was only anxious that his readers should be struck with profound admiration for the linguistic attainments of the "Young Orientalist," as he is careful to style himself in his preface. Now there is no means of ascertaining whether Mr. Bleeck translated all these different specimens himself, but, even if he did, I will venture to say that any adult with a taste for languages, and possessed of moderate ability and perseverance, could acquire a sufficient knowledge of these fourteen languages to translate these specimens from them, in less time, than it would take him to acquire a thorough knowledge of any one of them. I should be sorry, howerer, to accuse Mr. Bleeck of anything more than vanity, but sometimes actual dishonesty is practised for the purpose of attaining the same end, which Mr. Bleeck had in view. A gentleman, from whom I learned an Oriental language, and himself a native of the East, once coolly suggested to me that I should write a pampllet in English, give it to him to translate into his native language, and then publish the translation under my own name; and he adderl, as an inducement, that he had already done this for another pupil, who had thereby obtained some reputation as an Orientalist!!! 
to do more than to make himself tolerably familiar with the alphabets of these languages, to learn the interchanges of letters between them and Hebrew, and to run through their grammars, noting the principal rules, so as to be able to refer to them if necessary.* He would then know what a Hebrew root might become, + in any one of these kindred tongues, and he would, therefore, know what to look out for in his dictionaries. But he might do less than this, and content himself with learning the Alphabets only, inasmuch as for the interchanges he could always refer to Gesenius, who gives them in his Thesaurus, and Lexicon, at the beginning of each letter. + At the same time, if he could learn to translate a little from these languages, he would be amply repaid for his trouble, for is it not entirely owing to the very numerous quotations from the Arabic, and to the translations which accompany them, that Lee's Commentary on Job not only still keeps afloat, but is assigned the highest rank among the English Commentaries on this book, by the author of the article "Job" in Smith's Dict. of the Bible?

It must not be supposed, however, that I deprecate the study of these cognate languages; far from it-I only deprecate the interpretation of Hebrew by their means. It is, I think, very interesting and instructive to compare Hebrew with the other members of the same family, but this, it seems to me, is the business of the Philologist, or of the Grammarian, rather than of the Commentator, who should make it his amusement only. It is the business of the Philologist to learn

* That I may not be charged with exaggeration, I may mention that some five years ago, when I was in Berlin, I accidentally met one of Dr. Bernard's former pupils, who had now learned, however, to look down upon his old master (though he still allowed him to be unrivalled as a practical Hebraist), and had come to Germany for the purpose of studying the cognate languages. Being at that time uninitiated, I expressed my astonishment at the magnitude of the task which he had undertaken. "Oh," said he, "it is not quite so bad as you imagine; for example, I am assured by an eminent Orientalist that I shall not require more than four hour's (!!!) to learn as much Eithiopic as will serve my purpose."

† Let us take for example the Heb. root לחי. He would know that i in Heb. corresponds to $i$ or $\neg$ in Chald. and Syriac, and to $j$ and $j$ in Arabic, whilst $\pi$ corresponds

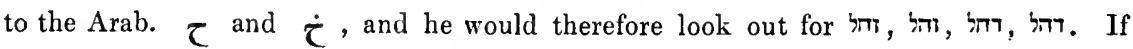
he found nothing, he would then possibly, remembering that $ל$ is sometimes replaced by 2 and 7 in the cognate dialects, as a last resort, look out for $ו$ והר, \&c. It would be strange if, with all these chances, one did not sometimes find something.

‡ Under the letter ', I notice a very singular mistake in Tregelles' Transl. of Gesenius' Lexicon. ל is said, namely, to be interchanged with 2 , and as an example is given "לחיץ and ${ }^{2} ;$ to burn." Knowing the meaning of these verbs to be, to urge, press, oppress, and not to burn, I turn to the letter $b$ in the Thesaurus, and find them interpreted ursit, which Dr. Tregelles has therefore transl. as though it were arsit. This is not mere carelessness; for, though one might, perhaps, inadvertently read arsit for ursit, yet Dr. Tregelles, if he pretends to be a Hebrew scholar, ought to have known at least the meaning of the verb ' לדי (which occurs several times) independestly of Gesenius' translation. Nor is this the only mistake which I have had occasion to notice in Dr. 'Tregelles' 'Transl., for he gives quarrel as one of the meanings of $\square$, whereas Ges. has querela, complaint! Here, I think, it must be allowed that Dr. Tregelles has laid himself open to the charge of ignorance, both of Latin and of Hebrew. 
a great number of languages in the superficial manner which $I$ have described (a deeper knowledge would frequently be useless to him), and to compare them ; it is the business of the Commentator, on the other hand, to study the language, to which he especially devotes himself, profoundly, and when commenting, to stick resolutely to that language; for, if he once allows himself to invoke the aid of a kindred dialect, he will quickly become impatient whenever he meets with a difficult passage, and, instead of thinking over it, and resolutely endeavouring to puzzle out its meaning, he will quickly abandon the contest, and fly off for help where he thinks he has found it before* A Philologist will seldom make a good Commentator, because, in the first place, he will but seldom have devoted himself sufficiently to the study of one language; and in the second, even if he has done this, he will but rarely, when commenting, have sufficient command over himself to lay his philology for a time upon the shelf. (1863.)

(4) p. xiv. It may be interesting to Dr. Bernard's pupils to learn how the Commentary and Translation were written. When I went to Cambridge (3lst of May, 1856), in order to help Dr. Bernard with them, I expected to find the materials for the work, or at any rate a portion of them, already collected, for he had told me that he should not require my assistance for more than about two or three months. Great, therefore, was my surprise, when I found absolutely nothing ready, but that eternal little list of the principal references, which every pupil of Dr. Bernard's, who read the Book of Job with him, must remember well! We set to work, however, at once, and the Commentary and Translation, exclusive of the Prefaces, were finished by about the end of April, 1857. The plan we adopted in writing them was as follows: Eacli Chapter was thoroughly completed before the next one was commenced. I began by reading over the whole Chapter to Dr. Bernard in Hebrew; then I read the English Version to him; next followed Wolfssohn + , Umbreit, and Schlottmann's German translations, and, lastly, whatever other translations we made use of. (Hebrew Commentary) $\$$, together with Ilomberg's eriticisms upon it, and nearly the whole of Rosenmiiller's Commentary; but of the remaining Commentaries which we had before us, such as those of Aben-Ezra, Jarchi, Ralbag, Schultens,

* He is, in fact, like a school-boy with a crib.

+ Hebrew Commentary on the Book of Job, with a German translation in Hebrew letters. Edited, with additional notes, by Herz Homberg, under the nom de plame of המורס the Tine-dresser. See Second Preface, p. lxxxv, note $\dagger$.

† These it would be tedious and useless to enumerate, and I will therefore say, that, with the exception of Ewald's work, which did not come into my hands till 1862, there was no Commentary or Translation of importance, which was not consulted by us.

$\S$ This work may be said to have formed our text-book. The Commentary is very good as far as it goes, but it is much too brief. It is characterized by soberness of judgment and great good sense, and especially by frankness, for Wolfssohn-forming therein a great contrast to arrogant and dogmatic Ewald, self-sufficient Conant, \&c.-never fails to inform the reader when he is unable to gire a satisfactory explanation of a passage. Wolfssohn was a great farourite with Dr. Bernard, especially, I think, on account of the elegance of his Hebrew, for in opinion they very frcquently disagree. 
Umbreit, Schlottmann, Conant *, \&c., I only read the notes on such passages as presented any difficulty $\dagger$. Then, if there were any words of doubtful meaning, I read out what Kimchi and Ben-Zev, in their Hebrew Lexicons, said about them. Thus equipped, Dr. Bernard proceeded to dictate the Commentary to me

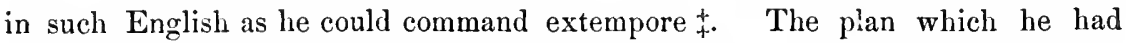
originally proposed was that he should go over each Chapter with me, explaining his riews, and communicating to me, in substance rather than in detail, the notes which he thought ought to be made, and the criticisms which he thought ought to be passed upon the interpretations of others, and then that I should elaborate the Commentary out of these materials to the best of my ability, and afterwards submit it to him for revision. But I thought that in this way much time would be lost, and that in the end his own views would, in spite of my familiarity with them $\S$, probably be less clearly set forth than if he limself expressed them fully in his own words; and I therefore begged him to dictate to me, and he assented to my request. Ultimately, it proved very fortunate that this plan had been adopted, for, considering the length of time which elapsed after Dr. Bernard's death before I was able to put the manuscript into the printer's hands, I should otherwise certainly have been sorely teased with doubts, and that continually, as to whether the Commentary always faithfully expressed his views, and I should have fancied that I had misunderstood him, or that he had misunderstood me-whereas, by the plan which we did adopt, I had his own words before me $\|$. As soon, then, as he had dictated a Chapter to me, I proceeded to add, alter, or retrench $\boldsymbol{T}$ as $I$ thought fit; and then, on the following day, or as soon as I had finished, I read the revised Commentary to him, as well as the translation of the Chapter, which I had made in the mean time in accordance with the Commentary. Any alterations which he suggested were made, and then the Chapter was put on one side,

* The first part of Conant's translation of Job appeared just before we commenced the Commentary; the second part came out whilst we were engaged on our work; the third and last part, however, which began with chap. xxx., was not published, or did not reach England, until after our Commentary was finished.

$\uparrow$ I believe that Dr. Bernard had never previously consulted any Commentaries on Job excepting the Hebrew ones above-named. His own Commentary was not based upon what he found in other writers, but upon a profound and independent study of the original, and hence, I think, its chief value. If I had read no Translations or Commentaries to him, his Commentary would have remained essentially the same, for he borrowed but very little from what he heard. His opinions were the result of mature reflection, and as such were not likely readily to be disturbed.

I And very good English this frequently was.

$\S I$ had read the Book of Job twice with Dr. Bernard, the last time about two years before I undertook to help him with the Commentary.

\|I In writing from Dr. Bernard's dictation, I always kept the lines so wide apart as to enable me to make all the necessary corrections upon the same paper; and, as I merely passed my pen lightly through the words or sentences which I removed, I still know how the original stood.

I This process Dr. Bernard used to designate by the Germ. verb feilen, to file, but this verb which, strictly speaking, only indicates removal, scarcely expresses what was really done, as I certainly added much more than I took away. 
and the next Chapter proceeded with in the same manner. As soon as ten Chapters were thus completed, they were again read over to him, and any further improvements which suggested themselves were made. The last ten or twelve Chapters, however, were not subjected to this second revision *, and this I much regret, as they certainly include some of the most difficult Chapters in the book.

From this account it must be evident that the language of the Commentary is neither Dr. Bernard's, nor yet mine, but a mixture of the two $\uparrow$, and as suchI trust it will not be too severely criticized.

The foot-notes in the Translation, which were added at my suggestion, were made in the same manner.

As for the literal renderings in the margin of the Translation, some were made by me at the time that I made the Translation, and these were submitted to, and revised by, Dr. Bernard; but the greater number have been added since his death; and as I could not well distinguish between these two classes, and they are therefore inextricably mingled, I must be held responsible for them all. And my responsibility extends also to the marginal references, $\ddagger$ which were all added whilst the work was in the press. (IS63.)

[Of the dogmatism of Materialists, to which I have referred supra p. xx, note *, I may, perhaps, venture to quote the following really ridiculous specimen, which has just come under my notice, and will be found in the Anthropological Review for August, p. 231, in a translation of an address on the "Creation of Man and the Substance of the Mind," delivered at Goettingen in 1854, by Prof. Rudolph Wagner, a very distinguished ComparativeAnatomist. Prof. Wagner, after stating, as the opinion of an eminent philosopher, then present, "that materialistic theories, which have existed at all times, have in recent times been greatly encouraged by the progress of natural science," goes on to quote some passages "from the second edition of a work by a well-known and highly-gifted author" (whom, however, out of friendship perhaps, he forbears to name)-from which I select the following : "The seat of consciousness, of the will, is solely to be found in the brain. To assume the existence of a soul which uses the brain as an instrument, with which it can work at pleasure, is pure nonsense." . . . . " All mental activity ceases with death." ... . "Physiology thus decidedly and categorically declares against individual immortality, and against all notions which attach themselves to the special existence of a soul." The conclusion he arrives at is: "With regard to myself, I can only say that every Naturalist, if he thinks logically, must come to the same conclusions. I will not, however, deny that there are idiotic and obtuse Naturalists." That is, if a man of abilities at least equal to my own, and equally competent to pronounce an opinion upon a given subject, happens to differ from me, therefore he is obtuse and idiotic!! But why he and

* It was put off from time to time, until I left Cambridge without its having been done.

$t$ If any one, who is now studying with the view of becoming a Biblical critic after the manner of Ewald, Davidson, Colenso, \&c., wishes to test his critical acumen, let him point out to me what Dr. Bernard and what I myself have written, and I pledge myself not to conceal the truth from him.

$\ddagger$ I do not wish, or expect, the reader to consult all these references, but I would recommend to his notice those which are from the Book of Job itself (cross-references), as by their aid light will sometimes, I think, be thrown upon Dr. Bernard's interpretations and views. 
not I? It is really wonderful that a man like this should presume to appeal to logic! His deductions are, however, the only ones which can be legitimately drawn from his premises, but they are by no means new, and have been defended, amongst others, by Miss Martineau (see Carpenter's Human Physiol., 4th edit., p. 795, note). They are, that "Free-will does not exist, and consequently no responsibility and accountability, such as moral or criminal jurisprudence would impose upon us. TWe are at no time masters of ourselves-of our intellectual faculties; - as little as we are masters that our kidneys should secrete or not secrete."

It must be observed that I myself hare nothing to do here with the question, whether Materialism is, or is not, true. My object is only to point out the extreme presumption and inconsistency-to use mild terms - of a man (and his is by no means an isolated case), who maintains that his mind is merely an attribute of his brain (i.e., of perpetually changing and shifting matter), and yet, in the same breath, holds up his opinions, the products of that brain, as infallible guides for other men, his equals! Dogmatists upon points like these would do well to turn to Job, chaps. xi. 7-9, xii. 2, 3, xxviii. (throughout), Sc., and to ask themselves whether, in spite of their boasted learning, and, in spite of the boasted intellectual progress of mankind, they may not learn a lesson from a man wholived 3000 years ago; and whether, in spite of the boasted advances of science, there are not many of the questions asked in chap. xxxviii, which, though apparently quite rudimentary, scientific men of the present day are still as altogether unable to answer, as Joh. It would be well, too, if they would remember that maxim twice quoted by Ben-Zev (in his Preface to Job, see pp. xlvii, lxvi), and proclaimed in other words by Job himself (or by Zophar, see chap. xxriii. 28), namely, that The perfection of human knowledge is $t 3$ know how small that knowledge is (1863). .

* It is only due to Prof. Wagner to state, that he expresses himself most prudently and cautiously, and that he, at least, if forced by his convictions into Materialism, would find therein cause for lamentation, rather than for exultation. 


\section{אI}

\section{הברו \\ יהודא ליב בן זהב ק"ל}

\section{ב א}

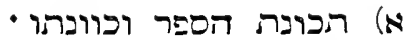

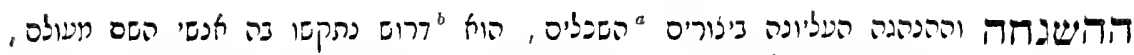

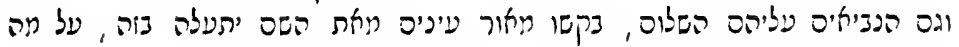

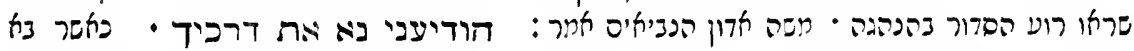

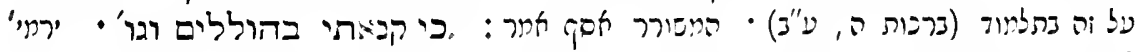

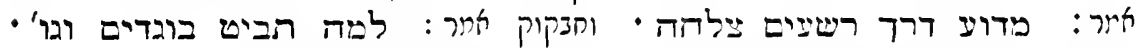

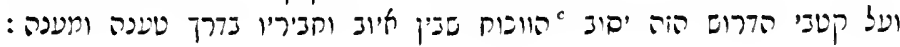

a Adjectives in ' - form their plurals, sometimes in $\Xi-$, and, sometimes in $\Xi "-$.

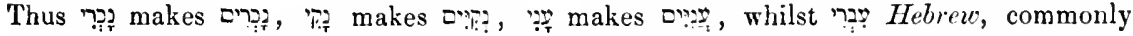

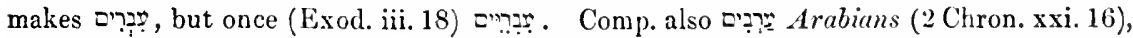
and (2 Chron. xvii. 11). See Nordheimer, vol. 1, p. 233. These adjectives do not often occur in Hebrew (excepting as patronymica or gentilia), but in Rabbinic they are very common, and $I$ think that in this dialect the termination $\Sigma "-\rightarrow$ is the more usual, whilst in Heb. the term. - קדבונים (as in Heb.) and not קימני . Observe that in Helb. the shorter words seem, as a rule, to take the longer ending, as though the object were to increase their length; and certainly euphony does not suffer therehy, as a for example, sounds much better than

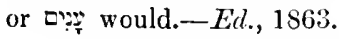

'Obs. that דרוש is here fom. but, infra line 6, mase., but the student must not be surprised at any irregularities of gender, number, construction, \&c., which occur in Rabbinical writings. $-E /$., 1863.

- This word occurs freq. in this pref., and is everywhere, I think, spelled, as here, with two 's, excepting in sect. 2, par. ', last line, where it is spellerl ויפוח, and in the heading of

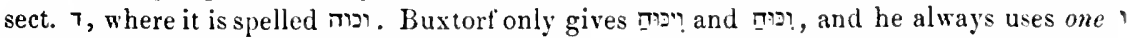

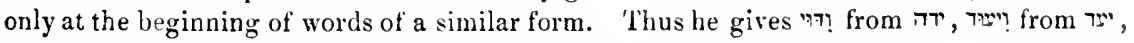

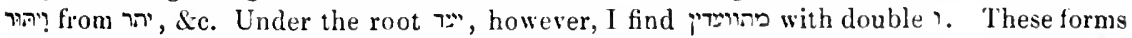
seem for the most part to be derived from the Pi-al, (or Hithp.), and hence one reason for

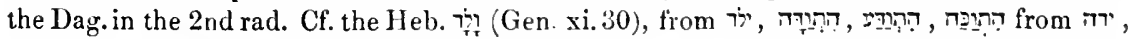
s', and 'יכח Why then does Ben-Zev use the double '? Winer (Gr. d. Bibl. u. Tar. Chald. p. 18), and Schaaf (Op.Aram. p. 2) say that the double' is freq. used in the middle (or body) of words to shew that the $'$ is a consonant, ${ }^{*}$ either simple or dugeshed; and this rule certainly

\footnotetext{
* It may be noticed tliat we use doulde $u(x)$ as a consonant, and that in Germ., when written with Hebrew letters, the $w(=$ our $v)$ is always lepresented by $n$.
} 
הספר העתיק האה, קדמון לכל ספרי העבריס, נפלא a דור עס עולם ומסאר עד דור אחרון.

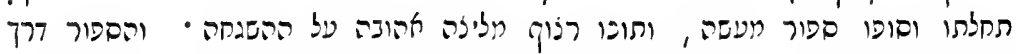

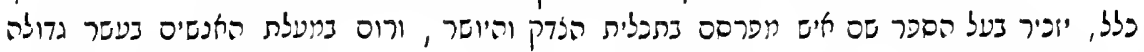

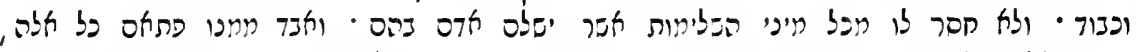

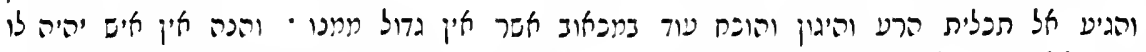

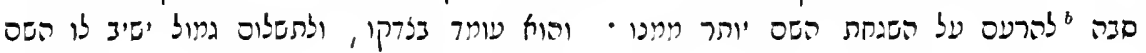

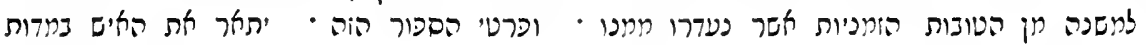

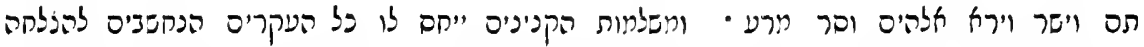

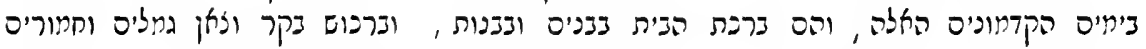

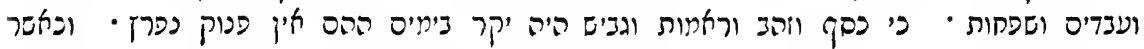

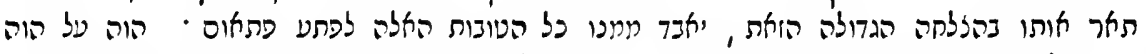

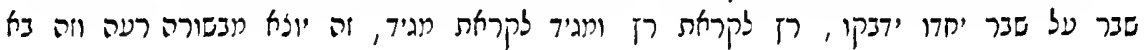

accounts for the double 1 here, and we have other exemplifications of it in this preface, as

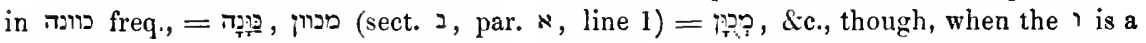
simple consonant, Ben-Zev seems to prefer to write it single, for I find מהובהים four times (viz., sect. ב, par. ', lines 4 and 5, sect. 7 , pars. 1, 4, lines 4 and 1 resp.), and התוכה once (sect. T, par. 7, line 8), whilst with a double ' I only find one example, viz., ההווכח (sect. T, par. 5, line 3).* But in this rule no mention is made of double 1 at the beginning of a word, as in ווכוד (without a prefix, sect. ב, par. ד, line 1), and (sect. 2, par. 1, line 5), nor will the rule explain this double 1 , inasmuch as 1 the conj. occurs a great many times in this preface as a consonant beginning a word, and yet it is never written $M$. It seems to me probable, therefore that the double $\rightarrow$ is used at the beginning, in order to distinguish, radical from 1 servile, the latter being very common whilst the other is comparatively very rare, so that the tendency, in the case of a word which was not familiar, would be to regard , initial as 1 the conj.t At all events, it is a fact that Ben-Zev in this preface never uses the double 1 at the beginning of a word, excepting when the 1 is radical. ' is also doubled in much the same cases. Thus, מיוב (2:), and sect. ג, pars. $3,4,5$, line 1, resp., מתיהס, all with only one '. ' at the beginning, if written single, might be mistaken for the preformative of the future.-Ed., 1863.

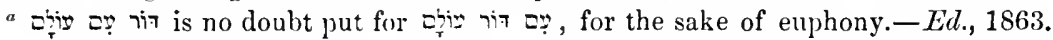

${ }^{b}$ As Buxtorf gives the Hithp. of this verb only in the meaning of to murmur, הרז be either a misprint for התרים , or else a contracted form for it, like (Isa. xxxiii. 10), for אֶרוֹ Or can it be the Niph. =, as is freq. the case, the Hithp.? In this section, par. 4, line 3, and sect. 7 , par. 4, line 7 , we find התרשם in the same sense. Similarly, in

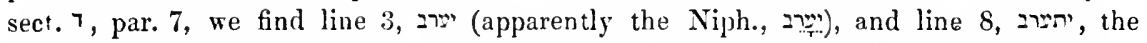
Hiph., although, the Niph. is not used in Heb., and, if we are to believe Buxtorf, is not found in Rabb. $-E d ., 1863$. [הרכם is the correct reading, see p. Ixxiv $\left.\left({ }^{2}\right)\right]$.

* But in these words מהוכח and the 1 is really initial. See next note.

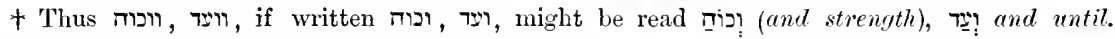
Another argument in favour of this view is that, when a simple 1 , though radical and really initial (as in מהוכה , מהוכחים) yet, from its position, cannot be mistaken for 1 the conj., Ben-Zev, as already noticed, prefers to write it single. It must be owned, however, that even such men as Ben-Zev are rather loose in their Rabbinical orthography (perhaps designedly so in imitation of older writers), and manifest a decided tendency to the employment of the seriptio plena, the love for which is so characteristic of the Rabbins, - still, in the present case, there seemed to tne to be some method, and, therefore, I have called the attention of the student to the matter. 


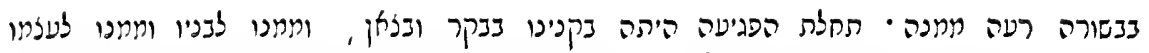

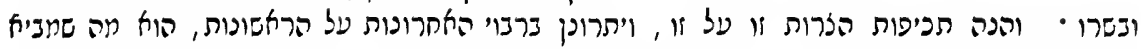

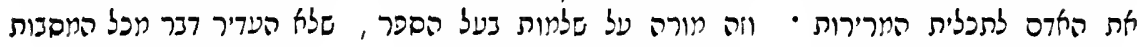

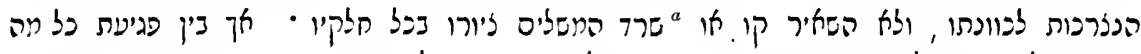

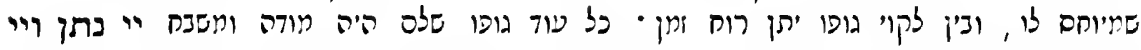

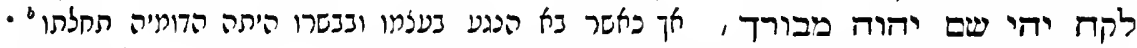

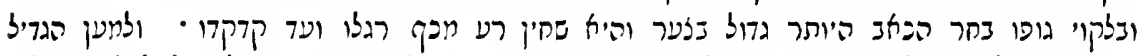

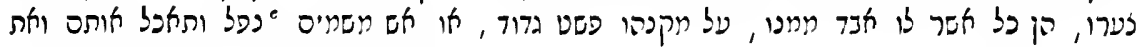

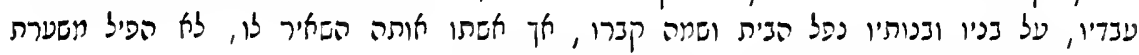

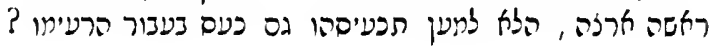

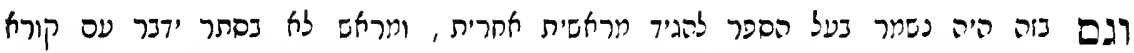

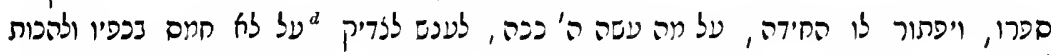

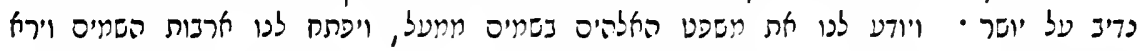

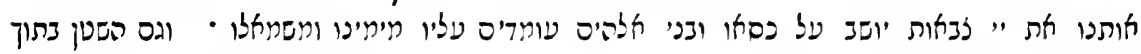

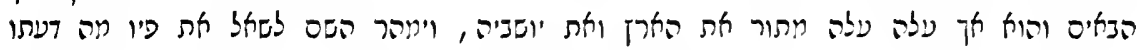

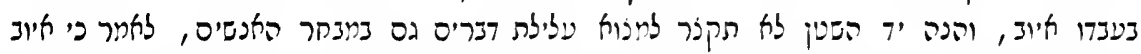

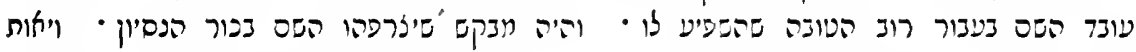

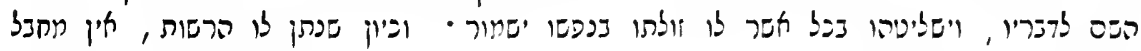

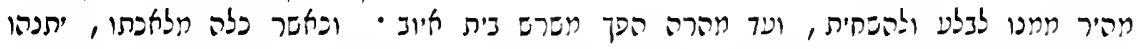

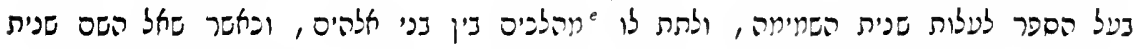

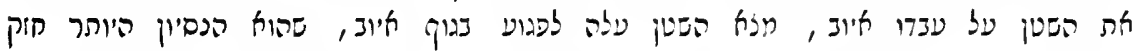

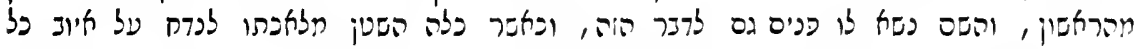

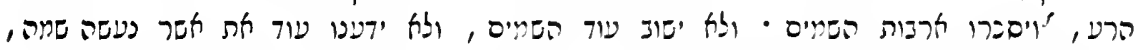

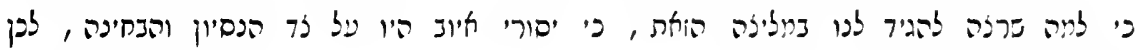

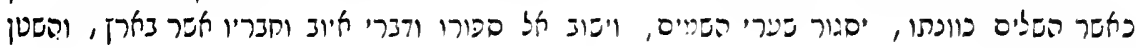

שכת וינפס: כשר :

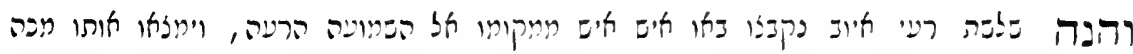

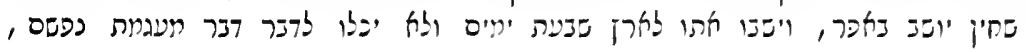

a That Ben-Zev takes סִ lineas ducere), is evident both from its connection with in his Heb. Lexicon, s.v. רu, he suggests that this word (which is only found in Isa. xliv. 13, and there is connected, as here, with $T_{T}$ ), is $==3$, and so means line, though Kimchi transl. it red-chalk, and Gesen., acl, style.-Ed, 1563.

' In my edition there is in his heginning (was silence). This makes very good sense, for Job did remain silent for some time; still, as Ben Zev is very lond of using

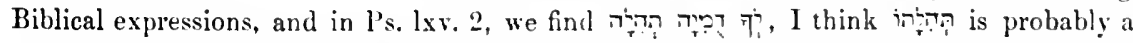
misprint for הִִּ his praise, and this both accords better with the context, and yields a much finer sentiment. See p. xxx, note ${ }^{g}$, p. xxxii, note ${ }^{a} .-E d ., 1863$. [הזר is right, see p. $\left.1 \mathrm{xxiv}\left({ }^{3}\right)\right]$.

' is of com. gend. Comp. Job xx. 26, where it is used in both its gend. in the same hem.-Ed., 1863 .

`See Job xvi. 17.-Erl., 1863.

- See \%ech. iii. 7.-Zid., 18133.

s See Gen, viii. 2.-Fid., 1863. 


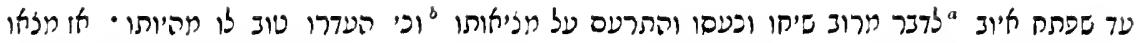

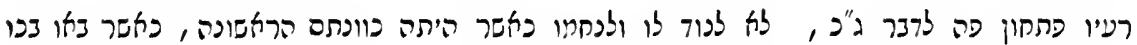

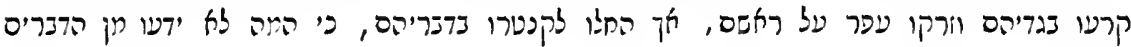

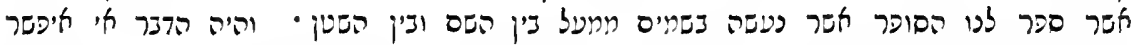

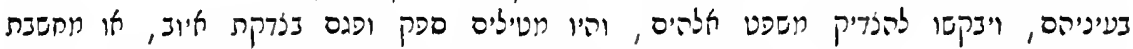

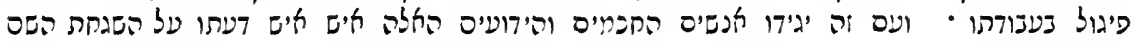

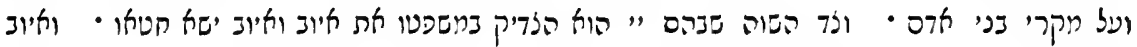

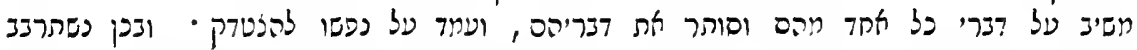

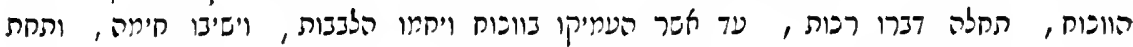

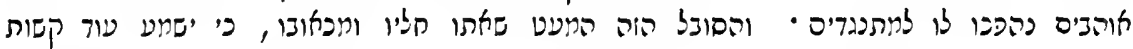

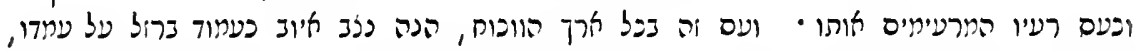

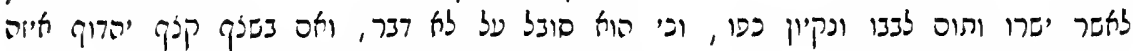

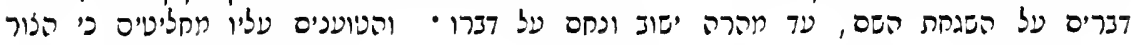

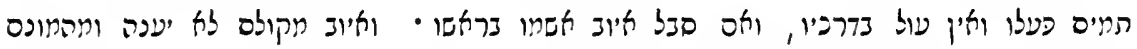

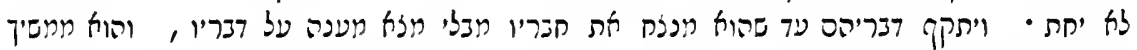

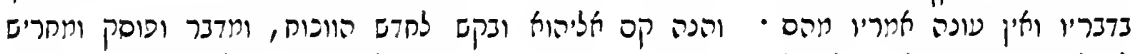

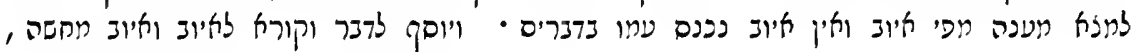

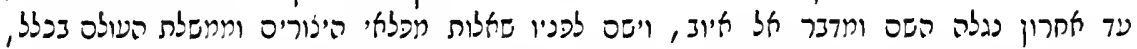

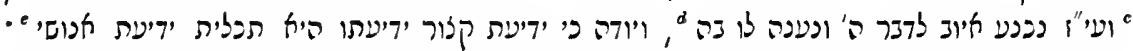

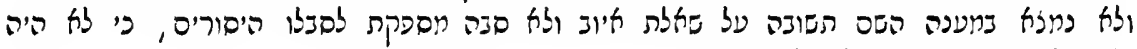

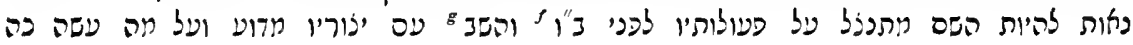

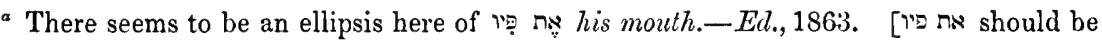
inserted, see p. lxxiv ( $\left.{ }^{4}\right)$ ].

- Before וכי (or must, I think, supply some verb from as said or complained. See eleven lines farther down, where וכ occurs in just the same way, and where we have supplied maintaining before it. See p. xxxii, par. $\star$, line 2, where there is another וכ of the same kind.-Ed., 1863.

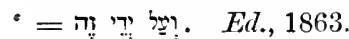

d ș seems to mean in it $=$ in this matter; or perhaps it means by it, and corresponds to i" $^{\prime \prime}$. - Ed., 1863.

e אמנ: prop. an adj. = mortal, human, seems, here to = a mortal-one, a human-one,

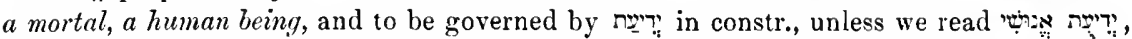

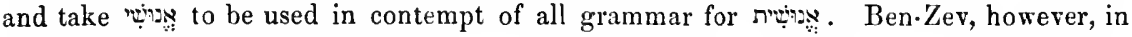
common with all Rabbinical writers, does freq. violate the rules of gender in this Preface, but never so flagrantly, I think, as he does here, if the second suggestion be correct.

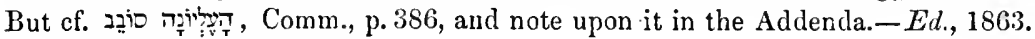

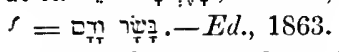

$g$ This I have transl. as though it were 2 , misprint ( $\pi$ and $\pi$ are very freq. interchanged by compositors, see p. xxxii, note ${ }^{\alpha}$ ), as in

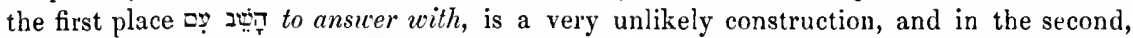
infra section 7, par. 8 (beginning המצנה), line 3, we find השב עם קינהו, i.e., the very same construction, and evidently the very same meaning, only השב . Bשב ה השב Besides, if we read חשב, we can take it to be the part. Kal (2),,$^{*}$ which would correspond with

* In Rabbinic, indeed, the part. Kal is very commonly written with full Chovlem; still, if BenZev's own rule be true, that Chourlem should be written defertire when w follows, as then one dot 
ובהי איך די פי יתוה אנוש בגבולו ואל יהרוס ממלבו ואל יפרן aלהדר בסתרי תעלומות השם

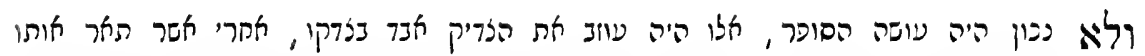

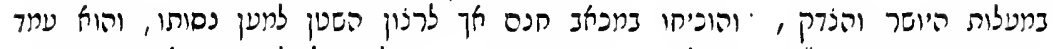

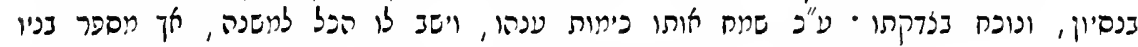

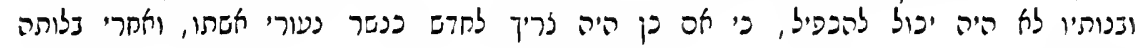

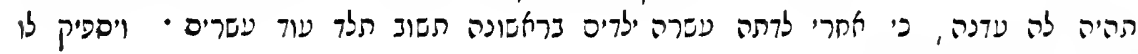

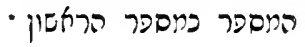

\section{ב) שם איוב אם הוא איש נמצא או לא}

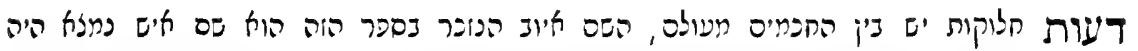

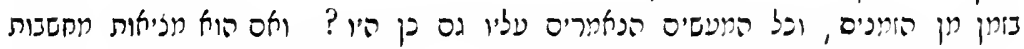

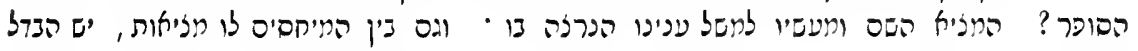

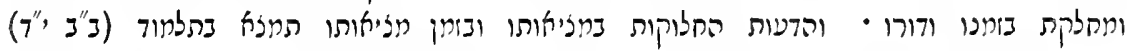

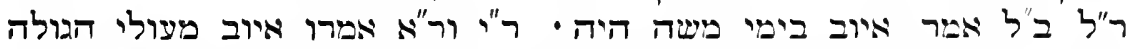

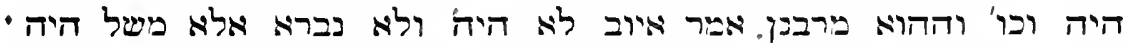

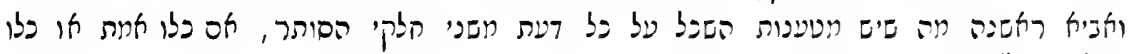

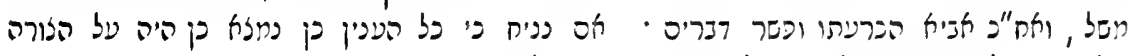

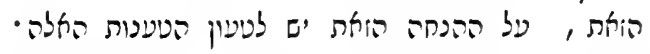

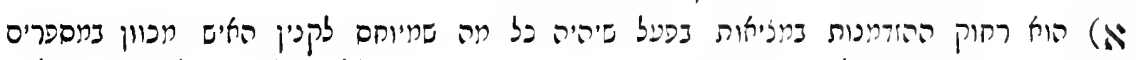

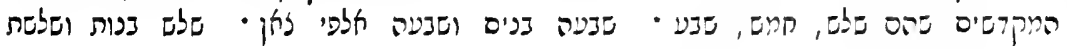

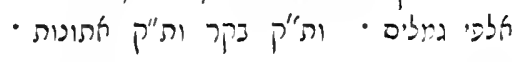

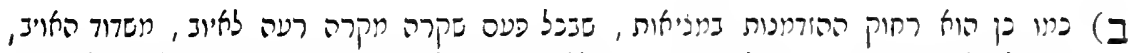

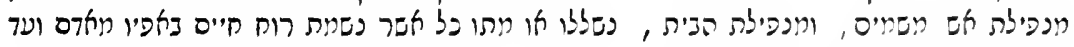

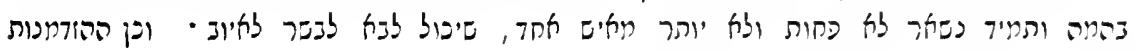

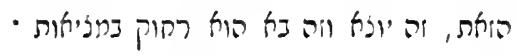

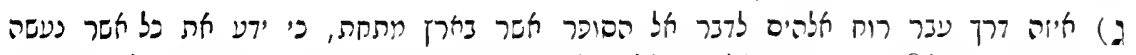

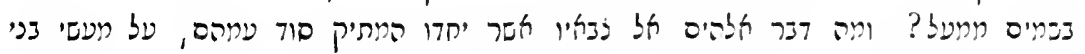

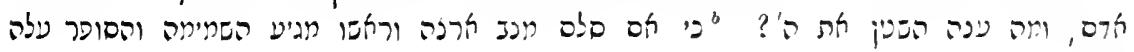

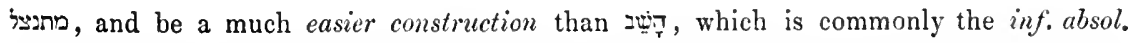
(Hiph.) of (שוב (see p. xlii, note $\downarrow$ ). Tשב את = to reckon with is found in 2 Kings xii. 16, xxii. 7. [But see p. lxv, note ${ }^{27}$ ]. If, however, we retain 2 , we must transl. to keep answering questions with his creatures, i.e., to hold Himself responsible to them.-E l., 1863. [Ben-Zev has והשי, see p. Lxxiv $\left.\left({ }^{6}\right)\right]$.

"See p. xlvi, note *.-Ed., 1863. [Ben-Zev has לחרי, see p.lxxir ( $\left.{ }^{7}\right)$ ].

[ ${ }^{b}$ Here ז' should be inserted; see p. Jxxiv $\left.\left({ }^{8}\right)\right]$.

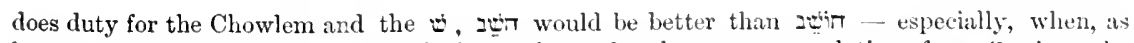
here, $r$ is prefixed, for he says himself, in another rule, that an accumulation of serriles is to be. avoided. See his rules with regard to Full and Defective ('howlem in his Talmud 1.'Shom

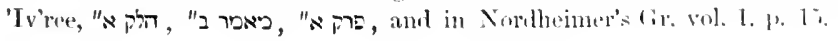




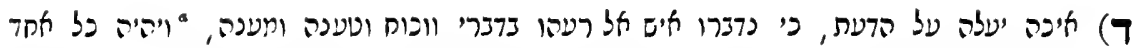

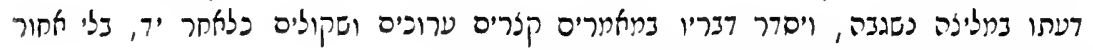

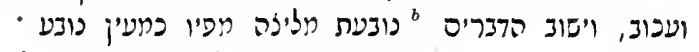

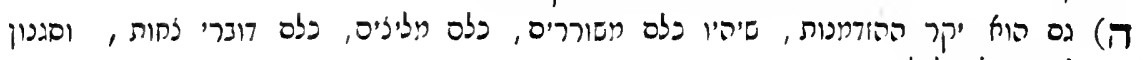

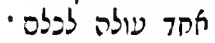

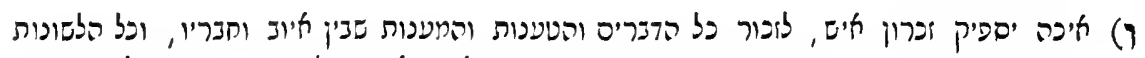

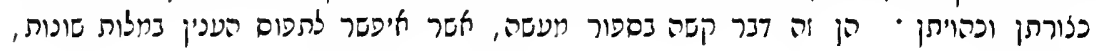

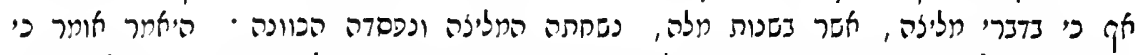

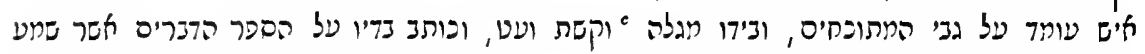

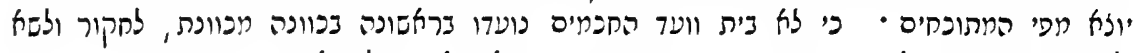

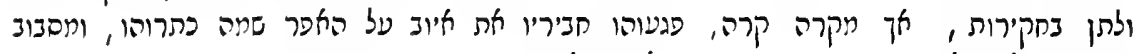

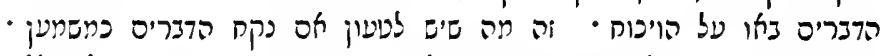

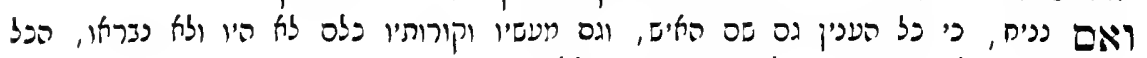

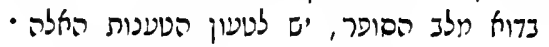

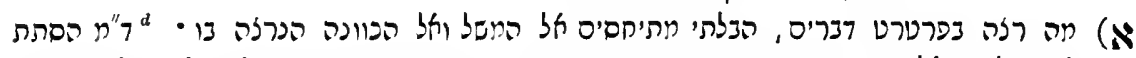

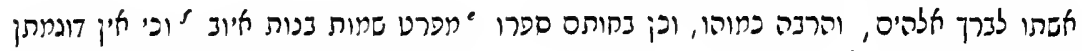

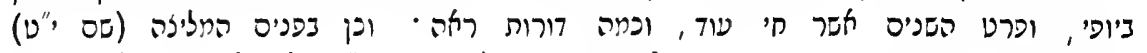

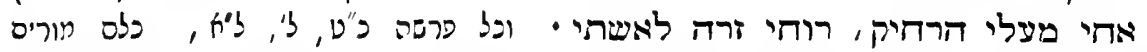

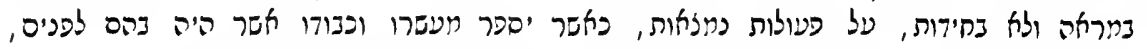

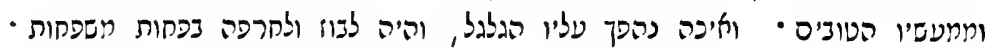

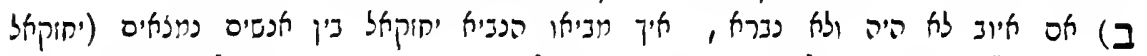

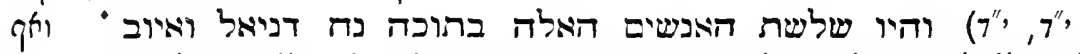

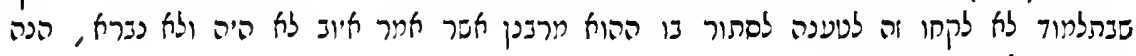

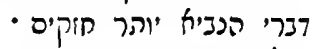

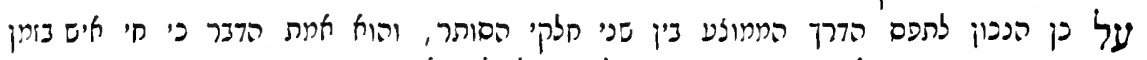

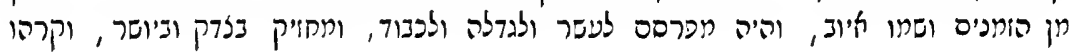

a This I believe to be a misprint for הַח (which verb is very freq. used with $\mathrm{Job}$ ), and I have transl. accordingly. If היה is retained, we must transl. and yet [as to] every one, his opinion should be, when there would be an irregularity of gender.Ed., 1863. [Ben-Zev has ויהוה, see p. Ixxiv $\left.\left({ }^{9}\right)\right]$.

${ }^{b}$ See p. xxvii, note ${ }^{b}$. $-E d$., 1863.

- This must be read prob. a misprint, as, though the Rabb. freq. use $D$ for the Heb. $\bullet, I$ believe that they do not (or very rarely) use $\uplus=$ the $\mathrm{Heb} .0$, though this latter interchange is rather common in Job, and is, I think, an argument in favour of the antiquity of the book. Comp. (for 0 vo ii., vi. 2, x. 17, xvii. 7, and in no other book. But, perhaps, Ben-Zev, trusting to his memory, thought the word was spelled in the Bible wị with

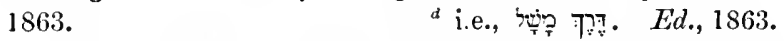

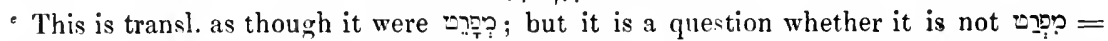
is the next clause, detail. Buxtorf gives neither the $P i-a l l$ of

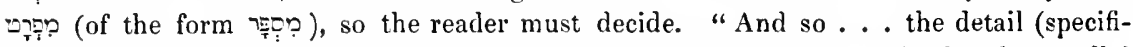
cation) of the names, \&c.," would make very good sense, and מפרש would then be parallel in constr. to הסתת. I think, however, it is prob. a part., הוא being omitted.-Ed., 1863.

ובי 5 . Before this we must supply some such verb as alds, if מפרט is a verb, and if it is a subst., some such subst. as addition, information, fact. See p. xxx, note ${ }^{b}$. $-E d .1863$. 


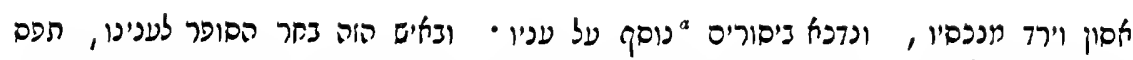

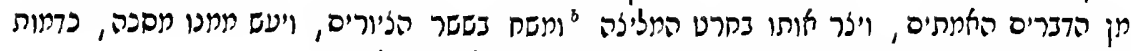

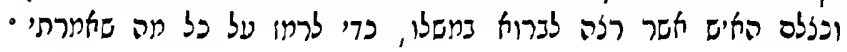

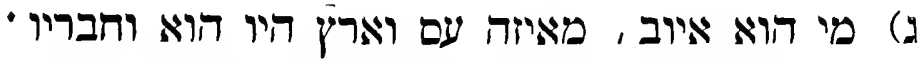

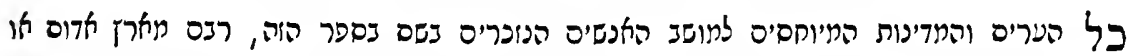

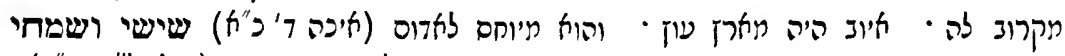

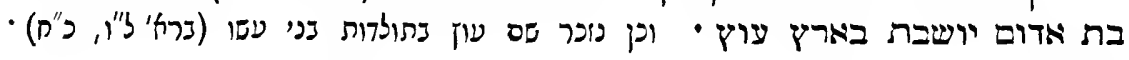

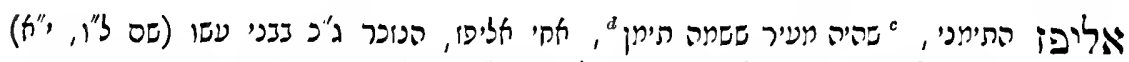

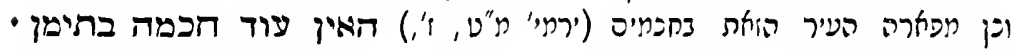

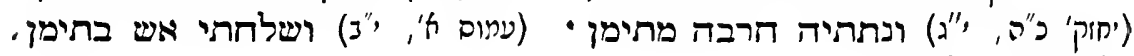

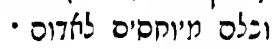

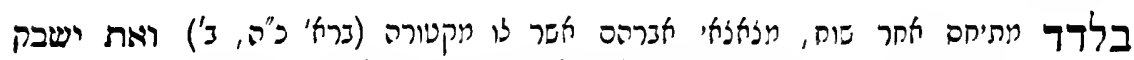

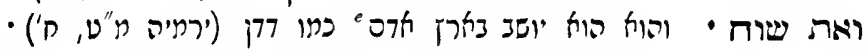

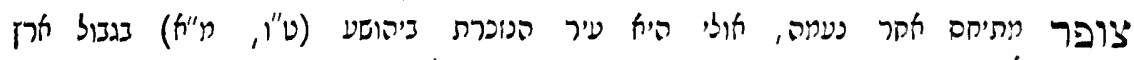
- אדוס

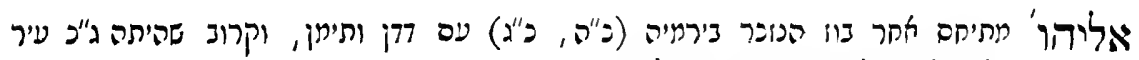

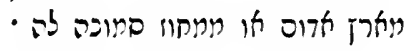

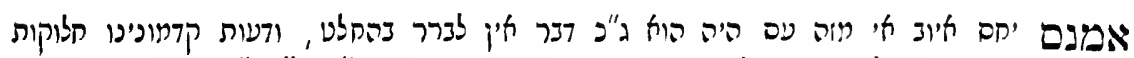

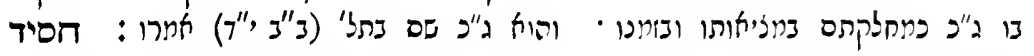

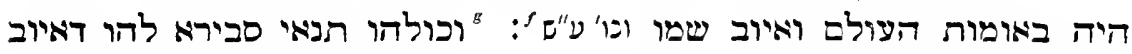

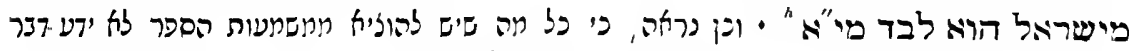

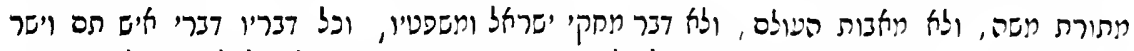

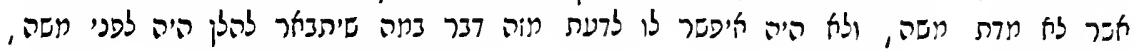

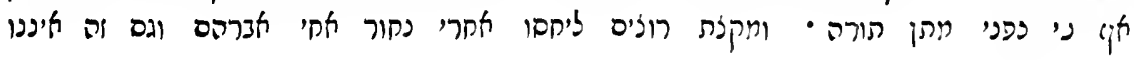

-

${ }^{a}$ See p. xxvii, note ${ }^{b}$.-Ed., 1863.

${ }^{\circ}$ See Jer. xxii. 14. $-E d ., 1563$.

"The ש שה in rather puzzling; but we shall understand it, I think, if we lay stress on התימנ, Eliphaz the Temanite, "because (for) he was fron .... Teman," Eliphaz, the Temanite, so-called, because \&c., or - Eliphaz was called the Temanite, because, \&c., החימנ corresponding, therefore, pretty nearly to מתיהם אהר הימן, the form used in the next three paragraphs. For this suggestion I am indebted to Mr. Randolph. $E d ., 1863$.

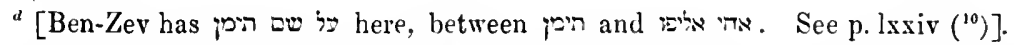

- In the original, there is ארז Syria, but this must be a misprint for (spelled supra and infia (אדום) Edom. T is very freq. printed for T, and vicc versá.-Ed., 1S63. [BenZev has ארום, see p.lxxiv (")].

$f$ i.e., שָ

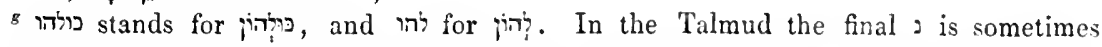
omitted in the affixes of the 2nd and 3rd. pers. plur. See Schaaf, Opus Aram, p. 3y. For סביר, , שביר , there is in the original gross misprint. See p.xxxr., note*, and p. Ixxvi.-Ed., 1563.

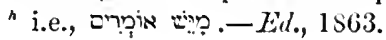




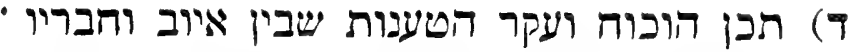

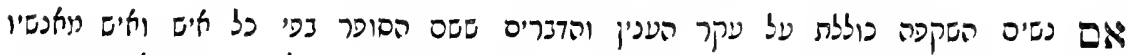

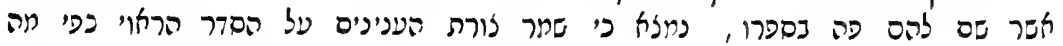

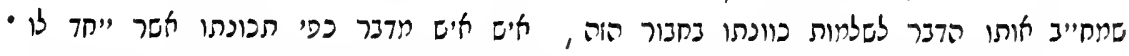

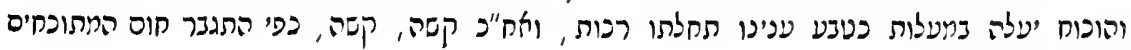

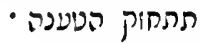

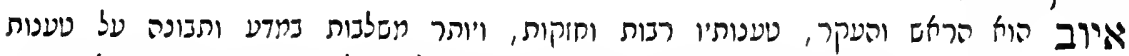

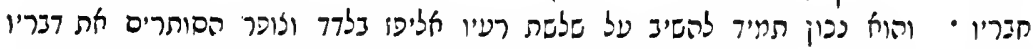

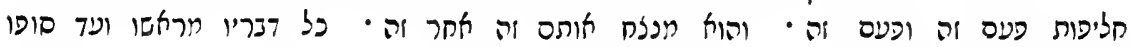

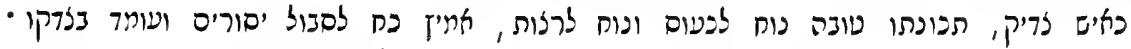

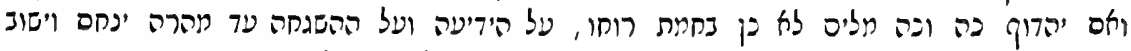

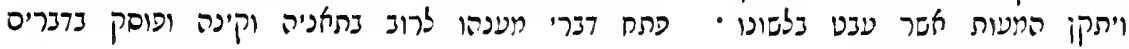

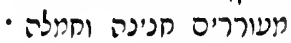

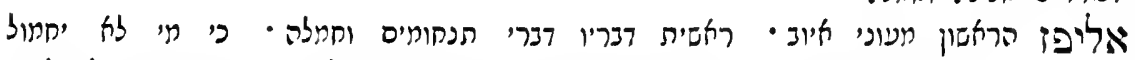

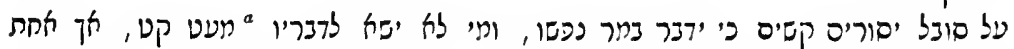

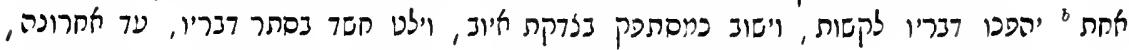

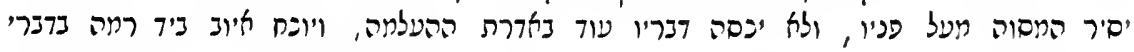

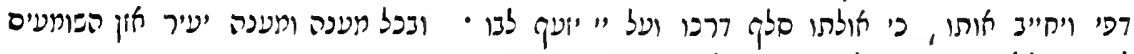

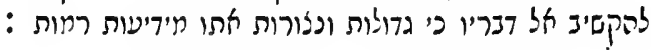

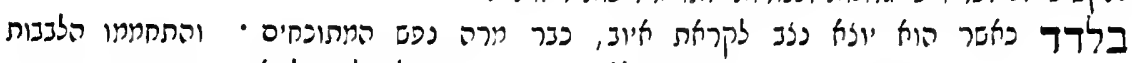

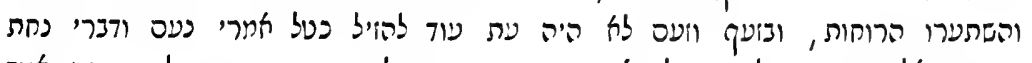

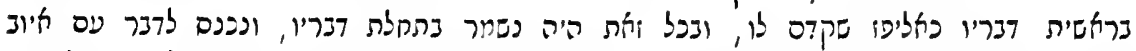

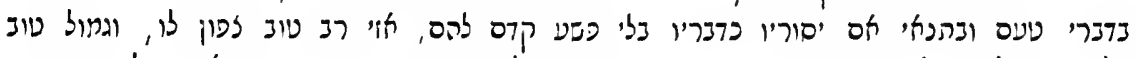

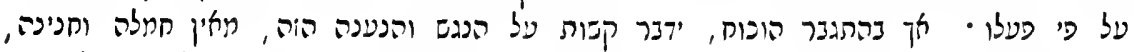

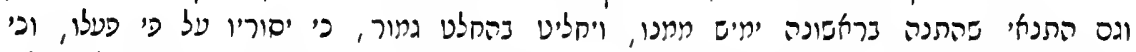

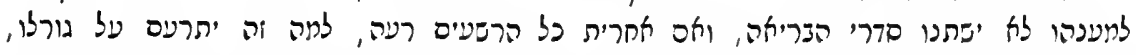

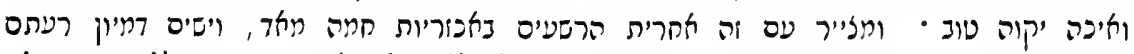

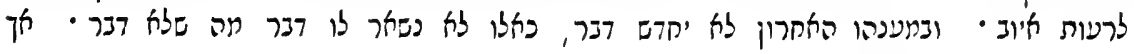

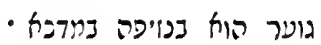

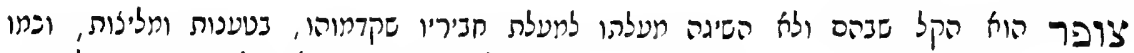

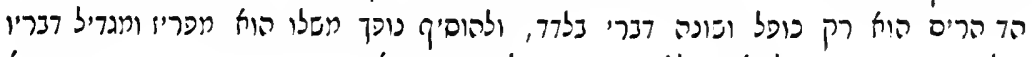

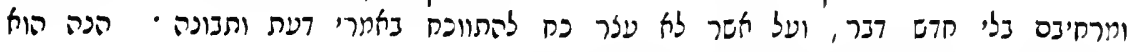

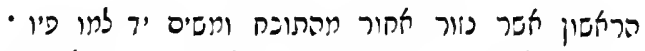

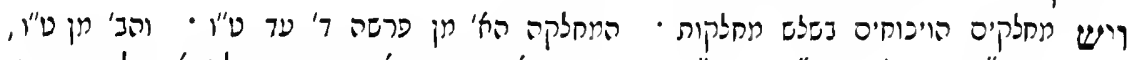

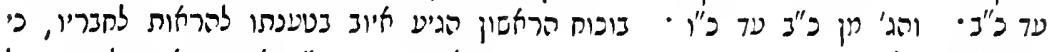

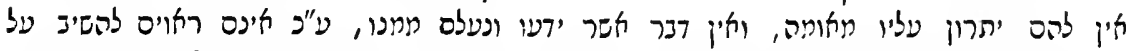

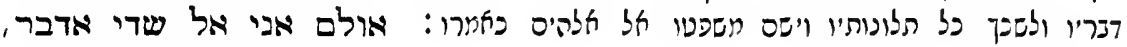

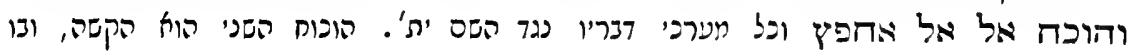

a In Ezek. xvi. 47, the only place where this expression occurs in the Bible, we find קט. -Ed, 1863.

'In Eccles. vii. 27, we have אחַ ; 


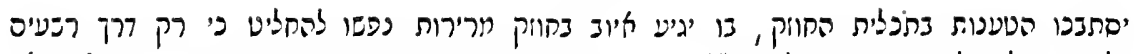

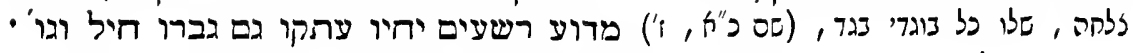

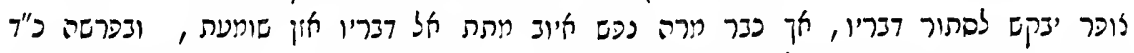

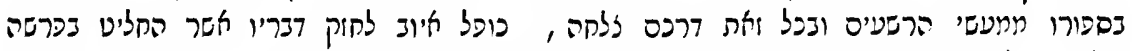

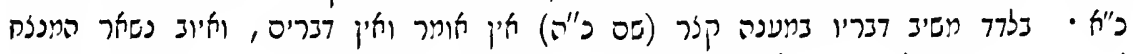

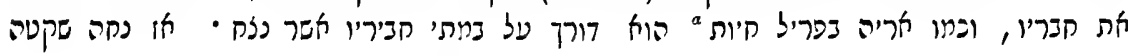

\section{a If we compare אריה בפריל דיוה with}

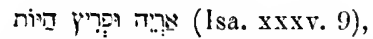

and remember that we have had sereral examples in this Preface of Ben.Zev's tendency to press Biblical expressions into his service, we shall be disposed to believe that misprint for ופרי וריל Hebrew, or Chaldee and Rabbinical, Lexicons, and of which not even the apparent root is known. At the same time, it must be allowed that it is not easy to explain how 1 and $;$ have become changed into such, apparently, very dissimilar letters $I$ and $\zeta$. It may be observed, however, that between 1 and $ב$, there is some connection, inasmuch as 2 without dag. lene, is, by the Jews at least, pronounced, like 1 ; and besides, it is not absolutely necessary to suppose a misprint here in the case of the 2 , as Ben-Zev may have intended to write פרי" ( when the beasts would be a complinentary epithet applied to Job's friends. But what resemblance is there between $ל$ and $i$ ? Well, it must be remembered that Ben-Zev, or the transcriber of his Preface, probably wrote it out in cursice Hebrew, ${ }^{*}$ as beirg much more readily written than square Hebrew, and in cursive Hebrew there is undoubtedly considerable resemblance between the lower part (the body) of a final Tsaddik (of which the hooks at the top would readily become entangled in the line above and so escape observation) and Lamed, and still greater between final Tsaddil and final Lamed (which is sometimes used in curs. IIeb.). At any rate, if does not stand for can offer no other explanation. Mr. Randolph, however, who is scarcely satisfied with my suggestion, and thinks that the misprint is too gross to be probable, $f$ suggests, that פ may be the Lat. prelium, when the meaning would be as a lion in the battle of the beasts. This suggestion I own to be rery ingenious, but I consider it to be even more improbable than my misprints, for, in the first place, why should Ben-\%ev use a word, which, from its not appearing in the Lexicons, he must have known would not be understood by one in 500 of his readers, especially when he had the choice of two IIebrew words (מלדמה and קרב meaning buttle, wat? Again, Lat. words are, I think, rarely introduced into Rabb. Hebrew, though Greek words are, with many Rabb. authors, very common. We have, however, in this preface (sect. 2, par. ה, line 1), the Lat. word signum. And, lastly, whenever, short Lat. and Greek words are used in Rabb. they are, as far as 1 have ob-erved, commonly not abbreciuted, but retain their terminations in full. Thus $\lambda_{\eta l} \sigma \tau \eta^{\prime}$ s has become ל ל (see Comm., p. 43, line 14 from bottom of texi), and signum has become $j: 0$, though we have made sign of it; and similarly I should expect prelium would become פוטיר from $\pi$ otíptov, polerium). I cannot, therefore, approre of Mr. Randolph's suggestion. [The correct reading seems to be בהריין היות, see p. Ixxir (i2)].

* I know that Mr. Mason wrote ont at least a part of the Hebrew in Mason and Bemard's Gramm., in cursire Hebrew, and cursive Hebrew is much better kmown in Germany than England. + For this note, see p. lxxiii.

¥ It should be borne in mind, however, that very few compositors know much Hebrew, am that exceedingly few, if any, would be able to seize the meaning of such a preface as Ben.7ev's, whilst they were setting it up in type, and everyboly, who has had to revise proofs in lar. guages miknown to the compositors, is well aware that the blunders committed ly them in these cases are infinitely more gross than, aml cannot be measured by, the misprints of 


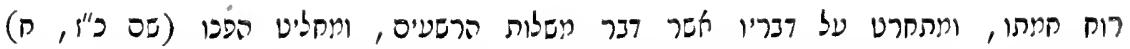

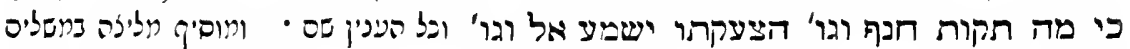

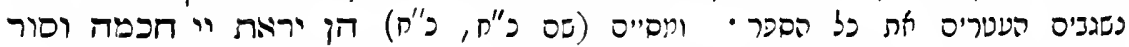

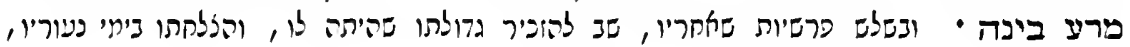

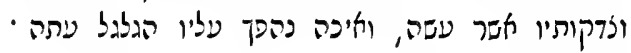

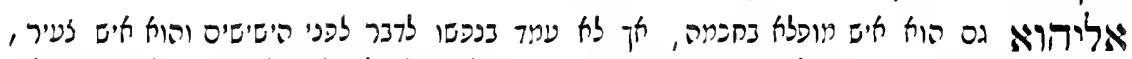

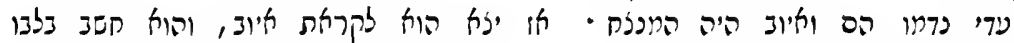

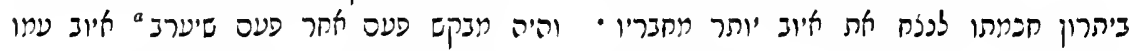

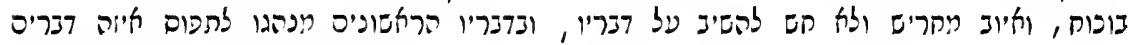

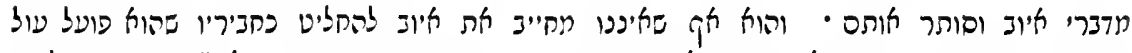

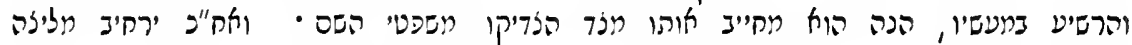

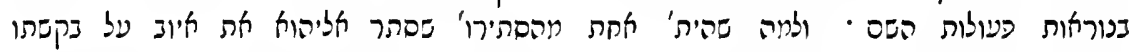

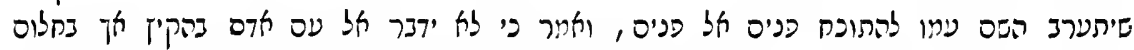

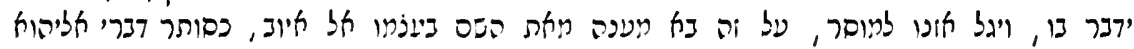

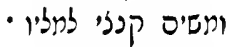

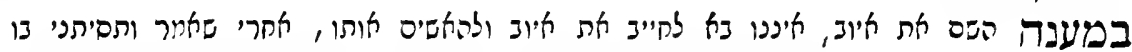

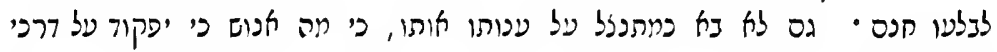

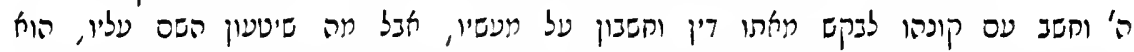

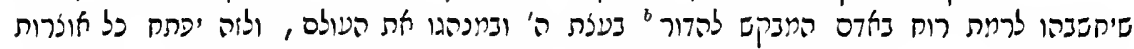

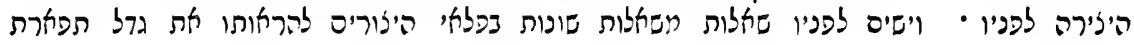

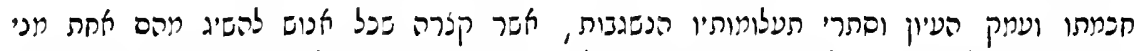

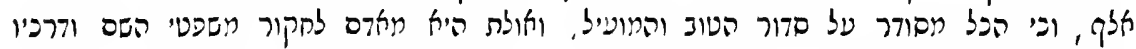

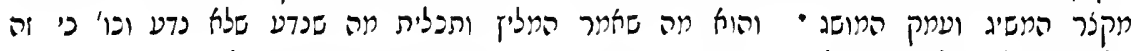

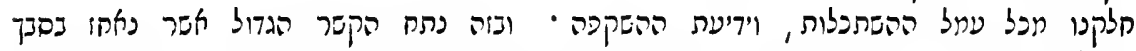

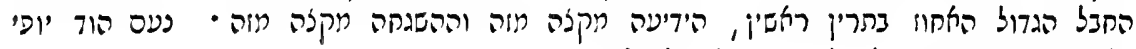

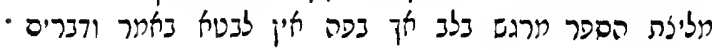

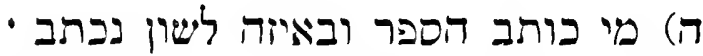

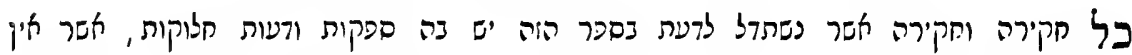

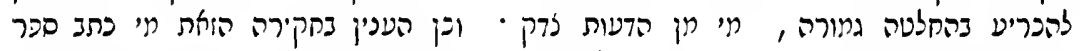

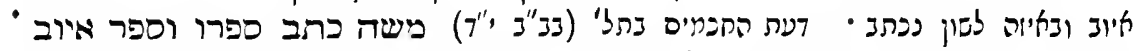

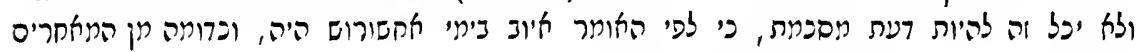

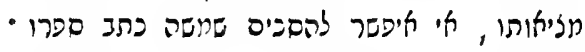

which they would be guilty in a langrage familiar to them. Thus I lately found atom printed for the Lat. atque. This was quite explicable to me when I looked at the manuscript, for I there found the tail of the $q$ faint, so that hurriedly glanced at, it looked like $o$, whilst the $u e$, as having three down-strokes, did look something like $m$; but, if $\mathbf{I}$ had been unable to refer to the manuscript-and in our present case I of course cannot refer to the manuscript-this misprint would have seemed to me quite as inexplicable as those now under my consideration. Besides, one cannot, from considering printed alphabets, form any opinion as to what letters may, or may not, be confounded when vritten, inasmuch as in the licence taken almost invariably in handwriting (a licence sometimes really quite intolerable), letters are very frequently cunfounded, which ought to be as distinct as night from day.

${ }^{a}$ See p. xxviii, note ${ }^{b}$, and p. lxxiv $\left({ }^{13}\right)$.

"See p. xlvi, note $*$, and p. xxxi, note ${ }^{u}$. [It should be להדור, see p. Ixxiv (14).] 
אמקנם אם לחבמה נקרא, ולתבונה נתן קול, ואל הרגשותיעו נשמע, אשר פלס יעידון ויגירון

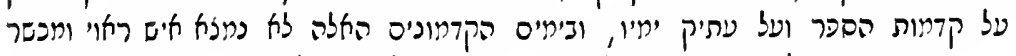

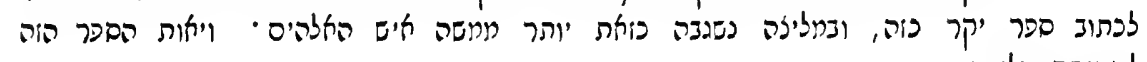
להתיחס עלין - לקרי

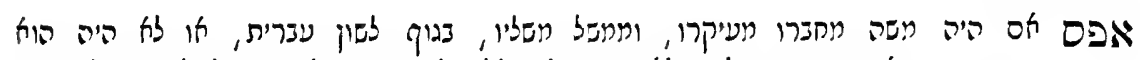

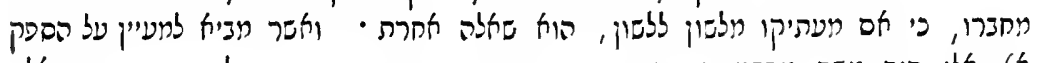

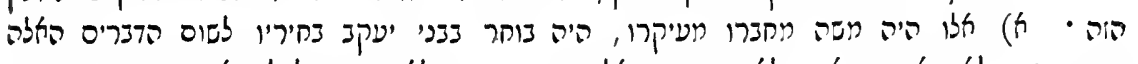

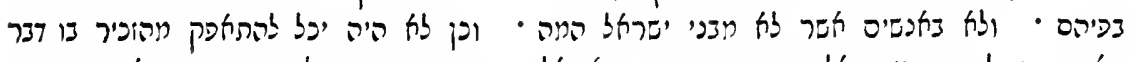

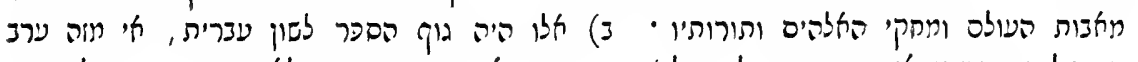

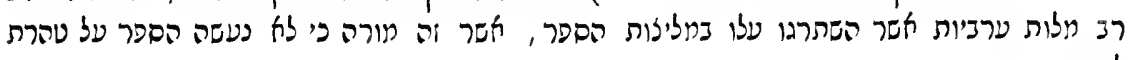

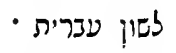

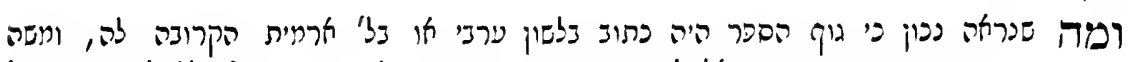

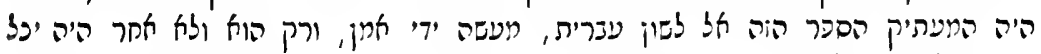

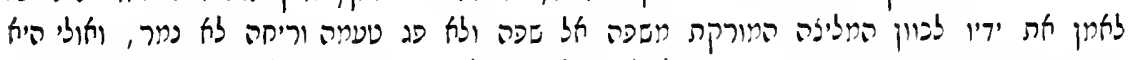

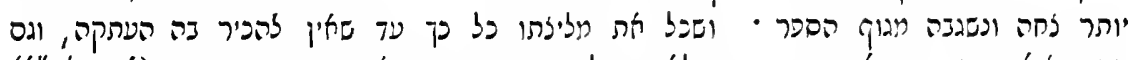

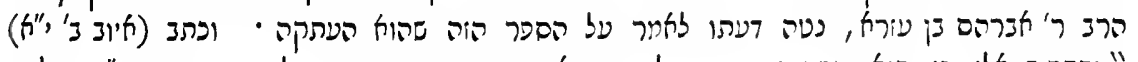

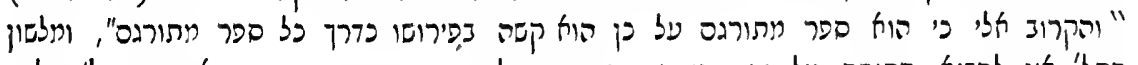

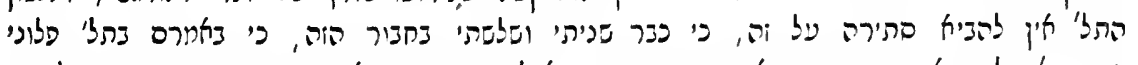

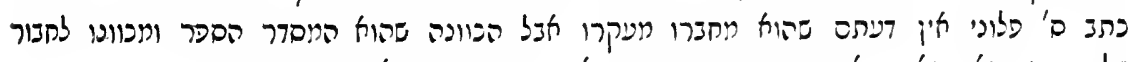

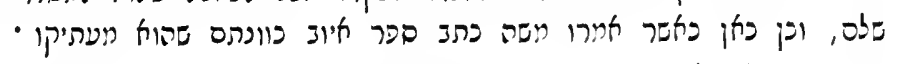

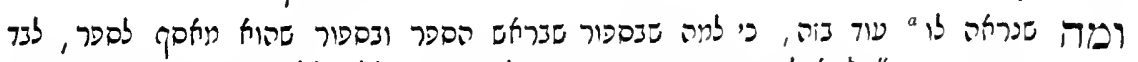

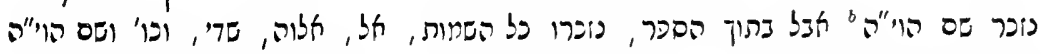

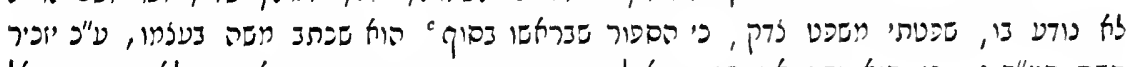

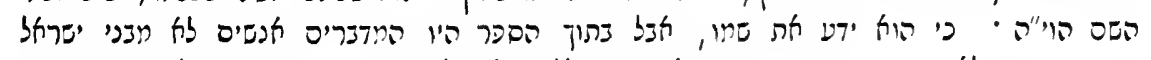

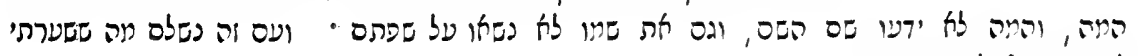

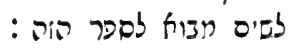

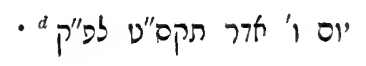

"No doubt should be 'h. According to my experience, the compositors very frequently interchange' and '.-Ed., 1863. [It should be 'h; see p. Ixxiv $\left({ }^{15}\right)$.]

b Two strokes put over a word, do not always indicate an abbreviation; they are sometimes used with the view of indicating that the word, whilst retaining its ordinary sense, has a second and special meaning (see Buxtorf, de Abbrev. Hebr. (1708), p. 9). This seems to be the reason why הויה essenee, has here two strokes, for, whilst retaining its usual meaning of essence, it is here used specially of the Divine essence, i.e., Jehovah, for Jehovah, as coming, like הויה, הוה or , היה to be, denotes especially the Essexcy of God. But why Ben-Zev here uses $\pi^{\prime \prime}$ and not " the ordinary abbreviation for זוה, $\pi$, which, though, according to Buxtorf, standing for $ם$, still is commonly

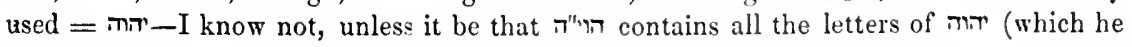

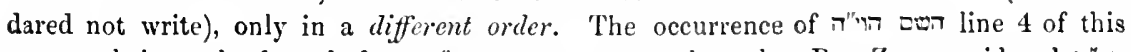

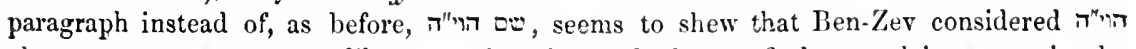
almost = a proper name, like הוה, though, no doubt, we find several instances in the Bible, in which a noun with the def. art. is used instead of a noun in construction.Ed., 1863.

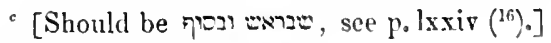

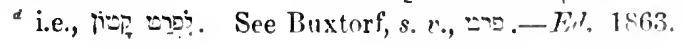




\title{
INTRODUCTION
}

\author{
COMPOSED BY \\ J U D A II L E V B E N-Z E V.

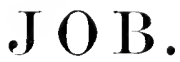

\section{THE ARRANGEMENT OF THE BOOK AND ITS OBJECT.*}

1 Supreme Providence and its dispensations with regard to intelligent creatures, 2 form a subject of inquiry, in which men of renown, ${ }^{3}$ [that were] of old, hare found great difficulty; yea, even the prophets, peace be with them! sought for ${ }^{4}$ light upon this [matter] from God, may He be exalted! ${ }^{5}$ on account of the badness of the arrangement which they perceived ${ }^{6}$ in such dispensations. Moses, the

* Ben-Zev's Hebrew, his purely Biblical, as well as his Rabbinical, stands, as must be admitted by every one familiar with his writings, after that of Aben-Ezra, unparalleled and unmatched. Indeed, of those, who have attempted to write in the style of AbenEzra, he is the only one who has been successful ; concise, therefore, and idiomatic as his model, he is equally difficult to translate. To render him literally, indeed, is a mere sheer impossibility; still, for the benefit of the Hebrew student, I have endeavoured, in this translation of his preface, which is written in Rabbinical Hebrew, to keep as close to the original as it is possible to do without injury to the sense. The reader will therefore excuse any disregard that may be shown to the syntax or idiom of the English language. - (Note of Editor.) [For the correctness of this translation, I must be held entirely responsible. I did, indeed, read over both the original and the translation to Dr. Bernard, and he gave me his opinion with regard to the meaning of the difficult passages, of which there are, in my opinion, not a few ; but this was done so hastily, that it would be quite unfair to throw any part of the responsibility upon his shoulders. After he had thus heard the translation, and made his suggestions, which - as haring him always at hand, and trusting to

1 The supreme Providence and Conduct (i.e., rule, government, discipline). ${ }^{2}$ This [is] an inquiry in which, \&c. " 3 This might be understood " in which men of renown have of old (or, from of old, see 1 Sam. xxvii. 8), found great difficulty;" but, as the

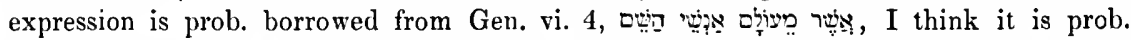

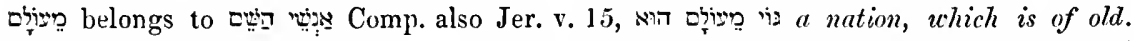
4 light, enlightenment, of eyes. ${ }^{5}$ for that (because that) they saw [the] badness of the arrangemert. ${ }^{6}$ in the [Divine] conduct (rule, \&c.) See note '. 
master * of [all] the prophets, said [Exod. xxxiii.13]: "Make me, I beseech Thee, to know Thy ways," $+{ }^{1}$ as it is explained in the Talmud (B'rachoth, fol. $7 \ddagger$ ). The poet Asaph said [Ps.lxxiii. 3] : "For I was envious of the foolish, [when I saw the prosperity of the wicked]." Jeremiah said [Chap. xii. I] : "Wherefore doth the way of the wicked prosper?" And Habakkuk said [Chap. i. 13] : "Wherefore lookest Thou upon them that deal treacherously, [and holdest Thy tongue, when

my memory-I did but imperfectly note down, I carefully went over the whole of it again by myself, and made very numerous annotations in pencil, with the view of submitting them to him at some future time, when I should also have fully discussed the difficult passages with him, and have asked him to construe at least some of them to me-but his death, alas! upon which I had not counted, broke off my plans, and threw me entirely upon my own resources. Fortunately, however, I found in Mr. Randolph (see 2nd Pref.), a friend able and willing to assist me, and with him I have discussed all the difficult passages-with great advantage to myself, though I have been but seldom able to record my obligations to him.

As for the numbered literal translations and notes in the margin, they have all been added in the course of the present year, 1863.]

* Master must be understood here in the sense of teacher, the prophets being in some manner considered as the disciples of Moses, since he brought down the Law from Sinai. -(Note of Editor.)

† The Eng. Vers. has here Thy way, wrongly, for

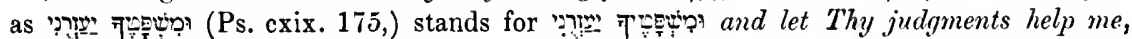
as correctly rendered in the Eng. Vers. Thy way (in pause) would have been expressed

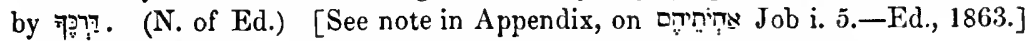

$\ddagger$ See p. lxxiv ( $\left.{ }^{1}\right)$. The passage in the Talmud referred to runs thus :-

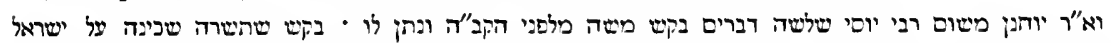

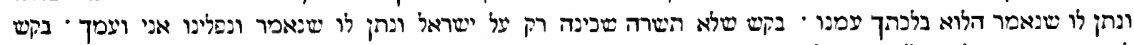

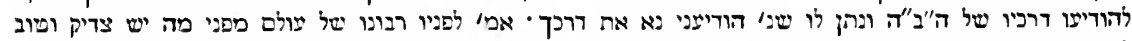

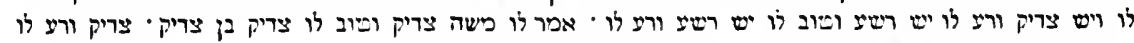

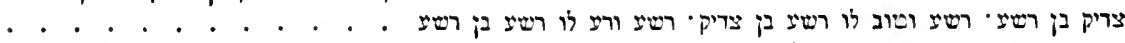

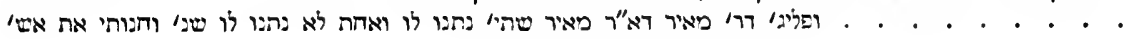

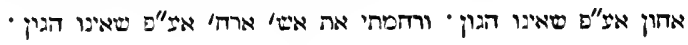

"And Rabbi Jochanan said in the name of Rabbi Jose:-Three things did Moses ask " of the Holy One, blessed be He! and He granted [them] to him. He asked, that the "Shechinah" should dwell in †Israel, and He granted [it] to him, for it is said: [For " wherein now shall it be known, that I and Thy people hace found grace in Thy sight?] "Is it not in that Thou goest with us? [Exod. xxxiii. 16.] He asked, that the Shechinah " should dwell only (i.e., exclusively) in † Israel, and He granted [it] to him, for it is said : "So shall we be separated, I and Thy people [from all the people, that are upon the face of "the earth [Ibid.]]. He asked to make him know the ways of Jehovah, blessed be He? "(i.e., the rules, by which the dispensations of Providence are regulated), and He granted "it to Him, for it is said: Make me now to know Thy ways [Ibid. ver. 13]. He "(Moses) said before Him: O Lord of the universe! why is there a righteous man,

1 as it comes (occurs, as we find) concerning this in the Talmud. 2 to come, seems here to be used = the Germ. vorkommen, to occur.

* i.e., the Majesty of God.

t or with; but lit. orer (Israel). 
the wicked devoureth him that is more righteous than he?"] Now upon the poles of this investigation ${ }^{10}$ turns the controversy, which [takes placc] between $\mathrm{J}_{0 \mathrm{~b}}$ and his companions in the form of objection and answer.

This ancient book, anterior to all ${ }^{11}$ Hebrew books, [considered] ${ }^{12}$ wonderful by generations of old, and glorious ${ }^{13}$ by latter generations_- its beginning and end are a narrative of facts, and the ${ }^{14}$ middle thereof is paved with lovely poetry concerning Providence. And as to the narrative ${ }^{15}$ generally, the author of the book mentions the name of a man, distiuguished for the "lhighest degree of righteousness and uprightness, and [his] ${ }^{2}$ high position in the ranks of men in respect of riches, greatness and honour, nor was there wanting to him ${ }^{3}$ any sort of perfection, by which a man is made ${ }^{4}$ perfect ; but all these were ${ }^{5}$ lost to him suddenly, so that he ${ }^{6}$ came to the ${ }^{7}$ highest pitch of evil and ${ }^{8}$ misery, and was moreover chastised with a pain, greater than which there is not. Beliold then [there

"who fares well, and a righteous man, who fares ill? A wicked man, who fares well, "and a wicked man, who fares ill?-He (God) said to him: O Moses! the righteous " nlan, who fares well-[he is] a righteous man, [who is] the son of a righteous man; "the righteous man, who fares ill-[he is] a righteous man, [who is] the son of a "wicked man; the wicked man, who fares well-[he is] a wicked man, [who is] "the son of a righteous man; the wicked man, who fares ill-[he is] a wicked man, [who " is] the son of a wicked man

«. . . . . . . . And they (the Rabbins above mentioned) differ from Rabbi "Mayeer, for Rabbi Mayeer said: Two [requests] were granted to hin, and one was not "granted to him (i.e., the two requests respecting the Shechinah dwelling in Israel, and "exclusively in Israel, were granted to him, but the request respecting the ways of "Providence was not granted to him), for it is said: And $I$ will be gracious to whom $I$ "will be gracious [Ibid. ver. 19], although he be not worthy, and I will shew mercy upon "whom I will shew mercy [Ibid.], although h? be not worthy (i.e., My motives for "shewing mercy must remain a mystery to man)."

In the treatise Avoth (Chap. 4) we have the following Mishnah:-

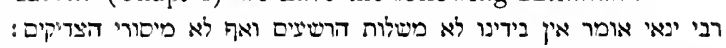

"Rabbi Yanai says: * It is not in our power [to account] either for the prosperity of " the wicked, or the afflictions of the righteous (i.e., the rules, in accordance with which "rewards and punishments are distributed in this world, must remain a mystery to man)." (N. of Ed.)

.10 is turned, turns itself.

1 books of the Hebrews.

12 wonderful with (i.e., in the estimation of) generation[s] of old. $\quad{ }^{13}$ even to latter (later) generation[s]. ${ }^{\prime 4}$ i.e., the interior, body; see p. liv, note ${ }^{11}$. ${ }^{15}$ [by] way of generality. " perfection of. $\quad{ }^{2}$ keight. $\quad{ }^{3}$ of all [the] sorts of perfection [or prosperity]. $\quad{ }^{4}$ or, prosperous. ${ }^{5}$ perished from him suddenly (see Job xi. 20). $\quad{ }^{6}$ attained. ${ }^{7}$ see note ${ }^{1}{ }^{8}{ }^{8}$ is more comm. rend. grief, but it may also $=$ affiction or misery. So we use affiction $=$

* The lit. transl. is apparently, "there is mought in our hands, either of the prosperity...... or of the afflictions," \&c.- - i.e., they are not at all in our hands, we have nothing whatever to do with them, we have no control at all over them, they do not rest with, depend upon, us in any way (cf. Eccles. v. 13, Ezra vii. 25) - the מ being taken partitively, and serving with the help of the neg. pe, to express the total alsence of any share or part, whereby the force of the expression is greatly increased;--unless, indeed, we supply some such verb as to give an explanation, or to pronounce decidedly (לt), when מ would = eoncerning, with reyand to, in which sense it is used in this Pref. after דריר, \&e., as e.g., in seet. 7, par. 6, line 5 from ent. 
is] no man, ${ }^{8}$ who could have more reason to murmur against God's Providence than he, yet he ${ }^{9}$ perseveres in lis righteousness; so, ${ }^{10}$ by way of paying him his reward, God restores to him ${ }^{11}$ twofold the temporal blessings, ${ }^{12}$ of which he had been deprived. And, as to the details of this narrative, he (the author) portrays the man ${ }^{13}$ as being pious, and upright, and one fearing God, and eschewing evil; and ${ }^{14}$ with regard to the perfection of possessions, he ${ }^{15}$ bestows upon him all the principal things, which were considered [necessary] for prosperity in those primeval days, ${ }^{16}$ namely, ${ }^{17}$ a house blessed with sons and daughters, and with substance, oxen and sheep, camels and asses, men-servants and maid-servants; for silver and gold, and ${ }^{18}$ highly prized jewels and diamonds, ${ }^{19}$ were scarce in those days, ${ }^{20}$ neither were luxuries abundant. And just after he had depicted him with this great prosperity - all these blessings ${ }^{21}$ were lost to him in the most sudden manner ; woe upon woe, breach upon breach cleave together ; one runner ${ }^{22}$ meeting another runner, and one ${ }^{23}$ messenger ${ }^{22}$ meeting another messenger, the one going away ${ }^{24}$ after [having brought] sad tidings, and another coming with tidings ${ }^{25}$ yet more sad. ${ }^{26} \mathrm{His}$ first stroke came upon his possessions, upon [his] oxen [namely], and [his] sheep, and from ${ }^{26^{\prime}}$ these [it came] upon his children, and

sorrow and calamity; and grief is also rulg. used = calamity. At any rate, Ben-Zev gives Elend as one of the meanings of ' $\quad{ }^{8}$ ' there could be to hin cause to murmur ..... more than he. ${ }^{9}$ [is] standing, persisting. ${ }^{10}$ for (as) retribution, payment, of reward. " $\quad$ to, up to, or into double, i.e., so as to be double, of the temporal blessings. משs, being a subst., could not well be used adverbially without the addition of some prep., and here ל seemed most suitable. Comp. היה לה to become, in Germ. z ש Etwas werden; and Job xlii. 10. In the lines from המאשח, however, quoted in p. xlii., we find The meaning scems to be soME of the temporal blessings twofold (i? being used partiticely, see p. xl, note ${ }^{*}$, this par. lines 4,8 , p. xxx, line 3, sect. 2,1 st. par., line 7 , and last par., line 2 from end); for, as Ben-Zev tells us, though indirectly, in the last par. of this sect. (p. xlviii), God did not restore everything to Job twofold. If this is the sense, the construction would

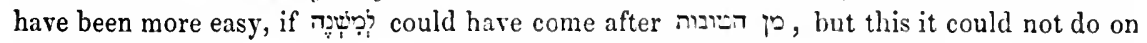
account of the relative sentence which follows. I do not think that ip here can = more than, twice more than. [But see Exod., xri. 5]. Or, as Mr. Randolph suggests, the $i$ may be used for the purpose of distinclly singlingout the blessings which are meant, just as we say, "of gold he gave him double the quantity," i.e., of gold, and not of anything else; still, the pould then be somewhat pleonastic, and, indeed, doubly so, for, in the first place, nothing can be restored to a man which he has not had before, and, secondly, the relative clause distinctly points out what blessings are spoken of. And, lastly, the in may possibly be merely a genitive, "double of the blessings," and be used instead of the stat. constr. Comp. Job xx. 3. So in כל ספר מספרי הנביאים, an expression which I have just met with, the $D$ is prob. a pure genitive, though it may mean out of. Comp. sect. 7 , par. 3 , last line, par. 7 , lines 5 and 7 , par. 8 , lines 5 and $6 . \quad{ }^{12}$ which had failed from him (see note ${ }^{5}$ ). ${ }^{13}$ with the qualities of pious (perfect, pure, blameless, (integer)), sc. See p. xlriii, line 2. " or, of the perfection, \&c.; perfection of possessions, in opposition to the perfection of moral qualities. ${ }^{15}$ attributes, assigns. $\quad{ }^{16}$ and they [are]. ${ }_{17}$ the blessing of the house with sons, $\mathrm{Xc}$. ${ }^{18}$ high-things. ${ }^{19}$ was precious, rare, or a rarity. See p. xxvii, note". ${ }^{20}$ no luxury (delicix) [was] spread abroad, diffused, general, abundant; or we may, perhaps, supply

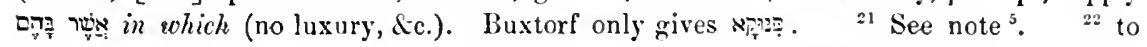
meet. $\quad{ }^{23}$ teller, announcer. $\quad{ }^{24}$ from. $\quad{ }^{25}$ worse than they (lit. it). ${ }^{26}$ the beginning of the stroke was. $\quad{ }_{26}$ ' lit. from it to his, \&c., the sing. referring to each, or to 
from these [again] upon his own bone and flesh. And behold ! the sudden succession of the troubles one upon another, and ${ }^{27}$ their gradual increase in magnitude, the later ${ }^{28}$ above the earlier, this is what brings a man to the ${ }^{29}$ highest degree of bitterness. And this ${ }^{30}$ shews the perfection of the ${ }^{31}$ author, that be has not omitted ought of all the ${ }^{32}$ circumstances, which were needed for his object; and [that] he has not left out a line or a stroke, which could make his picture perfect in all its parts. But, between the ${ }^{33}$ blow [dealt] to everything, which ${ }^{34}$ belonged to him (Job), and the smiting of his body, he (the author) allows a space of time. As long as his (Job's) body was whole, he was ${ }^{35}$ giving thanks and praises [saying, ] Jehovah gave, and Jehorah hath taken avay, blessed be the name of Jehovah; but, when the stroke came upon bis bone and his flesh, ${ }^{36}$ his praise consisted in silent-resignation.* And, with regard to the ${ }^{37}$ blow [to be dealt] to his body, he [the author] ${ }^{38}$ selected that, which was the most painful among afflictions, that is, grievous sores from the sole of his foot ${ }^{39}$ to the crown of his head; and, in order ${ }_{40}$ to make yet greater his affliction, lo! everything he had ${ }^{41}$ was lost to him ; upon his cattle rushed a troop, or fire ${ }^{42}$ came down from heaven and consumed them, as well as his servants; upon his sons and daughters the house fell, and there they were buried; but, as to his wife, her he left him, ${ }^{43}$ not one hair of her head did he suffer to fall to the ground-[was] not [this], in order that she might ${ }^{1}$ very sorely provoke him, so as to make him chafe? $\dagger$

* And they sat down with him on the ground seven days and seven nights, none speaking unto him a word; for they saw that his pain was very great. After this opened Job his mouth, \&c. (Chaps. ii. 13; iii. 1.)-Note of Ed.

$\dagger$ Dr. Bernard recollects having, about half a century ago, read in a number of the Berlin Periodical חפ some lines, which ran about as follows :-

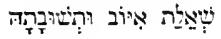

$$
\begin{aligned}
& \text { (איוב שואל את האלהים) }
\end{aligned}
$$

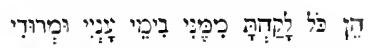

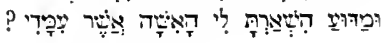

$$
\begin{aligned}
& \text { (האלהים משיב) } \\
& \text { ליד }
\end{aligned}
$$

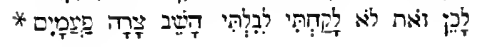

the last, of the preceding nouns. $\quad{ }^{27}$ their superiority, or excess. $\quad{ }^{28}$ over, beyond. ${ }^{29}$ perfection of. ${ }^{30}$ (is) pointing upon, to, the perfection (weist auf die Vollkommenheit), or teaches concerning, \&c. $\quad{ }^{31}$ master, lord, of the book. $\quad{ }^{32}$ revolutions, turns, circuits,

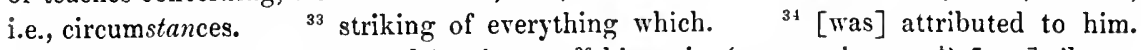
${ }^{33}$ or confessing (praising) and celebrating. ${ }^{36}$ his praise (see p. xxix, note ${ }^{b}$ ) [was] silence. ${ }^{37}$ the smiting of his body. $\quad{ }^{38}$ he chose the pain, [which was] the greatest among affliction(s); or, perhaps better, the greatest in anguish. $\quad{ }^{30}$ even unto his crown (vertex) ${ }_{40}$ to make great. $\quad$ "perished from him. $\quad{ }^{42}$ fell. $\quad{ }^{43}$ he did not make fall [any] of the hair of her head.

1 provoke him even a provocation. See 1 Sam.i. 6, whence the expression has been

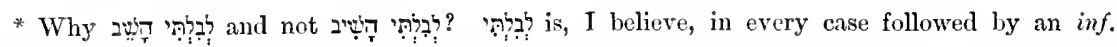
constr., whereas in is generally regarded as, and certainly commonly is, the inf. absol. In a note in the Append. however, on ix, 18, I suggest that Tị may, perhaps, be also sometimes a 


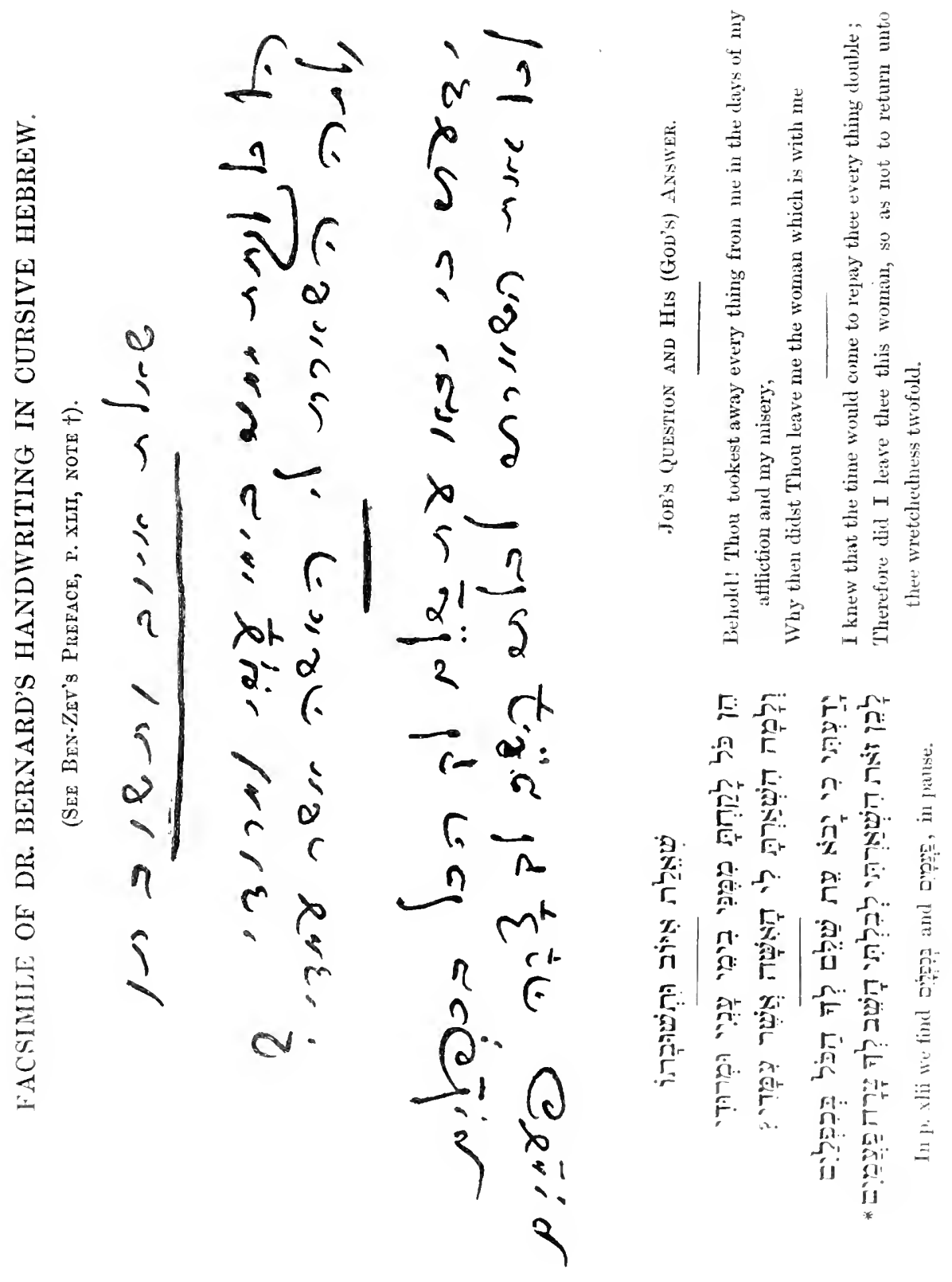



And in this, too, the ${ }^{2}$ author of the book ${ }^{3}$ was careful *; [namely], in shewing from [the very] beginning ${ }^{4}$ how the matter would end; and from the [very] beginning he does not speak mysterionsly with the reader of his book, but [at once] solves him the enigma, why Jehovah had acted thus, to punish a just man ${ }^{5}$ without there being any wrong in his hands, and to smite a nobleminded man ${ }^{6}$ in spite of [his] uprightness ; and he makes known to us the ${ }^{7}$ ways of God in the heavens above, and opens to us the windows of heaven, and shews us Jehovah of hosts sitting upon His throne, and the sons of God standing near Him on His riglt hand and on His left. And Satan also is among the comers; and he had but ${ }^{8}$ just ascended from ${ }^{9}$ taking a survey of the

* He had said before that the author had omitted nothing which could make his picture perfect, or, in other words, he had praised his great carefulness. (1863.)

borrowed. $\quad{ }^{2}$ See p. xlii, note ${ }^{31} . \quad{ }^{3}$ was guarded, wary, taking heed, careful, to declare. ${ }^{6}$ [the] end. See Isa.xlvi. 10. ${ }^{5}$ in spite of [there] not [being] violence (wrong), or, in spite of no-wrong (i.e., in spite of blamelessness, innocence, integrity); or, if the transposition be adopted, "not because of any wrong," i.e., without any wrong. 'That לא המש is here used as a compound word = no-wrong (i.e., innocence, blamelessness) is prob. from the

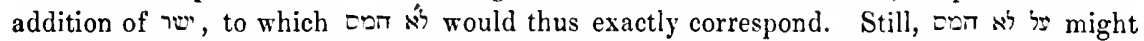
well be taken $=$ "in spite of (or, because of) [there] not [being] wrong," just as

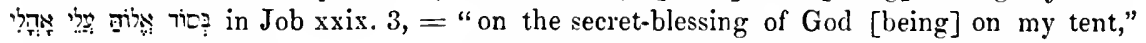
where we have to supply הֶיות. It is not clear how Ben-Zev took צמל לא המס in Job xvi. 17. It might also mean, "for, because of, no-wrong " (i.e., beeause of blamelessness, innocence), and על לי לecause of uprightness, and it was indeed because of Job's uprightness that God allowed Satan to smite him, in order that he might be proved; but I doubt whether BenZev uses the words in this meaning (cf., however, p. xlvi, note ${ }^{23}$ ). Could ${ }_{2}=$ for, in exchange for $=$ ח Sa ? See note in Comm. and Append. on chap. xri. 17. ${ }^{6}$ against, i.e., notwithstanding, in spite of (see Comm. on xiii. 14). $\quad{ }^{7}$ the manner of God, i.e., His goings on, proceedings. ${ }^{8}$ the inf. seems to be coupled with the tense here, for the purpose of indicating the continuasce of the action of ascending, until the bcginning of the next action described (i.e., God's speaking). We thus see, as it were, Satan completing his ascent before us, and great viridness is hereby imparted to the description. We may transl. therefore, lit. "and ascending he had but ascended," = and he had but completed his ascent, or he had but just ascended, just giving the force of the inf., which thus virtually adds strength to the $T^{N}$, as much as to the tense. The construction is evidently

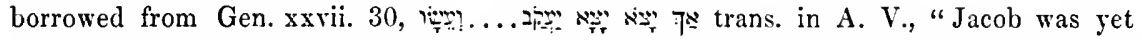
scarce gone out.... when Esau." Ges. indeed (see Tregelles' transl. s. $v$. 끄) renders

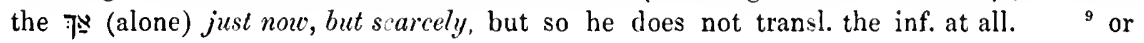

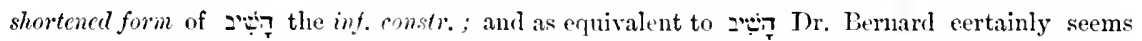
to have regarded it here. (1863.) [There are the following discrepaneies between these lines as given lere, an!l in the fae-simile :-

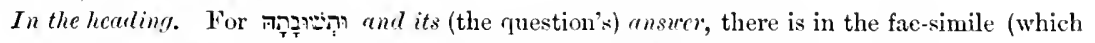

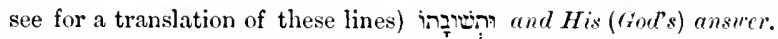

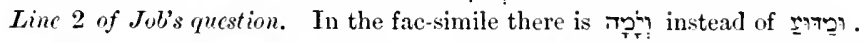

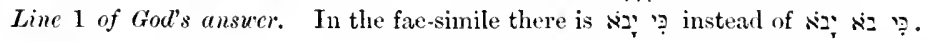

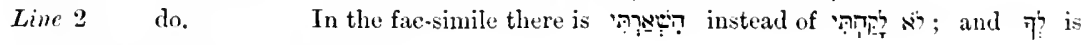

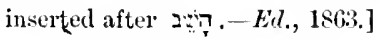


earth and the inhabitants thereof, when God hastened to ${ }^{10}$ ask lim what his opinion [was] with regard to his servant Job; and behold! "Satan lacks not power to find ${ }^{12}$ occasions for speech even against the ${ }^{13}$ best of men, saying that Job serves God on account of the ${ }^{14}$ greatness of the blessings which $\mathrm{He}$ has abundantly bestowed upon him. And he ${ }^{15}$ asked that God should try him (Job) in the furnace of trial, and God consented to his words, and gave him power over everything he had ${ }^{16}$ with the exception of his person, which he was to preserve. And when ${ }^{17}$ the power is given to him, there is not a destroyer more prompt than he to consume and to destroy, and with ${ }^{18}$ the greatest celerity he overthrows the house of Job from the [very] root. And after he has completed his work, the author suffers him to ascend a second time to heaven, ${ }^{19}$ and allows him ingress among the sons of God; and when God asked Satan a second time respecting his servant Job, Satan found a ${ }^{20}$ pretext to smite [even] the body of Job, which was ${ }^{21}$ a much more severe trial than the former, and God

searching, spying out. ${ }^{10}$ to ask (inquire at) his mouth. As it is by the mouth we are answered, we may well be said to ask questions of a person's mouth. See p.xlvii, line 11. "the hand of Satan is not short. "Ben-Zev, like the Hebrew

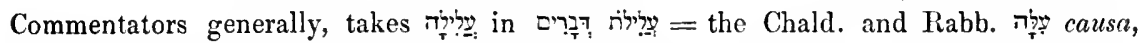
occasio, and he transl. this expression in Deut. xxii. 14, 17 (where alone it occurs) falsche Beschuldigungen, false accusations; and therefore, as Ben.Zev is the author of this Preface, we must take this to be the meaning intended here. ${ }^{13}$ choice of men. ${ }^{14}$ or multitude. $\quad{ }^{15}$ was seeking, petitioning. $\quad{ }^{16}$ In the translation given above, which had

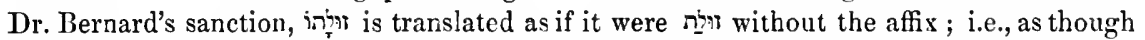
the I were paragogic. Now, in Heb. we do find șiּs with ' paragog., but never with with paragog. '; and it is a question whether in is so used in Rabb., although I rather think Ben-Zev in his Lexicon sometimes uses it so. זולתו might, however, be a misprint for זולתי (see p.xxxvii, note ${ }^{a}$ ). As, however, in Job ii. 6, from which the pres. pass. is evidently

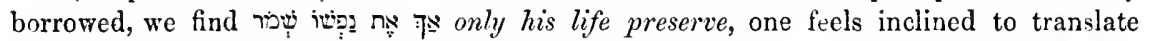
here excepting this (lit., it) [that] he should preserve his life, but here again the affix is in the way, and the constr. of with $ב,=$ to preserve, is somewhat uncertain, though Ges. transl. it so in 2 Sam. xviii. 12. In this pass., however, Kimchi takes w to mean to beware (cf. Josh. vi. 18), and explains, beware (take heed) that no one touch the youth. Mr. Randolph would adopt this meaning here, and then the sense would be, "excepting this, that he should beware of (touching) his life," or better, inasmuch as it is harsh to supply the verb to touch, "that he should beware in regard to, as to, his life." I think, however, that Ben-Zev probably uses שמר in the sense in which it is used in Job ii. 6. Ben-Zev does not quote the pass. in Sam. in his Lex., so that I do not know how he understood שמר ב זולהו may, I think, possibly be simply pleonastic ; "and gave him power over everything he had, excepting this [viz.] over his life." It is well known that in Rabb. pron. aff. are very freq. used pleonastically, cf. p. xlix, note ${ }^{19}$. At any rate, iำ alone would have been very inharmonious. ${ }^{17}$ or, He has given him the power. 18 we might, I think, say, "with the utmost alacrity," for alacrity implies both promptitude and eagerness. ${ }^{19}$ even so as to give him walks, i.e., so as to allow him to walk among, consort with, Ben-Zev transl. מִַּ in Zech. iii. 7, whence he has borrowed this expression here, Umgang, Wandel. The inf. with ל here seems almost $=\mathrm{a}$

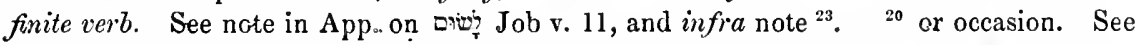
note ${ }^{12}$. ${ }^{21}$ the trial the more severe than the former (with emphasis on the the), i.e., the trial the most more severe than the former, i.e., which exceeded the other in the greatest 
22 acceded to him even in this respect. And after Satan had completed his work ${ }^{23}$ and heaped every sort of calamity on Job, then the windows of heaven were closed ${ }^{24}$ [to the reader], so that he should not again return to heaven, and we do not any longer know what is being done there ; for, seeing that he [the author] wished to tell us in this poem that the afflictions of Job were ${ }^{25}$ by way of trial and ordeal, therefore, when he has ${ }^{26}$ effected his intention, he shuts up the gates of heaven, and returns to his narration and to the words of Job and his companions, who are on earth. And Satan [too] ceased [from his work], and ${ }^{27}$ was at rest.

And behold! the three friends of Job gathered themselves together, [and] came everyone from his own place at ${ }^{28}$ this sad report, and they found him stricken with sores, sitting among ashes. So they sat down with him on the ground seven days, and were not able to speak a word because of the sadness of their souls, until Job opened [his mouth] to speak, out of the abundance of his complaint and ${ }^{1}$ grief, and murmured ${ }^{2}$ because of his existence, ${ }^{3}$ seeing that his ${ }^{4}$ non-existence would have been better for him than his existence. Then his friends ${ }^{5}$ also opened their mouths to speak-not to mourn with him and comfort him, as their first intention had been, when they came, wept, rent their garments, and sprinkled dust upon

possible degree. There were other more severe trials, but this was the more serere one par excellence, i.e., the most more severe one, the sererest of the more serere trials. So in Heb. the superlative is freq. expressed by the addition of the def. art. to an adj. Thus

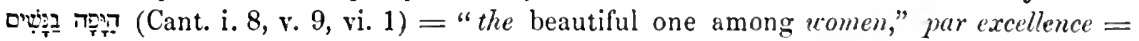
the most beautiful, \&c. See p. lxi, note ${ }^{27}$, and sect. 7 , par. 5, line 1. See also p. xlii, note ${ }^{38}$, and p. xl, line 13. It was certainly Satan's wish to select the severest trial possible, for he knew that he could not otherwise possibly attain his object. See Appendix, p. 567, near top. Still, as the def. art. is freq. used with a noun in Heb. when we should use the indef. art. (cf. הכ2 last line of this section), and as when the subst. has the def. art., the adj. must also have it, it is possible that the meanirg here may be merely, "a more severe trial than the former." היותר prefixed to an adj. does, howerer, certainly sometimes mean the most, as in the pass. quoted above from the preface (par. 2 of this sect., line 4 from end). Comp. the Fr. le plus sage = the wisest. ${ }^{22}$ accepted [his] face for him even as to (or for) this matter. See Job xïii. 8. ${ }^{23}$ so as to thrust, or in thrusting, erery evil upon (or against) Job; or [which was] to thrust, \&c. $\quad 24$ This clause and the next might refer to Satan, who did not again return to heaven, and it is certainly easier to take Satan (or the author, see four lines farther on (in text)), to be the nom. to 21 , and the interpunctuation in the text, though this is very bad, certainly points to one of these two interpretations. The transl. would then be, and he (Satan, or the author) does not return again to heaven. $\quad{ }^{25}$ on the side of. See p. lxiv, note 14. ${ }^{26}$ completed, perfected. $\quad 27$ drew his breath. See Exod. xxxi. 17, whence this pass. is borrowed. 2 the.

'See 1 Sam. i. 16, whence this pass. has been borrowed and where Ben-Zev renders (as freq. in Job) Klage. " or, against his existence. "B Between the 1 and the we must supply from ההריש some such verb as complained, and he conplained that. See p. $x x x$, note ${ }^{b}$ A depriration, lack [of life]. " $\quad$ found opening of mouth (see Ezek. xvi. 63, xxix. 21), to speak likewi-e, i.e., found their tongue, found utterance; they had not been able to speak for grief, but now they found they had recovered the power. Ben-Zev in the second of these pass. transl. ה Muth zu sprechen, and this would 
their heads, but they began to ${ }^{6}$ provoke him with their words, for 7 they knew nought of the things which the writer has narrated to us ${ }^{8}$ as having taken place in heaven above between God and Satan. So the matter was impossible in their eyes, and they sought [therefore] to justify the judgment of God, and cast ${ }^{9}$ doubts and aspersions on the righteousness of Job, or [imputed to him] ${ }^{10}$ impure motives in his service [of God]; and, ${ }^{11}$ in addition to this, these wise and notable men ${ }^{11}$ declare everyone their opinion with regard to God's Providence, and ${ }^{12}$ that which befalls the sons of men, but, ${ }^{12 \prime}$ they all agree in this point [that] Jehovah is right in His ${ }^{13}$ controversy with Job, and that Job bears [the consequence of] his sin. And Job returns answer to the words of everyone of them, and combats their words, and ${ }^{14}$ stands up for himself to justify limself, and by this means the dispute increases. At first they spake ${ }^{15}$ gentle words, until they plunged deeply into the controversy, and their hearts grew warm, when they answered ${ }^{16}$ wrathfully, and instead of ${ }^{17}$ friends turned to [be] his opponents. Now, as to this sufferer, was it little ${ }^{18}$ for him to bear his disease and his pain, that he should besides hear ${ }^{19}$ hard words, and the ${ }^{20}$ angry speeches of his friends, who provoked him? Yet, ${ }^{21}$ notwithstanding [all] this, ${ }^{22}$ during the whole length of the dispute, behold! Job stands like an iron pillar upon its base, ${ }^{22^{2}}$ praising his uprightness, and the integrity of his heart, and the purity of his hands, and maintaining [that] he is suffering ${ }^{23}$ for nothing; and if, in the overflowing of his indignation, he ${ }^{21}$ vents some words against God's Providence, he very

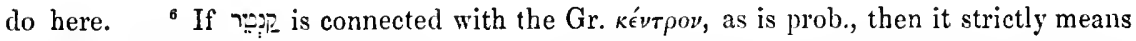
to prick, sting, goad (stimulare). ${ }^{7}$ did not know [any (one)] of the things. ${ }^{8}$ which was (were, had been) done. See p. xxrii, note ${ }^{b} .{ }^{9}$ doubt and stain. ${ }^{10}$ lit., or [cast] thoughts of uncleanness on his service, worship. ${ }^{11}$ with this.

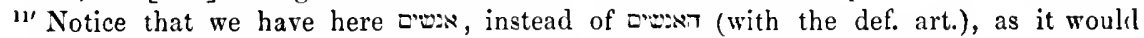
be in Heb. It is a common practice in Rabb. (I suppose for the sake of economy) to leave out the def. art. before the subst., and to put it only before the adj., or adjs., belonging to the subst. — and several examples occur in this Preface. See note ${ }^{1{ }^{12}}$, and p. lxvi. note ${ }^{36}, \&$ c. No ambiguity results herefrom, as the definite article with the adjective is quite sufficient to shew that the substantive is to be taken definitely. 12 upon the chances, accidents, of the sons of men.

equal (i.e., the point of agreement) among (between) them [is that] Jehorah, He is the righteous just one, \&.r. $\quad{ }^{13}$ his cause. $\quad{ }^{14}$ This phrase פמד צל נפשו is borrowed from Esth. viii. 11, ix. 16, where it is transl. in the A. V. to stand for one's life, and by Ben-Zev, sich vertheidigen; else one feels inclined to transl. it to stand upon one's will, purpose, to persist in one's determination. And, indetd, Ben.Zev gives עמד עי this meaning, viz. = beharren, in Ezra x. 15, and he quotes

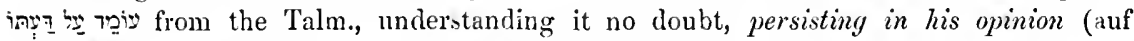
seine Meinung bestehend). Comp. infra, p. lxiii, note ${ }^{5}$. ${ }^{15}$ soft things (Job xl. 27). ${ }^{16}$ wrath. ${ }^{17}$ lovers, were turned, turned thenselves to (for) him to opponents. ${ }^{: 8}$ his bearing. ${ }^{19}$ hard-things. See note ${ }^{15}$. $\quad{ }^{20}$ anger. $\quad{ }^{21}$ with this. See note $\left({ }^{11}\right)$, where by Dr. Bernard was "[and] notwithstanding all the length (i.e., the long duration) of the dispute," but against this is, firstly, the absence of 1 and, and secondly, the presence of the word כל בל . ${ }^{22 a}$ to bless, praise. ${ }^{23}$ for no-thing. This looks as if Ben-Zev understood in the preceding par., line 2, for no-krong; see note on it. ${ }^{24}$ pushes 
speedily turns and repents of his ${ }^{25}$ words. But they, who reason against him, assert, that, as for the Rock, His work is perfect, and there is no iniquity in His ways, and [that], if Job suffers, his guilt is upon his head (i.e., he has brought his sufferings upon himself by his guilt); but Job is not humbled because of their noise, nor is he dismayed because of their ${ }^{26}$ multitude (i.e., because they are three to one), and he prevails against their words, until [at last] he gets the better of his companions, so that [they] cannot find any answer to his words, and [then] he extends his speeches, and there is ${ }^{27}$ none ${ }^{97}$ among them answering his words. Then behold! Elihu arises, and seeks to renew the controversy; so he speaks, and then stops and holds his peace, ${ }^{29}$ [in the hope] of obtaining an answer from the mouth of Job; but Job does not enter into ${ }^{30}$ discussion with him. Then he speaks again, and calls to Job, but Job [is still] silent, till at last God reveals Himself, and speaks to Job, and puts questions ${ }^{31}$ to him concerning the ${ }^{32}$ wondrous things of [His] creation, and the government of the universe generally. And ${ }^{33}$ thus Job ${ }^{34}$ becomes humbled at the words of Jehorah, and ${ }^{35}$ abases limself before Him, and confesses, that the knowledge of the ${ }^{36}$ shortcomings of his knowledge is the ${ }^{37}$ perfection of a human being's knowledge. But in the answer of God no reply is found to the questions of Job, nor any sufficient reason for his suffering ${ }^{38}$ such afflictions; for it would not have been suitable ${ }^{39}$ for God to excuse Himself for His doings before flesh and blood, or to reckon with His own creatures, why and wherefore $\mathrm{HIe}$ had done so and so; but it is enough that man should limit himself to his own boundaries, ${ }^{1}$ and should not break, nor burst forth, from the station assigned to him, to * pry into the ${ }^{2}$ recesses of the mysteries of God and His ${ }^{3}$ dispensations.

* Two copies of this Preface which we have before us do not agree as to the word translated here to $m y$; one has לחדר , לחרי, but, as neither of these would make sense, we suppose that the right reading must be accordingly.-Note of $E d$. [I leave this note, because the suggestion made in it is very

[forth]; cf. the Germ. ausstossen. $\quad{ }^{25}$ wold. $\quad{ }^{28}$ This might mean, however, "their tumult." Cf. Isa. xxxi. 4, whence the words have been borrowed, though Ben-Zev has transposed the two verbs, apparently because הדי : is a stronger word, and has a fuller and more pausal form than

${ }^{27}$ see Job xxxii. 1.2, whence the expression has been taken. ${ }^{28}$ from, out of, them. ${ }^{29}$ [so as] to find an answer. ${ }^{30}$ words. ${ }^{31}$ before him. ${ }^{32}$ wonders of formed (created) things. $\quad{ }^{33}$ by means of this. $\quad{ }^{31}$ bowed himself. ${ }^{35}$ humbled himself to Him in it (this matter), or by it. See p. xxx, note ${ }^{d .}{ }^{36}$ shortness, brevity, imperfection. $\quad{ }^{37}$ end, limit, perfection, or completion, i.e., the utmost extent. ${ }^{38}$ the (these) afflictions. $\quad{ }^{39}$ for God to be defending Himself.

${ }^{1}$ lit., and should not break forth from his station, and should not burst forth; but as, when two verbs refer to the same noun, it is not unusual in Heb. to place one rerb before, and the other after, the noun, I have transl. in the text as though

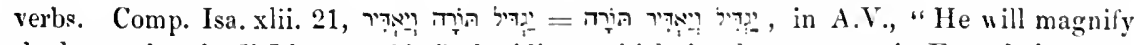
the law and make [it] honourable," the idiom, which is also common in Eng., being freserved, though we have to supply a pronoun after the second rerb. Comp. also note in

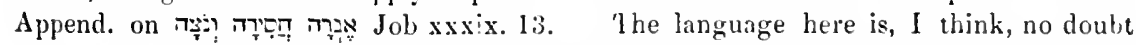

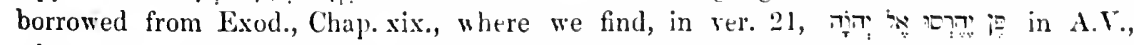

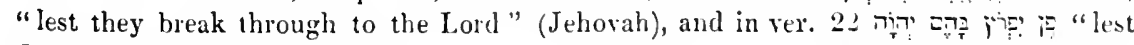
Jehovah break forth upon them." " secrets of. "IIis custum, habit, i.e., 
And the writer would not have done right, if he had left the righteous man ${ }^{4}$ to perish in his riglteousness, after having represented him with the excellencies of uprightness and righteousness, and aftlicted him with pain without a cause, merely for the gratification of Satan, in order to prove him, and yet he stood fast in the trial, and ${ }^{5}$ vindicated his righteousness —- therefore he (the writer) made him glad ${ }^{6}$ according to the days wherein he had afflicted him, and restored him everything twofold; only the number of his sons and daughters he could not [well] make double, for, ${ }^{7}$ had he done so, it would have been necessary [for him] to renew his (Job's) wife's youth like [tlat of] an eagle ${ }^{7}$, so that, ${ }^{8}$ after she had waxed old, she should [still] have pleasure ; for, ${ }^{9}$ after having first borne ten children, she ${ }^{10}$ would have had to bear twenty more; and therefore ${ }^{10}$ a number [of children] like the first number seemed sufficient to him (the writer).

ingenious, and is Dr. Bernard's and not mine. הדר might well be a misprint for הרהר, for I have more than once caught myself, when transcribing these rediplicated verbs, leaving out the reduplicatcd, or the apparently reduplicated, letter. This would give us here הדר is very easy, for every one, who has had Hebrew printed, must know that the compositors frequently print $T$ for $\urcorner$, and vice versa See p. xxxiii, note $d$. Again, הרהר is just the word we require here, for do not we

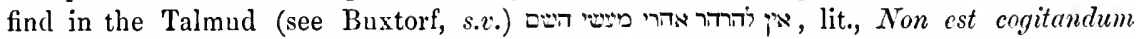
post opera Dei. At the same time, I think it is pretty nearly certain that Ben-Zev

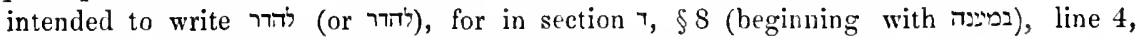
we find להדור (used exactly in the same sense), where the use of the ? forbids the supposition that there is a misprint for להרהר. The question therefore is, whether, or חרר, can have much the same meaning as הזרה. Dernard seems to think they cannot, but I am inclined to believe they can. As for it properly means to return, and Buxtorf gives exactly to the Fr. rentrer en soi-même, and the Germ. in sich gehen = to reflect upon one's ways, to repent. Again, under, which also means to return, we find $=$ with exactly the same meaning as בדב the Hith-paâl. See Mason and Bernard's Grammar, vol. ii., p. 291. I think, therefore, that הדight well be taken in the sense of to refleet upon, and so in a bad sense $=$ to scrutinize, pry into. But there seems to me but little doubt that לחדר is the true reading here, for Ben-Zev (in his Lex.), following Kimchi, gives the verb תדר in the disputed

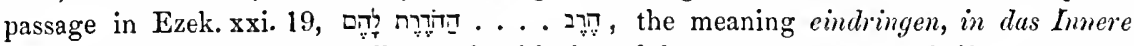
dringen, a meaning, which well accords with that of the noun pronetrale (from penetro) inneres Gemaeh (and fig., (like penetrale), imnermost part of a thing, recess), and is exactly

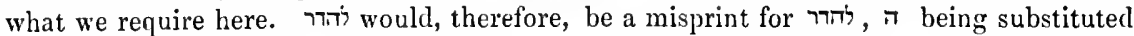
for $\pi$, as it very freq. is by compositors. See p. xxx, note g. -Editor, 1863. [Ben-Zev has ל ל ל , see p. lxxiv ( $\left.\left.{ }^{7}\right)\right]$.

His way with men; but מנהג seems also to be used = הנהגה (see p.xxxviii, note ${ }^{1}$ ), conduct, vule, government (see infia p. lxv, note ${ }^{31}$ ) ${ }^{4}$ perishing; prob. part.,

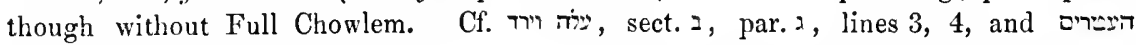
sect. 7 , par. 6, line 3 from end. ${ }^{5}$ The lit. rend. seems to be, and disputed, contended concerning, on behalf of, his righteousness, contested, maintained, his righteousness. $\quad{ }^{6}$ according to the days of (i.e., during which) He had afflicted him-a tense governed by a noun in constr. See Ps. xc. 15, and note in Comm. and Append. on Job xxix. 2. ${ }^{7}$ if so. $\quad{ }^{\prime \prime}$ See Ps. ciii. 5; and infra note ${ }^{11} . \quad{ }^{8}$ see Gen. xriii. 12. ${ }^{9}$ after her having borne. $\quad .{ }^{10}$ more lit., she would again have borne twenty more. ${ }^{101}$ the number, i.e., the number which was like the former. See p.xliv, note ${ }^{21}$. Mr. 


\section{II. "WHETHER THE NAME OF JOB IVAS [THAT OF] A REALLY EXISTING MAN OR NOT?}

${ }^{11}$ 'Various opinions there ${ }^{12}$ were among the wise men ${ }^{12 \prime}$ of oll, as to whether the name of Job, mentioned in this book, [was] the name of a ${ }^{13}$ real man, [who] existed at a certain period of time, and all "the events told of him also took place, or whether ${ }^{15}$ it was a creation of the ${ }^{16}$ fancy of the writer, [who] called the name and ${ }^{17}$ the events connected with it into existence, ${ }^{18}$ so as to express in the form of a parable ${ }^{19}$ the lesson he intended to convey. But even among those who attribute to him (Job) real existence, there is a difference and disagreement as to his time and generation. Now the different opinions with regard to lis existence, and to the time of his existence, ${ }^{20}$ will be found in the Talmud (Treatise "Bava Bathra," fol. 14), [where we read], Rabbi Levi, son of Lachma, says Job was in the days of Moses. Rabbi Jochanan and Rabbi Eliezer say Job was "2t among those, who went up out of the captivity, \&c. : and ${ }^{22}$ a certuin Rabbi says, Job neither cxisted nor was created,

Randolph would take הoct.= suppediture, a meaning which it sometimes has, and would render, "So he (the writer) supplies him with the number [which was] like the first number." The rend. in the text had Dr. Bernard's sanction, and I think it ayrees better with the context. See sect. $\ltimes$, par. 4 , line 4 from end, and sect. 2, par. ', line 1. I think, too, that if the other meaning had been intended, we should prob. have had another verb, such as BenZev's favourite $\mathrm{ar}$ to assign, attribute. " the name of Job, whether it [was that of] an existing man, \&c. The Hebrews, having no other way of expressing thut of, than by repeating the noun, frequently do repeat it; but sometimes, finding, perhaps, the repetition tedious, leave it out as here. Thus, we might have had here in the rery next line. Comp. the preceding par., line 3 from the end, where הוא here, however, might possibly be referred to w, but, then Ben-Zev would be guilty of careless writing, whereas, according to the other view, he has only adopted a well-known Hubrew idiom. " " divided opinions. So in Fr. atis partagés. ${ }^{12}$ are. 12 See p. xxxriii, note ${ }^{3}$. $\quad{ }^{13}$ an existing man [who] was in a time of the times, i.e., at some time among: all the times (ages) which have passed. It the deeds, actions, facts, which are toll concerning him. 15 might well refer to 15 and be transl. he (was a creation, \&c.). $\quad{ }^{16}$ thoughts. $\quad{ }^{17}$ its deeds, actions, facts. ${ }^{18}$ for the parabling of (i.e., to serve as a parable for) his subject (or object) the (one) intended by him. The expression

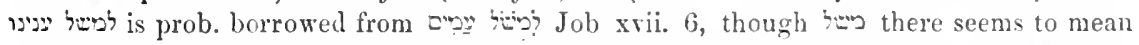
rather to serve as an Example * (see Comm. and Append.), than to serve as a P.ARABLE as here-still the constr. is the same. The meaning eviclently is, so as to allegorize, or for the allegorization of, his subject, Sc., i.e., so as to form his subject (object, meaning) into an

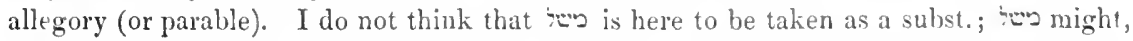
however, I think, well be regarded as the $\mathrm{Pi}$-all, and so mean at once, to perable, make inte a parable, \&c. Sce p. lxix, note 14. ${ }^{19}$ The expression

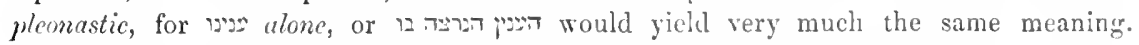

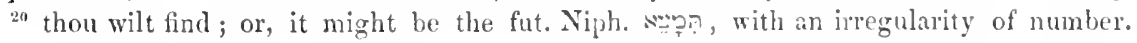
I). Bernard, however, adopted the former riew, which I also think the more probable. "1 from, out of, those, de cenx, con denen. ${ }^{22}$ lit., that one of the

* But would not to excmplify make very gool sense here? 
but was [only $]^{23}$ an allegorical personage. Now, I will first bring forward ${ }^{24}$ what ${ }^{25}$ reasonable objections there are ${ }^{26}$ to every opinion on both sides of the question, whether the ${ }^{27}$ whole of the book is ${ }^{2 x}$ fact or an allegory, and afterwards I will bring forward the decision and explanation of the matter. If [then] we ${ }^{29}$ suppose, that the whole matter ${ }^{20 \prime}$ was so [and] so existed according to this description (i e., according to the description given in the work), against this supposition ${ }^{30}$ the following ohjections may be raised :

1. It is very ${ }^{31}$ unlike an occurrence ${ }^{32}$ in real life, ${ }^{33}$ that everything assigned to the man in the way of possessions ${ }^{34}$ should tally with the sacred + numbers, which are, three, five, and seren,-[namely], seven sons and seven thousand sheep, three daughters and three thousand carnels, five hundred [yoke of] oxen, and five hundred she-asses.

2. 'In like manner, it is ${ }^{2}$ very unlike an occurrence in [real] life, that every time an evil chance befell Job, [whether] by the spoiling of the enemy, by the falling down of fire from heaven, or by the fall of the house, everything which had ${ }^{2 a}$ the

$\dagger$ i.e., numbers, which on certain occasions (such as in the descriptions of religious ceremonies, sacred buildings, \& c.), are employed in the Bible in preference to others. Comp. Gen. xv. 9, "Take me an heifer of THREE years old, and a she-goat of THREE years old, and a ram of THREE years old;" 2 Chron. iii. 11, "One wing of the one cherub was FIVE cubits . . . . . and the other wing was likewise five cubits, \&c." Job xlii. 8, "Therefore take unto you now SEVEN bullocks and SEVEN rams."-Note of Ed.

Rabbins. See supra, p. xxxii, par. 2, line 3 . ${ }^{23}$ a proverb, parable, an allegory. ${ }^{24}$ ce qu'il y a d'objections raisonnables. $\quad{ }^{25}$ objections of intelligence, i.e., intelligent, sensible objections. $\quad \because 6$ against every opinion from (of, on) the two parts (sides) of the opposition, contradiction (dispute). $\quad{ }^{27}$ the whole of it. $\quad{ }^{28}$ truth, or the whole of it [is] an allegory. $\quad{ }^{29}$ lay down, suppose; cf. the Fr. poser, Germ. setzen. $\quad{ }^{291}$ so existed, so was. ${ }^{30}$ lit., il y a à objecter ces objections. ${ }^{31}$ far of crincidence, or occurrence, i.e., unlikely to coincide, occur. הורות is not given in Buxtorf; but we find the

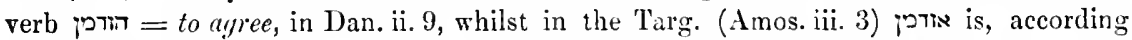
to some, used in the same sense, and, in other places, like מה in Rabb. = occurrere, olvenire, convenirc, to meet, come together, from which meanings it is easy to derive that of concurrence, coincidence, or occurrence. Comp. the Fr. rencontre $=$ meeting and occurrence, and se rencontrer $=$ to meet, agree, coincide. For זin far $=$ improbable, comp. our far-fetched and its equirs. in Fr., Germ., \&c. The opposite בiרק near, is used $=$ probable, e.g., p. xxxiii, sect. $\lambda$, par. 5, line $1 .{ }^{32}$ in existence in fact, deed, reality, i.e., in actual, real existence, life. The periphrasis with seems to have been used,

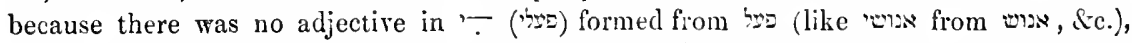
and corresponding to our actual (from $a c t$ ). $\quad{ }^{33}$ that all that which is assigned fur the possession of the man. Job is also called "the man" supra p. xli, lines 4, 5 , and infia p. liv, line $5 . \quad{ }^{34}$ should be set, disposed, arranged in (or according to) the sacred numbers.

${ }^{1}$ like thus (this).

${ }^{2}$ See supra note ${ }^{31}$.

${ }^{2 a}$ borrowed from Gen. vii. 22. The meaning is, lit., the breath of the spirit of life; or, according to Kimchi, the breath,

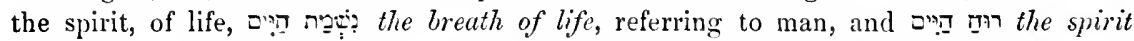
of life, to animals. But I prefer Mendelssohn's opinion, that ?ִ refers rather to the act of breathing, to the motion backwarls and forwards of the breath.

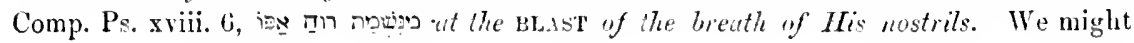


breath of life in its nostrils, ${ }^{3}$ should be either spoiled or should die, ${ }^{4}$ man as well as beast, and that there ${ }^{5}$ should be always left neither more nor less than one man, ${ }^{6}$ to come and ammounce the tidings to Job; and likewise this ${ }^{7}$ coincidence, ${ }^{8}$ that one should go out just when the other came in, ${ }^{9}$ would be very singular in real life.

3. Which way did the Spirit of God pass to ${ }^{10}$ commune with the writer, who [was] in the earth below, so that he should know everything, which was done in heaven above, and what God spake to His hosts, "with whom He held together sweet counsel, with regard to the actions of the sons of men, and what Satan answered Jehovah? [This could not be] ${ }^{12}$ except a ladder was set up on earth and the top of it reached to heaven, and the writer ${ }^{13}$ was ascending and descending on it.

4. How can ${ }^{14}$ one conceive that they ${ }^{15}$ should be talking every man with his ${ }^{16}$ fellow ${ }^{17}$ in words of controversy, and with ${ }^{18}$ objections and answers, and yet every one should ${ }^{18}$ declare his opinion in ${ }^{19}$ lofty poetic language, and arrange his words in short ${ }^{20}$ sentences, well-ordered and weighed, [and all this] ${ }^{21}$ as it were off hand, transl. then, lit., which had the breathing of the breath of life in its nostrils, i.e., through whose nostrils the breath of life passed backwards and forwards. ${ }^{3}$ was (or, should have been) spoiled and died (or should hare died). ' from man and even unto cattle. ${ }^{5}$ was (or, should have been) left remaining. ${ }^{6}$ who was (or, should have been) able to eome (i.e., who might come) to announce. "or, occurrence. ${ }^{3}$ [namely] this-one going out, and this-one coming in. ${ }^{9}$ it [would be] far (improbable) in existence. 10 to speak to the writer. " with whom together He sweetened, made sweet, counst. 1 . See Ps.lv. 15. ${ }^{12}$ If we put a dash before except, and add indeed (-except (unless) indeed, a ladder, \&c.), it is, I think, hardly necessary to supply anything. Still, as the words כי (except) are so far distant from the first clause in the sentence

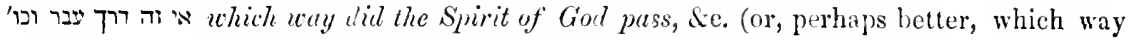
eould . . . have passed, Sc.), upon which they evidently depend, and as the connection between them, therefore, would be but obscure, even with the help of a

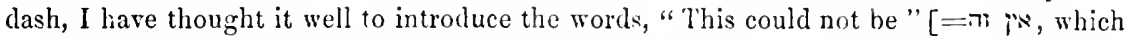
ought really to have been in the text. Sce p. lxxiv ("s)]. ${ }^{13}$ is and are parts. and not pasts, though they have not Full Chouclem. The pass. is borrowed from Geu.

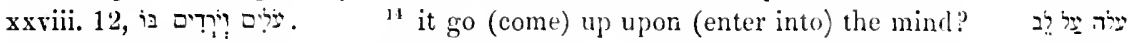
is found in Heb., viz., Jer. iii. 16, vii. 31, \&c. ${ }^{15}$ lit., were talking together; comp. the Fr. S'entreteni:. It is, I think, more in accordance with the Enx. idiom to use should be than the past, were, and I am entitled to do this, for Ben-Zev himself uses the future in the rest of this paragraph. We, however, are more strict than the Rabbins, and do not like to change from one tesse to another as they do, but generally keep on with the tense we have begun with. We might, however, say, ucre talling, declared, arranged, was; or, even wore talling, and then should declare, should arrange. should be. In this latter case, the meaning would be, "how can one conceire that, thongh they vere talking, yet that every one should declure," S.c.? This note applies, also, to supro, pars. 1 and 2 of this sect., in the first of which the fut., and in the second the past, is used, though in Eng. I have found it better to transl. both as futs. (i.e., by should). ${ }^{16}$ to his friend, neighbour, fellow. ${ }^{17}$ or, on matters of controversy; but urols is, I think, better. See par. 6, line 1. ${ }^{18}$ and [with] oljjection and answer, the = being supplied rom . We might equally well transl. "with words of controversy, objections and answers," the 1 before טיבה being omitted as superfluous in Eng., as infra, par. 6, line 1. ${ }^{1 s}$ See p. xxxii, note $a . \quad{ }^{19}$ exalted poetry. $\quad{ }^{20}$ sayings, expressions. $\quad{ }^{21}$ as [it were] after 
without any hesitation or delay-and [that] the ${ }^{22}$ arrangement of the words should be welling with poetry from his mouth like a gushing spring.

5. This also [would be] a ${ }^{23}$ strange coincidence, that they should ${ }^{23 \prime}$ all be bards, all poets, ${ }^{24}$ all elegant speakers, and that one ${ }^{25}$ style ${ }^{26}$ should be adopted by all of them.

6. How could the memory of man suffice to remember all the words, ${ }^{27}$ objections and answers, which [passed] between Job and his companions, and all the ${ }^{28}$ speeches ${ }^{29}$ just as they were formed and really were? Lo ! this were a difficult matter [even] in ${ }^{30} \mathrm{a}$ historical narrative, ${ }^{31}$ the subject of which might be treated

(behind) hand=carelessly. The expression may be derived from one's tossing out of one's liand backwards over the shoulder what one does not care about. See Buxtorf, s.v. T. 22 This word ישובי is very puzzling. It is, no doubt, to be pointed, indeed, in my copy, the word has an indistinct dagesh in the $\mathbb{w}$, as though to prevent its being taken for שיזי, שיזי, the fut there is no dagesh in Ben-Zev. See p. lxxiv]. But what is the meaning of eni? ? Buxtorf gives it two meanings, riz., orbis, vel terra habitabilis (as opposed to pִ̣ terra deserta), and soliditas, solidus sensus, but neither of these meanings make sense here. I would derive it, therefore, from the Pi $a l$ of 2 ", which is used in Ezek. xxv. $4=$ to make to sit, sct, place, and in Rabb. has, according to Buxtorf, the meaning collocare, disponcre, digerere; when we should obtain the meaning setting, disposition, arrangement-a meaning which does not ill agree with the words (should) arramge, well-ordered and veighed. And the beanty of poetry certainly does depend in no slight degree upon the harmonious arrangement of the words, for people, and people of intellect, have frequently been known to recite verses which delighted them by their harmony, although, when asked to explain their meaning, they have been obliged to confess themselves unable to give it.* This interpretation had the sanction of Dr. Bernard, who, indeed, was inclined to translate 2wi, flow, which is about equivalent to harmonious arrangement. We might, therefore, almost render ישוב הדרים by our one word diction. If again ex could mean the setting of precious stones, \&c., we should also obtain a very good meaning; but, in Hebrew, at any rate, the verb pras was used in this sense. Notice the, to Eng. minds, awkward, but very Heb., repetition of the word מובע, and see p. lxiv, note ${ }^{16} \quad{ }^{23}$ rare of occurrence, coincidence. ${ }^{23 \prime}$ all of them. $\quad{ }^{24}$ all of them speakers of bright-things. See note in App. on Job xii. 20, p. 705, note $\ddagger$; and also Isa. xxxii. 4, whence the lang. has been borrowed. ${ }^{25}$ jo is the Lat. signum, and means standard, seal (cf. our signet), and style. Comp. the Fr. cachet $=$ seal and stamp. $\quad{ }^{26}$ should be coming up (i.e., should suggest itself, occur, present itself) to all of them; the style offers itself to them, and they adopt it. See Buxtorf, who s.x. ספני in in a very similar passage obrenit. Comp. the phrase עלה על הרצת, supra, par. 7 , line 1. $\quad 27$ and the objections and the answers. ${ }^{28}$ tongues, but in Kabb. also speeches, words. $\quad{ }^{29}$ according to their form and according to their essence, i.e., just as they were in form and essence. $\quad{ }^{30}$ a narrative (relation) of fact(s), a history, which virtually $=$ prose, as histories are commonly composed in prose. $\quad{ }^{31}$ [in] which [it is] possible to grasp, handle, treat, the subject with different words, i.e., in which, as being prose, the same subject-matter might be reproduced by the hearer in different words, without its suffering any great disfigurement or distortion. Even in the case of a long piece of prose, when the reporter would not be tied down to the precise words used, there would be great difficulty, if he trusted to his memory alone, in reproducing all the statements, arguments, $\& c_{c}$, of the speaker-how much greater then

* In "Rogers' Table Talk" (p. 253) there is an instance given of this kind. 
of in different words-nuch more in ${ }^{32}$ poetical language, where, by changing one word, the poetry is marred and the meaning is ${ }^{33}$ lost. ${ }^{34}$ Will any one say, that a man [was] standing ${ }^{35}$ near the disputants, with a roll in his hand, ${ }^{36}$ an inkstand, and a pen, and writing down with ink 37 in a book the words which he heard ${ }^{38}$ proceeding from the mouth of the disputants? ${ }^{39}$ Surely, at first they were not gathered together, as it were ${ }^{40}$ in a loouse of assembly of ${ }^{41}$ wise men with ${ }^{42}$ the fixed intention of investigating and ${ }^{43}$ discussing matters of investigation,

the difficulty in the case of a long poem, of which every single word would have to be reproduced! $\quad{ }^{32}$ words of poetry. $\quad{ }_{33}$ or destroyed, spoiled. $\quad{ }^{34}$ will a sayer say? For this idiom comp. 2 Sam. xvii. 9, Deut. xxii. 8, Sc. Comp. also Matt. xiii. 3, "Behold, a soucer went went forth to sow." $\quad{ }^{35}$ upon, at, near, the backs, of those disputing. ב2 זִ Job xvi. 11. ${ }^{36}$ and an inkstand. For this repetition of 1 before every noun see note in Append. on s? Job i. 2. $\quad{ }^{37}$ upon the (a) book. $\quad{ }^{38}$ notice the sing.

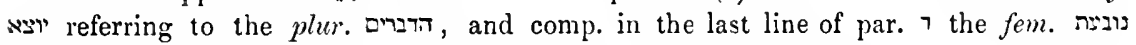
referring to שוב, which is, no doubt, masc.; and see p.xxvii, note $b . \quad{ }^{89}$ or But. ${ }^{40}$ according to the rule I have laid down in the Append., note on n?, Job i. 4 (p.519), we ought to have ביה וויז be regarded as an acc. = did not come together, were not gathered together, to, into, a house. ${ }^{*} \quad{ }^{41}$ But is it not better to take נירני to be the nom. "Surely, at first the wise men were not gathered together in a house of assembly, \&c." ב'ת alone seems freq. to $=\mathbf{a}$ house of assembly of wise men. Cf. p. l, line 9, where Job is called Tire, and not THIS, man. $\quad{ }^{42}$ with a fixed intention to investigate, $S \cdot c . \quad{ }^{43}$ and to take (receive) and give (arguments) in (or concerning) investigations, i.e., to discuss investigations, matters of investigation. These two verbs graphically express the intershange, or bandying, of arguments, or the exchange of ideas. Buxtorf gives ניא ונה: בדבר agere $\mathrm{DE}$ re aliqua. It is a question, however, whether הan be taken neutrally $=$ matter of investigation. Infra, sect. $\pi$, line 1 , it is used actively; still nouns of the same

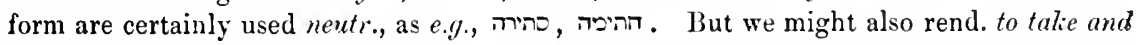
give in investigutions, $=$ to exchange ideas whilst investigating, or to adduce and receive arguments in the course of investigation. Or may in investigations mean in the matter of (the Fr. en fait de) investigations? They might have discussed other matters, plain matters of fact for example, but they did not, they occupied themselves with investigations. This would be the meaning also if we took investigatingly. 2 is often thus used with a subst. See ביפי in (or concerning) [their] investigations," i.e., to discuss their several investigations. If in to investigate, alone had been used, it might have meant that they confined their

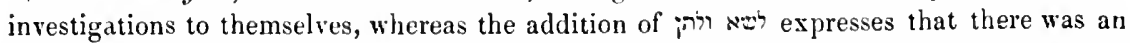
interchange between them, and that they communicated their investigations one to the other. See Job v. 27, where Job's fricnds say to him, "Lo this, we have searched it (our very verb $2 \pi$ ), so it is; hear it, and mark it, for thyself." I do not know exactly how Dr. Bernard understood the pass. It seems that in Eng. to give and take, is sometimes used in much the same way. Thus, in the "Saturday Review" of Oct. 17, 1863, it is said of the late Archbishop Whately that, "in the quick give-and-talie of Oxford conversation, he was perhaps unrivalled." For a similar form of expression, cf. the Fr. ca-et-rient.

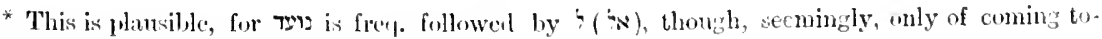
gether with a person, and nut $t 0$ or at " place. 
but ${ }^{44}$ it so happened [that] his companions ${ }^{45}$ found Job [sitting] ${ }^{46}$ in the ashes, [and ${ }^{46^{\prime}}$ ] there they ${ }^{47}$ came around him, and ${ }^{47}$ in consequence of the turn which the words took, ${ }^{4 s}$ became involsed in the controversy. This is ${ }^{49}$ what may be objected, if we take the words ${ }^{50}$ in their strict sense.

But, if we suppose that the whole subject-both the rame of the man, and his doings and lis fortunes, ${ }^{51}$ none of them ever were, or had any existence, [but that] all was invented 'by the mind of the writer, ${ }^{2}$ the following objections may be raised :

1. What intention ${ }^{3}$ could he (the writer) have had in ${ }^{4}$ particularizing matters which bear no relation to the allegory, and to the object ${ }^{5}$ aimed at in it; for example, 'Job's wife's enticing [him] to curse God, and many [things] like it ? ${ }^{7} \mathrm{So}$ in like manner at the close of his book, ${ }^{8}$ he specifies the names of $\mathrm{Job}^{\mathrm{s}}$ daughters, and [tells us] that ${ }^{9}$ they had not their like for beauty; also, the ${ }^{30}$ precise number of years, which he still lived, and how many generations he saw. And so [again] in the " middle of the poem (chap. xix), [Job is made to say] Myy brethren hath He put far from me (ver. 13); My breath is beeome offensive to my wife (ver. 17); and, as to all the chaps. 29, 30, 31, they all point ${ }^{12}$ visibly, and not enigmatically, to real ${ }^{13}$ events, just as though he were giving an account of the riches and dignity with which he was [invested] in former times, and of his good deeds, and how the wheel [of fortune] ${ }^{11}$ had turned against him, and how he had become [an object of] contempt and reproach ${ }^{15}$ to the lowest of fanilies.

2. If Job ${ }^{16}$ never was, and never existed, how [is it that] the prophet Ezekiel introduces him among ${ }^{17}$ men that hal really existed [saying, namely,] (clsap. xiv.

${ }^{14}$ a chance chanced; cf. note ${ }^{34}$. Observe the omission of the that, which is common with Ben-Zer. See last par. of this sect. line 2 ; sect. 1, par. 4 , line 9 (in original), p. xlvi, line 8 (in transl.) ${ }^{45}$ his companions hit upon, came upon, lighted upon, fell in with, met him [namely] Job; stiessen auf ihn. Notice the pleonastic affix, and comp. Exod. ii. 6. ${ }^{46}$ on the ashes. $\quad 46^{\prime}$ For the onission of the 1 , see p. lxii, note ${ }^{43} . \quad{ }^{47}$ surrounded him. 'si' by means of, through, the turning, going round, of the words. Comp. our "in the course of conversation." $\quad{ }^{48}$ they came upon the dispute, i.e., got into the dispute, entered upon it. ${ }^{49}$ lit., ce qu'il y a à objecter. ${ }^{50}$ according to their hearing (or sound), i.e., literal meaning. $\quad{ }^{51}$ all of them were not, and were not created.

${ }^{1}$ out of the heart of. ${ }^{2}$ lit., il y a à objecter ces objections. ${ }^{3}$ or, what did he wish, ain at? où en roulait-il? "Buxtorf has the subst. פשרוש, but does not give the verb פרe still our word $i$; prob. a verb and not a subst. ${ }^{5}$ see note ${ }^{3}$. The neaning may be "aimed at hy him;" see the first par. of this section, line 3 in the original, and line 6 in the transl. "lit, the enticing, incitation, of his wife to curse. " and so. ${ }^{8}$ see p. xxxii, note.$\quad{ }^{9}$ there was not their example, like. ${ }^{\text {jo }}$ the detail, specification, of the years. $\quad{ }^{11}$ interior, body. Ben-Z ${ }^{3}$ probably cousidered the historical parts (i.e., chaps. i., ii., and part of chap. xlii.) as in some measure without, outside of, the poem (see Buxtorf, s. $v$. פיa), and if so, within (or in the bolly of) the poem would be more correct here than in the mirldle of the poem, which would generally be understood to = about chap. xxi. See p. $x$ l, note ${ }^{14}$, and p. Ixxii, just before note ${ }^{12}$ in text. ${ }^{12}$ by sight and not by riddles. $\quad{ }^{13}$ deeds, facts, acts, circumstances. $\quad 14$ was turned, turned itself. ${ }^{15}$ lit., with, in, among, the low of fimilies. Observe the masc. sing. פהות with the fem. plur. ninew; and see p. liii, note ${ }^{3}$. ${ }^{16}$ was not and was not created. ${ }^{17}$ existing men. 
14), Though these three men, Noah, Daniel, and Job were in it? And although in the Talmud they did not ${ }^{18}$ adopt this as an objection, so as to oppose with it that one of the Rabbins, who said Job ${ }^{19}$ never was, and never existed, behold ! the words of the prophet are more ${ }^{20}$ weighty.

Therefore, what is right is to ${ }^{21}$ take the ${ }^{22}$ middle course between the two opposite extremes, ${ }^{23}$ namely, [that] the truth of the matter is, that there lived a man ${ }^{24}$ at a certain period of time, ${ }^{25}$ whose name was Job, and who was celebrated ${ }^{26}$ for riches, dignity, and honour, and took fast hold ${ }^{27}$ of righteousness and uprightness, and yet misfortune befell him, and he ${ }^{28}$ lost his possessions, and was crushed with afflictions in ${ }^{29}$ addition to his poverty. And this man the writer selected for his subject; [and] ${ }^{30}$ taking up some of the ${ }^{31}$ real facts, he fashioned him with the graving-tool of poetry, and ${ }^{32}$ painted the pictures with bright colours, and made of him an image, according to the likeness and ${ }^{33}$ form of the man, whom he wished to ${ }^{34}$ give life to in his allegory, in order to ${ }^{35}$ illustrate everything that $I$ have mentioned.

\section{WHO JOB WAS-FROM WHAT PEOPLE AND COUNTRY HE AND HIS COMPANIONS WERE.}

With regard to all the cities and ${ }^{352}$ regions assigned as the dwelling-place of the men, who are mentioned by name in this book, ${ }^{36}$ most of them are from the land of Edom, or ${ }^{37}$ its neighbourhood. Job was of the land of Uz, which is assigned to Edom (Lament. iv. 21), Rejoice, and be glad, O daughter of Edom, that dwellest in the land of $\mathrm{Uz}$ ! And the name ${ }^{38} \mathrm{Uz}$ is likewise mentioned among the generations of the sons of Esau (Gen. xxxvi. 28).

\section{${ }^{18}$ take, receive.}

of the middle way, path.
19 was not and was not created.

\section{2n strong.}

(in the two parts (sides) parts, sides. $\quad{ }^{23}$ and it, that, is. We must here supply after It could not well be expressed, on account of the second ' 2 immediately afterwards. Ben-Zev. freq. omits a כ. Cf. sect. א, par. 4, line 9, כי יהוה וכו' for, and s'pra par. ', line 6,

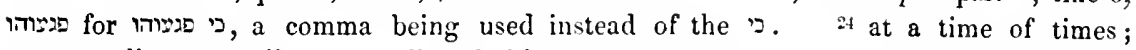
see p. xlix, note ${ }^{13}$. ${ }^{25}$ and his name [was] Job, and he was celebrated, \&c. $\quad{ }_{26}^{26}$ for riches and for greatness and for honour. Notice the repetition of the prep. and conj., and comp. note in Append. on Job i. 16 (p. 551), and supra p. liii, note ${ }^{36}$. 27 on righteousness and on uprightness. See note $\left({ }^{26}\right)$. 25 went down, descended, (fell) from his riches, property. $\quad{ }^{29}$ added upon his aftliction, misery, distress, poverty. For the sing. For referring to the plur. $匚$, see p. liii, note ${ }^{3 s}$, But Iוסף may, perhaps, be used as a subst. (like in Job xxxriii. 38, Sc.). and, if it can, then the meaning will be $[a s]$ an addition. Comp. ה In Isa. xr. 9, which is transl. in the marg. of the A. V. additions. ${ }^{30}$ took hold of, grasped, seized. ${ }^{31}$ true. ${ }^{32}$ and anointed (smeared)......... with vermilion (i.e., with bright and vivid colours). See Jer. xxii. 14, and infia p. lx, note ${ }^{8}{ }^{33}$ and according to the form of. Notice the repetition of the 3 , and comp. note $\left({ }^{26}\right)$, and p. liii, note $\left({ }^{36}\right), \quad{ }^{34}$ to create; i.e., the author wished his chief character to be life-like, and, therefore, he based it upon a man who had really lived. $\quad{ }^{35}$ lit., to make a sign by nodding, to indicate, point out, allurle to, hint at. $\quad{ }^{35 a}$ or provinces, but these countries could scarcely be called provinces.

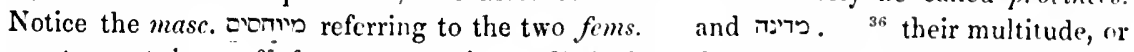
greater part, is. $\quad{ }^{37}$ from near to it. ${ }^{34}$ And so the name of $U_{Z}$ is mentioned, sic. 
${ }^{39}$ Eliphaz, the Temanite, was of a eity, the name of which [was] Teman [ ${ }^{39}$ after Teman], the ${ }^{40}$ brother of Eliphaz, who is also mentioned among the sons of Esau (Gen. xxxvi. 11). ${ }^{40}$ This city [was] moreover celebrated for wise men (Jer. xlix. 7) : ${ }^{41} I s$ uisdom no more in Teman? [It is also mentioned in Ezek. xxv. 13, And I will make it "2esolate from Teman; [and in] Amos i. 12, But I will send a fire upon Teman; and 43 all of them ${ }^{44}$ belong to Edom.

Bildad [was] related 'to Shuah, [who was] of the offspring of Abraham, which lie had by Keturah (Gen. xxr. 2), And Ishbak and Shuah. And, as for him (Shuah), he dwelt in Edom, as did Dedan* (Jer. xlix. 8).

Zophar ${ }^{2}$ belonged to [the city] Naamah. This [may], perhaps, [be] the city mentioned in Joshua (chap. xv. 4l), on the border of the land of Edom.

Elihu ${ }^{3}$ belonged to Buz, which is mentioned in Jeremiah (chap. xxv. 23), together with Dedan and Teman; and it is ${ }^{4}$ probable that it was also a city of the land of Edom, or of a ${ }^{5}$ region adjoining it.

But, as to the ${ }^{6}$ extraction of Job, of what people he was, this is also a matter 7 which cannot be absolutely cleared up, and the opinions of our predecessors are divided thereupon ${ }^{8}$, just as they are divided with regard to his existence and his time. And this is also [mentioned] ${ }^{9}$ in the place already quoted from the Talmud (Bava Bathra, fol. 14). They say, There was a pious man among the nations of the world (i.e., not among the Israelites), whose name [was] Job, \&c. (Vide in loc. $)$ But all the Tannaim + think that Job was of [the people of ] Israel,

* Ben-Zer seems to think that, as Shuah and Dedan were of the same family, and Dedan dwelt in Edom, as shown by there being a city of that name there, Shuah must also have dwelt in Edom.-Note of $E d$.

+ The passage in the Talmud runs as follows:

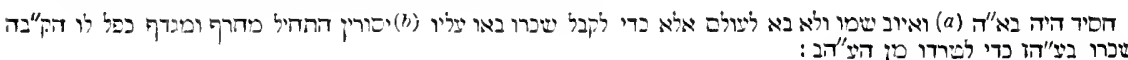

"There was a pious man among the nations of the world (i.e., not among the Israelites), whose name [was] Job, and he only came into this world in order to receive his reward. When afflietions came upon him, he began blaspheming and reviling (God); then the Holy One, blessed be He! doubled him his reward in this world, in order to thrust him out from the world to come." -Note of Ed.

‡ The Tannaim (הבאים from the Rabbinical verb toach) are the doctors of the Talmud.-Note of Ed.

${ }^{39}$ lit., Eliphaz, [called] the Temanite, for he was. See p. xxxiii, note ${ }^{c}$. $39^{\prime}$ should be "after the name of Teman," and not in square brackets; see p. lxxiv $\left({ }^{10}\right) . \quad{ }^{40}$ Ben-Zev here makes a mistake, for accorling to the pass. in Gen., Teman was the son of Eliphaz. $4 w^{\prime}$ and so, also, this city, $\mathbb{k c} \quad$ "I or, Is there no longer any wistom in Teman? $\quad$ "2 a desolation. 43 i.e., all these Temans, ${ }^{44}$ are assigned to Edom.

1 after. 2 was related (lit., registered, enrolled) after. $\quad{ }^{3} \mathrm{See}^{2} . \quad{ }^{4}$ near. See note on רar $f$ improbable, p. 1 , note ${ }^{31} . \quad{ }^{5}$ or province. $\quad{ }^{6}$ family, race. ' [which] it is not [possible] to make pure, clear, absolutely (cf. the Germ. etwas in's Reine bringen). $\quad{ }^{8}$ also (likewise), like their division, but in Eng. the also is scarcely wanted. ${ }^{9}$ there in the Talmud, i.e., in the place already quoted (see pp. xlix-l). In the Edition of the Talmud in the British MIuseum, it is in fol. $\mathrm{xri}$.

(i.e., באוכות הזולם.

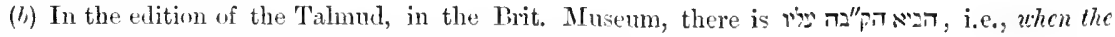

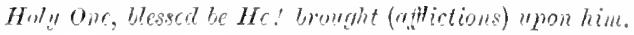


excepting ${ }^{9}$ some few who say [the opposite ${ }^{10}$ ]. And so it would seem, for ${ }^{11}$ [from] all that one can get ${ }^{12}$ out of the book, according to its plain-meaning, ${ }^{12}$ [it is evident that] he knew nothing of the Law of Moses, nor of the fathers of old, ${ }^{13}$ nor of the statutes of Israel and its ordinances. And all his words are the words of a pious and upright man, who ${ }^{14}$ does not belong to the Law of Moses; nor was it possible for him to know anything of ${ }^{15}$ it, [inasmuch as], according to what will be clearly shown farther on, he was before Moses, much more before the giving of the Law. And some ${ }^{16}$ would make him related to Nahor, the brother of Abraham, ${ }^{17}$ which is also a thing not out of the way.

\section{THE ${ }^{18}$ PLAN AND CHARACTER OF THE DISPUTE, AND THE ${ }^{19}$ PRINCIPAL FEATURES OF THE REASONINGS ${ }^{20}$ BETWEEN JOB AND HIS COMPANIONS.}

If we ${ }^{21}$ take a general survey of the main ${ }^{22}$ features of the subject, and of the words, which the writer has put in the mouth of every one of his ${ }^{23}$ personages to whom he has ${ }^{23}$ given a mouth in his book, we shall find that he has ${ }^{24}$ preserved his subject-matter in proper form and fitting order, in accordance with that which the case ${ }^{25}$ required of him for the ${ }^{1}$ complete attainment of his object in this composition - every one speaking according to the 2 character, which he lias ${ }^{3}$ assigned him. So the dispute ${ }^{4}$ gradually rises according to the nature of its subject ${ }^{4}$; ${ }^{5}$ in the beginning it is carried on gently, but afterwards with more and more violence, the discussion waxing more and more vehement in proportion as the lieat of the disputants grows fiercer and ficrcer.

${ }^{9 \prime}$ there are saying, there are who say. $\quad{ }^{10}$ i.e., that he was not an Israelite. "quant à tout ce qu'il $y$ a à faire sortir (tirer). "from the plain-meanings of the book. ${ }^{12}$ See p. lxviii, note ${ }^{\prime \prime} . \quad{ }^{13}$ and not a thing of, Sc. ${ }^{14}$ [is] not of the Law of Moses. $\quad{ }^{15}$ this. $\quad{ }^{16}$ wish to relate him, make him related, after Nahor. $\quad$ and [as for] this too, it is not a far (improbable) thing. See note ${ }^{4}$. $\quad{ }^{18}$ arrangement, disposition, plan $=$ in the heading of the first section; but הכונה also (see infra, notes ${ }^{2},{ }^{13}$ ), means disposition, character, so I think we might transl. הכhere plan and character, which nearly agrces with essentinl arrangement and essenee, the renderings approved of by I). Bernard. ${ }^{19}$ root; i.e., the essence, mair features of. $\quad 20$ which [are, take place] between. $\quad{ }_{21}^{21}$ set, place (take) a general look, glance upon (at). $\quad{ }_{22}^{22}$ root; see note ${ }^{19} . \quad{ }^{23}$ men. $\quad{ }^{23}$ set, assigned. 24 kept the form of the subjects on (or, according to) the proper order. By suljects BenZev seems to understand the different personages, their language, arguments, and all that appertains to them; and all these diflerent parts of his sulject (see line 1 of this par.), or subjeet-matter, the writer has, whilst taking care that each part shall be consistent with itself throughout, so skilfully arranged and fitted together, as to form an harmonious and artistically graduated whole. ${ }^{25}$ [was] making him a debtor, condemning him, i.e., obliging him, requiring, exacting of him, making it his duty.

'perfection of. $\quad 2$ his disposition; sce supra note ${ }^{14}$, and infra ${ }^{13}$. ${ }^{3}$ singled nut for him, set apart for him, appropriated to him. "ascends by degrees. "i.c., as one might expect from the nature of the subject. ${ }^{3}$ its beginning [is] gentle-things, but after this, it is hard, hard (i.c., violent, riolent, inereasing in violence); according as the heat of the disputants makes itself strong (beeones strong, mighty), the argumentation (dicussion) strengthens itself. התגבר is the inf. and not the past. 
${ }^{6} \mathrm{Job}$ is the chief and principal [personage]; his arguments are many and forcible, and ${ }^{7}$ more in unison with knowledge and intelligence ${ }^{8}$ than the arguments of his companions. And he is always ready to return answer ${ }^{9}$ to his three friends, Eliphaz, Bildad, and Zophar, who combat his words ${ }^{10}$ alternately, sometimes one, and sometimes another; and he overcomes them, one after another. All lis words ${ }^{11}$ from beginning to end [are] ${ }^{12}$ like [those of] a just man; his ${ }^{13}$ disposition is ${ }^{14}$ kind, ${ }^{15}$ and though readily irritated, he is readily ${ }^{16}$ conciliated ; [he is] mighty in power to bear ${ }^{18}$ afflictions, yet ${ }^{19}$ remains steadfast in his righteousness, and, if here and there, in the fury of his spirit, ${ }^{20}$ he rashly utters words [that are] not right, respecting the ${ }^{21}$ Omniscience and Providence [of God], he speedily repents, and again makes straight ${ }^{22}$ that which he had made crooked ${ }^{23}$ in his language. The ${ }^{24}$ opening words of his discourses are for the most part with lamentation and wailing, but he ${ }^{25}$ closes [them] with words which excite pity and compassion.

Eliphaz is the first of those who answer Job. ${ }^{26}$ In the beginning, his words are words of consolation and pity, for who would not have pity upon ${ }^{27}$ one suffering cruel afflictions, when he speaks in the bitterness of his soul, and who would not for a little while forgive [him] his words? But one by one his words ${ }^{25}$ become

${ }^{6} \mathrm{As}$ for Job, he is the head and the root. $\quad$ 'joined to, connected with knowledge, \&c., or" might it be rend., joined, put together with more knowledge and intelligence, than, \&c.? the position of the is, perhaps, against it. ${ }^{8}$ over, beyond. For this use of comp. Job xxiii. 2. ${ }^{9}$ towards, against. ${ }^{10}[$ in $]$ successions, changes. $\quad$ "from his head (beginning) and (even) unto his end. ${ }^{2}$ The Hebrews having, no expression exactly equiv. to that of, those of, \&.c., are obliged either to leare it out (as here) or to repeat the subst. which they freq. do. Thus we might have had here ברברי אים צריק See Append., p. 586, note $\ddagger$; and supra, p. xlix, note ${ }^{11} \quad{ }^{13}$ See note ${ }^{2}$, and p. lvii, note ${ }^{18}$. ${ }^{14}$ good. ${ }^{15}$ [he is] easy to be irritated, but easy to conciliate. It is much better, I think, to supply הוּ (which is freq. omitted before parts. and adjs., see App., note on

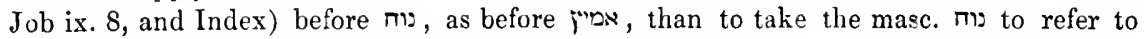
the fem. הכונה, though this constr. would be quite possible. See p. liii, note ${ }^{38}$, and Addenda, on p. 386 (in Comm.). 16 לרצות should prob. be pointed (see Job xx. 10), for though לכוש is the Kal, and so must mean To BE irritated, I do not know that $\mathrm{Kal}$ ) can = to be appeased, conciliated - a meaning which seems to be appropriated to the Rabb. התרצה (see Buxtorf). 1s or chastisements. ${ }^{19}$ [is] standing, abiding, enduring. This might mean, yet he persists in his righteousness, i.e., in asserting his righteousness, but this does not agree with what precedes, or what follows, where Ben-Zev praises Job. 20 thrusts out, i.e., rashly or angrily utters, gives vent to (the Germ. ausstossen). $\quad{ }^{21}$ knowledge, i.e., as applied to God, Omniscience. See note in Conm. on דב Job x. 7. ${ }^{22}$ the perverted (crookerl), which he had made crooked (perverted).

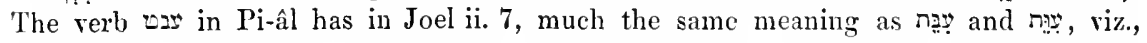
pervertere. It is scarcely probable, I think, that עות , עות a mough this as following מעוח (part of the same verb) would, perhaps, be a more idiomatic IIebrew. [Ben-Zev has עב w see p. lxxiii.] ${ }^{23}$ or with his tongue. Dr. Bernard pronounced in farour of the rend. given in the text. ${ }^{21}$ the opening of the words of his replies (lit. reply). $\quad{ }^{25}$ [is] ceasing, ceases, breaks off. ${ }^{26}$ the beginning of his words [is]. See supra note ${ }^{5} \quad{ }^{27}$ one bearing hard (cruel) afflictions (or chastisements). See supra note ${ }^{18}$. $\quad 28$ are turned into hark, cruel ones. Observe 
harsh, and he turns [round] as though ${ }^{29}$ he had doubts about the righteousness of Job, and ${ }^{30}$ hides suspicion ${ }^{31}$ in the secret covert of his words, till at last he removes the veil from his face, and no longer covers his words with the ${ }^{3 z}$ cloak of concealment, but rebukes Job with a high hand, with words of censure, and lays to his charge that his own foolishness has ${ }^{33}$ perverted his way, and [yet] his heart frets against Jehovah. And in every ${ }^{34}$ one of his replies he arouses the ear of the hearers to attend to his words, for with him [are] great and ${ }^{35}$ hidden things of ${ }^{36}$ sublime knowledge.

${ }^{37}$ When Bildad comes forth ${ }^{38}$ to stand up against Job, the soul of the disputants has already become embittered; ${ }^{33 \prime}$ their hearts have waxed hat, and their spirits stormy ; so [he (Bildad), being already] ${ }^{39}$ in anger and fury, it was no longer time [for him] to distil ${ }^{40}$ pleasant speeches, and ${ }^{41}$ gentle words like dew at the commencement of his speeches, as Eliphaz [had done], who ${ }^{42}$ spake before him. But, for all that, he was guarded at the beginning of his speeches, and ${ }^{43}$ entered into discourse with Job with ${ }^{44}$ reasonable words, and ${ }^{45}$ with the assurance [that], provided his afflietions ${ }^{46}$ (as he himself said) had not been preceded by transgression, then a great deal of good [was still] stored up for him, and a good ${ }^{47}$ reward, according to his works; when, however, the dispute ${ }^{48}$ becomes more vehement, he speaks ${ }^{49}$ harsh words against this oppressed and aflicted man, ${ }^{50}$ without compassion or mercy, and even the ${ }^{51}$ conditional language he at first

that דבר is made fem., or used both as a masc. and fem., and comp. supra note ${ }^{15}$; but,

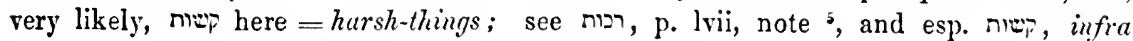
note ${ }^{49}$, and p. xlvi, note ${ }^{19}$. ${ }^{29}$ doubting. $\quad{ }^{30}$ wraps up, hides. $\quad{ }^{31}$ i.e., in the ambiguity of his words, in his ambiguous words. ${ }^{32}$ garment, or mantle, cloak. $\quad{ }_{33}$ overturned his way, i.e., ruined him; notice the masc. verb following the fem. noun, though in Prov. xix. 3, whence the lang. is borrowed, the verb is fem. $\quad{ }^{34}$ reply and reply. $\quad{ }^{33}$ guarded, kept, hidden-things. Comp. Isa.

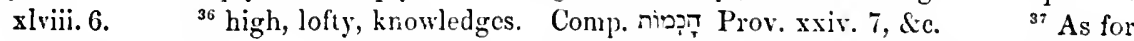
Bildad, when he. $\quad{ }^{3 s}$ standing up to meet. $\quad{ }^{39 \prime}$ and the hearts, Sc.; cf. sumra, p. liii, note ${ }^{36}$. היה דin to be in a rage with one, is found 2 Chron. xvi. 10. "sayings, words, of pleasantness. "words of rest, quietness, gentleness. ${ }^{42}$ preceded him. ${ }^{43}$ entered to speak, upon speaking, began to speak. דב must, I think, be a verb (꼭), and not a subst. "words of taste, discernment (see Job xii. 20), judgment. ${ }^{45}$ with the condition. ${ }^{46}$ were, according to his [own] words (i.e., as he himself said, maintained), without transgression before them. sz requital, retribution, recompense. $\quad$ ts makes itself strong, mighty. See note ${ }^{5}$. " ${ }^{19}$ hard, cruelthings. $\quad{ }^{50}$ away from, apart from, no (i.e., any] compassion, de., i.e., so that there is

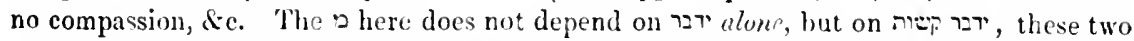
words forming together the opposite ille to that expressed by המיר a for, when $D$ is thus used pricaticely after verbs, it is always prefixed to a worl (verb, subst., \&c.) expressing either just the opposite to, or something remored from, in opposition to, contrasted, or incompatible, with, the notion eontained in the verb. See note in App. on Job xix. 26. 'The $i^{\mathrm{w}}$ here is not abs,lutely necessary, but, as is not unfreq. the ease with a double negative in Heb., imparts much additional force, and expresses the total absence of any compassion or pity, whilst at the same time it shews unmistakeably how the $D$ is to be

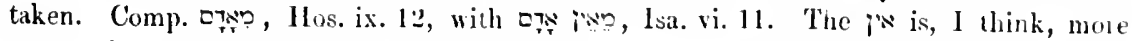
commonly added when we can use any in Engr. $\quad$ st condition which he conditioned to 
made use of to him, he ${ }^{52}$ removes from him, and ${ }^{53}$ asserts in the most absolute manner that his afflictions are according to his works, and that for his sake the ${ }^{54}$ order of creation ${ }^{55}$ cannot be altered. For why [says he], if the end of all wicked men is ${ }^{56}$ evil, should he thus murmur at his lot, and how can he hope for good? And ${ }^{57}$ after this he depicts the end of the wicked with ${ }^{58}$ very cruel wrath, and makes a comparison of their calamity with the calamities of Job ; and, in his last reply, he ${ }^{1}$ introduces nothing new, as though there was ${ }^{2}$ nothing left him which he had not already said, but he [again] rebukes the crushed man ${ }^{3}$ censoriously.

${ }^{4}$ Zophar is the least among them, and his degree does not come up to the degree of his companions who preceded him, in ${ }^{5}$ argument or in poetry of language. And, like ${ }^{6}$ an echo, he only ${ }^{7}$ repeats and reiterates the words of Bildad; and, in order to increase the ${ }^{8}$ brilliancy of his ${ }^{9}$ figures, he ${ }^{10}$ strains and ${ }^{11}$ exaggerates his ${ }^{12}$ language, and ${ }^{13}$ amplifies it ${ }^{14}$ without saying one new thing. And inasmuch as he ${ }^{15}$ has not power to reason with words of ${ }^{16}$ wisdom and understanding, behold! he is the first who ${ }^{17}$ draws back from disputing, and puts his hand to his mouth.*

* Ben-Zer, of course, like many others, thought that Zophar spoke only twice, whilst the other two friends each spoke three times, but the reader will find that, according to our arrangement of the book, Zophar really speaks three times. (N. of Ed.)

him. $\quad{ }^{52}$ or it may he, le goes back, withdraws, from it (the condition) see Job xxiii. 12. The rend. given in the text is that sanctioned by Dr. Bernard. המיש is used both trans. and intrans. $\quad{ }^{53}$ declares absolutely with perfect absoluteness. ${ }^{54}$ orders of. $\quad{ }^{55}$ camnot alter themselves. Ben-Zev is very fond of Hithpa-als. See notes ${ }^{48},{ }^{5}$. $\quad{ }^{56}$ bad, calamitous, miserable. $\quad{ }^{57}$ with this. See p. xlvi, notes 11 and "1, where $\pi$ is transl. in addition to this, and notwithstanding this, resp. Here it may either mean after this, as in the text, or along with this, at the same time. I)r. Bernard sanctioned the first of these rend., and I think this is the best, for Ben-Zev is evidently alluding to chap. xviii., in the first part of which Bildad tells Job "the earth cannot be forsaken for him," i.e., the order of creation cannot be altered on his account, and then goes on to describe the terrible fate in store for the wicked. Still along with this might be understood in much the same sense. ${ }^{58}$ cruelty of wrath exceedingly. מאר seems to be used nearly as an adj. See Comm. and App. on Job xxxv. 15.

${ }^{1}$ he does not make a thing (or word) new. " not left to him some (any) thing which,

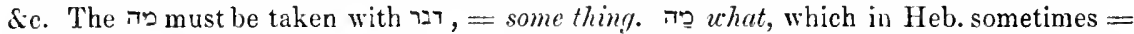

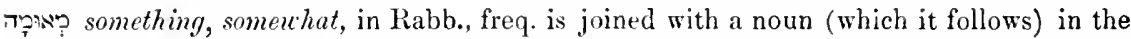
sense of some. See Buxtorf s. $v$. So the Germans familiarly use vas=etwas, and say, etwas Wilch, lit., sonething milk=some milk. ${ }^{3}$ with rebuke, reproof, reproach, upbraiding. 'As for Zophar, he is the least who is among them. ${ }^{5}$ arguments and poetries. ${ }^{6}$ the sound of mountains, borrowed from Ezek. vii. 7 , where Ben-Zev transl. הִ echo. The more usual Rabb. for echo is the very expressive $t_{i}$ g the daughter of a voice. "doulles and repeats. ${ }^{8} 7$ (Ezek. xxrii. 16, xxriii. 13, \&c.) is a precious stone, by Ben-Zev and others interpreted emerald, by Sept. ä $\nu \rho p \xi=$ carbuncle. Here it seems to be used metaphorically = brilliancy. Similarly above Ben-Zev used vermilion = bright colours in general. See p. lv, note ${ }^{32}$. 10 extends, amplifies.

14 without making new a word. 9 figure, figurative language. has not strength enough left, 'or simply, has not strength enough. ${ }^{16}$ knowledge. 1. See Isa. i. $t$, whence the expresion has been borrowed. Ben-Zev there transl. 
And there are those who divide the ${ }^{18}$ controversy into three ${ }^{19}$ parts, the first part from chap. iv. to chap. xv., the second from chap. xv. to chap. xxii., and the third from chap. xxii. to chap. xxvi. In the ${ }^{20}$ first, Job has [just] ${ }^{21}$ come so far in his arguments as to shew to his companions that they have not 22 the least superiority over him, and that there is not one thing which they know ${ }^{23}$ that is concealed from him, [and that] therefore they are not ${ }^{24}$ competent to answer his words, and make all his murmurings subside. And he then ${ }^{25}$ lays his cause before God-when he says [namely, chap. xiii. 3], But it is to the Almighty that I wish to speak, and to reason with God that I desire-and all the ${ }^{26}$ ordering of his words is before God, may He be blessed! The second dispute is ${ }^{27}$ the fiercest one, and in it the arguments ${ }^{28}$ are hurled backwards and forwards with the ${ }^{29}$ extremest violence. In it Job, in the ${ }^{30}$ vehemence of the bitterness of his soul, ${ }^{31}$ goes so far as to declare positively that only the way of the wicked is prosperous, [and that] all ${ }^{31}$ 'they that deal very treacherously ${ }^{32}$ enjoy peace, [for he says], (chap. xxi. 7), Why do the wicked live? They become old, yea, grow mighty in power, \&c. Zophar seeks to ${ }^{33}$ overthrow his words, but the soul of Job has alreacly become ${ }^{34}$ too much embittered for [him] to give an attentive ear to his words, and in chap. xxiv., ${ }^{35}$ when he rehearses the deeds of the wicked, ${ }^{36}$ whose way, for all that, is prosperous, ${ }^{3 \pi}$ he reiterates the assertions which he hat matle in chap. $x \times i$. ,

it sich zurïcliziehen, sich entfernen. For the connection between strangeness and withdrawal to a distance, remoral (Entfernung, éloignement), comp. Job xix. 13, where

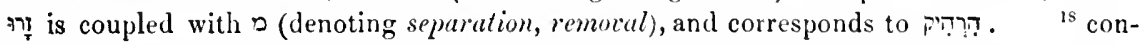
troversies, disputes. $\quad{ }^{19}$ or divisions. $\quad{ }^{20}$ first controversy, i.e., the first division of the controversy. "2l reached, attained. Comp. the Fr. est PARvexu a démontrer; and see infra ${ }^{31}$. ${ }^{22}$ superiority over him [in] anything. See 1 Sam. xxi. 3, where מאומה seems to be used adverbiclly $=$ in anything, in any respect, at all; though, perhaps, it is used adjectirally here, like מין יהרין מימה would hare much the same meaning as in ${ }^{\prime N}$. ${ }^{23}$ and it is hidden. $\quad "$ fit, suitable. ${ }^{25}$ sets, directs, his cause to God. ${ }^{26}$ arrangements, orderings. The meaning, of course, is, "and all his words are ordered," or, "he orders all his words." In chap. xiii. 1s, he says, he has ordered his cause (before God). ${ }^{27}$ the hard, harsh, cruel one par excellence, i.e., the most hard, \&c. See p. xhiv, note ${ }^{21}$. $\quad{ }^{28}$ lit., twist, entwine, interweave, themselves, and so interlace, intermingle, pass to and fro, are bandied about. Just as an interlueement of threads is produced by the swift to and fro movement of the shuttle, so here a ueb of arguments is formed. Comp. also our to retort, lit., to twist (hurl) back-torquere meaning both to twist and to vibrate, hurl. Originally I had turn, which looks as if I had read סבג from, but the absence of a ' (Full Chowlem) after the $ה$ is against this reading, else the word would yield good sense. Note the Hithp. which is eertainly much more freq. used in Rabb. than in Heb. See $\mathrm{p} . \mathrm{k}$, note ${ }^{55}$. $\quad{ }^{29}$ perfection, or extremity, of strength, violence. $\quad{ }^{30}$ strength. $\quad{ }^{31}$ reaches, attains, arrives, to declare, at declaring, absolutely, i.e., goes so far as to declare absolutely, positively. See note ${ }^{21}$ " s"deceivers of deceit, or they that deceive deceit, i.e., deal very" deceitfully, treacherously. The expression is borrowed from Jer. xii. 1, and so is the preceding elause. ${ }^{92}$ or happiness, prosperity. ${ }^{33}$ or to contradict; but to destroy, demolish, and we speak of demolisting a man's arguments. $\quad$ st bitter frum giving, i.e., so bitter as not to give. See p. lix, note ${ }^{511}$. ${ }^{35}$ in his relation of (lit., from ; $c$ f. the Germ. von, and Fr. de $=$ of and from). $\quad{ }^{36}$ and for all that their way is prosperous. ${ }^{3 i}$ Job doubles, in order to strengthen, confirm [them], his words which he had asserted in 
by way of enforcing [them]. Bildad ${ }^{38}$ returns answer in a short discourse (chap. $\mathrm{xxv}$ ), ${ }^{39}$ [as having] no [longer] speech or language, and $J_{\mathrm{ob}}$ remains ${ }^{40}$ the victor over his companions, and, ${ }^{41}$ like a lion, or fierce beast, he ${ }^{42}$ tramples upon the high-places of his companions, whom he has vanquished. Then the spirit of his wrath ${ }^{43}$ becomes tranquil [and] is at rest, and he repents bim of lis words, which he spake concerning the prosperity of the wicked, and he asserts ${ }^{44}$ the reverse (chap. xxvii. 8), For what is the hope of the hypocrite, dce? Will God hear his ery, \&c.? and all [the rest of] the matter there. And he adds a poetical piece with lofty figures ${ }^{45}$ which forms a crown to the whole book, and he concludes (chap. xxviii. 28), Behold! the fear of the Lord that is wisdom, and to turn away from evil [that is] understanding." And in the three chapters which 'follow, he ${ }^{2}$ again speaks of the dignity which had

* The reader will perceive that according to our arrangement, the last eleven verses of chap. xxvii., and the whole of chap. xxviii., are spoken not by Job, as Ben-Zev considered them to be, but by Zophar. (N. of Ed.)

chap. xxi. According to this, which seens to me the true construction, דבריי

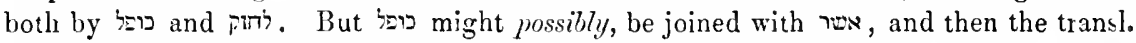
would be, "Job repeats, in order to strengthen (confirm) his words, that which he had asserted," \&c., but this is less natural, for דבירי A seems to belong to A third mode of understanding the passage is, "Job repeats (i.e., repeats what he had before said, the Fr. se répète), in order to strengthen, confirm, his words, which," \&c. And one does not see why כפל should not be used neutrally in this way, as (to do a second time, repeat) certainly is. I do not, however, know that is thus used, whilst in the pass. quoted from the Talmud p. lvi, it is used acticely, and in sect. 7 , par. 5 , line 2, it is followed by an acc. 'רבר, just as here, and = to repeat. Lastly, in might be taken absolutely $=$ to strengthen, i.e.,

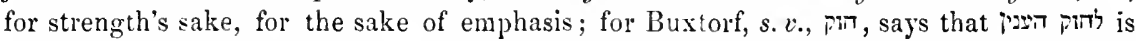
freq. used $=a d$ corroborandum sensum, ad emplasin. In all these explanations I have

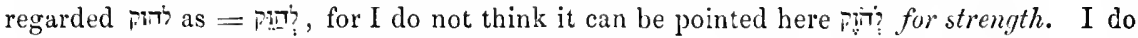
not exactly know how Dr. Bernard understood the pass. At all erents, whichever construction be the correct one, the meaning is quite clear. ${ }^{38}$ [is] returning his words, i.e., returns answer, says what he has to say in answer. דבריי might, possibly, refer to $J o b ' s$ words, but, in this sense, Ben-Zev commonly uses השיב על דבריו, as in lines 3-4 of this paragraph, sect. i., par. 4, line 10, sect. iv, par. 7, line 4, \&c. $\quad{ }^{39}$ see Ps. xix. 4, whence the expression is borrowed. $\quad{ }^{40}$ the one vanquishing his companions. $\quad{ }^{41}$ see Isa. xxxv. 9, whence this expression has, I believe, been taken; and for the supposed

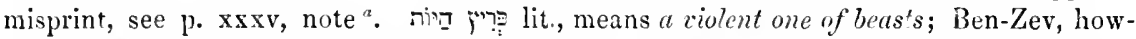
ever, gives ${ }^{\prime}$ in the pass. in Isa. the meaning of verwegen, vermessen=bold, audacious. ${ }^{42}$ treads upon the heights, high-places of bis companions, i.e., tramples upon their haughty crests, casts them down from the lofty position which they had assumed. ${ }^{43}$ This pass. is borrowed from Isa. xiv. 7. Note the omission of 1 , and see note in

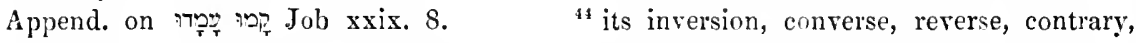
opposite. $\quad{ }^{45}$ the crowning (i.e., which are crowning), the whole book. היפרים course refers to משל figures, but in English it is better, I think, to transl. as though it referred to מליצה.

' [are] after it. " he returns to call to remembrance, commemorate, make mention of. 
been ${ }^{3}$ his, and of his prosperity in the days of his youth, and ${ }^{4}$ of his righteous deeds, which he had done, and how the whet [of fortune] has been turned against him now.

As to Elihu, he also was a man wonderful for [his] wisdom, but he ${ }^{5}$ could not bring himself to stand up to speak before ${ }^{6}$ these very old men, ${ }^{7}$ he himself being young, until they were silenced and Job was the victor; then came he forth to meet Job, ${ }^{8}$ thinking in his heart to prevail against ${ }^{8}$ him by the superiority of his wisdom, more than his friends [had been able to do]. So time after time he ${ }^{9}$ challenges $J_{0} b$ to engage with him in dispute, but Job keeps silence, and does not ${ }^{10}$ care to answer his speeches. And in ${ }^{11}$ the beginning of his words it is his custom to take hold of "11" some of the words of Job, and "1" to oppose them ;

${ }^{3}$ to him. $\quad{ }^{4}$ his righteousnesses. $\quad{ }^{5}$ The interpretation given abore had Dr. Bernard's sanction and makes very good sense, and I, therefore, leave it, although it is not altogether

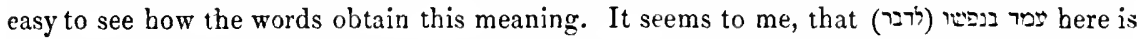

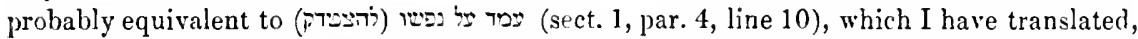
stands up for himself (to justify himself), and we may comp. in the same par., line 13, ניב איוב כשפוד ברול על צמדו (לאשר) Job tands like an iron pillar upon its base (to praise), i.e., was extremely firm and resolute in praising. The meaning here would then be he did (or could) not stand up for himself to speak, i.e., he shrank from speaking, could not bring himself to speak; and this is no doubt the meaning, for Ben-Zer eridently wishes to express here in other words the same meaning which is conveyed in Job xxxii. 6, where Elihu says: על מן therefore hung I back (xar ich schiuchternBen-Zer) and was afraid to shcw yru my opinion. The difliculty here is that in the transl. in the text, to stand is taken quite in a conerete sense, whilst in stunding up for oneself, to stand is more funuratively used, or rather is merged in the meaning of resolution.

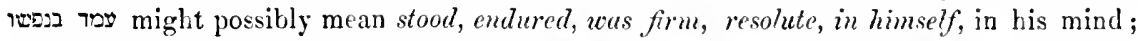
and then the meaning would again be he lid (or eould) not bring himself to speuk, but not to stand (up) to speak, becauve here again, was has already been userl up in eliciting the meaning to bring himself. Comp. Ezek. xxii. 14, ר. ENDURE? and where Ben-Zer gives עמי the maning of Muth hatch. And, indeed, the phrase 2 he explains in much the same manner, for he says its meaning is

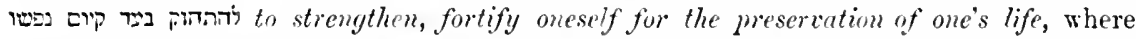

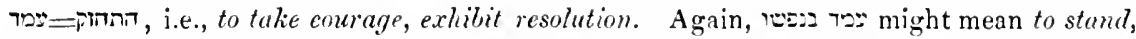
take up one's stanl, upon one'self, to rely upon, have confidence in meself. But this again gives much the same meaning. ${ }^{6}$ the very old men. See Ch. xv. 10. ${ }^{7}$ and he a young man. ${ }^{8}$ and he [was] thinking, or thought, according as we take it to be the pres. part. or the past. ${ }^{81}$ Job. See p. lxv, note ${ }^{24}$. $\quad{ }^{9}$ he setks that Job should be mixed up, mix himself up with the dispute, i.e., he tries to bring about that .Job should, Sc.; or he asks that Job should mix himself up, i.e, he asks, challenges Job to mix himself up, engage. 1)r. Bernard seems to hare preferred the latter interpretation, which agrees better with what really took place (cee chap. xxxiii. 5, xxxii. 4). See infia note ${ }^{12}$. For the form

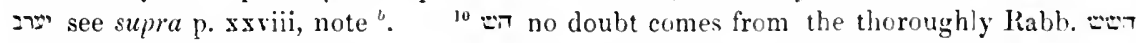
sollicitum esse, curare (see Buxtorf), though, as far as form goes, it might come from to hasten, or הוש (Rabb.) sentive. The last, however, would hardly make sense unless it could = to give heed; whilst הo to hasten, scarcely yiclds a better meaning, inasmuch as Job, so far from hestening to answer Elihu, did not answer him at all_-unless, indeed, which I think improbable, לא דy = our he made no haste, was in no hur., (to answer), which latter is freq., though rather vulgarly used $=$ he took care not (to auswer). "his first work, i e., in the first part, or chapters, of his discourse; in

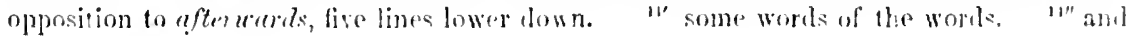


12 and, though he does not absolutely condemn Job, so as to declare, as his companions [had done], that he is a worker of iniquity and has ${ }^{13}$ acted wickedly, yet, behold! he does condemn him, ${ }^{14}$ in that he justifies the judgments of God; and afterwards he ${ }^{15}$ enlarges poetically upon the ${ }^{15}$ awful works of God. And, seeing that one of the ${ }^{16}$ attacks, which Elihu made upon Job, was on account of ${ }^{17}$ his asking that God should engage with him ${ }^{18}$ in dispute face to face, and that he [Elihu] had said that God does not speak with a man ${ }^{19}$ when awake, but only speaks with him in dreams, and [then] opens his ear to instruction, ${ }^{20}$ therefore an answer comes to Job ${ }^{21}$ from God ${ }^{22}$ himself, as it were upsetting the ${ }^{22}$ assertions of Elihu, and putting ${ }^{23}$ an end to his words.

2a' When God answers Job, He does not come to condemn

[he is] opposing them. $\quad{ }^{12}$ and, as for him, although he is not condemning Job, so as to declare absolutely, positively. $\quad{ }^{13}$ done wickedly in his deeds. $\quad{ }^{14}$ lit., from the side of his justifying = from, because of, his justifying, the as The use of the may, however, be explained here. There are two sides to every question, and two opposite ways in which erery moral action at least may be performed. And so here; it was possible for Elihu to condemn Job either directly (explicitly), or indirectly (implicitly), and he adopts the latter course, he turns to the latter side; and from that side, i.e., from the side of justifying God, he condemns Job, and not from the side of declaring him to be wicked. And so again in the case of פל צר הנסין quoted above. Afflictions may come upon man from God, either as a punishment, or as a trial; in the former case, they are on the side of punishment, in the latter on the side of trial. So we may say "to err on the side of humility." In translating, therefore, as I

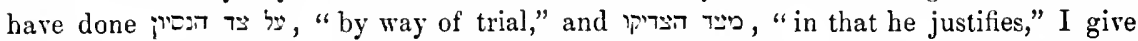
rather the sense than the true meaning of $ד$, which I hope I have shown can scarcely be called pleonastic. $\quad{ }^{15}$ he widens, enlarges poetry. In these cases the noun may commonly be rend. in Eng. by a verb, and the ITiph. by an adecrb. Thus he poetizes widely (at length) would express the sense here. See App. note on Job v. $7 . \quad{ }^{15 \prime}$ prob. the fearful (awful) things of the works of God, for else the adj. would precede the subst.,--though instances of this do occur. See note in App. on ראיזון אob xv. 7. He could not have said

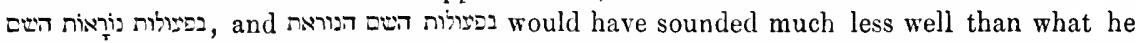
has. I think, therefore, בוראולות may be a part. agreeing with that it may be pointed תișis. It could scarcely be in apposition to $1{ }^{16}$ oppositions (attacks) [with] which Elihu opposed (attacked) Job. Observe that the Heb. are very fond of using a verb with a noun from the same root, whilst we as a rule studiously aroid it. There are many examples of this fondness in this preface. See the first line of the preceding par. They also freq. repeat a subst., where we should either use a different one, or else a pronoun, or even leave the second subst. out altogether. See supra lines 4 and $S$ of this par., and (in the original), line 1 of the next, pars. 5 and 6 of this sect. line 1, sect. ii, par. 7, last line, \&c., \&c. ${ }^{17}$ his petition, request. This is in favour of the interpretation given in the text of מבקש, line 3 of this par. (see note ${ }^{9}$ ). $\quad{ }^{19}$ to dispute. $\quad{ }^{19}$ on [his] waking, being awake. ${ }^{20}$ on account of this. ${ }^{21}$ from with God. $\quad{ }^{22}$ in Himself, in propria personat. ${ }_{229}$ words. $\quad{ }^{23}$ ends. See Job xriii. $2 . \quad{ }^{23 \prime}$ on God's answering Job. Notice that a substantice here govcrns an acc., and for examples, in the Bible, see note in append. ou "רol Job vii. 19. We have here one of the innumerable instances which shew that the IIebrew writers (i.e., those who write in Hebrew), although in their Grammars, Commentaries, \&ic., they do not note all the idiomatic constructions so fully as their Christian (non-Jewish) rivals, such as Gesenius, Ewald, \&ce, yet are really perfectly familiar with 
${ }^{24}$ Job, and pronounce him guilty, ${ }^{2 v}$ seeing that He had said, Aud thou hast moved Me to destroy him without cause (chap. ii. 3) ; ${ }^{25}$ nor does He come as excusing Himself for ${ }^{25}$ having afflicted him ; for what is frail man, that he should ${ }^{26}$ examine into the ways of Jehovah, and reckon with his ${ }^{27}$ Maker, to require ${ }^{28}$ of Him an account of His doings ! But what God ${ }^{29}$ urges against him is this, that $\mathrm{He}$ regards it as haughtiness of spirit in a man, ${ }^{30}$ when he seeks to ${ }^{31}$ pry into the counsel of Jehovah, and into ${ }^{31}$ His superintendence of the world. And ${ }^{32}$ on this account He lays open before him all the treasures of creation, and ${ }^{33}$ puts many and various questions to him concerning the wonders of things created, in order to show him the greatness of the glory of His wisdom, and the depth of His ${ }^{34}$ search-

them, so familiar, indeed, that they are able to use them in writing. The fact is, it is because they are so familiar with these idioms, that they do not deem them worthy of note; the very circumstance that they are not struck by the idioms proves their great knowledge of the language. Thus, an Englishman is much less struck by the idioms in his own language, than a Frenchman is. ${ }^{24}$ Notice the two Jobs, which are awkward Eng., but not in Heb., and see p. lxiii, note ${ }^{8 \prime} . \quad{ }_{24 \prime}$ after that. $\quad{ }^{25}$ also he does not come. ${ }^{25 \prime}$ His afflicting him. $\quad{ }^{26}$ visit upon, i.e., cast one's eyes upon attentively, scrutinize. ${ }^{27}$ his Possessor, Owner, Master. Ben-Zev, howerer, gives the verb קבה in Ps. cxxxix. 13, Gen. xiv. 19, \&c., the meaning of create, in which he has been followed (though prob. unconsciously) by Gesenius. It is probable, therefore, that we ought to translate here his Maker, Creator. And, indeed, Mendelssolm in these two pass. gives קיה the meaning of bauen, hervorbringen, whilst Jarchi says, קis in the pass. in Gen. = though he qualifies this statement by adding - that $\mathrm{He}$, God, made heaven and earth as a possession for himself. The present pass. is, however, no doubt borrowed from Lev. xxv. 50 , where we find

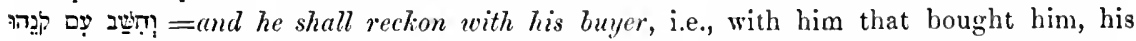
owner, master, lord, so that it is not improbable that Ben-Zer uses pare in this sense - and, indeed, I originally, had Master, which Dr. Bernard sanctioned. The consideration of this pass. also inclines me to believe that I have erred in taking השישב עם והש mect. 1, par. 4, line 3 from end (see p. xxx, note ${ }^{R}$ ), to be the pres. part. Kal, for seems to have the meaning of to reckon only in the $P i-a ̂ l$, and if so, rist must be

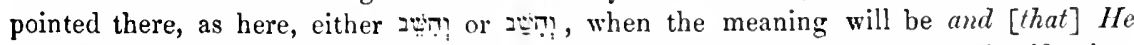
should reckon, or so that He should reckon. ${ }^{2 s}$ from with Him pleading (i.e., justification, excuses), and account concerning His doings. We have transl. $\rceil^{\prime}$ pleading, in Job xxxvi. 17. רין ודשבין is probably a set phrase, though I cannot find any other examples of its use. At first sight there seems to be but little connection between the words, but by comparing their equivs. in other lang. we discover some. Thus השבין = reason in Eccles. vii. 27 , and = the Lat. ratio in more than one sense, while $\eta^{\top}=$ cause, Lat. causa, and cause, and reason like causa and ratio, are certainly akin in meaning. $\quad$ "9 argues, objects, urges against him, charges him with. The sense is of course, The reason why God rebukes him is that $\mathrm{He}$ regards it as haughtiness, \&c. There is, however, some incongruity between the first clause and the second. ${ }^{30}$ who seeks. ${ }^{31}$ see p. xlvii note*.

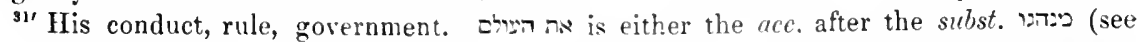
note $\left.{ }^{23 \prime}\right)$, or means with, toureds-but I much prefer the first explanation. If, however, כיהג here has the meaning custom, habit, way (the only meaning given it by Buxtorf?, then will certainly mean with, towards. See sum . p. xlvii, note ${ }^{3}$. The rend. superintendence given above had, howerer, the sanction of Dr. Bernard, and considering the meaning of the root ducere, seems a natural one. $\quad{ }^{32}$ for this. ${ }^{33}$ sets before him questions from [among] various (different) questions. $\quad{ }^{34}$ lit., of the (= His) cyein!, inspection, consideration, contemplation (or scrutinizing glance), i.e., of His view into 
ing-ken, and the recesses of His sublime mysteries, of which the intelligence of frail man ${ }^{34^{a}}$ falls short to comprehend ${ }^{35}$ even a thousandth part, and that everything is arranged ${ }^{36}$ in a good and profitable order, and [that] it is folly ${ }^{37}$ in man to search out the ${ }^{38}$ judgments of God and His ways, because of the ${ }^{39}$ shortcomings of him who ${ }^{40}$ would comprehend, and the profundity of that which is to be comprehended. And this is what the poet said-that the ${ }^{41}$ uttermost we can know is [to know] that we do not know, \&c. ; for this is our portion of all the labour of ${ }^{42}$ our understanding, and of [our] knowledge of Providence. And by this means $\mathrm{He}$ (God) severs the great knot which ${ }^{43}$ is tied in the coils of

created things, amongst which is of course included the heart of man, and especially Job's heart. The allusion is, perhaps, to הָis in Job xi. 7, which is rend. in the transl. the searching-ken of God, and which I have suggested in the Append. may mean the depth (i.e., the unfathomable wisdom) of God, a meaning which may, therefore, also, perhaps, have. That the definite art. in Heb. sometimes $=$ a poss. affix and $=$ his, her, \&c., is well known. See note in Append. on wa․ xxxv.15; note ${ }^{42}$; and p. lix, note ${ }^{38^{\prime}}$. Originally $I$ had the depth of the incestigation [into such matters], and I believe this had the sanction of Dr. Bernard, though he would seem himself to have been doubtful how to understand העיו . Buxtorf does not, inded, give עי עי the neuter meaning, but I see no reason why it may not be used neutrally, as our corresponding terms speculation and investigation sometimes certainly are. The for $m$ says nothing, for words of the same form are freq. used neutrally, as בִּ commentary, composition, treatise, \&c. The def. art. is certainly rather in favour of this view, as is also the use of the word עepth, which is, I think, more appropriate as applied to an investigation, than as applied to a glance, when it would have to be taken $=$ the power of penetrating to a depth. Nor can it be objected that this view does not accord so well with the context, for two lines farther on we have צמק המושג the depth of that which is to be comprehended-or exactly the same sentiment. Moreover, God's discourse is not intended to point out to Job so much the piercing ken of God, of which, as is evident from chap. xxvi., 5, 6, Job was already perfectly aware-as the depth, nay the utter unfathomableness, of the wonders of God's creation, and so, implicitly, of His ways in general, which Job had presumed to pry into. $\quad{ }^{34 a}$ has been, is short. Notice the fem. verb referring to the mase. subst., 5 , which is very unusual in Heb., when, as here, the noun and verb agree in number. See p. xxvii, note ${ }^{b}$, and Ges. Lehrgeb., p. 718. ${ }^{35}$ one thing from (of) a thousand. See Job ix. 3. $\quad{ }^{36}$ upon, according to, the good and profitable order, arrangement. In Heb. the def. art. would be required before in Rabb. this is freq. left out, as the reader will have inferred from the numerous examples of the idiom which occur in this Preface. See p. xlvi, note ${ }^{11}$. The same idiom is, how-

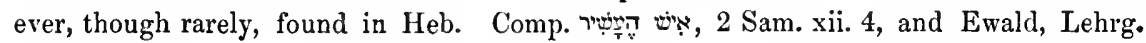
(1863), p. 740 . p. xliii, note ${ }^{7}$ ).

${ }^{37}$ from, on the part of, man.

${ }^{39}$ shortness, imperfection.

${ }^{38}$ or, the ways of God (see participle frequently denotes, in Heb., not the act of the person to whom it is applied, but his intention, or wish, and the same of course, holds good of the past part. See Appendix, p. 543, note *. ${ }^{41}$ the end, limit (or perfection), of that which we know [is] that we do not know. $\quad{ }^{42}$ the understanding, i.e., our understanding. Here again the def. art. replaces a poss. pron. aff. See note ${ }^{34}$. $\quad{ }^{43}$ which takes hold of, cleaves to-or, perhaps, better, which is caught, entangled in, the intertwining, entanglement, coils ; for the expression is taken from Gen. xxii. 13, where פאחז בסבך means caught in a thicket (or hedge). We should, indeed, scarcely speak of " a knot's being caught or entangled in a rope," but I can imagine that such an expression might be used by people who look upon knots as distinct entities, and speak loosely-and, incleed, I am informed by a lady that workwomen 
the mighty cable, which is fastened ${ }^{44}$ at its two extremities [namely], [to] the Prescience (of God) ${ }^{45}$ at one end, and [to] the Providence [of God] at the other end.* The pleasantness of the ${ }^{46}$ glorious beauty of the poetry of this book is felt in the heart; but with the mouth ${ }^{1}$ it is not possible to express it in words and speeches.

\section{V.-WHO THE WRITER OF THIS BOOK [WAS], AND IN WHAT}

\section{LANGUAGE IT WAS WRITTEN.}

${ }^{2}$ In every investigation which we may endearour to make concerning this book, we meet with doubts and different opinions, ${ }^{3}$ respecting which it is impossible to decide with absolute certainty, which of the opinions is ${ }^{4}$ correct, and this also is the case in our present inquiry, [namely] as to who wrote the book of Job, and in what language it was written. The opinion of the sages ${ }^{5}$ of the Talmud (Bava Bathra, fol.† 14), [is that] Moses wrote his own book, and the book of $J o b$; but this ${ }^{6}$ cannot be an opinion generally agreed upon, ${ }^{7}$ for, if we look to the fact that there is one [sage], who says Job was in the days of

* i.e., He summarily disposes of the great difficulty which there is in reconeiling the Fore-knowledge with the Providence of God, i.e., in understanding how it is that, if God fore-knows what is to come to pass, He allows so much that is wrong to take place; and His summary solution consists in pointing out to Job that man should not transgress his limits, and endearour to penetrate mysteries which, although of course admitting of a satisfactory explanation, yet never can be fathomed by a being of such limited intelligence -though of such unlimited conceit-as frail-man. See p. xlvii, near end (of text). - Note of Editor.

+ In the edition in the British Museum, it is fol. 15.-Ed. IS63.

do talk of knots being caught in their thread. It is merely an inversion of "a rope (string, thread, \&c.) caught in a knot," which I certainly have heard myself. "at (to) two heads (i.e., to two points of support, Fr., points (tapmii), [which, are] the fore-knowledge, \&c. . cable, as the two points to which the two ends are fastened, as the chains of a suspension-bridge are to its abutments; and these two points, these two abutments, here are the Prescience of God on the one side, and the Proridence of God on the other, and the cable (or chains) represents the connection between these two, the knot (i.e., the difficulty) in which God refuses to untie, and severs. ${ }^{45}$ at [the] end on this [side], and . . . at [the] end on this [side]. $\quad{ }^{46}$ glory of the beauty.

1 there is not to babble, i.e., it is not possible to express eren weakly and feehly. ${ }^{2}$ [as for] every in restigation and investigation (i.e., every single investigation) which we may endearour to know (i.e., to prosecute, or to ascertain the truth of) concerning . . . . there are in it, \&c. ${ }^{3}$ as to which (or, which) it is not (i.e, it is impossible) to deeide with complete (perfect) absoluteness. $\quad$ justice. $\quad{ }^{5}$ in. ${ }^{6}$ is not able to be. ${ }^{7}$ for, according to (i.e., if we consider, julge from) the one who say's Job was in the days of Ahasuerus, and similirly from (i.e.. judging from, aecording to) those who retard (delay, defer) his existence, it is impossible [for them] to agree that IIoses wrote his book. מ would thus almost $=$ ל which might be substituted for it. Iit., and as like, similar, $=$ and the like, and likewise, and similarly. See the vocabulary in 1)r. Bernard's Maimonides. $\quad w$ might, however, perhaps, be taken $=$ conceming, with regard to, (as 
Ahasuerus, and that others again place his existence later [still, we see that ${ }^{7}$ ] it is impossible that they can have agreed that Moses wrote his book (i.e., the book of $\mathbf{J o b})$.

But, if we ${ }^{8}$ appeal to wisdom, and address intelligence, and ${ }^{9}$ also listen to our own feelings, ${ }^{10}$ [behold] they all bear witness to, and declare, the early origin of this book, and ${ }^{10}$ that it is ancient of days ; and in those early days there was not found a man ${ }^{11}$ more proper and fit to write a book so precious as this, and in such sublime poetry as this, than Moses the man of God, and this book ${ }^{12}$ is quite worthy to be attributed to him.*

* It must not be supposed that all the views put forward by Ben-Zev in this Preface have met with the approval of Dr. Bernard and myself. Ben-Zev generally writes very sensibly, but here he ventures upon ground, from which we have deemed it prudent to keep ourselves aloof (see 1st pref. p. xii), and indulges in speculations, in which, in spite of his assertions, wisdom and intelligence have had but little share. It must not be supposed either that, because I do not think fit to enter upon the consideration of the age of the Book of Job, I have not read what the most eninent modern Critics (?) say upon this point. I have read what they say, but — in spite of Davidson's ultimatum (Introd. to O. T., vol. 2, p. 200), viz., that "Between these limits" [Solomon and the exile] " true criticism will soon fix the proper date to half a century" (I wonder he did'nt say to half a year!)

sect. T, par. 6, line 5 from end דבר מ to speak of, Concernisg, and sect. $\&$, par. 4 , line 6 from end, מש: CONCERNING, WITI REGARD TO, the wonders of created things, thus $=$ = ${ }^{2}$ in sect. 7 , par. 8, line 5)-and then the meaning would be, "and similarly with regard to those, \&c.," i.e., and the same may be said of those, \&c. We could scarcely,

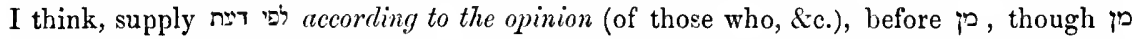

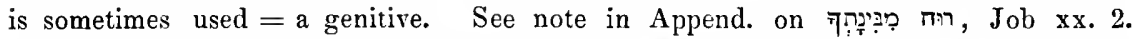
may indeed, perhaps, mean accoraing to those [others], who [also] place his existence late, i.e., as well as the one who says Job lived in the days of Ahasuerus; still I prefer the interpretation place his existence LATER STILL, as being more natural, and I here have the sanction of Dr. Bernard. " "It is freq. necessary in Rabb. to supply some such phrase as $v v$ see that. Comp. the next par., line 2 (note ${ }^{11}$ ); p. lvii, line 3 from top, and ibid., line 7 , where I originally supplied it will be seen that before " he was before Moses." Sometimes, however, we do find an equiralent phrase in Rabb., as sect. iv, par. 1, line 3 (in the transl.). $\quad{ }^{8}$ call to wislom, and to intelligence utter [our] voice. The pass. is borrowed from Prov. ii. 3 , only there ambiguity, for בתן קול לתבונה might well mean, to give, lend a voice to intelligence, make her speak; just as in sect. 7, line 2, we find אשר שם להם פה a mouth, where doubtless גight well be substituted for 2 . ${ }^{9}$ hear (i.e., hearken to) our feelings. ${ }^{10}$ [we shall find, see] that all of them testify and declare concerning the early origin (antiquity). wִ here cannot well be taken with must be regarded as $=\urcorner$ that, and some rerb (such as, we shall sce, or find) must be supplied before it. See supra, note ${ }^{7 \prime}$, and p. xxx, note ${ }^{b} . \quad{ }^{10 t}$ prob. and concerning [its being] ancient of its days.

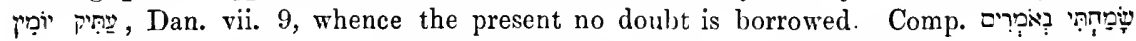

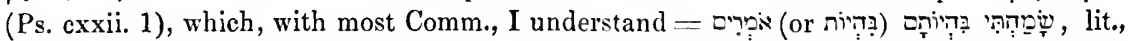
I rejoice on their being saying, or, on there being people-saying (i.e., when they are saying, or, when therc are people saying), פה being understood as in here. here. The root why Ben-Zev used the more difficult adjective. " lit., suitable and made right, fit (i.e., adapted, fit, proper) ....... more than Moses, \&.c. ${ }^{12}$ is 
But as to whether Moses was ${ }^{13}$ the original author of it, and ${ }^{14}$ composed his allegory ${ }^{15}$ in the Hebrew language itself, or whether he was ${ }^{16}$ not the author of it, but [only] the translator of it from one language to another language-this is another question, ${ }^{17}$ and one which must lead him who reflects upon this doubtful point [to the following considerations]:-1. If Moses had been its original author,

- their writings have only confirmed me in the belief which I previously entertained, viz., that, for the want of sufficient data, it is impossible to arrive at any satisfactory conclusion. I would especially recommend Davidson's work to the notice of the reader. His continual substitution of cool assertion for argument is highly entertaining, though I cannot but infer from it, either that his mind has not been properly trained, or that, from constitutional defect, he is totally incapable of weighing evidence. Let me advise those, who place unlimited confidence in the judgment and acumen of these Biblical Critics, to read a letter in the Athenæum of Oct. 24, from Mr. J. Rubens Powell, in which that eminent Art-Critic, Dr. Waagen, is deservedly held up to ridicule for having, in a work of his, unhesitatingly pronounced paintings to be genuine and admirable Claudes, Greuzes, and Reynolds', which Mr. Powell had himself copied from the originals!!! What a pity it is, that it is impossible to subject the dicta of Ewald, Davidson, \&c., to an equally unerring test, for we should, indeed, to borrow Mr. Powell's language, most assuredly find "a marvellously grotesque harvest" of blunders of a similar species! Still, I can almost fancy I hear Moses exclaiming in the indignation of his wrath:-

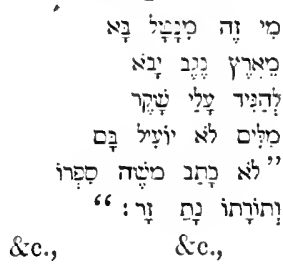

Sc.

beautiful, or suitable, to attribute itself upon (to) him; or, perhaps, it is fit, suitable, as to this book, to be attributed to him, i.e., that it should be attributed to him. It is not easy to say whether were is to be pointed a rabb. word, for which see Buxtorf; or ni: when it would be the fut. Kill (according to Kimchi and Ben-Zev) of the root $\mathrm{n}$, which, however, in the meaning of to be fit, suitable, seems only to be used impersonally. אוץ , however, seems to be used both personally and impersonally. Another instance of the use of a Hithp. ${ }^{13}$ its composer from its root, origin, beginning. $\quad{ }^{14}$ and was parabling his parables, i.e., making his parables, allegories, or, merely, composing his poetical figures, his lofty and poetical language. The expression is borrowed from Ezek. xxi. 5 (A. V.xx. 49). Besides the meaning of parable, Ben-Zev gives to משל the meaning of "lofty and poetical language upon a noble theme." However, from p. lv, end of sect. ii., it would seem that Ben-Kev regarded the book as an allegory, based upon fact, and so allegory may pass here, though the use of the plur. of משל seems to shew that the meaning is rather poetical figures. The aftix in מig might possibly refer to D. its figures. ${ }^{15}$ in the body, substance, of the Ilebrew tongue. 7 is here used as in Heb. and Rabb. ${ }^{2}$. $\quad{ }^{16}$ not its composer, but its translator, from tongue to tongue. ${ }^{17}$ and which brings (suggests) to the one reflecting upon this doubt [the following considerations]. 'This interpretation, which is paraphrased in the text, had, l believe, the sanction of $\mathrm{L}_{1}$. Bernard. Or the meaning may possibly be: "and what it brings (suggests) to him who reflects upon this doubt (duubtful point) is," sce. The punctuation is in favour of this rend. Or, again, (as Mr. Randolph suggests), it may mean : "and which brings him, who reftects, upon (to) this doubt," i.e., surgests this doubt (i.e., the following doulte, 
he would have selected ${ }^{18}$ his clrosen ones [from] among the sons of Jacob, to put these words in their mouth, and not [from] among men who were not of the sons of Israel; ${ }^{19}$ neither would he have been able to refrain from mentioning in it something of the ancient fathers, and of the statutes of God and His laws. 2. If ${ }^{20}$ the book had really been [in] the Hebrew language, whence that great mixture of Arabic words which ${ }^{21}$ have found their way into, and been interwoven in, the poetry of the book?-[a fact], ${ }^{22}$ which shews that the book was not composed ${ }^{23}$ in the purity of the Hebrew tongue.

But what seems right is, that the ${ }^{24}$ real book was written in the ${ }^{25}$ Arabian language, or in the Aramean language, which is kindred to it, and that ${ }^{26}$ it was Moses who translated this book into the Hebrew language ${ }^{27}$ with a master's hand, for he only and no other ${ }^{28}$ could have guided his hands so skilfully as to ${ }^{29}$ preserve

or questions) to him. The objections to this last interpretation are, in the first place, that למציץ is made an accus., instead of a dat., and, secondly, that, while we Do know that the verb

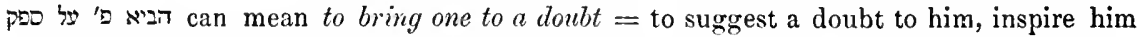
with a doubt (cf., however, p. liv, note, ${ }^{48}$ ). The masc. מביא does not refer so much to the fem. שיאלה, הוא 18 , The construction given above had the sanction of Dr. Bernard, and seems to make the best sense here, but it may be observed that בהזיר might well be in apposition to בני "יקב, and that in the Bible it really does occur twice (viz., Ps. cv. 6, I Chron. xvi. 13), in apposition with ביני ( The meaning would then be, "He (Moses) would have chosen (i.e., made his selection) among the sons of Jacob, his (Moses') chosen ones." הבודר יבהר . Here again Ben-Zev uses a verb with its kindred noun, and evidently on purpose, whilst to an Eng. ear he would have chosen his chosen ones is so unpleasant, that I have substituted selected for the first chosen. See supra p. lxiv, note ${ }^{16}$. ${ }^{19}$ and so (also, likewise) he had not been able, \&c. $\quad{ }^{20}$ the body, substance of, the book, the book itself, the very book, the real, original, book. $\quad{ }^{21}$ have been entwined (interlaced) [and] have come up (been introduced) into the poetries (poetical portions) of the book. The two verbs have been borrowed from Lam. i. 14. Notice the absence of $>$ between them, and see p. lxii, note ${ }^{43}$. $\quad{ }_{22}$ which this [is] shewing $=$ which shews. ${ }^{23}$ according to the purity. 5 is freq. used in this Preface $=2$ (or rather $=$ our in), as in sect. 7 , last par., line 5 from the end. "In the purity of the Hebrew tongue" will then = "in pure Hebrew." ${ }^{24}$ See note ${ }^{20}$. ${ }^{25}$ tongue of [the] Arabian. When ir is followed by a

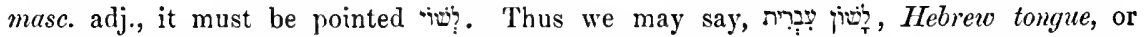

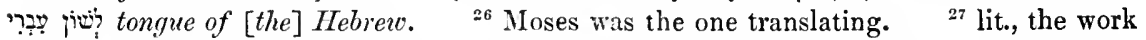
of the hands of an artificer, a cunning workman. The expression is borrowed from Cant. vii. 2. ${ }^{28}$ had (would have) been able to guide, \&c. If the rend. in the text is correct, Ben-Zev seems to have made up the Pi-âl אמ⿰氵

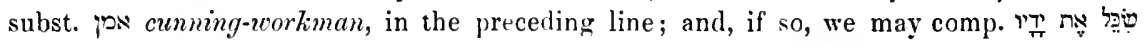
(Gen. xlviii. 14), transl. in the A. V. he guided his hands wittingly, and which Ben-Zev, who renders it in much the same way, very likely had in his mind. We should, however, also obtain excellent sense by giving readily obtainable from the notion of steadiness or firmness which there is in the root, as shown by the pass. (Exod. xvii. 12) and his hands were steadiness, firmness, i.e., firm, steady-by האבי = to stand still, in Job xxxix. 24,-by irs firm, sure, \&c. Still the meaning obtained in this way is very much akin to that first mentioned, as a hand cannot be skilful or dexterous without being firm and steady, nor could anything be successfully poured from one vessel into another, if the hand holding the former vessel at least were not firm and steady. $\quad{ }^{29}$ to direct, regulate, order, make firm, keep up, 
the poetry which was poured out ${ }^{30}$ from one language to another, so that its taste ${ }^{31}$ sloould not become insipid nor its scent ${ }^{32}$ evaporate; and perchance it (the poetry) may be even more pure and more sublime than [that of] the ${ }^{33}$ real book. And ${ }^{34}$ so skilfully did he compose his poetry, that it is impossible ${ }^{35}$ to detect that it is a translation. ${ }^{35}$ And, indeed, also the great Rabbi Abraham Ben-Ezra-his opinion inclined [him] to say respecting this book, that it was a translation, so that he writes (on Job, chap. ii. 11), ${ }^{36}$ Now what seems probable to me is, that it is an interpreted book; therefore it is difficult ${ }^{1}$ of interpretation, as is the case with every interpreted book. ${ }^{2}$ Nor from the language of the Talmud, can anything be brought forward in opposition to this, for I have already ${ }^{3}$ told you twice or three times in this ${ }^{4}$ work that, ${ }^{5}$ when they say in the Talmud, "So and so has written such and such a book," it is not their meaning that he was ${ }^{6}$ its original author, but ${ }^{6 \prime}$ they only intend to say by it, that he ${ }^{7}$ arranged the book, and ${ }^{7}$ fashioned it into a complete work, and so here, when they say Moses wrote the book of Job, their meaning is, that he was the translator of it.

And ${ }^{8}$ another opinion which I hold with regard to this question is, that, seeing in the narrative which is at the ${ }^{9}$ beginning of the book, as well in the narrative which ${ }^{10}$ closes the book, only the name of the ${ }^{11}$ Divine Essence (i.e., the sacred name Jehovah) is mentioncd, but that in the midst of the book all

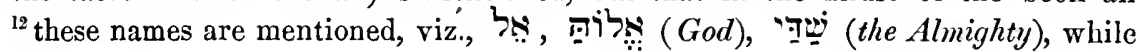

sustain, maintain, i.e., he maintained the poetry at its original level, and did not allow it to sink; he preserved its spirit. Comp. the Lat. regere, sometimes = to direct (כוי), with the Ital. reggere = to support, sustain. Comp., again, our right (regere) as a subst., an allj., and as a verb $=$ to set UPRIGHT (of a ship, \&c). And so in the words to rule (regere) and to govern (gubernare, to steer, direct) are certainly contained the notions of firmness, steadiness, maintenance, support, as well as that of direction, gridance. $\quad{ }^{30}$ from lip (language) to lip (language). $\quad{ }^{31}$ did not languish, become weak, fail, cease. $\quad{ }^{32}$ was changed, see

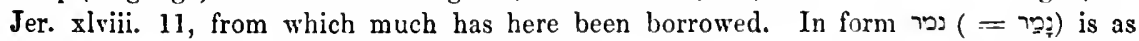
though from מרו to be bitter, from which some derive it. ${ }^{33}$ See note ${ }^{24}$, and (for the that of) p. xlix, note". $\quad{ }^{34}$ made prudently his poetry so much (lit., all thus, so), i.e., so skilfully put together, composed, or arranged, ordered, disposed; see Gen. xlviii. 14 . ${ }^{85}$ there is not to recognise (lit., il n'y a pas à reconnâitre) a translation in it. ${ }^{35 \prime}$ and also as to the great Rabbi . . . . his opinion inclined to say. Notice the irregularity of gender. ${ }^{36}$ Now the near to me [is], i.e., what seems probable to me [is]. See p. Iri, note .

' in its interpretation, according to the way of every, $\& \mathrm{c} .{ }^{2}$ And from the tongue (language) of the Talmud, there is not (i.e., it is impossible) to bring an objection against this. ${ }^{3}$ seconded and thirded, done a second and third time, i.e., said or written a second and third time, one of these actions being that implied here by the general verb do. 4 composition, treatise, i.e., no doubt, the rolume containing Ben-Zev's prefaces to different books in the Bible, for his prefaces were thus published; see p. Ixxiii, note *. At any it is not in the present Preface that he has given his readers the information which he now repeats. ${ }^{5}$ on their saying. ${ }^{6}$ see p. lxix, note ${ }^{13} .{ }^{61}$ the (their) intention; see p. $\mathbf{x r}$, note ${ }^{34}$. " was disposing, arranging, ordering. $\quad{ }^{7}$ making it up. $\quad{ }^{8}$ what has appeared (appears) still (besides) in this [matter, question] (i.e., probably, with regard to the question of the authorship of the book). ${ }^{9}$ head. ${ }^{10}$ brings up the rear, claudit agmen, and so $=$ closes. See Numb. x. 25, Josh. vi. 9,13 , \&c. " $\quad$ See p. xxxvii, notes. 12 the names. 
the name of the Divine Essence ${ }^{13}$ is not mentioned in it ${ }^{*}{ }^{14}$ I have come to the just decision that the narrative ${ }^{15}$ at the beginning and the end [of the book] is what Moses ${ }^{16}$ himself wrote. Therefore he mentions [in it] the name [of the Divine] Essence, for he knew ${ }^{17}$ this name, but in the midst of the book, the speakers are men [who were] not of tlie sons of Israel, and so they knew not the ${ }^{18}$ name of God, nor did they bear ${ }^{18^{\prime}}$ His name upon their lips.* And with this is concluded what I have thought fit to place [as] an introduction to this book.

The 6 th day of ${ }^{19}$ Adar, 569 (i.e., 1809) according to the ${ }^{20}$ lesser computation.

* It has escaped Ben-Zev (unless, indeed, he had before him a copy with another reading), that the name Jehovah is mentioned by Job in chap. xii. 9.-Note of the Editor. [Renan (Pref. to his 'Transl., p. xix.) is guilty of the same oversight (1863).]

13 is not known, i.e., is ignored, not mentioned.

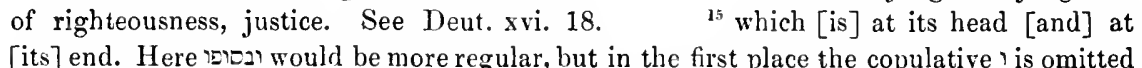

${ }^{14} I$ have judged a judgment (see p. ixii, note ${ }^{43}$ ), and secondly the pron. affix is left out as superfluous. [But see p. lxxiv $\left.\left({ }^{16}\right).\right] \quad{ }^{16}$ by himself. $\quad{ }^{17}$ His name, i.e., God's. $\quad{ }^{18}$ lit., the name of the name, i.e., the name of the true God, the God of the Israelites, viz., Jehorah, for הe commonly used $=$ the name of all names, the name par excellence, i.e., Jehovah. Ben-Zev could not well say שם (ה)אלה here, because there would have been more or less ambiguity; but we can say the name of God, because with us God, without an article, is only used of the true God. See p. xxxvii, note ${ }^{b}$. ${ }^{18}$ i.e., His own peculiar name, Jehovah. ${ }^{19}$ Adar is the month included between the new moon in February, and the new moon in March. ${ }^{2 \theta}$ little detail, computation, i.e., leaving out the thousands, which are 5. We are at present (August 4, 1863) in the Jewish year 5623; 5624 will begin with the new moon on the 13th September. It seems that a Rabbi Hillel, in the 4th century after Christ, fixed the creation of the world at 3761 years before Christ. $\dagger$ If he had said 4001 years (the year 4001 corresponding with our year 1), then the Jewish year would, with the exception of the thousands, have agreed with ours, at least for the greater part of the year; but, as 3761 is 240 less than 4001 , therefore we must add 240

+ This is the number given in the Conversations-Lexikon, s.v., Aera, but what is meant, apparently, is, that the Jewish year 3761 had begun in the September preceding the 25th Dec. on which Christ was born, or the 1st of January immediately following his birth, from which the year 1 was counted. The year 3761 would thus (for nine months at least) correspond to our year 1. There seems, however, to be some doubt as to whether the year 1 was counted from the 1st January immediately preceding, the 1st of January immediately folloxing, Jesus' birth, or from the second 1st January following his birth. Thus, in the Conversations-Lexikon I find the following : "Die Epoche dieser christlichen Aera ist nach Dionysius selbst (its originator), der unter incarnatio, nach der Weise der Kirchenväter, die Verkïndigung Mariä verstand, und diese mit dem ihr vorangegangenen bürgerlichen Jahresanfang combinirte, der 1 Jan. des Jahres, in welches die Geburt Christi nach seiner Berechnung fiel..............nicht aber, wie man erwarten konnte, der nur durch nur eine Woche von ihr geschiedene 1st Jan. des zunächst auf die Geburt Christi folgenden Jahres." + In Renan's "Vie de Jésus," on the other hand, p. 21, I

I The announcement of the angel to Mary, or the incarnation (conception) of Christ, which Dionysius regarded ns having taken place at the same time, must, if Christ was born on Dec. 25, and the order of nature was followed, have happened on (or about) the 25th March preceding; only, as the year begins on Jan. 1, and not on March 25, Dionysius, who (according to the Conv. Lex.) wished to make the incarnation of Christ the starting-point of his era, substituted the 1st Jan. immediate!y preceding Christ's birth for the real date of His incarnation, Mar. 25. 
to the Jewish year, in order to give the year according to our reckoning. As, however, the Jewish year begins in September, and thus has for more than three months the start of ours, which does not begin till the 1st of January, we must add 239 between the new moon in September, and the 1st of January, and 240 from January 1st, till the following September. Thus, (1) 863 corresponds to the Jewish year (5)623-(5)624, (5)624 beginning on the 13th of September. During nine months in the year', therefore, one will be right, if one adds 240 , and so this is the rule generally given.

\section{Page $x x x v$, note + .}

I must observe, however, that the Rabbinic of the Preface here laid before the reader is a reprint from a reprint (viz., from Ben-Zev's Preface as it stands at the beginning of my copy of one edition of Wolfssohn's Job, by Homberg), and not from the original work (see p. lxxi, note "), published under the immediate supervision of Ben-Zev himself. There is, therefore, a double chance of error, and, as I now have but one copy of the Preface, viz., that mentioned above (though it would seem, from p. xlvii, note *, that in $1857 \mathrm{I}$ had two of different editions,), and have as yet been unable to procure a copy of any other edition by Homberg, * or of Ben-Zev's original work-it is impossible for me to say what misprints are to be laid at Ben-Zer's, and what at Homberg's, door. Some carelessness of revision there evidently has been on the part of somebody, for there are, I think, at least some undoubted misprints among the readings which appear to me unsatisfactory, and to which I have'called attention in my notes; though in every other case, excepting that now under our consideration (and, perhaps, that noted in p. xxxiii, note ${ }^{g}$ ), the errors have been by no means gross, and are readily to be accounted for. If this Preface had been a very important part of the present work, I should, of course, not have contented myself with mere conjectures as to whether such and such readings were, or were not, misprints; but I should have waited until I had procured a copy of every edition that had been published of the Preface, and then I should have carefully compared them. It seemed to me, however, desirable to publish the Commentary with as little delay as possible, and therefore it is that I have ventured upon conjectures from which I might otherwise have deemed it more prudent to abstain. But, before the Appendix is completed, I dare say I shall have succeeded in procuring the copies which I am now in search of, and, if so, and I learn from them anything with regard to the disputed passages, I will lay it before the reader.

I am, fortunately, able to redeem my promise sooner than I expected-for I have at length (Nov. 7) had the long wished-for opportunity of examining a copy of Ben-Zev's original work $\dagger$; and $I$ have the satisfaction of stating that all my conjectures prove to be

find, "On ignore la date précise de sa naissance (i.e., of the birth of Christ). Elle eut lieu sous le règue d'Auguste, vers l'an 750 de Rome, probablement quelques années avant l'an 1 de l'ère que tous les peuples civilisés font dater du jour où il naquit;" whilst Lardner, in his "Common Things Explained," tells us that the year 1 was dated from the moment that Christ completed his first year. Theoretically, Lardner is, undoubtedly, right, for now-a-days, at least, a laby i^ never called 1 till it has eompleted its first year. Perhaps, however, Renan's meaning is only that the Christian Era (and not year 1) is dated from Christ's birth. But it matters little here when the year 1 became entitled to its number, for, however this be settled, the Jewish year 3761 must have corresponded to our year 1, as else the rule for converting the former into the latter, and rice vers $A$, will not hold good.

* Homberg seems to have arlded Ben-Zev's l'reface, which was not written until four year: after the appearance of the original edition of Wolfssohn's Commentary.

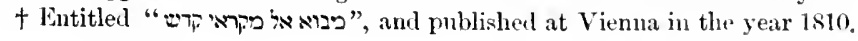


correct. In one case, however (see infia, last erratum in list), I was stupid enough not to offer a conjecture, though the construction seemed so odd to me that I endeavoured to explain it in a note.* Now, as no part of this preface is yet struck off, two courses lie open to me; I can either correct the Rabbinic in accordance with Ben-Zev's text, and cancel all the voluminous notes containing my conjectures, or I can allow the Rabbinic to remain as it is, and retain my notes. After much consideration, I have decided upon adopting the latter course-in the first place, because I could not now remove the notes without giving a great deal of trouble, causing a great waste of time, and incurring much expense; and, in the second place, because it seems to me that these misprints, which have afforded some exercise to my mind, may prove serviceable to the student, who will thus be made acquainted with the most common errors which he has to look for in Rabbinical works. I will now, therefore, give a list of the misprints and omissions, with regard to which my collation with Ben-Zev's work has enabled me to pronounce decisively. $\dagger$

\section{ERRATA IN THE TEXT OF BEN-ZEV'S PREFACE AS GIVEN IN THIS WORK.}

(1) P. xxvii, line 4 from top (of text), for (ברכות ה , צ"ב) there is in Ben-Zev ה צ'ב, i.e., fol. 8 , column (or page) 2, whilst in the transl. there is fol. 7 , which is, $I$ expect, where I found it in the edition of the Talmud which I consulted.

(2) P. xxviii, line 6 from top, and note ${ }^{b}$, Ben-Zer has ההריזם

(3) P. xxix, line 6 from top, and note ${ }^{b}$, Ben-Zev has החלר .

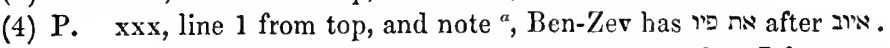

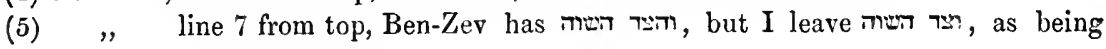
more Rabbinic.

(6) " last line (in text), and note ${ }^{g}$, Ben-Zev has

(7) P. xxxi, line 1 from top, and note ${ }^{a}$, Ben-Zev has לדרד.

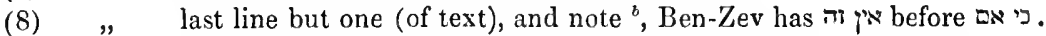

(9) P. xxxii, line 1 from top, and note ${ }^{a}$, Ben-Zev has ויחוז

(10) P. xxxiii, line 8 from top, and note ${ }^{c}$, Ben-Zev has על של הימן according to (after) the name of Teman, before אהי אליפו. I had supplied, after Teman.

(11) " אדים 13 from top, and note ${ }^{e}$, Ben-Zev has

(12) P. $\operatorname{xxx}$, last line of text, and note ${ }^{a}$, Ben-Zev has in which the 2 strikes both Mr. Randolph and myself as rather odd. It may possibly be a misprint, and, if not, I prefer my suggestion, ופרי

(13) P. xxxvi, line 8 from top, Ben-Zev has יערבי , but this may be a misprint for p. xxviii, note ${ }^{b}$.

(14) " line 19 from top, and note ${ }^{b}$, Ben-Zev has

(15) P. xxxvii, line 7 from bottom (of text), and note ${ }^{a}$, Ben-Zev has $i$.

(16) " שבראשו בשות Ben-Zev has 5 from bottom (of text), and note ${ }^{d}$, for שבראש ובשיף. I failed, but ought to have recognised this misprint, which is a very intelligible one, and must frequently occur. Indeed, Ben-Zev himself has allowed the converse to escape his notice once in this preface, for line 7 from top (of this page, xxxvii), he has אלו היה אל והיה.

\footnotetext{
* I might easily have erased this note and altered the text, but I thought it only just to record my failure as well as my successes; and, besides, the misprint seems to me a very instructive one.

+ In justice, however, to Homberg, or whoever else revised Ben-Zev's Preface as it stands in the edition of Wolfsolm's Job, from which the copy given in the present work has been reprinted, I must state that he correeted at least as many misprints in Ben-Zev's original work as he suffered new ones to escape his notice.
} 
From this list of errata we learn :-

1. That $\boldsymbol{B}$ is frequently substituted for $\pi((1),(3),(6),(7),(9),(14))$. [The converse certainly also holds good, though there is no example here, and it is, perhaps, less common.]

2. That the $\pi$ of the $\pi$ in a Hithpa-âl may be left out ((2), and comp. (13)).

3. That two or three words may be left out $((4),(8),(10))$.

4. That 7 may be printed for $T((11))$. [The converse is also true.]

5. That ' may be substituted for ' (15)). [The converse also certainly holds good.]

6. That a , beginning a word may be tacked on to the end of the word preceding, especially when it will thus make (some sort of) sense ((16)). [That the converse also holds good will likewise be seen from (16). This mischance is, I think, peculiarly liable to befall ', which freq. ends and begins words; but other letters are no doubt exposed to it; and this confusion of words must be more common in languages in which, as in Hebrew, \&c., the letters are not joined, even in manuscript.]

7. That, when two short and contiguous clauses end with the same xords, the second clause is apt to be left out, as, the last and common word catching the eye of the transcriber or compositor, it is imagined (when the eye returns to the original) that the second clause has been already written or set up ( (10)).

8. That ' may be printed for final Tsaddik ((12)). This must be very uncommon, and is hardly to be explained; see, however, p. xxxv, note ${ }^{a}$.

The following are a few of the more common misprints, of which $I$ have myself seen examples :-

I for $\mathrm{I}$, and vice versâ.

ofor $\square$, and vice versa. This is esp. common in Rabb., where the two letters $\checkmark$ (final Mem) and $p$ (Samech), are still more alike than in Hebrew.

$\checkmark$ and $\checkmark$ for $\triangleright$, and vice versâ.

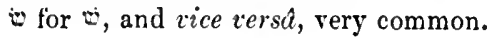

Less common are :-

$\checkmark$ (in Rabb.) for $₫$ ( $\zeta$ ), and $\$$ for $>$ (which I have noticed also in Heb). Here sound may have some influence. ' $\mathrm{I}$ for ', and vice versê, I am almost sure I have noticed in Rabb.

$\Delta$ for $D$ (once).

$\supset$, and more commonly I think $\unlhd$, for $\Sigma$; 0 for $\gtrsim$, very likely, but not noticed.

7 for 7 .

7 not unfreq. for $\uparrow$. *

$\checkmark$ for $\pi$ (twice).

2 is said to be substituted for 2 , and 2 for 2 , but though a very likely misprint, I have not noticed it. In printing (or transcribing) Kabb. from Rabb., a (g) might readily be substituted for $\square(\zeta)$, and vice vers $A$, but I have not noticed either of these possible mistakes. $\partial$ for 2 (once), for 1 (once), and for 2 more than once (esp. in Rabb.).

Final Nun ( $i$ ) for $i$ (once).

$P$ for $\rightarrow$ (once).

$\checkmark$ for 1 and 1 for $\urcorner$, both more than once.

$\checkmark$ for' (once), a large and badly made' looking something like a small $\urcorner$.

$\pi$ for $\pi$ (freq.) ; $\pi$ for $\pi$ (less. freq.) $\pi$ for $\pi$ (once).

* Where vice versî is not added, it has not been noticcd. The reader laust judge when the rice versâs are probable. 


\section{Very rare are:-}

$\rightarrow$ for $F$, the tail being left out (once).

$\pi$ for $*$ (once-quite anomalous* in Heb., but readily explicable in Rabb. ( $D$ and $f$ ). See p. xxxiii, note ${ }^{g}$, where $I$ have been a little hasty in characterizing this misprint as gross.)

$\zeta$ for $ל$ (at end of word, once-explicable).

$\supset$ for $\urcorner$ (once-explicable).

ל for $\mathrm{T}$ (once-explicable).

D for ה (once-explicable).

$\checkmark$ for (once-a sort of faux air between them; in Rabb., however, there is considerable resemblance between these letters, but I cannot now say whether my example was in Rabb. or Heb.).

In transcribing Hebrew one is apt to write:-

$\aleph$ for $\longleftarrow$, and vice versâ,

I for ', ,

$\bullet$ for $\Omega$, and vice versá,

$\pi$ for $y$, ,

$\unlhd$ for $P$, $\quad$,

iv for 0 , "

on account of the little difference in the sound; and thus misprints may arise.

And, lastly, I have frequently noticed the transposition of two contiguous letters, as

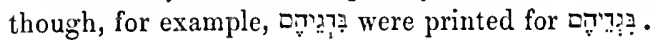

I should be glad to see a list drawn up, both of common, and of unusual, misprints in English (I mean, of course, such as have actuclly occurred), as then our Shakspearian and other critics would have something a little more solid to base their conjectures upon, than what is at present too often their foundation, viz., conveniently remembered, but unauthenticated misprints, or, still more frequently, I think, mere fancy. That there is, however, actually, no limit to misprints, even in the mother-tongue of the compositor, may, I think, be fairly inferred when I state that, in one of the proofs of this preface, I found accuracy substituted for meaning, though the result was utter nonsense!! The compositor would, however, I imagine, tell me, that, if there are no limits to misprints, it is because there are no limits to bad writing.

In a note appended to the commencement of this Preface (see p. xxxviii, note ${ }^{*}$ ), I spoke in terms of high praise of Ben-Zev's style, but that note was written before the translation of the Preface was made, and was based, rather upon Dr. Bernard's opinion of Ben-Zev, than upon my own experience. Now, however, that I have toiled through the Preface-a very fair specimen, I believe, of Ben-Zev's Rabbinical Hebrew-and have, to adopt his own figurative language, cleared away for the reader a path through the tangled thickets of his words, + I must confess that my admiration for his style has materially diminished. He writes, indeed, for the most part, very judiciously and sensibly, and,

* Wherever I have not added quite anomulous, I consider the misprints are more or less readily explicable, and therefore such as one might expect to meet with. Some apparently anomalous misprints may, however, be accounted for, if we remember that the compositors keep their types in little compartments or cells, one for each letter, and that letters which have no resemblance often lie in adjoining compartments, and may thus be confounded, the compositor's fingers dipping, in the hurry of composing, into the wrong compartment. Sometimes, again, mistakes are marle in consequence of letters slipping into wrong boxes (cells), in the course of distribution. Curiously enough, 2 and 2 are in contiguons cells.

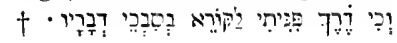


where he is clear, one cannot but admire the great force and pithiness of his language; but when-and this is not seldom-he chooses to deal in ambiguous expressions and in harshly elliptical and concise constructions, then I cannot discover that the thoughts which he thus wantonly obscures, are so very brilliant, original or profound, as, in any way, to compensate for the trouble which there is in digging out their meaning. Upon the whole, therefore, I much prefer Wolfssohn's style, which is always clear, lucid and elegant, without being either too concise or too diffuse. It is, I conceive, the first duty of a writer to express his thoughts with clearness and precision; and there is no thought so profound that it may not, if distinctly pictured in the mind, be reproduced in clear language. Clear language, however, may at the same time, be concise-though perhaps the combination is rare-and conciseness coupled with clearness must by all be allowed to be a beauty; but, when the two cannot be had, then, as I place conciseness after clearness, I greatly prefer lucid diffuseness to obscure conciseness. Many German writers of the present day, however-nay most perhaps-contrive to combine obscurity with diffuseness, and this combination I regard as the most intolerable and inexcusable of all. Yet what can we expect but much mud and water from brains which can always make words, but cannot always elaborate clear thoughts? and such brains, are, I expect, common in Germany, and would, perhaps, have been traced, in part, by Mr. Buckle, if he had lived to write upon the German intellect, to the great consumption of wishy-washy soups, watery regetable stuff (cabbage, salads, gherkins, Sauerkraut, \&c.), as compared with solid animal food, and above all to the inveterate habit of smoking from six in the morning till nine or ten at night. Here we have both the clouds' and the water!* It no doubt sometimes happens that the concise writers are obscure also, in part at least, because their ideas are not clear, but with them, I imagine the obscurity commonly arises from other causes. What causes? Well, in the first place, they may be naturally of a dry and fibrous, close and costive temperament, both of body and of mind, and then they will dislike waste and profusion of all kinds, even of words. Or they may designedly trick up their ideas in terse and epigrammatic language, because they think it is admired, and then there is, no doubt, great nipping and paring before the result aimed at is attained. Or they may themselves admire conciseness and strive to imitate some celebrated model. With the second class I have the least patience, whilst the first and last are at least entitled to respect. Still, they should all of them bear in mind, that there is much presumption in setting such a high value upon one's own ideas, as to imagine that other people will take the trouble to puzzle them out. But, unfortunately, no style meets with more admirers than the concise and obscure one! In the first place, such writers are, I think, almost always, if not always, men of talent, and, therefore, their ideas, if not of the first order, are still worthy of note. Then, with many, obscurity which they cannot penetrate passes for profundity, and looking up to the writer, they look down upon themselves. Others again, who can puzzle out the meaning, delight in this exercise for their intellect, and are proud of their acuteness. Here self-love is involved, and when they praise the author, they are in reality indirectly praising themselves. And, with regard to classical authors, the concise and obscure ones, being read only in the highest classes, are naturally regarded by the school-boy, and even by the student + , with reverence and awe, and the impression thus early made, is frequently preserved through life. But I must stop, or else I myself shall be numbered with the diffuse. I have said enough to shew that with me perspicuity of style holds the principal place.

* There is, however, much truth in Buckle's theories, anc I an quite disposed to believe that not only the quantity, but also the quality of the food which a nation lives upon, has great influence upon its destinies.

† 'Thus, for example, Caesar, as being a low-class book, ranks, in their estimation, far beluw Tacitus, which is a high-class book. 


\section{THE EDITOR'S SECOND PREFACE.}

If, as I have elsewhere remarked, Dr. Bernard's Commentary on Job is naturally much inferior to what it would have been if he had written it whilst he was in possession of his eyesight, so now that, in consequence of his death, it has wanted his revision while passing through the press, it is necessarily less complete than if he had lived to revise the proof-sheets. That he himself hoped to make further improvements is evident from a letter which he wrote to me in September, 1857, and in which he said that he would never consent to the publication of the work with his name upon the title-page, unless he and I were together in the same house whilst it was passing through the press. His death has also produced two other results. In the first place, it has led to a delay of about four years in the publication of the work; and in the second, it has entailed upon me the necessity, which I would gladly have avoided, of writing a voluminous Appendix. With regard to the first of these results, I refer the reader to p. xcv, note *, where this delay is explained. With regard to the second, when, after the lapse of four years, I came to re-examine the Commentary, as it was passing through the printer's hands, I was surprised to find, that, though I still fully agreed with Dr. Bernard in the main, i.e., with regard to the general scope of the work, the principles put forward by Job, and by Elihu, the two characters with regard to which the greatest difference of opinion prevails, \&c., yet I differed from him with regard to many of the details; that, for example, there were several passages, 
some of them presenting no difficulties of construction, to his interpretation of which I could not assent; that there were other passages again of which he seemed to me, indeed, to have given the true meaning, but of which he did not seem to me to have explained the construction correctly; that his views upon many points of grammar did not accord with mine; that there were difficulties of construction, irregularities of gender, number, \&c.*, of which he had offered no explanation whatever, but which, notwithstanding, would cause considerable perplexity to the student; and lastly, that in doubtful passages he did not sufficiently notice the comments of others. The work, indeed, might, as far as the body (large type) of the Commentary and the Translation were concerned, satisfy the Hebrew scholar, and those who knew no Hebrew; but the explanations contained in the small type in the Commentary seemed to me too copious, and in many cases of too elementary a character, for the scholar, whilst for the student, and, indeed, for the large intermediate class, comprising those who are neither students nor yet scholars, they were far too scanty.

Dr. Bernard did not strictly adhere to his original intention, which was to write rather for those who were intimately acquainted with Hebrew than for the student, but allowed himself occasional deviations in favour of the student-the result being an inequality in the character of the notes, many difficult passages being left unno-

* The difficulties of construction, irregularities of form, \&c., would of course strike him less when blind, than if he could have seen them. He, no doubt, knew the whole Book off by heart, but, still, he could not carry in his memory all the peculiarities of gender, number, orthography, \&c.. which present themselves in crowds in the Book of Job. It may be said that I ought to have called his attention to all these points ; but, as my knowledge of Hebrew was then, and is still, though $I$ have made great advances sinee 1857 , far inferior to his, and as, in addition, I had not been accustomed to consider Hebrew with the critical eye of a Commentator, it is not surprising if I failed to call his attention to many passages which he ought certainly not to have left unexplained. Still, perhaps, it is fortunate that I did not trouble him too much; for, had he made the Commentary much more copious, it would not have been completed. I must say, however, that Dr. Bernard, fearing to make the Commentary too long, refused to comment upon many passages which I pointed out to him, though he did listen to some of my suggestions. He used to say that his Commentary was less for students than for scholars. 
ticed, as being difficult only for the student and those of the next grade above him, whilst other much less difficult passages were explained for the benefit of the two latter classes. It was, however, of course, quite out of the question that I should either add or take away anything from Dr. Bernard's Commentary-my duty clearly being to publish it just as it was left, and this I have done, with the exception of a few verbal changes. The only course left open to me, therefore, was to write an Appendix, and this course I have pursued, my chief objects being,- firstly, and principally, to vindicate Dr. Bernard's interpretations, constructions, and explanations where they seem to me correct, yet not so obviously so, as not to require vindication; secondly, to point out those passages in which I differ from Dr. Bernard; thirdly, in the case of passages (and there are many of them), which seem to me likely always to remain doubtful, to make suggestions of my own, or to adduce the interpretations of others and compare these suggestions, or these interpretations with Dr. Bernard's renderings; fourthly, to explain grammatical difficulties, which Dr. Bernard has either left unnoticed, or of which he has, to my mind, given an insufficient, or even erroneous, explanation. At first I thought that the Appendix would not comprise more than 100 or 150 , or at most 200 pages, but the notes, as notes are wont to do, grew rapidly under my hands, until at last I perceived that, if they were included in one volume with the original work, the result would be an unwieldy and unsightly book, and I therefore determined to publish them separately. And to this determination I was the more easily led when I reflected, that Dr. Bernard wrote his Commentary chiefly for the use of his Hebrew pupils, and that it was his Commentary which they wanted, and not my additional notes. I thought, too, that it was inexpedient to keep back the Commentary which had been ready some months, until the Appendix - which slowly drags its weary length along *-- should be finished; and, lastly, I was unwilling to compel those, who only wished for Dr. Bernard's work, to

* The Appendix was not begun until after the Commentary was in the press, and as $I$ have had and have to write the later chapters whilst the earlier ones were and are passing through the press, it may be conceived that the work does 
take mine also. The two volumes, therefore, will not only be published, but will also be sold, separately. The Appendix will, I hope, be provided with two copious Indices, the one containing

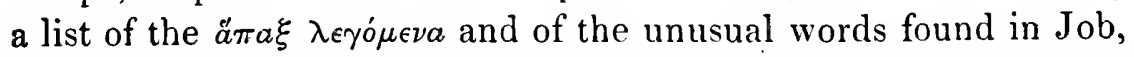
whilst the other will form a general Index to the Commentary and Appendix.

It must not be supposed, however, that the Commentary, together with the Appendix, will contain exhaustive information upon every point connected with the Book of Job. Far from it. The questions considered in both are nearly all of a practical, and very few of a speculative, nature. A work, which would satisfy the requirements of all readers, would fill many large volumes, and will never be written by one man, nor by two, who, like Dr. Bernard and myself, hold nearly the same opinions.

The literal renderings in the margin of the Translation have been given, chiefly, of course, with the view $\cdot$ of assisting the student to understand the original, but also in part for the purpose of enabling him to compare the differences of idliom between the Hebrew and English, and also to turn back, if he should feel so inclined, from English into Hebrew-a very useful exercise.

The Italics in the Translation are used as in the A. V., that is, they denote words which have no equiralent in the Hebrew, but are introduced into the English, either because they are absolutely required, or because they make the meaning clearer. In translations from the Bible I think they ought to be used, as else the reader has no check upon the caprice of the translator, who might add ad libitum, and so delude his unsuspecting readers. In the translations given in the Commentary, the opposite plan has necessarily been followed, and there the added words are

not proceed very rapidly. Still, nearly half of it is now ready for the press ; nearly all of it is written; and nearly a third of it is printed, so that I hope it will be completed in the course of a few months. It is, however, my intention to publish it in three parts, each containing fourteen chapters; the first of these parts will soon be ready, and I trust it will appear within a month or two of the publication of the present volume. 
in the Roman character, whilst those which have equivalents in the original are in Italics. I expect, however, that, both in this part of the Commentary and in the Translation, some words will be found in Italics which ought to be in Roman type, and vice versâ, for I found that I had a great tendency to make, and to overlook, mistakes of this kind.*

Hyphens are frequently used both in the Commentary and in the Translation, for the sake of marking that two or more words in the English are represented by only one in the Hebrew; but this rule has been by no means steadily adhered to.

In the Commentary and Appendix I have not been at great pains always to follow the original with regard to the dagesh lene in the letters בגדכפת when beginning a word, or to the dag. forte euphon. in the first letter of the words following הצ, $\& c$, as I did not consider the matter of much importance.

Since we began to write the Commentary in 1856, four new works on Job have appeared, or have been completed, viz., those of Conant (1856-1857), Carey (1858), Renan (1860), Davidson (1st vol., 1862). Of these works I do not feel called upon to give a detailed account, for the editor of a rival work cannot be an impartial judge, but I will say a few words about them.

In Conant's work I find but little originality, whilst self-sufficiency is abundantly evident. His translation is disfigured by the adoption of the modern third pers. sing. pres. in $s$, instead of the old form in eth, and lis language does not appear to me well-chosen, its meagreness and want of harmony being rendered the more apparent by his having, imprudently, placed his translation and the Auth. Vers. in parallel columns. Still, his work is useful as exhibiting, in the case of many of the difficult pass., the views of the most celebrated Germ. Commentators in a brief compass; and his analysis of Ewald and Hengstenberg's views in his Introduction is also valuable.

* I believe, however, that no important mistakes of this kind have been made; and such as there are the Hebrew student will, I am sure, at once be able to correct. 
As for Carey, both Translation and Commentary must, I think, be pronounced bad, though he sometimes manages to hit upon what we hold to be the true meaning of a doubtful passage. Of the taste which presided over his translation, the following specimen (from xvi. 12) will enable the reader to form some idea:

I was at ease, but he smashed me,

And seized me by the neck, and dashed me.

Renan has certainly succeeded in translating Job into elegant French, and this is the chief merit of his work. He does not pretend to be original (indeed, he boasts that he is not! (p. vi)) - but has contented himself with selecting what he conceives to be the best interpretations from modern Commentators, and his book is valuable from the clearness with which he exhibits the results, at which his more misty-headed neighbours, the Germans, have arrived. At the same time, in consequence of the paraphrases which he never scruples to employ when he thinks perspicuity demands it, and in consequence of the want of a poetical vocabulary in the French language, and of its positivism,* much of the poetry of the original is lost in his

* By positivism* I mean the tendency to call a spade a spade, or, as the French have it, a cat a cat, i.e., to call things by their right names; a very praiseworthy tendency, as it has, or ought to have, its origin in a love of truth; only some trutbs are the better for being veiled, especially in poetry. And yet what people, by a seemingly strange contradiction, understand the art of veiling, and piquantly veiling, too, better than these same French! But even this is due to positivism; an Englishman would hold his tongue altogether with regard to the suljects which most require this veiling; a Frenchman can't hold his tongue about them, and so being constrained to respect that feeling of decency in others of which he commonly has so little himself, he is obliged to devise some means of expressing his indecent thoughts in outwardly decent terms-and hence his wonderful proficiency in the art of veiling. $\dagger$

* Since writing the above, I have more than once seen realism used $=$ what I here call positivism. Both terms seem to me defective, in that they do not express their own meaning, but require the help, either of the context, or of a note. But this is a defect, which will be lost sight of, if either word succeeds in becoming naturalized. A more weighty objection is that they are, both of them, already in use to denote two different systems of philosophy.

t The French term gazer, to gauze (over), is a more appropriate designation for their mode of effecting the process, as the very transparent covering which they make use of is almost too thin and delicate to be called a veil. The two words, therefore, as is frequently the case with equivalent terms in languages, mark pretty exactly the difference in the practice, in England and France. 
translation. There is nothing, moreover, in the work to shew that Renan possesses more than a superficial knowledge of Hebrew.

Of Davidson's work only the first volume has yet appeared. He devotes much more space to the consideration of the difficulties of construction and of grammar than any of his English, and than most of his German, predecessors, and he has in this respect to some extent forestalled me in my Appendix. Still, I much doubt whether his Commentary (I speak of the small type) will ever become a favourite with students, for too much is compressed into a little space in it, and it is too full of abbreviations, references, and repulsive grammatical terms of which one is sometimes puzzled to guess the meaning. Nor do I think that the large type will find more favour, excepting with those who, having no imagination of their own, like others to imagine for them-so dry does he suck, or attempt to suck, every passage, in his eagerness to present every beauty to his reader's, whilst the language in which he expresses his ideas is very laboured and stilted. $\dagger$ As for his translation, it does not become me, who have written one myself, to say much about it; I will merely observe that scarcely a chapter seems to me free from some uncouth expression, from

* Compare his rendering of chap. vii. 5, with that of the same passage in the Eng. Vers.

Ma chair est revêtue de vermine et d'une croûte terreuse,

Ma peau est couverte de cicatrices et de pus.

My flesh is clothed with worms and clods of dust;

My skin is broken and become loathsome.

The Eng. Vers. is not only much more literal, but (like the original) veils over, without obscuring, what is simply disgusting, when told in wantonly crude and harsh words like those of Renan. The Hebrew poet did not forget that disgust very commonly excludes interest and pity, and he, therefore, did not wish to represent Job as repulsive and disgusting. But the French love thoroughly concrete terms.

† Occasionally he has a very strange note. Thus on his transl. of iii. 12, "why two breasts," \&c., he remarks, "the dual ought to be preserved as more voluptuous and accurate" - a comment, of which the extreme appropriateness will be appreciated, if the reader will bear in mind that, when Job uses the word 口: שִ The is cursing bis birth, and that the breasts of which he speaks are his mother's ! ! 
which the advice of a friend would have saved him. Comp. v. 11, "get elevated into safety" (A. V. may be exalted to safety); vii. 5, "my skin stiffens and runs again ;" vii. 16, "my days are a vapour;" ix. 6, "and her pillars get rocked to pieces;" ix. 27, "I will leave off my faces and be cheerful," \&c., \&c.

I will conclude my brief notice of these four writers by observing that they are all advocates of the practice of interpreting Hebrew by the aid of Arabic roots (see 1st pref., pp. vii, xi, xv).

It will not, I think, be out of place here to observe that Dr. Bernard's views concerning the book of Job, although first made known to the world in 1864 , must not be regarded as belonging to this date, or even to the time $(1856-1857)$, when they were embodied in the present Commentary, inasmuch as Dr. Bernard certainly held them in 185:, when I first read the book of Job with him, and probably held them for many years before this. ${ }^{*}$ Indeed, I think it by no means improbable that it was before he came to England, $\dagger$ that he made this Book his study (see first pref., p.xii), and first conceived those views of it which are now given to the world-but here all data fail me. Still, it should be borne in mind that this Commentary in its essence is by no means new, nay very likely older than Ewald's, of which the first edition appeared in 1836. Nor can Dr. Bernard's views have failed to become known to many Hebrew scholars in England, who never studied under him, and very likely do not even know his name;

* My friend, Mr. Randolph, who read Job with Dr. Bernard in 1848, tells me, that, though Dr. Bernard then understood several passages differently, yet his views of the Book in general were precisely the same as those now put forward in this Commentary.

+ I form this opinion, because I think it unlikely that Dr. Bernard increased his knowledge of Hebrew much after lie came to England in 1825, when he was 40 years old. After that time he devoted himself to teaching others; it was before, that he had tanght himself. Still, it is possible, that it was by reading Job with his pupils that his attention was especially directed to this Book. I have the copy of Wolfssohn's Job, of which he always made use, but no date indicates the time at which he became possessed of it. Nol do I even know when it was published, as the title page has been deliberately cut out, but the preface by Homberg, the Editor, is dated-Vienna, 1817. 
for it is now thirty-three years since he settled in Cambridge, and, during the seven and twenty years that he was teacher there, he imparted these views, no doubt, to the majority of his pupils, by some of whom, become teachers themselves, they must have been widely propagated. I make these remarks, because it may be urged by some critics that there is nothing new in Dr. Bernard's treatment of the Book of $\mathrm{Job}$, and that the same views have been entertained and advanced before. This may be so-there may be nothing new-but then let us hear by whom and when these views have been before advanced, so that we may see whether Dr. Bernard is entitled, or not, to the priority.

And now let me return my heartiest thanks to Mr. Randolph, formerly of Jesus College, Cambridge, pupil of Dr. Bernard, and Tyrwhitt's University Hebrew scholar. Unfortunately, I did not make his acquaintance until the Commentary was printed, but since that time he has afforded me the most valuable assistance. He has read over the whole of the Commentary for errata, and has made an Index* of all the passages in the Bible to which reference is made in it. But in the Translation he gave me much more important help. Every sheet was sent to him as it appeared, and he not only made his own criticisms upon it in the most frank and open manner, but exchanged a vast number of letters with me, examining into and weighing the merits of the various renderings which I proposed to him, and making in his turn many valuable suggestions, of which I adopted such as pleased me, though necessarily without acknowledgment. $\dagger$ And since this time we have been continually in correspondence, for most of the longer and more important notes in the Appendix have been submitted to him; and latterly he has undertaken the very

* For the correctness of this Index, which he first suggested to me, and which he volunteered to make, he begs me to say he holds himself responsible.

+ I think that no one ought to publish a translation of an important book without first submitting it to the criticism of a friend. The author, by reading and re-reading it, loses at last his power of discrimination, and words and sentences, which, if written by another, would infallibly call down upon them his speedy and severe censure, appear to him appropriate and, perhaps, elegant. 
laborious task of reading over the text of Ben-Zev's preface for errata, and of criticising my translation of it. My original preface also, and this second one have likewise been submitted to him. In short, whenever I want advice, I turn to him, and he gives it me forthwith.

To my friend, Dr. Harris, also I am much indebted for his kindness in freely passing his judgment upon the Translation.

The portrait of Dr. Bernard, of which an engraving forms the frontispiece to this volume, was taken in Cambridge by Mr. Nichols, the photographer, about June 1856, shortly after my arrival in Cambridge, and has been very successfully engraved by $\mathrm{Mr}$. Adlard, of Hatton Garden. The likeness is, I think, a very striking one,* and those of Dr. Bernard's pupils, who possess a copy of the photograph, will observe that the engraver has been able to soften down much of the harshness of the original, and to give a more pleasing expression to the countenance, without, in the slightest degree, impairing the resemblance. $\dagger$ Dr. Bernard said, when sitting, that he wished to look mournful and melancholy as one ought to look who was blind, but as, in spite of his affliction, he was really neither mournful nor melancholy, but almost invariably cheerful, and in good spirits, he did not succeed in communicating to his features the expression which he wished, and looked rather as though he were of a morose and sullen disposition. The autograph is taken from a letter which I received from him in 1854 , when he had already been blind some years. During the last two or three years of his life he shortened his signature to H. B., so that I had some difficulty in finding a letter in which his name appeared in full.

* The hair is, howerer, considerably shorter than Dr. Bernard commonly wore it, for he had had it cut only a few days before he sat.

$\dagger$ As Mr. Adlard had never seen Dr. Bernard, it may be imagined that this result was not obtained without much trouble, and that several alterations were made in accordance with my suggestions; aud my thanks are due to Mr. Adlard, both for the readiness with which he received these suggestions, and for the great pains which he took in carrying them into effect-whilst the result does great credit to his skill and intelligence. 
With regard to the facsimile of Dr. Bernard's hand-writing in cursive Hebrew* (p. cv), the responsibility of its insertion belongs to me alone, for, had Dr. Bernard lived, it is probable that the portrait would never have been engraved, and it is certain that no facsimile of his handwriting would have accompanied this work. It may be objected, and it has, indeed, been objected to me, that I might have chosen for the facsimile a piece of Hebrew at once less trivial and better written, for it is not a favourable specimen of Dr. Bernard's cursive Hebrew, which was commonly much more neat; but, in the first place, this happened to be the only piece in my possession + , and though I might have obtained more pleasing specimens from pupils of Dr. Bernard, who (as Mr. Randolph, \&c) had read with him before he became blind, and who had been taught to write cursive Hebrew by him, yet, as this piece is eminently apropos, and has been thought worthy of

* How very little this cursive Hebrew is known in England, the following anecdote, which I had from Dr. Bernard, and which I may, perhaps, be pardoned for relating, will shew. A Polish Jew having been arrested in London, a document, written in an unknown character, was found among lis papers. It was, naturally enough, supposed to be in Hebrew, and was, accordingly, sent to Dr. Lee, who was then Professor of Hebrew at Cambridge, with the request that he would translate it. But he was altogether unacquainted with the character, and so, concluding rather hastily that it must be Polish, as the man in whose possession the paper had been fuund was a Pole, he wrote to Dr. Bernard and begged him to translate the accompanying Polish document! Unfortunately, the Polish turned out to be Cursive Hebrew (!!), of which Prof. Lee, it would seem, did not even know the existence.

+ And it came into my possession by a singular chance. One day-during the time that I was helping Dr. Bernard with the Job-I went to the University Library for the purpose of consulting some musty old Hebrew book-a volume of the Talmud I think. Whilst turning over the leaves, I came upon a piece of paper with some cursive Hebrew upon it. I carried it away with me, and read out the Hebrew to Dr. Bernard. "Why," he cried, "I must have written that; nobody in the University knows those lines but myself and one or two of my pupils. I remember writing them out some "years ago" (Dr. Bernard had then been totally blind at least six years) "for Mr. M_-, naming a former pupil and intimate friend of his; "he must have left them in the book which he often uses. I will ask him." The lines were accordingly shown to Mr. M- and immediately recognised by him as those which Dr. Bernard had written out for bim; but he graciously waived his claims to the paper in my favour-and thus it is that the fac-simile has found its way into this book. 
insertion by Dr. Bernard himself (see p. xlii), I decided in favour of it. I am, of course, responsible also for the translation into English.

A few months before his death, Dr. Bernard dictated to me a short account of his life, and this I subjoin with a few additions of my own. I have left the English just as he dictated it, and if it is not remarkable for its elegance, it must be remembered that he did not draw up his sketch with the view of putting it at the beginning of this book, and, indeed, that he never dreamed of its appearing in print. His English varied much, but, as I have before remarked, was often very good.

\section{LIFE OF DR. BERIARD.}

* Hermana Bernard was born of Austrian parents $\dagger$ in Uman, or Human + , a small town in Southern Russia (at that time, Poland), in the year 1785. His native language is that of his parents, spoken.

† I believe that Dr. Bernard's father was a Jew, but that he liad become a Christian before his only son's birth; at any rate, I have M!iss Bernard's authority for stating that her father was brought up in the Christian religion. His father, it would seem, had also a profound knowledge of Ilebrew, for my friend, Mr. Randolph, tells me that Dr. Bernard informed him, that the interpretation of Isa. liii., given in Mason and Bernard's Grammar, was not his own, but his father's.

$\ddagger$ In the Government (province) of Kiev. In Black's Atlas it is spelled Ouman, and in Fullarton's Gazetteer (s. v. Kiev) Uuman. 
namely, German*, and, though sufficiently familiar with the Russian and Polish languages, to speak them with fluency, he never made these languages his study $\dagger$. The other languages with which he is acquainted, + ancient as well as modern, were

* Although Dr. Bernard was not born in Germany, and only paid, I believe, one or two short visits to it, he spoke a very pure, good German, and not such as is frequently lieard in the mouths of Austrian gentlemen. Upon this point I am able to speak decidedly, as, during the whole time of my acquaintance with him, and especially during the last year, when we lived in the same house, he certainly much more frequently conversed witb me in German than in English.

† Dr. Eernard is here too modest. There is no doubt that he spoke and wrote Russian and Polish so well, that no ordinary Russian or Pole would have suspected him to be of foreign origin (see p. xci, note*). I have heard him say that, whilst he was in Cambridge, he had the opportunity of speaking and writing to several Poles, and that they did not, any of them, suspect that he was not a Pole. Nor was lie altogether ignorant of the literature of these two languages, or, at any rate, of Russian literature, for he sometimes would recite to me pieces of Russian poetry which he knew by heart. I frequently pressed him to teach me Russian and Polish, but this he steadily refused to do, or, at any rate, to teach them to me otherwise than as a friend, for it was his fixed rule not to accept payment for teaching any language with which he did not consider himself to be grammatically acquainted-and yet he had quite as grammatical a knowledge of Russian and Polish as most Englishmen have of their own language! But, unfortunately, one cannot press a friend to teach one a language, when all the trouble is to be on one side and all the advantage on the other, and the consequence was, that I learned from him but little more than the pronunciation of these two languages. (1863.)

$\ddagger$ The languages he here alludes to are, probably, Hebrew, Rabbinic, Chaldee, Syriac, Latin, French, and Italian. The last two he spoke with fluency*. I have heard him say that he could not remember the time when he did not speak German, Russian, Polish, and French, and I have reason to believe that he commenced Hebrew at a very early age. Of English he did not know one word when he came to England + ; but, although forty at that time, he succeeded in

* In common, however, with many persons who speak two or three foreign languages well, he spoke every language with which he was at all acquainted as far as he knew it. Thus, I remember his telling me that he once held a long conversation in Old Syriac with some Syrian Bishop who had come to Cambridge, and was made nuch of there. He and I have spoken Hebrew together; and if we did not speak it oftener, the fault did not lie with him.

+ It has sometimes been discussed (see Rogers' Table Talk, p. 263), what word (or phrase) would be most useful to a person, if his knowledge of a language was to be limited to a single word (or phrase). This question Dr. Bernard discussed with himself, with reference to the English language, during his passage to England, and the conclusion he came to was, that he had better ascertain as quickly as possible the English of "Wie heisst das?" 


\section{imparted to him by able and distinguished private tutors, whom his father, being a wealthy man, could afford to keep for him}

acquiring a far better knowledge of our language, than is usually acquired by foreigners. His pronunciation was remarkably good, and he spoke English with as much ease as he did German, and with great correctness, although, in addition to his slight foreign accent, a few trifling mistakes occasionally betrayed the foreigner. I must, however, allow that, on the occasion of my first short interview with him, I did not discover that he was not an Englishman (his name said nothing); and, although I noticed some peculiarity in the tone of his voice, I attributed it to his age, and to some slight provincial tinge, rather than to its true cause. He was well skilled also in English composition, and would frequently write long letters in not only correct, but really elegant, English. At times, however, he would commit slight blunders, and this arose, as he himself confessed, from his never having been able to acquire that fine discriminating power both of eye and ear, which commonly enables us, in the case of our own language, to determine when this and when that word (or construction) must or may be used, but which, I think, no one ever yet did possess in an equal degree with regard to even two languages.* He likewise translated from Hebrew into English with the greatest ease, and, indeed, I beliere that it was much easier to him, from constant habit, to translate from Hebrew into English than into German; for, though, as I have before observed, he nearly always spoke German to me, as being almost the only one among his friends with whom he could converse

"Was ist das?" or, "Wie nennt man das?" because then he would at once be able to learn the English name for anything he saw. He acted upon this conclusion, and I believe, indeed, that the Captain of the ressel communicated to him the talismanic words (What is that? What do you call that?), which he was in search of ; so that, with the aid of his wonderful memory, he was not long in acquiring a knowledge of English. When asked how, though he had begun so old, he had managed 10 acquire so good a knowledge of English, he used to reply; "Impudence! Impudence!" and he certainly never was afraid to ask a question. His first teacher in English was a Frenchman, of whom he took lessons for some time, until one evening his master took it into his head to descant upon the beauties of the opening line of Young's "Night Thoughts," "Tir'd Nature's sweet restorer, balmy sleep," and wound up by saying to his attentive pupil, "Vous voyez, il y a en l'homme trois natures, et sa troisième nature, c'est le sommeil" (the malheureur had taken TIR'D nature = TuIRD nature!!)-and Ir. Bernard then perceived that he knew more than his would-be instructor.

* My own observation leads me to the conclusion, that those who are brought up from their childhood to speak two or more languages indiscriminately and with equal ease, really never posscss a mother-tongue, i.e., a tongue free from all foretin admixture; for I have invariably noticed-and every fresh example which comes before me confirms my observation-that these many-tongued individuals cannot speak even the language of the country in which they have passed the greater part of their lives, and with which, of course, they are commonly the most familiar-without introducing into it some idioms borrowed from one or more of their other languages; whitst, when speaking these other languages, some slight (often very slight) peculiarity of accent betrays them, independently 
at home. He also kept for him a mathematical tutor.* In 1825, Hermann Bernard came over to England, $\dagger$ which country he has never left since that time, and in which he has ultimately become naturalized. In 1830 he established himself at Cambridge, where he soon afterwards was unanimously elected by the Senate Hebrew teacher in the University, with an annual stipend-an office which he still holds. Soon after his establishing himself in Cambridge he was engaged by six distinguished members of the University $\ddagger$

in his native language, yet, when translating to me from Hebrew, he invariably made use of English. And this will not surprise any one who considers bow plain and straightforward English is, in comparison with tortuous, intricate, and longwinded German. A German friend of mine, who, as compared with Dr. Bernard, had only a moderate acquaintance with English, confessed that it was by no means easy, even to him, to translate from Latin (a language, too, to which German is not unlike in construction) into German, and that English was much better adapted for the purpose. The fact is, English is a practical language, and the language of a practical people-and it, therefore, commends itself to any one-who, like Dr. Bernard, is a practical man. German has, however, the advantage of frequently being less ambiguous than English, which has no genders and no cases.

Dr. Bernard also had some knowledge of Arabic, but where he acquired this I do not know ; I expect, however, in England, as the grammar which he used, and which is now in my possession, was not published till 1825, and was procured for him from Germany by an English bookseller. (1863.)

* Dr. Bernard had no great knowledge of mathematics, to which be had devoted but little time, but he had a very great liking for them; and, with his remarkably clear head and logical mind, they could have offered him no difficulties. (1863.)

$\dagger \mathrm{He}$ came over with the view of acquiring the language and then returning to Russia. In the first instance, he settled, I believe, at Lincoln. He fully appreciated the liberty which he enjoyed in England, and always spoke in bitter terms of the Russian Government, so that the issue of the Crimean war was a source of rejoicing to him. He used particularly to complain of the practice, which it seems was prevalent in Russia whilst he lived there, of quartering officers and soldiers upon the inhabitants. There were constantly some, he said, in his father's house or in his, and their general practice was to appropriate all the best rooms in the house to their own use, and to treat the owners as though they were servants. (1863.)

+ Among these were, if I am not mistaken, the late Dr. French and Prof. Lee, Mr. Skinner, and the present Professor of Hebrew in the University of Cambridge (Dr. Jarrett). (1863.)

of the blunders which they can scarcely fail to commit. Dr. Bernard used to relate of the daughter of a Russian prince to whom he was banker, that, whenever she signed a receipt for her father, she invariably wrote, "Pour le conte de mon père." 
to expound to them the Yad Hachazakah of Maimonides, and this gave rise to "The Creed and Ethics of the Jews, exhibited in selections from the Yad Hachazakah of Maimonides," which he published in 1832.* In 1839 he edited the "Guide of the Hebrew Student," which is a selection from the Hebrew schoolbooks published by Wolfssohn and Ben-Zev, but to which he added some Hebrew essays of his own composition, as well as some of his own Hebrew translations of passages from Plautus, Juvenal, Shakespeare, Pope, Young, $\dagger$ and others. In 1853, after he had already been afflicted for some time with total blindness from cataract, $\ddagger$ he published jointly with the Rev.

* I strongly recommend this book to the notice of those who wish to learn Rabbinical Hebrew. (1863.)

$\uparrow$ Dr. Bernard was by no means ill-rersed in English literature. His favourite work was Young's “Night Thoughts.” In German literature he was also well versed, and here his favourite authors were Lessing, and (many may be surprised at this) Kotzebue. (1863.)

$\mp$ I believe he lost the sight of one eye, so far at least as to be unable to use it in reading, about twenty years before his death. He used to relate that he first discovered the fuilure of siglit in this eye accidentally. He was in the habit, namely, of running over to the Bull IIotel (at Cambridge), near to which he lived at that time (in Trumpington-street, I believe), between two of his lessons, for the purpose of glancing over the "Times." One day, as he was on his way to the hotel, something flew into, I think, lis left eye. After trying in vain to dislodge the intruder, he said to himself;" "I will leave it till I get back hone, I can read the paper with the other eye." But, to lis astonishment, he found, as it were, a mist spread over the paper, so that he could not distinguish the letters. This is not, however, an isolated case, for I think that people occasionally have incipient cataract in one eye for some time before they perceive any failure in their powers of vision. When he totully lost the sight of this eye, and when the other first became affected, I neither know, nor is it of much importance, but he does not seem to have become totally blind until about the year 1850 . I first became acquainted with him in 1852, and he was then totally blind, i.e., lie could merely distinguish light from darkness. Notwithstanding his infirmity, he had pupils up to the time of his death; but for several years before this he had the assistance of his friend and former pupil, Mr. Mason, who most generously went to Fitzwilliam-street every day and corrected a part, at least, of the Hebrew exercises which Dr. Bernard's pupils lad written. I frequently advised Dr. Bernard to consult some oculist with regird to his eyes, as the cataracts could, of course, have been removed, and he might, very likely, lave regained his sight; but, though he seemed at times tempted to follow my advice, he procrastinated and procrastinated until death overtook him. IIe used to say that he was, 


\section{P. H. Mason (now Fellow) of St. John's College, Cambridge, a} Hebrew Grammar, in two volumes, arranged in letters from a teacher of languages to an English duchess.* In the titlepages of all his works the name of Hedwig, $\dagger$ being that of a departed sister, whom he wished to commemorate, is joined to his own Christian name, which is Hermann. He is now engaged, together with Dr. Chance, of Trinity College, Cambridge, in

and always had been, "eine feige Memme," and that he never could submit to any operation; but, though he may really have been timid, yet other causes, and among them want of time, and unwillingness to break through the routine of his usual habits, certainly contributed to prevent him from taking any steps towards the removal of his blindness. (1863.)

* This grammar, well called by its authors the "gently flowing waters," is better adapted for the student than any Hebrew Grammar I have seen. It tells the student just what he requires to know and no more, and gradually conducts him from the elements to the niceties of the language, whilst all the other grammars which have come under my notice, and especially those of Ewald, Gesenius, and Nordheimer, though indispensable, it may be, to those who have made themselves familiar with Hebrew, so mix up together that which is useful to the student with that which is beyond him, that I am afraid-instead of enabling him to surmount, insensibly almost, the difficulties of the language, by presenting them to him, one by one, in the order in which they may be most suitably met and most readily overcome-they are likely only to dishearten and rebut him, by plunging him at the very onset into a sea of difficulties, from which only the greatest acuteness and the greatest perseverance will ever enable him to emerge, without the loss of all further inclination for the study of Hebrew. The latest Grammar is that of Kalisch, which, though very practical, and very useful to one who already knows Hebrew, will, I think, find but little favour with the student, who ean scarcely fail to be speedily disgusted with the great number of dry, and to him incomprehensible, details, which are set before him from the very first. Kalisch is, I believe, generally accurate; still, without looking for errors, I have stumbled upon a rather gross, though at first sight, perhaps, not very obvious, blunder. $\mathrm{He}$

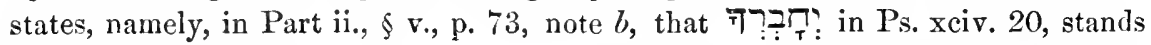

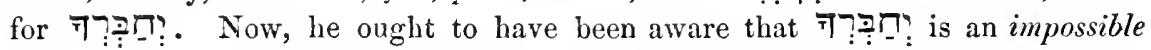
form, for it = דירבְ:, in which we have two Sh'vahs following one another at the beginning of a syllable (the second), which is impossible. He should, there-

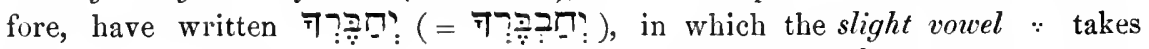
the place of the first of the two Shvahs. Comp.

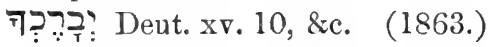

+ Dr. Bernard told me more than once that he had promised his sister Hedwig, who was much older than himself, and who died, I believe, many years before him, that, if he ever wrote a book, her name should appear on the titlepage, and this promise he religiously redeemed. (1863.) 
preparing for the press a Translation with Commentary of the Book of Job, which, according to all probability, will be before the public before the end of the present year, 1857.*

(Dictated to me, I believe about July, 1857.-Ecitor, 1863).

To this account which Dr. Bernard gives of his life $I$ have but little to add. I will merely state, on the authority of a member of his family, + that it was chiefly in consequence of his devoting himself to his books rather than to his business (he was a Banker), that he was overtaken by the reverse of fortune $\ddagger$

* Even, if Dr. Bernard had lived, the present work would certainiy not have been published in 1857 ; for the manuscript was not completed until May or June; and soon afterwards it was thought desirable that I should complete my medical edueation by passing a year in France and Germany; and, as I did not return from abroad until October, 1858, the work could not have appeared before 1859. At the time that Dr. Bernard drew up the sketch of his life, however, I contemplated remaining at Cambridge until the work was published. (1863.)

+ He left two sons and five daughters, and at the time he died, the son of one of his daughters, a young man of twenty-five or twenty-six, was a professor at the University of Moseow.

$\ddagger \mathrm{Had}$ it not been for this reversc of fortune, Dr. Bernard would probably have remained a banker, and never have become an author, and he certainly would never have been a teacher. At the same time, if this reverse had been rather less severe, so that he would not have needed to give up so very large a portion of his time to teaching, and if he had preserved his eyeright, we should doubtless have had other works from his pen, whilst his Commentary on Job would have left less to desire, than is now the case. It is impossible that a work of the nature of a Commentary, written by a blind man with the assistance of one, who, like myself, had only just ceased to be his pupil, could be equal to what he would have written, if, with the help of his own eyes alone, he had been able to gather the materials for his work. Dr. Bernard had a remarkably retentive memory, and lie had read, or lieard read, the Book of Job a great number of times, so that he no doubt knew every word of it off by heart (as I myself now almost do); still eren thus all the irregularities of orthography, gender, number, construction, \&c., with which the Book of Job swarms, would not be brought home to him by any means so strongly, as if he had them constantly before his eyes; and, I am afraid that, when I was helping him, I was not so much alive to this fact as $I$ am now, and that consequently $I$ did not call his at. tention to these irregularities so much as I might hare done (see p. Ixxix, note ${ }^{*}$ ). Hence, I think, has arisen in a great metsure the necessity for an Appendix, although, as Dr. Bernard wrote rather for the Ilebrew scholit thin for the Hebrew student, some additional notes would, at all everits, have been required, in order to seuder the work suitable for the stulint. At the same time. 
which led to his coming to England. His death, which was rather sudden, and was, as far as I can judge from the symptoms, caused by heart-disease, took place on the 15 th of November, * 1857 , so that he was in his $72 \mathrm{~d}$ or $73 \mathrm{~d}$ year.

Of his knowledge of Hebrew I need scarcely speak. The public will be able to form their own opinion after having read his Commentary, and the opinion which they will then form, they will, I am sure, prefer to any judgment pronounced by me. I will content myself with saying that he not only had all the Hebrew of the Old Testament at his fingers' ends, $\uparrow$ but that he had also a most intimate and accurate knowledge of the Talmud, and was well acquainted with the Commentaries and writings of all the most eminent early and modern Rabbinical authors, and with the works which some of those authors composed in Biblical Hebrew. $\neq$ Of his really wonderful know-

Dr. Bernard's Commentary is much more complete than, I think, any other Commentator would, under the same circumstances, have made it, because Dr. Bernard was a man who had very decided opinions of his own, and therefore naturaily preferred to interpret the Book of Job according to his own judgment, than according to that of any other Commentator. By far the greater part of the Commentary, therefore, issued from his own brain, and accordingly it made but little difference whether he limself wrote down his thoughts, or whether another wrote them down for him.

Had Dr. Bernard lived, I think it is very probable that he would have published selections from the Talmud.

* He was taken suddenly ill on Monday, the 9th November, 1857, and the attack was of so violent a nature that he at once thought he was likely to die; he recovered, however, very speedily, more or less, and during the rest of the week I believe he received his pupils much as usual. On Sunday morning, the 15th, howerer, he had a second and still more violent attack; and he then felt convinced that his life was fast drawing to a close. He sent for a solicitor and dictated his will, which, however, he did not live to sign, and in the afternoon, whilst calmly conversing with his friends, Mr. Mason, and Mr. Mason's father, he suddenly sank back in bed, and immediately expired, though so gently did his death take place that he was at first thought to be only asleep.

$\downarrow$ At his tongue's end would be the more correct expression, for I hare heard him say, that at one time he could complete any verse in the Hebrew Bible, of which the first two or three words were repeated to him.

‡ The titles of some of these works will be found in Dr. Bernard's "Guide to the Hebrew Student," Preface p. xii ; and I would also recommend to the attention of the reader pp. ix-xii of this Preface. 
ledge of Rabbinical Hebrew I may give some idea when I state, that, though, whilst we were preparing the Commentary on Job, I read to him the most various extracts from Rabbinical Commentaries, I never found him in the slightest degree embarrassed or puzzled by them, unless, indeed, the text were doubtful ; they were to him as so much German or English; and it happened but seldom that $I$ had to read them over to him more than once.* Now, how many Latin or Greek scholars are there, who would be able to translate off hand any passage that might be read aloud to them from any Latin or Greek author! That it was as easy to him to translate into Hebrew, as it was to translate from Hebrew, every pupil of his will readily testify; and it was, I will venture to say, principally owing to his enforcing upon his pupils continual exercise in Hebrew composition, that they nearly always succeeded

* He was always anxious that his pupils should study Rabbinical Hebrew, not merely because there were a great many very valuable Commentaries written in this dialect, but also because he considered it of some service in the interpretation of Biblical Hebrew (see p. vii.). Again, as Rabbinical Hebrew is always found without points, and one cannot read it aloud without supplying the points, it follows that to read it aloud is equivalent almost to putting the points to a piece of Biblical Hebrew-an exercise which is generally, and justly, regarded as exceedingly useful, from its tendency to impress the points, i.e., the grammar of the language, upon the student's mind. And, indeed, when reading Rabbinic to oneself, one is apt to supply the points mentally more or less, or, at any rate, one feels uncomfortable when a word starts up which one is unable to point, and, even when we know the meaning of the word, we seek to remore this discomfort by appealing to the Lexicon. Moreover, Rabbinical Hebrew is the continuation of Biblical Hebrew down to the present time, and may be regarded as what Biblical Hebrew would, or might, have become, if it had never ceased to be a spoken language-and considered merely from this point of view, werely as a link between the past and the present, the Rabbinical dialect is well worthy of being studied. Putting all these considerations together, therefore, I fully agree with Dr. Bernard that no one, who is unable to read Rabbinical Hebrew, can be regarded as an accomplished Hebrew scholar; and I am sure that one, who can read Rabbinic well, will always be fuund to possess a better knowledge of Biblical Hebrew, than one who confines himself to the latter. With regard to the objection, that the Rabbinical student is liable to introduce Rabbinical words into what he intends shall be pure Biblical Hebrew, I think, from my own experience, that it is of but little weight, for Rabbinical words bear, as a rule, such a distinctive impress, such a cachet, of their own, that no one, who is at all familiar with Ribbinic, is likely to confound them with pure Hebrew. 
in carrying off the Tyrwhitt Hebrew Scholarships. During the two years I studied Hebrew under him, I never left his house without having translated a certain portion of English into Hebrew*, and I have no doubt that the majority of his pupils conformed to his system. Another element in his success as a teacher was his skill in adapting the pabulum, which he laid before his pupils, both in grammar and reading, to their digestive powers. To the beginners he allowed nothing but the most simple food. Until the grammar written by Mr. Mason and himself appeared, the only grammar he allowed his pupils to use was that by Hurwitz, and from this he used to cut out $\dagger$ all that he considered might puzzle them. The consequence was, that, so far from being disgusted with the difficulties of Hebrew, as they infallibly would have been, had he allowed them to use such grammars as those of Gesenius, Ewald, Lee, $\ddagger$ \&c., they learned Hebrew, as a child learns to speak, without knowing how they learned it. $\S$

But Dr. Bernard not only translated with great readiness into Hebrew, he also composed with remarkable facility and elegance in that language. This would be inferred by any one who had read his compositions in the "Guide to the Hebrew Student," \&c.;

* This was part of Dr. Bernard's plan of teaching. He knew that if he requested his pupils to bring him a piece of Hebrew every time they came, they would frequently bring him nothing but excuses, but, as pupils (I speak of adults) commonly leave their master's presence full of good intentions (which afterwards evaporate at home), he took advantage of this, and when they left him, after they had read their exercises to him and translated what they had prepared, they were ushered into another room, where they found a piece of English ready for conversion into Hebrew, and thus he rarely failed in obtaining a piece of composition from them. At any rate, whether this was his object or not, the effect produced was-in my own case, at least-that which I have described, for to this arrangement of his I can certainly attribute the fact, that I wrote much more Hebrew for him, than I did Latin or Greek for my other coaches.

$+I$ use the verb cut out in its most literal sense; he cut out the pages containing the offensive matter, just as Voltaire is said to have cut out of all the works which were presented to him, whatever he thought was not original.

$\ddagger$ One might as well put Matthiæ's Greek Grammar into the hands of a boy just beginning Greek! See p. xciv, note*.

$\S \mathrm{He}$ taught Hebrew in fact much as Latin and Greek are taught at public schools. Practice first, and then theory, if you like, was his motto; whereas Ewald's seems to be theory, theory, theory, toujours de la théorie. 
but I had unusual opportunities for observing how great this facility was, inasmuch as he more than once dictated to me long letters in Hebrew, one at least of which I still possess. * Now, as it is above all by speaking and writing a language, and not by studying its syntax alone, that one can attain to that remarkable power of discrimination of the eye and ear, to which I have before alluded (p. xc, note $\ddagger$ ) $\dagger$, and by which the mind often (instinctively

* This letter I may possibly give in the Appendix.

$\dagger$ In nothing, perhaps, is this power of discrimination better shown than in the detection of ellipses. The Hebrew language is, as is well known, very rich in ellipses, richer perhaps than any other language, especially in its poetry. Of these ellipses many are obvious, even to the learner, but there are many also which escape even those who consider themselves to have a profound knowledge of the language. In fact, every one who has studied Hebrew deeply, and can still remember the different phases through which, in its progress, his knowledge of the language passed, will, I am sure, bear me out when I say that, the more intimately one becomes acquainted with Hebrew, the more readily do ellipses suggest themselves, and the more elliptical, therefore, does the linnguage of the Old Test. appear. This is so true, that I am in the habit of estimating a Commentator's knowledge of Hebrew, in some degree, by the readiness with which he detects ellipses. Now, in no Commentary on the Book of $J_{0} b$ will a greater number of passages be found to be regarded as elliptical, than in Dr. Bernard's, and herein, to my mind, he especially shews his great superiority over, at least, all the Christian (non-Jewish) Commentators. I remember well that, when I first read the Book of Job with him, I was astounded at the number of ellipses which he supplied, and that I entertained very great doubts as to whether he was justified in doing so. But gradually, as my knowledge of Hebrew alvanced, that, which had at first seemed harsh and arbitritry, became straightforward and natural, and I found myself, even in books which I had never read with Dr. Beruard, constantly detecting ellipses, which before I should strenuously have refused to admit. Nor do I consider myself yet by any means to have reached the limits of this ellipse-defecting faculty, which is sharpened by nothing more than by the study of Rabbinical Hebrew; for this dialect, especially as written by Aben-Ezra and by Ben-Zev, is much more elliptical than Biblical Hebrew. I would recommend the critic, therefore, before he pronounces any of Dr. Bernard's elliptical constructions * to be harsh and forced $\dagger$, to pause a little and consider whether the beam may not be in his own eye, and whether a more profound knowledge of Hebrew might not convert into excellencies what he now can look upon only as faults. For the detection of these ellipses no certain rules can be laid down, it is by intuition only that they can be discovered, and this intuitive power is developed in proportion as a more extended knowledge of the language is acquired.

- These remarks apply also, of course, to his constructions generally.

† Comp., for example, chaps. xxii. 11, xxxiii. 17. 
almost), seizes upon the meaning of a difficult passage, it cannot be wondered at, if I consider Dr. Bernard, whom I know to have written Hebrew with such remarkable facility and correctness, a far, an infinitely far, greater authority with regard to the interpretation of the Hebrew Bible, than Schultens, Rosenmüller,* Gesenius, Ewald, and other Christian (or perhaps rather non-Jewish) Commentators, in facour of whose practical knowledge of Hebrew we have scarcely one tittle of evidence.

Hitherto I have considered chiefly Dr. Bernard's acquirements; let me now say a few words concerning the faculties and qualities of his mind. Acute, ingenious and original, he was prevented from plunging, like so many of his countrymen, $\dagger$ into vain fancies and speculations by great clear-headedness, soundness of judgment and caution, qualities, the development of which had doubtless been furthered by the business pursuits of his early life. Whatever theories he did advance, were based upon facts, or upon what he regarded as facts, and he did not form his theory first, and then make his facts bend and bow to his theory. As might be expected, therefore, he was very exact, accurate, and methodical, and he always expressed himself with great accuracy and precision, so that there was never any difficulty in ascertaining the meaning of what he said or wrote. At the same time, however, he was a little apt to refine (betraying therein, perhaps, his Jewish origin), so that if a passage in the Bible could be interpreted in two ways,

* Rosenmiiller sometimes ventures to supply an ellipsis in Hebrew, but, as pointed out in the Comm., he seldom does so, without committing some egregious solecism. Ewald rarely ventures upon writing a word in Hebrew. Gesenius, whom as a practical Hebrew scholar, I place far before the other two, sometimes does supply an ellipsis or so in Hebrew, and I think his Heb. is generally correct, as far as it goes. Schultens, I think, has not much to do with Heb., and if he writes a word, takes care not to point it. But as for one whole sentence in Hebrew, it will be sought for in vain in the writings of these Commentators. Ewald does, indeed, sometimes supply whole verses (e.g., Job xii. between vers. 12 and 13), which he thinks have disappeared, but he supplies them in German, not in Hebrew. If then it be true that the mouth (or pen) flows over with that with which the heart is full, we must infer that these Authors were unable to write such Hebrew, as to venture to lay it before the public.

$\dagger$ I mean the Germans, for Dr. Bernard looked upon himself as a German. 
the one very simple and obvious, and the other a little more subtle, he would sometimes choose the more subtle interpretation, and some examples of this tendency may be met with in his Commentary.* He respected the authority of those whom he considered to be learned, but he carefully weighed their opinions, and did not scruple to reject them. $\dagger$ Indeed, he relied, I think, a little too much upon his own judgment-I speak of course of matters, with which he considered himself competent to dealand he has thus exposed himself sometimes to the charge of dogmatism. He had great perseverance, so that whatever he undertook he would work at, steadily and uninterruptedly, until it was finished. His memory was remarkably retentive, still he did not disdain to invoke the help of a Memoria technica ${ }_{\ddagger}^{+}$It might be inferred from the foregoing that he had not much imagination, but this was not so. It was only in the business of life that he was so methodical and practical; out of business hours he would give his imagination the rein, and then he was as though he knew not what business was. He was very cheerful, in spite of his blindness; his feelings were warm, and he delighted in the society of his friends of whom he had a large number. He had great conversational talent, and his conversation was always instructive and amusing, as he had a vast fund of general information and was full of anecdote. But he was not only a good talker, he was also-which it is much more difficult to be-a good listener, and, ever eager for information, he sought to make those in whose company he happened to be, talk upon those subjects to which they

* It must be remembered, however, that he had been carrying the Book of Job about with him in his head for years, and had reflected upon it much and constantly; and it is not, therefore, surprising that some of his interpretations should be a little too elaborate and artificial.

† There are people who sacrifice their own judgment to a great name. Dr. Bernard was not one of these. See note in Comm. on 9 ? and on chap. xxi. 13, p. 185 .

$\ddagger$ He had shares in different railways, and it was principally for the purpose of remembering their numbers, which happened to be very high, that he made use of his Memoria technica. He always converted his numbers into Hebrew words, which is not surprising, as every Hebrew letter has a known numerical value, and he, therefore, had not the trouble of giving to English or other letters the value of numbers. 
had especially devoted themselves. His avidity for every species of information, whether important and useful, or unimportant and merely interesting or exciting, was very remarkable, and I see him now bending forwards, or stretching his body over the table, towards me, and rising even from his chair, in his eagerness not to lose a word of what I said-when I was about to read to, or tell, him something, which he considered would be interesting. $\mathrm{He}$ retained in fact until his death-and this was, perhaps, his most striking characteristic-all the freshness and thirst for knowledge of a child. Had he lived a thousand years, his susceptibility for fresh impressions would, I believe, never have been blunted, his mental appetite never have become palled. As might be expected from this strong admixture of the nervous in his temperament, he was very sensitive and extremely passionate, but here again his caution and his self-command stepped in, and he very rarely discharged his passion excepting where habit had blunted its edge, I mean upon the head of his servant-boy.* He was a man of very high principle, but he had an overstrict and too stern a sense of duty, especially of the duty of a wife towards her husband, and of children towards their parents, so that he was altogether unable to forgive what he conceived to be a flagrant violation of it. In eating and drinking he was extremely temperate, nay almost ascetic, for, whilst I knew him, he took but one very small meal daily, and he never drank either wine or spirits, or, indeed, any alcoholic beverage.

With regard to his religious belief, I can form no opinion, as his caution and dislike of argument led him to avoid the subject of religion, and I cannot remember that he ever spoke to me either about the religious belief of others, or his own. $\dagger$ He always professed to have great fear of death, but he shewed no fear of it when he knew it to be at hand; indeed, it was whilst he was calmly engaged in making arrangements which he considered to be

* He was, however, substantially just, kind and liberal to him.

$\dagger$ Mr. Randolph, however, tells me that Dr. Bernard once assured him that he was in the habit of daily using a prayer, which he himself had composed, and which is to be found in Mason and Bernard's Grammar, vol. ii., p. 294. This prayer, which I venture to give here, with a translation, partly because I think the 
necessary in view of his approaching end, that he suddenly sank back dead upon his bed.

In conclusion, he was a man who commanded admiration by his intellect and learning, and, in particular, by the extent and soundness of his knowledge of Hebrew; esteem and respect by his moral worth; and sympathy and affection by his warmth of heart and remarkable social qualities.

51, Wimpole-street, Dec. 13th, 1863.

Grammar may not be accessible to many who read this book, and partly because it is a good specimen of Dr. Bernard's Hebrew, runs as follows :-

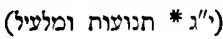

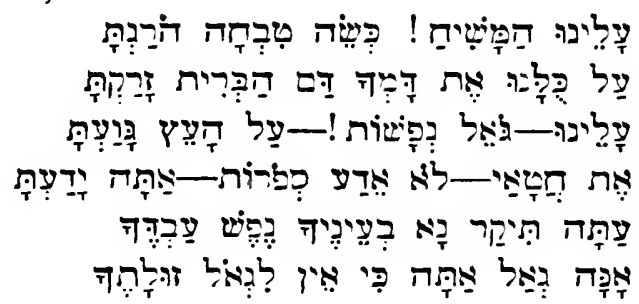

For us, O Messiah ! wast Thou slain as a lamb doomed to slaughter !

For all of us didst Thou pour out Thy blood, the blood of the covenant !

For us-O Redeemer of souls !-didst Thou die upon the tree !

My sins-I know not [their] numbers-'Thou knowest-

Let now, I pray Thee, the soul of Thy servant be precious in Thine eyes !

I beseech, do Thou redeem [me] ! for to redeem there is none beside Thee.

* i.e., 13 vowels (or syllables), and [the accent of the last word in each verse] penultimate. Sh'vahs of course are not counted either as vowels or syllables. $-N$. of Fd. 
civ

N.B. - For a summary of the speeches of Job, . . see pp. 15- 17 .

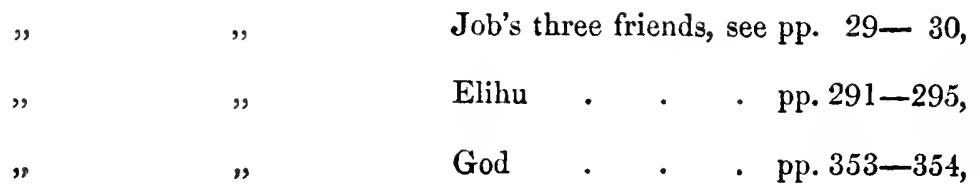

(and compare Ben-Zev's Preface).

Extracts from Rabbinical writers (see 1st Pref. p. xii) are to be found in pp. 3, 4, 7, 8, 10, 11, 22, 24, 26* $35,36,43^{*}, 47,50,51,54,56,68 \cdot 69^{*}, 72$, $75,76,80,81,86,91,96,105,109,111 *, 118+, 120^{*}, 122^{*}, 123,126,127 \dagger$, $130,140^{*}, 149,150^{*}, 170^{*}, 178,188^{*}, 191,199,201^{*}, 204^{*}, 205,214,217^{*}$, $223^{*}, 224,230,247-248_{+}^{*}, 250^{*}, 251,258 \dagger, 261,264^{*}, 265,269,271^{*}, 278^{*}$, $280,283,287,289^{*}, 299^{*}, 316^{*}, 317,326,330,331,332,350,358,359,363^{*}$, $374-375 \ddagger, 381,383,386,393,394,500 . \ddagger$

* Pieces of from two to five lines in length.

+ Pieces above five lines and under ten lines in length.

$\ddagger$ Pieces above ten lines in length. 


\section{0 M M E T A R Y.}

Trose, who are acquainted with the original of the Old Testament, will do well to have the Hebrew Text open before them, while reading this Commentary. The accents, as far as regards interpunctuation, should be neglected, for they are altogether irregular in this book, as well as in Psalms, and Proverbs.

In the Commentary, where accuracy and fulness of sense, rather than elegance of expression, have been kept in view, passages may very often occur, rendered in language somewhat different from that of the Translation, but the sense will, it is trusted, always be found to be precisely the same. It is hoped that the reader will generously refrain from passing judgment on the Translation, till he has referred to the Commentary and Notes.

The Sacred name Jehovah, where it occurs in the Translation, must not be regarded as a proper name given to the Deity, but is intended by us to represent, as far as it is possible to do in English letters, the Hebrew

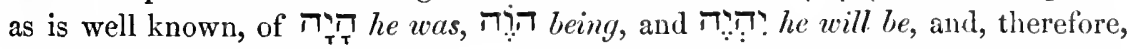
signifying a being, who was, is, and ever will be, an Eternal Being), so that by Jehovah we mean in reality the Eternal One.

\section{CHAPTER I.}

Ver. 1. The name ע, applied to a country, is found three times in the Old Testament, viz., in the verse before us, in Jeremiah xxv. 20 , and in Lament. iv. 21 ; applied to persons, it is also found three times, viz., Gen. x. 23, xxii. 21, xxxvi. 28.

The name בi’̣, which so frequently occurs in this book, is only found once elsewhere, viz., Ezek. xiv. 14, and there evidently alludes to the same person.

וִ ?ִ This, being a past tense with the 1 conversivum, is used to denote an habitual state, and implies that $\mathrm{J}_{0} b$ aluays (i.e., ever, constantly) was pious, \&c. With regard to the doctrine of the tenses and the I conversivum, the reader is referred to Mason and Bernard's Hebrew Grammar (Letters 51-55), in which it has been laid before the public in all its shades, and supported by arguments, which have not hitherto met with any refutation, although a considerable time has elapsed since the publication of that book. 
To render the word tionable for two reasons; 1 st, the epithet perfect is so comprehen-. sive as hardly to admit of any other; and 2ndly, a human being even with his greatest endeavours to attain perfection must always fall far short of his object. It appeared, therefore, more advisable to give $\delta_{\tau}$ here the meaning sincere, pious, a meaning based upon

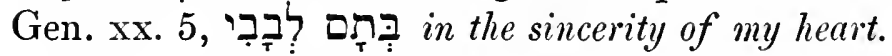

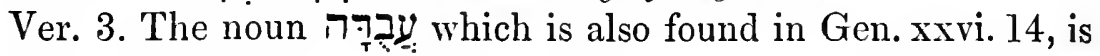
evidently derived from the verb עבד,* to serve, but also, to till, as in Gen. iii. 23, and may, therefore, signify a body of servants, (household), or arable land.

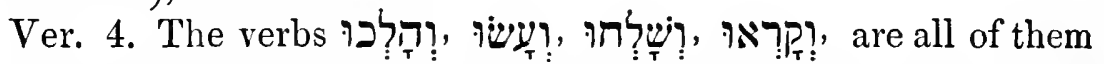
converted past tenses, used in a frequentative sense, to denote that the sons and daughters of Job were in the habit of going, \&c.

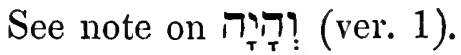

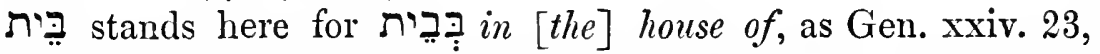

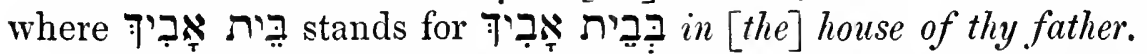

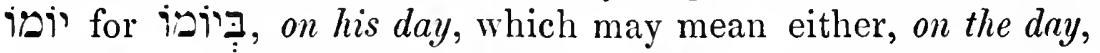
when his turn came, or on the day of his birth, as infra iii. 1, where

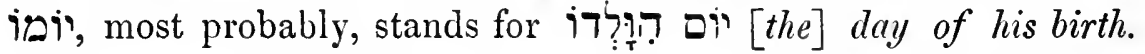
That in ancient times, as at present, the custom prevailed of celebrating one's birth-day by feasting, appears from Gen. xl. 20, where we read, that Pharaoh "made a feast unto all his servants," on the occasion of his birth-day.

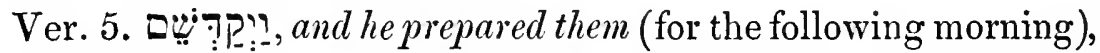
probably by words of admonition and exhortation; that the verb קדש in Pi-âl, is used to express preparation, is evident from Jer. vi. 4, li. 27, 28, Joel iv. 9 , in every one of which passages we find the word clearly in the sense of prepare ye.

To give pר, in this instance, the signification of sanctifying, as generally is done, would be to suppose $\mathbf{J}_{\text {ob }}$ to have been either a priest, or a prophet, but nothing that we read concerning him warrants this supposition.

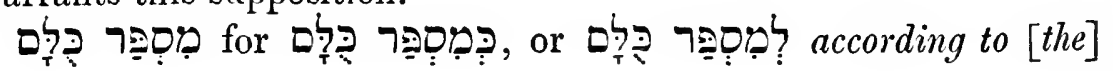

* The roots of verbs will, throughout the whole of the Commentary, be given without points, so as to leave it to the option of the reader to consider them either as the Infinitive Mood or the Past Tense, 3rd pers. sing. masc. (See Mason and Bernard's Grammar, Letter xxvii. \$3.) 
number of them all. A similar ellipsis occurs in 1 Sam. vi., where

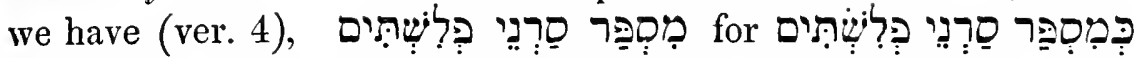
according to [the] number of [the] lords of [the] Plitistines; and

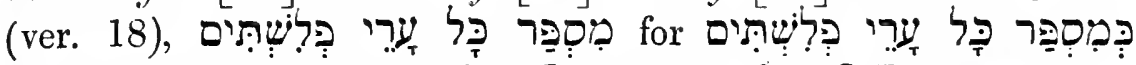
according to [the] number of all [the] cities of $[$ the] Philistines.

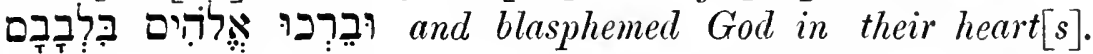
In many languages, ancient as well as modern, we find words having two opposite meanings, of which the one intended can only be determined by the context. Thus, for instance, the Latin, facinus, sometimes signifies a noble action, sometimes, a crime; the English, to cleave, as an active verb signifies, to disjoin, and as a neuter, to join, adhere to. But Hebrew abounds with such instances; thus, the noun, דֶ, which generally signifies grace,

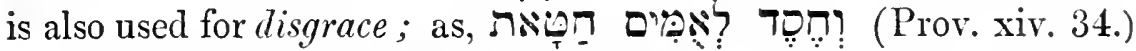
but [the] disgrace of nations [is their] sin. So also, in Lev. xx. 17, it is said of incest,

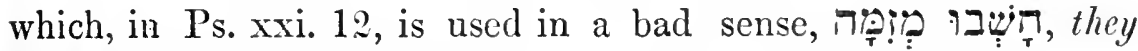
imagined a mischievous-device, is used in a good sense, Prov. i. 4,

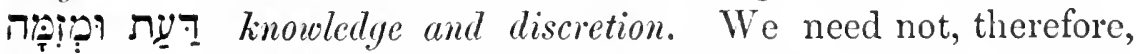
be surprised at seeing the verb ברך, which, in Pi-âl, generally signifies, to praise, to bless, used in this verse in a diametrically

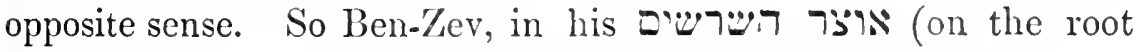

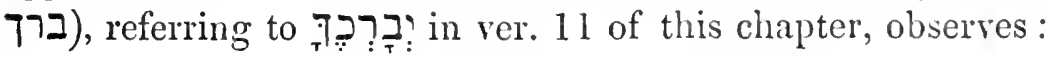

\section{וכן 'המר דרך כנוי על הפך הברכה}

"And so by way of epithet (euphemism) it may denote the reverse of blessing." One may compare the Italian benedetto, blessed, which is sometimes used as an imprecation. Wolfssohn observes, and, may be, justly, that the verb ברד is here used euphemistically, by way of respect towards the Supreme Being. 'These are his words:

\section{דרך כבור כלפי מעלה}

"By way of reverence towards the Supreme [Being]."

The use of such euphemisms is very frequent in the Talmud, and in the Commentaries of the later Rabbins; thus, in the treatise Brachoth, chap. I., the question, why, in Ps. cxlv. which is arranged in alphabetical order, ${ }^{*}$ the letter $\mathrm{I}$ is omitted, is answered by the observation, that that letter is an ominous letter, as announcing the fall of Israel, since in Amos v. 2, we read, "The

- i.e., the first rerse begins with $w$, the second with 2 , and so on. 


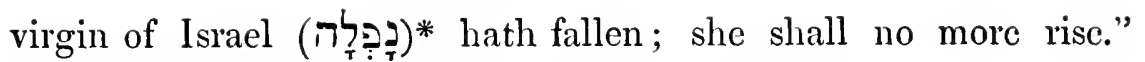
But, instead of saying, that that letter announces,

מפלתו של ישריאל

"The fall of Israel,"

they say, euphemistically,

\section{מפלתו של שונאי ישראי}

"The fall of the enemies of Israel."

We could quote many more instances of this sort, if we were not afraid of trespassing too much upon our readers' time. Similar euphemisms are to be met with in most languages. Thus the Greeks, by an euphemism, called the Black Sea, єü $\epsilon \iota \nu o s$, the hos-

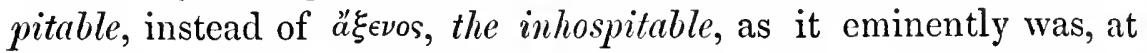
any rate, in early times, from the savage tribes surrounding it. So, again, they termed the Furies, the gracious [goddesses], Ev $\mu \epsilon \nu$ ídes (from $\epsilon \dot{v} \mu \epsilon \nu \eta_{s}$ ); and many other such instances might be adduced.

Those who are inclined to give to ברד, in the passage before us, the signification of, bidding farewell, taking leave, and hence, also, of renouncing, derive, perhaps, some authority for their interpretation from Gen. xlvii. 10, where we read, and Jacol blessed (took leave of) Pharaoh, and went out from before Pharaoh; but those who are bent upon keeping up the common signification of ברד, viz., to bless, and,

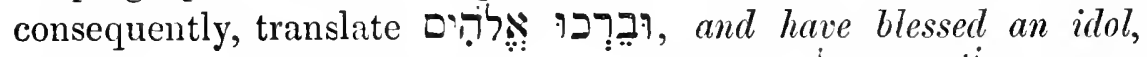

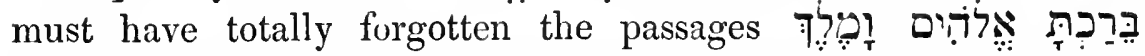
(1 Kings xxi. 10) thou didst blaspheme God and [the] king; and

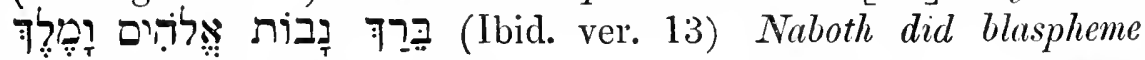
God and [the] king; in which, to give to ברד בlessing, and to șat of an idol, is altogether out of the question, as blessing an idol could not have been imputed to Naboth as a crime by such an idolatrous king and queen as Ahab and Jezebel.

From the word it may be fairly inferred, that in public the sons of Job always conducted themselves as pious and religious men, but that their father apprehended that this assumed piety might not be sincere. So the Psalmist says of the nation of Israel (Ps. hxviii. 36): "Nevertheless they did flatter Him with their mouth, and they

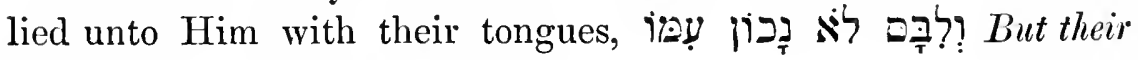
heart [was] not right with Him."

* Observe, this word begins with 9. 


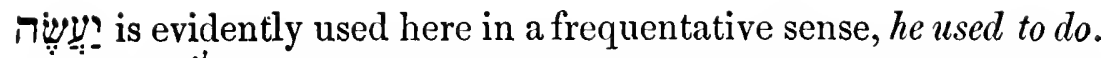

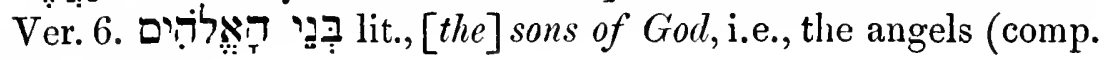
chap. xxxviii. 7.)

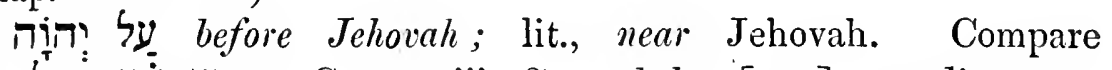

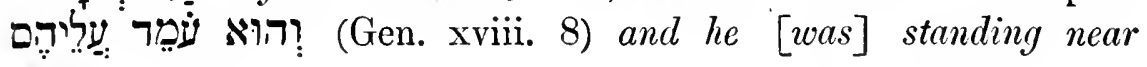
them.

הָ lit., the adversary (of mankind), the accuser, from the verb

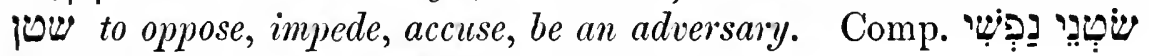
(Ps. lxxi. 13) [the] adversaries of my soul.

Ver. 9. From Satan's answer to God, it is evident, that he wished Job's piety to be considered as proceeding from mercenary motives.

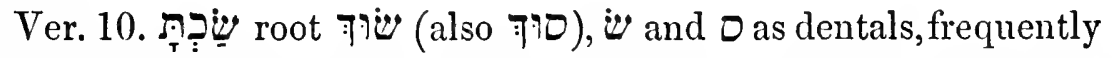
interchanging, to make a hedge, to hedge. It may be used in a good sense, to fence in, by way of protection, as it is in this instance; or, in a bad sense, to coop up, to straiten, as infra iii. 23.

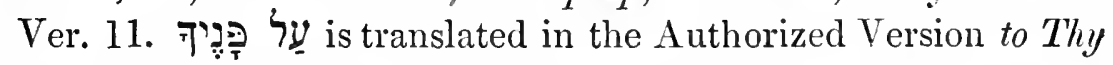
face, by which, of course, must be meant, in Thy presence, openly, publicly; and so, Schultens, "in faciem tuam;" Rosenmüller also, in his Commentary, says, "Contra faciem tuam, quasi in os tuum, non amplius corde tantum, sed, abjecta omni numinis reverentia, palam, profitebitur vanum esse, Deo servire." Now, though the term reference to the wicked tyrant, it is said, rendered in the English Version, Who shall declare his way to his face? - it is, nevertheless, difficult to understand how, with regard to God as an Omniscient and Omnipresent Being, it could make any difference, whether the blasphemy were committed openly, or in the heart, and we, therefore, have thought it better to take the noun

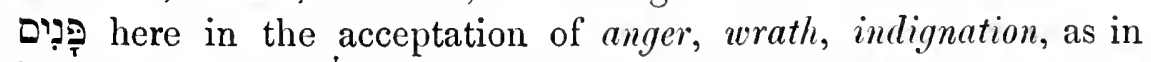

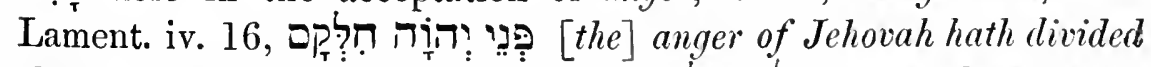
them; and would translate pheme Thee because of Thine anger? אָ being, in this instance, used not as a conditional, but as an interrogative, particle; as

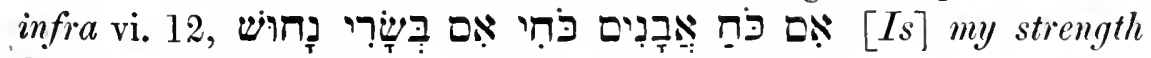
[the] strength of stones?' [Is] my. flesh brass?

Ver. 14. The collective noun $7 p_{T}$ בT, being, like the Latin bos, of common gender, is here coupled with תịị, a fem. part., while, in 
Exod. xxi. 37, we find it joined with the masculine numeral

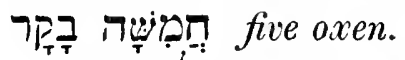

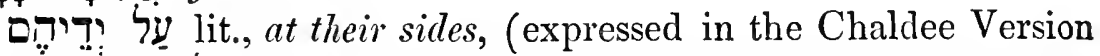

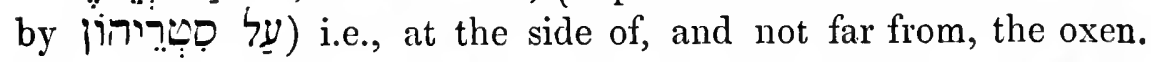
Comp. 1 Sam. iv. 13, יב דִ lit., side of [the] way, i.e., way-side.

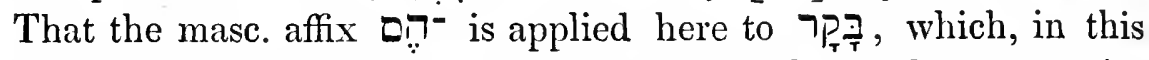
instance, is coupled with a feminine participle, need not surprise

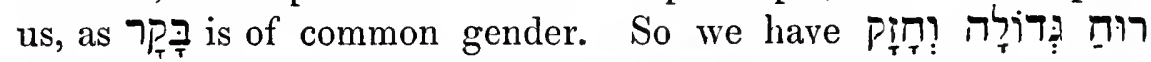
(1 Kings xix. 11) a wind great and strong, where the noun being also of common gender, is qualified by the feminine adjective

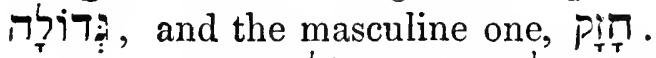

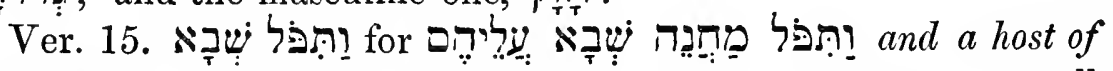
Sabaans fell upon them. Ellipses of this sort are not at all

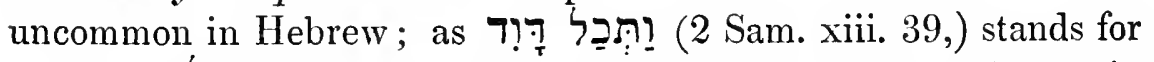

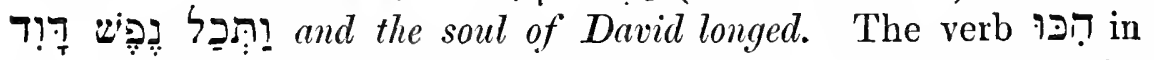
this verse is in the plural, as referring to the men composing the host.

The name of the country, Streba, Sabaa, is used here by metonymy for its inhabitants, the Sabceans, just as in Exod. xiv. 9, 23, מִצ Egypt, is used for Egyptians.

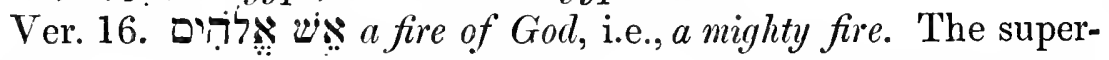
lative in Hebrew is frequently expressed by coupling the noun with one of the attributes of the Deity ; as אר? (Ps. lxxx. 11), lit., cedars of God, exceeding-goodly cedars; אלק (Cant. viii. 6), lit., a flame of $\mathrm{J}_{\mathrm{AH}}$, i.e., a very mighty flame. Those, who understand by this fire, lightning, materially weaken the force of the event here recorded, it being more probable, that this was a supernatural fire, unattended by any storm or thunder. So the fire mentioned

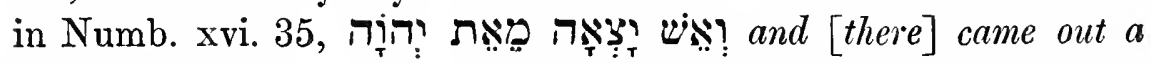
fire from Jehovah, may also be more reasonably regarded as a supernatural fire, than as mere lightning.

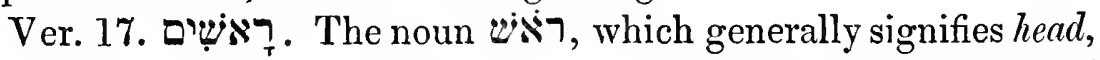
and also, chief, is used here in the meaning of a band (of

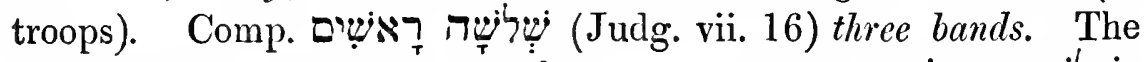

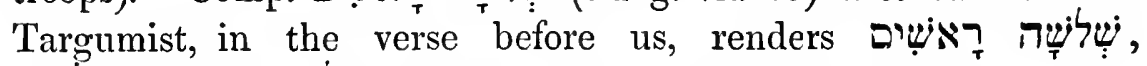

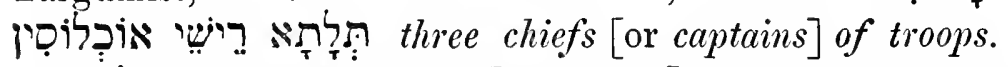

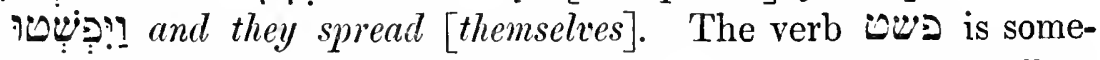
times used for the unfolding and stripping off of a garment, as Lev. 
vi. 4, times, for the unfolding, or spreading out, of a host, (like the French,

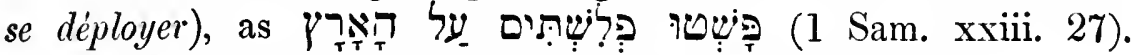
[The] Philistines have spread [themselves] over the land.

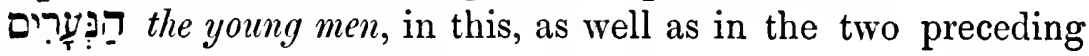
verses, refers to the herdsmen.

Ver. 18. עַ in this instance is synonymous with Ti Comp.

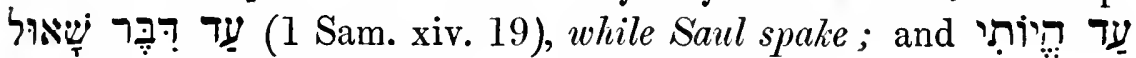
(Jon. iv. 2) on my yet being, i.e., whilst I yet was.

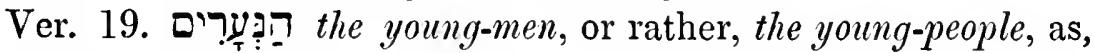
in this instance, it evidently refers to the sons and daughters of Job. Jarchi, indeed, seems to have taken it, in this verse, in its strict meaning, viz., that of young men, observing,

\section{איכל אין לריך להכיר הבנות}

"But there was no occasion to mention the daughters,"

meaning thereby, that the daughters were of little consequence;

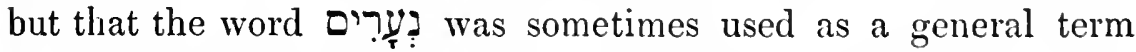
for young-people, whether male or female, is evident from Ruth ii. 21, for Ruth there says to her mother-in-law concerning Boaz,

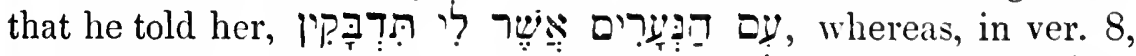

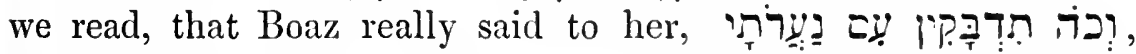
and we cannot suppose such a virtuous woman as Ruth would tell her mother-in-law an untruth.

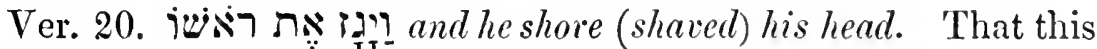
was the custom of mourners in those times, appears from Jer. vii. 29, 7?

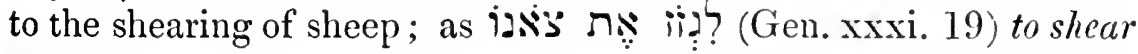
his sheep, an example, which proves beyond doubt, that iid means to remove the hair with an instrument gently, and without pain. Violently pulling out one's hair, as an act of despondency and

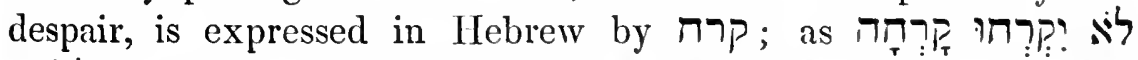
בְר (Lev. xxi. 5) they shall not make baldness upon their

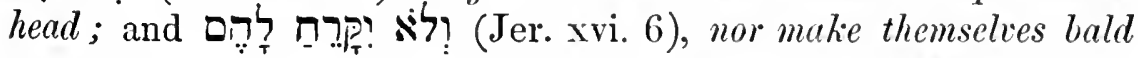
(i.e., pull out the hair violently) for them; also Micah i. 16,

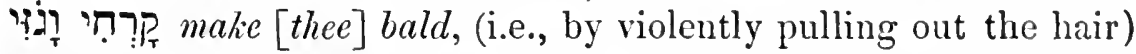
or shear (shave) [thee]. We were sorry, therefore, to find Jarchi

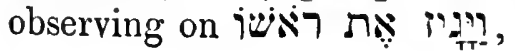

\section{תלש}

"He pulled out," 
an explanation the more surprising, as $J_{0 b}$ is not only not described as violent and impatient, but is, on the contrary, represented as patient and calmly resigned to the decrees of Providence. The only thing that might be said in excuse for Jarchi is, that he was perhaps nolens volens obliged to translate here as he has done in order not to shew himself at variance with the Rabbins of the Talmud, before whom, of course, he was obliged to bow, and according to whom, a mourner so far from being allowed to cut off his hair, is, on the contrary, expressly enjoined to let it grow wildly. 'Thus, in Lev. chap. x., where the catastrophe of Nadab and Abihu is recorded, we read (ver. 6), that Moses said to Aaron and his two sons by way of desiring them to make an exception to

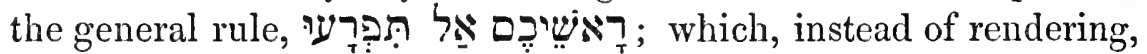
as the translators of the Auth. Vers. well do, Uncover not your heads, (i.e., either by shaving off your hair as mourners, or perhaps by not wearing a turban), they translate, do not let your hair grow wildly, and, consequently, come to the conclusion, that mourners generally ought to let it so grow, as Jarchi there observes:

\section{מכאן שאול אסור בתספורת}

"Hence [we see] that a mourner is forbidden to shear [his hair]."

The Rabbins in the Talmud seem to have based the signification they give to the verb פרע that, namely, of letting the hair grow wildly, upon the erroneous conclusion, that, because the noun פִּ iviv to let grow [the] lock of [the] hair of his head, the verb must necessarily imply the letting grow the hair, altogether forgetting that we sometimes find verbs expressing the removal, or destruction, of the object represented by the noun of the same root. Thus, in the description of the altar to be made by Moses, it is said (Exod. xxvii. 3), "And thou shalt make its pans (i) to REMove-its-ashes," (from "דֶ ashes); and of the foal of an ass he

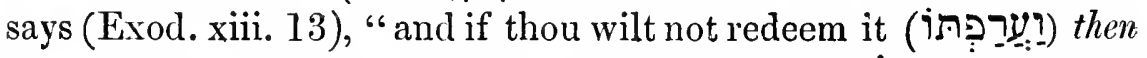
thou shalt BREAK-its-neck," (lit., neck it, from ๆา a neck); and many more such instances might be quoted.

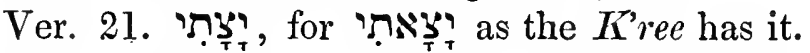

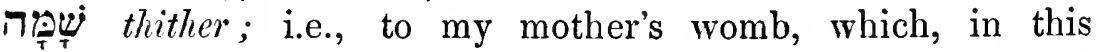
instance (viz., in the 2nd clause of the verse) evidently is used figuratively for the earth, as it also highly probably is in the first 
Job considering himself, as a human being, the offspring of the

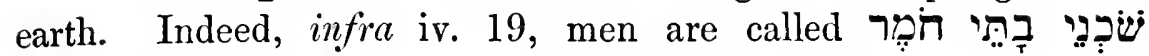
dwellers in houses of clay; again, infia xxxiii. 6, Elihu says, I waisas cut out of clay; and in chap. xvii. we find Job himself indulging in similar figurative language, when, longing

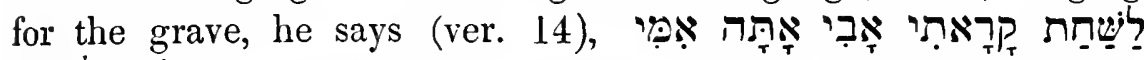

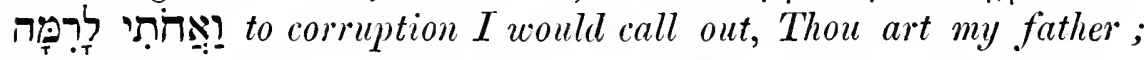
to the worm, $O$ my mother, and $O$ my sister! The Psalmist also

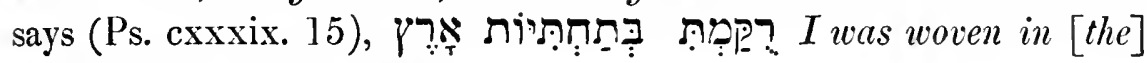
lowest-parts of [the] earth.

Ver. 22. Since the adjective of insipid, tasteless, the noun signified insipidity, tastelessness; but, just as the verb באש to be offensive to the smell, is also used when transformed into a noun, to express everything that is bad (thus, in Isa. v. 2-4, we find

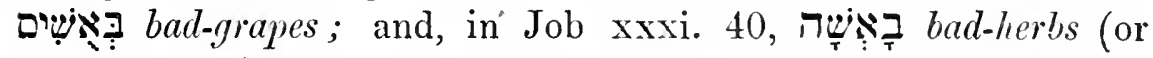
noisome-weeds); while in Chaldee, the verb בהש (Dan. vi. 15), is used to express, bad-temper, ill-humour, and the nouns בִיָָׁא

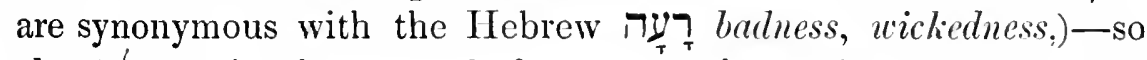

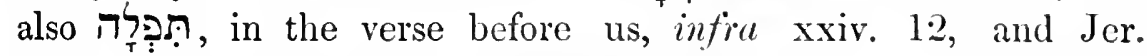
xxiii. 13, is used to express, injustice, malice; so that the words

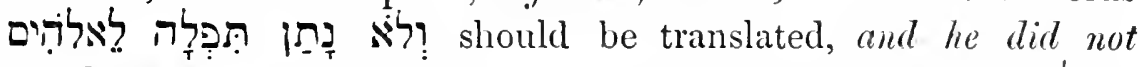
ascribe malice to Gorl. The verb נתן, when construed with ? or with $\underset{7}{2}$, signifies the act of attributing, ascribing, imputing; as דתמנו (Ps. lxviii. 35), ascribe ye strength unto God, and (P. 1. 20), thou ascribest faultiness (i.e., attachest a blemish) to [the] son of thine [own] mother.

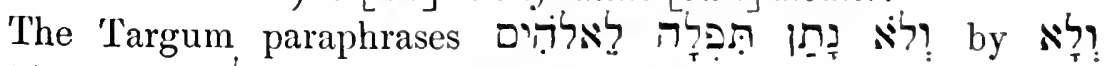

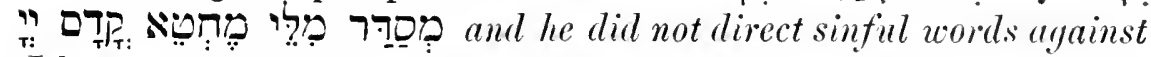
Jehovah. This way of understanding the verse seems to have been relished by Schultens, and Wolfssohn; the former translating it, "neque edidit futilitatem in Deum," the latter,

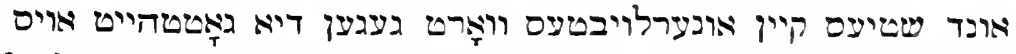
Both then have given to the verb נתן, in this instance, a meaning (that, namely, of uttering [words, or speeches]) in which we do not find it used in Hebrew, mless when followed by some noun expressing sound (noise); as hip IPs. (Ps. civ. 12) they utter [their] voice; is (Job xxxv. 10) uttering songs. Unless, 


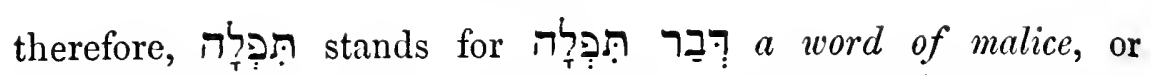
something like it, these translations must be considered objectionable. Nor can that of Rosenmüller, viz., "Neque quidquam in Deum inepte commisit," be regarded as less so, for where, we would ask, is a to be found = commisit?

\section{CHAPTER II.}

Ver. 2. For the explanation of the process, by which the particle

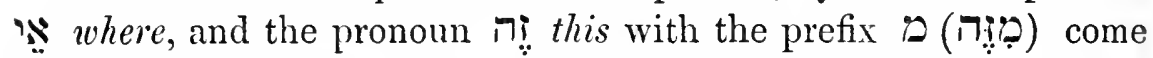
to have together the meaning whence, we are indebted to Jarchi, who comments upon it as follows :

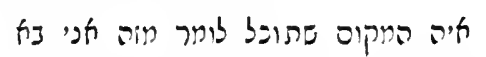

"Where is the place, respecting which thou couldst say, from that [place] I am coming?"

Mason and Bernard have applied the same reasoning to the particle

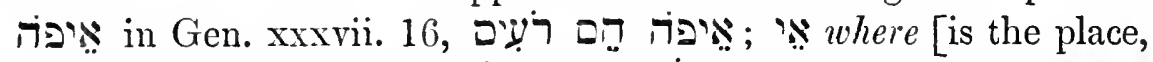

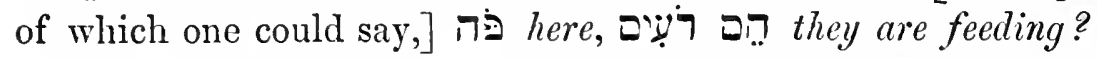

Ver. 3. The root סות, in Hiph-êl, signifies to move away, and, therefore, sometimes is used to express a change of place, as 2 Chron. xviii. 31, quently, to express a change of mind, as in this verse, יתִ Iִ although thou movedst me. The prefix I has here the sense of though, although, as in Ruth ii. 13, 'כ̦iș though $I$ (be not like unto one of thine hand-maidens).

The root בלע, though strictly signifying, to swallow up, is very frequently used in the sense of ruining, destroying.

Ver. 4. It is a matter of common observation, that man is wont to consider one member of his body as of more vital importance to him than another, and that he will, therefore, in order to protect a more important one, readily sacrifice a less. Jarchi, bearing this

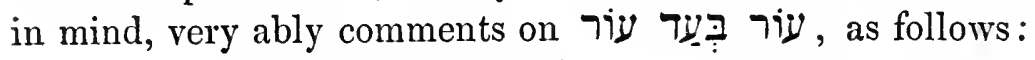

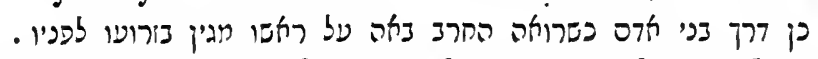

"This [is] the way of the sons of men; when one sees the sword coming [down] upon his head, he protects it with his arm." 
So also Aben-Ezra,

ענהג האדס להסתיר עינו בידו אם יפחד ממכה בעבור היותה נכבדת

"[It is] the custom of man to shelter his eye with his hand, when he is afraid of a blow, because of its (viz., the eye) being valuable."

Now, upon this fact, Satan builds the argument he here brings forward, that, namely, if a man will readily submit to sacrifice one member of his body for the sake of another more valuable to him, it is not at all to be wondered at that Job submits to lose all he has, rather than provoke God, who can take away his life. Had Schultens and Rosenmüller seen these simple, but most able, comments, they would scarcely have said what they have done on this passage.

The noun 7 , ע, though generally meaning skin, is once used in

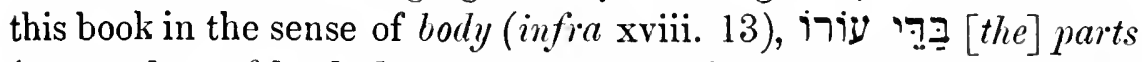
(or, members-of his body; in the verse before us, it signifies a part,

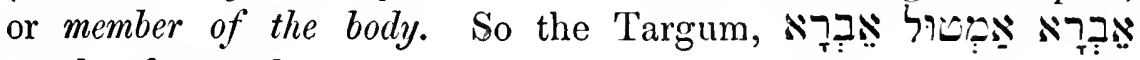
member for member.

The words be understood in the second, so that Satan's argument, expressed in

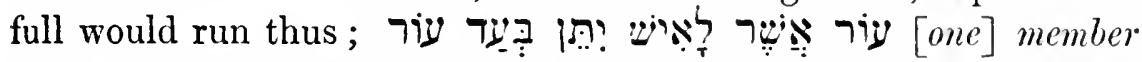
which [belongs] to a man would he give [up] for [another] member;

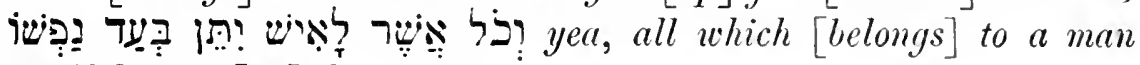
would he give [up] for his life.

The verse thus written would, indeed, be very clear and intelligible, but it would be also very prosaic. The adversary of mankind, however, was, it would seem, so elated by his previous success, recorded in the preceding chapter, as to wish to suit his language to his feelings, and he accordingly clothed his malicious insinuation in a ternary verse.*

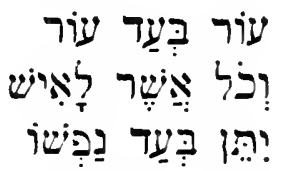

Perhaps, however, this saying was current as a proverb at the time this book was written.

Ver. 5. Here we find the verb 1 ganstrued with with $ב$ as in the preceding chapter, ver. 11. 19, so that it would seem not to signify as there, to smite, but to touch; as though he

- The rest of the chapter is in prose. 
would say, Put forth Thine hand, and touch his bone and flesh ever so slightly, \&c.

We find here chap. ver. 11 ; this, however, cannot in the least invalidate the remark made there, seeing that we very frequently find standing for $k$, and vice versî; e.g., 1 Sam. i. 10, "and she prayed עַ (for to (Jehovah);" Lament. iii. 41, "let us lift

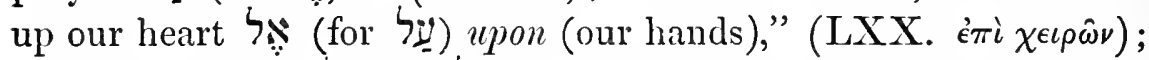
and, Ezek. xliv. 7, אער (עֵ) (for) "because of (all your abominations)."

Ver. 7. It is supposed, that the malady, with which Job was afflicted, was that commonly known by the name of Elephantiasis (Elephantiasis Arabum).

Ver. 8. The root 7 ג, of which we have here the Hithpa-âl, is not to be met with in any other part of the Bible.

That persons, afflicted with any great calamity, or humbling themselves before God, used to sit in sackcloth and ashes, is manifest from what we read in Isa. lviii. 5, and Esth. iv. 3; but, as in this instance we have רָּר THE ashes (definite), some have been led to think, that by it not common ashes are to be understood, but the dust-like particles which Job scraped off with the potsherd from his thickened and scaly skin; whilst others suppose it to refer to the powder, which they conceive him to have sprinkled over the sores, with which the whole of his body was covered, as is still the practice in many cutaneous diseases. But it is more natural to suppose, that he had sprinkled ashes upon his head in sign of mourning, just as we shall see below, ver. 12, his friends did, and that allusion is here made to that circumstance. It might, perhaps, be urged against this explanation, that the historian has nowhere informed us, that Job really had thus besprinkled himself, but such objection would be totally devoid of weight, as we often find instances in the Bible, in which the reader is left to infer an act not expressly recorded. Thus, in Exod. ii. 20, where Reuel says to his daughters, "Call him (Moses) that he may eat bread;" the very next words are, "And Moses was content to dwell with the man," without our having been actually told that they did go to call him, or that he came.

Ver. 9. Before 7 Tִ ע the interrogative 7 must be supplied, just as in 1 Sam. xxi. 16, חָסָ stands for wo whether in need of? \&c. 
תִ. The more proper form would be as it is the imperat. Kal of מוות. At the first glance, this imperative might be supposed to stand instead of a future, just as in Deut. xxxii. 50,

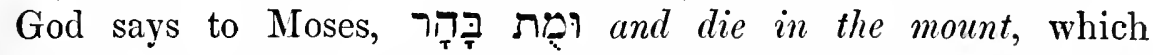
evidently stands for seeing that dying a natural death is an act which one cannot be commanded to perform; but it is difficult to imagine that the wretched woman, who speaks here, used תִ in this sense, as, of course, such an impious creature could not have thought, that blaspheming God would needs be followed by instant death. It is, therefore, more natural to suppose, that she advised him to defy God, and by his own hands to put an end to his existence.

Ver. 10. The particle

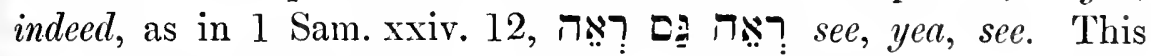
one quotation might suffice, but as so much has been said about the meaning of this little word here by Rosenmüller, Ewald and others, to no purpose, the reader is referred also to Numb. xvi. 13 ; 1 Sam. i. 6 ; Ps. cxxxiii. 1 ; in all of which instances the will be found to be hardly translatable.

The words immediately after the severe rebuke administered by Job to his wife, seem to express that, notwithstanding the agonizing feelings, which, independently of those arising from the other calamities which had been brought upon him at the instigation of Satan, Job must have laboured under, on sceing himself thus taunted and plagued by the impious woman, to whom it had been his unfortunate lot to be united-that, notwithstanding all this,-notwith-

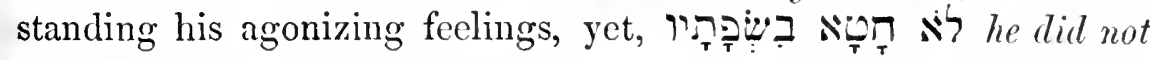
sin with his lips. It would be erroneous to suppose, that by this expression, he did not sin with his lips, was meant, he did not blaspheme God, as his wicked wife wanted him to do, since his refraining from so atrocious a sin could hardly have been recorded by the historian as a favourable feature in his character; we must, therefore, understand by it, that he had not hitherto even complained, or grumbled, but had persevcred in his patient and calm resignation to the decrees of Providence. The words לה then, might be taken to mean, he did not miss, (err, trip) with his lips, he did not say anything anIss, to miss being the primary signi- 
fication of the verb $N$ ח, which only derives its commoner one of to sin, from sinning being equivalent to deviating from, or missing the way of rectitude; so Judges xx. 16, "Every

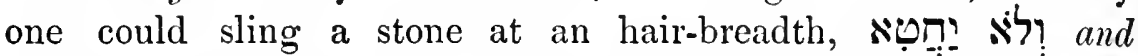
not cause [it] to miss;" Prov. xix. 2, "And one hastening with his

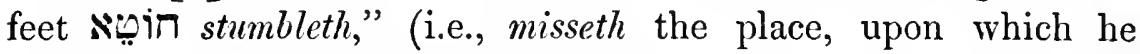
ought to have put his foot). In like manner, the expression בִִֶ so as not to sin with my tongue, used by the Psalmist, Ps. xxxix. 2, refers only to his not having shown any impatience, or manifested any surprise, at the prosperity of the wicked and his own sufferings, as is evident from the context.

דָָָּּה that has come. The definite article is used here for the relative pronoun șive which or, that, and when this is the case it may be prefixed to a tense. (See Mason and Bernard,op. cit., Letter xlvi. \$2.)

Ver. 11. The verb גורע to shake, or move, like the verb applied to the head, is sometimes used to express contempt, or

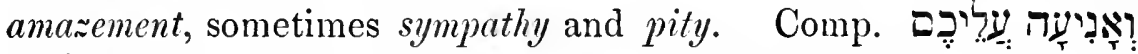
(infira xvi. 4), and I would move my head at you ; i.e.,

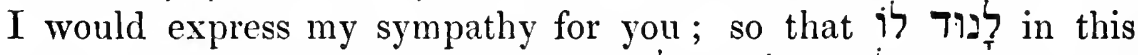

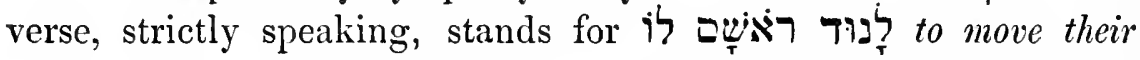
head at him, by way of expressing their condolence. The same ellipsis occurs also infia xlii. 11, where we have is for iל

Ver. 12. From our being told here, that his friends lifted up their eyes from afar, and did not recognise him, together with the fact, that he was sitting amidst ashes, we may fairly conclude, that Job had taken up his seat in the open air; and there the reader will do well to imagine he continued during the whole time occupied by the events recorded in this book, as, thereby will not only the grandeur of the description given, in the latter chapters of this book, of the phenomena of nature, and of the approach of the whirlwind, from which God addresses Job, be greatly enhanced, but also some passages be cleared up, which might otherwise seem obscure.

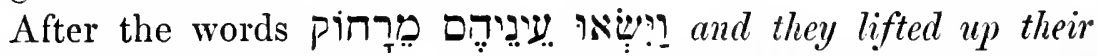
eyes from afar, the words inis או? understood. We have already had occasion to notice the frequency of such ellipses in Hebrew in our note on ver. 8 of this Chapter. 


\section{PROLOGUE TO CHAPTER III.}

SUMMARY OF THE PRINCIPLES AND VIEWS ENTERTAINED BY JOB, AS GATHERED FROM THE WHOLE RANGE OF HIS DISCOURSES WITH HIS FRIENDS.

(Those who wish to verify the quotations here given will do well to refer to the Translation which accompanies this Commentary, rather than to the Authorized Version, according to which the passages in question would frequently convey a very different meaning.)

That Job was pious, upright, and a man fearing God not only does the historian bear witness, but also God himself (chap. i. 1, 8); at the same time, however, he was a man of a philosophical turn of mind, who was not satisfied with taking things as they came, but would thoroughly sift and examine them, in order to arrive at their true causes and effects. Knowing, therefore, that he is suffering unspeakable torments undeservedly, he is amazed, and astounded at it; he curses the day of his birth (iii. 1-9); he wishes that he never had been born (iii. 11, 16; x. 18, 19); he longs for death and the grave (vi. 9 ; xvii. $13,14,16)$; he is sometimes tempted to put an end to his existence, but immediately rejects the idea (vii. 15, 16); he will readily submit to death, but not to protracted suffering (xiii. 15 ; vi. 11, 12); he laments that death is denied by God to those who pray for it ( $\mathrm{xxx} .24)$; he is astonished at the prosperity of the wicked (ix. 24 ; xii. 6 ; xxi. 7-13), and the sufferings of the innocent (xxiv. $3,4)$; he cannot comprehend, how an Omniscient and Omnipresent Being can suffer the atrocities of the wicked and their triumph over the just, in this world (xxiv. 1, 5-12), for even the sudden removal of the wicked, which his friends bring against him as an argument, he considers rather as a blessing, than as a punishment (ix. 23 ; xxi. 13); he asserts, that he is not only free from guilt, but that he has also done a great deal of good, and appeals to God as a witness (xvi. 19 ; xxiii. 10 , 12 ; xxvii. 5, 6 ; xxix. $12-17)$; he protests that he is grievously wronged by God 
(xvi. $12-17$; xix. 6,7 ); he is very much irritated, when his friends tax him with crimes, which he had never committed (vi. 15 ; xix. 2,3 ); he expresses his suspicion, that they desire to magnify themselves at his expense (xix. 5), and that they speak against their conscience, with a view to ingratiate themselves with God (xiii. 7-9); he represents to them, that such a mode of proceeding against an unfortunate friend may drive him to despair and apostasy (vi. 14); he tells them it is very easy for the fortunate to make the unfortunate an object of derision (xii. 4, 5); he challenges them to produce arguments instead of finely-worded speeches (vi. 24-26); he regards it as great presumption on their part to preach to him the Omnipotence of God (xxvi. 2-4); and tells them he considers it to be rather his place to preach it to them (xxvii. 11, 12); he cannot conceive, how so majestic a Being as God can be offended at the acts of frail and abject man (vii. 20 ; xiv. $1-4$ ); he would have man enjoy the privilege, not only of praying to God, but also, of justifying himself before Him (ix. 15); he asks why it should be considered sinful in a man to think himself innocent, when he really is so (ix. 20-22); he longs to be in the presence of God, and to reason with Him (ix. 34, 35 ; xiii. 3, 17-24; xxiii. 3-10); he demands a regular court of justice for the trial of man, so that he may be allowed an advocate to defend him, and may be admitted to bail (xvi. 21 ; xvii. 3 ; xxxi. 35-37); he is a staunch believer in the existence of an Eternal God (xix. 23-27); but knows nothing of a future state, and thinks that man's existence finishes with this world (vii. 8,9 ; xiv. 10-15).

That Job had not the remotest idea of a future state, and a life hereafter, is evident, not only from the passages quoted above-more particularly those which contain his profession of faith (xix. 23-27)-but also, from the whole tenour of his arguments, complaints, and murmurings against Providence, which are such as entirely to forbid the supposition, that he knew anything of another world. Suppose for a moment, that, in our days, a sufferer like Job were to indulge in such unbecoming outbursts against God, could not a mere child, who had but read the first of the four Gospels, at once put him to silence and to shame by exclaiming to 
him, "How as nothing are the sufferings which you endure during this handbreadth of life, in comparison with the eternal blessings which you might expeet to enjoy if you did but humble yourself before your Maker, and resign yourself to His will !" How is it, then, that not one of Job's friends, not even his young friend Elihu, held such language to him, or any language at all approaching to it? How is it, that Job himself, sensible as he certainly was, did not see that he was laying himself open to a rebuke of this sort? Simply because neither he, nor his friends, knew anything of a life beyond the preeinets of the grave. Indeed, God Himself, in His address to Job from the whirlwind, makes not the least allusion to such a life, nor need we wonder that He does not, since the preaching of the doctrine of the Kingdom of Heaven was reserved for Him, through whom alone we can attain to the Kingdom of Heaven. It also deserves consideration, that, in the New Testament, not one passage from Job is quoted, as alluding to a future state. The Patriarchs, who held direct communion with God, and the Prophets, who were inspired by God, must no doubt have felt, that a being, who could hold communion with the Deity, could not perish as a beast, but must have an immortal soul; but neither Patriarch, nor Prophet, was allowed to preach the Kingdom of Heaven publicly; and, if they did sometimes allude to it, we should most certainly not have discovered their allusions, had not our eyes been opened by the New Testament. But Job was no Prophet, nor had he before held direct communion with the Deity; it ought not therefore to surprise us, that he looked upon himself as the being of a moment, till God revealed Himself to him, as recorded in the later ehapters of this book. Then, and then only, did he perceive, that he must be something more than a mere animal, that he must have a soul, which was immortal, and could not perish with his body; and, on perceiving this, he at once acknowledged he was wrong, became a convert, and exclaimed, "I have heard of Thee by the hearing of the ear, but now mine eye seeth Thee; wherefore I abhor myself, and repent in dust and ashes." (Chap. xlii. 5, 6.) *

- To suppose for a moment, that Job knew anything of a future state, would not only tend to deprive his arguments of their force, and to render his complaints unreasonable, and absurd, but would also be equivalent to setting him down as an utterly wicked man, for such would any man in our days be justly considered, who gave vent to similar expressions against God, and His Providence. Nor would it be possible to conceive, how such behaviour and such expressions could deserve the approbation and commendation of God, who said to the three friends, "for ye have not spoken of Me that which is sincere, like My serrant Job." (Clap. xlii. 8.) Had Job known anything of a future state, the greater part of what he says would be not the language of sincerity, but downright insult to Him, who expressed IIimself so highly pleased with his words and sentiments. 


\section{CHAPTER III.}

1. I resolved : I will guard my ways, That I may not transgress with my tongue ;

I will keep a check upon my moutb, So long as the wicked are in my presence.

2. I was altogether dumb; I held my peace from good and bad; But my pain rankled,

3. My heart within me was hot, Through my sighing the fire kindled;

I spake with my tongue.*

(Ps. xxxix. 1-3.)

THese verses are strikingly applicable to the innocent sufferer, whose discourse composes this chapter. Seven days, and seven nights, was he altogether dumb, and held his peace; seven days, and seven nights, did he keep a check upon his mouth; seven days, and seven nights, was he sighing over his miserable lot; till, at last, his heart grew hot within him, and he spake with his

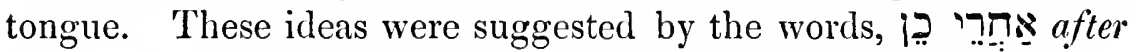
this, which imply that, after having thus forborne complaining, he at length gave vent to his pain in bitter exclamations.

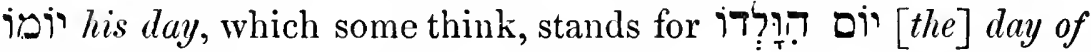
his being born, i.e., the day of his birth; or ir may perhaps be used here in the sense of fate, as it is infia xxx. 25, hard of day, i.e., ill-fated.

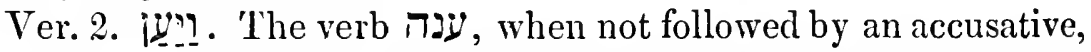
is sometimes used to express the opening of a discourse, and is almost synonymous with to speak, or to begin to speak; as (Deut. xxi. 7), and they shall speak, and say, and קุ: (Ibid. xxvi. 5), and thou shalt speak, and say; and in this sense, [1ית must needs be understood here, as it cannot be translated, and he ansu'ered, seeing that we are told by the historian, that not one of the party had as yet spoken a word. A similar use of the verb aтокріронає, is very common in the New Testament.

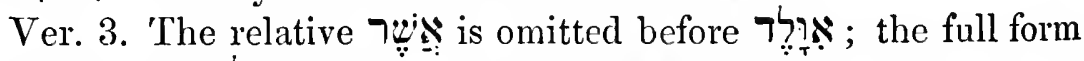

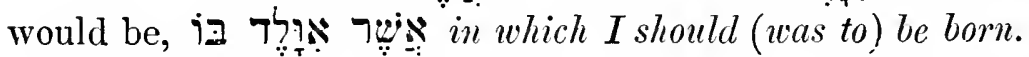

אִָ is used here impersonally, one said; i.e., it was said; as

* From Dr. French, and Mr. Skinuer's very elegant translation. 


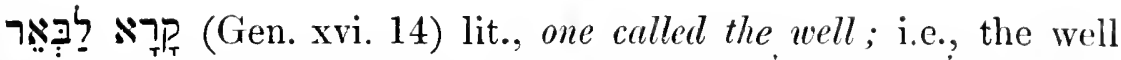

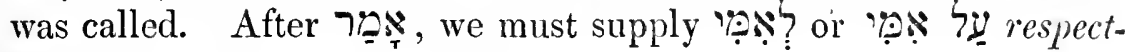
ing my mother, of my mother.

הרדה She [is] bringing forth. The verb דרו, though generally signifying to conceive, is also used to express bringing forth, in

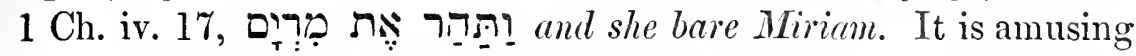
to see how those, who were bent upon giving to הרד here its ordinary signification of conceiving, have treated this verse. They of course saw that it was very difficult to understand how it could have been ascertained precisely upon which night the conception took place, not to speak of the infinitely greater difficulty, which, even if the question of the night were satisfactorily settled, wonld still present itself, as to the manner in which the child then conceived could have been determined to be of the male sex at such an extremely early period of his existence; and, therefore, to get over this difficulty, instead of making the verb sonal, they have, in the first place, taken הָלִ הe to be its

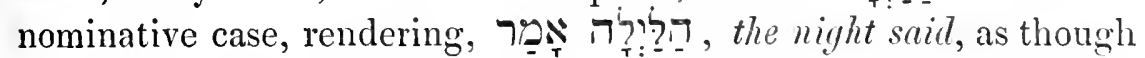
the night could know, when the conception took place, and what it would produce; and, in the second place, made הרָה, evidently the part. fem. Kal of the verb הרד which is only used in this voice, a past Pu-al, translating the whole, "Et nox, quæ dixit, Conceptus est Masculus." (Schultens.) "Et nox, qux marem conceptum esse dixit!" (Rosenmüller.) "Und die Nacht, die da sprach : Es ist ein Männlein empfangen!" (Schlottmann.)

The words

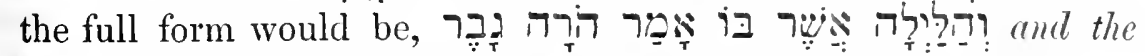
night, in which it was said, She is bringing forth a man [child].

Job, probably not knowing, whether he was born in the day, or in the night, curses them both; the force of the letter 9 in וְה that of the disjunctive or, as in Exod. xxi. 15, "he who smiteth his father, in: or his mother, \&c."

Ver. 4. The verb דריש, though mostly used to express inquiring after, also signifies caring for, or facourubly noticing, a thing; as in Deut. xi. 12, "A land, which Jehovah thy God דרֵּ careth for it," i.e., noticeth favourably. Job, therefore, prays, that God may not take any favourable notice of that day.

c 2 
Ver. 5. The verb $\mathbf{5}$, independently of its usual meaning to redeem, occurs also in the signification of to stuin, soil, pollute; as.

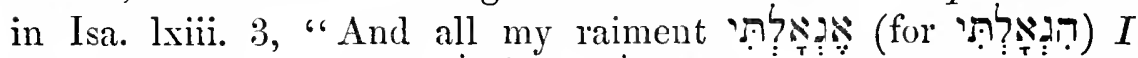

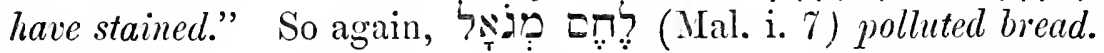

The verb כמר is used to express becoming blick, in Lament. v.

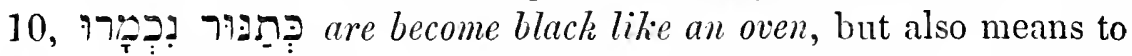

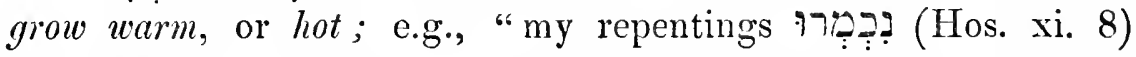

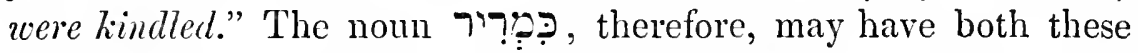
meanings, viz., blackness, and heat, or sultriness; consequently,

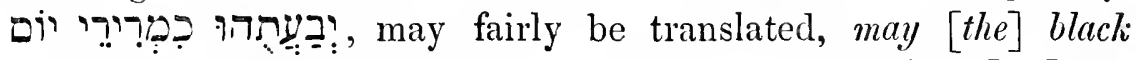
vapours (or clouds) (arising from heat and sultriness) of [the] day affiright it (viz., by holding forth to it the prospect of impending darkness and tempest). A complete parallel is thus established with the first clause of the verse, "let darkness and the shadow of death pollute it." So Ben-Zev explains this noun by,

חום השציק

"Distressing heat."

It is well known, that sultry days commonly terminate in a thunder-storm.

The third radical of the verb פיר is doubled in the noun,

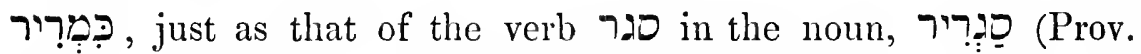
xxvii. 15) rain. The translation adopted here is rejected by Rosenmïller, on the ground, that the $\supset$ in has short-

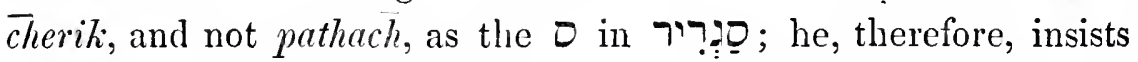
upon making the $\supset$ a prefix, and, not being able to attach any meaning to it, is obliged to say it is a mere expletive, and to translate this clause in such a manner, as to deprive it of its parallelism with the first. Is it then so very unusual to see the first radical of one noun take short-cherik, where that of another

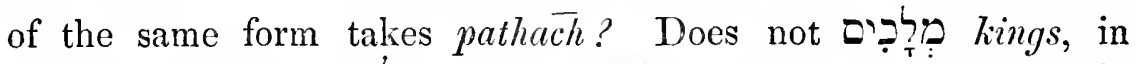

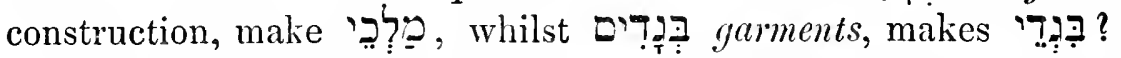

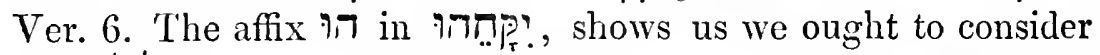

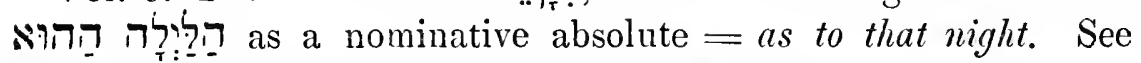
Mason and Bernard's Grammar, Letter xlvii. \$ 9 .

The punctuation of the word 7ח?, at once shows the root to

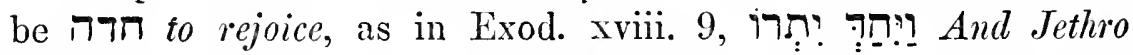
rejoiced. Had its root been 7 T to join, unite, as the translators of the Auth. Vers. must have been of opinion, it would have been 


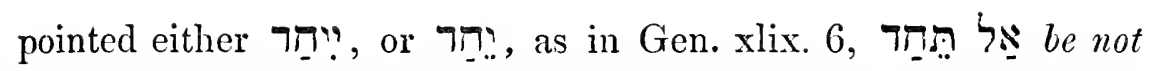
thou united (as it is translated in the Eng. Vers.), and there would have been no occasion for the dagesh in the T. See Mason and Bernard, op. cit., Letter xxxix. $§ 17$.

Ver. 7. The? In Isa. xlix. 21, we find this word used of women, in the sense of sterile, clitdless; in the verse before us, it probably signifies sterile (of joy), joyless, cheerless, and in the same acceptation, it will also be found infia xv. 34, and xxx. 3.

Ver. 8. The verb בקב is very frequently used in the sense of

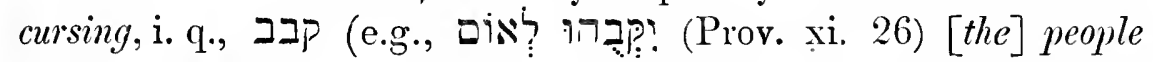
will curse him, and in many other places), but the same root is also used in several passages, in the sense of pointing out, or

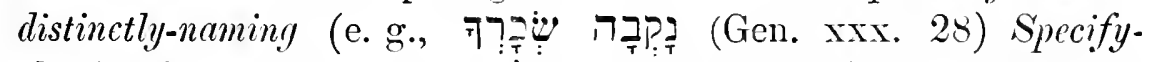
clearly thy wages; Jehovah shall distinctly-name it; ; (Lev. xxiv. 11) And ....pronounced-distinctly the xame, and blasphemed,*) and in this latter sense we prefer to take it here, as it would be difficult to understand, low Job could expect men, who wished to curse their own day, should curse his.

As, in the poetry of even modern languages, fabulous animals, such as, dragons, griffins, \&c., are sometimes introduced, so in Hebrew such an animal is to be met with in the nom 2 ? ?, which very frequently occurs (e.g., in Numb. xxiii. 2.2 , and also in this book infira xxxix. 9), and which in the Eng. Vers. is commonly rendered unicorn (itself a fabulous animal), while Mendelssohn always leaves it untranslated. In like manner, in the verse before us, ליד might with some show of reason be taken as the desig. nation of a certain fabulous monstcr, and as such be fairly left untranslated, as has been done by Schlottmann, who renders, "die bereit sind, den Leviathan zu wecken." But, on the other hand, it must not be forgotten that the word in this book (chap. xl. 25-Auth. Vers. xli. 1), where it represents a most powerful and terrible animal, the whole structure and conformation of which are fully detailed, and correspond very accurately

* So Mendelssohn,

by which rendering he very cleverly avoids the tautology which would result from giving to 2ing the sense of cursing, as is done in the Eng. Vers., "blasphened the name of the Lor $D$ and cursed." 
with those of the crocodile. The verb רעy (root to awake, arouse, would also be very fitly applied to that animal, as we are told by natural historians, that it is the most dangerous of all voracious animals, inasmuch as it is in its nature to lie watching for its prey for hours, if necessary, on the bank of the river, from which it has emerged, motionless, and like the trunk of a tree, till some unfortunate wretch (or, it may be, animal) has come within its reach, when it starts up, as if roused, from its simulated sleep, and rushes upon its victim. There is not perhaps, therefore, anything very unreasonable in the supposition, that Job, who wished to call upon the most unfortunate and miserable of human beings to point at and cite his own accursed day, would regard as such, and as such invoke, those ill-fated, ill-starred wretches, who were on the point of being devoured by so terrible a monster, as the crocodile. With this explanation we can now proceed to construe the verse under consideration. It runs thus:

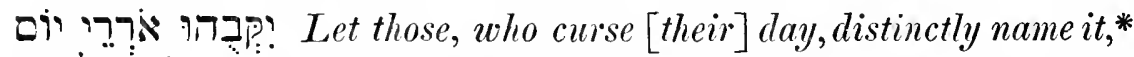
[Even] those destined to arouse [the] crocodile.

Rosenmüller refuses to admit this translation of the second hemistich on account of there not being a $ל$ prefixed to as it would seem, altogether unaware, that this infinitive is not a constructive, but an absolute one, which in itself signifies to arouse, and cannot admit of the $ל$ of בב"לם. But were it even a constructive infinitive, there would be nothing to wonder at in the $ל$ being understood, and not expressed, as this is an ellipsis, which is very frequent in prosaic, not to mention poetical, Hebrew ; comp.

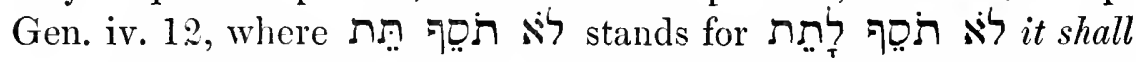
not again yield; and many other similar instances might be adduced.

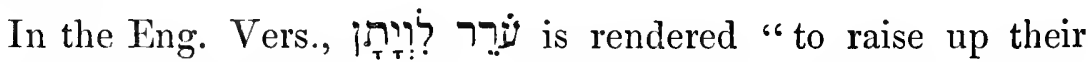
mourning," a version, which they must have founded upon the passage in the Talmud,

\section{לא תעורד אשה לויתה בטוער}

"A woman must not raise up her mourning at a festival."

(Jerusalem Talm., treatise Moed Katon, chap. i.), a passage referred to also by Aben-Ezra, who observes, at the same time, that the pronominal affix $i$ stands for final $\square$.

* i. e., let them say, " May our day be accursed like that of Job !" 
Ver. 9. In chap. xxxi. 26, we find רiא used to express the sun, in opposition to ריר mean, may it wait for [the] sun and [there be] none, and upon this Job, becoming more vehement, improves, by adding, הצי?

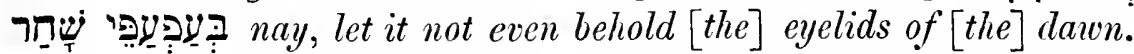
שِ dawn, is here personified by our poet, who gives it eyelids;

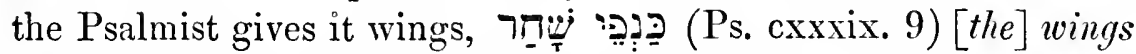
of [the] dawn. The latter figure is intelligible enough, as we can easily imagine the dawn, approaching us gently, soaring upon

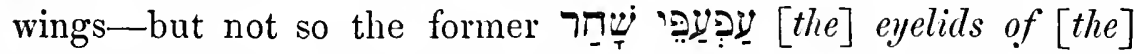
dawn, unless we understand by it that Job would not have the night, in which he was born, behold the dawn even in its very first stage, when it is, as it were, half-slumbering, with its eyes all but hidden by its eyelids. Comp. our expression "the peep of day."

The 2 in

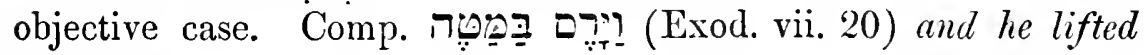
up the rod.

Rosenmüller tells us that Jerome understood the prefix $\beth$ before

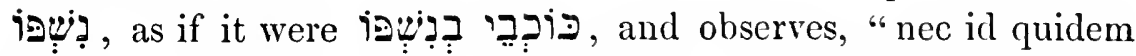
male;" a noun in construction followed by a preposition!! and yet "nec id quidem male"!!! we devoutly wish for his sake, that he had said, "pessime."

Ver. 10. As we have seen Job cursing, first, the day of his birth, and then, the night, the verb either of them; but, as the night is the last mentioned, it is more probable that it is to it that it refers, and that he assigns in this verse the reason for his cursing it, as though he said, I curse it,

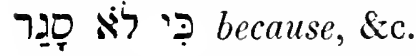

The Hebrew possessive affixes are frequently open to an ambiguity, which the context only can remove. Thus, by בַלִ in

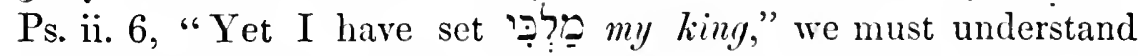
him, whom I have made king; whereas, in Ps. lxxiv. 12, "For God is פִַ my king," the meaning is, king over me. So the context in the verse before us shows us we should take בִ my belly, to mean the belly (i.e., the womb), which conceived me. When Job says, he curses the night, because it did not shut up the belly (the womb), which conceived him, he means because it did not render his mother sterile and incapable of conception. 
In the Eng. Vers., the neg. part. 1 ל which we have in the first hemistich of this verse, is supplied to the second, and רת?

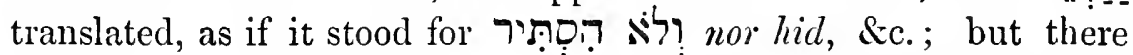
is not the least occasion to suppose any such unusual change of form, as we may simply understand Job to say thus, "I curse it, because it did not shut up my mother's belly (womb) רתיר and

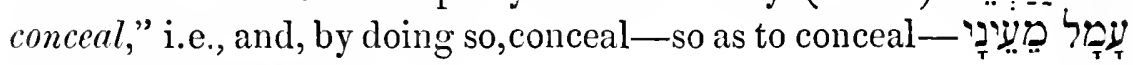
" misery from my eyes."

Aben-Ezra gives to the affix in בְִִִ its more natural sense, and refers it to the speaker himself, understanding him to say, the doors of my [own] belly, i.e., navel (by which, when an embryo, I received my nourishment). His words are:

\section{הטבור שמטנו יבא המאבל לולד קודס שיולד}

"The navel, by means of which the food enters the embryo before it is born."

By Rosenmüller we are told, that Aben-Ezra takes God to be the subject of the verb סָּ, although $\mathrm{He}$ is not expressly mentioned, according to which Job would curse the night, because God did not shut up, \&c. This would, indeed, have been strange reasoning on the part of such a man as Aben-Ezra, but, fortunately, we cannot find he ever said anything of the sort; all he says, when

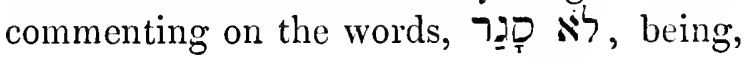

\section{יקסר סותח הרחס}

"The opener of the womb (i.e., the one, who left it open), is not mentioned";

by which he evidently merely intended to say, that the verb was used here impersonally (just as "אيָָ in ver. 3), and might, therefore, be rendered by a passive, "Because the doors of my belly (i.e., my navel) were not shut up." It will be perceived, that AbenEzra in this instance uses $[\Pi]$ ?

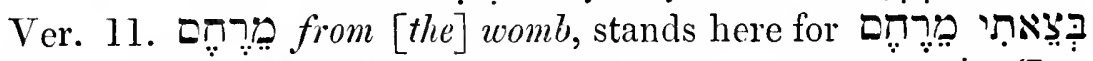

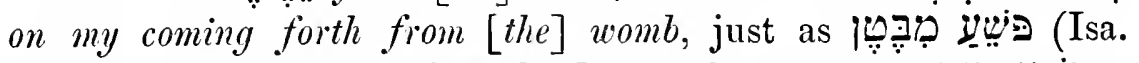
xlviii. 8) a transgressor from [the] belly for transgressor on thy coming forth from [the] belly (wast thou called). Those, who understand by, from the womb, that Job wished he had died, in the womb, and refer in support of their opinion to Jer.

* In order not to use in English one word for an object expressed in Hebrew by two, viz., רֶ? as the word belly is often used in poetry for womb, though of course strictly speaking, the womb only, and not the belly, can conceive. 
xx. 17, have forgotten, that Job only refers to that earlier stage of his existence (when, namely, he was in the womb), in ver. 16, after having first enumerated its later stages.

תמוּ לה is used here conditionally, should I not have died, as, in

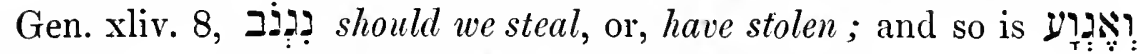
in the second hemistich, then, I ought to have died.

Ver. 12. ำ ㄱำ knees, i.e., the midwife's knees, which were put forward to catch, and so met, him, hindered him from falling to the ground, by which he might have been killed.

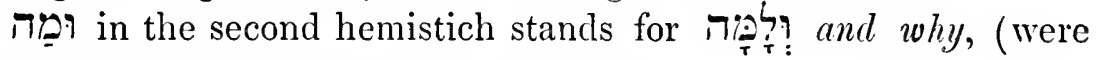
breasts (tendered me,) that I should suck ?)

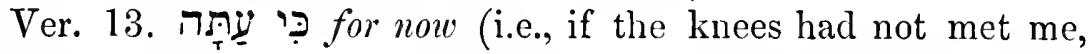
and no breasts had been tendered me),

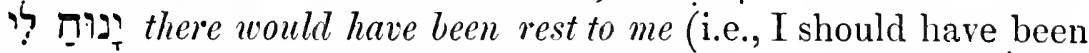
at rest), the verb being used here impersonally. Comp. לִ צִ (1 Sam. xxviii. 15) [It is] distressing to me, i.e., I am distressed; and 2 (Ruth i. 13) [It is] bitter to me, i.e., I am grieved.

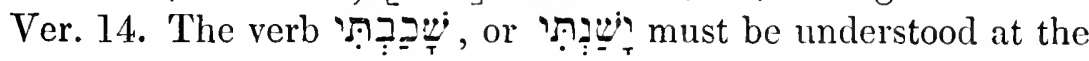
very beginning of this verse; "I should have lain (or slept),

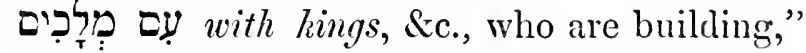

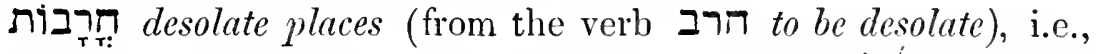
mausoleums, splendid buildings, but intended only is? for themselves, to contain nothing but their remains, and, therefore, in some sense desolate. Such buildings we know from history were very frequently erected in ancient times to contain the ashes of celebrated personages.

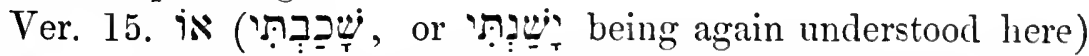
"Or I should have lain (or slept), שִׁ with princes, \&c." That the relative evident.

Ver. 16. In the preceding verses we have heard Job lamenting, that he did not die, as soon as he came into the world; here he goes further, and says, it would have been still better he had never come out of the womb at all, or in his own words:

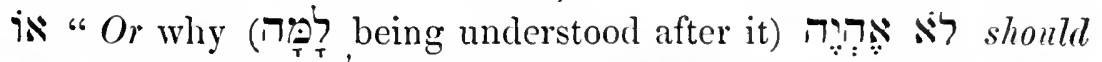
I not liave been like an untimely birth, which is quickly removed and hidden from the sight. 
In the second hemistich

Ver. 1\%. In a note on Ps. i. 1, Kimchi gives us the following.

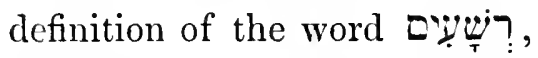

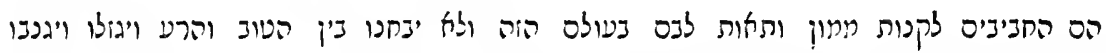

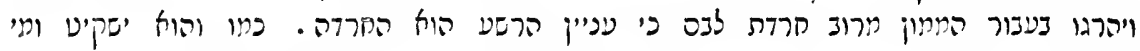

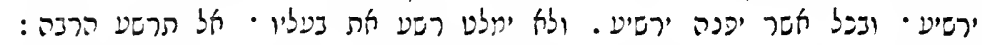

"They are those who are fond of acquiring wealth, and that which their heart lusts after in this world, so that they make no distinction between that which is good, and that which is evil, and rob, and steal, and slay, for the sake of wealtl, on account of the restlessness of their heart; for the [primary] meaning of restlessness (or disturb)? (Job xxxiv. 29); and whithersoever he used to turn, he caused restlessness (disturbance) (1 Sam. xiv. 47); and restlessness will not rescue him who hath it (Eccles. viii. 8); be not over restless (Eccles. vii. 17)."

With such an eminent authority before us, we need not hesitate

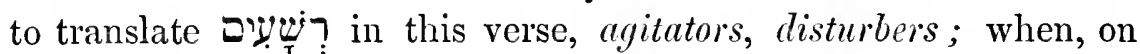
supplying before the word iר the prefix $מ$, with which the verb חדל to cease, refiain, is generally construed, the first hemistich will run thus:

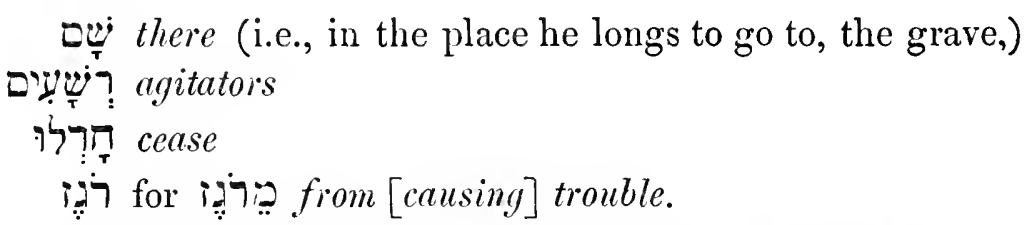

In contradistinction to this hemistich, in which wicked agitators are declared to be rendered harmless in the grave, we have in the second hemistich,

\section{טִִ and there}

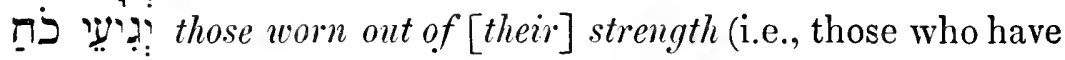
been tyrannized over by wicked agitators,)

ing? find rest.

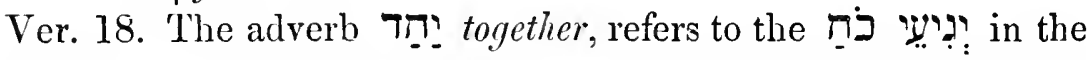
preceding verse, that is, together with, or like them, prisoners repose.

Ver. 19. The pronoun Ting singular, refers to each of the adjectives iop and לis: separately, that is, [the] little-(or lowly-) man is there, and so is [the] great-man; they are both in the same place, without distinction of rank.

Ver. 20. The verb 'תי,, being here used impersonally, like the 
verb אֵֵָ in ver. 3 (which see), may also be rendered by a

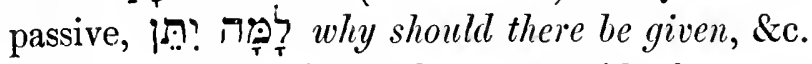

Vers. 21, 22. In order to avoid the necessity of supplying

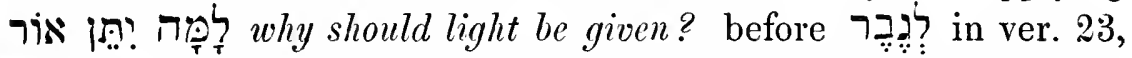
as is done in the Auth. Vers., we need only consider the two verses

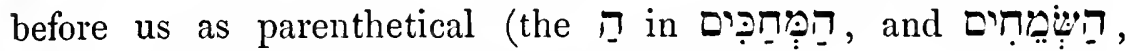

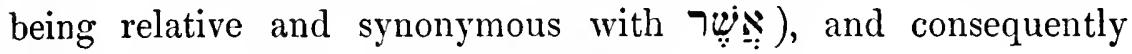

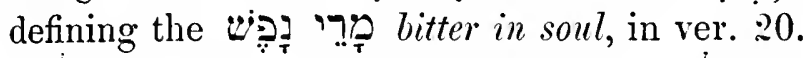

אל in ver. 22. is the poetical form of $t o$.

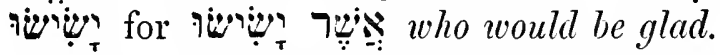

Ver. 23. It has already been observed on ver. 4, that the verb דרש which literally signifies to inquire, or look for, a thing, is also used in the sense of favourably noticing; the verb סתר to hide, or conceal, on the other hand, may (in Niph.) be fairly supposed to express, not being cared for, or not being taken notice of, as in

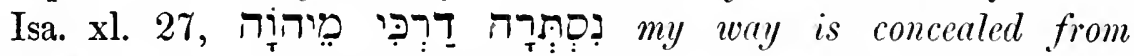
Jehovah; i.e., Jehovah does not care for my way; and so here, if

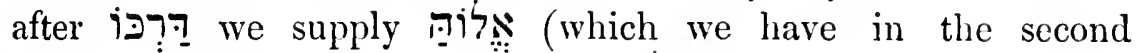

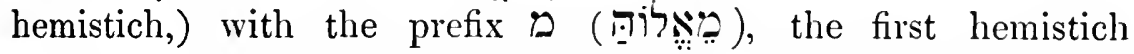
will run: To the man, whose way is concealed from, i.e., not cared for by, God.

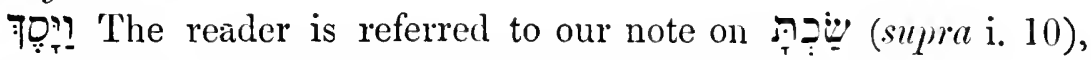
where it was observed, that the root 70 , to hedge, may be used in a good sense, as it is there, and also in a bad one, as here. In the first hemistich, Job speaks of a man, whose ways are not noticed by God, whilst, in the second, he goes a step further, and

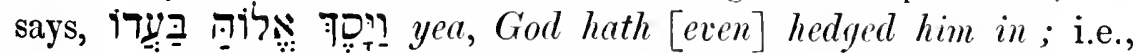
He not only does not favourably notice lis way, but has even made a hedge about him, has cooped him up, so that he cannot stir. A similar figure we find in Lament. iii. 7 , where the verb

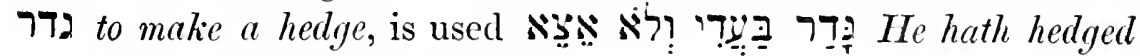
me about, that I cannot get out.

Ver. 24. Some think that the particle, for, because, with which this verse begins, is intended to introduce a reason for the invectives poured out by Job against his day, but this he had

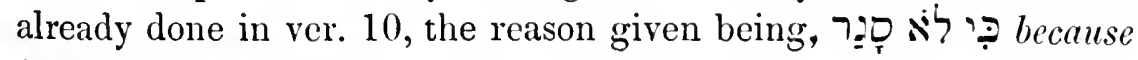
it did not slut up, \&c. It is, therefore, more to the purpose to suppose, that the here is intended to introduce the reason, why 
the words not cared for, \&c., may fitly be applied to himself, as though he said, I myself am the man whose way is not cared for by God, and whom He has hedged round about in a manner which makes my life quite burdensome to me, for (?) before my meal my groaning cometh, \&c.

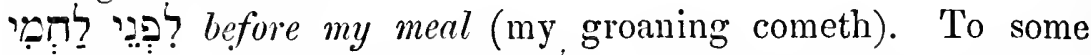
commentators the preposition ?ִִִּ has been very embarrassing, and among them, to Schultens, who has been driven to give it a meaning, which is quite inadmissible; whereas nothing is more natural than to take it in its usual signification, and understand Job to say in this verse, that his moaning and groaning begin with the very beginning of the day, before he has broken his fast.

Vers. 25, 26. It certainly, at the first glance, is not easy to understand, how a man, who had lived in such prosperity and affluence, as had been enjoyed by the unfortunate speaker of this discourse, before he was given up to the mercy of Satan, could possibly say, that he never was at peace, never was quiet, and never was at ease; a difficulty, which has led Schultens to propound such out-of-the-way views concerning these verses, that it would be mere waste of time to quote them. The difficulty, however, will soon vanish, if we recall the salutary injunction of

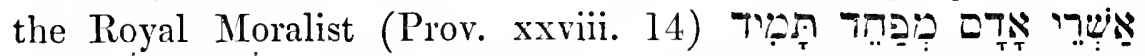

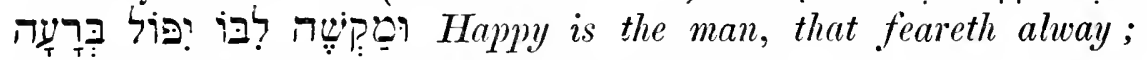
but he, that hardeneth his heart, shall fall into evil; for it is highly probable, that Job penetrated with the same pious sentiment, had never, even in the most brilliant part of his career, considered himself secure and safe, but had always, from his knowledge of the instability and transitory nature of all things belonging to this world, and their absolute dependence upon the will of Providence, entertained some fears with regard to the continuance of his prosperity; and that he now complains, in these two verses, that, in spite of his having been constantly impressed with this pious fear, trouble had come upon him, as though he had been one of those who harden their hearts, and deservedly fall into evil.

The coupling of a verb with a noun of the same root and corresponding signification gives in Hebrew a high degree of inten- 


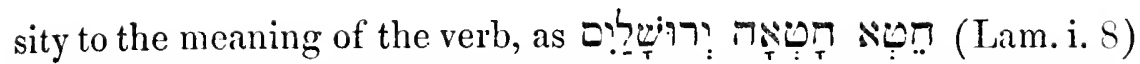

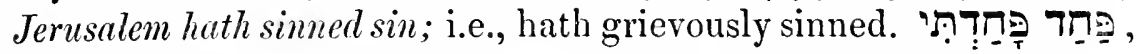
therefore, in ver. 25, might be rendered I greatly feared, but, as the relative natural to supply it in the first after 9חָ.

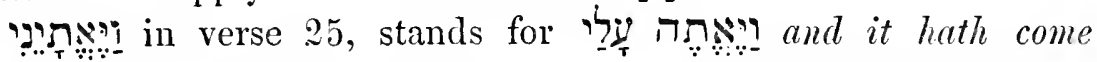
upon me; an objective affix being used instead of a preposition,

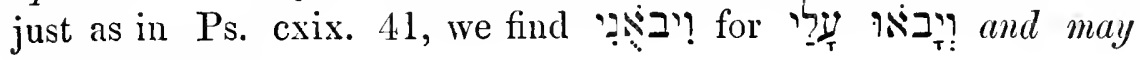
come upon me.

\section{PROLOGUE TO CIAPTER IV.}

SUMMARY OF THE PRINCIPLES AND VIEWS ENTERTAINED BY JOB'S TIIREE AGED FRIENDS, ELIPIIAZ THE TEIIANITE, BILDAD THE SIUUIITE, AND ZOPIIAR THE NAAMATHITE, AS GATHERED FRON THE WHOLE RANGE OF THEIR DISCOURSES WITH JOB.

That these three friends were old men, and of great experience, we hear from the mouth of one of them (xv. 9-10,) as well as from the young man, who speaks in chap. xxxii. (vv. 6, 7); they are in the highest degrec orthodox, and deprecate man's desire to philosophize, and dabble in wisdom (xi, 7-9 ; * xxviii. 31-39); they peremptorily deny, that the wicked prosper, and innocent suffer; nay, stoutly assert the contrary, appealing, in support of their assertion, to ancient history (iv. 7-9; v. 3-5; viii. $8-10,11-22$; xi. 20 ; xv. 17-19, 20-24, $29-30$, $34-35$; xviii. 5-21; xx. 4-29; †xxviii. 1-11); they strenuously maintain Job's guilt, and thereby justify the visitation of God (xi. 6 ; xxii. 4-11); they use invectives, and charge him with hypocrisy, and with absolutely denyingr the divine superintendence ( $.1,2$; xi. 3,$4 ;$ xv. 5,6 ;

* According to the division of the chapters in our translation; in the Auth. Vers. xxviii. $20-28$.

† In Auth. Vers, xxvii. 13-23. 
xviii. 4 ; xxii. $13-15$ ); they tell him, that he sets a bad example to others, and recommend him resignation and. prayer, by which he would attain to a prosperity far greater than he enjoyed before (xv. 4; v. S; xxii. 21-23; v. $24-26$; xi. $15-19$; xxii. $23-30)$. Their chief object being to establish his guilt, and deny what he says concerning the prosperity of the wicked, there is no necessity for them to bring forward any other arguments than such as bear upon these two points, and hence the sameness in the reasoning of these three aged friends. As a sort of compensation, however, they very frequently indulge in highly figurative language, and delight in expatiating upon the Omnipotence of God, though this is a theme, upon which they are often outrivalled by Job (iv. $10-21$; viii. $11-19$; v. $9-16$; xxv. $2-6$; xxviii. 35-37; xii. 7-25; xxvi. 5-14; xxvii. 11-12).

As the chief object of their arguments is to bring Job to a confession of his guilt, and he, so far from doing this, on the contrary boldly asserts his innocence, they abandon the contest in despair.

That these three friends knew no more of a future state than did Job himself, is evident from the circumstance of their never even so much as alluding to it, although they might plainly have derived thence an argument which would have silenced their opponent at once.

\section{CHAPTER IV.}

Ver. 2. In a later chapter (xxix. 9-10) we shall hear Job say, that, in the days of his prosperity, young and old stood in great awe of him, and that neither prince nor noble ever ventured to utter a word in his presence; the speaker of this discourse, therefore, very naturally thinking it possible, that Job might have become so accustomed to see every one bow to his opinion, as to be utterly impatient of contradiction, begins his speech with these words:

* In Auth. Vers, xxviii. $24-26$. 


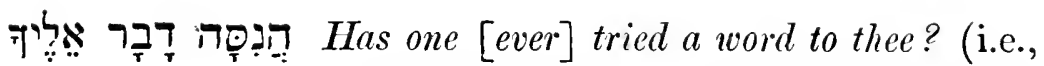
has any one ever ventured to express himself as differing from thee in opinion?)

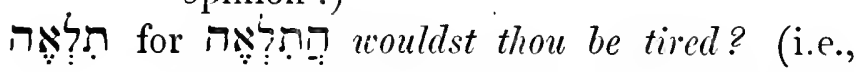
wouldst thou be out of patience with any one, that should contradict thee?)

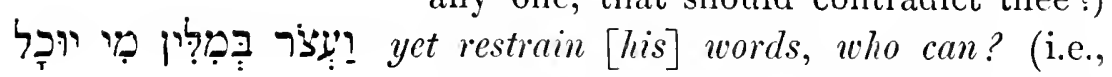
even at the risk of incurring thy displeasure, who could refrain from speaking, on hearing thee utter such terrible imprecations and curses?)

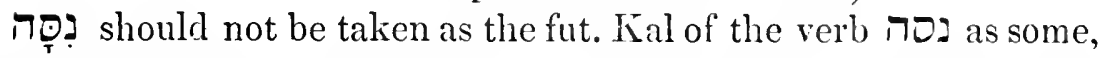
nor as the 3rd pers. past Niph., as others, take it; but as the 3rd pers. sing. past Pi-âl, seeing that this verb is only used in that roice. Aben-Ezra, to be sure, does, take it to be the lst pers. plur. fut. Kal, but then he says the $\boldsymbol{O}$ stands for $\mathbb{E}$, and the $\boldsymbol{\nabla}$ for $\boldsymbol{N}$, and consequently supposes the root to be $\mathbf{N} \boldsymbol{W}$ ג which is used in Kal. For our own part, however, we can see no cogent reason for this

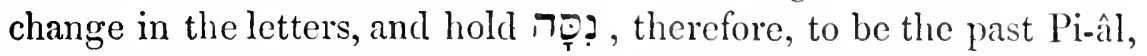

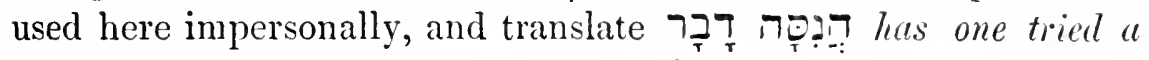
word? i.e., has a word been tried, \&c.?

The dative English idiom requires with thee. Comp. Judg. iii. 19, דִבַר שֶתר ?ִ I I have a secret word for thee.

, פִירים , the form of the Chaldee plural, is used here for which would be the Hebrew plural. The reader may be prepared often to meet with Chaldee forms in this book. With regard to the prefix $ב$ see note on

Vers. 3-5. The speaker reminds Job that, in former days, he used to reprove others, when they murmurect at the decrees of Providence, and expresses surprise, that he does not himsclf adhere to the line of conduct he had laid down for others.

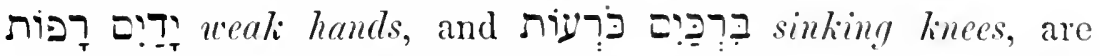
used figuratively to express men wavering in their faith and confidence in God.

Ver.6. Instances of passages in the Hebrew Bible, which cannot be construcd, or properly understood, without transposition, are 
very numerous indeed, not only in the poetical, but also in the historical books. As early as Gen. ii. 19, we find,

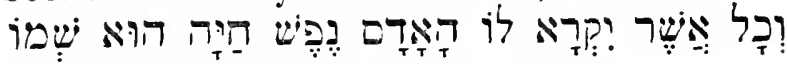

which, to make sense, must be construed thus:

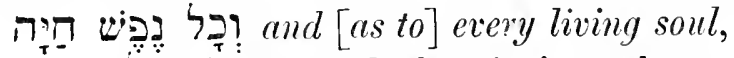

is

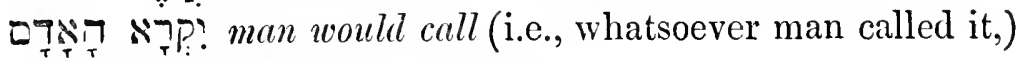

הוּא

And so, in Prov. vii. 23, we read,

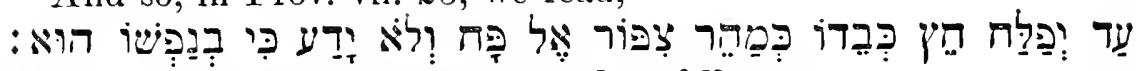
which of course must be construed as follows:

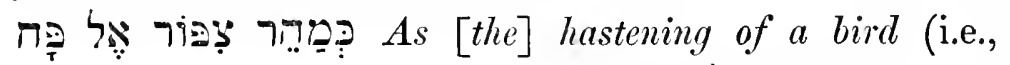
as a bird hastens) to a snare,

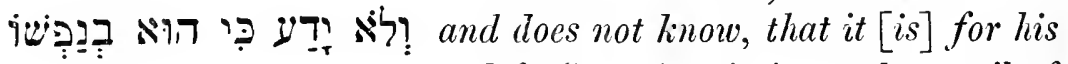
life (i.e., that it is at the peril of his life,)

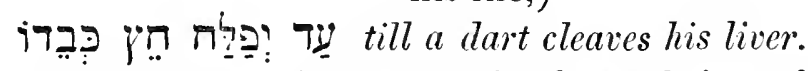

These examples have been brought forward, in order to show that, by making a slight transposition in the second hemistich,

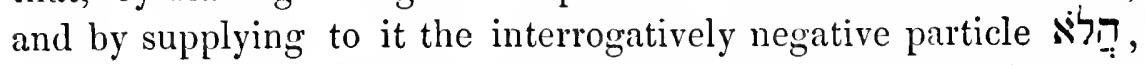
which is at the beginning of the first, we shall find this verse, which has proved so embarrassing to many commentators, as clear and intelligible as any of the most clear and intelligible verses in the Bible. The verse with these changes introduced will run as follows :

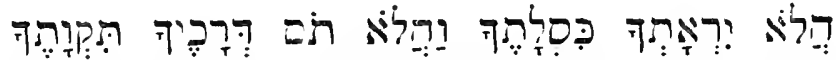

We heard Job wind up his discourse by saying, that he had always feared God, and been well aware, that all he possessed, and all his prosperity and happiness, proceeded from His bounty, and might be taken away by Him in a moment (see note on vv. 25, 26, of the preceding chap.); to these words of his, his friend now refers, telling him, that the circumstance of his always having had the fear of God in his heart, instead of serving him as a ground for complaint and murmuring, ought rather to be to him a source of great consolation and confident hope, inasmuch as if he really knew himself to have always been good and pious, he must feel assured that his sufferings cannot possibly be of long continuance, seeing that, though. God may chasten those He loves, He will 
ultimately manifest the fatherly delight He takes in them. The verse should be construed thus:

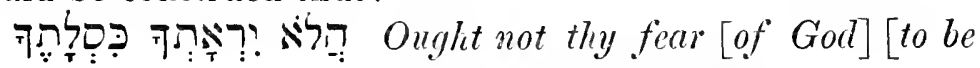
rather] thy confidence,

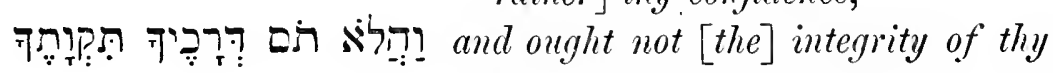
ways $[$ to be $]$ thy hope?

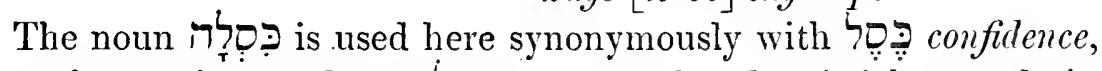
as infra xxxi. 24, where פכִ in the first hemistich, stands in parallelism with بִבְטֵ my safety, or security, in the second.

Ver. 7. In the summary at the head of this discourse, it has been mentioned, that Job's friends staunchly assert, that the wicked only come to a miserable end, while the just must always ultimately triumph; the friend, however, who here addresses Job goes further, and challenges him in this verse to point out a single instance, in which he has seen an innocent man perish.

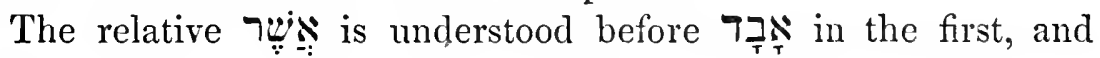
before נִבְדָדו in the second hemistich, as though the verse ran thus:

who is he, [the] innocent-man, that has perished,

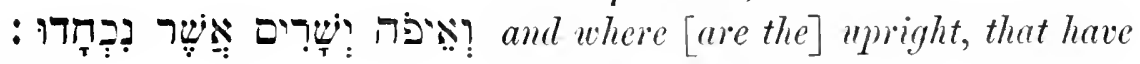
been ammihilated?

Vers. 8-10. After having defied Job to show him an instance, in which innocent men have come to a miserable end, Eliphaz, in his turn, offers, as it would seem, to name, if asked to do so, many wicked men, and among them eren powerful tyrants, whom he has seen, either utterly destroyed, or at least rendered impotent and harmless by the chastisement of God.

The verb חריט to plough, is figuratively applied to just as, in Prov. iii. 29, we see it coupled with Do not plough (i.e., plot) evil.

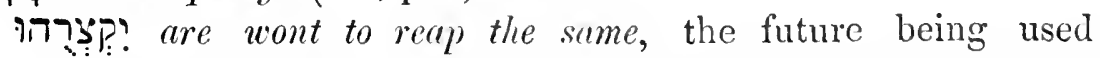
frequentatively to express, that this is what usually happens to wicked men; the affix ${ }^{-}$refers to עד

Verses 10, 11 must be understood figuratively to express, that, however powerful and oppressive tyrants (here designated as lions) may be, their end must always be wretched and miserable. 


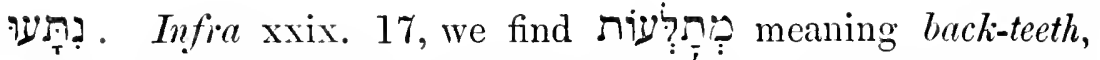
grinders, the root of which is of course $\pi$, and in Ps. lviii. 7, by a transposition of the letters $ת$, לתילְת (root) with the same meaning, and applied to young lions; if, therefore, we

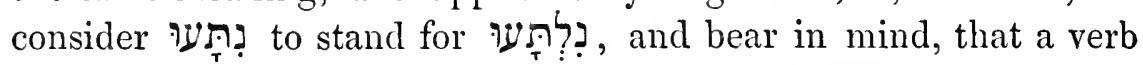
may sometimes express the removal or destruction of its kindred noun (see note on $\underset{T}{1}$ - supra i. 20,) this verb will express the destruction of the grinders. Some refuse to allow that the dagesh in the $\Omega$ can supply the place of a $ל$ (though a $\zeta$ is certainly replaced by a dagesh in the future of the verb propose to adopt the root בתע i. q., נת to break, or crush; an expedient by which, in our opinion, they gain but little. But, whatever the root of this verb may be, there can be no doubt but that it has the meaning of breaking, or crushing, and the only question is, whether it should be referred to the roaring of the lion, and the voice of the fierce-lion, as well as to the teeth of the young-lions (when it would constitute a Zeugma, such as is found in Exod. xx. 18, "and all the people "x̣i [were] seeing the thunderings, and the lightnings, and the NoIse of the trumpet," \&c.), or should be taken to refer only to the tecth of the lions, and the words

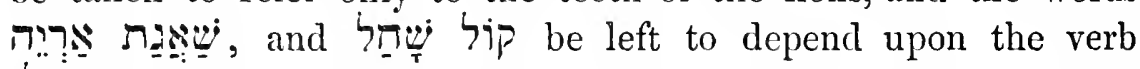
יכִלו In the preceding verse. In this latter case, the first hemistich would have to be considered as standing for,

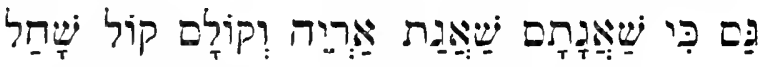

and the meaning would be; they are consumed,

though theiv roaring be the roaring of a lion, and their voice the voice of a fierce lion.

In our translation, we have adopted the former view, but, as such a Zeugma conld scarcely be tolerated in English, we have supplied (to the first hemistich), from the idea of removal, or destruction, implied in 9 צת the words, are silenced.

Ver. 12. That Job may see he (the speaker) has some ground for the confidence, with which he challenges him (Job) to point out a single innocent man who had perished in despair, he tells him, that this confidence is not derived from mere supposition or conjecture, but from a vision in the night.

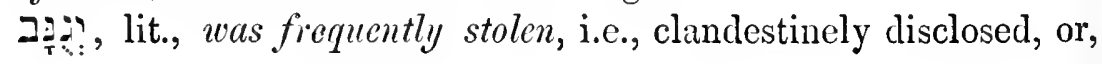


as Herz Homburg would understand it, was betrayed (to me). His words are as follows:

גלוי סו7 סוא כמו גניבה שהמגלה סו7 הוא נותן לאסר דבר שנמסר לו בפקדון • "The revealing of a secret is like theft; for the revealer of a secret imparts to another a matter which was intrusted to him as a deposit."

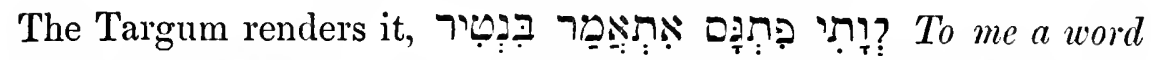
was said guardedly. The translators of the Septuagint, which has

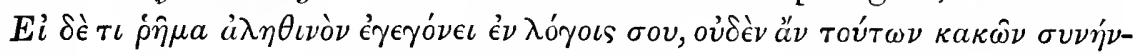

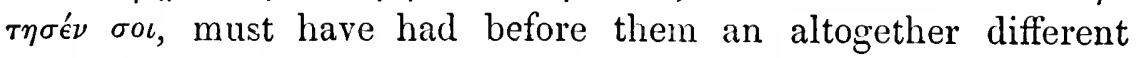
reading from that which we have in the text.

نֶ $a$ trifle. In this form the word is to be found only once more in the Bible, viz., infra xxvi. 14; but in Exod. xxxii. 25, we find a

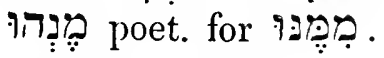

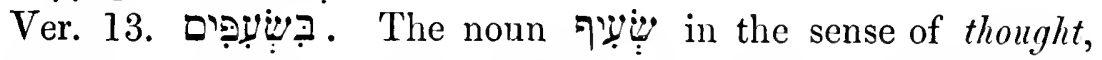
cogitation, is to be found again infia xx. 2. Before the following

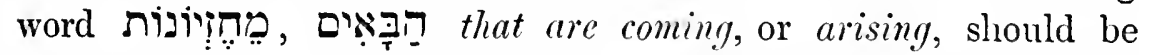
understood, the sense being, the thoughts arising from the visions of the night.

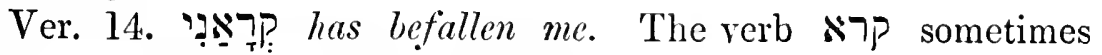
stands for to happen, to befall.

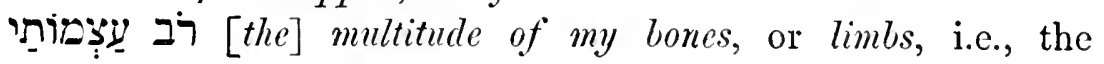
greatest part of my body.

הִִִּ it caused to be afraid, or made to quake.

Ver. 15. סמר in Pi-âl means to make to bristle, or stand on end;

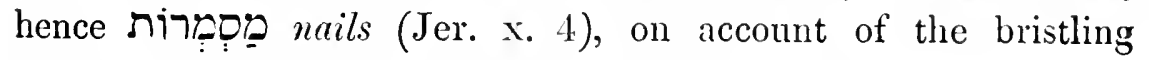
appearance they present, when only partially knocked in.

Ver. 16. T:- it, (i.e., the spirit) would (i.e., used to) stand (before me);

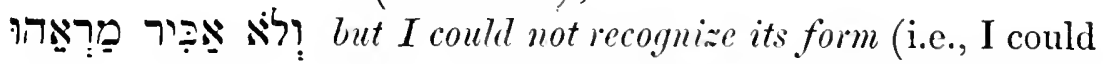
not say I had even seen such a form before); all that I could say was,

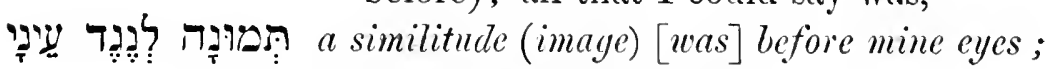
[at first, there us] silence,

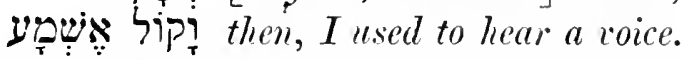

As the verbs here are all in the future, and not in the past, it would seem that this vision had appeared to him frequently.

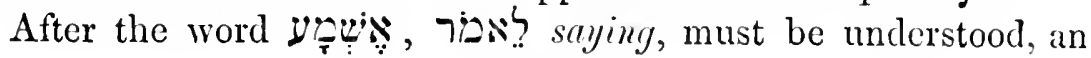


ellipsis which very frequently occurs; e.g., "The lings of the earth set themselves, and the rulers take counsel together, against Jehovah, and against His anointed, (לאמר) saying, 'Let us break their bands asunder, \&c." " (Ps. ii. 2.)

Ver. 17. The chief aim of Job's friend in this discourse being to impress him with the truth, that the just must be the object of the divine grace and favour, and the wicked that of the divine wrath and punishment, is greatly furthered by the words uttered by the Spirit (as cited by Eliphaz) in this verse; for, if a mere man, whether of low or high station, provided that he be just, cannot be an indifferent looker-on, when the good and innocent suffer, and the wicked prosper, how then can God, the perfection of justice, be so?

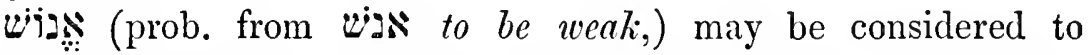
represent man as a frail being, frail man; whilst (prob. from גבר to be strong), represents him as a dignified being, as the lord, as it were, of the Creation, who has "dominion over the fish of the sea, and the fowl of the air . . . . and over all the earth."

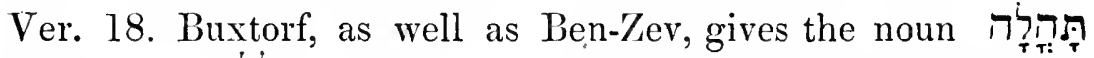
under the root הלל, and so does Kimchi, with this difference, that he also suggests הלדה as its root. Now the verb הלל very frequently signifies to be foolish, mad, but, also, sometimes, to be bright, to shine; the noun דָד , therefore, might be translated, either folly (and consequently, fault, blemish), or brightness, in which latter acceptation it is taken by Ralbag, a very high authority indeed, who supplies the negative ל hemistich to the second. For the former acceptation, however, we have a greater number of authorities. Thus, Aben-Ezra observes on this word:

כמו אמרתי להולליס הל תהולו

"I said unto the fools, Deal not foolishly."

(Ps. lxxv. 4); to which he adds,

בעבור קסרונם

"On account of their imperfection,"

meaning, He, God, imputes faultiness to the angels on account of their imperfection. So Jarchi :

"An expression of folly (or madness)." 
And Ben-Zev:

\section{גנור ודסרון}

"Plame and imperfection."

The Chaldee version renders it therefore, that we could not do better than subscribe to the interpretation given by so many eminent authorities, and translate the verse thus; Lo! in His servants He putteth no trust, and to His angels He imputeth faultiness.

After having, in the preceding verse, made a comparison between the justice of man, and that of God; the Spirit now declares this latter to be so incomprehensibly great and perfect, that the justice of no living being, whether man or angel, is as anything before it. Similarly the Psalmist says, (Ps. cxliii. 2),

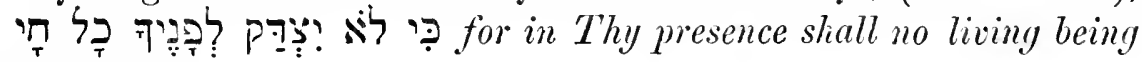
be justified.

Those who feel inclined to embrace Ralbag's opinion, and supply the negative לא in the second hemistich, may translate this verse thus: Lo! in His servants He putteth no trust, and to His angels He doth not attribute brightness (purity). The argument will of course in both cases remain the same.

The Chaldee translator is certainly wrong in understanding

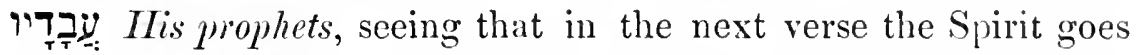
on to say, "Much less dwellers in houses of clay," words, which render it impossible we should regard any of the beings in the verse under consideration as mortals. The fact is, that angels, as ministering before Almighty God, are sometimes designated in the

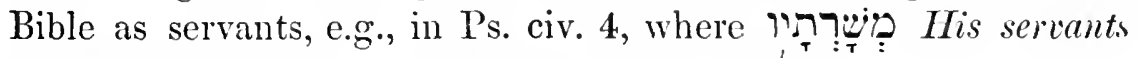

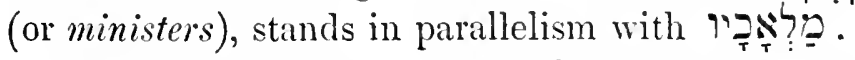

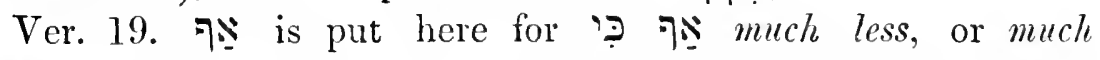
more, according to the context. Infra xxr. 6 , it is found in the former, in Prov. xi. 31, in the latter, sense. In the present instance, the difficulty was this; if we took it in the sense of much more, it could only refer to the second, if, in that of much less, only to the first, hemistich of the preceding verse, whereas there can be no doubt, but that it refers to both; besides this, if we had made use of either of these expressions, we should have had to supply בִ from or before is in the present one. To mect this difficulty, therefore, 
we have preferred translating let alone, understanding thereby, not to speak of, to say nothing of:

ברֶת houses of clay, fig., for human bodies.

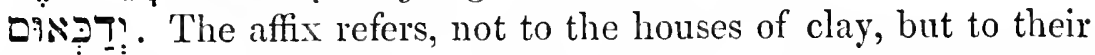
inhabitants, i.e., to men generally, who are figuratively called, dwellers in houses of clay. The verb, being here used impersonally, may be rendered by a passive, and translated they are crushed before [the] moth, i.e., their removal from life is sometimes effected in a shorter time than that in which a moth

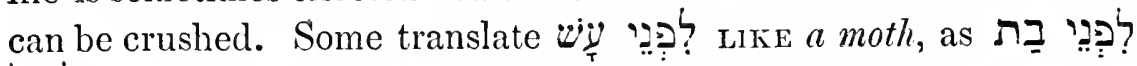
בִִּ (1 Sam. i. 16), like a daughter of Belial; as this, however,

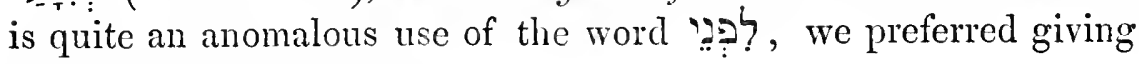
it here its usual meaning.

Ver. 20. In Eccles. xi. 10, we find תinge used in the sense of youth, from רשי [the] dawn, and fig., the dawn of life; and again, infra xxxvi. 20, we have Supported by these examples, we are strongly inclined to believe, that 7 moming, is here similarly used for the beginning, and עִ evening, for the last moments, of life, for it seems to us that the Spirit, who, in the preceding verse, had expatiated upon the shortness and uncertainty of human life, wished in the present one to impress Eliphaz with the sad but great truth, that man not only dies at the moment when, in common parlance, he is said to do so, but that, from the very instant he comes into existence, he begins to die, seeing that every moment he has lived is dead for him, and that it may consequently be said with great truth, that he is incessantly dying, though he is unfortunately not aware of it.

After the word ọ we supply 2 heart (an ellipsis, which will also be found infra xxiii. 6), and construe the verse as follows :

จง? they (viz., those dwellers in houses of clay) are broken (or crushed)

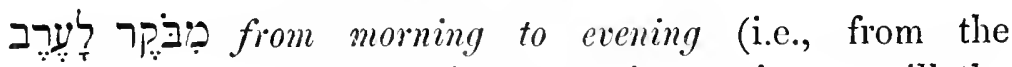
monient they come into existence till the moment they leave it);

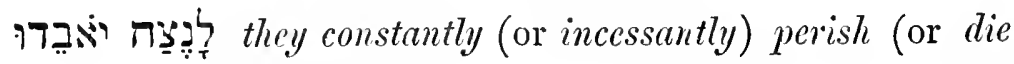
away) 


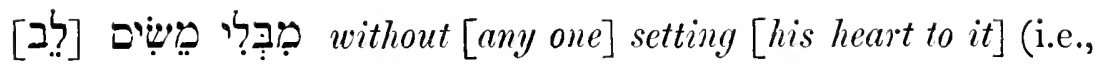
without their being aware, any of them, that they are so dying).

Ver. 22. The noun ית should here be taken in the sense of superiority (from the verb יתר? (Eccles. x. 10), and רתָז (Eccles. iii. 19) in which latter place

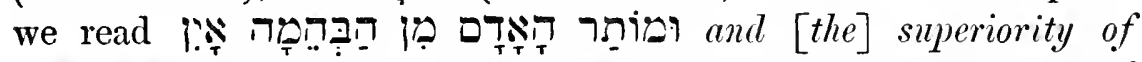
man over the beast is nothing, which superiority we must, of course, understand to consist in his possession of intellect. But this intellect, which renders him superior to animals, ought surely to teach him the great truth, that he is dying every moment; and, therefore, if he is not aware of it, it is as if his intellect were altogether removed from him. The Spirit, then, with an expression of surprise at this circumstance, concludes as follows:

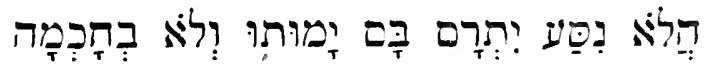

which must be construed thus:-

םרת: [as to] their superiority,

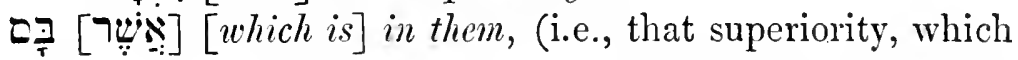
they have over the brute-creation, and which ought to make them aware of the fact, that they are constantly dying,)

הִל has not it been removed? (i.e., have they not, as it were, been deprived of their intellect?)

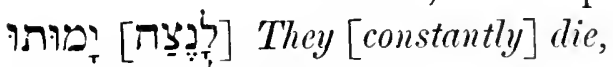

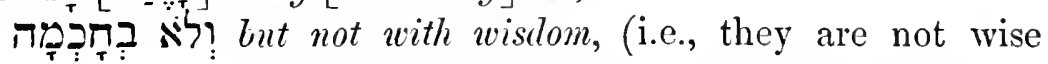
enough to see they are constantly dying).

It will be perceived, that we have supplied before from the second hemistich of the preceding verse, though this is, perhaps, hardly necessary, since 'מיזתו, as a frequentative future, may of itself be translated, they constantly die. 


\section{CHAPTER V.}

Ver. 1. In the preceding chapter, Eliphaz had dwelt upon the sinfulness of Job in complaining of the dispensations of Providence; now he tells him that, independently of this flagrant sin of his, he will also ruin himself in public opinion, so that his best friends will shrink from him; meaning, of course, to intimate, that even he himself and the two friends, who, like himself, had come to assure him of their condolence and sympathy, will, if he continues in the course he has adopted, be compelled to renounce his friendship, and abandon him to his fate. He says:

Now that thou hast uttered all these curses, call for sympathy and consolation, and see whether there will be found any one responding to thy call! And to whom, amongst good and pious men, canst thou turn? that is, look up with the hope that they will commiserate thy affliction?

The epithet ploly-ones, is applied to good men in Palm xvi. 3.

Ver. 2. Eliphaz goes on to say:

If thou find thyself at last deserted by God and man, thou must not be surprised, for the anger of a foolish man, when God sends suffering upon him, must ultimately slay him, and his envy at the prosperity of the wicked must ultimately kill him. Not only will his indulgence in these passions bring him to ruin, but it will also fritter away his health, and at last cause his death.

The in ?y is either pleonastic, or the mark of the objective case. Comp. (2 Sam. iii. 30) they slew Abner.

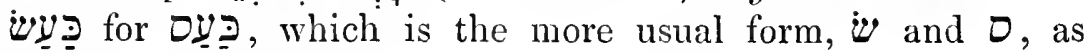
dentals, frequently interchanging. See infira xvii. 7.

The noun 7Nָּ? generally means, zeal, jealousy, envy, but, in a few instances, indignation, as in Deut. xxix. 19. Some wish to give it this meaning in the present verse, so as to make it stand in parallelism with it is to be taken here in its usual signification of envy. 
Ver. 3. Instead of being jealous of the prosperity of the wicked, proceeds the speaker, I, whenever I have seen a fool (i.e., a wicked man) in the height of prosperity, have not for a moment hesitated to pronounce, in the most positive terms, the fate which awaited his divelling.

אי a fool, stands here in the sense of a wicked man, like נָָר $a$ fool, in Ps. xiv. 1. In the preceding verse, however, the same word stands in parallelism with therefore, be taken in the sense of a foolish man, i.e., one who is silly enough to think the prosperity of the wicked man is lasting.

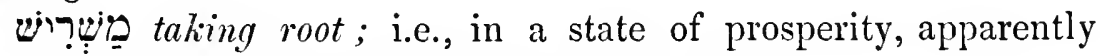
built upon a firm basis, and likely to be lasting.

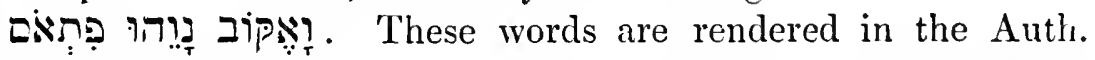
Vers., "But suddenly I cursed his habitation." By suddenly we must understand, at once, without hesitation; but it is difficult to comprehend what merit the speaker could take to himself for having pronounced a sudden curse on a wicked man, as every one, who is not himself wicked, might do the same, and yet not possess any great amount of foresight. But we have already observed

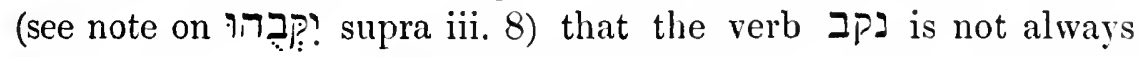
used in the sense of cursing, but, sometimes, in that of distinctly naming, pronouncing, and in this sense we take it here; so that Eliphaz boasts, and says:

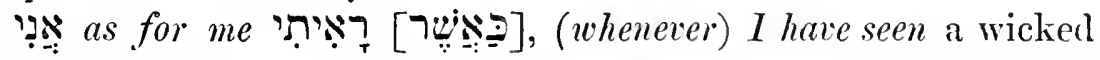
man prospering, no matter how great, or apparently lasting his prosperity, I have at once, without a moment's consideration, distinctly pronounced, with regard to his dwelling, what its encl would be, saying,--

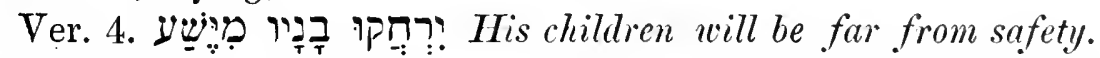
Not only will the wicked father, who was so wonderfully prosperous, be held in public execration, but even his posterity will inherit the odium of their parent, and live in a constant state of insecurity.

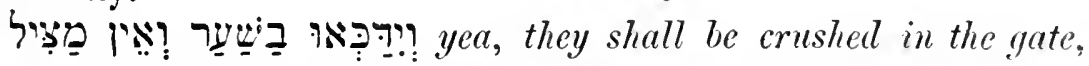
and [there will be] no one rescuing [them]. It is well known, that all judicial proceedings were, among the Hebrews, carried on in the gates of the city (see Deut. xxi. 19, Ruth iv. 1-11); 
Eliphaz, therefore, to increase the force of his prediction, says, that the posterity of the wicked man will have inherited to such a degree the hatred with which their ancestor was regarded, that, even in the court of justice, where such feelings ought to have no influence, their voice will not be heard, and they will be crushed.

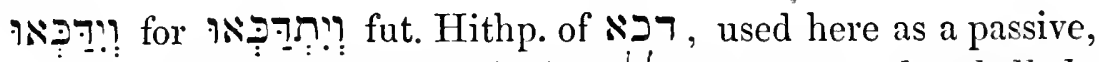
or Niph. Comp. Prov. xxxi. 30, דִיָ she shall be praised.

Ver. 5. This verse is rendered as follows in the Eng. Vers. : "Whose harvest the hungry eateth up, and taketh it even out of the thorns, and the robber swalloweth up their substance."

Now, it is difficult to see, what difference it could make to the wicked man, whose fate is here prognosticated, whether the one who takes away his harvest from him be hungry or not, or how it could be a greater punishment to him to be deprived of a bad harvest, such as the robber would have to gather amidst thorns, than of a good one; on the contrary, one would have thought, that the punishment in the latter case would be infinitely greater.

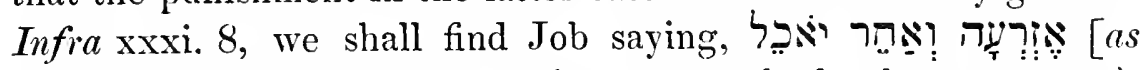
often as] I sowed [it], A NoTHER (no matter whether hungry or not), ought to have eaten it; and so would, doubtless, Eliphaz have said here, and nothing more, if his meaning had been that which is attributed to him in the translation above quoted. But the reasoning in this verse will assume an altogether different aspect, if we bear in mind, that, among the promises given by God to the Israelite nation, "if they walked in his statutes, \&c.," was that he would bless their harvest to such a degree, that they would have to remove the old store to make room for the new;

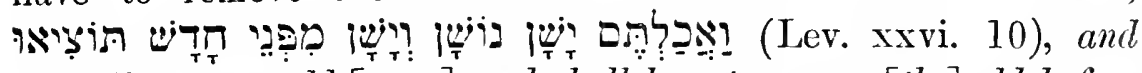
ye shall eat very old [store], and shall have to remove [the] old before [ye bring in] [the] new; (i.e., the harvest of one year shall be so plentiful, that, at the time of the one next following, there shall still be corn in abundance left from the old). Now the case with regard to the wicked man shall, we are told by the speaker, be just the reverse; he shall be cursed with one bad harvest after another, and not only will he not have anything left from the old 
harvest on the arrival of the new, but this shall find him already famished, and shall itself be so scanty, that he will be compelled to go, and gather from among the thorns what few ears it may have produced. Eliphaz's words must, therefore, be understood thus:

\section{whose harvest}

רציעב יאֵָל predicted,) shall eat, famishing,

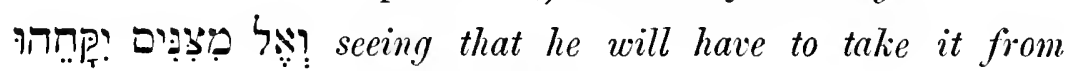
among thorns.

The preposition 48 is often used pleonastically, when it precedes $\boldsymbol{Q}$, as (Lev. iv. 12), without the camp, and so is its substitute $\zeta$, as in aip? (Judg. xix. 30) from the day (of the going up of the children of Israel out of the land of Egypt, \&c.

Of the word ș in the second hemistich some want to make

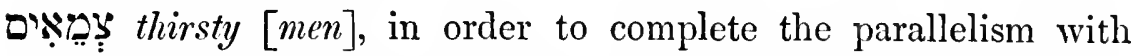
iִ in the first hemistich, but this interpretation we reject, as it makes sad havoc with the word, and, besides, is incompatible with our version of the first hemistich. The Auth. Vers. translates it robber, probably following Kimchi, who says:

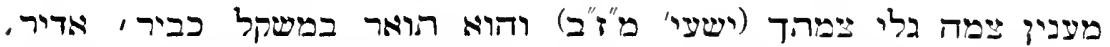

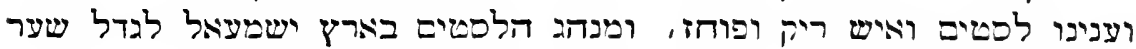

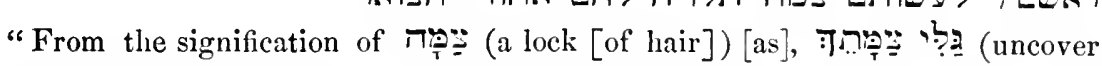
thy lock) (Isa. xlvii. 2) ; and it is an adjective * of the form, רצ (much), רצי (mighty), so that its meaning is, a robber, a good for nothing, and rash man ; and it is the custom of robbers in the land of Ishmael (i.e., in Arabia) to let the hair of their head grow long, to make a lock (a tail) hanging down behind the neck." . . . .

The reader will hardly blame us for not adopting this explanation of the word, to which we prefer giving the signification of trap, as we find it again, (infra xviii. 9), used as a noun sing., and in parallelism with $n \supseteqq$ snare, trap, or gin, to which, therefore, it is doubtless akin in meaning. We translate accordingly:

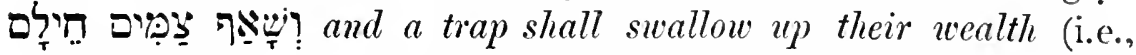
their wealth shall vanish, as though swallowed up; not a trace of

* He means to say, the word signifies a hairy.person. 
it shall be left). The word דֶָ, having the plural affix, would seem to refer to the wealth both of the father and his posterity. In Prov. xxii. 5, we read, שִִּ thorns [and] snares [are] in [the] way of [the] froward. This saying may perhaps have been proverbial in the time of Eliphaz, so that having introduced into the first hemistich the word thorns, in the second he made use of It will of course be perceived, that we take the second $D$ in

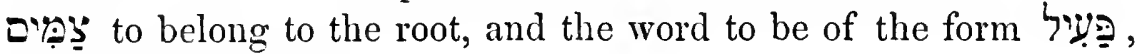
like a hammer.

Vers. 6, 7. The primary meaning of the noun toil (of the body) as in Eccles. i. 3, "What profit hath a man 政 in all his labour;" secondarily, it has been applied to labour of the mind, i.e., trouble, misery, mischief, when it is synonymous with to this word, however, the same signification (viz., that of trouble, or misery), in ver. 7 , as has been done by the translators of the Eng. Vers., as well as by many other translators and commentators, would, in our humble opinion, be to put in the mouth of the speaker a sentiment totally at variance with what we should expect from him. His object being to calm Job, and to recommend him patience and resignation, how could he say anything which would encourage him not only to persist in his grumblings and murmurings, but even to extend their range? Job asked (supra iii. 20):

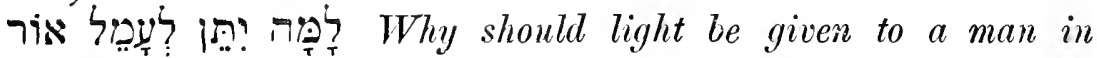
misery? But, if all men are born to misery, he might surely have asked in a more general way,

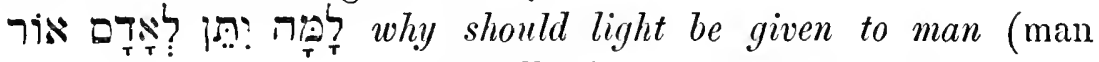
generally)?

Besides, if Eliphaz had actually used the words attributed to him by the said translators and commentators, he would have held a doctrine diametrically opposed to that inculcated in Scripture, e.g., in Lament. iii. 33, "For He doth not afflict willingly, nor grieve the children of men," for if man had been created to be miserable, could he be said not to be afflicted by God? We thought, therefore, that, if we subscribed to this view of the verse, we should be doing the speaker great injustice, and we have consequently preferred 
giving to the word or toil, (of the body). Eliphaz, then, after citing the words, in which he was wont to predict the end of the prosperous wicked man, reverts to the idea, which he had expressed in ver. 2 of this chapter, that anger, namely, and envy bring death upon the simple, and goes on to say, that mischief does not proceed from the dust, nor misery spring up from the ground; meaning, that, if man were but to bear in mind that, after his fall, he was sent forth from Eden to till the ground, and to eat his bread in the sweat of his brow, he would abstain from endeavouring to raise himself above the low sphere assigned to him, by indulging in metaphysical speculations which are altogether beyond his reach, and would forbear all attempts to scrutinize the inscrutable ways of Providence; and that so he would never get into mischief, nor be as miserable as he is, owing to his unfortunately forgetting his destination here below, and always evincing a disposition to strive to clamber up heights which he never can scale, whereby he

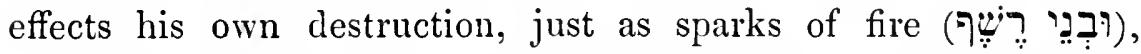
when they have left the burning mass, from which they sprang, are annihilated, as fast as they attempt to fly up on high and soar.

To the word ובְבי in the second hemistich of ver. 7, we supply the $\supset$ of comparison, an ellipsis very frequent in poetical language,

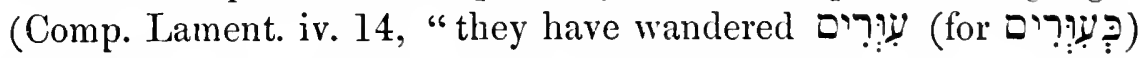
as blind men in the streets," \&c.), and construe the two verses under consideration as follows:

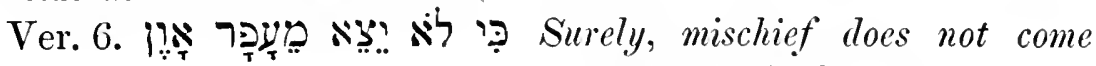
forth from $[$ the $]$ dust,

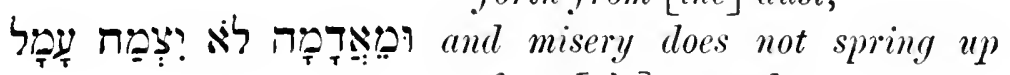
from [the $]$ ground;

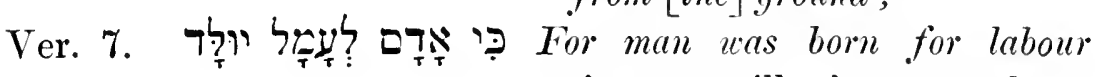
(i.e., to till the ground, to toil, \&c.)

fort, like sparks of fire, they are wont to fly up on high.

Eliphaz therefore plays upon the word לָ̦ in its secondary meaning, trouble, misery, and in ver. 7 , in its primary one of labour, toil. A similar play upon words we find 
in Exod. xxiii. 5, where בiע is first used in its ordinary sense, viz., that of leaving, forsaking, and then in that of unloading, easing from a burden.

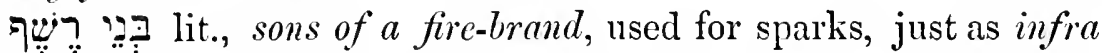
xli. 20, (xli. 28, Eng. Vers.) for an arrow.

אָ in vel. 7, being used for the human race generally, we

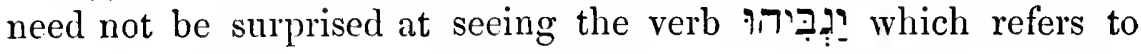
it, in the plural. A similar construction will be found in Ps. xxxix. 7, where we see verb jộ: they make a noise, which refers to it, in the plural number.

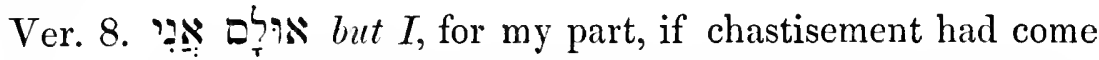
upon me, as it has upon thee, instead of endeavouring to pry into its cause, and philosophizing, should at once have felt satisfied that, as it had come from God, I must have deserved it, and I should therefore have sought God in prayer, \&c., as I should advise thee now to do. It will be perceived, that, according to our way

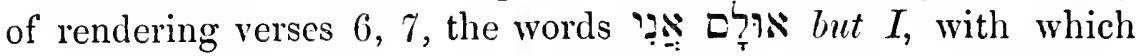
this verse begins, chime in very well, which they can hardly be said to do in the translation commonly given of these two verses.

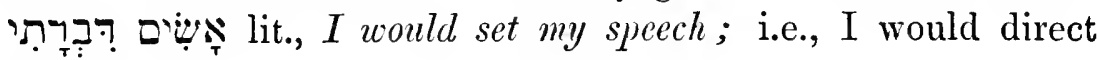
my prayer.

Ver. 9. Having made mention of God, he avails himself of the opportunity to dwell on His infinite power and goodness, and occupies with his description this, and the seven following verses (9-16, inclusive).

The sentiment expressed in this verse is found infra ix. 10 in the mouth of Job, with one slight change in the words.

Ver. 10. חוץ , The noun literally signifies a thing which is without, is sometimes used to designate a street, as being without (outside) the houses, as infra xxxi. 32, (the stranger did not abide); but here, it signifies that which is without a town or village, i.e., fields, or commons.

This verse being the only one in which the speaker dwells upon the phenomena of nature, whilst, in the following verses up to ver. 16, he expatiates upon the Omnipotence of God, as displayed in IIis relations with man, it may perhaps be fairly considered as 
parenthetical; and by thus taking it, the words so as to set the lowly, \&c., with which ver. 11 begins, will depend upon ver. 9, (the meaning being, that since God "doeth great things, \&c.," He is well able " to set up the lowly, \&c."), and will lose all the awkwardness they present in those translations, in which ver. 10 is not placed in a parenthesis.

ו! lit., and [those] black [with mourning], but here used figuratively of ill-fated men generally, as is observed by Ralbag:

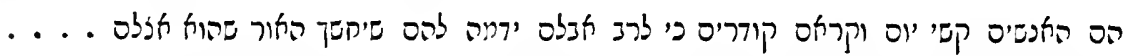

"These are ill-fated men, and he calls them [men in] black, because that, on account of the greatness of their mourning (sorrow), it appears to them that the light which is with them is become dark."

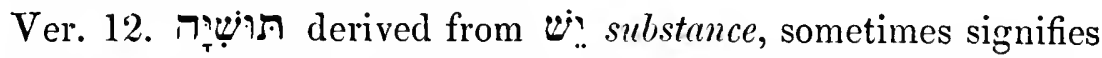
anything substantial, or essential; sometimes (as infra xi. 6), substantial (i.e., practical) wisdom, to which man is led by common sense; sometimes also (as infra xii. 16) that essential (or real,) wisdom, which belongs only to the Highest Intelligence. Wolfssohn remarks on this word in the verse before us :

\section{נגורת מן מלת יש כלומר דבר שיש בו ישות .}

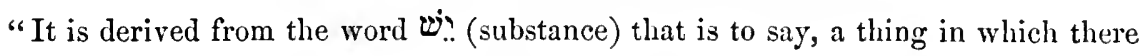
is something real."

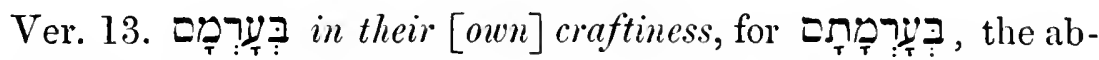

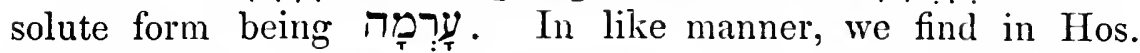

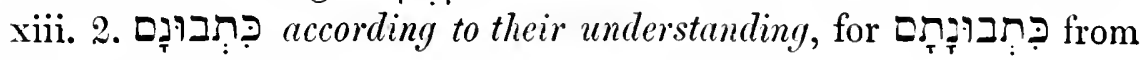

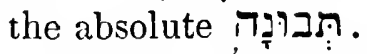

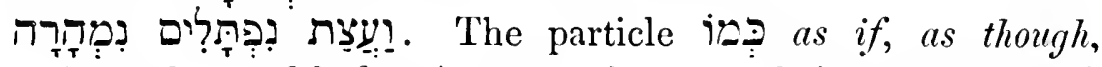

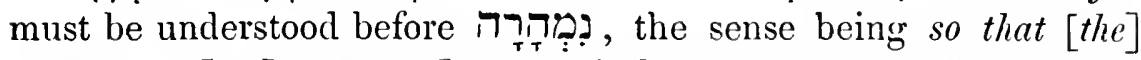
counsel of [the] perverse [turns out] [as though it had been] hasty, rash; by which is meant, that, however well preconceived and maturely weighed their plan may have been, yet, by the decree of Providence, it is frustrated, and assumes the appearance of having been rashly determined upon.

Ver. 14. וּבְ: To this word the prefix ב must be supplied from noon-day they grope about as they would do in the night. ליל?

* aver lit., to put, i.e., so that He can put. Comp. infra xxriii. 25, where we have תimilarly used and also followed in the second hemistich by a past tense. 
night-time, but here it has the definite article, and must, therefore, be regarded as a noun.

Ver. 15. The figure, by which a slandering tongue (or mouth) is compared to sharp-edged instruments, is very frequent in Hebrew,

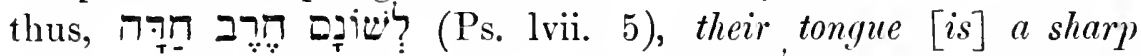
suord; so, in Ps. lii. 4, it is compared to razor: So also, in the verse before us, larly figurative way, being explained by Before this word we supply I from iplo in the second hemistich, as though the text were from their mouth (which is as bad as a sword). An instance of this sort, where, namely, the $I$ is used, not as a copulative, but as an explanatory, particle, is found in 1 Sam. xxviii. 3, where we read, that Samuel was buried i⿱ say, in his own city. The verse should, therefore, be construed thus:

So So that He saved [the] needy-man (by frustrating, namely, the plans of the tyrants)

from [the] sword, that is to say, from their mouth (which is as hurtful as a sword),

Pi্ণ

By this simple contrivance, we avoid the necessity of completely changing the punctuation of wasted-man, as was suggested by Michaelis, and so much relished by Ewald.

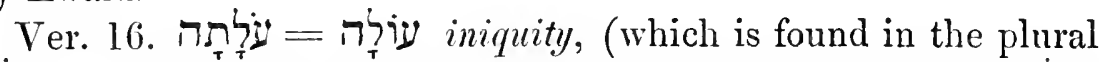

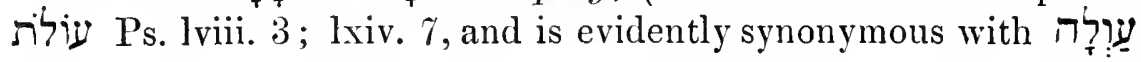

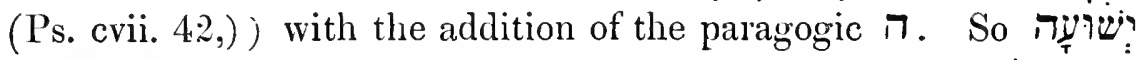
salvation, under similar circumstances becomes iii. 3).

Ver. 17. Having preached to his unfortunate friend the compassion God evinces towards the unfortunate, Eliphaz now encourages him to hope for His mercy, and says, Behold! happy is the man, whom God correcteth ; His corrections being commonly a sign of His love towards the person corrected. So Solomon tells us, Prov. iii. 12, "For whom Jehovah loveth, He correcteth."

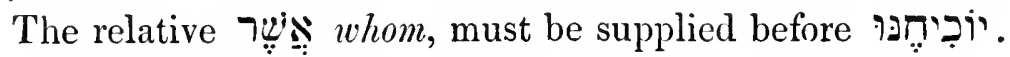

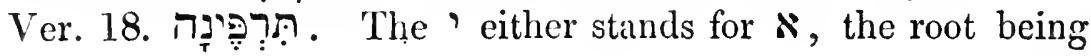


The poet, perhaps, made use of Tiv in the second hemistich with the intention of forming with טiv one of those paronomasias so frequent in Hebrew.

Ver. 22. Pדִָ̣̣ thou shalt laugh (at destruction and famine), in thy confidence, that God will preserve thee from them.

Ver. 23. For with the stones of the field shall be thy league; i.e., thou shalt never dash thy foot against them. The reader will, no doubt, on reading this verse, be at once reminded of the passage in Ps. xci. 12, "Lest thy foot dash (strike) against a stone."

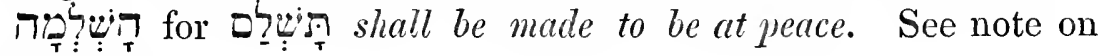
ๆ

Ver. 24. In the last two verses, the poet, supposing Job to be in the fields, looking after his affairs, promised him security against injury there; now, he tells him, that his confidence in God should be so great as to make him, during the whole time he is occupied out of doors, feel quite at ease with regard to what is going on in his tent-and that, on his returning home, he shall really miss nothing.

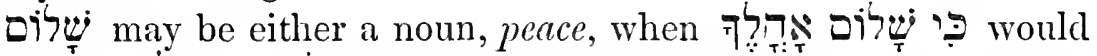

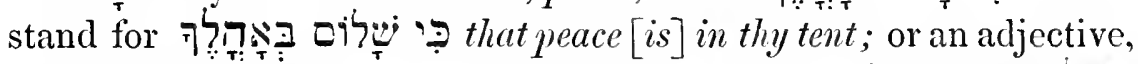
signifying peaceful (i.e., in peace) of the form iט great, when the translation would be, thy tent is in peace. The word seems to be used in a similar manner infia xxi. 9 .

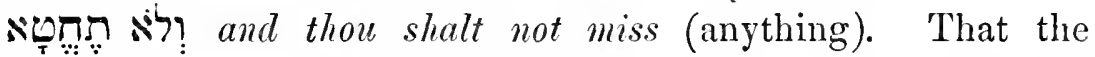
primary meaning of the verb in our note on $\boldsymbol{N}_{\mathrm{T}}^{\mathrm{T}} \mathrm{T}$ supra ii. 10. We will here quote Jarchi on this verse :

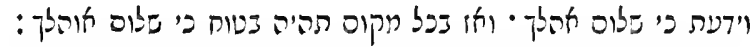

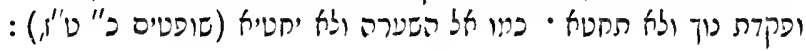

" "And thou shalt know, that thy tent is in peace'-even then, (i.e., even, when absent from home,) wherever [thou art], thou shalt be confident, that thy tent is in peace.

" And, when thou shalt visit thy house, thou shalt not miss'-as ('every one could sling a stone) to a hair, and not cause [it] to miss.' (Judg. xx. 16)."

Ver. 25. But thou shalt be confident, not only that the blessing of God will be extended to thee during thine own lifetime, but also that thy posterity will similarly be blessed.

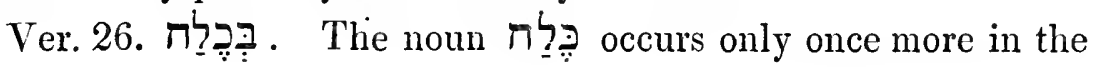


Bible, viz., infia xxx. 2. We cannot, therefore, do better than quote the opinions of some of the highest authorities upon this word. Those we select are as follows:

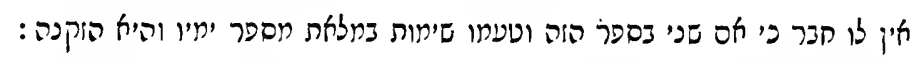

"It has no fellow, excepting one other in this book, and its meaning is, that he will die in the fulness of the number of his days, that is to say, in old age." (Aben Ezra.)

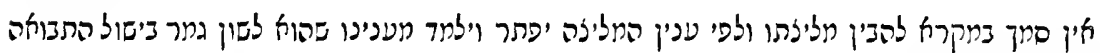

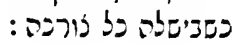

"There is no support in Scripture whence to understand its poetical meaning, and so it must be interpreted according to the context of the poem; and from the context it may be learned, that it is an expression of the completion of the maturity of the produce [of the ground], when it has ripened as much as it ought." (Jarchi.)

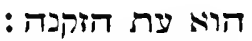 \\ It [means] the time of old age. (Kimchi.) \\ וענינו זהנה ........... והולי פררובו לפי עפינו כחות הגוף:}

"And its meaning is old age ..... . but its interpretation [may also be], in accordance with the subject, the powers of the body." (Ben-Zev.)

After having maturely weighed all these interpretations, we came to the determination to render ${ }^{2}$

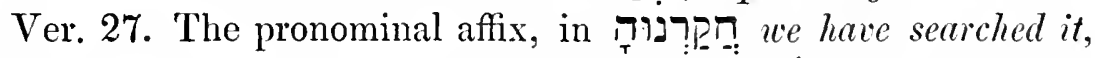
shews us we must consider the demonstr. pron. absolute $=\left[\begin{array}{ll}\text { as to }\end{array}\right]$ this $[$ thing $]$; i. e., as to all, that has been advanced in this discourse of mine, we have maturely examined it, and found it to be universally true.

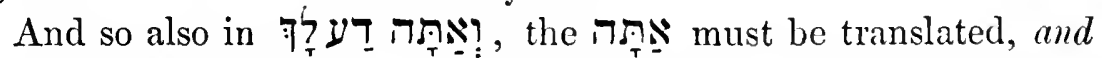
[as for] thee-(know (i. e., mark) [it] for thyself (for thy own advantage)); meaning to say, we, on our part, are quite convinced of the truth of the sentiments here advanced, and, as for thee, mark well the infinitely great advantage thou mayest derive from them. 


\section{CHAPTER VI.}

Ver. 2. It must be admitted that the speaker of the discourse contained in the two preceding Chapters has shown himself to be, not only a religious and pious man, but also an orator of great talent; on the other hand, it cannot be denied, that his words, though fraught with laudable sentiments, and excellent advice, do not contain a single argument bearing upon the point in question, viz., how it came to pass, that a man, who, according to the testimony of God himself, was "pious, upright, and a fearer of God" should undergo such terrible torments. Job is indeed told, (chap. iv. 6), that his piety ought to be to him a great source of consolation and confident hope for the future, but it is difficult to see, how he could derive any grounds for such hope from a piety, which had failed to shield him from the grievous calamities that now afflict him. Again, he is counselled to consider himself happy, that God corrects him, and is advised not to reject the chastisement of the Almighty. Now, a man with a character, such as was attributed to Job by God, would, no doubt, at all times, be ready to kiss the rod, with which God chastised him, provided only he felt, that he deserved such chastisement-but what had he done, unfortunate man, to deserve chastisement? This is the difficult point, which his friend ought to have grappled with, but which he had altogether avoided dwelling upon. To be sure, he rebukes Job in unmeasured language, and justly so, for the sin he has been guilty of, since his sufferings have come upon him, in murmuring against the decrees of Providence, but not one charge is brought against him, not one sin is pointed out to him, by which he could have deserved such affliction. The rest of the discourse is filled up, partly with harsh invectives stigmatizing $J_{0 b}$ as being either a fool, or a simpleton, (chap. v. 2), partly with expatiating upon the Omnipotence of God (a subject upon which we shall hear Job say, it was rather his part to preach to others, than for others to preach to him), and partly, with a grand display of figurative, and highly poetical, language. Now, it is very easy for a man in good health 
to choose his words, and employ eloquent and elegant language, such as a great sufferer cannot be supposed to emulate, and therefore Job, by way of protesting once for all against their expecting any eloquence from him, begins his reply by saying: Oh, that my grief could be thoroughly weighed, and my calamity laid together in a balance! (Ver. 3.) Surely now, they would be either of them heavier than the sand of the seas; therefore have they swallowed up my words. My grief and my calamity are so great, as to choke my utterance.

Ver. 2. 'יל: lit., they could carry, used here impersonally for could be carried,

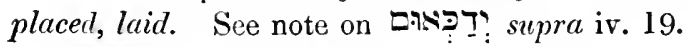

Ver. 3. T꾹' it would be heavy. 'This verb, being in the sing., must refer to

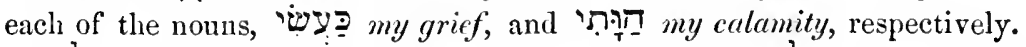

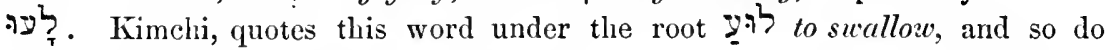
Ben-Zev and Buxtorf; but, though they refer the reader to Obad. ver. 16,

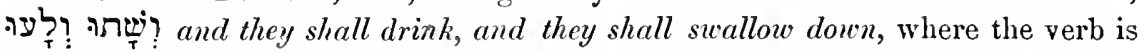
evidently used transitively, they seem in the present passage to have taken it, either in an intransitive, or even in a passive sense; so that, according to them,

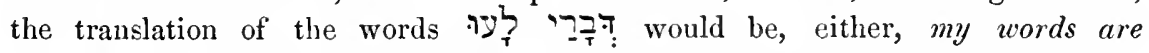
stammering, or, my words are swallowed up. Presumptuous as it may seem on our part to differ from such high authorities, still we think we owe it to truth to say, that we cannot embrace their views, and for two reasons; first, because we do not wish, where we can avoid it, to give to a transitive verb an intransitive, or passive, sense; and secondly, because, if 구ㄱㅜㅜ my words, were really the

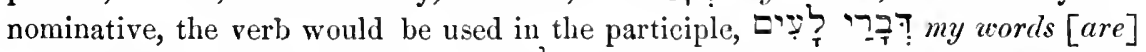
stammering, and not in the past, We have, therefore, made up our minds to consider, not ירָ : my words, but

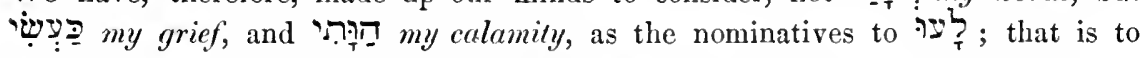
say, my grief and my calamity have swallowed up my words, i.e., have made my speech inarticulate, confused, and destitute of all ornament.

Gesenius, with his wonted love for adopting roots, which none of the old Lexicographers ever dreamed of, assumes the root of the word in question to be לעח ; but, puzzled by the accent being here penultimate (as it onght to be, and is also in Obad. ver. 16, where he almits the root to be לריע), he accounts for it by

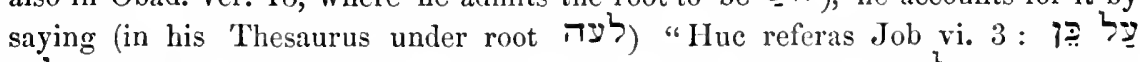

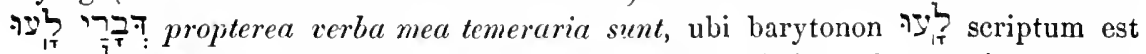
pro the accent is transferred from the ultimate, to the penultimate, syllable, in consequence of the lengthening of the vowel produced by the pause, is to help us to account for the supposed transference of accent in לצי , where no vowel is lengthened !!! But pray why in Jer. iv. 29, does the pause-accent, Ethnach, not cause a

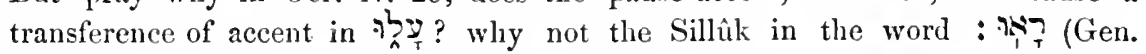
ix. 23 ; Deut. xxi. 7 ; Isa.v. 12 ; Ezek. xiii. 3)? why not? Because of course the accent must remain in its proper place-the last syllable-when there is no 
vowel lengthened. It is certainly bad enough, that one, who has ventured upon writing a Hebrew Grammar and Lexicon, should commit such a glaring mistake, but it is a thousand times worse, that Tregelles and Robinson should have translated his article without perceiving the sad blunder it contained. Let this serve as a caution to the Hebrew student, how he bestows his confidence upon Lexicons, which are not written, either in Hebrew, or by men able to write in Hebrew as well as Kimchi and Ben-Zev.

Ver. 4. Having, in the preceding verse, said, that he is altogether weighed down by his grief and calamity, Job now mentions the causes that have produced them, and compares them (in order to shew how deeply the one rankles in his mind, the other in his body), to sharp arrows dipped in poison, which, besides inflicting grievous wounds, would contaminate the whole current of the blood. He says:

For the arrows of the Almighty are with me. That is, stick fast in me. The poison of which my spirit drinketh up; the terrors of God set themselves in array against me.

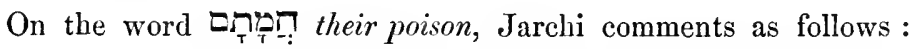

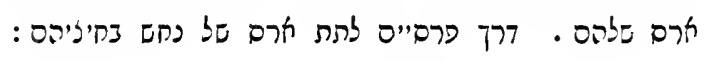

"Their venom; it is the manner of the Persians to put the venom of serpents on their arrows."

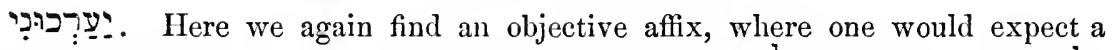

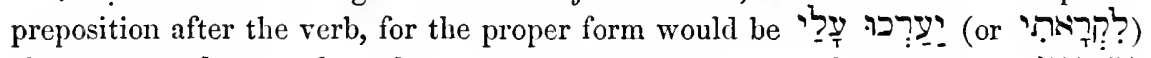
they constantly set themselves in array against me. See note on ?ריר:? supra iii. 25.

Vers. 5-7. As fault had been found with him by his friend for crying out so loud in his affliction, Job now tells him that, where there is a lond cry, there must also be pain to extort it; that even a brute would not cry out without a cause for it; and then since the discourse held to him just now was intended to console him, and soothe his pain, he goes on to say, that he cannot receive such consolation, that he wants arguments, and not mere words, empty and tasteless as the most insipid food. No, he says (Ver. 7): $M y$ soul refuseth to touch them; they, your unmeaning, insipid words and similes are as the loathsomeness of my food; are as loathsome to my soul, as food now is to my body. It stands to reason, that a man, afflicted with such. sores from the sole of his foot to the crown of his head, could not relish any food. 
Having explained, to the best of our humble faculties, the train of reasoning in these three verses, which have been considered so intractable by almost all the commentators, we will now proceed to remark upon them in detail.

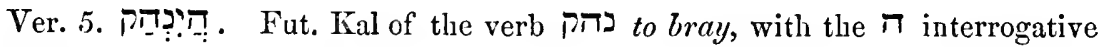
prefixed.

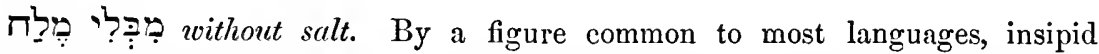
discourses are said to want salt, and vice versâ, spirited ones are said to have salt. So the German says, "Es ist Salz in seinen Reden;" or, as the French would render it, "Il y a du sel dans ses discours." There is, of course, no necessity to quote from the Latin, where the figure is so very common.

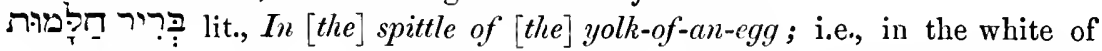
an egg, which, in its raw state, certainly looks like spittle, and is very insipid.

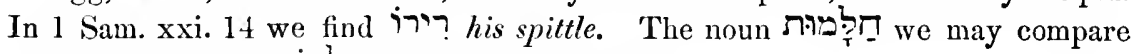
with the Talmudic $[$ [the] yolk of an egg.

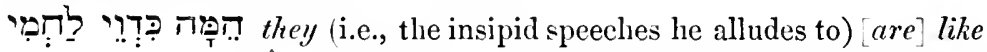
[the lorthsomeness of my food (i. e., like my loathsome food; just as my body now loathes food, so my soul loathes such insipid reasoning as that you offer me.)

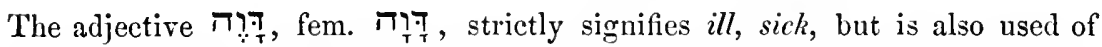
anything loathsome, or disgusting, there being some affinity between the ideas of sickness and loathsomeness. Hence, $\prod_{T} \underset{T}{T}$, in Isa. xxx. 22, means a menstruous cloth. So the noun 'רָ? , or, as it would be, were it not for the lengthening caused by the pause, 'T? constructive form, "T?, in the verse before us, in the sense of loathsomeness. It is one of the prominent features of the Hebrew language, that one noun is often qualified by another noun, by being put in construction with it; the second noun,

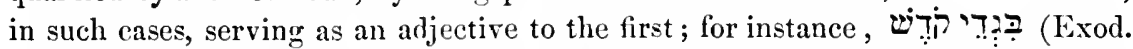

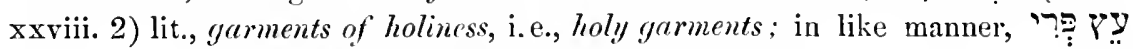
(Gen. i. 11), lit., a tree of fruit, stands for, a fruit-tree: or, the qualifying

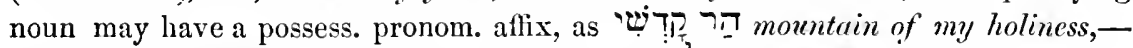
my holy mountain (Isa. Ivi. 7). So here, Ṣִִ? lị lit., [the] loathsomeness of my food, is really equivalent to my loathsome food.

Vers. 8-12. After having solemnly protested, that he cannot admit reasonings destitute of argument, Job continues: "Oh, that my request might come, and that God might grant my hope! (viz.) (Ver.9.) And that God might be pleased to crush me; that He might let loose His hand, and make an end of me! (Ver. 10.) Then would this still be my consolation-were I even to burn with pain-were He even not to spare me. However excruciating the pain of the final blow might be, this consolation, at least, would still be left me, That I have 
not denied the words of the Holy-One. That I have not disregarded His commandments. Having then nothing to reproach myself with, I might, perhaps, submit with patience to my afflictions in expectation of better times, but (Ver. 11.) What is my strength, that I should hope, or what would be my end? What could I expect? Were I to prolong my life? (Ver. 12.) Is my strength the strength of stones, is my flesh brass?

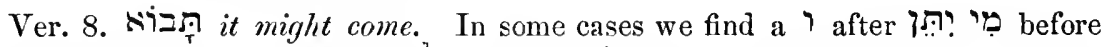

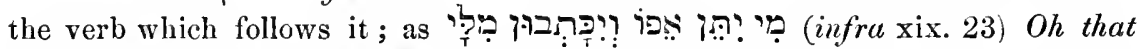
now my words were written down! but, sometimes, as here, the $I$ is omitted.

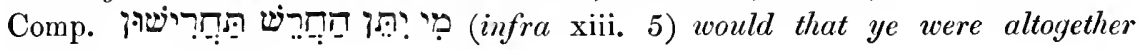
silent!

Ver.9. 9.

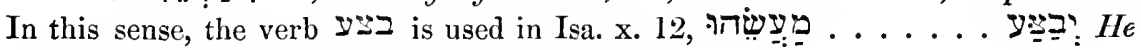
will finish (or despatch) . . . . . . His work.

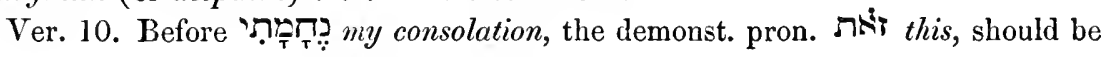
supplied.

The verb כלד is not to be found in the Bible, excepting in this instance, but is used in the Talmud in the sense of boiling, scalding, burning, as

\section{שמן אף על פי שיד סולדת בו}

"Oil, although the hand [be] scalded with it." (Treatise Sabbath, fol.40. 2.)

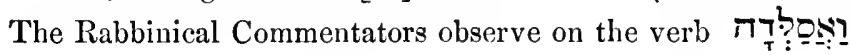

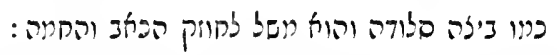

"[The same] as [ביצה סלודה in the Talmudic language, signifies] a boiled egg, and it is used [here] figuratively of the intensity of the pain and the heat." (Aben-Ezra.)

$$
\text { ר"ל אט"ס בהיה מתקמס ונבוה בסיל ובמבאוב אשר הביא עליו השם ית' }
$$

"He means to say, though he were heated, and burning with pain and anguish, which God, blessed be $\mathrm{He}$, had brought upon him." (Ralbag.)

The 1 of the word 1 I I $\boldsymbol{k}^{2}$ in the same verse, and be taken in the sense of though, although, as in Prov.

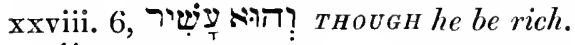

קדiT [the] Holy-One. This epithet is here applied to God, as it is also in Isa. xl. 25.

In Mason and Bernard's Grammar (Letter lvi. $\$ 18$ ), several passages have been adduced from the Bible, containing sentences, which must be regarded as parenthetical ; we shall content ourselves here with quoting one of them. "Hath

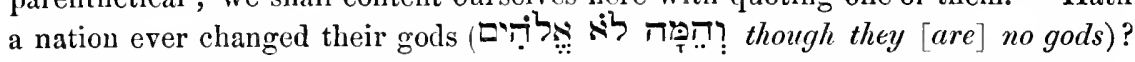
yet my people have changed their glory for that, which cannot profit." (Jer. ii. 11.) It will be perceived that the words verse, are, in like manner, conșidered by us as parentlietical, and that the verb

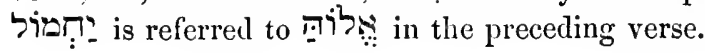


The five verses, therefore, which we have grouped together, will run thus:

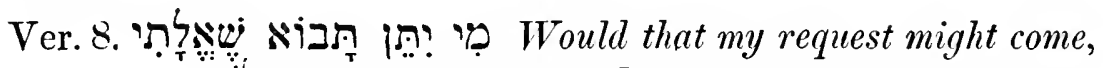
And [that] God might grant my hope!

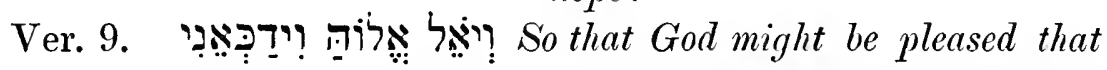
He should crush me, (That) He should let loose His hand, and despatch me.

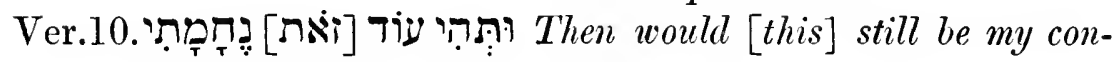
solation,

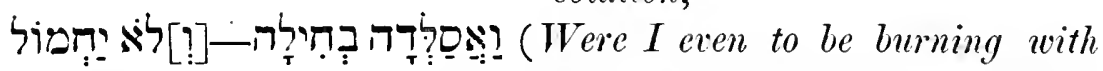
pain-were He even not to spare), That I hare not denied [the] words of [the $]$ Holy-One.

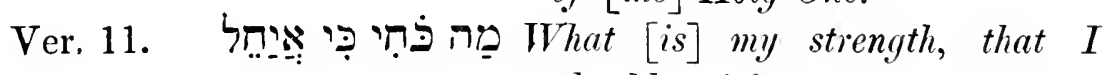
should wait?

Or, what [would be] mine end, if I should prolong my life?

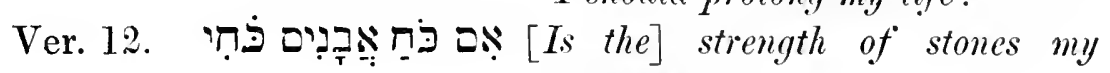
strength?

[Is] my flesh of-brass?

Vers. 13, 14. The reader will recollect, that the great sufferer, who is now speaking, had been classed by his friend with fools and simpletons (supra v. 2), as though he were enduring the fate which they deserved; to this he, no doubt, alludes in ver. 13, where he says with much bitterness: Because my help is not in me. Because I have become helpless. Must common sense therefore also have been driven out from me? Am I a fool because I am helpless? He then, in Ver. 14, goes on to say: To one, who is pining away with grief, kindness should be shown by his friend. He ought to be treated kindly, not tormented with galling invectives, as I have been by thee; Or, else he might actually be driven to despair, and leave (give up) the fear of the Almighty, which he always had had in his heart. These two verses should therefore be construed thus:-

Ver. 13. הַאִם אִין עִזְרָתִִי בִי [Because there is] not my help in 


\section{me (i. e., because I have become helpless,)}

Has common-sense also been driven out from me? (i.e., must, in consequence of my helplessness, my common-sense have departed from me?)

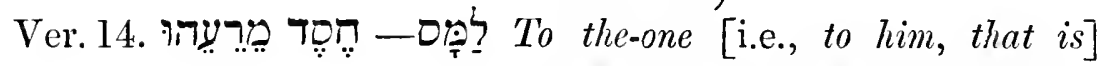
pining-away, [there should be] kindness on the part of his friend (i.e., kind, and not harsh, words, ought to be addressed to him,)

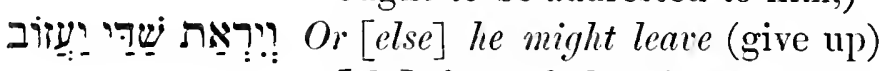
[the] fear of the Almighty (i. e., he might be driven to despair, and to heresy, however pious and religious he had been before).

With regard to the word תתריש:דיד supra ve note on this word, 12.

Vers. 15-21. 'The reader need not be told, how much travellers in the desert suffer through scarcity of water; how eagerly they look for it, and how great their disappointment and misery are, when they come to the place, in which they expected to find it, and find none. Our innocent sufferer therefore, who was longing for the solacing and refreshing words he had expected to hear from the mouth of his friends, while he had hitherto heard from them nothing but harsh and galling reproaches, compares them to the waters in the desert, upon which the tired and exhausted traveller never can rely, either in summer, or in winter. His words are as follows:-My brethren have dealt-faithlessly, like a torrent, like the stream of torrents, that pass by; (Ver. 16.) Which grow-turbid by reason of ice, by reason of the snow, which concealeth itself in them. Which falls into them, and, instantly melting, disappears. (Ver. 1\%.) Again, when they grow hot, they become extinct; on their (lit., on its) being heated, they vanish from their place. (Ver. 18.) They change (lit., turn) the patis of their way; they ascend in a shapeless-mass, and perish. Instead of flowing horizontally, the usual direction of their course, they rise, owing 
to the heat, perpendicularly, as shapeless vapours, and vanish. (Ver. 19.) The caravans of Tema looked-out, the wayfaringcompanies of Sheba hoped for them. (Ver. 20.) They were ashamed, that they (lit., he, i. e., every one of them) had confided in them; when they had come to it. The place of the water. Then they blushed. (Ver.21.) Surely now, ye have been turned into it. Into the torrent I have spoken of. You treat me in exactly the same way, as the torrents do the travellers, who hoped for them. Ye see horror, and therefore are affaid. You see a horrifying example before you, of the dreadful manner in which God can punish a man when he is angry with him, and therefore you are afraid of acknowledging that I suffer innocently, lest, by doing so, you should provoke God, and bring equally great sufferings upon yourselves.

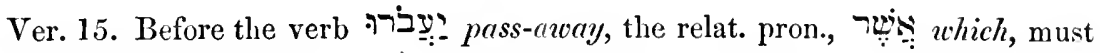
be supplied.

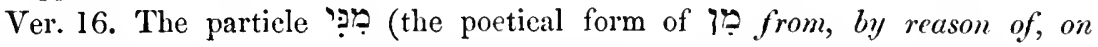
account of, and oceurring again, infra xvi. 16), should be supplied in the second

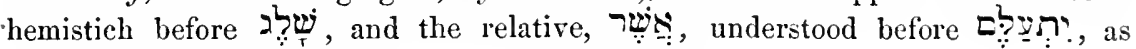
though the second hemistich had been worded thus:

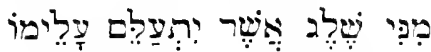

by reason of [the] snow which hides itself within them.

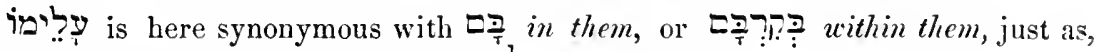

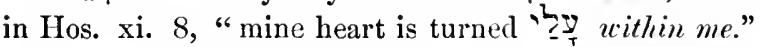

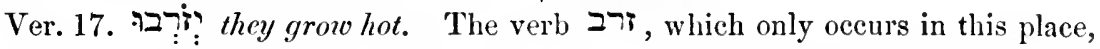

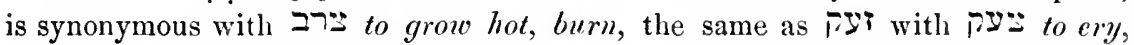
$\checkmark$ and $\Psi$, as dentals, interehanging with each other. The verb 2 ¿

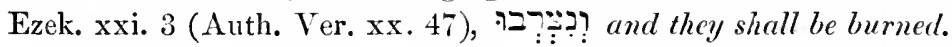

A singular verb, when preceded by its nominative in the plural, refers to

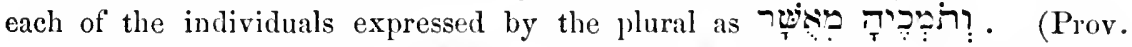
iii. 18.) And, [as for] those laying hold of her, levery one of them is This explanation will apply also to the possessive aflix $i^{-}$in the word its being heated, i.e., on every one of the פְחד therents, mentioned in the preceding verse but one, being heated.

Ver. 18. The verb $ת$ ל in Niphal signifies to turn, change position, as in Ruth iii. 8, תר and he turned, changed position.

בַּ in the (i.e., as a) shapeless-mass (of vapour). The force of the prefix 2 here corresponds to that of the French en, in en ami. Comp. Ps. xxxvii.

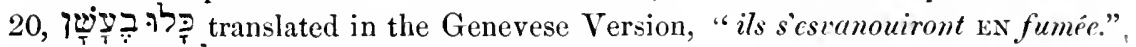

Ver. 19. ist to them, in the second hemistich, should be understood after חדִִּיטנ: they lookcd, in the first. 
Ver. 20. ברָָָ he trusted ; i.e., every one of them trusted. See note on ver. 17.

Ver. 21. The verb

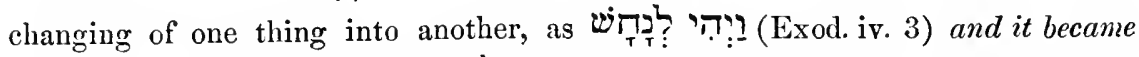

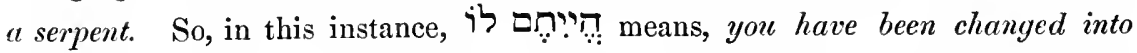
$i t$; i. e., into the torrent mentioned in ver. 15. You are become as the torrents of the desert; you play the same deceptive and delusive part towards me, that the torrents of the desert do towards the traveller, who hopes for them.

It will be perceived, that we read it as it is in the $K^{\prime}$ ree and not לccording to the K'theev. This should always be done, when practicable, as the K'ree is supposed to correct the K'theev.

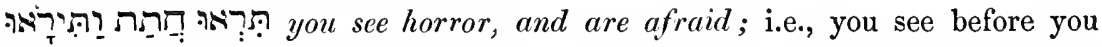
a horrifying example, and are deterred by it from acknowledging the truth, that I am suffering innocently, lest you should yourselves furnish another example of the terrible manner in which God punishes those who provoke Him.

Vers. 22, 23. If a man applies to his friends for pecuniary aid, and that aid is refused him, he may be disappointed, but he cannot at once condemn them, and charge them with unkindness, as they may be under circumstances which render it perfectly impossible for them to comply with his request. But, if he asks of them nothing but commiseration and sympathy, and even these are denied him, he cannot but consider such denial as a great piece of inhumanity and cruelty. Now, this was precisely the case with the unfortunate speaker; had he been imprisoned and tortured by some tyrant, and then complained of his sufferings to his friends, they might perhaps have been expected to receive him coolly, as thinking his complaints were made with a view to induce them to open their purses for the purpose, either of bribing the governor of the prison, in which he was kept a prisoner, or of ransoming him from the tyrant who held him imprisoned. But his complaints were, that he was afflicted, not by man, but by God, and, therefore, his friends must of course have known, that he could want nothing from them but sympathy; to refuse him this was, therefore, naturally regarded by him as very cruel, and he, consequently, says :-

Have I said to you, "Give me anything?" Or, "Bribe any one for me, with your wealth?" (Ver. 23.) Or, "Deliver me from the hand of an adversary?" Or, "Ransom me from the hand of tyrants?" 
Ver. 22. Just as חָ power. valour, is also used in the sense of wealth, (e.g.,

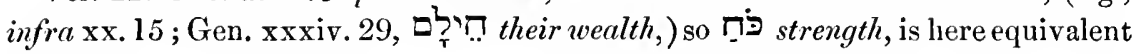
to wealth; the explanation of this secondary meaning of the two words being of course, that one, who has money, has strength, and is not so helpless, or so easily injured, as one destitute of it. Comp. Prov. v. 10, "Lest strangers be filled

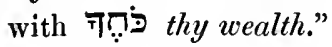

and bribe ye. The noun

Vers. 24-27. At the very opening of this discourse Job protested, and said no eloquent, loftily-worded, speeches could be expected from a man, suffering as he was; he now reverts to the same subject, but dwells upon it at greater length, and cries out against his friends for taking advantage of his position in bringing all the powers of their eloquence to bear upon him, when they well know, that he would have to seek for words. He says:

Instruct me. Bring forward real arguments. Then, will I hold-my-peace; but, make me perceive, what I have erred in. (Ver. 25.) How powerful are words of rectitude! Words, which present a matter in its true light, will always be powerful, whether they be plain and unvarnished, or elegant and ornate. But what argument can one get out of you? (Ver. 26.) Do ye think to argue with me in words? Do you mean to use fine words instead of arguments? Then, the words of a man-in-despair must go for (be esteemed as) wind. For a man in despair cannot, of course, choose his words, as one who speaks at his ease. (Ver. 27.) But, if you can be so cruel as to take advantage of my unfortunate position, then, indeed, you might as well cast-yourself upon the fatherless-child, and devour your friend.

Ver. 25. 'The verb פרץ, in Neph., signifies to be strong, or powerful; as, in

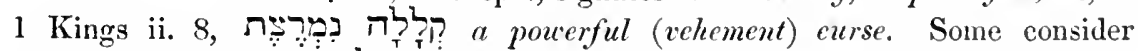

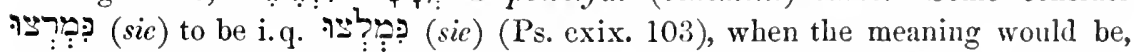
"How pleasant are, \&c.," but the reasoning remains the same. We certainly do find an instance, where $\zeta$ and 7 interchange; viz.

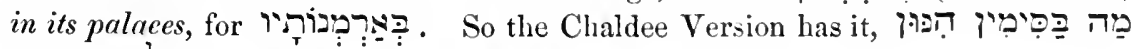
How pleasant are straight-forward words!

יill will one indeed argue out-the infinit. Hiph. of with the fut., to give emphasis. 'The inf. ought, by rights, to precede the tense, but we find it in some instances following it, as it does here. Comp. Gen. xix. 9, טוֹ

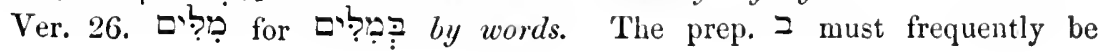




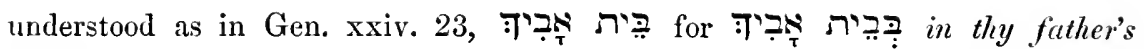
house.

בెֹ lit., one given up to despair, it being the part. Niph. of the verb שיאי to despair.

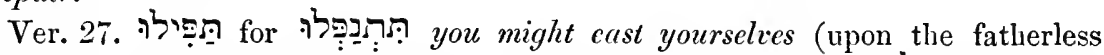
child ; i.e., in order to oppress him). In the same sense, the verb נפל is used in

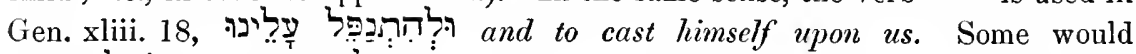

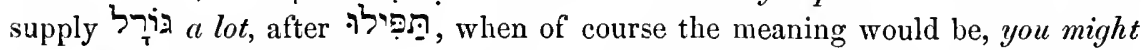
(as well) cast lots (for the property of a fatherless child, i.e., take it away wrongfully). But, if we are at all to assume an ellipsis here, we would much

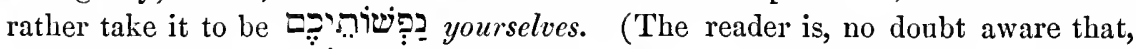
in Hebrew, the noun בְּפ soul, or person, when it assumes affixes, is sometimes used as a periphrasis for the reflective pronoun self.) And so we find infra xix. 5,

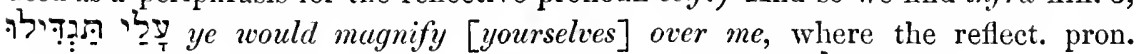
must be understood. But may not the Hiph. of the verb נפל be, for once, used here in the sense of the Kal, just as the verb קשב as it has in Kal, in which voice, however, it is only found once, Isa. xxxii. 3,

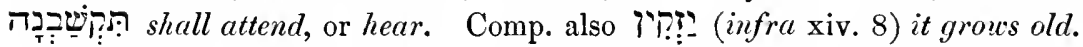

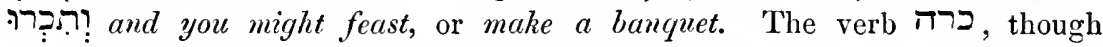
generally signifying to dig, is also used in the sense of feasting, or banqueting;

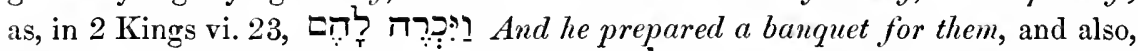
iufra xl. 30 (Eng. Vers. xli. 6,)

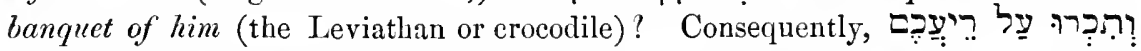
lit. means and you might make a banguet (or feast) upon your friend. One who wreaks his vengeance upon, or treats another with great cruelty, is said in Hebrew (and the expression is especially frequent in this book), to eut, to glut

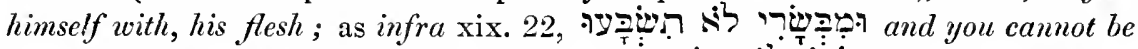

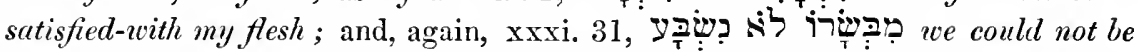
satisfied-with his flesh. Some wish to take the verb כרח in this instance in its

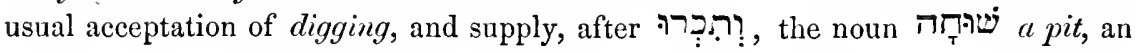
ellipsis, to which we should willingly agree, if we could but account for the preposition instauces, where it means to dig, and is construed with a preposition, it is with $\zeta$ for, and not with צू against, that we find it.

Vers. 28-30. Eliphaz, in his discourse, had (speaking for himself and his friends) held out a threat (chap. v. 1) of leaving Job to his fate, and withdrawing altogether from him; this Job now deprecates, as an act, by which he should be very much wronged, seeing that he had not yet explained to them the nature of his case, nor the manner in which he intended to lay it before God, for not one word in his first discourse had he addressed to God himself, though we shall presently hear him doing so, (infra vii. 7-21). For his friends, therefore, to desert him now, would be condemning 
him without a hearing; he entreats them, therefore, not to carry their threat into execution, until, at any rate, they are quite convinced that there is falsehood or iniquity in his tongue. His words are as follows: Now therefore be pleased; tum to me. Instead of turning your back on me, turn round, and consider me, as well as my case. Then will it be before you. Be evident to you. If $I$ speak-falsely. (Ver. 29.) Come back to me, I pray; let there be no wrong. Do not wrong me, by deserting me without first hearing me. Yea, come back; then will ye be convinced, that my righteousness is still in it. (That is, in ?ivi? my tongne, found in the next verse.) 'Then, you will perceive (Ver. 30.) Whether there be any wrong in my tongue; whether my palate cannot discern perverse-things.

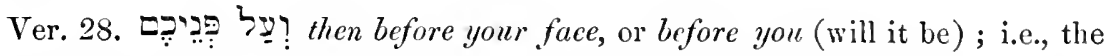
thing will be quite as evident to you, as if you had it before your face.

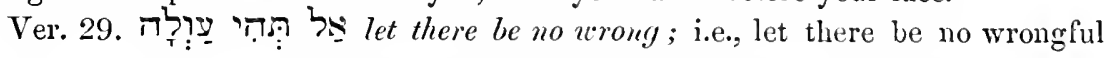
act on your part, such as the condemning of a friend without a hearing.

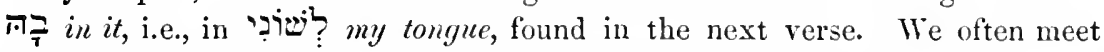
with a pronoun referring to a noun, not preceding, but following, it. So, infra xxiv. 6, in ${ }^{2}$ 근 his fodder, in the first hemistich, the pron. affix i- his, refers

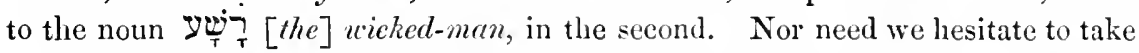
the pron. I ב the next verse; since we very frequently meet, even in the listorical books, with two verses so closely connected by the sense, as to require to be read as if they formed only one. Thus, Exod. xxv. 8, 9, "And let them make me a sanctuary, (that I may dwell among them.) Accorting to all that I shew thee, \&c.", where the words, that I may dwell among them, are, evidently, parenthetical, the command being, that they should make Him a sanctuary according to what He shewed them; and yet, the verses are divided. Indeed the only way, in which we can account for the def. art. being, in the first chap. of Genesis, given to the sixth, and not to any of the other days, is, to connect the latter part of the last verse of the 1st chap. with the 1st verse of the 2nd, as follows: "And there was evening, and there was morning, even that sixth day, when the heaven and the earth were finishel, \&c." ; where we give to the 7 in that it has in Gen. xix. 23, "The sun was risen on the earth "2i'? whes Lot came to Zoar." 


\section{CHAPTER VII.}

Vers. 1-3. In the preceding Chapter (Vers. 8, 9), we heard the unfortunate speaker praying for death, and here again it would seem the idea of death once more came across his mind, conjoined with a feeling of wonder, how it is, that men-beings, whose days are numbered-should ever long to see the last of them. This he accounts for, by the terrible sufferings which they sometimes have to endure in this world, and brings himself forward as an example. His words are:

Is there not an appointed-time for frail-man upon earth? Indeed, his days are like the days of an hireling. Just as the hireling continues only a certain number of days with his employer, so man remains only his allotted time upon earth. (Ver. 2.) As a slave panteth for the shadow (shade). As a slave, while toiling in the heat of the day, longs for (and obtains,) a mere nothing, the shade. And as the hireling waiteth-for his wages. Longs for (and obtains,) money, in itself a paltry thing, which has no value but in the imagination of man. (Ver. 3.) So have I been made to possess months of vanity, and nights of trouble have been prepared for me. So, whatever may have been my longings, I have been allotted a life, which is not only altogether unprofitable, but also full of trouble.

Ver. 1.

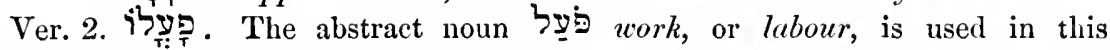
instance for the result of the labour, i.e., the wages; as in Jer. xxii. 13, "that maketh his neighbour work for nought, and giveth him not, לוֹ his wages." In like manner, the synonymous noun

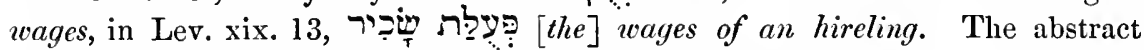
noun עצ עוֹ iniquity, is, similarly, used for punishment (the consequence of iniquity),

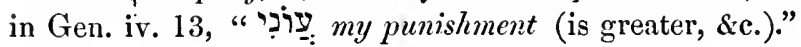

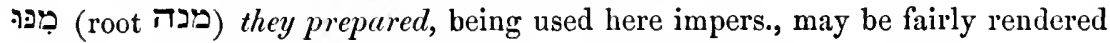

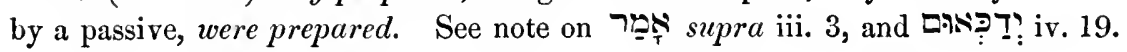

Vers. 4-6. At the beginning of chap. vi. we heard Job complaining of his sufferings in general, but now, before directing 
his speech to God, he enters somewhat more into detail concerning them, as they affect both his body and his mind; probably, with the intention of throwing out a hint to his friends, that they should make every allowance for the situation he is in, and not be surprised, if, in the address he is about to make to God, words should escape his lips, such as he ought not to utter. He says:

When I lie down. For my night's rest. Then I say, When shall I arise? His sufferings during the night are so great, that he longs for the morning, as people invariably do, who are ill and afflicted with sleeplessness. So among the curses enumerated in Deut. ch. xxviii. we read in ver. 67 , "and at even thou shalt say, Would God it were morning!" But the evening is measured out. The evening (by which he means the night), seems an eternity to me. And, so, I am filled-with tossings to and fro till the morningtwilight. (Ver. 5.) My flesh hath put on. Is become covered with. Worm[s], and clod[s] of dust; my skin is broken, and become loathsome. He appears to allude to the state of his skin, induced by his disease, for it is well known, that, in elephantiasis (as occurring in hot countries), the skin becomes of a muddy hue, thickened and rugous (like that of an elephant), so as to have very much the appearance of the ground when dried up and cracked by the heat. With regard to the worms, it is said that, after ulceration has occurred in the progress of the disease, worms are bred in great numbers in the ulcers; Job's body then, being covered with such ulcers, would swarm with worms. (Ver. 6.) My days have been swifter than a weaver's-shuttle; and are consumed without hope. It may be that, in the first hemistich, he refers to his former days of happiness, and in the second, to his present days of misery, spent without hope.

Ver. 4. רִִ̣ (lit., but one measures (is wont to measure), i.e., extends, lengthens out), being used here impersonally, may be rendered, but is lengthened out, i.e., seems

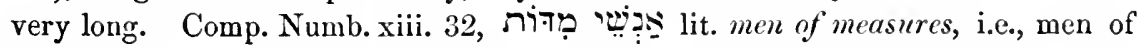
great stature. The verb is here used in l'i-âl, the second radical taking Pathacth,

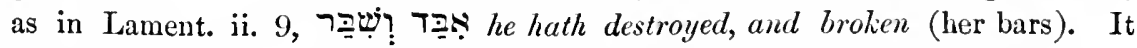
was on account of this Pathach that Rosenmüller rejected מדד as its root, though nothing is more common than to find Pathach replacing the more regular Tsayre of the Pi-âl.

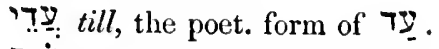

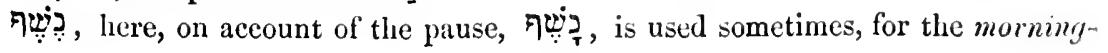


twilight, as in 2 Kings vii. 5 ; and sometimes, for the evening-twilight, as in Prov. vii. 9. Here, it is evidently used in the former sense, though, infra xxiv. 15, we shall find it taken in the latter.

Ver. 5. wiּg clod, is a $\ddot{\alpha} \pi \alpha \xi \lambda \epsilon \gamma^{\prime} \rho \epsilon \gamma o v$.

Yרָ was broken. We have the authority of Aben-Ezra, Kimchi, Ralbag, and Wolfssohn, for giving the verb this signification.

DṆ:? so that it has become loathsome. Some assume the root to be מס, and think that $X$ may stand for $D$, an anomaly we find in Ps. lviii. 8 ; we, however, cannot see why we should favour this view, since we obtain excellent sense by regarding the word as a regular Nipll. of the verb פס, to loathe.

Ver. 7. In no language do we meet with such striking instances of bold and vigorous Ellipsis (a figure, full of elegance, when no ambiguity can arise), as in Hebrew. In Mason and Bernard's Grammar (Letter xviii., $\$ 4$,) several examples are given of this figure, but we shall content ourselves here with quoting two of the most remarkable of them. In Ps. cxxxvii. 5, the inspired bard, lamenting his captivity "by the rivers of Babylon," when summoned to sing "one of the songs of Zion" before the

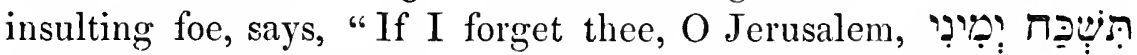
let my right-hand forget___." He does not say, what he bids it forget, but he cannot be misunderstood; he must of course mean the skill with which it was wont to sweep the strings of his harp.

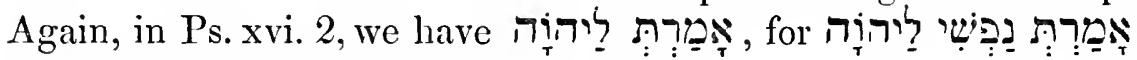
Thou, O my soul, hast said unto Jehovah . . . In like manner, in the verse before us, הis o God, or sis my God, or one of the other names attributed to the Deity, should be understood here, in the vocative case, after the word 7 i remember. This verse, and those that follow, to the end of the chapter, are so evidently addressed to God, that it was not thought necessary by the speaker to name Him. He says:

Remember, that my life is but a breath. That my life hangs but on a breath, that if my breath be interrupted only once, I am dead, and that, when dead, My cye shall not again see good. I can never be restored to happiness.

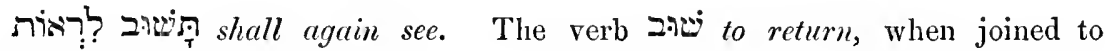
another verb, is used adverbially, in the sense of again; as 2 Kings i. 13,

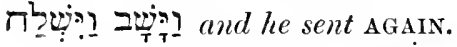

Ver. 8. The eye of him that seeth me, shall no longer see me; 
yea, Thine own eyes shall look for me, but $I$ shall be no more. Once I have left this life, I shall be completely annihilated.

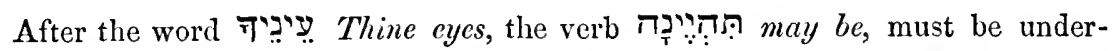
stood ; thine eyes may be upon me, in Hebrew, being equivalent to thine eyes may be directed towards, or may look for, me.

Ver. 9. As the cloud is consumed, and gone, so he that goeth down to the pit, shall not come up again.

Before the verb

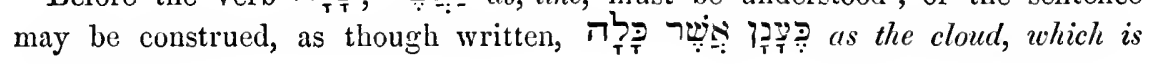
consumed.

Ver. 10. He shall not again return to his house, nor shall his place again discern him. .

The verb בכר, in Hiph., is sometimes used in the sense of disccrning, noticing,

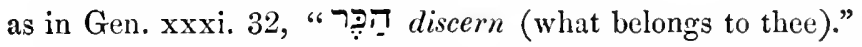

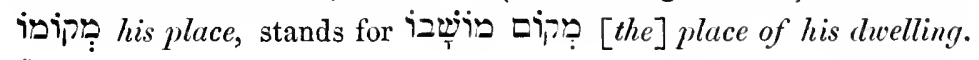

Ver. 11. This verse should be understood, as though it began

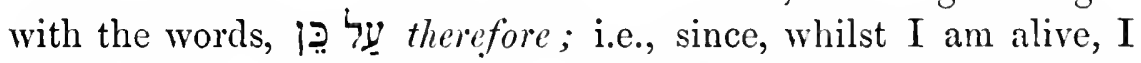
am to be tormented, and, when dead, to be completely annihilated, I have nothing to risk, and consequently,

I also will not restrain my mouth. I care not if I express myself in unmeasured terms, provided only I can give vent to my indignation. I will speak in the anguish of my spirit, I will complain in the bitterness of my soul.

Ver. 12. In the preceding chapters, few in number as they are, more than one verse has come before us, which we were surprised to find had proved embarrassing to the majority of the translators and commentators, as we had ourselves discovered no real difficulty therein. Now, however, we have come to one, which most of them have passed over in silence, and which Schultens, who does say something about it, seems to treat very lightly, apparently quite satisfied with his own explanation, whilst to ourselves it is not one of the most difficult verses, but the most difficult verse, in the whole of this book. Almost all the words it contains must be familiar 
to any one who has read Hebrew but a few months; its grammar is quite correct, and its construction very natural and easy; the difficulty is to penetrate its meaning. It is, no cloubt, intended as a simile, but how to apply the simile to the speaker-hic haret aqua. We shall, of course, offer our own views upon the subject, but the reader will do well to receive them with great caution, as we must confess they are anything but satisfactory to ourselves. We lay them before him only, as having nothing else to offer, and he should certainly himself strain every nerve to find out something better than we propose. The verse runs thus:

An I a sea, or a sea-monster, that Thou shouldest set a dam (guard) about me?

In Jeremiah we read (v. 22), "Fear ye not me? saith the Lord: will ye not tremble at my presence, which have placed the sand for the bound of the sea?" Now, as we are told by the historian (supra ii. 8) that Job was sitting surrounded by ashes; and by Job himself, in this chapter (ver. 5), that his body was covered with clods of dust, may not he possibly in his despair be justified in asking, What am I? What do I look like? Do I look like a human being, or am I not rather like a sea with its boundaries of sand, or like some sea-monster, which is confined in the sea, and is prevented from escaping from it by its sandy shores? We are so much dissatisfied with what we say, that we think it but right to quote what Schultens says, and give the reader the opportunity of deciding which is the worst:

"Mira comparatione atrocitatem malorum suorum, et plagas, quibus premebatur, inculcat, rogans, num mare esset? num bellua marina? ut necesse fuerit, furentem vim et sævitiam, obicibus et repagulis circumdatis, frangi atque coërceri. . . Negat elgo, se tantis terroribus, doloribus, pœnis, esse comprimendum, contundendum, includendum, quippe qui nec tam sæva ac importuna, nec tam valida ac robusta, sit natura, ut immanes illos ictus, vel meruerit, vel diutius sustinere queat."

We will also quote Herz Homburg's words, which certainly contain a more reasonable explanation than that which we have heard from Schultens : 
יעבור על גבוליו ועל וה אומר איוב היס אם תנין אזי שתשיס גבול לאמרי פי ולומר לי עד פה תבוא

"A bound, and a limit, has the Creator made for the sea, and He said to it, Thus far shalt thou come; and, in like manner, He also bade the sea-monster remain in the sea, and not pass orer its bounds; and, with regard to this, Job says, Am I a sea, or a sea-monster, that thou shouldest set a bound to the words of my mouth, and say to me, Thus far shalt thou come with thy words?"

Considering that, in the preceding verse, Job said, he would henceforth set no bounds to his words, Homburg's explanation deserves notice.

Vers. 13-16. When I say, MIy bed may comfort me, my couch may remove my grief. Whenever I am inclined to try, whether rest and sleep may not alleviate my sufferings. Then, Thou scarest me with dreams, and terrificst me by visions. His sleep is disturbed by frightful dreams and visions, as might be expected would be the case with one, afflicted with the dreadful disease he laboured under.

So that my soul would prefer strangling, death, inflicted by my own limbs. That is, by my own hands. The agony of lis pain is so great, that the idea of suicide flashes across his mind, but only to be immediately and indignantly repelled, for he says in the next verse, No, this I abhor-I shall not live for ever. However great my pain and misery are, they must, as I am mortal, come to an end at last, without any intervention on my part. Away, then, thou thought of suicide! Desist from me, for my days are but a breath.

Verse 13. The prefix $工$ in objective case. See note on iִ supra iv. 2.

Ver. 14. The prefix is in signifies by means of, as in Gen xlix. 12, פִיז: by means of wine,

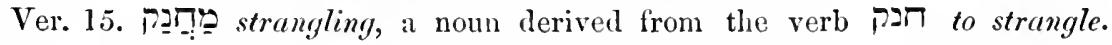
Thus, we read (2 Sum. xvii. 23) of Ahithophel that, being in despair at his counsel not being followed, "he put his household in order Fạ?"? lit., and was

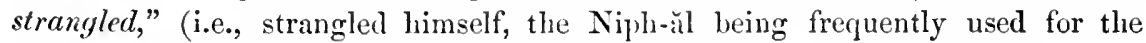
Hithpa-âl, as, in Gen. iii. 10, ארדำ

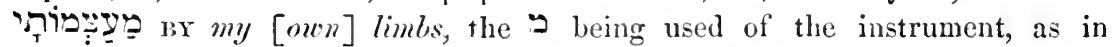

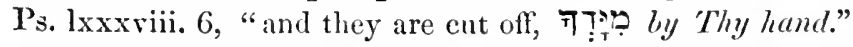

It will be perceived that ver. 16 is parenthetical, being direeted, not to God, but to the thought of suicide, which intrudes upon him. 
Ver. 16. הבקי: a breath. This is the original signification of the word; as, in Ps. lxii. 9, "to be laid in the balance they are altogether פִ̣ less than a breath" (i.e., they would affect the balance less even than a mere breath.) Hence, this word is used figuratively to denote anything light and vain.

Ver. 17. Having chased away the terrible idea of suicide, which had infested his mind, he now again addresses God, saying:

What is frail-man, that Thou shouldest exalt him? Or, that Thou shouldest set Thine heart upon him?

לִ to put, or set [one's] heart, is used to express, to care for a person, or thing. So in Prov. xxvii. 23, שִׁית set thine heart to (upon) [the] herds, i.e., pay attention to them, care for tliem.

Ver. 18. That Thou shouldest visit him every morning, that Thou shouldest try him every moment?

פר? with the def. art., is found in Lament. iii, 23.

Ver. 19. Thou dost not turn away from me for an instant, nor let me alone, till I swallow my spittle!

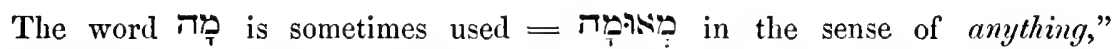
as in Prov. ix. 13, "and she doth not know here be taken to mean as anything, so that the passage, literally translated, would be, Thou dost not turn away from me as ANYTHung, i.e., for the least particle of time, an instant, a moment.

Ver. 20. If I have sinned, how can I affect Thee? How can the actions of so low, and contemptible a creature as frail man affect such an exalted and glorious Being as Thou art? But, supposing that I am of such a nature, that my actions can affect Thee, then I still more wonder, and ask: O! Thou preserver of man, why hast Thou made me to clash with Thee? Why hast Thou made me of such a nature, as to be able to come into collision with Thee? So that I should become a burden to myself. So that for having offended Thee, I should be visited with chastisements, or be tormented by my own conscience, till my life is become a burden to me.

Before 


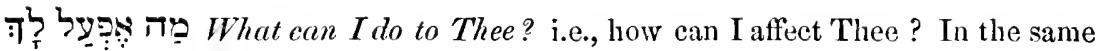

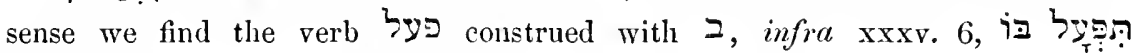
can'st thou produce an effect on Him?

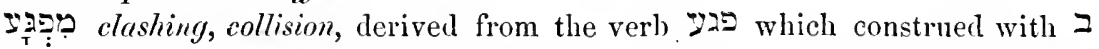

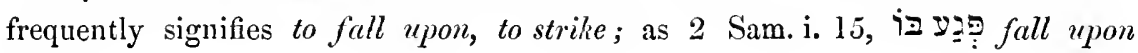
him.

Ver. 21. And why shouldest Thou not rather forgive my transgression, and remove my iniquity? 'That is, blot it out, as though it had never been. For presently, I shall lie down in the dust, and, though Thou shouldest diligently seck me, I shall be no more.

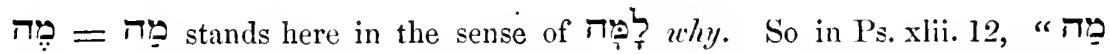
why art thou borved down, O my soul? הֶיר and why art thou moaning, \&c.?"

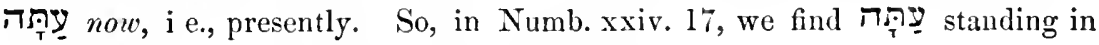
parallelism with =iר nigh, near (used of time).

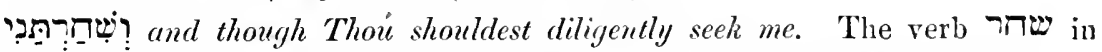
Pi-âl, strictly speaking, signifies, to seek early (from however, applied to all diligent search, whether in the morning, or at any other time of the day, or night. Thus, in Prov. vii. 1.5, we find to seek thy presence, though the artful woman, who utters these worls, is described as holding her conversation with the young man in the depth of night.

\section{CIIAP'TER VIII.}

If the reader will poruse this chapter, as it is in the Authorized Version, he will no cloubt see, that one part of it contradicts the other; that, in the simile introduced into it, the wicked man is first compared to a weak and fragile recd, loosely sticking in the mire, and immediately afterwards, to a fresh and thriving tree, deeply rooted, and standing near a stately house of stone. 'The same inconsistency will be perceived also in Rosenmüller and Schultens' translations. We are, we think, therefore, greatly indebted to Mendelssohn, who, by the definition he gives of the words, פִ̣ justice, and pִ̣ righteousness, as they occur in 
Eccles. iii. 16, has opened our eyes to the true reasoning in this seemingly contradictory chapter. His words are:

\section{הנה גמול הרע לעושי הרע יקרז משפט וגמול הטוב לעושי הטוב יקרז לדקי}

"Behold, the requital of evil to the doers of evil is called טִ̣ justice; and the requital of good to the doers of good is called rדָ righteousness.

Now, as these two words occur almost at the beginning of this discourse (Ver. 3), we at once perceived, that the chapter would turn upon two distinct topics, viz., the miserable end of the wicked, and the final triumph of the just; and, though the greatest part of it is clothed in allegorical language, yet the figures and similes employed are so striking, that a little common sense only is required to perceive, which are intended to refer to the good, and which to the wicked, man, without its being stated in distinct terms, for whom they are intended. It has already beell observed (see note on רi supra vii. 7), that, where no ambiguity can arise from their employment, ellipses are used in Hebrew with great elegance. A striking example of an ellipsis, of precisely the same nature as those which we shall have to notice in this chapter, occurs in Ps. xxxiv., where, vers. 15, 16, we read, "The eyes of Jehovah are upon the righteous, and His ears are open unto their cry. The anger of Jehovah is against them, that do evil, to cut off the remembrance of them from the earth;" and immediately afterwards (ver. 17), "THEY cry and Jehovah heareth," \&c. The Psalmist indeed does not tell us who they are that cry, and are heard of God, but would common sense allow us to doubt for a moment to whom he refers? The same conciseness, the same reliance upon common sense, we shall find in the chapter before us. We shall have the figure of a frail and short-lived reed, and that of a vigorous and lasting tree, and the hearer will be left to apply each of these figures to the right person; nor is there any fear whatever entertained by the speaker as to the possibility of his being misunderstood by his audience.

We next call the attention of the reader to the fact, that this discourse consists of two distinct parts; one, comprising the words of the speaker himself, the other, words uttered by men who lived in former generations, and quoted by the speaker for the instruction of Job. Again, the words thus quoted, must, in their turn, be 
divided into two parts, of which common sense will teach us to apply the one to the wicked, and the other to the good man. With these few remarks, we now proceed to comment on the chapter.

Ver. 2. How long wilt thou speak such-things, and the words of thy mouth be like a violent wind? How long wilt thou continue thus, as little able to restrain thy words, as thou wouldst be to restrain a violent wind?

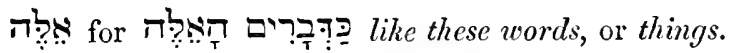

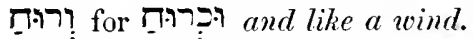

The adj. רַּ signifies, sometimes, much, plenty, as infra xxxi. 25 ; some-

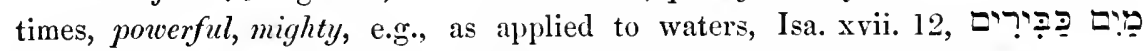

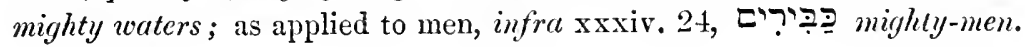

Ver. 3. Shall God pervert justice? Is it possible, that He should not punish the wicked? Or shall the Almighty pervert right? Is it possible, that He should not reward the good? (See the passage from Mendelssohn, quoted in the preliminary remarks on this chapter.)

Vers. 4-6. If thy sons sinned against Him, He despatched them by their transgression. If they simned, His attribute of justice required, that $\mathrm{He}$ should at once despatch them without giving them any respite, for so is He wont to deal with those who provoke Him greatly. (We may refer to the history of Pharaoh, Korah and his band, and others.) On the other hand, the very circumstance, that He hath not despatched thee, as He did thy sons, proveth that there is still great hope of thy conversion, and that He correcteth thee from love, just as a father doth the son he delighteth in. (Ver.5.) If thou wilt diligently seek unto. Pray unto. God, and make supplication to the Almighty. (Ver. 6.) If thou art pure and upright. If thou art not hardened in sin as thy sons were, but art capable of repentance, and conversion. Surely, He will presently awake for thee. He will not overlook, but will favourably notice thee. And make thy righteous dwelling prosperous.

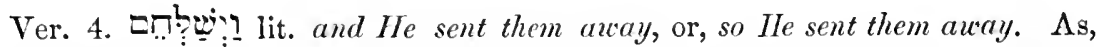
however, the English idiom would here hardly admit of a conjunction, we have translated as though the 7 , which is certainly used here for the purpose of eonvert- 
ing the future into the past, were, in itself, not conjunctive, but conductive, as is the ${ }^{*}$ in (Exod. xii. 19.) that soul shall be cut off.

Tำ lit. by hand of, very frequently stands merely for $b y$, as in 1 Sam.

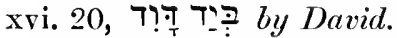

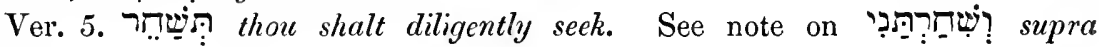
vii. 21.

Ver. 6. Tִיעיר He shall awake. When the wicked flourish, and the innocent suffer in this world, God is, in the poetical language of the Hebrews, said to be asleep; but when their conditions are reversed, He is said to have awaked from His sleep. So the Psalmist says, Ps. xliv. 24, when complaining of the sufferings

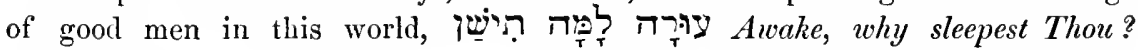
עיע is here used in Hiph., but intransitively, as in Ps. xxxv. 23, where

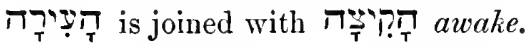

Ver. 7. In the Auth. Vers., this verse is rendered, "Though thy beginning was small," \&c.; but it is difficult to conceive, how the wealth, which, we are told by the historian, Job possessed, and which rendered him "greater than all the sons of the East," could possibly be considered small by the speaker of this discourse. We prefer, therefore, translating the verse thus :

So that even thy beginning shall comparatively be small, seeing that thy latter-end will be so exceeding great. Thy former wealth and prosperity, great as they were, shall be so small, in comparison with those, which thou shalt enjoy in the latter part of thy life, as to appear a mere trifle.

Ver. 8. For ask now the former generation, and prepare thyself for the searching of their fathers. Do not content thyself with consulting one generation, but, if thou really wishest to know how things go on in this world, inquire of several, yea, investigate ancient history as far back as it goes.

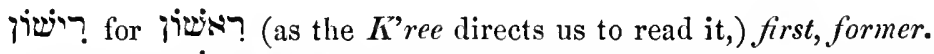

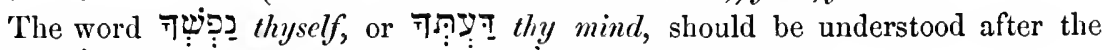

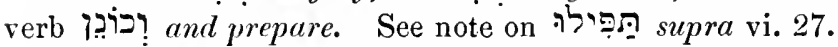

ס

* The Arabic

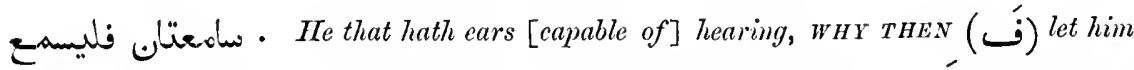
hear (Natt. xi. 15), where we obtain the best English by leaving the ${ }^{\prime}$ untranslated. Note of Editor, 1861. 
think it strange, that the plur. affix in 7i generation, since this is a collective noun. So, in Deut. xxxii. 20, THEy [are] a perverse generation.

Ver. 9. This verse should be considered as parenthetical, the object of it being only to assign a reason for referring Job to ancient history, and this the speaker says, is: Because we are but of yesterday, and know nothing; because our days upon earth are a mere shadow. 'The duration of our life upon earth is so short, that it would be in the highest degree presumptuous in us, without consulting ancient history, to pretend to know how matters go on in this world.

a shadow. We might perhaps have expected to find the $\supset$ of comparison has been purposely dropped, to give more force to the simile, the speaker wishing to express, that the days of man are not merely like a shadow, but actually are a shadow. A similar omission of the $\supset$ of comparison, with the same intention, occurs in Cant. v. 14, where we read: his hands [are] rolls of gold, on which Bril and Wolfssolnn very judiciously comment as follows:

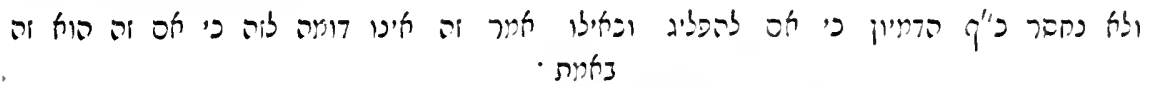

"And the $\supset$ of comparison is only omitted, to render [the simile] more striking; as though he said, This is not [merely] like the other, but this really is the other."

Ver. 10. Will not they. The former generation, and their fathers. Instruct thee, tell thee, and from their heart utter words such as these?

חיל though strictly a negatively interrogative particle, is sometimes used to assert emplatically a positive fact; as in Ruth ii. 9, where Boaz says to Ruth,

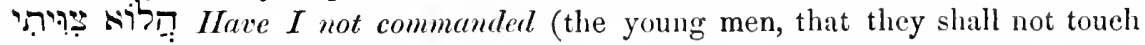
thee?) i.e., I have INDEED commanded, \&c. And so it is in this instance; the meaning being, "they will indEED instruct thee."

"ריר: And from their heart; i.e., sincerely; not merely to amuse thee with figures and similes, will they say the following words, but to tell thee what they really feel in their hearts.

FIRST SIMILE.

Vers. 11, 12. Can the rush shoot up without mire? Can the flag grow without water? Consequently we can predict of any 
place in which we see rushes and flags growing, that it must so abound with water and mire as to render all fears, entertained for these plants on the score of the absence of rain, utterly groundless. (Ver. 12.) Whilst it is still in its greenness, and not cut off, yet before all grass will it wither. In spite of its being provided with such a superfluity of nourishment, in spite of its looking so fresh and flourishing, it is the weakest of all herbs, it dries and withers up before them all.

So Ralbag comments on this latter verse:

עודנו בלחותו ורעננתו לא היה ראוי שיקטף ויכרת ועם כל וה "בש בקלות קודם כל סליר.

"While it is still in its freshness, and its greenness, so that, by right, it ought not to be destroyed and cut off, yet, notwithstanding all this, it easily withers before all grass."

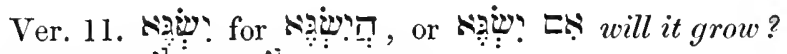

Ver. 12. אל for

\section{APPLICATION OF THIS SIMILE BY THE MEN OF THE FORMER GENERATION THEMSELVES.}

Vers. 13-15. So are the paths of all that are forgetful of God; yea, the hope of the hypocrite shall perish. The career of those forgetful of God, however splendid, and brilliant it may seem, will be as little lasting as the freshness and greenness of the reed. (Ver. 14.) Whom his own confidence shall cut off. His confidence in his wealth will be his ruin, inasmuch as it makes him arrogant and presumptuous enough to rebel against God. Seeing that his trust. That upon which he trusts. Is a spider's web. His wealth can no more support him, than could a spider's web, if he were to lean upon it. (Ver. 15.) He may lean upon his house, but it will not stand; he may take fast hold of it, but it will not endure.

Vers. 14. טip' will cut off. We have the authority of Kimchi and Jarchi for taking the verb קוּר thus transitively.

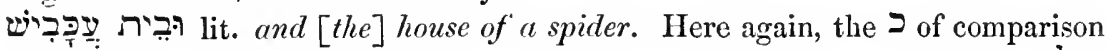
is intentionally omitted, to give more force to the simile. See note on ver. 9.

Ver. 15. in 근 his house, by which, of course, is understood all it contains, as wealth, slaves, and other things which he looked upon as permanently his.

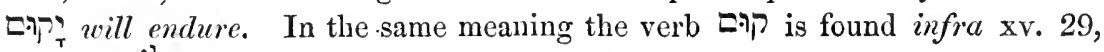

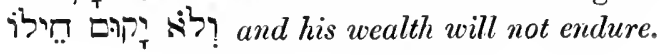




\section{SECOND SIMILE.}

Vers. 16, 17. The reader will recollect that, at the very opening of this discourse, the Speaker proposed to himself to establish two points ; viz., that God cannot pervert Pִ justice (i.e., that He cannot suffer the wicked man to remain unpunished), and that the Almighty cannot pervert Pִִ right (i.e., that $\mathrm{He}$ cannot suffer the good man to remain unrewarded). Having established the first of these two points by a simile (supposed to be uttered by the former generation), in which the fate of the wicked man was compared to that of a reed, he now endeavours to establish the second, by a second simile, which he also puts into the mouth of the former generation, and in which the good man is spoken of under the figure of a healthy, thriving tree. This is not the only instance in the Bible, in which a person is spoken of under the figure of a tree. In' Ezek. xxxi., the Assyrian is described (vers. 3-9), as a cedar of Lebanon, and with much more detail than we meet with in this second simile, which runs thus:-

$H e$ (the pious man regarded as a tree) is full-of-sap), even before the sun, so that his sucker mojecteth over his garden. He is so healthy and vigorous, that, far from being dried up by the burning heat of the sun, he is always full of sap, and spreads his branches widely over the garden, protecting other trees with his shade, instead of being shaded by them; and the reason he is so healthy and vigorous is that (Ver. 17.) His roots are entwined beside a spring, and therefore he can overlook a house of stone. Owing to this hidden source of nourishment, he is enabled to overtop even a stately house of stone.

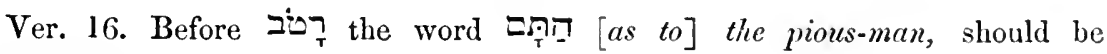
understood.

בטָ lit. moist, fresh, from the verb =טר to be wet, which occurs infra xxiv. 8.

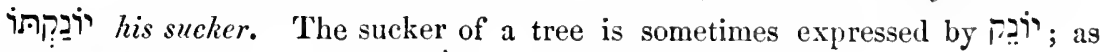
Isa. liii. 2, and sometimes by $\mathrm{n}$.

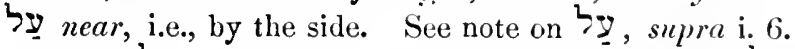

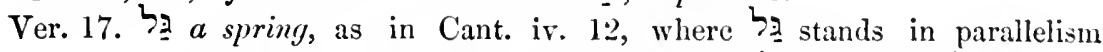
with (Josh. xv. 19), and in many other places.

Vers. 18, 19. The speaker continuing the simile (quoted by 
him), now goes on to say, that, though the pious man may sometimes meet with misfortunes, and be obliged to change his place of residence, yet the eye of God will be upon him, wherever lhe may be, to bless him, and make him prosperous, so that he will only have pronited by the change, like a vigorous tree, which only thrives the better for being transplanted. His words are as follows:

If one should pluck him up from his place, so that it should deny him, saying, I have not seen thee. (Ver. 19.) Lo! this is his joyful journey. Is a joyful journey to him. Seeing that he will grow up out of another ground. Though he should be uprooted so completely, that the ground in which he stood should become as entirely a stranger to him, as though it had never nourished him in its bosom, this would only be a pleasant journey for him, seeing that he would thrive again in whatever place he might be transplanted to.

Ver. 18. After the words iפ שִ̣? so that it should deny him, the word ibs saying, must be understood.

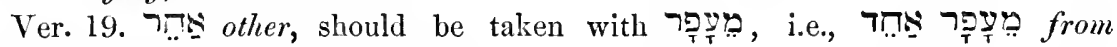
another ground. Rosenmüller would join it to iș for not at all to the point. Thus, amongst others he refers to they were ashumed, because he (i.e., every one of them) trusted, but there the sing. verb stands after the plur. one, implying that every one of them was ashamed, as observed in our note on that passage; whilst here the word רחָ stands before the verb, so that the case is altogether different.

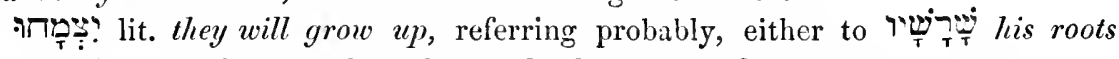
in ver. 17 , or to the stem, branclies, and other parts, of the tree.

\section{APPLICATION OF THE SECOND SIMILE BY FHE SPEAKER.}

Vers. 20-22. Having, in the first simile, quoted by him, pointed out the fate of the wicked, and in the second, that of the pious, man, Bildad now triumphantly exclaims:

Behold then God will not reject the pious-man, nor will He take hold of the hand of evil-doers. (Ver. 21.) He will yet fill thy mouth with langluter, and thy lips with shout $[s]$-of-joy. If thou wilt submit to Him, and acknowledge the justice of His correction, thou shalt be restored to thy former happiness. (Ver. 22.) They that hate thee shall put on. Shall be covered with. Shame, and the habitation of the wicked shall be no more. 
Ver. 21. עַ עִ yet, as supra i. 18, on which see note.

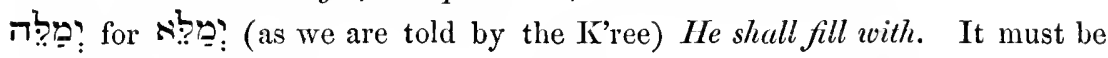
supplied before

Ver. 22. Twive thine enemies, meaning depraved and impious men, since such

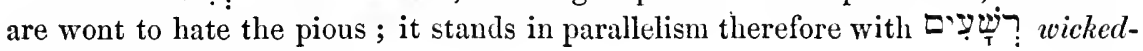
men, in the next hemistich.

In concluding our comments upon this chapter, we would, with deference, ask of those, who do not divide the simile, introduced into it, into two parts, and who, consequently, make the whole refer to the wicked man-we would ask of them, we say, whether it is likely that those wise men, who are supposed to bring forward this simile for the instruction of Job, would confine themselves to the description of the fate which awaits the impious man, and not say one word respecting the way in which the good man fares in this world? And, again, we should like to know how the speaker could exultingly exclaim, as he does, "Behold, then, God will not reject $\mathrm{IT}_{\mathrm{T}}$ a pious-man," if he had never once mentioned him, but had left us in entire ignorance respecting his fate?

\section{CHAP'TER 1X.}

Vers. 2-4. The friend, who spoke last, had said to Job (supra viii. 6), "If thou art pure and upright, surely He will presently awake for thee," \&c., and, in reference to these words of consolation, Job says:

Of a truth, I know that it is so. I know that, if I could but have an opportunity of proving my innocence, God would again extend His mercy to me. But how can fiail-man be just with God? How can he prove his innocence, if he never be allowed to plead before God? (Ver. 3.) If he (man) should desire to contend (argue) with IIim, He would not answer him one of a thousand questions. (Ver. 4.) He is wise in heart, anl mighty in strength; consequently, Ile cannot be summoned before any tribunal to give 
an answer; and, moreover, one addressing Him must be very guarded in his language, for Who hath ever spoken fiercely to Him, and been left at peace?

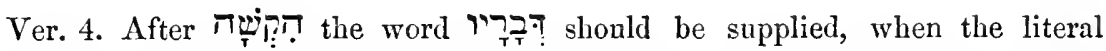
meaning would be, has made hard his words, i.e., has spoken harshly, or fiercely, to Him. So we read in 2 Sam. xix. 44 ; (lit. word) of [the] men (lit., man) of Judah were fierce, \&c.

ธלุ:

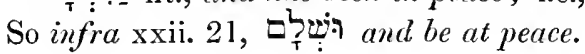

Vers. 5-13. Job having, in the preceding verse, alluded to the wisdom and power of God, seizes this opportunity to enlarge upon His omnipotence, and ubiquity, probably with the intention of throwing out a hint to his friends, that he has no need of any instruction from them upon these subjects. As the reasoning of these verses is clear enough, we shall content ourselves with briefly noticing the words, or passages, which require comment.

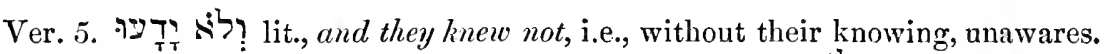
Comp. Ps. xxxv. 8, "Let destruction come upon him, עד.. אי lit., and let him not know" (i.e., unawares).

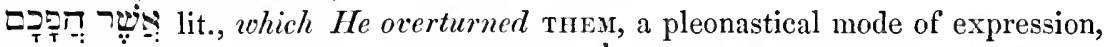

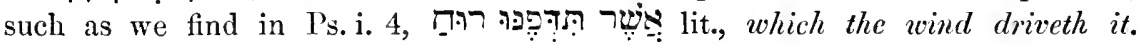
Pleonasms of this sort are of such frequent occurrence in Hebrew, that we should not have thought it wortl while to make any remark upon this passage, had not the reader been told by Rosenmiiller to consider for which there is not the least occasion.

Ver. 6. Tำ So that the pillars thereof. Here the poet has given pillars to the earth; infra xxvi. 11, we shall find him giving them also to the heavens, [the] pillars of heaven.

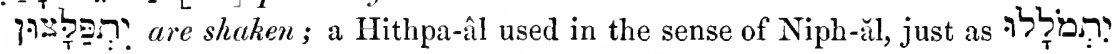

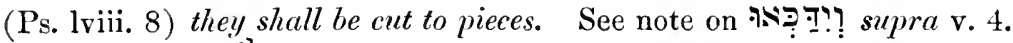

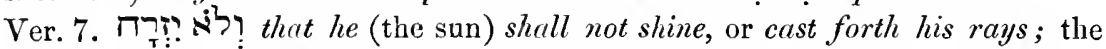
allusion being, of course, to an eclipse of the sun. The verb $\boldsymbol{T}^{-} \mathbf{i}$, though commonly used of the rising of the sun, is also sometimes found in the acceptation of

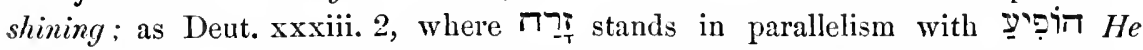
shone forth. Indeed, one of the twins brought forth by Tamar was called $\pi_{-T}^{\text {T }}$ (Gen. xxxviii. 30) on account of the shining colour of the scarlet thread, which the midwife bound upon his hand, when he put it forth before his brother came out. So Jarchi on the passage observes, that he was called so,

$$
\text { ע"ש זריקת מרזית השני • משים }
$$

"On account of the shining appearance of the scarlet." 
Mendelssohn likewise, in his * Commentary, says :

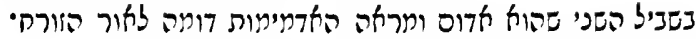

"On account of the scarlet, which is red, and the appearance of the redness is similar to [that of] a sHining light."

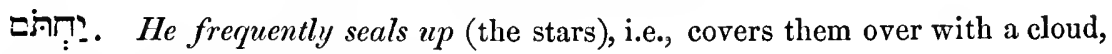
so that their light cannot be seen.

ذ [He is] stretching out. Some want to translate, $[H e$ is $]$ bowing down; but, as in Isa. xliv. 24, we find

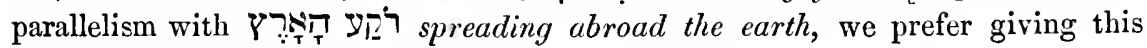
verb the same signification here.

Ver. 8. לִ לבֵּר by Himself; i.e., He needs no assistance from any one. So in

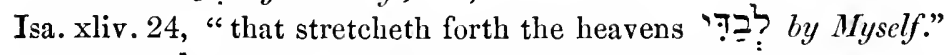

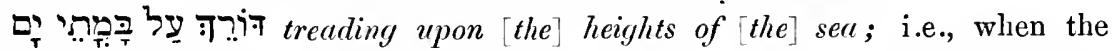
billows of the sea tower up proudly, He humbles them, treads them down under His feet, and levels them. So the Psalmist (Ps. lxxxix. 10), "Thou rulest the pride of the sea ; when the waves thereof arise, Thou stillest them."

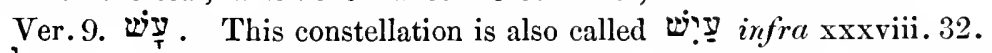

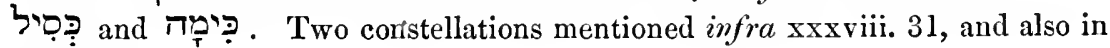
Amos v. 8.

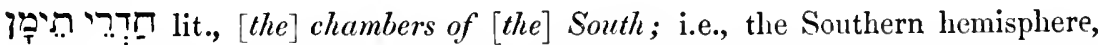
the stars in the remote parts of which, not being visible to the inhabitants of the Northern, are regarded by the poet as locked up in hidden chambers. So Aben-Ezra :-

\section{בעבור היות הישוב בפאת שמאל ולא יראו אותן הפוכביכ על כן קראם קדרי כאלו הם במקו' ינחביא}

"Seeing that the population [to which Job belonged,] was quarterch on the left side [of the globe, i.e., the North, so that those stars [which are in the South] were not visible [to them]; therefore he calls them 'chambers-of,' as though they were in a hidden place."

Ver. 11. Here the poet dwells upon the Omnipresence and Invisibility of the Deity, who is always near us, and around us, without our eyes of flesh being able to perceive Him.

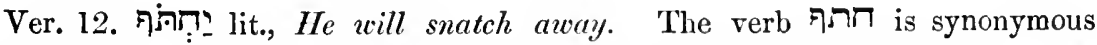
with

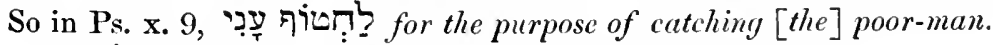

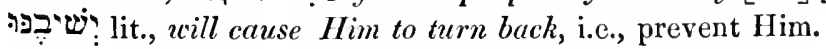

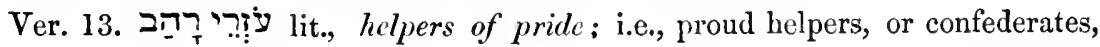

* The באור, or Commentary on the Book of Genesis, was not written by Mendelssohn himself (though he did write the German translation), but by Solomon Dubnau under his superintendence. 
who hasten to the assistance of the wicked tyrant, on whom God is about to inflict punishment.

Vers. 14, 15. In order to see the force of the words less, with which Ver. 14 begins, the reader should take the inter-

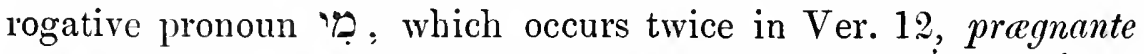

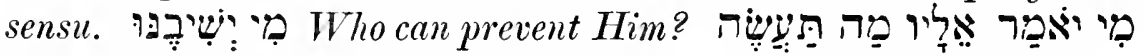
Who can say to Him, What doest Thou? Who is the being, that can prevent Him, can say to Him, \&c.? Is it man, however powerful or distinguished in rank? Is it an angel, however pure? Is it an archangel, however bright? אֵַ Much Less, shall $I$ speak to Him, shall I choose out my words to reason with Him! Shall I be able to compose a speech, suitable to His greatness and majesty! I (Ver. 15.) Who, though I am just, must not utter it, but must make supplication to my Judge. Though I am just, I must not proclaim myself just before Him, I must not bring forward arguments to justify myself and vindicate my innocency, as I ought to be allowed to do, but I must present myself as a suppliant before my Judge, yea, I must even cry for mercy to Him. Is this just? Is this reasonable? Ought one, who can prove his innocence, to have to cry for mercy?

Schultens concludes his comment on Ver. 15 with these words : "Hoc dicit Noster, Tantum apud me Dei Numen, ut, si, descendens de supremo Majestatis solio, mecum disceptare haud refugeret, atque in jus ire, ultro potius supplex ei accederem, quam, vel perfecte justus, cum ipso contenderem. Opponit hunc interiorem animi sui sensum injustis criminationibus Amicorum, quasi contumax et prefractus in Deum insurgeret."

Now surely, if Schultens understood Job in this verse to say, that he would prefer making supplication to God to reasoning, and arguing, with Him, he must have been greatly surprised at hearing him in the following discourses, over and over again, contradict his own words. Indeed, in this very chapter, ver. 17, Job says of God, "Who crusheth me with a storm, and hath multiplied my wounds without a cause;" and, in vers. 33-35, "There is not between us an umpire, who should exercise his authority over both of us. Let Him remove His rod from me, and let His terror not affright me: then would I speak and not fear 
Him," \&c. Is this the language of one who would prefer making supplication to God, to reasoning with Him? Again, infira xiii. 3, he says, "But I should like to speak to the Almighty, and I desire to argue with God;" and we could quote numerous other passages, which would prove Job, if he is to be understood, as Schultens understands him, to be altogether inconsistent, and at variance with himself. But the truth is, that, in spite of the entreaties of his friends, he absolutely refuses to make supplication, where he thinks he has a right to justify himself, and prove his innocence. This is his character, and in this he is consistent with himself from beginning to end. Infra xxvii. 6, he says, in plain language; "I have taken hold of my righteousness, and I will not let it go: my heart cannot reproach any one of my days;" and, in his very last discourse (infia xxxi. 35,) in which he has, as it were, put in a summary of his life as his written defence, he says: "Oh that I had one hearing me! behold! this is my writing, let the Almighty answer me, or [let] the book [answer me, which] my adversary hath written." Such is the language of Job, which our commentator must have altogether overlooked, when he commented on this verse.

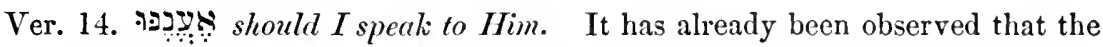
verb עפה is not always used in the sense of answering, but, sometimes also, in that of speaking, delivering a discourse. See note on 1 :'? supra iii. 2.

עִ for for rason with Him.

Ver. 15. '?ִ lit., to one judging me, i.e., to my judge. The legitimate form of the word, since it is the pres. part. Kal with the pron. affix $\because$ would be

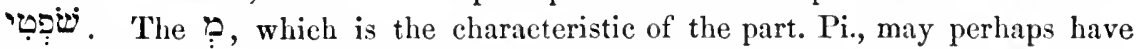
been prefixed to the part. Kal, with a view to intensify its signification, so that

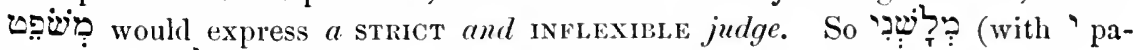

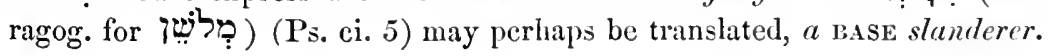

Vers. 16, 17. We did not conceal from the reader the great difficulty we had in making anything of chap. vii. 12, and we confess that, at one time, the first of the two verses now before us seemed entitled to rank next to that verse in point of difficulty; this difficulty having, however, yielded to more mature consideration, we expect we shall be able, in this instance, to offer a more satisfactory explanation, than we were able to do, in the case of the verse above alluded to. Regular as its grammar, and easy as its 
construction is, the present verse seems nevertheless, at the first glance, to be very paradoxical: for how can a man call upon any one, and receive an answer from him, and yet not believe, that his voice was heard by him, who gave the answer? This difficulty all the translators and commentators must no doubt have felt, but they either say nothing about it, contenting themselves with a mere verbal translation, or, if they do say anything, say that which it is almost to be wished they had left unsaid. We think, however, that we shall be able to dissipate the mist, which lies heavy upon the verse, if the reader will but allow us to preface our comment with a simile, plain indeed, and devoid of ornament, but calculated, we think, thoroughly to elucidate the passage in question.

Suppose that a man, on being convicted of a crime, were sentenced to receive corporal purishment, the judge not specifying the number of lashes to be inflicted, but leaving it to the discretion of the officer appointed to see the punishment carried into effect; the criminal, during its infliction, would naturally cry out, implore mercy, and, may be, also promise to reform; were then the officer at last to call out to stop the punishment, the culprit might reasonably conclude he had been moved by his cries, and promises of amendment. But suppose, on the other hand, that a savage Bashaw, without the least shadow of a cause, or reason, had ordered some immocent man, passing before his palace, to be dragged in, and receive the bastinado, the poor fellow, during the agony of its infliction, would, of course, also cry out, and implore mercy; but, when at last the tyrant commanded to release him, could he, after having been, though innocent, so dreadfully tormented, for an instant suppose, that his cries or supplications had at all availed him? Of course not. He would say to himself, I do not know why the tyrant ordered me to be tormented, nor do I know why he commanded my release. I must consider the one, as well as the other, as an unaccountable whim and caprice. Now, this is precisely what the innocent sufferer, who is now speaking, says in these two verses. His friends had advised him to pray to God, instead of indulging in complaints and murmurs, and to this he says: Even, if I had called upon Him. In prayer, as advised by you. And He had heard me. 
Had granted what I prayed for, and had ceased to afflict me, yet could I not believe, that He had given-ear-to my voice. I could not take upon me to say, that it was my prayer which had availed me. If, indeed, I had felt myself really guilty, I should have had reason to suppose, that He punished me for my guilt, and was at last moved by my prayers and supplications; but, innocent, as I feel myself to be, how conld I for a moment imagine, that $\mathrm{He}$ had removed my affliction, because I made supplication to Him ? (Ver. 17.) Who crusheth me as it were with a storm, and multiplieth my wounds without cause. Had there been any cause for the punishment, I might perhaps, if this were remitted, endeavour to account for its remission; but, as it was inflicted without cause, how could I attempt to explain its cessation? Its discontinuance, therefore, as well as its original infliction, would always appear to me equally unaccountable.

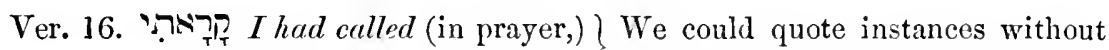

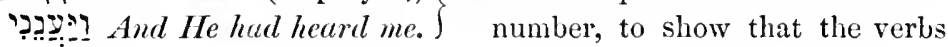
ערוה when applied to God, mean, respectively, to pray, and to hear, or hearken to, a prayer. We shall, however, limit ourselves to quoting, from Ps.

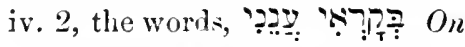
my calling, hear me; i.e., when I make my supplications unto Thee, vouchsafe Thou to grant them.

Ver. 17.

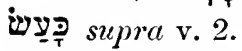

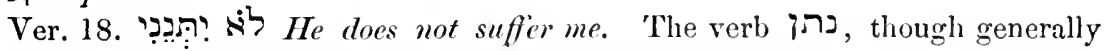
signifying, to give, is also frequently used in the sense of to allow, suffer; as in

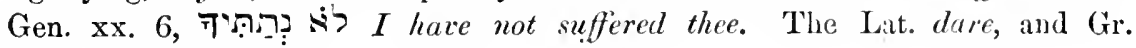
$\delta \iota^{\prime} \omega \mu \iota$ are similarly used.

Ver. 19. The first hemistich should be construed thus:

$$
\begin{gathered}
\text { If for strength-belold! IIe is } \\
\text { powerful (i.e., if I speak of } \\
\text { strength, how can I think of } \\
\text { contending with Him, who is so } \\
\text { powerful?) }
\end{gathered}
$$




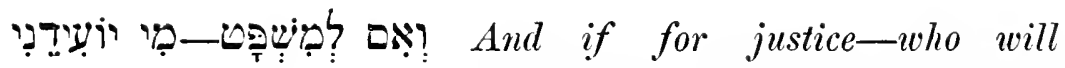
appoint me a time? (i.e., and, if I speak of justice, who will appoint me a time, when I can meet Him, to plead my cause ?)

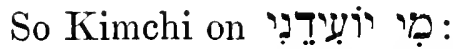

\section{מי יממינני למשפט עם השם יתברך יוריני}

"Who will appoint me a time to [plead my] cause with God, blessed be He."

Vers. 20-22. If the reader wishes to convince himself of the perplexity, into which these verses have thrown the commentators, he need only refer to Rosenmüller, who, whilst quoting others, betrays his own embarrassment. To us, they appear to be not only among the most beautiful, logical, and philosophical, but also among the most easily intelligible, of the whole book. Before commenting on them, however, we beg to recall $*$ the attention of the reader to two points. The first, of which, no doubt, he is as well aware as we are, is, that the noun 2 soul, or person, on taking possessive affixes, is frequently used for the reflective pronoun, self, as e.g., infra xxxii. 2, "Against Job was his wrath

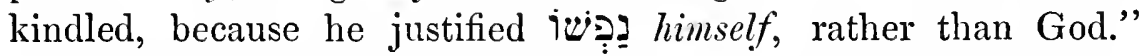
The second point is, that we are sometimes unavoidably compelled, in the Old Testament, to transpose the words of a sentence, in order to make sense ; as e.g., infra xvi. 17, עַל for for because of ([any] injustice in mine hands). We will now proceed to construe, and translate, these verses, confidently appealing to the judgment of the reader, as to whether, or not, we are right in saying, there is no difficulty whatever in them.

Ver. 20.

\section{אִ If I should justify myself (i.e., if I should plead my inno- cence, and prove my up- rightness),}

My own mouth would condemn me (i.e., How can I plead with God? If I say I am just these very words of mine will be regarded by Him as a sin, and will consequently

\footnotetext{
* See note on supra vi. 27, and on Chap. iv. 6.
} 
Ver. 21.

condemn me, seeing that no man is allowed to look upon himself as just before God);

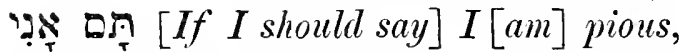
רִיע: stance of my saying so) would make me perverse (i.e., would be the cause of my being considered by God perverse).

Ver. 22.

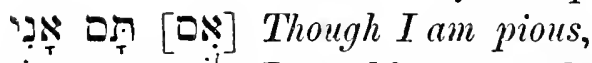
I I myself must not know [it] (i.e., I myself must not venture to betray my being aware that I am pious);

חָרִ I I Iespise [then] my life (for what life can there be more burdensome than that of a being who strives and endeavours to be just and pious, and yet, not only must not say that he is so, but must not even be conscious of his being so ?)

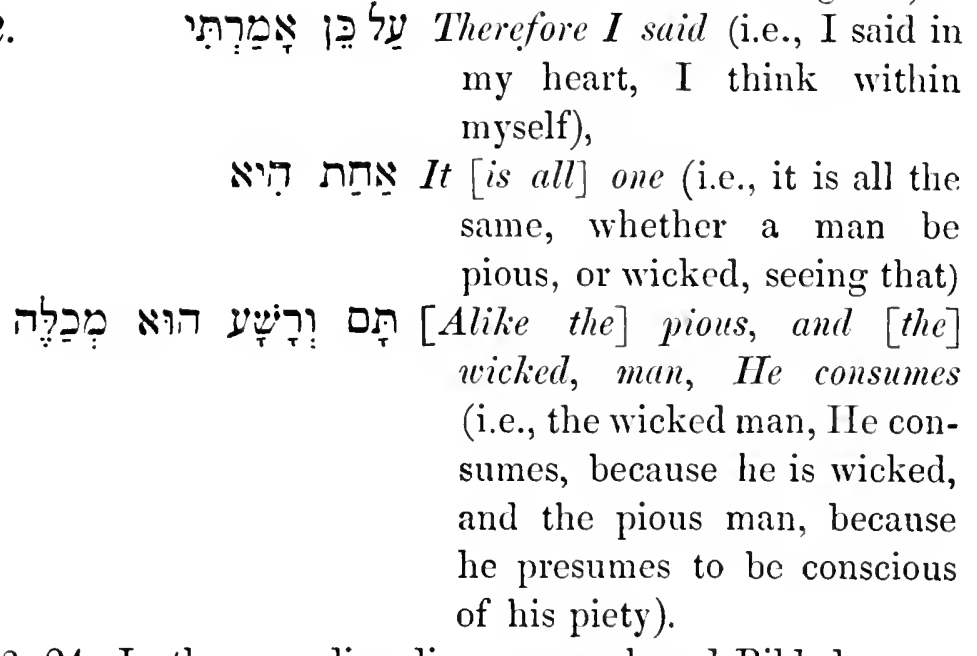

Vers. 23, 24. In the preceding discourse we heard Bildad represent the wicked tyrant under the figure of a frail and short-lived reed; to this Job now refers, and says : 
If the scourge slay (the wicked man, עיָָ Verse) suddenly, he (the wicked man) may laugh at the trial of the innocent. The sudden death of the wicked man may, in comparison with the ordeal which the innocent one has to pass through in this world, be considered as a real blessing,* seeing that (Ver. 24) The earth is given into the hand of the wicked-man. He is absolute master of his actions; nobody dares call him to account, because He veileth the face of the judges thereof. With his bribes he veils, as it were, their faces, so that they connive at, and do not appear to see, the tyrannical actions he commits. If not so-if it is not the wicked man who rules in this world, who, pray, is he? who else, I should like to know, has rule in this world, and may do as he likes? Consequently, if the wicked man, after a most prosperous and flourishing career, be at last removed from the world by a sudden blow, without the least pain, he may surely laugh at the innocent man, whose life is a continual trial, and who, perhaps, in addition, does not quit the world until after a painful and protracted illness.

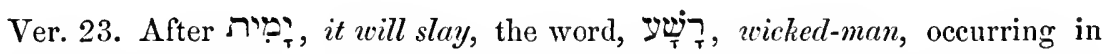
the next verse, must be understood. That two verses sometimes stand in such close connexion, that a word must be supplied from the second to the first, has already been observed in our note on $\overline{7} \underset{T}{T}$, supra vi. 29.

Ver. 24. iฐs, i.q., sițș, now, stands here as a mere expletive, pray; so the particle, $N_{\tau}$, now, is very frequently used as a particle of entreaty.

Vers. 25, 26. Whereas, my (happy) days were swifter than a runner; they have fled, as though they had not seen prosperity. 'They passed away with such rapidity, that all the happiness I enjoyed in them seems to me but a dream. (Ver. 26.) They have gone by like Joppa's ships; like an eagle which pounceth upon its prey.

Ver. 26. עִ is used here in the sense of like, as Ps. cvi. 6, "We have sinned, Еу, like our fathers."

* So Pope, in his Essay on Man, Ep. III., 1. 67, 68 :-

Which sees no more the stroke, or feels the pain,

Than favour'd Man, by touch ethereal slain;

on which he has the following note:-

Several of the ancients, and many of the Orientals since, esteemed those who were struck by lightning as sacred persons, and the particular favourites of heaven. 
S. If the reader were to consult Rosenmiiller on this word, he would find such a bill of fare as would inspire him with serious fears for his mental digestion. Having been wont ourselves to look upon this word as a proper name, we were of course gratified to find Jarchi concurring with us, though, instead of taking it to be the name of a river, as he does, we would rather regard it as some sea-port famed for its shipping. Such a sea-port we find mentioned in Jonah i. 3, viz., is, Joppa, and for this we venture to suggest not one letter in the one which there is in the other,* but when we remember

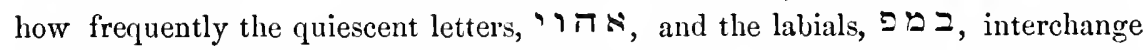
amongst themselves, and also, moreorer, take into consideration that many ages may have intervened between the period at which the book of Job was written, and the time of Jonah, by whom alone of all the Old Testament writers Joppa is mentioned, our conjecture will perhaps not be regarded as unreasonable. We are, however, very indifferent about our view being adopted, provided only it be admitted that the word in question is the name of a place, and that such it is we think the reader will be very glad to admit, when even only up to the ankles in his endeavours to wade through the miry explanations heaped up by Rosenmüller.

Vers. 27, 28. If my saying is. When I say. I will forget my grief, I will lay aside my indignation, and cheer up. (Ver. 28.) Then I dread all my pangs. I cannot close my eyes to the fact that I shall always continue to be a sufferer, because $I$ know that thou wilt not hold me innocent.

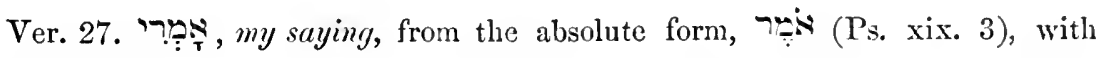
possess. affix.

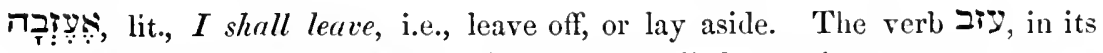
common acceptation of to leave, or forsake, is applied sometimes to persons, as Gen. ii 24, "Therefore, wיז: - shall a man leave his father, and his mother,

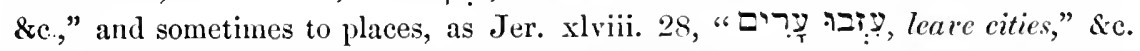
It is, however, also used to cxpress the abandoning of one disposition of the mind

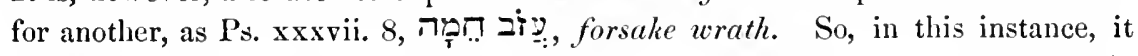
stands in the sense of ceasing (to be indignant). In Exod. xxiii. 5, the verb is used to denote the unloading of a beast, viz., by cutting or loosening the cords with which the burden is fastened to it, whereby the burden would be, as it were, left to its fate, and fall to the ground. We might then, even in the verse before us, fairly translate ${ }_{\text {T: }}$ :

\section{Vers. 29-31. I know that I shall be considered wicked. The}

* This will be found to be the only instance in which we have even suggested an interchange of letters in a word; and here we should most certainly have abstained from meddling with the word as we do, if we had not been convinced of its being a proper name. 
very fact of my proving my innocence would be considered a sin. (See above, vers. 20-22.) Why should I labour in vain? Why should I at all attempt to prove my innocence? (Ver. 30.) If even I had washed myself with snow-water, and cleansed my hands with lye. If I had proved my innocence ever so clearly. (Ver. 31.) Even then Thou wouldest plunge me into a muddy ditch, so that my garments would make me an object of abhorrence. My presuming to consider myself innocent would be regarded as a crime of the blackest dye.

Ver. 29. Before from the preceding verse, must be supplied.

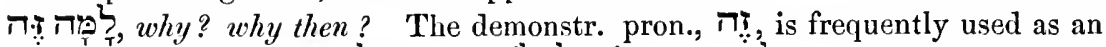

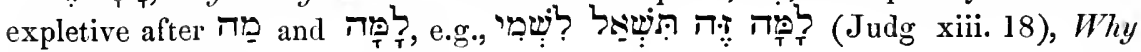
shouldest thou ask for my name?

Ver. 30. רבְּ with lye or soap, as the Chaldee version has it, In the Rabbinical dialect $ת$ רeans soap.

Ver. 31. . to this word here, but it should be taken as synonymous with שִח a hole, pit, or ditch, which occurs in Jer. xviii. 20, 22.

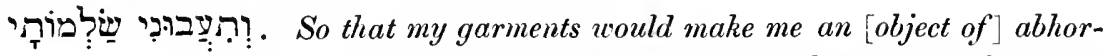
rence; i.e., my garments would become so dirty, that people would look at me with disgust. In this sense, viz., making to be held in abhorrence, must the verb

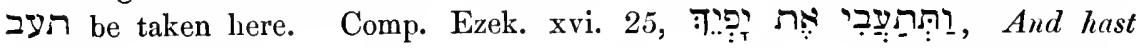
made thy beauty to be abhorred. The Auth. Vers., and all the other translations we have consulted render the passage, "And mine own clothes shall abhor me," in which we can see no sense.

Vers. 32, 33. For He is not a man like me, that I should say to Him, Let us enter together into judgment. (Ver. 33.) There is no umpire between us who should put his hand on, that is, exercise his power over, both of us.

Ver. 32. After הרֶּ i.e., "not a man like me is He."

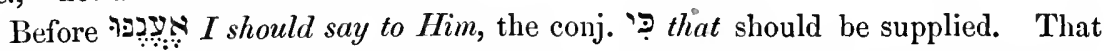
the verb ענה is frequently used in the sense of speaking has been already noticed more than once. (See note on Yֵַ supra iii. 2.) Instead of is to Him, the

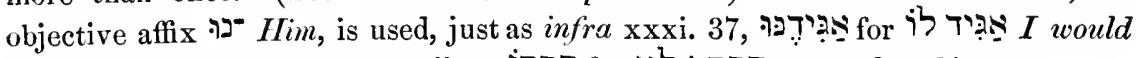

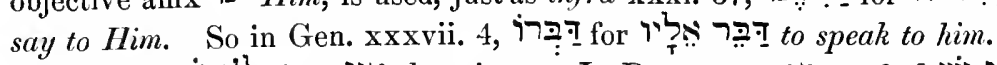

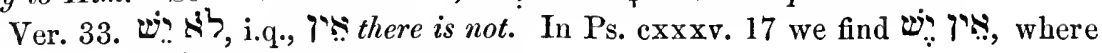
of course the is altogether pleonastic.

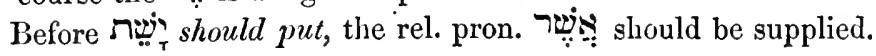


Vers. 34, 35. Let Him (God) remove from me His rod, and let His terror not affright me. (Ver. 35.) Then will I speak out, and not fear Him; for am I not upright with myself? Am I not conscious of my innocence? If, therefore, He were to remove His torments from me, what cause should I have for fear? what motive for bridling my tongue?

Ver. 35. Before

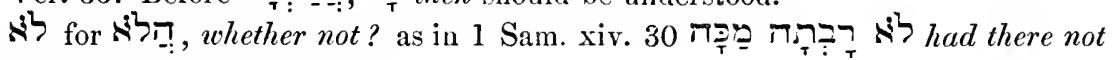
been a greater slaughter? \&c.

1ִּ right, upright, as Gen. xlii. 11,

Though we consider this explanation to be the correct one, yet we will not leave unnoticed the view Aben-Ezra takes of the second hemistich of this verse. His words are :-

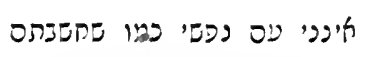

"I am not within myself as you think" (i.e., you, my friends, think that I am guilty, but I am conscious of my innocence).

\section{CHAPTER X.}

Vers. 1-3. In the preceding chapter, Job had said (Vers. $34,35)$ that, if God would but remove His wrath from him, he would fearlessly speak out his mind; now, he goes further still, and says, that, even while still labouring under his aftlictions, he will give free course to his words, seeing that, if the worst comes to the worst, he can only lose a life, which has become a burden to him. He says :

My soul is disgusted with my life; I will disburden my grief which is upon me. My life is become a burden to me; therefore, at whatever risk, I will alleviate my grief, by giving vent to it. I will speak in the bitterness of my soul. (Ver. 2.) I will say to God, Condemn me not; shew me, wherefore Thou contendest with me. (Ver. 3.) Is it seemly for Thee, that Thou shouldest oppress, that Thou shouldest reject the labour of Thy hands? A 
being, made by Thee, pure and innocent as I am. Whereas, Thou hast shone upon the counsel of the wicked. Hast made all their plans to prosper.

Ver. 1. קוּ for for which verb, when construed with $ב$, signifies to loathe, become disgzsted with; e.g., Ezek. xx. 43, , sight. The punctuation in the word under consideration is certainly very irregular, and Gesenius, as usual, cuts the Gordian knot by adopting the root ט, 2, which, however, is not to be found, either in Kimchi, or Ben-Zev.

I vִ I will disburden. See note on this word, supra ix. 27.

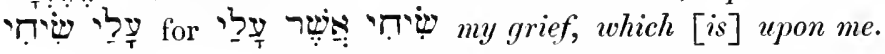

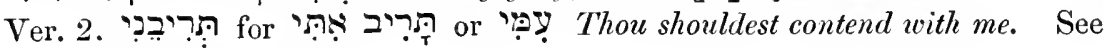
note on supra ix. 32.

Verse 3, as it stands in the original, seems to be devoid of all logic, since the

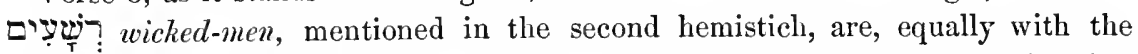
good, the work of God's hands. To make, therefore, the third clause antithetical to the first and second the word [the] work of Thy hands, like me, i.e., a being innocent and harmless as I am.

Vers. 4, 5. Hast Thou eyes of flesh? Seest Thon, as fiail-man seeth? Art Thou like a short-sighted mortal, who can judge of things only according to their appearance? Hast Thou not an unerring eye, which seeth every thing, as it really is? How then is it, that Thou dost not see my innocence? Having begun to dwell upon the frailty of man, he continues:

(Ver. 5.) Are Thy days, like the days of frail-man? Are Thy years, as the days of the years of man? The eye of man can be as little compared to the eye of God, as the number of man's days to that of God's.

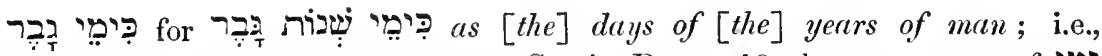

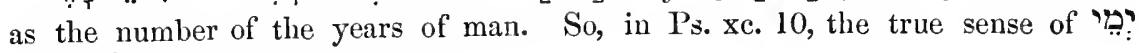
is the NUMBER of our years.

Vers. 6, 7. Job's language in these two verses leaves no doubt, that the idea must have crossed his mind that, God, though aware of his piety, might, nevertheless, have brought these terrible afflictions upon him as a test of its genuineness. Such a course of proceeding he considers not only exceedingly wrong, but also in the highest degree absurd; wrong, because thus placed, as it were, upon the rack, he might be compelled, in his 
agony, to speak or act against his will, and, perhaps also, against his conscience-it being well known, that men have, whilst undergoing torture, confessed to crimes they had never committed: absurd, because there could not be the slightest occasion for God to put a man to such a test. A man, indeed, might apply it to his fellow-man, for the purpose of ascertaining something he could not otherwise find out; but God, who is omniscient, what need can $\mathrm{He}$ have to prove a man, knowing, as He does, beforehand, how he will behave? (And yet we have been told by the historian, that God had really acted in this way towards Job, overwhelming him with unheard-of afflictions, for the purpose of seeing whether he would not then blaspheme, though He well knew, all the while, that he would not.) With these few observations, we now proceed to the translation of the verses.

Surely Thou demandest mine iniquity, and requirest my sin. Thy tormenting me thus, in order to see whether I shall sin, amounts in reality to desiring my sin; a great piece of injustice on Thy part. But not only is it unjust, it is also very absurd, because (Ver. 7) It is within Thine Omniscience, that I shall not act wickedly. What occasion is there, then, to subject me to such a terrible ordeal, in order to see whether I shall sin? But there is none delivering me from Thy hand. No consideration can induce Thee to free me from my affliction.

Ver. 6. Thou demandest; as, in Isa. i. 12, "Who The The hath demanded this at your hand?"

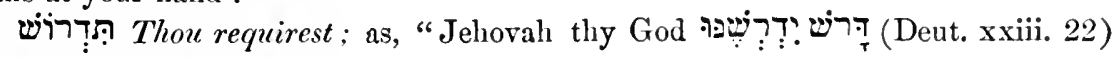
will surely require it of thee."

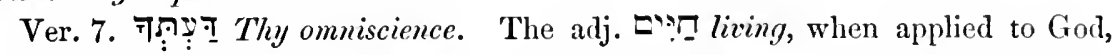
must, of course, always be understood in the sense of Etervally living, e.c.,

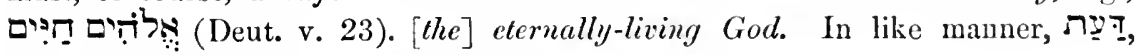
when applied to God, must needs mean oxrr-science.

Vers. 8, 9. In these two verses, Job observes how much it is to be regretted that a creature whom God has condescended to fashion from the commonest materials, and vouchsafed to exalt to the dignified rank of an intelligent being, should have so short a time assigned for its existence. He says :-

Thine own hands have fashioned me, and moulded me; yea, made me altogether round about. Every atom of my body did Thy 
fingers form and set in its proper place. And now Thou hast destroyed me! (Ver. 9.) Remember now, that Thou hast moulded me as the clay, and wilt again bring me unto dust.

Vers. 10-13. In the first three of these verses, Job gives us his ideas as to his progressive formation in the womb from the earliest period of his existence; how that he was at first nothing but a liquid; then a shapeless solid; and, lastly, a solid moulded into the human form. As, however, during the whole of the time occupied in these successive transformations, he could, in his opinion, have received neither air nor aliment, he must, he conceives, have been, almost miraculously, preserved by God's especial care; and, therefore, in the last verse he laments that God should, even while lavishing on him His favour and His mercy, have been sketching out for him a life so full of wretchedness and misery as his had proved; there being no doubt in his mind that all the afflictions with which he had been visited were decreed him at the very first stage of his existence as an embryo. He says:-

Didst Thou not pour me out like milk, and make me to coagulate like curd? (Ver. 11.) Thou clothedst me with skin and flesh, and fencedst me with bones and sinews. (Ver. 12.) Life, and favour, didst Thou grant me, and Thy care preserved my spirit. (Ver. 13.) Yet all these punishments hadst Thou hid (secretly planned) in Thy heart. I know that this was with Thee. I know that Thou wast harbouring this design of sometime afflicting me in Thy mind at the very time when Thou wast lavishing thy favours upon me in my mother's womb.

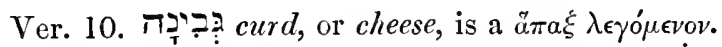

Ver. 12. There is here a Zeugma, the verb applied to two nouns of altogether different signification, viz., חָ life, and

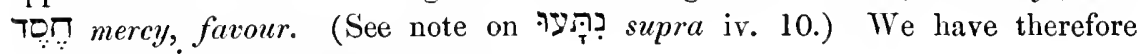

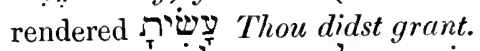

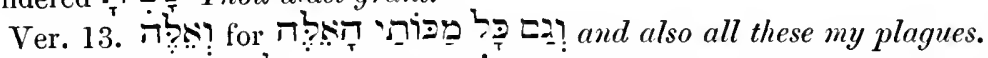

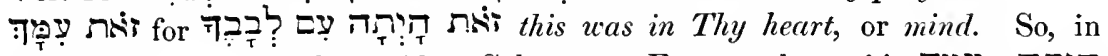

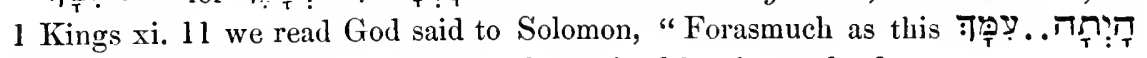
hath been.. with thee," i.e., has been determined by thee to be done.

Vers. 14, 15. If I had sinned, then wouldest Thou have marked me, and wouldest not have acquitted me from mine iniquity. If I 
had done anything wrong, I know I could not have done it with impunity. But what have I gained by refraining from evil, seeing that I could not possibly have suffered more if I had been a sinner? (Ver. 15.) If I had been wicked, woe would have been to me; and now, though I have been just, I cannot lift up my head. $\mathrm{My}$ countenance is fallen, as falleth that of those whom Thou rejectest. I am full of disgrace, see therefore my affliction. Vouchsafe to notice my sufferings, and the disgrace they bring upon me, and free me from them.

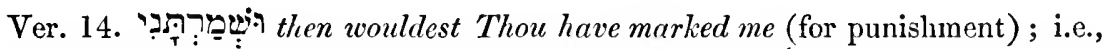
have kept punishment in store for me. The verb $7 \mathfrak{W}$ is sometimes used as synonymous with כטר in the sense of keeping, retaining (anger), as in Jer. iii. 5,

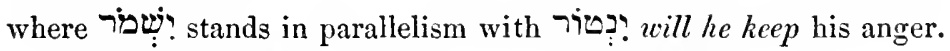

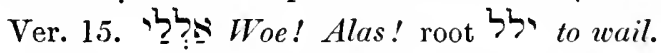

I cannot lift up my head. Malefactors are commonly described in the Bible as letting their countenanees fall ; as Gen. iv. 5.

Ver. 16. And will it then be so glorious for Thee, that Thou shouldest hunt me, as a fierce lion hunteth his prey, and, at the same time, shew Thyself mysterious to me? When a lion hunts its prey, the victim, however great its terror, at least sees by whom it is hunted; but when it flies, conscious of being pursued, yet unable to discern its pursuer, then there must be something supernatural at work; in other words, God must be the huntsman. So reasons our unfortunate victim, Job; I am being hunted, he says, yet I cannot see the huntsman; I know then it must be God who hunts me; a very marvellous and wonderful feat no doubt, but is it also glorious? Is it befitting His majesty to display Ilis wonderful power in such a manner?

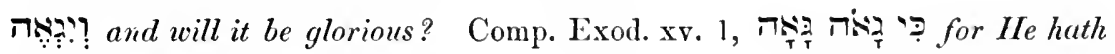
been exceedingly glorious.

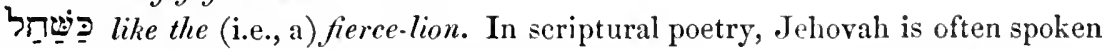
of under the figure of a lion. Comp. Hos. xi. 10, "They shall walk after Jehovah ; He shall roar like a lion."

(וֹ lit., and shouldest again show Thyself mysterious; i.e., invisible, and secret. The root 2 , which generally signifies to be wonderful, is also sometimes used to express mystery. Thus, Judg. xiii. 18, when Manoah asked the angel to tell him his name, the angel answered him: "Why askest thou after

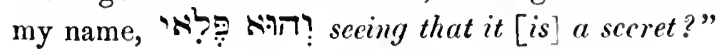


That the verb שפו to return, when coupled with another verb, is used adverbially for, again, has already been observed in our note on בהָּ supra vii. 7. Here it should be taken in the acceptation of at the same time, in which sense the German wieder (again), is sometimes used.

Ver. 17. In order to enable the reader fully to enter into the meaning of this verse, we must translate and explain here Chap. xvi. 8, And that Thou hasi made me full of wrinkles, hath become a witness against me. 'The fact of my body's having become so shrivelled and wrinkled, is considered by my friends as a proof of my guilt. "So that my very leanness riseth up against me ; it beareth witness to my face." The emaciated state of my body is regarded by every one as bearing witness against me, that I must have deserved such punishment. The same sentiment is uttered by Job here in other words. He says to God:

Thou renewest Thy witnesses against me. Every day I am afflicted with fresh sores, which are considered by my friends as so many witnesses giving evidence against me; and, in proportion as these witnesses increase in number, so, Thou increasest Thine indignation towards me. Of these witnesses there is A constant-succession, yea, a whole host with me. They relieve each other like so many sentinels, and seem to be without number.

Ralbag comments on צִ בִדריד as follows:

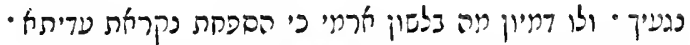

"Thy sores; and [there is] something similar to it in the Syriac language, for [in that language] a scab is called עדיתא."

דִ lit., clıanges; i.e., the witnesses (sores) come one after another; no sooner does one go, than another comes.

Vers. 18, 19. Why, then, hast Thou brought me forth out of the womb? I ought to have expired, when no eye had yet seen me. (Ver. 19.) I ought to have been, as though I never had been; 1 ought to have been borne from the womb to the grave.

Ver. 19. Should be construed thus:

הִִּ I should have been,

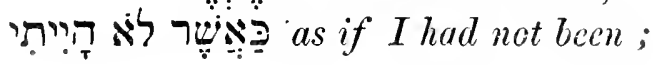




\section{אובר I ought to have been borne

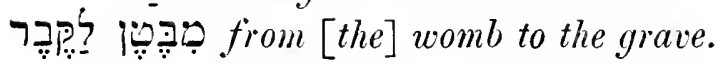

Vers. 20-22. Are not my days few?. Therefore, desist from me, and put-away Thine hand fiom me, so that I may cheer-up a little, (Ver. 21) Before I go-so as not to return-to a land of darkiness, and shadow-of-death; (Ver. 22.) A land, where there is gloom, like deep-darkness; where there is shadow-of-death, without any order; and where, even, when it shineth, it is like deep-darkness. Comp. Milton: "No light, but rather darkness visible." (Paradise Lost, B. i )

Ver. 20. Iח I (according to the K'ree) therefore desist. After this word, מִִ from me, should be supplied from the second hemistich. Comp. supra vii. 16.

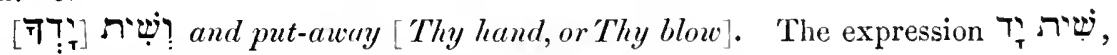
though in a different sense, is to be fond supra ix. 33.

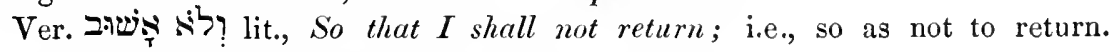
These two words should be considered as parenthetical.

Ver. 22.

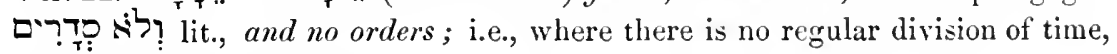
no dawn, morning, noon, \&c.

บํำ and [even] when it shineth; used impersonally.

\section{CHAP'TER XI.}

Vers. 2-6. The discourse we have just heard from Job extended over two Chapters, and was certainly of considerably greater length than any which had preceded it. The friend, who now speaks, therefore, alludes to this circumstance, and says:

Shall a multitude of worls not be ansurered? Or shall a man of talk, on that account, be right? Dost thou think, that, by making long speeches, thou wilt prevail upon us to give in, and admit that thou art suffering without a cause. (Ver. 3.) Thy fictions 
may reduce mortal-men to silence, and them thon mayest mock, none putting thee to shame. (Ver. 4.) And to any one of them thou mayest say, My doctrine was pure. I always inculcated the principles of true religion. And, at the same time, I myself was clean in thine eycs. Thou canst not point out a single instance, in which thou hast seen me do amiss. So, O Job, mayest thou say to mortal men, without any fear of contradiction, seeing that they cannot dive into the recesses of thine heart. (Ver. 5.) But oh, that God would speak, and would open His lips with thee! Oh that IIe would reveal Himself to thee, and speak to thee face to face! (Ver.6.) And that He would shew thee the mysteries of wisdom (for soundwisdom is tuofold)! It is divided into two parts-the ordinary wisdom of man, and the impenetrable wisdom of God. And then thou wouldest know, that God still deferreth for thee part of thy punishment. So far from His having punished thee more than thou didst deserve, thy punishment falleth even greatly short of thy deserts. Not only, then, doth He not proceed against thee with rigour, but He hath mercy upon thee, and spareth thee, deferring His anger, in the hope that thou wilt mend thy ways, and resign thyself to His will with calmness and resignation, as it behoveth a sincere penitent.

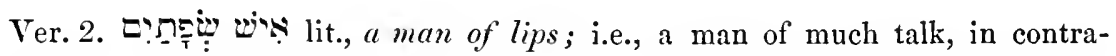
distinction to speaker.

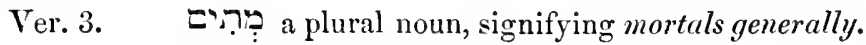

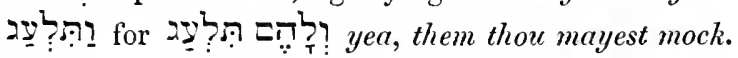

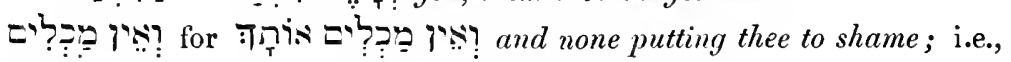
there would not be found even one, who could contradict thee.

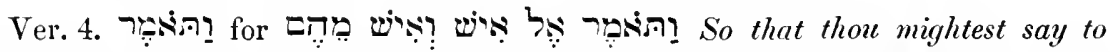
any one of them, \&c. Schultens, not perceiving that to any one of the mortals, whom Job is told by his friend he might mock, and deceive, comments as follows: "Postremum magno consensu refertur ad Deum, quasi Jobus repræsentetur, Deum compellans his verbis, purus existo in oculis tuis. Suspicabar aliquando commodius fore, si ad Jobum referretur, Dixisti quippe purus existo; in oculis tuis scilicet. Sic cap. xxxii. 1, reperio כי הוא צדיק בעיציו Quia justus ille in oculis suis." Let the reader accept this interpretation, if he sees any necessity for it, which, we confess, we cannot.

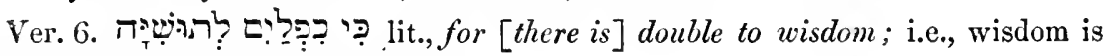
twofold, or of two different natures. 


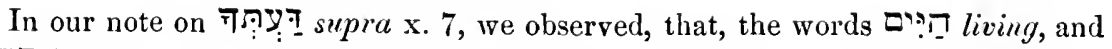
דַּ knowledge, when applied to God, must be taken in a much wider sense, than when used in reference to man. The same may be said of תמרטשידה, which, when applied to God, signify that profound and unfathomable wisdom, which is altogether beyond the reach of a mortal.

So in Isa. 1v. 8, 9, God says : "For my thoughts are not as your thoughts.

- . - . . . For, as the lieavens are higher than the earth, so are . . . . . . . my thoughts (higher) than your thoughts."

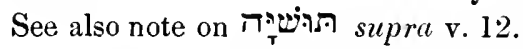

It will be perceived, that the words parenthetically.

บ?! for $Y$ บก! and [then] thou wouldest know. The imperat. stands here for

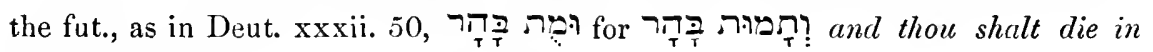
the mount. See note on תִ supra ii. 9.

T? used for, deferreth for thee. Just as the lenient creditor accommodates his debtor, by allowing the payment to stand over for a time, so God, when he pleases, allows the punishment due to the sinner to stand over, and defers its infliction.

פִ part of thy punishment, the prefix is being here used in a partitive

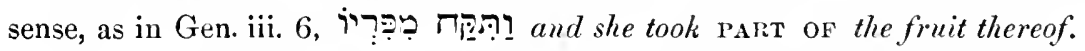

The noun iोy iniquity, is used here for the consequence of iniquity (to him

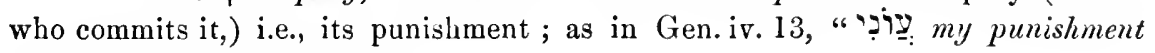
(is greater than I can bear)."

Vers. 7-9. Hitherto, Job has been represented by the speaker, as it were, boasting of his innocence before his fellow-men, although it was intimated at the same time, as evidently shown by the employment of the words "T⿱一ך) thy fictions (may silence mortal men, \&c.)," that he might in this be acting contrary to his conscience, but now it is suggested as a possibility, that he may have committed many sins, of which he himself is not aware, sins, which are concealed from him, and which only the searching eye of God can discover (Comp. Ps. xix. 13, "Who can understand his errors? Cleanse Thou me from secret faults.") Zophar tells him then, that though he may not discover any sin in himself, it is no proof, that God may not have done so, since that, which God can search out, may remain inscrutable to mortal man.

Wilt thou attain-unto the searching of God? Wouldst thou compare thy powers of scrutiny to those of God? Wilt thou attain even unto the perfection of the Almighty? Dost thou pre- 
sume to imagine thou canst know everything as fully, and as perfectly, as He doth? (Ver. 8.) To aim at this perfection of His is the heights of heaven-how canst thou effect it? Deeper than the pit. How canst thou know it? (Ver.9.) The measure thereof is longer than the earth, and wider than the sea.

How then canst thou presume to declare thyself free from all sin, when it requireth such perfection as I here describe to be able to determine this point?

Ver. 7. תִ lit., wilt thou find, find out, i.e., attain unto, reach. Comp.

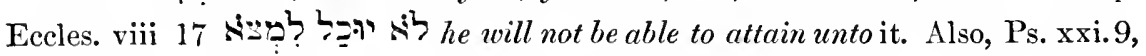

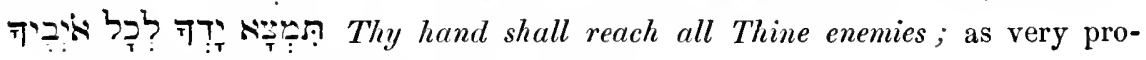
perly translated by Dr. French and Mr. Skinner.

บِ as far as, in the second hemistich, should be taken in the acceptation of even to.

Ver. 8. לivi pit ; i.e., the unfathomable depths of the earth.

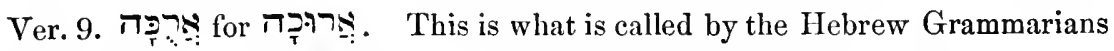
פדגש תמורת כח. See Mason and Bernard's Grammar, Letter xli., §5.

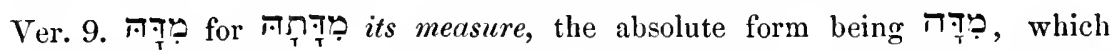
occurs infra xxviii. 25. In like manner, we find, Prov. vii. 8, ल.

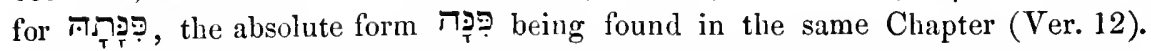
Gesenius, true to his principle of cutting the Gordian knot on every occasion, takes the absolute form of פִִ to be and that of which no Hebrew Grammarian ever dreamed.

Vers. 10-12. The speaker, having shown the unreasonableness of Job's assertion (supra x. 3) that he was oppressed and rejected by God, now proceeds to point out how little justified he was in expressing (in the second hemistich of the same verse) his surprise at the prosperity of the wicked. This he does by the following beautiful, and most philosophical, reasoning. In the first place, namely, he proclaims (Ver. 10) the Omnipotence of God, that He can do whatever He pleases, without let or hindrance, so that nothing would be easier for Him, than to punish the wicked man, immediately upon the commission of his wickedness. Secondly (Ver. 11), he declares the Omniscience of God, that none of the thoughts, or movements, of the sons of men can be hidden from Him, and consequently that no wicked action can by any possibility be committed without His being aware of it. And 
lastly, he affirms, that, though the Almighty thus sees, and is aware of, every guilty deed, yet, in His infinite wisdom, $\mathrm{He}$ finds it good and right not to appear to perceive it, and, consequently, does not visit it with immediate punishment; and, indeed, for this reason (Ver. 12), that if the penalty followed close at the heels of sin, mankind would, of course, shrink from committing sin. If the slanderer were to be struck dumb, with the slander still distilling from his lips, men would be afraid to slander; if the hand of the thief were to wither, while yet grasping the object of his theft, men would be deterred from thieving; if the murderer were to fall dead upon his victim, no man, however depraved or abandoned he might be, would be mad enough to attempt murder. And what would be the consequence? Why, men would no longer dare to do wrong, and would, therefore, cease to be free agents; they would refrain from iniquity and from crime, not from any feeling of piety or religion, but from mere fear of the punishment; all men would then be alike, and he, who by nature was the most prone to sin, would remain as guiltless as the purest and most virtuous of men. And where, then, would be the claim of the just man to reward? No, man, to be a free agent, must be allowed to continue in his sin for some time with impunity; the more flourishing he is allowed to become, the greater, of course, the temptation held out to others to be a sinner like him, and the greater, also, the merit of the good man, who resists such temptation, and refrains from sin, not through dread of punishment, but from a motive of real piety, and from a sincere wish to be acceptable in the sight of his Maker. This reasoning the speaker compresses in to the following words:-

If He cut off , or deliver over. A man into the hands of his enemies. Or bring-on-a-multitude. Of enemies to overwhelm and crush the tyrant in battle? Who can prevent Him? He is allpowerful, therefore, and so can punish at any time lIe pleases. Nor could it avail the sinner to commit his sin in secret, for (Ver. 11), Surely He knoweth vain mortals, and He seeth iniquity. Allknowing and all-seeing, $\mathrm{He}$ witnesses the commission of every sin, however secretly it may be committed. Though He seews not to perceive it. Though He behaves in such a manner, as to make it appear to men, that He does not perceive the commission of the 
crime. And this He does, because, in His supreme wisdom, He has willed it, that, in this world, man should be a free agent. But this he could not be, were punishment to follow immediately on his committing any sinful action. It would then be so manifestly to his disadvantage to sin, that (Ver. 12) even the worthless-man would have sense enough. To refrain from crime, knowing, as he would, that he could not commit it with impunity. But not only the worthless man, but even the most savage, fierce, and untameable of men, would remain unstained by guilt, Even a man born as savage as the colt of a wild-ass.

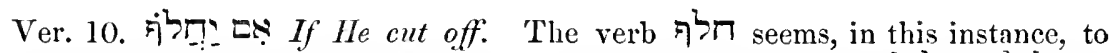

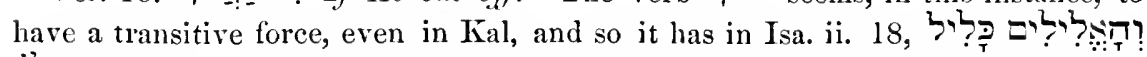
יִ- And the idols Ile shall altogether abolish. As these are, perhaps, the only two instances in which this verb is used transitively in Kal, we are glad to perceive we have, in both, the Auth. Vers. with us.

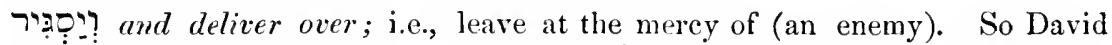

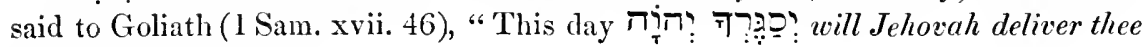
over (into mine hand)."

ו! Iit., and cause to assemble; i.e., bring on legions (of foes against a wicked tyrant).

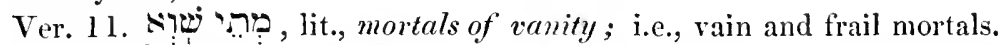

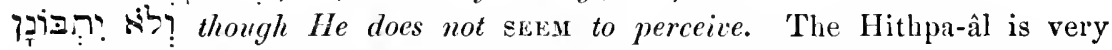
frequently used to express feigning, or pretending, as Prov. xiii. 6, "There is one who פִת maketh himself rich (i.e., who seems (pretends) to be rich), yet hath nothing; one who wivִ makcth himself poor (i.e., who seems (pretends) to be poor), yet hath great riches."

Ver. 12. ברבד hollow; i.e., without worth, worthless. Gesenius considers it to be the past part. Kal of נבב, whilst both Kimchi and Ben-Zev take it to be the

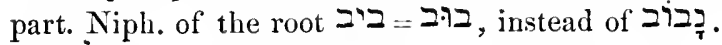

יליר? ל. heart being very frequently (e.g., infra xii. 24, and conp. xii. 3) used for good sense.

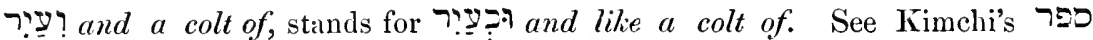
השרשים, sub voce.

Before

Vers. 11, 12, should be construed thus:-

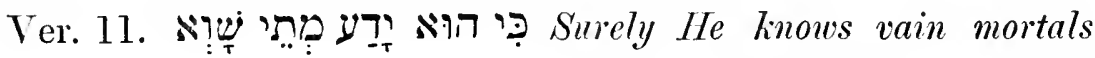
(i.e., He knows all their thoughts, and movements),

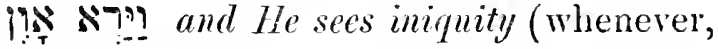


and wherever, it may be committed),

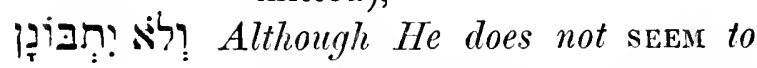
perceive [it] (i.e., although He does not inflict the punishment immediately; which, if He were to do),

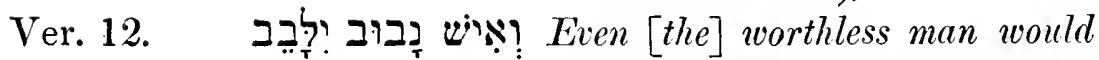
become sensible (enough to refrain from sin, on account of his dread of immediate punishment),

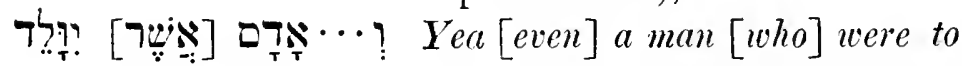
be born (i e., who were by his nature fierce, savage, and untameable),

\section{[ִ [like] the colt of a wild-ass.}

Vers. 13, 14. But there is another very weighty reason for God's not immediately punishing the sinner; it is, that he may be allowed time for repentance. If the wicked were to receive forthwith the punishment of their iniquity, there could be no such thing as repentance, nor would God have any opportunity for displaying His forbearance and long-suffering towards them. But, $\mathrm{He}$ is "a gracious God and merciful, slow to anger, and of great kindness," and therefore affords the sinner every opportunity for lamenting over his sin, and turning to Him with a penitent heart. It is to this great truth that the speaker now directs Job's attention, telling him that, greatly as he must have offended God by his murmuring, and by the unsuitable words which he has rashly suffered to escape his lips, there is still hope that he may, by testifying his sorrow and repentance in sackcloth and ashes, yet secure for himself the forgiveness, as well as the blessing, of Him, who rejoices over the repentant sinner. In this strain, Zophar goes on till Ver. 19 of this Chapter inclusively. He says :-

If thou prepare thine heart. If thou commune with thyself, and tune thy heart and thy soul to true repentance, and then spread out to Him thine hands. In prayer. (Ver. 14.) If there is iniquity in 
thine hand, put it away far from thee. Let thy prayer be accompanied by a real mending of thy ways. And do not suffer wrong to dwell in thy tents.

It will be perceived, that, in these two verses, the conditions are laid down, upon which Job might hope for brighter days, the speaker going on to state what would be the result of his fulfilling these conditions.

Ver. 15. Surely then shalt thou lift up thy countenance without spot. Thou shalt no longer let it fall, no longer hang down thy head, as malefactors are wont to do, because they dare not shew their face before an offended Creator, who, being pure Himself, can only look with pleasure on that which is pure, and unspotted. And thou shalt be steadfast. In thy faith and confidence in God, and not wavering, as thou art now. And thou shalt not fear. Any fresh calamities.

ציathout spot. The prefix מ has here a privative sense, as in Psalm lxxxiii. 5, "Come, let us cut them off יạ from [being] a nation" (i.e., that they be no longer a nation).

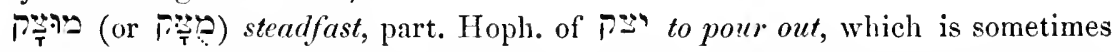
applied to the pouring out of metals in a state of fusion into a mould, when they again become hard and firm. Hence it is metapliorically applied to anything firm and solid, and likewise to a steady, unwavering state of the mind.

Ver. 16. In the preceding verse, Zophar had assured his unfortunate friend, he would lose all fear of fresh calamities; in the present one, he explains why he is so confident that this will be the case; it is because his friend will utterly forget his former miseries. As long as men continue to bear in mind sufferings they have had to undergo, they are apt to give way to a groundless dread of an impending renewal of them; but when they can once bring themselves to banish them altogether from their thoughts, they are freed from such ominons forebodings, and this Job is told will be his case.

For thou shalt forget thy misery; thou wilt think of it as of waters, that have passed by. If a recollection of thy former sufferings should at any time rise up in thy mind, thou wilt be in no apprehension, but feel assured they can as little return as waters, which have once passed by. 
The relat. צְִִּ

Ver. 17. And a life shall arise for thee, brighter than noon-day; thou shalt soar; thou shalt be like the morning. We find that the Psalmist gives the morning-dawn wings (Ps. cxxxix. 9), "If I take the wings of the morning," \&c., and so here, the speaker compares the happiness and prosperity, which he predicts for his friend, to the morning, and tells him, that, as the morning comes, flying on its wings, and constantly increases in brightness, till it becomes noon-day, so he shall go on mounting higher and higher in his splendid career, until his glory shall be as radiant as the mid-day sun.

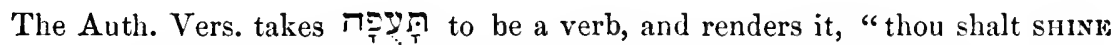
forth." How they managed to extract this sense from it quite passes our understanding, as it was only in the preceding chapter, ver. 22, that we saw the word

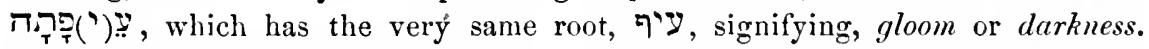

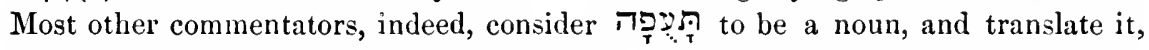

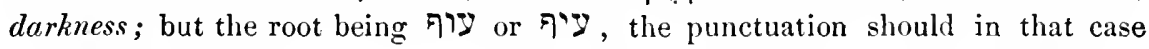

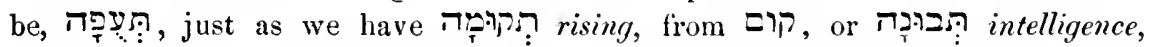

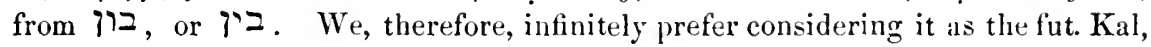
with $\pi$ paragogic, of עוף to fly (Kibbuts taking the place of Shurek, as very frequently is the case), and understanding it as explained above.

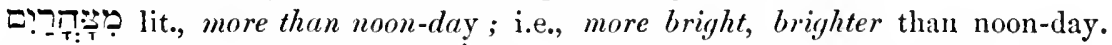
It has already been observed (on arise, ellipses of this sort are considered in Hebrew as a great elegance. So Prov. xviii. 19, "A brother offended is i is harder to be won than a strong city. So Jarchi comments on the word

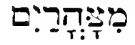

$$
\text { יותר מיאור נהריס יקוס לך מלדי }
$$

"Nore than the light of noon-day will a life arise for thee."

חָלֶ time, or life-time; as Ps. lxxxix. 48. T? for thee, must be supplied before it, so that the first hemistich of this verse should be construed as follows:

$$
\begin{aligned}
& \text { !ח and a life } \\
& \text { [T?] [i: shall arise [for thee] }
\end{aligned}
$$

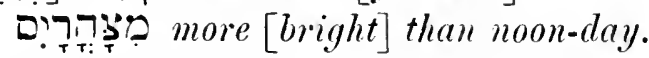

Ver. 18. And thou shalt be confilent, whenever thou shalt entertain any hope. Whenever, in the course of thy future life, thou entertainest a wish or hope, thou shalt confidently look forward to its realization. 'The Eng. Vers. is: "and thou shalt 
be secure, because there is hope." This translation is certainly very literal, and is adopted, with but little variation, by others, but we must confess we see no sense in it. And when thou lookest about thee. Before retiring to rest, to see whether all is safe. Thou shalt find, that thou mayest lie down in security.

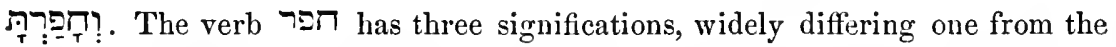
other. 1. to dig; 2. to blush; 3. to look out, scarch out, as Josh. ii. 2,

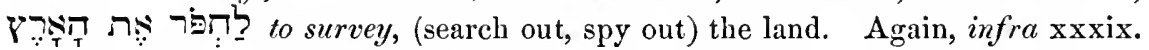
29, "From thence $7 \Xi_{\top}$ it looketh-out-for (the prey)." Now, since in this, as well as in the next, verse, the speaker supposes Job to be on the point of retiring to rest, it seemed to us most natural to give to the verb, in this instance, the sense of looking about, to see if all be safe, as men usually do before they retire. The Auth. Vers. translates, "thou shalt dig about thee;" but we should think the life of a man to be anything but happy, who had to dig a ditch around his tent every night before he went to bed, in order to protect himself. Nor are those, who prefer the sense of blushing, any better off; they translate, as we are told by Rosenmüller, "Etiamsi nunc pudefactus sis, tunc tamen, cum ad Deum te converteris, sccure cubabis ;" but, we cannot see, either connection, or antithesis, between blushing, or being ashamed, and sleeping soundly.

Ver. 19. And when thou liest down, none shall scare thee up; yea, many shall make suit to thee. Many shall seek thy favour, just as we find that Abimelech paid court to Abraham (Gen. ch. xxi.), and to Isaac (Gen. ch. xxvi).

?ִ past $\mathrm{Pi}$. with 1 conversive of the verb with the noun

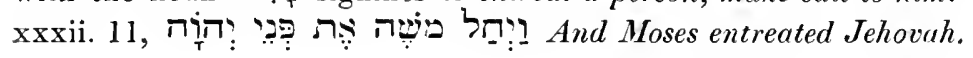

Ver. 20. It has been observed (in our note on vers. 10-12), that the speaker has taken as the theme of his reply Job's words in chap. x. 3, where he complained of being oppressed, and rejected, by God, and lamented the prosperity of the wicked. Having now disposed of the first part of Job's complaint, he concludes by replying to the latter, and assures his friend, that, however splendid and brilliant the career of the wicked may be, it must inevitably come to a miserable termination. His words are:

Whereas the eyes of the wicked shall fail. With longing; their hopes shall never be realized. And refuge vanisheth from them. When calamity and misfortune come upon them, like a whirlwind, 
they look in vain for shelter. And their hope shall be the breathing out of their life. Their miseries shall be so great, that they shall find no relief from them, but in death.

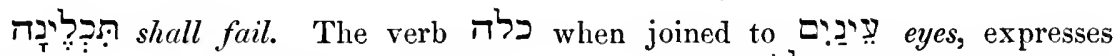

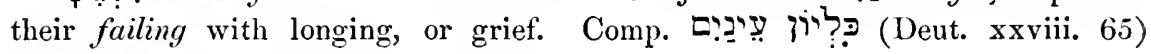
failing of eyes (with longing, or grief).

חפ breatling out of ; root חפב to blow, breathe.

\section{CHAPTER XII.}

Vers. 2, 3. The friend, whose speech we have just heard, had opened it by charging Job with the design of overwhelming his opponents with the multitude of his words. Job now retorts, and says that it is they who seek to overwhelm him with their number and the display of their unanimity, for they are three to one, and all of the same opinion, that, namely, he must have been a great sinner ; as if, forsooth, three men could not agree in their conclusions, and yet err. He says :

Indecd, because ye are a company, must on that account wisdom die with you? Must you, on that account, have so entirely monopolized all wislom, that, when you are no more, it, too, will perish with you, and become extinct. (Ver. 3.) I also have sense, like you; I by no means fall short of you. I am in no wise inferior to you, as far as sense is concerned. And who hath not things like these? Who could not utter such trivial and common-place sayings as yours are, so miserably poor in argument, so rich in taunts and jeers? The idea of the monopolization of wisdom by one, to the exclusion of all others, we shall find again expressed, infia xv. 8, "And hast thou taken away wisdom to thyself?" 'The sentiment, also, that, when many coincide in opinion, they need not always be correct, will be found infia xxxii. 9, "Not multitudes are wise" (i.e., that many agree on a point is no proof that they must be right). So Job 
tells his friends here, that it does not follow that, because they all three come to the same conclusion, this conclusion must needs be the correct one, especially as it is not in any way supported by arguments, but only by insult and mockery.

Ver. 2. Eָָ lit., a people, is sometimes used to express a body of men, or

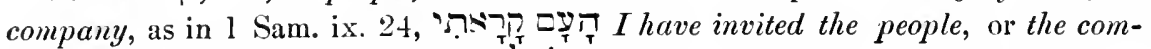

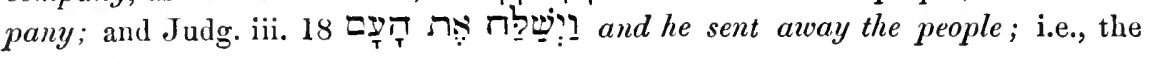
party (who bore the presents).

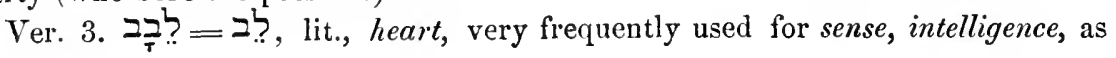
Ver. 24.

פִִּ as [to] you, for in English, if we translate literally, a to must be supplied, with which, or the equivalent of which, the Hebrew idiom dispenses. Comp. לxָָ as [to] God, infra xl. 9.

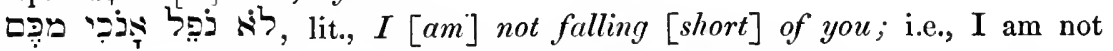
inferior to you. The same phrase occurs again, infra xiii. 2.

Vers. 4, 5. I am like one, who is a laughing-stock to his neighbour. Like one, whom his neighbour derides and taunts, saying, "Look at that simpleton, he calleth on God, that He should answer him!!!" But this is mockery, and not argument; to laughi a man down is a very easy matter, but it proves nothing. Even $a$ perfectly righteous man may be made a laughing-stock. (Ver. 5.) The mind of one, who is at ease, hath contempt for calamity; it hath it quite ready for those who totter with their feet. It is not at all unusual to see people, whom success has rendered arrogant, laugh at those who are labouring under calamity, and are on the point of falling from their greatness. This sentiment is also expressed by the Psalmist (Ps. cxxiii. 4), "Our soul is exceedingly filled with the scorning of them that are at ease, and with the contempt of the proud."

Ver. 5 is rendered in the Eng. Vers., "He that is ready to slip with his feet is as a lamp despised in the thought of him that is at ease." The reader will at once perceive from this how greatly the verse stood in need of a somewhat more intelligible translation.

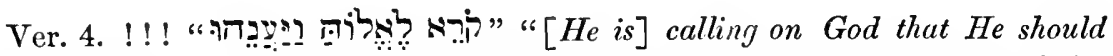
answer him" !!! 'These words are supposed to be said, by the neighbour, of him who is his laughing-stock. 


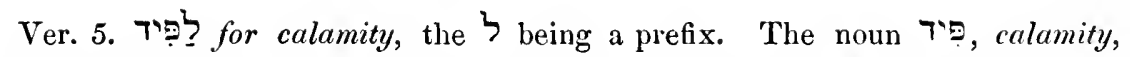
occurs in Prov. xxiv. 22, and also, infra xxx. 24, xxxi. 29. We must thankfully acknowledge, that it was Aben-Ezra who opened our eyes to the fact that the $ל$ in לִִ is not a radical, but a servile, his words being-

\section{הלמ"ד נוסל}

"The Lamed falls off" (i.e., is a mere prefix, seeing that the word has a meaning without it).

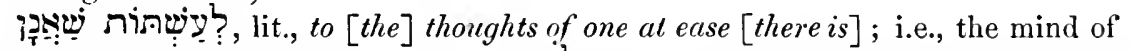
one who is at ease has, \&c. The prefix $ל$ very frequently denotes the belonging

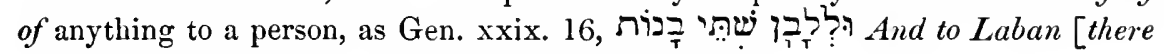
were] two daughters; i.e., Laban had two daugliters.

The two verses before us should, therefore, be construed as follows:-

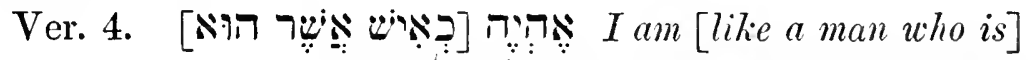

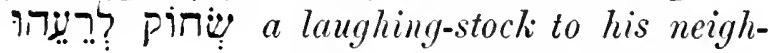
bour (i.e., like one whom his neighbour sneers at, saying),

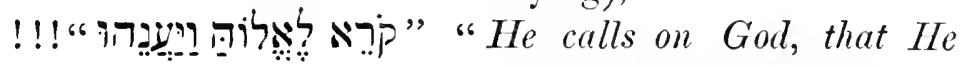
should ansuer him" !!!

[Even] a perfectly righteous man

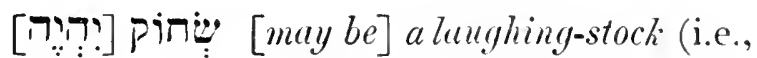
one, who is prone to laugh at and deride the unfortunate, will not spare any man, however just).

Ver. 5.

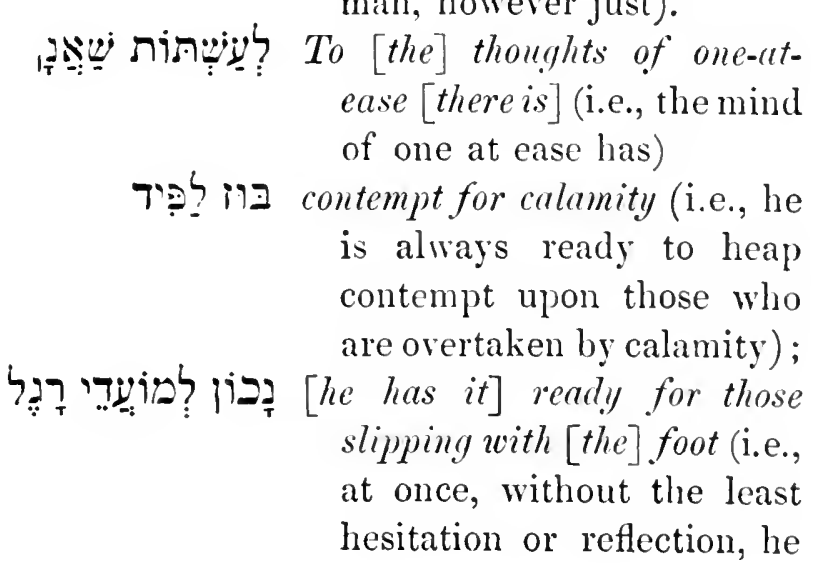


loads with his contempt those who are about to fall).

Rosenmüller advises us to consider אִ אָ in Ver. 4, as put

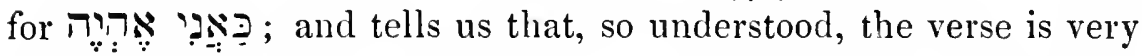
easy; but we shall, perhaps, not be blamed for rejecting the advice of one who writes such Hebrew as be considered to be Hebraists

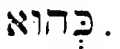

Ver. 6. Having rebuked his friends for the scorn and contempt they had poured upon him, he now emphatically asserts, that, what he has already stated concerning the sufferings of the just, and the prosperity of the wicked, in this world, is not mere fiction, as his friends would have it to be (xi. 3), but real, positive, fact. He says :

Yes! the tents belonging to robbers are prosperous, and security there is for those provoking God, and also for those provoking the man, into whose hand God hath brought (good things). " Those who provoke both God, and the good man God has blessed, enjoy perfect security. God and man are often thus coupled together in the Bible; e.g., in the parable of Jotham (Judg. ix. 9) we find the expression, "they honour God and man;" and (Ibid. ver. 13,) "which cheereth God and man." In Luke, also, xviii. 2, we read, "which feared not God, neither regarded man." And so here, our poet stigmatizes the restless tyrants he alludes to, as men, who regard neither God nor man.

As Wolfssohn himself considered this verse to be so difficult, as to call it מקר סת lit., a closed-up (i.e., unintelligible) verse, and so many other commentators, who are anything but Wolfssohns, have said so much, to so little purpose, about it, we think it but right to shew how we construe it.

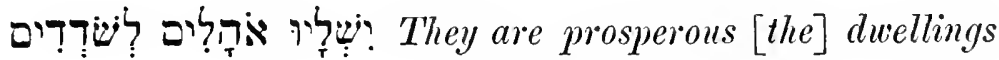 [belonging] to spoilers,

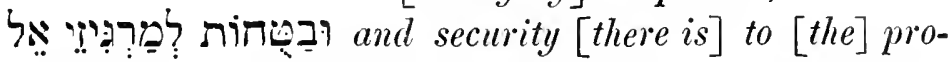 vokers of God,

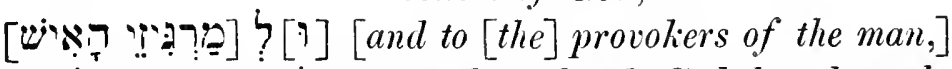 into whose hand God has brought (good things).}


That is, they, who provoke God, as well as the good man, whom God has favoured with the blessings of this world, enjoy security.

We could not bring ourselves to refer the third clause of this verse, viz., "into whose hand God has brought" (i.e, to whom God has given, whom He has blessed), to the wicked, as most commentators have done, since God, though He may suffer the wicked to enrich themselves by plunder, and to enjoy themselves for a time, surely cannot be said to have bestowed on them such riches, or such prosperity.

If this clause is at all to be referred to the wicked, it would be best to understand it, as Aben-Ezra and Ralbag * do, to refer to an idol, when the sense would be, that the tent even of him is secure, who carries an idol in his hand. So Isaiah, when ridiculing the worshipper of an idol, says (xlvi. 7): "They bear him upon the shoulder, they carry him, \&c." We might perhaps have adopted this view, if we had anywhere found in our author allusion made either to idols, or their worshippers, but such is not the case. In Chap. xxxi. 26 Job does indeed speak of worshippers of the sun and moon, but these, of course, belong to quite a different category from worshippers of images.

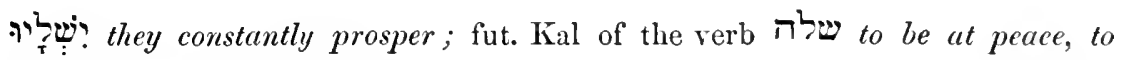
prosper.

[לִ [belonging] to spoilers. That the prefix $ל$ sometimes expresses

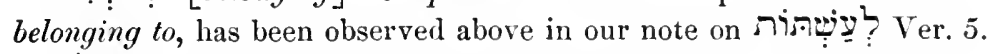

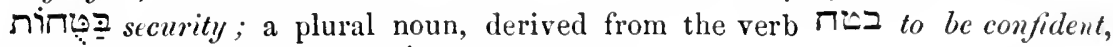
secure, and synonymous with

Vers. 7-9. Having thus reiterated his assertion with regard to

* Ralbag's words are :-

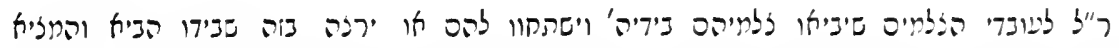

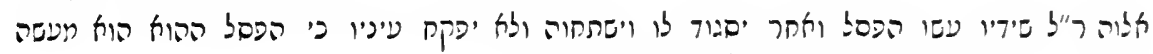

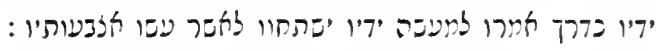

"Meaning to say, [belonging] to the worshippers of idols who carry their idols in their hands, and bow down to them. Or, he may mean by this, that he (the idolater) has produced and brought into existence the idol by his hand, that is to say, that his hands have made the image, and then he casts himself down before it and bows, and does not open his eyes [so as to see,] that this idol is the work of his own hands, as [the prophet] says (Isa. ii. 8) "they worship the work of their (lit., his) own hands, that which their (lit., his) own fingers have made." 
the grievous trials of the good, and the brilliant fortunes of the wicked, in this world, he goes on to say, that he is quite at a loss to reconcile this with the wisdom and justice of so majestic a Being, as God shews Himself, in all his works, great as well as small. His words are :

And yet, ask now the beasts, and they will instruct thee; or the bird of heaven, and it will tell thee; (Ver. 8.) Or speak to the earth, and it will instruct thee; yea, the fishes of the sea will declare it to thee. Ask any one of these, and inquire, by whom it was created, and mark the answer it will give thee. But, even, without asking them, by merely reflecting upon the wonders, which are displayed in them (Ver. 9), Who would not know by all these that the hand of Jehovah hath made them? The more I consider, therefore, all these evidences of His wonderful power, the more I am amazed at the amount of wickedness which is constantly being wrought in this world with impunity.

Ver. 7. จר וִ and it (i.e., every one of the beasts) will instruct thee.

Ver. 8. שִיש imperat. of the verb שיח to speak, think, meditate.

Ver. 9. הָיה these. The sing. is perhaps used to express that every one of these has been made by God; or perhaps ז this earth.

Vers. 11-13. It is well known, that the senses of man (or, to speak more correctly, the mind, as evidenced through the senses,) become $[\mathrm{s}]$ sharpened by practice, and experience. 'The gourmet trains his palate to the nicest appreciation of the qualities of wines; the gourmand educates his to the most accurate perception of the merits of a dish. Similarly, the ear of him who loves to hear and weigh the speeches of orators will acquire no mean skill in the discrimination of rhetorical excellence; and the longer such a man has lived, the more exercised will have become his ear, the greater, therefore, his discernment and judgment, and, as a consequence, his wisdom. The wisdom of God, therefore, whose existence is without beginning, and without end, must be infinitely great. This syllogism is contained in the three verses before us, which run thus:

Doth not the ear try words, just as the palate tasteth its food? 
(Ver. 12.) In very-old-men, therefore, must be wisdom, and in length of days, understanding. (Ver. 13.) With Him, therefore, must be wisdom and might; to Him must belong counsel and understanding.

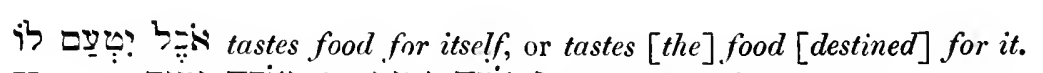

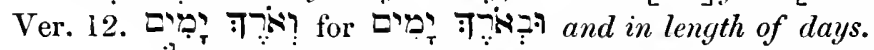

Ver. 13. is to Him (there is, or belongs), i.e., He has. See note on

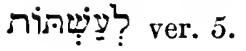

It has already been observed, that nothing is more annoying to the unfortunate Job, than for his friends to call his attention to the power and wisdom of God, (we shall, by-and.by, hear him give full vent to his displeasure on this score,) and, generally, it will be found that, whenever they do touch upon this topic, he strives to outvie them as he does here in answer to what Zophar had said (ch. xi. 7-11).

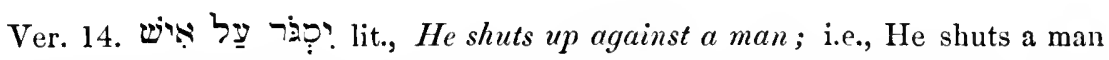

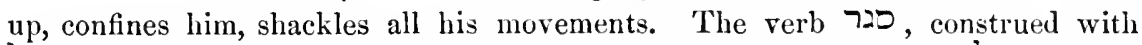
עַ wilderness hath shut them in.

Ver. 15. Lo! He stoppeth the waters. He makes them stagnant. Then they dry up; on the other hand, when He letteth them loose, they devastate a land.

Ver. 16. is to Him [belong]; i.e., His are, or in His power are. See note on

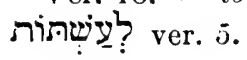

Ver. 17. He maketh counsellors to go stripped (of their clothes).

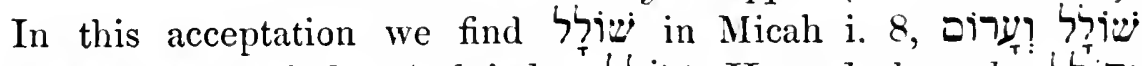

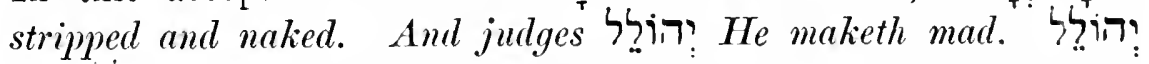
and in meaning, seeing that people, whose intellects are affected, seem, not unfrequently, to have a fancy for going naked. Thus we are told of Saul (1 Sam. xix. 24), when he was troubled with the spirit, that he lay down $\mathrm{N}_{\mathrm{A}} \mathrm{KED}$ all the day.

Ver. 18. The confederacy of kings He dissolveth. When kings 
enter into a lengue against $\mathrm{His}$ will, He visits them with a spirit of discord. And girdetle a girdle on their loins. He moves them to fight one with another.

We often find in the Bible the expression girding a givdle upon the loins figuratively applied to a man who prepares himself for battle, or summons up courage for any other great effort. So

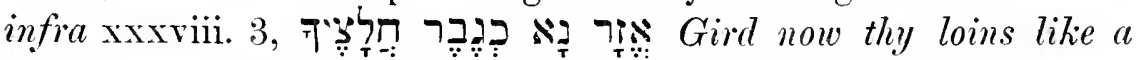
man; i.e., summon up courage. Comp. also 2 Kings iii. 21.

מוּר lit., bond of; i.c., union, confederacy, league, of.

חִָּ lit., opened ; i.e., looses, dissolves.

רזיר we have translated these words, and He girdeth a girdle, rather than He bindeth a girdle, in order to preserve the jingle of the original.

Ver. 19. He maketh chiefs to go stripped, and overthroweth the mighty.

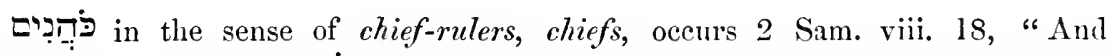

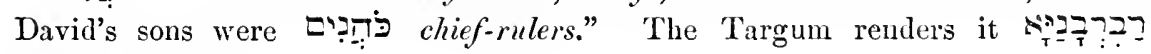
grandees, rulers.

Ver. 20. He removeth the speech of orators, and taketh away the sense of the elders.

The word בִּמִ is rendered in the Eng. Vers. "trusty," and a similar meaning is attached to it by Schultens, Rosenmiiller, and Schlottmann ; but we cannot see what necessary connexion there is between speech (i.e., eloquence) and trustworthiness. Men may be very trustworthy, and yet stammerers, or even dumb; while, on the other hand, very eloquent speakers may be anything but trustworthy. We, therefore, prefer deriving this noun from the verb 2 do to speak, which occurs in Jer. xxiii. 31, M.

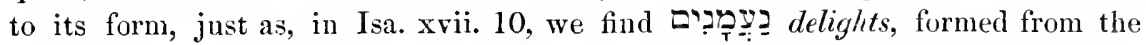

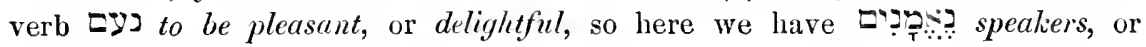
orators, formed from the verb בא to speak.

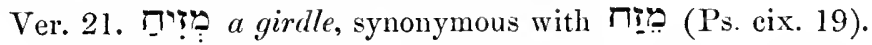

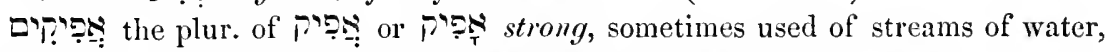

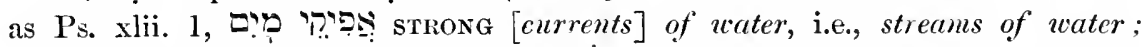

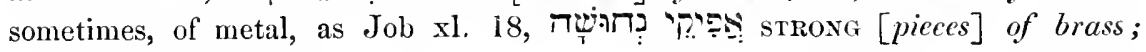
and, in the verse before us, it is applied to mighty men. The second hemistich is translated by Michaelis (as quoted by Rosenmüller) thus: "situlam scuturiginum laxat, vel, solvit, i.e., scaturigines exsiccat." How beautifully the second hemistich would then correspond with the first, we leare to the judgment of the reader! 
Ver. 23. The prefix $ל$ in 2 ב stands as the mark of the accusative case. See note on bis? supra v. 2.

םחְ:? and leads them (into captivity, or exile).

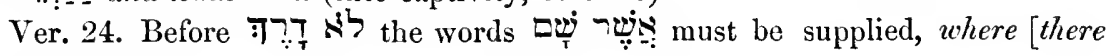
is] no way.

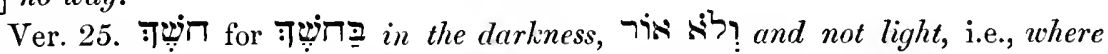
there is no light. The same pleonasm occurs Lament. iii. 2. We have already more than once had occasion to remark that ellipses are often used with great elegance in Hebrew; we now see that the same holds good of their opposites, pleonasms. So 2 Sam. xiv. 5, "I am indeed a widow-woman, and mine husband is dead." Again, Isa. xxxviii. 1, "for thou shalt die, and not live ;" and many others might be quoted.

\section{CHAPTER XIII.}

Vers. 1, 2. Lo! mine eye hath seen all this; mine ear hath heard and marked it. With mine own eyes have I seen and noted a great part of the wonders of God as displayed in His works, animate as well as inanimate, and that also which others have recorded concerning them, both during my lifetime and before I was born, has come unto my ears; yea, I have consulted ancient history, and that long ago, long before you advised me to consult it (supra viii. 8, 9); and I did so of my own accord, because I knew it to be absolutely necessary that every shortlived human being should consult it. (Ver. 2.) As ye know this, I also know it; I am not inferior to you.

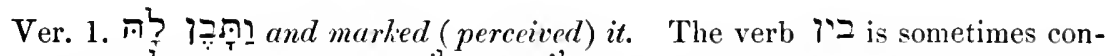

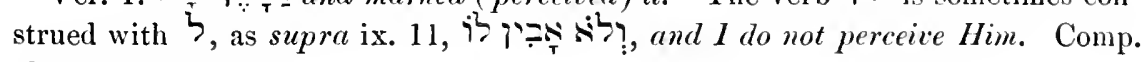
also infra xiv. 21.

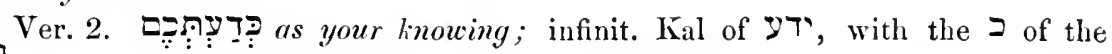
בכ"לִ

Ver. 3. But, what doth it profit me to know the omnipotence, omniscience, and profound wisdom of God as I do, if I cannot obtain a hearing from Him? What will my knowledge of these wonderful attributes of His avail me, if I cannot come into His 
presence, to justify myself, and to prove my innocence? For $I$ wish to SPEAK to the Almighty, and I desire to ARgue before God.

Ver. 4. But ye are patchers-up of falsehood, worthless physicians are ye all. Just as a physician, who does not understand his profession, will often apply to bodily sores remedies which, instead of soothing, irritate them, so you, instead of pouring balm upon my inward wounds, and soothing their pain by kind and sympathizing words, only render them more irritable and painful, by galling mockery and exasperating insult.

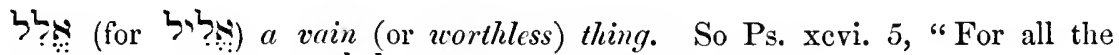
gods of the nations are "צ'? vain (or vortlless) things."

Ver. 5. In Prov. xvii. 28, we read, "Even a fool, when he holdeth his peace, is counted wise." This proverb may possibly have been current in the days of $\mathrm{Job}$, and if so, the rerse before us must have been intended as a delicate repartee to Eliphaz, who, in ch. v. 2, had, in plain language, stigmatized his unfortumate friend as a fool, and a simpleton, and now, in return, must hear the following delicately expressed, but deeply cutting words. Would that ye were altogether silent, and it would be accounted to you for wisdom! It would be much wiser in you not to speak at all, than to oppose my arguments and just complaints with a deluge of empty and unmeaning words.

Vers. 6-12. Hear now my reasoning, and attend to the pleadings of my lips. Give me a fair hearing, before you condemn me. (Ver. 7.) Will ye, on behalf of God, say that which is wrong? Or, on His behalf, say that which is false? Will you, in order to justify Him, bring charges against me, as iniquitous as they are unfounded? (Ver. 8.) Will ye accept His person? Will you, in order to curry favour with Him, speak against your own conscience? Will ye contend in behalf of God? (Ver. 9.) Will it be good for you, when He shall search you out? Can you expect that He will brook your saying things which, in your hearts, you know to be untrue? Will you mock Him, as one mocketh frail-man? To me and to others, you may say with an impudent face that you believe me to be guilty, though, in your hearts, you think otherwise; but can you say so with 
impunity to Him who searcheth our hearts? (Ver. 10.) He will indeed reprove you, if ye secretly accept persons. If, in condemning me, you only aim at ingratiating yourselves with Him, whilst, in the secret recesses of your hearts, you know your condemnation to be unjust, He will certainly not allow you to go unpunished. Moreover, whenever flattery is used, weakness must be supposed in the party whom it is meant to please ; if, therefore, you think for a moment you can find favour with God by accepting His person, and justifying His proceedings towards me, against your own conscience, you must needs attribute to Him one of the greatest frailties of man, viz., that of being pleasurably tickled by flattery. But dare you suppose such weakness in God? (Ver. 11.) Ought not His majesty to deter you? From imputing such a frailty to Him? And ought not His terror to fall upon you? Ought you not to shake and tremble at the very thought that you could for a moment entértain so detestable an idea? Do you not perceive that, if you can harbour such notions with regard to your Maker, you are, in fact, materialists, and are lowering your glorious and majestic God to the level of an abject and despicable mortal, made of clay, dust, and ashes? Away, then, with all your boasted knowledge of the power and wisdom of God! A being, susceptible of flattery, however powerful and however wise he may be, is still a frail being, is like a being dwelling in a "house of clay." (Ver. 12.) Your records. All your high-flown speeches, in which you have recorded His greatness, power, and works. Are, in reality, parables befitting one made of ashes. Fine poetical figures, which might be addressed with some chance of pleasing to one made of dust and ashes. Figures suitable for bodies of clay, like your bodies.

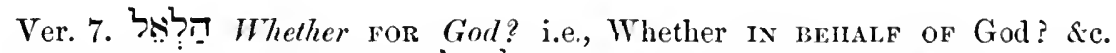

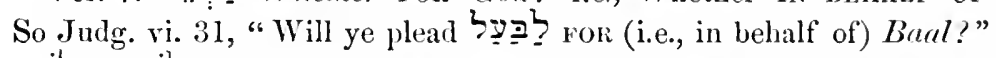

ול for for And whether for Him? i.e., Whether in nenalf of Him?

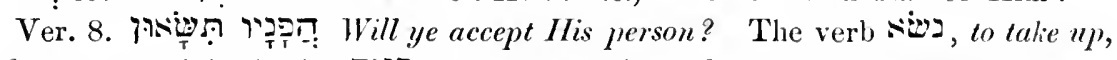

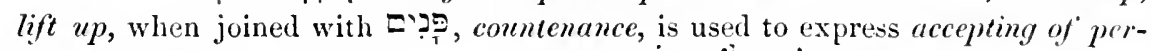

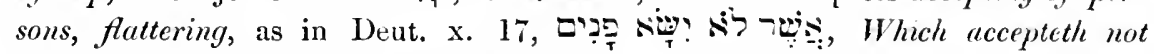
persons, in the present Verse and Ver. 10. Sometimes, however, it signifies to comply with one's request, or accept one's supplecation, as in Gen. xix. 21, where the angel says to Lot, who liad begged of him to allow hin to talke refuge in 


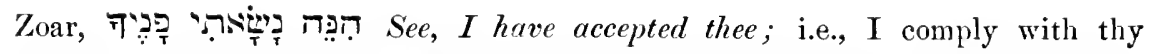
request. So also God, infra xlii. 8, "And my servant Job shall pray for you ; הִ for verily him will I accept ; " i.e., his supplication will I grant.

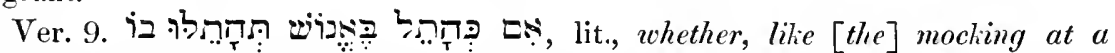
frail-man will you mock Him? i.e., Will you mock Him, as you would frail-man?

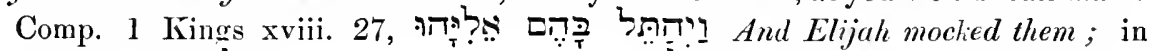

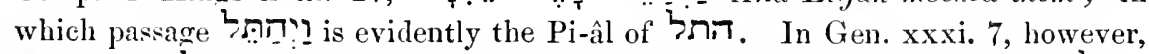

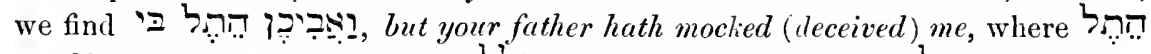

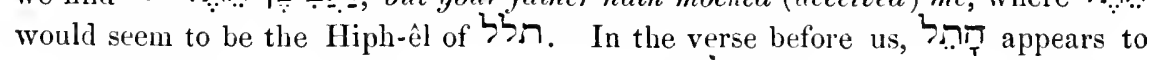
be the inf. Hiph. of this same root, but the form

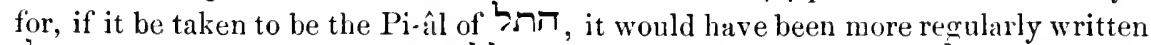

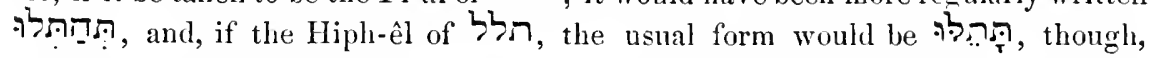
indeed, the $\pi$ of the Hiph-êl may be here anomalously retained, as in 1 Sam.

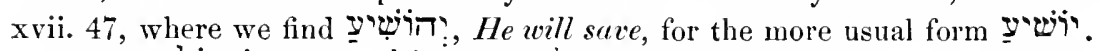

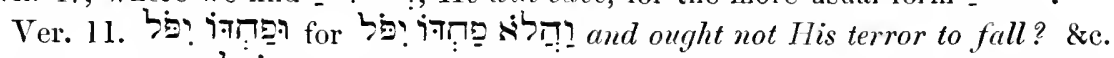

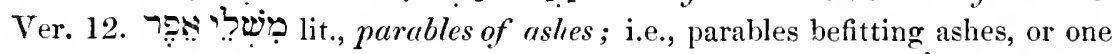

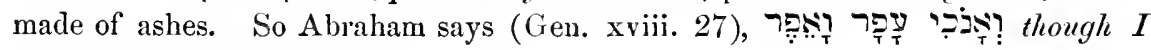
am $[$ but $]$ dust and A sHes.

In Mason and Bernard's Grammar, Letter 47, $\$ 1$, which treats of the various modifications of the sense, in which a Hebrew noun, in the state of construction, is connected with its corsequent (the word, that is, with which it is in construction), the reader will find, Art. VIII. the following:- "In a few instances, a verb or participle must be understood after the antecedent, to express

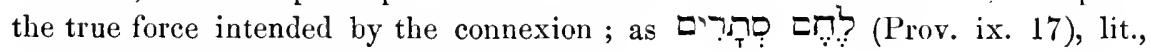
bread of secrets; i.e., bread eaten in secret."

In like manner, פִשְׁ? in the verse before us, though lit. signifying parablcs of ashes, should be considered as intended to express, parables BEFitTing ashes.

ם

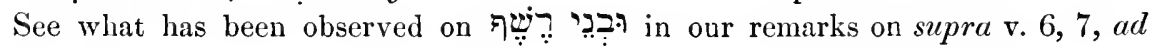
finem.

We are glad to perceive, that Wolfssohn has understood ver. 12 in nearly the same way as we do. If we had really borrowed the idea from him, we should of course have at once acknowledged it; as it is, we are, to say the least, very proud to have so high an authority on our side. His words are as follows:

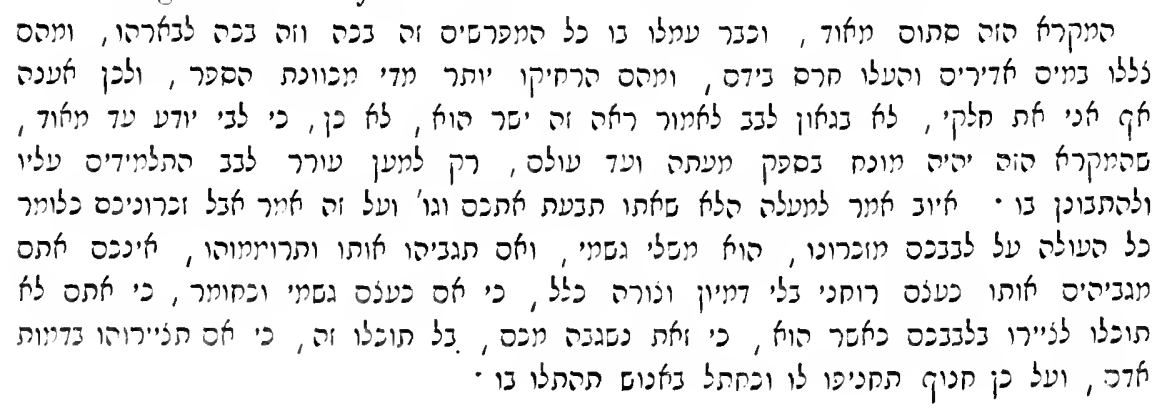


"This verse [is] very unintelligible (lit., stopped up), and all the interpreters have before now taken great pains with it, one in this manner, another in that, to explain it; and [some] of them have dived into mighty waters, but brought up [only] a potsherd in their hand; and [others again] of them have rambled more than enough from the object of this book; and, therefore, I also will say my share, not with pride of heart, so as to say, Look here, this is right; not so, for my heart knows [but] too well, that this verse will remain in doubt, henceforth, and for ever; but [I do so only] to rouse the attention of students to it, so that they should refleet upon it. Job said above (ver. 11), 'Ought not His majesty to deter you, \&e. ?' and, with regard to this, he [now] says, 'But your records,' that is to say, every thing, which arises in your mind of what you record of Him, [consists of] parables, having reference to a body, and although you extol, and exalt Him, you do not exalt $\mathrm{Him}$ as a Spiritual object, without any semblanee, or form, whatever, but, as a Corporeal object, and bodily mass ; for you cannot imagine Him in your heart, as $\mathrm{He}$ [really is], for this is far beyond you ; you cannot [do] this, but you imagine Him under the likeness of a man, and, therefore, you basely flatter Him, and, as one would mock frail-man, you mock Him."

Vers. 13-16. Be silent, desist fiom me, so that I may speal, and let come upon me what will. (Ver. 14.) Come on what will, I will take my flesh in my teeth, and I will put my life in mine hand. I know, that by speaking frankly, I risk my life, and that God may deprive me of it, if He resent my freedom of speech. (Ver. 15.) Lo! He may kill me, yet will I hope for Him. Even to the very last moment of my life, I shall entertain the confident hope, that, provided only Ie listens to my cause, He will at once see its justice, and declare me immocent. But my ways. The course of my life. I will plead before Him. I will submit to anything, even to the loss of my life, rather than allow it is wrong in me to maintain, that the life I have led has been free from blemish. But stay, I do not see how I have come to think, that, by speaking the truth, I risk to lose my life ; on the contrary, as a God of truth, He ought to love truth, and, therefore, be pleased at hearing it from my lips. (Ver. 16.) Yea, He ought to be a help to me. He ought to help me for the very reason, that I do speak the truth. For a hypocrite camot come before Him.

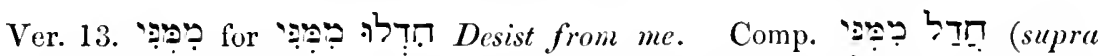
vii. 16) desist from me. So in Jer. xxxviii. 27,

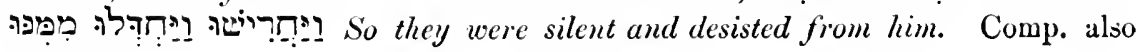
1 Sam. vii. 8. 
כפר

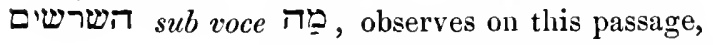

\section{כלומר יעבור עלי מה שיעבור ואיבי חושש •}

"That is to say, Come upon me, what may come, for I do not care."

A similar ellipsis we find in 2 Sam. xviii. 23, where Ahimaaz, after begging Joab to allow him to run, to announce the death of Absalom to David, and being advised by him not to do so, says, יִִ Bִ But be what [may], I will run; on which Kimchi likewise observes,

\section{בלומר ויהי מה שיהיה איצי תושש ארוצה ואגידה •}

"That is to say, But be, what may be, I do not care, I will run, and tell."

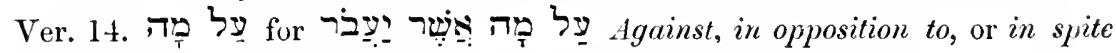
of, what may [come to] pass; i.e., come on what will.

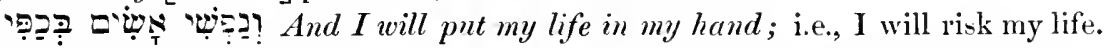
The figure is probably derived from the fact, that what is held in the hand is liable

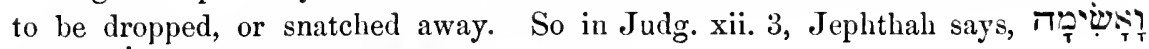
Then I put my life in mine hand.

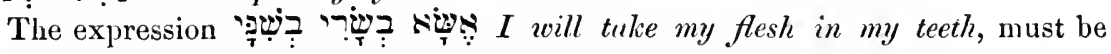
understood in an analogous sense, $=$ namely, I will venture my life.

This verse in the Eng. Vers. as follows: "Wherefore do I take my flesh in my teeth, and put my life in mine hand?" And in like manner, it is translated by Schlottmann: Wozu trüg' ich mein Fleisch zwischen den Zülenen fort, und nähme mein Leben in die Hand? But how could Job, who is bent upon risking his life, as the next verse plainly shows, possibly say, wirY should I risk my life, \&c. ? This incongruity was felt by Wolfssoln, who, to avoid making Job speak so illogically, translates the verse as we do. He says :

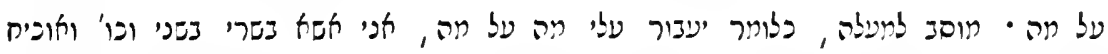

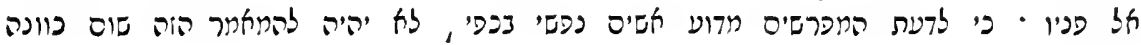

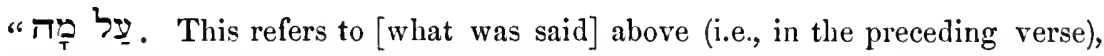
that is to say, Come on me what may, upon what may (i.e., one danger after another), I will take my flesh in my teeth, \&c., and I will reason to His face. For according to those who interpret it, wHY should I put my life in mine hand? this sentence would have no meaning whatever."

We are glad to see Schultens, also, felt the inconsistency of the usual translation of this verse.

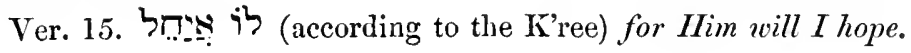

Vers. 17-19. Hear diligently my speech, and let my declaration enter into your ears. (Ver. 18.) Behoid now, I have arranged my cause! I am quite prepared to defend myself against any accusation. I know, that I shall come out just. I am confident, that every impartial judge must declare me not guilty. (Ver. 19.) But who is He that will plead with me? I am quite prepared 
with my defence, but I do not see my accuser. Who is he? Where is he? If I am to be tried, no time should be lost, For presently I shall be silent, and give up the ghost, when of course, all chance of clearing myself will be gone for ever.

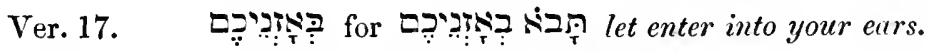

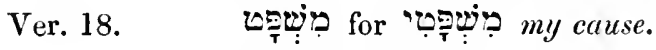

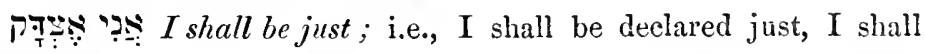
come out just from the trial.

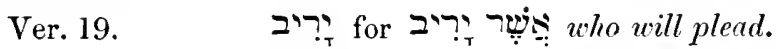

עִ now; i.e., presently, shortly. See note on this word, supra vii. 21.

Vers. 20-22. Having requested his friends to listen attentively to his statement of his case, he now addresses himself to God, saying:-

Only, the following two things, do not do to me, then, will I not conceal myself from before Thee. Then, I shall have no occasion to skulk away, as a malefactor would do, who dared not face his judge. Let not, namely, 'Thine hand press heavily upon me, and Thy dread terrify me, but, on the contrary, (Ver. 21,) Remove Thine hand far from upon me, and let Thy terror not affirght me. (Ver. 22.) And then call, and I will ansuer, or, iet me speak, and answer Thou me. I am so confident of the justice of my cause, that, whether it is Thy divine will that I should consider myself as the defendant, or the plaintiff, it is all one to me, I am prepared.

Ver.21. 7ִ

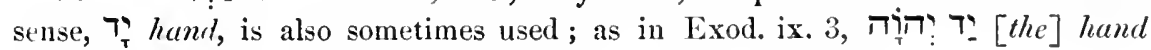
of Jeloval, (i.e., the plague of Jehovah) is upon the cattle, \&e.

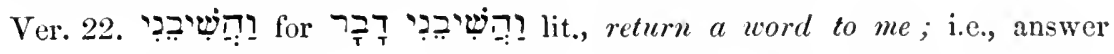

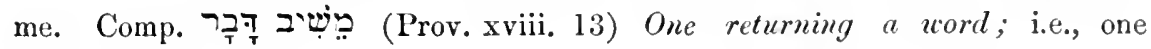
answering a matter.

Job, having left it entirely to God, either to call upon him for an answer, or to allow him to plead, could not very well go on speaking, without first waiting to see, whether God would, or would not, propose a question to him. It is, therefore, very pro- 
bable, as Wolfssohn most judiciously obscrves, that Job here checked himself and paused a little, till at length, hearing no roice, he concluded it was for him to speak, and said:

Ver. :3. How many iniquities and sins have I? Make me to knou my trespass and my sin.

? many liave I ?

We shall give here Wolfssohn's own words on Ter. 22, referred to above :

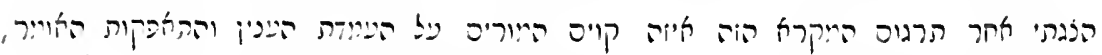

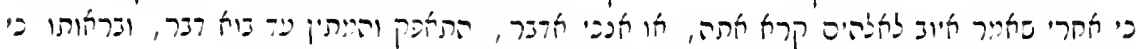

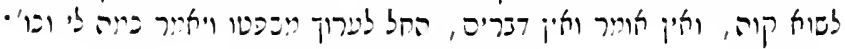

"After the translation of this verse (Ver. 22) I have placed several lines, which are to indicate a pause in the reasoning, and the cheeking himself of the speaker ; for, after Job said to God, 'Call Thou, or let me speak,' he checked himself, and waited till a word should come [to his ear, but, on his perceiring, that he was wating in vain, and that there was no speech and no words, he began to arrange his cause, and said, "How many, \&c."

Ters. 24-26. Why shouldest Thou hide Thy countenance from me? Why refuse to have regard unto me, and to my prayer? And consider me as Thine enemy. As a hardened and incorrigible simmer, who says within his heart, There is no God. (Ver. 25.) Wilt Thou crush a driven leaf, or wilt Thou pursue dry stubble? (Ver. 26.) That Thou writest doun bitter things against me. Decreest bitter punishments against me. And entailest upon me the punishments incurred in my boyhood. I do not remember ever to have done anything deserving punishment; I may indeed have done so, when a boy, without even knowing that I was doing wrong, but wilt Thou risit upon me now all that $I$ sinned in then?

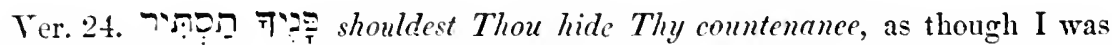
held in abomination by 'Thee. We find that it is said of Cain, that Jehovah had no respect unto (i.e., dill not look upon) him, and his offering (Gen.iv. 5). And so the Psalmist prays, in Ps. cii. 2, "Hide not 'Thy face from me, \&c."

T?

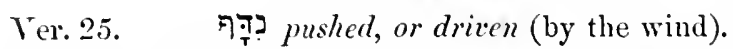

Ver. 26. יר̣ lit., and shouldest make me to possess; i.e., shouldest entail upon me. 


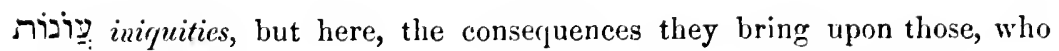
commit them, punislıments, as in Gen. iv. 13. See note on פָָָ supra vii. 2.

\section{Vers. 27, 28. And puttest my feet in the stocks, and watchest all} my paths. All my movements; as those of a prisoner are watched, lest he should escape from his punishment. They (the stocks) imprint themselves upon the ankles of my feet, (Ver. 28) And it (each of my feet) wasteth away like a rotten thing, like a garment, which the moth hath consumed.

Ver. 27. To lit., a block of wood, by which is evidently meant here, either stocks, in which the legs of prisoners are put, or a block, or clog, of wood, such as is fastened to the leg of an animal, to impede its movements. We are incliner to think the latter is meant, in consequence of what is said in the next clause, and that thou shouldest watch all my paths (i.e., movements', sinee this eould hardly be said of one, whose legs were put in stocks of the ordinary description, which do not allow of the slightest movement.*

lit., the roots of my feet; i.e., my ankles, which are thus very appropriately termed, since with them the legs terminate and feet begin. It would be upon them of course, that the stocks or elogs would exercise their chief pressure, a pressure which, in Job's case, must have been more than ordinarily severe, seeing that his ankles were, no doubt, greatly swollen and ulcerated.

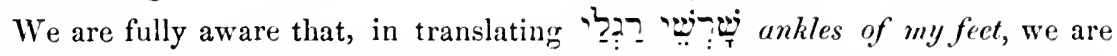
guilty both of tautology and inexactitude; as for the tautology, the Autl. Vers., which has, heels of my feet, may, with equal right, be accused of it; as for the inexactitude, which consists in adding of my feet, when the two Hebrew words together mean only my ankles, as being the roots of the feet, it has been intentionally committed, for the purpose of referring the $\mathrm{N}$ ?

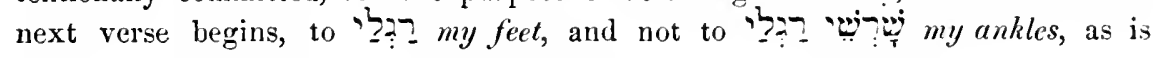
done in our translation, where we wished to avoid the tautology.

תִ lit., it (i.e., the block of wood) imprints itself. We take this verb to be the third pers. sing. fem. fut. Ilithp. of तir to impress, or imprint, agreeing with xxxiii. 11, and which very likely was either of fem., or common, gender. The circumstance, that stocks in English is a plural noun, obliged us to render

* Herz Homburg is of the same opinion, for he remarks on the word

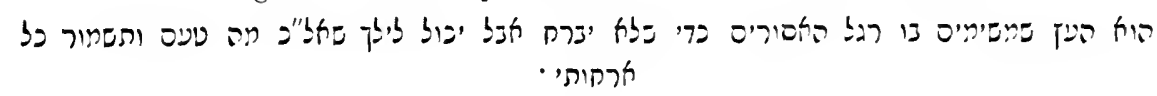

"'That [is] the [block of] wood, in which they put the feet of [every one of] the prisoners, in order that he may not run away; but, nevertheless, he is able to walk about, for if [it be] not so (if by $\urcorner$ be not meant, a block or clog of wood), what [would be] the meaning of, "And that Thou shoulde'si watch all my jaths'?" 
Tקת THEY imprint themselves. The Auth. Eng. Vers., as well as all other translations, which we have consulted, makes this verb refer to God; by doing which, however, a transitive signification is given to a Hithpa-âl.

Ver. 28.

We must confess that we are quite amazed at the manner in which 5 ? been handled by all the Commentators and Translators, we have had the opportunity of consulting. The translators of the Auth. Vers. render it, and he, without telling us to whom the pronoun refers. Others say it refers to Job himself, and that he speaks of himself in the third person. Others would make it refer to man generally. Others, again, would transpose it to the next Chapter, which, comparatively speaking, is not half so bad. But we cannot see why it

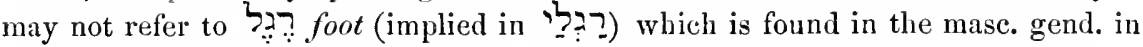
Jer. xiii. 16 ; and surely, a man. who was full of sores from the sole of his foot to the crown of his head, might well say that his feet, unable to support their vitality on account of the pressure exercised on his ankles by the tight grasp of the stocks, were wasting away "like a rotten thing."

That a sing. pron., referring to a plur. noun, individualizes the objects comprised in the plur. noun, must be known to every one at all familiar with the Hebrew language, as it is of very frequent occurrence. We have already had occasion several times to notice this construction.

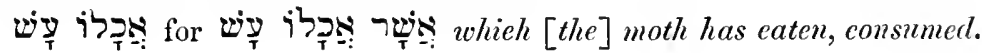

\section{CHAPTER XIV.}

Vers. 1-4. Man-born of woman, short of days, yet full of trouble, (Ver. 2) Cometh forth like a flower, and is cut off ; yea, he fleeth like the shadow, and abideth not. (Ver. 3.) Even npon such an one. So low, so abject, and so shortlived, a creature. Dost Thou open Thine eyes, and $\mathrm{m} \mathrm{E}$ wilt Thou bring into judgment with Thee? (Ver. 4.) Oh, that, from an unclean-thing, a clean-thing could come out! Oh, that a man could be born sinless of sinful parents! Not one. Ever will. The Psalmist says, Ps. li. 5, "Behold, I was shapen in iniquity; and in sin did my mother" conceive me," and from the present verse, it is evident, that Job was fully aware of this great, though sad, truth. He wishes it 
had been otherwise, but has no hope it ever will be so, and is, therefore, amazed at God's dealing so severely with a creature "shapen in iniquity, and conceived in sin." The Auth. Vers. translates this verse, "who can bring a clean thing out of an unclean? Not one," and in a similar way, it is rendered by many others. We could not, however, bring ourselves to adopt this translation, and for two reasons. First, the phrase is? though of very frequent occurrence, is never used excepting in an optative sense, like the Latin utinam; and secondly, to say, that no one can bring out a clean thing from an unclean one, would, we fear, in some manner, be limiting the Omnipotence of the Almighty.

Ver. 3. $\mathrm{Ni}$ is not to be taken here in its usual demonstrative sense of this, but in the descriptive one of such; i.e., such an one as here described. Comp.

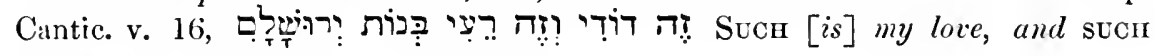
my friend, $O$ daughters of Jerusulem!

Vers. 5, 6. If his days are determined, if the number of his months is with Thee. If they are known to none but Thyself. If Thou hast made his boundaries, that he cannot pass them. (Ver. 6.) Then, at least, look away from him. Be not thus ever on the watch for any little error he may commit, but rather look with indulgence on his faults, so that he may cease to suffer, until he shall be pleased with his last day, as an hireling. Just as a hireling, who, having engaged to work with his master for a certain time, is pleased, when the last day of that period arrives, so let man pass through his career comfortably, and without suffering, until, owing to old age, and the infirmities inseparable from it, he shall look forward with longing to his approaching end.

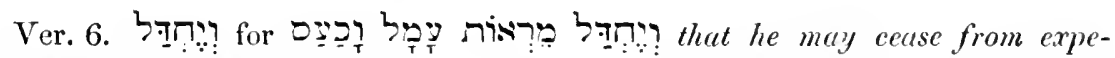
riencing trouble and vexation.

ini his [last] day. Comp. Ps. xxxvii. 13, "Jehovah shall laugh at him, for He seeth that ivi his last day is coming." So 1 Sam. xxvi. 10, "Or, ini his last day will come, and he will die." Also, infra xv. 32, "It will come to an end ivi when his last day slall not yet be," (i.e., even before his last day slaall come.)

Vers. 7-12. Having bewailed the short duration of human life, as well as the miseries, which attend it, Job now liments, that 
there should be no hope whatever for man beyond the grave. He says:

Surely, there is hope for the tree, though it be hewn-down, that it will again flourish, and that its branch will not fail. (Ver. 8.) Though its root uax old in the earth, and its stem die in the ground; (Ver. 9) Yet, through the scent of water, it will bud, and produce a bough, like a young plant. (Ver. 10.) But when a man dieth, after he hath been ill, when a man expireth, then, where is he? (Ver. 11.) The waters will have failed from the sea, and the river have wasted, and become dry. (Ver. 12.) And yet the man, who hath lain down, will not arise. Sooner will the sea and the large rivers waste and dry up, than the dead arise from their graves. Till the heavens are no more, will they not awake, nor be aroused from their sleep. 'Their sleep is for eternity.

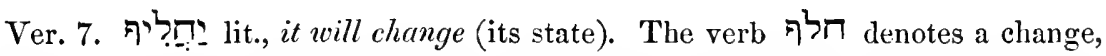
either of place, or condition; when of condition, the change may be either for the better, as Isa. xl. 31, "and those, who wait for Jehovah, 15? ?-:- will change (for the better ; i.e., renew) their strength ;" or for the worse, as in Isa.

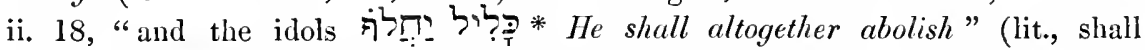
make to change (their state), i.e., shall make them pass from existence into non-existence. When this verb has reference to a plant or tree, it is generally used in a good sense, to denote, namely, that, from being leafless, and withered,

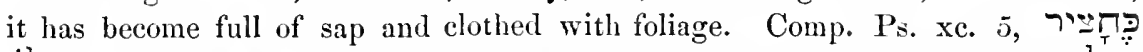

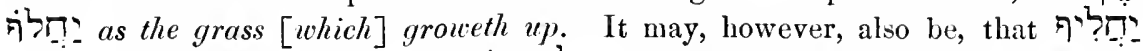
in the verse before us stands for by which of course would be meant its sap.

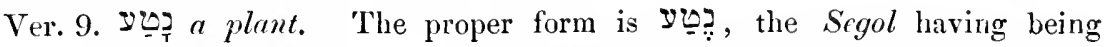
changed into a Kawmets by the panse. Wolfssohn, however, considers it to be a verb, and comments upon it as follows :-

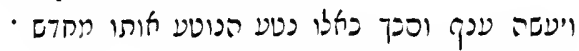

"And it will produce a branch and foliage (lit., a shed,) as if the planter lad planted it afresh."

Ver. 10. win? after that he has been ill. This word is quoted by Kinchi, in order to prove, that the 1 which converts the future into the past, has in addition the power of making a future tense refer to a past time, antecedent to the time referred to by another verb preceding it, and, in accordance with his

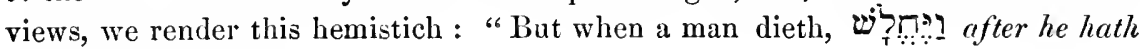
previously been ill."

As Kimchi adduces, in proof of this power of the I conversivum, several other passages from Scripture, and, as, before Mason and Bernard's Grammar

* See our note on this word, supra xi. 10. 
was published, very few in this eountry, if any, seem to have known anything about what he says upon the subject, and certainly not those, who have published Hebrew Grammars, we cannot help thinking, that we shall be rendering the Hebrew student a service, by quoting from the מכלול, and translating, his remarks on this most important feature of the 1 conversivum. They are as follows :

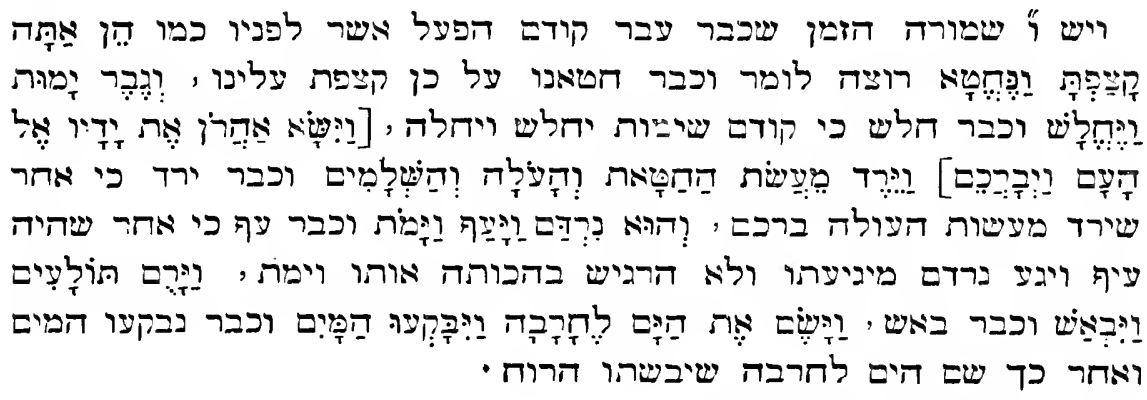

"And there is a ' which points to a time that luas already past before [the aetion expressed by] the verb that is before it, 'Behold, Thou ( S $_{\mathrm{r}}$ ) hast been

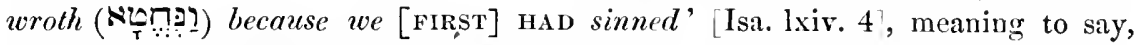
For we HAD previonsly sinned [and] therefore Thou hast been wroth against us :

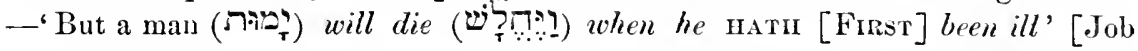
xiv. 10], [meaning to say] 'when he IIATH previously been ill, for before that he will die he will be taken ill and be sick : - '

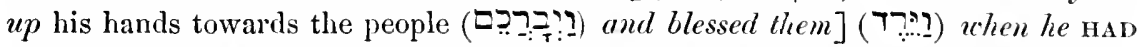
[FIRst] come down from offering the sin-offering, and the burut-offering, and the peace-offerings' [Lev.ix. 22], [meaning to say] When he In D previously come down, for after that he had come down from offering the sin-offering [then] he

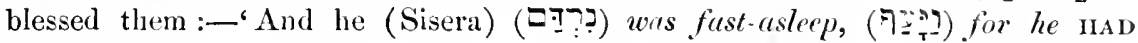
[previously] been [eery] tired, so he died ' [Judg. iv. 21], [meaning to say] Seeing that previously [to going to sleep] he mav been [very] tired; for after that he was [very] tired and weary he went fast to sleep by reason of his wearines;, and so he did not perceive her smiting him, and died:-“(ロ???) And it (the

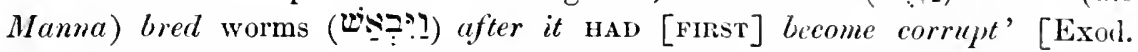
xvi. 20], [meaning to say] that it HAD previously [to producing worns] become

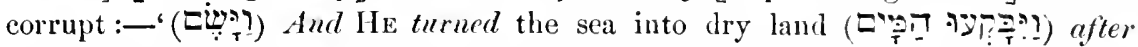
that the waters WERE [FIRsT] divided [Exod. xiv. 21],' [meaning to say] that the waters wene first divided, and afterwards He turned the sea into dry land, for the wind dried it up."

Vers. 11, 12. 'These two Verses are thus translated in the English version:

"As the waters fail from the sea, and the flood decayeth, and drieth up : So man lieth down, \&c.;" and the authors of all the other translations we have eonsulted, English, German, Freneh, Latin, \&e., with one exception, take the figure in the same sense, though some of them, having seemingly felt the absurdity of making the sea, and a river, sueh as could stand in parallelism with the sea, fail, and be dried up, thought to remedy the evil by rendering $\mathrm{E}_{\mathrm{T}}^{\prime}$ pool, or lake, 
altogether overlooking the simple way of explaining the passage, which we have followed, and by which as beautiful a figure is obtained, as ever was offered by a poet. Wolfssohn, alone, has understood it as we do, though we did not borrow the idea from him.

Vers. 13-15. To these three verses, we crave the reader's particular attention, as, in our humble opinion, they irrefragably prove our assertion, that Job was aitogether unaware of any future state of existence. For here he says in plain language, that were there but the least chance of his existing in any other state, at any future time after death, he would resign himself patiently to the sufferings he is now undergoing. But, as, up to the close of his last discourse, we shall hear him constantly complaining and murmuring, and that in even stronger terms than he has hitherto employed, he must needs have been quite settled in his conviction, that death would effect his complete annihilation. He says:

Oh that Thou wouldest hide me in the pit (grave), that Thou wouldest conceal me there, till Thy wrath be past! Would that my descent into the grave did not bring with it my complete annihilation, but that, instead of ceasing to exist, I were only to be kept there until such time as Thine anger should be appeased! Would that Thou wouldest appoint me a set-time, when Thou wouldest again remember me! Would that my inprisonment in the grave were only for a fixed period, no matter how long, if I but knew that a time would ultimately arrive when Thou wouldest again remember me! 'Then would I patiently and calmly resign myself to 'Thy will, as long as I was in this world, in confident hope, that there would come one day, indeed, when my sufferings would find their termination in the grave,--but another also, when the grave would again open, and I should once more live, as a one time corrected, but ultimately favourably accepted, child, before Thee! But alas, alas, will this ever be the case? (Ver. 14.) When man dieth, will he ever live again? No such thing. All the days of my life-time, only, can I hope (only, till my transition cometh). Only so long as I live in this world, only till the time when I shall pass over into the region of the dead, can I hope, that (Ver. 15) Thou wilt call, and I shall anwer Thee. That Thou wilt condescend to interrogate me about the course of my life, and, by doing so, give me an 
opportunity of proving my innocence. Only so long as I am in this world, can I hope, that Thou wilt again long for the work of Thine hands. That Thy bowels will yearn after Thine own child, to whom Thou hast assigned so short a period of existence.

These three verses are of such great importance, that we hope to be excused, if, notwithstanding our somewhat lengthy comments upon them, we place them again before the reader in the way we would have them construed.

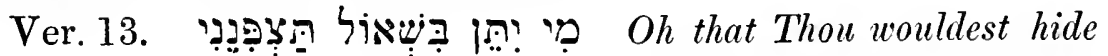
me in [the $\rceil$ pit (grave)!

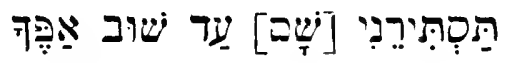

[That] Thou wouldest conceal me [there], till [the] turning [away] of Thine anger! (i.e., till'Thine anger have passed away!)

[That] Thou wouldest appoint for me a set-time, when Thou wouldest remember me! (i.e., that Thou wouldest confine me in the grave, only for a certain time, till it should be Thy divine pleasure to recall me into life! But will this ever be so?)

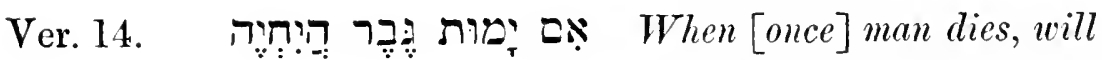
he live [again]? Certainly not, only

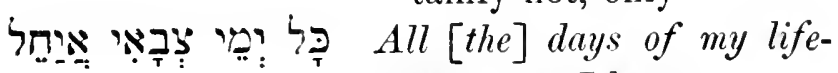
time, can I hope,

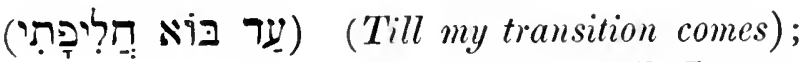
(i.e., only until I pass from this world into the grave can I hope,)

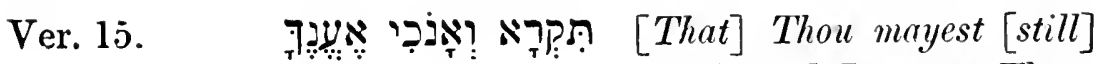
call, and I answer Thee; 
(i.e., that Thou mayest still give me an opportunity of proving my innocence to Thee,)

[That] Thou wilt [again] long for [the] work of Thine hands.

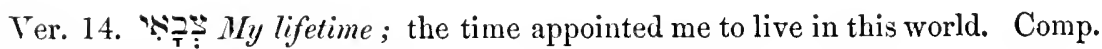
N⿳亠幺冖 supra vii. 1 .

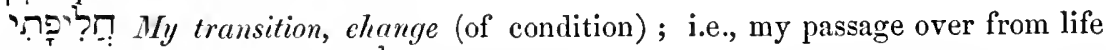
into death. (See note on 7? ?-, ver. 7.) It will be perceived that we take

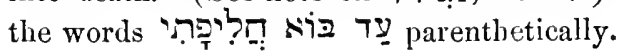

Vers. 16, 17. (Surely now, Thou numberest my footsteps. Thou notest all my movements, and resentest every little deviation from the path of rectitude. Dost Thou not watch over my sin? Dost Thou not keep Thine eye upon all my doings, so as not to overlook even the most trifling fault? (Ver. 17.) My trespass is sealed up in a bag. As a miser putteth his money in a bag, and setteth a seal thereon, that nothing may be lost, so dost Thou hoard up my trespasses. Thou patchest it (the bag) up to prevent the escape of mine iniquity. With such care dost Thou store up my iniquities in Thy bag, that, if Thou seest the slightest possibility of its giving way in any part, so that some of them might slip out and be lost, Thou immediately stoppest up the hole with a patch.)

These two Verses are evidently parenthetical.

Jarchi comments as follows upon the first hemistich of Ver. 17 :

$$
\text { סתם ומשומר בלרור בגר כבסף ומרגליות שלא תאבדי }
$$

"[It is] sealed-up, and kept, in a bag of cloth, like silver and pearls, that it may not be lost."

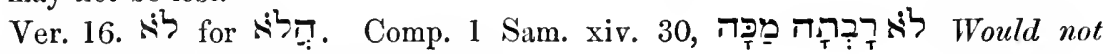
[the] slaughter have been greater?" \&c.

We quote the following from Schlottmann, on the second hemistich of this verse, and boldly appeal to the judgment of the reader, whether this commentator had any right to indulge in such far-fetched and unnatural, if not blasphemous, explanations, when the verse may be rendered so plain, simple, and intelligible, by merely prefixing the interrogative $\boldsymbol{\pi}$ to the negative part. $\boldsymbol{\Sigma}^{\prime}$, an ellipsis of which we have quoted an example here; and might have quoted many more, had we not 
feared that, by doing so, we should lay ourselves open to the charge of unnecessary prolixity. Schlottmann says, namely :- "Und wägest meine Sünde nicht $a b$. Dies nehmen wir mit Ewald als den wahrscheinlichsten Sinn der Worte

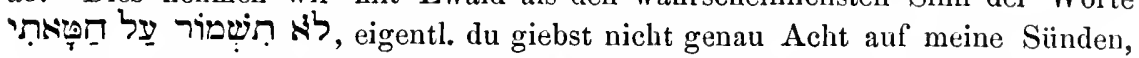
sondern nimmst sie mit einer gewissen Willkür für eine grosse Summe an."

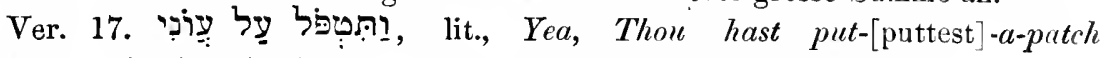
AGAINST mine iniquity, j.e., so as to prevent it slipping out of the bag.

Vers. 18-22. Having, in his present discourse (Vers. 5, 6) alluded to the limited duration of human life, the poet now, lest he should be misunderstood, and be thought to have expressed the wish that human life had no end, declares the contrary, saying:

But surely, a falling mountain must wear avay, and a rock may be removed from its place. Since, then, the most solid and lasting of the works of God, such as mountains and rocks, come to an end, how could frail man live for ever? But what I lament is this, that while, from the havoc and ruin which arise in the inanimate world, through the strife of the elements, there generally results some good, indeed, sometimes, very great blessings-this is by no means the case with man, when he is destroyed. (Ver. 19.) When waters have ground stones to powder. When an inundation occurs so violent, that the stones hurried along by it are, through their friction and mutual attrition, ground to powder (an inundation, therefore, attended with great devastation and havoc), there is generally (especially in Egypt) great hope that the ground will thereby be enriched and fertilized to such a degree, that the soil of the earth will abundantly overflow with its second crops. That the following harvest will be so rich, and the ears so large and full of grain, that an after-crop will spring up of its own accord. Whereas, the hope of frail-man Thou hast destroyed. As soon as he is removed from this world, no trace is left of him, and no good can possibly come out of him. Neither is there any hope left for him, but, on the contrary (Ver. 20), Thou overpowerest him for ever, after he is gone. There is no chance at all left of his ever being productive of any good. He changeth altogether his appearance, after. Thou hast despatcher him. When mountains fall, or rocks are rubbed away, their particles still remain the same; but, when man dies, skin, flesh, blood, and sinews, all are transformed into mould, bearing no resemblance whatever to what 
they were during his life-time. Feeling and sensation cease at the same time, pleasure and pain, joy and grief, all die together with him, (Ver. 21.) So that his children may be numerous, yet he will not know it, or they may be few, but he will not perceive them. (Ver. 22.) Only as long as his flesh is upon him, can it feel pain; and only as long as his mind is with him, can it moum.

The verses before us should be construed thus :

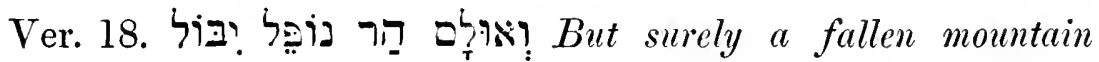
must wear away,

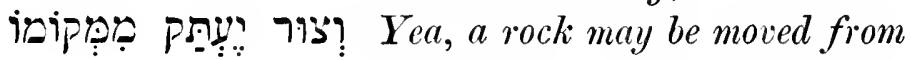
its place. (So that everything in this world is transitory, and therefore, man; but it is heartrending to know, that)

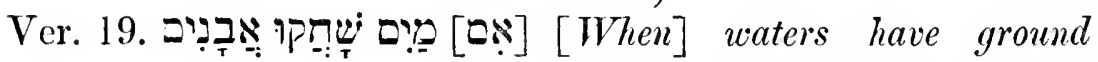
stones to powder (hope may be fairly entertained that)

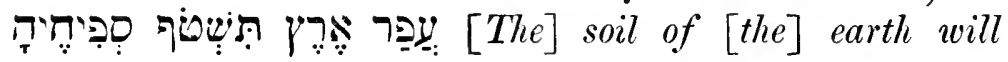
overflow [with] its second crops (so that ruin itself carries with it the elements of blessings ;)

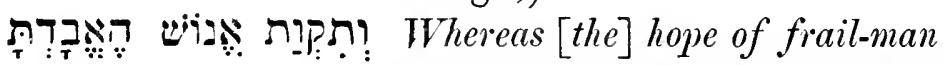
Thou hast [utterly] destroyed (so that no hope whatever can be entertained with respect to him ;)

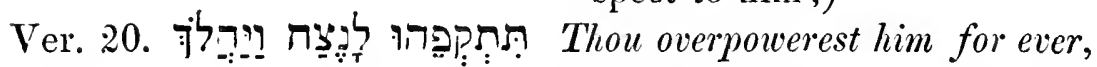
after he is gone.

\&c., \&c.

Ver. 19. x. 22,

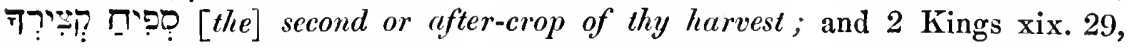
Isa. xxxvii. 30, where meaning of what grows of its own accord, i.e., after-crop, second crop.

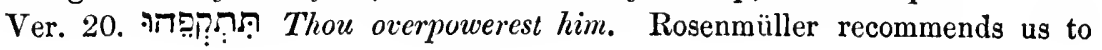


consider it as put for iב תרֶ, but we should like to know what occasion there is for this. The verb רקר occurs only three times, viz., here, infra xv. 24, and Eccles. iv. 12 ; and in all these instances is found with an objective pronominal affix, and not with a preposition.

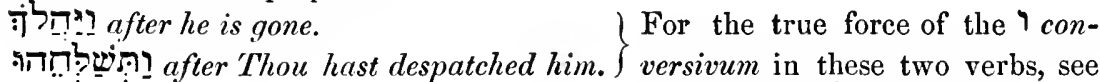
our note on wirn?!?, ver. 10.

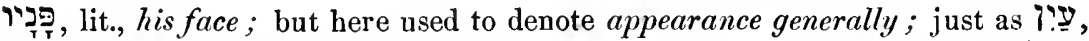

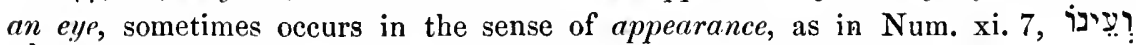

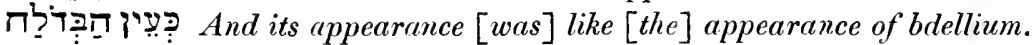

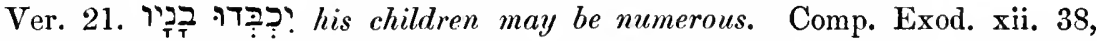

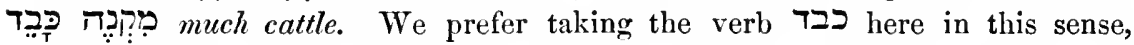

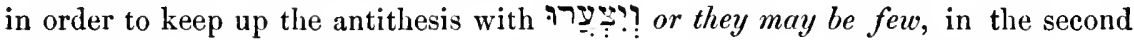
hemistich. We are glad to see Kimchi is with us, though we cannot deny that equally great authorities favour the translation given in the English Version.

Ver. 22. Before the word stood, and the same words should be supplied in the second hemistich.

\section{CHAPTER XV.}

Vers. 2-6. Should a wise-man utter windy thought [s], and fill his belly with the east-wind? (Ver. 3.) To reason on a matter which cannot profit, and that with words wherewith one can do no good. 'To reason about afflictions, which are sent by God, is in itself altogether absurd, as the sufferer cannot expect to remove them by his reasoning; if, however, he must complain, he should accompany his complaints with prayers and supplications to Him from whom his sufferings come, when haply He might be moved to pity; and not use harsh words, from which no good can possibly result. But not only is such reasoning idle and useless, it is positively mischievous. (Ver. 4.) Yea, thou sappest the fear of the Almighty, and takest away prayer before God. 'Thou settest a bad example. Since, in the days of thy prosperity, the people used always to look up to thee, as to their leader and instructor, they will of course not fail to note how thou bchavest now that 
affliction hath been sent upon thee by God; and, hearing thee indulge in grumbling, murmuring, and cursing, instead of seeking help in prayer, they will naturally be led to conduct themselves similarly under similar circumstances. (Ver. 5.) Surely, thine own mouth teacheth thine iniquity. Appriseth and informeth us of thine iniquity. Although thou hast chosen the language of the crafty. Even though thou avoidest saying in plain words that there is no God, this will avail thee very little; for, if thou maintainest that God does not care how things go on in this world, but allows the wicked man to do what he likes with impunity, thou dost in reality deny the providence of God, and, consequently, declarest thyself, in spite of the gloss thou givest to thy speeches, by expatiating upon the power and wisdom of God, to be neither more nor less than an atheist. (Ver.6.) Thine own mouth condemneth thee, and not $I$; and thine own lips testify against thee. Do not, therefore, say, "My brethren have dealt deceitfully" (supra vi. 15); it is not thy friends who condemn thee, it is thine own mouth, thine own lips.

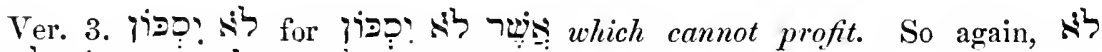

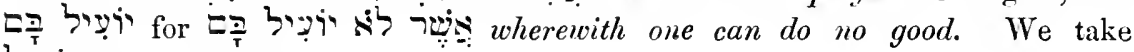
'יוֹצי to be impersonal.

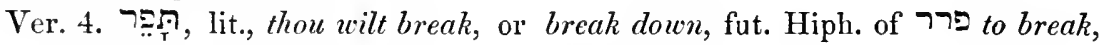
destroy, \&c.

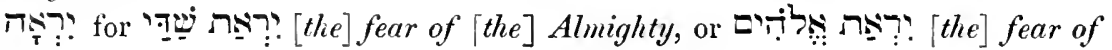
God.

Vers. 7-16. Wast thou, O man. O Job. First made? Before all other men. Or wast thou formed before the hills? Job, having said (supra xii. 12), "With the aged then will be wisdom, and with length of days understanding," his friend now asks liim whether he had lived before the world began, that he esteems himself so wise. (Ver. S.) Didst thou hear the counsel of God? When He communed with the sons of God, who assembled round Him, to celebrate in chorus the creation of the world. (Comp. infia xxxviii. 7.) Or. hast thou takin auday wisdom to thyself? So as to leave none for any one else. (Ver. 9.) What knowest thou, that we know not? What dost thou understand, which is not with us? Which is beyond us. It will be scen (infia xriii. 3) that, in the discussion carricd 
on between Job and his friends, he is not always regarded as a single individual, but rather as the representative of the party whose views he holds, that of the philosophers, namely, who wish to understand, and account for, everything ; while his friends, on the contrary, represent the orthodox party, whose principle it is to declare everything that comes from God good and right, whether it be comprehensible or incomprehensible to the human intellect. Hence the plural Bildad (though speaking to Job alone) in the chapter alluded to, that is, in the eyes of you philosophers. In like manner, in the verse before us, Eliphaz says (Ver. 10), Both grey-headed, and very aged, men are amongst us. Amongst us orthodox people. Men, that number more days than thy father. (Ver. 11.) Are our powerful consolations too little for thee? We have offered thee many powerful and efficacious consolations; we have told thee more than once, that thou hast only to humble thyself before thy Maker, and to acknowledge His justice, and He will not fail to extend to thee once more His mercy. Is this then too little for thee? Hast thou tried and followed our advice, and been disappointed? By no means; nay, hitherto, thon hast only given way more and more to passion, and hast vented thy spleen in expressions altogether insulting to God. To be sure, our consolations being powerful, were naturally couched in powerful language; we have spoken boldly and fearlessly, as became old and sincere friends; but, on the other hand, W'as there any gentle word with thee? Hast thou spared us more than we thee? Hast thou been more measured in thy terms towards us than we towards thee? Were we not called by thee "patchers up of lies, worthless physicians?" (See supra xiii. 4.) Where, then, is thy claim to leniency on our part? (Ver. 12.) Why should thine heart carry thee away, and what do thine eyes wink at? What is meant by those terrible hints thou throwest out about the nonexistence of a Providence, and about this world's being left to mere chance, without a supreme superintendent? (Ter. 13.) That thou shouldest turn thy spirit against God, and bring forth such words from thy mouth. (Ver. 14.) What is firail-man, that he should be pure; or he that is born of a woman, that he should be just! (Ver. 15.) Lo! He hath no confidence in His holy-ones, and the 
heavens are not pure in His eyes. (Ver. 16.) Much less, that abominable and filthy being, man, which drinketh iniquity like water. Which thirsteth after what is iniquitous and wicked, like one that is parched with thirst after water.

Ver. 7. The first hemistich of this verse must be construed as though written :

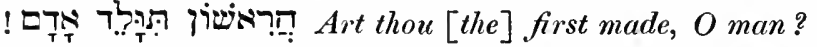

We gratefully acknowledge that we are indebted to Herz Homburg for this ingenious rendering. All the other commentators, we are not a little surprised to find, translate to have this meaning, should stand thus :

The verb ליר in Niph. literally means to be born, but, as this cannot be said of the first man, we have preferred translating it to be made, or produced.

Ver. 8. הברסוֹ, lit., whether [the] counsel, the ב being either pleonastic, or the mark of the object. case. See note on

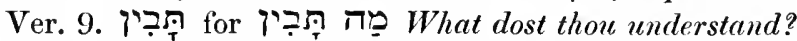

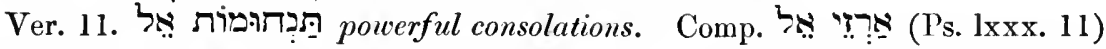
mighty cedars. We could not possibly follow the usual translation, viz., consolations of God, as it would be, in our opinion, in the highest degree absurd to tell an unfortunate sufferer, who had complained of the continual renewal of his sores by God, that he was receiving consolations from Him.

ט.

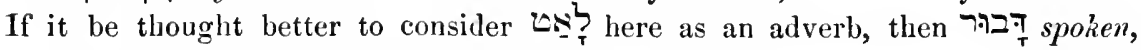
should be understood after ${ }_{\tau} \underset{T}{7}$ a word gently spoken.

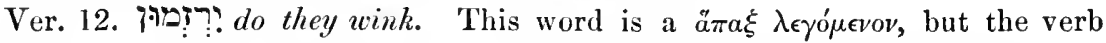
im, in the same acceptation, very frequently occurs in the writings of the Rabbins.

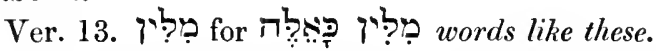

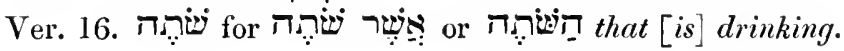

Vers. 17-21. I will shew thee; listen to me ; I will declare, both that which I have seen, and also (Ver. 18) That, which wisemen tell (without concealing it), as having received it from their fathers. (Ver. 19.) (To them, alone, the land was given, and no stranger passed among them.) I am going to relate, both what I have learned from my own experience, and also what I have heard wise men say, freely and without reserve communicating all that they had learned from their fathers. These, having lived in a happy age, when their country was not disturbed by foreign invasion, were enabled accurately to observe the course of things in this world, and their testimony may, therefore, be received by thee with implicit reliance. 
And the result of their experience, as well as that of my own, is, that (Ver. 20) All the days of the wicked-man, he is tormenting himself. With gloomy presentiments. And, that, during the number of years, which are laid up for the tyrant, (Ver. 21) There is a dreadful voice in his ears, telling him, that in peace even. When he has every reason to think himself secure and safe. A spoiler will come upon him.

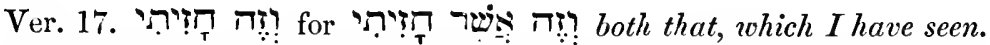

II I I will even declare, the See note on

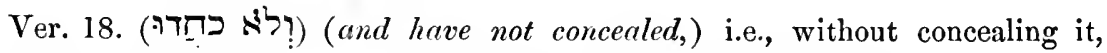
without reserve. These two words should be taken parenthetically.

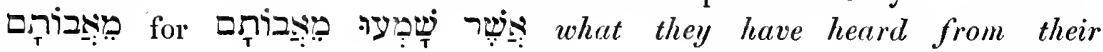
fathers.

Ver. 19. The whole of this verse should be taken parenthetically.

Ver. 20. The second hemistich of this verse should be connected with the first of the next. (See note on $\mathrm{N}_{\mathrm{T}}$ ' supra vi. 29.)

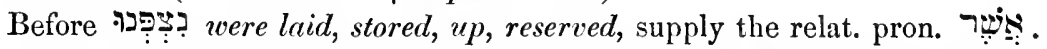

Ver. 21. After understood.

Vers. 22-24. He doth not believe, he will return from darkness. That he will ever be able to extricate himself from the gloom and misery, which will be his lot. Seeing that he is watched by his fate for the sword. He is impressed with the belief, that his fate is watching him very closely, ready to smite him with the sword, and he is therefore afraid to venture ont from his dwelling. If at all (Ver. 23) IIe doth stir abroad, it is to ask for bread, saying, "Where is it?" Nothing but urgent hunger can induce him to go out, because He knoweth, that the day of durkness is ready at his hand. He is aware, that his doom is sealed, and his end is close upon him. (Ver. 24.) Trouble and calamity affiright him; it (calamity), like a mighty and irresistible king, will overpower

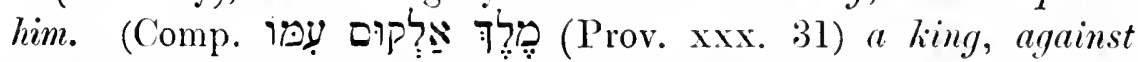
whom [there is] no rising up;) he is destined for its ball. He is destined to be incessantly tossed about by calamity, like a ball. (Comp. Isa. xxii. 18, where Shebna, the treasurer, is told, that God will surely violently turn and toss him like רכּ $a$ ball, \&c.) 


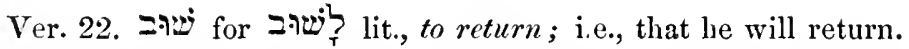

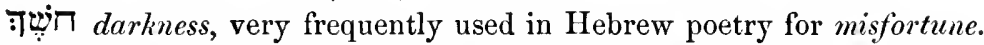

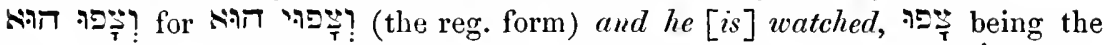

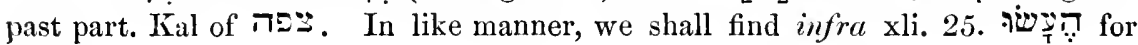

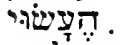

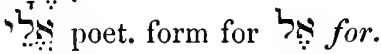

Ver. 23. The first hemistich should be construed as follows :-

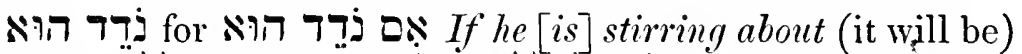

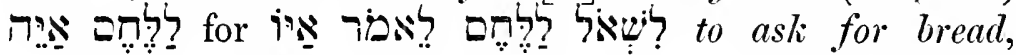
saying, Where is it? Where can it be had?

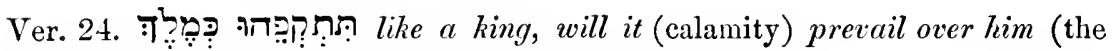
wicked man); he will be utterly unable to stem its torrent.

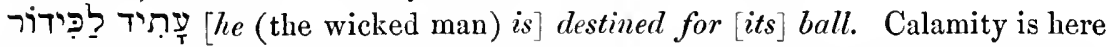
personified (just as in Lament. iii. 1-13, affliction is represented as a tyrant, with a rod of wrath in his hand, \&c.) [See Mason and Bernard's Grammar, Letter xlvii. P.S. (c)]-and the wicked man is described as destined to be tossed about by it, like a ball. (The reader is again referred to Isa. xxii. 18, quoted above.)

That 2 is only another form of רִידוֹ just quoted from Isaiah, is admitted by Kimchi, as well as by Ben-Zev, though neither of them take it as we do; Kimchi, quoting the opinion of some, who consider it to be figuratively used for a military movement performed in a circle, while Ben-Zev offers several other views which our space does not allow us to quote. We appeal, however, to the judgment of the reader, whether we ought to indulge in such fanciful explanations(?) when the verse can be so well construed and understood without them. We said, indeed, at the very beginning of our commentary, that no reliance should be placed upon the accents in this book, still there can be no harm in observing, that the $\$, \supset \supset(1)$, after the word דִִִּ quite agrees with the manner in which we divide the second hemistich of this verse.

So many strange things lave been said, by commentators, on this verse, that we may be well excused for quoting here the opinion of Jarchi ; which is, that

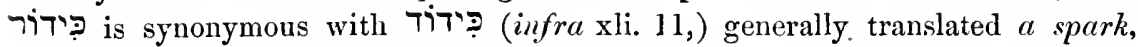
but which he seems to have taken to mean, $a$ flame. That the letters $\neg$ and $T$ sometimes interchange, is proved by him by the proper name ריפָר (Gen. x. 3,)

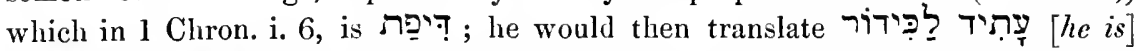
destined for the flame, and his opinion might be supported by what is said of the fate of the wicked man, infia xx. 26, "A fire not blown shall consume lim." The two words in question, however, should, by no means, be applied to the king, as it is by Jarchi, but only to the wicked man.

Vers. 25-28. But, whence comes that panic terror, which has befallen him ? Why has he all at once become so cowardly, as not to venture out from his place, excepting when driven by the 
pangs of hunger? It is because he is conscience-stricken, because he knows that he deserves terrible and unheard of punishments; Because he hath stretched out his hand against God; and strengthened himself against the Almighty. . Because he has defied God, just as he defied his rivals and adversaries. (Ver. 26.) He used to run against Him, with neck erect. Proudly, with defiance in his looks. With the thick bosses of his shields. Shielded as he was against the weapons of his foes, he thought himself proof also against the "arrows of the Almighty," against all punishments from on high. (Ver. 27.) Because he hath covered his face with his fatness, and made him rolls-of-fat upon his flank $[s]$. By gormandizing and stuffing himself with dainties, without leaving the least morsel for the poor, he had "waxen very fat," and, as a consequence, had grown very proud. So the Psalmist says of proud and wicked tyrants (Ps.xvii. 10), "They are inclosed in their own fat, with their mouth they speak proudly." Again, he had been very proud of his conquests, of the victories he had obtained over his enemies, of the devastation he had carried into their territories, of the cities he had laid waste; installed in his tent, and surrounded by his numerous retinue, he had looked down with pride and arrogance upon the ruins, which he thought would hand down his name and fame to the latest generations. (Ver. 28.) And because he hath dwelt among ruined cities, amongst houses, which man could no longer inhabit, which were destined by him to be eternal heaps. Therefore he thought he had immortalized his name, and that the pages of the latest historian would be filled with his heroic deeds.

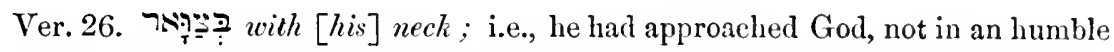
position, as the Psalmist exhorts us to do, saying (Ps. xev. 6), "O come, let us worship and bow down : let us kneel before Jehovah our Maker," but in a proud and arrogant manner, with his neck erect. We are really at a loss to understand what the authors of the Eng. Vers. can have meant by their translation of this passage : "He runneth upon him, even on his neck."

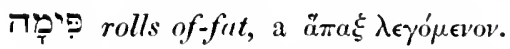

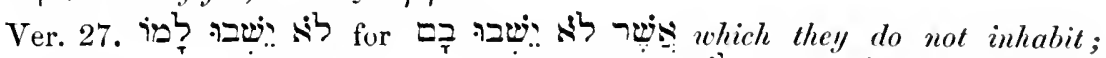

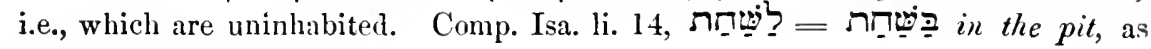
translated in the Auth. Vers.

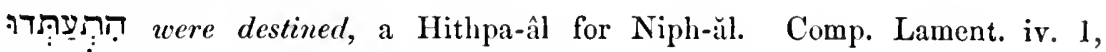

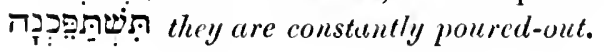


Vers. 29-30. But how vain are the calculations of the tyrant, inflated though he be with pride and arrogance, in consequence of his successes! How futile are his plans! How easily are they rendered fruitless by the decrees of Providence! The destructions he caused will one day come to a perpetual end, the cities he laid waste-even the memorial of them will perish ; * the spoils he carried off, the treasures he hoarded up, what will become of them? Will they be lasting? Will he continue to enjoy them for any length of time? No, he shall not be rich, and his wealth shall not endure; neither shall his (lit., their) achievements extend on the earth. The fame of his victories and heroic deeds shall not spread, they shall not be spoken of, or even remembered, long. (Ver. 30.) He shall not depart out of darkness, a fame shall dry up his tender-branch, and he shall depart from life in one breath of his mouth. Though so stout and strong, and in the enjoyment of such perfect health, he will suddenly drop down, and, with one gasp, expire.

Ver. 29. פִִ lit., their accomplishment; i.e., the great deeds they have accomplished, or achieved, their achievements. The absolute form of this word is not to be met with in the Bible, but would seem to be מִכְל and to be derived from the verb כל כo finish, to bring to an end, itself found only in

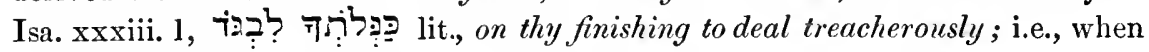
thou hast ended thy treacherous dealings.

It will be perceived, that the poet, instead of speaking of the wicked tyrant in the sing. numb., as he has hitherto done, says referring to tyrants in general. Changes of person and number in Hebrew are of very frequent occurrence, particularly in this book. So Wolfssolın observes on the word before us:

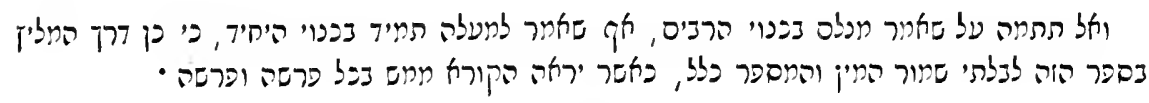

"And do not marvel at his saying, מכנל with a plural affix, although he above has constantly spoken with a singular affix, for this is the manner of the poet in this book, to pay no attention whatever to gender and number, as the reader will actually perceive in every section."

Vers. 31-35. Let him that hath been led astray. By his wicked propensities. Have no confidence in that which is vain, for vain also will be his reward. (Ver. 32.) It (the reward) will-come-toan-end before his last day, so that his branch will not be flourishing.

* Comp. Ps. ix. 6. 
(Ver. 33.) He will shake off his unripe-grape, as the vine, and, as the olive, will he cast off his blossom. (Ver.34.) For the community of the hypocrite shall be cheerless, and fire shall consume the dwellings of bribery. The dwellings, in which bribery has been practised. (Ver. 35.) He conceived mischief, and so he shall bring forth evil. For himself. Yea, their belly. Their inward parts, their mind. Prepareth their own deceit. They deceive themselves with exaggerated ideas of their own greatness, and this overweening pride of theirs will lead to their ruin.

Ver. 31. The first hemistich of this verse should be construed thus:

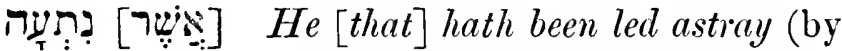 wicked propensities, or self- delusions).}

政 Let him have no confidence (according to the Kree) $\mathrm{N}$ - in that which $[$ is $]$ vain ;

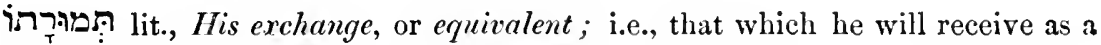
reward from the vanity in which he placed his confidence.

Ver. 32. See note on isiv supra xiv. 6.

Nלִ lit., it (the reward he will receive) will become full; i.e., will come to an end.

Ver. 34. has been practised.

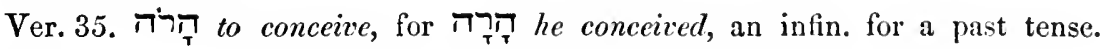

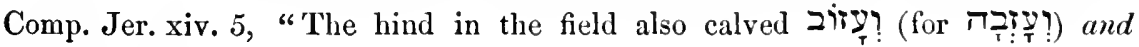
forsook (it)."

?ִ infin. for a past tense, which, in this instance, is converted into a future by the $?$.

产 lit., their belly; the poet, again, changing the number from the sing. to

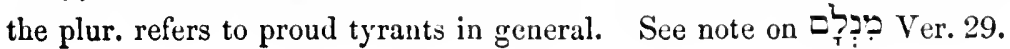




\section{CHAPTER XVI.}

Vers. 2-6. I have heard many such things. I have often heard evil prognosticated to the wicked man, but I have very rarely seen such prognostications realized; it is very easy for you to predict all sorts of calamities, as sure to befall him, but it would by no means be so easy to adduce instances, in which such have really befallen him. Troublesome comforters are ye all. (Ver. 3.) Will there ever be an end to windy words? Will you ever cease adducing such futile reasons? Or what emboldeneth thee, that thou shouldest answer? Is it thy belief in the excellence of thy arguments? If so, undeceive thyself, thy arguments are so utterly miserable, that, if thou hast no others to advance, if thou canst bring no charge against me, to prove that I suffer justly, it were a great deal better for thee, not to speak at all. (Ver. 4.) Should I also speak as ye do, if ye were in my place? If I were to see you suffering as unjustly, as you see me, should I impute it to you as a crime, if you complained of the injustice done you? Should I say, that your own mouth condemned you, that your own lips bore witness against you, that your own mouth taught your iniquity? (Supra xv. 5, 6.) Should I aggravate your pain, by treating you with injustice, though I saw you already smarting with the sense of that done you by another? No, I could not be so cruel; but rather would I join myself to you with my words. I should give you to understand that I entirely agreed with you, that you had great reason to complain; my words would be in unison with your words, as my heart with your heart; And I would move my head at you. I would express my sympathy and condolence. (Ver. 5.) I would either strengthen you with my words. Address you with words of solace and comfort. Or my moaning would restrain my speech. My grief would be so great, and my moaning so incessant, as entirely to prevent my speaking. But, as it is (Ver. 6), If I speak, my pain is not restrained, and, if I refrain from speaking, what part, or particle, of my pain departeth from me? I am now in that condition, that, if I do not gain anything by speaking, I at least know, that I shall gain equally little by holding my tongue. 
Ver. 3. ๆִיְ:- lit., will, or can, make thee strong; i.e., can make thee bold, embolden thee. WV have already seen the verb פרץ in Niph. in the signification of to be strong, powerful; in Hiph. of course it has a causative sense, to cause to be strong, make strong. See note on بִ supra vi. 25.

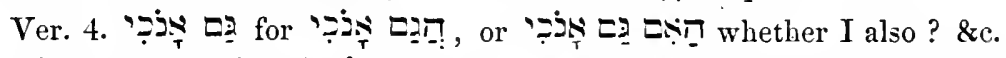

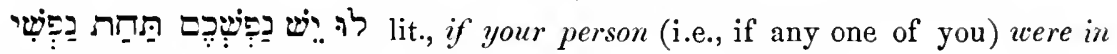
stead of my person; i.e., if any one of you were in my place:

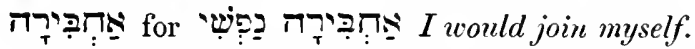

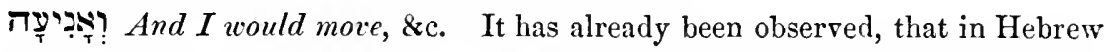
poetry the phrase, to move one's head at one, is not used exclusively to express derision, but sometimes also expresses sympathy and condolence. See note on לִ supra ii. 11.

Ver. 6. The second hemistich of this verse should be construed thus:

$$
\begin{aligned}
& \text { T'? Or, moaning (i.e., or my moaning) } \\
& \text { 习ंنr:- would restrain } \\
& \text { หฺ: my lips (i.e., my speech). }
\end{aligned}
$$

The noun בִ ביד is evidently dericed from the verb, amongst its many significations, has that of moaning, grouning. Comp. Jer. xxxi. 18, "I

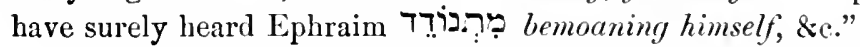

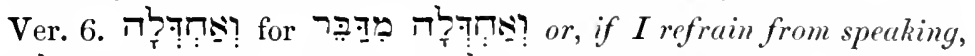

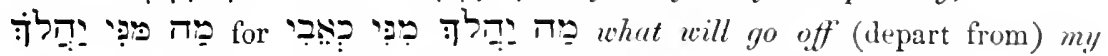

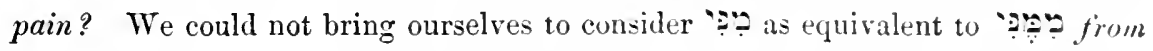
$m e$, as most seem to do, since then it should be pointed ?a as infraxi. 16; xxii. 18 ; but we take it to be the poetical form of $i ?$ (as in this very chapter, ver. 16, supra xv. 22, and in many other places), and supply after it the word

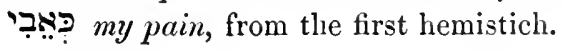

Vers. 7-9. Surely now, He (God, who will be named in Ver. 11) hath wearied me out. I am so exhausted, that I really scarcely know what I am about, and cannot therefore determine whether I ought to speak, or be silent. Thou hast destroyed all my company. The whole company of my children. The reader' will perceive, that there is a change of person in this verse; the poet, in the first hemistich, speaking of God in the third, and in the second, in the second person. Such changes are so frequent in Hebrew, partictalarly in poetry, that we could fill whole pages with examples; we shall, however, content ourselves with quoting one, viz., Judg. v. 31, where Deborah closes her song with the 
following words: "So shall perish all איקְּ Thine enemies,

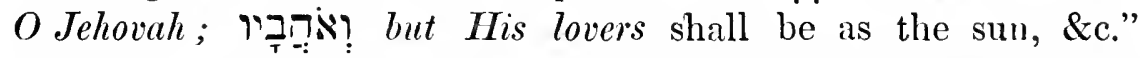
(Ver, 8.) And that Thou hast-made-me-full-of-wrinkles, hath become a witness against me. The very circumstance of $\mathrm{my}$ body having become covered with wrinkles, in consequence of my disease,* is considered by my friends as a witness, giving evidence of my guilt. So that my own leanness riseth up against me, and beareth witness to my face. The emaciated state of my frame is regarded by my friends as furnishing clear, palpable, proof of my guilt; for they cannot believe for a moment, that I should have been reduced to such a miserable and frightful condition, unless I had committed some crime to merit it. This sentiment the reader will recollect had already been expressed by Job (supra x. 17), when he said to God, "Thou renewest Thy witnesses against me," meaning thereby the fresh crops of sores, which were continually coming out, and were regarded as so many witnesses, rising up against him, to bear their testimony to his guilt, as was explained in our comment on the passage. (Ver. 9.) In His anger, He hath torn me to pieces, and hated me; He hath gnashed His teeth against me; like mine adversary, He sharpeneth His eyes against me. Just as I might expect an adversary of mine to do, He fixeth His eyes intently upon me, that none of my movements may escape Him.

Ver. 8. This verse should be construed thus:

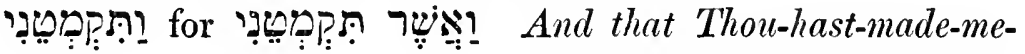
full-of-wrinkles (i.e., the very circumstance, that Thou hast made me full of wrinkles,)

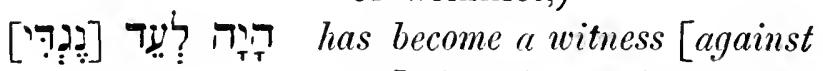
$m e$ ] (i.e., is considered, by those, who see me, to bear witness to my guilt);

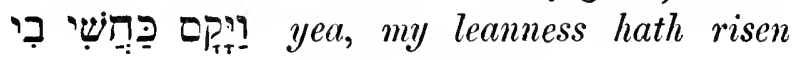
up against me,

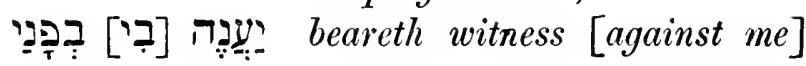

* The skin in Elephantiasis does become thickened and rugous. 
to my fuce (i.e., seems publicly to proclaim me a sinner, deserving unheardof punishments).

By way of amusing the reader, we will quote here Dr. Good's version of this and the preceding verse, together with a portion of his remarks upor them, in which, whilst his own views are propounded with a degree of modest assurance quite pardonable in one who shows such a very accurate knowledge of Hebrew, he pronounces the translation given in the Auth. Vers. (with which ours in substance agrees) to contain no definite idea! He translates as follows: "Here, indeed, hath he distracted me. Thou hast struck aghast all my witnesses. And hast cut off myself from becoming a witness. Yet my calumniator riseth up against me ; He chargeth me to the face." On these verses he observes: "This period, in conjunction with the ensuing verse, is supposed to comprise one of the most difficult passages in the whole poem : yet $I$ trust, as I have now rendered it, both verses are clear and easy; while at the same time $I$ have literally adhered to the Hebrew text. 'The perplexity is, incleed, that of the translators themselves, and not of the original writer. Our common version ...... gives no definite idea," \&c. This, we repeat, we quote merely for the amusement of the reader, for the comment and translation of one, who can say he has literally

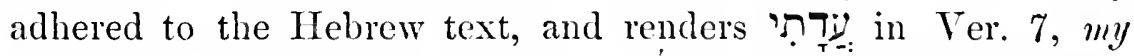

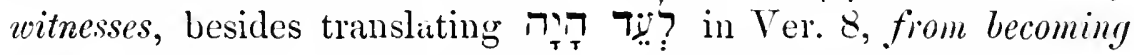
a witness, are of course unworthy of a moment's serious attention. 'The rest of his Commentary and Translation, as far, at least, as we have consulted them, are quite of a piece with what we have quoted above, everywhere displaying the same imperfect acquaintance with the first principles of Ilebrew Grammar; and yet, strange to say, the learned Doctor has his admirers, the boldness with which he puts forward his astonishingly faulty translations, making them, it would seem, pass current. Those who praise him, however, should be made aware, that, in doing so, they only proclaim to the world their own inability to detect the glaring blunders with which his pages are so thickly beset. 
Ver.9. 9פ for for in xxiv. 23) in [the] house of thy father. Comp. also

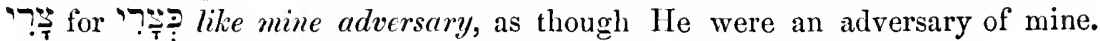

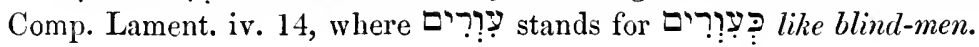

Vers. 10, 11. But not only do I suffer directly, through the indignation of God, I suffer also indirectly, and that very greatly, from the bad odour into which His indignation has brought me with men generally; for they, seeing that I am abhorred and abominated by God, think they must needs also regard me in the same light, and hence the constant persecution I suffer at their hands. They have opened their mouth wide against me. They pour out a continual stream of invectives against me. They have smitten my cheeks contemptuously. They assemble themselves together against me. They all to a man stand up and discharge their gall upon me. (Ver. 11.) God giveth me up to any worthless-man. Any vile fellow may now insult and trample on me with impunity. And overthroweth me by the hands of ungodly men. Besides the afflictions which He directly sends upon me, He overwhelmeth me also indirectly by placing me at the mercy of every wicked man that wishes to maltreat me.

Ver. 10.

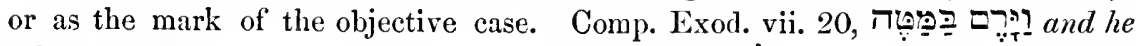

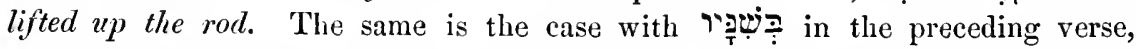
though the pleonasm is there less striking from the English idiom's admitting a with after the verb to gnash.

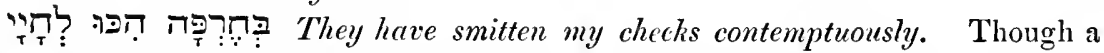
blow inflicted upon any other part of the body may be equally painful with one upon the cheek, or even more so, yet it is by no means so degrading. So the elegist says, Lam. iii. 30, "Let him give his cheek to him that smiteth him ; let lim be filled with disgrace ;" and so our Saviour, when enjoining on his disciples the highest degree of humility and self-denial, says (Luke vi. 29), "And unto him that smiteth thee on the one cheek offer also the other."

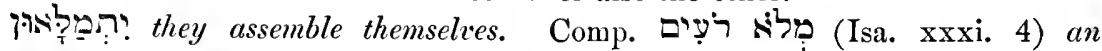
assembly of shepherds ; also Gen. xlviii. 19.

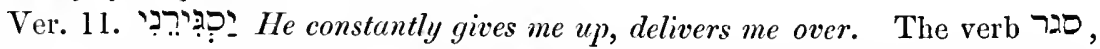
which in Kal signifies to shut, slut up, has in Pi-âl and Hiph-êl the sense of giving up, delivering over. So David said to Goliath, "This day הịin! T? ( 1 Sam. xvii. 46) will Jehovah deliver thee (into mine hand)" ; and in Ps. xxxi. 9,

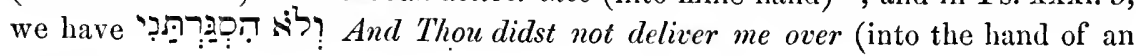
enemy). 
'?ִִִ He constantly overthrows me; fut. Kal of טר' to pervert, over-

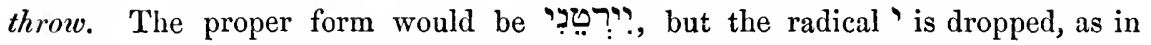

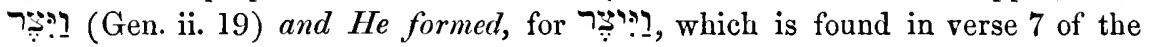
same chapter, and is the regular form.

Vers. 12-19. I was at ease, and He brake me in pieces; yea, He took hold of my neck, and dashed me to atoms, and set me up for a mark for Himself. As a mark for His arrows, or those of His archers. (Ver. 13.) His archiers encompass me; one cleaveth my reins and spareth not; another poureth out my gall upon the earth. (Ver. 14.) Again, one breaketh through me with breach upon breach. Just as in the case of a strong fortress containing great treasures, the besiegers endeavour to make as many breaches as they can in the walls, in order to get at the treasures, so here the archer breaches the outer defences of the body, that he may reach the vital parts. Another rumeth against me like an hero. Displaying his prowess, forsooth, in overcoming so frail a being as I am! (Ver. 15.) I have sewed sackcloth upon the-scab-of-mysores. A very irritating and galling application to an ulcerated surface. And I have defiled my horn in the dust. It is well known that קר: horn is used in Scripture to express strength, dignity, glory. Comp. Ps. cxxxii. 17, "There will I cause to spring up ip: a horn (for David);" and again, Ps. cxii. 9, "iq p. his horn (shall be exalted with honour)." The poet, then, here laments that his horn, that is, his dignity, has been brought down to the very dust. (Ver. 16.) My face hath become red through weeping, and the shadow-of-death is upon mine eyelids. (Ver. 17.) Not because of any wrong in my hands. 'These sufferings cannot have come upon me in consequence of any wrong I have done, nor of any disrespect on my part towards God, for My prayer also was pure. The prayers I addressed to Him in the days of my prosperity, and particularly at the time I offered up the sacrifices according to the number of my sons (supra i. 5), were not mere outward show, but were made in all sincerity of heart. (Ver. 1S.) O earth, cover not my blood! The unfortunate sufferer, looking upon himself as in process of being slowly murdered without a cause, implores the earth not to drink in his blood, so that, meeting the gaze of all passers-by, it may strike them with amazement and horror. We read in Gen. iv. 11, that the 
earth opened her mouth to receive the first innocent blood that had been spilt; but this Job entreats her not to do in the case of such innocent blood as his. And let there be no space for my cry! Every sound is, we know, produced by vibrations in the air, or other media; as far, therefore, as these vibrations extend, so far will the sound they give rise to be heard. Supposing, then, that one were to cry so loud, as that these vibrations should be propagated throughout all space, the cry would of course be heard everywhere; but this is not enough for the innocently suffering poet; his affliction is so great, so unheard-of, and so undeserved, that he wishes his cry may be loud enough to penetrate even beyond the limits of space. (Ver. 19.) Even now, behold, my witness is in heaven, and my testimomy is in the high-heaven. In spite of the terrible pain I suffer, and the burning indignation I feel at having to endure such torments undeservedly, the only charge to which my words can possibly lay me open is that, perhaps, of expressing my feelings too loudly and openly; I have indeed spoken from my heart, but I have done so to relieve my agony, and by no means with the intention of offending my God and my Maker.

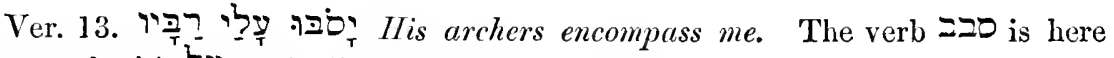
construed withı

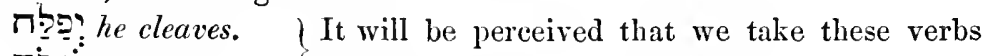

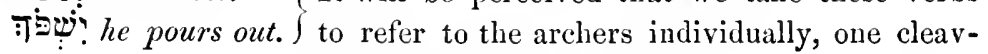
ing, another pouring out, \&c.

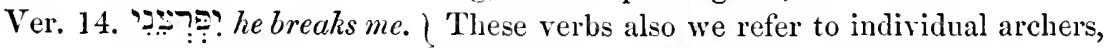
Y $\because$ he runs. $\quad \int$ instead of to God, as is usually done, since we

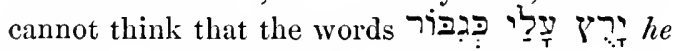
runs against me like a mighty-man, or a hero, can be fitly applied to God. In like manner, Mendelssolın, in commenting on Gen. xix. 9, where we have, in the same verse, "רan'? and they said, twice, the second time seemingly pleonastically (and where, moreover, Lot is spoken of, sometimes in the second, sometimes in the third person), makes the one refer to one part of the men of Sodom, assembled around Lot's house, and the other, to the other, translating, and [SOME] said-and [others] said. Again, in Mason and Bernard's Grammar, Letter 57, $\S 9$, the 9th verse of Prov. xxix. is translated thus: 
"A wise man contending with a foolish man,

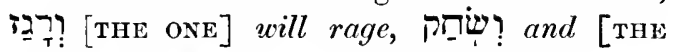
oTHER] will laugh, and there will be no peace."

Ver. 15. 'רִ בִלִ my seab; i.e., the scabs of my wounds. Instead of putting lint, or any thing soft, upon them, he put sackcloth, which would be very irritating. The noun בלד is only to be met with here, but, as in the Talmud it is used to express the scab, which forms on a sore, and this acceptation suits our text very well, we could see no reason for not adopting it. Thus we read in Mikvaoth, chap. 9,

\section{גליד שחוץ למכה}

"[the] scab which is outside of a sore."

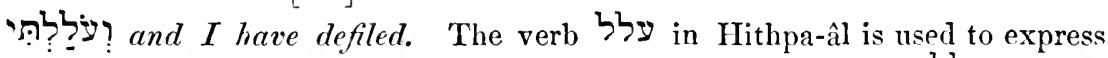

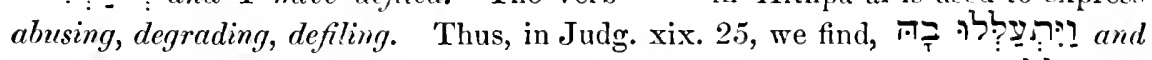

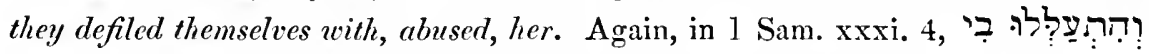
and may abuse me. We cannot see, why the same sense may not be given here to the Pi-âl; it suits the context admirably, and we are glad to see the Auth. Vers. is with us.

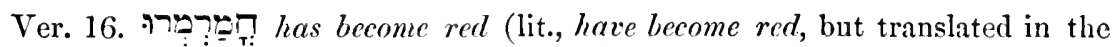
sing. because my face in English is sing., while the corresponding Hebrew "פ subject of the verb here) is plural), from

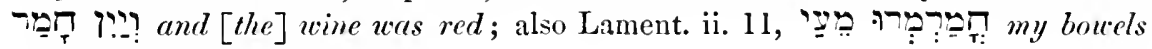
have become red, i.e. inflamed.

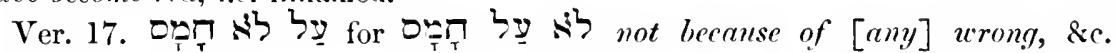
The very same words occur in Isa. liii. 9, where the same transposition must of course be made.

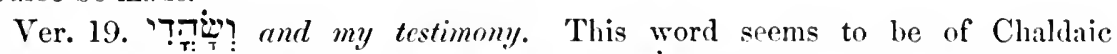
origin, as we read in Genesis xxxi. 47, $N_{\top}$ testimony, the same heap being named by Jacob in Hebrew Tבֵ have the same meaning.

Vers. 20, 21. The reader will recollect, that $\mathrm{Job}$, in one of his preceding discourses (ch. ix. 33), said,

Nor is there between us any umpire,

Who should lay his hand upon us both ;

shewing that he longed for some third party, to act as mediator between himself and God. He now again touches upon the same point, and exclaims, $O$ my mockers! O my friends! O ye that mock me, though my friends! Mine eye droppeth tears unto God, entreating Him, (Ver. 21) That one might plead for man with God. That there might be some one to come forward and plead, in favour of man, before God. As every son of man ought to plead in farour of his fellow-man. As it is the duty of every 
human being to come forward, and plead in behalf of his fellowman, when he sees injustice done him, so I would there were some one, whose duty it were to plead in favour of man, when undeserved punishments come upon him from above.

Wolfssohn takes ָㅗำ in ver. 20, in the sense of judge, in which signification =ה: is unquestionably sometimes used in Scripture (Comp. Exod. xxi. 6,

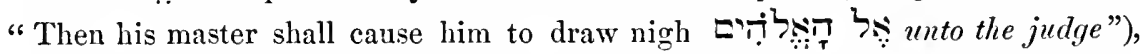
and would therefore make Job say, that he longs for a judge, who might decide between man and God, as judges do decide between man and his fellow-man. Much as we are struck with the ingenuity of this interpretation, and great as is the support it receives from the verse quoted above, in which Job regrets there is no umpire between God and himself, who should lay his hand upon both, we still could not make up our minds to adopt it, as we do not meet with any instance, in which iㅏㄴ: is used in the sense of judge. We cannot, however, refrain from transcribing here the remarks of this great Hebraist and most able commentator, convinced as we are, that they cannot fail to call forth in the reader the same feelings of pleasure and admiration they eroked in ourselves. His comment is as follows :

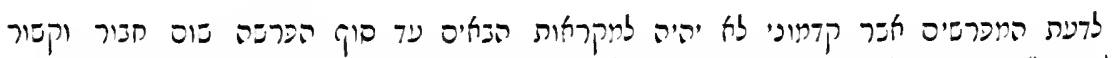

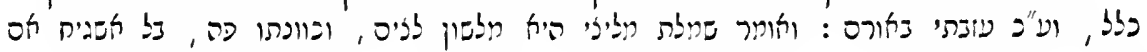

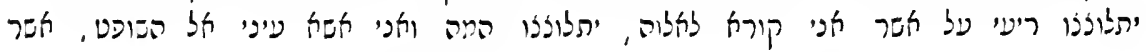

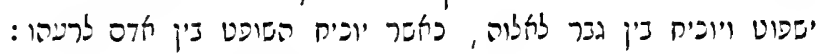

"According to the opinion of the interpreters, who have preceded me, the verses, which follow till the end of the chapter, would not have any connection, or relation, whatever, and, therefore, I have abandoned their interpretation. And I say, that [the] word ?ִ? should be taken in the same sense as (mockers); ' and its meaning here [is] I will not mind, if my friends mock at my calling for a judge; let them mock, but I will look up to the judge, who shall judge and decide between man and God, just as a judge decides between man and his fellow-man."

Having quoted Wolfssohn's comment upon these two verses, we will also quote his translation.

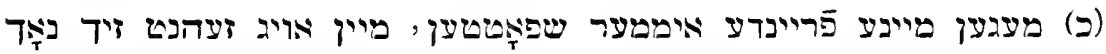

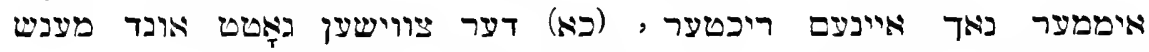

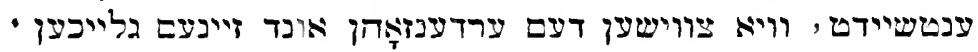

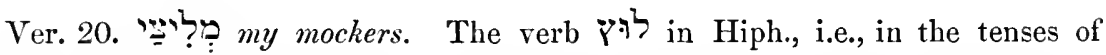
that conjugation, is, it must be admitted, very frequently used in the signification of mocking; we cannot, however, find one instance, in which it is decidedly so used in the pres. part. In Gen. xlii. 23, preter, but, as interpreters in those times were employed, not merely to translate 
verbatim, but also to set forth the cases of their employers,* the word is also

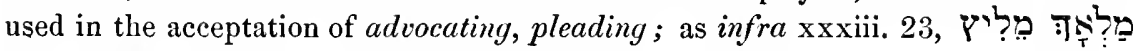
an' advocating angel. Again, as advocates are supposed to possess oratorical talent, the noun

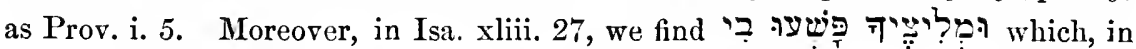
our humble opinion, ought to be translated, and thy advocates (i.e., thy intercessors, who ought to use what rhetorical powers they possess, in thy behalf), have rebelled against me. We were therefore very much inclined to translate the word tary title bestowed by Job upon his friends, and intended to express, that, though he differed from them in opinion, be could not help admiring their oratorical talent; we preferred, however, not putting ourselves in opposition to the greater number of commentators, and particularly, to the Auth. Eng. Vers., where there was no absolute necessity for our doing so.

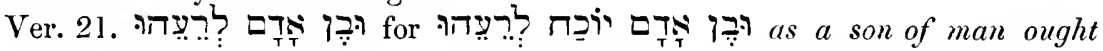
to plead for his fellow-man. The prefix $\rightarrow$ in the word 1 should be taken in the sense of as, like. Comp. supra xii. 11, गח̣ as [the] palate, \&c.

Ver. 22. But if my eye droppeth tears for one, who should plead my cause, and vindicate my innocence, before God, he must come forward, and not tarry, as I shall not be here for ever ; For the numbered years assigned to me will come one after another, and then $I$ shall go the way, whence $I$ shall not return.

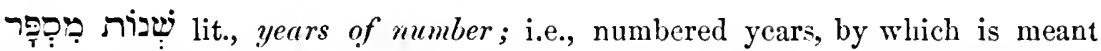

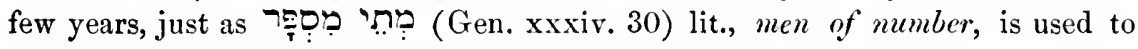
signify men, that can be easily numbered, few men.

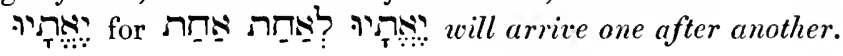

The second hemistich of this verse should be construed thus:

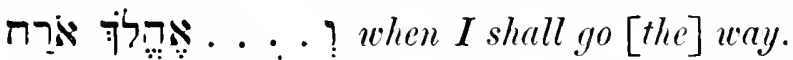

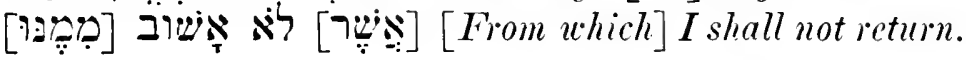

* The Chaldee התוּר, which is synonymous with the Hebrew interpreter, has, we are inclined to think, been metamorphosed into the word Dragoman, a person who, as every one knows, not merely translates rerbatim what he hears, but speaks and enlarges upon the subject of the message he bears to the Porte, with all the eloquence and oratorical power he possesses. 


\section{CHAPTER XVII.}

Vers. 1, 2. My breath is corrupt. Has become intolerably foctid and offensive.* My days are extinct. They are so full of gloom and misery, that their light may be said to be extinguished. They are graves to me. They are as joyless, yea, as loathsome as the grave; I am, as it were, buried-alive. Aye, well may I consider my life to be insupportable, for, besides my frightful sufferings, (ver. 2) Are there not deriders with me? Yea, mine cye constantly dwelleth on their provocation. I am constantly witnessing their endeavours to excite and provoke me.

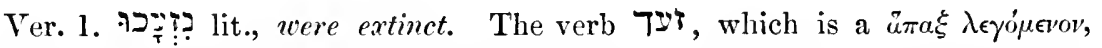
is synonymons with דעד a verb frequently to be met with in Scripture in the

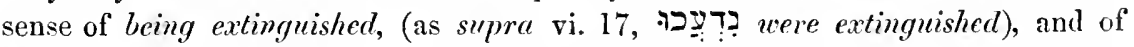
which indeed it may fairly be considered to be the Chaldee form, since $i$ and $T$ very often interchange in the two languages; as e.g., the Hebrew רב to remember, is in Chaldee רכ, \&c.

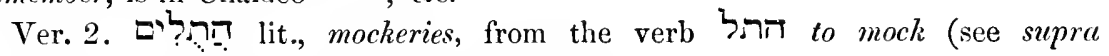
xiii. 9), but used here concretely for mockers.

 of the verb מרה to rebel, in Hiph., to excite to rebellion, to provoke. The dagesh in the $\mathrm{s}$ cannot be accounted for.

ליו or $i$ ? which, though frequently signifying to lodge, to pass the night, is also sometimes used to express, constantly remaining, or dwelling; as e.g., Cant. i. 13, which should be translated thus: "My friend is unto me like the bundle (bunch)

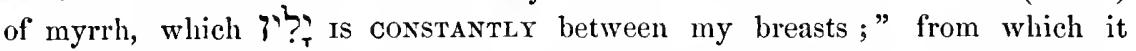
appears, that, in those times, women used to carry about them bunches of spices, for the sake of the scent, just as now-a-days they wear nosegays.

Vers. 3-9. We confess that it has cost us not a little pains and trouble to find anything like a continuous train of reasoning in the verses before us. We have of course consulted Wolfssohn and Homburg, also Rosenmüller and others, but have found in them no help whatever. Before beginning our own comment, however, we would beg of the reader to bear in mind, that Job has been more than once heard to complain very bitterly, that

- Such we are told is the case in Elephantiasis, as occurring in the East. 
a man should receive punishment from above, without having been previously allowed the opportunity of pleading his cause, defending, and clearing, himself; in other words, that a man, when he offends against God, is not tried before a tribunal, as is the case when he offends against man. In one of his discourses (supra xiii. 18, 19), he said he was quite prepared with his case, and was only at a loss to know, who was going to oppose him; in the last chapter, (ver. 21,) he went a step farther, and expressed a wish, that a man might be allowed an advocate, as he would be before a worldly tribunal; and now, going farther still, he would have God admit him to bail, until the time of trial. His words, which are again addressed to God, are as follows:

Arrange it so, I pray, be-Thou-surety-for-me with Thyself.* Be Thou Thyself my bail, that I do not escape, but duly surrender at the time of trial; for, if Thou Thyself wilt not, Who is he, that will strike hands for me? Who is there will be generous enough to come forward and bail me? (Ver. 4) For their heart. The heart of my three friends here. Thou hast hid fiom understanding. Thou hast concealed the way of their heart from understanding, so that she hath not been able to enter therein. Seeing that Thou wouldest not exalt them. Thou hast not given them to experience those elevated feelings, with which generous men are penetrated, when they see a friend in trouble. Who is there then, I ask again, that will come forward and bail me? But, supposing even, that some one, moved by pity and commiseration, should come forward. (Ver. 5) He would say, "Friends should go shares." He might naturally be expected to say; If I, a stranger, take pity on this unfortunate man, and consent to become surety for him, surely, his old friends ought to share the responsibility with me. But even the eyes of his children would fail. Not only would he himself never persuade my friends to join him in giving security, but even his children would look to them in vain; they would never consent. (Ver. 6.) Then would he set me up as an example for peoples. He would publish on all sides the shocking perfidy of my old friends, and their inhuman behaviour towards me.

* If God had accepted this proposai, Job's sufferings would, of course, at once have come to an end; he would forthwith have been released, at any rate until after his trial, from the "stocks," in which, as it were, his feet were set. Noto of Editor, 1 S61. 
So that I should be like a tabret in former times. I should play the part the tabret [drum] did in former times; its roll resounded throughout a city, giving the alarm, whenever anything very extraordinary or dangerous had occurred, and even so would the fame of my treatment at the hands of my perfidious friends be trumpeted abroad in the ears of all men, as a warning never to put too much trust in those, who should profess to be their friends. For all would look at me, and see the wretched condition to which I have been reduced. (Ver. 7.) Inasmuch as mine eye hath become dim, by reason of vexation. Such is the vexation I feel at the conduct of my perfidious friends, that my sight hath become dim with weeping. My limbs also are all of them wasting like a shadow. (Ver. 8.) Upright men would be amazed at this. That is, at this cruelty on the part of my friends. And the innocent-man would bestir himself against the hypocrite. He would no longer suffer himself to be caught by his bland words, but would at once put him to the test, and so lay bare his perfidious heart. (Ver.9.) Whilst the just-man would hold fast his way. Would never swerve one finger's breadth from the course he had laid down for himself. The shame, which would befall the unmasked hypocrite, would greatly encourage the good man to persevere in the path of rectitude. And he that had pure hands would increase his firmness. The man of clean hands, who had never imbrued them in crime or guilt, would gain additional strength to hold on his way.

\section{Ver. 3. שִ put, arrange (it so); i.e., arrange matters so.}

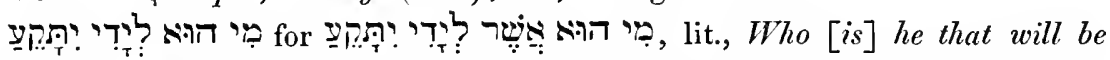
struck for my hand? i.e., that will have his hand struck, instead of mine, will become surety for me. It was the custom in those times for one who gave bail to strike hands with him who accepted it ; e.g., Prov. vi. 1, "My son, if thou hast given surety for thy friend, hast stricken thine hand with a stranger," \&c. Job therefore, to procure bail, would have to find somebody to strike hands for him, as of course he could not give bail in his own cause.

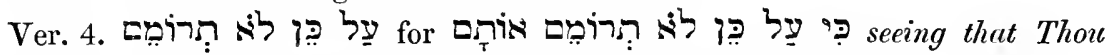
wouldest not exalt them. It was not Thy will that they should be susceptible of the generous and exalted feelings of genuine friendship.

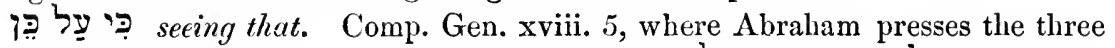

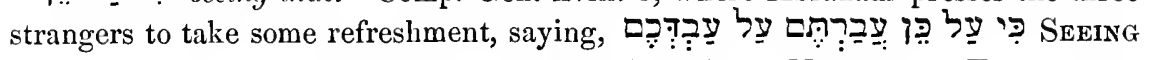
тHAт ye have passed near your servant. The Auth. Vers. has, “For THERErone are ye come to your servant." Unless, in King James's time, therefore and 
seeing that were synonymous, we are at a loss to understand how the translators could make Abraliam invite strangers to partake of his hospitality in terms which would have made any man, possessed of the least particle of delicacy, shrink from accepting it. In like manner, in Gen. xxxiii. 10, Jacob presses his brother Esau

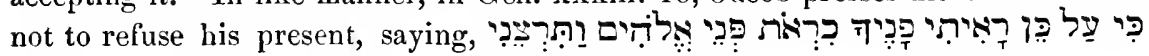
SEEING THAT $I$ have seen thy face, as [the] seeing of (i.e., as though I had seen) [the] face of an angel, and thou wast pleased with me. Here, again, the Auth. Vers. has "For tHeREFore I have seen thy face," \&c., which again makes no sense.

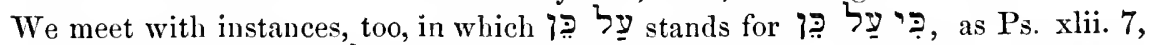

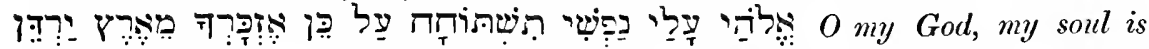
drooping within me, SEEING TIIAT $I$ must make mention of Thee from [the] land of Jordan (i,e.,"instead of from Thy sanctuary in Jerusalem). We strongly recommend the reader to consult Eichel's most masterly translation of Prov. vii. 15,

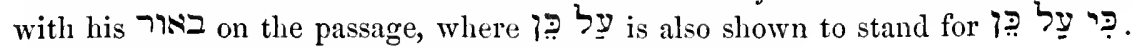

It will be perceived that this verse is parenthetical.

Ver. 5. This verse should be construed thus:

Ti: He would say (i.e., supposing one should come forward to strike hands for me, he would naturally say,)

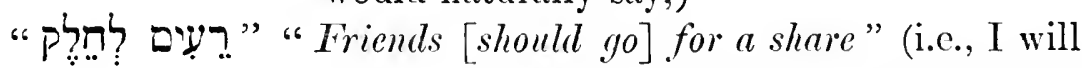
readily bail him, provided his friends share the responsibility;)

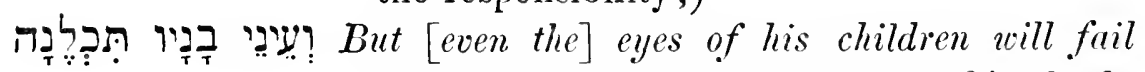
(i.e., will look in vain to see my friends do that).

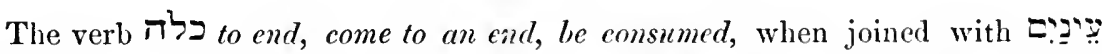
eyes, as it very frequently is, expresses looking in vain, longing in vain, for a

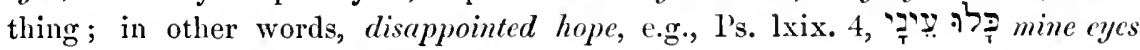
have frailed (whilst I am waiting for my Goll).

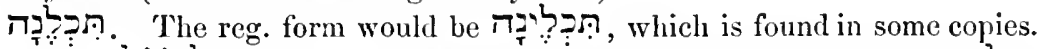

Ver. 6. hivi? lit., for a comparing of (it being an inf. kal with 3 of the בבע"ל (ב), i.e., he would set me up as one to whom every one deceived by his friends should be compared, that is, as an eximple.

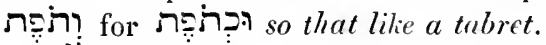

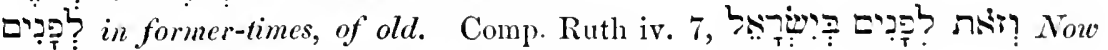
this [was the mammer] in former times in Israel.

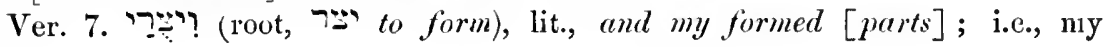
limbs.

Ver. 10. Having concluded his address to God, Job now says to his friends, But notwithstanding all of them. In spite of the upright 
man, who would be amazed, in spite of the innocent man, who would bestir himself against the hypocrite, in spite of the just man, who would hold fast his way, and him, clean of hands, whose fortitude would be increased. Te would come back. With your empty arguments. Nothing would deter you, and you would have the effrontery to continue your unmeaning speeches in the face of all good men, who would sympathize with me, and be shocked at the terrible lot which had been assigned to me. But I do not care for you, or your reasonings, Fea, come ye even now. With your shallow arguments; I heed them not, For I know I shall not find one vise-man among you.

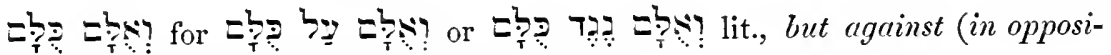
tion to) all of them; i.e., in spite of all of them.

Ters. 11-16. Job seems now to muse over his miserable condition, and to speak what follows, as it were, to himself. My days have passed. My happy days are over. My plans have been broken off-even the possessions of my heart. That is, my fondest hopes, my much-cherished schemes, which I had so long harboured in my heart. It will be recollected, that Job was assured by one of his friends (supra xi. 1\%), that a life-time would arise for him, brighter than noon-day, and that he would be like the morning; referring to this, he now says to himself. (Ver. 12.) They (my friends) want to make of niglit day. They would have me believe, that my present gloom and misery, constantly on the increase as they are, will soon be exchanged for sunshine and happiness. They want to make out, That light is near at hand, before darkness cometh. When darkness is on the point of coming, they would persuade me light is near at hand. 'The reader, it is hoped, need hardly be reminded, that darkness is used figuratively for calamity, and light for happiness. (Ver. 13.) Truly, I hope for the grave to be mine house. I hope for the time, when I shall have spread out my couch in the darkness. Dreadful as is the idea of rotting and mouldering in the grave, yet so great are my sufferings now, that I am become quite reconciled to it-nay, death were for me a most happy and welcome change, so happy and welcome indeed, that with joy (Ver. 14) I would call out to comption, 
Thou art my father! to the worm I would call out, $O$ my mother, and $O$ my sister! (Ver. 15.) For where is now my hope? What can I yet hope for? What use to prolong a life so utterly miserable, and bereft of hope? Yea, as to my hope, who will ever see it realized? (Ver. 16.) As to these limbs, destined to the grace, let them go down. Terily, quiet is altogether in the dust. There is neither quiet nor peace in this life for man, and it is only in the dust (the grave), that he can look for them.

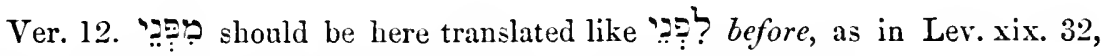

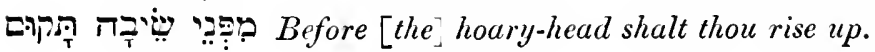

Verses 14, 15. The second hemistiches of these two rerses should be construed thus:

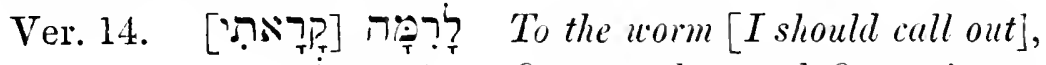

O

Ver: 15.

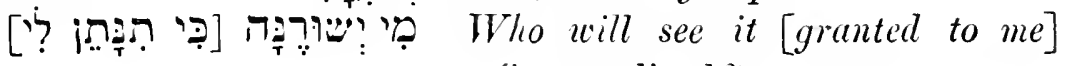
(i.e., realized?)

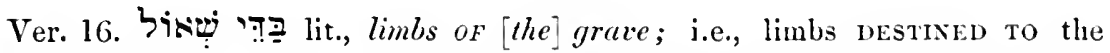
grave, this being one of the many significations, in which the state of construction in Hebrew is used. (See Mason and Bernard's Grammar, Letter xlvii.

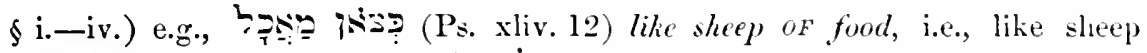

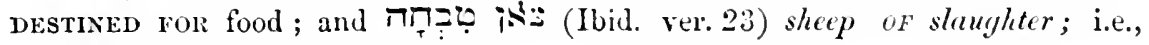
sheep IxTExDED for slaughter.

The primary meaning of the noun $7 \underset{\text { Z }}{-}$ seems to be a staff, or pole, to carry

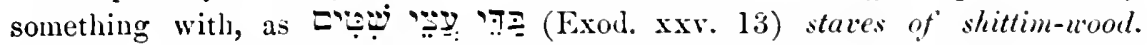
Hence it came to signify the branch of a tree, as Ezek. xvii. 6, "and brought

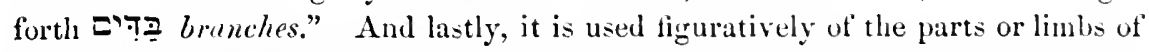

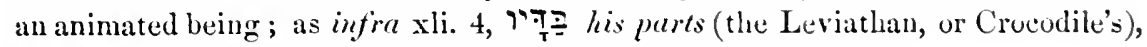
and infra xviii. 13, 구ㄲㅡㅡ his limbs (applied to man).

- The verse before us should be construed thus:

[as to these] limbs, destined to [the] grate,

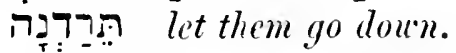

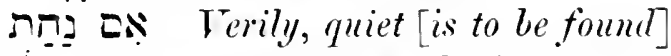

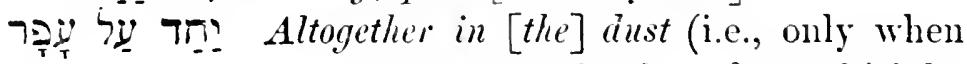
man returns to the dust, from which he was taken, can he find quiet). 


\section{CHAPTER XVIII.}

Vers. 2-4. The first of these verses has puzzled almost all the commentators and translators, and justly so, since the words, as they stand, express just the opposite to what we should expect Bildad to say; there is then, manifestly, an ellipsis, and this has been variously supplied. Some have understood the adv. טֶ? before, ere, after Auth. Vers. Others supply the negative particle $\leqslant$ ' not. For our own part, we must say, that, considering that the friend, who holds this discourse, is the same, who spoke in chap. viii., and that, in both instances, his speech begins with the words $\underset{\text { in }}{\text { Y }}$, or

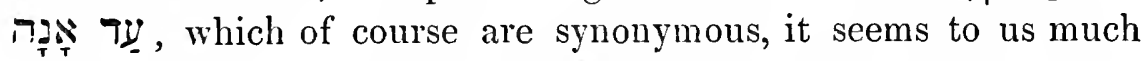
more natural to supply after עִ עִ עִ here, the words which follow is here addressing Job in the plural, instead of the singular,

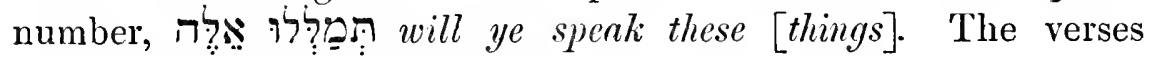
before us will then run as follows:

How long will ye (i.e., thou Job, and the whole party of philosophers thou representest) speak these things? $\boldsymbol{Y}_{e}$ should put an end to words; ye should first consider, and then let us speak. What use is it talking at random, without first well considering, whether, or not, our arguments and assertions rest on a solid foundation? It is very easy to say, * that no wise man can be found amongst us orthodox people, who have full confidence in the justice of Providence; but is there any real ground for such an insulting remark? (Ver. 3.) Why are we accounted as beasts? Why are we unclean in your eyes. It has already been observed, (see our comment on ch. xv. 9,) that Job and his friends in their discussions do not regard each other so much as single individuals, as the representatives of the parties to which they respectively belong; Job being considered to represent the philosophers, who wish to account for every thing; his friends, the orthodox party, who firmly believe that

* Chap. xvii. 10. 
already been said by himself, as well as his friends, with regard to the fatal termination of the wicked man's career, however splendid and brilliant it might at first have appeared to be. He says:

Tes, the light of the wicked shall be extinguished, and the blaze of his fire shall no longer shine. However dazzling the blaze of his prosperity, it shall be utterly extinguished. As, in the first

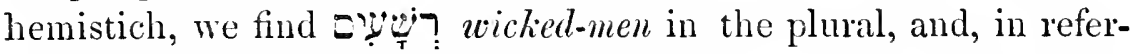
ence to them, in the second, ị̂ his fire, this must of course refer to every one of the wicked men individually. (See note on iอr? sapra vi. 17.) (Ver. 6.) Light becometh dark in lis dwelling. And his lamp over him. The lamp suspended over his head. Shall be extinguished. Not only shall the rays of the sun no longer penetrate into his dwelling, but it shall want even the feeble light of a lamp. All will be wapt in gloom and darkness, desolation will reign there. (Ver. 7.) His mighty steps shall be straitened. The gigantic strides of his ambition shall be shortened into mincing stejs. And his own plan shall cast him headlong. His plans shall prove so rash and improvident as to cause his ruin. (Ver. 8.) For he was let loose with a net attached to his feet. Although, as a man, and, consequently, a free agent, he had entire control over all his movements, so that he could direct his steps in whatever path he chose, yet there was a net attached to his feet, ready to catch and entangle him, as soon as, in his self-willed career, he had overleaped all bounds. ${ }^{*}$ Yea, he walketh upon net-work. He thinks he is walking upon solid ground, but he is grievously mistaken; it is but a delicate network, spread over an unfathomable abyss, into which, therefore, he every moment risks to be precipitated. (Ver.9.) The snare shall take hold of his heel, the trap shall prevail over him. In vain shall he endeavour to escape from it. (Ver. 10.) His noose. 'The noose destined to entangle him. Is concealed in the earth, and his gin upon the path. (Ver. 11.) Terrors affiright him on every side, and drive him about, following at his feet.

Ver 7. 7 . mighty steps. The reader need hardly be reminded, that a noun in construction

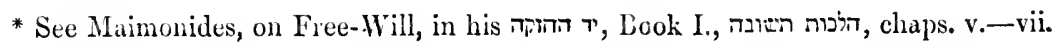


with another is very frequently qualified by it. By his steps being said to be straitened is meant, that he has no longer the same freedom of movement as

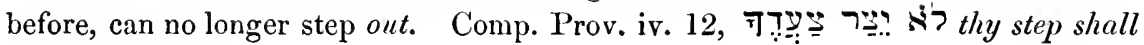
not be straitened.

jis strength, night. Comp. infra xl. 16, isin' and his might.

Ver. 8. חציִ lit., he was sexit off, i.e., let go, let loose, left entirely to himself. Comp. Gen. xlix. 21,

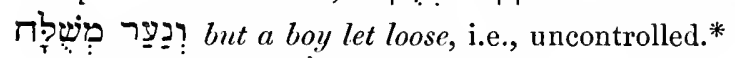

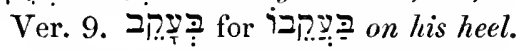

口ִִ a trap. See our note on this word, supra v. 5 .

Ver. 10. Tָ, lit., his cord; i.e., the cord, the noose, destined to entangle him.

Ver. 11. verb פר in Hiph. is generally rendered to scatter; but, as one person can scarcely be said to be scattered, it must, when applied to a single individual, as here, be rendered by, to drive about in different directions, or some equivalent expression. Comp. Habak. iii. 14,

?רבְ: [following] at his feet; i.e., close upon his heels. Comp. 1 Sam. xxv. 42, "With five damsels of her's, which went her."

Vers. 12-16. Bildad, having now described the misery which is to befall the wicked man himself, proceeds to declare the fate which awaits his progeny. He says:-

The beginning of his might. That is, his first-born son. Shall be famished, and destruction shall be ready at his side. (Ver. 13.) That first-born, destined to death, shall gnaw the limbs of his body, yea, his own limbs shall he gnau. The agonies of starvation shall drive him to gnaw his own limbs. The speaker now reverts to the wicked man himself. (Ver. 14.) His confilence shall be rooted out of his dwelling, yea, it shall make him step-over to the king of terrors. His arrogant self-confidence will be the true cause of all the terrors, which will ultimately seize upon him. By "king of terrors," of course, the highest degree of terror must be understood. (Ver. 15.) It (terror) shall abide in his dwelling (not indeed his own, but violently taken away from the legitimate owner). Brimstone shall be scattered upon his habitation. (Ver. 16.) His roots beneath shall dry up, and his bough above shall be cut offi.

Ver. 12. isis for isis ת [the] beginning of his might, a periphrasis used in Hebrew poctry to express first-born son; thus, in Gen. xlix. 3, the dying patriarch

- As well rendered by Dr. French and Mr. Skinner. 


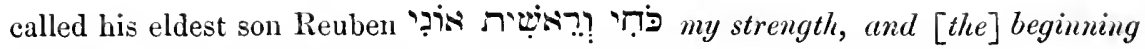
of my might. 'To remove any ambiguity that might have arisen from the omission of the word Juis? beginning, before isis, the poet, in the next verse,

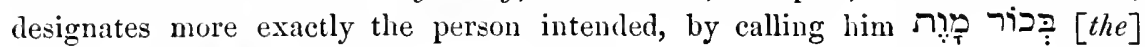
first-born destined to death. So the Chaldee, in the verse before us, translates

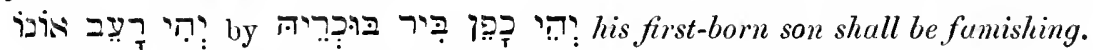

iעy? at his side. We may, perhaps, be allowed here to suggest, that, in the same manner as, in the first hemistich, isis his might, is used by the poet to express first-born son, so iv? in the second hemistich, may possibly have been intended by him to signify his rib $=$ his wife, his widow. We have not ventured to translate it so, for the simple reason that we are unable to bring forward any instance in which

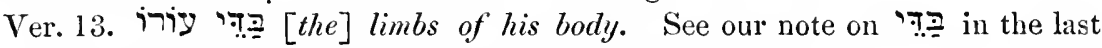
verse of the preceding chapter. used for the whole body, as in Exod. xxii. 26, "It is his raiment iniy? for his body."

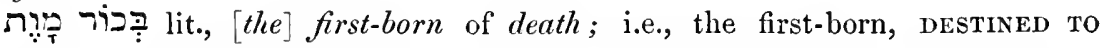

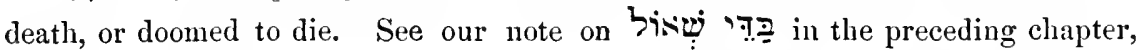

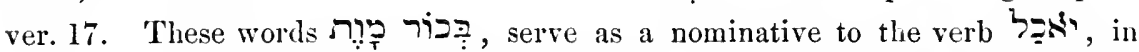
the first, as well as in the second, hemistich, so that the verse, written in full, would run as follows :

[The] first-born, doomed to death, shall gnaw [the] limbs of his body;

[The] first-born, doomed to death, shall gnaw his [own] limbs.

is ?ִִ lit., without [its being, or belonging] to him; i.e., without, in reality, its being his property. These words are to be taken parenthetically, and seem to have been added by the poet with a view to qualify in some degree the expression iל Tr:T: though in point of fact it is anything but his, taken away, as it has been, by violence from its rightful owner."

Vers. 17-21. The speaker, having detailed the calamities, which will befall the wicked man, as well as his first-born son, now proceeds to consider what will become of lis name and fame, when he shall be no more. He says:

His remembrance shall perish from the earth, and he shall have no name in the street. In the public places, where, during his life-time, he made so conspicuous a figure, his name shall be altogether forgotten. (Ver. 18.) He shall be thrust fiom light into darkness, and removed from the world. He shall be buried 
in eternal night, and his name be consigned to oblivion. (Ver. 19.) He shall have neither son, nor grandson, left among his people, nor shall there be a survivor in his dwelling-places. His divellingplaces shall become, on his death, altogether empty and desolate; not one of his family, slaves, or friends shall any longer harbour there. (Ver. 20.) Latter generations shall be astounded at his last-day, just as their predecessors (that is, those, who were contemporaries of the wicked man,) were seized with horror. (Ver. 21.) Surely such are the dwellings of the iniquitous-man, and such the place of him that knew not God.

Ver. 17. Tָּ lit., has perished. The poet is so certain, that the wicked man's memory must perish, that he considers it as a fact already accomplished. See

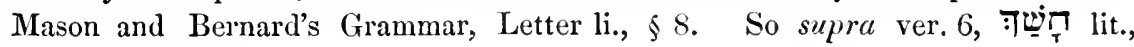
has become dark.

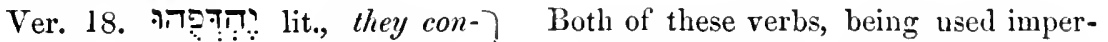
stantly thrust him;

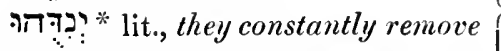
him. (See note on TI?! infra xx. 8.) sonally, may be rendered in English in the passive. See our note on רָּ supra iii. 3.

Ver. 20. in his [last] day. See note on ivi supra xiv. 6.

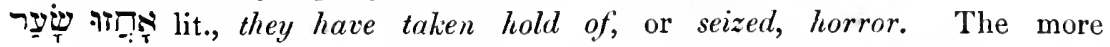
usual expression would be, horror has seized them, as in Exod. xv. 14, חִיל Sorrow has taken hold on the inhabitants of Palestine; and (Ibid. ver. 15) inverted mode of expression used here by the poet approaches somewhat to the English, "to take fright," but may be intenled to shew, that it was not a transitory, but a lasting, horror, so that, when the horror took hold of them, they, in their turn, took hold of the horror, preventing its departure. A similar expression we shall find infra xxi.6. 6. So that my flesh (body) lays hold of trembling.

Ver. 21. הצלִ lit., these lit., this. $\left\{\begin{array}{l}\text { are both used here as descriptive, rather } \\ \text { than as demonstrative, pronouns. }\end{array}\right.$

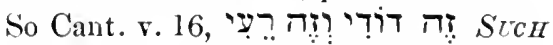
[is] my love, and stcrt my friend. See Mason and Bernard's Grammar, Letter xlviii. \& 2.j.

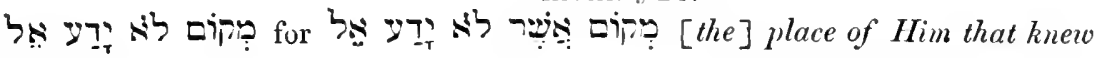
not God.

* From ג, fut. Hiph. third pers. plur. masc. (יד: with pron. affix. Some copies

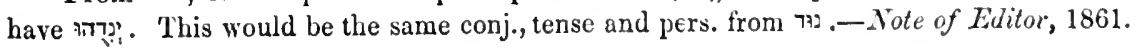




\section{CHAPTER XIX.}

The discourse we have just heard, did not contain a single argument, the speaker no doubt thinking, it would be quite enough for him to confirm and corroborate that, which had already been said over and over again by himself, as well as the other two friends, concerning the terrible end awaiting the wicked, to stop the mouth of all those, who, when labouring under afflictions from above, murmur and complain. He had only to establish the fact, he thought, that the end of the wicked is invariably punishment from on high, to prove clearly and indisputably, that those who receive such punishment, must be wicked. His reasoning may be resolved into the following syllogism: Every wicked man must become a great sufferer; Job has become a great sufferer; therefore, Job must have been a wicked man; a conclusion, as falsely drawn, as if, from the premises, that every $\mathrm{A}$ is $\mathrm{B}$, and every $\mathrm{C}$ is $\mathrm{B}$, we should conclude, that every $\mathrm{C}$ must be $\mathrm{A}$. The unfortunate Job then, feeling, that the whole of his friend Bildad's discourse had for its object to prove his wickedness from the very sufferings which he was undergoing, says:

Vers. 2-7. How long will ye vex my soul, and crush me with your words? (Ver. 3.) These ten times. Ever so many times. Do ye put me to the blush; are ye not ashamed to behave impudently to me? (Ver. 4.) And yet, indeed, if I have erred, the-consequencesof-my-error will abide with me. You mock and jeer at me, but you are unable to bring any charge against me, else you certainly would not have waited till now; but, even if there were any ground for accusing me-if I had done anything wrong unawares, and were now suffering for it, it wonld be most cruel on your part to insult me, whilst I was receiving my punishment. Where is the barbarian, who, even in common life, could stand by and mock at a criminal undergoing corporal punishment? (Ver. 5.) But the truth is, ye-wish-to-magnify yourselves over me. You boast of your being free from affliction, as a proof of your righteousness. And bring my degraded-state as an argument against me. You 
would prove my guilt from the degraded state, to which I am reduced, but this is unjust as well as cruel. (Ver. 6.) For, know ye now, that God hath wronged me, and hath cast His net around me. Like an innocent bird, which never gave, nor could give, offence to the fowler, I am entangled in a net, from which I cannot escape. (Ver. 7.) Lo! I cry, " Wrong!" but I am not auswered; I cry aloud, but there is no justice.

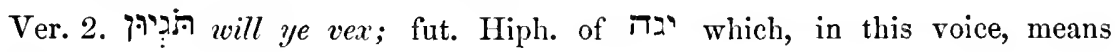
to vex.

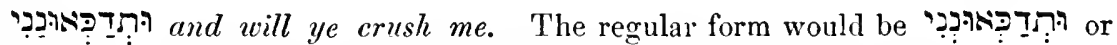

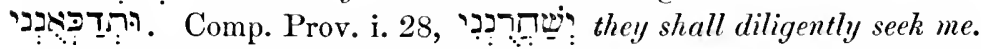

Ver. 3. הt this (ten times). In phrases of this sort, and=already, is always found, and not ה? these. Comp. Numb. xxii. 28, זִ lit., THIs three times, i.e., already three times.

In English too, in similar phrases, we find this sometimes used for these. So Dryden :

\section{I have not wept this forty years, but now}

My mother comes afresh into my eyes.

บู ten, used for an indefinite number, =ever so many times. Comp. (Gen. xxxi. 7.) Ten (i.e., ever so many) times. See our note on chap. v. 19.

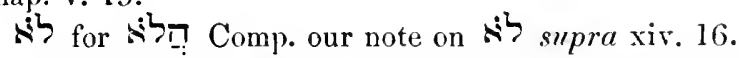

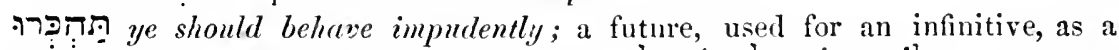

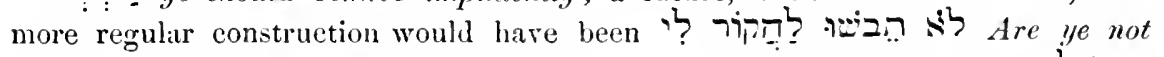

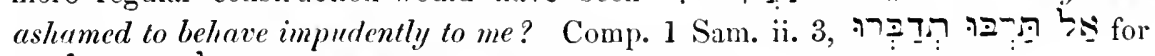

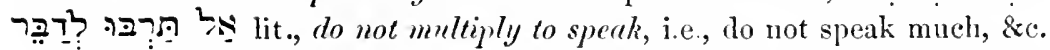

The root as a verb, occurs only here. We find, however, in Isa. iii. 9,

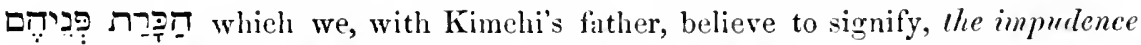
of their countenance, and to have nothing to do with the well-known phrase

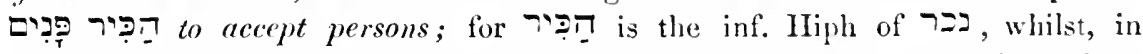

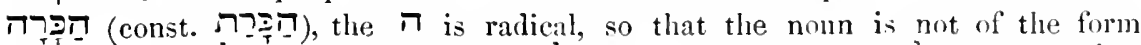

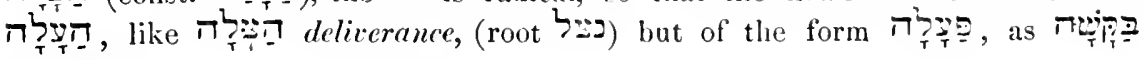
a request.

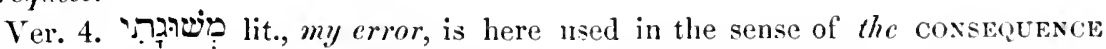
of my crror, i.e., my punishment, or the punishment I receive. Comp. Gen.

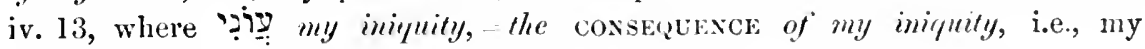
punishment.

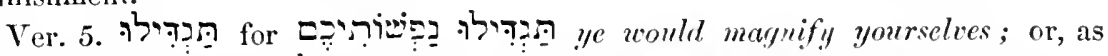

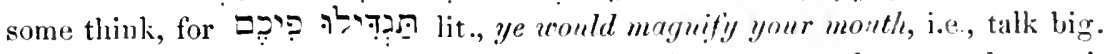

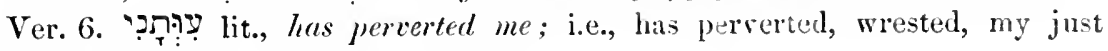
cause, hias wronged me.

Ver. 8-20. IIaving expostulated with his friends on account of their heartloss behaviour to him, he now enters into a somewhat 
lengthened detail of God's proceedings towards him, and of his sufferings, mental as well as bodily, saying:

He hath hedged up my way, so that I camnot pass. He impedes

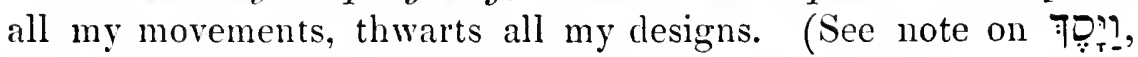
supra iii. 23.) And upon my paths He putteth darkness. So that I cannot see my way. (Ver. 9.) My glory He hath stripped firom off me. He has robbed me of all that rendered me honourable and glorious in the eyes of men, so that I am become despicable in their sight. And He hath removed the crown firom (lit., of ) my head. He has taken away all my honour and dignity. (Ver. 10.) He demolisheth me on every side, and I pass away; and He hath removed my hope, as one would remove a tree. He has destroyed my hope; for a tree, when uprooted, dies. (Ver. 11.) And He hath kindled His wrath against me, and counted me unto Him as one of His adversaries. (Ver. 12.) His troops come together. 'The misfortunes, which He has sent, gather themselves against me in troops. And raise up their way against me. They omit no means, by which they can gain access to me. The metaphor is taken from the siege of a city, one of the first steps in which was, in those times, to cast up a raised way against the city, in order to facilitate the approach of the besieging army. And encamp around my dwelling. (Ver. 13.) He hath removed my brethren far from me. They keep aloof from me in consequence of the degraded state, to which He has reduced me. And they, that know me, have verily become estranged from me. (Ter. 14.) My relations have failed. They have dropped off one by one. And my acquaintance have forgotten me. (Ver. 15.) The inmates of my house, and my maids, count me for a stranger; an alien have I become in their eyes. (Ver. 16.) I call my servant, but he will not answer; with my mouth, must I make supplication to him. Instead of commanding him, as I used to do, I nust now entreat him to do for me what I want. (Ver. 17.) My breath hath become loathsome to my wife, and so would the demonstrations of my afiection now be to my children, if I had any. They would loathe my affectionate caresses. (Ver. 18.) Yea, wicked-little-children despise me; when I stand by, they speak against me. Even in my presence, they insult and mock me. (Ver. 19.) All my familiar friends abhor me, and such, as I loved, are turned against me. (Ver. 20.) My bone. All 
that is bone in me. Cleaveth to my skin, and my flesh. I am reduced to such a state of emaciation, that my bones and skin are glued together. And I am escaped only with the skin of my teeth, that is, with my gums; they have escaped the fate of the rest of my body; of them only can I say, that they do not cleave to their bones, that is, to my teeth, for I have no teeth, they have all dropped out.

\section{Ver. 11. 1.}

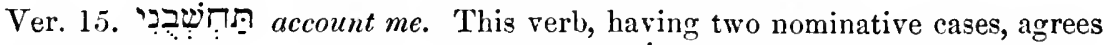
in gender with the one nearer to it, viz., 'sֵ my maids. Comp. Ezek. xxxv, 10.

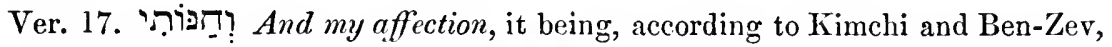
an irregular infinitive Kal of

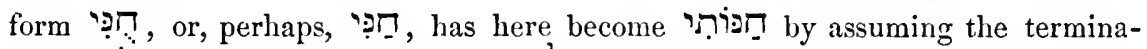
tion ( $\left(\mathrm{Ni}^{-}\right)$of the inf. of the verbs $\boldsymbol{\pi}^{\prime \prime}$. Gesenius, ready, as he always is, to favour us with Hebrew nouns, of which the Hebrew Lexicographers never

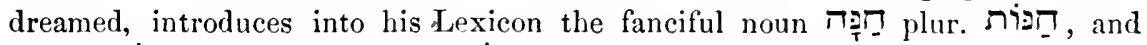

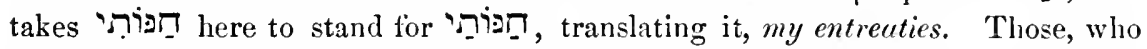
can read Kimchi and Ben-Zev in the original, and are Hebrew scholars enough to admire the beauty of their style, will not find fault with us for following them, rather than one, who has never ventured to write one line of Hebrew, and who, as has been shown by us, (see note on לָ supra vi. 3,) betrays such a glaring want of knowledge of the true principles of Hebrew punctuation and accentuation. The reader is referred to Ps. lxxvii. 10, where תivi is also used as an infinit. Ilath God forgotten to be merciful, affectionate?

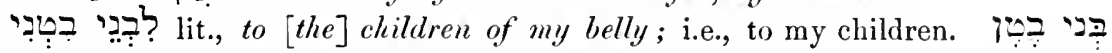
children of [the] belly, or womb, should be considered as a periphrasis for children, in the same manrer that בֶּ fruit of [the] belly, or uomb, very

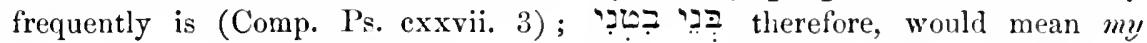

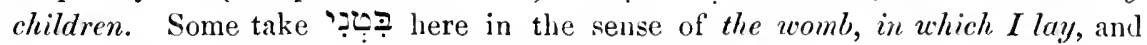

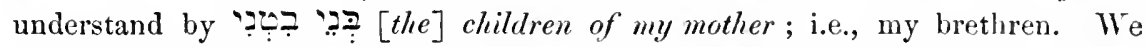

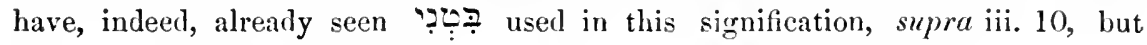
there no ambiguity whaterer could arise from its employment; here, on the contrary, by using it in this sense, Job would have run such risk of having his meaning misunderstood, as

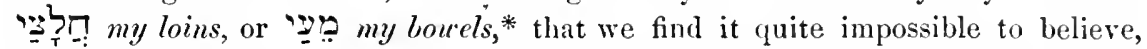
that, if he had really wished to speak here of his brethren, he would have applied to them such a very ambiguous epithet. Those, who take it here in this sense, are obliged to confess that they do so, in order to get over the difficulty of accounting for Job's speaking of his children, when, as we learn from the historian, they had all been destroyed; but, for our own part, rather than

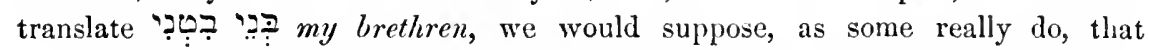

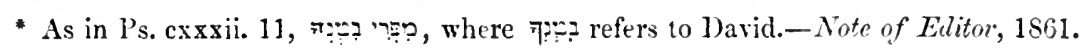


Job either had had children by concubines, or that his wife had borne him some in the interval (considerable perhaps) which had elapsed between his being struck with poverty, and afllicted with bodily disease. There is not, however, in our opinion the least occasion for indulging in any such supposition, since, even if the common view be adhered to, that Job had no children at the time he spoke this, the verse may very well be understood as follows: "My breath hath become disgusting to my wife, and so wOULD my affection BE to my children;" i.e., if I harl any children, they would not be able to endure my caressing and fondling them.

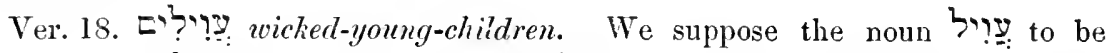

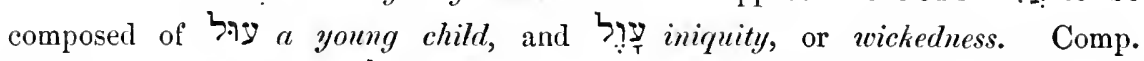

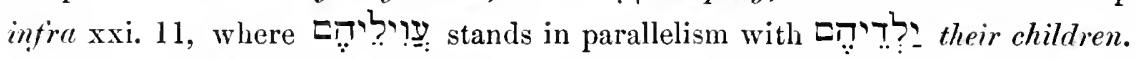

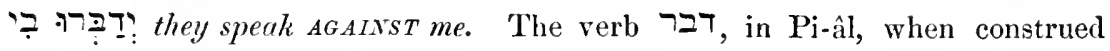

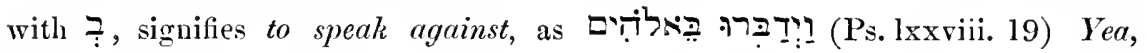
they spake AGaINST God.

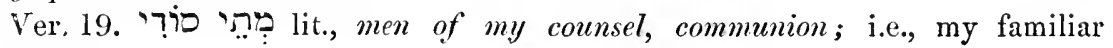
fiiends.

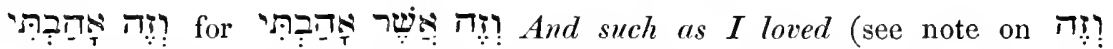
supra xviii. 21) ; or may not 7 i here, contrary to the opinion of Mason and Bernard (Letter xxv., P.S. (d)), be really synonymous with רשי? If it is, as we are inclined to think it is, the difficulty of accounting for its being joined with בִ in the plural will vanish.

Vers. $21-27$. Dreadful as are the torments, bodily, as well as mental, enumerated by the unfortunate speaker here, there is yet one, a mental one, far more agonizing than them all, and that is, the abominable supposition indulged in by his friend Bildad (supra xviii. 4) that he (Job) believed "the world to be deserted by its Maker, and the Rock to be moved from His place," a supposition equivalent to a charge of downright Atheism. What are bodily pains however excruciating, what are mental sufferings however agonizing, when compared with the pangs with which the mind of a pious and upright man like Job would be seized, on hearing such a charge brought against him-him, a man, who had, not only during the whole course of his life, preached the power and excellence of God to others, but even now, in his sufferings, longed, nay panted, for the privilege of defending himself and proving his innocence before Him! He is so utterly confounded by this charge, that, feeling his complete inability to find words to express his indignation, he prefers appealing to his former friends for pity and compassion, and imploring them, as it were on his 
knees, and with tears in his eyes, to spare him, and abstain from harrowing up his soul with such false and utterly unfounded accusations. He says :-

Have pity upon me, have pity upon me, O ye my friends, for the hand of God hath smitten me! 'The afflictions sent upon me by God are already greater than a human frame can bear, why then add to them by imputing to me a crime of the blackest dye, that, namely, of denying my God and Maker? (Ver.22.) Why should ye persecute me like God? I am already undeservedly suffering chastisement at the hand of God, is not this enough, without your striving to emulate Him by loading me with accusations and charges, which I as equally little merit? Yea, ye seem never to be satisfied with my flesh. Your rancour against me seems to be so immeasurably great, that you could, as it were, altogether devour me, and even then not be satisfied, but long for more of my flesh. You say, that I deny God, and think, that the "Rock of the universe is removed from His place;" but here is my answer to this your charge-here you have, in a few words, my profession of faith, which I only hope may be handed down and transmitted to the latest generations. (Ver. 23.) Oh, now, that my words were written down! Oh, that they were engraced in a book! Nay, but that were not enough; worls, written and engraved in a book, are not lasting; would, then rather, that (Ver. 24.) With an iron style, and with lead, they were graten in the rock for ever! These words namely, (Ver. 25) That I know, that my Redeemer liveth, and that Ite will remain the last upon the earth. That I know Him to be a Being, whose existence will have no end or limit.* So in Isa. xlviii. 12, God says,

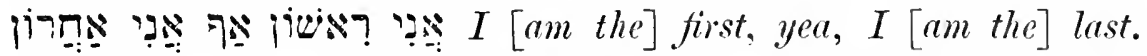
(Ver. 26.) Even after my skin hath thus been pierced. That is, consumed, and eaten into holes by ulcers, as it now is. Yet, even from my flesh can I see God. Even from the flesh, which peeps out through these holes, disgusting as it is, I can see, that it is so wonderfully wrought, that none but God could be the

* So far from my beliering, therefore, that He has been mored from His place, and has deserted the earth, I know, upon the contrary, that, long after every mortal has left his place on earth, God will still remain behind, immovable, the last. 'This seems to be the force of the 
maker of it, God, (Ver. 27) Whom I can see for myself. I have no need to be told by others of His existence, I myself can plainly see Him in His works, yea even in a frame so wasted, and so disgusting as mine now is. Yea, my own eyes see Him, and not another. There is no occasion for another to point Him out to me, I see Him, with my own eyes, in myself. My reins are consumed for Him within me. Not only do I not deny His existence, but I wish, desire, long for nothing else, than to be brought into His presence, that I may clear myself, and prove my innocency before Him.

Ver. 21. 'דקדִ The pity upon me. The repetition of this word imparts emphasis to the entreaty. See Mason and Bernard's Grammar, Letter xlviii., § 6, II.

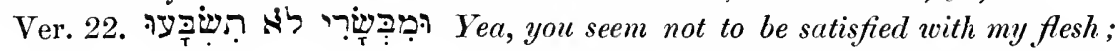
i.e., it seems you cannot have enough of it, cannot glut yourselves therewith. The rancorous hatred of an enemy is well depicted in Hebrew by his being said to devour the flesh of him he hates.* So the Psalmist says, Ps. xxvii. 2, "When

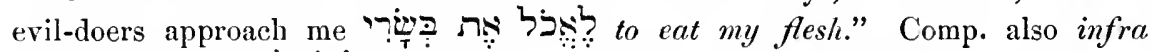

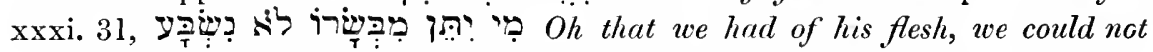
be satisfied! i.e., we could never eat enough of it.

Ver. 23. צִ Would that they were engraved in a book!

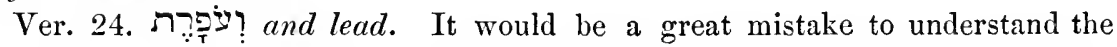
word soft a metal to be able to cut a rock. The wish of the poet evidently is, that his words might first be graven in a rock with an iron style, and then filled up with lead; a mode of proceeding, by which the inscription would be rendered at once more conspicuous, and less perishable. So Jarchi observes:

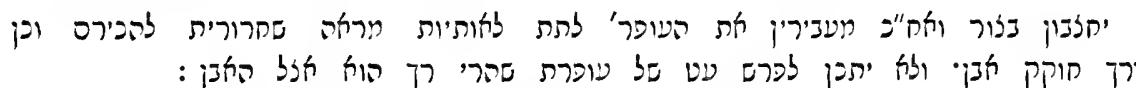

"They usually cut in the rock, and after this insert the lead, to give the letters a blackish appearance, in order to make them distinct, and this [is] the way of a stonecarver. But it is not right to explain [it as though signifying] a style of lead, for, behold, it is soft beside stone."

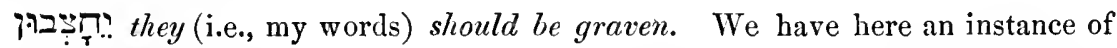
the figure Zeugma, for the verb used can, as has just been observed, properly

* Similar expressions might now very appropriately be introduced into the Italian language, and perhaps also into Papal Latin, for did we not read in the "Times" two or three months ago (Aug. 27, and comp. also Aug. 23 and Sept. 6)-and the report has not, I believe, been contradicted-that a party of Neapolitan Reactionists (by others called brigands), hearkening to the incitements and instigations of their priests, actually roasted alive and ate the bodies of some unfortunate Piedmontese soldiers (their determined enemies), whom they had treacherously surprised and captured.-Note of Editor, Nov., 1861. 
be applied only to the iron style, and not to the lead, with which the letters were not to be cut, but to be filled up. See note on בִקָ supra iv. 10.

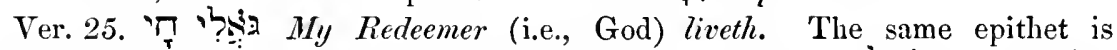

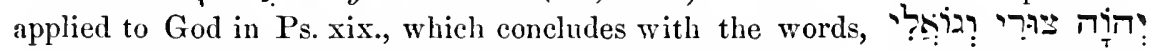
O Jehovah, my Rock, and my Redeemer! Now, as in the preceding Chapter, Ver. 4, Bildad had applied to God the epithet 7.93 Rock, and taxed Job with the horrible crime of supposing the "Rock to be removed from His place;" so Job, in repudiating this abominable charge, calls his Maker hị: Redeemer (the word which is found in conjunction with 7 ב in the Psalm above quoted), saying, "I know that "'ș my Redeemer liveth."

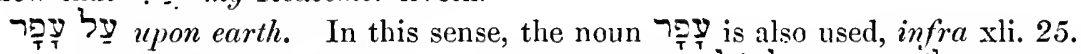

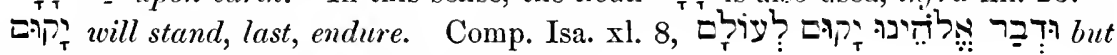
[the] word of our God shall endure for ever.

Ver. 26. בִ they have pierced. This verb is to be taken impersonally, so that

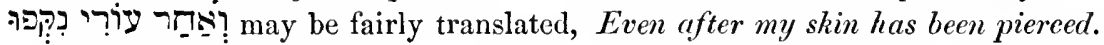

Sר thus, in this manner. In Mason and Bernard's Grammar (Lett. xlviii., $\S 24$ ) instances have been quoted in which the masc. demonst. pron. T! is used = this manner, fashion, and so its fem. תาit should be considered here ; or

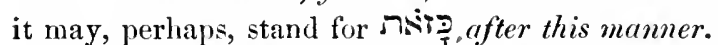

רet, from my flesh (i.e., when I consider the flesh, disgusting as it is, which peeps out through the holes in my skin), I ean [still] see God; i.e., I can see that it is so wonderfully wrought that it can be the wort of none else than God. Nothing is more certain than that a close examination into the structure of the human body, feeble and frail though it be, cannot but give rise to serious meditation upon the marvellousness of the works of God, and to sincere and heartfelt prayers and praises to its Maker. Thus the Psalmist says (Ps. cxxxix. 14), "I will praise Thee, for I am fearfully and wonderfully made: marcellous are 'Thy works, and that my soul knoweth right well."

Ver. 27. ז thee (and not thine own mouth).

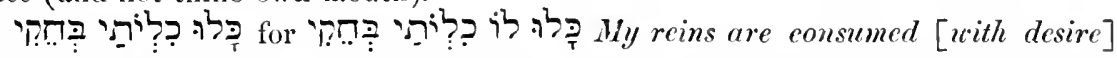
for Him within me (lit., in my bosom) ; i.e., my only wish is to be brought into His presence, that I may clear myself of the terrible charges which are laid at my door. Comp. Ps. lxxxiv. 3, desire, longing).

Vers. 23-27 seem to have been so embarrassing to all the translators and commentators, Wolfssohn himself (to whom none of the other modern commentators can, in the least degree, be compared) not excepted, that we think it but right to shew the reader how we construe them :-

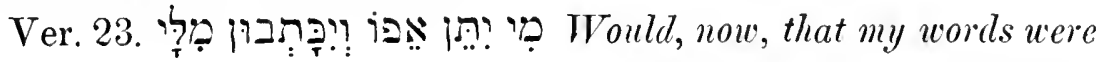
written doun!

Would that they were engraved 
in a (lit., the) book! (or, in order to render them more lasting and durable, )

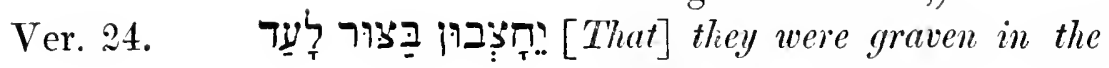
rock for ever,

With an iron style, and [filled up with] lead! (See above, our note on words, namely,

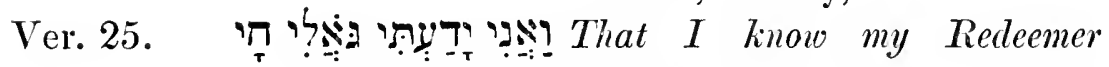
liveth,

品 And will remain last upon earth (i.e., that, after all beings have ceased to exist, He will exist).

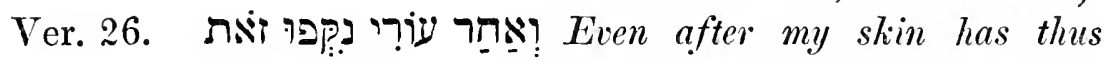
been pieveed, Met from my flesh can I see God (i.e., from the flesh, which is visible through my pierced skin, I can see God; I can see that God, and none else than God, is the Maker of it).

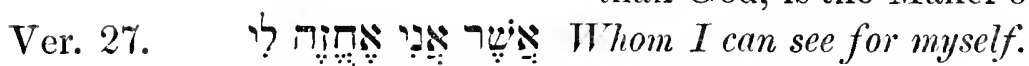

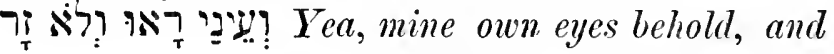
not another; (so that I do not stand in need of another to tell me, or remind me, of His existence. All that I wish for is to be allowed to justify myself in His presence.)

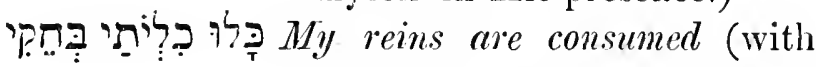
longing) [for Him] in my bosom (i.e., within me).

Vers. 28, 29. Having now cleared himself from the terrible charge of atheism, he warns his friends to be careful how they bring such unfounded accusations against him, reminding them that, by so doing, they incur an awful responsibility, since the very making a 
false charge is in itself a great crime, and one that will certainly ultimately be visited with the severest punishments. His admonition runs thus:-

But ye say, What is a persecuted-man to Him (God)? What object, what pleasure, can He have in persecuting an innocent man? and hence you draw the conclusion, That the root of the matter must be found in me. That in me must lie the cause of all the calamities that have been sent upon me by God ; that I must needs be a very wicked man, richly deserving such punishment. But to this I say, Mind well, what you are doing, mind well how you attribute to your friend guilt and crimes of which you can afford no proof, and respecting which he can appeal to Him who knoweth the secrets of the heart, that he is altogether innocent of them. (Ver. 29.) Be ye afraid of the sword. 'That is, of the avenging sword, with which the Divine justice is sure ultimately to visit such malicious accusations. For furious are the punishments of the sword. 'That is, the punishments inflicted by the sword. Ye should therefore know that there is judgment.

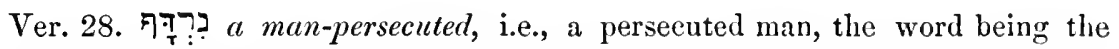
part. Niph. sing. mase., and not the 1st pers. plur. fut. Kal, as it has been taken to be by all the Translators and Commentators we have before us, although there is only one example (viz., Judg. vii. 25), in which רדף is followed by a dat. (i.e., by

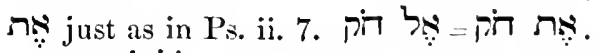

רִำ of the matter.

Ver. 29. חָ lit., wrath, fury; in English, however, it must be rendered furious, as though it were an arjective. Comp. Ps. xxxv. 6, "Let their way be

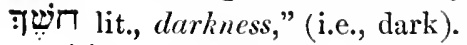

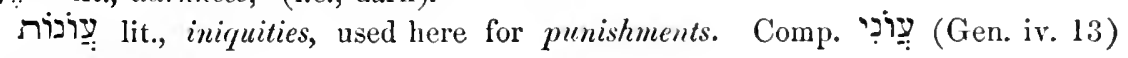
my punishment.

?ִּe therefore. This is the sense, in which this word should be taken here, as also in Prov. ii. 20, where the royal Proverbialist, after warning the young man against the bland words of the artful woman, exhorts him thus,

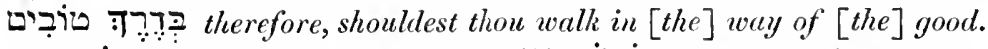

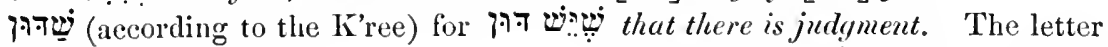
$\mathscr{w}$, which in later Hebrew is very frequently used for pointed with Segol, and followed by Dagesh; in the word before us, however, it has

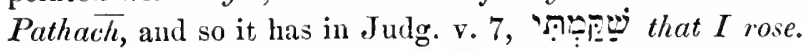

היה (Thore commonly judgment, is a verbal noun, formed from the inf. 


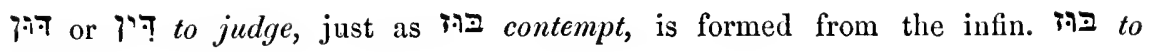
despise.

These two verses should be construed thus:

Ver. 28.

But ye say,

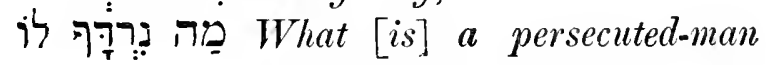
to Him (God)? (i.e., what advantage, or pleasure, can He have in seeing a man persecuted?)

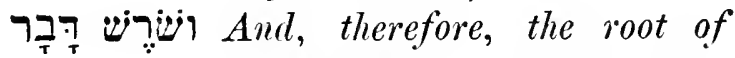
[the] matter (i.e., the real cause of my sufferings.)

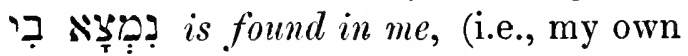
guilt must needs be the real cause, which has brought these calamities upon me; against this most pernicious conclusion, however, it is my duty to warn you. I say then,)

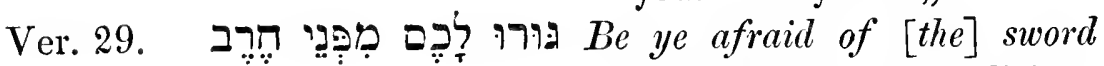
(with which such malicious accusations are sure to be visited,)

Tִ For furious [are the] punishments of $[$ the $]$ sword (i.e., the punishments inflicted by the avenging sword are furious.)

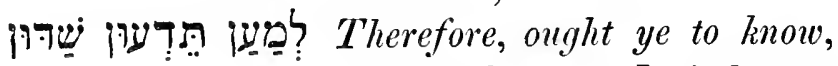
that [there is] judgment (i.e., you ought to bear in mind, that you will be called to account for these false accusations, and not escape with impunity). 


\section{CHAPTER XX.}

A Hint having been thrown out by one of the three friends (suiprac $\mathrm{x}$ viii. 2), that it was quite time to "make an end of words," or that, at least, every speaker should well consider what he was going to say, Zophar, before beginning his discourse, thinks it but right to apologize for his not complying with that request, and to explain, that he considers himself bound, in justice to himself, not to suffer the charge of $\mathrm{Job}$, that all the accusations brought against him are false and malicious, to remain long without its refutation. He says :

Vers. 2-9. On this account do my thoughts cause me to reply. Prompt me to answer. And for this reason is my haste in me. The reason for my not delaying to answer is this, that (Ver. 3) $I$ hear a correction intended for my shame. I hear my friend Job launching against me accusations and charges which, if substantiated only in part, would load me with shame. Therefore the spirit of my understanding maketh me to answer. My reason biddeth me not keep silence, but defend myself by shewing that I do not speak from malice or ill-will, but from my intimate conviction that, inasmuch as the wicked-man always pays a terrible penalty for his wickedness, the torments which my friend Job is now enduring must have their origin in such very serious offences and sins against God, as His attribute of justice could not allow of His suffering to remain unpunished. (Ver. 4.) Dost thou know this? Art thou aware of this great truth? From ancient-times, from the time of man's being placed upon earth. That is, from having studied ancient history. (Ver. 5.) That the triumphantshout of the wicked is of recent date, and the joy of the hypocrite but for a moment? (Ver. 6.) Though his excellency mount up to the heavens, and his head reach unto the cloud[s]. (Ver. 7.) Yet, like his own dung, shall he perish for ever. His head, which may be said to touch the very clouds (so exalted is he in honour, dignity, and pride, above the common herd of men), shall be abased to a level with the dung which falls from him to the ground. So 
utterly shall he perish, that, Those seeing him. Those, who were wont to see him in his high station. Will say, "Where is he?" (Ver. 8.) Like a dream, shall he fly-away and not be found; yea, he shall be chased-away as a vision of the night. (Ver. 9.) The eye, which hath seen him, shall see him no more, neither shall his place any more behold him.

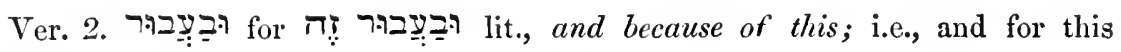
reason.

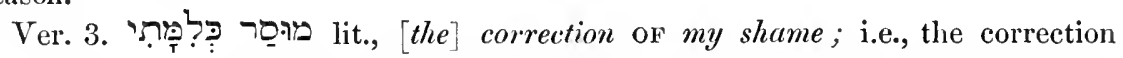
INTENDED For my shame, intended to bring shame upon me. See note on

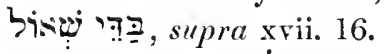

Ver. 4. שִָ lit. [one's] placing man; i.e., man's being placed. Comp.

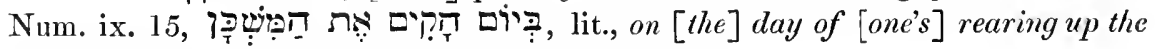
tabernacle, i.e., of the tabernacle's being reared up.

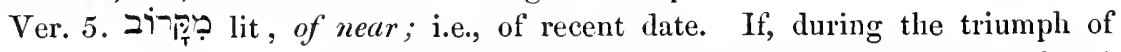
the wicked man, inquiry should be made as to when it began, it would be found to have had no long existence. This is the purport of the first hemistich, whilst in the second, we are told that the joy of the hypocrite will be but for a moment; so that his joy, or triumph, is comprised within very narrow limits of time, extending but a very little way into the past, and about to extend but a very little

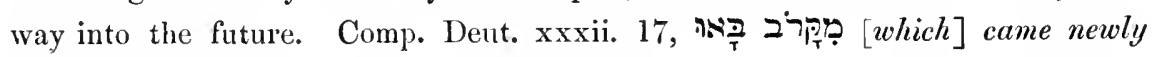
up; i.e., whose existence is of very recent date.

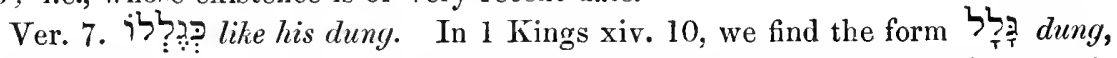
from which, however, the word under consideration can hardly be derived, as it

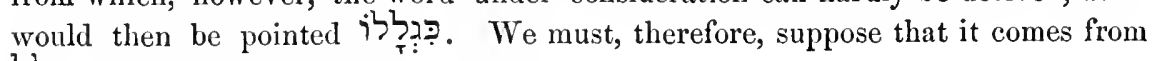
ל?: though this form does not occur.

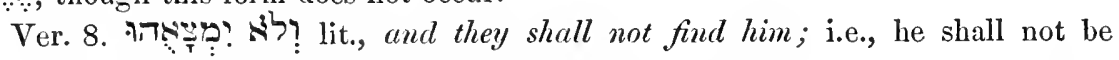
found, the verb being used impersonally.

? lo lit, and it shall be caused to move away (it being the Hoph. of פדרד to move); i.e., it shall be chased away.

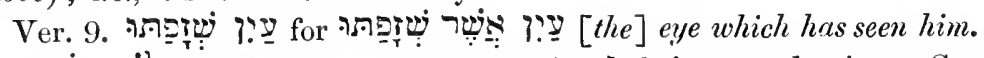

ๆ

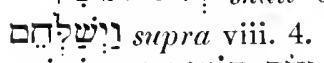

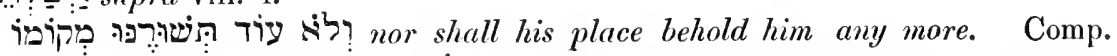
supra vii. 10, where, however, in the Bible. Even here there is no absolute necessity for regarding it as feminine, as it is well known that the verb, when it precedes its nominative case,

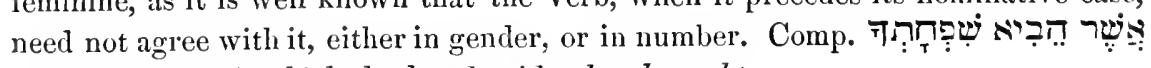
(1 Sam. xxv. 27) which thy handmaiden has brought.

Vers. 10, 11. His children shall have to conciliate the poor. To win back the hearts of those whom their father has made poor. Or, even his own (the father's) hands will have to restore 
to every one his substance. Inasmuch as the wicked man was described in Ver. 6 as one whose excellency mounted up to heaven, and whose head touched the clouds, it is evidently of no common robber, that the poet speaks here, but of a great and tyrannical conqueror; and of him he prognosticates, that his fortune will one day take such a turn, that either his children will have to sue for peace to those weaker princes, whom their father had stripped of provinces, treasures, \&c., or that even he himself, in his lifetime, will be obliged to restore to every one of his victims all he had plundered them of. (Ver. 11.) Though his limbs be full of his youtlful-vigour. Whilst even in the prime of life, and full of youthful strength. Yet with him shall it (his youthful vigour) lie in the dust. He shall be carried off suddenly in spite of his youth and vigorous constitution.

Ver. 10. isis for הist his substunce, i.e., the substance of every one of those he has

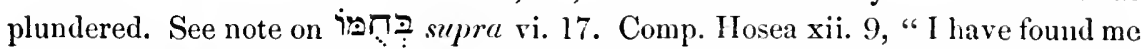
out jis substance." But, perhaps, there is nooccasion to adopt this unusual signification, seeing that, by simply taking בִּ in the first hemistich, in its primary meaning of weak, feeble (whence only its signification of poor has been derived, inasmuch as people, who are poor, are commonly weak and helpless, and liable to be injured with impunity), iv in the second hemistich, would form an excellent antithesis to it, in its usual meaning of strength, might (see note on isis supra $\mathrm{x}$ viii. 12); and the sense of the verse would be, that those, weakened by having been stripped of their wealth, would again be invigorated by having, one and all, their former strength

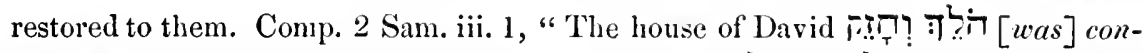

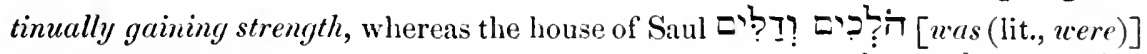

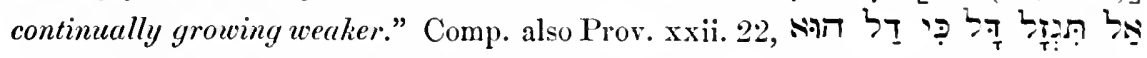
which should be translated thus, lob not a poor-man, though he be weak; (i.e., though he be helpless, and can offer no resistance, and may therefore be injured with impunity) . . . . . . For Jehovah will plead their cause, \&z.

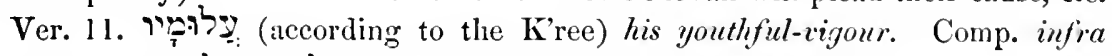

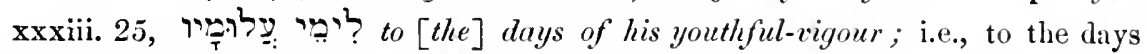
when he was in the prime of his youthful vigour. Comp. also Ps. lxxxix. 46,

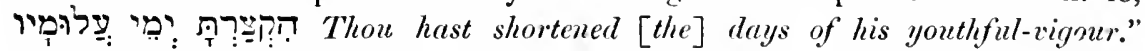

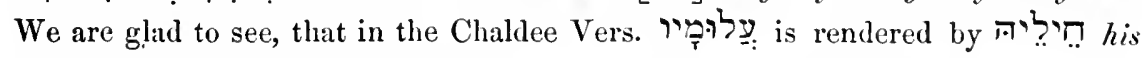
strength ; for, to translate this verse, "His bones are full of the sin of his youth," \&c., as is done in the Auth. Vers, and other translations, is, in our liumble opinion, to divest it of all meaning, for what connexion could there be in the

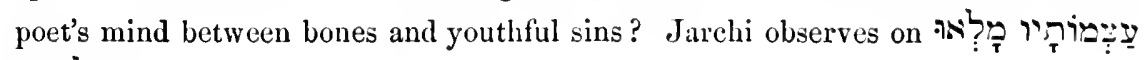
- - 
כס נערותיו

and, on $[$ [The] vigour of his youth ;"

$$
\text { כי ימות סתואם עם כמו: }
$$

"For he will die suddenly with (i.e., whilst in possession of) his vigour."

Vers. 12-16. The poet, in these verses, compares wickedness to a dainty morsel in the mouth. As a child, for instance, plays with a sugar-plum, rolling it under his tongue, pressing it against his palate, using every device, in short, to extract all its sweetness and perfume; so does the wicked man play and dally with his wickedness, not a whit less luscious to his taste.

Thongh his wickedness be sweet in his mouth, so that he hide it under his tongue. (Ver. 13.) Though he spare it, and part not with it, but lieep it back within his palate. (Ver. 14.) Yet his food. For his wickedness is to him as food and dainty food. When in his bowels, is changed. It turns out to be altogether different from what its scent and flavour made it appear to be. The gall of asps it proveth to be within him. (Ver. 15.) He hath swallowed down wealth, but shall vomit it up again; God will drive it out from his belly. It was no dainty morsel he had in his mouth; it was (Ver. 16) The gall of asps he was sucking; It will slay him as thongh it were the tongue of a viper.

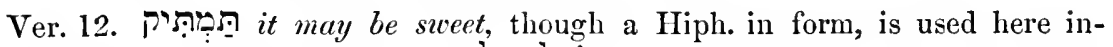
transitively. Comp. Isa.i. 18,

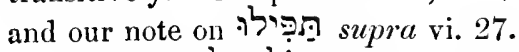

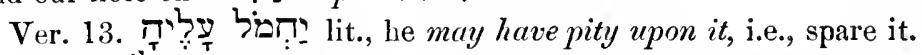

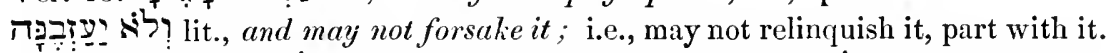

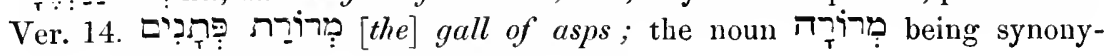
mous with פִ̣ gall, which we had supra xvi. 13.

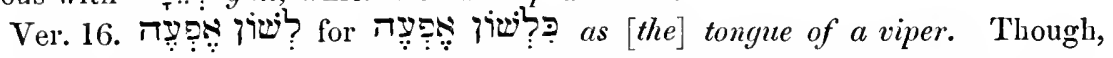
strictly speaking, it is not the tongue of the viper which contains the venom; yet, since this member is darted out at the moment of the infliction of the bite, it was anciently considered to do so. So the Psalmist says, Ps. cxl.4: They have sharpened

Vers. 17-23. The poet having stated that wickedness, however great the pleasure attending its commission, will ultimately lead to the destruction of the wicked man, now goes on to enumerate some of the disappointments and miseries in store for him, before he is removed from this world. He says : 
He shall see no floods, rivers, or lrooks, of honey and milk. He shall no longer enjoy that abundance of good and rich things, he was used to in the days of his prosperity. Hyperbolical as the language in this verse may appear to the reader, such, to our minds, overstrained figures are by no means unfrequent in the mouth of Hebrew poets. Thus, infra xxix. 6, he will hear Job say, by way of depicting the smooth and easy flow of his former prosperity, that his footsteps were washed with milk (cream), and that the rock poured out for him rivers of oil. (Ver. 18.) He must restore that which he laboured to obtain. By dishonest means. And shall not swallow it down; as the substance. Of which he unlawfully deprived his fellow-creatures. So shall be the restitution thereof, and he shall not rejoice in it. The restitution he will have to make shall be to the uttermost farthing; not one particle of his dishonestly gotten wealth shall remain with him, to cause him rejoicing. (Ver. 19.) Seeing that he hath crushed, hath abandoned the poor. He first ruined them completely, and then left them to their fate, without the least commiseration. Seeing that he hath violently-taken-away a house, which he never built. (Ver. 20.) Seeing that he never felt quietness within him. He was always restless, and bent upon doing mischief. Therefore, he shall not escape with that which he delighted in. (Ver. 21.) Seeing there was nothing left of his meat. For the poor. Therefore, shall his prosperity not last. (Ver. 22.) In the very fulness of his sufficiency. When his plenty is great to superfluity. He shall be put to straits; every blow of the miserable. Every blow, every plague, that can render a man miserable. Shall come upon him. (Ver. 23.) He will be about to fill his belly, when He (God) will send upon him His fierce anger; yea, He will vain it down upon them. Every one of them. While at his meal.

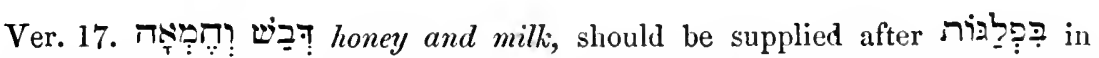

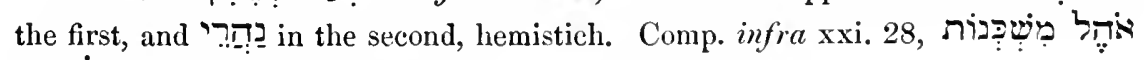
[the] tent, [the] hubitations, of [the] wicked.

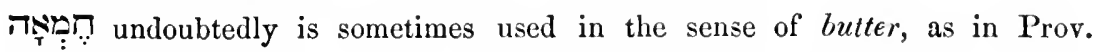

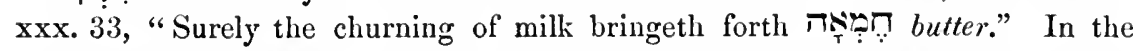
verse before us, however, where floods, rivers and brooks of it are spoken of, it can hardly have this meaning; it may perhaps be intended to denote the richest 
part of milk, viz., cream, but we thought it best to render it simply, milk. In Jurlges

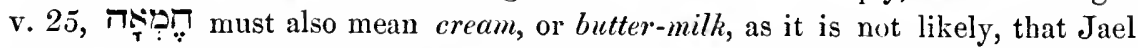
should have brought forth butter, when Sisera asked for water, to quench his thirst. Besides, so frequently mentioned together in the Old 'Testament, that we have no doubt but that here

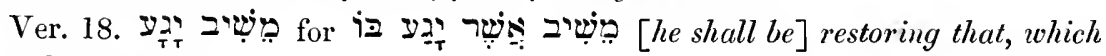
he laboured for.

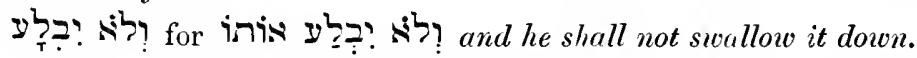

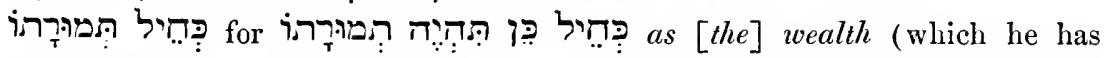
unlawfully gotten), so shall be the restitution thereof; i.e., he shall have to make full restitution.

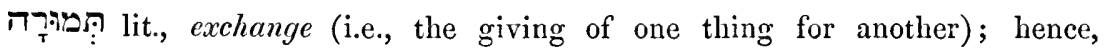
compensation, restitution.

$\Pi$, in this instance, is not the const. form of $\Pi$, but an independent noun in its absolute state, and synonymous with חיל Comp. Isa.xxxvi. 2,

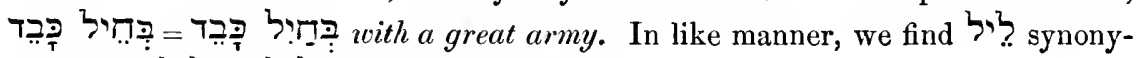

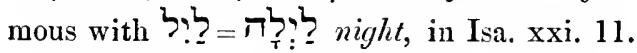

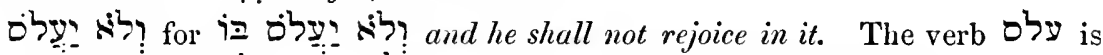
synonymous with

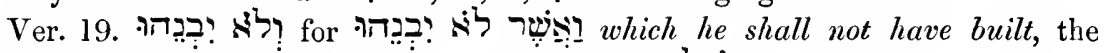

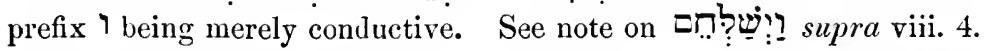

Ver. 20. שִ שָ prop. an adject. (see supra xvi. 12) quiet, tranquil, here used as a subst. quiet, tranquillity.

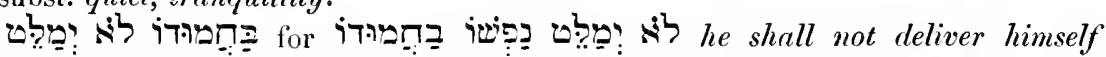
together with [that which was] his delight; i.e., he shall not escape with that, which was his delight. Comp. Amos ii. 15, where, in the same verse, טל: stands

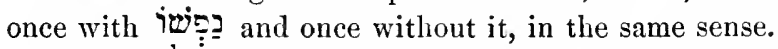

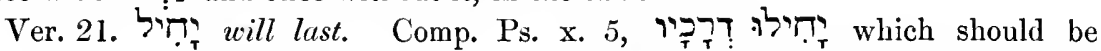
translated, his (the wicked man's) ways are lasting; i.e., everything he undertakes in the course of his life is durable and lasting.

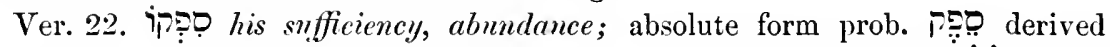

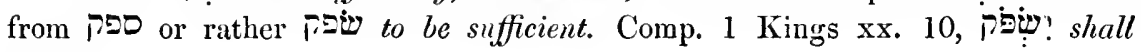
suffice.

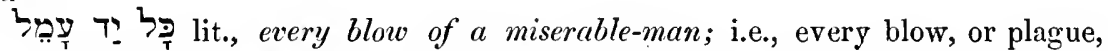
which can render a man wretched and miserable. The noun $T_{T}$, though originally signifying hand, is very frequently used in Scripture for blow, stroke, plagne, \&c. Comp. infra xxiii. 2, when 'ד̣ stands for my blow; i.e., the blow I have received.

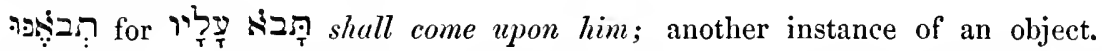

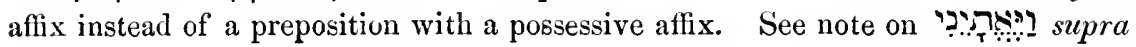
iii. 25.

Ver. 23. M? to since ver. 15 , yet the poet did not consider it necessary to repeat His name 
here, as no doubt could possibly arise, as to whom he intended as the subject to this verb.

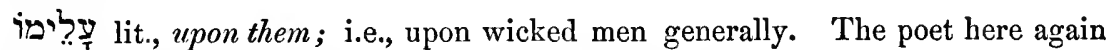
changes the number. See note on

Vers. 24-28. The wicked man, environed as he is, according to the description of the poet, with dangers of all sorts, is not overwhelmed by them all at once; he may escape one, but, whilst he is congratulating himself on his good fortune, another, greater, will come upon him; this too he may surmount, his self-confidence, arrogance, and pride, increasing with his success, but soon other dangers will overtake him, more terrible still, and following one upon another in quicker succession, till at last, fairly hemmed in, he must succumb. He will be in fact, to use the language of the prophet," "As a man, who fleeth from a lion, and a bear meeteth him; and then cometh home, and leaneth his hand against the wall, and a serpent biteth him." Our poet's words are as follows :

He may flee from the iron weapon. Escape injury from it, but, straightway, The bow of brass will strike him through. With its arrow. (Ver. 25.) This may be drawn, and come out, fiom his body; yea, the glittering-weapon may be drawn out from his gall. The weapon may be skilfully extracted, and the wound heal, but immediately, other Terrors will come upon him. (Ver. 26.) Every sort of darkness. That is, calamity. Is concealed for his hiddentreasures. 'The dangers, with which his treasures are threatened, are not perceived by him, till they are no longer to be shunned. A fire not fanned. By human hands. Shall devour him. Misfortunes shall befall him, the origin of which neither he, nor any other, shall be able to discover. 'The one remaining in his dwelling shall fare ill. (Ver. 27.) 'The heavens shall reveal his iniquity; yea, the earth riseth up against him. All nature will unite in bringing on his ruin. (Ver. 28.) The increase of his house shall depart, flowing away in the day of His (God's) wrath.

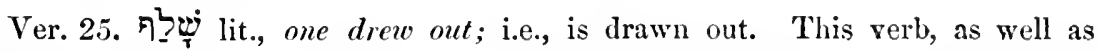
ㄴ.?ㄴ.?

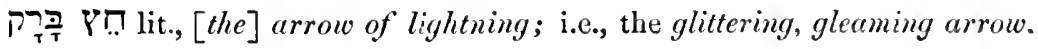




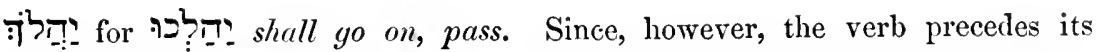
nom. case terrors, it need not agree with it in number. See Mason and Bernard's Gramm., Lett. xlix. $\$ 8$.

Ver. 26. תiש lit., darkness, used figuratively for calamity, misfortune.

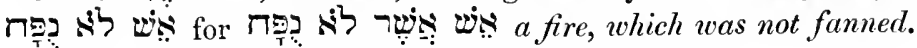

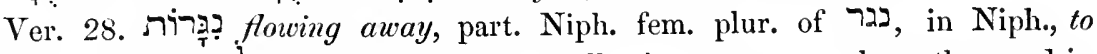
flow, referring to בוּ?

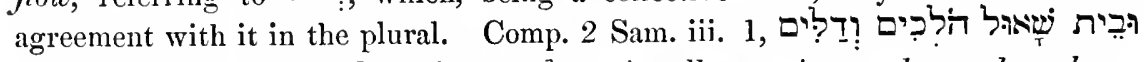
and [the] house of Saul [was lit., were] continually growing weaker and weaker.

Ver. 29. Having now completed his description of the calamitous life and miserable end of the wicked man, Zophar triumphantly exclaims :

Such is the portion of the wicked-man from God, and the heritage appointed unto him of God.

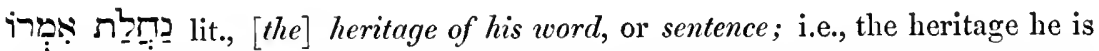
sentenced to (by God). The absolute noun רִיִ, from which the word under consideration seems to be formed, is not to be met with in the sing. numb., and even the plur. numb. mostly occurs in the poetical books. We find, however,

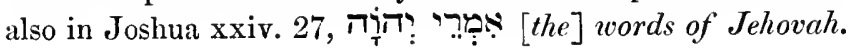

\section{CHAPTER XXI.}

Hitherto the unjustly tormented Job had, as might reasonably be expected, made his own unfortunate and unparalleled case the prominent topic of his discourses-describing minutely his bodily as well as mental sufferings, declaring most solemnly his innocence, complaining in unmeasured terms of the wrong that was done to him, and lamenting bitterly that there was no judge or tribunal to which he could appeal for redress. With regard to the condition of the wicked in this world, he seemed but little inclined to dwell upon the subject, his mind being naturally rather taken up and engrossed with his own grief; if, now and then, he did make allusion thereunto, it was but very briefly (supra ix. 24 ; xii. 6 ), and in all probability the matter would not have engaged his attention further, had it not been that his 
friends so continually obtruded it upon his notice. He now begins to feel, however, that the miserable lot, which they strenuously maintain must befall the wicked, is pressed upon him so repeatedly and vehemently-and that, not so much as a matter of fact, or historical truth, as to serve as premises, from which, if admitted, his friends might draw the conclusion, that his lot too is miserable, merely and solely because he is wicked (see preiminary remarks on chap. xix. 2-7) - that he can no longer pass over the subject in silence, and he therefore now proceeds to shew, not only the fallacy of their conclusion, but also the utter falsity of their premises-and this he does as follows:-

Ver. 2-15.-Listen attentively to my speech, and let this be your consolations.* I do not ask you for consolations; my wounds are far too deep to be soothed by any balm you could pour upon them; all that I beg of you is to give me an attentive hearing. (Ver 3.) Bear-with me, and let me speak; and, after I have spoken, thou mayest mock. Allow me first to speak out my mind, and then mock, one or all, as much as you please. (Ver. 4.) As for we, doth my complaint refer to any other man? Did I ever mix xp any other man in my complaints? Was I the first to introcuce the subject of the fate of the wicked, or to institute a comparison between their lot and mine? If I had done so, I could not cemplain of your following in my track; it would have been only natural in you to take up what I had said, and, after having thoroughly examined and sifted it, to point out wherein I was right or wrong; but such is not the case, I was altogether occupied in bewailing my own sufferings, and cared not for the lot of others. You have introduced the subject; And if so, why, I ask you, why may I not well lose my patience? (Ver. 5.) Look on me, and be amazed, and put your hand upon your mouth. See the condition I have been reduced to, and be amazed at yourselves, that you could treat me thus, that you could think of wasting so many words upon the fate of others, and altogether overlook what my own fate is. (Ver. 6.) And surely, when I do think of it. When I reflect that, contrary to all one might expect from the sympathy of friends, you have had the heart to introduce and

- That is, the consolations you offer me.-Note of Eclitor, 1861. 
speak at such length upon a subject altogether foreign to my case, and to remind me of the lot of the wicked, I am troubled, and my body is seized with shuddering. But when, besides reflecting upon your behaviour towards me, I also consider the manner in which I, an innocent man, am treated by God, who deals so very differently with those who are notoriously wicked and ungodly, my horror increases tenfold. (Ver. 7.) Why, indeed, should the wicked live? Why are they at all allowed to exist, to be the plague and scourge of their fellow-creatures? They do live, however, and not only live, but become old; yea, grow mighty in power. Their power increases with their years. (Ver. 8.) Their seed is established before them, and with them, yea, their offspring is before their eyes. 'They have the delight of seeing their children comfortably established and settled around them; they know they are near them, and prospering, not rambling about the rorld, striving for their living. (Ver. 9.) Their houses are in peace, without fear, neither is the rod of God upon them. (Ver. 10.) His bull. That is, the bull of every one of them. Gendereti, and iailcth not; his cow calveth, and casteth not her calf. (Ver. 11.) They send forth their wicked-little-children. Not only are they themselves wicked, but their children shew themselves such, even from their tenderest years. Like a flock, yea, their children skip about. Like lambs. (Ver. 12.) They take-up the tabret, and harp, and they rejoice at the sound of the lute. (Ver. 13.) They spend their days in prosperity, and in a moment are crushed (and hurled) into the grave. The reader will recollect, that death coming on, not by lingering disease, but suddenly, was considered by Job as a blessing. (See our comment on supra ix. 23.) (Ver. 14.) Therefore they say to God, "Depart from us, for we "desire not to know Thy ways. (Ver. 15.) What is the Almighty, " that we should serve Him, and what profit can we have, if we pray " unto Him?"

Ver. 3. תַ תֵלִִיג thou mayest mock. Job's object in changing the number here (the second pers. plur. having been used in the first hemistich) seems to have been to individualize his friends, whom he had before addressed collectivcly-as though, when pronouncing this word, he looked at his friends in turn, as much as to say, "Thou Bildad, or thou Zophar," \&c. 'The verb, though a Hiph., is used in the same significution as in Kal. See note on Pיפת supra xx. 12. 


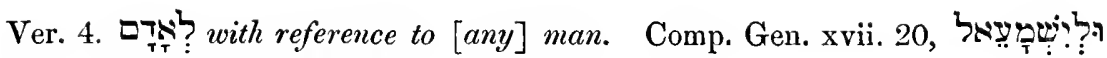
and with reference to Ishmael, I bave heard thee, \&c.

The first hemistich of this verse should be construed thus :-

הָאִ As for me,

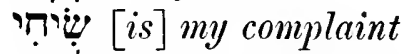

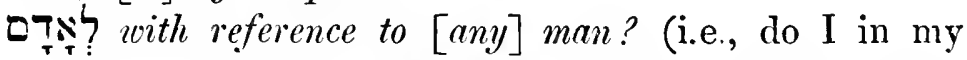
complaints mix up any other man than myself? Why, then, do you continually keep instancing the fate of wicked men?)

lit., should my spirit (temper) not be short; i.e., should I not

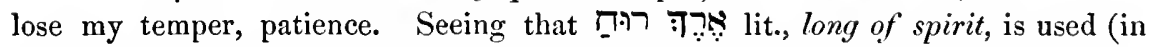

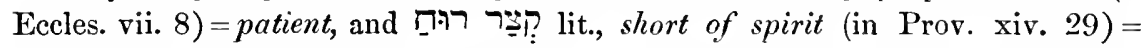
impatient, we cannot conceive how the translators of the Autl. Vers., and others, overlooked the very evident connexion between these phrases, more especially the latter, and the expression in the text.

Ver. 6. . shuddering takes hold upon my flesh. See note on supra xviii. 20.

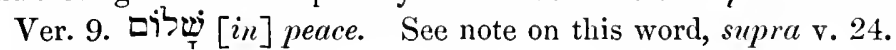

?ִ supra xi. 15.

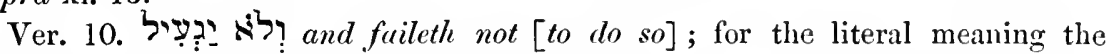
reader is referred to Ben-Zev's אובר השרשים, in which lie will find the following words, the translation of which he may perhaps dispense with :-

$$
\text { לא יכבב פליש' הזרע הנקלט בפרה (אויס=ווערכטן, סאן זיך געבן). }
$$

Jarchi and Kimchi explain it nearly in the same manner.

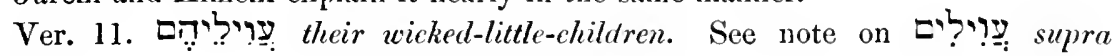
xix. 18.

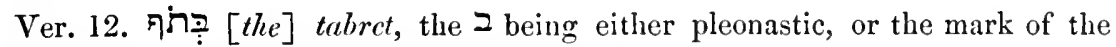
object. case. See note on

Ver. 13. . חהתו. they are broken in pieces, crushed. The form so plainly shews this to be the fut. Niph. of Tרת to break, crush, that we could not venture to follow those authorities, however great, who translate the word here as if it were derived from دרות to descend. We find, moreover, in 1 Sam. ii. 10, the very same word translated in the Eng. Vers., shall be broken to pieees, thongh here it is given the sense of going down.

Vers. 16-26. Scveral passages have been quoted by Mason and Bernard in their Grammar (Letter lvi. § 19), in which it is absolutely necessary to supply inverted commas (marks, which the Hebrew language does not possess), in order to arrive at their 
true meaning, seeing that, without this help, they would either be altogether unintelligible, or even convey an idea just the opposite to that, which was intended. In this very chapter, we shall find three instances of the sort; indeed, the first hemistich of the verse we are now about to comment upon, absolutely and indispensably requires to be understood, as if Job said to his friends, I know what you will reply to the statement I have just made about the blasphemous language of the wicked, and the foolishness, rashness, yea, madness, of the defiance they dare to breathe against Him, in whose hand and power they, and all they have, unquestionably are. You no doubt will say:

* "Lo, their prosperity is not in their hand." Their prosperity, as well as they themselves, may be annihilated by God in one moment; how then can they dare to hold such insulting language to God? But my answer is, The counsel of the wicked is far from me. I never undertook, nor ever will undertake, to justify, or even explain, their daring to use such blasphemous language; I never had any intercourse with the wicked, never approached them, never came into their counsels, how then can I know their motives for speaking with such arrogant impiety? All I know is, that they do speak so, that they do defy God, as if they were altogether independent of Him. But I would ask you (Ver. 17) How often doth it happen, that the lamp of the wicked is extinguished, and that their calamity. That is, the calamity due to them. Cometh upon them, even the sorrows God distributeth in His anger? Can you shew me many instances of it? Certainly not. (Ver. 18.) How often doth it happen, that they are as stubble before the wind, or as chaff, that the whirlwind snatcheth away? Can you shew me many instances, I again ask you, where this has happened? Certainly not. But then you will say: (Ver. 19.) * "God layeth up his affiction for his children." You will say it certainly sometimes happens, that God does not

* We leave it to the judgment of the reader, whether Job himself, who maintains, that the prosperity of the wicked is steady and unshaken; who would have them receive punishment in their life-time; and who moreover delights in philosophizing and accounting for everything, and finds fault with matters, as they generally go on in the world-could use, as expressing his own sentiments, the words in this chapter, which we give with inverted commas. 
punish the wicked man in his lifetime, but then $\mathrm{He}$ is a God "visiting the iniquity of the fathers upon the children unto the third and fourth generation," and consequently the iniquity of the wicked man, if not punished in his own person, will certainly be expiated by his children and descendants. But such an answer as this I could by no means regard as satisfactory; such a proceeding on the part of God would be anything but just; $\mathrm{He}$ ought to requite it to the wicked-man himself, that he should know. 'That there is a God judging upon earth. (Ver. 20.) His own eyes should see his calamity, and he himself should drink of the wrath of the Almighty. (Ver. 21.) For what concern hath he in his house after him? What does he care for his family, when he is dead? When the number of his months is cut off: That is, completed, ended. But to this again you will object: (Ver. 22.) * "Shali one teach God knowledge? Seeing He judgeth even the exalted-beings?" Angels, archangels, yea, the highest in the hierarchy of Heaven, are judged by Him, how then can we, frail and abject men, be so presumptuous as to suppose we can teach Him, what would be best for Him to do? But to this, plain facts shall be my answer; what do they tell us? How do matters go on in this world? Why, we find, that (Ver. 23.) The one (the wicked man) dieth in the very perfection of his strength, being wholly at ease and quict. (Ver. 24.) His vessels are full of mill, and the marrow of his bones is moistened. (Ver. 25.) While the other (the good-man) dieth in the bitterness of his soul, secing he never tasted pleasure. And yet (Ver. 26.) Alike they will lie down in the dust, and the worm will cover them. Where then, I ask, is the difference between the good man, who deserved a reward, and the wicked man who deserved chastisement?

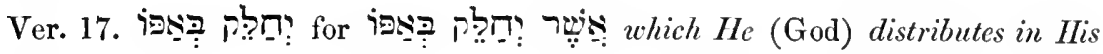
anger.

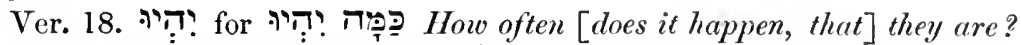

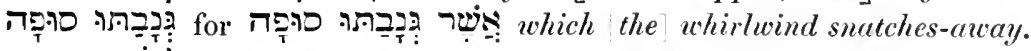

Ver. 19. isis his affliction, i.e., the aftliction which ought to come upon him,

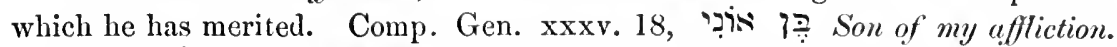

Ver. 20. פִִִ his calamity. The noun Ezra observes: 


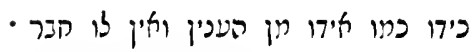

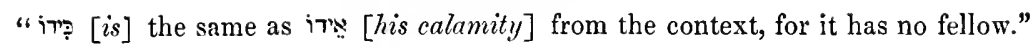

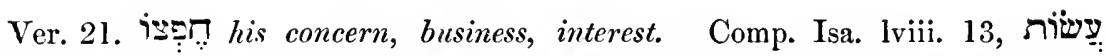
ד: (sic) which should be translated, doing thy business, transacting thy affairs. ר? lit., were cut off; i.e., were ended.

Ver. 22. יִיר: impers. should one teach.

Ver. 23.

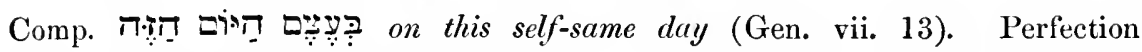
should here be taken, not in a moral, but in a physical, sense $=$ the perfection of his health and strength.

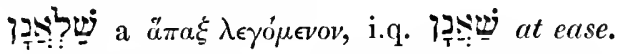

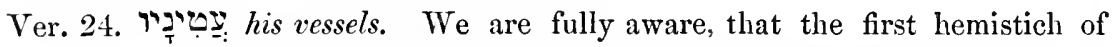
this verse, as translated by ourselves, and others, does not form a parallel with the second, as vessels full of milk have but very little connection with bones and

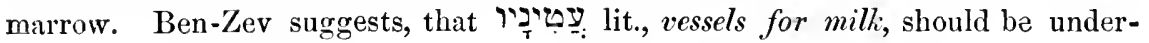
stood of the lactcals of the human body, and the are said to be full, of the chyle, which is found in these vessels, and has, when healthy, very much the appearance of milk ; this meaning would very well suit the connexion, and we confess, that we should have been greatly tempted to adopt it, if we could have supposed, that the physiology of the human body was so well known in Job's days. We give, however, Ben-Zev's comment on the word, which, it should be remembered, only occurs here. . . . He says :

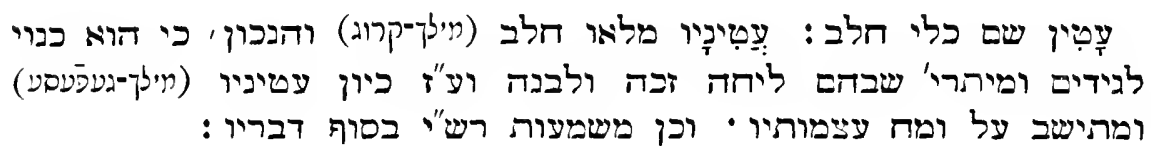

" A noun signifying a vessel for milk;" (Here he quotes the first hemistich of this verse) " $[a$ mill-jug]; but what seems right [is], that it [is used as] a figure of the nerves and sinews, in which * [there is] a pure and whice humour, and to them he applied [the word] : [lacteal vessels], which very well tallies with 'and the marrow of his bones,' (mentioned in the second hemistich); and so R. Solomon Jarchi seems to have understood it in the concluding-part of his words."

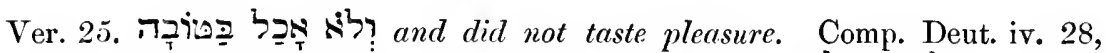
where it is said of idols, that they "neither see, nor hear (nor smell)" where the context shews the verb אבר to express the sense of

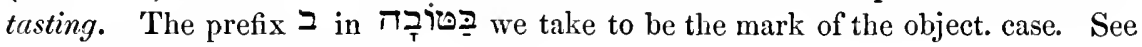
note on

Ver. 26.

* We of course do not hold ourselves responsible for Ben-Zev's physiological errors ; we quote him as a Hebraist, and not as a physiologist. 
Vers. 27-34. It is really astonishing to us, that the Translators of the Auth. Vers., as well as many others, could render the verses before us as they have done, and so make Job, at the close of his discourse, contradict almost every word he had previously said in it. Hitherto we have heard him speak of nothing but the success, happiness, and enjoyments of the wicked, but now he is made (by the Translators alluded to) to speak of their miserable end in terms nearly as strong as those used by his friends, whose opinion upon this point he had always so strenuously combated. Two Hebrew words also occurring in these verses, have had their meaning most unaccountably perverted by them; the noun נָדיב, namely (Ver. 28), which, though generally used to express everything, that is generous and noble, they have chosen here to take in a bad sense, so as to stand in parallelism with men, in the second hemistich; and secondly, wigh, which. in every other instance, where it occurs, and even in this book itself (supra v. 26), is unanimously translated a shock of corn, but here, by some process or other, has been made to signify a tomb. Vexatious as it is to see Hebrew words divested of their usual meaning, and, by needless ingenuity, made to assume a significition quite different from, or even contrary to, their real one, yet we could have passed the matter over in silence, if we had but seen, that the Translators had in this way contrived to maintain the consistency of the train of reasoning; but when we find the result of all this tasking of their brains is to put into the mouth of the unfortunate speaker words diametrically opposed to his previous ones, we feel ourselves really bound to expose such practices. We trust, then, to be able to shew, that the usual meaning of these two Ilebrew words may be adhered to, and yet no difficulty be found in giving of the verses before us a translation, which shall be in harmony and unison with all that has been said by Job in the preceding part of his discourse. We understand him, namely, to say as follows:

Lo, I know your thoughts, and the devices ye wrongfully-imagine against me. (Ver. 28.) For ye say, "Where is the house of the noble-minded-man, and where the duelling, the habitations of the wicked?" You say, that it is quite impossible for short-sighted 
mortals to decide positively with regard to any house, whether it harbours a good or a wicked man, because, judging as they do, only from appearances, they may mistake one for noble-minded who in reality is wicked and depraved, or hold another to be wicked who is secretly, and without ostentation, acting in a manner altogether pleasing and acceptable to Him, who "knoweth the secrets of the heart." By thus disputing the competency of a man to pronounce any one of his fellow-men to be either just or wicked, you, of course, mean to insinuate that I too, though you can bring no distinct charge against me, may have all my life been wicked and depraved. But to this I reply, that, although men may, as it must be admitted, sometimes be mistaken in the judgment they form of their fellowcreatures, yet it is not likely that ALL should be ALWAYs mistaken. If, therefore, you have no confidence in what. I say, as having seen it with my own eyes, touching the manner in which wicked men fare in this world, and if you place no reliance upon what you yourselves have observed with regard to them, let us appeal to travellers, to men who have travelled far and wide, and have noted down what they have seen and heard in the course of their travels, and I therefore put the question (Ver. 29.) Have ye never asked great travellers? (but ye must not deny whatthey-have-marked-down). In their notes. You must not say, that all the observations they have made are incorrect and false. Now, what will you find recorded by them? You will find (Ver. 30) That, in the day of calamity, the wicked man is spared, even in the day, when wrath is brought on. That, when punishment comes down from above, it usually leaves the wicked man unscathed. (Ver. 31.) Who will, in his presence, mention his course-of-life? Who will venture to his face to blame, or even allude to his misdoings? Yea, when he hath done. A thing, however wrong. Who will requite it him? But, not only in his lifetime, do people stand in awe of him ; his influence is so great, his wealth so immense, and his children so powerful, that the greatest respect will be paid him even after his death. (Ver. 32.) Yea, he is carried to the burying-place. With the same respect. As he was held in, when he used to watch over his shock $[s]$-of-corn. Just as in his life-time people, were obliged 
(through their fear of him), to salute him humbly, when they passed before him as he stood watching over his shocks of corn, that no poor man might glean an ear, so must they testify their respect to his body when carried to the grave. (Ver. 33.) The clods of the valley are therefore sweet to him. Death has lost its terrors for him; when he thinks of it, it is but to revel in the contemplation of the honours which will be paid him, when his body has been committed to the tomb, Seeing that every man will be obliged to draw after him. That is, to follow his funeral procession. And before him will move men without number. There will be great numbers preceding, as well as following, his remains. (Ver. 34.) How then comfort ye me with that, which is vain, seeing, that your answers-every one of them proveth to be a fallacy!

Ver. 29. עוֹבְרִי דָרחד lit., passers of [the] way; i.e., those, who travel far and wide, great travellers.

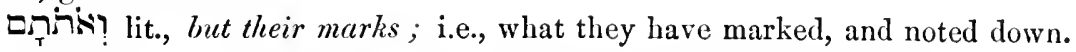
you must not deny. So Ben-Zev explains this passage :

\section{שהם ברורים כל כך באמרתם , עד שלא יהיו זרים בעיניכם לדמות}

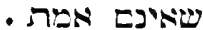

"For they (the things, which the travellers have marked down) [are] so clear in their truth, that they cannot be strange in your eyes, so that you should think that they are not true."

It will be perceived, that the second hemistich of this verse is parenthetical.

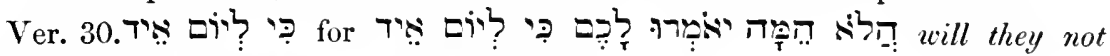
tell you, that in the day of calamity, \&c.?

ם'? in the first, as well as in the second, hemistich of this verse, stands for

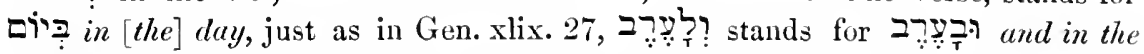
evening.

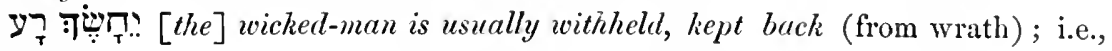
spared.

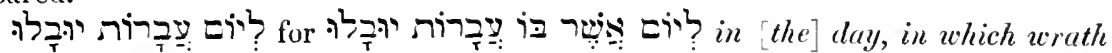
is brought upon (lit., wraths are brought on).

Ver. 32. This verse should be construed thus:

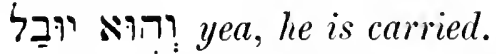

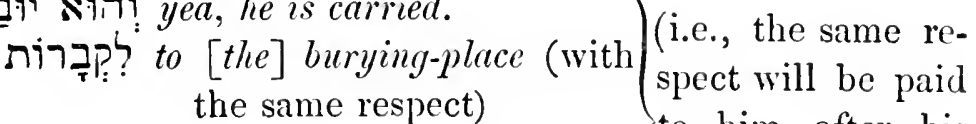

7ipẹ:... as (he was held in) when...
he used to watch. 
שי שִ

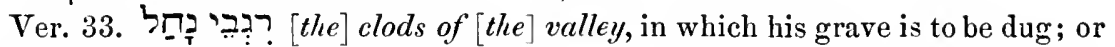
פֵֵַ may perliaps itself mean the ditch dug out for his tomb. The noun רג? ?ִג occurs only twice in the Bible, here and infra xxxviii. 38, and in both places in the plural number.

习ฺ̛̣:? lit., will draw; i.e., move on, go. 'The French tirer, and the German ziehen are also used in the sense of to go.

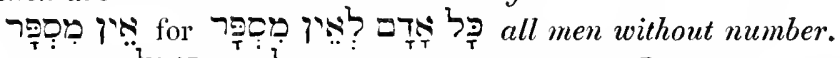

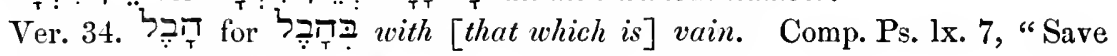

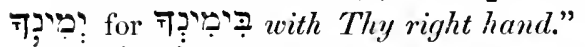

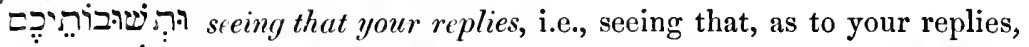

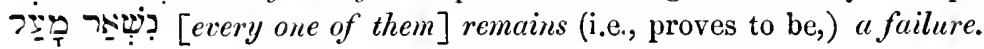

\section{CHAPTER XXII.}

Vers. 2-10. Can a man be profitable unto God? Surely, to himself is a wise man profitable. God can derive no benefit from the pious life of a man, but the man, who has wisdom enough to perceive that his whole object should be to serve God, and obey His commandments, he benefits himself. (Ver. 3.) Hath the Almighty any interest in thy being (lit., that thou art) righteous, or any gain, if thou makest thy ways perfect? Since then it is altogether impossible to impute any motive of self-interest to the Almighty, it must needs follow, that, if He has favoured man more than all other animated beings by endowing him with intellect, it was purely from His love to the human race, and from the delight He feels at seeing His creatures walk in the right way, and, by doing so, deserve His grace, His blessing, and His bounties. But the chief ground of thy murmuring, my friend Job, seems to be, that punishments have been sent upon thee by God without His explaining to thee the reason why $\mathrm{He}$ sent them. But is it not in the highest degree absurd to expect, that the Maker should be willing to explain His doings to the creatures He has made? When a man requires an explanation from his fellow-man, he 
thinks of course he has a right to demand it of him, and founds his expectation of its being given, upon the feelings of respect or fear, with which he conceives himself to be regarded by him, to whom he addresses the demand. But can a man expect God to give him an explanation of His dealings with him from any such motives? (Ver. 4.) Will He reason with thee, because He standeth in awe of thee? Will He enter into judgment with thee? Will He seek to justify His proceedings towards thee, by enumerating to thee all thy past misdoings, saying? (Ver. 5) "Was not thy wickedness great?" Yea, there was no " end to thine iniquities. (Ver. 6.) For thou wouldest take a pledge " of thy brethren without a cause, and the garments of those thereby " left naked wouldest thou strip off. (Ver. 7.) Thou wouldest give " the faint no water to drink, and from the hungry-man thou with" heldest food. ((Ver. 8.) As though the powerful man-to him " should belong the earth, and as though the man of authority " alone ought to dwell in it.) (Ver.9.) Thou didst send widows " away empty." With their just claims unsatisfied. "So that the arms of the fatherless should be crushed." So that the fatherless might be rendered feeble and helpless, and be exposed to injuries of all sorts without any hope of redress. (Ver. 10.) "Therefore were snares round about thee." Therefore, even in the time of thy prosperity, though without being thyself aware of it, thou wast by thy misdeeds encircling thyself with snares, in which thou shouldest at some future time be caught. "And therefore did sudden terror confound thee." Therefore didst thou on a sudden fall into the very trap thou hadst prepared for thyself._Canst thou expect that God will give thee any explanation like that?

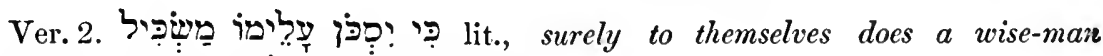
profit. See note on

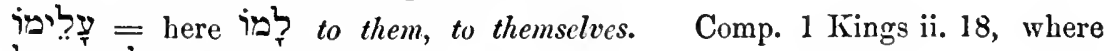
?ִ for thee, on thy behalf.

Ver. 3. חֶ? in the first hemistich corresponds to therefore must be understood to signify advantage, interest, or something similar. (See our note on חृ supra xxi. 21.) We are very sorry to find the word in this instance rendered in the Auth. Vers., as well as in other translations,

* But this is really the converse, for here it is the plural which is irregular, there the singular. The present passage I would rather compare with which see note in Appendix. Note of Editor, 1861. 
pleasure-the hemistich rumning, "Is it any pleasure to the Almighty that thou art righteous?"- -since it is putting into the mouth of Eliphaz, so orthodox in all his discourses, a sentiment diametrically opposed to what we are told over and over again in Scripture of the pleasure God takes in the peace and welfare of those who serve Him. Of the many instances we could quote, the one in Ps. xxxv. 27 will perhaps suffice; be magnified, which delighteth in [the] prosperity of his servant.

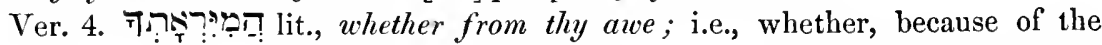
awe, in which He stands of thee. See our remarks on the ambiguity of the Hebrew possessive affixes in our note on בִִִִִ , supra iii. 10.

N.B. At the end of this verse, ראל saying, should be supplied, the following verses, till ver. 10 inclusively, being supposed to be the words of God.

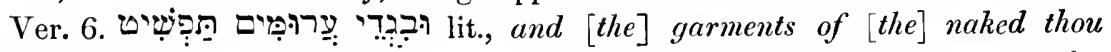
usedst to strip off; i.e., thou usedst to strip off the garments of those, who thereby were left naked, thou didst strip men naked. Comp. Hos. ii. 5,

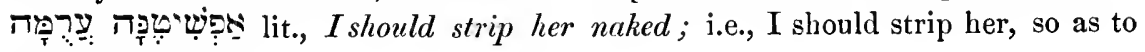
leave her naked.

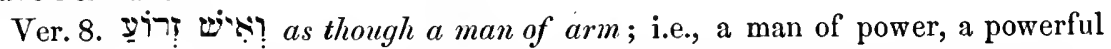
man. These two words should be taken absolutely, when the hemistich would

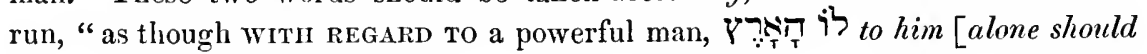
belong] the earth;" i.e., as though he, the powerful man, had alone a claim to the earth.

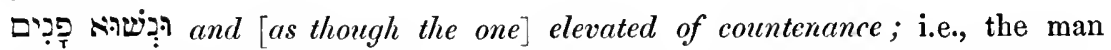
of authority (Comp. 2 Sam. v. 2). These two words must also be taken absolutely, and the hemistich rendered, "And as though, wITH REGARD to the man of

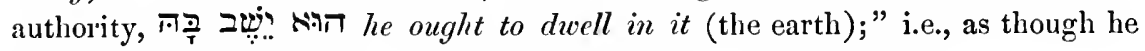
alone had a right to inhabit the earth. It will be perceived, that this verse is to be taken parenthetically.

Ver. 9. '쿠?': should be crushed. This verb in the sing. numb. individualizes the plur. noun ז̇: arms, to which it refers, and so expresses that every individual arm would be crushed. See note on ịִ? supra vi. 17.

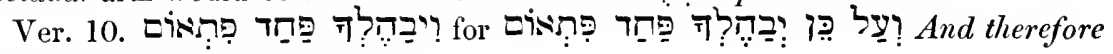
did sudden terror confound them.

N.B. The verses we have given with inverted commas contain the explanation which the speaker supposes Job might expect from God of His proceedings towards him. All the Translators and Commentators, Wolfssohn, their king, not excepted, have looked upon them as spoken by Eliphaz himself, in his own name, and as real charges brought against Job. But, if Eliphaz and the other friends had known Job to have committed such atrocities, as are enumerated in these verses, we can hardly believe that they would have come to sympathize with him, and comfort him; much less, that they would have torn their garments and sprinkled 
dust upon their heads on account of the fall of such a barbarous oppressor. Moreover, since Job had challenged them as early as (Chap. vi. 24) to point out to him, in what he had erred, it is difficult to understand how-if they had had charges like these to bring forward against him, charges which they would not have failed to perceive must put him to the blush and silence him for ever-they could have kept them back till now. The truth of the matter is, Eliphaz merely meant to say this: We certainly cannot point out to you a single thing in which you have done wrong, but this does not prove that God could not, as He may have seen you commit many atrocious crimes, which remain concealed from us, as well as all others, who know you.

Vers. 11-20. The speaker, having shown Job how absurd it was of him to think, that God would ever condescend to give him an explanation of His proceedings towards him, now goes on to point out to him the equally great absurdity of his supposing, that there is no Providence at all, but that everything in this world is left to chance, God interfering in nothing that goes on here below-either because it would be quite impossible for Him to do so, owing to the great height at which $\mathrm{He}$ sits enthroned, and the thick clouds that intervene between His throne and the earth, or because it would be altogether beneath the dignity of so majestic a Being-who is much more fittingly engaged in ruling in the realms of heaven, and employing Himself there with objects of a nature more sublime, and more worthy of His Divine care-to occupy Himself in the least about poor miserable mortals.

Before proceeding to translate, and comment upon, these verses, we must beg to own that Verse 11 has caused us great trouble, and we would pray the reader not to pass his judgment upon our translation of this verse, till he has read the three succeeding ones, which, in our humble opinion, were intended by the speaker to illuminate the obscurity of its somewhat too great brevity and conciseness. He says:

(Ver. 11.) Or canst thou not conceive. The possibility of a Providence regulating things here below. On account of the darkness. Of the clouds. And the abundance of their water, which is above thee? Are these dark clouds thou seest above thy head, 
and the floods of water they contain, the cause of thy being unable to conceive, how it can be possible for God to watch over the affairs of this world? (Ver. 12.) Is not God in the height of heaven? Yea, look at the summit of the stars, how high they are! (Ver. 13.) And so thou mayest, perhaps, say, "How can God know? What is going on here below. Can "He judge through thick-darkness? (Ver. 14.) Thick-clouds are " a covering to Him. He is altogether veiled in thick clouds. So " that He cannot see.* And it is in the circuit of heaven that He " moveth." He employs Himself with sublime objects, more befitting His glory and majesty, and more worthy of His Divine care.

But, if thou art really imbued with this pernicious doctrine of magnifying God and humbling thyself in order to be able to deny altogether His control over thee, thou must not take credit to thyself, as if it were an idea of thine own. It is an old, hackneyed tale, concocted by those depraved men of olden time before the flood, whose wickedness was so great, as to exhaust even the long-suffering of God Himself. (Ver. 15.) Dost thou keep to the old path, which iniquitous men have trodden? Long before thee. (Ver. 16.) Which became shrivelled corpses before their time. Whose depravity was so great, that the justice of God could not allow them to live out their time. Is it in their footsteps that thou art treading?

Indeed, their foundation. 'That is, the wicked principles, on which they strove to establish their most pernicious and dangerous doctrine. Is like an overflowing river. Such is the spreading and contagious nature of these principles, that it is by no means unlikely they have infected thee; and if so, it can be with no slight taint, for, thy conscience's opposing barrier once overborne, they cannot have failed to mar all that was good and holy in thee, in the same manner that a river, which hath overflowed its banks, spreadeth its devastations far and wide among the corn-fields. I mean the doctrine of those, Who say to God, "Depart from us." But, thou wilt ask, what hath God done to them? What hath He done to them, that they should fall out with Him? (Ver. 18.) Seeing that Me hath filled their houses with good-things. 'To this question, I must

\footnotetext{
* Comp. Ezek. viii. 12 ; ix. 9 ; Isa. xxix. 15.
} 
answer in thine own words.*. Indeed, the counsel of the wicked is far from me. It is as far from me, as it is from thee, and therefore thou canst not expect me to give any reason for their using such wicked and rebellious expressions. All I know is that there will come a time, when (Ver. 19) Righteous-men will see that they have reason to rejoice. That they have not been drawn into the vortex of such atrocious principles. And when the innocent-man will mock at them (the wicked), saying, (Ver. 20) "Verily, our substance lath not been destroyed, whereas a fire hath consumed their abundance." So that their miserable end will be a full vindication of the justice of God, as well as an evident proof, that everything here below takes place as decreed by Him.

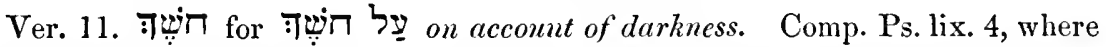

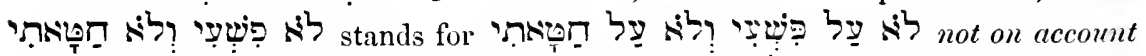

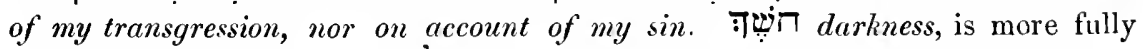

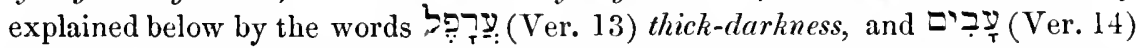
thick-clouds, and, therefore, means the thick and dark clouds, which intervene between earth and heaven.

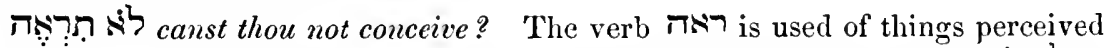
by other senses than by that of sight; e.g., by the ear, as Gen. ii. 19, תרז?

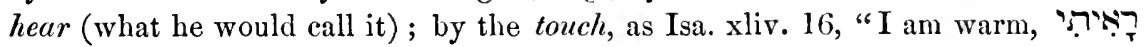
I have felt (the fire)." It is used also of the perceptions of the mind, $\dagger=$ to

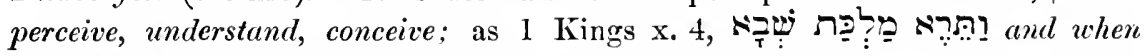
[the] queen of Sheba perceived (all Solomon's wisdom, \&c.) Again, in 1 Sam. xxiv. 12, הִִּ ำ know and understand, (that there is neither evil nor transgression in mine hand). In like manner here, understand, conceive, (how it is possible, that God should regulate the course of events here below)?

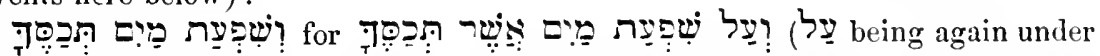
stood, as in Ps. lix. 4,) lit., or, on acconnt of [the] abundance of water, which covers thee; i.e., the abundance of water contained in the clouds above thy head. Many Commentators take "the abundance of water" to be used figuratively for misfortunes, calamities, but we are not, it seems, the only ones, who could not

* Supra xxi. 16.

$\dagger$ Perhaps rather of the operations of the mind which are the results of its perceptions through the senses; for when we see, hear, or feel, and recognise the nature of the objects with which we have thus been brought into communication, we have then also to deal with perceptions of the mind, and these mimary, or direct, perceptions may, or may not, give rise to secondary, or indirect, and higher ones, produced by the aid of reason from the first. If, therefore, we say things are perceived $\mathrm{BY}$ THE SExsEs, we can only mean perceived BY THE MIND THROUGH THE sExsts, for the senses (sensorium) can only perceive (i.e., become conscious of) impressions - which thus grasped become sensationsand cannot perceive things. Comp. Carpenter's Physiology.-Note of Editor, 1861. 
digest such an explanation. Homburg too was so reluctant to admit it, that he even preferred to understand the words of the drops of sweat which often stand out upon the body, when one is struck with sudden terror. We need scarcely, we think, apologize for not accepting this desperate interpretation, which was evidently only had recourse to because nothing better suggested itself. The perplexity, into which this verse has evidently thrown all the Commentators, without exception, seeming to us to have chiefly arisen from their connecting ver. 11 with ver. 10, we were led to take it in connection with the three succeeding verses, and, by doing so, hope we have surmounted this seemingly insurmountable difficulty.

Ver. 12. 位 already so many times had occasion to notice the ellipsis of the prep. $\beth$, that we do not think it necessary to quote an example here. The Chaldee version las expressed the $\mathrm{Z}$, rendering,

רִ רִּ lit., how they are high; i.e., how has here the sense of how, as in 1 Sam. xiv. 29," " "ִ how (mine eyes have been enlightened)."

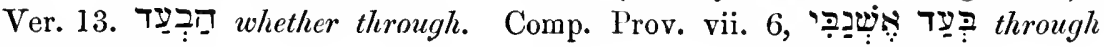
my casement.

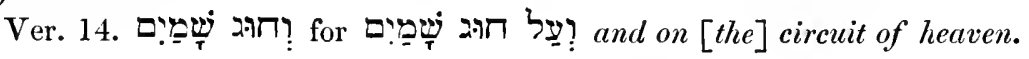

Vers. 11-14. should be construed thus:

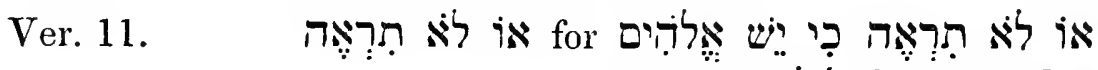

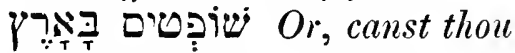
not conceive, that there is a God, judging on earth,

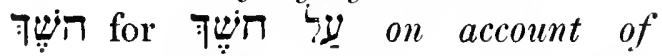
darkness (i.e., on account of the dark clouds, which intervene between Him and thee,)

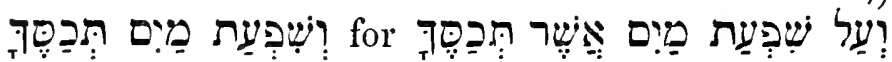
lit., Or, on account of [the] abundance of water, that covers thee? (i.e., on account of the abundance of water, contained in the clouds over thy head. Are these the cause of thy not being able to conceive it possible, that the eye of Providence can watch what passes here below?) 
放 for for of heaven? (i.e., in the high heaven?)

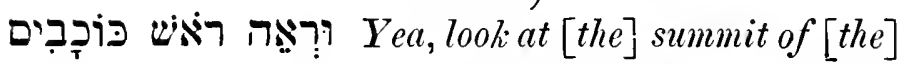
stars,

how high they are!

Ver. 13 .

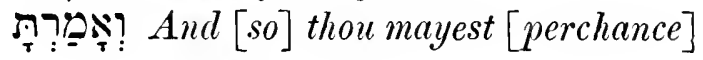
say:

" "פhat does God know (of things here below?)

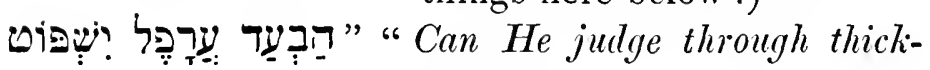
darkness?

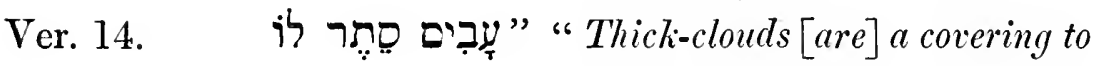
$\mathrm{Him}$ (i.e., $\mathrm{He}$ is veiled in thick-clouds, )

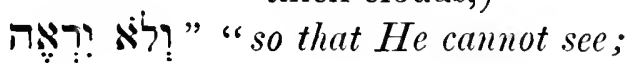

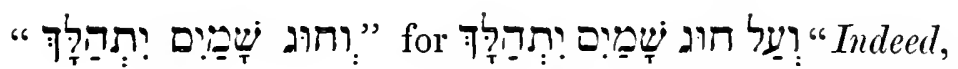
He moveth on [the] circuit of heaven [only]," (i.e., the heavens are His sphere of action, inasmuch as they, and only they-but not this insignificant clod of dust, called earth-contain creations and creatures, worthy of His divine notice.)

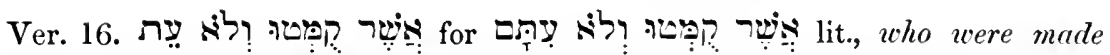
shrivelled [corpses], when their time [was] not; i.e., who were swept away before their time. The verb טמק to be wrinkled, or shrivelled, occur's only here, and supra xvi. 8.

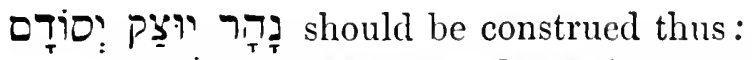

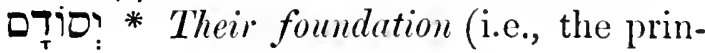

* Tio' foundation, is very frequently used by the Rabbins for the rrinciple, or base, upon which a doctrine is founded. 'Thus Maimonides begins his great work, ההin with the words

\footnotetext{
יסור היסורות ויממוד התכמות לידצ שייש שם מצוי ראשון
}

"The foundation of foundations (i.e., the most important of all principles, and the pillar of wisdom, [is] to know, that there is a first heing." 


\section{ciple, on which their nefarious doctrine is based) [is]

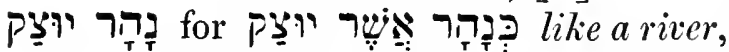 which should be poured out. (i.e., their doctrine is like an overflowing river, calculated to sweep away everything before it; and so, perhaps, thou hast been carried away by its torrent.)}

If this verse were meant by the poet to convey an allusion to the men, who were destroyed by the deluge, as, with other Commentators, we are disposed to think, the second hemistich may perhaps, in addition to the meaning we have given to it, also have been intended to express, that the doctrine of those desperate and abandoned men was as destructive, and overwhelming, as the flood, which swept them from the earth.

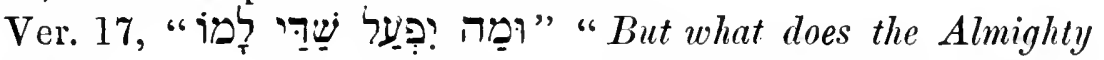
do unto them?" So, O Job, thou wilt be disposed to ask.

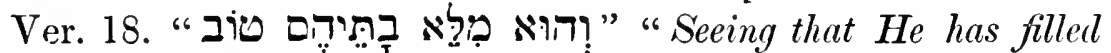
their houses with [everything that is] good." The reader will recollect, that, in the preceding discourse, (ch. xxi. 14, 15,) Job had said, that the greater the blessings wicked men enjoy, the greater the defiance they bid God; Eliphaz, therefore, thinking it likely Job might here interrupt him with a shout of triumph at hearing him acknowledge the truth of his (Job's) assertion, subjoins: but, if thou ask me, why these wicked men are so ungrateful to God, who has so bountifully bestowed His favours upon them, I can only answer thee in thy own words, (See supra

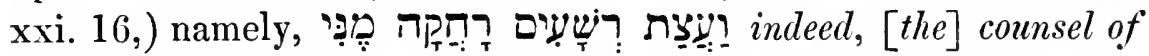
[the] wicked is far from me. Their motives for shewing themselves so ungrateful to their maker and benefactor are as much a mystery to me as to thee; all that I know is, that there will come a time, when the righteous will see, \&c.

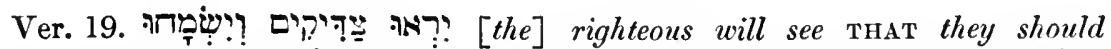

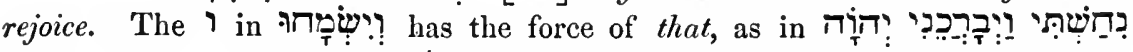
(Gen. xхx. 27) I have divined (I divine) тнат Jehovah hath blessed me; and in 


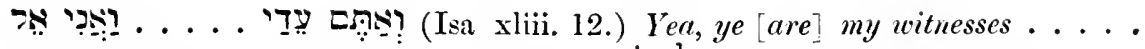
THAT $I[a m]$ God. At the end of this verse 7ian? saying, must be supplied.

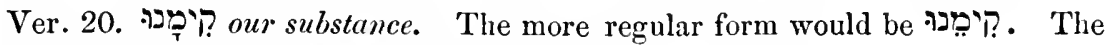

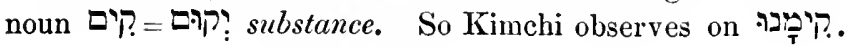

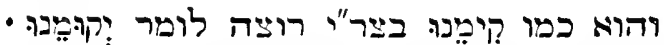

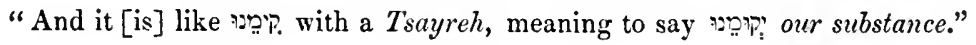

Those Commentators, and, alas, they are not few, who have taken the liberty

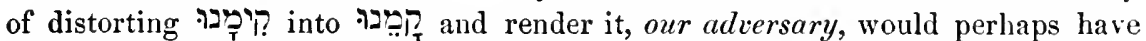
had more mercy upon this word, if they had consulted Kimchis כפר השרשים.

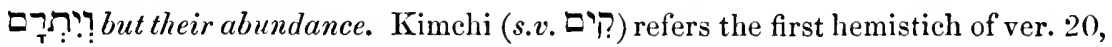
to Noah and his household, who, by the grace of God, were saved from the flood, and the second, to the men of Sodom and Gomorrah, who were destroyed by a

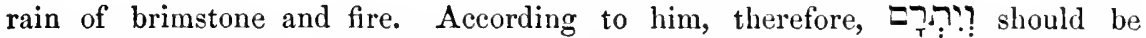
translated, but the rest of them; i.e., the wicked men among the descendants of Noah. He paraphrases this verse in the following words :

\section{באטת לא נכחד יקובנו מכל וכל במבול, כי,נשטאו נה ובניו, וירגם הכלה

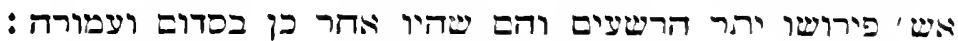

"Verily, 'our existence was not altogether destroyed' by the flood, for Noah and his sons remained; 'but the rest of them fire consumed, meaning to say, the rest of the wicked-men, namely those, who were after [that time] in Sodom and Gumorrah."

Vers. 21-30. Having pointed out the utter ruin and perdition, which those wicked men drew down upon themselves, who were infatuated with the idea, that God does not notice the doings of man, the speaker now entreats his friend $J_{0 b}$ to follow an altogether different course. He says:

Acquaint, now, thyself with Ifim (God), and then thou wilt prosper. Instead of imagining that $\mathrm{He}$ is only in heaven, far away from thee, and not caring at all about thee, impress thyself rather with the great and salutary truth, that $\mathrm{He}$ is also on earth, and near thee, and that $\mathrm{He}$ is noticing, not only thy movements and thy doings, but also the most secret thoughts of thy heart; on this condition, and this only, canst thou expect to be prosperous. By these-things. Which I am about to recommend thee. Good will come unto thee. By these namely, (Ver. 22.) Receive. I pray thee, the law from His mouth. Shut not up thy heart against His law, but do all His commandments. And lay up His words in thine heart. Let all His precepts be graven in thy heart. (Ver. 23.) If thou wilt return altogether to the Almighty, thou 
shalt be built up. All thy losses shall be repaired, the breaches in thy fortune closed. If thou wilt but remove iniquity far from thy dwelling-places. (Ver. 24.) And put gold on a level with dust, and the fine gold of Ophir, with the pebble[s] of the brooks. Attach no more value to gold, even the finest gold, than to dust and stones. (Ver. 25.) But rather let the Almighty be thy gold. And His might, thy silver. Put thy confidence in the Almighty rather than in gold and silver, let Him be thy treasures. (Ver. 26.) Then, surely, shalt thou have thy delight in the Almighty, and shalt lift up thy face unto God. Then will there no longer be any cause, why thou shouldest let thy countenance fall, as malefactors do,* but thou wilt confidently look up for help to thy God and thy Creator.

Vows are commonly made by men, when they either ardently wish, or pray, for anything. Thus Jacob, on his journey to Padan-Aram, made a vow when he prayed to God to preserve him on his way; Hannah made a vow when she prayed for a male-child. Men, therefore, who have often to perform their vows, may justly be regarded as greatly blessed, since the performance of them proves that the object of their desire has been attained. This will explain the words of the Psalmist (Ps. lxi. 8), "So will I sing praise unto Thy name for ever, that I may daily perform my vows; "-as also those of the speaker here, who thus continues his promises to Job (Ver. 27); Thou wilt pray unto Him, and He will hear thee, so that thou shalt have to perform thy vows. Nothing thou prayest for will ever be denied thee, so that every vow thou makest thou wilt have to perform.

'The Scriptures tell us, that, whenever the true servants of God required anything, however extraordinary, to take place, even changes in the course of nature not excepted, they had only to say the word, and it was done. Joshua needed only bid the sun and moon stand still, and they did stand still. A similar power is promised, in the following verse, to Job, when he shall once more have become the favourite and beloved of God. (Ver. 28.) When thou wilt decree a thing, it shall be established unto thee; yea, light shall shine upon thy ways. Instead of the 
darkness, which thou sayest God hath set upon thy paths,* bright light shall be everywhere about thee, everything thou undertakest shall prosper.

We learn from the Scriptures also, and in more than one place, that even wicked men may be, nay, actually have been, saved by the merit or intercession of good men. Had there been but ten righteous men in Sodom, that city would have been spared for their sake (see Gen. xviii. 32). It was through the prayer of Abraham that Abimelech was healed (Gen. xx. 17); nay, at the close of this very book, we shall hear God say to Job's three friends (infia xlii. 8), "And my servant Job shall pray for you ; for him will I accept, lest I deal with you after your folly." So also here Eliphaz tells Job, that (Ver. 29), When men are brought low, then thou wilt say, "Pride" (was the cause of it). It was their pride which was the cause of their fall. (Comp. Prov. xvi. 18, "Pride goeth before destruction, and an haughty spirit before a fall.") "Seeing that one humble-minded-man might have saved them all. "(Ver. 30.) Yea, he (the humble-minded-man) might have de"livered even him, who was not innocent," and so shall he (who may not be altogether innocent) be delivered also (O Job!) by the pureness of thine hands. Many a man, who has deserved to incur the wrath of God, shall be delivered by thy prayer and intercession, as soon as, by the purity of thy hands, thou shalt again have been received into the favour and grace of God.

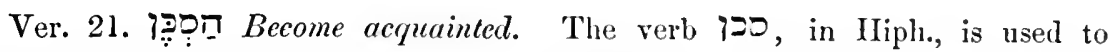
express habit, as Numb. xxii. 30 ; also acquaintance, knowledge, as Ps. cxxxix. 3,

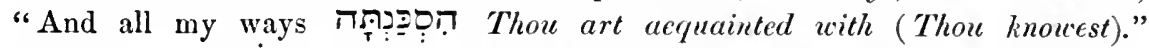

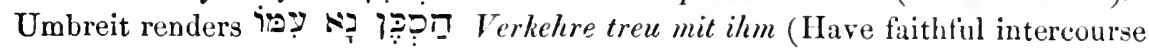
with Him), by which, of eourse, he meant, "Be not estranged from God," though his translator, the Rev. Joln IIamilton Gray, has, we are sorry to see, understood him otherwise, rendering the passage, "I'urn truly to hin." The Rev. Gentleman has here been guilty of the very gross error of taking the German verb verkehren (to have intercourse) = Kehren (to turn), an error against which the use of the prep. mit (with) should have warned him, for had the verb the meaning he so erroneously assigns to it, it would most assuredly have been construed with $z u$, or an, and not with mit, which is never equivalent to the English to. Only a few verses back we had observed a very glaring mistrauslation by the same gentleman of the following words in Umbreit (Ver. 15):

- See supra xix. 8. 
Willst du denn fest am Weg der Vorwelt halten, den des Verderbens Menschen gingen?

which properly should be translated thus :

Wilt thou then hold fast the way of former ages,

(The way) which men of corruption (i.e., corrupt men) went?

but which Mr. Gray, connecting the des Verderbens with the den (an impossible construction), instead of with Menschen, renders :

Wilt thon keep fast the ways of the ancient world?

The ways of destruction which mortals followed. !!!

It would be well if translators would but test their knowledge of the language they undertake to translate, before they favoured the public with their translations! This is the only chapter of Mr. Gray's translation that we have happened to compare with the original, and we do not therefore know whether or not any such mistranslations are to be found in the previous chapters.

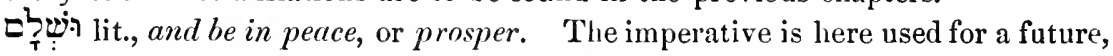
as in Gen. xlii. 18, "Do ye this "ְְִִ and live," for

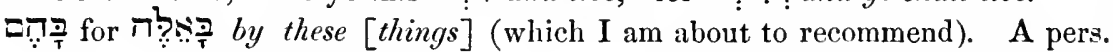

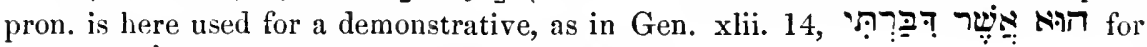

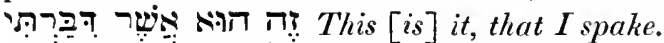

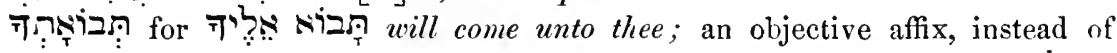

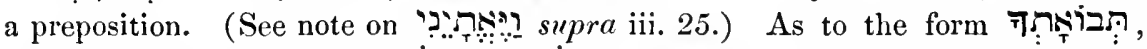

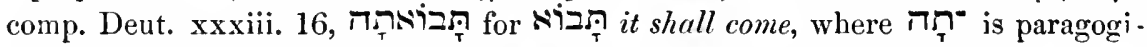
cally added, according to Kimchi, to give emphasis, the meaning being, it shall CERTAinly come. In the word before us, the objective affix $\nabla^{-}$is the cause that the $\boldsymbol{\pi}$ has been struck out.

Ver. 23. צִ lit., as far as, close up to. We are told by Rosenmüller that עֵ stands here for that it is purposely made use of in its real signification, namely, as far as, even to, right up to, close up to, in order to encourage Job, who was looked upon by the speaker as a very great sinner, by shewing him that, notwithstanding the enormities of his sins, he need not despair of coming through penitence again close up to his offended Creator. What Maimonides says on the subject in his is too beautiful and too consoling to a penitent sinner, not to be quoted on this occasion. He says (in "הלכות תשובה פרק ז): *

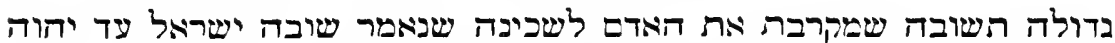

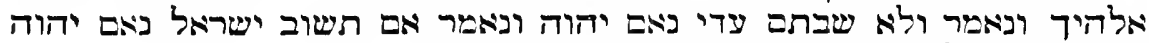 אלי תשוב כלומו אם תחזור בתשובה בי בי תדבק:}

"Repentance is of the greatest importance, inasmuch as it brings a man near to the " Shechinch ; for it is said, 'O Israel, return we close to the Lord thy God' (Hos. xiv. 2); " again it is said, 'Yet have ye not returned 'צָ close to Me, saith the Lord' (Amos iv. 6); " and it is also said, "If thou wilt return, O Israel, saith the Lord, return unto Me, “(Jer. iv. 1); meaning, if thou wilt but turn with repentance, thou wilt cleave unto Me."

* See Dr. Bernard's Selections from the החזקה (Cambridge, 1832), p. 62, l. 2 of the text, and p. 288 of the translation.- Note of Editor, 1861. 


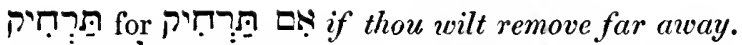

Ver. 24. "עv stands here in the sense of the same as, as in Gen. xxxii. 11, "Lest he should come and smite me i.e., mother and children without distinction.

The first hemistich should therefore be construed thus:

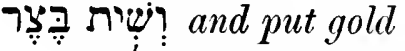

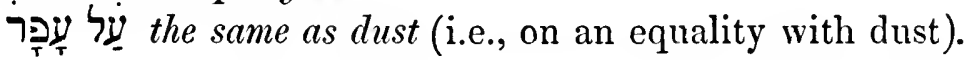

רציר shews us that 3 must here be taken in the sense of stone, pebble.

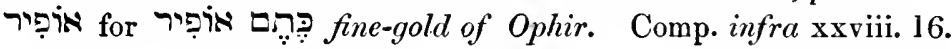

Ver. 25. ๆ ๆרָำ lit., thy golds; i.e., thy treasures. Kimchi, however, tells us :

ויש ספרים מדויקים אין בו יו"ד אש כן יהיה לשון יחיד וסגול הרי"ט

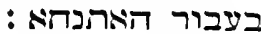

"But there are carefully revised copies [where there is] no Yod in it (i.e., in this word); if so, it would he in the sing. numb., and the Segol under the Resh [would be] on account of the Ethnach."

It would seem therefore that Kimchi assigned to the noun בשר two forms, namely

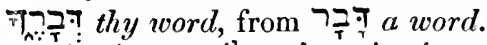

[the] strength (or might) which [belongs] to Him ; i.e., His might. Comp. Ps. xcv. 4, וְ Iִ Iea, [the] strcngth of $[$ the $]$ hills $[i s]$ His.

'This verse should be construed as follows:

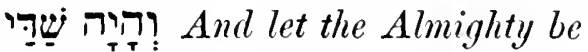

Tาרูำ thy gold,

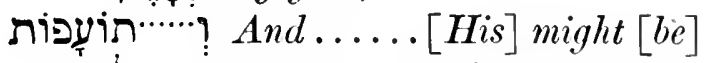

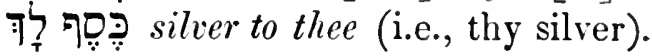

Ver. 29. עִ When they (i.e., men), have lowered themselves; i.e., have brought themselves very low, have ruined themselves.

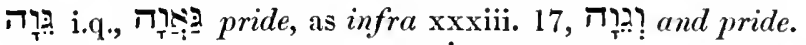

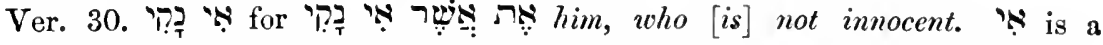
neg. part. constantly used by the Rabbins, but to be met with also in the Bible,

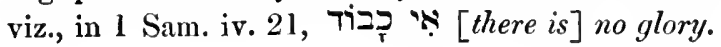

Vers. 29, 30 should be construed thus:

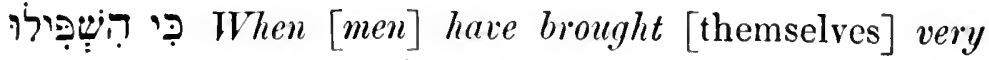
low (i.e., have ruined themselves),

רֶֶ, then wilt thou say, 
ำ " [It was $]$ pride (which was the cause of their ruin,)

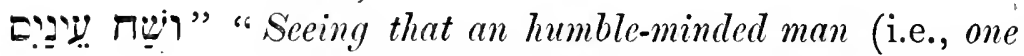
humble-minded man, if he had been found among them),

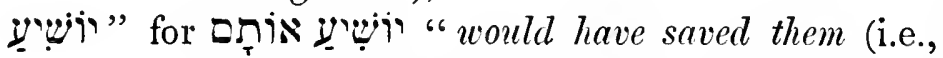
God would have spared them for the sake of that humble-minded man).

Ver. 30. יפריל:" "He (the humble-minded man) would have delivered [even]

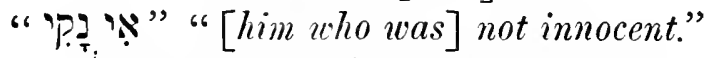

So (O Job)shall he (the one, (i.e., thou thyself, who is not innocent) be becoming a truepedelivered nitent, shalt again enjoy the favour and grace of God to such a degree as to be able, by thy prayer and intercession, to turn away His wrath from one who is

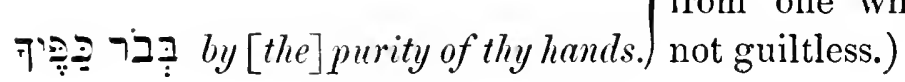

\section{CHAPTER XXIII.}

To a true believer in, and a fearer of, God, such as Job was, nothing could be more distressing than to hear, especially from the lips of an intimate friend, that he was suspected of following in the wake of that most wicked and depraved generation of old, of whom it might justly be said, that they polluted the ground they trod upon, and contaminated the air they breathed. $\mathrm{He}$ therefore, in the agony of his mind, commences his reply by asking, 
Vers. 2-12. Will to-lay, too, my complaint be considererl rebellion? From the manner in which my friends have behaved to me since my fall, I have every reason to apprehend that, to-day too, every sigh, every groan, every word, which pain the most excruciating may extort from me, will be considered by them as rebellion against God; but that I cannot help, I must give vent to my agonizing feelings. My blow is heavier than my groaning. My groaning is not at all commensurate with the blow I have received from above; my afflictions would warrant complaints far bitterer than mine. My friend, indeed, recommends me to acquaint myself with God, and to return close to Him, * but this is my wish, this is my most ardent desire; my heart pants for God, my soul thirsts for Him. (Ver. 3.) Oh that I knew where I could find Him! that I could come unto His seat! (Ver. 4.) Then would I order my cause before Him, and fill my mouth with arguments. (Ver. 5.) I should then know the words He would answer me, and understand what He would say to me. (Ver.6.) Hould He plead with me with great power? Would He bring His boundless might to bear against me, whilst pleading with me, so that, dismayed and confounded, I might not be able to utter one word? No; He would by no means take this advantage of my weakness, but rather Would give heed to me. And what makes me so sure that He would do so is, that (Ver. 7) There the upright might argue with Him, and so I should free myself for ever from my Judge. I can with certainty predict, that, if I am only allowed to argue, I shall be acquitted for ever. But, alas, how can I come close up to Him! (Ver. 8.) Lo, I go eastucerd. and IIe is not there, and westuard, but I cannot perceive Him ; (Ver. 9) When IIe worketh in the north, I camot behold Him; IVe veileth Himself in the south, and I cannot see IIim. (Ter. 10.) Surely, had the but known the way, which zas mine. Had He but known the course of life I have led. IIal He but tried me, I should have come out as pure as gold. As fine gold which, when assayed, is found to be pure of all alloy. If I had but been fairly tried before a judge, and my manner of life thoroughly investigated, it would have been seen that I had led a life pure and without spot. (Ver. 11.) My foot hath laid fast hold of His footstep. I have

- See supra xxii. 21, 23. 
followed closely in His footsteps. I have obeyed all His precepts. Ilis way I have kept, and have not declined from it. (Ver. 12.) The conmandment of His lips have I kept, and have not gone back from it; by-reason-of-the-rule-I-made-for-myself, I laid up. In my heart. The words of His mouth. It has ever been a fixed rule with me to treasure up in my heart the words of His mouth, and there is therefore no occasion for my friend Eliphaz to recommend to me* that I should receive the law from His mouth, and lay up His words in my heart-I have done so during the whole of $\mathrm{my}$ life.

\section{Ver. 2. 조 whether also?}

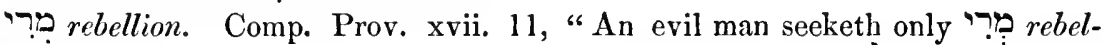

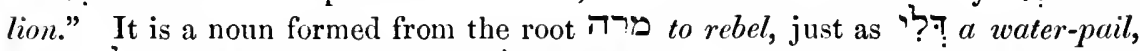

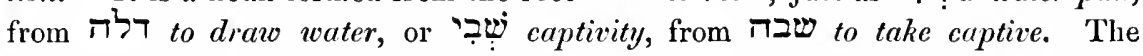
translators of the Auth. Vers., who render it bitter, seem to have derived the word from מרר to be bitter, but we cannot see by what process the third radical \urcorner has become a quiescent'. Rosenmüller defends this rendering, saying that the

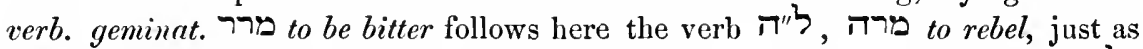

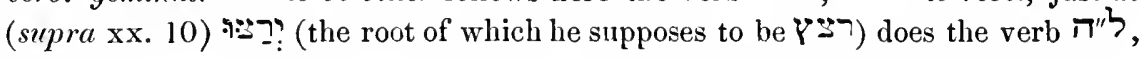
רצ to please; but this is begging the question, since both Kimchi and Ben-Zev

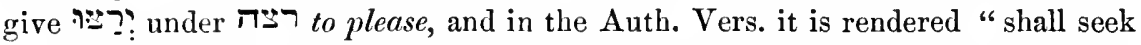
to please." Some, indeed, do assume the root to be $ץ \geq ר$, but we should hope for their credit that they took יר:? would be supplied by the Dagesh in the third, and not to follow the form of גליר to reveal, as Rosenmüller most erroneously seems to suppose.

'The first hemistich of this verse should be construed thus:

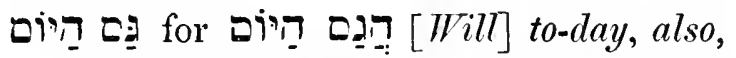

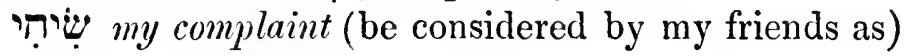

$$
\begin{aligned}
& \text { קִevellion (against God)? }
\end{aligned}
$$

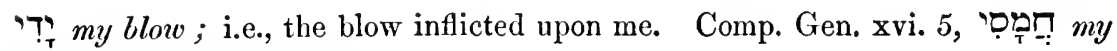
wrong; i.e., the wrong done to me.

לู above; i.e., more than.

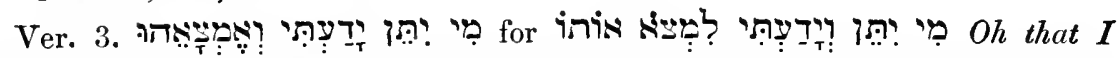
knew [where] to find Him! so that a tense is used here instead of an infinitive.

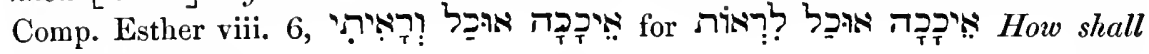
I be able to see?

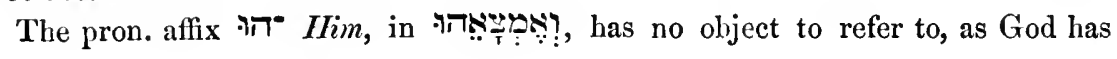


not yet been mentioned in this discourse. $\mathrm{He}$ is, however, so unmistakeably referred to that the speaker relies upon the common sense of his hearers to apply it to Him. In like manner we shall have (infra xxv. 1) yith him, referring to God, though His name had not yet been mentioned in that discourse.

Would that I could come!

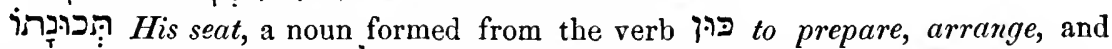

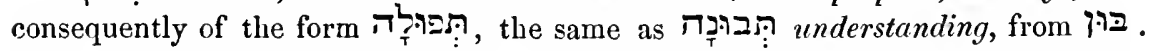
The noun under consideration is to be met with again in Ezek. xliii. 11, Nah. ii. 10 ; and all these passages are quoted by Ben-Zev, as well as by Buxtorf, under כפי ביו Gesenius, for reasons he has kept to himself, tells us that the word here is derived from

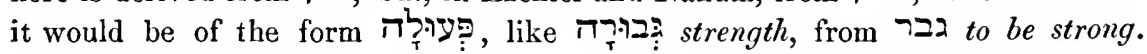
If the reader will but refer to what we quoted from this learned lexicographer in our note on לָץ (supra vi. 3), he will, no doubt, at once form his decision as to whom he ought to take for his guide, Ben-Zev and Buxtorf, or Gesenius.

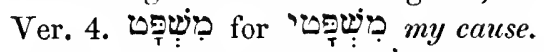

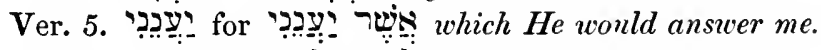

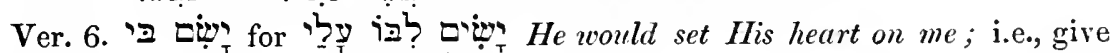

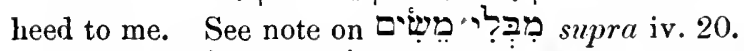

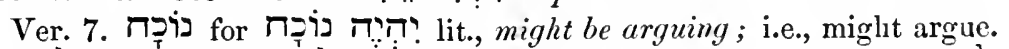

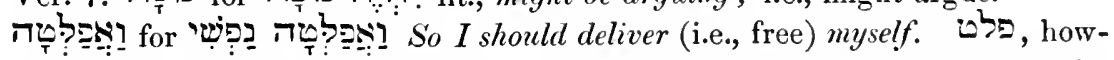
ever, in $\mathrm{Pi}$-âl, may be intransitive, as it is in Kal, when of course the strict meaning would be, I should escape, or get off. So הלד has in Pi-âl an intransitive signification. Comp. Prov. vi. 28, שִ הan a man go (upon hot

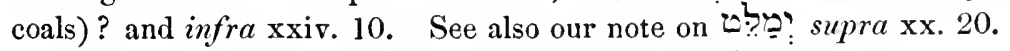

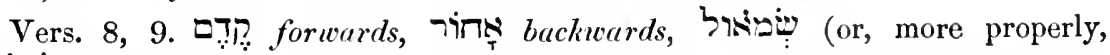
שִ globe. On looking towards the rising sun, ${ }^{*}$ the East is in front, the West, behind, the North, to the left, and the South, to the right.

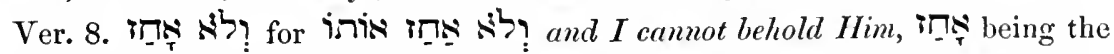

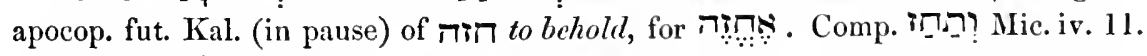

Ver. 9. . works. Umbreit would, in this instance, make the verb עשה synonymous with ף ע in the second hemistich, and give it, therefore, the signification of covering, veiling, instead of its usual one of doing, working, and he tells his readers that, "Die gewöhnliche Uebersetzung, wcun er zur Linken wirket, klingt matt." Most of them will, however, probably be of opinion, that to give to so common a verb as עשה a signification which no lexicographer ever dreamed of, klingt, to say the least of it, sehr seltsam.

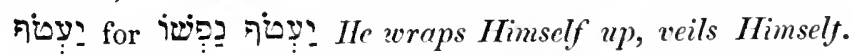

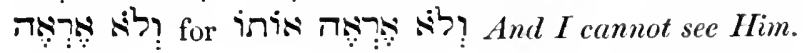

- The Jews, even in our days, always turn, when they pray, to the East, and this having probably been the custom also in the time of Job, he naturally begins with the East, instead of the North, as we should do. 
Ver. 10. Tיר The he known. ( These two verbs must be understood condi-

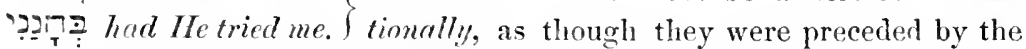

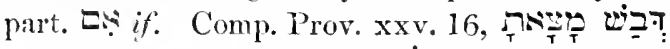
liast thou found honey = thou hast found honey.

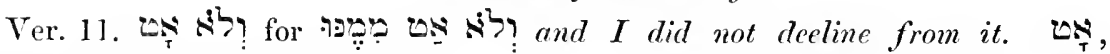

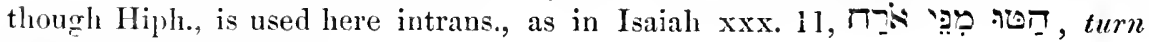
aside ont of [the] path.

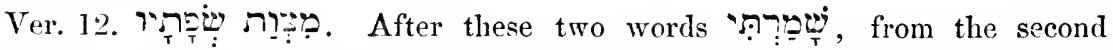
hemistich of the preceding verse, must be supplied, as though it were ' [the] commandment of ITis lips I have kept.

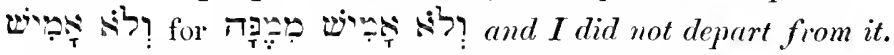

?y by rason of my rule; i.e., by reason of my having made it a rule. The force of the prefix i here is the same as in Prov. xxiii, 4, "Labour not to be

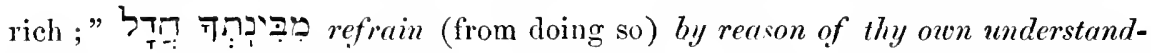
ing; i.e., thy own understanding should teach thee not to labour to become rich.

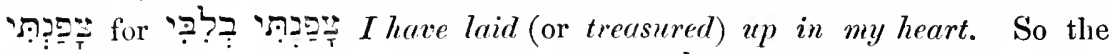

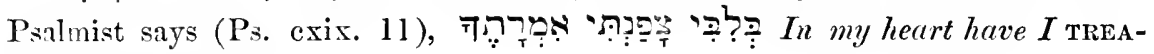
SLRED up thy word.

Vers. 13-17. Yet Me, being mique. That is, without an equal. Who can hinder Ifim? He being one God, Eternal and Omnipotent, who can prevent Him from doing what He pleases? Yea, what Ilis soul willed, He hath done. What it was His will to do unto me, He has done. (Ver. 14.) Surely, He will complete what-is-decreed-for-me. No argument, no reasoning, will induce Him to leave what He has decreed for me unaccomplished. Yea, like these. Like these afflictions. There may still be many more with Him. In store for me. Terrible as are my sufferings, there may be many more like them, or even worse, stored up for me, which I cannot foresee, so that I have not even the consolation of knowing that I have seen the worst. (Ver. 15.) Therefore am I confounded before IIim. This is the reason why I am in such trepidation. When $I$ consider. When I consider, that even now the measure of my calamities may not be full. I am in dread of Him. (Ver. 16.) But it is God Himself who hath made my heart faint, yea, the Almighty it is who hath confounded me. He it is who, by sending on me calamity after calamity, every one more grievous than the last, by depriving me, first of my property, then of my children, and finally of my health, has 
made me so faint-hearted as to dread even greater evils than those I have already seen. (Ver. 17.) Because I was not cut off before this darkness. Before this misery came upon me. As He was not merciful enough to spare me these woes, I have no right to expect mercy from Him for the future. Then He would have concealed from me this gloom. Had $\mathrm{He}$ but cut me off before these calamities befell me, I should never have seen this gloom which is now around me.

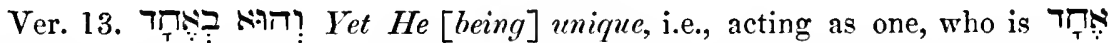

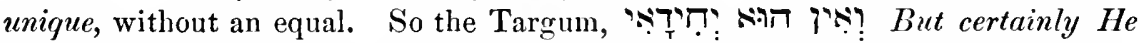
$[i s]$ unique. It will be perceived, that we take the prefix $Z$ here to be pleonastic, as it is taken by Mendelssoln in in "Sein Name ist Ewiger" (His name is Eternal-Being), and also by Dr. French and Mr. Skinner, who, in their masterly translation of the Psalms, render the passage, “Jehovah is His Name!" See also the Rev. J. Phillip's Commentary on the Psalms. Perhaps, however, the prefix $=$ in

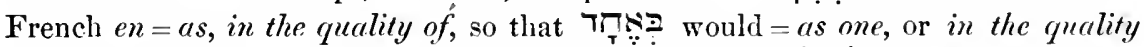
of one; and this may also be the import of the $Z$ in in (or attribute) of $\mathrm{JAH} *$ [which is] His name.

lit., So, who can make Him turn back (from His purpose ?) i.e., so, who can prevent, hinder Him ? Comp. supra ix. 12.

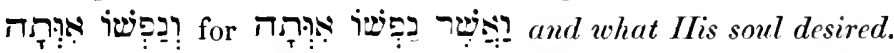

Ver. 14. . Tִ Tִ lit., my decree; i.e., the thing decreed for me. See note on (Ver. 1).

רִִּ yea, like these; i.e., miseries and calamities like these.

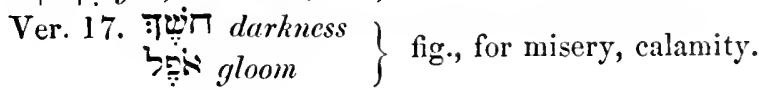

- Better, I think, expressed in French, en sa qualité de Jah. Editor, 1861. 


\section{CHAP'TER XXIV.}

Vers. 1-11. Eliphaz having, in his last discourse, again reverted to the fate of the wicked, and asserted that their end must be so wretched and miserable, as to be a matter of triumph to the just and innocent (supra xxii. 19, 20), Job cannot pass over the subject in silence, but is prompted by his love of truth to protest against that which his friend had said, and to declare the contrary. At the same time, we shall hear him say, that, though he loves God with all his soul and all his might, and is desirous of being introduced into His presence, he must nevertheless confess, that he cannot see any signs of His Providential care and Divine retribution here below, inasmuch as the just and the innocent are altogether at the mercy of the wicked and depraved, who may tyrannize over them, rob them, and even slay them, with perfect impunity-a course of things, which causes him not only the deepest regret but also the greatest surprise. He says :

Why is it so? Events are not concealed from the Almighty, seeing that His omnipresence and omniscience altogether preclude the possibility of any event's being hidden from Him, Yet those, who love Him, do not see His days! His days of retribution. Why do they not see crime meeting with that punishment, which it so richly deserves, and ought to receive without the least delay? Wherever we turn, we see atrocities of the blackest dye committed with impunity. (Ver. 2.) Here they (the wicked) remove landmarks. They set them up on their neighbour's land, so that the extent of their own may be increased. There they violently take away a herd, and feed it. As though it were their own property. (Ver. 3.) Some drive away the ass of the fatherless; they take the widow's ox. Her only means of support. For a pledge. (Ver. 4.) Others turn the needy ont of the way; yea the poor of the earth are altogether concealed. The oppression and violence they have to endure from the wicked are so great, that they dare not shew themselves in the street. (Ver. 5.) Behold, they must go forth to their work in the desert, like wild asses. Like wild asses which 
are never seen but in the desert, where they seek for pasture, so the poor, not being suffered to abide in the villages and towns, must work in the wilderness, Diligently seeking for food; the wilderness must furnish him. Every one of them. Bread for his young-children. (Ver. 6.) In the field, they must reap his (the wicked man's) grain, and gather the produce of the wicked man's vineyard. (Ver. 7.) They pass the night naked, without clothing, and have no covering in the cold. (Ver. 8.) They are wet with the shower [s] of the mountains, and embrace the rock for want of a shelter. They are obliged to squeeze themselves into the crannies and crevices of rocks in order to avoid exposure to the inclemency of the weather. (Ver. 9.) They. That is, the wicked. Pluck the fatherless-child fiom the breast of its mother, and take that, which is upon the poor-man as a pledge. The scanty clothing, which the poor man has to cover himself with, they take away from him as a pledge, careless of leaving him altogether naked. (Ver. 10.) They. That is, the poor. Go about naked, without clothing, and hungry are they, when they carry the sheaves. The wicked man's sheaves. It was considered cruel to suffer even a beast to starve in the midst of plenty, whence the precept, "Thou shalt not muzzle the ox, when he treadeth out the corn," (Deut. xxv. 4), and yet the poor are suffered by their wicked oppressors to famish, whilst carrying their sheaves. (Ver. 11.) They press out oil within their (the wicked men's) walls; they tread their wine-presses, and yet suffer thirst.

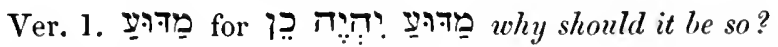

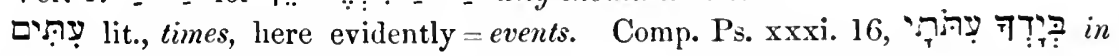
Thine hand [are] my times, i.e., the vicissitudes of fortune, which await me, the events of my future life. So also, 1 Chron. xxix. 30, and the times (events) which passed over him.

?ִ ?ִ (according to the K'ree) lit., and those knowing Him; i.e., those

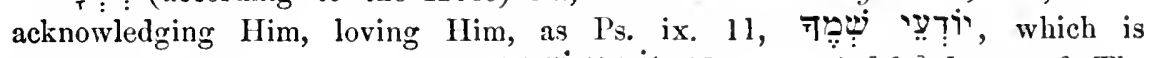

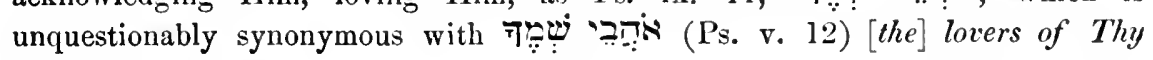
name.

יצי lit., His days. By the day of Jehovah is generally understood, the day

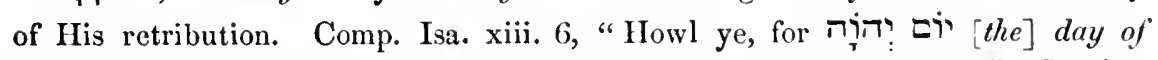
Jehovah is near ; it shall come as a destruction from the Almighty." So also,

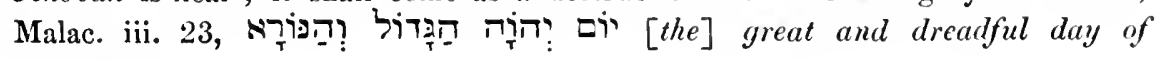
Jehovah. 
Ver. 2. 2 -

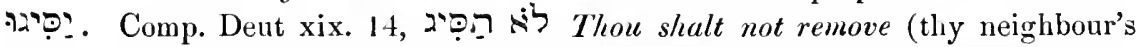
landmark); also (Ibid xxvii. 17 :) "Cursed be he, that is פִִ removing (his

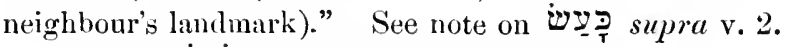

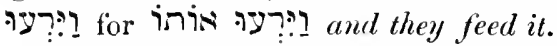

Ver. 5. エ

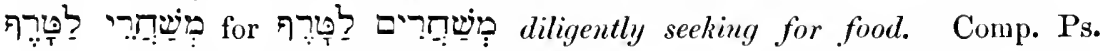

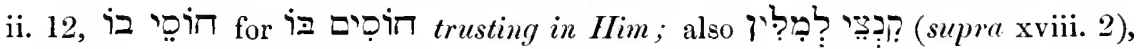
on which see note. Qִ is not always used in the sense of prey, but also in that of food, victuals. Comp. Prov. xxxi. 15, "and she gave forth ๆ7? food (for her household)."

Ver. 6. . the second hemistich. See note on הר where $\sqrt{\mathrm{T}}$ in $i t$, in the first hemistich, refers to second.

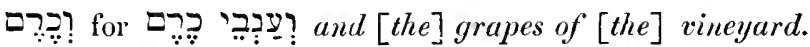

לקש The? occurs as a verb.

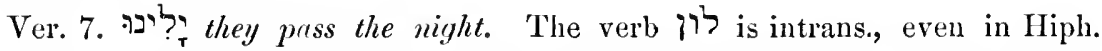
Those, who think that it has a trans. signif. in Lev. xix. 13, and Deut. xxi. 23,

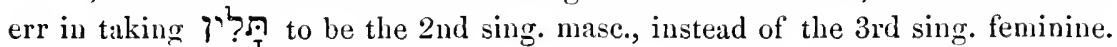

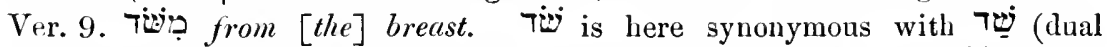
घ!

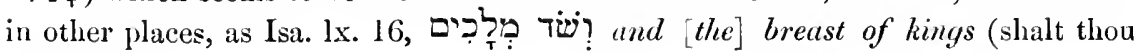
suck.)

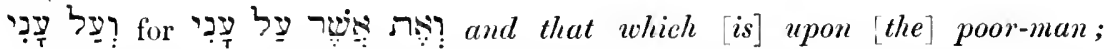
i.e., his elothing. So Ralbag, to whom we are greatly indebted for lielping us out of the clilemma, in which the use of the prep. ל⿻ here had placed us. He

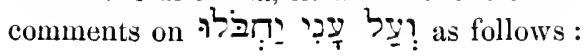

$$
\text { ר"ל מה שעל עני והוא לבושו אשר יתכסה בה יקחו למשבון: }
$$

"Meaning to say, that which [is] upon [the] poor-man, that is to say, his garment, wherewith he covers himself, they take away as a pledge."

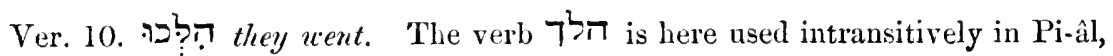
as was observed in our note on

עִ פִּר

Ver. 11. i끌 lit., between, i.e., within.

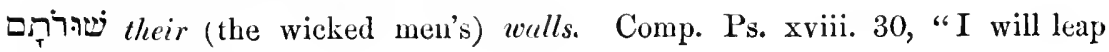

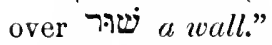

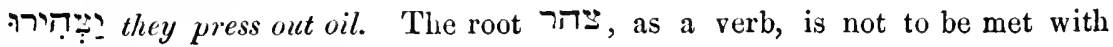
elsewliere.

Vers. 12-18. Having described the oppression which those suffer, whom the tyranny of the wicked had obliged to flee from 
the city, Job now proceeds to depict the atrocities, that are practised in the city itself, saying:

From the city men groan, and the soul of the slain crieth out. From the city there is nothing to be heard but the groans of dying men, and the cry for vengeance of the blood of the slain. Yet God doth not impute to them (the wicked) injustice. Job now divides the wicked into two classes-the one composed of such hardened villains, as are bold enough to commit the most horrid crimes in broad daylight-the other, of those who, being too cowardly for this, dare not face the light, but sneak away to their dens at its approach. He says: (Ver. 13.) Some of them are among those, who rebel against the light. That is, who, as it were, bid defiance to the light, and ply their horrible trade in the middle of the day. Others again there are, who do not know its ways, nor abide in its paths. Who are so much afraid of the light, as to avoid it altogether. (Ver. 14.) The murlerer riseth with the day-light. Not because he dreads the full light of the sun, but so as to have the whole day before him. And killeth the poor and needy. He is quite indifferent to the sun's shining upon his murderous deeds. But in the night he is again, as though he were a thief. Though, in the day time, he displays more boldness than those sneaking cowards, who only venture to carry on their depredations under the cover of deep darkness, yet, he is not ashamed to imitate them; his greediness is so great, as to induce him to stoop to thieving in the night. (Ver 15.) The eye also of the adulterer waiteth for the evening-twilight, "No eye," saith he, "must see me." 'This precaution, however, not seeming to him sufficient to secure him against recognition, he adds a second. He even putteth on a mask. His conscience renders him as great a coward as the despicable thief who haunts the streets at midnight. (Ver. 16.) Another again, digs through houses in the dark. In order to enter and plunder them. Whilst in the day-time they shut themselves up ; they do not like the light. (Ver. 17.) For the morning is to them all like the shadow of-deuth, for they experience the terrors of the shadow-of-death. When the morning comes, they are in as great a fright, as though they felt themselves seized with the pangs of death. But, when surprised by the light, the paltry thief, coward though he is, plucks up courage from the very 
greatness of his terror, and to effect his escape, would be bold enough even to plunge into a river; and, did he do so, his usual success would still attend him; far from being drowned, he would quickly reach the other side in safety, for he swims like a cork. (Ver. 18.) He is light upon the surface of the water. Their parcel-of-ground is accursed in the land. 'That is, the site of their fastnesses, being waste, barren, and rocky, is regarded as accursed of God, and only fit to harbour men equally accursed. He turneth not. That is, not one of them turns. By the way of the vineyards. When they are in danger of being taken, they dare not take their flight across the vineyards, where they might be arrested by the husbandmen, but prefer unfrequented paths and by-ways, or even crossing rivers.

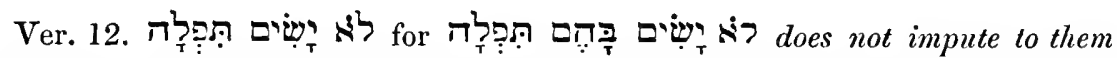
(the perpetrators of these crimes) injustice, as shown by the fact, that they are

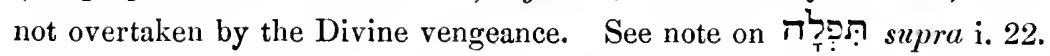

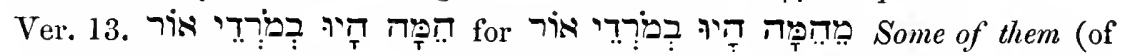
these wicked men) are among those rebelling against [the] light ; i.e., they belong to that class of bold and hardened villains, who set the light at defiance, and are ready to do anything, however atrocious, in the face of the sun.

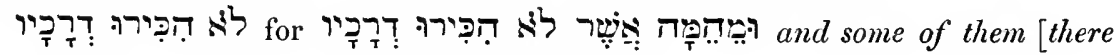
are] who do not know the ways thereof (of light).

Ver. 14. בִ לִ lit., at (i.e., with) the light [the] murderer rises. Those, who have not, as we have done, considered the preceding verse to treat of two distinct classes of villains-the bold and hardened on the one hand, the timid and cowardly on the other-have felt great difficulty in explaining how the murderer could here be said to arise with the light, after it had been stated in the preceding verse (as usually translated), that men of his class dread and shun it. Some of the Commentators, therefore, would take before the light, whilst others understand by it just at daybreak, when the feebleness of the light would allow the murderer to escape recognition or detection. The first of these interpretations we could not for a moment entertain, as $\zeta$ never means before, nor was it possible for us to admit the second, seeing that as often as we meet with רזָ in Scripture, the context 
rather points to the full light of day, than to the feeble light of early dawn; e.g., supra xii. 22, "he bringeth out ראוֹ to light (the shadow of death)," where רiא is surely not intended to express a glimpse of light or faint light, but rather a bright light. Therefore it was, that we preferred considering the preceding verse to treat of the two different classes of villains designated above; and to the first of these classes the murderers, whose practices are recorded in the verse before us, must of course be referred.

Ver. 15. שמר is is wats formetimes used in this sense, as in Ps. lix. 10. אִ אִלִ for The do I wait.

סִת lit., a covering of face; i.e., a mask. So Wolfssohn observes :

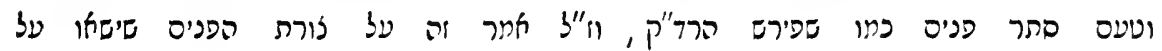

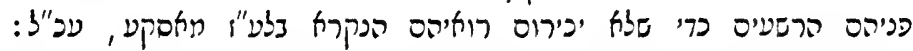

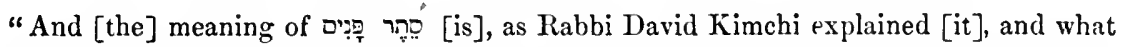
he says is this: he (Job) says this with reference to the image of the face, which wickedmen wear on their faces, in order that those seeing them may not recognise them, [and] which in a foreign language is called ' mask.' Thus far [is] his (Kimchi's) language."

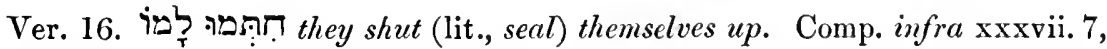
where, when speaking of the heavy rain, which prevents both man and beast from stirring abroad, Elihu says, "דis?: He (God) shuts up (every man in the place, where he is," so that he cannot move about). Kimchi comments on the passage before us as follows :

\section{כלומר ביום יעשו הגנבים חותם וסימן בכותלים ובלילה יחתרו באותו

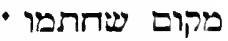

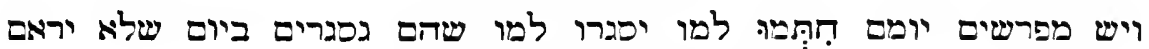

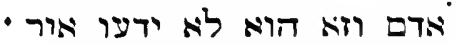

"That is to say, in the day-time the thieves make a mark and sign on the walls, and in the night they dig in that place, which they had marked."

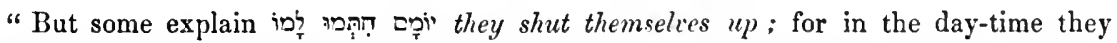
[are] shut up, that no man may see them; and this is [the meaning of what is said in

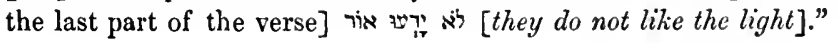

On referring to the Auth. Vers., the reader will find this passage translated in accordance with the first explanation given by Kimchi; we, however, have given our preference to the second, and that for two reasons; first, because it agrees better with the last clause of the verse, as observed by Kimchi himself; and secondly, because, as mentioned above, we find the word שing:- occurring in this very book, in the sense of shutting up.

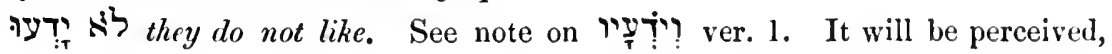


that there is a change of number in this verse, the verb in the first clause being sing., while those in the second and third are plural.

Ver. 17. רֵיפ lit., he knows; i.e., becomes acquainted with (the terrors of the shadow of death, which he had never experienced before).

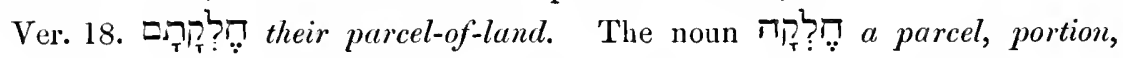
is generally used in construction with

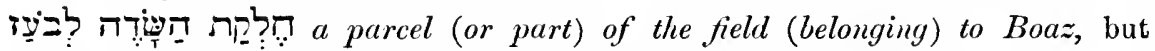
is, however, also met with in its absolute form, as, e.g., in 2 Sam. xiv. 30.

We will not pollute our pages by quoting the disgusting obscenities, which Sehultens would wring out of this and some of the following verses. If the reader do not mind wading through a couple of pages $*$ of dirt and filth, he will receive a salutary warning as to what value he ought to set upon the explanations of Scripture given by this commentator and others like him, who are unfortunately taken for their light and beacon by those who cannot read the Commentaries of Mendelssohn, Wolfssohn, Eichel, Bril, Homberg, \&cc.

Vers. 19-25. It will be recollected that Job had already spoken of the sudden death of the impious as one of the blessings they enjoy (see supra ix. 23; xxi. 13), since they ought not, in his opinion, to be permitted to depart from life without having first undergone lengthened and excruciating sufferings. Having now enumerated the various crimes committed by the wicked, he again reverts to this topic, and laments their easy and speedy release from the world, saying:

Just as drought and heat steal away snow-water. For, under their influence, it gently and imperceptibly vanishes. So the wicked slip-down into the grave. Without any pain or suffering, which is not as it ought to be, for it were but just that they should be plagued with such frightful and loathsome diseases, as would chain them to the bed of sickness, and render them an object of the greatest horror and disgust even to their best friends and nearest relations. (Ver. 20.) She, who bore him, ought to forget him. The horrible nature and lingering character of his disease should be such, as to drive even his mother away from his bedside, and make her forget he is her son. The worm ought to be sweet to him. His misery, what from bodily sufferings, consequent upon his protracted disease, what from mental agony at seeing himself deserted by his nearest relations, should be so

* See the Leyden Edition [1737], pp. 688, 689. 
intense, as to make him long for the worm and corruption of the grave. He should be remembered no more; and so iniquity would be broken like a stick. The poet, anxious to justify his imprecations upon the impious, endeavours to heighten what he has already said of them, by giving a sketch of another class, not included among those we have just heard him describe. He now introduces us, namely, to a tyrannical conqueror, who not only himself spreads ruin and desolation on all sides, but, by his example, has stimulated a number of other, minor, tyrants, whom he has subdued and brought under his sway, to emulate him in his acts of oppression and cruelty; while they, in their turn, tremble at his nod, and, as his vassals and satellites, are obliged to follow him, obey his commands, and pay him onerous tributes. He says, (Ver. 21) He crusheth the barren, that beareth not. One, therefore, who is already distressed enough on account of her sterility, a great reproach in those times. $\quad \boldsymbol{Y} e a$, also, to the widow. A woman left without support or protection. He doeth no gool. But, not satisfied with the atrocities committed by himself. (Ver. 22.) He also, by his power, attracteth to himself other powerful-men. 'These, following his example, oppress and spoil all they have to do with, but to him they truckle, so great is the awe in which they stand of him, seeing that, when he riseth up against them, not one of them is sure of his life. (Ver. 23.) Yea, he. That is, every one of them. Must give him tribute, in order that he may be in safety, and be able to stay limself upon him; yet, his (the tyrant's) eyes are upon their ways. The eye of the great tyrant closely watches the movements of the petty tyrants he domineers over. (Ver. 24.) As soon as they are a little exalted, he. That is, every one of them. Is undone. As soon as they shew the least disposition to raise up their heads, and attempt to shake off his yoke, they are either at once plunged by him into utter ruin, Or they are humbled, silenced, like all others, or even cut off' as the tops of ears-of-corn. (Ver. 25.) Now, if this be not so, who can make me a liar, and make my speech nothing worth? I challenge any one to disprove the statements I have made in this discourse of mine. 
Ver. 19. before לש: in the second, hemistich.

The verb

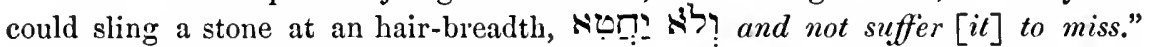
Hence it has come to signify, to miss one step, to slip, as Prov. xix. 2, "and he that hasteth with his feet Nب̣in slippeth." Lastly, it has been taken figuratively in the meaning of to sin, its ordinary acceptation, from the fact, that one who sins, has missed, or slipped from the path of rectitude.

The verse should be construed thus:

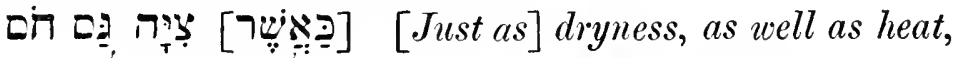 Steal-away snow-waters, ל [So] they (the impious) slip down to [the] grave (i.e, gently, without pain or suffering).}

Ver. 20. $\square \Pi 7$ lit., womb ; i.e., the womb, which bore him, used fig. for his mother.

Ver. 21. רִִּ lit., [he is] breaking, i.e., oppressing, crushing. The verb רעיה, in this instance, = רוע to break, the same as to dise = Comp.

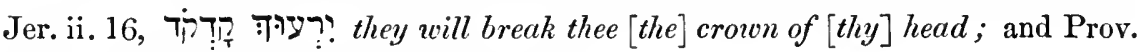

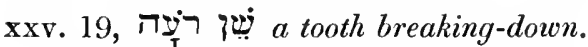

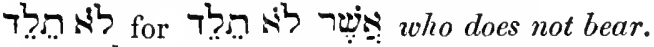

ליר:י.:. (Prov.

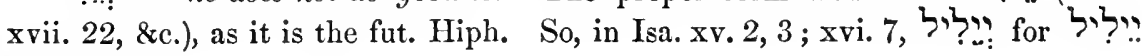
* will howl.

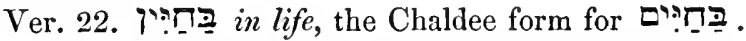

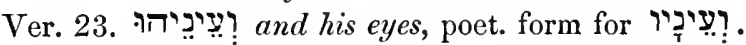

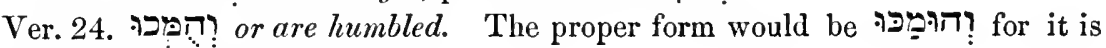

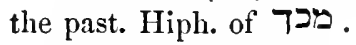

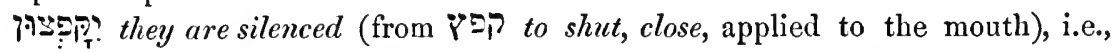
they are so struck with awe, that they dare not utter a word. Comp. Ps. cvii. 42,

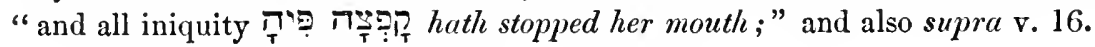

Ver. 25. 'ㄴ? for אל? to nothing.

* Which is, however, never found, though we do meet with וֵָٕילָילָה Mic. i. 8. In every other passage the irregular form of this fut. is met with. Thus we have șer.

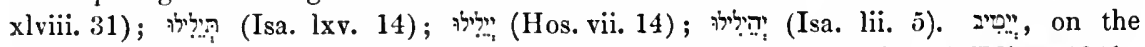
contrary, is the only instance of the irreg. form, in the fut. Hiph. Note of Editor, 1861. 


\section{CHAPTER XXV.}

BILDAD, finding that his efforts to prove to Job, that the impious and wicked must ultimately meet with severe and condign punishment, and the pious and just, with abundant reward from above, have had no effect, does not again revert to the subject, but confines himself in this short, but energetic speech, to calling the attention of Job to the unlimited power and profound wisdom of God; topics, which, if duly reflected upon, must convince us, that the dispensations of Providence are as just as they are unerring, and that, if events sometimes occur, which, according to our narrow views of right and wrong, seem to ns to be the reverse of what we might have expected, it is only because we are too short sighted to perceive the end, to which such events are intended to lead by the decree of Him, in whose hands are the destinies of man. He says:

Ver. 2-6. Dominion and fear are with Him. That is, God. The terror, which He can strike into those, who attempt to rebel against Him, is in proportion to the greatness of His sovereign power. He maketh peace in His high places. He maintains harmony among the heavenly bodies, which, great as is their number, and immense their magnitude, never clash or jar with one another, but move with the greatest smoothness and precision, in the track assigned to them by Him. (Ver. 3.) Is there any mumber to his hosts? Can any one number the stars, which fill the universe? Yet, upon which of them doth not His sun rise? Is there any constellation so distant, as to be out of the reach of the rays of the sun ? * (Ver. 4.) How then can frail-man be right with God? How can he think he has a right to find fault with the decrees of God, or how can he dare to challenge Him to enter into judgment with him, as Job more than once has done? (Supra ix. 32, 33, and passim.) And how can he be clean, that is born of a woman? How can

* The reader will perceive, that we are here merely explaining Job's ideas, without necessarily subscribing to them. 
one, that was shapen in iniquity, and conceived in sin, think himself so clean and free from all guilt, as to have a right to murmur, when corrected and chastised by his Maker? (Ver. 5.) Behold the spoliation of the moon, how she no longer pitcheth her tent in the heavens! Consider, how the moon, when eclipsed, is at once stripped of her brightness, and becomes invisible, as though she did not exist, and no longer had her pavilion in the heavens! (It will be recollected, that, in the poetical language of the Bible, the great luminaries are represented as pitching their tents in the heavens. Comp. Ps. xix. 5, "In them hath he set a tabernacle for the sun.") Iea, the stars are not pure in His eyes. His brightness is so great, that the stars in His sight are as opaque bodies. (Ver. 6.) How much less frail-man, that is but a worm, and the son of man, that is but an insect!

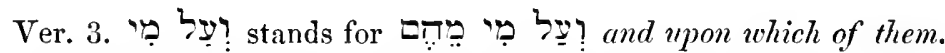

is His sun. The sun, as being the origin of light, is called רis infra xxxi. 26, where it stands in parallelism with חר? moon; in Habakkuk, too, (ch. iii. 4,) some, with great propriety, render רis lik like the sun. In the same

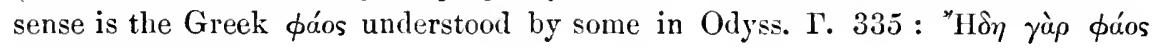

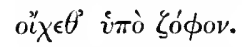

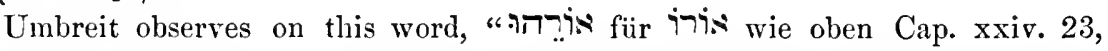

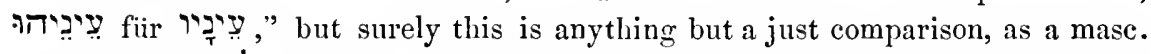
noun. (e.g., שִיניר sing. masc., has two regular forms, given in almost every Grammar, viz., שִירו and שי?ירהו, the latter of which cannot even be said to be the poet. one, as it is very frequently met with in the historical books ; e.g., לִִ after its kind, is found several times in Genesis, whilst

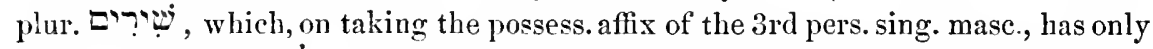
one form, viz., שִירָ, nor would any Grammarian venture to give a second; and if, in writing Hebrew, one were to render his songs, it would make him rub his eyes, who read it, since this is a very extraordinary, and, we may almost say, anomalous form. Indeed, Eichenbaum has been found fault with by Hebrew scholars in the University of Cambridge for having, in his poem בקָר , once

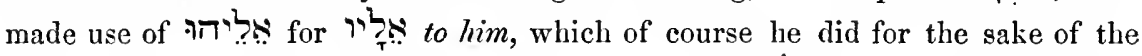
rhyme, though unjustifiably. To sum up, then, ה is is a most regular and

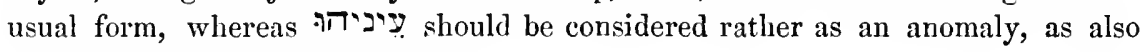

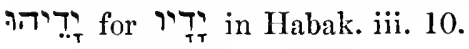

The mistake here made by Umbreit has been fallen into also by Rosenmüller, though for him it is but a mere trifle, as the reader may convince himself by referring to our note on supra xii. 4, where we pointed out such a very gross, nay unpardonable, blunder on the part of this Commentator. 
Ver. 5. עִ [the] spoliation, or stripping, of. From the verb של ה which, in

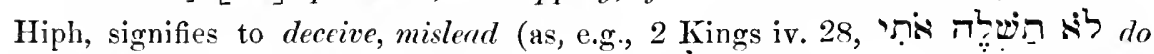
not deceive me), we have the derivative noun error. In like manner, from the verb עדה, which, in Hiph., signifies to take

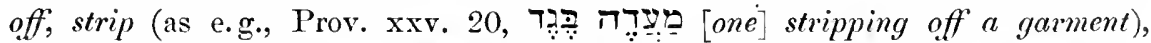

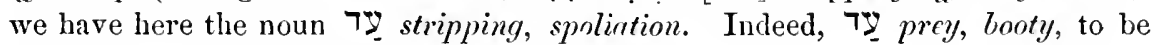
found in Gen. xlix. 27, Isa. xxxiii. 23, may, in our humble opinion, also be referred to the verb עדה in its meaning of taking away, stripping off.

?ִ: So that she docs not pitch-her-tent. In Ps. xix. 5, we read

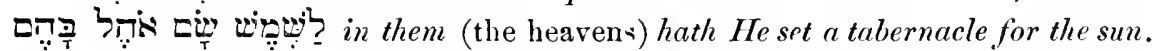
Here, our poet assigns a tabernacle, or pavilion to the moon also, and bids his unfortunate friend consider how, when eclipsed, she is as though she had no longer any pavilion in the heavens.

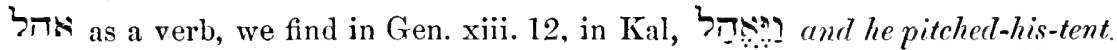
In Isa. xiii. 20, we have his-tent there, where of course this verb appears in its proper, and regular form, and it is, therefore, much to be regretted, that the Translators of the Auth. Vers, and many others, have given to it the meaning of slining, as though it were the fut. Hiph. of הלל , in which case, however, its form ought surely to have been $\left.{ }_{2}\right]_{r}$, as infra xxxi. 26.

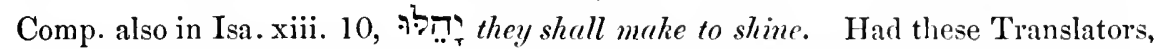
by offering such violation to this verb, added to the beauty of the poetry, we should perhaps have said less, but, in our opinion, the only result of their misplaced ingenuity has been materially to mar it. As, however, we are, we think, the first, in the English language at least, to give to the verb Sin:- the signification, which its form demands, we may perhaps be allowed to say, that we have both Kimchi and Ben-Zev with us; and with such authorities on our side we can, we think, boldly face any real or would-be critic. Kimchi's words (under the root

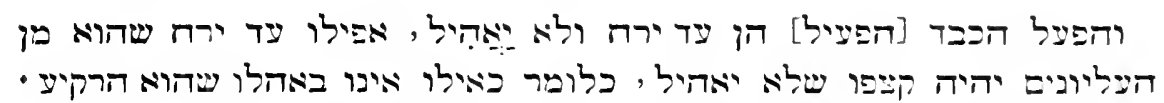

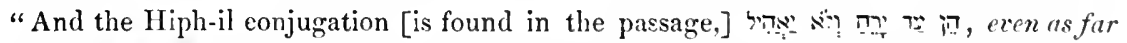
as [the] moon, which [is one] of the superior-bodies, will His wrath attain [lit., be], so that she will not pitch-her-tent; that is to say, as though she [would be] no longer in her tent, by which is meant the firmament."

It will be perceived that Kimchi, though agreeing with us as far as the signification of the verb which he treats as a prep., in the meaning of as far as, even to. Ben-Zev, however, agrees with us in both points, with this difference only, that, instead of understanding the poet to allude to the eclipses of the moon, as we do, he thinks he refers to her setting. Ine las the following remarks upon (vide root 5 הN): 


\section{ר"ל יסתיר הירח שלא יטע אהלו ברקיע •}

"Meaning to say, He hides the moon, that she should no longer pitch-her-tent in the firmament."

And under עדדה, he observes on עַד :

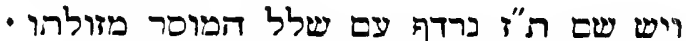

"And there is a noun-adjective masculine (viz., צִי), synonymous with (prey, booty), which [is] taken away from another thing."

Ver. 6. רִָּ for for who [is] a worm.

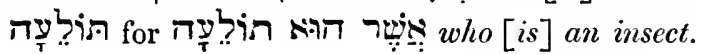

\section{CHAPTER XXVI.}

THE reader will have perceived, that, whenever any one of Job's friends has thought it necessary to remind him of the Omnipotence and Omniscience of God, the unfortunate man not only immediately takes up these subjects himself, but generally dwells upon them at much greater length than his friend had done, with a view, probably, to make him feel the impropriety of preaching that to him, which he himself, as was well known, had been in the habit of preaching to others during the whole of his life. This custom of his we shall see him follow in the discourse he is about to deliver. Bildad had, in his last speech, brought forward no argument whatever, contenting himself with setting forth in a few words the unlimited power and profound wisdom of the Almighty; this is felt by Job very keenly, and is looked upon by him as a real insult. He therefore replies:

Vers. 2-4. What assistance hast thou given to him that hath no strength? What help hast thou afforded to the arm which hath no might? In the feeble and helpless condition I am now in, what assistance, or what help, can I possibly derive from the speech which I have just now heard from thee? (Ver. 3.) What 
counsel hast thou given to him that hath no wislom, or what practical-wisdom hast thou made him abundantly to know? A stranger I confess myself to be to wisdom, but doth it, I ask, require much wisdom, to know all that thou hast declared in thy speech? Doth it require even much practical knowledge to know that God is omnipotent, and that all His works are under His control? Even supposing thou regardest me as an arrant simpleton, what necessity was there for thee to tell me that which thou hast told me? I further ask (Ver. 4), To whom hast thou uttered these words? Was it to one who heard something in them he knew not before? Nay, whose breath was it, I pray, came out from thee? Were the words thou madest use of in thy speech thine own, or were they not rather a repetition of the words thou hast so often heard from me? Didst thou not in thy speech merely re-echo, as it were, what I have over and over again preached to others?

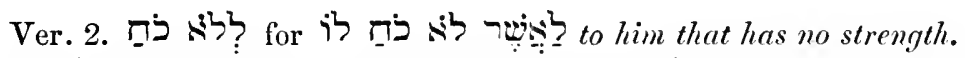

מִ What help hast thou afforded to $[$ the $]$ arm which has no might?

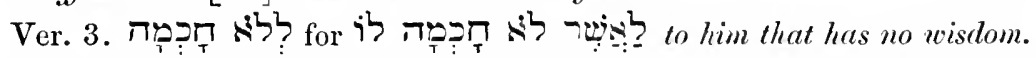

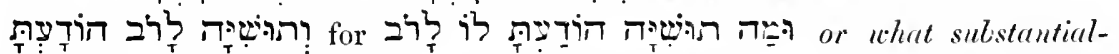

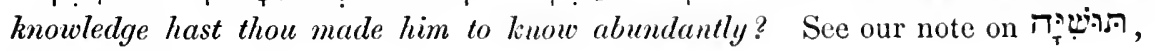
supra v. 12.

Vers. 5, 6. Moreover, what was the subject of thy discourse? The heavenly bodies, and the unlimited power God has over them, so that, after all, thou didst only direct my attention to objects visible to the eyes of every man ; but I will tcll thee more than that; I will call thy attention to things not visible to the eye of man, and yet unveiled before $1 \mathrm{im}$, from whose eye nothing is concealed.

The place, where the giants of the deep are formed-that is, the place, where all the huge and monstrous animals of the sea, such as whales, sharks, \&c., are produced-yea, that which is under the waters, and the inhabitants thereof - V Ver. 6) the grave also- - cvery one of these lieth naked before IIim; yea, there is no covering to destruction. Even the grave and destruction lie open and uncovered before IIim, so that, just as IIis eye watches His creatures 
whilst in the beauty and freshness of life, so it sees them also in every stage of their decomposition and decay.

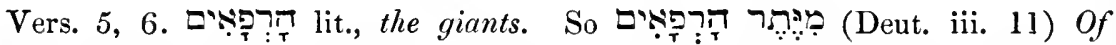
[the] remnant of the giants. This word is here applied to the monstrous

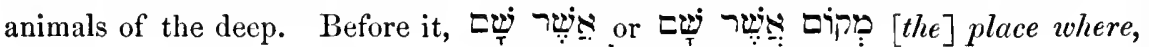

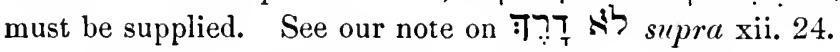

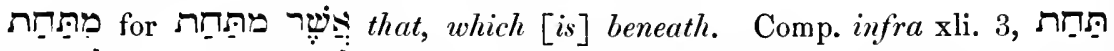

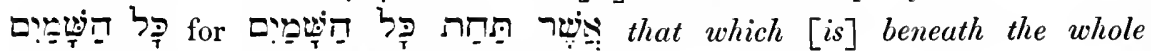
heavens. Comp. also infra xxviii. 24.

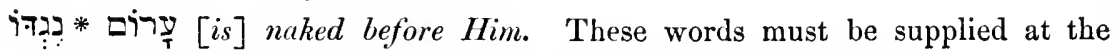
end of the first, as well as the second, hemistich of Ver. 5, so that

The construction of Vers. 5, 6, will be as follows:-

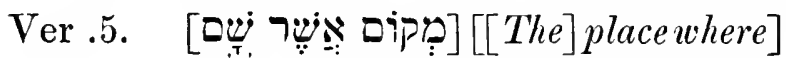

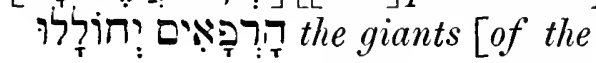
deep] are formed -

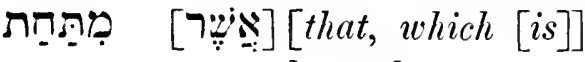 beneath}

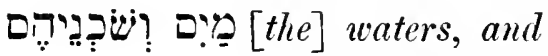
the inhabitants of them Ver. 6._- [the] grave

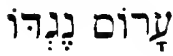

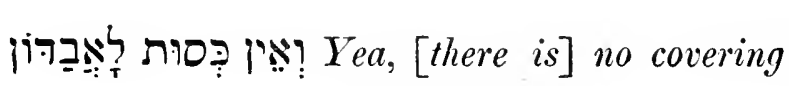
to destruction \begin{tabular}{l|l}
{$[i s]$ naked } \\
beforeHim
\end{tabular} $\begin{aligned} & \text { (i.e., the } \\
& \text { grave and } \\
& \text { the de- } \\
& \text { composi- } \\
& \text { tion and } \\
& \text { decay } \\
& \text { which go } \\
& \text { on there, } \\
& \text { lie naked } \\
& \text { \&open be- } \\
& \text { foreHim.) }\end{aligned}$

We will not conceal from the reader, that, in giving to the word monsters (of the sea), we stand quite alone; we shall lay before

- Here we have another instance of the poet's relying upon the common sense of his

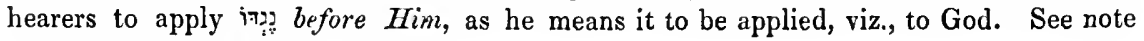

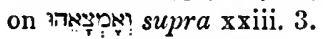


him, therefore, the renderings of some of the other commentators and translators, and leave it to him to decide in our favour, or against us. The word is certainly very frequently used in the Bible in the meaning of [the] dead (as e.g., Prov. ii. 18), and so it is taken here by Rosenmüller, Umbreit, Schlottmann, as well as by Wolfssohn, who, with those that can read and understand his Commentary, must have infinitely more weight than the three others put together. They agree, namely, in rendering the shades tremble, and must, of course (for else there would be no sense), have understood after these two words,

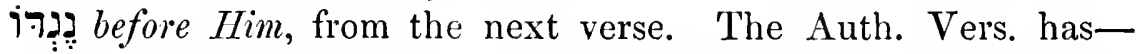
" Dead things are formed," \&c., which we suppose hardly deserves a comment. The reason why we preferred to giving signification of gigantic sea-animals is, because the first hemistich is by this rendering made to agree admirably with the second, which speaks of the waters and the inhabitants thereof.

Ver. 7-13. He stretcheth out the North. That is, the Northern heavens; he does not speak of the Southern, probably because they were hidden from his sight. Over empty-space; He hangeth the earth upon nothing at all. (Ver. 8.) He bindeth up the waters in His thick-clouds, yet the cloud is not rent under them. (Ver. 9.) He shutteth up the face of IIis throne, and widelyspreadeth His cloud over it. (Ver. 10.) IHe hath drawn a circular bound upon the face of the waters, a bound, which will endure till the end of light and darkiness. That is, to the end of all days. (Ver. 11.) The pillars of heaven are shaken, and are amazed at Itis rebuke. (Ver. 12.) By Itis power Ile clove the sea, and by Ilis understanding He smote its pride. The waves and billows thereof, which tower up so proudly, humbled themselves before Him, when He clove the sea, which He moreover did. (Ver. 13.) By His blast, which beautifieth the heavens. By dispersing, namely, any clouds that may disfigure them. Even by His hand, which formed the swift serpent. That is, lightning.

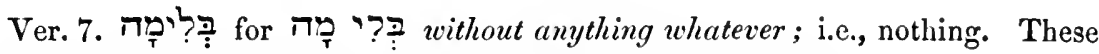
two words are blended into one, in the same way that we find

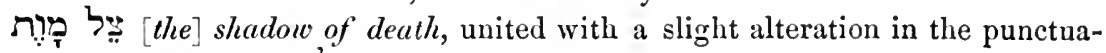

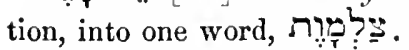

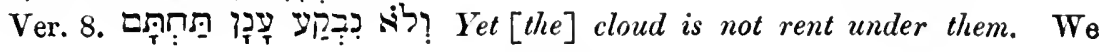




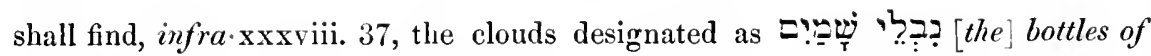
heaven, and so here the poet, picturing the clouds in his mind as delicate vases, marvels greatly low, in spite of the fineness of their structure, they are able so effectually to sustain the weight of the great abundance of water which they contain.

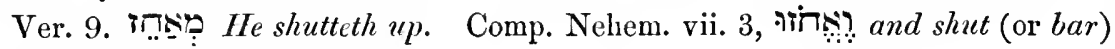
[them (the doors)].

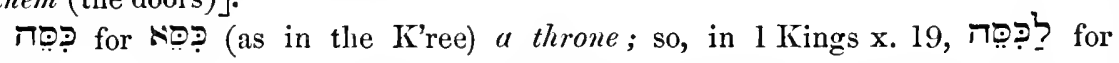

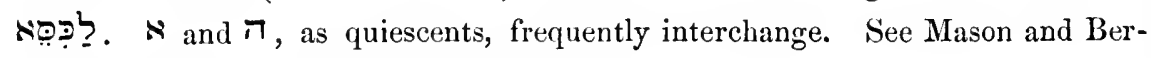
nard's Grammar, Letter xxxviii., P.S. (e).

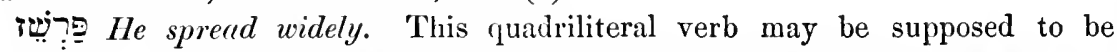
compounded of פרש פo spread, and the root פר find in the form cities.

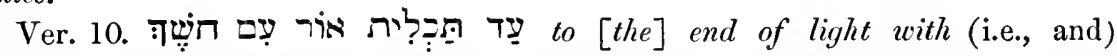
darkness; i.e., to the end of day and night, till day and night shall cease to be; for the poet here calls day, light, and night, darkness, giving to each its original name, as found in Gen. i. 5, where we read, "And God called the light day, and the darkness He called night." רin then, is, in this instance, synonymous

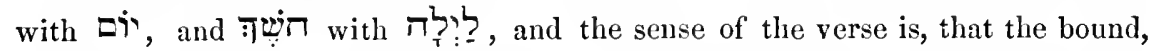
with which God has encircled the waters, is to last to the end of day and night, i.e., to the end of all days. It is well known, that the night together with the day following make up, in Biblical language, aiv a day; and the words before us, therefore, express the same idea as the more usual phrase end of days. Umbreit translates this hemistich, und bestimmte scharf Licht neben Finsterniss; Schlottmann, scharf scheidet er Licht und Dunkel. Obscure (to use a mild term), as are these renderings, we could perhaps make allowance for them, if we found they established a parallelism between the two members of the verse, which, we must confess, we cannot perceive that they do. The Translators of the Auth. Vers., on the other hand, seem to have understood the passage in the same way that we do.

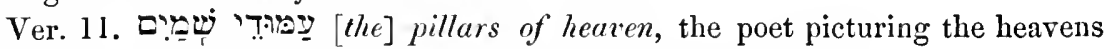
in his mind as the dome of a stately temple resting upon pillars.

Ver. 12. רָרבְ lit., He broke; i.e., clove. This verb occurred supra vii. 5, where it had a passive sense ; here, it is evidently used actively.

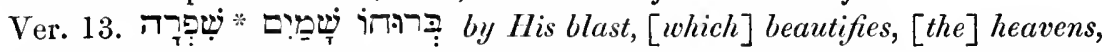
(by dispersing, namely, the clouds, with which they are sometimes overcast). Comp. infra xxxvii. 21, "but the wind passeth, and cleanseth them (the clouds) away."

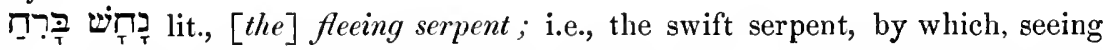
that the next verse alludes to thunder, is evidently meant lightning; and a very appropriate and beautiful figure it is, if we consider the serpentine, or zig-zag,

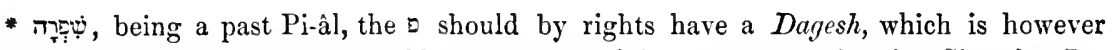
omitted, as it often is when it would come to stand in a consonant bearing Shevah. See Mason and Bernard's Grammar, Letter xvi., P.S. (d). 
shape of this phenomenon, and the velocity with which it glides, gleaming, through the heavens.

Most of the English and German Translators apply שִ שִ to God, taking, of course, the $\pi$ to be paragogic ; but a paragogic $\pi$, in the third pers. sing. masc. of the past, is of such rare occurrence, and may, in the few instances in which it is supposed to be found, so easily be explained away, that we could not make up our minds to follow their example.

We, therefore, construe Vers. 12, 13 as follows:

Ver. 12.

$$
\begin{aligned}
& \text { กับ Bบ Bis power, }
\end{aligned}
$$

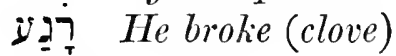

$$
\begin{aligned}
& \text { בד the sea, }
\end{aligned}
$$

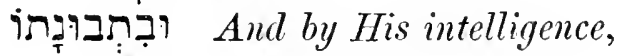

$$
\begin{aligned}
& \text { רָּר }
\end{aligned}
$$

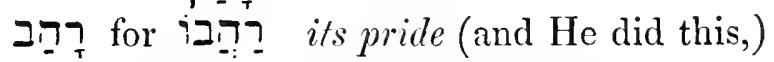

$$
\begin{aligned}
& \text { Ver. 13. Tבּר With His blast, }
\end{aligned}
$$

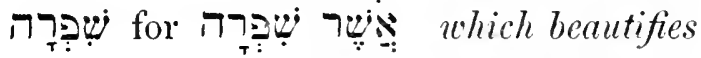

$$
\begin{aligned}
& \text { [ִ [the] heavens, (even) } \\
& \text { iד for iד with His hand, }
\end{aligned}
$$

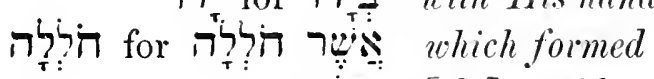

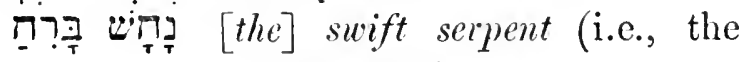

$$
\begin{aligned}
& \text { lightuing). }
\end{aligned}
$$

Ver. 14. Having thus enumerated some of the wonderful and marvellous works of God, Job closes his discourse as follows:

Lo, these are but outlines of IIs works, and uhat a triffing matter hath here been heard in that, which I have said! Great and stupendous as are those works and deeds of His which I have touched upon in this discourse, what are they, compared to the sum of those which might be recorded of Him? A mere nothing; indeed, less than nothing! Iea, the thunder of His might who can understand? The nature of His mighty thunder passes all human understanding. Job had, in the preceding verse, alluded to lightning, and now, therefore, naturally speaks of thunder, saying, as it were: yea, and His thunder also, which I omitted to mention, who is able to understand its nature?

Ver. 14. קוֹ lit., ends-, extremities-of ; i.e., outlines.

דָרָָ (according to the K'ree) lit., His ways, by which is here meant His

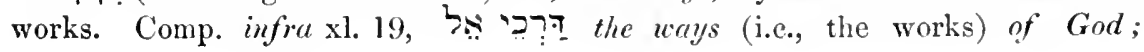




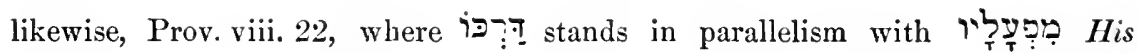
works.

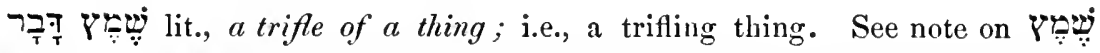
supra iv. 12. We take this word in the acceptation given to it by Aben-Ezra, Jarchi, Kimchi, Ralbag, Ben-Zev, and Buxtorf. In the Chaldee Version, too, it is rendered $ט$ ?ִ Version. The Vulgate renders it susurrus; and Ben-Zev, after having translated it as we do, adds :

\section{וי"מ ענינו לחישת קול במוד}

"And some interpret its meaning, [the] whisper of a low voice;"

alluding probably to the Vulgate, which none of his readers will, we presume, consider of greater weight than the authorities quoted above.

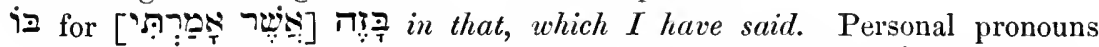
are sometimes found used for demonstratives, e.g., הוּא (Gen. xlii. 14) for

\section{CHAPTER XXVII.}

$\mathrm{J}_{\mathrm{OB}}$, having (as already observed), with the view of expressing his sense of the impropriety of Bildad's preaching to him the Omnipotence of God, in his turn taken up this subject, and dwelt upon it at greater length than his friend had done, might now naturally have been expected to wait to see whether anything would be advanced against him, the more especially as Bildad's speech, being totally devoid of argument, had offered him nothing to refute. He does not, however, so wait, but returns, the writer of the book tells us, to the consideration of his own case.

Vers. 1-6. And Job again took up his impressive-discourse, and said: (Ver. 2.) As God liveth, who hath tumed away. That is, rejected without noticing. My just cause, and, as the Almighty liveth, who hath embittered my soul. As certain as it is, that God Almighty liveth for ever, so certain is it, (Ver. 3.) † That,

* I do not now know where I found this pִ a word, which one would hardly expect to meet with in a Chaldee Version. In Buxtorf's Bible

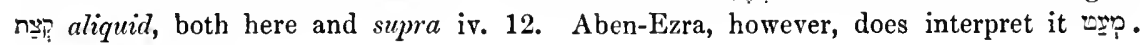
Note of Editor, 1861.

† In the Translation, the that has been omitted, as its employment would have necessitated the insertion of a number of words not in the text. 
as long as my breath is in me, and the Spirit of God is in my nostril[s] (Ver. 4.) My lips will not speak iniquity, and my tongue will not utter deceit. If I were to confess myself a guilty man and a sinner, my lips would speak iniquity, and my tongue would utter deceit, which they never shall; therefore, (Ver. 5.) Far be it from me, that I should pronounce you to be right. In the conclusion you have come to, that I needs must be a great sinner, richly deserving the punishment I have received. I will not put off mine integrity from me, till I expire. (Ver. 6.) I have taken fast hold of my righteousness, and will not let it go. I cleave to my righteousness, and firmly maintain, it has always been with me, nor ever, even for a moment, left me. My heart. That is, my conscience. Cannot blame any of my days. There is not a single day in the whole course of my life, in which I have done anything I could reproach myself with.

Ver. 1. מִ his impressive discourse. The noun לָ̣, being evidently derived from the verb משל to rule, have power, is applied to any kind of speech, which is forcible, and calculated deeply to impress the hearer, and bring conviction to his mind, no matter whether it consists of a similitude or parable, or of a pithy and sententious saying, or whether it constitutes a lengthened discourse, in which oratorical talent is displayed.

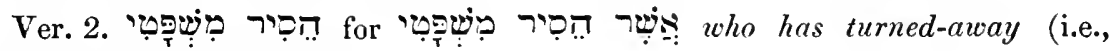
disregarded,) my just cause.

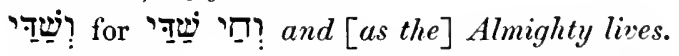

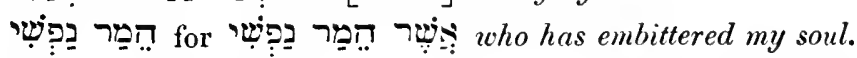

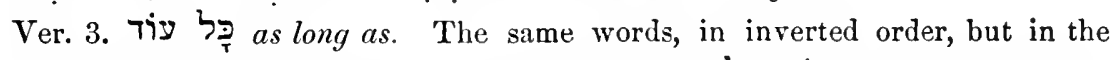

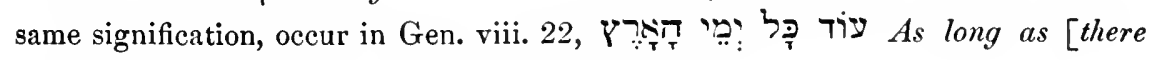
are] days of the earth ; i.e., while the earth remains.

Ver. 4. a. This particle, when used after an oath, expresses a negation. Comp. 2 Sam. xiv. 11, "As Jehovah liveth, hiפ? ạ there shall not full (one hair of thy son to the earth)." So also, Ps. xcr. 11, "So that I sware in my wrath, יב: לִ that they should not enter (into my rest)."

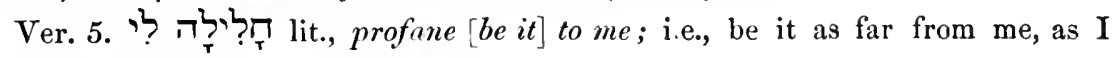
could wish a profane thing to be.

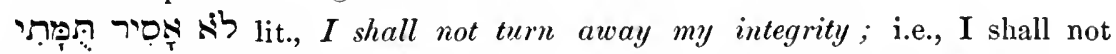
put off, strip (or divest) myself of, my integrity. Comp. Gen. xxxviii. 14,

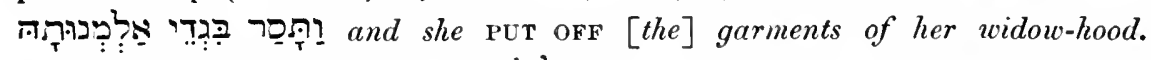

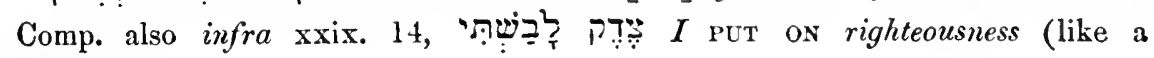
garment). 


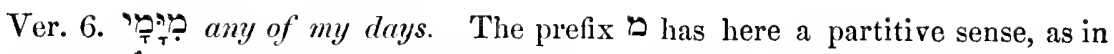

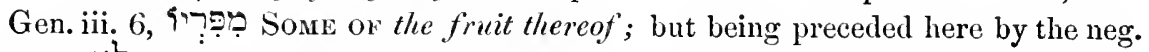
part. 5 , they are together equivalent to not any, or not one. So in 2 Sam.

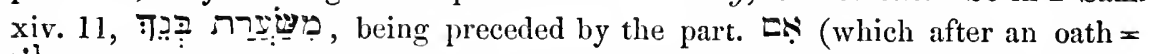
kל, as has just been observed in our note on ver. 4), must be rendered, NOT ANY (or NOT ONE) of thy son's hair[s].

Vers. 7-10. Job has so many times alluded to the prosperity of the wicked, that he is apprehensive he may be suspected of envying their lot, and of wishing to be in their place, a suspicion in the highest degree offensive to him. In order, therefore, to prevent his friends from entertaining any such erroneous notions, he says :

Let mine enemy be as the wicked-man, and mine adversary as the iniquitous-man. So far from envying the wicked, on account of their success and prosperity, I would not, for the world, exchange my condition, miserable and wretched as it is, for theirs, well knowing that the stings of my conscience would be infinitely more painful than these sores, with which I am covered from the sole of my foot to the crown of my head. Though my conduct has been ever such, that I cannot conceive it possible I can have an enemy; yet, if I have one, the worst thing I can wish him is, that he may feel those torments of conscience, which every wicked and iniquitous man must feel. I lament, it is true, very greatly, that the wicked fare so well, and I am very much surprised at it, but on no account would I exchange places with them. (Ver. 8.) For what is the hope of the hypocrite, though he get gain, though God suffer him to be at ease? (Ver. 9.) Will God hear his cry, when distress happeneth to come upon him? To be sure, whenever he does involve himself in difficulties, he never fails to extricate himself, but, still, while the danger lasts, he must be weighed down even to the dust by the overwhelming consciousness that he dare not look up to his Maker for help? (Ver. 10.) Can he delight himself in the Almiglity? Can he call on God at all times? As I do. Almost intolerable as are my sufferings, I have yet this great consolation, that I can call upon God, and with confidence declare to Him my readiness to appear at any time before His judgment-seat, for the purpose of clearing myself of any charge that may be brought against me, and of fully proving my innocence. Can the wicked man, 
can the iniquitous man do this? How absurd, then, would it be of you to suppose for one moment, that I envy their lot!

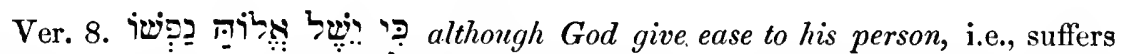
him to be at ease. We take לִי.., with Kimchi, to be the apocop. fut. Kal of שלה (used here actively), just as we have, in Gen. xliii. 34, רבה רתיח from from to be great, or much. Kimchi, indeed, says that some consider it to stand for

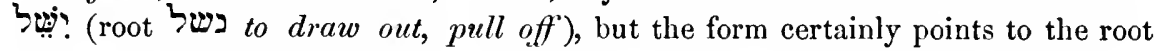
we have adopted, and a sense is thereby obtained in complete parallelism with

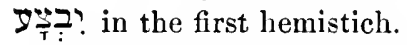

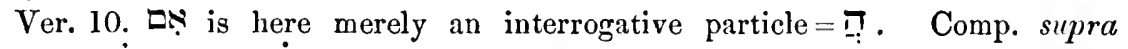

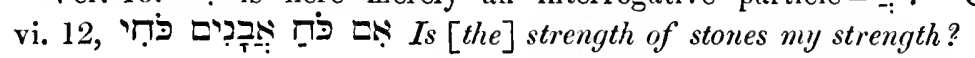

Vers. 11, 12. Lest any of his friends should again hurt his feelings by preaching to him the Omnipotence of God, Job concludes his discourse as follows:

I will teach you what, is in the power of God. It is not so much for you to proclaim to me the unlimited power of God, as for me to proclaim it to you. I have never been in the habit of concealing that which is with the Almighty. On the contrary, I have ever publicly taught and set it forth. (Ver. 12.) Behold, ye, all of you, have seen. Have seen me stand up, and proclaim the Omnipotence and Omniscience of God to those around me. Why then should ye thus indulge in that, which is utterly vain?

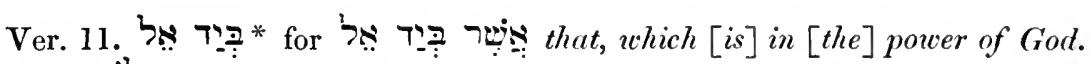

ל ל $I$ used not to conceal; i.e., it has by no means been my habit to keep that, which I know of the power of God, to myself; I have ever loudly proclaimed it to others. It will be perceived, that we take instance, as a fut. expressing frequency and habitual practice. See Mason and Bernard's Grammar, Letter xxix., § 1 .

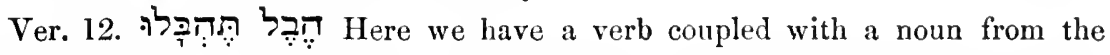
same root to give emphasis, and this we have endeavoured to express by translating, should ye indulye in that, which is utterly vain. Comp. Lament.

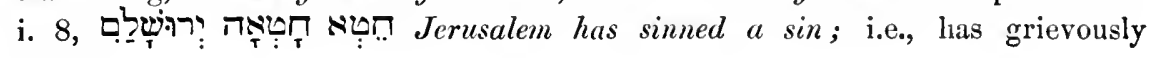
sinned.

- See note on 


\section{* CHAPTER XXVIII.}

\section{[And Zophar the Naamathite answered, and said.]}

Is justification of our opening here a new Chapter, and making Zophar the speaker of the first eleven verses of it (the last eleven of chap. xxvii. in the text), we quote the words of Kennicott (in his "Remarks on Select Passages in the Old Testament, Oxford 1787, pp. 169,170), which seem to us quite irresistible. It will be perceived, however, that we go farther still and attribute to Zophar not only these eleven verses, but the whole of chap. xxviii. in the text; our reasons for so doing we beg to be allowed to defer laying before the reader, till we have concluded our comments upon the Chapter.

\section{Kennicott's words are:}

"I shall now take notice of a matter of considerable moment, in chap. xxvii. The reader will allow the importance of it; because it relates to eleven whole $V$ erses, now ascribed to $J_{o b}$, which were probably spoken by ZOPHAR. Let it be first observed, that the plan of the former part of the Poem is as follows:

Chap. iv. and v. Eliphaz, Ist Speech-Job replies; Chap. vi. and vii.

\begin{tabular}{|c|c|c|c|c|c|}
\hline viii. & Bildad, & lst & Speech-Job replies; & , & ix. and $\mathrm{x}$. \\
\hline xi. & Zophar, & 1 st & ch--Job replies ; & $"$ & xiv. \\
\hline $\mathrm{x} \nabla$. & Eliphaz, & 2 nd & Speech_Job replies; & $"$ & i. \\
\hline xviii. & Bildad, & 2 nd & Speech-Job replies; & " & \\
\hline $\mathrm{xx}$. & Zophar & 2 nd & Speech-Job replies; & $"$ & $\mathrm{xxi}$. \\
\hline xxii. & Eliphaz, & $3 \mathrm{rd}$ & Speech-Job replies; & " & $\mathrm{x} x$ \\
\hline $\mathrm{xxv}$. & Bildad, & 3 rd & Speech_-Job replies ; & , & \\
\hline
\end{tabular}

"It is, therefore evident, that Eliphaz and Bildad speak three times; and are as often answered by Job : but, tho' the regular mechanism of the several parts leads us to expect a third Speech likewise from Zophar, yet we are greatly disappointed. But, that we really, even now, are in possession of a third Speech made by Zophar, will probably be allowed by most of those readers, who consider well the following remarks.

"The eleven Verses, which conclude the 27 th chapter, and are now given as the words of $J_{o b}$, cannot have been spoken by $J_{o b}$; because they contain such 
doctrine as $J o b$ himself could not hold, and which indeed he expressly denies : namely, that great calanities prove great wickedness. But these eleven verses perfectly express the sentiments of ZOPHAR, and are in his fierce manner of accusation; and they stand in the very place, where Zophar's third Speech is naturally expected. We should observe also, that if, in answer to Bildad's third Speech, Job's reply is contained in chap. xxvi. and in the first 12 verses of chap. xxvii ; that reply ends there very properly, thus-Behold, all ye yourselves have seen it; why then are you thus altogether vain? But, which is a stronger argument, the 13th verse, here supposed to begin Zophar's third speech, is the very same maxim, and nearly in the same words, with the conclusion of Zophar's second speech : so that he means to say-I abide by my last position; and what I before maintained, I maintain still. He had (xx. 29) concluded, that This (sc. misery) is the portion of a wicked man from God; and the heritage appointed him by God. And here he resumes the maxim, and persists in the justness of his observation: This is the portion of a wicked man with God; and the heritage of oppressors, which they shall receive of the Almighty. How miserably the Commentators are tormented, at finding the maxims of Job's accusers here ascribed to Job himself-may be seen in the remarks of the learned Alb. Schultens on this book;,pp. 729, 744 : and also Obscrvationes Miscell. in Job.; 8vo. Amstel. (Boullier) 1758, p. 252.

"It will be, however, objected-that there is no authority either from Hebrew MSS. or Antient Versions, for ascribing these 11 Verses to Zophar. The answer is-that if the words must, from their interual evidence, have come from Zophar, not from Job ; then the Title, ascribing them to Zophar, was probably omitted before the Versions were made, at a very early period, when several other corruptions took place likewise."

We heard Zophar close his second discourse, in which he described the miseries which must infallibly be the lot of the wicked-with the following words, (supra xx. 29:)

Such is the portion of the wicked-man from God, And the heritage appointed unto him by God.

These words he now, in his third, and last, discourse, repeats with a slight variation, the repetition having for its object to confirm their truth, as though he said: yes, the assertions I made in my last discourse, I was quite warranted in making,

Vers. 1-11. [* 13-23.] Such is the portion of the wickedman with God. Laid up for him with God. And the heritage of

* The numbers in square brackets are those of the corresponding verses of chap. xxvii. in the Hebrew text. 
oppressors, which they shall receive from the Almighty. (Ver. 2.) [14.] If his children are numerous, it is for the sword. I allow that he often has many children, but this must not be considered as a blessing, for they are only given him, that his punishment may be the heavier, seeing that they will all perish by the sword. And his offispring shall not be satisfied with bread. Not only will they come to a violent end, destroyed, namely, by the sword, but, as long as they are allowed to live, they will continually suffer the pangs of starvation. (Ver. 3.) [15.] Those that remain of him, when dead, shall be buried, but their widows shall not weep. Over their graves. (Ver. 4.) [16.] Though he heap up silver as the dust, and prepare raiment as the mire. Though he have silver and raiment in such abundance as to esteem them no more than dust and mud. (Ver. 5.) [17.] He may prepare it, but the just shall put it on, and the innocent shall divide his silver. (Ver.6.) [18.] He buildeth his house as the moth. Does hers. His house shall have no more firmness and stability than the frail cocoon, which encloses the moth as a chrysalis. And as the booth, which the keeper maketh. To shelter himself from the weather, during the time he watches over the gardens or vineyards, and which, being only intended for temporary use, would naturally be made of very frail and perishable materials, and quickly fall to pieces. (Comp. Isa. i. 8.) (Ver. 7.) [19.] He may lie down a rich-man, without the whole of his wealth being yet collected. He may have a great deal of wealth in his house, besides outstanding debts, and capital to a large amount, invested in vessels, merchandize, \&c., which he has sent out to distant parts of the globe. Yet he openeth his eyes, and it is gone. (Ver. 8.) [20.] Terrors will overtake him as waters. Will come upon him as suddenly as an overflowing river, or the rising tide, sweeps in upon those whom it surprises. $A$ whirlwind stealeth him away in the night. Destruction comes upon him in the night with the suddenness and violence of a whirlwind. (Ver. 9.) [21.] The east wind will carry him away, and he will depart; yea, as a storm, will it hurl him from lis place. (Ver. 10.) [22.] Then shall cast himself upon him, and not spare him, he, who constantly fled from his power. The very man, who, weak and timid, never dared stand up against him and resist him, but preferred seeking safety in 
flight, shall, when calamity has overtaken his oppressor, cast himself upon him, and avenge the wrongs he has suffered at his hands. (Ver. 11.) [23.] He. The weak and timid man. Will then triumphantly clap his hands at him, and hiss him out from his place.

Let the reader ask himself, whether the calamities, which are depicted in these eleven verses as sure to overtake the wicked, could possibly be assigned to them by one who, has, like Job, over and over again asserted, that they meet with nothing but unparalleled prosperity and success; whether such a description of their fate could possibly proceed from the same lips, which said, (supra xii. 6.)

Prosperous are the tents of the spoilers;

Yea, security is for them, that provoke God.

And (ch. xxi.) Ver. 7. Wherefore do the wicked live?

They become old, yea, wax mighty in power ;

Ver. 8. Their seed is established before them, yea with them,

And their offspring, before their eyes.

Ver. 9. Their houses are in peace, without fear,

Neither is the rod of God upon them.

Ver. 11. They send forth their wicked-little-children like a flock, Yea, their children frisk about.

Ver. 12. They take up the tabret and harp,

And rejoice at the sound of the lute.

Next, let the reader ask himself, whether the eleven verses under consideration could possibly be uttered by one, who so greatly lamented the honours which are paid to the wicked, even after their death (Chap. xxi. 32, 33); who found fault with God for removing them from the world so suddenly and without pain (Chap. ix. 23; xxi. 13; xxiv. 19); and who, finally, would not at all admit the correctness of his friend's assertion, that, though God does not punish the wicked in their lifetime, $\mathrm{He}$ will punish them in their posterity, but declared, that this would not satisfy his ideas of the Divine justice, which ought to require them themselves to drain the bitter cup they had so richly deserved (Chap. xxi. 19-21). We again beg the reader to compare these verses with the passages we here 
either quote, or refer to, and then calmly and considerately to form his own judgment, as to whether or not they should be attributed to Job. Commentators there are indeed, and those not few, who think that they can prove, nay demonstrate with mathematical certainty, that the sentiments expressed in these verses are not in the least incompatible with what Job has proclaimed and asserted; but, in our humble opinion, those who can maintain this, might confidently challenge the Royal Preacher to show them anything so crooked, that they could not make it straight.

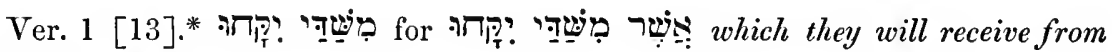
[the] Almighty.

Ver. 3 [15]. (Ps. iv. 2) " “ר

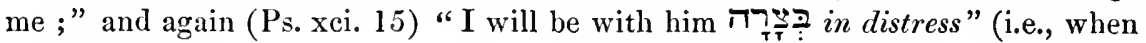
he is distressed). The speaker here predicts of the wicked man, that those of his children, who escape the sword, will indeed be buried, but that their widows will not weep over their graves, as was usual in those times. Comp. 2 Sam. iii. 32, "And they buried Abner in Hebron : and the king lifted up his voice, and wept at the grave of Abner ; and all the people wept." So John xi. 31, "she goeth unto the grave to weep there." This interpretation of the word will, we doubt not, appear to the reader, as it does to ourselves, so simple and so clear, that he will join us in regarding as utterly uncalled for such strained and tortured explanations of this verse, as we quote here from Rosenmiiller :

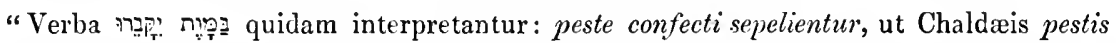

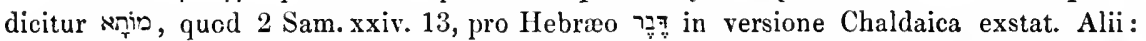
in ipsa morte sepelientur, i.e., subito, cum vix exspiraverint. Rectius alii : dum moriuntur, erunt simul sepulti, nec aliam habebunt sepulturam, quam mortem; mors ipsis erit sepultura, quatenus vel obruantur, vel mergantur, vel devorentur, vel absorbeantur. Ita Vavassor: 'Est hæc proprie insepultura. Mors illos sua sepeliet, nihil præterea honoris supremi consecuturos. Vult enim, mortem iis futuram pro sepultura, quasi qui inhumati projiciantur, aut jaceant sane inopes et infleti : quorum interitum honore sepulturæ cognati, affines, ipsæ conjuges, carere patiantur." "

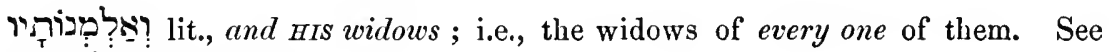
note on isח? supra vi. 17.

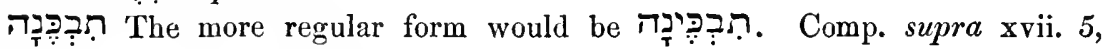

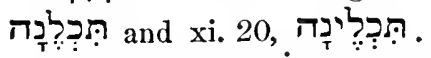

Ver. 4 [16]. רקי in this verse is taken by Homburg in the acceptation of heap, when the translation of the second hemistich would be, "he will prepare

* The numbers in square brackets indicate (until further notice) the corresponding verses of chap. xxvii. in the Hebrew text. 
raiment like heap[s]" (i.e., in great abundance), a rendering, which that most able Commentator very aptly supports by quoting (from Hab. iii. 15)

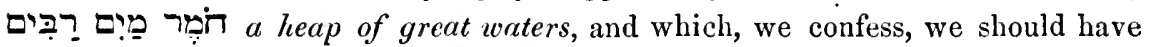
adopted, but that the parallelism between the two hemistiches would thereby have been impaired. We have translated דֶֶֶ clay, slime, mire, as supra iv. 19.

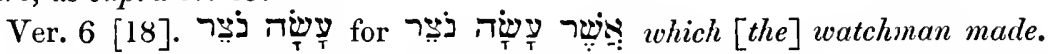

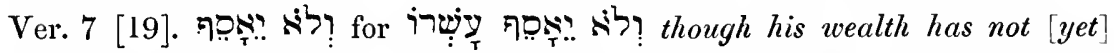
been collected; i.e., he is rich by what he possesses at home, and besides, he has a great deal of property in other, and distant, places. With respect to the rendering in the Auth. Vers., "The rich man shall lie down, but he shall not be gathered : he openeth his eyes, and he is not," we leave the reader to form his own judgment.

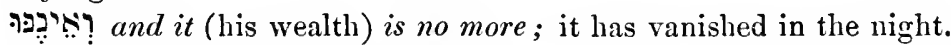

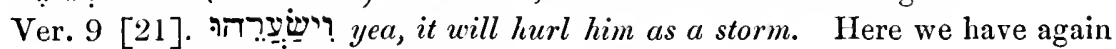
iv for 0 , as supra ix. 17 ,

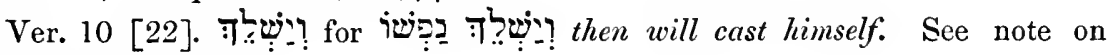

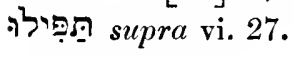

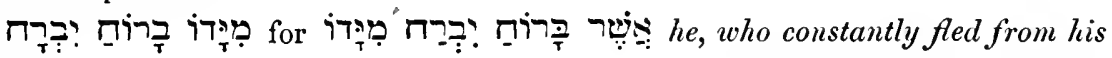
power.

This verse should be construed thus:

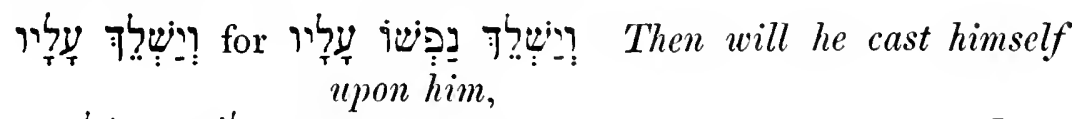

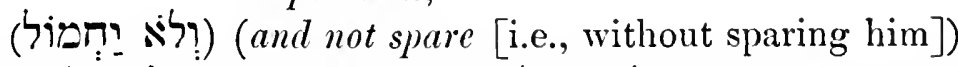

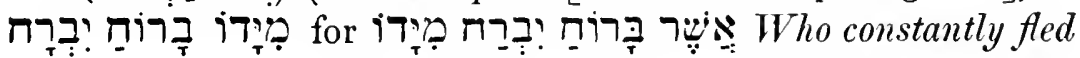
from his power (i.e., the very man, who used to be in such dread of him as on all occasions to flee from before him, shall now fall upon him, and wreak his vengeance).

We were very glad to find, that Wolfssohn has understood this verse just as we ourselves do, for the rendering of the Auth. Vers., "God shall cast upon him and not spare: he would fain flee out of his hand," seems to us hardly intelligible, and certainly very feeble.

Ver. 11 [23]. Pị:? he (the timid man, who used always to flee from before his oppressor), shall [now] clap, \&c. This verb is generally written with a 0 . 


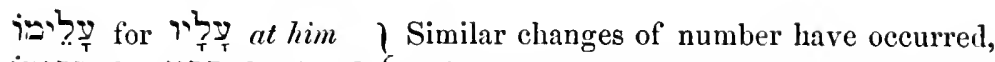
iמיכ for for his hands $\}$ and been commented upon so often, that we must refer to what we have already said.

(Here Chapter $x x$ viii. begins in the text.)

Having in the most positive terms, confirmed what he said in his second discourse respecting the terrible lot, which awaits the impious and wicked, Zophar is now about to meet his unfortunate friend on higher and much more advantageous ground. He is, namely, going to remind him, that, vast and wondrous as is the power, which man, by his intellect, industry, and experience, aided by the inventions of art and discoveries of science, may exercise on all the objects around him on this globe (the elements themselves not excepted), so as to keep them more or less under his control, and make them subservient to his plans and purposes, yet wisdom, that highest intelligence, which rules the universe, ordering all destinies and events, is not only beyond his reach, but even altogether beyond the sphere of his conception. He, man, therefore, was not sent into this world to scrutinize the dispensations of Providence, to philosophize upon them, trace them to their source, and reduce them to the puny scale of his own narrow and limited perceptions, but-and this is his whole destination here below-to admire his Maker in His works, to worship Him, stand in ave of Him, and obey His commandments. 'This speech, unparalleled for energy and sublimity, we shall find concluded with a sentiment, with which, in other words indeed, but in the same spirit, ages afterwards, he, who from his throne, preached to mankind the vanities of this world, wound up his discourse, saying (Eccles. xii. 13), "Fear God, and keep His commandments, for this is the whole duty of man."

Vers. 12-39 [*Chap. xxviii. 1-28]. Truly, there is an issue for silver. Man has devised means for extracting silver from the bowels of the earth. And a place, where they fine gold. To this more precious metal man has also access; he draws it out

* Henceforwards the numbers in square brackets indicate the corresponding verses in chap. sxviii. in the Hebrew text. 
and fines it. (Ver. 13) [2.] Iron may be taken out from the earth; and stone. That is ore. Molten into copper. (Ver. 14) [3.] He (man) putteth an end to darkness. He chases darkness from the places, which he wishes to make the sphere of his action. And every thing finite he searcheth out, even the stone of deepdarkness and the shadow-of-death. As long as man does not meddle with that which is infinite, he may fairly look forward to success in even the most difficult and arduous of his enterprizes; yea, even things, which are to be found only in the deepest recesses of the earth, he can dig out and make subservient to his purposes. (Ver. 15) [4.] He breaketh away river $[s]$ from the inhabitant. He can divert rivers from their original course, and, taking them away, as it were, from those, who dwell upon their banks, make use of their beds, as though they had always been dry land; yea, so completely can he turn them from their channels, That they are forgotten by the foot; they have been cxhausted, moved away by frail-man. Those, who tread the ground, thus become dry, altogether forget that it was once covered with water, and that in former times they knew a river flow there; and this so great a work is effected by the hands of frail man! (Ver. 16) [5.] The earth-out of it cometh bread, yet under it it is like fire stirred up. While the farmer ploughs his field, the miner under him maintains perpetual fires; and again, whilst in the bowels of the volcanic mountain the fire rages terribly, the husbandman calmly and fearlessly cultivates his land upon its sides. Ver. 17) [6.] He findeth out a place, the stones of which are sapphive[s], and which hath dust of gold (Ver. 18) [7.] A path, which the bivd-of-prey knoweth not, and the vulture's eye hath not seen. (Ver. 19.) [8.] The proudwild-beasts have not trodden it, nor the fierce-lion passed by it. (Ver. 20) [9.] He putteth forth his hand upon the rock; he overturneth mountains from their $\operatorname{root}[s]$. When, in the construction of a road, a mountain, or rock, impedes his progress, he is nothing daunted, but cleaves a passage through, or levels, it. Ver. (21) [10.] He cutteth out rivers in the rocks, and his eye seeth everything, that is precious in them. When rocks oppose him in his endeavours to change the course of a river, he cuts a channel through them, and will then of course discover 
anything precious they may contain. Again, when it serves his purpose (Ver. 22) [11], He bindeth up rivers, so that they do not trickle, and bringeth the thing, that is hid, forth to light. He makes canals, and lines them with stone, so that no water can escape; and in their construction he, of course, discovers many things, which had till then been hidden from the light. Comp. Herodot., B. II., chap. 127, where such a canal is spoken of. (Ver. 23) [12.] But as to wisdom-whence can she be obtained, and where is the place of understanding? Man may be able to find out precious stones and ores, and other valuable substances, concealed even from the piercing eye of the bird of prey, but can he discover the place where wisdom, where understanding, is to be met with? (Ver. 24) [13.] Frail-man knoweth not the value thereof, seeing that she is not to be found in the land of the living. (Ver. 25) [14.] The deep saith, "She is not in me;" and the sea saith, "She is not with me." (Ver. 26) [15.] Choice-gold cannot be given for her, neither can silver be weighed as her price. (Ver. 27) [16.] She cannot be valued with fine-gold of Ophir, with the precious onyx, or the sapphire. (Ver. 28) [17.] Gold and crystal cannot be compared with her, neither are vessel[s] of fine-gold an equivalent for her. (Ver. 29) [18.] Highly-prized-things and diamond[s] cannot be mentioned. Together with her. Seeing that the attraction of wisdom is greater than that of rubies. (Ver. 30) [19.] The topaz of Ethiopia cannot be compared with her, neither can she be valued with pure gold of Ophir. (Ver. 31) [20.] But, now, this wisdomwhence cometh she? And where is the place of understanding? That is, the place where understanding has her seat. (Ver. 32) [21.] Seeing that she is hid from the eyes of all the living, yea, is concealed from the fowls of heaven. (Ver.33) [22.] Destruction and Death say," We have heard the fame thereof with our ears." They, too, can give no account of her abode, seeing that they have only heard of, not seen, her. (Ver. 34) [23.] "God " understandeth her way, and He knoweth her place. (Ver. 35) [24.] "For He can look to the ends of the earth, yea, that which is "beneath the whole heavens, He can see. (Ver. 36) [25.] So as " to make a weight even for the wind; and the waters He hath " meted with a measure." That air has weight, is, as is well known, 
a discovery of modern times; to weigh, therefore, the wind or air was, at the time, when this discourse was delivered, considered as an evidence of supernatural power, as indeed to weigh the whole of it would still be. (Ver. 37.) [26.] "When He made a statute for the rain," when, where, and in what quantity, it should fall ; "And a way for the flash of the thunder," determining where the lightning should strike; (Ver. 38.) [27.] "Then did He see her and declare her ; He established her, and searched her out." (Comp. Prov. viii. 22-30, where we hear wisdom herself say, that she was with God at the time of the creation of the world.) (Ver. 39.) [28.] "But unto man He said: "Behold, the fear of the Lord, that is wisdom, and to depart from evil, that is understanding." "

Here we again ask, Can these twenty-eight verses have been uttered by Job? Job, the man with a philosophizing mind, ever ready to examine, scrutinize, and analyze, the dispensations of Providence, and who unhesitatingly ventures to assert that he has reason to complain of them, can he say, that man has nothing at all to do with wisdom? Can one, who has had the hardihood to speak of God in the most unbecoming, we might almost say, unpardonable, terms; one, whom we have heard throughout the whole of his discourses, do nothing but put questions to God, and betray the greatest impatience at finding these questions not answered; one, whose whole desire was, to reason with God, to plead with Him, and to find a tribunal, before which he could summon Him; one, who says :

To the wretched man, why is light given ;

And life, to those bitter in spirit?

(Chap. iii. 20.)

If I have sinned-what can I do unto thee?

O Thou preserver of man, why hast Thou made me so, that I should clash with Thee,

And become thereby a burden to myseif?

(Chap. vii. 20.)

It is all one, therefore did I say;

Alike the pious and the wicked, He (God) destroyeth.

(Chap. ix. 22.) 
There is no umpire between us, Who should lay his hand upon us both.

Let Him (Grod) remove His rod from off me,

And let not His terror affright me :

Then will I speak out, and not fear Him;

For am I not upright with myself?

(Ibid. 33-35.)

But, it is to speak to the Almighty, that I wish;

And to reason before God, that I desire.

(Chap. xiii 3.)

Then call Thou (O God), and I will answer;

Or, I will speak, and answer Thou me!

(Ibid. 22.)

To God doth mine eye drop tears,

That one might plead for a man with God,

As every son of man should plead for his fellow.

(Chap. xvi. 20, 21.)

There might the upright argue with Him;

So should I firee myself for ever from my Judge.

(Chap. xxiii. 7.)

Can one, we repeat, who has given utterance to such sentiments, be the man who preaches to his fellow-men, that they must have nothing at all to do with wisdom, as being altogether beyond their conception, but must hold the fear of God alone to be wisdom, and to depart from evil, understanding?

But, it will be said (and indeed has been said), may not Job have at last repented and become a convert? If so, we would beg of those, who take this view, to have the goodness to explain, how it is, that we hear him say, almost immediately after his supposed conversion (Chap. xxx. 21), that God has become cruel to him; and again, how he could, at the very conclusion of his last discourse (Chap. xxxi. 35), challenge God to answer him, either by word of mouth, or in writing? Is this the behaviour of a penitent man and a convert? 
Moreover (Chap. xxxv. 16,) we shall hear Elihu say of Job, that,

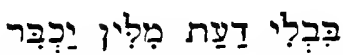

he multiplieth words without knowledge ;

Nay, we shall hear God Himself say (Chap. xxxviii. 2), that Job speaks,

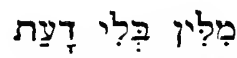

words without knowledge.

But, if Job were really the speaker of the discourse under consideration, we would ask, in the name of reason, how a sentiment, which deserves to be written in letters of gold in every place of public resort, how words such as those in verse 39 ,

\section{But unto man He said,}

Behold, the fear of the Lord, that is wisdom ;

And to depart from evil, that is understanding;

how such words could be pronounced to be

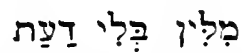

words without knowledge?

And yet, with one single exception, of which more presently, all the Translators and Commentators we have before us, English, German, French, \&c., as well as those who have written in Latin, Greek, \&c., not only unanimously agree in attributing to Job the twenty-eight verses under consideration, but endeavour to demonstrate, with a truly pitiful display of racked and tortured ingenuity, that it is quite right, natural, and consistent, to put them into his mouth. The reader will, we think, on referring to these authors, see that it may, with great truth, be said of them, in the words of the prophet Isaiah, "Woe unto them — that put darkness for light and light for darkness; that put bitter for sweet and sweet for bitter!" And why have they done so ? Merely because, forsooth, the words Zophar the Noamathite answered and said, are wanting at the beginning of the third discourse of that friend. Now, what are 
all these, "And . . . a answered and said"?-surely nothing but mere marks, such as might be used in any dramatic poem to indicate the speaker. Chap. xl. bears this heading, though it is evidently quite superfluous, and signifies absolutely nothing.

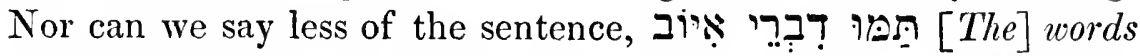
of Job are ended, with which Chap. xxxi. terminates. May not, then, in this instance, the writer of the book have gone to the contrary extreme, and for once have omitted this mark? May he not so have arranged his manuscript, that a mere dash, or other sign, should indicate the speaker? May he not have thought that, since Zophar's second discourse ended with the words,

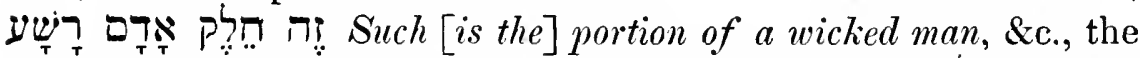
very fact of another discourse beginning with זִ זִ Such [is the] portion of a wicked man, \&c., would be quite sufficient to point it out as spoken by him, the more especially as the other two friends had each spoken three times, and Zophar only twice? Moreover, may not the writer have relied upon the common sense of the reader to see for himself, that these words could not possibly be spoken by Job? Do we not find, even in the historical books of the Bible, instances in which the writers did thus rely upon the common sense of their readers to supply what they did not consider it necessary to tell them. Thus, when Moses had helped the daughters of Jethro to draw water for their flocks, and the father said, "Call him that he may eat bread," we do not read that he was called, but the writer, leaving the reader to infer that it was so, at once proceeds to say, "And Moses consented to dwell with the man" (Exod. ii. 20, 21.) Again, when Ruth, on coming home early in the morning from the barn, was asked by her mother-in-law, who could not see her for the darkness, "Who art thou my daughter?"-we do not read that the answer was, "I am Ruth, thy daughter-in-law," which the reader was supposed to have wit enough to supply, but merely that Ruth told Naomi how she had fared (Ruth iii. 16).* We may then justly, we imagine, in our instance also conceive similar reliance to have been placed by the writer upon the common sense of his readers. How he misplaced his reliance, however, may be judged from the fact of so many Commentators having addled their brains with

- See Aben-Ezra on this passage. 
no other result than to make Zophar speak only twice, instead of three times, as though he had been suddenly deprived of speech; to make Job say that which Job could not say; to make Elihu say what Elihu could not say; and, alas, to make God say what God could not possibly say!

Had we stood quite alone in our view, but with such arguments to back us, we should still have considered ourselves strong enough to face any critic, who could bring himself to listen to reason; but in putting these twenty-eight verses, as well as the eleven by which they are immediately preceded, into the mouth of Zophar, we do not stand quite alone. We have, we are proud to say, with us no less an authority than Wolfssobn, who, though arranging the discourses we read in the 26th and 27th Chapters (according to the text) in a somewhat different manner from ourselves, yet fully agrees with us that to Zophar must be attributed all those verses to which we have affixed his name. Those who are able to read Wolfssohn, and can admire the soundness and logic of his reasoning, as well as the beauty and elegance of his style, will bear witness to the greatness of the authority we quote; and as for those who cannot read and understand such commentaries as Wolfssohn's, we frankly and candidly declare that we do not consider them Hebrew scholars, and would have them leave the criticism of the Old Testament to those who really are such. Moreover, we take the liberty of telling them, that as long as they are unable to read such commentaries as those of Jarchi, Aben-Ezra, Kimchi, Ralbag, Mendelssohn, Eichel, Wolfssohn, Friedländer, Ben-Zev, and Homberg, the Old Testament will remain for them a sealed book, as was the book of Ecclesiastes before Mendelssohn's Commentary upon it was translated for them by the Rev. Theodore Preston. Let them read that translation, and then ask themselves whether, before it stepped in to help them out of their difficulties, they ever understood as much as half a chapter of that book.

Wolfssohn's remarks on Chap. xxvii. 13 (according to the text), are as follows:

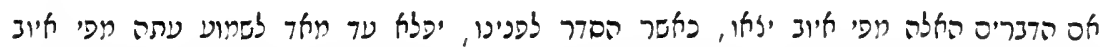

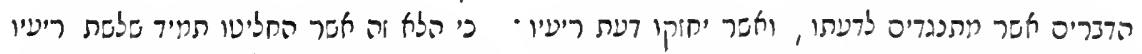

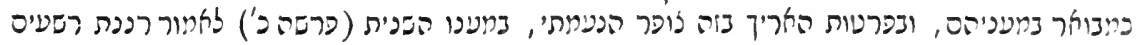




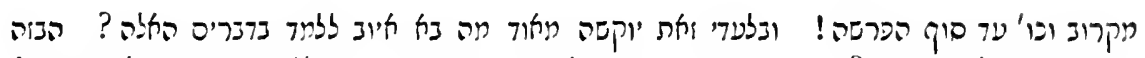

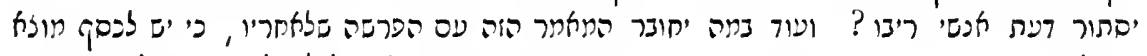

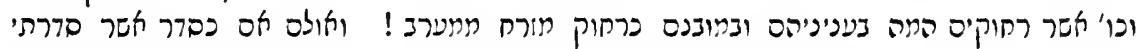

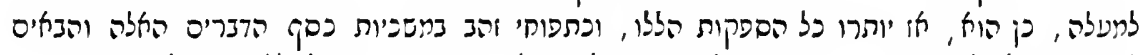

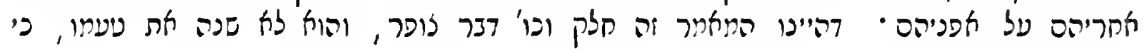

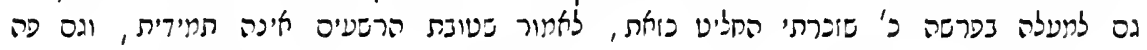

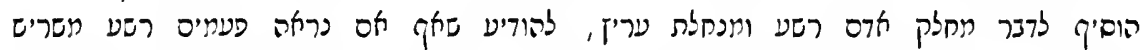

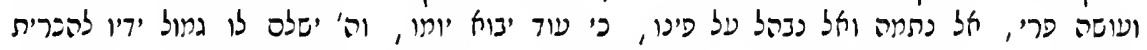

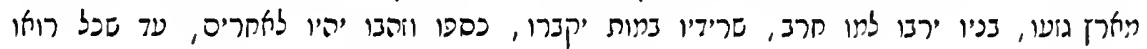

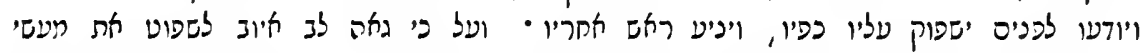

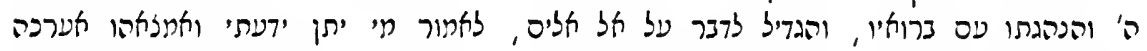

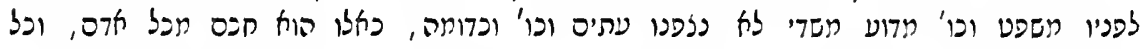

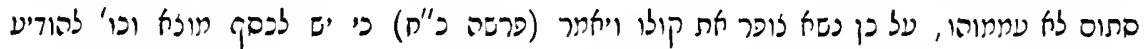

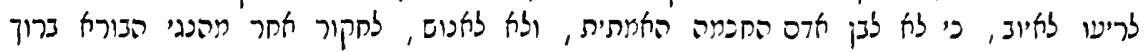

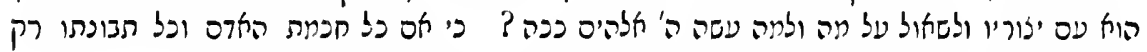

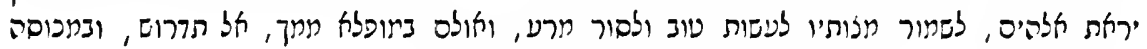

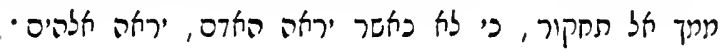

"If these words had come out from the mouth of Job, [as they do] according "to the arrangement before us, it would be exceedingly surprising to hear now "from the mouth of Job words, which [are] opposed to his own opinion, and "which [rather] confirm the opinion of his friends; for is not this what his three "friends have all along asserted, as [is] plainly stated in their discourses? And "Zophar, the Naamathite, in particular, has dwelt upon this at length, in his "second reply (Chap. xx.), saying (Ver. 5), "The triumphant-shout of [the] " wicked [is] of recent [date],' \&c., to the end of the Chapter ; and, independently " of this, it would be very difficult [to understand] what Job wishes to teach by "these words. Will he, by them, upset the opinion of his opponents? And, "moreover, what connection would there be between this speech and the Chapter " following it [beginning], 'Truly, there is an issue for silver,' \&c., which are " as distant [one from the other], in their subjects and ideas, as [the] sunrise is "distant from [the] sunset? But, if the arrangement be such as I arranged it "above," then, all these doubts will be resolved, and, as apples of gold in "pictures of silver, [so will be] these words, and those following them in their

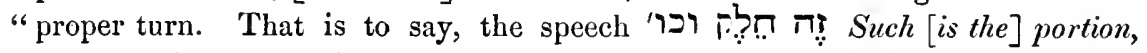
" \&sc., are the words of Zophar, he not having changed his opinion; for, above "also, in Chap. xx., as I have mentioned, he made the same assertion, saying, " that the prosperity of the wicked [is] not permanent; and here, also, he again

* The following is the arrangement proposed by the Commentator whose words we here quote :

Bildad speaks Ch. xxv., and Ch. xxvi., Vers. 5-14 incl.

Job speaks Ch. xxvi., Vers. 2-4 incl., and Ch. xxvii., Vers. 2-12 incl.

Zophar speaks from Ch. xxvii. 13 to the end of Ch. xxviii.

(These references, are all, of course, according to the text.) 
"speaks of the portion of the wicked man, and of the heritage of [the] oppressor, "declaring that, although we may sometimes see [the] wicked-man taking root, " and producing fruit, we must not wonder, nor rashly speak with our mouth, for " his day will yet come, when Jehovah will repay him the recompense of [the " work of] his hands, so as to cut off his stock from the earth. "His children may " be multiplied [but only] for the sword ;' 'they that remain of him, when " dead, shall be buried' (Chap. xxvii. 14, 15); his silver and his gold will belong " to others; so that every one who hath seen and known him in former times will " clap his hands at him, and wag his head after him And, seeing that Job's heart "was [so] proud as to pass judgment upon the works of Jehoval, and His pro"vidential care with [regard to] His creatures, and that he had magnified [himself] " so as to speak against the God of gods, saying, 'Oh that I knew where I might “ find Him !' 'I would order my just-cause before Him,' \&cc. (Chap. xxiii. 3, 4). "“Why [is it so]? Events are not concealed from the Almighty,' \&c. (Chap. "xxiv. 1), and [expressions] like these, as if he [were] wiser than all men, and "no secret-thing were obscure to him-therefore Zophar lifted up his voice, and " said (Chap. xxviii. [according to the text]), 'Truly there is an issue for silver,' " $\& \mathrm{cc}$., in order to declare to lis friend Job, that true wisdom [does] not [belong] " to the son of man, and [that it is] not for frail man to investigate the dispensa" tions of the Creator, blessed be He, towards His creatures, or to ask why, and " wherefore, Jehovah God should act thus ; but [that] the whole wisdom of man, " and his whole intelligence, [consist] only [in his] fearing God, so as to kcep "His commandments, to do good and depart from evil. But that which is too "wonderful for thee, thou must not inquire after, and that which is concealed "from thee thou must not search after, for God does not see as man sees."

It will perhaps be urged against us that the fact of Chap. xxix.

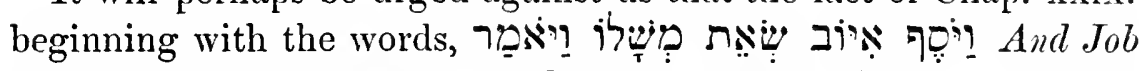
again took up his impressive discourse, and said, tends to shew that the preceding discourse was also spoken by him; but this would be no argument whatever, as these words are evidently introduced for the purpose of shewing that Job would not-as might reasonably have been expected of him, seeing he had been the first to speak-allow his friends to have the last word, but was determined to keep it for himself.

As the alterations we have here introduced in the arrangement of the text, and those which we may have occasion to propose, or actually to make, in the chapters yet to come, will, in all probability, raise against us the cry of some, we may perhaps be allowed, in extenuation of our guilt, present and prospective, to quote what Mendelssolnn says on this subject in his Commentary on Ecclesiastes, Chap. iii. 22: 


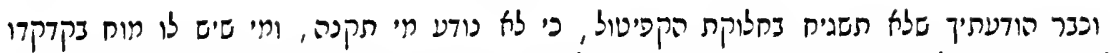

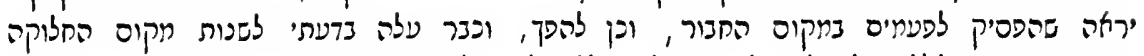

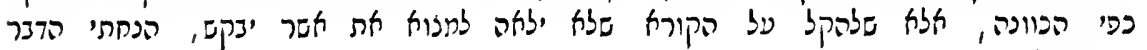

"And I have already informed thee that thou needest not mind the division "into chapters, for it is not known who arranged it, and every one that has "brains in his skull must see that he (the one who arranged the chapters) some" times stopped where they ought to have been joined, and vice versî. At first, "indeed, it came into my mind to change the place of division according to the "sense, but, in order to make it easier to the reader, so that he might have no " trouble in finding what he wanted, I suffered the matter to remain as it was."

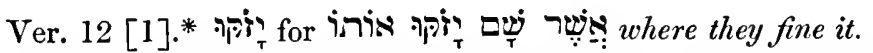

Ver. 13 [2]. Tis] molten. It will be perceived that we take this word to be the part. pass. Kal. of $\mathbf{P}$ ' to pour out, melt, cast.

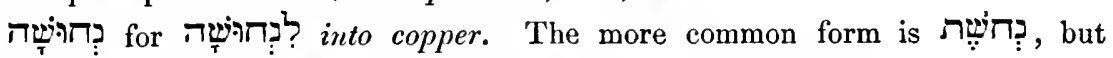

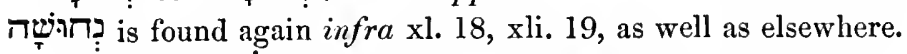

Ver. 14 [3]. অ the judgment of the hearer to supply the nom. case to the verb שָ , in accordance with the requirements of the context. See note on xxiii. 3.

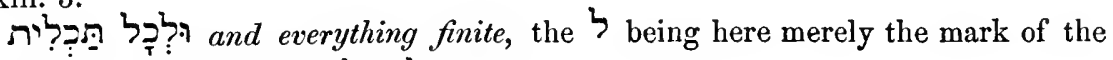
object. case. See note on לִיר supra $\nabla .2$.

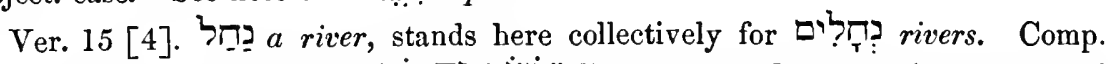

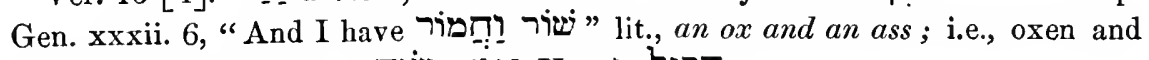

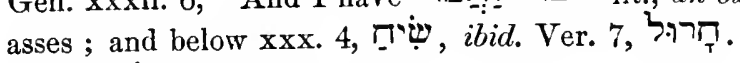

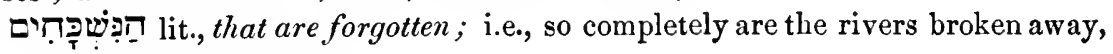
that they are forgotten, \&c.

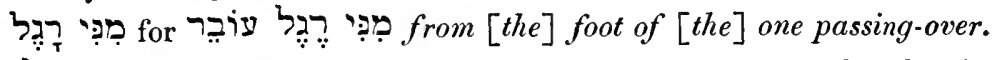

דָּלְלי are exhausted."

The last three words of this verse should be construed thus:

רִּ they (the rivers) have been exhausted,

נָ' they have moved away (from their place),

"ֶ: by means of frail man (i.e., frail man is the cause of their having been removed from their place).

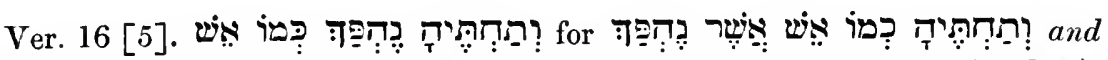
under it (i.e., in its bowels) [it is] like a fire that has been turned (i.e., stirred up),

* The numbers in square brackets again indicate the corresponding Verses in Ch. xxviii. in the Hebrew text. 
a very strong fire. There are passages in the Hebrew Bible from which no sense whatever can be extracted without a transposition of the words. So we shall

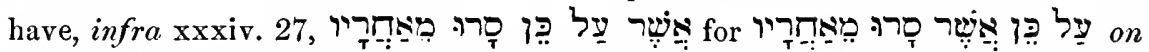
this account, that they have turned away from after Him (God). Again, in

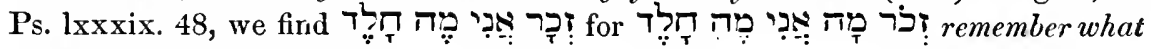
$I[a m]$, what $[m y]$ lifetime $[i s]$. Such a transposition we thought it much better to make in the passage before us, than to render it, with the Auth. Vers., "And under it is turned up as it were fire," of which we cannot see the sense.

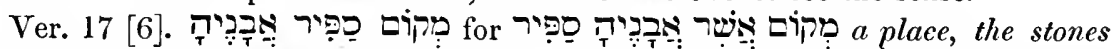

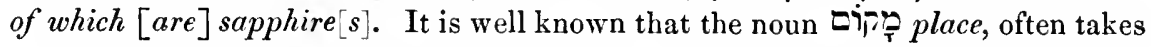

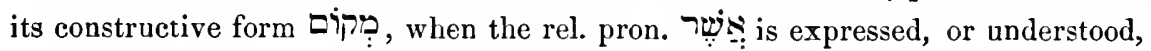

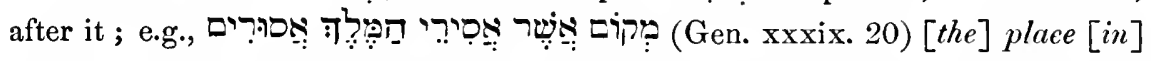
which (or where) [the] prisoners of the king [were] bound; and

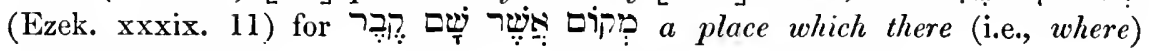
[there is] a grave.

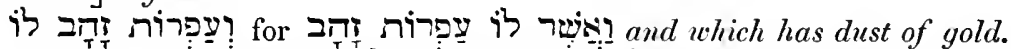

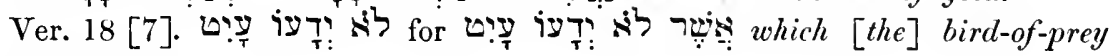
does not know.

Ver. 19 [8]. beasts, as infra xli. 26. In the Babylonian Talmud (treatise Sabbath, fol. 62, col. 2), we read :

\section{הבשי ירושלם אנשי שחקי היו}

[The] men of Jerusalem were men of pride; i.e., proud men.

Ver. 22 [11]. פִִִִ lit., from weeping, or trickling = that they should not trickle; that is, he binds up the rivers so closely, that not even a drop can escape. Here we have another instance of the prefix $\supset$ being used in a privative sense. See note שי supra xi. 15.

רוֹ for רin light. Comp. supra xii. 22.

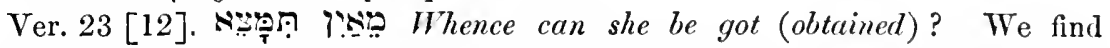
instances in which the verb 2 is used in the sense of getting, obtaining, as in

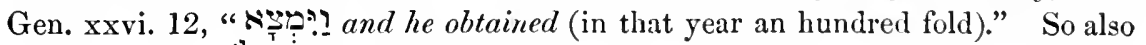
2 Sam. xx. 6, " signification here, we are enabled to preserve the usual meaning of the word פיר, namely, from where, whence, as supra i. 7 , and infra Ver. 20. Some, in consequence of their giving to Niv here its usual sense of finding, have been compelled to translate

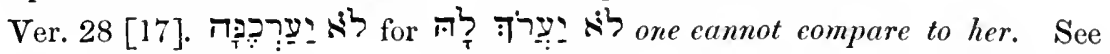
note on supra iii. 25. The same words occur Ver. 30 [19], and must be explained in the same way.

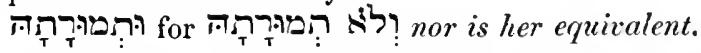

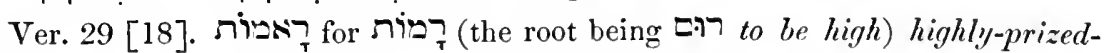
things, or jewels. This word is found in the same acceptation in Ezek. xxvii. 16.

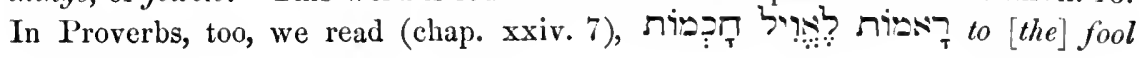


highly-prized-jewels [are] wisdom; i.e., when he possesses jewels, he thinks himself wise. So this passage ought to be translated and understood, though we do not find it las been done so by any of the Translators or Commentators we have consulted. In the second hemistich we are told that he (the fool) will find himself grievously mistaken, for that, when his turn comes to speak in public, he will see that he must not venture to open his mouth, and that his jewels avail him nothing.

?רגָרִיש: and diamond $[s]$. It is, of course, very diffieult, if not impossible, to determine with certainty what are the precious stones named in this chapter, but,

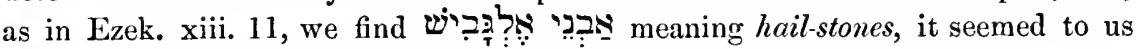

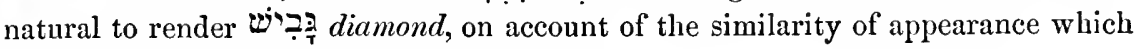
there is between this precious stone and hail.

习习̣ and $[$ the $]$ attraction of. With regard to this word, we may say with great truth of all the Translators and Commentators we have consulted, Quot homines, tot sententice. One translates it price; another, value; a third, the getting; the German translators render it Besitz (possession); all of them overlooking its natural meaning of attraction, as derived from the verb משד to draw, altract. Had these gentlemen consulted Ben-Zev, they would have spared their brains much torture. And, after all, they are driven out of the field by a lady, a Miss Smith, who takes consulted Ben-Zev, however ; for her translations contain abundant evidence of her never having been guilty of such a crime. Nor did we ourselves, either, borrow from him, having always understood the word in this sense, though we are, of course, proud to find so eminent an authority agreeing with us.

Ver. 35 [24]. התח for for that which [is] beneath.

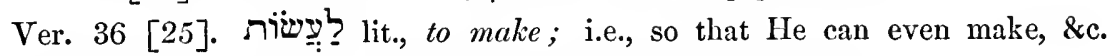

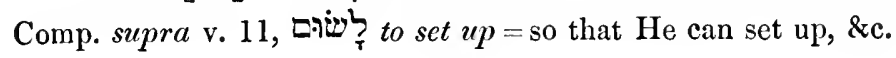

\section{CHAP'TER XXIX.}

$J_{0 R}$, bent, as was observed by us in our comments on the preceding Chapter, upon having the last word, as he had had the first, will not allow the controversy to rest where it is, but, after having spoken nine times, and received nine answers, now enters upon his tenth and last discourse, which, as will be perceived, extends over three Chapters. In the first of these, the Chapter now under consideration, we shall hear him give a sketch of the happiness he had enjoyed in his better days, the good he 
had done, the services he had rendered to his neighbours, and the great veneration he was held in by them in consequence. $\mathrm{He}$ says:

Vers. 2-10. Oh that I were as in months past, as in the days when God preserved me! From evil. (Ver. 3.) When His lamp so shined upon my head. With such vivid brightness. That, by its light, I could walk even in darkness! If, in those happy days, I was sometimes enshrouded in the gloom of adversity, His (God's) light (i.e., His favour and help), guided me in it, and quickly led me out of it. (Ver. 4.) As I was in the days of my youth, when the secret-blessing of God was upon my dwelling! When God, though invisible to me, gave me evident marks of His having my dwelling in His providential keeping. (Ver. 5.) When the Almighty was yet with me, when my children were round about me. (Ver. 6.) When my steps were bathed in milk, and the rock poured me out rivers, of oil. An Oriental figure denoting the enjoyment of great ease and comfort in the midst of superfluity. (Ver. 7.) When I went out to the gate through the city, and prepared my seat in the market-place. (Ver. 8.) The young-men saw me, and hid themselves. They withdrew from the street, that they might not impede my progress. Yea, very-old-men rose. From their seats. And stood up. To testify their respect for me. (Ver. 9.) Princes restrained their words, and laid their hand upon their mouth. They could not venture to speak in my presence, and therefore hastened to put an end to their conversation on seeing me approach. (Ver. 10.) As to the voice of the noblesthey altogether hid themselves, and their tongue cleaved to the roofof-their-mouth. The nobles, on perceiving that even princes held their peace on seeing me draw near, were struck with such awe, that, their words dying away upon their tongues, they hurriedly withdrew.

Ver. 1. See our remarks upon this verse towards the conclusion of our comments on the preceding chapter.

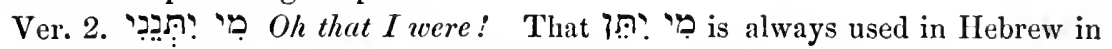
the sense of the Latin utinam, has already been observed supra xiv. 4 ; on taking affixes it must be rendered according to the person denoted by the affix ; e.g.,

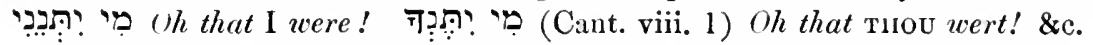

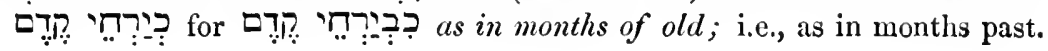




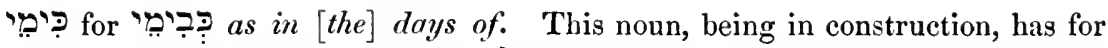

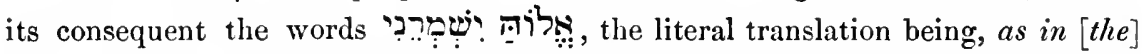
days of God used to protect me; i.e., as in the days when God used to protect me. See Mason and Bernard's Gramm., Letter xlvii., \$2. Comp. also Ps. xc. 15,

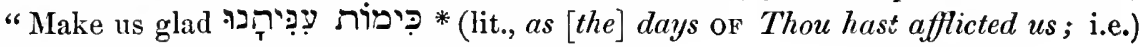
as in the days wherein Thou didst afflict us."

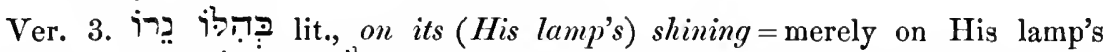

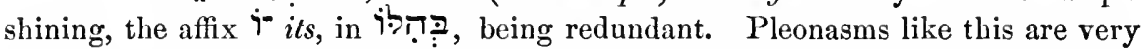
frequent in the Talmudic dialect, as well as in the Syriac language. They are, however, sometimes to be met with even in the Old Testament, as Exod. ii. 6,

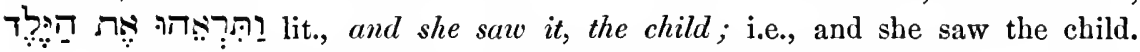
So in Ezek. x. 3, man's entering.

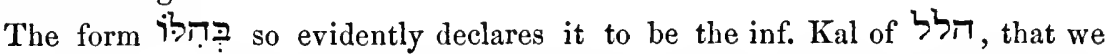
were rather surprised at finding Rosenmüller observing, "Pluribus est infinitivus

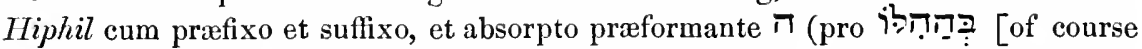

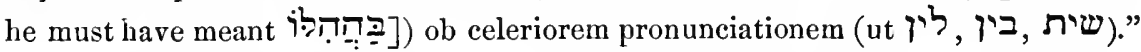
In the first place, it is very strange to determine the form of a verb belonging to the geminata, according to that of verbs "Y; and, secondly, he seems quite to have forgotten that it is considered by the best grammarians and lexicographers doubtful whether the verbs he quotes belong to

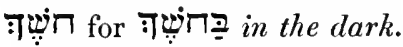

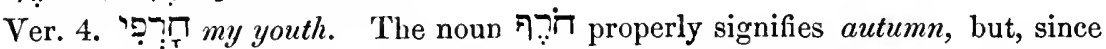
with the Hebrews (as it still does with the Jews), the new year began with the autumn, it is also used to denote youth, just as we speak of the spring of life, the spring being the early part of our year.

7io. This noun is sometimes used in the sense of counsel, as supra xv. 8 ;

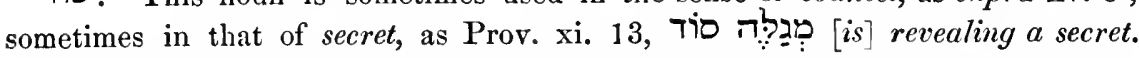
Sometimes, however, it denotes the favour, or blessing, shown by the Almighty to those He loves, as a mark of His being pleased with them ; e.g., Prov. iii. 32, "For the froward is an abomination to Jehovah, but with the righteous is His secret-blessing." In this acceptation we take it here.

Ver. 6. milk, of which butter (in which sense the word is sometimes used) is made. See our note on this word, supra xx. 17.

זיציז is here the third pers. sing. fut. Kal of ;.q.,

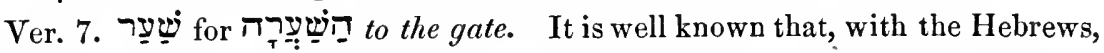
all public business was transacted in the city gateways. Comp. Deut. xvi. 18.

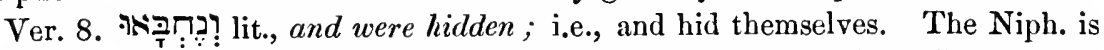

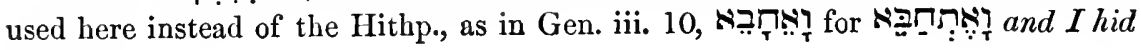
myself.

* In the second hemistich of this rerse שִ (for way with the verb רִיז. The meaning of these elliptical expressions of course is, Let our joy now be as great as was our sorrow then. See Appendix. Note of Editor, 1861. 


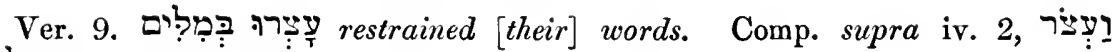
.

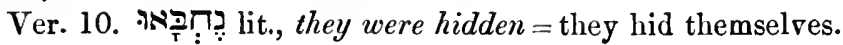

The first hemistich of this verse should be construed thus :

—

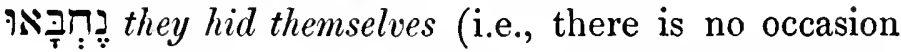
for me to tell you that they did not speak, since, when they saw even princes restrain their words, they were, of course, at once awed into silence).

The second hemistich of this verse, which Umbreit translates,

und ihre Zunge blieb an ihrem GAUMEN hängen.

lit., and their tongue remained suspended to their PALATE.

is rendered by $\mathrm{Mr}$. Gray, his translator,

and their tongues did cleave unto their gurs.

the Reverend Gentleman having, it appears, considered the German Gaumen to be synonymous with the English gum!!!

Vers. 11-17. Afraid that his hearers should think, the homage thus paid to him by all classes, had had its origin in the fear and dread inspired by his tyrannical and despotic rule, Job assures them, that it was not so, nay, that precisely the contrary was the case. This deference, he says, was shown to me by my neighbours, (Vers. 11, 12.) Because the ear, which heard. My fame. Blessed me, and the eye, which saw me, bare me witness, That I used to deliver the poor, that cried, and the fatherless, who had no helper. (Ver. 13.) The blessing of him, that was ready to perish, came upon me, and I caused the widow's heart to sing. For joy. (Ver. 14.) I put on vighteousness, and it fitted-me-as-a-garment, my justice I put on as a robe and turban. (Ver. 15.) I was eyes to the blind, and feet was I to the lame. I rendered every assistance to the helpless, giving to every one that which he most stood in need of. (Ver. 16.) I was a father to the needly, and the cause of those I knew not I searched out. When I sat as a judge, I suffered myself to be influenced, neither by the wealth of those, who 
appeared before me, nor yet by my private feelings; I saw justice done even to the needy, and to those who were utterly unknown to me. (Ver. 17.) And I brake the grinders of the iniquitous, and plucked out his spoil from his teeth.

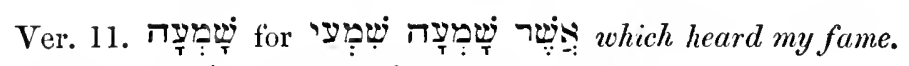
wher waich saw me.

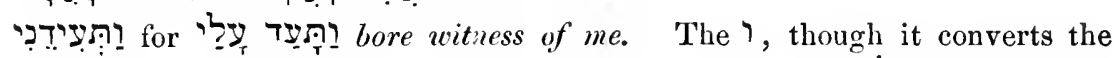
tense, is not copulative, but merely conductive, as also in וַ in the first hemistich.

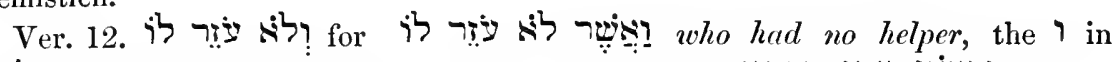

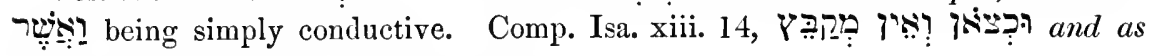
sheep, whici no-man gathers together.

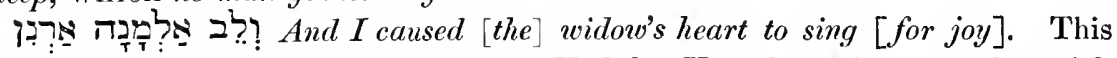
hemistich is rendered by Schlottmann, "Und das Herz der Wittwe machte mich fröhlich." How much is that reader to be pitied, who from a want of knowledge of Hebrew, is obliged to put his faith in a translation containing such a gross blunder as this, a blunder, which we should not expect from one, who had read Hebrew only a montl, and by which the sense, so far from being improved, is utterly ruined.

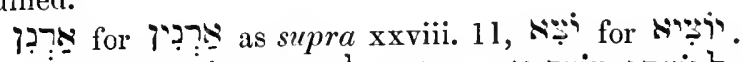

Ver. 14. 1and turban I put on my justice.

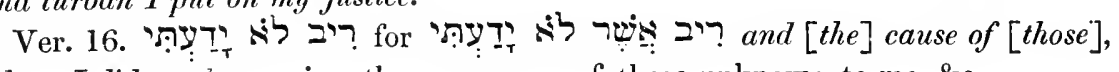
whom I did not know; i.e., the cause even of those unknown to me, \&c.

Vers. 18-20. In his last discourse (chap. xxvii. 6, we heard Job say, his heart could not reproach any of his days; now, he goes farther and tells his friends, that the manner in which he had acquitted himself of his various duties, had ever been such, as not only to secure for him the love and esteem of his neighbours, (as he had already said it had done in the early part of this chapter), but also to leave his conscience free from remorse, and to inspire him with confidence, that he would be allowed by the Almighty to lead for many years a life, which could not be otherwise than pleasing to Him. He says:

So that I thought, "I shall die in my nest, and I shall multiply my days as the sand." I thought I should die in peace, in my own house, with all that were near and dear to me around me, and not prematurely, but in a good old age. I moreover thought, (Ver. 19) "My root is open to the waters, and dew lieth all night 
upon my branch." I thought I was like a healthy and vigorous tree, abundantly supplied with nourishment by water below, and dew above. (Ver. 20.) "My glory is fresh with me, and my bow, which is in mine hand, will renew its strength." The dignity, with which I was invested, would, I conceived, constantly receive new lustre, and the authority, which had been conferred upon me by the common consent of the people, grow firmer and firmer.

N.B. In the Translation, we have marked these three verses (B), and the remainder of the chapter (A), to shew, that, in our humble opinion (the opinion also of Wolfssohn), the former should be read after the latter, though as the transposition was not absolutely necessary, we did not make it. We shall quote Wolfssohn's remarks at the end of the notes on the three verses alluded to.

Ver. 18. thine heart."

!ְכ and like the sand. A great number, or multitude, is very often in the Old Test., compared to the sand of the sea, as Gen. xxii. 17. We will not, however, conceal from the reader, that some of the old Commentators, and among them Jarchi, tell us, that hin is the name of a certain very long-lived bird-probably meaning the phœnix, which, according to the fable, lived some mythical number of years, and then burned itself in its nest, which it had constructed with twigs of scented woods, and filled with spices; an interpretation adopted, no doubt, with a view to explain how Job came to speak of dying in his NEST.

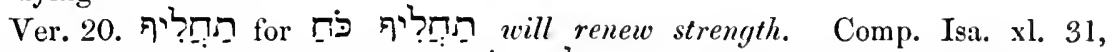

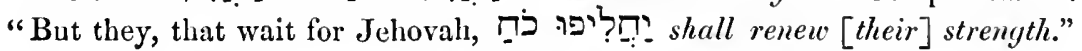

Whese three verses (1S-20) would read much better after Ver. 25, for the reasons very clearly stated by Wolfssohn, and to which we fully subscribe. As, however, we have made it a rule never to introduce any alterations into the text, without there being an absolute necessity for doing so, we have contented ourselves, in the present instance, with marking these three verses (B), and the remaining verses to the end of the chapter $(A)$; and we leave it to the reader to assign them the places he thinks they ought respectively to take up. Wolfssohn's observations are as follows : 


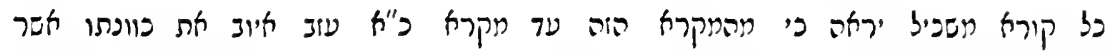

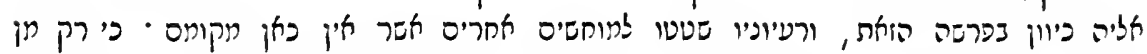

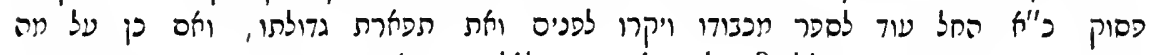

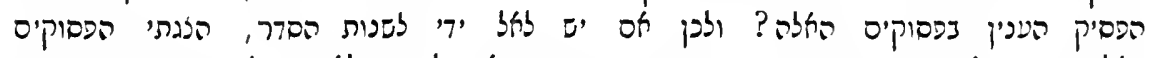

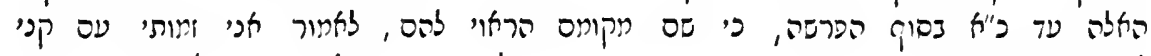

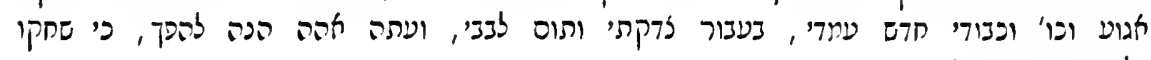
עלי לעיריס ופו' ופורי

"Every intelligent reader will see, that from this Verse (Ver. 18) to Verse 21 " Job has departed from his [primary] object, at which he aimed in this Chapter, " and [that] his thoughts have wandered away to other subjects, which are here " out of place; for [it is] only from Ver. 21, [that] he again begins to tell of his " former honour and dignity, and of the glory of his excellency, and if so, why " did he interrupt the subject by these Verses (viz., 18-21)? If, therefore, I " had had it in my power to alter the arrangement, I should have placed these "Verses (from Ver. 18) to Ver. 21, at the end of the Chapter, for there is their " proper place, saying (i.e., Job saying) ' I thought I should expire in my nest, “ \&c.,' ' and my glory [would be] fresh with me,' on account of my righteous" ness and the integrity of my heart, but now alas it is [just] the reverse, since " young men laugh at me, \&c. (as the next chapter begins)."

Vers. 21-25. After this short digression, Job returns to the description of his former dignity and glory, and of the popularity he enjoyed with his fellow-citizens. He says :

Unto me men gave ear, and waited. For my advice. Yea, they kept-silence at my counsel. When, in a public assembly, it was seen that I was preparing to deliver my opinion, such eagerness was felt to hear it, that a breathless silence prevailed, which was only interrupted by my own voice. (Ver. 22.) After my word [s] they would not speak again, so that my speech should still drop upon them. When I had concluded my discourse, the orators, who had spoken before me, would not rise again, in order that I might be induced to continue. (Ver. 23.) Yea, they waited for me. That is, for the continuation of my speech. As for rain, and opened their mouth wide as for the latter-rain. Just as the husbandman waiteth with impatience, in the autumn, for the early, and in the spring, for the latter, rain, so did my audience long for the continuation of my discourse. (Ver. 24.) When I smiled at them - they would not believe me. When by a smile I gave them to understand, that my discourse was actually at an end, that I really had nothing more to say, and that consequently the assembly 
was dissolved, they would not believe me, they would not take the hint and go away. Yet they did not cause the light of my countenance to fall. Impatient as they were for my speech, still they betrayed their impatience by no word or look that could offend me, or make me change colour. (Ver. 25.) I used to choose out their way. At any public procession I used to lead the way, and they followed whither I chose to go; and when we took our seats, $I$ sat at their head, yea, $I$ abode as a king amidst his host, as one that comforteth mourners. It is the custom among the Jews of our day for mourners to sit on the ground, whilst he who wishes to comfort them occupies a seat, and this appears, from the present verse, to have been the custom also in the time of Job.

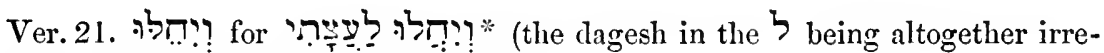
gular) and they used to wait for my advice.

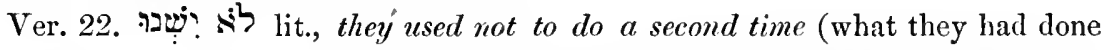
before ; i.e., speak). The verb שבה signifies, to do a second time, or again (what has been done before). Thus, in 1 Kings xviii. 3t, when Elijah wished to confound the priests of Baal, after water had, in compliance with his orders, been poured once upon the sacrifice, he said, the verse before us, it is used by Job for the purpose of informing his hearers, that, whenever, in former times, he had finished speaking in the assembly, the orators, who had preceded him, were so well satisfied with what they heard from his lips, that they would not speak a second time.

So that my speech should [still] drop upon them. It is a common figure in Hebrew poetry to compare a smoothly-flowing and instructive speech to the dropping of rain or dew. So (Deut. xxxii. 2), "My doctrine shall drop as the rain, my speech shall distil as the dew, \&c."

Ver. 23. It will be perceived, that the $ל$ of שip?

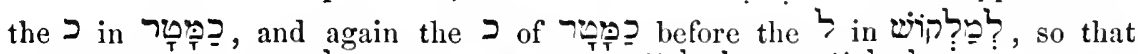

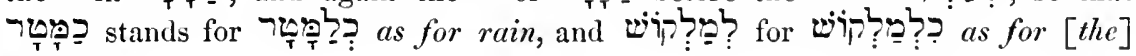
latter rain.

רטָ⿳亠幺冖 in the first hemistich, though signifying rain generally, is here used = तריi early rain, as is evident from the second hemistich.

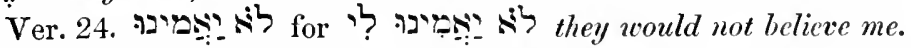

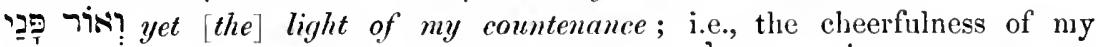

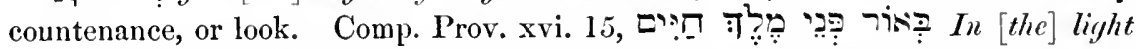
of [the] king's conntenance [is] life; i.e. a cheerful, or gracious, look from a king revives, gives confidence to, all around him.

*

s 2 


\section{CHAPTER XXX.}

In the preceding chapter, we saw the poet choose the brightest and most vivid colours in order to portray his former happiness and glory; in the present chapter, wishing to present a powerful contrast between these and the misery and degradation he is now suffering, he selects the darkest and most sombre tints.

He says :

Vers. 1-8. But now they, that are younger than I, have me in derision, whose fathers I disdained to set with the dogs of my fiock. In my happier days, very old men rose and stood up at my approach (chap. xxix. 8); but now those, that are younger than I am, hold me in derision. In my happier days, princes and nobles paid me homage (Ibid. 9, 10); but now the very outcasts and dregs of society, whose parents offered their services to help the dogs to guard my flocks, and were rejected by me, treat me with the greatest contempt. And I had reason to reject their offers, although they were strong and vigorous, for ((Ver. 2.) Of what use, indeed, was the strength of their hands to me? With them mature-age was lost. Vile and worthless men, they made no proper use of their strength and vigour, employing them only in the accomplishment of their nefarious designs; their time, therefore, was spent altogether unprofitably, was utterly lost, nay, worse than lost, for the longer they lived, the more crimes only did they heap up.) Having assigned a reason for his rejection of the fathers, he now proceeds to give a full description of the vileness of the sons, whose object of derision he now is. They are, he says, young men, who are (Ver. 3) Cheerless, through want and starvation, who flee into a wilderness, dark, waste, and desolate. (Ver.4.) Who pluck up salt-wort by the bush[es], and the root of the broom is their food. The reason, why they are reduced to such a miserable state as to have to seek their food in the desert, is, that (Ver. 5.) They have been driven forth from the midst. Of the city. They cried after them as after a thief. (Ver. 6.) They must dwell in the cleft $[s]$ of vallies, in holes in the 
earth and rocks. (Ver. 7.) They groan among the bushes, they are huddled together under the thorn $[s]$. To escape the inclemency of the weather, and keep one another warm. (Ver. 8.) They are children of impious men, yea, children of men without a name. Their fathers were the lowest of the low; they never emerged from obscurity; their names remained utterly unknown. They have been beaten out of the land. They rendered themselves so notorious by their crimes in the country which gave them birth, that they were ignominiously chased out of it with blows.

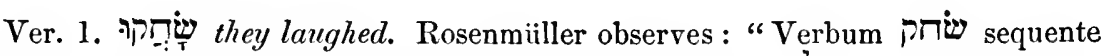
לִ, in bonam partem dicitur, ut supra xxix. 24., et cum in malam, pro subsannare, et illudere." For our part, who can see no difference between the particle $\zeta$ and the prefix $\zeta$, we cannot possibly admit the accuracy of this observation, as we meet with innumerable instances, in which the verb שiv, construed with $\zeta$, is nsed in a bad sense; e.g., supra v. 22,

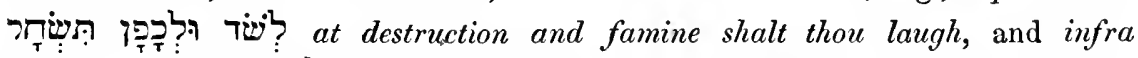

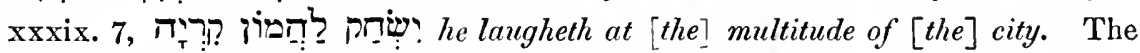
fact is, that the context alone can decide, whether this verb is used in a good, or in a bad, sense, as in the case also of the synonymous verb $7 \pi$. Thus, in Gen. xvii. 17, when Grod promised Abraham he should have a son by Sarah, we read, that he fell upon his face $\Gamma_{T}$ in no wise reproved, because it was the laughter of joy; whereas of Sarah we

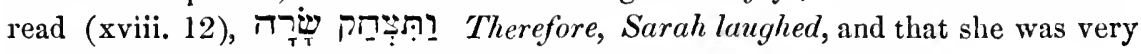
severely rebuked for it, because it was the laughter of contempt.

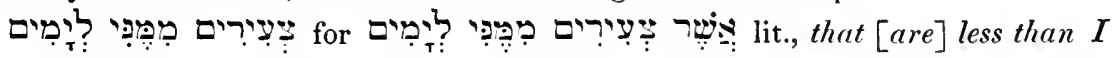
for (or, in respect to) days. The adj. דציר

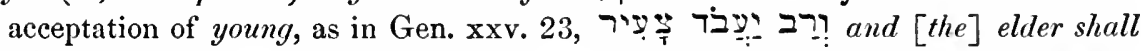
serve [the] younger; since, however, it also had the signification of little,

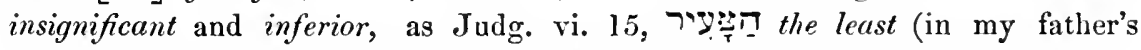
house), Jer. xiv. 3, "and the nobles have sent poet here, to remove all ambiguity, added better omitted in English.

Ver. 2. It will be perceived, that, as this verse only contains the reason assigned by Job for his having rejected the services of the fathers, it should be considered as parenthetical.

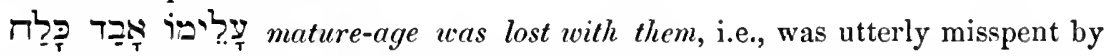
them ; they led such a wicked and profligate life, that it would have been almost better if they had died in their infancy. So Ralbag (as quoted by Wolfssohn):

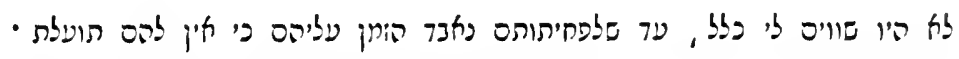

"They were of no use at all to me, seeing that, on account of their worthlessness, time was lost with them, for [there was] no profit in them." 
Tֶָ mature-age. That this word is used here, not in the sense of old age, (as supra v. 26), but rather in that of mature and vigorous age, is evident from the first hemistich, in which mention is made of strength of hands, which would hardly have been attributed to very old men.

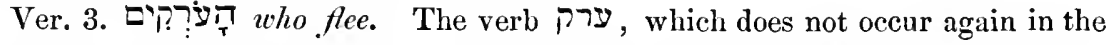
Old Test., is used in Chaldee as the equivalent of the Hebrew ברח . Thus, in Isa. xlviii. 20,

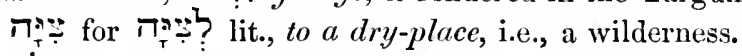

צִ lit., last night, but used here in the sense of night generally, darkness. A desert is often designated in Hebrew poetry as dark ; e.g., Jer. ii. 31, "Have I been a wilderness unto Israel ? A land of darkness!"

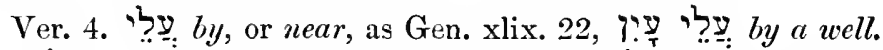

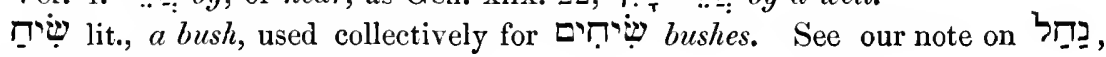
supra $\mathrm{xxviii} 15$ (in text xxviii. 4).

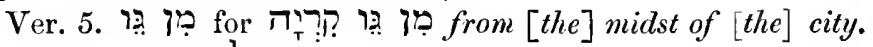

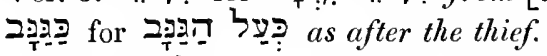

Ver. 6. בל lit., so as to dwell; i.e., so that they are obliged to, or must, dwell. The $ל$ of the בכ"לם is sometimes used to express what must, or must not, be done, as in Ps. xxxii. 9, בלבל so that one must hold in; and 1 Chron.

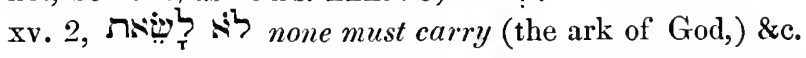

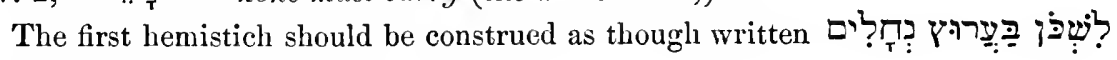
they must divell in [the] clefts of vallies.

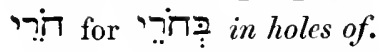

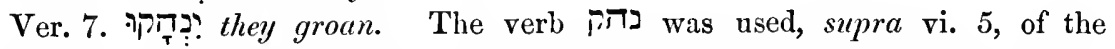
braying of an ass, and some take it here in the same sense; we prefer, however, making it synonymous with יבְיָה they groan, which occurs supra xxiv. 12.

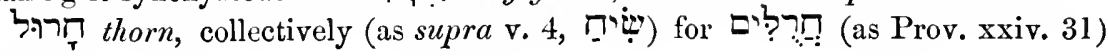
thorns.

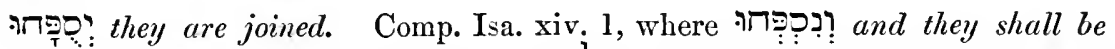

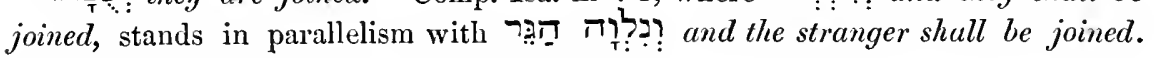
Wolfssohn understands it of sexual intercourse.

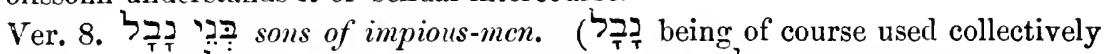

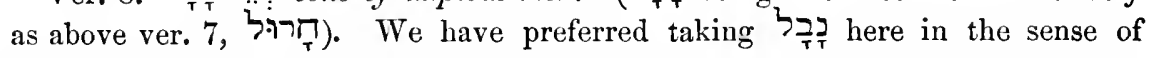
impious, rather than in that of fool. In Ps. xiv. 1 too, it should also be rendered impious, as has been done by Dr. French and Mr. Skinner in their masterly and most elegant translation.

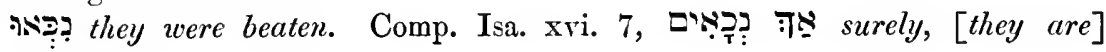
stricken.

Vers. 9-15. The poet, having completed his, in accordance with the usual style of Oriental poetry, somewhat hyperbolical description of the vile and miserable condition of those who mock and scoff at him, now proceeds to describe the vexation and suffering he endures at their hands. His words are : 
And now I have become their song. They compose satirical songs, of which I am the subject. Yea, I am a bye-word to them. (Ver. 10.) They abhor me, they stand aloof from me, and spare not to spit before my face. The poet now proceeds to explain to his hearers how it is, that men, so abject and degraded as those he has described, have the hardihood to insult one, who, like himself, had formerly been invested with such high authority and dignity; it is (Ver 11.) Because He (God) hath loosed my string. The string of my bow. And afficted me. Job had said in the preceding chapter (Ver. 20), that he thought the bow in his hand would renew its strength (i.e., that his authority would become more and more assured), but now he tells us, that, so far from this expectation of his being realized, God has, on the contrary, loosened the string of his bow (i.e., has taken away his authority from him,) Therefore, (he says, they. Those wretched men. Have let loose their bridle before me. As long as I retained my authority, they were restrained by fear and awe, like horses or mules, which are bridled; but now that they can insult me with impunity, they shake off all restraint, they cast away their bridle. But not only they themselves, their children also are a source of great annoyance to me. (Ver. 12.) Upon my right hand, riseth up the young brood; they push away my feet. They push my feet from under me, trip me up. And they raise up against me their calamitous ways. Whenever they are bent upon injuring me they contrive to reach me with as much ease, as though they had raised up a high-way against me. The metaphor is taken from the siege of a city, one of the first steps in which was, in those times, to cast up a raised way against the city, in order to facilitate the approach of the besieging army. (Comp. supra xix. 12.) (Ver. 13.) They break up my path. They throw every possible obstacle in my way. They contribute to my calamity, although they derive no help from it. So gratuitously malicious are they, that they harass me without the expectation of deriving any advantage from it. (Ver. 14.) They come upon me as through a wide breach. 'That is, in great numbers, inasmuch as in the case of a besieged city (from which the metaphor is taken), the wider the breach in its walls, the more soldiers can rush in at the same time. They roll themselves in instead of a tempest. When there is a wide breach in a house 
the inmates have reason to be afraid of a tempest's bursting in and carrying everything away, but, instead of a tempest, the poet says these mischievous and malicious men rushed violently in. (Ver. 15.) Terrors are turned against me. Are levelled against, brought to bear upon, me. Every one of them (i.e., the terrors) pursucth my soul like the wind. With the violence of a raging wind. So that my safety passeth away as a cloud. Just as a raging wind maketh the clouds to scud before it, so do these terrors chase along my safety.

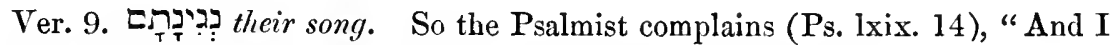
[was] the song of the drunkards."

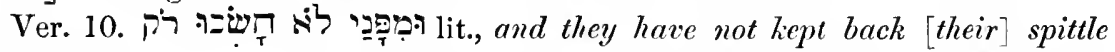
from before me; i.e., they do not mind spitting in my presence. Wolfssohn observes:

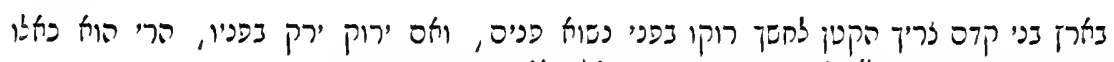

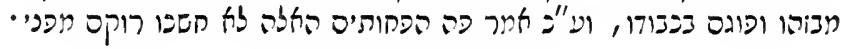

"In eastern countries, an inferior-man must keep back his spittle before a man of rank, " for, if he should indeed spit in his presence, behold, he [is] as though he [was] slighting " him, and vilifying his honour; and therefore he says here, these vile-persons do not "keep back their spittle from before me."

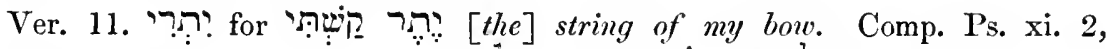

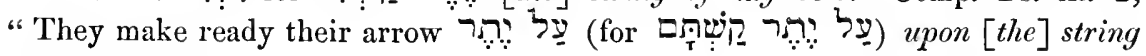
(of their bow)."

חঙ. He (God) loosened. Here the poet again relies upon the judgment of his hearers to supply the proper nom. case (sc. God), as we have already seen him do in several instances. Wolfssohn comments on this verse as follows:

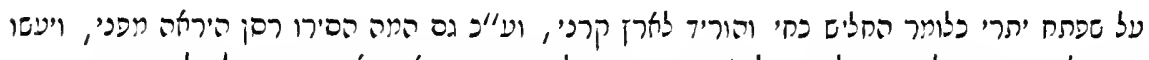

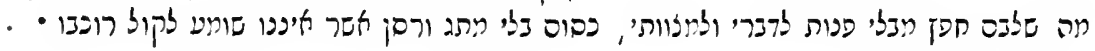

"Because He (God) has loosened my string, that is to say, has weakened my power and " brought down my horn to the earth; therefore they also have removed the bridle of " [their] awe before me, so that they do what their heart pleases, without regarding my " words or commands, like a horse without bridle or bit, which hearkens not to the voice " of its rider."

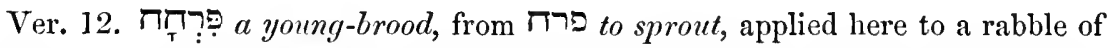
young men, who have not yet completed their growth. From the same root is חִ the young of birds, which occurs (in the plural) in Deut. xxii. 6,

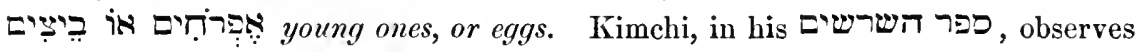
on the word

בהכפל הלצ"ד • ופירישו ההקטגים והפערים יקומו על ימינו ללעג עליו' ובi 
"The third radical being doubled; and its meaning [is], young children and boys rise " up on his (Job's) right hand, to mock at him; and so the young of birds are called

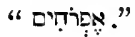

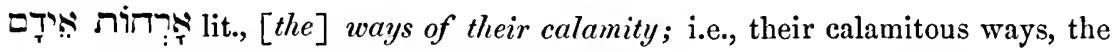
ways by which they bring calamities upon me.

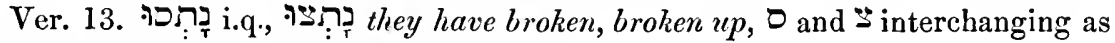
dentals. See note on סי:- supra xx. 18.

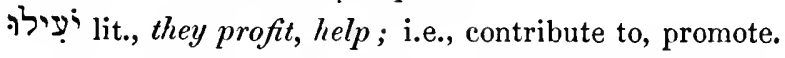

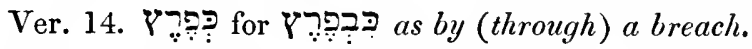

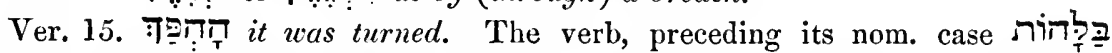
terrors, need not agree with it, either in gender or number. See note on

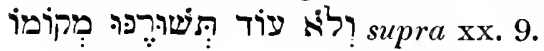

תุ it (i.e., every one of these terrors) pursues. See note on vi. 17.

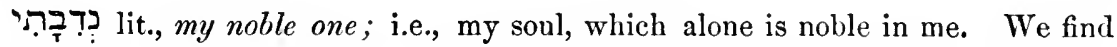
more than once, in Hebrew poetry, similar endearing epithets bestowed upon the

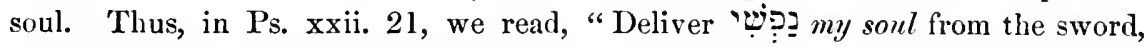

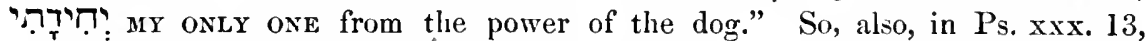

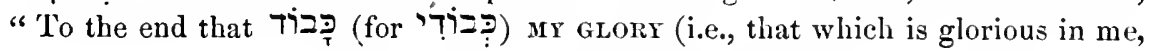
my soul) may sing praises to Thee;" and again in Ps. ciii. 5, which, in our humble opinion, should be translated thus, "Who satisfieth with good-things פע. עִ thy soul" (lit., thy ornament; i.e., that which adorns thee), so as to keep

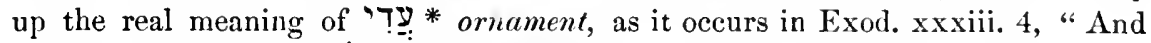

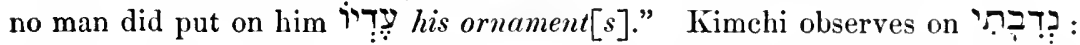

\section{ירכי לפירשו על הנפש כמו שפאמר במקום החר ורוח נדיבה תסמכני כי הנפש}

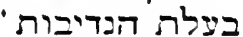

"It may be applied to the soul, just as it is said in another place (Ps. li. 14),

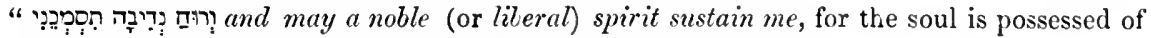
" nobleness (or liberality)."

* Nor need any other than the real meaning of the word namely, ornament, be given to עִ in Ps. xxxii. 9, for the verse should be translated thus: "Be ye not like a horse,

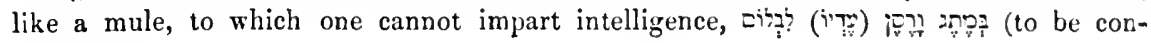
strued thus):

פל? to hold in (i.e., which one must hold in *)

with bridle and bit,

(Y) (its ormament) (i.e., to these animals the bridle and bit are an ornament, but to thee they would be a disgrace; thou, therefore, must not be wild and untameable like them,)

[so that there should be] no coming near to thee" (i.e., so that people should be afraid of approaching thee, but thou shouldest, on the contrary, be mild and gentle, and be able to restrain and check thyself when necessary).

* Or better, So that one must hold (it, or them) in. See note on it? (ver. 6, of this chap.) p. 262. Elitor, 1862 . 
Vers. 16-22. Now that he has given these details of what he suffers from men, Job returns to the subject dwelt upon by him at much greater length in his former discourses, the sufferings, namely, with which he has been visited by Providence. He says:

And now my soul is poured out within me. I am exhausted by my sufferings; my life is ebbing fast. Days of affliction have taken hold upon me. (Ver. 17.) By night my bones are pierced in me. When night comes on my pains are greatly increased, and penetrate even to my bones, which they pierce and rack. And my sinews find no rest. (Ver. 18.) My garment must be changed with great effiort. Owing to the numberless ulcers with which he is covered from head to foot, and the matter they discharge, his garments stick so firmly to his body that their removal is effected with great difficulty, and causes him excruciating pain. It givdeth me like the collar of my tunic. The whole of my tunic now holdeth my body in as firm a clasp as its collar doth my neck. (Ver. 19.) He (God) hath cast me into the mive, so that I am become like dust and ashes. (Ver. 20.) I cry loudly unto Thee, but Thou answerest me not; I stand up in prayer, but Thou dost not regard me. (Ver. 21.) Thou art become cruel to me. Cruelty hath replaced Thy kindness of former days. Thou shewest Thy hate towards me by the might of Thine hand. (Ver. 22.) Thou usedst to raise me up, to make me ride upon the wind. To make one ride upon the wind is to raise him to the highest pitch of prosperity and glory. We find other very similar figures used in the Bible to express the same ideas. Thus, in Isa. lviii. 14, it is said of Israel, If thou "call the Sabbath a delight," \&c., "then shalt thou delight thyself in Jehovah, and I will cause thee to ride upon the high places of the earth." And so the King of Babylon is represented by Isaiah (ch. xiv. 14) to have said in the pride of his heart, "I will ascend above the heights of the clouds." Indeed, of God Himself, appearing in His glory, it is said (Ps. xviii. 10), "He did fly upon the wings of the wind." Job uses this figure, then, in order to contrast in the most forcible manner his former glory with his present degradation. And now Thy wisdom dissolveth me away.

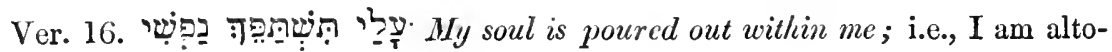


gether exhausted with my sufferings. In like manner, the Psalmist says

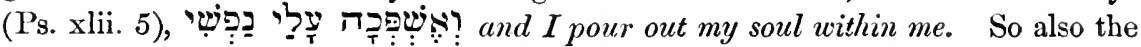
Elegist expresses himself (Lam. ii. 12), when speaking of infants, exhausted with

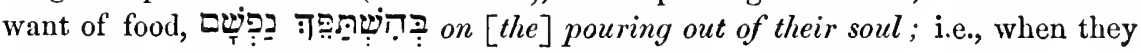
sink down exhausted

Ver. 17. בְבק lit., pierces through ; a past Pi-âl, used impers., and to be translated, therefore, by a passive. We have already had several examples of a similar construction.

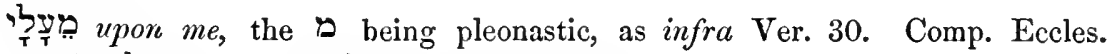

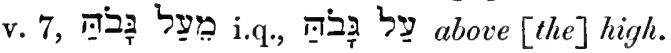

'ำ and and sinews. So Aben-Ezra and Kimchi, who derive it from the Arabic.

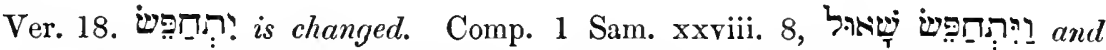
Saul disguised himself (i.e., changed his garment). If we were to quote what has been said by other Commentators upon this verse, we should fill whole pages; we hope, however, that the short explanation we have offered above will shew how little real difficulty it offers.

lit., as [the] mouth (or opening) of my tunic; i.e., the upper part, or collar, of the tunic, which would, of course, fit more tightly than any other part of it.

Ver. 19. הוֹרבי He (God) has cast me. Here, again, the poet leaves it to the hearer to supply the nom. case to the verb, according to the sense of the passage. ירורד (with suffix), has here the same sense as it has in Kal, e.g., in Exod. xv. 4, ם $\square_{T}^{\prime 2}$ ב

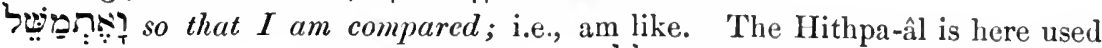

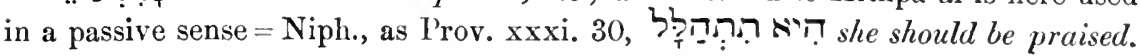
The verb is here followed by $\supset$, as it is in Ps. xlix. 13, 21.

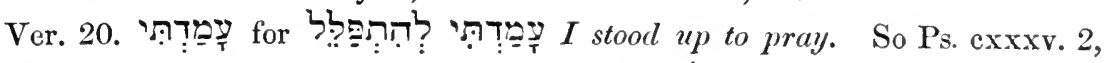
"Praise him, O ye servants of Jehovah, שֶׁעִ who [are] standing (for

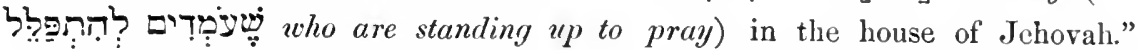
Another instance occurs, in which the verb עמד expresses this idea of standing up in prayer, viz., in Num. xvii. 13, where it is said of Aaron, when the plague

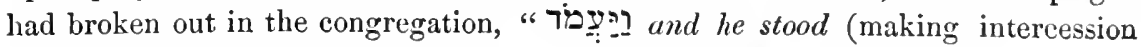
in prayer) between the dead and the living, and the plague was stayed."

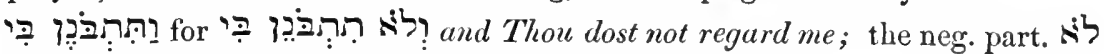
of the first hemistich being understood in the second.

lit., Thou art changed towards me into a cruel-one. Thou art not as Thou wert towards me; instead of kindncss, I experience no longer anything but cruelty from Thee.*

Ver. 22. אִִ for for for

* We cannot refrain here from again asking those who put the 2Sth Chap. (according to the text) into the mouth of Job, and tell us that it was uttered by hin after he had been converted, whether this is the language of a convert and a penitent. 


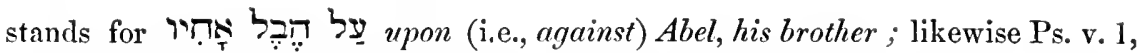

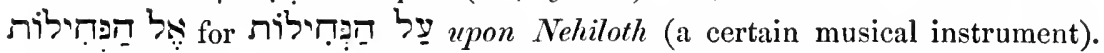

תק (according to the K'ree) wisdom; i.e., Thy wisdom. We very frequently find in Hebrew poetry that the possess. affixes must be supplied. We

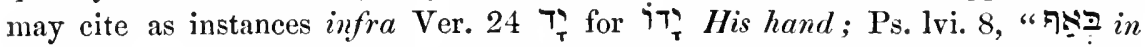
anger (i.e., in Thine anger) cast down the nations ;" Ps. xxix. 9, "And in His

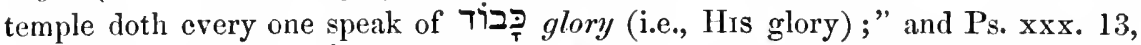
"To the end that רָּ כָ glory (i.e., MY glory, my soul) may sing praise to Thee." It will be perceived that we take the noun ${ }_{r}$

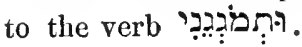

The verse should be construed thus:

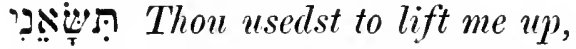

תַת Thou usedst to malie me ride

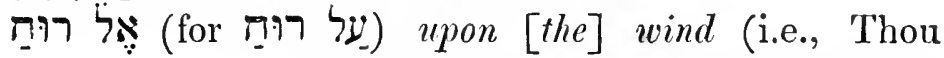
usedst to raise me up to the highest pitch of dignity and glory);

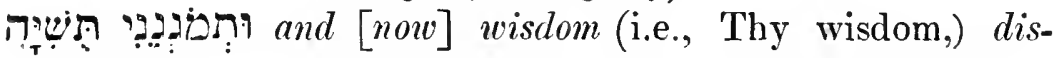
solveth me (i.e., 'Thou, in Thy wisdom, hast resolved to make an end of me).

Vers. 23, 24. The unfortunate speaker admits the certain knowledge which he has, that death and the grave will ultimately deliver him from his sufferings, to be a source of consolation to him, but laments that these deliverers are not sent by God as soon as man in his misery longs and prays for them. He says:

Of a truth I know, that Thou wilt bring me back to death, and to the house of assembly for all living. I know, that these sufferings of mine must have an end put to them by death and the grave. (Ver. 24.) Howbeit, He (God) will not put forth His hand. To bring man to death and the grave. When there is prayer for them. When man prays Him for death and the grave. He will not put forth His hand to bring them upon man, When, in calamity proceeding from Him, there is a loud-cry for them. When men are afflicted with miseries sent upon them by God, and cry loudly for death and the grave, $\mathrm{He}$ will not hearken to their cry.

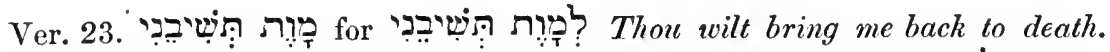

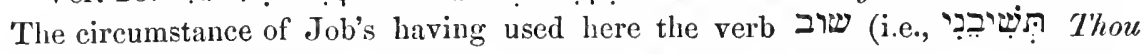

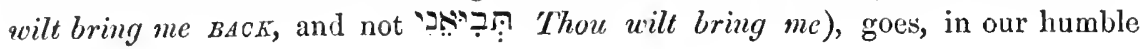


opinion, very far to corroborate what we have said over and over again, and consider to be the only key to this apparently difficult book (which, indeed, without it would be nothing but a chaos of incongruous sentiments and conflicting ideas), namely, that Job knew nothing at all of a future state, but thought, that men ceased to exist, when they ceased to live. Death and the grave were, then, with him synonymous with annihilation, or non-existence, and therefore it is he says, Thou wilt bring me back to that state of non-existence, from which I sallied forth to be born. I was nothing, and Thou wilt make me again become nothing.

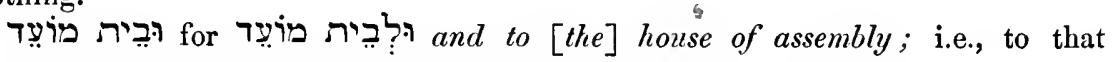
house, to which all living men must ultimately resort, viz., the grave.

Ver. 24. Previously to entering upou the details of this verse, we must remind the reader that, as words must sometimes unavoidably be supplied from the first hemistich of a verse to the second, so on the contrary it is, not unfrequently, impossible to make sense of the first hemistich, without introducing into it a word, or words, from the second. Thus, in Prov. xiii. 1, the first hemistich is,

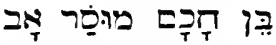

words which convey no meaning whatever unless we supply the verb the second hemistich, as though the text were,

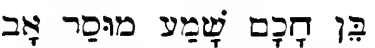

"A wise son listeneth to [the] instruction of his father."

מלדֶן being supplied from the second hemistich), when $[$ there is] a praying for them.

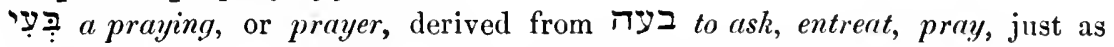

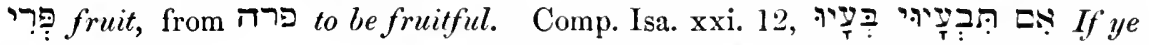

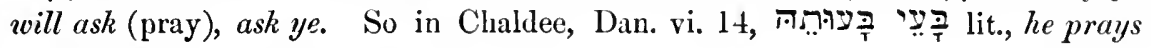
his prayjer.

范 lit., in His calamity ; i.e., in the calamity proceeding from, inflicted by,

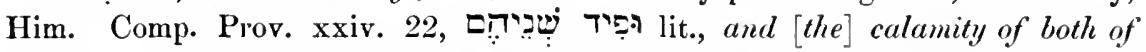
them; i.e., the calamity proceeding from both of them (God and the king). See what has been observed on the ambiguity of poss. pron. affixes in our note on בְְִִבִ , supra iii. 10.

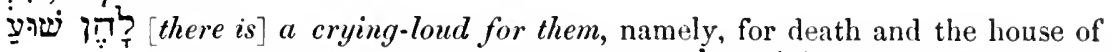

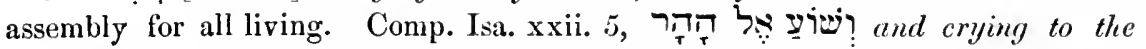
mountains, where we observe Shûrik instead of Chowlem, an interchange of these

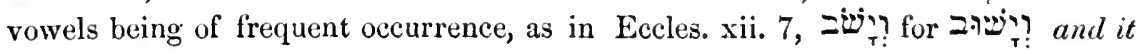
shall return. 
These two verses should therefore be construed thus:

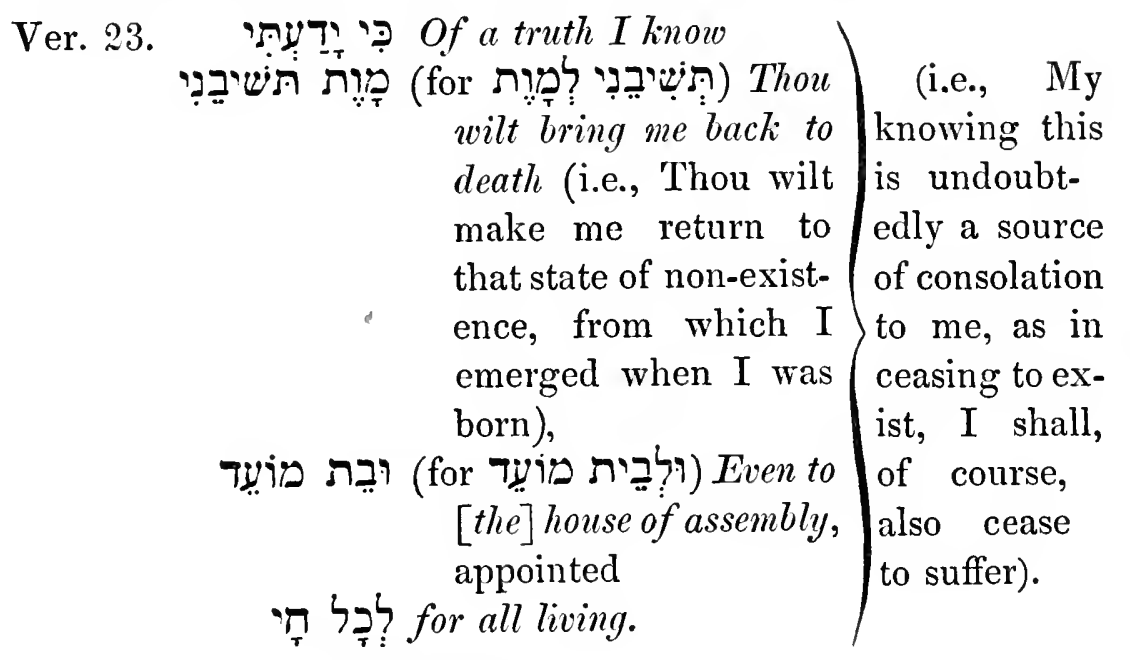

Ver. 24.

\section{可 Howbeit,}

דיז forth [His] hand (to bring men back to death and the grave),

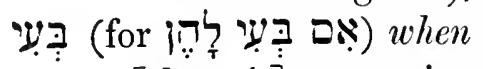

[there is] a praying for them (i.e., when men pray for death and the grave);

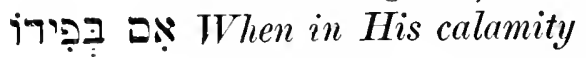
(i.e., when on calamity being sent by Him on men),

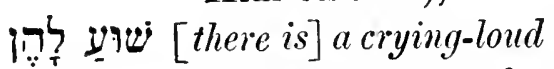
for them (i.e., for death and thegrave). (i.e., when men, on being afflicted with calamities sent upon them by God, pray and cry aloud to Him for death and the grave, He will not put forth His hand to bring them back to them, and so put an end to their misery).

We wish the reader would consult, as we have done, the Auth. Vers., Rosenmüller, Umbreit, Schlottmann, \&c., and then ask himself, whether we should not have deserved great blame, if we had adopted any one of the numberless far-fetched explanations(?) offered by those Commentators, in preference to the very simple and straightforward one proposed by us above. For our own 
part, we could not consent to abandon it even for that of Wolfssohn, though he, as usual, shews himself infinitely superior to the Commentators above alluded to; and indeed that great Hebraist himself is not only dissatisfied with his own explanation, but regards it as impossible that a satisfactory one should ever be arrived at. He prefaces his comment upon the passage with the following words :

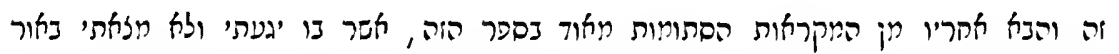

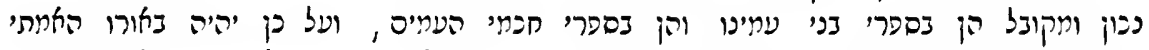

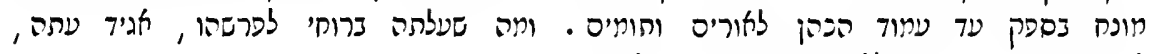

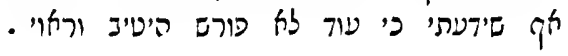

"This [verse], and the next to it, are among the most obscure in this book, " and upon them (lit., upon which) I have bestowed [much] labour, though without " finding a correct and acceptable explanation, either in the books of the men of " our own nation or in the books of the wise men of [other] nations; and therefore " their true explanation will remain in doubt, until the priest shall stand up [to "consult the] Urim and Thummim.* And that, which has suggested itself to " my mind [as to how] to explain them, I will now set forth, although I know " that they are not yet well and properly explained."

Vers. 25-31. The Chapter concludes by Job's telling his friends that his course of life had been by no means of a nature to lead him to apprehend, that he would one day be reduced to such a state of misery as to pray for death and the grave-and, alas, to pray for them in vain-but that, on the contrary, his conduct had always been such as to inspire him with the hope, that God would continue to watch over him, and to have him in His keeping. His words are as follows:

Did I not weep for the ill-fated man? Did not my soul grieve for the needy? Had I been unfeeling, and callous to the sufferings of others, I should certainly have deserved myself to suffer; but this is very far from having been the case; on the contrary, I was always pained by the pain of others, and grieved by the grief of others. (Ver. 26.) Verily, I looked for good. I had every reason to hope, that God would continue to bestow

* A figure, by which the Rabbins commonly express their conviction, that the passage of Scripture under their consideration is so difficult, that all endeavours to explain it will be entirely fruitless, and that nothing short of an oracular revelation can disclose its bidden meaning, 
His blessings upon me. And yet evil came. Instead of good. Yea, I hoped for light, but deep-darkness came. (Ver. 27.) My bowels boil, and are not quiet; the days of affliction came unawares upon me. My afflictions have come upon me so suddenly, and are so completely the reverse of what I had any reason to anticipate, that I cannot possibly gather strength enough to calm my emotions. (Ver. 28.) I go about black, but not through the sun. If my complexion looks so sallow and dark, it is not that it is sun-burnt; it is in consequence of my mental suffering and bodily disease. I rise up, and cry aloud in the assembly. Nuch as $\mathrm{I}$ am ashamed to utter cries and groans in the presence of others, yet I cannot help doing so; the excruciating pains which rack me, press them out from me against my will. (Ver. 29.) I am become a brother to dragons, and a companion to young owls. My torments extort from me dismal and doleful shrieks, resembling those of dragons and owls. (Ver. 30.) My skin is become black upon me, and my bone $[s]$ are burned with heat. (Ver.31.) So that my harp is turned to mourning, and my lute into the voice of them that weep. Cries and groans are now my only music.

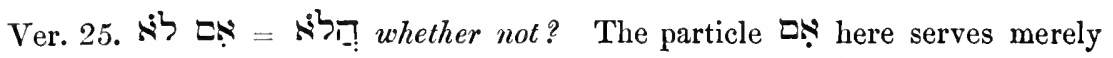
to mark a question, as supra vi. 12.

םi ה who is ill-fated.

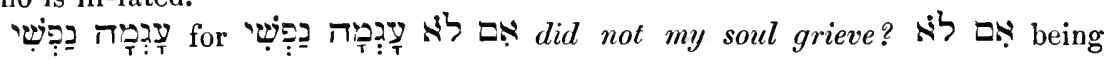

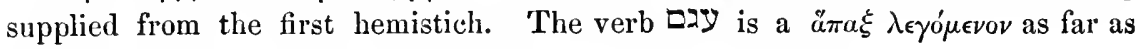
regards the Bible, but is very frequently used by the Rabbins.

Ver. 26. רis light, and אi deep-darkness, are, of course, to be understood in a figurative sense of happiness, and the depths of misery, respectively.

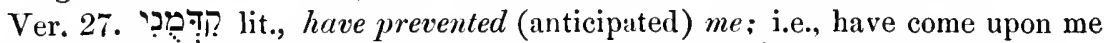

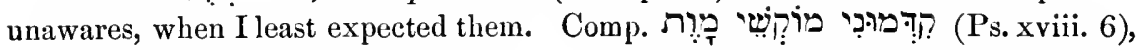
[the] snares of death anticipated me; i.e., came upon me, when I did not expect them, unawares.

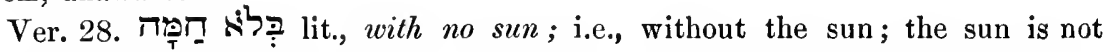
the cause of the darkness of my complexion; this should be attributed to the intensity of my grief, and the virulence of my disease. A similar form of expression is found in Isa. li. 21, "drunken, but not witl wine."

Ver. 30. רִעָד See note on this word, supra ver. 17.

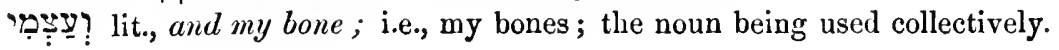




\section{CHAPTER XXXI.}

Jов closes his last discourse by reading to his friends the statement which, as will appear from Ver. 35 , in this chapter, he had drawn up of his case, and by challenging God to bring a single charge against him, either by word of mouth, or in writing. In this document, Job, as might well be expected, gives a detailed account of the manner, in which, in his prosperous days, he had conducted hinself as well towards his Naker, as towards his fellow-creatures; and his object in reading it to his friends was, no doubt, to repel their attacks upon his character, and to make them feel, that the sins and crimes imputed to him by them had no foundation in truth. He, moreover, avails himself of this opportunity occasionally to turn their reasoning against themselves, thus fighting them, as it were, with their own weapons. He asks, for example, how their assertion, that "the trimmphing of the wicked is of recent date and the joy of the hypocrite but for a moment," (supra xx. 5), can be reconciled with the fact, that, though, in their opinion, guilty of so many atrocious sins, and crimes, he had flourished and prospered for such a number of years. If he really had, as they supposed him to have done, taken a pledge from his brother for nought, and stripped the naked of their clothing; if he had not given water to the weary to drink, and had withholden bread from the hungry; if he had sent widows away empty, so that the arms of the fatherless might be broken (supra xxii. vers. $6,7,9)$; how then was it, he asks, that such a tyrant, such a monster, should not only have been suffered by God to exist, but should have received from Him innumerable blessings and bounties, and that during a long series of years without one moment's interruption? In this statement of his, Job also declares himself to have been innocent of two sins much greater, and much more heinous than those imputed to him by his friends, adultery, namely, and idolatry, and he begins with the former, as being, from the violence of the passion, and the frailty of human nature, much the more prevalent of the two. He says : 
Vers. 1-12. I made a covenant with mine eyes. I strictly forbade them to be lustful, or to dwell on lascivious objects. How then could I bring myself to look upon a young-uoman? (Ver. 2.) And yet. In spite of this my continence so rigilly enforced. What is the portion that hath been allotted to me by God, from above, and what the inheritance assigned to me by the Almighty from on high? A virtue, which ought to have been rewarded with the greatest of blessings, has been recompensed with the most intolerable of sufferings. (Ver. 3.) Ought not calamity to be allotted to the iniquitous, and estrangement from God to the workers of iniquity? Why then should that be the lot of a good man, which ought only to befall the wicked? (Ver. 4.) Doth He not see my ways, and count all my steps? "(Ver. 5.) Have I followed after vanity, or hath my foot hastened to deceit? (Ver. 6.) Let Him weigh me in just balances, and then will God know mine integrity. Let Him strictly examine the whole course of my life, and He will see, if I ever gave myself up to vanity and deceit. (Ver. 7.) If my step had turned from THE way, and mine heart walked after mine eyes. If I had not restrained, but had yielded to, the lustfulness of my eyes. And any blot had cleaved to mine hands. (Ver. 8.) Then, whenever I sowed, another onght to have eaten. My harvest. And all my produce ought to have been uprooted. How then was it, that I was blessed with such rich and abundant harvests year after year? (Ver. 9.) If my heart had been enticed by a woman, so that I laid in wait at my neighbour's door. To watch his coming out, that I might have an opportunity of satisfying my lust. (Ver. 10.) Then my wife ought to have ground for another, yea, more still, others ought to have bowed down before her. Greatly and deservedly as I should have been punished in seeing my wife degraded to the state of a menial servant, grinding corn for other's, yet this punishment would not have been proportionate to the enormity of my crime, for I should have deserved that greatest of all torments, that, namely, of seeing my wife prostitute herself to others. (Ver. 11.) For it (i.e., adultery) is a flagitious-crime, yea, it is an iniquity to be punished by the judges. Even mortal judges could not suffer such a crime to be committed with impunity, how then could He do so, by whom one day the judgres will themselves be judged? (Ver. 12.) 
For it (adultery) is a fire, that consumeth to destruction; it ought, therefore, to have uprooted all mine increase.

Ver. 1. ?ִִִּ lit., to (or for) mine eyes; i.e., with mine eyes. The phrase

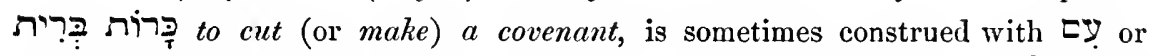

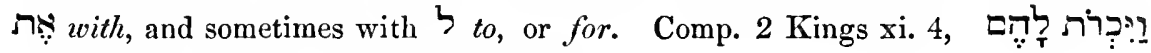
תר? And he made a covenant with them.

חיר: others translate it virgin; one and all are mistaken. That express only an unmarried woman is evident from Joel i. 8, where we read,

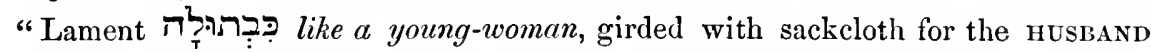
of her youth." Nor does it signify virgin, in the strict sense of the word, unless it be, besides, expressly stated, that she has had no intercourse with man; as,

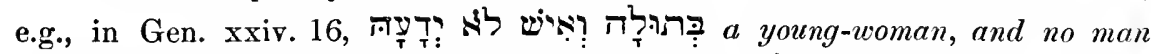

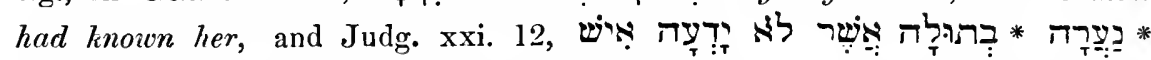
damsels, young-women, which had not known man. To be sure it might be said that, in these two passages, the phrase, which we regard as explanatory, is merely one of those pleonasms, which are not of infrequent occurrence in Hebrew, and which we have already had occasion to notice; but, as it has been shown, by the passage just quoted from Joel, that a see why we should consider as pleonastic an additional definition which may be essential; nor should it be urged, that because

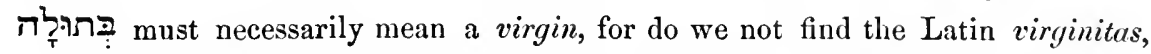
derived from virgo, $\dagger$ which is sometimes applied to a married woman, as in Virg.

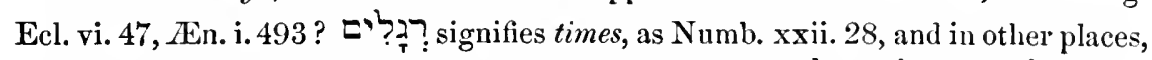

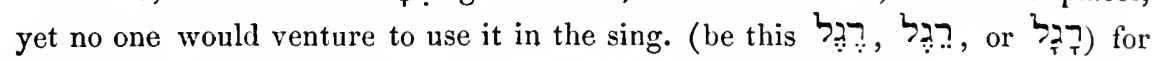
time, and so it is, we think, in other languages, e.g., physics has nothing to do with physic. Besides we cannot see why Job, when declaring, that he never permitted his eyes to indulge in lascivious glances, should limit himself in his asseverations to maids or virgins, as a lustful eye would very likely just as wantonly regard a married, as an unmarried, young-woman.

The real Hebrew word for virgin, is that employed by Isaiah (chap. vii. 14),

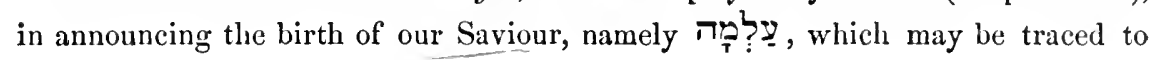

* These two words stand here in the singular (though they must be translated in the plural), as nouns usually do in Hebrew, when they follow a number greater than ten.

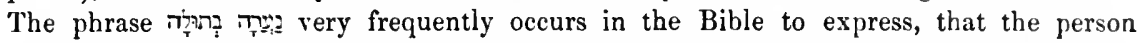

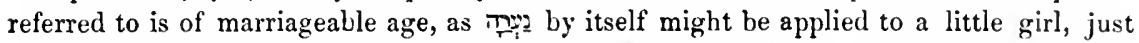
as 2 is sometimes used synonymously with where Ishmael is called

+ And so, in our own language, the term maiden (maid), which is frequently used to express merely a young unmarried female, without reference to her virginity, has a derivative (of similar meaning to ä which can hardly be applied excepting to a virgin in the strictest sense of the word. Editor, 1862. 
the root על על to hide, conceal, and therefore primarily means a woman who is altogether concealed and hidden from the other sex. Gesenius, as we are very much grieved to find, is diametrically opposed to us upon this point, for in his Lexicon (as

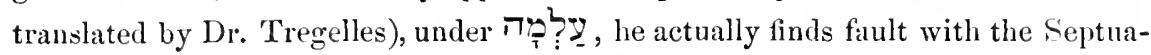
gint for having translated this word in Isaiah, loc. cit., $\pi a \rho \theta$ évos, asserting that is the only word in Hebrew, which conveys the idea of unspotted virginity, though the passage quoted above from Joel must have stared him in the face. He lays some

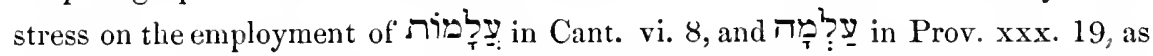
though he regarded these passages as invalidating the translation of the Sept. above quoted. We think, therefore, that we need make no apology for here examining these two passages, in order to see whether they are actually opposed to the meaning

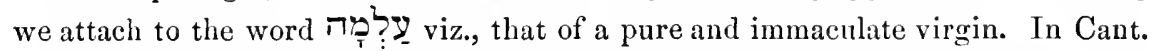
vi. 8 , the poet, wishing to represent his love as altogether unmatched and unrivalled in her excellencies, to whatever class of women she might be compared,

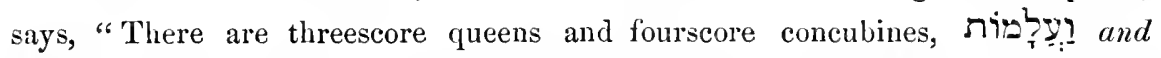
virgins without number. But one is my dove, \&c." Now we should like to know what in the world proves that strict sense of the word, for, whether it refers to the maidens in attendance upon the queens and the concubines, or to others, why may they not have been pure virgins? Gesenius, surely, cannot mean to say that concubines, which would be a most insufferable pleonasm in a poem.

Let us now consider the passage in Proverbs, in which we find the Royal Moralist enumerating several things, which pass his understanding. He is at a loss to conceive, namely, how the eagle without any adventitious help, without map, chart, or mile-stone, finds his way back to his nest, from a distance of many miles; how the serpent, which creeping along the ground, can hardly be guided by its sight, yet contrives, unprovided though it be with feet or other means of prehension, to make its way even over slippery rocks and reach its little hole ; how the ship can find her way across the ocean, a feat, which, when the science of navigation was in its infancy, must have appeared marvellous to the landsmen of those times, as, even in our days it does to those, who do not understand the principles of that science; and lastly how a man can contrive to gain the atfections of an $\pi$ ?ִ two sexes never mix together, and that women there, are, when within doors, strictly secluded from all society, and confined and guarded like prisoners in their cells, whilst, when they are allowed to go out, they are most closely veiled; how, therefore, a man can overcome all these obstacles and win the affections of a virgin, is a matter of marvel to the Royal Bard. Now, if by chaste and unspotted virgin in the strictest sense of the word, how the poet came to put her in comparison with the other three subjects of his wonder, is intelligible enough ; but, if, on the contrary, the word in this instance, must be understood of a profligate, or adulterous, woman, as it seems to have been understood by Gesenius, then, instead of an acute and true remark, we shall have nothing before us but hopeless nonsense, for what difficulty would a man meet with 
in gaining access to such a woman, and where, consequently, could there be any matter for surprise?*

Ver. 2. חָרִ portion

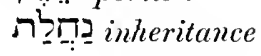

are both taken liere in a bad sense, as supra

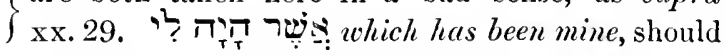
be understood at the end of the first hemistieh, and the same phrase (only with הדיד: instead of $\boldsymbol{T}_{T}^{\top}$ ) at the end of the second.

Ver. 3. בִִּ estrangement, alienation, (from God) aceording to Kimchi and Wolfssohn.

Ver. 5. is merely an interrogative particle, as supra vi. 12, and also in the verse before us, though it will be found used in the sense of if several times in this Chapter. The two significations being then here found intermingling, it becomes of the greatest importance to distinguish by the context when the one is intended, and when the other, as is well shown by the fact, that those interpreters, who everywhere adopt the sense of if; are in ensequence frequently obliged to supply an apodosis, -an expedient, to which our renderings will, we trust, slew there is not the slightest occasion to resort.

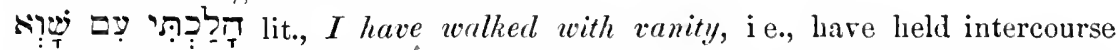
with vanity, made it my companion, my friend, vanity being here personified.

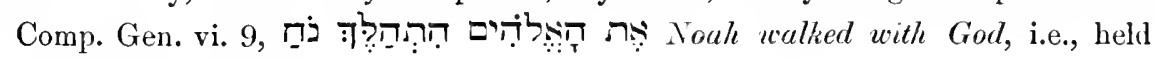
communion with Him.

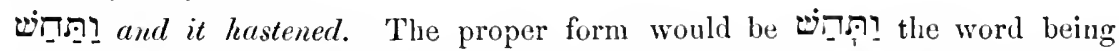
the fut. Kal of

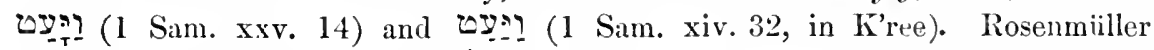

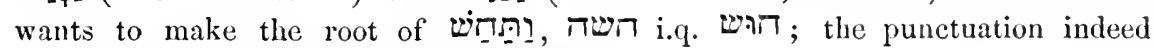
favours his view, but he stands quite alone.

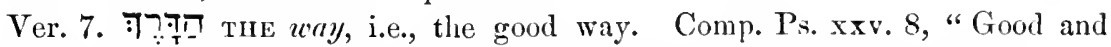

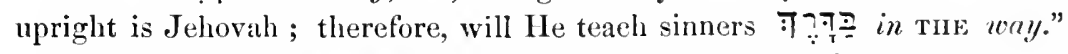

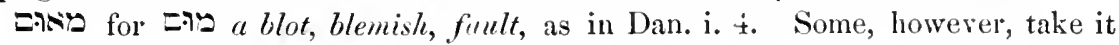

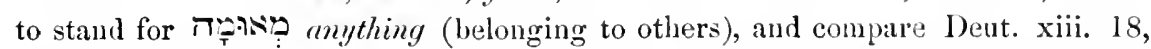
帒 And there shall cleave nought of the cursedthing to thine liasd.

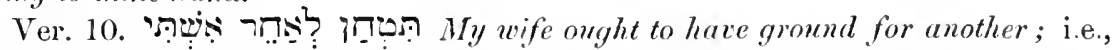
slie ought to have been obliged to perform the most menial and degrading oflices for others. Comp. Exod. xi. 5, "from the first-born of Pharaoh that sitteth upon his throne, even unto the first-born of the maid-servant that is behind the mill." Some of the Rabbins understand the verb 2 in the verse before us of sexual intereourse, so that, aecording to them, Job would say, that, if he had looked with eyes of

* The Proverbialist, having had his thoughts directed, in this passage, to a chaste and strict virgin, is led to think of her opposite, a profligate and abandoned woman, and to such an one devotes the next verse; just as in the same Chapter, vers. 25-28, after treating of weak and contemptible animals, such as the ant, conies, \&c., he proceeds, in the verses immediately following, to enumerate some porrerfu' and noble ones, such as the lion, greylound, sic. 
lust upon another woman, he ought to have had the mortification of seeing his own wife prostitute herself to others. So the Chaldee Version takes it, rendering,

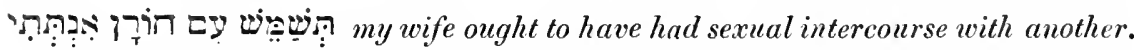
It must be admitted, that the first hemistich, so translated, would tally admirably well with the second, and we might perhaps have adopted this interpretation of the passage, had it not been that the Rabbins give the same signification to the verb ט 0 in Judg. xvi. 21, saying, namely, that the Philistines, desiring to raise up a breed of strong men, such as Samson, brought women to him whilst in prison-an explanation, which seemed to us so fanciful and so unnatural, that we rejected the whole. This absurdity of the Rabbins leads us to notice here another one still greater (to use a gentle term), which we find in the Rev. Mr. Gray's translation (?) of Umbreit. Umbreit namely, translates this hemistich,

dann hätte MaHLEN sollen einem andern mein Weib,

then should my wife have Ground for another,

but which Mr. Gray prefers to render,

then might another have WEDDED my wife !!!

This is, we believe, the third time that we have exposed this gentleman's ignorance of the German language ; let it not be supposed, however, that we have quoted all his mistranslations; others we have ourselves observed, and many more we have no doubt, remain in the verses (and their name is legion, for it is only here and there that we have compared the two translations), the correctness of which we have not tested.

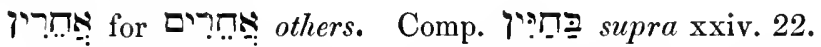

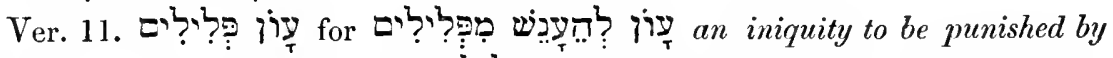
judges. Gesenius tells us that absolute sing. is 3 לִ Th, thus making it of the form consulted an oracle, we would venture to ask, why the absolute sing. might not

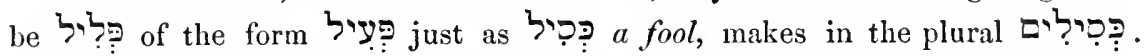
Ben-Zev, who, it wonld seem, had no oracle to consult, and did not think he possessed the gift of divination, warns us against assigning to any particular form such nouns as are not found in the absolute sing, and have $S h$ 'vah under the first radical. He says :

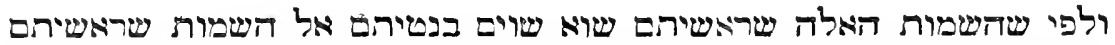

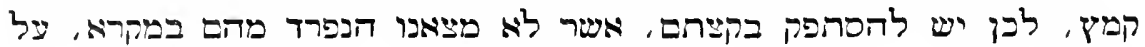

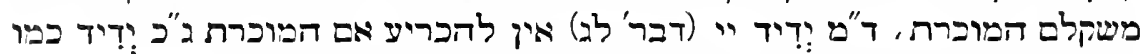

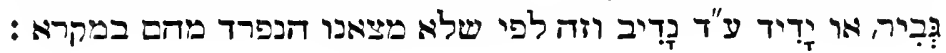

"And seeing that these nouns which begin with Shvah, are, in their oblique cases, like those which begin with Kawmets, therefore a doubt arises with regard to some of them, the absolute form of which we do not find in Scripture, as to what would be their form in the absolute state; e.g., [in the case of] "T?: (Deut. xxxiii. 12) the beloved of Jehovah,

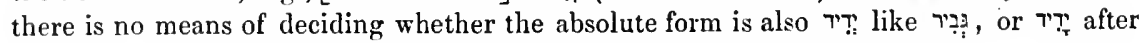
the form of בִיב , and this [arises] because we do not find the absolute-state in Scripture." 


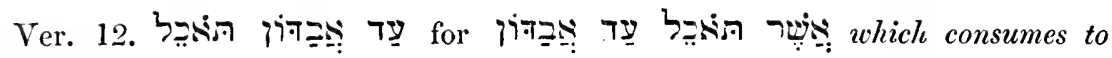
destruction.

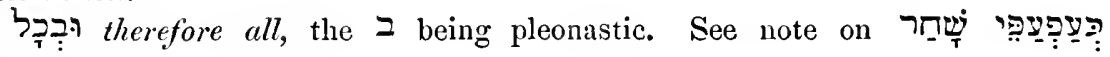
supra iii. 9.

Vers. 13-15. Eliphaz having thrown out a hint (supra xxii. 8), that he suspected Job had, in his prosperous days, been so selfish and arrogantly proud as to think that only men of his own rank and dignity ought to enjoy themselves in this world, whilst men of inferior station might be dealt with in a very summary and arbitrary manner, Job repels this insinuation, and asks, why, if he had actually behaved with cruelty and injustice to his inferiors, God had not at once taken him to task for it, and visited him with condign punishment, which he must have submitted to without a murmur, as he could not possibly have urged his superiority of rank and dignity as an excuse before God. He says:

If I did slight the just-cause of my man-servant, or my maidservant, when they contended with me. If, whilst I held the office of judge, I did not exercise the same impartiality with respect to any complaints that my servants made against me, that I should have exhibited had they been made against another. (Ver. 14.) What then should I have done if God had arisen; and if He had visited me. Had punished me. What could I have ansuered IIim? What excuse could I have offered in palliation of this behaviour of mine towards my servant? Could I have urged that I was his superior? or better than he? Assuredly not, for, (Ver. 15.) Did not $\mathrm{He}$, who made me in the belly also make him, and fashion him in one womb? In a womb of precisely the same nature.

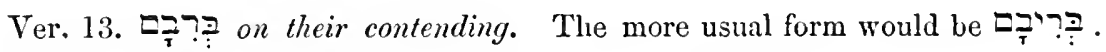

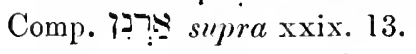

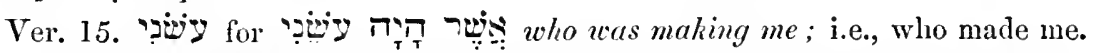

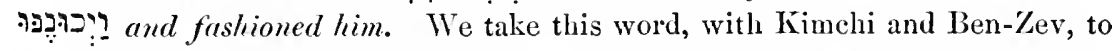
be the fut. Kal of כוץ, and so have no occasion to refer, as Umbreit recommends us, to Gesenius' Lehrgebïude (a book which we do not possess, and which we expect will never ornament our shelves), in order to account for the Shûrik in the $\supset$. In his Lexieon, however (according to Dr. 'Tregelles' translation), we are told that

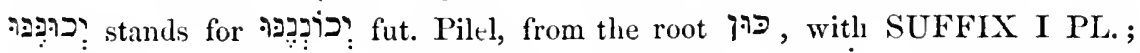
that both Nuns have coalesced into one doubled; that $i$ is SHORTENED into ' ; and that the meaning is he will fashion US!!! statements which, 
astounding as they are, we shall allow to elicit from us nothing but a shrug apiece for the author and translator.

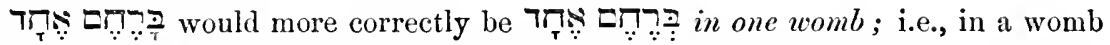
precisely similar to the one in which $I$ was formed. Ben-Zev remarks on these two words :

אחד במקוש הזה אינגו אחד בהספר כ"א אחד בהשואה ודמיון (איינרלייא)•

, in this place, does not signify one in number, but one in similarity and comparison (=of the same kind)."

This verse should be construed thus :

דַל Has not He that uas making me (i.e., that made me) in the belly

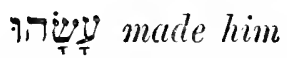

דִ womb of the same nature as the one in which I lay).

Or the first hemistich might be construed thus:

דִ Has not my Malier

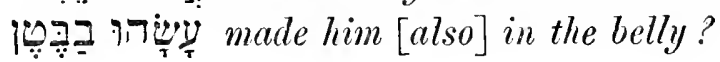

Vers. 16-15. Job now gradually proceeds to clear himself from the other charges brought against him by his friend Eliphaz (supra xxii. 6, 7,9), viz., that, in the days of his prosperity, he had had no commiseration or pity for the hungry, the naled, the widow, or the orphan. He says:

Did I withhold the poor firom their desire? Or did I canse the eyes of the widow to fail. With longing (See note on supra xvii. 5). (Ver. 17.) Or did I eat my morsel myself alone, and the fatherless did not eat thereof? (Ver. 18.) Surely, from my youth he (the fatherless) grew up with me as with a father, and her (the widow) I guided, as though she had come out from my mother's womb. As though she had been my sister.

Ver. 16. The first hemistich should be construed thus:

פִ Did I withhold poor-men

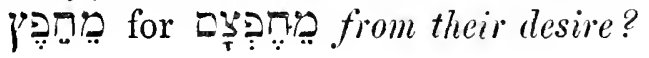




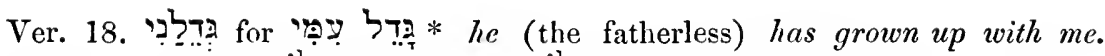

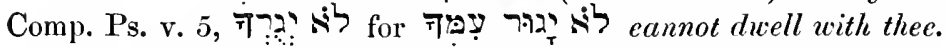

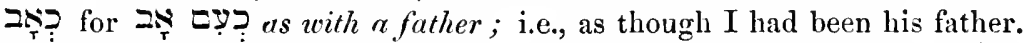

and as though she (the widow) had eome forth from.my mother's belly. It is really very distressing to see what sad havoc all the Commentators and Translators we have consulted, with the exception of Wolfssohn, have made of this verse. Some of them, in the greatness of their perplexity, have resorted to the truly

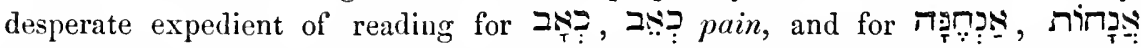
sighs, groans, thus breaking, as it were, the verse on the wheel, and marring all its beauties. By simply supplying, however, the $\supset$ of comparison of $2 \underset{T}{ }=$ after the 7 of most beautiful and touching verses of the book. To translate the second hemistich, as it is done in the Eng. Vers., namely, "And I have guided her from my mother's womb" (a new-born babe guiding a widow !!) the reader will, we think, admit would be employing a liyperbole at which even an Oriental writer would be startled.

This verse (which we had explained in the same way that we now do, long before we saw the comment of that extremely judicious writer, Wolfssohn, who, besides, does not take precisely the same view of the first hemistich that we do), should be construed as follows:

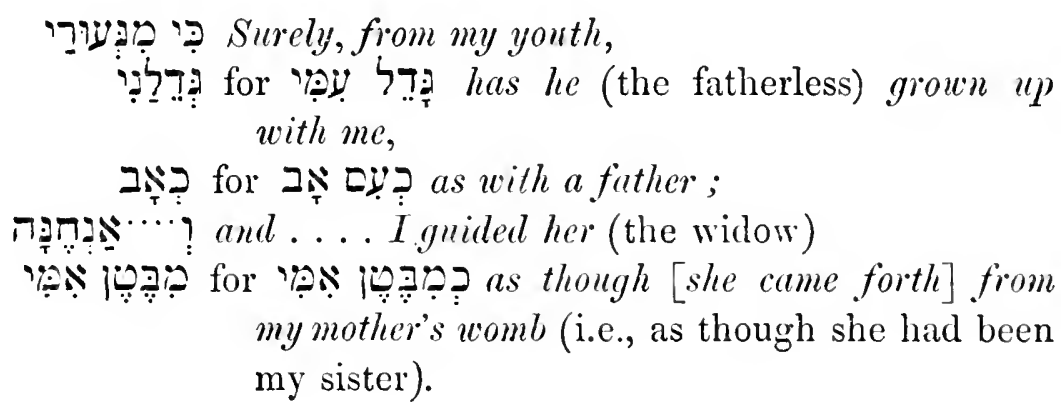

* ${ }_{7}:$ is the only form of the third pers. sing. masc. past Kal, which actually occurs in the Bible, and it is only found three times (Gen. xxvi. 13, xxxviii. 14, Job ii. 13). As, however, $37 \mathrm{~g}$ is found as the part. Kal (e.g., 2 Chron. xvii. 12), we have, after the analogy

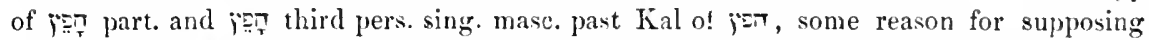
that (Zeph. iii. 2) the fem. (in pause) verb there is no room for any doubt, as the past Kal occurs in both forms and אָ , though the latter is much more frequently found. See Mason and Bernard's Gram., Letter xxx. \$20, where we rad. "The Verbs of the form have the same forms in the Kal for . . . . their Third Persons Sing. Masc. Past, and their Sing. Masc. Pres. Participles; so that 
Vers. 19, 20. Job, having been taxed by Eliphaz (supra xxii. 6) with the cruel act of stripping the poor of their clothing and leaving them naked, now repels this accusation, declaring that he had ever done the contrary. He says:

Could I bear to see any one perishing without clothing, or the needy-man without covering? (Ver. 20.) Did not his loins rather bless me, seeing that he kept himself warm with the fleece of my lambs?

הצִ Could I see? i.e., Could I bear to see? Comp. Lam. iii. 36, "To

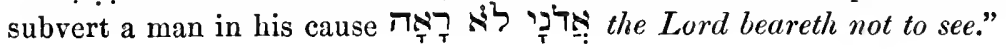

Vers. 21-23. If I had shaken mine hand against the fatherless. If I had threatened him with uplifted arm. Because I saw my help in the gate. Because I was convinced the judges in the forum would side with me, if any charge were brought against me. (Ver. 22.) Then ought my shoulder* to have fallen from my shoulder-blade, and mine arm ought to have been brolen from its bone. My forearm should have been severed from my upper arm. So cruel did it appear to Job even to menace a fatherless child with a blow, that he thinks the member employed in the act should at once, and without delay, by the miraculous interposition of Providence, have dropped from its body. But, if it had entered my mind to behave so cruelly towards an orphan, it would not have been the fear of any punishment that the judges who sit in the gate could have assigned me, that would have deterred me, but the dread of the punishment of Him who sits a Judge on high. (Ver. 23.) Surely, calamity from God was terror to me. The penalty which He most certainly, and most deservedly, would have exacted from me-that was what deterred me. And on account of His Majesty I could not act so. I could not possibly bring myself to commit such a cowardly and

* Probably meaning the bone of the upper arm, the humerus, unless, indeed, Job alludes to a fracture of the neck of the scapula (!!!) as Dr. Good seems to have understood him, when he says, "May my shoulder-bone (scapula) be shivered at the blade"! and certainly, if shoulder be taken in its strict sense, this is the only meaning which can be attached to the words. The objection to this interpretation is, of course, that it would be making Job too much of an anatomist, though, indeed, he might have considered the bone of the shoulder as separate from the shoulder-blade. 
dastardly act, in the presence of so majestic a Being as God. Comp. supra xiii. 11,

$$
\begin{aligned}
& \text { Should not His majesty deter you ? } \\
& \text { And His dread fall upon you? }
\end{aligned}
$$

Ver. 21. ברּפ

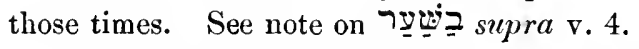

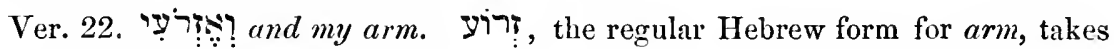

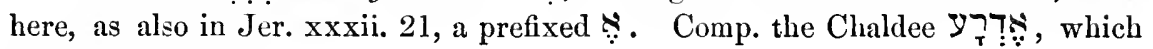
occurs in Ezra iv. 23.

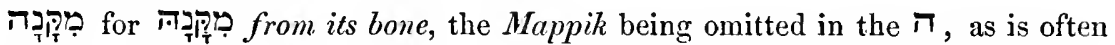

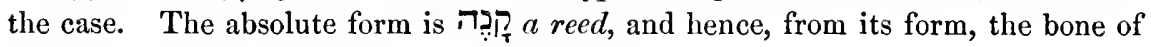
the upper arm, the humerus. Kimchi tells us:

\section{והה"א נחה ומשפטו במפיק והוא פפרק הזרוע ועד פרק הכרףף •}

"And the $\boldsymbol{\pi}$ is quiescent, though, by rights, it ought to have a Mappik; and this is from the joint of the forearm (elbow-joint), as far as the joint of the shoulder."

Ver. 23. לִ̣ [ִ̣ [the] calamity of God; i.e., proceeding from God. See note on

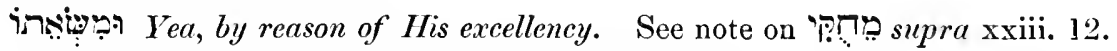

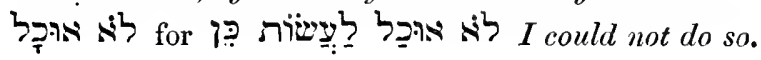

Vers. 24, 25. Job, when admonished by his friend Eliphaz (supra xxii. 2:3) to return to the Almighty, was admonished by him at the same time to despise riches, and put gold, yea, even the finest gold, on a level with dust and pebbles (ibid. Ver. 24). To this admonition Job now refers, declaring it to have been totally uncalled for, as his heart had never clung to gold, nor silver, nor, indeed, to any such vain and transitory possessionsand, consequently, it is not the loss of these he laments, but the loss of his children and his health. He says :

Did I ever make gold my confidence, or say unto fine-gold, "Thou art my trust?" (Ver. 23.) Did I ever rejoice because my wealth was great, and because my hand had gotten much?

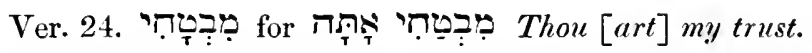

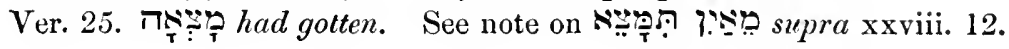

Vers. 26-28. Did I consider the sun when he shined, or the glorious moon moving; (Ver 27) So that my heart was secretly enticed, and my mouth kissed my hand? By way of paying 
homage and obeisance to them, of declaring myself their worshipper. (Ver. 28.) This also would have been an iniquity cognizable by a judge, for I should have denied God, who is above. I should have rendered myself guilty of a crime which, even to a mortal judge, appears most heinous, and deserving of the immediate infliction of the severest and most rigorous punishment; how, then, could the everlasting Judge have suffered me to commit so abominable a deed, and that for so long a time, with impunity?

Ver. 26. רis lit., light, used here $=$ = xxv. 3.

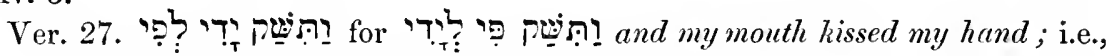
by way of paying homage (to the sun and moon). Comp. 1 Kings xix. 18, "all the knees, which have not bowed unto Baal, and every mouth

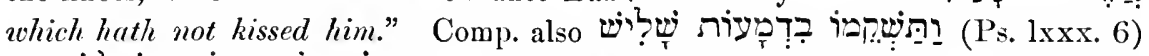

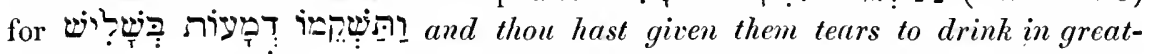
measure. That when the verb precedes its nom. case, it need not agree with it either in number or gender. See Mason and Bernard's Grammar, Lett. xlix., § 8. Perhaps, however, I signifies here and it touched, ${ }^{*}$ in which sense we find the verb 7 ב

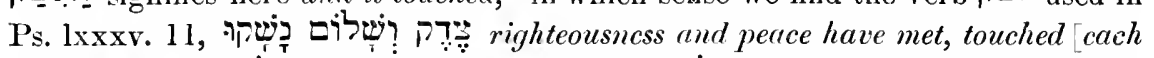

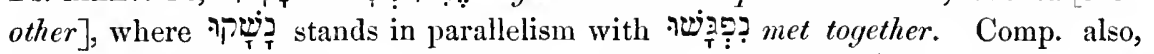

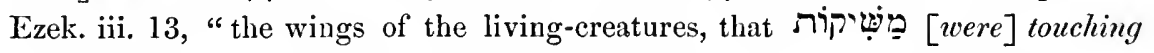
(one another)." In this case, there would be no need of any transposition, as 'T? mouth. Or, lastly, it is possible that such a liypallage as, and my hand kissed my mouth, instead of and my mouth kissed my hand, had nothing startling in it to Hebrew ears; and, indeed, we have already met with two instances of this figure, occurring in our author, viz., supra xviii. 20, as they, that were before [them], took hold upon horror, for as horror took hold upon them, that, \&c.; and xxi. 6, and my flesh taketh hold of shuddering, for and shuddering taketh hold of my.flesh. And so in other languages; e.g., in Virg. An. iii. 61, we find dare classibus austros, which evidently stands for dare classes austris. The French, too, commonly say, enfoncer son chapeau dans la tête, for enfoncer la tête dans son chapeau.

* In English too to kiss, is sometimes used in the sense of to touch, although it is much more full of meaning. Comp. Shakespeare:

$$
\text { For kissing of their feet- (they) beat the ground }
$$

('Temp. act 4, sc. 1.)

When the sweet wind did gently kiss the trees.

(Merch. of Ven. act 5, sc. 1.)

Again the part of a loaf which has touched another in the oven is called the kissing-crust. The French baiser, and German kiissen are also similarly used. Editor, 1862. 


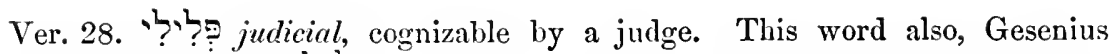
tells us is derived from what rendered them so certain, that it did not come from (Zech. xi. 15) is derived from hיצ the only answer they could give to such a question would most assuredly be ipse dixit. See our note on supra Ver. 11.

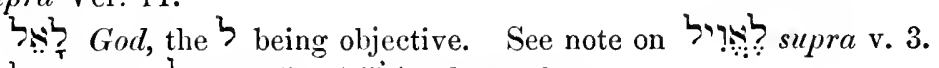

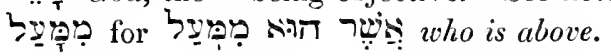

Vers. 29-31. Bildad, when offering his consolations to Job, had held ont the hope to him (supra viii. :2:) that he would yet see the time, when his enemies would be clothed with shame; in allusion to this, Job now says, that as he had never entertained the slightest particle of ill-will against any of his enemies, so their confusion and shame could by no means be a source of gratification to him. He says :

Did I ever rejoice at the calamity of mine enemy, or exnlt when evil befell him? (Ver. 30.) Nay, I did not suffer my mouth to sin, so as to ask for his life with a curse. I never allowed any imprecation against my enemy to escape my lips. So far was I from harbouring any rancour against him, that (Ver. 31) Did not the inmates of my tent say? By way of reproaching me for what appeared to them my misplaced forbearance. "Oh, that we had of his (the enemy's) flesh, we could not be satiated with it!" Our hatred of him is so great, that we never could tire of eating his flesh. 'This sense has been given to the second hemistich by many besides ourselves; but Rosenmüller does not hesitate to set his face against it, without, however, assigning any better reason than that it contains "nescio quid atrox et immane." Ile appears altogether to forget that Job had himself made use of this so fierce and savage an expression, when he said to his friends (supra xix. 2:) :

Why should ye persecute me like God?

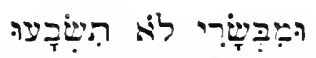

I'ea, ye scem never to be glutted with my flesh.

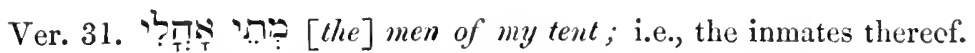

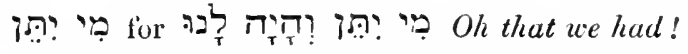

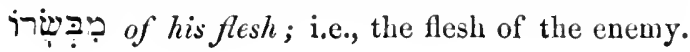


Ver. 32. Job now protests that he had ever been most hospitable to strangers, saying:

The stranger-did-not-pass-the-night in the street? I did not suffer the stranger to spend a miserable night in the street, but invited him to take shelter under the shadow of my roof. $M y$ doors I opened to the way-faring-man.

Ver. 32. .

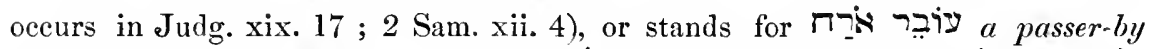

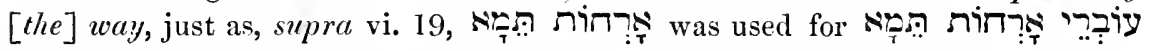
[the] passers-by [the] ways of (i.e., the wayfaring companies of) Tema. The

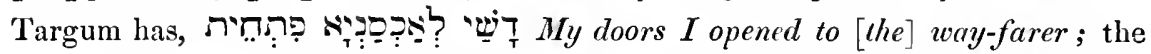

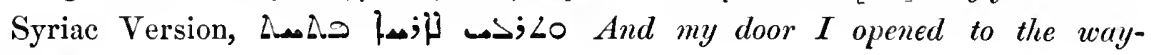
farer.

Vers. 33-34. Job, having been taxed by Eliphaz with want of sincerity, with hypocritical language, and with having chosen the tongue of the crafty (supra xv. 5), now solemnly protests against this charge, declaring it to be quite foreign to his character to speak otherwise than he thinks, the frankness and sincerity of his nature being such, that, if he had chanced to commit a fault, he could not have concealed it, but must, regardless of shame and all other consequences, publicly have confessed it before God and man. He says:

Could I have covered my transgressions after the manner of man, so as to conceal mine iniquity because of my self-love? (Ver. 34.) Because I dreaded the great multitude, or because the contempt of famities terrified me. Should I have been deterred from acknowledging my sin, by fear of falling into disgrace with the people, or meeting with the contempt of the great families, who were on intimate terms with me? So-that-I-should-have-been-obliged-tostay within, and not go out of the door? So that I should have been ashamed to shew my face in the street? It will be perceived that we understand $J_{0 b}$ to express himself in these three verses conditionally, that is, that, IF he had committed any transgressions, he most certainly would not have concealed them, but would have publicly confessed them, for we cannot bring ourselves to believe, as most others seem to have done, that he here wishes to record the fact, that whenever he had happened to transgress, he had 
always made a public confession of it, since he would thus contradict his own words (supra xxvii. 6), "My heart cannot reproach any of my days."

Ver. 33. Tִּ like-man ; i.e., after the manner of man, or conformably to human nature, which is weak, and therefore prone to omit doing what is right through false shame.

꾺끌 because of my self-love, because my self-love would have prevented me. By all the Commentators and Translators we have consulted this word is rendered in my bosom, a meaning which we have endeavoured in vain to trace to any pure Hebrew root. We therefore, with Kimchi and Ben-Zev,

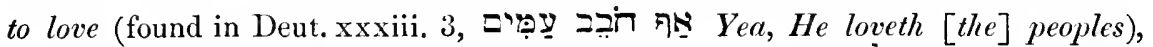
and take it to be either the inf. Kal with the $\beth$ of the $\square$ ב ב , and possess. affix, or a noun of the same form as חק my statute, from

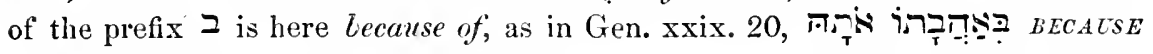
of his loving her. If we had stood alone in this our view of the meaning of the word, as for a long time we thought we did, we should still have held it fast and not have let it go, inasmueh as we are unwilling to derive words from the Chaldaie, or Talmudical, dialéct, when excellent sense can be obtained by referring them to pure Hebrew roots.

Ver. 34. פרדּד so that I shonld have been obliged to remain still; i.e., remain within doors. The rerb

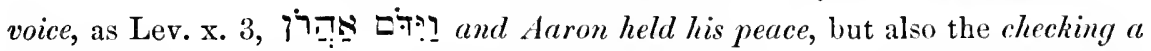

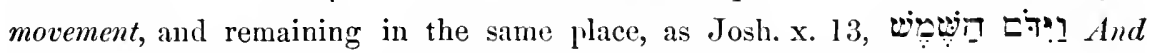
the sun stood still. In this second sense we take it here, and here stand quite alone, but we could not very well see what holding one's peace had to do with going out of doors.

Vers. 35-3\%. Having finished reading his defence, Job now emphatically exclaims: Oh, that I had one hearing me! Behold what I have marked down! Let the Almighty answer me, or let the book answer me, which my Adversary hath written. $\dagger$ Let the Almighty either verbally point out any false statement I have made, or name any other sins and crimes He may have to impute to me, not comprehended in my defence. But, if He will not deign to speak to me, then let Him produce in writing the

* Kimchi makes refer to (my iniquity); i.e., because of my love for it (iniquity), but Ben-Zev takes it precisely as we do, and assuming the absol. form to be הפר

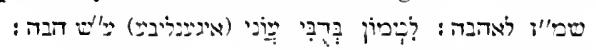

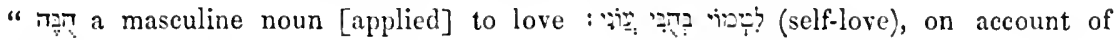
love."

+ That is, the list of charges He has drawn up. 
charges there may be against me. (Ver. 36.) Would I not bear it. The book, written by my Adversary. On my shoulder? I would bind it as a diadem (lit., diadems) to me. * So confident am I, that a history of my life, even though written by my Adversary himself, would prove me innocent, that I would on no account let the book go; nay, I would constantly carry it about me, and make it my glory and my boast, $\dagger$ well knowing that it would be unto me an ornament as brilliant and as proud, as a diadem to the prince that weareth it, encircling his brow. (Ver.37.) I would tell him. My Adversary. The number of my steps. I would not conceal from Him any of my movements or actions during the whole course of my life. I would approach him as though he were a prince. Instead of assuming before Him that attitude of haughty and arrogant defiance which people often do in the presence of their adversaries, strong in the consciousness of my innocence, I would draw near to him with the greatest respect, as I would unto a prince.

Ver. 35. 'רָ lit., my mark; i.e., what I have marked down. Comp. Ezek. ix. 4,

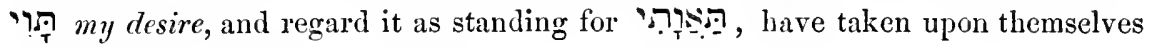
more than we could venture to do.

ơ or let [the] book answer me, which my Adversary has written.

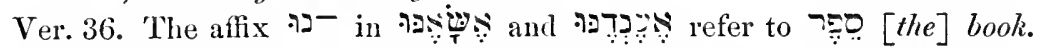

Ver. 37. The affix - (which stands instead of a proposition with a case), in

The reader will see for himself, we trust, that Job's exclamation, contained in these three verses, ought to stand after the three following, which conclude the summary of his conduct during the time of his prosperity-that

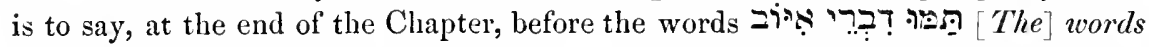
of Job are ended, a sentence, which, as we have already had occasion to observe (see supra, p. 246), we look upon as a mere distinctive mark. Some of the Translators and Commentators have, we are rejoiced to perceive, seen the necessity for this transposition, and have actually made it; for our own part, however, as we have inposed upon ourselves the rule to transpose verses only when there would be absolutely no sense without it, we have confined ourselves here to including (an expedient we have alrearly found it convenient to adopt,

* Or-I vould bind it, so that it might be as a diadem to me. Editor, 1862.

$+\mathrm{Or}$-in the full assurance that it would as certainly declare the dignity of my past life, as the diadem declares the dinnity of him that wears it. Editor, 1862. 
see supra, p. 257), the three verses in question, in one bracket, marked (B), and the three following in a second, marked (A). Wolfssohn remarks upon these three verses:

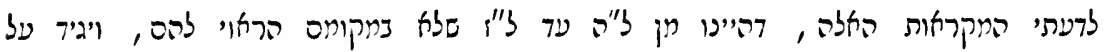

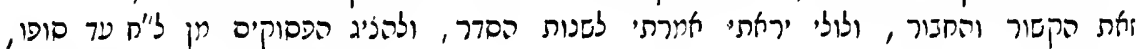

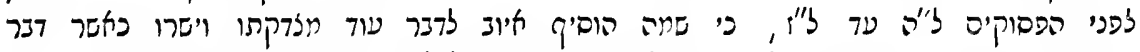

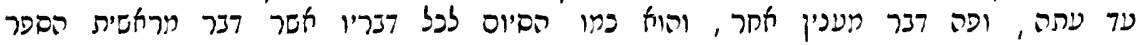

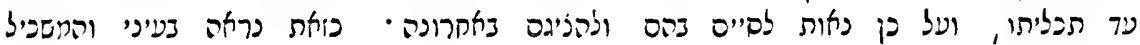

יקרב ויבחרי

"According to my opinion, these verses, viz., Vers. 35-37, are not in their proper "place, and [indeed] the connexion and context shew this; and, if I had not been afraid, I " should have thought of changing the order, so as to place the verses from Ver. 38 to " the end of the Chapter, before the Vers. 35-37; for there (Vers. 38-40) Job goes on " to speak of his righteousness and uprightness, as he had hitherto done (Vers. 1-31), "whereas here (Vers. 35-37), he speaks of another subject; and they are, as it were, the " finish to all his words which he has spoken from the beginning of the book to the " end thereof, and therefore, it would be proper to conclude with them, and to place them " at the end (of the Chapter). So it has seemed right in my eyes, and the intelligent " [reader] will adopt and make his choice."

Vers. 38-40. Job concludes his defence by declaring that, in pecuniary matters also, his dealings would bear the strictest scrutiny; that all his former possessions had been lawfully and honestly acquired, and that he had never injured any man. He says :

If my land had cried out against me, and, at the same time, its furrows had wept because of me. It is not at all unusual in Hebrew poetry to find inanimate objects represented as speaking and weeping. Thus, in Gen.iv. 10, we read, "the voice of thy brother's blood crieth, \&c.;" in Habak. ii. 11, "For the stone shall cry ont of the wall, and the beam out of the timber shall answer it ;" in Lament. ii. 18, "O wall of the daughter of Zion, let tears run down like a river day and night: give thyself no rest, \&c." In like manner, the poet here says, If the ground in my possession had cried out, and its furrows wept, on account of the unlawful and violent means I had employed for their acquisition. (Ver. 39.) If I had eaten the fruits thereof without payment, and made the legitimate owners thereof to breathe out their soul. If, by violently dispossessing them of their land, I had reduced them to starvation, ending in their death-if I had done this, how was it, that, year after year, I was blessed with a rich and abundant 
harvest? It ought surely to have been quite otherwise. (Ver. 40.) Instead of the wheat, which I had sown, thorn $(s)$ ought to have come up, and, instead of barley, noisome-veed(s).

The words of Job are ended. That is, the words which he addressed to his friends, for we shall still hear him say a few words in answer to the questions addressed to him by God. We have already observed, that we consider this concluding sentence as a mere mark, introduced by the writer to assist him in the arrangement of his manuscript.

Ver. 39. הतָं lit., its strength, by which, of course, is meant its fruit, or produce. The same word is used by God in the curse pronounced upon Cain, Gev. iv. 12, "When thou tillest the ground, it shall not henceforth yield unto thee

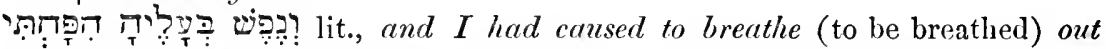
[the] soul of its owners; i.e., if, by violently taking away the land, I lad made

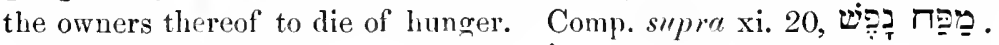

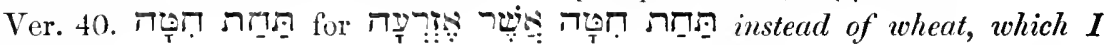
used to sow.

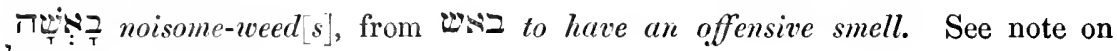

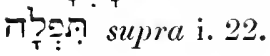

* The Eng. Vers. has, "When thou tillest the ground, IT shall not henceforth yield unto thee HER strength," though both it and her refer to ground. In Hebrew, indeed, we sometimes find a noun of com. gend. construed both as a masc. and as a fem. in the same verse, e.g., Job xx. 26;1 Kings xiii. 10, \&c., but in the passage now before us the $i t$ and the her are both expressed in the original by a feminine. The Hebraism, therefore, with which the translators of the Auth. Vers. have here favoured us, is a purely gratuitous one. Surely, such a jumbling of genders would now-a-days be pronounced to be inaccurate, inelegant, and ambiguous, yet the passage has remained for two centuries unaltered. Is then the Auth. Vers. (a mere translation after all) so very sacred, that not even such a trifling blemish as this may be removed?-Editor, 1862 . 


\section{PROLOGUE TO ELIHU'S SPEECH.}

SUMMARY OF THE PRINCIPLES AND VIEWS ENTERTAINED BY ELIHU, THE SON OF BARACHEL.

The three friends, who have hitherto been Job's opponents in the controversy, have, in their eagerness to vindicate the dispensations of Providence, declared their unfortunate friend to be a fool, a sinner, a tyrant, a sceptic, and a hypocrite. (Chap.,v. 2 ; xi. 6 ; xxii. 5; 6-9, 13-14; xv. 5.) The justice of God could not, in their opinion, be established otherwise than by the assumption of Job's guilt, and by the assertion that, if the afflictions which had come upon him, were terrible, the sins and crimes, which had called down those afflictions, must have been more terrible still. Either Job-so they must have reasoned with themselves-is guilty and God just, or Job is innocent and God unjust; and, seeing no other alternative, they determined, one and all, to abandon their fallen friend, and to offer up, as it were, the friendship and esteem they formerly felt for him as a holocaust upon the altar of piety and devotion to God. What success this determination on the part of these three friends met with has been seen in the Chapters we have already commented upon; not only did they not succeed in inducing the unfortunate sufferer to confess himself guilty of sins and crimes which he had never committed, but they irritated and exasperated him so much as to cause him to exchange the mere complaints in which he had at first indulged, for violent grumblings and murmurings, and these again for words and expressions against God, which would have been in the highest degree insulting if addressed to a man. This 
Elihu perceived, and he was displeased. It vexed him to find, that three aged and talented men could not see that the justice of God was by no means incompatible with the innocence of $\mathrm{Job}$, inasmuch as afflictions sent down from above do not always betoken the Divine wrath, but very often the Divine love and grace. For these afflictions are by no means sent exclusively upon wicked men, for the purpose of punishing them for offences, which they have committed, but very often also upon good men as an admonition and warning against offences which they might be upon the point of committing. Man, who is shapen in iniquity and conceived in sin, is unstable as water, nor can he at any moment of his life answer for what may be his conduct towards God or man in the next moment. However willing his spirit, his flesh is weak. He may have been humble-minded the greater part of his life, yet all at once become proud; he may have been a fearer of God from his youth upward, and yet suddenly turn a rebel against God. This is particularly the case with those, who live in ease and comfort, in the enjoyment of riches and wealth, in affluence and abundance. That this is so, that the enjoyment of temporal blessings is apt to make even the best of men degenerate, and to lead them to become quite the reverse of what they have been, we are told over and over again in Scripture. We read for example: Lest, when thou hast eaten and art full, and hast built goodly houses, and dwelt therein. And, when thy herds and thy flocks multiply, and thy silver and thy gold is multiplied, and all that thou hast is multiplied. Then, thine heart be lifted up, and thou forget Jehovah thy God, which brought thee forth out of the land of Egypt, from the house of bondage. (Deut. viii. 12-14.) But Jeshurun waxed fat, and kicked: thou art waxen fat, thou art grown thick, thou art covered with fatness: then he forsook God, which made him, and lightly esteemed the Rock of his salvation. (Deut. xxxii. 15.) For there are no bands in their death: but their strength is firm. They are not in trouble as other men; neither are they plagued like other men. Therefore, 
pride compasseth them about as a chain; violence covereth them as a garment. Their eyes stand out with fatness: they have more than heart could wish. They are corrupt, and speak wickedly concerning oppression: they speak loftily. They set their mouth against the heavens; and their tongue walketh through the earth. (Ps. lxxiii. 4-9.) Remove far from me vanity and lies; give me neither poverty nor riches; feed me with food convenient for me. Lest I be full, and deny Thee, and say, who is Jehovah? \&c. (Prov. xxx. \&, 9). Whether Job and the other four men, who speak in this book, were contemporaries of any one of the inspired writers, whose words we have just quoted, or whether they lived before, or after them, matters here very little; it is sufficient to know that Elihu, the young man who is now about to speak, was fully aware of this great truth, namely, that God has the good man ever in His keeping, but that, when He sees that, owing to the prosperity and the exalted station in which it has been given him to live, the root, "which beareth gall and wormwood," is becoming implanted in his heart, He subjects him to afflictions calculated to kill that root, and thus saves him from the ruin which it would have brought upon him (Chap. xxxvi. 7-9). Elihu, moreover, was aware that, when God, in His love and mercy, docs send afflictions upon a good man, to prevent him from becoming degenerate, that good man's future fate depends upon himself, that is, upon the manner in which he conducts himself while subjected to these afflictions. If he bows to the will of God, if he kisses the rod which chastises him, if he is penetrated with the conviction, that that which comes from God must be intended for his good, then his aflictions last but for a moment, and he is again received into the bosom of Him who chastened him, as the father chastens the son he delights in. But, if he proves refractory, murmurs, and rebels against God, his end must be dreadful (Chap. xxxvi. 11, 12); and the afflictions, which were at first a mark of God's love for him, will be continued to him as a mark of Ilis anger (ibid. Ver. 18). 
The good man, therefore, is actually saved by the afflictions he has to undergo; they are no punishment, but a salutary warning, a finger of God to point out to him that he is in danger of falling (ibid. Ver. 15). Now, as Job's afflictions seem to Elihu to have been sent upon him by God for this very purpose, the essence of this friend's discourse may be given in about the following words. Thou, O Job, sayest that thou hast always been a good man, that thou hast ever been meek and kind towards thy fellow-men, submissive and humble towards thy Maker; this I admit, this I fully believe thee to have been, and have the greatest pleasure in believing; yea, I delight in regarding thee as a most virtuous and pious man, and a fearer of God (Chap. xxxiii. 32); but, wouldest thou have continued to be so, if thou hadst been allowed to remain in the enjoyment of comfort, affluence, dignity, and all other temporal blessings? - this I do not know, this thou thyself canst not know, this only $\mathrm{He}$ could know, before whom lie open the recesses of man's heart, and this I maintain He did know. He did know that the seed of corruption was beginning to germinate in thy heart, that, from being pious, upright, and a fearer of God, thou wast-unaware of it thyself-about to become the very contrary, and therefore, desiring to save thee, to rescue thee from ruin and perdition, He sent afflictions upon thee. In so doing, $\mathrm{He}$ wished to snatch thee from the grasp of the worst enemy a man has in this world, namely, too great ease and too great comfort, to pluck thee from the jaws, as it were, of an adversary, who panted to devour thee (Chap. xxxvi. 16). Now, hadst thou proved thyself submissive to the dictates of thy Maker, these thine afflictions would have been but for a moment, and thou wouldst have received blessings greater even than those thou didst formerly enjoy. But how didst thou behave? Instead of humbling thyself in prayer before God, thou gavest vent to rage and fury that would have disgraced even the most wicked of men; therefore is it that thy sufferings are continued to thee (ibid. Ver. 17); and now, God will not, nay cannot, re- 
move them. Indeed, I myself pray to Him not to remove them, since His indulgence in this respect would serve as a pernicious example to other men, who would be led to imitate thy behaviour when sufferings were sent upon them from above, if thou wert now to be allowed to triumph, and to boast that thy murmurings against God had availed thee (Chap. xxxiv. 36, 37). Yea, I warn thee, and tell thee that the afflictions under which thou still continuest to labour are no longer the signs of the love and mercy of God, as they were when they first came upon thee, but are now actual chastisements, are now marks of the indignation and wrath of God. Take heed, therefore, to thyself, lest He should give thee the finishing stroke (Chap. xxxvi. 18). Having thus made allusion to death, Elihu thinks it right to warn Job (ibid. Ver. 20) against the most horrible of all crimes, suicide, which he had confessed he had been, owing to the agony he suffered, sometimes tempted to commit (Chap. vii. 15).- And then Elihu concludes his discourse by calling upon Job to admire God in the works of His creation, and in the great phenomena of nature, rain, thunder and lightning-phenomena which probably preceded the whirlwind from which God was soon to manifest Himself, and therefore engrossed the attention of the speaker.

The fact, that God, as will be seen in the last Chapter of this book, not only rebuked the three aged friends of Job, but also required of them an atoning sacrifice, and bade them seek the intereession of Job, whilst with the young man Elihu Ile found no fault, goes, in our humble opinion, very far to shew that Elihu had spoken the truth, and that the afflictions which were sent upon Job, had really just come in time to prevent a sad change, which wals on the point of being operated in his mind, and would, in all probability, have come to pass, even if Satan had not interfered. If therefore Satan, in the pride and malice of his heart, thought that it was at his instigation, and in eonsequence of his slander, that Job was given up into his hands, he wals most egregiously mistaken, for the afflictions of our sufferer were not sent upon him by God for the purpose of gratifying the enemy of mankind, but for the purpose of rescuing from eternal perdition one, whom God knew to be pious and upright and a fearer of Himself. 


\section{CHAPTER XXXII.}

Vers. 1-5. So these three men ceased from answering Job, because he was just in his own eyes. These three men, thinking that the only means of vindicating the ways of Providence lay in the establishment of Job's guilt, did everything they could to induce $J_{0 b}$ to confess himself guilty; but, when they saw that neither advice, entreaties, nor even invectives, could bring him to acknowledge his guilt, and that he even called God to witness that, till he died, he would not remove his integrity from him, that he would hold fast his righteousness, and not let it go, that his heart could not reproach any of his days (Chap. xxvii. 2-6) - when they saw, moreover, that even Zophar's noble closing speech-the most sublime and emphatic of all the discourses in the book-could not prevail upon Job to acknowledge the great truth, that man has no business to philosophize and investigate the ways of Providence, seeing that his wisdom alone consists in fearing God and departing from evil_— but that, on the contrary, he continued to speak of his piety, generosity, and the good he had done during the whole course of his life, and forgot himself so far as to call God אַ: cruel (Chap. xxx. 21), and, at the conclusion of his long discourse, to challenge the Almighty to point ont to him, either by word of mouth, or in writing, what he had done to deserve punishment_ - when they saw all this, they became convinced that no good could arise from following up the line of argument they had adopted, and they therefore came to the conclusion, that the best course they could pursue would be to desist from their purpose, and leave off speaking. (Ver. 2.) Then kindled the anger of Elihu, the son of Barachel, the Busite, of the family of Ram; against Job did his anger kindle, because of his considering himself more righteous than God. It was not because Elihu suspected Job (as the other three men did) of having acted wickedly, that his anger was kindled against him, but on account of his (Job's) entertaining and expressing the opinion, that, seeing he had done nothing wrong, God could not have acted justly in sending afflictions upon him-an opinion which a really pious and good man ought never 
to have entertained, much less expressed — whereas he should, on the contrary, when affliction came upon him, have thought and said: Although I am not aware that I have done anything to deserve these afflictions, yet, inasmuch as they have come upon me from One, whose wisdom and mercy pass all human understanding, I feel convinced that they have been sent upon me for my good. Had Job spoken thus, Elihu would, it would seem, have been quite satisfied with him, and his displeasure only arose because Job thought (agreeing in this with his three aged friends), that the justice of God was incompatible with his own innocence. (Ver. 3.) And against his (Job's) three friends did his (Elihu's) anger kindle, because they had found no answer, and therefore declared Job wicked. Because, unable to vindicate the proceedings of God towards Job, otherwise than by imputing to the latter crimes and sins even more enormous than would justify the afflictions under which he laboured, they had straightway pronounced Job guilty-no real answer to his complaints and murmurings. (Ver. 4.) Now Elihu had waited with his words regarding Job. He had deferred uttering what he had to say with regard to the fate and sufferings of Job. For they. The other three friends. Were older than he in days. Ont of respect to the old age of the three friends he had refrained from speaking until they had ceased. (Ver. 5.) But, when Elihu saw that there was no answer in the mouth of these three men. That they still were of opinion, that, unless they assumed Job to be guilty, they could not establish the justice of God. Then his anger kindled.

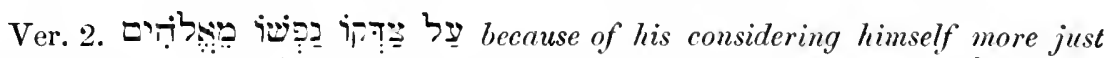

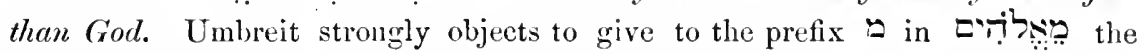
sense it usually bears when serving to institute a eomparison, namely that of more than, asserting that Job had never said that he was more just than God. He prefers, therefore, bestowing upon that prefix a force, ${ }^{*}$ which, in our opinion, it would be diffieult for him to prove it ever has. Job, indeed, had never said totidem verbis that he was more just than God, but, by implication, he had said a great deal more, and that, not once only, but over and over again-the inference his hearers must have drawn from his words being, that he was just and God unjust. Comp. supra ix. 22 ; xvi. $14-18$; xix. 6,7 ; xxiii. $11-16$; xxiv. 12 ; xxx. 21. As well might Umbreit, if, in his hearing, a white man should say to a blackamoor, that he was white and the blackamoor black, object that the white man never said

* He gives it the sense of ror (before) and translates: "weil er sich für gerecht hielt vor Gott."-Editor, 186?. 
he was whiter than the blackamoor. Elihu, indeed, did not draw such over nice distinctions, for we shall hear him say in the next Chapter (vers. 8-11) to Job, Surely, thou hast spoken in mine hearing, and I have heard the voice of thy words, saying, I am clean without transgression, I am innocent; neither is there iniquity in me. Behold! He findeth occasions against me, He counteth me for His enemy, \&c. For this signification of the $\square$ we are referred by the same translator to supra iv. 17, where, however, he is just as much in error as he is here.

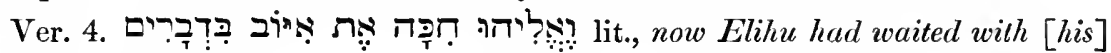
words regarding $J o b$; i.e., he had deferred uttering what he had to say with reference to Job for the reason assigned in the second clause of this same verse, namely, that they (i.e., the three friends, who had hitherto spoken) were older than himself. As we never meet with the verb case, we have been induced to consider the particle accus., but as giving the proper name בin an absolute sense. Comp. 2 Kings

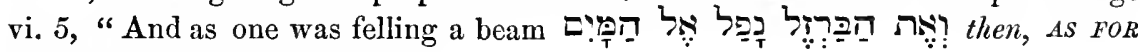
the iron, it fell into the water."

The verse should, therefore, be construed thus:

$$
\begin{aligned}
& \text { Now Elihu had waited }
\end{aligned}
$$

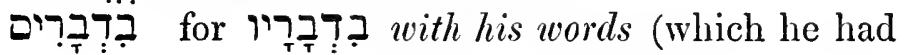

$$
\begin{aligned}
& \text { to say) } \\
& \text { אֶֶ in regard to Job, }
\end{aligned}
$$

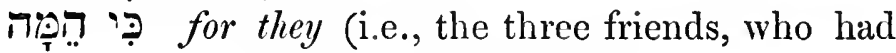

$$
\begin{aligned}
& \text { hitherto spoken) [were] }
\end{aligned}
$$

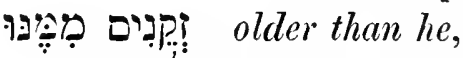

$$
\begin{aligned}
& \text { ?ִיְִים as far as regards days. }
\end{aligned}
$$

The seemingly pleonastic לִיזיצים here as well as in ver. 6, may perhaps have been intended to express that the three friends were not superior to him in rank or dignity, but only as far as regards the respect to which age entitles, as, in our opinion, wherever זִ i? is used in the sense of elders (of a city), not the most aged men are necessarily meant, but the leading men of the city. For the force

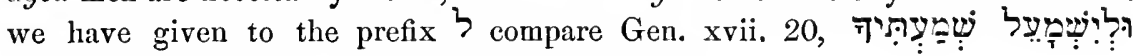
and, WITH REGARD to Ishmael, I have heard thee.

Vers. 6-12. And Elihu, the son of Barachel, the Buzite, tookup-his-discourse, and said, As far as regards days. I am young, and ye are very old. Though there may be no difference in the station we fill in life, yet there is a vast difference in our respective ages. Therefore was I slow. To come forward. And afraid to shew you mine opinion. I knew that old age ought to be respected and venerated (Ver. 7.) I thought, days ought to speak. I thought that such only as have seen many days have a right publicly to declare their opinions. Seeing that a multitude of 
years make men to know wisdom. And that, therefore, those, who have lived many years, and have grown wise by experience, should alone command the public ear. (Ver. 8.) But verily I find that it is not as $I$ thought, that it is not that which men receive through their senses which makes them sensible, but that it is the spirit which is in man, and the breath of the Almighty, which rendereth them intelligent. And that consequently those, upon whom the Almighty has been pleased to bestow that spirit of intelligence, may become sensible and wise before they have attained any considerable age. (Ver. 9.) Multitudes are not always wise, nor do oldmen always perceive what is just.* Although ye, who have hitherto opposed $J_{0 b}$, are three, and are all of you agreed in regarding Job as a guilty man, and though I, who am not of your opinion, am alone and single-handed, it by no means hence follows, that you must be right and I wrong. Neither does your age entitle you to believe that you have arrived at the truth, and that I am mistaken. (Ver. 10.) 'Therefore, I say, Listen, O Job, unto me, $I$, yea $I$ also, will shew thee mine opinion. (Ver. 11.) Lo! I have waited for your words; I gave ear to your reasonings, waiting until you should have searched out matters. I was in no hurry to come forward with my opinion, but waited to hear to what conclusions you would come, after having thoroughly sifted the case of our unfortunate friend. (Ver. 12.) But, though I attended unto you, yet, behold! there was not one of you convincing $J_{0} b$, or answering his words. As you have none of you been able to convict $J_{0 b}$ of any of the enormous crimes you imputed to him, his complaints and pleadings have remained totally unanswered by you, whose arguments based upon the supposition, that he ( $\left.J_{0 b}\right)$ fully deserved the punishments that have been inflicted on

* We cannot refrain quoting here the sentiments of the Rabbins of the Mishnah on this subject from Treatise Aboth, Chap. iv. :-

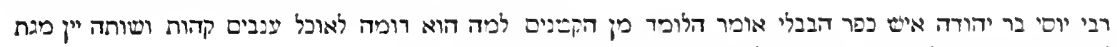

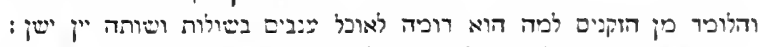

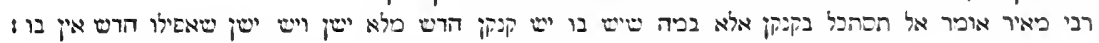

"Rabbi Jose the son of Judah a man of K'phar-Habbabelee says : He who Jearns of young-men, unto what is he like? [He is like] unto one [that is] eating sour grapes and drinking wine from its press (i.e., before it has sufficiently fermented); but he who learns from old-men, unto what is he like? [He is like] unto one [that is] eating ripe grapes and drinking old wine."

"Rabbi Mayeer [in opposition to the above Rabbi] says: Do not look at the pitcher, but at that which is in it, there being a new pitcher full of old [wine], and an old [pitcher] in which there is not even now [wine]." 
him-a supposition entirely unwarranted-could not do otherwise than fall to the ground.

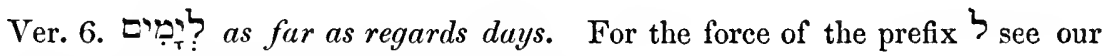
note on the same word in the preceding verse.

Ther lit., I crept; i.e., I was slow in coming forward. We take the verb לדז in the sense it was taken in by Rabbi Jonah, as quoted by Kimchi in his . Comp. Deut. xxxii. 24, ספר השרשים serpents of the dust. Some suppose $2 \pi$ in the present instance to be i.q. the Chaldee Tri to fear, but, though the Hebrew $T$ is very frequently exchanged for 7 in Chaldee, we preferred embracing Rabbi Jonah's opinion, as we thereby avoid tautology.

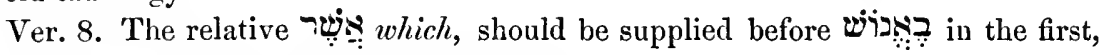
and before תִבְביָם

Ver. 9. ברבָּים many, or multitudes; i.e., it does not follow, because you are three against me, who have no one to support me in my opinion, that you must therefore be in the right. So we heard Job say (supra xii. 2) :

Indeed, because ye are a company,

Must therefore wisdom die with you?

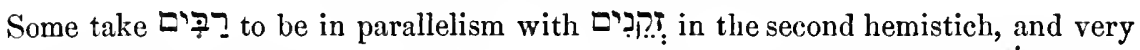

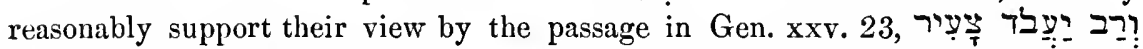
and [the] elder shall serve [the] younger. For our own part, however, we have preferred giving the word its more usual meaning, as we shall then make Elihu utter the same sentiment as we have just shown had been expressed by Job.

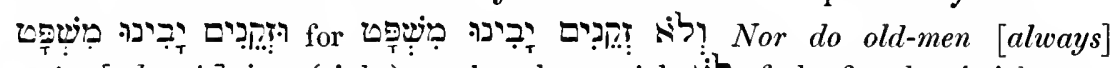
perceive [what is] just (right), so that the particle ${ }^{2}$ of the first hemistich must be understood in the second, either in the place we have assigned to it, or after

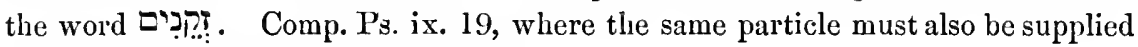
from the first hemistich to the second.

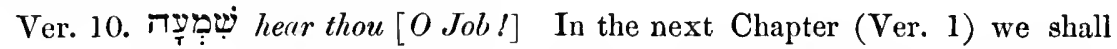
find the speaker addressing himself to Job by name, and here he may fairly be supposed to have indicated, by lis gestures, that he was speaking to Job, unless, indeed, by using the singular, he intended to call the attention of every one of the party present to what he was about to say.

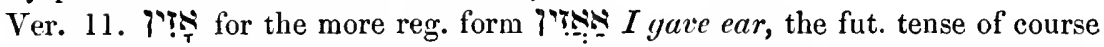
expressing constancy, and implying that he never for one moment ceased to lend an attentive ear to the speeches delivered by his friends. See note on infra xxxiv. 31 (note).

we take here to be synonymous with פילִיץ which sense بִ prs very frequently used in Chaldee. Comp. Dan. ii. 8, 15, 17.

Ver. 12. The particle $1 \checkmark$ in the first hemistich must be supplied before the

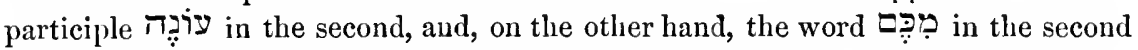
hemistich must be understood after the $Y$ is in the first, so that, expressed in full, the first hemistich would run, 


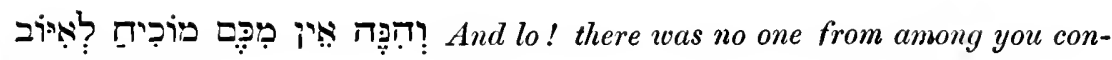
vincing $J o b$;

and the second,

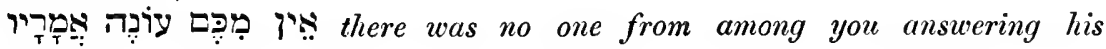
speeches.

Vers. 13-22. Having paid his tribute of respect to the age of the three friends, whom he is about to oppose, Elihu now proceeds to shew them that he fully perceives the drift of all their arguments, but cannot approve of them. He says:

Peradventure ye will say, We have found out wisdom. Does not that strong and conclusive argument which we wielded against Job shew this?- the argument, namely, that it is God that thrusteth him down, and not a man. Could we possibly have used a better argument than this? If Job had complained, that for his afflictions he was indebted to a man, we should have considered it our duty to examine whether his complaints were or were not just, and whether he had actually been wronged by that man or not; but, as his afflictions proceed directly from God, there can be no doubt but that he has in the fullest degree deserved them. To this, in fact, your arguments amount. (Ver. 14.) But why did he (Job) not direct his words to me? I indeed should not have replied to him with your speeches. I should not have adopted a line of argument like yours, which could not fail to exasperate a man conscious of his innocence, and to drive him to despair.* (For what did Job's friends gain by the course they thought fit to pursue? Were they not, so far from reaping any advantage from it, signally defeated by Job, and reduced to an ignominious silence?) (Ver. 15.) They were confounded; they answered no more; they put away the matter from them. They declined investigating the matter; they said, since the punishment came from God, it must needs be just; what necessity, then, for proving its justice? (Ver. 16.) So I waited, until they spake no longer, until they stopped, and answered no more. (Ver. 1\%.) I also will speak my part. I will say my say. Yea, I also will shew mine

* It will be observed that in the next two verses there is a change of person, and that Elihu no longer addresses himself to the three friends, but speaks of them. But whether he now begins a soliloquy, or whether he turns round and addresses himself to Job, I must leave to the reader to decide. It was for the purpose of marking this change of persons somewhat that I inserted the brackets, which were not in the manuscript._Editor, 1862. 
opinion. (Ver. 18.) For I am full of words. If I have hitherto been silent, it was not because I had nothing to say; on the contrary, I have a great deal to say upon the subject, and at the same time a great desire to say it. The spirit within me constraineth me to speak. (Ver. 19.) Behold! my belly is like wine, which hath no vent. Just as wine, when allowed to ferment in a cask or other vessel which has no vent-hole, may be expected to burst that vessel's walls, so does the subject I have to speak upon ferment and work within me. It (my belly) is ready to burst like new bottles. These would be more likely to burst than old bottles, because new wine was put into new bottles, as we read in Matt. ix. 17. By bottles here, as well as in Matthew, of course leathern bottles or wine-skins must be understood. (Ver. 20.) I will speak, then, that I may ease myself; I will open my lips, and take-up-my-discourse. (Ver. 21.) I will not now accept the person of any man, neither will I use-bland-uords to any man. (Ver. 22.) For I know not how to use-bland-words; my Maker will almost have to forgive it me. No one can charge me with ever having used bland and flattering words to any one who required correction; my tendency lies towards the other extreme, so that God may perhaps find fault with me for conveying my correction in too frank and open a manner.

Ver. 13. i? which usually signifies lest, or for fear that, is evidently used here synonymously with 's perchance, peradventure. So in 2 Kings ii. 16, "Let them go, we pray thee, and seek thy master; 19 peradventure, the Spirit of Jehovah hath taken him up, \&c." The reason for our objecting to give to this particle liere the sense of lest, which most of the Translators have assigned to it, will no doubt be obvious to the reader, for lest cannot be used unless there be some word or sentence for it to depend upon, and what could it depend upon here?

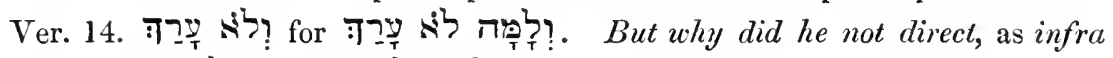

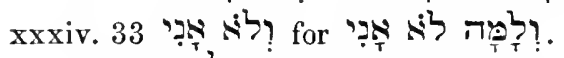

Ver. 15. פִִ מִלים we again take here to be synonymous with rather matter in the sing., to meet the requirements of the English idiom), as we did above in Ver. 11.

Ver. 16. 'כ in the first, as well as in the second, clause, evidently stands for פִ until that ; after

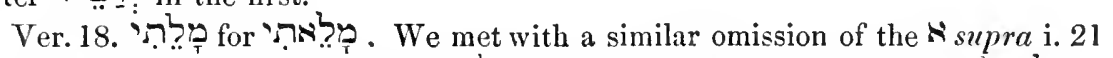

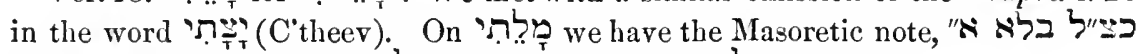

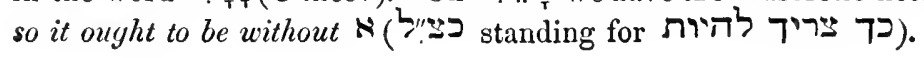




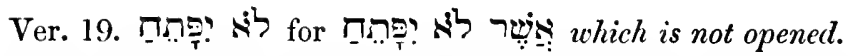

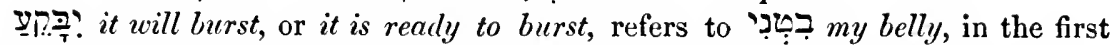
hemistich ; the meaning being, my belly is ready to burst like new bottles. New bottles are mentioned, as being more likely to burst than old ones, in consequence of the fermentation of the new wine which it was customary to put in them. Comp. Matt. ix. 17.

Umbreit, and others, who are reputed to hold the highest rank among German critics, seem to vie in running down Elihu. Umbreit terms him a conceited and idle prattler, and, indeed, goes so far as to maintain that the author of this book himself intended to turn him into ridicule, when he put into his month the words upon which we have just commented, namely, "My belly is ready to burst, \&c." The reason why these German critics speak so disparagingly of Elihu, seems to us clearly to be this, that, namely, to none of them has been revealed the real pith of his powerful and decisive arguments; but what we are puzzled to account for is, how one like Umbreit, who doubtless professes intimate acquaintance with Oriental literature, could forget that expressions and figures, which to European ears would appear unnatural and bombastic, are in Oriental languages not only admissible, but frequently considered elegant and highly poetical. Among such expressions and figures we may quote the following: "Put 'Thou my tears into Thy bottle" (Ps. Ivi. 8); "For I am become like a bottle (wine-skin) in the smoke" (Ps. cxix. 83) ; " Thy navel is like a round goblet, which wanteth not liquor; thy belly is like an heap of wheat set about with lilies . . . . thine eyes are like the fish-pools in Heshbon ..." " thy nose is as the tower of Lebanon, \&c." (Cant. vii. 2, 4). We could cite many more such, or even more extravagant, hyperboles from the Bible, but our space will not allow us to do so.

Ver. 20. '? ח!? ? lit., that there may be ease to me; i.e., that I may be eased.

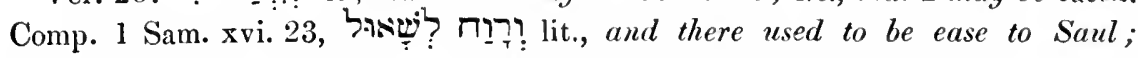
i.e., Saul used to be eased. See Mison and Bernard's Grammar, Letter xlix., P.S. (b).

Ver. 21. 1it., I will not give flattering epithets to any man ; i.e., I will not soften down the asperity of my rebukes by using bland and soothing expressions.

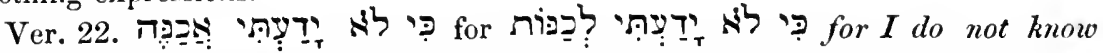
[how] to speak blandly; a tense being here used for an infinitive mood. Comp. 


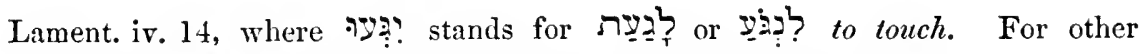
examples see Mason and Bernard's Grammar, Letter l., $\$ 13$.

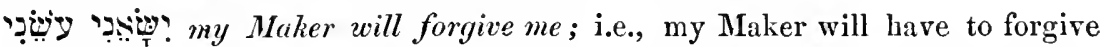
me my sometimes hurting the feelings of my friends by speaking too openly. We take the verb Sש In this instance in the acceptation of forbearing, or

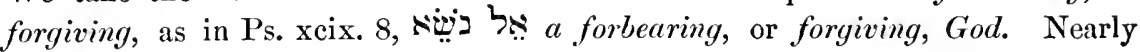
all the Translators we have consulted understand it in the sense of removing (from this world); but, besides there being, as far as we know, no one instance in which this verb is used in such a sense in the Bible, this interpretation of theirs has not even the merit of establishing a close connexion between the two members of the verse, as God certainly does not always immediately remove flatterers and sycophants, when they speak otherwise than they think.

\section{CHAPTER XXXIII.}

Vers. 1-12. Hear then, Job, I pray thee, my words, and give ear to all my speeches. (Ver. 2.) Behold, now! I have opened my mouth; my tongue hath spoken within my palate. As long as I could refrain from speaking, I did so, but now, that I have once begun to speak, I must be allowed to continue till I have uttered all I have to say, and, therefore, I crave thy constant and undivided attention. (Ver. 3.) The uprightness of my heart shall be my eloquence, and my knowledge shall consist in this, that my lips speak clearly. The speaker had not, it appears, forgotten Job's finding fault (supra vi. 25) with his friends for seeking to display their oratorical talent, on which occasion he had maintained, that words spoken with sincerity, though plain and unadorned with rhetorical ornaments, were more powerful than set speeches replete with elegance and eloquence. Referring to this, Elihu says, I do not lay claim to eloquence, or to any great profundity of knowledge-I lay claim to sincerity of heart ; no loftily-worded phrases must be expected from me ; all that I can promise is, that whatever I do say shall come out of my heart, and be expressed in plain and simple language, unvarnished and unadorned. Having 
thus modestly acknowledged his inability to play the orator, he next calls attention to the wish expressed by Job, that God would remove His rod and His terror from him, whereby he should be enabled to reason with Him, without being overwhelmed by His power and majesty (Comp. supra ix. 34, 35); and in reference to this, Elihu says, In me at least there is nothing whatever that can strike thee with awe, and deter thee from endeavouring to refute my arguments, if I am wrong, for I am a human being like thyself. (Ver. 4.) The spirit of God hath made me. Just as it hath made thee. And the breath of the Almighty preserveth me alive. Precisely as it doth thee. Therefore, (Ver. 5) If thou canst, answer me; set thy words in order before me, stand up. I am quite ready to hear what thou hast to say by way of objection and refutation. Thou didst wish to reason with God (supra xxxi. 35); this wish shall now be granted thee. (Ver. 6.) Behold! I am here instead of God, according to thy word. Thy desire then is granted to thee, and at the same time all cause for dread is removed from thee, for, although I take upon myself to represent God, thou needest not in the least be afraid of me, since I am a man as thou art. Just as thou hast been, so also have I been cut out of clay. Dust we are both of us, and to dust shall we, both of us, return. (Ver. 7.) Lo! my terror. The terror I am capable of inspiring. Need not affiright thee, neither can my importunity press heavily upon thee. Since we are both men, thou canst easily shake me off, if at any time thou shouldest perceive that I become importunate. (Ver. 8.) But, thou didst say in mine ears; yea, I heard the sound of words. Such as these. (Ver. 9.) "I am pure without transgression; I am clean, and there is no iniquity in me. (Ver. 10.) Lo! Ile findeth occasions against me. Occasions for doing me hurt. Ile counteth me for his enemy. (Ver. 11.) He putteth my feet in the stocks; He watcheth all my ways." All my movements. (Ver. 12.) Behold! in this thou art not right, let me tell thee. Thy three friends told thee, thou must needs have done wickedly in the former part of thy life, and in saying so they may have wronged thee; but I do not say so, I believe thee to have lived a righteous life, till these afflictions came upon thee, but then thou didst sin, ancl sin very grievously, in that thou couldest presume to utter such unseemly 
words concerning God, because He had afflicted thee, For God is greater than frail-man. He is a Being so great and so exalted, that it is not possible to suppose He would afflict such a weak and frail being as man, unless He knew that he would be benefitted by his afflictions.

Ver. 3. 'רָּ lit., my speeches, equivalent here to my eloquence. Comp. Exod.

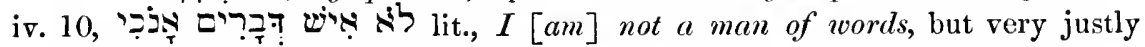
rendered in the Auth. Vers. I am not eloquent. The verse before us should be construed thus :

$$
\begin{aligned}
& \text { [The] uprightness (or sincerity) of my heart } \\
& \text { [shall be] } \\
& \text { אִִ my eloquence, }
\end{aligned}
$$

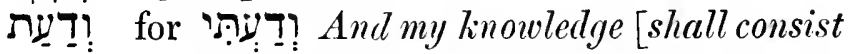

$$
\begin{aligned}
& \text { in this, that] }
\end{aligned}
$$

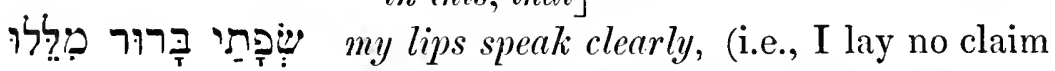

$$
\begin{aligned}
& \text { to either eloquence or wisdom, and can } \\
& \text { only undertake to speak sincerely and } \\
& \text { clearly.) }
\end{aligned}
$$

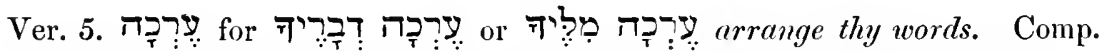

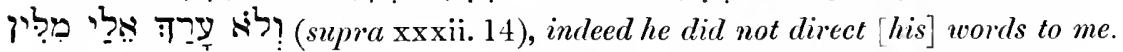

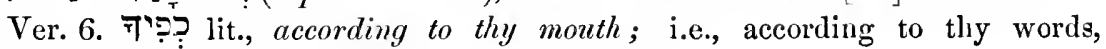
according to the request given utterance to by thee.

לִ לִ instead of God. Comp. Exod. iv. 16, "he shall be to thee instead of a mouth, and thou shalt be to him aיה instead of God."

Ver. 7. 'בְּ? ๆ

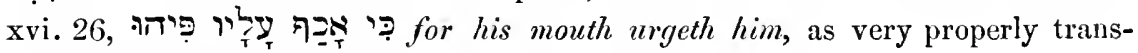
lated by Dr. French and Mr. Skinner.

Ver. 9. (part. Kal), which in Hebrew signifies to cover, sheltcr; but from this meaning no sense suitable to the passage before us can be extracted. Since, however, the same verb is used in the Talmud, in the significations of rubbing, scratching, scraping, Ben-Zev considers derived, namely, that of being rubbed bright, cleansed, clean. Comp. A Nazarite must not rub his head with earth. (Beza, chap. v. near the beginning.)

Ver. 10. Most of the Translators and Commentators

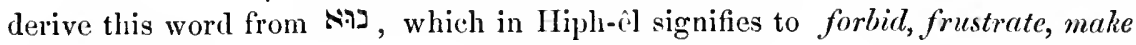
of none effect, but with all their elaborate discussions and explanations they

$$
\text { * Comp. אַ: (Isa. xlvii. 8, 10) from Editor, } 1862 .
$$


cannot succeed in elucidating the manner in which they have derived the sense they choose to give this word here from the above named root; nor can the word in this passage have the same signification as it has in Numbers xiv. 34. We are, therefore, glad to find that Ben-Zev considers the word before us to be synonymous with חק: (Judg. xiv. 4,) an occasion.

Ver. 12. ז for ת ת

Vers. 13-18. Why didst thou contend with Him? What was it that chiefly caused thee to complain and murmur against Him ? It was because He will not declare any of His words. Because, according to thee, He refuseth to offer the slightest explanation of $\mathrm{His}$ proceedings towards men. (Chap. ix. 2,3 ; x. 2 ; xiii. 22; xix. 7.) But this assertion of thine I flatly deny, for (Ver. 14) Certainly God doth speak to man in one way, yea, in two ways, if he doth not regard it. If no heed is given to the warning of God when conveyed in the first of the two modes, which He employs for the purpose, He conveys it in the second and more severe one, so as to secure attention to His admonition. The first mode He adopts is to speak to man (Ver. 15) In a dream, a vision of the night, when deep-sleep falleth upon men; in their slumberings upon their couch. (Ver. 16.) Then He shews men, that He will decree their chastisement. That He will most assuredly chastise them, if they give no heed to His first warning. $\dagger$ 'This is done by Him (Ver. 17) In order to remove from man his evilpractices, and also to remove from man the pride, which he concealeth. 'The pride, which he has in his heart, and which he either covers with a cloak of hypocritical humility, or may, perhaps, sometimes be infected with, without himself being aware of it. 'To remove this, warning is given in a dream, so that (Ver. 18) He (God) may keep back his person firom the pit, and his life from passing. Away from the world. By the sword. By a violent and untimely death.

Ver. 13. ריב ריבוֹ didst thou contend. This form is very irregular; for, if it be taken to be the pret. Kal (the root being רוּ ריב or

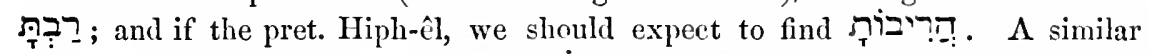

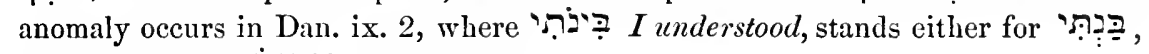

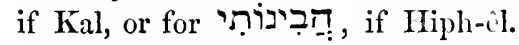

* The plur. of this would be הואור or and from the latter, by a transposition of some of its letters, we should obtain the word under consideration, המיאות. - Editor, 1862.

$\dagger$ As was the case with Abimelech (see Gen.xx. 3); and with Nebuchadnezzar (see Dan. iv. 5). 


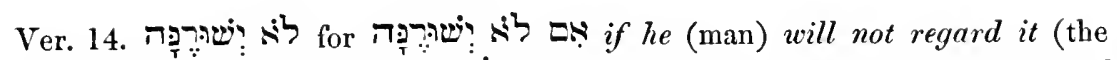
warning first given). The verb שיר to look, see, is sometimes used in the sense of to observe, regard. Comp. Hos. xiii. 7, רצָ I will observe, narrowly watch. In the same acceptation the verb ראד to see, is sometimes used, e.g., in Isa.

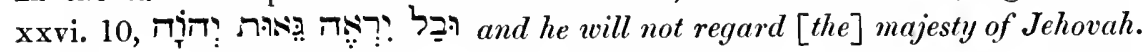

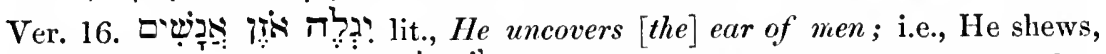
reveals, to men. The phrase isi is to uncover [the] ear, in the sense of to shew, declare, very frequently occurs; for one instance of the many that might be quoted, the reader is referred to 1 Sam. xx. 2 .

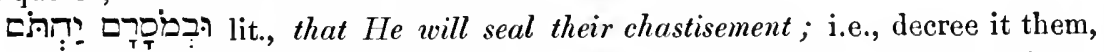
since, as we are informed in the Bible, decrees had to be sealed with the King's signet-ring before they acquired validity. Comp. Esth. viii. 8 . The $=$ in is either the mark of the objective case, or pleonastic. See note on

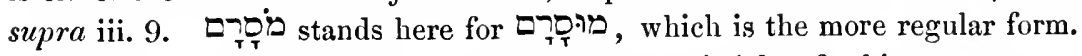

Ver. 17. The $\$$ of

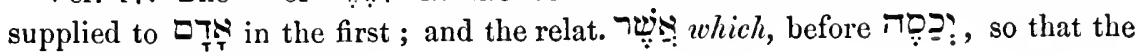
verse should be construed thus :

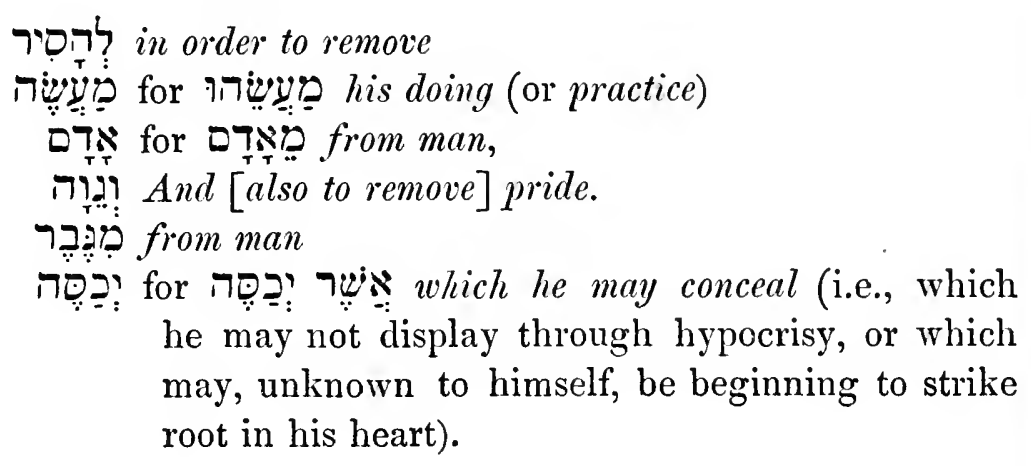

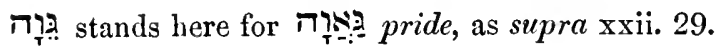

Vers. 19-26. Elihu now proceeds to speak of the more serious warning, which is given to man by God, if that conveyed in a dream is disregarded. He says:

Or he is chastened with pain upon his couch.* $\mathrm{He}$ is stricken with such a severe and painful disease, that he is obliged to take to his bed. So that the jarring of his limbs is vehement. So that the harmony which reigned between the different parts of the sufferer's body is disturbed, his whole economy disordered and deranged. (Ver. 20.) And his appetite loatheth bread, yea, his soul loatheth his favourite food. (Ver. 21.) His flesh wasteth so

- As was the case with Hezekiah, as recorded in 2 Kings $\mathbf{x x}$. 
that it cannot be seen, so that his bones, which were not seen. From being covered with flesh and fat. Stick out. (Ver. 22.) Yea, his soul draweth near to the pit, and his life to the destroyers. To the destroying angels, who bear commission from above to remove man from this world. However (Ver. 23), If there be in his behalf an advocating angel, even one from among a thousand angels, to shew respecting that man his uprightness. If, when God summons the sons of God before His throne that He may hear what report they bring of men on earth below, one, yea, only one out of a thousand of them can step forward and point to some good deed wrought by the man, who lies, racked with pains, and wasted with disease, upon his couch. (Ver. 24.) Then He (God) hath compassion upon him, and saith to the advocating angel, "Deliver him from going down to the pit, I have found a ransom." That one good action which thou recordest of yon diseased sinner I accept as a ransom for the sins he hath committed, and grant him absolution. (Ver. 25.) Then his fesh becometh fresher, than it was in his childhood; he returneth to the days of his youth. His constitution, far from becoming broken and shattered by the violence of the disease he has had to undergo, is, by the grace of God, so strengthened and renovated by it, that it becomes even firmer and more vigorous than it was in the days of his youth.

Ver. 19. Iו lind [the] strife, jarring, of. The C'theeb is וריב in consequence of which some 'Translators have thought, that, according to the $C^{\prime}$ theeb, the word signifies strife, but, according to the $\boldsymbol{K}^{\prime} r e e$, multitude. For our own part, however, we can see no reason why the $K$ 'ree should be interpreted differently from the $C^{\prime}$ theeb, as we also find ר in the signification of contending, striving,

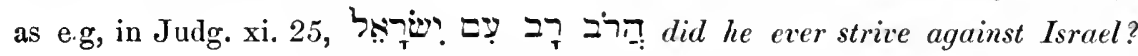

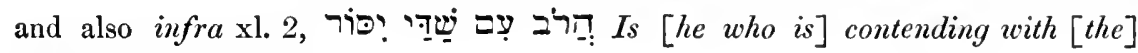
Almighty, corrected?

Ver. 20. This verse should be construed thus :

\footnotetext{
דָירית So that his appetite

ị loathes it,

לִָ viz., bread (i.e., his appetite loathes bread),

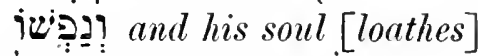

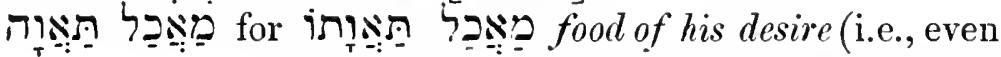
his favourite food, the food he always liked, he cannot now eat).
} 


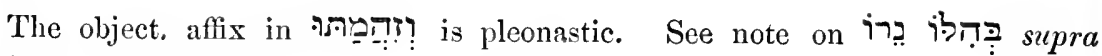

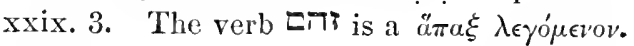

The noun

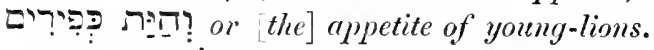

Ver. 21. פִיר lit., without sight ; i.e., that it cannot be seen, or, perhaps, imper-

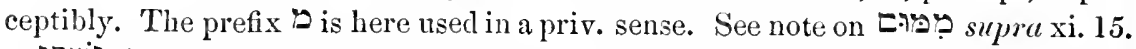
?ִ (according to the K'ree), lit., so that they are made high; i.e., so that they stick out, the root being $\pi \Xi$, and the conjugation Pu-âl.

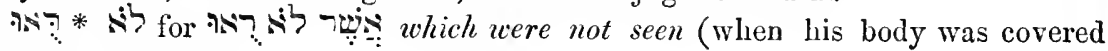
with flesh and fat).

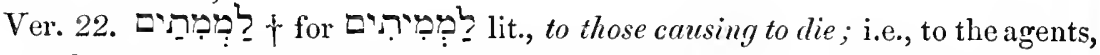
or angels, sent from above to remove men from the world. So in 2 Sam., Chap. xxiv., where we read of a pestilence having been sent upon Israel, we find that

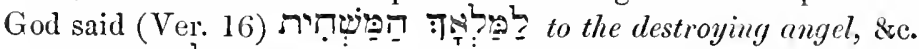

Ver. 25. W a force which the prep.

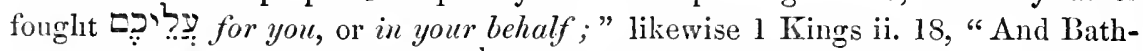
sheba said, Well, I will speak Tִ שָ for thee (i.e., in thy belialf) to the king."

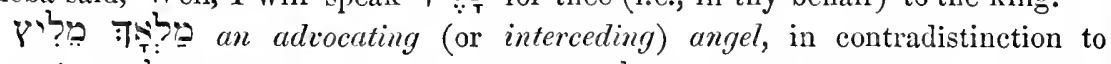

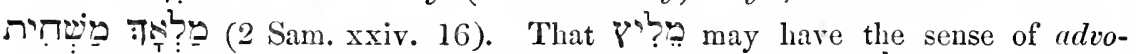
cating, or interceding, has been clearly shown in our note on

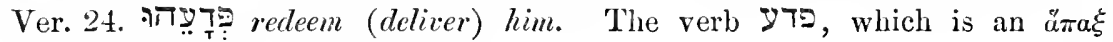
$\lambda \epsilon \gamma^{\prime} \mu \in \nu \circ v$, is synonymous with פדר

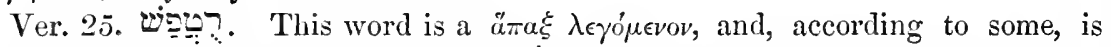
made up of בטר to be fresh, juicy, and to to spread; and, according to others, of =טר and 0 to be fat; so that its literal meaning would be, either it becomes fresh and full, or fresh and fat.

Vers. 26-33. The speaker now tells us how a really penitent man behaves, after that, having received punishment from his Maker, he has been again admitted into His favour. He says :

He (the man whom God had stricken with disease, but has now restored to health and favour) prayeth to God, and $\mathrm{He}$ accepteth Him; yea, he seeth His face with a shout of joy. He goes for the first time after his recovery from his disease to the house of God with great rejoicing. Becanse that He (God) huth requited to man according to his righteousness. However

* The Dagesh in the 7 is of course extremely irregular. It is, however, of the same character as that so common in the word next following

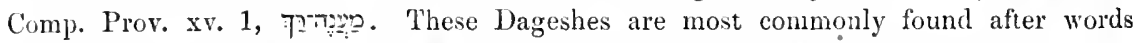
ending in $\pi$. See stppa xix. 27, infia xxxiv. 4, 7, 16, Exod.iv. 16, Jer, ii. 17, \&c. The Dageshed letter, though commonly, is not always, preceded by Mukkiph, e.g., Numb. xxv. 13. Editor, 1862 .

† For the omission of the Dag. in the Dsee note on نִ supra xx vi. 13 (note). Editor, 1862. 
many his sins and offences, yet, because only a single redeeming action has been recorded of him by his advocating angel (see Ver. 23), all his sins and offences have been forgiven him by God in His mercy, and therefore he rejoices. (Ver. 27.) He (the pardoned sinner) looketh upon men and saith. He makes his confession openly before men, saying, "I had sinned and had "perverted that which was right, although it did not profit me." So complete is his repentance, that he does not even conceal that his wickedness sometimes had had its origin, not in temptation, but in the depravity of his nature, inasmuch, as if he sinned, it was not from any motive of self-interest, but merely from that love of wickedness which gradually becomes firmly rooted in the breast of the most depraved men. And yet, notwithstanding I had thus reached such a pitch of wickedness (Ver. 28), " He (God) redeemed my soul from passing over into the pit, so that my life should still see light." (Ver. 29.) Lo! all these things God doeth oftentimes with man. He repeatedly warns and admonishes them, either in dreams, or by severe afflictions, these being, in fact, the language which $\mathrm{He}$ employs towards men, and a language well befitting the Creator, when He would hold communication with His creatures; a language which He employs (Ver. 30), To make his (man's) soul turn from the pit. To the brink of which he has either brought himself by the wicked deeds which he has committed, or would have brought himself by the wicked deeds which he was on the point of committing when he received these timely admonitions. To be enlightened with the light of the living. But I have not quite done yet. I have something yet to add, and therefore (Ver. 3l) Attend, O Job, listen unto me; keep silence, and I will speak. (Ver. 32.) If thou hast words. 'To oppose to my statements. Reply to me; speak, for I delight in pronouncing thee to have been righteous. Before afflictions came upon thee. Thou needest not fear that I will tax thee, as did thy friends, with sins and crimes to which thou mayest have been an utter stranger; on the contrary, it is my delight to think that thy former life was free from spot or blemish, and that thou only hast begun to wander and go wrong, since these afflictions came upon thee, and that for the simple reason that thou wast unable to penetrate the object with which they were sent upon thee. (Ver. 33.) If thou hast 
none. If thou beginnest to see, that what I say is true, then Listen thou to me; keep silence, and I will teach thee wisdom. I will shew thee that the wisdom of God passeth all human understanding.

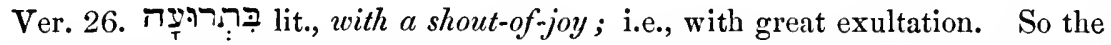
Psalmist says (Ps. xcv. 2), "Let us come before His presence with thanksgiving, and make a joyful noise unto Him with psalms."

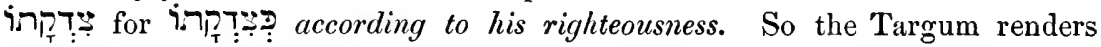

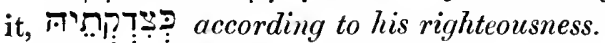

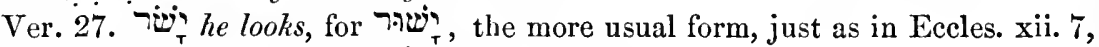

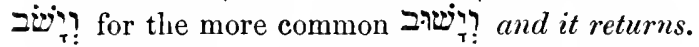

? ול lit., though it profited not to me; i.e., though I derived no benefit from it. Comp. Esth. iii. 8, הִי [it is] not profiting, or profitable.

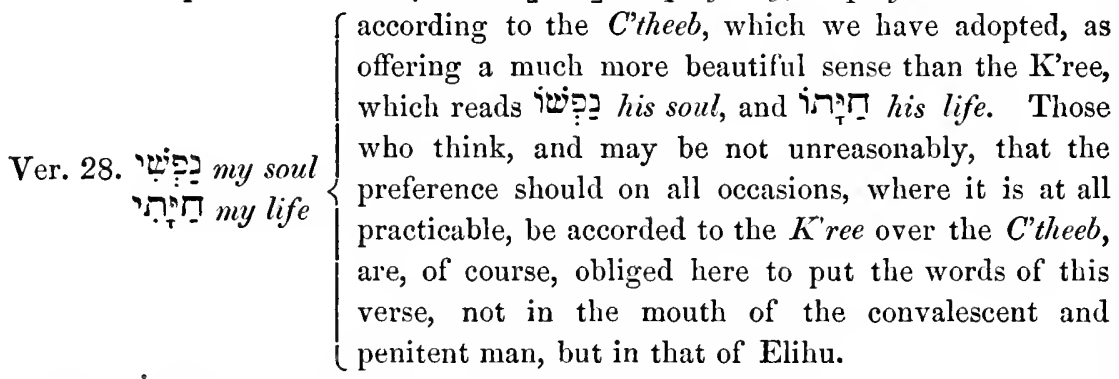

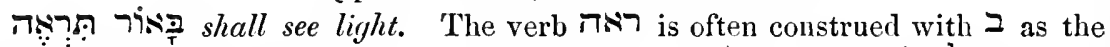

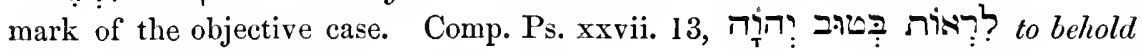
[the] goodness of Jehovah.

Ver. 29. our note on

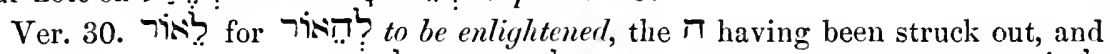

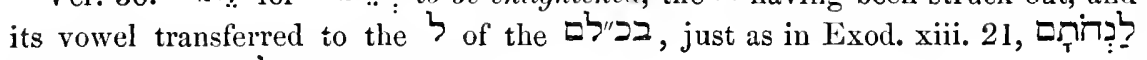
stands for

\section{CHAP'TER XXXIV.}

Vers. 1-12. And Elihu took up his discourse, and said. In the preceeding Chapter, Elihu had addressed himself exclusively to Job, whose grumbling on account of God's (according to his (Job's) opinion) not holding any communication with men, he wished to put a stop to-an erroneous opinion, which he supposed was entertained by no other of his auditors. Now, however, as he is about to vindicate the ways of Providence generally, he addresses the 
whole of those present. (Ver. 2.) Hear, O ye wise-men, my words, and $O$ ye intelligent-men, give ear unto me! (Ver. 3.) For the ear should try words, just as the palate tasteth that which one is to eat. Just as food cannot be pronounced to be pleasing or displeasing to the taste until it has passed through the ordeal of the palate, so a discourse cannot justly be either applauded or condemned, unless it has been proved by the ear. (The same sentiment had already been expressed by Job himself supra xii. 11.) (Ver. 4.) Let us choose for ourselves a mode of reasoning. Let us not ramble and speak wide, or indulge in mere similes and poetical figures, as has been done till now, but let us confine ourselves to the examination of what bears directly upon Job's case. Let us know between ourselves what is good. Let us come to an understanding as to the real bearings of the subject we are about to discuss. (Ver 5.) Surely Job said, "I am righteous, but God hath turned away my just-cause." My cause is just, only God rejecteth it, and will not take it into consideration. (Comp. supra xiii. 18, 19 ; xxvii. 2.) (Ver. 6.) "Shall I speak-falsely against mine own just-cause?" Shall I confess myself guilty, when I am conscious of mine innocence? (Comp. supra xxvii. 2-6.) "The arrow which hath wounded me (lit. my arrow) is very grievous, without any transgression." On my part. My pangs (due to the arrows of the Almighty) are extremely piercing and excruciating, yet rack me undeserved. (Ver. 7.) Who is the man, that like Job drinketh up scoffing like water? Can you point me out a man, who indulges in scoffs and jeers like Job against his Lord and Maker? Indeed, he is brimful of them, as men are wont to be with water, which, as costing nothing, and incapable of producing intoxication, they do not hesitate to swallow in copious draughts. (Ver. 8.) And goeth to associate with workers of iniquity, and to walk with men of wickedness. (Ver. 9.) For he said, "A man profiteth nought by delighting himself with God." By holding communion with God, and using all his endeavours to render himself acceptable to Him. (Comp. supra ix. 22, 30 ; x. 15.) (Ver. 10.) Therefore, $O$ ye men of understanding, listen unto me; far be it firom God to do wickedness! and from the Almighty to do iniquity! Far be it from entering into any one's mind to conceive God capable of wickcdness and iniquity, which is to Him 
as that which is profane!* (Ver. 11.) Surely, the work of man will He requite him, and according to the way of a man will He cause him to find. Men will meet at His hands with that requital which their course of life deserves. (Ver. 12.) Yea, verily, God cannot do wickedly, neither can the Almighty pervert justice.

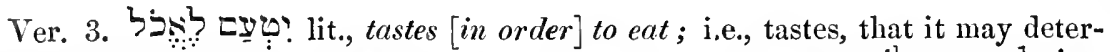

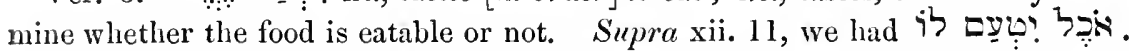

Ver. 4. טִִ̣ a mode, manner (of reasoning). Comp. 2 Kings i. 7, What [was the] namuer of the man?

Ver. 6. ח. lit., my arrow; i.e., the arrow which has wounded me. See note on 'T? supra xxiii. 2.

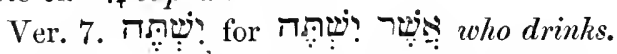

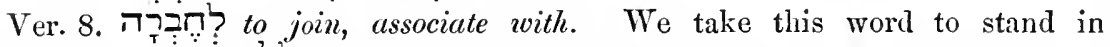

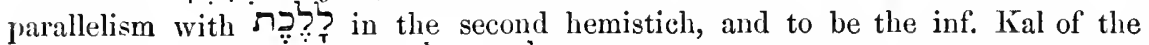
verb חברילם , and a join, with the $ל$ of aragogic $\pi$, after the form of $\pi \underset{T}{\pi} ! ?$ ? to fear (Deut. iv. 10, and many other places), $\pi$ preferring Segol to the slender sound of Short Cherik. Thus, whilst نِ

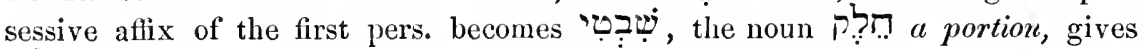
חת?:?יקי: Our reason for regarding an inf. was, that this word is not to be met with anywhere in the Bible as a noun, and that we were thus enabled to avoid giving the $\zeta$ a forced signification, whilst, at the same time, as alrearly observed, we establish a parallelism with

Ver. 9. iา us that, in the opinion of Rabbi Jonah, the verb

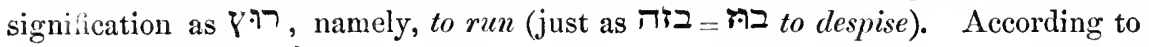

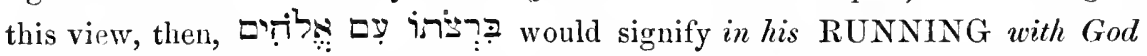
- a more emphatical way, perhaps, of expressing the idea conveyed by the words

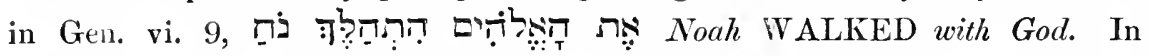
support of Rabbi Jonah's explanation we may quote Ezek. i. 14, where we find

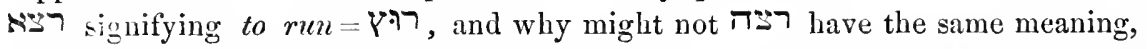
seeing that $\boldsymbol{\Pi}$ and $\boldsymbol{\aleph}$ so frequently interchange? We preferred, however, giving this verb here its more usual signification of being delighted. Rosenmuiller says: "Sed ad verbum רו רו si hebraa dictio referenda esset, scriptum foret iภำ" (!!!) Much as we admire this extremely novel and beautiful form, we must admit that it does not stand alone either as regards its novelty or its beauty, as the form 'ַָ: proposed by the same Commentator, and remarked upon by ourselves in our note upon supra xii. 4, lays at least equal claims to originality and elegance. Alas! what is to become of the Hebrew Bible, if people who write such Hebrew (?) will continue to comment upon it, and if those who cannot read the Rabbinical Commentators continue to consider as first rate critics men whom they should rather regard as blind leaders of the blind?

* See note on זִז supra xxvii. 5. Editor, 1862. 
Ver. 10. $2 \underset{\mathrm{T}}{\mathrm{T}}$ ? which signification $2 \underset{T}{\mathrm{~T}}$ ? has already occurred in this book, viz., supra xii. 3.

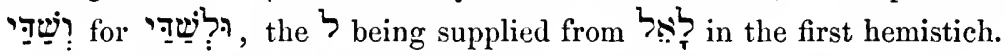

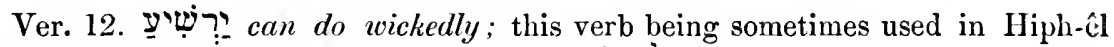

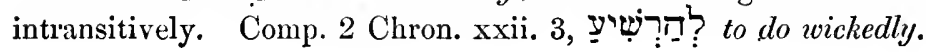

Vers. 13-15. After having laid down, as a principle, that God cannot possibly act unjustly, Elihu now proceeds to shew that this principle is based upon the truth, that no one (as a general rule) ever injures that which belongs to him-a truth which may almost be regarded as an axiom, as it would be in the highest degree absurd to suppose that any one could find a motive for injuring or maltreating that which was his own. An agent or a steward may act wrongfully from a motive of self-interest, but the proprietor himself, what motive can he have to damage his own property? He says:

Who hath charged Him with this earth? Or who hath put upon Him? Given unto Him in charge. The whole universe. If the earth, if the whole universe, were not His own, but belonged to another, He might be supposed to have some motive for governing it wrongfully. Since, however, they are all His own, His work, His creation, is it not the height of absurdity to think that $\mathrm{He}$ would act so as to injure His own? (Ver. 15.) If He were to set His heart upon Himself. If He could be supposed to act from a motive of interest, a motive which He could only find in the pleasure of wronging that which was His own. Ile would gather unto Himself His own spirit and His own breath. 'The spirit and the breath with which He had animated the sons of men. (Ver. 16.) When all flesh together would expire, and man return to dust. Who could call Him to account if He acted thus, or to whom would He be responsible for so doing?

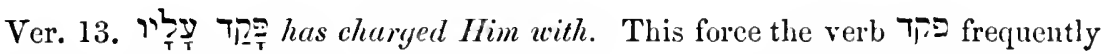

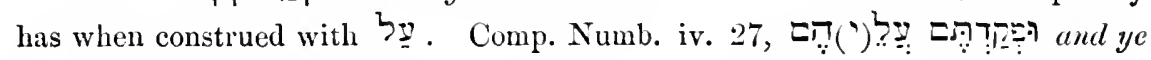
shall give unto them in charge.

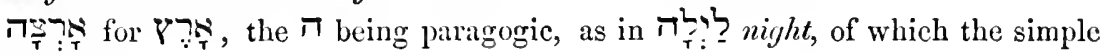
form is ל??

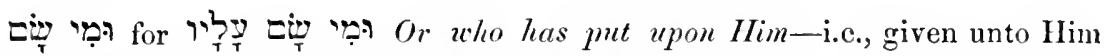
in charge, entrusted him with the government of ? It will be perceived that the עיד is is supplied from the first hemistich. 
[the] universe. In this acceptation this word is taken here by Homberg, who observes that iִ the whole of it, by which it is qualified, justifies us in so translating it.

Ver. 14. יר (in both hemistiches) to Him; i.e., to Himself:

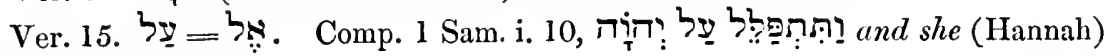
prayed unto Jehovah.

Vers. 16-20. Elihu now goes a step farther in his reasoning, and, turning himself again exclusively to Job, reminds him, that even among mortals it is contrary to all principles and rules of society to impute wickedness and malice to a sovereign, inasmuch as, being lord over his kingdom, and father to his subjects, he cannot have any motive for wronging those he rules; so that if any mismanagement be discovered in a kingdom, it is more natural to suppose it to have had its origin with the ministers and agents of the king, whose self-interest it may have served, than to bring it home to the crowned head, who should be placed altogether beyond the pale of any such suspicion.* Elihu's words are these:

Now, if thou (O Job) hast understanding, hear this. What I am going to say. Give ear to the sound of my words. (Ver. 17.) Shall, indeed, one who hateth justice, rule? Dost thou suppose that one who is chief over a nation, can hate justice? How then wilt thou pronounce wicked, one who is most just? But $\mathrm{He}$ does rule, and therefore must be most just; how then canst thou charge Him with injustice? (Ver. 18.) Doth it behove us to say even to a king, "O worthless-man?" Or to any one among princes, "O thou wicked-man?" (Ver. 19.) Much less should we say so to Him, who accepteth not the persons of princes, nor noticeth a rich-man before a poor-man, because they are, all of them, the work

* We may be allowed, perhaps, to give here a short extract from Mendelssohn's באור on Ecclesiastes viii. 2, where he remarks very pertinently to our subject as follows:

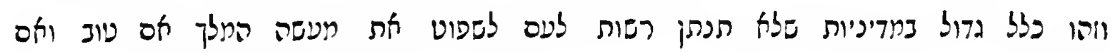

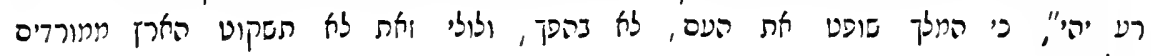
:

"Now this is a great rule in politics, that the people must have no power to pronounce judgment upon the conduct of a king, whether it be good or bad, for the king judges the people, and not the reverse; and if [it were] not for this (great rule), the country would never be quiet, and without rebels against the king and his law." 
for for one from among princes.

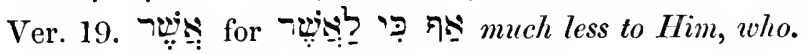

Ver. 20. רִ for for in a moment.

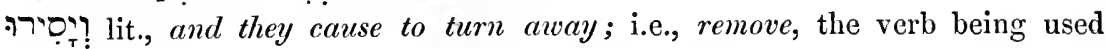
impersonally.

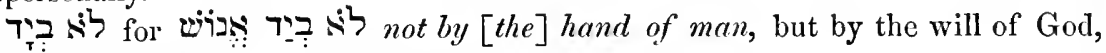
which is carried into effect without any visible agency.

Vers. 21-32. Having established the point, that every thing which proceeds from God must be right and just, Elihu goes on to speak of His omniscience and omnipotence. He says :

Surely, His eyes are upon the ways of man; indeed, He secth all his steps. By day or by night, in light or in darkness, every, even the slightest, movement of man is known to God. (Ver. 22.) There is no such darkness, and there is no such shadow-of-death, that it can be a place of refuge for the workers of iniquity to be concealed there.* (Ver. 23.) Surely He doth not lay upon man so much. He imposes no such heavy task upon man, that he should have any semblance of cause or reason To enter with God into judgment. All that God requires of man is to love Him, and believe in Him, and surely this is not so great a burden, that man should have any reason to murmur and to complain, that more is required of him than he can do. $\dagger$ (Ver. 24.) He breaketh-in-pieces mightymen in an unsearchable manner. Nobody can discover the means,

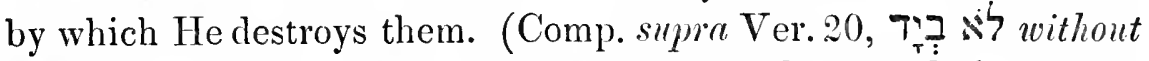
any [human] hand.) And setteth up others in their stead. (Ver. 25.) He therefore noticth their works, and overthroweth them in one night, so that they are crushed. (Ver.26.) In the very place of the wicked-men, He striketh them. To make His finger visible He punishes them upon the very spot, where they had shown themselves rebellious against Him. Yea, in the place where men were beholding them. In open rebellion against llim. + (Ver. 27.) For this reason that they turned back from after Him, and

* The same sentiment is expressed by the Psalmist (Ps. cxxxix. 11, 12) : "If I say, "Surely the darkness shall cover me; even the night shall be light about me. Yea, the " darkness hideth not from Thee, but the night shineth as the day; the darkness and * " the light are both alike to Thee."

+ So we read in Matt. xi. 30, "My yoke is easy, and my burden is light."

$\ddagger$ An instance of this sort is found in the history of Korah and his company, recorded in Numb. xvi. 
considered not any of His ways. (Ver. 28.) So as to bring before Him the cry of the poor-man, for He doth hear the cry of the afficted. No cry, no groan ever escaped the lips of an afflicted or oppressed man, without His hearing it.* (Ver. 29.) When He giveth-quietness. When He looketh upon a man, and bestoweth ease, peace, and comfort upon him. Who then can make-trouble? On the other hand, If $\mathrm{He}$ hideth His face. If He withdraws His favour from man. Who then can behold Him? Who can hope to behold His face, to enjoy His favour, as long as He remains unpropitiated? (It is all one, whether He doeth this. Whether He hides His face. On account of a whole nation, or on account of one man. Who has provoked him. (Ver. 30.) Whether on account of an hypocritical man's reigning, or on account of the snares of a people.t Whether the anger of God, which causes Him to hide His face, arises from the provocation He has received from a whole nation, or from that given by a single man; whether from the reign of a hypocrite, or from the corruption of a whole nation, it is an anger which will abide in the one case, as in the other, so long as the sins which called it forth remainunexpiated and unatoned for.) (Ver. 31.) Surcly, what is proper to be said to God. When chastisement has been received from Him, is, "I have borne. The punishment of my iniquity. I will not act corruptly any more. (Ver. 32.) Besides those sins which I can see, teach Thou me." As for those offences, which I am conscious of having committed, I entreat 'Thy pardon in dust and ashes, but if there are any others, of which I have been guilty unconsciously, or of which I am likely to render myself guilty unconsciously at some future time, point them out to me, that I may repent me of the evil which I have done, and be upon my guard against the evil of which the seeds lie hidden in my heart. "If I have done iniquity, I will do so no more."

Ver. 23. דiע much, a great deal. Comp. Gen. xlvi. 29, "and he wept on his neck עוֹ a great deal."

* "And it shall come to pass, when he crieth unto Me, that I will hear, for I am gracious." (Exod. xxii. 27.)

$\dagger$ The snares of a people; i.e., the corruption of a whole people. For instances of such universal corruption the reader may refer to Gen. xix., where an account of the men of Sodom is given; and to $2 \mathrm{Kings} x$ vii. $24-26$, where he will find recorded the wickedness which prevailed among the nations the king of Assyria had transplanted to Samaria. 


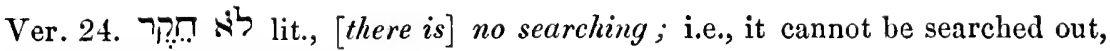
in an unsearchable manner.

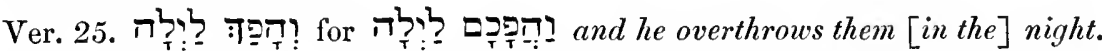
Great and sudden calamities are often described in Hebrew poetry as taking place in the night time. Comp. supra xxvii. 20.

"In the night a whirlwind stealeth him away."

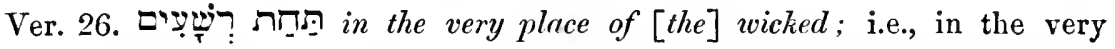
place, in which they are practising their wickedness. Comp. Exod. xvi. 29, "Abide ye every man

" lit., in [the] place of seers, i.e., in the very place, on the very spot, where men are beholding their evil practices.

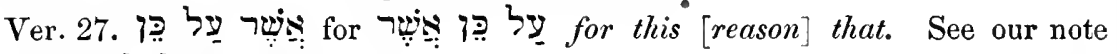

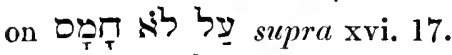

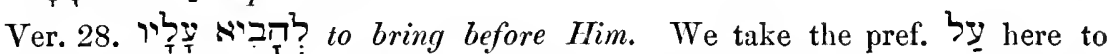

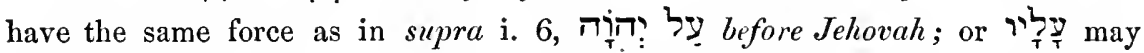

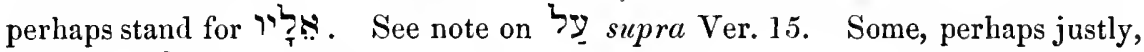
refer the the term the sense would be, that the acts of every one of them are so cruel, as to bring upon him the cry of the poor-man.

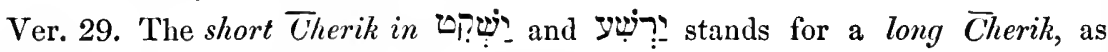

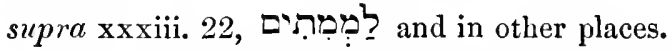

צִ יְ can cause trouble. That the idea primarily conveyed by the verb is that of restlessness and disturbance, has already been explained in our note on

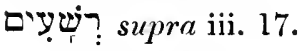

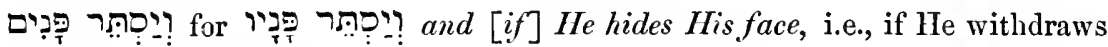
His favour; a phrase commonly used in Hebrew to express the indignation of God. Comp. supra xiii. 25.

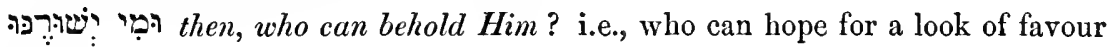
from Him.

Tִ alike; i.e., it is all one, it makes not the slightest difference, whether His indignation be provoked by a whole nation, or by a single individual ; whether by the reign of a hypocritical man, or by the corruption of a whole people. For

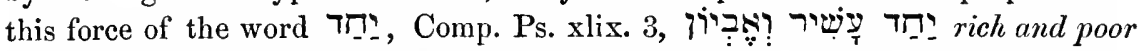
alike. It will be perceived, that we take the latter part of this verse, as well as the next verse, to be parenthetical.

Ver. 30. מִפר on account of [the] snares of a people, i.e., the corruptions of a people, by which they ensnare both themselves and others.

Ver. 31. דֶה it is meet to be said. That the infinitive is used in Hebrew to express finess and propriety, has been mentioned in our note on הִַּ supra Ver. 18. The Segol under the $\boldsymbol{B}$ stands for Tsayreh, the word being the inf. 


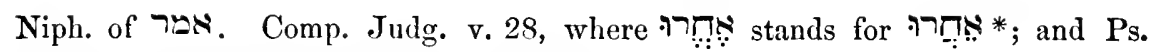
li. 7, where we find

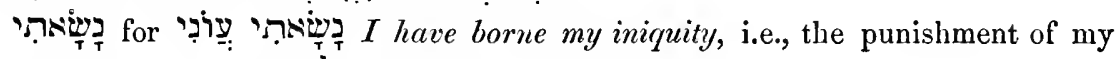
iniquity. See note on

I will not act corruptly any more. Comp.

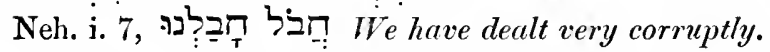

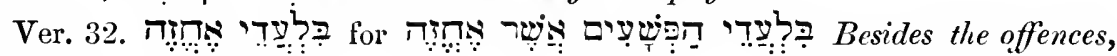
which $I$ see; i.e., if there are any offences I have already committed, or may commit, unconsciously.

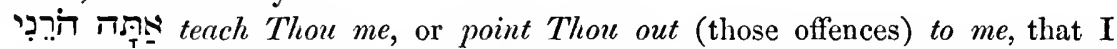
may repent of those $\mathrm{I}$ have committed, and refrain from those $\mathrm{I}$ otherwise might commit.

I shall not do so again.

Vers. 33.-35. Elihu now proceeds to prove to Job by an incontrovertible and overwhelming argument, that for a man to desire that the ways of Providence should be regulated according to his own views and opinions, is an absurdity bordering upon folly and madness, inasmuch as, from the very opposite opinions which prevail among mankind, if God acted according to the opinion of one man, He must needs act in a manner diametrically opposed to that of another. 'Ihe speaker's worls to Job are : Shall He requite it according to thy mind? Shall He requite the conduct of a man according to what thou deemest right? Shall $\mathrm{He}$ omit to do a thing, Because thou rejectest it? Because thou refusest thy approval; and, on the other hand, shall He do a thing, Because

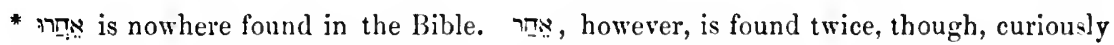
enough, as two very different parts of the same verb. Once, it is used as the third pers. sing.masc. past Pi-al (Gen. xxxiv. 19); and once, with ר conv. (זָה , Gen. xxxii. 5), as the first pers. sing. fut. Kal. Buxtorf, indeed, in his Concordance gives $P i-\hat{a} l$, but Mendelssohn in his comment on the passage states that it is Kal, and compares

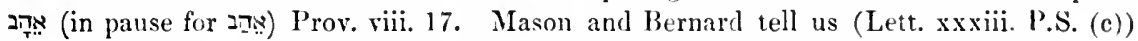

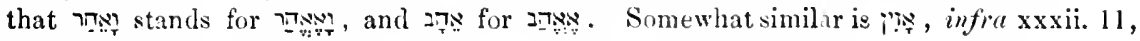
for

므: occurs twice, viz., Deut. xix. 6, and (in pause 5 הत्.) Ecc'es. iv. 11. In both places it appears to be the fut. Kal (from $\approx \pi$ ), or the fut. Niph. from הכב . Kimchi, in his

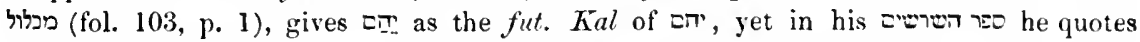
the

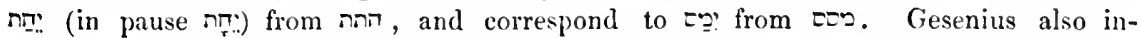
clines to this latter view, which he speaks of as if it had originated with him. In

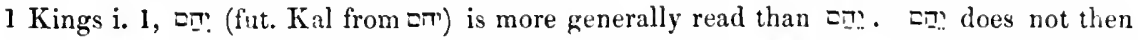
occur as a past Piâl, though, to judge from the form which gave rise to this note, the past Pial, third pers. sing. masc. of 2 ' would have this form.-Editor, 1862. 
thou choosest it? Because thou approvest of it, so that thou shouldest first pronounce what is fit, and what unfit, for Him to do; But why not $I$ also? Why should not I have the same privilege of suggesting to Him what I think fit, or unfit, for Him to do? And this question of course every one may ask of thee as I do, why, namely, he should not enjoy the same privilege, which thou wonldest have, of dictating to God the course $\mathrm{He}$ must pursue. And what knowest thou? By which thou couldest meet that question. Spreak. If in any way thou canst upset this my argument, speak out, and do not keep back thy wisdom from me. (Ver. 34.) Men of understanding will say for me. I need not say it, every sensible man will say it in my stead. $Y e a$, every wise man hearing me. Will at once come forward, and say, (Ver. 3j.) "Job speaketh without knowledge, and his words are without wisdom." There is not one man of sense, who has heard this my argument, who will not take upon himself to answer thee in these words, and so spare me the necessity of answering thee myself.

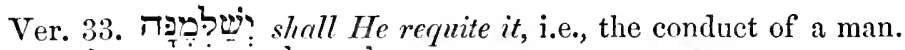

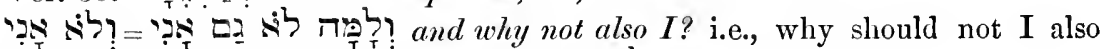

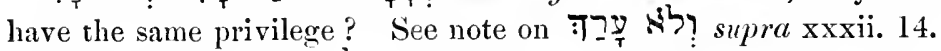

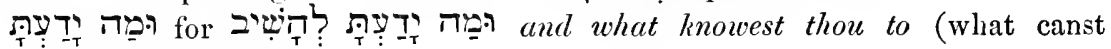
thou) answer (to this question)?

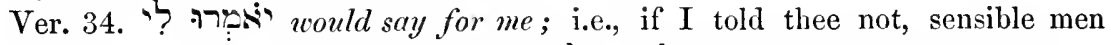

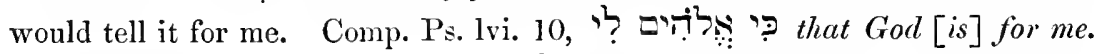

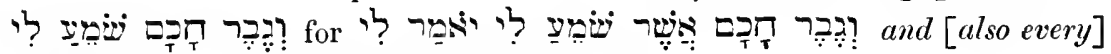
wise man, who listens to me, would say for me.

Vers. 36, 37. Elihu now addresses his words to God, saying:

$O$ my heavenly Father! let Job be proved for ever. Do not now release him from his sufferings, but let this ordeal continue, in order that auswers may be given to iniquitous men. In order that, in case other iniquitous men should murmur and rebel, when afflictions came upon them, the example of Job might be held up as a warning to them to desist, —of Job, whose murmuring and rebellion against God availed him nought. (Ver. 37.) For, otherwise. If he were now to be released from his sufferings, he would think that it was on account of his grumblings and murmurings. He would add rebellion to his sin, and imagining he had gained 
his release by finding fault with the dispensations of Providence, He would triumphantly clap his hands amongst us, and would multiply his worls against God. He would actually go so far as to say, that by grumbling and nurmuring he had forced God to release him.

Ver. 36. ירָ $O$ my Father. We could see no reason (as many others have done), for giving this word any other than its simple and natural meaning, seeing that God is addressed as Father twice in Isaiah, viz., in Chapters lxiii. 16 ; lxiv. 7.

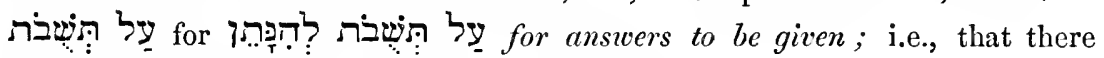
should be answers ready to be given (to iniquitous men.)

Ver. 37. 'כִ for for, worthout this; if this should not be the case, if he should now cease to be proved.

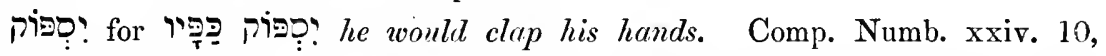

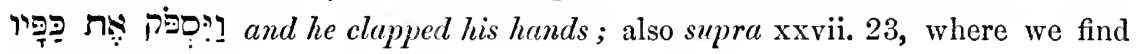
pien? with a ש.

\section{CHAPTER XXXV.}

IN one of his discourses (supra xxiv. 1) Job had plainly said, that matters go on here below in a way so contrary to human notions of right and wrong, that even pious men, men loving God, can perceive nothing to intimate that He rules the world-thus expressing strong doubts as to the existence of a Divine Providence; and these doubts we shall hear Elihu, at the end of this Chapter, reprove him for harbouring, in energetic and emphatic terms. On the other hand, one of Job's three friends, when accusing him of entertaining the heretical and erroneous idea, that, because God is enthroned in the highest heavens, $\mathrm{He}$ employs Himself only with the government of the sublimer beings, who there surround Him, without bestowing a thought upon this insignificant and abject world,- - had asked him, whether he intended keeping to the way which wicked men of old, heretics like himself, had trodden. (See supra xxii. 12-15.) 
With this question Elihu is also very much displeased, as, in his opinion, Job, in doubting the existence of a Divine Providence, was infinitely worse than those wicked men of old, to whom his friend had compared him, inasmuch as there is a vast difference between a nation, or community (such as those wicked men alluded to may probably have been), groaning under the scourge of an oppressor and tyrant, and a man, who (like Job) suffers from afilictions sent upon him by God, and is fully aware that these afflictions proceed directly from God. In the case of the nation or community, if, after they have cried to God for help, and no help has been sent them, they then declare it to be their opinion that it is quite useless to cry to Him, for that He does not seem to notice what is going on here below-they give, indeed, such evidence of the wickedness of their heart, that every rightlythinking person must condemn them as great sinners, but still it cannot be said, that there is not some semblance of reason on their side, or that their words involve any inconsistency or contradiction. In the case of the man, on the contrary, who admits he is fully aware that the afflictions, under which he labours, proceed directly from God (as Job had admitted over and over again), and yet declares his doubts as to whether there is a Providence, he, indeed, may be pronounced deficient in consistency and judgment, seeing that he manifestly contradicts himself. To compare him therefore to the wicked men of old, as Eliphaz had done, is, in Elihu's opinion, to pay him a compliment which he very ill deserves.

It was thought necessary to make these few prefatory remarks, as they are the hinge upon which the whole of Elihu's reasoning in this Chapter turns, and it is only owing to their not having discovered this fact, that the Commentators and Translators we have consulted have, one and all, exhibited as incoherent and void almost of meaning, a Chapter, which is a master-piece of close and solid reasoning.

Vers. 2-14. Dost thou think this right? This, namely, that thou saidst, "My righteousness is more than that of God." (Ver. 3.) 'That thou saidst, what will thy righteousness profit thee, What advantage shall I derive from my righteousness more than from my sin? (Comp. supra ix. 22; x. 15). (Ver. 4.) I will answer thee, and thy firiends with thee. I will give thee such an answer, 
that thy friends will perceive that they too were at fault. (Ver. 5.) Look unto the heavens, and consider; and behold the clouds, which are higher than thou. Which are so high above thee. (Ver.6.) If thou hast sinned, what effect canst thou produce on Him? And, if thy transgressions are numerous, what canst thou do unto Him? (Ver. 7.) If thou art righteous, what givest thou Him? Or what doth He receive of thine hand? (Ver. 8.) A man like thee only can thy wickedness affect, and thy righteousness only a son of man. Consequently, if God desires to see thee a good man, it is not for His, but for thine own, benefit. (Ver. 9.) If men cry unto God on account of the multitude of oppressions. Which they suffer at the hands of those high in power. If they cry aloud on account of the arm. The power. Of great-men. Who tyrannize over them (Ver. 10), When, namely, the oppressor, who uttereth songs in the night. Who passes the whole night in feasting and revelry. Doth not say within himself, "Where is God my Maker? Is there not in heaven a God, who has made them as well as me? (Ver. 11) Who teacheth us men to be more than the beasts of the earth, and hath made us wiser than the fowl of heaven." If there is a God in heaven, who has blessed us with intellect and reason, and given us a conscience to teach us, that might is not right, that, when we take advantage of our strength and power against the feeble and the weak, we degrade ourselves to the level of the brute, and that we then resemble rather wolves and tigers than men-if there is such a God, how can I venture to oppress my fellow-creatures in His presence? (Ver. 12.) Then. When the tyrant is one who does not indulge in such reflections. Men cry (when God doth not answer them), on account of the arrogance of the evil-doers, saying, (Ver. 13.) "Surely, in vain do we cry, God heareth not, and the Almighty doth not behold it." Our oppression and misery. Impressed as they are with the stamp of corruption and sin, such words are still intelligible, and cannot be said to be altogether illogical. (Ver. 14.) But canst тноч, O Job, indeed say, that thou dost not behold Him (God)? Canst thou at all say, hast thou any pretext for saying, that everything in this world is left to chance, and that God cares not for what goes on on earth ? (Comp. supra xxiv. 1.) Thy cause is before Him. It has been admitted by thee, over and over again, that thy afflictions proceed 
directly from God (Comp. supra vi. 4 ; ix. 17, 18 ; xvi. 11-14, et passim), so that thou hast involved thyself in contradictions, such as no man of sense could do; and these contradictions it was of the highest importance to point out to thee, in order that thou mightest submit with patience and resignation to the will of God, And mightest wait for IIim. For His help.

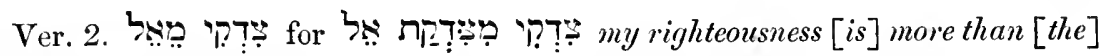
righteousncss of God.

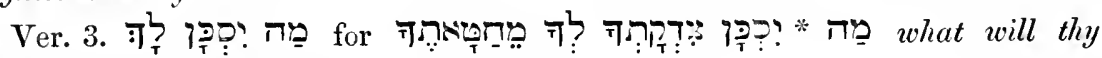
righteousness profit thee more than thy sin?

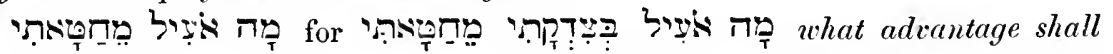
I have from (lit., by) my righteousness more than [from] my sin? So Jarchi understood this verse, for he observes on it :

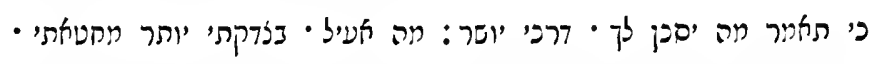

"For thou sayest, What will profit thee? [namely] the ways of righteousness; what advantage shall I have? [namely] from my righteousness more than from my sin."

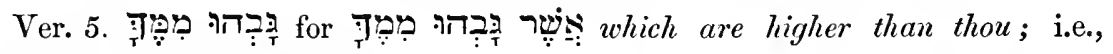
which are so far above thee.

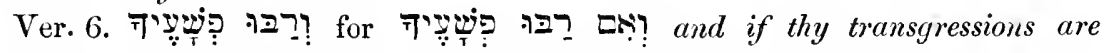
numerous; the part. being supplied from the first hemistich to the second.

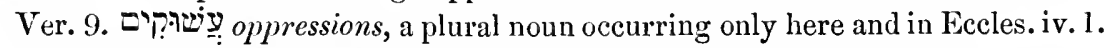
זעי to be in this instance intransitive in Hiph-êl, as it is in Kal ; and as in-

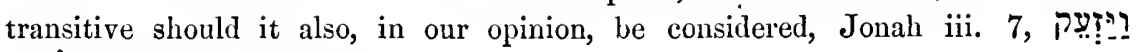

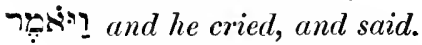

ำ 1 lit., from [the $]$ arm of $[$ the $\rfloor$ great; i.e., from the power of great men. Comp. רִ̣ (supra xxii. 8) a man of arm; i.e., a man of power, a powerful man.

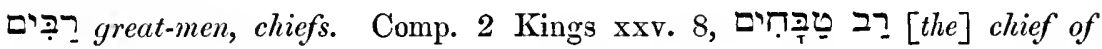
[the] guards.

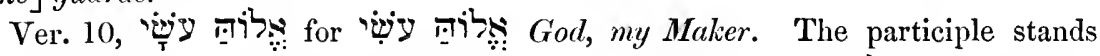
in the plural as a plural of excellency; or it may be that تئis is here used

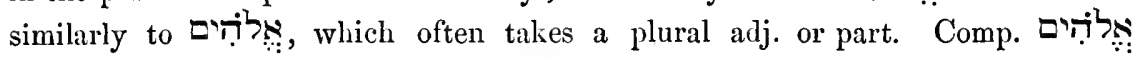

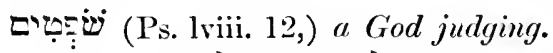

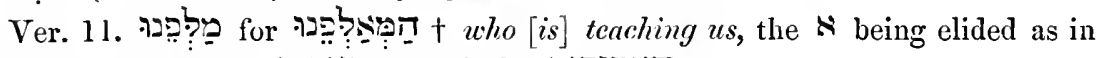

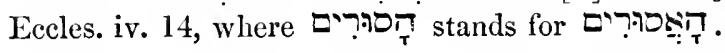

* As the noun is fem. and the verb precedes, the masc. gend. may be used. See note on supra xx. 9. Editor, I862.

$\dagger$ The affix being object. and not possess., the employment of the def. art. together

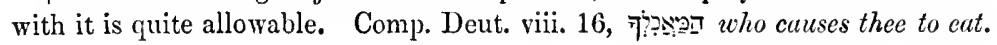


Ver. 12. שָ then, as in Ps. cxxxii. 17, and Eccles. iii. 17.

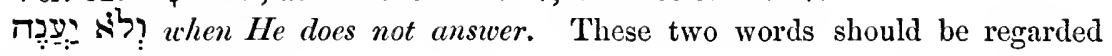
as parenthetical.

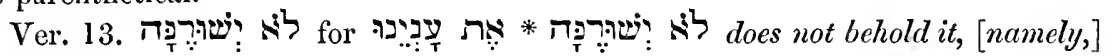
our misery.

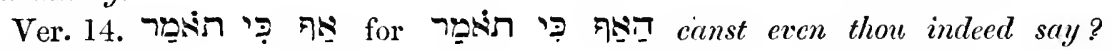

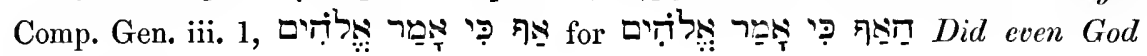
indeed say?

דִ דִינ: thy cause.

Vers. 9-14. Should be construed thus:

Ver. 9.

אִ When they cry, (i.e., when men cry)

מֵרוֹב יעיטשוּקים on account of [the] mullitude of oppressions (which they have to endure);

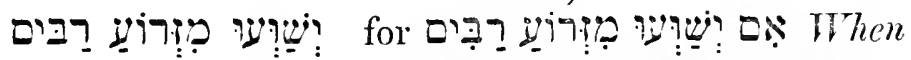
they cry-loud on account of [the] arm (power) of greatmen (i.e., of the great men, who oppress them);

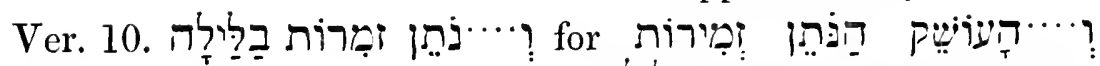
And the oppressor, who utters songs in the night (i.e., who indulges in noisy revelry the whole night long),

לה אֵֵָ Does not say (i.e., does not ask himself),

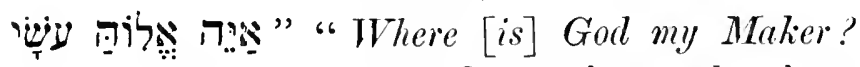
(i.e., God, who made them as well as me?)

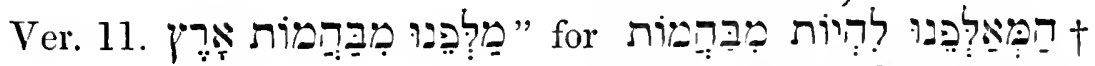
"Who teaches us to be more than [the] beasts of [the] earth (i.e., who gave us intellect and reason to control

* For a pleonasm of this sort, Comp. Exod. ii. 6, הציב and she sav it [namely] the child.

† The employment of the def. art. here has been explained, page 326 (note). 
our passions, and warn us against degrading ourselves to the level of brutes, by taking advantage of our strength and power),

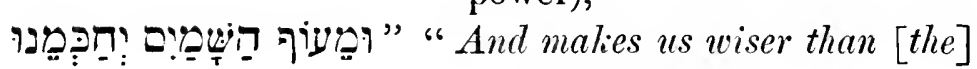
fowl of heaven ;"

Ver. 12.

こய̛ं Then (i.e., when men cry because of oppressions, and their hardened oppressor does not make the above reflections),

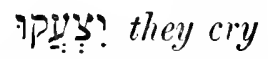

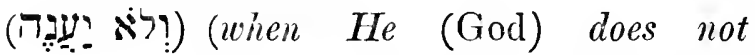
answer, i.e., does not release them from their sufferings), Ong of account of [the] arrogance of [the] wicked, [רisk?] [saying],

Ver. 13.

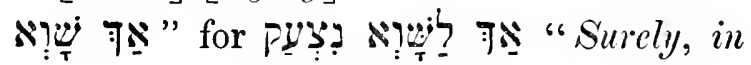
vain do we cry,

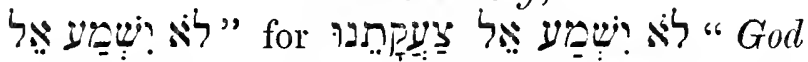
does not hear our cry,

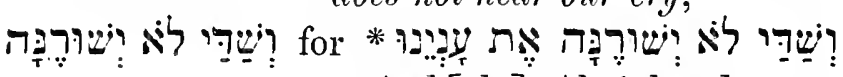
"And [the] Almighty does not behold it" (namely, our misery. Words like these must shock every good man, and deserve the severest punishment, still they cannot be said to be altogether uncalled for; but with thee, $\mathrm{O}$ $\mathrm{Job}$, the case is altogether different, )

Ver. 14.

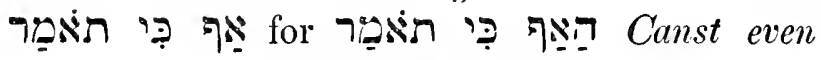
thou indeed say

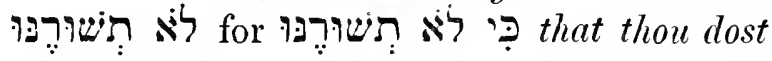

* This pleonasm has been supported by an example, page 327 (note). 
not behold Him (God) (i.e., that thou dost not recognise the finger of God in thy afflictions)?

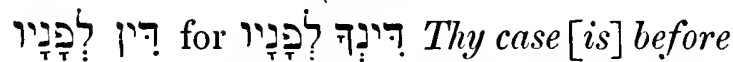
Him (i.e., thou thyself hast admitted that thy sufferings are his work);

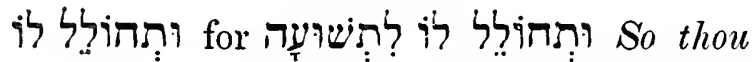
must wait for Him for help (but do not indulge in such palpable contradictions as thou dost, when thou sayest, that this world seems to be without a supreme ruler, and at the same time admittest that thy affliction came upon thee from God).

Vers. 15, 16. Having thus exposed the contradictions in which Job had involved himself, Elihu proceeds to say:

And now. Now that I have shown thee, O Job, that thy doubts as to the existence of a Divine Providence are not only in the highest degree sinful, but also clash with thine own words, I maintain that that, which His anger hath visited upon thee, is, compared to thy sinfulness, as though it was nothing. Thy sins are so great, that the chastisement thou hast received is anything but commensurate with them-indeed, may be considered as a mere nothing in comparison to what thou didst deserve. Indeed, He (God) hath not taken cognizance of a great multitude of thy sins. (Ver. 16.) So that Job hath opened his mouth with vanity. His reasoning has been anything but solid and substantial. And multiplieth words without knowledge.

Ver. 15. שפ multitude, either from פo abound, to be numerous, or הivis to spread widely.

Jarchi seems to have understood this verse as we do. His words are : 
ברוב מטאיך התנהג הבורא כואילו לא ידעם

"With regard to a great multitude of thy sins, the Creator conducts himself as though He did not know of them."

This verse should be construed thus:

?ִעִ And now (i.e., now that I have convicted thee of having spoken not only sinfully, but also inconsistently and incoherently, I say that)

政 has visited upon thee (i.e., the punishment, which He has inflicted upon thee, is)

aִ as though nothing (I consider it as a mere nothing in comparison to the enormity of thy sins);

草 So that IIe did not tuke cognizance of a great multitude of thy sins (i.e., in His infinite mercy $\mathrm{He}$ has overlooked thy sins to a great extent).

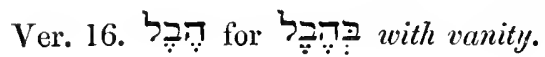

\section{CHAPTER XXXVI.}

Vers. 2-7. Elihu opens the present discourse (which is addressed to Job), by overturning that most pernicious doctrine which he had referred to in the preceding one, as entertained by those deluded and benighted people, who think that, because God is majestically enthroned in the highest heavens, He cannot humble Himself so far as to notice what is going on on earth. (Comp. Chapter xxii. 12-15.) He says:

Wait for me a little. Have yet a little patience with me. And I will shew thee, that I have still words to bring forward on 
behalf of God. (Ver. 3.) I will take up my reasoning from afar. I will now dive more deeply into the subject, and bring up arguments more forcible still than those which I have hitherto employed. And I will ascribe righteousness to my Maker. I will shew that all my Maker doeth is just and right. (Ver. 4.) For truly my words are not false. The words I addressed to thee, $\mathrm{O}$ Job, in my last

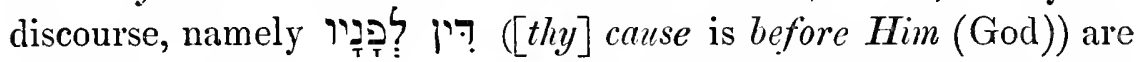
not false, but quite true. He who is perfect in knowledge is with thee. Although so gloriously enthroned in Heaven, yet God is with thee, by thee, and around thee; He noticeth all thy movements, even the most hidden of thy thoughts lieth unveiled before $\mathrm{Him}$, and $\mathrm{He}$ dealeth with thee according as $\mathrm{He}$ hath decreed concerning thee in His high wisdom. (Ver. 5.) Lo! God is mighty, yet He doth not despise. The work of His hand. Although mighty in power and wislom. Notwithstanding His majesty and omnipotence, He condescendeth to notice the doings of men here below.* (Ver. 6.) He will not preserve the wicked-man alive; but He will establish the justice of the afflicted. Of those afflicted by the wicked man. And as He taketh vengeance upon the wicked for their oppressions, so, on the other hand, doth He favourably look upon the righteous, to reward them for their justice. (Ver. 7.) He withdraweth not His eyes from the righleous, but with kings doth $\mathrm{He}$ establish them on the throne for ever, so that they are exalted.

Ver. 2. רอ wait. This verb, which every where else signifies to surround, is here used in the sense of to wait, which it has in the Aramaan and Chaldaic

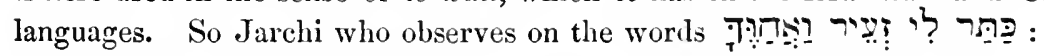

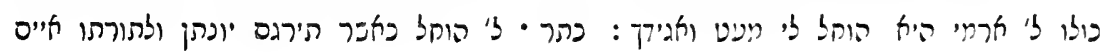

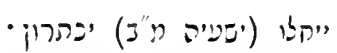

"The whole is in the Aramæan language [signifying,] Wait for me a little and I will shew thee. רַּ Signifies wait; so in the passage (Isa. xlii. 4); (and for His law [the] islands wait) Jonathan renders ,

* Thus the Psalmist says, (Ps. cxiii. 5-8.) "Who is like unto Jehovah our God, who dwelleth on high. Who humbleth Himself to behold the things that are in hearen, and in the earth! He raiseth up the poor out of the dist, and lifteth the needy out of the dunghill; that He may set him with princes, even with the princes of His people." And again, (Ps. cxxxviii. 6,) "Though Jehorah be high, yet hath He respect unto the lowly, \&c." So also in Isaiah we read (Chap. lvii. 15.) "I dwell in the high and holy place with him also that is of a contrite and humble spirit, to revive the spirit of the humble, and to revive the heart of the contrite ones." 


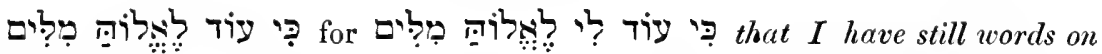
behalf of God. For this force of the $ל$, comp. note on הִ supra xiii. 7.

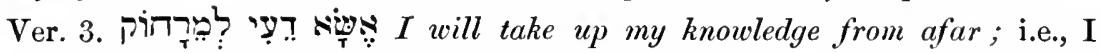
will dive more deeply into the matter, which he actually does by applying what he had before said in general terms to Job's case in particular (See infra vers.

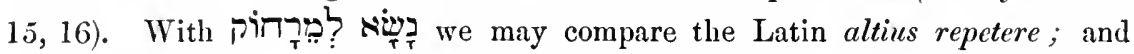
the French reprendre une cliose de plus haut. Those who understand Elihu to say that he intends speaking of the great phenomena of nature, rain, dew, light, \&c., as matters that have escaped the attention of the other speakers, must have forgotten, that these phenomena had been referred to more than once before Elihu interposed. Comp. supra v. 10 ; xii. 15 ; xxv. 5 ; xxvi. 8, 13, 14;

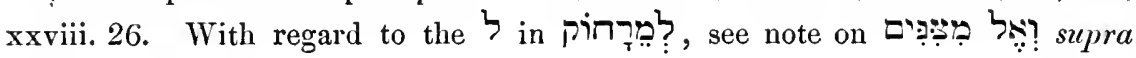
v. 5 .

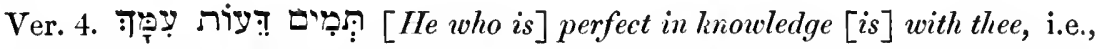
deals with thee. Many Commentators are of opinion that Elihu here refers to himself, in which case the passage would be grist to the mill of those (and they are not few), who are determined to see in Elihu a presumptuous and arrogant young man; but we cannot for a moment think that he would bestow on himself an epithet, which in the next Chapter (Ver. 16) he gives to God Almighty. There is no means of discovering whether the Translators of the Auth. Vers. referred the epithet to God or to Elihu, but we should for their credit hope that they took it to apply to the former. Aben-Ezra considers it to refer to God as we do, but Jarchi regards it as applied ironically to Job, when the verse would read as follows : For verily my words [are] not false, [O thou, who] with thyself (i.e., in thy opinion) [art] perfect in knowledge, i.e., who art presumptuous enough to think thou surpassest all other men in knowledge. Jarchi's paraphrase of the verse runs thus :

\section{הנה אתקיל עתה לדבר עמך שאתה סבור שדעתך שלימה:}

"Behold! I will now begin to speak with thee, $O$ thou, who art thinking that thy knowledge is perfect."

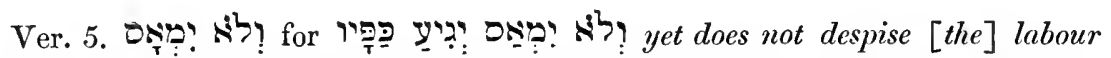
(the work) of His hands, i.e., men, whom He has wrought. Jarchi supplies the

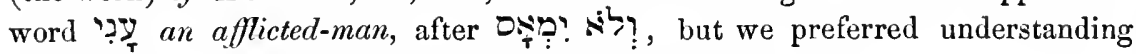

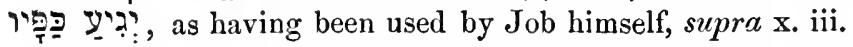

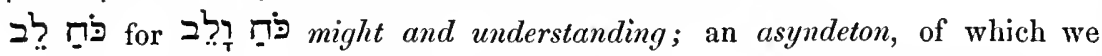
have had more than one instance in this book. Comp. also Habak. iii. 11.

Ver. 7. Iִ In He establishes them, the 1 being redundant; or it may have

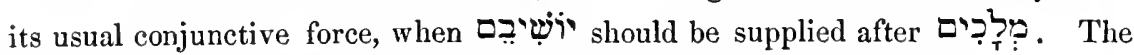
plural affix $\square:$ refers to

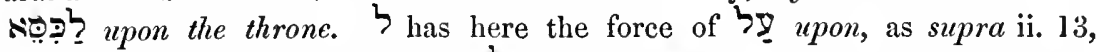

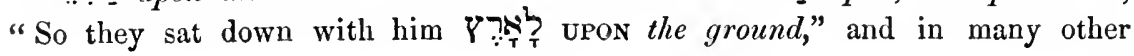
places. 
Vers. 8-14. Having shown that the eye of God is open upon all the ways of the sons of men, and that both the wicked and the just ultimately meet with the reward which they deserve, the speaker proceeds to say that, when affliction comes even upon the best of men, we must not be surprised thereat, as such affliction is not to be regarded as a chastisement inflicted on them by God in His wrath for past offences, but rather as a warning sent by Him in His love and mercy, that they may know that they were upon the point of transgressing in some way, although unconsciously, and that they indubitably would have transgressed, if they had been suffered by Him to continue to flourish and live in happiness and ease. He says :

And if they (the righteous mentioned in ver. 7) are sometimes bound in chains. If their prosperity receives a check. If sometimes they are caught in the cords of affiction, by this means (Ver. 9,) He sheweth them what their work would be, if their transgressions should prevail. He intends their affliction as a hint that the seed of corruption was beginning to germinate within their heart, and that they were on the eve of becoming degenerate, and would have become, degenerate, had they been suffered to live any longer in the enjoyment of ease and comfort. (Ver. 10.) So that by this chastisement He openeth their ear to instruction, and telleth them, that they should draw back from iniquity. He tells them that sin is crouching at the door, * waiting to devour them, thus warning them of their danger, and bidding them beware. Consequently, when affliction is sent by God in His mercy on good men, it is not-as being merely a warning-intended to be of any long duration, so that their future fate will depend upon their own conduct during that affliction. (Ver. 11.) If they obey, and serve Him. Even when affliction comes upon them, and are wise enough to see and to know that, inasmuch as it comes from God, it must be for their good, their sufferings will soon have an end, and They will again spend their days in prosperity, and their years in pleasures. (Ver. 12.) But, if they do not obey. When affliction comes upon them, and, instead of serving God, rebel and kick against the pricks. They will pass away by the sword. They will die an untimely death. And expire for want of knowledge.

- Gen. iv. 7. 
Because they were unable to perceive that their afflictions were sent upon them for their good. (Ver. 13.) So that the hypocrites in heart lay up anger. They turn the mercy of God into anger, so that the affliction, which was, and ought to have been considered by them, a mark of the grace of God, is now continued upon them as a mark of His wrath. Because they do not cry unto Him for help, when He bindeth them, but, instead of making prayer, indulge in grumbling and rebellious murmurings. (Ver. 14.) Their soul, therefore, dieth in their youth, and their life is spent with the unclean. They will come to a miserable and untimely end, and even during the short time they are suffered to exist, they will be ranked among the vilest outcasts of society.

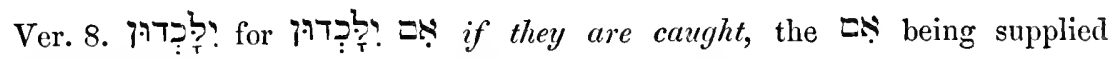
from the first hemistich.

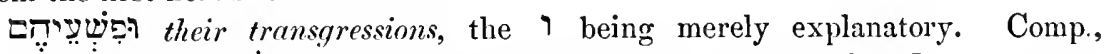

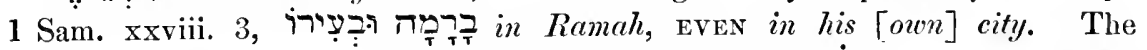

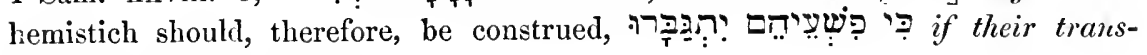
gressions should prevail.

Ver. 14. The noun $ש T_{T}$ an unclean-man (sodomite), occurs also in Deut. xxiii. 18.

Vers. 15-19. Elihu now brings the beautiful train of reasoning contained in Vers. S-14 to a close, and applies it to Job's case. He says: From what I have observed, results, that $H e$ delivereth the afflicted-man by his affliction. The very affliction which is sent upon a good man, and which, if properly received, would only last for a very short time, is intended to rescue him from total ruin and destruction, which would have been his lot, had he not received such a warning. And openeth their ear by chastisement. By the very chastisement He inflicts upon them, He reveals to them, that they are on the point of falling and becoming degenerate, and warns them to stand upon their guard. (Ver. 16.) Yea, also thee, O Job, hath He removed! By means of the afflictions IIe hath sent upon thee. From the mouth of an adversary, who was lurking for thee, and was greedy to devour thee, namely, Ease, in the place of which there was no straitness. Ease, uninterrupted, unbroken, for one moment. And that which came down upon thy table, full of fatness. That ease and that opulence, in which thou hast lived so many years, 
were the worst and most dangerous adversaries thou ever hadst to encounter, as they would have tempted thee to deviate from thy former course of life, to become proud instead of humble, and rebellious against God instead of devoted to Him. Now, from all this, from all these perils and dangers, God intended to release thee by the afflictions, which He sent upon thee, and which would in all probability have lasted but a very short time, hadst thou humbled thyself before Him in prayer, and received His chastisement with resignation. (Ver. 17.) But thou hast been full of the pleading $[s]$ of the wicked-man. Instead of praying, thou hast done nought but murmur and grumble; instead of bowing with submission to God's will, thou hast kicked against the pricks, therefore Judgment and justice lay hold on thee. As it is, God will not free thee from thy sufferings, nor can $\mathrm{He}$ in justice do so, as long as thou shewest thyself rebellious against Him. (Ver. 18.) For now it is wrath. The very sufferings, which were originally sent upon thee through the grace and mercy of God, now torture and rack thee because of His wrath; I warn thee therefore, yea, take heed, Lest He should remove thee with one blow, which no ransom, however great, will enable thee to avoid. For that which is a ransom among men is no ransom with God. (V. 19.) Will IIe esteem thy riches? No, neither gold, nor all the endeavours of strength. The only ransom He will accept is a penitent and contrite heart.

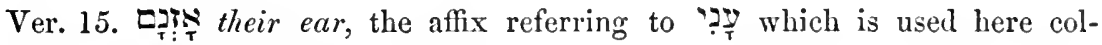
lectively = afflicted - men .

Ver. 16. בחר רִ lit., width; i.e., roominess, ease.

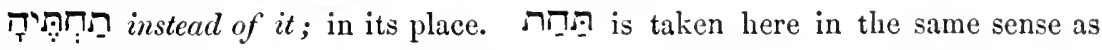
supra $\mathrm{xxx} .14$.

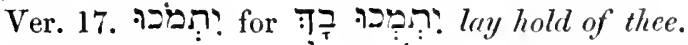

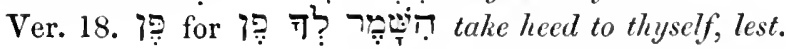

Vers. 16-1S should be construed thus:

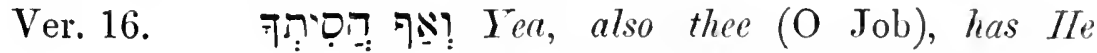
removed (i.e., snatched away)

fiom [the] mouth of an adversary (who was about to devour thee; and that adversary was)

ב끈 Roominess (i.e., ease) 


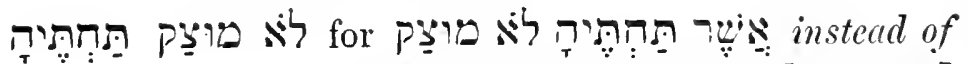
which [there was] not [even any] straitness (i.e., ease never interrupted by any straitness),

And [the] coming down of thy table (i.e., and that which came down, which was set, upon thy table),

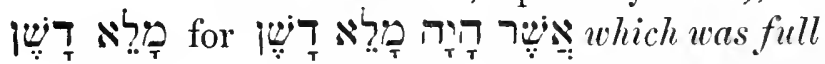
of fatness (i.e., that uninterrupted ease which thou didst enjoy, and the luxuries, with which thy table was loaded, were the most dangerous adversaries thou couldst have had, inasmuch as they had nearly led thee to become proud, arrogant, and rebellious against God. But from this dangerHe hath rescued thee by sending on thee thy present afflictions, which, however, if thou hadst received them with resignation, would have been of very short duration indeed).

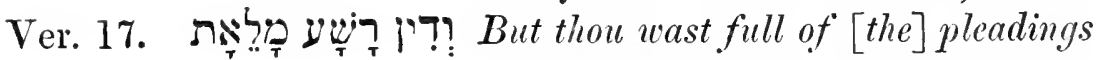
of a wicked-man (i.e., instead of resigning thyself to God's will, thou hast done nothing but murmur, and use the language of invective and insult, and therefore)

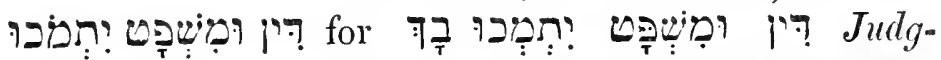
ment and justice lay hold on thee (therefore, thy sufferings still weigh heavily upon thee).

Ver. 18.

בִּ Tor [there is] wrath (i.e., now God is really angry with thee. When He first sent thy sufferings upon thee, He shewed Himself full of grace and mercy towards thee, inasmuch as His object was to 
rescue thee from ruin and perdition, but now thy sufferings are a mark of His wrath, and therefore)

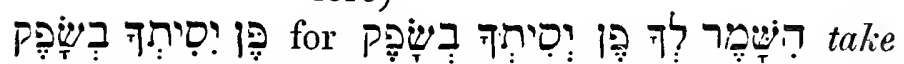
heed to thyself, lest He remove thee with a blow (i.e., lest with one blow He despatch thee, and cut thee off from among the living).

Vers. 20-26. Job having said that he longed and prayed for death (supra vi. 9,11 ; xvii. 16), nay, that in the agony of his pain, he was sometimes tempted to commit suicide (supra vii. 15), Elihu admonishes him not to allow such sombre ideas entrance into his mind-as death would be sure to come some day and carry him away, without there being any occasicn for him to hurry to meet it-and concludes his admonition by recommending him to admire God in his works, instead of brooding over his miseries, and indulging in metaphysical researches, which are altogether beyond the sphere of a human being. He says:

Do not thou pant for that eternal night (death), which is sure to cut off whole nations on the spot where they are. Thou mayest feel confident, therefore, that it will not overlook thee; what need, then, to run with open arms to meet it? (Ver. 21.) Be on thy guard! do not turn to this sin. To suicide, a sin, which in enormity far surpasses all others, inasmuch as it is one which cannot be atoned for by repentance. I think it my duty to warn thee against this terrible $\sin$, Because thou seemest to choose this rather than affiction. (Ver. 2.2.) Lo! God is exalted in His power; who is an instructor like Him? Who knoweth like Him the precise time, when man requireth admonition and instruction, and the means, by which such admonition and instruction can best be conveyed to him? (Ver. 23.) Who hath enjoined on Him His way? Who hath traced out for Him the course He is to pursue? Or who ever said to Him, "Thou hast wrought iniquity?" Instead of scrutinizing the acts of God, which are altogether inscrutable (Ver. 24). Remember that thou oughtest rather to exalt His work, which men contemplate. (Ver. 25.) All men behold it, even frail-man can perceive it from afar. His works 
are so great and so wonderful, that even men of the lowest order of intellect cannot fail to be struck with them, and are irresistibly led to admire and adore Him, who planned and exccuted them. (Ver. 26.) Behold! God is exalted beyond our comprehension; the number of His years is unsearchable. We can as little conceive His greatness and His majesty, as we can set limits to the eternity of His existence.

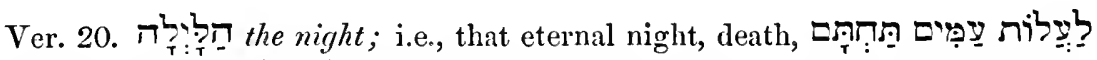

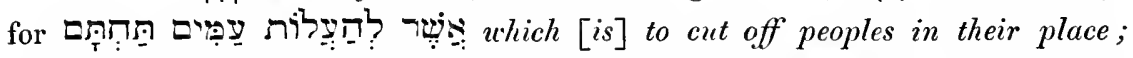
i.e., which is sure to destroy whole nations in the very place where they are-thus coming to seek them out, and not requiring them to go to him. That the verb עלה is used in Hiph-êl in the sense of cutting off, or removing from this world,

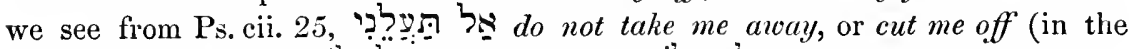

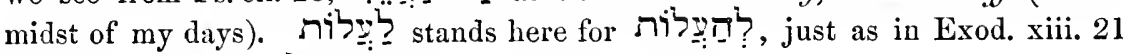

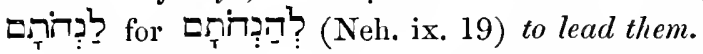

פת this word is used infra xl. 12. When the reader has consulted the passages here referred to, he will, we doubt not, be puzzled to understand how Schultens came to characterize this simple verse as "Profundissimus locus, velut vortice quodam nos circumacturus." Ralbag's interpretation, we are glad to see, agrees with our own.

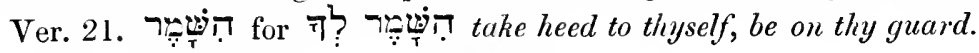

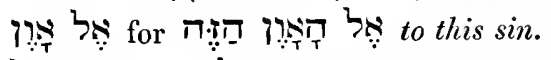

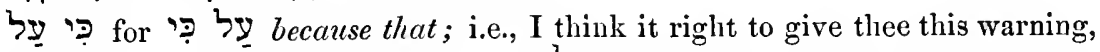
because, \&c. Comp. Deut. xxxi. 17, פִ פַ because (my God is not with me,

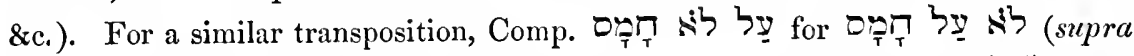
xvi. 17). Comp. also supra xxxiv. 27. It was in consequence of the verb בחב being nowhere found construed with tion; the second hemistich of this verse, therefore, should be construed thus:

(It is my duty to give thee this admonition,)

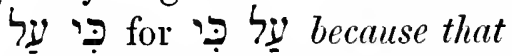

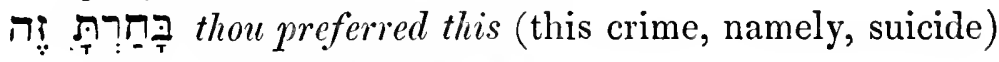
פִ rather than affiction.

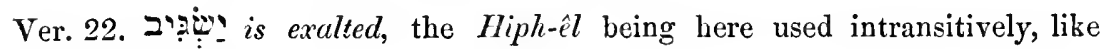

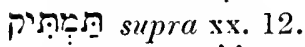

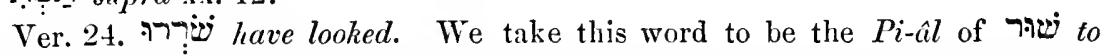
look, and to stand in parallelism with

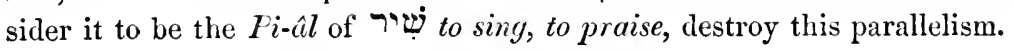

Ver. 27-33. Having advised his unfortunate friend, instead of 
brooding over his own miserable condition, to consider the wondrous works of the Almighty, from the contemplation of which he would be more likely to derive consolation, Elihu follows up this advice by calling his attention to the rain, thunder, and lightning, which now probably were beginning to be seen and heard, ushering in the storm, out of which God was presently to speak to Job.

When He taketh away the drops of water. From the seas, rivers, and other collections of water, as also from the earth generally, by means of evaporation. They. These drops. Distil rain for His mist. These imperceptible particles derived by evaporation from the sources just named, unite into drops (which Elihu terms rain, even before they have ascended to form clouds), when but a short distance above the face of the earth, and constitute mists. (Ver. 28.) Rain, which the clouds drop, pour forth upon man in abundance. (Ver. 29.) Yea, can one understand the spreadings of the thick-cloud $[s]$, or the noise of His tabernacle? The roaring of the thunder heard among the clouds, in which God dwells as in a tabernacle.* (Ver. 30.) Lo! ITe hath spread IIis lightning over it. Look there, how it lightens! See, the lightning spreads over the clouds like a curtain. And so hath covered the offspring of the sea. 'The drops of water which are contained in the clouds, and which, as contributed in a very far larger proportion by the evaporation of the sea, than by that of other bodies of water, are here termed the offspring of the sea exclusively. (Ver. 31.) For by them He executeth-judgmentupon nations. He punishes nations by means of these drops, when, namely, He sends them down in such excess as to devastate the earth. And by their means again He giveth food in great abundance. When He suffers them to fall in such quantity only as will fertilize the earth. (Ver. 32.) Again, with IHis hands Ile covereth the lightning. He takes it like a ball in His hands before He hurls it. But on hurling it He giveth it a charge. He commands it where to strike, and there, and there only, it does strike. (Ver. 33.) Its crash sheweth respecting it. That it is in conse-

* Comp. Ps. xviii. 12, 仿 Tis pavilion (round about Him were dark waters and thick clouds). 
quence of jealous-anger; $*$ it shews it to be in consequence of wrath because of iniquity. $\downarrow$ Of iniquity wrought by man.

Ver. 27. 2ריצ: takes away. In this, the only instance in which it occurs in $\mathrm{Pi}$-âl, the verb $\mathrm{y} 2 \mathrm{I}$ has the same signification as in Kal.

iș? for His mist, vapour. Ṭִ (without a $Y o d$ ) signifies mist, vapour, as in Gen. ii. 6 ;

Ver. 28. $2 \chi_{T}=2 i$ ?

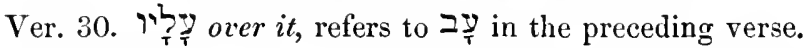

inis His lightring. The noun רis, which generally signifies light, means sometimes also the sun, as the great origin of light (as supra xxxi. 26); here it is used in the sense of lightning (as also infra xxxvii. 3). The reader will do well to keep these two secondary meanings in his recollection, as in the next Chapter he will find the noun employed first in the one, and then in the other of them, so that it is only by a careful consideration of the context that one is able to discriminate which should be adopted.

בה: drops of water, which arise from it by evaporation. By a similar figure we find, infra xli. 20, an arrow, as being an offshoot from a bow, called son of a bow. The noun wivi, though it generally means root, is sometimes

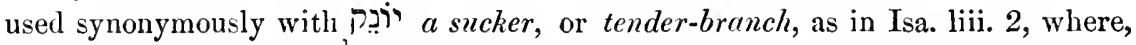
seeing that the verb עלה to go (grow) up, is used in reference to it, it can scarcely be taken in its usual meaning of root. Perhaps also in Isa. xi. 10,

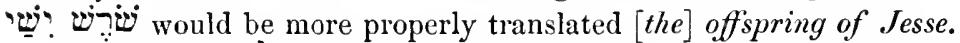

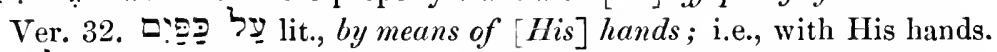

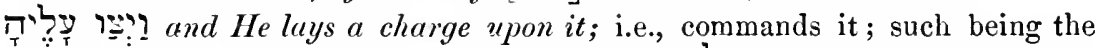

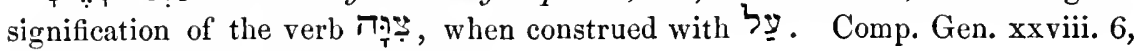

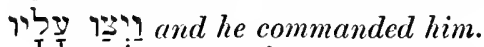

The affix in $\prod_{T}^{T}$ is feminine, though it refers to 7 is, which in this instance exchanges its own proper gender, the masculine, for that of its synonym (Ps. cxxxix. 12). In like manner, the fem. affixes in ii. 15) refer to

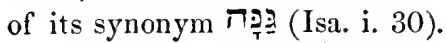

ֵㅡำ for throwing, hurling it.

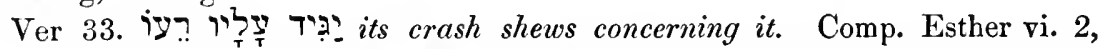

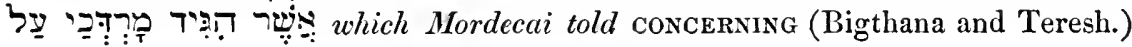

"Comp. Exod. xx. 5, "For I Jehovah thy God am ي a jealous God."

+ That God shews His indignation by rain, thunder, and lightning, we see from 1 Sam. xii. 17,18 , "Is it not wheat-harvest to-day? I will call unto Jehovah, and He shall send thurder and rain, that ye may perceive and see that your wickedness is great, which ye have done in the sight of Jehovah, in asking you a king. So Samuel called unto Jehovah; and Jehovah sent thunder and rain that day; and all the people greatly feared Jehovah and Samuel." 
Comp. also Exod. xxxii. 17, "And when Joshua heard the noise of the people בִּר (K'ree

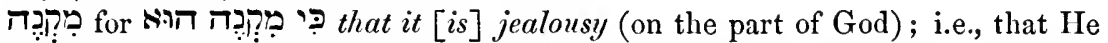

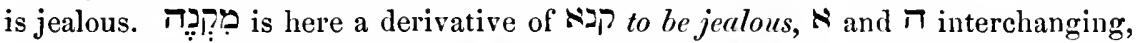
as they very frequently do, e.g., infra xxxvii. 6, הִֶ? for be. See Mason and Bernard's Gramm., Lett. xxxviii., P.S. (e). So in Ezek. viii. 3, "Where was

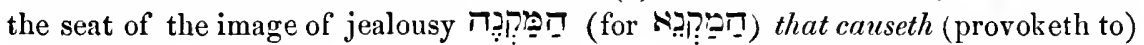
jealousy;" i.e., that maketh God jealous, a term which is applied to Him, Exod. xx. 5.

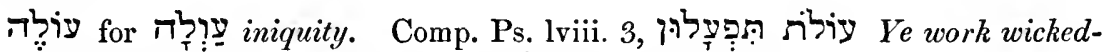

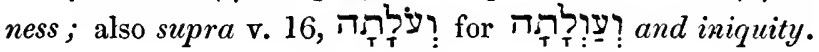

Ver. 33 should be construed thus :

ivา. Its crash (i.e., the tremendous crash of the thunder)

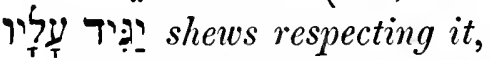

that it [is] jealousy (on the part of God ; i.e., that God is jealous (comp. Exod. xx. 5) on account of the misdoings of men);

רֵ for that it [is] wrath (i.e., that the Almighty is wroth)

עֵ עֵל עולֶה because of iniquity (i.e., because iniquity is rife among men).

(1) As several Commentators, comparing w שִ a field, plur.

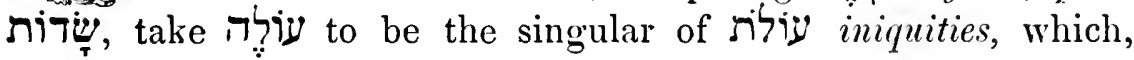
besides in the passage already quoted, occurs also in Ps. lxiv. 7, we have adopted this opinion, and translated accordingly. Strong doubts must, however, be entertained as to whether the sing. would not rather be עילד, and to this view Dr. Bernard inclines, the more especially when he compares the form על עלתָה, which we met with supra v. 16. He would, therefore, prefer considering

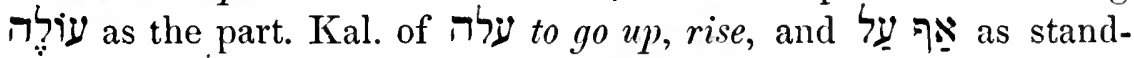
ing for עַ (a transposition of which we had an example in supra xvi. 17, on which see note), when the latter part of the verse would be construed thus:

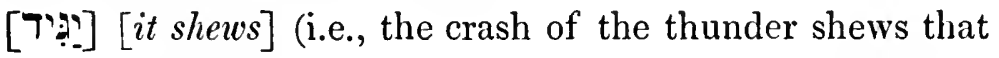
it is sent)

עecause of rising wrath (i.e., because the wrath of God is beginning to arise on account of the 
sinful conduct of men. Comp. Ps. lxxviii. 31,

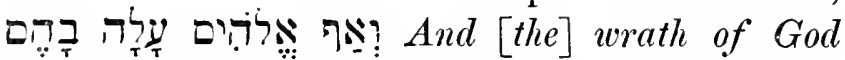
arose against them; also ibid. ver. 21 , and 2 Chron. xxxvi. 16, 16util [the] wrath of Jehovah arose against His people.)

Note of Editor.

\section{CHAPTER XXXVII.}

Vers. 1-5. The youthful speaker continues to dwell upon the thunder and lightning, with the consideration of which he had been engaged at the close of the last Chapter. He says:

$Y e a$, my heart also trembleth at this, and leapeth from its place. The fearful roaring of the thunder causes, Elihu tells us, his heart to palpitate greatly; it is ready, to use a vulgar but forcible expression, to jump into his mouth. (Ver. 2.) Hear attentively the rumbling of His voice. The rolling of His (God's) thunder. And the roaring which proceedeth from His mouth. (Ver. 3.) Under the whole heaven doth He direct it, and His lightning $\mathrm{He}$ directeth to the ends of the earth. (Ver. 4.) After it. After the lightning. The thunder roareth; He thundereth with His majestic voice, yet one cannot trace them. Yet none can trace the thunder and lightning. Although His thunder is heard. Although the noise of the thunder is as perceptible to the ear as is the flash of the lightning to the eye, yet neither the ear nor the eye can afford to the mind any accurate information as to the source or course of these phenomena. (Ver. 5.) God thundereth marvellously with His voice; great-things doeth He, which we cannot comprehend.

Ver. 1. Most Translators connect the conjunction רֵ also, with תir? at this, and render the first hemistich, At this also my heart trembleth, a translation calcu- 
lated to lead the reader to expect to find Elihu abandoning the subject he was treating at the end of the preceding Chapter, for some new one. Such is, however, by no means the case, as the thunder and lightning still constitute his theme. It is therefore much better to connect the speaker to say, Yea, my heart also trembleth; i.e., not only am I deafened by the crash of the thunder, and dazzled by the blaze of lightning, but my very heart knocks against my ribs with dread.

Ver. 2. case.

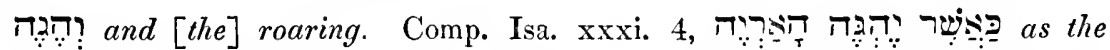
lion roars. That the act of roaring is in the Bible attributed to God we find in Hos. xi. 10, "They shall walk after Jehovah : He shall roar like a lion : when He shall roar," \&c. The relat. "ִ̣ should be understood before r.

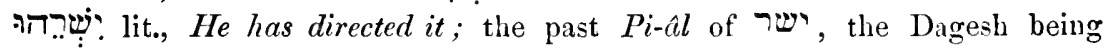
omitted, as is often the case when it would occur in a letter bearing Sh'vah.

Ver. 3. inis Hislightning. In this sense the word רis is used here, as it was in the preceding Chapter, in Vers. 30, 32. See note on inis in the first of these verses.

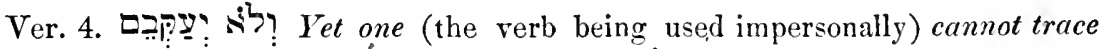

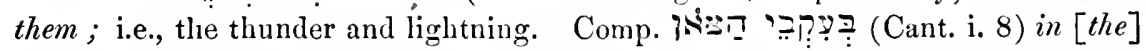
traces (foot-prints) of the flock. Those who give to this word the meaning of delaying, or staying, translate it as though there were a $\supset$ instead of a $P$, the verb 2 ע being used by the Rabbins in the sense of to delay; but, surely, a signification derived from Biblical Hebrew must be esteemed far preferable.

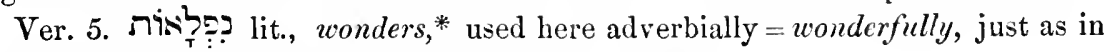
Ps. cxxxix. 14, תiֹ sust be translated fearfully.

Vers. 6-10. Elihu now begins to describe the inclemency of the winter and rainy season. He says:

For to the snow He saith, $\mathrm{Be}$ on the earth, and likewise to the gentle shower, and to the heary rain of His might. (Ver. \%.) In the place of every man he sealeth him up. By means of His snow * and heavy rains He confines every man to the place he is in, impeding and shackling his movements. In order that all the men whom He hath made may know Him. May know that they themselves, as well as all their movements, are under the direct superintendence of God. (Ver. 8.) The wild-beast, also, checked and impeded in its movements, must enter into its covert, and must abide in its den. (Ver. 9.) The whirlwind cometh out fiom the store-chamber. From the place where the winds are stored up. And the cold cometh from the constellations. Is caused by their

- Rather vonderful-things.-Editor, 1862. 
influence. (Ver. 10.) By the blast of God ice is produced, so that the wide-waters are turned into a compressed-mass.

Ver. 6. הֶֶ? be thou, which form occurs in Gen. xxvii. 29. The more regular form would of course be

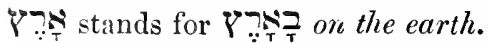

רָּ

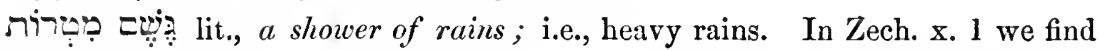

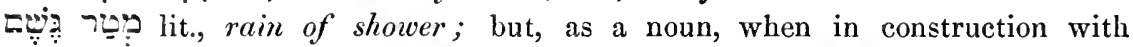
another, is very frequently qualified by that other (see Mason and Bernard's

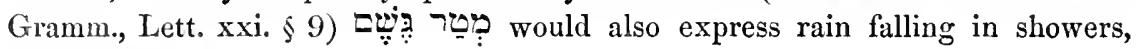
gentle rain.

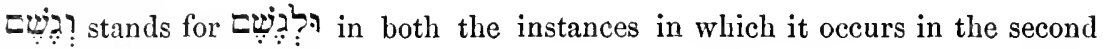
hemistich of this verse.

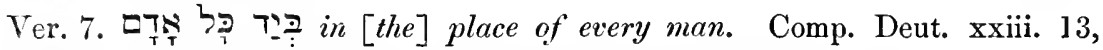
T'? and a place (shall be to thee), i.e., thou shalt have a place, \&c.

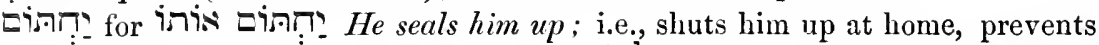

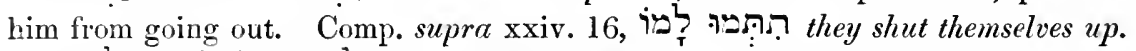

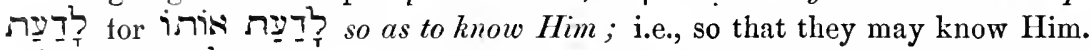

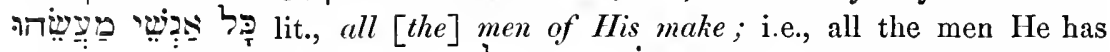

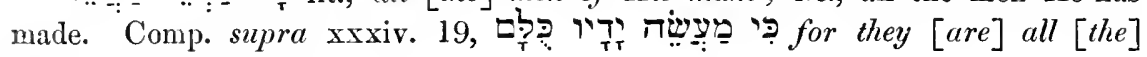
work of His hands.

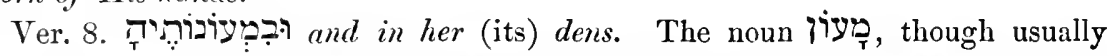
found in the signification of dwelling, is sometimes applied to the den of a wild

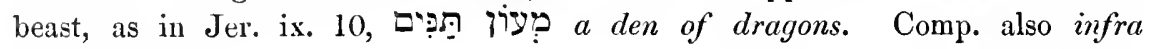
xxxviii. 40.

Ver. 9. according to the notion of the poet, were stored up. So Virgil :

Nimborum in patriam, loca foeta furentibus austris,

Eoliam venit. Hic vasto Rex Rolus antro

Luctantes ventos, tempestatesque sonoras

Imperio premit, ac vinclis et carcere frenat.

Æn. i. 51-54.

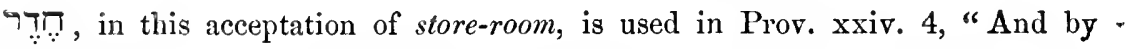
knowledge הִדְרים store-rooms, are filled with all precious and pleasant substance."

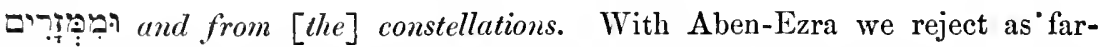
fetched the opinion of those who translate פִ the North, as also that of those who take it to be the part. Pi-Âl of זר to scatter; and with Aben-Ezra and

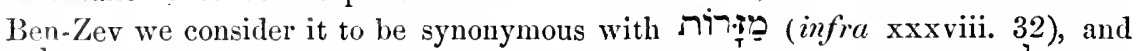
פד (2 Kings xxiii. 5), both of which signify constellations (the 7 and $ל$ interchanging, just as in Isa. xiii. 22 we have palaces).

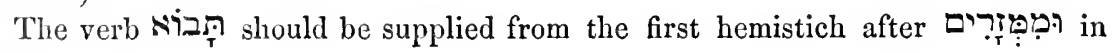
the second. 
Ver. 10. 1:̣: one puts; i.e., is put, or produced, the verb being used impersonally.

Iit., so that [the] width of waters; i.e., wide waters. Comp. Gen.

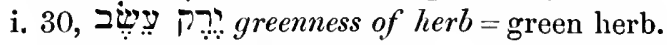

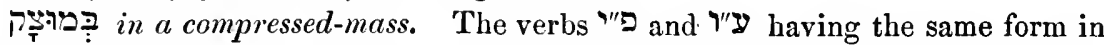

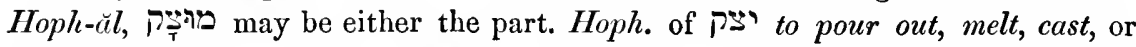
of בצי (in Hiph.) to press, compress. Here we are inclined to regard Pas as its root, and therefore translate it compressed; but infra Ver. 18, the context requires that we should derive it from $\Gamma$ '

Before from the first hemistich.

Vers. 11-13. Before commenting upon these three verses, we would beg to recall to the mind of the reader the passage in Amos (chap. iv. 7, 8), "And also I have withholden the rain "from you, when there were yet three months to the harvest; " and I caused it to rain upon one city; and caused it not to rain " upon another city; one piece was rained upon, and the piece "whereupon it rained not withered. So two or three cities " wandered unto one city to drink water," \&c. From what we here read, it is evident that God sometimes shews His favour and His anger at the same moment by simultaneously giving and withholding rain ; giving it unto those He loves, and withholding it from those who have provoked His indignation. With these few remarks we will now proceed to consider the words of Elihu. He says :

Yea, the bright-sun weareth out the thick-clond; he scattereth the cloud containing His (God's) lightning. (Ver. 12.) And it. The cloud thus dispersed. Turneth itself circuitously. Moves tortuously across the sky. By IIis (God's) plans, that they. The scattered fragments of the cloud. May work out all that He commandeth them upon the face of the world, in the earth. (Ver. 13.) He causeth it (the cloud) to come either as a general chastisement. When He sends rain in torrents, so as to cause great havoc. $\mathrm{Or}$ for His land. When He bestows rain (gentle and fertilizing) on that land alone to which He wishes to shew favour. Or as a general kindness. When $\mathrm{He}$ waters the earth generally with seasonable showers.

Ver. 11. 'רָ serenity (according to Aben-Ezra, Ralbag and Ben-Zev), we take here to be used concretely of the sun (just as we saw רis light, applied 
concretely to that luminary, supra xxxi. 26), and translate it therefore the bright-sun.

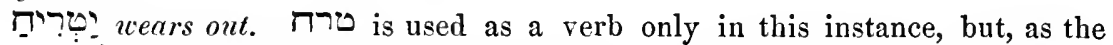

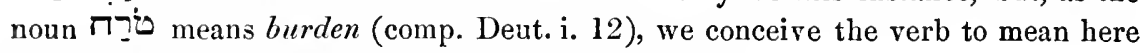
to canse to bear a burden, and so oppress, wear out.

iרis lit., [the] clond of his lightning; i.e., the cloud containing His

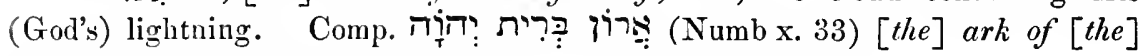
covenant of (i.e., the ark containing the covenant of) Jehovah.

Ver. 12. ㄱำ lit., turnings, is used here adverbially = circuitously, just as

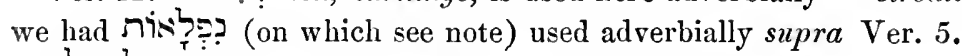

的? lit., for their working; i.e., that they may work.

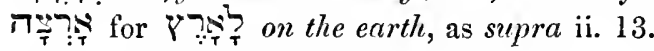

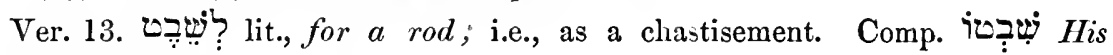
rod, supra ix. 34 .

izר: for His land; i.e., for that particular tract of land, which $\mathrm{He}$ has chosen to bestow His blessings upon.

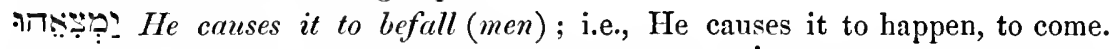
Comp. Exod. xviii. 8, " and all the travail upon) them," as very properly translated in the Eng. Vers.

Vers. 14-24. Clouds big with thunder, lightning, and rain, are wont to overspread the sky in layers, black and thick, and seem one molten, leaden, mass, immoveable. As soon, however, as, disburdened of their contents, they begin to feel the power of the solar rays, they set themselves in motion (and this is the first indication of approaching fair weather), and, ere long, they may be seen becoming gradually thinner and thinner, just as a mass of metal does, when hammered out into a plate; till at last riven asunder, they are hurried away in fragments by the wind, and the golden sun once more emerges into view. Such a description of the process by which a cloudy, tempest-darkened, sky is gradually exchanged for one serene and bright, we shall hear Elihu give in the following verses. He then closes his discourse by observing, that the splendour of the sun, great as it is, when he reappears after a thunder-storm, is nothing at all in comparison with the splendour of Him, "who commandeth the sun and he shineth not, and upon the stars doth set His seal." He says :

Give ear unto this, $O$ Job; stand, and consider the wondrousworks of God! (Ver. 15.) Dost thou know when God setteth the sun over it (the cloud); and causeth the sun to shine upon His 
cloud? Canst thou determine the precise moment at which the sun receiveth the Divine command to bear with the whole power of his rays upon the cloud, until, growing thinner and thinner, it be dismembered and dispersed? (Ver. 16.) Knowest thou aught of the balancings of the thick-cloud[ [s]? (Oh, wondrons-works of Him, which is perfect in knoulcdge)! Canst thou tell by what that oscillating movement of the clouds, which is the first indication of the approach of fair weather, is produced? (Ver. 17.) Dost thou know how it is, that thy garments are warm, when he (the sun) quieteth the earth by the south-wind? By calling from the south a warm and gentle wind to efface all traces of the recent storm. Well may the sun be said to hold the winds at his disposal, since it is by his heat that they are in a great measure produced. (Ver. 18.) Dost thou with him (the sun) beatthin the clouds, which appear to the eye firm as a molten mirror? Dost thou help him, when with his rays he, as it were, hammereth out those dense masses of clouds, which so much resemble a darkened mirror* of molten metal? (Ver. 19.) Teach us what we are to say respecting him! what we must suppose has become of that bright and splendid sun, who so much dazzled our eyes before the intervention of these clouds; what fate we must assign to him; where he is now concealed. We cannot arrange our words on account of the darkiness. We cannot say where he is now, owing to the darkness caused by these clouds, a darkness so profound, that even the piercing rays of the sun cannot penetrate it. (Ver. 20.) Shall it be told of him, shall I indeed pronounce, or will any man say, that he is destroyed? Could I or any other man be simple enough to say, that the sun is annihilated, because we no longer see him? (Ver. 21.) But now, though men do not see the sun, he is still bright in the clonds. The clouds have, indeed, concealed him from our sight, but they have not been able to annihilate him, or even to divest him of his glory; he is indubitably there behind those clouds, as bright as he ever was. And as soon as a wind shall have passed, and cleared them away. (Ver. 22.) Yea, by means of a north-wind. Which will disperse the clouds. Ile will come out gold. In the fulness of his radiance and brilliancy, and as glorious as ever. But that

- That is to say, a mirror turned away from the light. 
glory, great as it is, what is it, compared with the glory and majesty of God? Nothing, absolutely nothing, less than nothing. The glory, which is with God, is awful. It is not a glory which can inspire admiration only, but a glory, which must also strike every one with awe. (Ver. 23.) As to the Almighty, we cannot find Him out. Of the sun, though we see him not, though we know not even where he is, we can still with certainty predict that we shall see him, as soon as the clouds which shroud him from our view shall have been dispersed by the wind; not so with God. No one can see Him excepting those to whom $\mathrm{He}$ condescendeth to reveal Himself, and not even they can foretell when, at what time, and in what manner, He will so condescend. $\mathrm{He}$ is great in power and justice; and in the abundance of His vighteousness He will not afflict. Any of His creatures willingly, and without cause. (Ver. 24.) Therefore, men can only fear Him, but not any even of the wise in heart can see Him. 'The only thing that men can do, therefore, is to convince themselves of His existence, His glory, and His majesty, and to regard it as their bounden duty to love Him, to serve Him, to worship Him, and stand in awe of Him; but as for seeing Him they must not hope for that; thereunto even their wisdom will avail them nought, and they must rest content with the conviction, that they can see Him only when He is pleased to shew Himself to them.

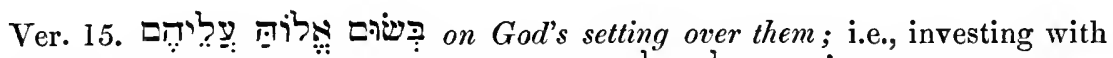

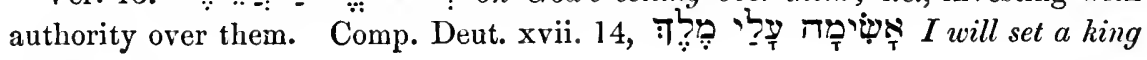
over me.

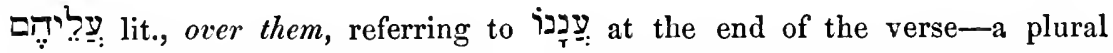
affix used in reference to a sing. noun. Comp. supra Ver. 12, where the affixes in

רis [the] sun (a sense, in which we saw this noun employed supra xxxi. 26), must be supplied from the second hemistich to the first, as is the case with in Prov. xiii. 1.

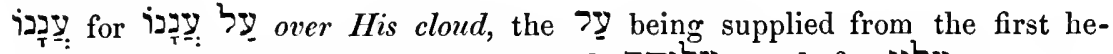
mistich, where, as has already been observed,

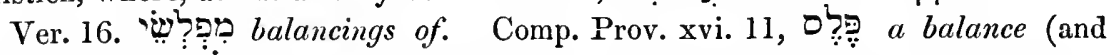
just scales), \&c., $i$ and $D$ interchanging, as they very frequently do. See note

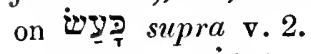

Ver. 17. जִ how, this word being here not a relative pronoun, but a conjunction, as in Josh. ii. 10.

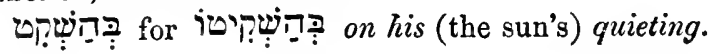




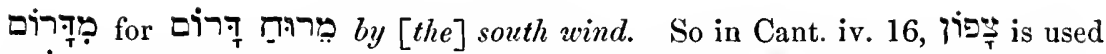

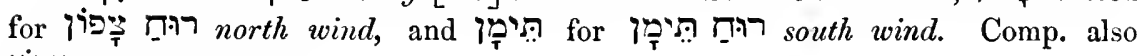
טִ infra Ver. 22.

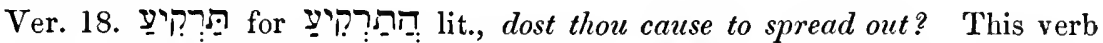
has here in Hiph-êl the same sense that it has in Pi-âl, in Exod. xxxix. 3, where it denotes the beating out of a mass of metal with a hammer, or other tool, into a thin plate, capable of being cut into threads, or wires. The passage is,

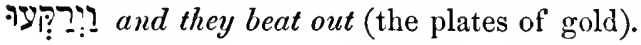

ị with him, i.e., with רis the sun, last mentioned in ver. 15. All the Commentators and Translators we have consulted, without exception make the unfortunate mistake of referring the affix in yִ to God, whom they also make the subject of the next three verses, to the very great detriment of the sense, as the reader will very quickly discover, if he will consult them. If their reason

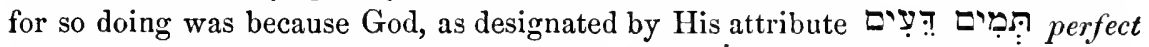
in knowledge, is the subject, which last precedes ivy, they must have entirely forgotten, that but little regard is paid in this book, by the holders of the several discourses, to such niceties of grammar, as they believed their hearers to be possessed of a sufficient share of common sense to enable them to refer to their proper subjects whatever pronouns and verbs they might hear employed. Thus, for example, in Chap. xxii. 21, ỵ with Him, refers to God, who had not been mentioned since vers. 17, 18, although the last subject is is in ver. 19. Comp.

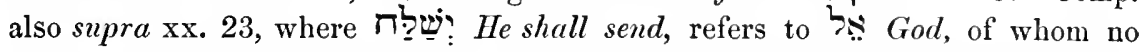
mention had been made since, ver. 15 , the intervening seven verses relating to the wicked man first mentioned in ver. 5 of the same Chapter. Indeed, the whole of Chap. xxv. and vers. 6-14 of Chap. xxvi. refer to God, whom, though not once therein mentioned by name, ${ }^{*}$ common sense requires us to consider as the subject. This is the case also with Chap. xxiii., vers. 3-15. So again, in Chap. xxviii., all the he's, which occur in vers. $3-11$, must be referred by common

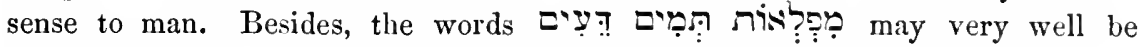
regarded (as it will be seen has been done by ourselves) as parenthetical, in which case yִ would really refer to רis [the] sun, in ver. 15, the last subject.

לִ: ? supra $\mathrm{v} .2$.

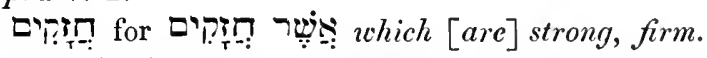

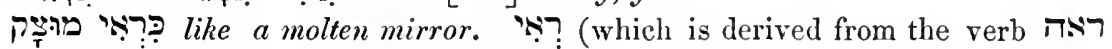
to see, look) is synonymous with מַר a looking-glass, mirror, which occurs in

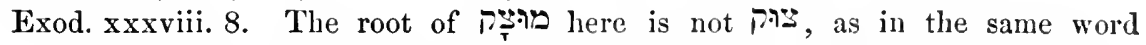
ver. 10, but 13 to pour out, and also to pour molten metal into a mould, to cast.

Ver. 19. it respecting him (the sun). Comp. Gen. xx. 13, "Say '? respecting me, He is my brother."

we cannot arrange our words; i.e., we do not know what to say. $\Lambda$ similar ellipsis we met with supra $\times x \times$ xiii. 5, where

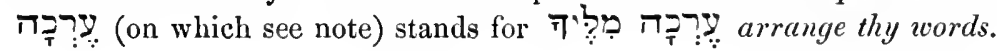

* This is a mistake. God is once mentioned by name in Chap. xxv. (viz., Ver. 4), though not in the Yerses quoted from Chap. xxvi.-Editor, 1862. 
Ver. 20. iो respecting lim (the sun), as in the preceding verse.

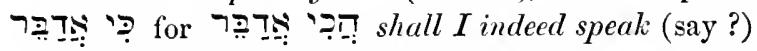

ธง whther, used here merely as an interrogative particle. Comp. supra vi. 12.

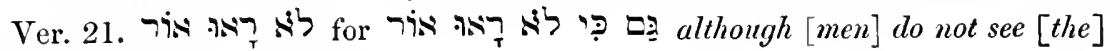
sun. See note on רis ver. 15.

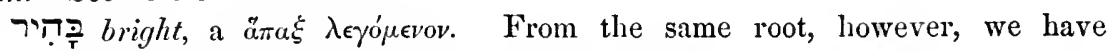
תרכ (Lev. xiii. 2, \&c.), a white (or bright) spot.

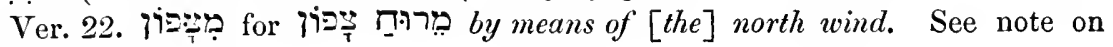

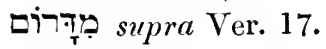

חירז comparison is intentionally omitted here, in order to increase the force of the

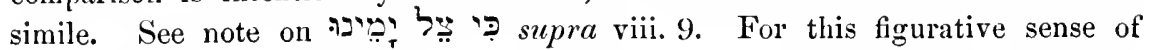

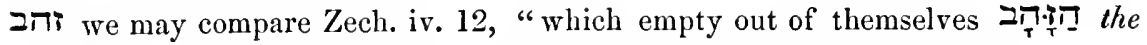
gold," * i.e., the clear, bright, oil, as explained by Kimchi, who observes :

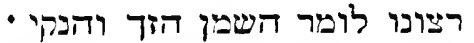

"He means to say the bright and pure oil."

So Shakespeare :

So sweet a kiss the golden sun gives not

To those fresh morning drops upon the rose,

Nor shines the silver moon one half so bright

Through the transparent bosom of the deep.

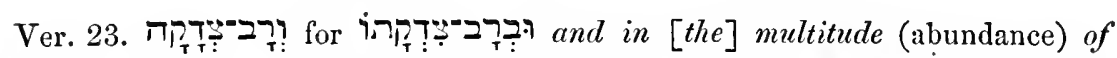
His rightcousness. Those who translate these words, and great in righteousness, have confounded 27 , which stands for $2 i 7$, and is a noun and not an adjective, (the Chowlem having been changed into a short Kawmets on account of the Makkiph connecting the word to the one next following),-with the adjective 2 ? great, which could not possibly take a short-Kaumets.

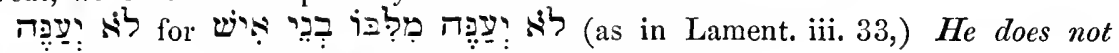
afflict $[$ the $]$ sons of men from His heart, i.e., willingly.

The view we take of Vers. 15-24 of this Chapter so widely differs from that embraced by all the Commentators and Translators whose works we have before us, that we must beg to be allowed to set forth the manner, in which we construe these seemingly incoherent verses - a manner, by which not only a most logical and close connection is shown to subsist between them, but also a finale is obtained worthy to crown the discourse of the only one of the wise men who speak in this volume, that is not found fault with by Him, who "giveth wisdom unto the wise, and knowledge to them that know understanding."

* Similarly, the purest treacle is often called golden syrup.-Editor, 1862. 
Ver. 15.

$$
\begin{aligned}
& \text { Dost thou know. }
\end{aligned}
$$

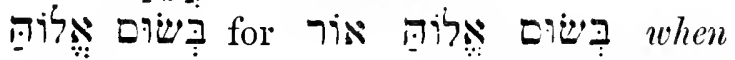

$$
\begin{aligned}
& \text { God appoints [the] sun }
\end{aligned}
$$

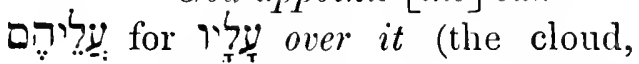

$$
\begin{aligned}
& \text { which is here, as in verse } 1 \% \text {, } \\
& \text { designated by a plural affix ; } \\
& \text { i.e., when God charges the } \\
& \text { sun to disperse the cloud), }
\end{aligned}
$$

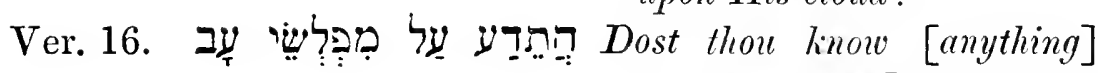
respecting [the] balancings of $[$ the $]$ thick-cloud $[$ s]?

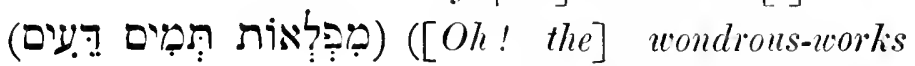
of [Him, who is] perfect in kinoutedge.)

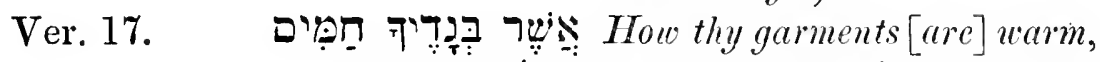

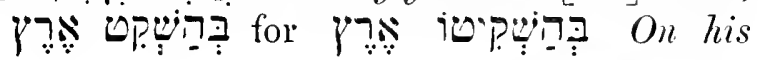
(the sun's) quieting [the] earth,

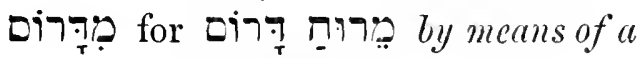
south wind?

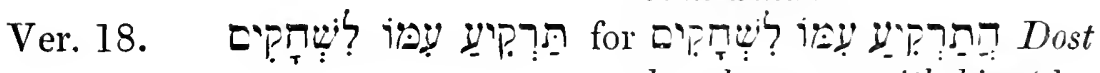
thou beat out with lim (the sun) $[$ the $]$ clonds (i.e., dost thou help him to rarefy the clouds)?

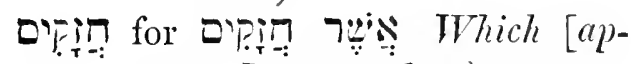
pear] strong (firm),

Ver. 19.

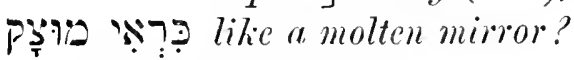

Teach us

is sun; i.e., if we are asked what is become of him, tell us, what shall we answer!)

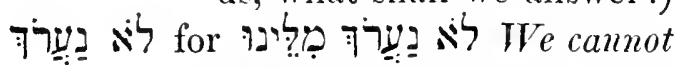
arrange our words (i.e., we 
Ver. 20.

are at a loss to say what is become of him,)

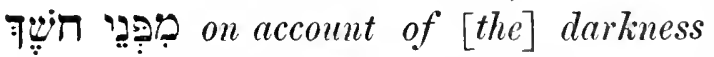
(of the clouds.)

iל Can it be told of him (the sun-)

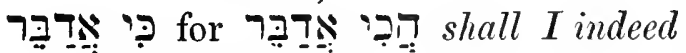
speak-

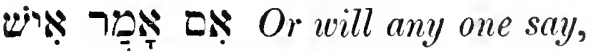

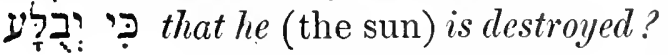

(i.e., that he is altogether annihilated, because we no longer see him?)

Ver. 21.

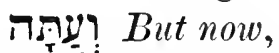

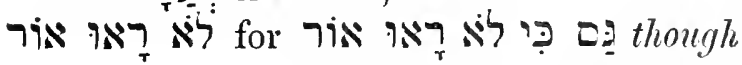
[men] do not see [the] sun,

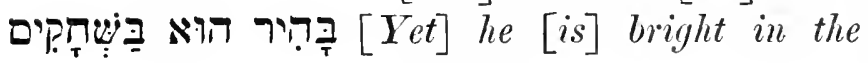
clouds ;

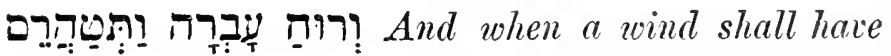
passed, and cleared them away,

Ver. 22.

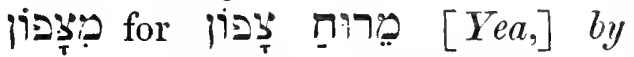
means of a north wind

กת.: he (the sun) will come out-

ברָז gold (i.e., so dazzling bright that he looks a globe of gold. But splendid as he will be, his splendour will be as nothing, when compared with the glory and majesty of God)

דiT [The] glory,

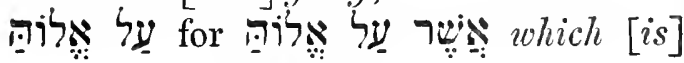
with God,

א $[i s]$ awful (not only an object of admiration, but an object of awe.)

Ver. 23.

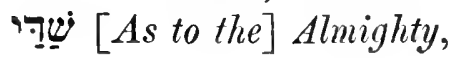


Chapter xxxvil. $23,24$.

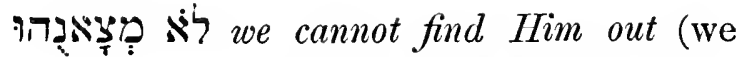
cannot know, when $\mathrm{He}$ will reveal Himself);

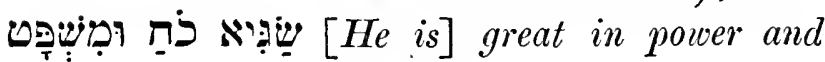
justice,

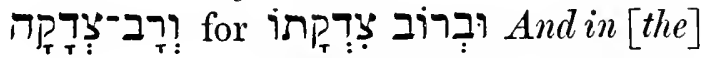
multitude of His righteousness,

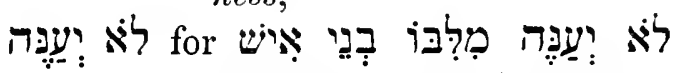
(Lament. iii. 33) He will not willingly afflict [the] sons of men.

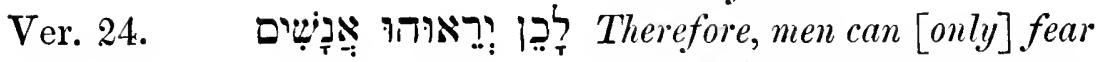
Him (the only thing they do, as they cannot see Him, is to have faith in $\mathrm{His}$ existence, to revere and fear Him).

Not any of [the] wise in heart

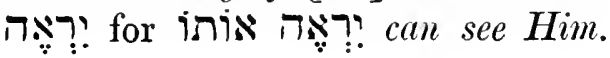

\section{GOD'S ADDRESS 'TO JOB.}

Since the murmurings and grumblings of Job had arisen solely from his not having had (before God revealed Himself to him), the remotest idea, or even the faintest conception, of an immortal soul, and its existence in a future state, all that was required to convert him, and arouse in him the most bitter repentance for what he had so rashly said, was to convince him of the great truth, that man is not a mere animal, but a being of a more dignified and

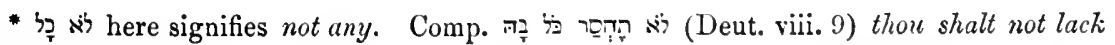
anything in it. 
exalted nature than all the living creatures which surround him, and that his existence will not, like theirs, terminate with his life. Now, this conviction must have taken possession of his mind, the very moment God revealed Himself to him, and therefore arguments on the part of God would have been as needless and superfuous, as explanations, unbecoming. Lest, however, dazzled by the exaltation and dignity of the new position, which he so unexpectedly found himself occupying in the creation as a man, he should become even more inclined to self-conceit and pride than he had been before he was visited with affliction, God thinks fit to teach him humility by shewing him, that the soul of man, immortal though it is, and exalted in its nature, nevertheless cannot, so long as it is hampered with a body of clay, penetrate into the mysteries of the most common phenomena of nature, or even always learn to perform by reason, that which mere animals are taught to perform by instinct, whilst the body it tenants is but very weak and frail in comparison with the gigantic frames of some of the brute-creation. This admonition is followed by a short dialogue between God and Job, which ends in Job's confessing himself vile, but contrite, penitent, and heartily ashamed of what had escaped his lips in consequence of the ignorance of his own nature, in which he had been plunged all the days of all his life, until God vouchsafed to enlighten his mind by revealing Himself to him.

\section{CHAPTER XXXVIII.}

Ver. 1-11. Then Jehovah answered Job out of the tempest. Which had been gathering towards the conclusion of Elihu's discourse. And said, (Ver. 2.) Who is this, that darkeneth My counsel. My purposes; My designs. Who would dim the lustre reflected upon Me by My dealings with mankind. With words 
without knowledge? (Ver. 3.) Gird up now thy loins like a man. Summon up all thy courage, for thou wilt need it, to contend with Me. For I will ask thee questions, and do thou inform me. (Ver. 4.) Where wast thou, when I founded the earth? Declare, if thou art acquainted-with understanding! (Ver. 5.) Who determined the measures thereof, if thou knowest? Who assigned it its dimensions? Or who stretched the measuring-line upon it? (Ver. 6.) Upon what were its foundations settled? Or who laid its corner-stone, ((Ver. 7.) While the morning-stars were singing in chorus, * and all the sons of God shouted-for-joy?) (Ver. 8.) And shut up the sea with doors, when it burst forth as though coming out of a womb? (Ver. 9.) When I made the cloud its garment, and deep-darkness its swaddling-band; (Ver. 10.) And decreed for it $M y$ boundary. The bound with which I, and I alone, have encircled it. And set upon it a bar and doors, (Ver. 11.) And said, Thus far shalt,thou come, and no farther, and here shall the pride of thy waves be stayed?

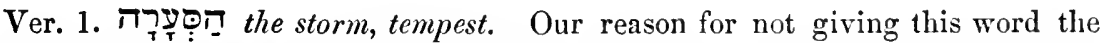
signification of whirlwind, wlich has been assigned to it by the Translators of

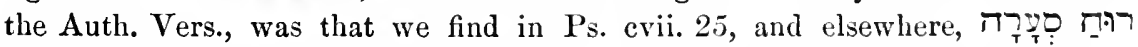
(where the meaning whirlwind would produce an insufferable tautology), lit., $a$ wind of storm, i.e., a stormy wind.

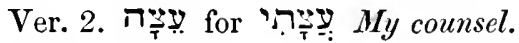

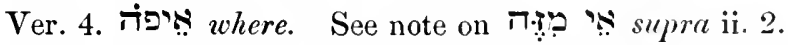

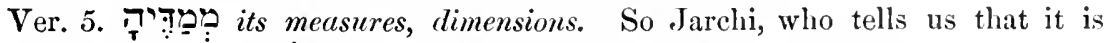

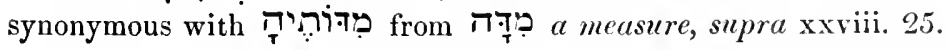

Ver. 7. Tח together; i.e., in chorus. 'This verse should be taken parenthetically, when there will be no occasion to supply a pra the beginning of ver. 8, as is commonly done.

Ver. 8 i⿱⺈

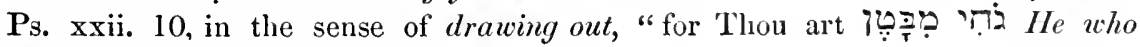
drew me out from [the] womb."

* It would seem that it was customary among the Jews to celebrate the foundation of stately edifices with songs and shouts of joy and music. Thus we read in Ezra iii. 10, "And when the builders laid the foundation of the temple of Jehovah, they set their priests in their apparel with trumpets, and the Levites the sons of Asaph with cymbals to praise Jehovah, after the ordinance of David king of Israel. And they sang together by course, in praising and giving thanks unto Jehovah ...... And all the people shouted with a great shout, when they praised Jehovah, because the foundation of the house of Jehovah was laid." 


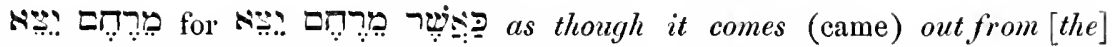
womb. Or the hemistich may he translated as it stands, "when it burst forth,

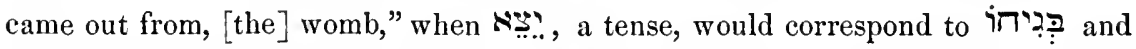
therefore, be equivalent to iתר on on its going forth, just in the same way that

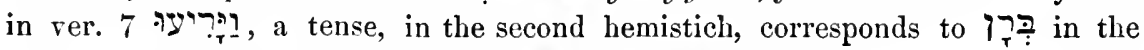
first, and, therefore =

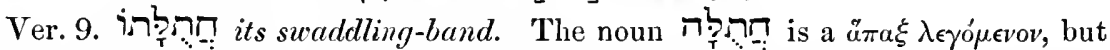

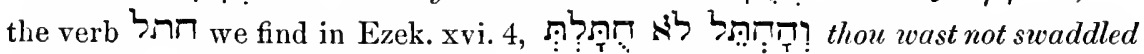
at all. As He had compared the sea to a babe coning forth from the womb, He naturally compares the thick and dark vapours which at times overhang or enwrap the sea to the garments of a babe, its swaddling-clothes.

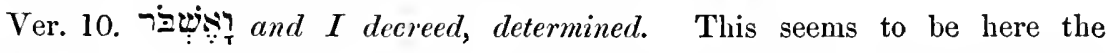
meaning of the verb שבר, which generally means to break. In a very similar manner, the verb 7 I , which lit., signifies to cut, is used in the sense of deciding, determining, decreeing (as supra xxii. 28).

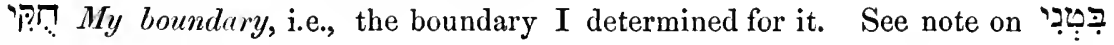
supra iii. 10.

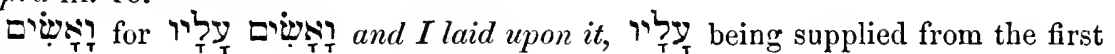
hemistich.

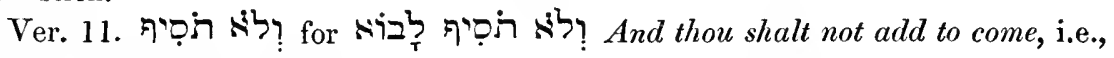
shalt not come any farther.

איר for and here. So the marginal note, "אי המקוש ה instead of $\pi "$.

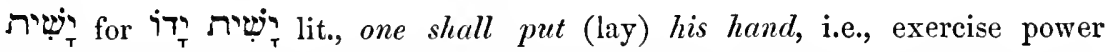
(Comp. supra ix. 33), = power shall be exercised (over the pride of its waves); i.e., their pride shall be controlled, stayed.

Vers. 12-15. Having dwelt on the creation of the world, God proceeds to speak of that which He had next created, namely, light; and as Job had himself in one of his discourses described the dread which wicked men feel on the approach of light,* we shall find God alluding to this. He says :

Hast thou ever commanded the morning? To dispel the darkness of night, and to illuminate all objects. Hast thou made the day-spring to know its place? Is it in obedience to thy directions, that it constantly varies in position? (Ver. 13.) So that it should take hold of the corners of the earth and the wicked should be shaken out of it. As dust or: crumbs are shaken out of a cloth held by the four corners, so light, as it were, seizes the earth by its corners, and shakes the wicked (under whom Job had especially 
included robbers and adulterers, who carry on their mal-practices at night) out of it, causing them to beat a hasty retreat into their dens, and so, for a time at least, to disappear from its surface. (Ver. 14.) It (the earth) is changed like the clay of a seal. Just as images are suddenly evoked upon a shapeless lump of clay (or, as we should say, wax) by the impression of a seal, so the eartl, which in the darkness of night becomes a confused and formless mass, has stamped upon it, by the morning dawn, the endless variety of forms which diversify its surface. And they. The corners of the earth. Stand up, as though they had put on $a$ garment. The objects on the surface of the earth, which, in the darkness of night, were undistinguishable one from another, stand forth prominently and conspicuously at daybreak, as easily to be distinguished by the variety of colours with which the light has (so to say) clothed them, as human beings are by the variety of their dress. (Ver. 15.) But their light. The light of the morning and the dawn. Is withheld from wicked-men. Who skulk away at its approach, full of consternation and terror: So that the high arm is broken. So that the arm of those, who practise violence in the gloom of night, falls powerless on the appearance of the light of morn.

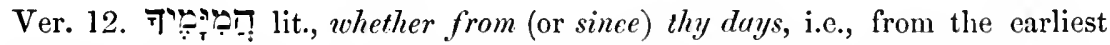
period of thy existence, as long as thou hast lived. Comp. 1 Kings i. 6, "And his father had not displeased him "צִ at any time," (de ses jours.)

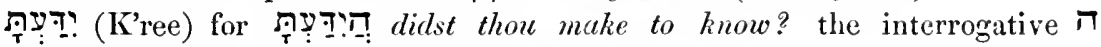
being supplied from the first hemistich.

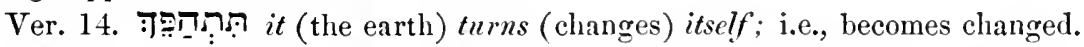

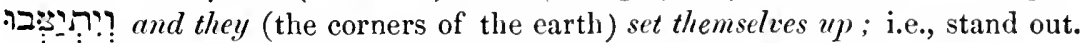

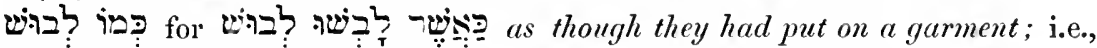
objects are distinguished from one another, as though each of them was dressed in its own peculiar dress.

Ver. 15. פרָ their light; i.e., the light of the morning and the day-spring.

Vers. 16-21. The globe and the light still continue to form the theme of God's discourse, but when speaking of the sea, which is composed of an element in which man cannot exist, the idea of death and the shadow of death naturally suggest itself. God therefore says :

Hast thou penetrated to the mazes of the sea, or hast thou wallied 
about in the recesses of the deep? (WVell is the sea said to be full of mazes, for even if a man could move beneath its surface like a fish, how could he direct his course, how could he ascertain in what direction he was going? No labyrinth could present greater difficulties). This of course thou knowest thou canst not do, and that there thou wouldest soon be overtaken by death, but dost thou know all the innumerable other ways by which death can reach thee? (Ver. 17.) Have the gates of death been revealed to thee, or canst thou see the gates of the shadow of death? Have thine eyes beheld the numberless portals, through any one of which he might sally forth from his gloomy mansion against thee? (Ver. 18.) Hast thou comprehended even the breadths of the earth? 'This very earth, which has been assigned to thee as thy abode-dost thou know the whole extent thereof? Canst thou say how far it reaches this way or that? Declare, if thou knowest it all? (Ver. 19.) Where is the way that leadeth to the place where light dwelleth? When on the command, "Let there be light," the light appeared, canst thou tell whence, or in what way, it came? Canst thou even say how it reaches the earth every morning? And as to darkness. By which that light is succeeded. Canst thou tell where its place is? ((Ver. 20.) For thou couldst no doubt take it. Either one or the other, light or darkness. To the bound thereof! And thou canst no doubt perceive the paths that lead to the house thereof! (Ver. 21.) Thou knowest all that, for thou wast then born! Thou wast present when light was first evoked, thou sawest and didst mark the way it came! Yea, the number of thy days is great!)

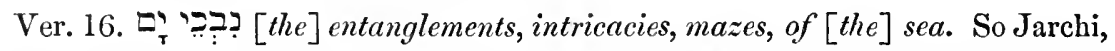

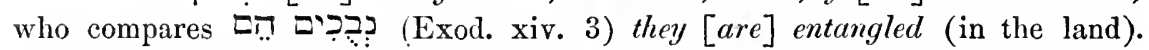

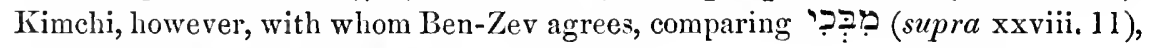
translates it springs, fountains of, as it is also translated in the Auth. Vers.

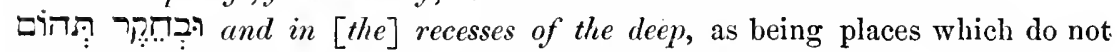
offer themselves to the view, but require exploration ( $า$ ก! for for discovery. Ben-Zev translates דrand (bottom), observing :

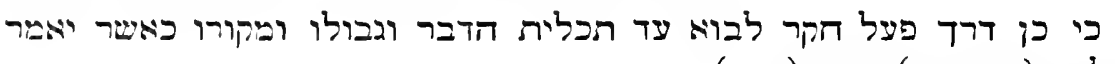

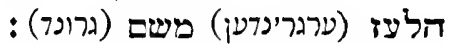

"For such is the signification of the verb חק , to come [namely] to the end of a matter, and its boundary and its origin, as the foreign-tongue (i.e., German) says, ergründen, from the noun Grual." 


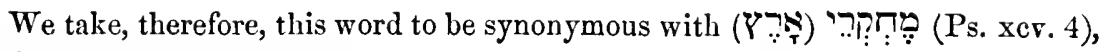
which Aben-Ezra explains :

$$
\text { תקתיות הרץ: }
$$

"The lowest parts (or deep recesses) of the earth";

and on which Ben-Zev also observes:

\section{תאר לתחתיות ארץ ואפסיה :}

"An epithet [applied] to the lowest parts of the earth, and the uttermost ends thereof."

Ver. 18. עַ even, in which sense the French jusque is frequently used, and by which preposition it is rendered here in the Gerievese translation, which runs : "As-tu compris jusques aux estendues de la terre?"

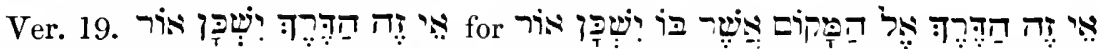
Where (which) [is] the way to the place wherein light dwells? For an explanation

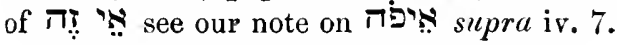

iț for iș (Prov. viii. 22) in olden times.

Vers. 20, 21, should be taken parenthetically.

Vers. 22-30. God proceeds to prove to Job the imperfection of human knowledge by shewing him his inability to account for, and explain, the most common phenomena of nature.

Hast thou, He asks him, entered into the storehouses of the snow? Or canst thou see the storehonses of the hail? I do not refer to usual and ordinary falls of snow and hail, which thou hast often seen, but to those supernatural snow and hail-storms with which I visit those I am displeased with-to that snow and hail (Ver. 23) Which I have reserved for the time of trouble, for the day of battle and war.* (Ver. 24.) Which is the way by which light is distributed? By which the light, which first appears in the east, is thence distributed over the whole earth. Which the way by which the east-wind. IIaring just spoken of the origin of light, which comes from the cast, He naturally mentions the east-wind in preference to any other. Spreadeth itself over the earth? (Ver. 25.) Who hath divided a watercourse for the pouring out of the rain-waters? Or a way for the flash of the thunder? (Ver. 26.) So as to cause it to rain upon

* That God has destroyed by hail armies that took the field against His will, we are told in Joshua x. 11, "And it came to pass............. that Jehorah cast down great stones from heaven upon them unto Azekal, and they died; they were more which died with hailstones, than they whom the children of Israel slew with the sword." 
a land where no man is, upon a desert, wherein there is no man. Even there, where men, the choicest part of my creation, do not dwell, I send the blessing of rain for the benefit of other living beings. (Ver. 27.) To saturate the waste and desolate place, and to malie the germ of grass to spring up. The grass, which is to satisfy the craving appetite of the beasts which inhabit there.* (Ver. 28.) Hath the rain a father? Other than Myself. Or who hath begotten the drops of dew? (Ver. 29.) From whose belly came forth the ice? And as to the hoar-frost of heaven, who hath brought it forth? (Ver. 30.) The waters hide themselves when the face of the deep cohereth like a stone.

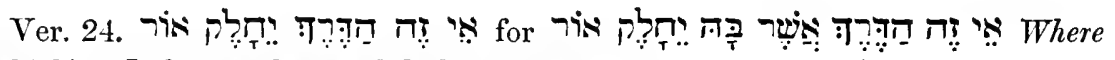
(which) $[i s]$ the way by which light is distributed?

Y? scatters (spreads) itself. This word, though in Hiph-êl (from the root Y $:$ ), is here used intransitively (though in English it must be translated reflectively, or passively), as in Exod. $\nabla .12$,

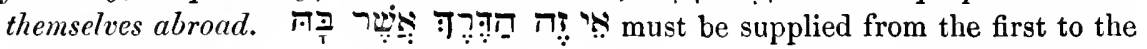
second hemistich.

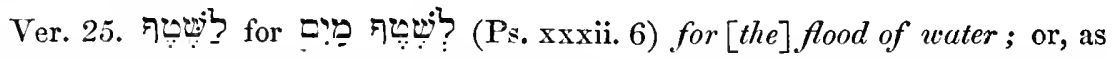
reference seems here to be made to rain, the more full and prosaic form would be

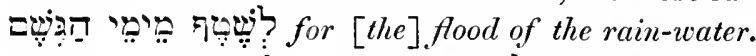

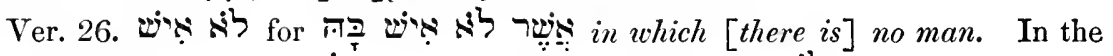

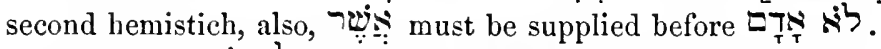

Ver. 27. שבע generally means to be satisfied (with food); but sometimes also with drink (e.g., Amos iv. 8), and hence it is used of the earth, or land in general (as here), when saturated with water.

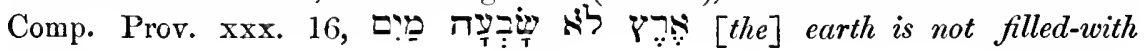
water.

ה met with excepting joined with the former (as supra xxx. 3 ; Zeph. i. 15), though

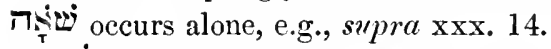

ל (root Comp. supra xxxi. 8, where Chap. xxviii. 1, מוז was used of a place from which silver issues (or is extracted).

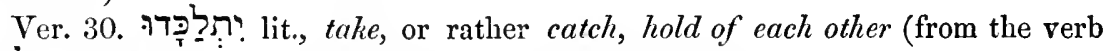
לבד to catch); i.e., cohere, congeal. Comp. infra xli. 9.

This Verse should be construed thus:

* Comp. Ps. cxxxvi. 25, "Who giveth food to all flesh; for His mercy endureth for ever." 


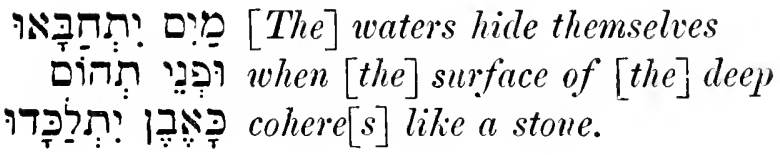

This way of construing the verse causes all the difficulties, which the word before us, totally to vanish. We should exhaust the reader's patience if we were to quote all the passages in the Hebrew Bible, of which the words have to be construed in a very different order from that in which they are written, and we shall content ourselves, therefore, with quoting Ps. xlv. 6, which runs thus,

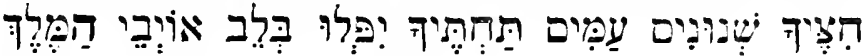

but must be construed as follows :

דִ Sharp-pointed [are] Thine arrows,

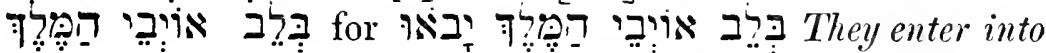
[the] heart of [the] enemies of the king,

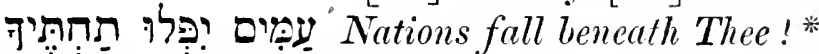

Vers. 31-38. Job is now asked whether he has any, even the slightest, control over the heavenly bodies, or can explain their influence upon the earth; also, whether the clouds and lightning would give any heed to his commands.

Canst thou fasten (lit. lind) the bands of the Pleiades? Canst thou tighten the bands which unite its stars, and so cause their influence upon the earth to cease? Or canst thou loosen the fetters of Orion? So as to increase its influence upon the earth. (Ver. 32.) Canst thou bring forth the constellations, every one in its season? And as to Arcturus with his children, $\dagger$ Canst thou guide them? (Ver. 33.) Inowest thou the ordinances of heaven? Canst thou set its dominion over the earth? Determine how far they influence the earth. (Ver. 34.) Canst thou lift up thy roice to the cloud $[s]$, so that abundance of water shall corer thee? + So that the clouds with water big should overhang thee like a canopy. (Ver. 35.) Canst thou send forth the lightnings, so that

* So the verse is rendered by Dr. French and Mr. Skinner.

$\dagger$ By the children of Arcturus it is commonly supposed are meant the three stars which compose the tail of this constellation.

\$ This same expression was used by Eliphaz, supra xxii. 11, as here, in reference to the water contained in, and not poured out from, the clouds. 
they shall go. Whither thou directest them. Or will they say to thee, "Behold, here we are? Ready to execute thy commands." (Ver. 36.) Who hath put wisdom in their inward-parts? Or who hath imparted intelligence to their mind?* (Ver.37.) Who can number the clouds by wisdom? Or, who can dispose the bottles of heaven (i.e., the clouds) in layers? (Ver. 35.) When the dust. Saturated with water poured out from those bottles. Floweth into a molten-mass. For, when dust is drenched with rain, its particles, like those of a metal on being fused, run together into a liquid, which afterwards-still maintaining herein a similarity to the molten metal-hardens into a solid mass. And the clods cleare fast together. First reduced to a liquid by the rain, they afterwards dry into one hardened cake of mud.

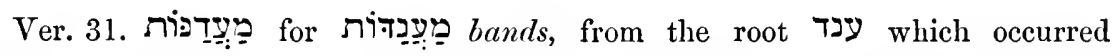
supra xxxi. 36, under the form $I$ would bind it. That in the noun before us the letters $7 \mathrm{~J}$ have been transposed is rendered extremely probable, if not certain, by the fact, that in the Talmud we find of bands, chains; but, even if this had not been the case, we should not have scrupled to assume the transposition, as we often meet with words which, in spite of an exchange of place in a couple of their letters, are universally allowed to have the same meaning. Thus, for example,

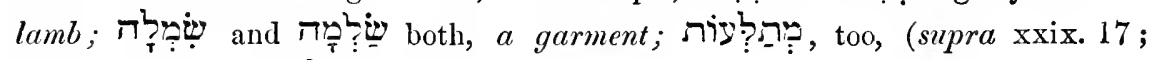

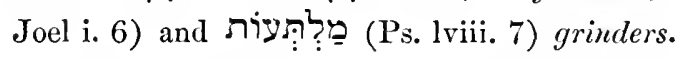

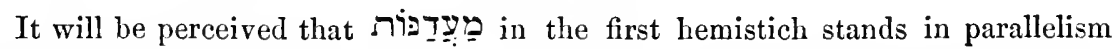

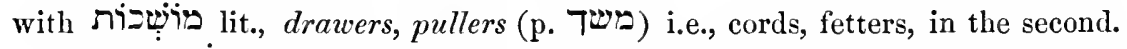

Ver. 32. ת מִּז constellations; i.e.,

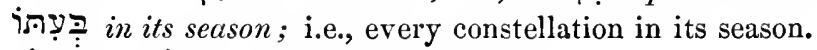

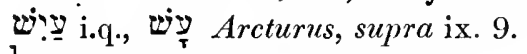

עַ together with, along with, as in Exod. $\operatorname{xxx} .22$, "And the men came together with (the women)."

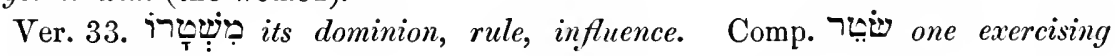
power, an overseer. Prov. vi. 7. The affix is singular, though it refers to

* Rosenmüller asks those who refer this verse to man, "At quem non offendat medias inter questiones de colestibus et aëreis phænomenis singula hæc de sapientia et intelligendi facultate homini impertita, interrogatio?" A very fair question certainly, and one we might ourselves have asked, for it will be perceived that we do not take the words

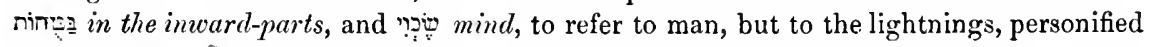
in the preceding verse, as agents who can receive and execute commands delivered to them by God, and who can come and say, "Here ve are;" and we greatly wonder that none of the Commentators (for of those who do not refer it to man, not one applies it to the lightnings) happened to hit upon this rery simple explanation of the verse. 


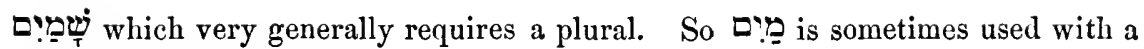
singular, e.g., Num. xix. 13.

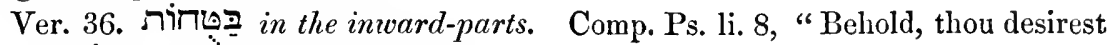

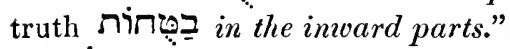

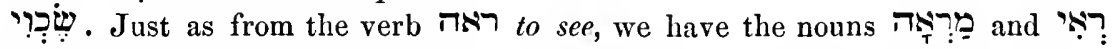
(supra xxxvii. 18), both signifying a looking-glass, i.e., an object at which we look,

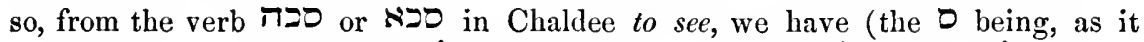

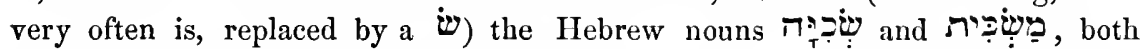

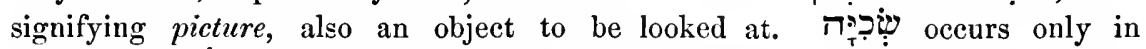

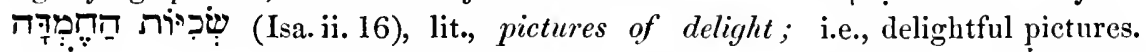
הֶבְ stone (or rather stones, for it is used collectively,) of imagery; i.e., stones disposed so as to form images, mosaic work (mosaic being probably derived from (Maskeeth)); and, in the plural, in Num. xxxiii. 52,

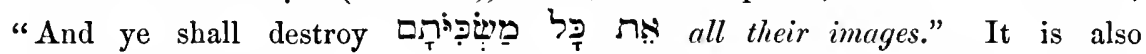
figuratively applied to the images of the mind, imaginations, as e.g.,

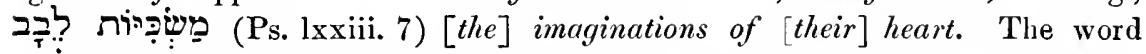
then, which no doubt is derived from the same root (a 1 having been inserted, as in חִדִ (1 Chron. xvi. 27) gladness, from דתדה), and of which the literal meaning is, probably, therefore thought, imagination, is used here of the seat of the thonghts, the mind,* as shown by its corresponding to ب̣ in the first hemistich.

This verse should be construed thus;

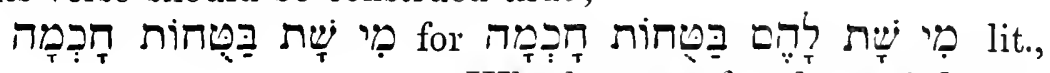
Who has put for them wislom in the inward-parts? i.e., who has put wisdom in their invard-parts?

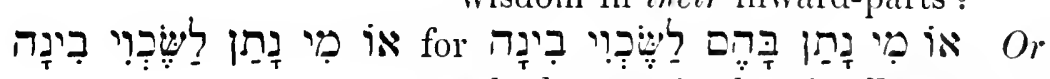
who has put in them intelligence for the mind? i.e., who has put intelligence in their mind?

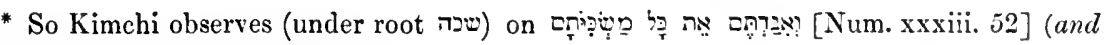
ye shall destroy all their pictures):

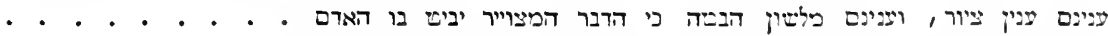

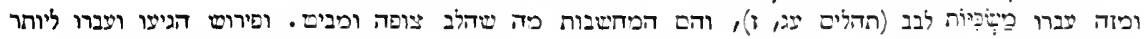

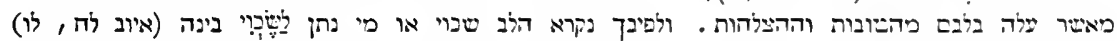

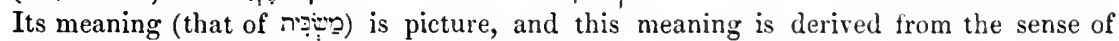
looking (which the root שבה has), for a thing which is pictured (painted), man looks at it

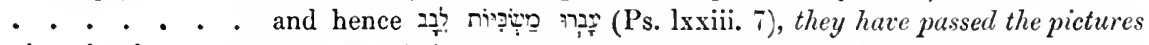
(imaginations) of their heart (mind), that is to say, the ideas, which the heart (mind) contemplates and beholds. And the interpretation is, that they attained unto and excelled that which came up in their mind concerning prosperity and success. And, therefore, the

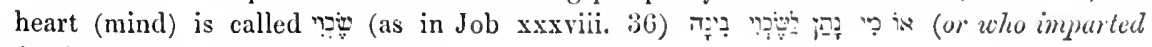
intelligence to the heart (mind)?) 
Ver. 37. ביפי lit., can cause to lie; i.e., lay out, dispose in layers. Similarly the Generese Version: "et qui dispose le giste (i.e, gîte) des barils des cieux?

Vers. 39-41. Having shown the utter inability of the human mind to penetrate the laws, which regulate the sublimer parts of His creation, God proceeds to demonstrate to Job that, even with regard to the creatures, which live around him on the globe, many of their instincts and habits remain a mystery to man.

Dost thou hunt prey for the lion? Or dost thou fill the appetite of the young-lions. (Ver. 40.) When they crouch in their dens, when they abide in the covert, in ambush? (Ver. 4l.) Who, besides myself, prepareth for the raven his food, when his young ones cry aloud unto God, when they wander for lack of food? $†$

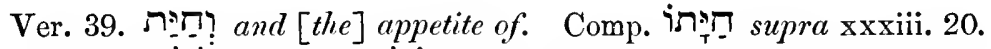

Ver. 40. .

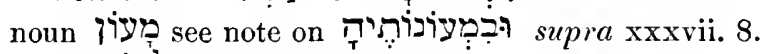

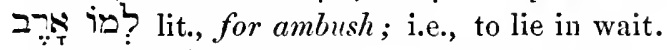

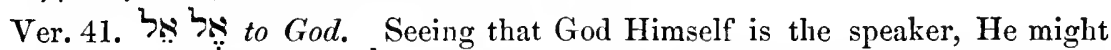
have been expected to say ș to $M e$; instances, however, do occur, where God employs, to designate Himself, one of His attributes, instead of a personal pronoun. Thus, in Gen. ix. 16, we read: "And the bow shall be in the cloud; and I will " "look upon it, that I may remember the everlasting covenant "between God, \&c.," instead of יבִ לetween Me. Again, Exod. xxiv. 1 we find

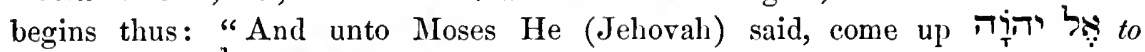
Jehovah," for "ל. to Me.+ See also infra xxxix. 17.

ית: for for wen they wander.

* Rosenmüller, perhaps justly, connects the following three verses with the next chapter.

† So the Psalmist says (Ps. clxvii. 9): "He giveth to the beast his food, and to the young ravens which cry."

$\ddagger$ Nor are instances wanting, in which men speak of themselves, or are spoken of, in the same manner. Thus, Jacob says to his sons (Gen. xlix. 2): "Gather yourselves together

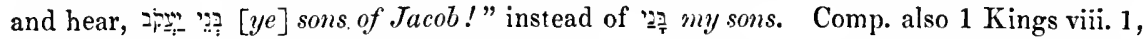
"Then Solomon assembled the elders of Israel . . . . . unto King Solomon in Jerusalem," where King Solomon stands in place of to him or to himself; and also Ibid. xii. 21.

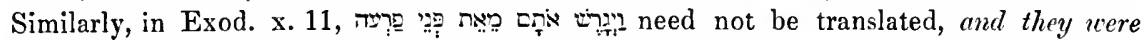
driven out from Pharaoh's presence, as though the verb were used impers., but may well be rendered, and he (i.e., Pharaoh who is speaking at the beginning of the verse) drave them ont from before Pharaoh, when from lefore Pharaoh would stand for from before him, or from his presence.-Editor, 1862. 


\title{
CHAPTER XXXIX.
}

Vers. 1-4. Dost thou know the time of the bringing forth of the wild goats of the rock? Dost thou watch the birth-throes of the hinds? (Ver. 2.) Dost thou number the months that they fulfil? Or dost thou know the time of their bringing forth? (Ver. 3.) They bow down; they cast forth their young; they dismiss their pains. By ridding themselves of their young, they rid themselves of the throes these caused them in their birth. (Ver. 4.) Their young ones wax strong, grow up in the open-field; they go forth, and do not return. Instead of needing the assistance of grown up animals of their own race, as human beings do that of adults, until they reach the age of maturity, these animals need no help, but can well take care of themselves.*

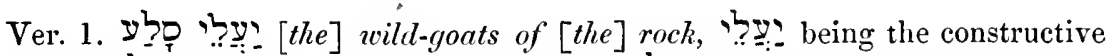

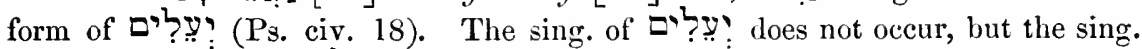

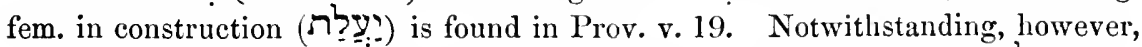
the existence of this fem., it would seem from the context here that common gender, and is used of wild she-goats. In like manner, also used to mean a hind in Ps. xlii. 2, as shown by its being followed by a fem.

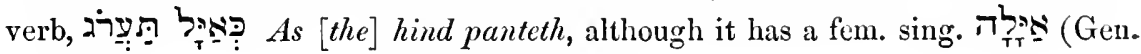
xlix. 21$) \cdot \dagger$

* So a well-known German poet says :

\author{
Kaum geboren, hiipfet schon \\ Jedes Lamm um seine Mutter; \\ Kaum geboren, findet schon \\ Jedes Huhn sein Bisschen Futter. \\ Nur der Mensch, das Gabelthier, \\ Kann sich keinen Schritt entfernen; \\ Und der Schöpfung stolze Zier \\ Muss erst gehen und essen lernen.
}

† As the verb th in Kal means to beget, as well as to bring forth (comp. Gen. iv. 18), "And Irad ילָ begat (Mehujael)), Dr. Bernard is strongly inclined to consider that "יע: in the verse before us should really be taken in its strict sense of wild he-goats of [the] rock, and strin in that of begetting or gendering, when the literal translation of the first hemistich would be, "Knowest thou the time of the gendering of the wild he-goats of the rock"? and a parallelism would be established between the two hemistiches of this verse, similar to that which we find in Chap. xxi. 10, where the first hemistich speaks of the gendering of the bull, and the second, of the calving of the corv. Kimchi, who, as well as

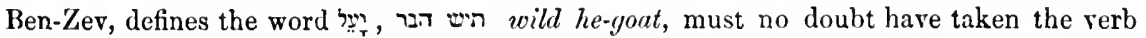
$\mathrm{n}$ in the same sense that Dr. Bernard would give to it.-Note of Editor. 
דלָ lit., [the] being in pain of ; for it is the inf. $P i-\hat{a} l$ of

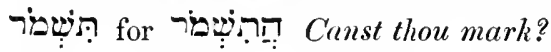

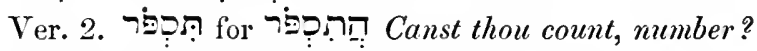

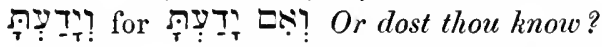

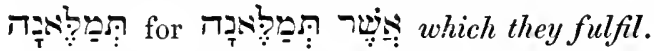

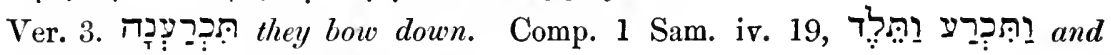
she bowed-down and travailed.

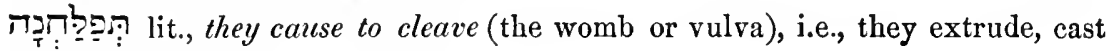
forth, give birth to.

Ver. 4. 극 근 in the open-field, this noun having here the same meaning that it frequently has in Chaldee, in the emphatic form $\times$ 굮. Comp. Dan. ii. 38,

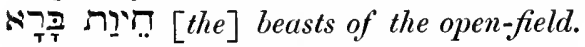

is being masc., cannot refer to the hinds, and must, therefore, be considered altogether pleonastic. There are several Hebrew verbs which take after them a

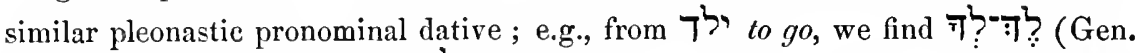

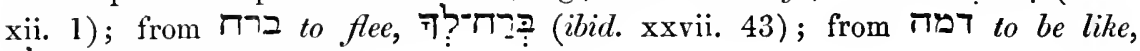

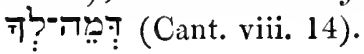

Ver. 5-8. Who hath sent out the wild-ass fiee? Who hath exempted him from the bondage of man, that he should not serve him, like his tamer brother, the domestic ass? Or who hath loosened the bands of the wild-mule?* (Ver. 6.) Whose house I have made the wilderness. To whom I have assigned the wilderness for his habitation. And his dwelling-places the saltland. That is, waste and barren land. (Ver. 7.) There he laugheth at the bustle of the city, neither heareth he the cries of the driver. (Ver. 8.) The searching of the mountains. What he can find on the mountains. Is his pasture. He is not, like the domestic mule, dependent upon a master for his food. And he seeketh after every green thing. No species of herb comes amiss to him.

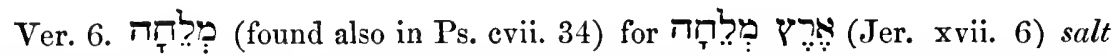
land; i.e., barren land. Comp. Deut. xxix. 23, "And the whole land thereof is

* The animal bearing this name seems to have derived it from its resemblance, in form and general appearance, to the domestic mule, without belonging, like it, to the class of hybrids, a class which probably requires the intervention of man for its production. [Why Dr. Bernard translated șild-mule, I do not know, unless it was for the purpose of avoiding the repetition of the word wild-ass. Kimchi, Ben-Zev, Buxtorf, Wolfssohn, and all other Commentators, as far as I know, take it to be synonymous with (wild-ass), and in no natural history can I find any mention of an animal bearing the name, wild-mule. 


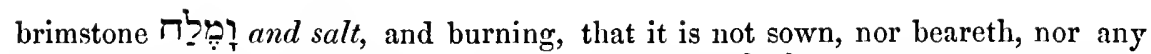

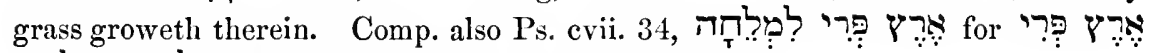
לִsִ a fruitful land into a salt (barren) land.

Ver. 8. יתוּר דירים : [the] searching of [the] mountains; i.e., what is obtained by searching the mountains; a noun formed from the verb רת to search, just as

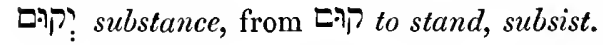

Ver. 9-12. Will the wild-bull be willing to serve thee? As the domestic ox does. Will he abide at thy crib? (Ver. 10.) Canst thou bind the wild-bull by his rope to the furrow? Canst thou, by means of a rope around his neck, compel him to make the furrows in thy land in a straight line, as thou wouldst wish? Will he harrow the valleys after thee? Dragging after thee the harrow. (Ver. 11.) Wilt thou have confidence in him, because his strength is great? Or canst thou leave thy labour to him? Entrust the tillage of thy land to him? (Ver. 12.) Canst thou trust him, that he will bring back thy seed? Canst thou rely upon his bringing back to thee the seed which thou hast sown, when grown into a crop and reaped? And that he will gather it into thy barn?

Ver. 9. רים a waild-bull (Ben-Zev, Waldstier) is more commonly written

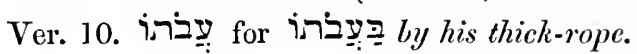

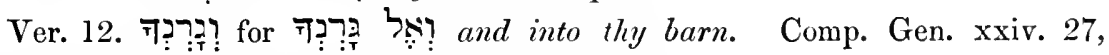

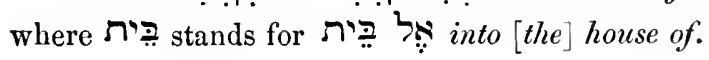

Vers. 13-18. The wing of ostriches is delightful. As far as regards colour and beauty, the wing of the ostrich stands wellnigh unrivalled, but can it, notwithstanding, be said to be really a wing? Is it the wing of the stork, or is it the plumage of the

Buffon, however, does describe a wild animal which bears some resemblance to a mule, and lives in the wilds of Tartary and Siberia, and he says that, in consequence of its thus partaking of the appearance of the horse and the ass, it has received from a German naturalist the name of mulet fécond de Daourie (a province of Siberia), in addition to its Tartaric name of Czigithai. Now, surely, an animal which is considered to be appropriately described by two such contradictory terms as fecund (or fruitful) mule, might with, at least, equal propriety be called a wild-mule, and I have, therefore determined to retain the name which seems to me to have been happily cliosen.-Note of Editor, 1862.]

* Ostrich feathers are worth, upon an average, about $8 l$. per lb., but when they are of a pure white their value is much greater, and they are sold (wholesale) for as much as $15 l$. per lb. See trial in Times, Feb. 7, 1862.-Note of Editor, 1862. 
stork? Can the ostrich use her wings and feathers for the same purposes that the stork does hers? Can the ostrich be said to be really a bird? Can she fly? Can she so much as leave the ground for an instant? No, she is not really and truly a bird; at most she is but half an one. (Ver. 14.) For she must leave her eggs to the ground. Instead of laying her eggs in a nest on the top of a high tree, or on some elevated building, she must confide them to the bare ground. And she must warm them by means of the dust. Instead of hatching them herself, as other birds are wont to do, she must leave them to be hatched by the heat of the dust and sand in which she has deposited them. (Ver. 15.) Yea, she forgetteth that a foot may crush them, or the beast of the field may trample upon them. If she could entertain any apprehension of her eggs meeting with such a fate, she would, as left without a remedy, feel most miserable, and therefore she has been created incapable of giving way to such apprehensions. (Ver. 16.) She hath been hardened; her young are as though they did not belong to her. She is as indifferent and callous to her young as though she had had no share in their production. Her labour. The trouble she took in disposing and arranging her eggs in the sand. May prove in vain. Nothing may come of the eggs which she has laid, since they may be trampled upon and crushed. Still she is without fear. She is free from all apprehension, because He whose "tender mercies are upon all His works" has had mercy upon her. (Ver. 17.) Because God hath made her to forget wisdom. And hath not allotted to her any share in intelligence. God having denied her real wings, and so rendered it impossible for her to lay her eggs, as the eagle, on some towering cliff, which neither man nor beast could ever hope to scale, blessed her with that callousness and indifference to her young, without which she would have been the most miserable of all His creatures. But not only are her eggs constantly exposed to danger, she herself, owing to the small size of her wings, is frequently thrown into the greatest trepidation, by the approach, namely, of mounted huntsmen. Yet (Ver. 18), if she could at the proper time. That is, when pursued by the hunters. Raise herself up on high. By means of her wings, as the stork and other birds do. She would langh at the horse and his rider. 


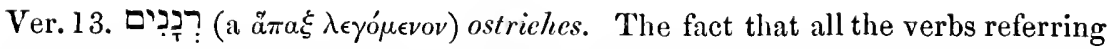
to this plural noun are used in the sing. indicates that every thing expressed by them is to be considered as predicated of every one of the individuals included in the plural. See note on iọ? supra vi. 17.

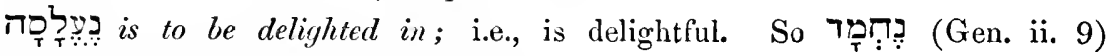
that is to be desired= desirable, pleasant.

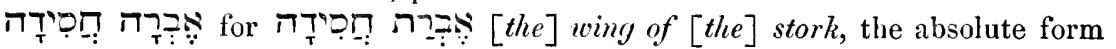

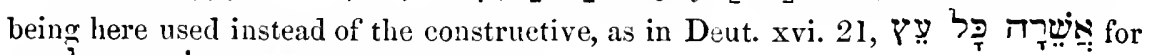

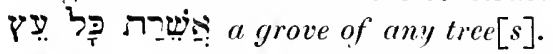

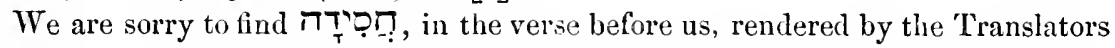
of the Auth. Vers., ostrich, although in Jer. viii. 7, and Ps. civ. 17 (passages, in which the context quite forbids us to understand it of the ostrich, since the bird spoken of is described as being in the heavens, and building its nests in firtrees), they have given it its true meaning, stork.

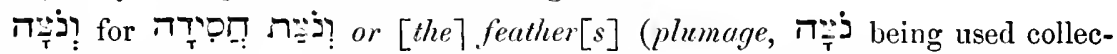
tively) of a stork. In the marginal reading of the Auth. Ver's, this word has, it would seem, been taken to mean ostrich; on what grounds we cannot even guess,

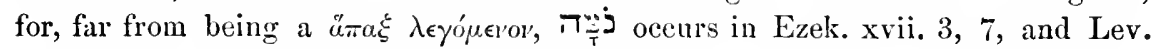
i. 16, and in all these passages signifies, and is rendered in the Auth. Vers., feather.

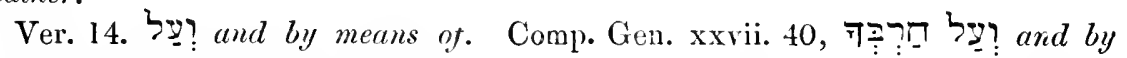
means of thy sword, by thy sword.

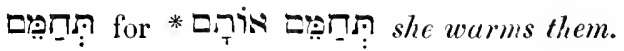

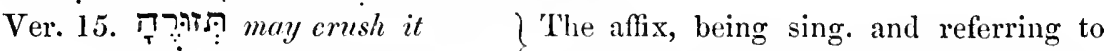

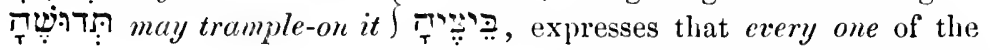
'ggs is liable to be crushed, or trampled upon.

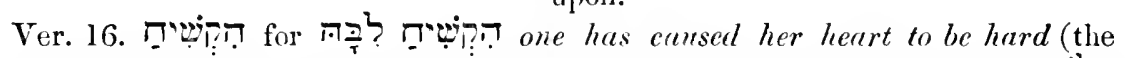
verb being used impers.), i.e., her heart has been made hard, hardened. Or God, may be supplied from the next verse as the nom., i.e., Gorl has hardened her

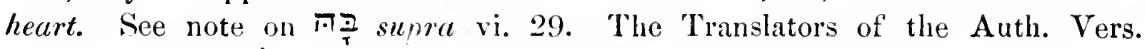

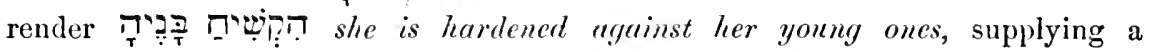
preposition ; but for this, in our humble opinion, they have no authority, as in the only other place in which this verb occurs, viz., in Isa. lxiii. 17, it is joined with

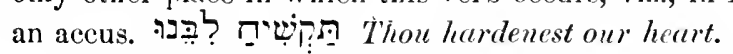

Ver. 17. הiר God, is again used here instead of a personal pronoun. See note on has supra xxinii. 41.

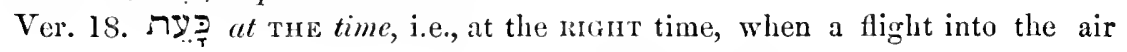

* Or, perhaps, rather was as, though has the form of a masc. plur., it is

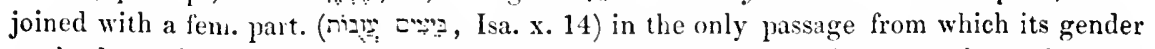
can be determined. The sing. Rabbins of the Talmud, though they also use the Chald. form str. The fem. affix of the two verbs in Ver. 15 renders it probable that in Heb. also the sing. was ביצr. As the

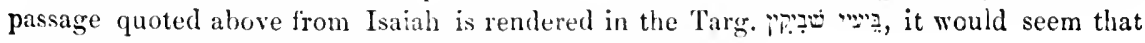

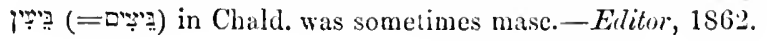




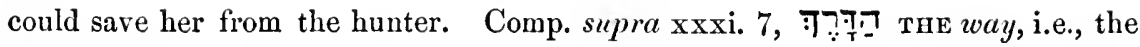
right way.

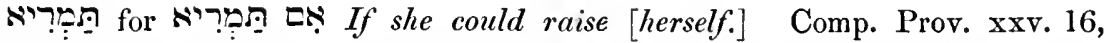

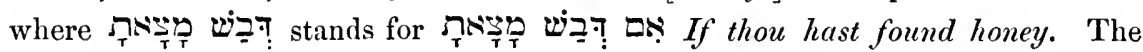

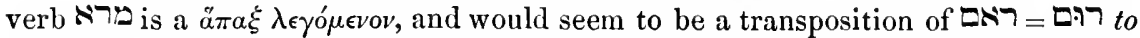

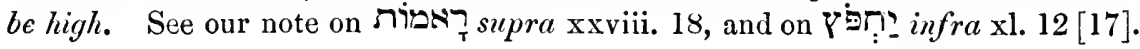

The six verses, which have just occupied our attention, namely vers. 13-18, have been considered by some Commentators (and amongst them by Wolfssohn) so difficult, and so many various opinions have been ventured upon them, that we feel we should not be doing justice, either to the reader, or to ourselves, if we omitted to point out the way, in which we construe them.

Ver. 13.

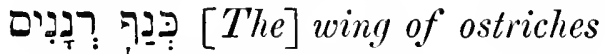

is is delightful;

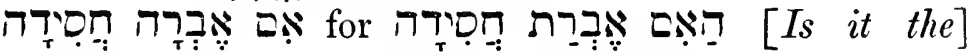
wing of a stork,

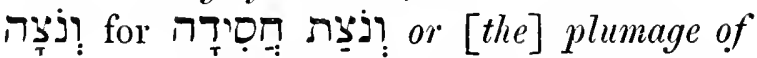
a stork? (i.e., is the ostrich really a bird? Can she fly, or build her nest on a high place, as the stork does? Certainly not!)

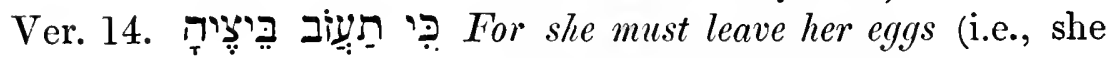
must entrust her eggs)

隹 to the earth;

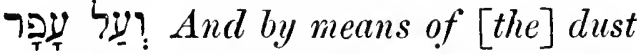

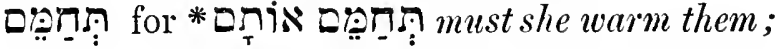
Ver. 15. The she forgets (i.e., she does not conceive any apprehension),

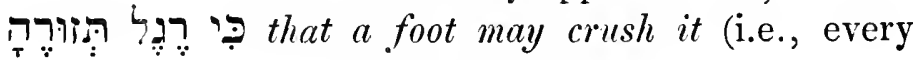
one of her eggs);

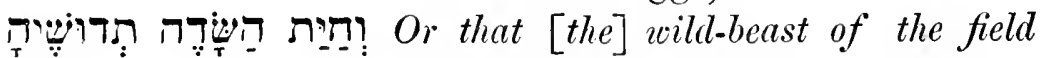
may trample upon it.

Ver. 16.

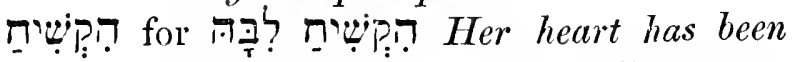
hardened (i.e., God, in His mercy, has hardened her heart);

רָּ

*. See note in preceding page. 


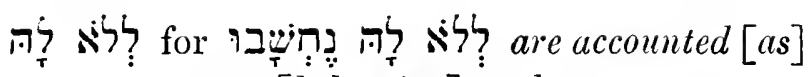
not [belonging] to her;

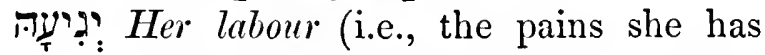
taken to bury her eggs in the sand)

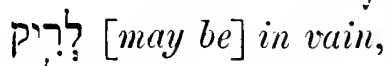

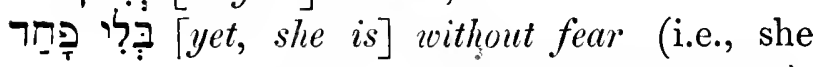

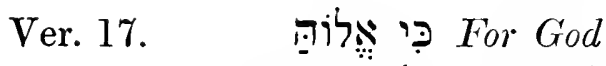
entertains no fear upon that score);

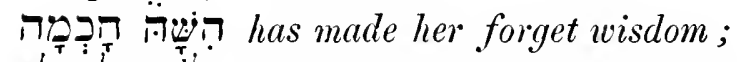
Nay, He never allotted her any portion in intelligence (i.e., God, having denied her wings, whereby she would have been enabled to fly, and build her nest in lofty places, has in His mercy also denied her intelligence to foresee the dangers which threaten her young ones, and which would by anticipation, have rendered her most miserable, as having no means of averting them.)

Ver. 18.

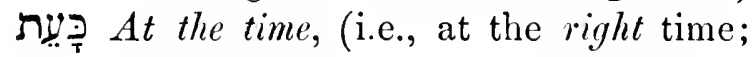
when pursued, and nearly overtaken, by the hunter),

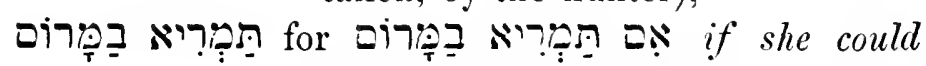
raise [herself] on high (i.e., mount up into the heavens as real birds do),

She would laugh at the horse, and his vider (i.e., instead of being thrown into agonies of terror, on being pursued by the horse and his rider, she would laugh at them both).*

* To understand Ver. 18, as all others before us have done, to express, that the ostrich, when with outstretched neck and expanded wings she prepares to fly before the huntsman, laughs at the horse and his rider, as feeling that she can easily outstrip them, seems to us exceedingly absurd. Her fleetness may, indeed, surpass that of the horse, but she must, nevertheless, all the while she is being pursued, be in a state of the most agonizing anxiety and alarm, a state, which none but a rery eccentric poet would dare venture to express by the verb שת to laugh. As, however, in Ver. 13 a parallel was drawn between the 
Vers. 19-25. Dost thou give miglt to the horse? Dost thou clothe his neck with the rustling-mane? (Ver. 20.) Dost thou make him to leap like the locust? The glory of his snorting is terrible! (Ver. 21.) He paweth in the valley, and rejoiceth in his strength; he goeth forth to meet the weapon. (Ver. 22.) He laugheth at fear, aml is not dismayed; and he turneth not back from the sword. (Ver. 2:3.) The quiver rattleth upon him, the glittering spear, and the lance. (Ver. 24.) With noise and fury he devoureth the ground, and cannot be steady when there is the sound of the trumpet. (Ver. 25.) When there is abundance of trumpeting, he saith, Aha! and from afior he scenteth the battle, he scenteth the thundering-cries of the captains, and their shouting.

N.B. In the Translation, we have marked Vers. 13-18 (B), and Vers. 19-25 (A), giving at the same time our reasons for doing so in a note. As, however, the transposition did not appear to us absolutely necessary, we have abstained from actually making it.

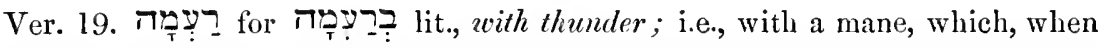
tossed upon the horse's neck, makes a rustling noise, here, somewhat hyperbolically, compared to thunder.

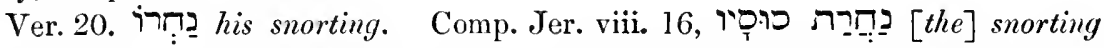
of his horses. We are grieved to find this word rendered in the Eng. Vers. his nostrils, as though it were

ה. איָָה lit., terror, used here instead of an adj. exciting terror, terrible. See note on חָָ supra xix. 29.

Ver. 21. יב בְּר lit., they dig, i.e., by pawing make holes in the ground. There is here a change of number from the sing. to the plur., as though, instead of one horse being taken as the representative of his race, horses were now spoken of generally. Such a change is by 110 means uncommon in Hebrew.

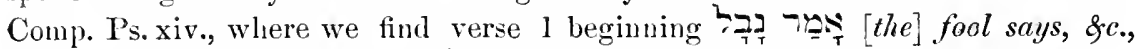

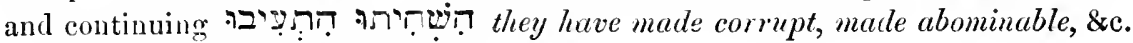

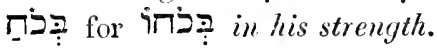

ostrich and the sto:k, Ver. 18 may, perliaps, be intended to apply to the latter and to form the conclusion to that parallel. It would then place in very strong contrast the facility with which the stork is enabled, by means of her powers of flight, to escape from her pursuers, at whom, man and horse, she might then well be said to mock, with the comparative helplessness of the ostrich as detailed in Ver. 13. Besides, sị being uniformly used of a

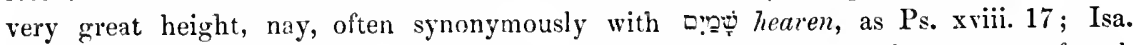
xxiv. 18,21 ; lii. 15 , would it not be extremely strange, if not ridiculous, to say of such an uncouth and heavy bird as the ostrich, a bird, which cannot quit the ground one inch, that she can raise herself oing on $h i g h$ ? Much more probable is it, that this word is in the present instance employed as synonymous with

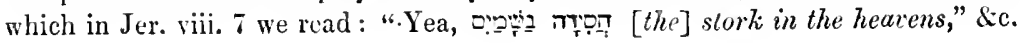




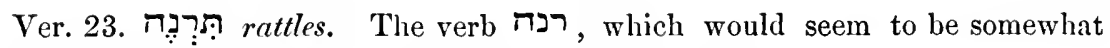
similar in meaning to $i ר$, is found only in this verse.

[-

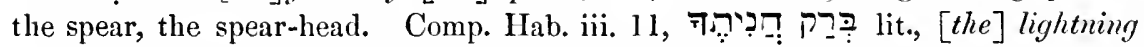
of $[$ Thy $]$ spear ; i.e., the glittering part of Thy spear.

Ver. 24. *Ną: lit., he drinks up, swallows; i.e., devours (the earth) in the swiftness of his gallop. So Shakespeare :

He seemcd in running to devour the way."

(Hen. IV., second part, Act I., sc. 1.)

Comp. also carpere prata fuga (Virg. Georg. iii. 142.), and the vorare viam of Catullus (xxxv. 7).

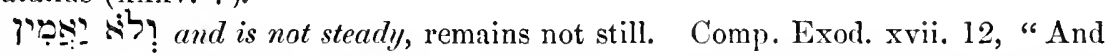
his hands were steadiness; i.e., steady. In the translation given of these words in the Eng. Ver. we can see no sense.

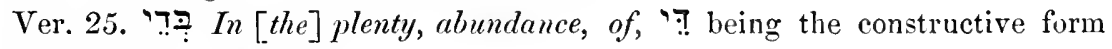
of 'רָ enough, or plenty.

Vers. 26-30. Is it by thine intelligence, that the hawk soareth, spreadeth out his wings towards the south? Hast thou, in thy wisdom, given him the instinct which prompts him to fly to the south on the approach of the cold season? (Ver. 27.) Is it by thy command, that the eagle taketh a high fight, or that he maketh his nest on high? (Ver. 28.) He dwelleth and abideth on the rock, upon the crag of the rock, and the fortress. On the natural fortress of a lofty rock. (Ver. 29.) Thence he seeketh out his food; his eyes behold it at a distance. (Ver. 30.) And his young ones suck up blood. From their very birth they begin to drink blood. And where the slain are, there is he.

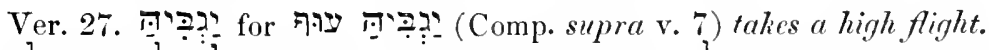

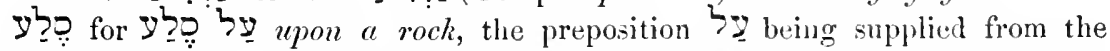
second hemistich; though this is, pcrhaps, unnecessary, as the verb sometimes found followed by a simple accusative, e.g., in Ps. lxviii. 7,

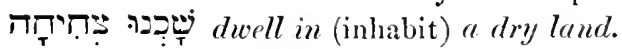

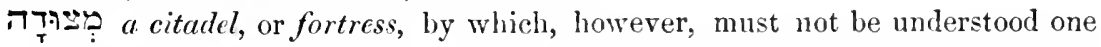
made by the hands of man, but one of natmre's fortresses, a lofty and inaccessible rock, sucl as the eagle commonly selects to build his nest upon.

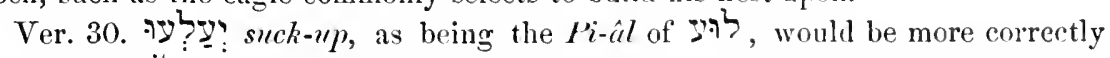
written secutive Y's would give rise, one of the two has been transposed and put before

* Dr. Bernard is inclined to think that horse often raises in clouds around him when galloping, and which of necessity inhaling he would appear to swallow.-Eiditur. 
the 3 . Such is the account given of this word by Kimchi and Ben-Zev. Modern Lexicographers have introduced the root על על, on what authority we know not.

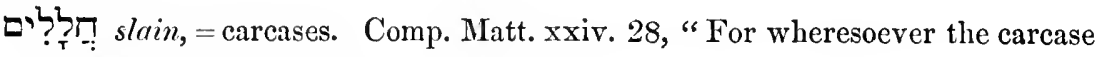
is, there will the eagles be gathered together."

\section{ARRANGEMEN'T OE CHAPTERS 40-42.}

In the course of the preceding Chapters we have met with, and called the reader's attention to, several passages, to which a more suitable place than that which they now occupy could easily be assigned. In these cases, however, the transpositions suggested by us were merely a matter of taste, and therefore we refrained from disturbing the arrangement of the text. In the Chapters upon which we are now entering, on the contrary, the transpositions we shall have to propose are a matter of absolute necessity, as ably shown by Wolfssohn, whose reasons, as entirely coinciding with our own, we cannot do better than give here in his own words. He commences with a brief summary of God's discourses, and then continues as follows:

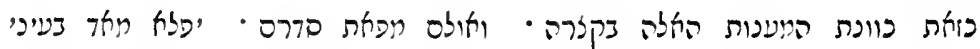

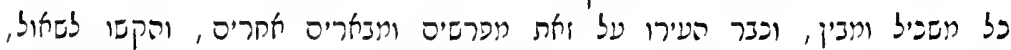

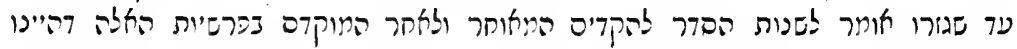

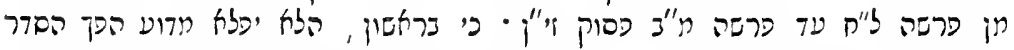

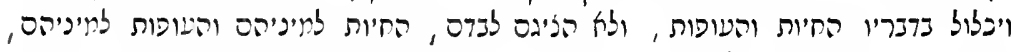

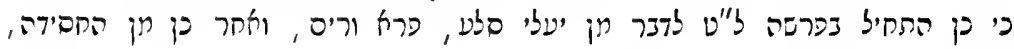

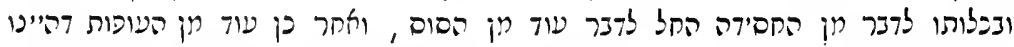

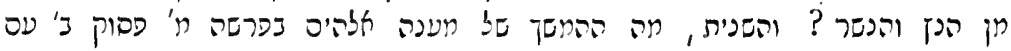

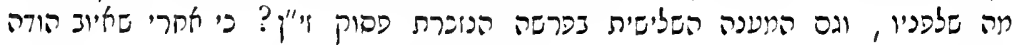

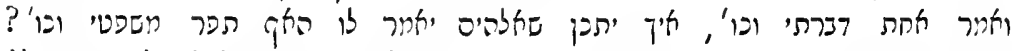

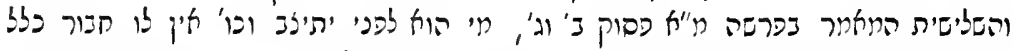

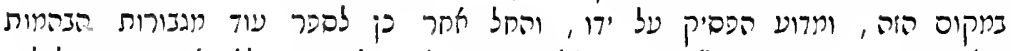

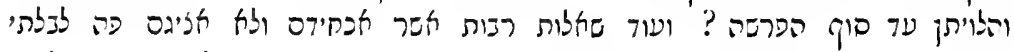

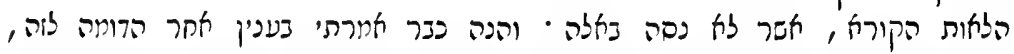

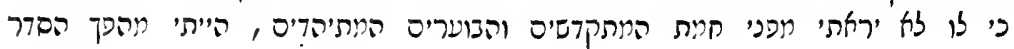




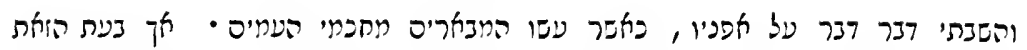

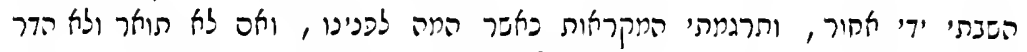

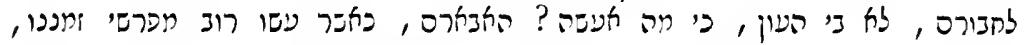

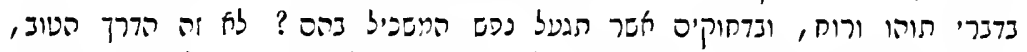

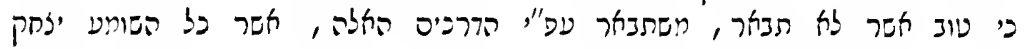

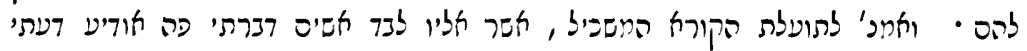

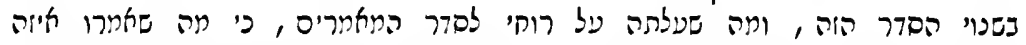

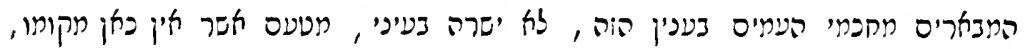

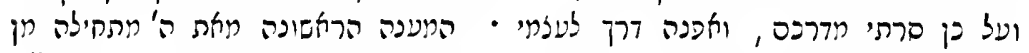

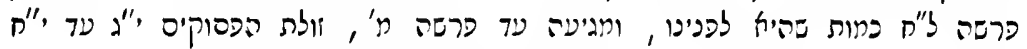

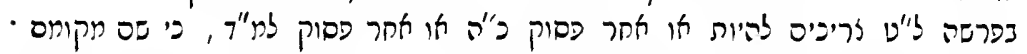

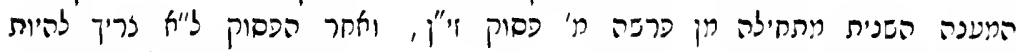

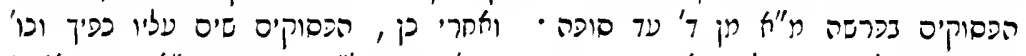

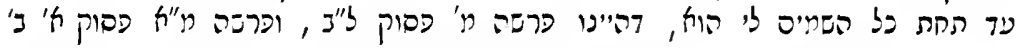

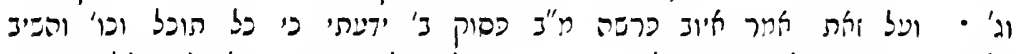

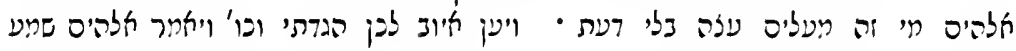

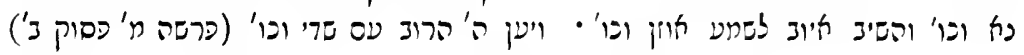

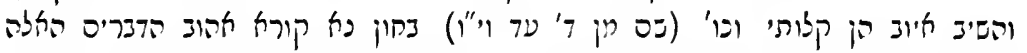

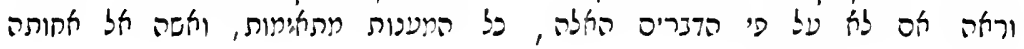

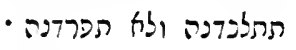

"Such is the drift of these discourses briefly. But, with regard to " their arrangement, this must appear very strange in the eyes of every " sensible and intelligent man, and other interpreters and commentators " have already called attention thereunto; and they raised such difficult "questions, that they ended by declaring their determination to change " the arrangement,- to place later passages earlier, and earlier passages "later, in these Chapters, viz., from Chap. xxxviii. to Chap. xlii. 7. "For, in the first place, is it not strange that (lit., why) He (God) has "perverted the order, inasmuch as IIe comprehends beasts and birds " in His discourse, yet does not place them separately, the beasts " according to their kinds, and the birds according to their kinds? "Thus, He begins, in Chap. xxxix., to speak of the wild-goats of the " rock, the wild-ass, and the wild-bull, and next of the stork, and, " on His finishing to speak of the stork, He begins again to speak of " the horse, and next to that again of the birds, namely, of the hawk " and the eagle. And, secondly, what connection is there between the " discourse of God in Chap. xl. 2, and that which precedes it, or also " [with] the third discourse in the same Chapter, ver.7? For, after " Job has confessed and said, 'Once have I spoken, \&c.,' how is it " possible that God should say to him, "Wilt thou, indeed, deny MIy " justice, \&c.?" And, in the third place, the passage in Chapter xli. 2, 3, " 'Who is he that can stand before Me, \&c. ?' has no connection whatever " in that place; and why did He conclude with this rerse, and then " again begin to speak of the might of the beasts and the crocodile, to 
" the end of the chapter? And there are still many questions, which "I will conceal and not place here, in order not to weary out the " rearer, who has bad no experience in such [matters]. Now, behold ! I " have already said on another, but similar occasion, that, if I had not " been afraid of the fury of those pretended saints, and of those brutish " men who feign to be [strict] Jews, I should have inverted the order, " and should have restored everything [so as to be] in its [proper] turn, " as the Commentators from among the wise men of [other] nations have " done. But, at the present time, I have withdrawn my hand backwards, " and have interpreted the verses as they are before us ; and, if their con" nection has neither comeliness nor beauty, the fault is not with me, for "what am I to do? Shall I explain them, as most of the Commentators " of our time have done, with empty and windy words, and with forced " explanations, which an intelligent mind must loathe? This is not the " right way, for better would it be that they should not be explained, than " that they should be explained in such a manner that every one who heard " it should laugh thereat. However, for the benefit of the intelligent " reader, to whom alone I here direct my words, I will make known my own " opinion with regard to the alteration of the order [in these Chapters], " and how it has occurred to me to arrange the passages, for that, which "some interpreters from among the wise men of [other] nations have " said upon this subject, does not seem right in my eyes, for reasons, "whose place is not here, and therefore $I$ have turned from their way, " and have prepared a way for myself. The first discourse of Jehovah " begins Chap. xxxviii., as it is before us, and extends to Chap. xl., with " the exception of Vers. 13-18 in Chap. xxxix, which ought to be " either after Ver. 25, or after Ver. 30 [of that Chapter], for there " is their [proper] place. The second discourse begins at Chap. xl. 7, "and after Ver. 31 [of this Chapter] ought to come the Verses of "Chap. xli., from Ver. 4 to the end thereof; and next [should come] the "Verses, 'Put thy hands upon him,' \&c., to 'whatsover is under the "whole heavens is mine,' that is, Chap. xl. 32, and Chap. xli. 1-3. "And, in reply to this, Job says, Chap. xlii. 2, 'I know that Thou canst " do everything,' \&c., to which God answers, "Who is he that hideth " counsel without knowledge?' Then Job replies 'Therefore have I “ uttered,' \&c., and God says, 'Hear, now,' \&c., when Job answers, " 'By the hearing of the ear,' \&c., and Jehovah rejoins, 'Is he who " contendeth with the Almighty,' \&c. (Chap. xl. 2), Job answering, " 'Behold, I have been vile,' $\mathcal{S}$ c. (ibid. Vers. 4, 5). Prove, I pray thee, " dear reader, these words, and consider, whether according to these " words, all the discourses will not exactly fit together, and so closely "stick one to another, that they cannot be parted." 


\section{CHAPTER XL.}

As Job had in plain terms (supra xix, 6, 7; xxrii. 2) impugned the justice of Him, who is Judge of all the earth, we shall hear him asked in the discourse we are now entering upon, whether he considers himself capable of taking the reins of supreme government into his own hands; whether he is sharp-sighted enough to discover pride, arrogance, and wickedness, wherever they exist on the face of the globe; and whether he is powerful enough to inflict upon such as harbour them the punishment they merit. He will moreover be shown, that not only would his sagacity be baffled, his power defied, by men, rational beings like himself, but that, even in the brute creation, many an animal might be found, which would quickly próve to him his utter impotence, were he so madly headlong as to measure his strength with it. The elephant, for example, a quiet, harmless, and inoffensive, beast,-would he undertake to cope with it? The hippopotamus, again, far less noble and sagacious than the elephant, and rather resembling the hog, like which it rolls and wallows in the mire,would he not have to yield even to it the palm in strength and power? Even the crocodile, a creature much lower than the preceding in the scale of creation, nothing in fact but a monstrous reptile,-would not his heart fail him at its very approach ?Such will be found to be the drift of the present Chapter, which God begins by saying:

Ver. 2-9. [*7-14]. Gird up now thy loins like a man! I will ask thee questions, and do thou inform Me! (Ver. 3) [8]. Wilt thou indeed deny My justice? Wilt thou condemn Me, that thou mayest appear just? (Ver. 4) [9]. Hlast thou then an arm like God? Or canst thou thunder with a voice like Ilim? (Ver. 5) [10]. Deck now thyself with excellency and majesty, and put on glory and splendour! (Ver. 6) [11]. Scatter around thee the fury of thy wrath, and look out for every one that is

* The numbers in square brackets indicate the correspondirg rerses in the Hebrew text. 
proud, and bring him low! (Ver. 7) [12]. Look out for every one that is proud; humble him, and crush the wicked in their place! Wheresoever thou discoverest them. (Ver. 8) [13]. Hide them altogether in the dust! Bind their persons in some hidden-place! (Ver. 9) [14]. Then will I also confess to thee, that thine own right hand can help thee. Then, but not till then, will I admit, that thou requirest not $\mathrm{My}$ help, but of thyself art able to govern and administer the world.

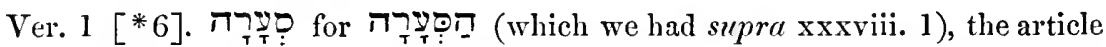

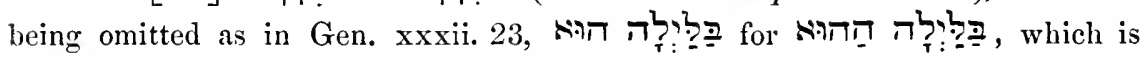
actually found at the end of the preceding verse.

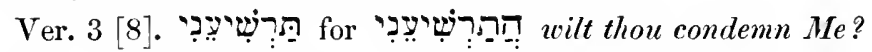

Ver. 4 [9]. rogative, particle, and it should be supplied in the second hemistich.

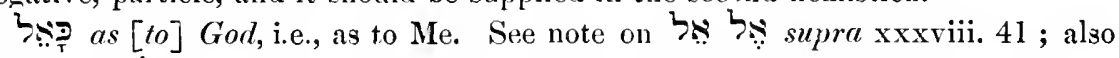

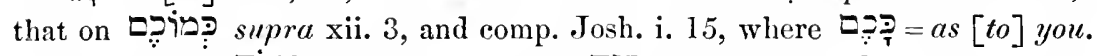

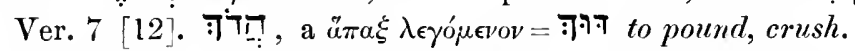

Ver. 8 [13].

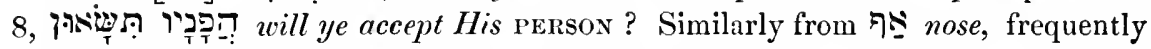
used (in the dual) in the sense of face, countenance (as e.g., Gen. xix. 1), we find in 1 Sam. i. 5, "one portion of

Vers. 10-19 [15-24]. But, if thou feelest thine utter inability to control men, thy fellow-creatures, come try thy strength on an inferior class of animals! with them, perhaps, thou wilt, have more success. Behold now the beasts, which I have made to be with thee. To inhabit the earth with thee. The one. The elephant. Eateth grass like the ox. He is not a carnivorous animal, he feeds solely on what the earth brings forth, and so is by no means savage or ferocious. (Ver. 11) [16]. Behold now his strength is in his loins, and his might is in the muscles of his belly. (Ver. 12) [17]. When he groweth lustful, his tail. Membrum intelligas virile. Is like a cedar. The sinews of his testicles become entwined. Scrotum non habet lixum et pendulum, sed-insigne virilitatis argumentum - valde constrictum et corrugatum. (Ver. 13) [18]. Iris limbs are like strong-pieces of brass; his bones, like bar[s] of iron! (Ver. 14) [19]. He is the chief of the works of God. He holds the first place among 
quadrupeds, not only on account of his size, but also on account of his sagacity, in point of which he stands next to man himself. He who wisheth to dress him-let him bring his knife near him! Let him approach him with his knife! Let the man who longs to taste his flesh come and slay him with his knife! for he is not a carnivorous animal, he grazes like an ox, and might, therefore, be supposed to be fit for food. (Ver. 15) [20]. Surely the mountains bear for him their produce. He pastures on the mountains, and so quiet is he, so harmless and inoffensive, That all the beast $[s]$ of the field may gambol there. Where he is. They may approach him without fear, he will not injure them. Why then not butcher and dress him, like an ox, a sheep, or a lamb?

(Ver. 16) [21]. The other. The hippopotamus. Lieth under shady-trees, in the covert of the reed, and in the mire. (Ver. 17) [22]. Shady-trees cover him every one with its shade; the willows of the brook $[s]$ surround him. (Ver. 18) [:3]. Lo! the river may become violent, lie will make not haste, to flee before it. He would remain confident, though Jordan were suddenly to swell up to his very mouth. Would any man dare to try his strength with him? No, man's love of life is too strong for that! (Ver. 19) [24]. It is by means of his eyes alone that he (man) can take him. It is only by enticing and alluring him-by placing something he delights in before his eyes, that he can be subdued and mastered. By means of snares only can he (man) bore his nostril[s.] Before he can put a ring through his snout, as he does through that of other animals, he must first decoy him into his snare; for by violence he could never effect it.

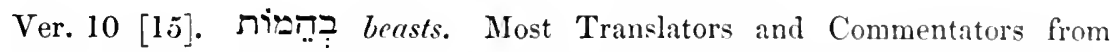
motives which we have been quite unable to penetrate, regard the whole of the ten verses before us as containing the description of one and the same beast, the elephant according to some, the hippopotamus according to others. It is not to be wondered at, therefore, that the plural תing? (B'haymowth) should have proved a source of great embarrassment to them. In such a dilemma, indeed, did they find themselves placed by this view of theirs (a view, in which the Translators of the Auth. Vers. participate), that they were reduced to seek their escape therefrom in the adoption of a most unwarrantable expedient, that, namely, of declaring one single animal, the elephant, or, as some would have it, the hippopotamus, to be designated by this noun in the plural. Rosenmiiller, it is true, who considers the hippopotamus to be the sole subject of these ten verses, tells us 
that the word תim as being equal in size to many others put together, adding "Pluralem numerum, etiam de singularibus, sed magnis et prestantibus rebus apud Hebræos usurpari, notum," but the examples he adduces in support of this chimera of his, are so very ineonclusive, vague, and unsatisfactory, that we will not even stay to notice, mueh less refute them. This very easy task we will leave to any reader, who may have patience sufficient to eonsult the passages of Scripture referred to by this Commentator, and we will at once proceed to bring forward our reasons for regarding as altogether erroneous, and unwarranted by the context, this view, which we have mentioned as being entertained by the majority of the Translators and Commentators, -and for believing that the first six verses refer to the elephant, and the last four to the lippopotamus. Our reasons, then, are that Vers. 16-19 [21-24], whieh depict a filthy amphibious animal, delighting, like a hog, to roll and wallow in mud and mire, ean certainly not be applied to the noble and stately elephant; while, on the other hand, Ver. 15 [20], as representing a gentle, patient, and good-natured, graminivorous animal, which suffers other animals to sport and gambol around it on the mountain, ean scarcely be referred to the hippopotamus, which is so timid and solitary in its habits, that it seldom leaves the water but at night, and certainly never ventures on the mountains; whilst, that it lives altogether upon herbs, esehewing the fish, which was formerly assigned it as the ehief constituent of its food, has only been maintained of late, and is as yet but imperfeetly made out. Moreover, the highly honourable title of [the] chief of [the] works of God, which, owing to the sweetness of its temper and to its great sagacity, might fairly be bestowed upon the elephant, could not by any possibility be eonferred upon the dull and stupid hippopotamus. We, therefore, prefer to supply (as will be shown more clearly in our notes upon the verses we are about to specify) 7 the one, in Ver. 10 [15], and $\pi ?$ and the other, in Ver. 16 [21], and understand Vers. 10-15 [15-20] to refer to the elephant, and Vers. 16-19 [21-24] to the hippopotamus, when the description given of each of these animals will be found most appropriate, and the plural תim most natural. An ellipsis of this sort we have already had occasion to notice when eommenting on the verbs whieh occur supra xvi. 13-14, and to our note upon them we beg to refer the reader.

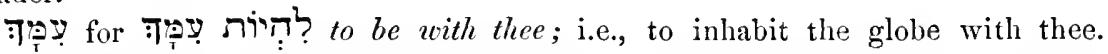

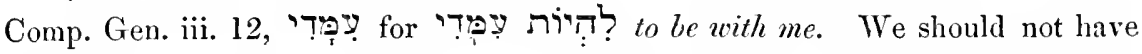
thought it worth while to dwell upon this word (ד⿳⺈⿴囗十丁), if we had not remarked, that very few Commentators have given it the meaning we do.

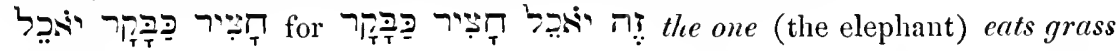
like the ox.

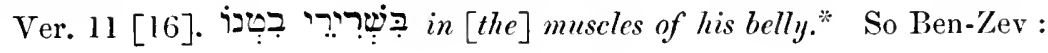

* Dr. Bernard is strongly inclined to translate בְִ his body (as in Ps. xxxi. 10

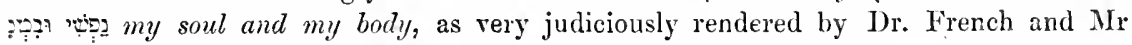
Skinner, and also in the Prayer-book version of the l'salm), when the meaning of the 


\section{השיתרים שחם חזקי הגוף , מוסקעלן}

"The sinews, which are the strong-parts of the body (Muskeln-muscles)."

We are sorry to see, that the Translators of the Auth Vers. have given the

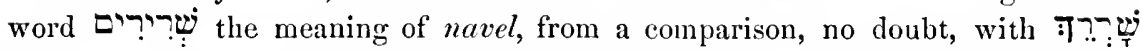
(Cant. vii. 3) thy navel, forgetting that the navel could scarcely be designated by a plural noun.

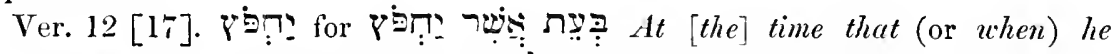
becomes lusiful. Comp. Ps. civ. 29, תַח [When] Thou hidest Thy face, they are troubled, as very properly translated in the Prayer-book. The Germans very frequently employ the same idiom, so that Yir:- might in their language very well be rendered here wird er lïstern $=$ wenn er lïstern wird.

iุi his tail, by which must be meant here his penis, or pizzle, as is evident from the next hemistich. The German Schwanz is sometimes, though very vulgarly, used in the same meaning.

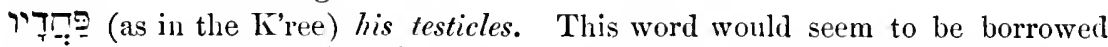

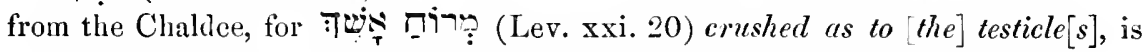
rendered by Onkelos

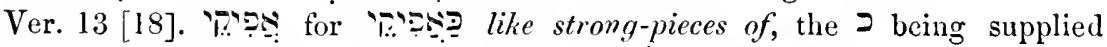

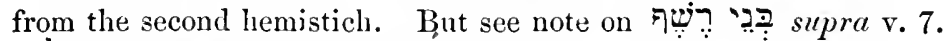

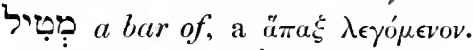

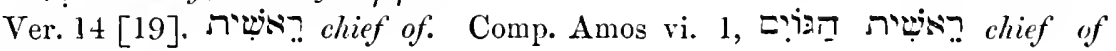
the nations.

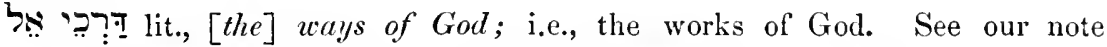

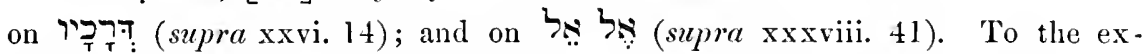
amples quoted in the former of these notes we will here add Ps. exlv. 17,

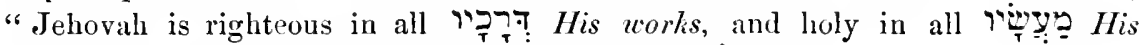

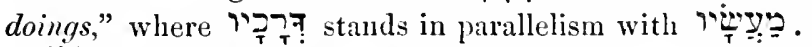

העיד the [one] dressing him; i.e., the one who has a mind to dress him for

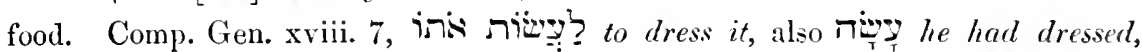
in the following verse; and many other passages might be quoted where the verb עשה yas this signification. The affix in article before it is quite admissible. See Mason and Bernard's Grammar, Letter xlvi. $\$ 2$ ad finem.

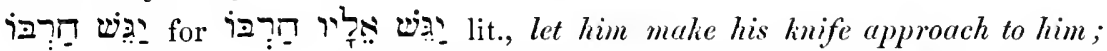
i.e., let him approach him with his knife. The noun 7 is not always used in the meaning of sword, but is sometimes applied to other cutting instruments.

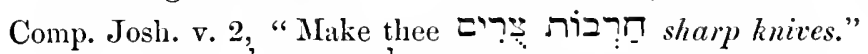

Ver. 15 [20]. ברויל i.q., [the] produce of.

second hemistich of the rerse before us would be, that the strength of the animal lies in all the muscles of his body, and not only in his loins. Struck though I was by the aptness of the reference, I still preferred to give the word its usual signification of belly, as in the first place it is somewhat of a truism to say that an animal's strength lies in the muscles of his body, for where else could it lie? and, secondly, belly forms a better parallel with loins. - Note of Editor. 
שדָ mountrins, stands here much as it does in Ps. cxlvii. 8, "who maketh grass to grow upon the mountuins."

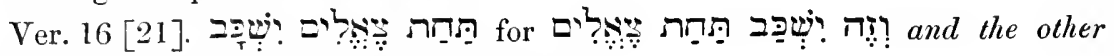
(the hippopotamus) lies under shady-trees.

The $k$ in $\Xi$ ? may perhaps stand in the place of $\zeta$, as in

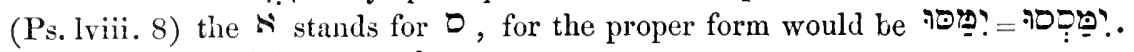

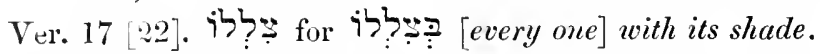

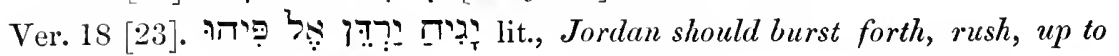
his mouth; i.e., suddenly swell up to a level with it.

Vers. $20-26$ [25-31]. Canst thou draw out the crocodile with an hook, and with a rope, which thou mightest sink into his tongue? Canst thou angle for the crocodile, as for a fish, with rod and line? (Ver. 21) [26]. Canst thou put an hook into his nose, or pierce his cheek with a ring? So as, by means of a cord thereunto attached, to make him follow thee whithersoever thou goest. (Ver. 22) [27]. Will he make many supplications unto thee? Will he speak soft-words unto thee? Will he fawn upon thee, and by his gestures seek to express his attachment to thee, as a dog might do? (Ver. 23) [2S]. Will he make a covenant with thee? Will he enter into an agreement to serve thee? Canst thou take him for a perpetual slave? As thou dost all thy domestic animals. (Ver. 24) [29]. Canst thou play with him, as with a bird, or canst thou bind him for thy maidens? For their amusement. Canst thou catch and cage him as a bird? (Ver. 25) [30]. Will the companies make a banquet upon him. As they might of a fish, whose flesh was delicate. Will they divide him anong the merchants? Will they traffic with his flesh, as they do with that of many a fish, when salted and preserved? (Ver. 26) [31]. Canst thou fill his skin with darts, or his head with fish-spears? Is his skin to be penetrated by any weapons of the sort?

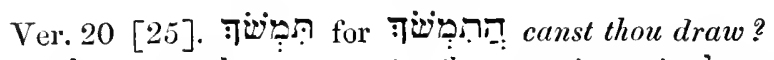

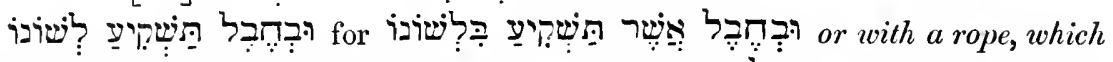
thou mightest sink into his tongue, the prefix $ב$ in before izivi?

Ver. 21 [26]. cation of reed, or bulrush, but here it is evidently intended to designate some bent and crooked instrument.*

* Infia xli. 9 [12] it has yet another meaning given to it, namely, caldron.-Editor, 1862. 
So Kimchi says :

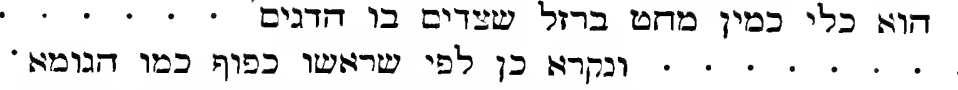

"It (אגמן) is an instrument like an iron needle, with which they catch fish - . . . and it is so called, because its head is curved like [that of] a rush."

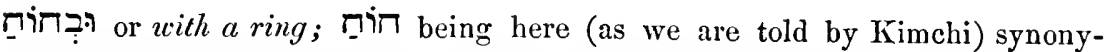
mous with $\pi \pi_{\tau}$, which in Exod. xxxv. 22, and also in Ezek. xxix. 4, in the plural (K'ree), as well as in other places, signifies a ring, or other circular object. The more usual meaning of ㄲiा is of course thorn, but this would make no sense here.

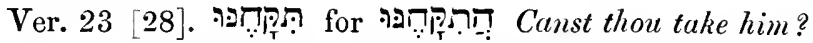

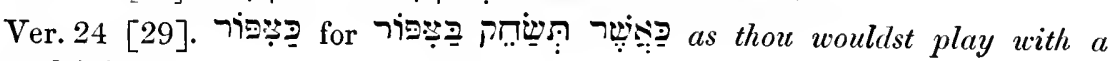
(lit., the) bird.

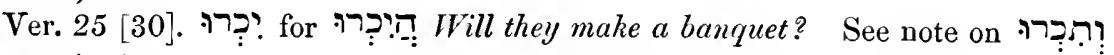
supra vi. 27.

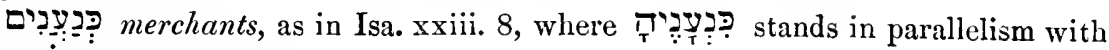
דָ

Ver. 26 [31]. תְְִִ with darts. Kimchi gives this word under the root Tiv, telling us that the Dagesh in the $\supset$ is in the place of the quiescent ?, while with regard to its signification, and that of some other words derived from the same root, his observation is :

\section{ועבינם ידוע}

"And their signification is well known."

Judging from which, and from the passages he quotes, wc suppose him to adopt the meaning thorns. Here, however, we have no doubt that the word is used to denote sharp missiles, pointed like a thorn.

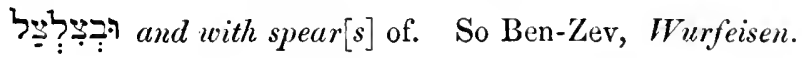

\section{CHAPTER XLI.}

Vers. 1-21 [4-24].* Of the three animals, which were introduced into the preceding discourse, two only, the elephant and the hippopotamus, were described in detail; the third, the crocodile, was simply mentioned, the consideration of its structure

- The numbers in the square brackets indicate, as before, the corresponding verses of the Hebrew text. 
and attributes being deferred to the discourse we are now entering upon. God says respecting this terrible animal:

(Ver. 1) [4]. I will not pass over his parts in silence, nor the matter of his strength, nor the gracefulness of his proportion[s]. This animal, on account of his extraordinary size and strength ${ }_{2}$ deserves more particular mention. (Ver. 2) [5]. Who hath uncovered the surface of his garment? The surface of the skin, which invests him as a garment, his scales. Who has ever ventured to lift up even one of them? Who can enter into the doubling of his jaw? Who would venture to trust a limb within his jaws? (Ver. 3) [b]. Who hath ever opened the doors of his face? His mouth. Around his teeth is terror! (Ver. 4) [7]. His strong shields are lis pride, shut up together as with a close seal. So strong and so closely joined are his scales, that he is filled with pride when he considers the weaker defences of other animals. (Ver. 5) [8]. They approach one to another so closely, that no air can come between them. (Ver.6) [9]. They are joined every one to its fellow; they take hold on one another, so that they cannot be separated. (Ver. 7) [10]. His sneezings cause light to shine, and his eyes are like the eyelids of the dawn. Are fiery red and glowing like the first rays of the rising sun. (Ver. 8) [11]. Out of his month go firebrands; sparks of fire escape therefrom. (Ver.9) [12]. Smoke goeth out from his nostrils, as from a bubbling pot, or caldron. The smoke from his nostrils is like the steam from boiling water. (Ver.10) [13]. Itis breath would inflame glowing-coals, and a blaze goeth forth fiom his mouth. (Ver. 11) [14]. In his neck abideth strength, and sorrow exulteth before him. So great and universal is the sorrow, caused by the approach of the crocodile, that it is well represented as an animated being, proudly preceding him wherever he goes. (Ver. 12) [15]. The folds of his flesh cleave fast together. The pendulous parts of his body are much less flabby than is the case with other animals. Every one of them is firm upon him; it cannot be moved. (Ver. 13) [16]. His heart is firm like a stone; yea, firm like the lower millstone.* (Ver. 14) [17]. By reason of his raising himself up, the mighty are afiaid; 'by reason of the breakers. By reason of the waves which

* See note on 386. 
he causes to break against the river's banks, when he rises out of the water, They are beside themsclves. They are so overwhelmed with terror, that they know not what they do. (Ver. 15) [18.] As to one coming up to him, his sword will not stand. Will shiver in his grasp. And so will his spear, dart, and coat-of-mail. The two former being utterly useless for offence, the latter for defence. (Ver. 16) [19]. Iron he accounteth as straw; brass, as rotten wood. (Ver. 17) [20]. The arrow will not make him flee; sling-stones with him are turned into stubble. Produce as little effect upon him, as stubble would, if thrown at him. (Ver. 18) [21]. Club[s] are accounted by him as stubble; and he laugheth at the whiz of the javelin. Why, indeed, should he dread any sharp-pointed weapon, seeing that (Ver. 19) [22] Sharp potsherds are under him. Such is the hardness of his scales, that he is equally at his ease when lying upon fragments of pottery, or other rough and pointed things, as when stretched out upon the mire. Nay, more than this, he himself spreadeth out sharp.pointed-thing $[s]$ upon the mire. He actually prefers a rugged and flinty couch. (Ver. 20) [23]. He could make the decp. If he ever were to come there. Boil like a pot; he could make the sca like a jar of ointment. He would lash the sea into foaming circles around him with the same ease, that the apothecary stirs his ointment in a jar. (Ver. 21) [24]. He would cause a path to shine after lim. He would leave a snowy-white, glistening, wake behind him. So that one would think the deep had become hoary.

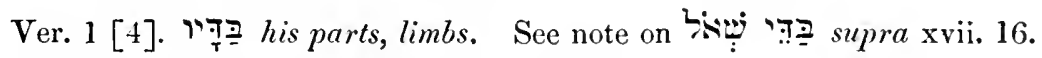

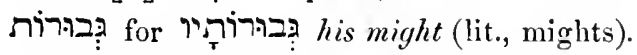

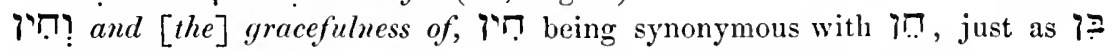
(Jon. iv. 10), with (1 Kongs xi. 36), with

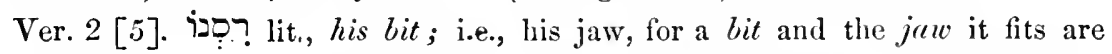

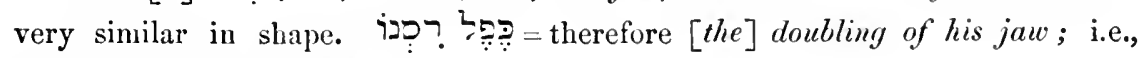
his double jaw, or his jaws.

Ver. 3 [6]. תְִִ (round about) used adverbially, as in Numb. xi. 24, round about the tent.

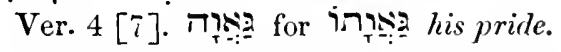

ס्ד [every one of them is] closed up. See note on

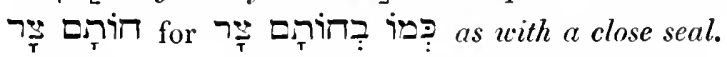

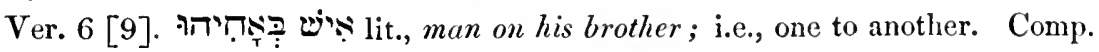
Exod. xxv. 20. The feminines of these two nouns are also similarly used, as 


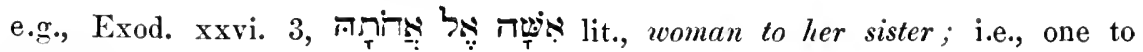
another.

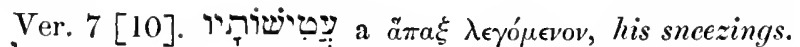

לֶุ [every one of them] causes to shine. See note on

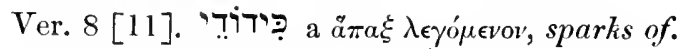

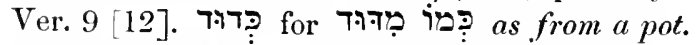

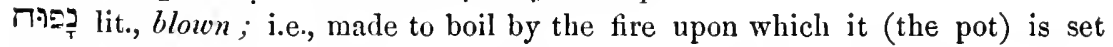
being blown.

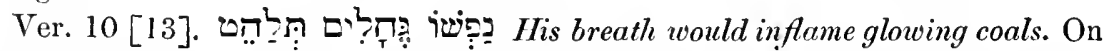
this verse Rosenmïller observes: "Ne quis offendat in constructione anomala

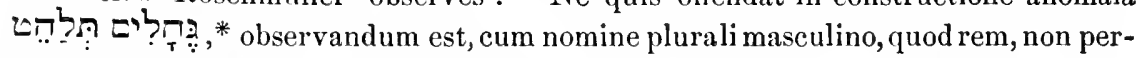
sonam, significat, conjungi posse verbum singulare femininum, cf. supraxiv. 19, et ibi not." Surely this learned Commentator's wits must have been wool-gathering when lye wrote the above, for he translates the three words in question precisely as we do (excepting that he renders the verb in the present, and not the conditional, as we

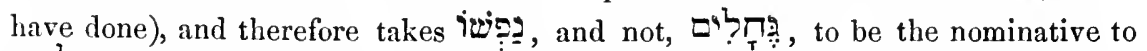
. : We have rendered this verb would inflame, and not, as is usually done. inflames, because it seemed to us extremely improbable that the crocodile's breath should ever come into contact with any coals at all, much less with glowing coals.

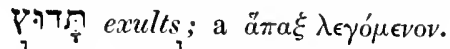

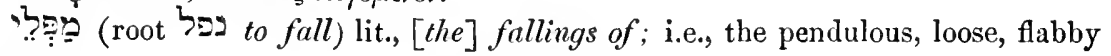
parts of.

F⿻:

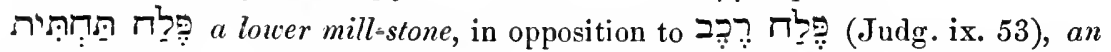
upper millstone. So Ben-Zev, unterer, und oberer, Mühlstein; in reference to the present passage he adds :

\section{כי הוה עומד דזק, ודהעליוצה סובב:}

"For it (the lower millstone) stands firm, whilst the upper whirls round."

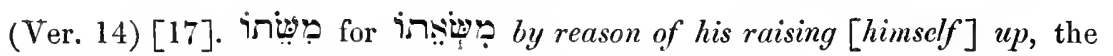

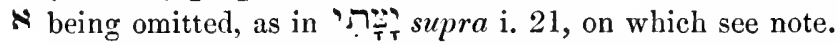

(Ver. 14) [17]. 문 produces by raising himself up. The Dagesh in the $\boldsymbol{E}$ proves the $\boldsymbol{\varphi}$ to be a preposition, so that the real word is

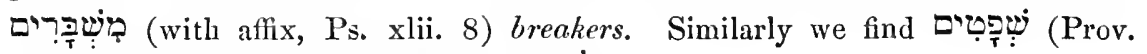
xix. 29) judgments, punishments = =

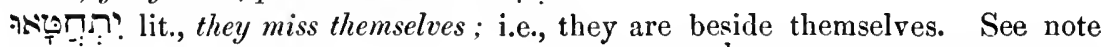

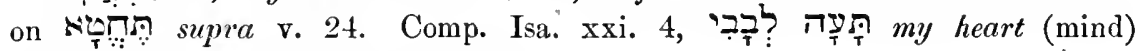
wandered; i.e., I knew not what I did.

Ver. 15 [18]. בר? for fĩ his sword.

Ver. 17 [20].

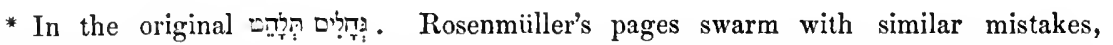
which, to put the best construction upon them, must have resulted from his own carelessness, and cannot be attributed only to his printer.-Editor, 1862. 


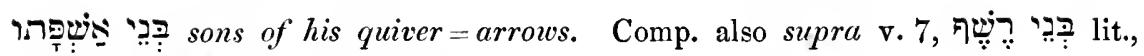
sons of a firebrand; i.e., sparks.

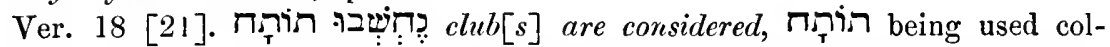
lectively, though, when a verb precedes its nominative case, it need agree with it neither in gender or number, as we have already, more than once, had occasion

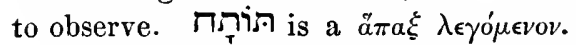

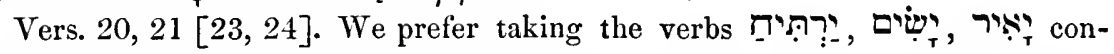
ditionally, as it does not seem to be established that the crocodile is ever met with in the sea.

Vers. 22-27 [Chap. xli. 25, 26; Chaps. xl. 32 ; xli. 1-3]. We have already stated the reasons which induced Wolfssohn to assign to these six verses another place than that which they occupy in the text. To every one, indeed, who reads the last four of them in the connection in which they there stand, it must, we should think, seem very extraordinary that God should first challenge man to engage with the crocodile, and then proceed to enter upon a minute description of its structure. Nor is Wolfssoln the only Commentator who saw the necessity for altering their position, since Boullier did so likewise. There is, however, another point which to us seems more extraordinary still-that, namely, an animal, which is in reality nothing more than a monstrous reptile, should (see the second verse of the group) be styled the king of all the proud beasts, and be said to see everything high; and it is therefore our firm belief that the subject of the whole of the verses under our consideration is not the crocodile, but man generally, Job of course being more particularly had in view. God says :

(Ver. 22) [Chap. xli. 25]. He (man), whose like there is not on earth. Whose wondrous mind places an unfathomable gulf between him and all other beings upon earth; yea, assigns to him a rank but little lower than an angel's. He (man) who is made to be without dread. Whose spirit of enterprise leads him to disregard dangers and perils of all sorts; who descends into the very bowels of the earth, dives into the recesses of the sea, and traverses oceans; he who, alone of animals walks not with head bowed down towards the ground, but carries it erect; 
(Ver. 23) [Chap. xli. 26] He who seeth every thing that is high.* Who raises his looks to the heavens, and the heavenly bodies. IIe who is king over all the proud beasts. A title deservedly bestowed upon him for the majesty of his appearance, and the absolute dominion he exercises over all inferior animals. Him I challenge, and say (Ver. 24) [Chap. xl. 32], "Put thine hand upon him!" The crocodile. "Think on the battle-thou wilt not do so again!" Reflect, while thou mayest, upon the dreadful conflict that awaiteth thee, for once engaged therein, thou wilt have no more time for reflection, thou wilt speedily perish. (Ver. 25) [Chap. xli. 1]. Lo! his hope. Of proving victor in the contest. Hath ficiled; is he indeed cast down even at his very aspect? Is the dread the animal inspireth him with so great that he falleth down paralyzed with fear, while yet at a distance, and uninjured? (Ver. 26) [Chap. xli. 2]. He is not so cruel to himself that he should arouse him-who then is he, that can stand before Me? If even the beasts I have created strike such terror into man, how then can he dare to set himself up against $\mathrm{Me}$, and find fault with My proceedings? (Ver. 27) [Chap. xli. 3]. Who hath anticipated Me. With a favour. Who hath ever laid Me under an obligation? That I should have to repay it to him. That which is under the whole heavens belongeth to Me. Every creature is dependent upon Me for all that it enjoyeth, and can therefore lay no claim to reward at My hands.

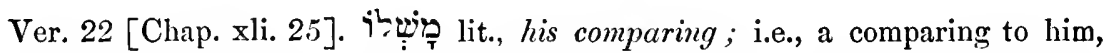
the inf. constr. פִ being used here as a noun. See our note on hive? supra

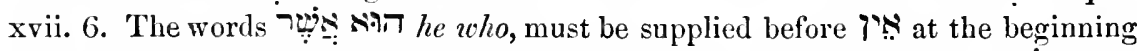
of the first liemistich of this verse, just as in Prov. xviii. 22, where stands for The who has found a wife.

הֶֶ, the regular form, as it is the past part. Kal of the verb

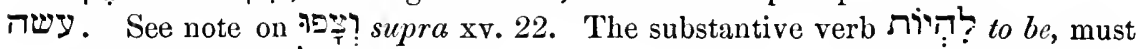

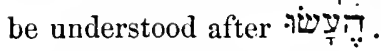

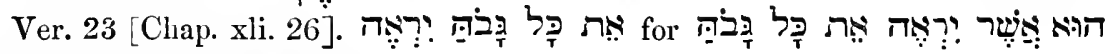
he who sees everything high.

* So the Roman poet says :

Pronaque cum spectent animalia cætera terram,

Os homini sublime dedit, cœlumque tueri

Jussit, et erectos ad sidera tollere vultus.

(Ovid Met. Lib. I., 84-86.) 


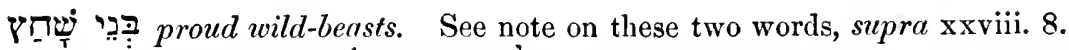

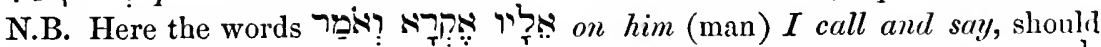
be understood. A similar ellipsis occurs in Ps. xxvii. 8, where we read רָָ T?

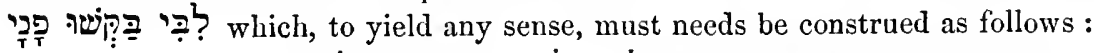

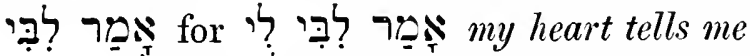

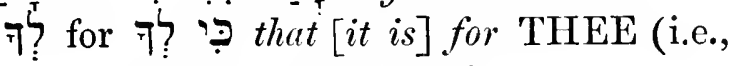 that it becomes Thee),}

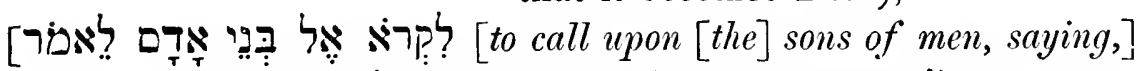

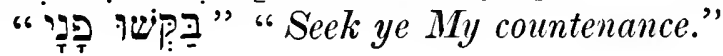

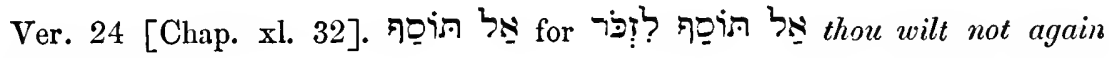
think $[$ of it].

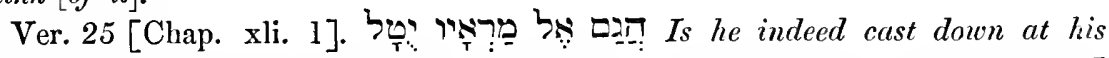
[very] sight? Spoken ironically, as though God said, That is more than I expected, I thought he would fight with the animal, but now it appears that the very sight of it prostrates him with fear. We make this remark, in order to shew that there is no occasion to supply a negative here, as though

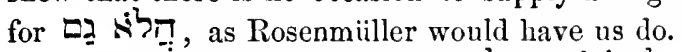

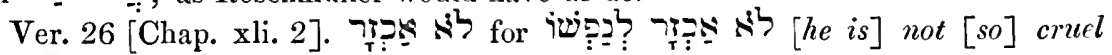
to himself.

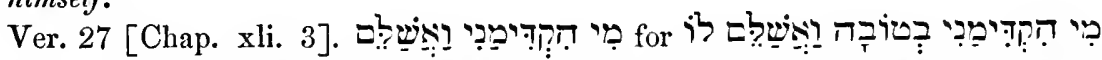
Who has anticipated Me with a kindness, that I should have to repay [it] to hin ? i.e., who ever bestowed a favour upon me, before I bestowed one upon him ?

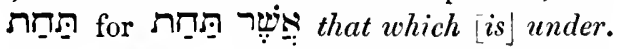

N.B. It will be perceived that in these verses there is a change of person, the second being substituted for the third in Ver. 24 [xl. 32]. Such a change is of very frequent occurrence in Hebrew. Of the numerous examples we could quote, we will here only bring forward three, the first occurring in Gen. Chap. xlix., where Joseph is, in vers. 22-24, spoken of by his father in the third person, and then, in vers. 25, 26, addressed by him in the sccond ; the second, in this book (from which, however, many other examples of the sort might be quoted) supra xviii. 4, where Bildad, in the first clause, speaks of Job, in the second to him, thus changing from the third, to the second, person ; the third, in Ps. xxxiv., where (ver. 12) the Psalmist exclaims, "Who is the man that desireth life, and loveth many days, that he may be good ?" and then, in the very next verse, addressing such a man, says, "Keep thy tongue from evil, and thy lips from speaking guile," to him I say being omitted between these verses, as between Vers. 23, 24 (according to our arrangement) of the present Chapter. 


\section{CHAP'TER XLII.}

Vers. 1-11. Of these eleven verses, which form a dialogue between Jehovah and Job, five (7-11) we have transposed from the beginning of Chap. $\mathrm{xl}$., for the simple, but very forcible reason, that, as they stand in the text, they render utterly unintelligible the verses, which immediately follow them. For, how could Jehovah, immediately after Job had (in Ver. 4)* expressed his great contrition and sincere repentance for his rash and inconsiderate language, by any possibility say, (Ver. 8 ) * "Wilt thou indeed deny My justice? Wilt thou condemn Me, that thou mayest appear just?" and again, Chap. xlii. 3, "Who is this, that veileth My counsel for want of knowledge?" Surely, so full a confession on the part of Job, instead of calling forth such a severe rebuke, would (as is actually the case according to our arrangement), be much more fittingly followed by a declaration of forgiveness and acceptance from the lips of Jehovah.

And Job answered Jehovah, and said, (Ver. 2.) I know that Thou canst do every thing, and that no purpose of Thine can be withholden from Thee. That there is nothing which Thou purposest, which 'Thou canst not perform.

Ver. 3. Jehovah. - Who is this, that veileth My counsel without knowledge? $\dagger$ Who, for want of knowledge, recogniseth not My wisdom and counsel in everything that befalleth man, but regardeth all as left to chance.

Joв. - For this reason have I said so, because I did not understand. The mysteries of 'Thy counsel. They were too wonderfiul for me, so that I could not know them.

Ver. 4. God.-Hear now, and I will speak; I will ask thee questions, and do thou inform Me. $\neq$

Ver. 5. Joв.-I have heard of Thee by the hearing of the ear. I have heard the heavens declare the glory of God, and the firmament shew forth His handywork; I have heard the speech, which day-poureth out unto day, and the knowledge, which night sheweth unto night; I have asked the beasts, and they

\footnotetext{
* According to the text. † See supra xxxviii. 2. † See supra xxxviii. 3.
} 
have instructed me-the fowl of the heavens, and they have told me-the fishes of the sea, also, and they have declared unto me-that the hand of Jehovah hath made them. But, whilst the beasts, the fowl of, the heavens, and the fishes of the sea, thus instructed me, and declared unto me Thy power and Thy glory, they never told me that I was not a mere animal like themselves, so that of this I remained in ignorance, and thought I was not better than they, and that my existence would, like theirs, terminate with my life. But now mine eye hath seen Thee. Now, that 'Thou hast condescended to reveal Thyself to me, I see, and know that I am not a mere animal, but that I am an object of Thy peculiar care, and that, within this body of mine, though but a house of clay, there divelleth an immortal soul, which will live even after I have returned to the dust from which I was taken, and that the days of my life here below are but a handbreadth, compared with those which I shall live with Thee to all eternity. (Ver. 6.) Therefore $I$ abhor. All that I have said. And, being thus instructed, I repent in dust and ashes. Ver. 7 [*1]. Then Jehovah answered Job, and said, (Ver. 8) [2]. Is he, who contended with the Almighty corrected? Let him, who reasoned with God, answer it! 'This question. If he, who hath been till now contending with the Almighty, standeth corrected, and repenteth, then let him answer Me, and tell Me that it is so. (Ver. 9) [3]. Then Job answered Jehovah, and said. (Ver. 10) [4]. Lo, I have been vile! what shall I answer Thee? So utterly worthless have I proved myself to be, that I dare not now open my mouth to utter a word, and must beseech Thee to accept my silence as a full confession on my part of the enormity of my sin. I put mine hand upon my mouth. (Ver. 11) [5]. Once have I spoken, but will not again utter. Any such rash and inconsiderate words. Yea, twice have I spoken. I am fully aware that $I$ have been more than once guilty of this rashness in $m y$ language. But I will not do so again.

Ver. 2. for that Thou art able to do everything.

- The figures in square brackets indicate the corresponding rerses in Chap. $x \mathrm{l}$. in the Hebrew text. 
(Comp. Gen. xi. 6), and [that] nothing which Thou purposest to do can be withholden from Thee; i.e., that everything which Thou purposest, 'Thou canst perform.

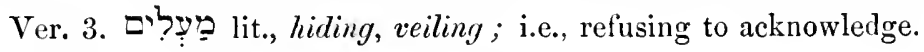

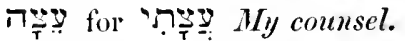

for want of knowledge.

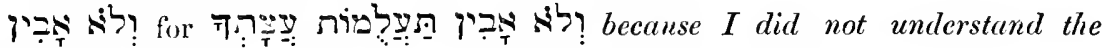
mysteries of Thy coumsel.

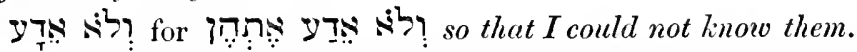

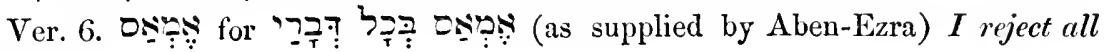
my words.

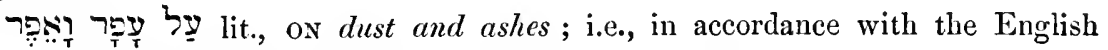
idiom, in dust and ashes.

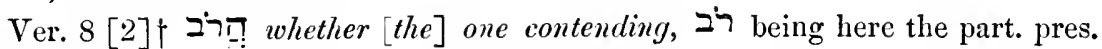
Kal. of the verb רוב or to contend, just as ריב is found as a part. in Prov. iv. 18.

ר. one corrected, it being a noun of the form one born.

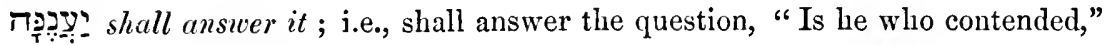
\&c.

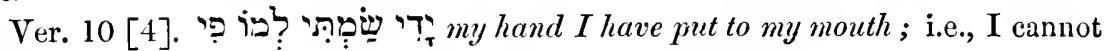
or dare not utter a word. Comp. supra xxi. 5 ; xxix. 9.

Ver. 11 should be construed thus:

הַח Once have I spoken,

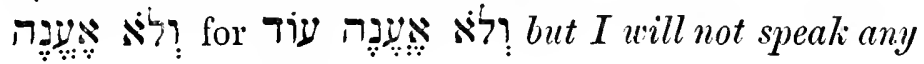
more ;

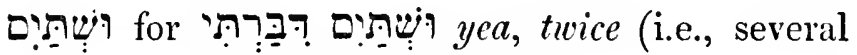
times) have I spoken,

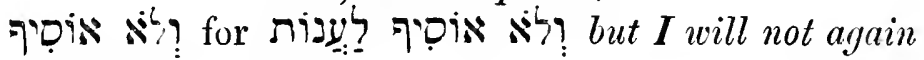
speak.

* We have here another instance, in which a masc. verb has for its subject a fem. noun

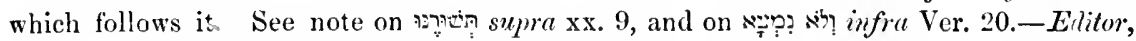
1862 .

t The numbers in square brackets indicate the corresponding verses of Chap. $x l$. in the Hebrew text. 
Ver. $12(7) . *$ 's respecting Me. Comp. Gen. xx. 2, "And Abralıam said, דִ צִ respecting Sarah."

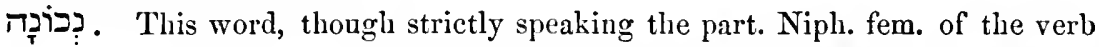
ברין, is used as a noun tin Ps. v. 10, in the meaning of faithfulness, or sincerity; here, however, it is evidently used adverbially = sincerely.

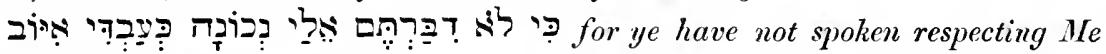
sincerely, like $M y$ servant $J_{o b}$; i.e., irreverent, nay, sinful, as were the words so rashly uttered by Job when ignorant of the dignified nature of his own being, yet they came from the depths of his heart; not so yours, for, when you reproached your unfortunate friend with crimes of the blackest dye, you did so, not from an intimate conviction that he deserved such reproaches, but with a view of pleasing Me, forgetting that nothing can please Me but the truth. When Job complained of the afflictions I sent upon him, instead of imputing to him sins and crimes, of which there was no reason whatever for believing him guilty, you should rather have confessed yourselves unable to account for these afflictions, and have contented yourselves with calling upon your friend to believe, that, as they had come from his Maker, they must be for his good.

Ver. 13 (8). . ִִ for verily. So, in Prov. xxiii. 18, םṣ for verily (there is an end, and thine expectation shall not be cut off).

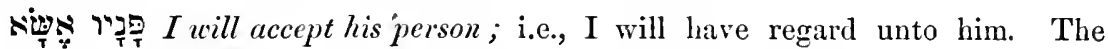
phrase nevertheless sometimes found, as here, expressing merely to accede to one's wishes. See note on

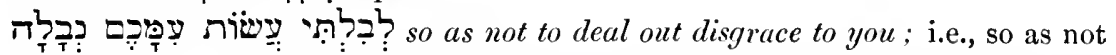
to inflict a disgraceful punishment upon you. So Kimchi, in his explains the word $\pi_{i}$ in this instance as

\section{דבר כעור ומגוגה}

"A disgraceful and degraded thing."

עִ lit., wrTn you, must here, in accordance with the exigencies of the

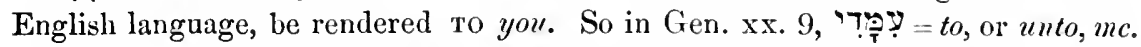
The verb עשה to do, or make, is often used in the sense of to execute, or deal

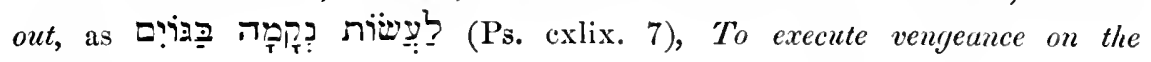
heathen.

Ver. 14 (9). רפּ for for (though Rosenmiiller, for reasons we cannot discover in any grammar, would supply ') and Zophar. When three things are joined together, the third sometimes dispenses with the copulative conjunction; thus in Ps. xlv. 9 we have

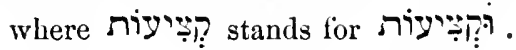

* The numbers in round brackets indicate the corresponding verses of Chap. xlii. in the Hebrew text.

+ We render it by a noun, it is true, but in other languages it need not be so rendered. Thus in Germ. it is usually translated by a neut. adj., Luth., [Nichts] Gevoisses, Mendels., [Nichts] Redliches. In a Dan. Bible, too, I fud [intet] bestandigt.-Editor, 1862. 
Ver. 15 [10]. i.e., restored to him everything He had taken from him; for, seeing that the property taken away from Job, at the instigation of Satan, was not taken away for good, but was, as it were, merely confiscated until he should have passed through the ordeal appointed for him, it might fairly be considered only to have gone into captivity, and now to be restored to him therefrom.

The verb $ح=\mathbb{E}$ is used here transitively in Kal, as in Jer. xxx. 18.

iל ברוֹצִיצ: On thy making to go forth; i.e., when, or after, thou hast made to go forth (brought forth).

לערז his friend; i.e., every one of his friends, or his friends severally.

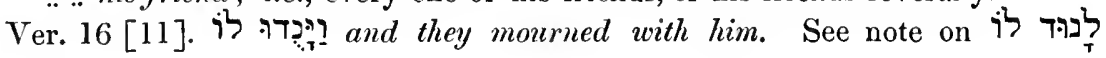
supra ii. 11.

קיצטיטָר a piece of money, as in Gen. xxxiii. 19.

口? an ear-ring, as in Gen. xxxv. 4.

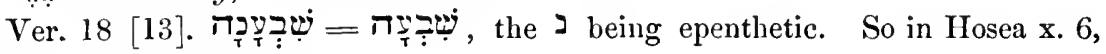
政

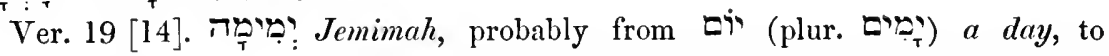
express that she was as bright and beautiful as the day, or, as the French would say, belle comme le jour. So the Targum :

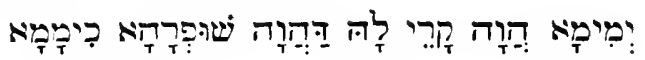

He called her Jemimah, because her beauty was like [that of] the day.

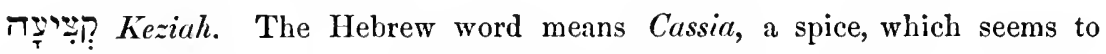
bave been very scarce in those days, so that the name was probably given her with a view to express the rarity of her beauty. So the Targum :

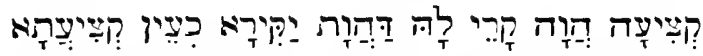

"He called her Keziah, because she was [as] rare as cassia."

ה־ Keren-Happuch; i.e., a horn for paint, or, as we should say, a paint-box. She had this name bestowed upon her probably on account of the beauty of her complexion, which we may suppose to have vied with the brightest colours of the paint-box. So Jarchi tells us this name was given her :

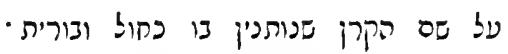

"From the name of the horn in which they put paint and soap."

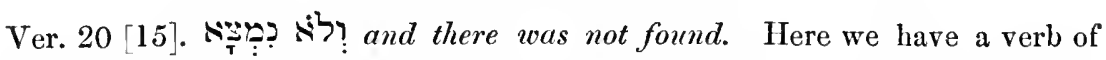
the masc. gender and sing. numb. referring to a fem. noun in the plur. numb., a fact which goes very far to prove the correctness of the rule we have already so frequently laid down, that, namely, when a Hebrew verb precedes its nominative case, it need agree with it neither in gender nor in number.

? to, would be the regular form. This trespass against gender is also committed in the case of 


\section{TRANSLATION OF THE BOOK OF JOB.}

\section{CHAPTER I.}

1 There was a man in the land of ${ }^{a} \mathrm{Uz}$, ${ }^{\omega}$ whose $a$ Jer. xxr. 20; Lam. name was ${ }^{b} \mathrm{Job}$; and that man was ${ }^{1}$ pious $\omega$ Job his name. and upright, and $\beta$ one that feared God, and $\beta$ a fearer of God eschewed evil. and turning away from evil.

2 And there were born unto him ${ }^{c}$ seven sons, $c$ infra slii. 13. and three daughters.

3 And his substance was seven thousand sheep, and three thousand camels, and five hundred yoke of oxen, and five hundred she-asses, and a very great household; so that that man was greater than all the sons of the East.

4 Now his sons used to go and $\gamma$ feast in the $\gamma$ make a feast. house of every one of them on his day; and they used to send and ${ }^{2}$ call $\delta$ their three sisters, to $\delta$ call to, for. eat and to drink with them.

5 And it was so, when the days of $\epsilon$ their feasting $\varepsilon$ the feast. were $\zeta$ gone about, that Job sent for, and pre- $\zeta$ gone round, in a pared, them, and rose up carly in the morning, and offered up burnt-offerings according to the number of them all: for Job ${ }^{3}$ said: "Peradventure my sons have sinned and blasphemed God

1 Or without blemish, blameless, pure, jnst (the Lat. integer, Fr. intègre). See Commentary and Appendix.-Editor, 1862.

2 Call is here used=send for, summon, invite, as in Gen. xx. 9, xli. 14, \&c. See Appendix.-Editor, 1862.

3 Or, perhaps, said in his heart, to himself, thought. Comp. Gen. xvii. 17, and rliv. 28.-Editor, 1862 . 
$\alpha$ heart.

$\beta$ all the days.

$\gamma$ set themselves up, stand. Lat. sistere se, sisti.

$\delta$ near.

$\varepsilon$ the adversary, or, the accuser.

$\zeta$ in their midst.

$\eta$ mayest thou come.

$\theta$ set thine heart upon.

$\kappa$ a fearer of God and turning away from evil.

$\lambda$ [Is] Job fearing? $\mu$ without cause.

$\nu$ that [is] to him.

$\pi$ round about.

$\rho$ hath spread [itself] abroad.

$\sigma$ touch.

$\tau$ that [is] to him.

$\phi$ all that [belongs] to him. $x$ to.

$\psi$ from with [the] face of.

$a$ at their sides.

$\beta$ Sabæa. in their a hearts." Thus used Job to do $\beta$ continually.

6 Now, when it was the day that the Sons of God came to $\gamma$ present themselves $\delta$ before Jehovah, then came $\epsilon$ Satan also $\zeta$ among them.

7 And Jehovah* said unto Satan: "Whence $\eta$ comest thou?" and Satan answered Jehovah and said: "From going to and fro in the earth, and from walking up and down in it."

8 And Jehovah said unto Satan: "Hast thou $\theta$ considered my servant Job? Surely, there is none like him in the earth, a man, pious ${ }^{1}$ and upright, ${ }^{*}$ one that feareth God, and escheweth evil."

9 And Satan answered Jehovah, and said: " $\lambda$ Doth Job fear God $\mu$ for nought?

10 "Hast not Thou made-an-hedge about him, and about his house, and about all $\nu$ that he hath, $\pi$ on every side? The work of his hands 'Thou hast blessed, so that his substance $\rho$ is increased in the land.

11 "But put forth now Thine hand, and $\sigma$ smite all $\tau$ that he hath; will he not blaspheme 'Thee because of Thine anger?" 2

12 And Jehovah said unto Satan: "Behold, $\phi$ all that he hath $i s$ in thine hand; only, $\chi_{\text {upon }}$ himself put not forth thine hand." So Satan went forth $\psi$ from the presence of Jehovah.

13 Now it was the day when his sons and his daughters were eating and drinking wine in the house of their brother, the first-born.

14 And there came a messenger unto Job, and said: "The oxen were ploughing, and the sheasses feeding a beside them;

15 "When a host of $\beta$ Sabæans fell upon them,

1 See note in preceding page.

2 Or, to Thy face. See Appendix.-Editor, 1862.

* For the signification of this word see Commentary. 
and took them; and the young men they have smitten with the edge of the sword, and I am escaped, only I alone, to tell thee."

16 While a he was yet speaking, $\beta$ another came, a this. and said: " $\gamma$ A mighty fire hath fallen from $\gamma$ a a fire of God. heaven, and burned up the sheep, and the young men, and consumed them; and I am escaped, ouly I alone, to tell thee."

17 While $\delta$ he was yet speaking, $\epsilon$ another came, ${ }_{\varepsilon}^{\delta}$ this. and said: "The Chaldæans $\zeta$ formed three bands, $\zeta$ set. and $\eta$ rushed upon the camels, and took them, $\eta$ spread them. and the young men they have smitten with the selves (se sont dé. ployés). edge of the sword, and I am escaped, only I alone, to tell thee."

15 While $\theta$ he was yet speaking, ${ }^{*}$ another came, $\theta$ this. and said: "Thy sons and thy daughters were eating, and drinking wine in the house of their brother, the first-born:

19 "And behold, a great wind came from beyond the wilderness, and $\lambda$ smote the four corners of $\lambda$ touched. the house, that it fell upon the young-people, and they died; and I am escaped, only I alone, to tell thee."

20 Then Job arose, and rent his garment, and $\mu$ shaved his head, and $\nu$ fell down upon the $\mu$ shore. ground, and $\pi$ worshipped.

21 And he said: "Naked came I out from my mother's womb,* and waked shall I return thither. Jehovah gave, and Jehovah hath taken away ; blessed be the name of Jehovah."

22 Notwithstanding all this, Job simned not, nor $\rho$ imputed malice unto God.

$\nu$ fell to earth. $\pi$ bowed himself.

\section{CHAPTER II.}

1 Now, when it was again the day, that the Sons of God came to ${ }^{\sigma}$ present themselves $\tau$ be- $\sigma$ supra i. 6 .

* i.e., probably the carth, which Job, as a human being, regards as his mother. 
$\alpha$ in their midst.

$\beta$ supra i. 6.

$\gamma$ mayest thou come.

$\delta$ set thy heart upon.

E supra i. 1, \&c.

$\zeta$ he [is] still hold. ing fast.

$\eta[$ is] to the man.

$\theta$ behold him.

$\kappa$ from with [the] face of.

$\lambda$ boil, sore.

$\mu$ with it.

a Jonah iii. 6 : infra xlii. 6.

$v$ in [the] midst of.

$\pi$ [Art] thou still holding fast.

$\rho$ thou art wont to speak.

$\sigma$ as [the] speaking of one, \&c. fore Jehovah, then came Satan also a among them $\beta$ to present himself before Jehovah.

2 And Jehovah said unto Satan: "Whence $\gamma$ comest thou? And Satan answered Jehovah, and said: "From going to and fro in the earth, and from walking up and down in it."

3 And Jehovah said unto Satan, "Hast thou $\delta$ considered my servant Job? Surely, there is none like him in the earth, a man, ${ }^{1}$ pious and upright, $\epsilon$ one that feareth God, and escheweth evil; so $\zeta$ that he still holdeth fast his ${ }^{1}$ piety, although thou movedst me against him, to ruin him without a cause."

4 Then Satan answered Jehovah, and said: "Limb for limb-

"Yea, all that $\eta$ man hath

"Will he give for his life.*

5 "But put forth now Thine hand, and touch but his bone and his flesh; will he not blaspheme. Thee ${ }^{2}$ because of Thine anger?"

6 And Jehovah said unto Satan: " $\theta$ Behold! he is in thine hand; only, preserve his life."

7 So Satan went forth $\kappa$ from the presence of Jehovah, and smote Job with grievous $\lambda$ sores from the sole of his foot even unto his crown.

8 And he took him a potsherd to scrape himself $\mu$ withal; and he was ${ }^{a}$ sitting ${ }^{\nu}$ among the ashes.

9 Then said his wife unto him: " $\pi$ Dost thou still hold fast thy ' piety? Blaspheme God, 10 and die." $\dagger$ But he said unto her: " $\rho$ Thou speakest $\sigma$ as one of the foolish women speaketh.

1 Or, integrity. See note, p. 395.-Editor, 1862.

2 Or, to Thy face. See note, p. 396.-Editor, 1862.

* If a man stretches out his arm, a less important part of his body, to save his head, a more important one, he may well be expected to offer up everything to preserve his life.

$\dagger$ i.e., put an end to thine existence. 
$\omega$ What! shall we accept that which is good $\omega$ shall we indeed $\beta$ from God, and not accept $\gamma$ that which is evil ?" Notwithstanding all this, did not Job ${ }^{a}$ err with $\underset{a}{\gamma}$ Ps. xxxix. 1. his lips.

11 Now three of Job's friends heard of all this evil that had come upon him, and they came, every one from his own place, Eliphaz the Temanite, and Bildad the Shuhite, and Zophar the Naamathite; and they agreed together to come to $\delta$ mourn with him, and to comfort him. $\delta$ shake[their heads]

12 And when they lifted up their eyes $\epsilon$ afar off, $\varepsilon$ from afar. and knew $\zeta$ him not, then lifted they up their $\zeta$ recognised. voice, and wept; and they rent every one his garment, and ${ }^{b}$ sprinkled dust upon their heads $b$ infra xri. 15; toward heaven. Josh. vii. 6 ; Lam. ii. 10.

13 And they ${ }^{c}$ sat down with him on the ground $c$ Lam. ii. 10. ${ }^{d}$ seven days and seven nights, $\eta$ none speaking $d$ Gen. $\eta$ and [there was] unto him a word; for they saw that $\theta$ his pain $\begin{gathered}\text { none. } \\ \theta \text { the pain. }\end{gathered}$ was very great.

\section{CHAPTER III.}

1 After this Job opened his mouth, and cursed his day.

2 And Job spake and said:

3 Perish the day, ${ }^{\circ}$ wherein I was born! Or the night, in which one said: * $\lambda$ "She bringeth forth a $\mu$ man-child!" $c$

4 May that day be darkness!

$\kappa$ I should, was to, be born in it.

$\lambda$ she [is] bringing forth.

$\mu$ a man (male).

e Jer. xx. 15.

God regard it not from above!

$\nu$ Neither let light shine upon it!

5 Pollute it darkness and the shadow of-death!

$\nu$ and let not light shine.

May there divell on it a clond!

Black-vapours of the day affright it!

6 As for that night__deep-darkness seize it!

Let it not rejoice amid the days of the year!

Let it not come into the number of the months!

$$
\text { * i.e., of my mother. }
$$


7 Lo, that night-may it be cheerless! May there come into it no sound-of-joy!

w cursers of day.

a infra xl. 25 (le. viathan).

8 May $\omega$ those that curse their day point at it, * Those ready to arouse the ${ }^{a}$ crocodile!

9 Darkened be the stars of its twilight!

Let it wait for the full light, and there be none! Yea, let it not behold even the eyelids of the dawn.

$b$ Jer. xx.17, 18. $\beta$ my belly.

$\gamma$ and so hid; or, so that it should hide.

c Jer. xx. 18.

$d$ Gen. sxx. iii.

$\delta$ [there] would have been rest to me.

$\varepsilon$ are building.

$\zeta$ have.

$\eta$ are filling.

e Ps. lviii. 8; Ecc vi. 3.

$\theta$ saw not.

$\boldsymbol{\kappa}$ have ceased.

$\lambda$ [from eausing] trouble.

$f$ Ps.xxxi. 17 .

$\mu$ of

$\nu$ will rest.

$\pi$ reposed.

$\rho$ heard not.
$10{ }^{b}$ Because it shut not up the doors of $\beta$ the belly I lay in,

$\gamma$ So as to hide misery from mine eyes.

$11^{c}$ Why should I not have died from the womb? When I came forth from the belly, then ought I to have expired.

12 Wherefore did ${ }^{d}$ knees $\dagger$ meet me?

Or why breasts, that I should suck?

13 For now had I lain down, and were quiet;

I had slept-then $\delta$ rest would have been mine.

14. Ihad slept with kings and counsellors of theearth, Which $\epsilon$ built desolations for themselves; +

15 Or with princes, that $\zeta$ had gold, Which $\eta$ filled their houses with silver.

$16 \mathrm{Or}$, as an hidden ${ }^{e}$ untimely-birth, why had I not been?

As infants, which ${ }^{\theta}$ never saw light.

17 There, $\S$ the ${ }^{1}$ turbulent ${ }^{\kappa}$ cease ${ }^{\lambda}$ from ${ }^{f}$ troubling,

And there, the wearied out $\mu$ in strength $\nu$ find rest.

18 Together with them, the prisoners $\pi$ repose; They $\rho$ hear not the task-master's voice.

1 Or, wicked.-Editor, 1862.

* i.e., may those who wish to curse their day (i.e., their birthday, or their fate), even those, who are about to become the prey of a crocodile, call out in their agony, Accursed be my day like that of Job!

$\dagger$ The knees of the midwife.

$\ddagger$ Or, desolate-places for themselves, i.e., mausoleums, pyramids, \&c., magnificent buildings, destined solely to harbour their remains, and therefore well deserving to be called desolate.

$\S$ He means, of course, in the grave. 
19 The small and the great a are there;

$a$ he [is] there.

And the servant is free from his lord.

20 Why $\beta$ is light given to the wretched,

And life, to $\gamma$ those bitter in spirit ?

21 (Which $\delta$ long for death, but $\epsilon$ it cometh not, ${ }^{a}$ And would dig for it more than for ${ }^{b}$ hidtreasures;

22 Which $\zeta$ would rejoice, even to exultation, Would be overjoyed, if they could find the grave). ${ }^{c}$

23 Why to the man, whose way is hidden ${ }^{d *}$ $\eta$ Whom God hath hedged round about ? ${ }^{e} \dagger$

24. Seeing that before my food ${ }^{f} \mathrm{my}$ groaning cometh,

And my roarings ${ }^{g}$ are poured out like water. ${ }^{g}$

25 For $\theta$ that which I greatly feared, is come upon me,

And what I dreaded, $\kappa$ is come unto me.

26 I was not at ease, neither was I quiet, Neither had I rest; yet trouble came. ${ }^{h}$

$\beta$ should [one] give light.

$\gamma$ [the] bitter of spirit (soul).

$\delta$ [are] waiting.

$\varepsilon$ it is not.

$a$ Rev.ix. 6.

6 Prov. ii. 4.

$\zeta$ who [wonld be] rejoicing.

c infra vii. 15 ; xiv. 13 ; xvii. 14 .

d infra xiii. 24 ; Isa. xl. 27.

$\eta$ yea, God hath hedged round about him.

$e$ infra xix. 8; Lam. iii. 7, 9; Hos. ii. 6.

$f$ Ps. cii. 4 .

$g$ Ps. xxii. 1, 14.

the water.

$\theta$ [the] fear I feared; or, for I feared a fear, and it is eome to me.

$\kappa$ cometh.

$h$ Prov. xxriii. 14.

\section{CHAPTER IV.}

1 Then Eliphaz the Temanite answered and said:

2 Hath one ever tried a word $\lambda$ with thee? $+\lambda$ to thee.

Wouldest thou $\mu$ lose patience?

Yet who can restrain his words?

3 Behold! thou didst correct many,

And feeble hands thou ${ }^{\nu}$ strengthenedst. ${ }^{i}$

4 Thy words $\pi$ did upraise the stumbling,

And $\rho$ sinking knees thou $\sigma$ madest strong. $\$$

$\mu$ be weary.

$\nu$ usedst to strength. en.

$i$ Isa. $\operatorname{xxx} .3$; IIeb. xii. 12.

$\pi$ used to upraise, caused to arise, raised up, esta. blished.

$\rho$ bowing, bending.

$\sigma$ usedst to make strong.

* i.e., on whom God bestows no favour.

$\uparrow$ i.e., whose movements He impedes.

$\ddagger$ i.e., Has one ever essayed to argue with, or contradict, thee, and if one were to do so, wouldest thou be impatient? Comp infra xxix. 9, 10.

$\S$ i.e., those wavering in their faith, and ready almost to despair, thou usedst to exhort and console. 
z supra iii. $\mathbf{2 5}$.

$\omega$ toucheth unto.

$a$ Prov. iii. 26; xiv. 26.

$\beta$ thy hope, even [the] integrity of thy ways.

$\gamma$ remember now.

$\delta$ who [is] he [being] innocent, [that] perished?

$b$ Ps. xxxrii. 25; Eccles. vii. 15; riii. 14.

$\varepsilon$ according to what. c Prov. xxii. 8; HIos. x. $12,13$.

$\zeta$ nostril.

d Ps. lviii. 6.

$\eta[$ is $]$ perishing.

$\theta$ sons of stout-lion (Bochart, lioness). $\kappa$ was stolen.

$\lambda$ receired. $\mu$ a trifle.

\section{$e$ infra $\mathrm{xxxiii.} 15$.}

$\nu$ met, befell.

$f$ Ps. Iv. 5.

$\pi$ and it made to fear.
5 But now * it is come unto thyself, $z$ and thou faintest!

It ${ }^{\omega}$ reacheth unto thee, and thou art confounded!

6 Ought not thy fear of God to be thy ${ }^{a}$ confidence, $\uparrow$

$\beta$ And the integrity of thy ways, thy hope ?

$7 \gamma$ Bethink thee now: $\delta$ who is he that hath perished being innocent?

Or where are the upright, which have been cut off ? ${ }^{b}$

$8 \in$ As far as I have seen, the ploughers of iniquity, And sowers of evil, reap it. ${ }^{c}$

9 By the breath of God they perish, And by the blast of His $\zeta$ nostrils they are consumed.

10 The roaring of the lion, + and the voice of the fierce-lion are silenced, And the teeth of the young-lions are broken. ${ }^{d}$

11 The strong-lion $\eta$ perisheth for lack of prey, And the ' $\theta$ stout-lion's whelps are scattered.

12 Now $\S$ the ${ }^{1}$ matter ${ }^{k}$ was stealthily-disclosed unto me,

And mine ear $\lambda$ caught $\mu$ a little thereof.

13 Amid thoughts, from visions of the night, When deep-sleep falleth upon men, ${ }^{e}$

14. Fear ${ }^{\nu}$ came upon me, and trembling, ${ }^{f}$ $\pi$ Which made the multitude of my bones to quake.

1 Or, a matter, or thing.-Editor, 1862.

* It, i.e., evil.

$\dagger$ If thou art really a feaver of God, ought not this very circumstance to make thee confident that thy sufferings cannot last long?

\& The animals introduced in this and the following verse represent powerful and wicked tyrants and their offspring. Comp. Ps. x. 9 ; xxii. 12, 13, 16, 21, \&c.

$\S$ 'The matter, i.e., the justice of the dispensations of Providence. 
15 Then a Spirit a passed before me$a$ used to pass.

It $\beta$ made the hair of my flesh to bristle up; $\quad \beta$ used to make, \&e.

16 It $\gamma$ stood, but I could not recognise $\delta$ the form $\gamma$ used to stand. thereof; $\delta$ its appearance.

17 A shape was before mine eyes;

There was silence-then $\epsilon \mathrm{I}$ heard a voice, $\varepsilon \mathrm{I}$ used to hear. saying :

18 "Can frail-man be more just than God?

"Man be more pure than his Maker?

19 " Behold! in His $\zeta^{a}$ ministers He ${ }^{\eta}$ putteth no $\zeta$ servants. trust, $a$ Ps. civ. 4. $\eta$ trusteth not.

"And $\theta$ to His angels He imputeth faultiness. $\theta$ on...... Heputteth. 20 "* How much more to the $\kappa$ dwellers in $\lambda$ tene- $\kappa$ dwellers of. ments of clay, ${ }^{b}$

"Whose foundation is in the dust.

$\lambda$ houses of clay.

b infra xiii. $12 ; 2$ Cor. จ. 1.

" $\mu$ They are crushed before the moth,

$\mu$ they erush them.

21 " $\dagger$ From morning to evening they are brokenin-pieces ${ }^{c}$;

" $\nu$ Without heeding it, they continually are perishing.

$2: 2$ " Hath not their superiority, $\ddagger$ which is in them, been removed ${ }^{e}$ ?

$c$ Ps. xe. $3,5,6$; Isa. xxxriii. 12, 13.

$\nu$ without [one]

set ting [his heart].

$d$ Isa. xlii, 25: Jur.

xii. 11.

e Ps. xlix. 20.

"They are ever dying, $\pi$ but without wisdom $f \pi$ but not with wisto perceive it."

\section{CHAPTER $V$.}

1 CALL now! $\rho$ will there be any, that will answer $\rho$ is [there] one anthee? swcring thee?

And to whom among the holy canst thou turn? $\$$

2 For his own wrath will kill the fool, And his own envy slay the silly one. ${ }^{g}$

* See Comment.

g Ps, xxxrii. 1, 2, T, 8 ; Prov. i. 32; xxiii. 17 ; xxiv. 1 , 19.

$\dagger$ That is, from their coming into existence, till they leave it.

$\ddagger$ i.e., their intellect which renders them superior to all other living beings.

$\$$ i.e., to whom amongst holy and good men canst thou, after uttering these curses of thine, turn for svmpatlyy? 
$\psi$ pointed out, pronounced.

a Ps. cix. 9, 10, 12 ; cxxvii. 4, 5 .

(w) and they shall crush themselres.

$b$ Prov. xxii. 22; Amos v. 15.

$\beta$ and none delivering.

$\gamma$ who; or whose harvest he shall eat.

$c$ infra xxxi. 40.

$\delta$ or, trap.

$\varepsilon$ their.

$\zeta$ sons of a fire-brand. $\eta$ they make high to fly.

d infiaxi. 7-9; xv. $8,9,12$; xxii. 11 , 12, \&e.; Prov xii. 11 ; xxviii. 19.

$\theta$ Or, But as for me (lit., But I), I would seek.

e infra, viii. 5 .

$\kappa$ set, dispose.

$\lambda$ doing.

$\mu$ and no searehing.

$y$, till no number.

finfra ix. 10.

$\pi$ [is] giving.

$\rho$ sending.

$\sigma$ to set up.

$g 1$ Sam. ii. 8; Ps. cvii. 41 ; cxiii. 7,8 .

$\tau$ and [the] mourning.

$\phi$ breaking.

$\chi$ thoughts.

$\psi$ do not do anything.

(i) taking.

$h$ Jer. viii. 9.

$\omega \omega$ is hastened, i.e., is made hasty, precipitate.
3 I-when I have seen the foolish * taking-root, Have forth with $\psi$ declared the fate of his dwelling,

(saying)

4 "Far shall his ${ }^{a}$ children be from safety; " $\omega$ And they shall be crushed in the ${ }^{b}$ gate, $\beta$ without any to deliver.

$5 \gamma$ He shall eat his harvest, famishing, " "Seeing he must take it even from among thorns ${ }^{c}$;

"And $\delta$ a snare shall swallow up $\epsilon$ his substance."

6 Surely, it is not from the dust, that evil cometh forth,

Nor doth misery spring up from the ground,

7 For man is born to labour ;

But, like $\zeta$ sparks of fire, $\eta$ they ${ }^{d}$ soar aloft. $\dagger$

$8{ }^{\theta}$ But I would ${ }^{e}$ seek unto God, Yea, unto God would I k direct my speech;

$9 \lambda$ Which doeth great-things, $\mu$ and unsearchable; Marvellous-things, $\nu$ without number ${ }^{f}$ :

10 (Which $\pi$ giveth rain upon the face of the earth, And $\rho$ sendeth water upon the face of the fields:)

$11 \sigma$ So that He can set up the lowly on high ${ }^{g}$ -

$\tau$ And those that mourn are exalted to safety.

$12 \phi \mathrm{He}$ frustrateth the $x$ plots of the crafty, That their hands $\psi$ effect nothing substantial.

$13 \omega$ He taketh the ${ }^{h}$ wise in their craftiness,

So that the counsel of the ${ }^{2}$ perverse ${ }^{\omega \omega}$ proveth hasty.

1 Or, And he will have to take it even from among thorns, i.e., famishing, when he begins to eat his harvest-in consequence of the badness of his crops the year before; he will speedily be famished, in consequence of the great scantiness of his new harvest. See Comm. and Append. Editor, 1862.

2 Or, deceitful, eunning, treacherous. See Appendix. Editor, 1862.

* i.e., wicked. Comp. Ps. xiv. 1.

+ i.e., they indulge in metaphysical speculations, which are altogether beyond them; whereas if they would confine themselves to that for which they were ordained, namely, to the tillage and culture of their land, evil and misery would not come upon them. 
$14 \omega^{\omega}$ In the day-time, they $\beta$ grapple with darkness, ${ }_{\beta}^{\omega}$ by day. And $\gamma$ grope at noon-day, as in the night. ${ }^{*}$

$15 \delta$ And so He saveth the needy ${ }^{b}$ from the swordeven from their mouth ${ }^{c}$,

And from the hand of the strong.

16 So the feeble hath hope, And iniquity ${ }^{\epsilon}$ shutteth her mouth. ${ }^{d}$

17 Behold! happy is the man, $\zeta$ whom God correcteth;

The chastening of the Almighty therefore, reject not: ${ }^{e}$

18 For He maketh sore, yet bindeth up;

He smiteth, but His hands $\eta$ make whole. ${ }^{e e}$

19 In ${ }^{f}$ six troubles, He will deliver thee;

Yea in ${ }^{g}$ seven, shall $\theta^{\theta}$ no evil touch thee.

$\beta$ meet, light upon, or (Ben-Zer) feel about, feel their way, in the dark. $\gamma$ feel. a infra xii.25; Dent. xxviii. 29; Isa. lix. 10.

$\delta$ and He saved.

6 Ps. lxxii. 4, 12 ; Isa. xli. 17.

$c$ Ps. Ivii. 4; Isa. xlix. 2; Lam. ii. 16; IIeb. iv. 12 ; Rev.i. 16 ; ii. 16 ; xix. 15.

$\varepsilon$ hath shut.

vide note on ver. 20. $d$ Ps. evii. 42.

$\zeta$ God eorrects him. $e$ Prov.iii. 11, 12, \&s. ee Deut. xxxii. 39 ;

Hos. vi. 1.

$\eta$ heal.

$f$ Prov. vi. 16.

20 In famine, $\mathrm{He} \kappa$ shall redeem thee from death. $g$ Prov. xxir. 16. And in war, $\lambda$ from the power of the sword. $\kappa$ hath redeemed

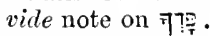

$21 *$ When the scourge of the tongue ${ }^{h}$ cometh, thou $\lambda$ from hands of. shalt be hid; $\dagger$

And when destruction, ${ }^{i}$ thou shalt not be afraid.

22 At destruction ${ }^{\mu}$ and famine thou shalt laugh;

$h$ Ps. lii. 2 ; lrii. 4 ; lxiv. $3,7, \mathrm{~S}$. Jer. ix. 3,8 .

$i$ Prov. iii. 25. And of the ${ }^{\nu}$ wild-beasts of the earth shalt thou ${ }^{\nu}$ wild-beast of. not be afraid.

23 For even with the ${ }^{k}$ stones of the field will be thy $k 1$ Sam. ii. 9; Ps. covenant; + xci. 12 ; exxi. 3 ; Pror. iii. 23,26 .

And the $\pi$ wild-beasts of the field $\rho$ shall be at $\pi$ wild-beast of. peace $\sigma$ with thee. ${ }^{l}$

$\rho$ hath been made to be at peace.

24 And thou shalt know, $\S$ that thy tent is in peace ; And when thou shalt visit thy dwelling, $\tau$ thou shalt miss nothing.

25 And thou shalt know, $\$$ that thy seed shall be $\tau$ then thiou shalt not great, ${ }^{m}$ miss.

$m$ Gen. xiii. 16 ; xv. 5, se.

* Ver. 21. lit.,

In the scourge of the tongue, thou shalt be hid;

Neither shalt thou be afraid of destruetion, when it eometh.

+ i.e., when slander is rife, it shall not affect thee.

+ i.e., no stone shall ever trip thee up.

\$ i.e., feel confident. 
$a$ herb,

And thine offspring, as the a herbs of the earth.

z Gen. xxv. 8; 1 Chron. xxix. 28.

$\beta$ as [the] going up of a sheat.

$\gamma$ and $[$ do $]$ thou know [it] for thyself.

of they could, would, lift into, \&e.

$\varepsilon$ it would be heavier. a Prov. xxvii. 3.

$\zeta$ [are] with me.

$b$ Ps. xxxviii. 2.

$\eta$ [is] drinking.

c Mat. v. 13; Col. iv. 6.

$\theta$ in [the] spittle of [the] yolk [of an egg].

d infra ver. 25.

$\kappa$ as [the] loathsomeness of $\mathrm{my}$ food.

$e$ Ps. eii. 4.

$\lambda$ might come.

$\mu$ Or, cut me off.

$\beta$ As the sheaf is taken up in its season.

27 Lo this, we have searched it, so it $i s$;

Hear it, $\gamma$ and mark $i t$, for thyself.

\section{CHAPTER VI.}

1 'Then answered Job, and said:

2 Oh that my grief could be thoroughly weighed, And my calamity $\delta$ be laid altogether in the balances!

3 Surely now, 6 either were heavier than the ${ }^{a}$ sand of the seas ;

Therefore have they swallowed up my words.*

4 For the arrows of the Almighty $\zeta$ stick fast in me, ${ }^{b}$

Whose venom my spirit $\eta$ drinketh in ;

The terrors of God array-themselves against me.

5 Doth the wild-ass bray, over his grass?

Or loweth the ox, over his fodder?

6 Can that, which is tasteless, be eaten without salt ? ${ }^{c}$

Is there any savour $\theta$ in the white of an egg? $\dagger$

7 No! my soul doth refuse to touch them;

"They are ${ }^{k}$ as $\mathrm{my}^{e}$ loathsome food. $\ddagger$

8 Oh that my request $\lambda$ might be fulfilled!

And that God would grant my hope!

9 Yea, that God were willing, and would crush me! That He would let loose His hand, and $\mu$ make an end of me!

* i.e., they have rendered my speech confused and inarticulate; they prevent me from employing such choice and elegant language as you do.

+ He here compares his friend's arguments to tasteless and insipid food.

$\ddagger$ i.e., thy arguments are as loathsome to me as food now is in consequence of my disease. 
10 Then were this still my consolation-though I were to burn with pain, and $\mathrm{He}$ not spare-

That I have not denied the words of the Holy-

\section{$\mathrm{One}^{z}$.*}

11 But what is my strength, that I should hope?

Or what would be mine end, if I should prolong my life?

l:I Is my strength the strength of stones?

Is my flesh a brass?

$a$ brazen.

13 Hath, then, because mine help is not in me,

Mine $\beta$ understanding also been driven out from me?†

¿4 $\gamma$ 'To him, that is pining-away, $\delta$ should kindness be shewed from his friend;

Or else-he may forsake the fear of the Almighty ${ }^{a}+$

15 My brethren have dealt deceitfully as a torrent, ${ }^{b}$

As the stream of torrents, that pass away;

16 Which grow turbid by reason of the ice,

By reason of the snow, that hideth itself $\epsilon$ within $\varepsilon$ upon them. them.

$17 \zeta$ What time they wax warm, they $\eta$ vanish;

$\theta$ When they grow hot, they ${ }^{k}$ are consumed from their place. $18 \mathrm{Yea}$, they turn from the paths of their $x$ are extinguished. way ;

They ascend in a shapeless-mass, and perish.

19 The caravans of 'Tema looked,

The wayfaring-companies of Sheba hoped, for them.

* i.e., that I have not disrcgarded His commandments. Comp. infra xxiii. 11, 12.

ti.e., because I am become helpless, am I also become a fool? See Ch. v. 2, where Eliphaz called him a fool.

$\ddagger$ i.e., a sufferer, by being galled and chafed, may be driven to shake off all reverence for God. z supra iv. 7,18 ; . 17. $\beta$ common seuse, practical wisdom, discretion, judgment.

$\gamma$ to the [one]pining away.

$\delta$ [there should be] kindness.

a supra iv. 6; infira xv. 4.

6 Gen. xlix. 4. $\zeta$ at [the] time of their becoming warm. $\eta$ are destroyed. them) growing hot.
$\kappa$ are extinguished. 
$a$ he (i.e., every one of them) bad trusted. $\beta$ they came unto it.

$\delta$ surely now ye hare become it. $\gamma$ blushed.

20 They were ashamed that ${ }^{a}$ they had trusted; $\beta$ They came thither, and $\gamma$ were confounded?

$21 \delta$ Such now surely are ye become;

Ye see horror, and therefore are afraid.*

22 Did I indeed say, "Give to me" ?

Or "Of your wealth bribe for me" ?

23 Or, "Deliver me from an adversary's hand"?

$\varepsilon$ violent-men, oppressors.

$\zeta$ may ye redeem me.

$\eta$ what I have erred [in].

$\theta$ words of rectitude.

$\kappa$ What can one at all argue out of you?

$\lambda$ lit, Do you think to argue [by] words?

a infra xi. 2 ; xii. 3 ; xiii. 5,12 ; xv. 3 ; xvi. 3 ; xviii. 2 ; xix. 3 ; xxi. 2 ; xxxii. 12.

$\mu$ theu [will be] for wind, will become wind.

$b$ infra xxii. 9; xxir. 9 ; хxxi. 21, \&e. cinfraxix. 22 ; xxxi. 31 ; Ps.xxvii. 2. $\nu$ before your face. $\pi$ let not be.

$\rho$ palate.
Or, "From the hand of $\epsilon$ tyrants $\zeta$ redeem me"?

24 Instruct me, and I will hold my peace;

Only, make me to understand $\eta$ wherein I have erred.

25 How forcible are ${ }^{\theta}$ right words!

But, ${ }^{k}$ what arguments can one wring out of you?

$26{ }^{\lambda}$ Do ye think to use mere words for arguments ${ }^{a}$ ? ${ }^{\mu}$ Then but as wind must be the words of the despairing. $\dagger$

27 As well might ye cast yourselves on the ${ }^{b}$ fatherless! ¥ Or make a banquet ${ }^{\circ}$ on your friend $! \S$

28 Now therefore be pleased, turn unto me; Then will it be $\nu$ evident unto you if I lie.

29 Return, I pray you; $\pi$ let there be no wrong; Yea, return again; my righteousness is still in it. $\|$

30 Is there iniquity in my tongue? Cannot my $\rho$ taste discern perverse-things ? I

* i.e., I expected to meet with consolation and sympathy at your hands, but $I$ have received nothing but reproaches and invectives; you have a horrifying spectacle before you, and therefore are afraid to own my innocence.

$\dagger$ i.e., if we are only liere to see which has the greater command of language, then of course I, who am reduced to despair, cannot hope to vie with you.

$\ddagger$ i.e., treat him with the greatest cruelty. Comp. Ps. xxvii. 2.

\$i.e., if you are capable of taking advantage of the situation of an unfortunate friend, then there is no cruel act which you may not commit.

$\|$ i.e., in my tongue, mentioned in the next verse. See Commentary.

Ti.e., can I no longer distinguish betwecu right and wrong? 


\section{CHAPTER VII.}

1 Is there not an appointed time for frail-man upon earth?

Truly, as the days of an hireling are his days.

2 As a slave panteth-for the shade, And as an ${ }^{a}$ hireling $\omega$ longeth for his wages;

3 So have I been $\beta$ allotted months of vanity,

a infra xir. 6.

$\omega$ waiteth.

$\beta$ made to inherit for myself.

And nights of trouble $\gamma$ have been prepared for $\gamma$ they have preme.

4. When I lie down, $\delta$ I say: pared.

$\delta$ then I say.

When shall I arise? $\epsilon$ But the night is length- $\varepsilon$ but one measured ened out, out [the] evening.

And I am $\zeta$ filled-with tossings until the morning- $\zeta$ glutted with.

twilight. ${ }^{a}$

$a$ Ps. vi. 6.

5 My flesh hath put on the worm, ${ }^{b}$ and clod of dust; $b$ Isa. xiv. 11; Aets My skin is broken, and become loathsome. ${ }^{c} \quad$ cinfic 23.

6 My days * were swifter than a weaver's-shuttle, ${ }^{d}$ d infra ix. $25,26$. But now they waste away without hope.

$7 \mathrm{O}$ remember $\dagger$ that my life is but a breath ;

$\eta$ Never again shall mine eye see good.

$8 \theta$ No more shall the eye of him that secth me behold me ;

$e$ Ps. eii. 3,11 .

finfra ver. 16.

$\eta$ mine eye shall not return to see good.

0 [the] ese of [the one] seeing me shall not see me.

Thine own eyes $\kappa$ shall look for me, but I shall $\kappa$ [shall be] on me. not $b e$.

$9 \lambda$ A cloud, when it hath wasted, is gone for ever; $\lambda$ lath a cloud So ${ }^{\mu}$ he that goeth down to the pit shall not come up. ${ }^{g}$

$10 \mathrm{He}^{\nu}$ shall no more return unto his house, And his place ${ }^{\pi}$ shall discern him no more."

11 Therefore, I too will not refrain my mouth; wasted, then it is gone.

$\mu$ [one] going down. $y$ infru xiv. $10-12$. $v$ sliall not return again.

$\pi$ shall not disceru lim again.

$h$ infra viii. 18.

I will speak, in the anguish of my spirit;

I will complain, in the bitterness of my soul. ${ }^{i}$ infrax. I.

$12 A m$ I a sea, or a sea-monster, That Thou shouldest set $\rho$ a dam ${ }^{k}$ about me ? $\ddagger$

* i.e., my former days of happiness.

+ Job liere addresses himself to God.

$\$$ For the explanation of this extraordinary comparison see

$\rho$ a guard.

k infroxiii.27; xxxiii. 11 ; xxxriii. 11; Prov. viii. 29; Jer. r. 20.

Commentary. 
a carry away.

13 When I say: My bed may comfort me, Ny couch may a remove my grief;

14 'Then 'Thou scarest me with dreams, And frightest me through visions;

15 So that mysoul would rather choose strangling,a infra ix. 21 ; x. 1; Jer. viii. 3.

$\beta$ from myown bones (limbs).

${ }^{a}$ Even death, $\beta$ by mine own hands.

16 (No! This thought, I loathe it, not for ever shall I live ;

$\gamma$ cease (desist) from me.

b supra ver. 7 ; Ps. xxxix. 4, 5 .

c Ps.viii. 4, 5; cxliv.3. $\delta$ at (of) mornings. $d$ Ps. lxxiii. 14.

$\varepsilon$ at moments.

$\zeta$ not like anything.

See Comm.

$e$ infra xiv. $6 ; \mathrm{Ps}$. xxxix. 13.

$\eta$ my swallowing.

$\kappa$ IIave I simned.

$\lambda$ for a clashing to Thee.

$\mu$ at, upon.

$\nu$ and Thou mayest ...... but I [am] not.

$f$ Ps. xxxvii. 10.

$\pi$ till when.

$\rho$ these [things].

17 What is frail-man, that Thou shouldest exalt him ?

And that Thou shouldest set Thine heart upon $\operatorname{him}^{c}$ ?

18 That Thou shouldest visit him $\delta$ every morning?

$\epsilon$ Every moment prove him?

$19 \zeta$ Not one instant wilt Thou look away from me, ${ }^{e}$ Nor let me alone, till $\eta$ I swallow down my spittle.

$20 \kappa$ If I have sinned, what can I do unto Thee? †

[But, if what I do can affect Thee, then]

O Thou Preserver of man! why didst Thou make me ${ }^{\lambda}$ so that I should clash with Thee,

And become thereby a burden to myself?

21 And why shouldest 'Thou not rather forgive my transgression,

And cause mine iniquity to pass away?

For presently I shall lie down $\mu$ in the dust;

$\nu$ And, though 'Thou mayest diligently seek me,

I shall not $b e .^{f}$

\section{CHAPTER VIII.}

1 Then answered Bildad the Shuhite, and said:

$2 \pi$ How long wilt thou speak $\rho$ such things, And the words of thy mouth be a violent wind?

* Addressed to the idea of suicide, which infests him. $\uparrow$ i.e., how can any action of mine affect Thee? 
3 Can God pervert justice?

Or can the Almighty pervert right? ${ }^{a}$

4 If thy sons sinned against Him,

$\mathrm{He}{ }^{a}$ despatched them, $\beta$ because of their trans- $\underset{\beta}{a \text { sent them away. }}$ [the] hand of. gression. $^{a a}$

a infra xxxiv.10,12;

Deut. xxxii. 4.

$a a$ Isa. lxiv. 7.

5 But thou, if thou wilt diligently seek unto God, And, to the Almighty wilt make supplication;

6 If thou art pure and upright;

Surely, He will presently awake for thee, ${ }^{b} \quad b$ Ps. vii. 6 ; xliv. 23.

And make prosperous $\gamma$ thy righteous habitation; $\gamma[$ the] dwelling of

7 So that even thy beginning $\delta$ will seem but small, $\delta$ will be [comparaSeeing thine end will be so exceeding great.

8 For inquire, now, of the former generation, ${ }^{c} \quad c$ infra xii. $7, \mathrm{~s}$. And prepare thyself to the searching of their fathers.

9 (For we are but of yesterday, ${ }^{\epsilon}$ and know nothing; $\varepsilon$ and do not know. For our days are a shadow upon the earth.) ${ }^{d} \quad$ d supra vii. 7,16 ;

10 Will not THey instruct thee, tell thee, Ps.xxix.5; cxliv.4. And from their heart bring forth words saying,

\section{First Simile.}

11 "Can the rush $\zeta$ shoot up, without mire? $\zeta$ become high, loft $\check{c}^{*}$ "Can the flag, " grow up, without water? " become great.

12 "It is still in its greenness, -it is not cut down,

"Yet, before all grass it ${ }^{\theta}$ withereth. $^{e}$

\section{Application of this Sinile bi the Mex of}

THE FORIER GENERA'TION THEMSELVES.

"So are the paths of all, $\kappa$ that forget God; $\kappa$ forgetters-of God. "Yea, the hope of the hypocrite shall perish;

4. " $\lambda$ Whom his confidence will cut off, "Seeing that his * trust is as the ${ }^{\mu}$ spider's web.

$\lambda$ Or, whose confi. dence will be cut ofr. $\mu$ a spider's house.

15 "He may lean upon his house, but it shall not stand;

* i.e., that on which he trusts. 
translation. Chap. Vili. $16-22 ; \mathrm{IX} .1$.

a Prov. xii. 7 ; xir.

" He may take fast hold of it, but it shall 11. not endure. ${ }^{a}$

\section{Second Simile.}

16 "But* He is full-of-sap in face even of the

$z$ Jer, xrii. S. sun, $\tilde{z}$

a sucker, tender-

branch.

$\beta$ goeth forth.

3 Gen. xlix. 22, Ps. 17 i. 3 ; Ezek. xvii. 5.

$\gamma$ house of stones.

$\delta$ destroy.

$\varepsilon$ I saw thee not.

18 "If one should o uproot him from his place, c supra vii. 10 ; infra xx. 9.

$\zeta$ joy of his way 19 (journey).

$\eta$ dust, earth.

$\theta$ they would springup.

d infra xiv. 7-9.

\section{Application of the second Simle by the Speaker.}

20 Behold then! God will not reject the pious, ${ }^{1}$ Neither will He take hold of the hand of the wicked.

$e$ Ps. cxxri. 2.

21 Even yet will He fill thy mouth with laughter, ${ }^{e}$ $\kappa$ shout-of-jog. And thy lips with $\kappa$ shouts-of-joy.

$\lambda$ thy haters.

$22 \lambda$ They that hate thee shall put on shame, And the tent of the wicked-it is not.

\section{CHAPTER IX.}

1 Then Job answered, and said:

1 See note p. 395.

* i.e., the good man under the figure of a tree. Comp. infra xv. $30,32,33$, xviii. 16 ; Ps. i. 3 , lii. 8 , xcii. 12 ; Jer. xrii. $8,8 \mathrm{c}$.

$\dagger$ i.e., he does not require the shade of other trees to shelter him from the heat of the sun ; nay, in spite of this, he grows to such a height as to overtop even a stately house of stone. 
2 Of a truth, I know that $i t$ is so; *

But how can frail-man be just with God?

3 If he should desire to contend with HIM,

HE would not answer him ${ }^{a}$ one of a thousand a one-thing. questions.

$4^{\beta} \mathrm{W}$ ise in heart, and $\gamma$ mighty in strength ${ }^{a}$ !

Who hath $\delta$ spoken fiercely unto Him, and been at peace ${ }^{b}$ ?

5 Which removeth mountains, $\epsilon$ ere they are aware ;

$\zeta$ Yea, ${ }^{c}$ overturneth them in His anger.

6 Which maketh the earth to tremble from her place $^{d}$,

So that the pillars ${ }^{e}$ thereof are sliaken.

7 Which $\eta$ commandeth the sun, and he shineth not; $†$

And $\theta$ upon the stars doth ${ }^{f}$ set His seal. $\ddagger$

$8 \times$ He spreadeth out the heavens ${ }^{g}$, alone,

And $\lambda$ treadeth ${ }^{h}$ upon the ${ }^{\mu}$ high-waves of the sea.

$9 \nu$ He maketh Arcturus, Orion, and the Pleiades, ${ }^{i}$

And the hidden-chambers of the south:

$10 \pi$ He doeth great-things, $\rho$ and unsearchable,

Yea, wonderful-things, ${ }^{\sigma}$ without number. ${ }^{*}$

11 Lo! He goeth by me, and I see Him not;

He passeth also, but I do not perceive IIim. ${ }^{l}$

12 Behold! He snatcheth away; who shall $\tau$ prevent Him ? ${ }^{m}$

Who shall say unto Him: "That doest Thou?" 13 God will not $\phi$ withdraw IIis anger; $§$

$\beta$ wise of heart.

$\gamma$ mighty of strength.

a infra xii. 13;

xxxvi. 5.

of made hard [his words].

$b$ Lev. xxiv. 11, 14, 16 ; 2 Kings xriii. 35 ; xix. 10, 22, $27,28,35$.

$\varepsilon$ and they know not.

$\zeta$ which (mountains)

He overturned.

c infra xxviii. 9.

d Ps. xviii. 7; lxxvii.

18 ; xevii. 4,5 , \&e.

e 1 Sam. ii. 8 ; Ps. Ixxv.3; infra xxvi. 11.

$\eta$ saith to the sun.

$\theta$ sealeth about [the] stars.

$f$ infra xxxriii. 31 ; xxiv. 16 ; xxxrii.7.

$\kappa$ spreading.

$g$ Isa. xl. 22.

$h$ Amos iv. 13 ; Mic. i. 3.

$\mu$ heights.

$\nu$ making.

i infra xxxviii. 31, $32 ; A \operatorname{mos}$ v. 8.

$\pi$ doing.

$\rho$ till no searching.

$\sigma$ till no number.

$k$ supra v. 9 ; infra

xxxrii. 5.

7 infra $x$ xiii. 8,9 .

m infra xi. 10 ; xxiii. 13.

$\tau$ cause Bim to turn back.

$\phi$ cause to turn back.

* Were I but allowed the opportunity of pleading my cause before God, I could speedily satisfy IIim of my purity and uprightness, (comp. infra xiii. 18 ; xxiii. 10), and then I know that, as thou sayest, I slould be restored to my former prosperity -but, alas, this opportunity will nerer be granted to me. See supra viii. 6 , infra vers. $28,29,32$; xiii. 19, \&c. Editor, 1862.

+ Alluding to the eclipses of the sun.

$\ddagger$ i.e., when they are hidden behind clouds.

$\S$ i.e., when IIe is bent upon punishing. 
$\omega$ helpers of pride have sunk.

$a$ Isa. xxxi. 3 .

$\beta$ utter.

l supra viii. 5.

$\gamma$ called.

$\delta$ and He had an. swered (by granting my prayer), had heard, me.

$\omega$ Proud helpers * sink beneath Him.

14. How much less shall I address Him, Shall I choose out my words to reason with Him!

$15 \mathrm{I}$, who, though I am just, must not $\beta$ proclaim it; But must ${ }^{b}$ make supplication to my Judge. $\dagger$ 16 If I had $\gamma$ prayed, $\delta$ and $\mathrm{He}$ had granted $\mathrm{my}$ request,

Yet could I not believe that He had given-earunto my voice; $\ddagger$

c infra xxvii. 20, 21. 17 He, who is crushing me with a tempest, ${ }^{c}$ And multiplieth my wounds without cause.

$\varepsilon$ to make to return.

$\zeta$ bitternesses.

$\eta$ if with respect to strength.

$\theta$ or, eite, summon, me.

$k$ then it would, de.

d supra vii. 15 ; infra x. 1.

e Ezek. xxi. 3.

finfra xxi. 13.

g supra ri. 9, 14; vii. 3,5 , \&e.

$\lambda$ corereth.

18 He will not suffer me $\epsilon$ to draw my breath, But filleth me with $\zeta$ bitterness.

$19 \eta$ If I appeal to strength-behold ! He is mighty ; And, if to justice-who will ${ }^{\theta}$ appoint me a time to plead?

20 Should I say: "I am just"-mine oun mouth would condemn me.

Or, "I am pious" — ${ }^{\kappa}$ that would prove me perverse.

21 Though I am pious, ${ }^{1}$ I myself must not know it; Therefore, I do loathe my life. ${ }^{d}$

22 It is all onc, therefore did I say; ${ }^{e}$ He consumeth alilie the pious, ${ }^{1}$ and the wicked. 23 If the scourge slay the wicked suddenly, He may mock at the trial ${ }^{g}$ of the innocent. $\S$

24. The earth is given into the hand of the wicked; $\mathrm{He}{ }^{\lambda}$ veileth the face of her judges;

1 Or, pure, upright, blameless. See note p. 395. Editor, 1862.

* i.e., the proud confederates of him, whom God will punish.

$\uparrow$ i.e., who can only supplicate my Jurge, instead of being allowed to plead my cause before Him.

廿 i.e., my punishment having been inflicted without cause, I should not, if it were to cease, attribute its removal so much to my prayers, as rather to some unaccountable change of mind on the part of Him, who sent it.

\$ Bildad having compared the wicked man to a reed which suddenly dries up, Job replies that it is better to die at once than to suffer as he has done. 
If not, who w then is he, that doeth so?

$\omega$ now, pray.

25 Whereas my days* were swifter than a runner ${ }^{a}$; a supra vii. 6 . They fled, as though they $\beta$ had seen no good. $\beta$ had not seen good. 26 'They have passed by, $\gamma$ like + Aveh's ships; $\gamma$ with. Like an eagle, that pounceth on his $\delta$ prey. ${ }^{b} \quad \delta$ food.

27 If $\epsilon$ I say: "I will forget my grief, "Lay aside mine anger, and $\epsilon$ cheer up ;"

28 Still, I dread all my pangs, For I know that Thou wilt not hold me innocent.

29 I know that I shall be accounted guilty; Why then should I labour in vain?

30 If even I had $\zeta$ washed in snow-water, And had cleansed mine hands with lye ${ }^{b b}$;

$\zeta$ washed myself.

bb Jer. ii. 22.

$\eta$ then. So that my garments would $\theta$ make me an $\theta$ makemeabhorred.

$\varepsilon$ my saying [is].

$\varepsilon \varepsilon$ or, take patience, forbear-sich gedulden (Ben-Zev).

$31 \eta$ Still wouldest Thou plunge me in the ditch, abhorrence.

32 For He is not a man like myself, that I should say to Him:

"Let us enter together into judgment.c"

c Isa. i. 18 ; sliii. 26.

33 'There is no umpire between us, Who should lay his hand upon ${ }^{*}$ us both.

34 Let Him remove His rod $\lambda$ from off me, And let not His terror affright me $;^{d}$

35 Then will I speak-out, and not fear ITim;

For am I not ${ }^{d d}$ upright with myself? $\ddagger$

N us two.

$\lambda$ from upon me.

d infra xiii. 21; xxxiii. 7.

dd Ps. lxxriii. 37.

\section{CHAP'TER X.}

1 My soul $\mu$ doth loathe my life ${ }^{e}$

I will unburden my grief, which is upon me;

I will speak in the bitterness of my soul. ${ }^{f}$

2 I will say unto God: Condemn me not!

Make me to know, wherefore Thou contendest with me! ${ }^{g}$

$\mu$ hath been disgusted with, abhorreth.

e supra vii. 15 ; ix. 21.

f supra vii. 11.

g supra vi. $24 ;$ infra xiii. 23.

* i.e., My former happy days.

$\dagger$ The name of a place, perhaps Joppa. See Commentary.

$\ddagger$ i.e., am I not conscious of my uprightness? 
TRANSLATION. CHAP. X. $3-12$.

a good.

$\beta$ labour.

a infra xxsir. 19; xxxrii. 7.

a a Yumb. ri. 25; Ps. xxxi. 16, sc.

$\gamma$ as [the] seeing of frail-man.

61 Sim. xri. 7 ; Isa. 1v. 8,9 .

$\delta$ before Thy knowledge (Thine $\mathrm{Om}$ niscience)

$\varepsilon$ none delirering.

$\zeta$ made.

$\eta$ now.

$\theta$ make.

c Isa. xlr. 9; lxir. S; Jer. xriii. 6.

d infra xxx. 23; Gen. iii. 19 ; $\mathrm{Ys}$ ciii.13,14; Eccles. xii. 7.

$\kappa$ the milk.

$\lambda$ the cheese.

$e$ Ps. cxxix.14-16.

$\mu$ hast Thou done with me.
3 Is it a seemly for Thee, that Thou shouldest oppress,

That thou shouldest reject the $\beta$ work of Thine hands ${ }^{a}$,

an When Thou hast shone upon the counsel of the wicked?

4 Hast Thou eyes of flesh ?

$\gamma$ As frail-man seeth, seest Thou ${ }^{b}$

5 Are Thy days as the days of frail-man?

Thy years, as the days of the years of man?

$6{ }^{1}$ Surely, Thou demandest mine iniquity, And requirest my sin. $†$

7 Iet is it $\delta$ within 'Thy Knnowledge, that I shall not do-wickedly ;

But, from Thine hand, there is $\epsilon$ no deliverance. $\neq$

8 Thine oun hands fashioned me, and $\zeta$ moulded me

Altogether round about; and now Thou hast destroyed me!

9 Remember, $\eta \mathrm{I}$ beseech thee, that Thou didst $\theta$ mould me as the clay, ${ }^{c}$

And that to dust Thou wilt cause me to return! ${ }^{d} \$$

10 Didst Thou not pour me out like ${ }^{\kappa}$ milk, And curdle me like ${ }^{\lambda}$ cheese ?

11 With skin and flesh Thou didst clothe me, With bones and sinews fence me in. ${ }^{e}$

12 Life-yea, favour $\mu$ didst Thou grant me,

1 Or, that Thou demandest. Editor, 1862.

* i.e., a being, made by Thee, as innocent as I am.

+ Thou temptest, provokest, me to sin, for sufferings such as mine might well make even the best of men rebel.

$\ddagger$ What need hath an Omniscient Being like Thee to put me to the test? yet no consideration can induce Thee to free me from my aftliction!

\$ i.e., remember that, made of such frail materials, I must suon die; hasten, therefore, to take pity on me. 
And Thy a care preserved my spirit. *

$a$ oversight, super. intendence.

13 Yet, these things wast Thou hiding in Thine $z$ infra xxiii. 14; heart; $\approx$;

I know that this was $\beta$ in Thy mind.

14 Had I sinned, $\gamma$ Thou wouldest have ${ }^{a}$ marked me, And from my iniquity wouldest not $\delta$ have acquitted $\mathrm{me}^{b}$ :

15 Had I done wickedly, woe would have leen unto me;

And now, though I have been just, ${ }^{c}$ I cannot lift up my head. ${ }^{d}$ I am full of disgrace: look then on mine $e 2$ Sam. Srii. 12; Ps. affliction. ${ }^{e}$ 16 And is it then so ${ }^{f}$ glorious, that, as a ${ }^{g}$ fierce- $f$ supra rer. 3.

lion, Thou shouldest ${ }^{k}$ hunt me, Deut. xxxii. 34, 35, \&c.

$\beta$ with Thee.

$\gamma$ then Thou wouldest, \&c.

a infra xiii. 27 ; xir. 16,17 .

o have held, pronounced, me innocent.

supra is. 2, 28; Ps. cxxs. 3.

c supra ix. 21 ; infra xxiii. 11, 12.

d infira xi. 15; xxii. 26 ; Gen. ir. 5, 6 ; xxv. 1S; Lam. iii.

$g$ Lam. iii. 10; Hos. xiii. 7,8 .

$\epsilon$ And at the same time shew Thyself ${ }^{i}$ mysterious towards me? +

17 Thou renewest Thy $\oint$ witnesses against me, ${ }^{k}$ And increasest Thine indignation $\zeta$ towards me ; $\|$

$\eta$ Troop after troop-yea, a whole host, are they with me.

18 Why then didst Thou bring me forth from the womb?'

I ought to have ${ }^{\theta}$ died $\times$ when no eye had yet beheld me;

19 I ought to have been, as though I had not been ${ }^{m}$; I ought to have been borne from my mother's h 1 sam. xxri. 20.

$\varepsilon$ and shouldest re. turn [and] shew thrself marrellous (see Comm.).

i supra ix. 11; infra xiii. 19,24 ; xxiii.3, S,9; Prov. xxp. 2 .

kinfra xri. 8 .

with me.

$\eta$ changes, succes. sions, relays.

l supra iii. 11; Jer. xx. $1 \mathrm{~S}$.

$\theta$ giren up the ghost, expired.

$\kappa$ so that an ere would not have seen me.

m supra iii. 16 . belly to the grave.

* i.e., when I was in my mother's womb.

$\uparrow$ Thou wast planning these punishments for me at the rery time Thou wast taking such eare of me in my mother's womb.

+ To be pursued and not to see one's pursuer, which is my lot, is very wonderful, but is it glorious for the pursuer ?

$\$$ 'These sores, which are considered by my friends as so many witnesses of my guilt.

\| Thine indignation increaseth in proportion to the increas in the number of these witnesses.

I i.e., these witnesses. 
a supra vii. 7 ; infra xiv. 1.

$\psi$ cease, desist.

$\omega$ or, eheer up, refresh me.

b sipra ix. 27.

$c$ infre xir. 6 ; Ps. xxxix. 13.

a so that I shall not, cannot, return.

dinfia xir. 12, and reterences there.

$e$ Ps. xxiii. 4; Isa. ix. 2 ; Jer. ii. 6,31 .

$\beta$ and not orders.

$\gamma$ Or, So that it shineth like deep darkness; or, And [where] it shineth like, \&c.

$f$ Ps. cxxxix. 12.

$g$ infra xxsir. 37 ; xxxr. 16; Prov. x. 19 ; Eccles. r. 2, 3,7 ; x. 14.

c man of lips.

h infra xv. 2, 3 .

io be justified, i.e., be held to be in the right.

E falsehoods, lies, fictions, fables.

$\zeta$ so that thou mayest mock.

$\eta$ and none putting to shame.

$\theta$ And so that thou mayest say [ to one of them].

$\kappa$ I Lave been clean, ever was clean.

i supra vi.10,30; x.7; infia xiv. 4 ; xxiii. $10-12$; xxxiii. 9.

$k$ supra vi. 8.

$\lambda$ for [there is] double to wisdom.

$\mu$ then know.

$v$ crediteth thee of thy punislment.

$l$ Ps. ciii. 8, 10; Ezra ix. 13.

$\pi$ searching; j.e., power of search, searching-power. Ger., Forschkraft.

$m$ infre xxri. 6 ; xxriii. 24; xxxiv. 21, 22; Ps. vii. 9; xiv. 21 ; trix. 5 ; crxix. 1-12; exlvii. 5 ; Prov. v. 21 ; $\mathrm{xr} .3$; xrii. 3; Is.s!. 2S; Jer. xi. 20 ; xri. 17 ; xxxii. 19; 2 Cliron. xri. 9, \&e.

n infra xxsii. 4; xxxvii. 16.
20 Are not my dars "few? $\psi$ Forbear then, And put Thine hand from off me, that I may $\omega^{b}$ recover me a little; ${ }^{c}$

21 Before I go- ${ }^{a}$ and return no more ${ }^{d}$ To a land of darkness, and shadow-of-death ;

2. A land of gloom like deep darkness, Of shadow-of-death, $\beta$ without any order; $\gamma$ And where, even when it shineth, it is like deep-darkness. ${ }^{f}$

\section{CHAP'TER XI.}

1 Then answered Zophar the Naamathite, and said :

2 Shall a ${ }^{g}$ multitude of words not be answered ? Or shall the $\delta$ babbler $^{h} \delta \delta$ be accounted right?

3 Thine $\epsilon$ inventions may put mortal-men to silence, $\zeta$ And them thou mayest mock, $\eta$ none putting thee to shame;

$4{ }^{\theta}$ Yea, to them thou mayest say: "My doctrine was pure,

" And K I was 'clean in thine eyes."

5 But, ${ }^{k}$ oh now that God would speak, And open His lips with thee!

6 And would proclaim to thee the secrets of wisdom,

( $\lambda$ For wisclom is twofold $*$ );

$\mu$ Then wouldest thou know, that God $\nu$ remitteth ${ }^{l}$ thee part of thy punishment.

7 Wouldest thou attain unto the $\pi$ searching-ken ${ }^{m}$ of God? †

Attain even to the " perfection $\neq$ of the Almighty?

* i.e., There are two kinds of wisdom, human and divine.

$\dagger$ Canst thou pretend to search out thine own heart as well as the unerring eye of God doth? How many times, therefore, mayest thou not have simned without being aware of it thyself:

¥ i.e., to His perfection in searching out the heart of man [or, perhaps, more generally, His omniseience.-Editor, 1862.] 
$8 \approx$ It is as $\chi$ high as heaven ${ }^{\circ}$-__ $\psi$ what canst $z$ Ps. crxis. 6 . thou do?

Deeper than the pit-what canst thou know? $\omega$

9 Longer than the earth is the measure thereof, And broader than the sea. ${ }^{b}$ *

10 If $\mathrm{He}$ cut off, or deliver over,

Or gather together, ${ }^{b b}+$ then who can prevent $\mathrm{Him}^{c}$ ?

11 Surely $\mathrm{He}$ knoweth a vain men,

And He seeth iniquity ${ }^{d}$, though He seEv not to perceive $i t^{e}$.

12 For else even a worthless man would $\beta$ get him understanding;

Yea, a man even that were born like a wildass's colt. $\neq$

$13 B u t$ if thou $\gamma$ prepare thine heart, ${ }^{f}$

And $\delta$ spread out thine hands unto Him- ${ }^{g}$

14. If iniquity $b e$ in thine hand ${ }^{h}$, put it far away, And $\epsilon_{\text {suffer no wrong to dwell in thy tents }}$ -

$15^{i}$ Then, surely, shal t thou ${ }^{k}$ lift up thy countenance without spot;

Yea, thou shalt be steadfast ${ }^{l}$, and not fear ${ }^{m}$. 16 For thou shalt forget thy misery;

* I have here thought fit to depart slightly from the translation given in the Conmentary, where there is some confusion, as the first hemistich of ver. 8 is made to refer to the supposed endeavours on the part of Job to attain to the perfection of the Almighty, whilst the second hemistich of the same verse and the whole of the next seem rather to refer to the perfeetion itself. I have here made all four lines refer to the same suljeet the perfection (i.e., the omniscience, and perhaps, also (see ver. 10) the omnipotence) of God. Still ceen so, What canst thou do? will refer to Job's endeavours.-Editor, 186\%.

$x$ [the] hicights of heaven.

a Ps. ciii. 11; crxxix. 6-12; Prov. xxv. 3 ; Isa. 1r. 9.

$\psi$ or, how canst thou effect [it, i.c., thy purpose, aim]?

$\omega$ know [of it]; or, how canst thou know [it, i.e., the perfection of God?? $b$ Lam. ii. 13.

bb Jer. 1. 9.

c supra ix. 12; info $\alpha$ xii. 14 ; xxiii. 13. a mortals of vanity.

a supraver. 7 ; infia xxxiv. $21,22$.

$e$ infira $\mathrm{xxi} .19,20$; xxii. 13, 14; xxiv. 1,12 ; Exod. $\mathrm{xx}$. 5 ; Deut. xxxii. 31, 35; Ps. x. 1, 11 ; xlir. 23 ; xeiv. 1-11; Eccles. vii. 15 ; viii. 11 ; Isa. xxix. 15; Jer. ii. 9, 22; xxxii. 18; li. 13; Ezek. riii. 12;

Rom. ii. 5, \&c.

$\beta$ become sensible, discreet.

$\gamma$ hast prepared.

f 1 Sim. vii. 3.

o wilt, or, shalt have, spread.

g Ps. Lrriii. 31;

lxxxviii. 9.

linfor xri. 17; 1 Sam. xxiv. 11 ; Ps. vii. 3 ; Jon. iii. 8 .

c make not, lot not, wrong dweit.

isupra viii. 5, 6 ; infra xxii. $21-$ $30,8 c$.

it supra x. 15 ; infra x vii. 20 , dic.

l P's. xxi. 7 ; xxri. $1,80$.

in supra r. 21, 2...

$\uparrow$ i.e., cut off, or deliver over, a man, or astemble nultitudes against him.

$\ddagger$ i.e., if He did shew that He perceived iniquity, by visiting it with immediate punishment, even the worst of men would be constrained to abandon their evil courses, and man consequently would cease to be a free-agent. [Comp. Lecles. viii. 11 . - Editor, 1862.] 
$\approx$ supra ri. 15 .

$\omega$ more than noonday.

a infra xxii. 28; xxis. 3 ; Dan. xii. 3; Matt. xiii. 43.

$b$ infra $x x x .22$; Isa. xl. 31.

c 2 Sam. xxiii. 4 ; Prov. iv. 18.

$a$ when there is liope. $d$ Prov. x. $2 S$.

$\beta$ when thou shalt have looked.

$\beta \beta$ securely, confidently.

e suprav. 24; Pror. iii. 24.

$\gamma$ shalt have lain down, couched.

$\delta$ then [there shall be] none alarming [thee, scaring [thee] up.

$f$ Prov. iii. 24.

$\varepsilon$ entreat thy countenance.

$g$ infra xxix. 8-10, 21-25; xlii. 8.

$\varepsilon \varepsilon$ shall waste away, consume [with longing].

$h$ Prov. x. 28; xi. $7,23$.

$\zeta$ hath perished.

$i$ Ps. cxlii. 4, 5 ; Prov xix. 5; Jel. xxv. 35; Amos ii. 14,15 .

k supra viii. 13, 14.

kk infra xv. 30 ; xxxi. 39.

$\eta$ a people, company.

$l$ infra xxxii. 9.

m supra xi. 5, 6; infra $\mathrm{xv.} 8$; xxxii. 13.

$n$ infra xiii. 2 ; x 9.9 .

$o$ infra xvi. 20.

p Ps. xxii. 7, 8; x]ii. 10 ; Matt. xxvii. $39-43$.

$\theta$ or, perhaps, a righteous (just) [and] blameless man.

$q$ Ps. xxxi. 18; Matt. ix. 24 .

$\kappa$ to [the] thoughts of.

r Ps. cxxiii. 3, 4.
Or remember it but as waters that have passed away. ${ }^{z}$

17 And a life shall arise for thee ${ }^{\omega}$ brighter $^{a}$ than noon-day ;

Thou shalt soar ${ }^{b}$; thou shalt be as the morning. ${ }^{c}$ And thou shalt be confident a when thou dost hope ${ }^{d} ; *$

18 And $\beta$ when thou hast looked about thee, $\uparrow$ thou wilt lie down $\beta \beta$ in security. ${ }^{e}$

19 And when thou $\gamma$ dost repose, $\delta$ none shall disquiet ${ }^{f}$ thee ;

Yea, many shall $\epsilon$ make suit unto thee ${ }^{g}$.

20 But the eyes of the wicked ${ }^{\epsilon}$ shall fail ${ }^{h}$; Nay, refuge $\zeta$ shall perish from them ${ }^{i} ;$ And their hope ${ }^{k}$ shall be the ${ }^{k k}$ breathing out of their life.

\section{CHAPTER XII.}

1 Then Job answered, and said:

2 Indeed, because ye are $\eta$ a multitude ${ }^{l}$, Must therefore wisdom die with you ${ }^{m}$ ?

3 I too have understanding, as well as you;

I fall not short of you ${ }^{n}$.

Yea, with whom are there not sayings like these?

4 I am as one who is a laughing-stock to his neighbour ",

"Aha! he calleth upon God, that He should answer him ${ }^{p} ! " \$$

But even ${ }^{\theta}$ a perfectly righteous man may be a laughing-stock ${ }^{q}$.

5 There is contempt for calamity $*$ in the thoughts of him that is at ease ${ }^{r}$;

* i.e., whenever thou entertainest a hope, thou shalt feel confident thou wilt see it realized.

† i.e., at night, before retiring to rest.

$\$$ i.e, not only shall their eyes fail-i.e., shall their hopes be disappointed, but there shall be no escape for them.

$\S$ The words of the mocking neighbour. 
It is ready for $\omega$ them that slip with the foot ${ }^{a}{ }^{*}$

6 Prosperous are the tents ${ }^{a}$ of the spoilers ${ }^{b}$;

Yea, $\beta$ there is security for them that provoke God And lim, into whose hand God $\gamma$ bringeth good things.

7 And yet, ${ }^{c} \dagger$ ask now the beasts, $\delta$ and they will instruct thee;

Or the $\epsilon$ fowl of the heavens, and it will tell thee:

$S$ Or speak to the earth, and it will instruct thee; Yea, the fishes of the sea will declare unto thee.

9 Who knoweth not, by all these, That the hand of Jehovah hath made Sthem?

10 In whose hand is the ${ }^{d}$ breath of every living thing,

And the ${ }^{d d}$ spirit of all flesh of man.

11 Doth not the ear prove words, As the palate tasteth $\eta$ its food ${ }^{e}$ ?

12 With the aged, then, will be wisdom; And, with length of days, understanding $f$.

13 With Him, therefore, must be wisdom and might, ${ }^{g}$

To Him belong counsel and understanding ${ }^{h}$.

* i.e., one who is at ease has always contempt in store for those overtaken by calamity; he has it ever ready for such as are about to fall.

+ Job seems here to revert to the thought to which he had given utterance supra ix. 24, "The earth is given into the hands of the wicked;" and yet, he goes on to say, when I contemplate the wonders which surround me, it is evident to me that God made this earth, God whom I know to be so wise and far-seeing that nothing can be hid from Him, and so mighty that whatsoever He willeth IIe is able to perform. Why then do the wicked prosper, and why do I, who am innocent, thus suffer? (See infra xxi. 7, xxiii. 13, xxiv. 1, ix. 21, xi. 4, \&c.) At the same time, however, he wishes to show his friends that it is useless for them to declare to him the infinite wisdom and power of God, as this is a subject upon which they can tell him nothing which he does not already know (See rer. 3, supra xi. 5, 6, infra xiii. 1, 2). Comp. also note (1) on infra xxi. 4. -Editor, 1862. $\omega$ [the] tottering of foot.

$a$ Ps. sxxviii. 16.

a [belonging] to [the] spoilers.

b supra ix. 23, 24; infra xxi. 7-13, \&c.; Ps. lxxiii. 12. $\beta$ securities [are] to [the] provokers of God.

$\gamma$ lhath caused to come.

c supra viii. 8 ; infra xxi. 29; Deut.iv. 32.

$\delta$ and it (i.e., every one of them) will instruct thce.

$\varepsilon$ bird.

$\zeta$ this.

d Dan. v. 23 ; Acts xvii. 28.

dd infra xxxiv. 14, 15; Isa. Ivii. 16 ; Eccles. xii. 7.

$\eta$ food for itself.

e supra vi. 30 ; infra xxxiv. 3 ; P's. cxix. 103.

$f$ infra ver. $20 ; \mathbf{x}$. 10 ; xxxii. $7,9$.

g supra ix. 4 ; infra rer. 16 ; xxxri. 5 ; Ps. xeii. 5 ; Isa. xxriii. 29; Jer. xxxii. 19.

$h$ Ps. exlvii. ó; Prov. viii. 22 ; Rom. xi. 33,34 , de. 
14 Behold! He pulleth down, and it cannot be built up ;

w upon, orer.

a supra iii. 23 ; infra xix.8; Ps.lxxxviii. 8 ; Lam. iii. 7,9 ; Rer. iii. 7 .

b Isa. l. 2, \&c.

$\beta$ when He, \&e.

$\gamma$ then they over-

turn, overthrow.

$\hat{\delta}$ erring, and causing to el'r.

$\varepsilon$ to $\mathrm{Him}$.

c 1 hings xxii. 20, 22,23 ; Ezek. xir. 9 ; Eccles. ix. 1, 2; 2 Thess. ii. 11.

$\zeta$ making.

$\eta$ stripped, spoiled.

d 1 Sam. xix. 2 í.

e Isa. xliv. 25 .

$\theta$ hathloosed,looseth. $\kappa$ making.

$\lambda$ stripped, spoiled.

$f$ Isa. xl. 23 .

$\mu$ lip [belonging] to orators, or [the] eloquent.

$v$ pouring.

$g$ Ps. cvii. 40.

h infi $a \times x x .11$; Isa. v. 27 ; $\mathrm{xlv} .1$; Dan. v. 6.

$\pi$ disclosing.

$i$ infia $x$ xviii. 11.

$k$ infra xxxiv. 22 , se. $\rho$ increasing.

$\sigma$ the nations.

$l$ Ps. crii. 33-35, 38, 39 ; Isa. xxri. 15.

$\tau$ spreading out.

$m$ Esod. Xxxir. 24;

Deut. sii. 20;

1 Chron. iv. 10.

$\phi$ removing, taking away.

$n$ Isa. xliv. 25; 1 Cor, i. 19.

$\chi$ heads.

o Ps. cvii. 40.

p suprav. 14 ; Dent. xxviii. 29; Isa. lix. 10.

ل and no light.

$q$ Isa. 1. 10; Lam. iii. 2 ; Amos $V$. 18,20 .

(1) wander.

$r$ Ps. cvii. 27 ; Isa. xix. 14 ; xxiv. 20.
He shutteth ${ }^{\omega}$ up a man, and he cannot be loosed ${ }^{a}$.

15 Lo! He stayeth the waters, and they dry up ${ }^{b}$; $\beta \mathrm{He}$ letteth them loose, $\gamma$ and they overwhelm the land.

16 With Him is strength and sound-counsel; The $\delta$ deceived and deceiver are $\epsilon$ His ${ }^{c}$.

17 ¿He maketh counsellors to go $\eta$ naked $^{d}$, And judges He rendereth $\operatorname{mad}^{e}$.

18 The confederacy of kings, $\mathrm{He}{ }^{\theta}$ dissolveth, And girdeth a girclle on their loins.*

$19 \times$ He maketh chiefs to go $\lambda$ naked, And overthroweth the mighty ${ }^{f}$.

20 He removeth the ${ }^{\mu}$ speech of orators, And the discernment of the aged $\mathrm{He}$ taketh away.

$21{ }^{\nu} \mathrm{He}$ poureth contempt upon nobles ${ }^{g}$, And the girdle of the mighty He looseth ${ }^{h}$. $\dagger$ $22 \pi$ He discloseth deep-things out of darkness, Yea, ${ }^{i}$ bringeth out to light the shadow-of-death ${ }^{k}$. $23 \rho$ II increaseth $\sigma$ nations, and destroyeth them ${ }^{l}$; $\tau \mathrm{He}^{m}$ enlargeth $\sigma$ nations, and leadeth them captive.

$21 \phi \mathrm{He}^{n}$ removeth the understanding of the $\times$ chiefs of the people of the earth,

And causeth them to wander in a waste, where there is no way ${ }^{\circ}$.

25 They ${ }^{p}$ grope in darkness, w where there is no $\operatorname{light}{ }^{q}$;

Yea, He maketh them to wreel like the drunkard ${ }^{r}$.

\section{CHAPTER XIII.}

1 Lo! all this mine eye hath seen,

* i.e., moveth them to war among themselves.

+ i.e., depriveth them of their courage and strength. 
Mine ear heard, and ${ }^{\omega}$ noted it. ${ }^{a}$

$2 \beta$ As ye know it, so I too know;

I fall not short of you. ${ }^{b}$

3 But, $\gamma$ it is to speak to the Almighty, that I wish ; And to reason before God, that I desire.

4. Whilst ye are $\delta$ contrivers of lies;

$\epsilon$ Worthless physicians, ${ }^{d}$-all of ye!

5 Oh that ye would be altogether silent, And it would be counted unto you for wisdom!

6 Hear, I pray you, my reasoning;

And to the pleadings of my lips, attend.

7 For God, will ye speak iniquity?

And for Him, will ye speak deceit?

8 His person will ye accept?

For God will ye plead?

9 Will it be $\zeta$ well for you, when $\mathrm{He}$ searcheth you out?

Will ye ${ }^{f}$ mock Him, $\eta$ as ye might mock frail- $g$ anfra frail-man. man?

10 He will surely chastise you, If ye secretly accept persons. ${ }^{g}$

11 Should not His $\theta$ majesty $\kappa$ deter you ? ${ }^{h}$ And His dread fall upon you ${ }^{i}$ ? $*$

12 Your records are $\lambda$ parables for ashes, Parables for ${ }^{k}$ bodies of clay $\mu$ like yours! $\dagger$

* Should you not be afraid to flatter such a majestic Being as God?

$\uparrow$ The language in which ye have recorded the wonderful power and wisdom of God is indeed eloquent and lighly poetical, and, if addressed to mortal-men-dust and ashesdwellers in houses of clay like yourselves-would no doubt find acceptance with them. But God it eamot please, as being the language of flattery. Ile hath searched out your hearts, and He knoweth that, if ye have exalted and magnified Hin, ye have done so less with the view of reproving me than in the hope of finding favour with Him, and thereby escaping the dreadful torments which He hath sent upon me, and which, as being undeserved (for so ye believe them to be in spite of what ye say), fill you with the greatest dread. But "be ye afraid of the sword," if ye condemn me, whom ye know to be

$\omega$ or, noted for itself. a supia v. 27.

$\beta$ As your knowing.

b supra xii. 3 ; infra xv. 9.

$\gamma$ as for me, I would speak to.

c supra xi. 5; ix. $19,32-35$; infra, vers. $19-22$; xri. 21 ; xix. 7 ; xxiii. 3--7; xxxi. 35--37.

$\delta$ patchers up of, botchers of, framers of.

$\varepsilon$ physicians of $\mathrm{va}$ nity.

d infra xvi. 2; Mark v. 26; Luke viii. 43.

e supra xi. 2; infra xxi. 2; Prov xrii. 27,28 . $\zeta$ grood.

$f$ Aets . $.3,9$.

$\eta$ as [the] mocking

ginfiaxuii. 21, 22;
хxхіr. $19 ;$ Ps. xii. 3.

$\theta$ eleration, dignity. $\kappa$ terrify, affright.

$h$ infia xxxrii. 22; Isis. ii. 10; Jer. r. 22.

i supro ix. 31 ; infira ver. 21.

$\lambda$ similitudes, similes, images, tigures.

k supra iv 19 ; infia x. 9 ; xxxiii. 6 ; Isa. lxiv. S: Jè. xriii. 6; Grll. ii. 7 ; iii. 19; Ps. ciii. $14 ; 1 \mathrm{Col} . \times 4.47$; 2 Cor. r. 1, \&c. Comp. also supra i. 21 .

$\mu$ [like] sour bodies. 
TRANSLATION. CHAP. XIII. $13-21$.

13 Hold your peace, cease from me, that I may speak,

$\alpha$ anything.

$\beta$ against, in spite of, anything.

a infra xxix. 17; Numb.xi. 33 ; Ps. lxxviii. $30,31$.

b Judg, xii. 3; 1 Sam. xix. 5 ; xxviii. 21 ; Ps. cxix. 109.

$\gamma$ argue, plead.

c supra vi. 10; ix. 21; x. 7,15 ; infra xxiii.11,12; xxrii. 5,6 .

$i$ for a deliverance to me.

d supra viii. 13.

e infra xxiii. 7 ; Ps. i. 5 ; v. 5 .

$\varepsilon$ my word.

ee infra $\mathrm{xxiii.} 4$; Isa. xliii. 26.

$f$ supra ix. 28 ; $\mathrm{x} .7$; xxiii. 10.

g supra ix. 32 ; infra xxiii. 4-9; xxxiii. 5, 7 ; xxxriii. 3; xl. 2,7 .

$\zeta$ expire.

h supra vi. 11,12 ; vii. 7,21 ; x. 20 .

$\eta$ with.

$\theta$ from Thy face.

$\kappa$ from upon me, with me.

i supra ix, 34; infra xxxiii. 7.
And let come on me ${ }^{a}$ what may.

14 Aye, $\beta$ come what may, I will take my flesh in my teeth, ${ }^{a}$

And put my life in mine hand. ${ }^{b}$ *

15 Lo! He may slay me, yet, will I hope for $\mathrm{Him} ; \dagger$

But my ways I will $\gamma$ maintain before $\mathrm{Him}^{c}$

16 Yet, He should rather be $\delta$ my deliverance, Seeing the ${ }^{d}$ hypocrite cannot come before $\mathrm{Him}^{e}+$

17 Hiear, then, diligently $є$ my speech;

${ }^{1}$ And let my declaration come into your ears.

18 Behold now! I have ${ }^{e e}$ ordered my cause; I know that I shall be declared just. ${ }^{f}$

19 But, who is He, that will ${ }^{g}$ plead with me? For soon shall I hold my peace, and $\zeta$ die. ${ }^{h}$

20 Only two things, $O$ God, do not $\eta$ unto me, Then will I not hide myself $\theta$ from Thee!

$21 \$$ Withdraw Thine hand far $k$ from me, And let not Thy dread affright me ${ }^{i}$

1 Or, And my declaration with your ears.-Editor, 1862.

innocent, for the sake of flattering your Maker. Think ye that ye can escape the judgment of God if ye pervert the cause of the innocent, and at the same time insult Him with your flattery? Comp. supra iv. 19 ; vi. $21,24,27$; xiii. $4,7-11$; xix. 28, 29; Ps. lxxviii. 36; xii. 2, 3.-Editor, 1862.

* Two phrases expressing in Hebrew the risking of one's life.

$\dagger \mathrm{I}$ know my life is at His merey, yet I hope, that He will investigate my case and pronounce me innocent.

$\ddagger$ Indeed, I do not see how I risk my life by speaking the truth, on the contrary, as a lover of truth, He should be a help to me.

§ Job, having said, "Do кот do two things," we might expect a negative sentence here as in the next line, whereas we have an affirmative one. The reason seems to be that "Withdraw Thine hand" is really equivalent to some such negative sentence as, "Let not Thine hand be heavy upon me!" See Commentary.-Editor, 1862. 
TRANSLATION. CHAPS. XIII. 22-2S; XIV. $1-4$.

22 Then call Thou, and I will answer ${ }^{a}$; Or, I will speak, and answer 'Thou me ${ }^{b}$ !

a infra xiv. 15.

$b$ infra xxxiii. 5 ; $\mathrm{xxxviii.} 3 ; \mathrm{xl} .7$.

a How many [are there] to me?

$\beta$ make me to know. c supra vi. 24; x. 2 .

d supraiii. 23; Gen. iv. 5 ; Ps. cii. 2, \&c.

$\gamma$ for an enemy to Thee.

23 a How many are mine iniquities and sins?

My transgression, and my sin, $\beta$ make known unto me. ${ }^{c}$

24 Why shouldest Thou hide Thy face, ${ }^{d}$ And hold me $\gamma$ for Thine enemy ? ${ }^{e}$

25 Wilt Thou crush a driven leaf ${ }^{f}$ ?

Or, pursue dry stubble ${ }^{g}$ ?

26 That Thou writest bitter-things against me, And $\delta$ entailest on me the ${ }^{\epsilon}$ sins of my youth. ${ }^{b}$

$27 \zeta$ That Thou puttest my feet in the stocks, ${ }^{i}$ And watchest all my paths. ${ }^{k}$

On $\eta$ mine ankles, $\theta$ they $\dagger$ imprint themselves ';

28 And $\kappa$ these consume, like a rotten-thing, Like a garment $\lambda$ which the moth ${ }^{m}$ hath eaten.

\section{CHAPTER XIV.}

1 MaN, born of woman, ${ }^{n}$

${ }^{\mu}$ Few ${ }^{\circ}$ of days, and full of trouble, ${ }^{p}$

2 Like a ${ }^{q}$ flower cometh forth, and is cut down; Yea, he fleeth as the ${ }^{r}$ shadow, and ${ }^{\nu}$ abideth not.

3 Even upon such an one, ${ }^{\pi}$ lost Thou open Thine eyes?

And wilt Thou bring ne into judgment with Thee ${ }^{s}$ ?

$4 \mathrm{Oh}$, that a clean thing could come from an unclean ${ }^{t} !+$

e infra xvi. 9 ; xix.11.

$f$ Isa. xlii. 3 ; Hos. xiii. 3.

$g$ infir $\times$ xxi. $18 ;$ Ex. xv. 7 ; Isa. xli. 2 ; Nab. i. 10, \&c.

$\delta$ and shouldest make me to poysess.

$\varepsilon$ penalties of the sins of my boyhood, early youth.

$h$ Ps. xxv. 7.

$\zeta$ And that.

i infra xxxiii. 11; Jer. xx. 2 ; xxix. 26 ; Lam. iii. 7.

k supra vii. 12, 17, 15 ; x. 20 ; infre xir. 6,16 ; xxxi. 4 .

$\eta$ [the] roots of my tect.

$\theta$ it impresseth itself. $l 2$ Sam. iii. $31 ;$ Ps. ev. 18.

$\kappa$ it (i.e., each of my ankles) eonsumeth.

$\lambda$ [the] moth hath eaten it.

m Ps. xxxix. 11; Jas. v. 2.

$n$ infra xr. 14; xxv. 4; Matt.xi.11, \&c. $\mu$ short.

o supra x. 20.

$p$ Ps. xxxix. 5, 6, 11. Eceles. ii. 23.

$q$ Ps. ciii. 15; Isa. xl. $6-8$.

$r$ supra viii. 9 ; 1 Chron. xxix. 15; Ps. cii. 11.

$y$ standeth,endureth not.

$\pi$ hast Thou opened. $s$ Ps. exliii. 2.

$t$ supra xi. 4; infra xv. 11; xxv. 4;

* The object of this line is fully explained in the Commenxxxiii. 9. tary.

+ i.e., the stocks.

†.e., how can a man possibly be clean and perfect, whose parents were uncleau and imperfect beings? 
$\psi$ or, [there shall] not one.

a supra vii. 1; 2 Sam. vii. 12 ; Ps. $\operatorname{lnxxix}_{\text {. }}$ 47; Lam. iv. 18; John vii. 6.

$b$ infia xxi. 21. (1) made.

c infra xxxviii. 10, 11 ; Jer. v. 22 ; Acts xvii. 26.

d supra x. 20; Ps. xxxix. 13.

a from upon him.

e supra vii. 1, 2.

$\beta$ renew [its vigour]. f supra viii. 19; infra xix. 10 ; Ezek. xrii. $22-24$.

$\gamma$ cease.

o make, produce.

$\varepsilon$ bough.

$g$ Isa. xi. 1.

$\zeta$ and hath been ill.

h 2 Kings $x x .1$, \&c.

$\eta$ hath expired.

$\theta$ then where, $\delta \mathrm{c}$.

$\kappa$ gone away.

$\lambda$ river.

$i$ Isa. xix. 5, \&e.

$\mu$ But man, when he hath lain down, will not arise.

$v$ until not heavens.

k Ps. Ixxxix. 29, 36,

37 ; cii. 25,26 ;

Isa. xxxiv. 4 ; li.

6 ; lxv. 17, \&c.

l supra rii. 8, 9, 21 ; x. 21,22 ; infia ver. $14,20,22$; xx. 7-9; Ps. vi. 5; lxxxriii. 5, 10-12; Is. xxxviii. 18, 19; Eccles. iii. 19-22; vi. $3-6$; ix. $4-6$, 10 , \&e.

$\pi$ till [the] turning [away] of Thine anger.

m supra ix. 19. $\psi$ Not one will ever.

5 If his days are determined, ${ }^{a}$ If the ${ }^{b}$ number of his months $i s$ with Thee, ${ }^{*}$ If Thou hast ${ }^{\omega}$ set IIs ${ }^{c}$ bounds, that he cannot pass ;

6 Then, ${ }^{d}$ look away ${ }^{a}$ from him, that he may cease to suffer,

Till, as an hireling, he find pleasure in his last day. $e^{e}$

7 For the tree, indeed, there is hope,

Even though it be cut down, that it will again $\beta$ flourish, ${ }^{f}$

And its tender-branch not $\gamma$ fail.

8 'Though its root grow old in the earth, And its stock die in the ground;

9 Yet, through the scent of water, it may bud, And $\delta$ put forth $\epsilon$ boughs, as a young plant. ${ }^{g}$

10 But man, when he dieth, $\zeta$ after that he hath been sick; ${ }^{h}$

Yea man, when he $\eta$ perisheth- $\theta$ where is he?

11 The waters will have ${ }^{k}$ vanished from the sea, The ${ }^{\lambda}$ rivers have wasted, and dried up, ${ }^{i}$

$12 \mu$ And man still lie there, and not arise; $\dagger$

Yea, $\nu$ till the heavens be no more, ${ }^{k}$

Shall they not awake,

Nor be aroused from their sleep. ${ }^{l}$

$13 \mathrm{Oh}$, that in the grave Thou wouldest hide me!

Wouldest conceal me, ${ }^{*}$ till Thine anger turn aucay!

Wouldest appoint me a set-time, ${ }^{m}$ and then remember me!

14. When a man dieth, will he live again?

(But will this be so ?)

* i.e., is known only to Thyself.

+ i.e., the waters will first have failed from the sea, and the rivers luave wasted and dried up before man, after he hath lain down, will again arise-that is, he will nerer rise again. 


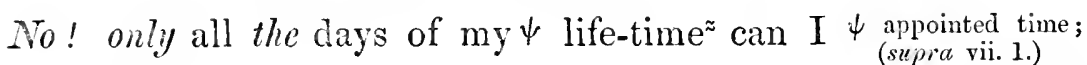
hope,
${ }^{1}$ (Only ${ }^{\omega}$ till my ${ }^{a}$ change * come),

15 That Thou mayest call, and I answer Thee;

That Thou mayest again yearn toward the work of Thine hands. ${ }^{b}$

16 (But now, Thon numberest my steps;

Dost Thou not watch over ${ }^{a} \mathrm{my}$ sins? $\dagger$

17 My transgression is sealed up in a bag, ${ }^{d}$ $\approx$ Isa. xxsriii. 18 , \&c. $\omega$ till [the] coming of my ehange.

a infra ver. 20 : Ps. cii. 26 ; 1 Cor. $x v$. 51 , Se.

b supra vii. $21 ; x .3$; infra xxxiv. 19; xxxrii. 7.

c supra xiii. 27 ; infre xxxi. 4; xxxiii. 11.

$a$ my sin.

d Hos. xiii. 12.

And mine iniquity Thou $\beta$ securest with a $\beta$ puttest a patch patch. $)^{e}+$

18 But surely a fallen mountain $\gamma$ wasteth, Yea, a rock $\delta$ may be removed from its place;

19 Yet, $\epsilon$ when the waters have worn away the stones to dust,

The soil of the earth will overflow with its afteragainst.

$e$ Deut. xxxii. 3t; Hag. i. 6; Ronn. ii. 5 .

$\gamma$ will fade.

$\hat{c}$ may move away.

$\varepsilon$ have [the] waters rubbed away, made dust. crops. \$

But the hope of frail-man Thou utterly destroyest. 20 Thou overpowerest him for ever, when that he is gone;

He ${ }^{f}$ changeth $\zeta$ his appearance, when 'Thou hast $f$ supra rer. 14; Ps. ${ }^{g}$ dismissed him. cii. $26 ; 1$ Cor. $x v$. 51, \&e.

21 His children $\eta$ may be numerous, but he will not know it ;

Or ${ }^{\theta}$ few in number, but he will not perceive them. ${ }^{\prime} \theta$ hor, mas. be broughr 2:2 Only, whilst upon him, will his flesh feel pain; Only, whilst $\kappa$ within him, will his ${ }^{i}$ spirit mourn. ${ }^{k}$

1 Or, Only till my change eome, his face.

y supre viii. 4.

$\eta$ or, may cume to

low.

l. supra r. 25.

N with, by.

isuria ini. 17.

$\lambda$ soul.

$k$ l's.xlii. 5,11; xliii. 5 .

15 Canst Thou eall and I answer Thee.

Canst Thou yearn towards the work of Thine hands.

$$
\text { -Editoi, } 180 \text { i2. }
$$

* i.e., change, transition from life to death.

+ i.e., so as not to overlook even the slightest fault.

$\ddagger$ i.e., Thou puttest a patch where the bag seems likely to give way.

\$ i.e., though the fallen mountain, the displaced rock, no longer exist as such, yet their substance, ground to powder by the inundation that overturned them, will be converted into such a fruitful soil as to yield even second crops. 
$a$ utter.

$\beta$ knowledge, thought, of wind, windy thoughts, airy notions.

a infra xvi. 3 ; Eeel. i. 17 ; ii. 11,17 , 26 ; iv. 6,16 .

乙) supra vi. 26 ; riii. 2 ; Isa. xli. 29.

c Jer. rii. 8.

$\gamma$ breakest down, sappest, minest.

d supra iv. 6 ; Ps. xxxvi. 1; Rom. iii. 18, \&c.

o infia ver. 12, 13 ; xxii. 13, 14, \&e.

$f$ supraix. 20 ; Prov. vi. 2 ; xiii. 3 ; Matt. xii. 36,37 ; Lnke xix. 22.

$g 2$ Sam. i. 16.

o born.

$h$ infia xxxviii. 4.

$i$ Prov. viii. 25.

$k$ Isa. xl. 13; Rom. xi. 34 .

$\varepsilon$ So that thon shouldest take away.

l. supra xii. 2 ; infra xxxii. 13.

m supra xii. 3 ; siii. 2.

$n 1$ Sam. xii. 2.

o supra xii.12; infra xxxii. 7,9 .

s more.

ל\% lit., consolations of God, i.e., migh$t_{y}$, powerful, potent, strong, consolations.

oo Heb. vi. 18.

$\eta$ less than thee.

$\theta$ a word [spoken] gently.

$p$ supra xii. 4 ; xiii.

4, $7-10$; xvi. 20. \&c.

$\kappa$ take thee away.

$q$ infraxriii. 4 ; xxii. 13,14 ; хxхі. 26 , 27.

$r$ infra ver. $25,26$.

$\lambda$ and shouldest eause to go forth.

s supra xiv. 1; infra xxv. 4; Matt. xi. 11, \&e.

$t$ supra iv. 18.

\section{CHAPTER XV.}

1 Then answered Eliphaz the Temanite and said,

2 Should a wise-man ${ }^{a}$ give vent to $\beta$ thoughts of wind, ${ }^{a}$

And with the east-wind fill his belly ${ }^{b}$ ?

3 To reason on a matter, which cannot profit, And in words, wherewith one can do no good ${ }^{c}$.

4. Nay more, thou $\gamma$ destroyest the ${ }^{d}$ fear of the Almighty,

And takest away prayer before God ${ }^{e}{ }^{*}$

5 Surely, thine own mouth teacheth thine iniquity, Though thou choosest the tongue of the crafty.

6 Thine own mouth doth condemn thee ${ }^{f}$, and not $\mathrm{I}$, And thine own lips testify against thee ${ }^{g}$.

7 Wast thou, O man, the first $\delta$ produced ${ }^{h}$ ?

Or wast thou formed before the hills ${ }^{i}$ ?

8 Didst thou overhear the secret counsel of God ${ }^{k}$, $\epsilon$ So as to take away all wisdom to thyself ${ }^{l}$ ?

9 What dost thou know, and we know not?

Or thou understand, and it is not with us ${ }^{m}$ ?

10 Both the "gray-headed and the very-aged aie among us ${ }^{\circ}$,

$\zeta$ Fuller of days than thy father.

11 Are our $\zeta \zeta^{\circ o}$ strong consolations $\eta$ too little for thee? But, was there ${ }^{\theta}$ a gentle word with thee ${ }^{p}$ ? $\dagger$

12 Why doth thine heart $k$ hurry thee away?

And thine eyes, what wink they at ${ }^{q}$,

13 That thou turnest thy spirit against God ${ }^{r}$,

$\lambda$ And ventest such speeches from thy mouth?

14 What is frail-man, that he should be pure?

Or he, of woman born's, that he should be justs ?

15 Behold, in His Holy-ones He trusteth not ${ }^{t}$,

* Other people, when suffering as thou now art, will be induced by thy example to murmur against God, instead of praying to Him.

$\dagger$ i.e., Our consolations being strong, were naturally couched in somewhat strong language-but, was thy language more measured ? Was there a gentle word with thee? 
And the heavens are not pure in His eyes ${ }^{a}$ !

$16{ }^{b} \mathrm{Far}$ less, that ${ }^{\circ}$ abominable and filthy being, Man, ${ }^{a}$ which drinketh in iniquity like water ${ }^{d}$.

17 I will shew thee; hearken unto me; And, both that, which I have seen, will I declare,

18 And that, which wise-men relate ( $\beta$ And hide not ought), as told them $\beta$; by their fathers ${ }^{e}$.

19 (To them alone the land was given, Nor passed a stranger in their midst. ${ }^{*}$ )

(What I have seen and heard is,)

20 That $\gamma$ all his days the wicked doth torment himself $f$,

And that $\gamma \gamma$ all the years, $\delta$ reserved for the tyrant,

21 A voice of $\epsilon$ terror $^{g}$ is in his ears, crying out that, Even in ${ }^{h}$ peace, the spoiler will come on $\mathrm{him}^{i}$.

$22 \mathrm{He}$ believeth not $\zeta$ that he will return out of darkness,

Seeing he is $\$ \zeta$ watched for the sword ${ }^{k} \dagger$

23 If he doth stir abroad, it is for bread ${ }^{l}$, saying; "Where is it?"

For he knoweth, that the day of darkness is ready at his hand.

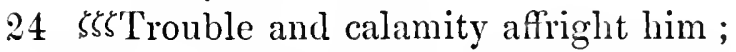

Like a king, $\$$ will it overpower him; he is $\eta$ reserved for its ball ${ }^{m} . \$$

25 Because he stretched out his hand against Gorl, And strengthened himself against the Al-

$$
\text { mighty }{ }^{n}
$$

$26{ }^{\theta}$ He ran against Him, with lofty neck,

$*$ With the thick bosses of his shield-

* i.e., they were not disturbed by foreign invasion, and consequently were able to watch the course of events.

t i.e., he thinks his enemies lie in wait for him, realy to slay him with the sword.-Editor, 1862. \&e.

$\ddagger$ i.e., like a king, whose power is irresistible, will it (calamity)

\$ i.e., he is destined to be tossed about by calamity like a ball. Comp. Isa. xxii. 18, "He will surely violently turn and toss thee like a ball." a infra xxv. 5.

l supra iv. 17, 19; хіт. 3,4 .

$c$ Ps.xiv. 1, 3 ; Nah. iii. 6 ; 1 Pet. iii. 21.

$a$ drinking in.

d infra xxsiv. 7.

$\beta$ and have not hid, concealed.

$\beta \beta$ from.

e supra viii. 8,10 ; Ps. Ixxviii. 3, 4t; Isa. xxxviii. 19, Sc. $\gamma$ all [the] days of [the] wicked, be.

finfira ver. $35 ; \mathrm{x} x$. 12-16; Ps. vii. 15,16 ; xxxrii. 14 , 15; Prov. xxri. 27 ; Eccles x. 8 ; Jer. $\mathrm{xx} .4$.

$\gamma \gamma$ [the] number of [the] sears.

$\delta$ [whieh] are resurved.

$\varepsilon$ terrors.

ginfra xx. 25; Dent. xxviii. 66,67 ; Ps. Ixxiii. 19.

$h$ Jer. iv. 10.

$i$ Jer, vi. 26 ; хт. 8.

$\zeta$ to return.

G\% lain in wait forfor [the] sword, that he may be a prey to [the] sword; or, seeing that he [holdeth himself] destined to [the] sword (Ben-Zer).

$k$ Jer. vi. $25 ; A$ mos ix. 1 .

$l$ Lam. i. 11 ; iv. 4 ; จ. 9.

५५. Or, distress and anguish.

$\eta$ reads for the [i.e., a] ball, i.e., about to become its ball. $m$ Isa. xxii. 18.

$n$ Numb, xiv. 9; Josh. xxii. 18 ; Kings xix. 22, Se; 1) an. จ. 23 , de.

$\theta$ He used to run.

o supra ix. 1 ; Exod. xxxii. 9 ; 2 Chron. xxxri. 13; Jer. xrii. 23.

* with [the] thickness of [the $]$ bosses of his shields. 
27 Because he covered his face with his fatness,

$\omega$ flank.

z Deut. xxxi. 20; xxxii. 15 ; Ps.xrii. 10 ; Ixxiii. 7 ; Jer. v. 28, sc.

a they could not dwell in them.

a Ps. ix. 6; 2 Kings xis. 25.

b supra จ. 5; riii. 15; infia xx. 15, 18, 26, 28; sxvii. 16,17 .

$\beta$ their achievements $\beta \beta$ extend, spread.

$\gamma$ turn away from.

c supra xi. 20; Ps. cxlii. 4, 5, \&c.

$\delta$ tender-branch, sucker.

d infra xviii. 16; Ps. $\operatorname{lxxx}, 15,16$.

$\varepsilon$ turn away.

es breath.

e supra ix. 23 ; xxi. 13, 23 ; Ps. civ. 29.

$\zeta$ hath been led astray.

$f$ Isa. lix. 4, sc.

$\eta$ his exchange.

$\theta$ his [last] day.

$\boldsymbol{h}$ shall be fulfilled.

$g$ supra viii. 16.

$h$ Isa. v. 2, 4; Jer. ii. 21.

$\lambda$ congregation of.

$\mu$ hath consumed.

$\nu$ to conceire.

$\pi$ and to bring forth.

$i$ Ps. vii. 14 ; Isa. lix. 4 , \&c.

$\rho$ their belly (inward-parts).

$k$ supra ver. 20.

$l$ supra xii. 3.

$\sigma$ comforters of trou. ble.

$\sigma \sigma$ or, windy words. m supra xv. 2, and references there.

$\tau$ if your person[s] [were] instead ot my person.

$\phi$ join [myself] to jou.
And made him rolls of fat upon his ${ }^{\omega}$ flanks ${ }^{z}$;

28 And dwelt in desolate cities,

In houses, a which none could inhabit,

Which were destined by him to become heaps ${ }^{a}$.

29 No, he shall not be rich, nor shall his wealth endure ${ }^{b}$;

Nor shall $\beta$ his achievements $\beta \beta$ be spread abroad in the earth.

30 He shall not $\gamma$ escape $^{c}$ out of darkness;

His $\delta$ branches $^{d}$ shall a flame dry up;

And he shall $\epsilon$ depart with one $\epsilon$ gasp of his mouthe .

31 Let not him, that $\zeta$ is led astray, * put his trust in vanity ${ }^{f}$,

For vanity shall be $\eta$ his reward;

32 Before $\theta$ his time it $\dagger{ }^{\kappa}$ shall come to an end, So that his branch will not be green. ${ }^{g}$

33 He shall shake off his unripe-grape as the vine ${ }^{h}$, And cast, like the olive, his blossom.

$3 t$ For the $\lambda$ houschold of the hypocrite shall be cheerless ;

And fire ${ }^{\mu}$ shall consume the tents of bribery.

35 'He conceived evil, $\pi$ and so, shall bring forth misery ${ }^{i}$;

Yea, $\rho$ his breast prepareth his own deceit ${ }^{k}$.

\section{CHAPTER XVI.}

1 Then answered Job, and said,

2 I have heard many such things as these ${ }^{l}$;

$\sigma$ Troublesome comforters are ye all!

3 Will there be an end to $\sigma \sigma$ words of wind ${ }^{m}$ ?

Or what emboldeneth thee, that thou shouldest answer?

4 Should I too speak like you, $\tau$ If ye were in my place?

No! I would $\phi$ join yon with my words,

* i.e., by his evil propensities.

t i.e., his reward. 
And $\omega$ bow mine head before you ${ }^{a}$.*

5 I would either strengthen you with my mouth,

(w) move at you with my head.

Or my moaning would restrain my lips. $\dagger$

$6{ }^{b}$ If I speak, my pain is not $\beta$ assuaged, And if I $\gamma$ forbear, $\delta$ how much of it departeth ?

7 Surely now, He $\ddagger$ hath wearied me out; Thou hast $\epsilon$ destroyed all $\zeta$ mine household ${ }^{c}$.

a supra ii. 11.

8 And that Thou hast filled me with wrinkles ${ }^{d}$, is become a witness ${ }^{e}, j$

Yea, $\mathrm{my}^{d}$ leanness $\eta$ is risen up against me; it beareth witness ${ }^{e}$ to my face. $\|$

$b$ infio $\alpha$ xxii. 18 20 ; Ps. xxxix. $1-3$.

$\beta$ restrained.

$\gamma$ cease.

$\delta$ what.

$\varepsilon$ laid waste.

$\zeta$ my company.

c supra i. $14-19$.

d infira xix. $20 ; \times x x$. 30.

e suprax. $17 ;$ infra xix. 5.

$\eta$ hath risen.

$9{ }^{f} \mathrm{In}$ His wrath hath $\mathrm{He}^{g}$ torn $m e,{ }^{\theta}$ and shewed $\underset{g}{f}$ infos. vii. 1.4. His hatred of $\mathrm{me}^{h}$;

He hath gnashed against me with His teeth ${ }^{i}$;

${ }^{1}$ As one that is ${ }^{k}$ mine adversary, sharpeneth $\mathrm{He}$ His eyes against me.

10 Men, too, have opened, wide their mouth against $\mathrm{me}^{l}$;

$\theta$ and hated me.

$h$ supre xiii. 24 ; infra xix. 11.

$i$ Ps. $x \times x$. 16 ; xxxrii. 12, \&c.

kinfia xxrii. 7 ; Lam. ii. 4,5 .

$l$ Ps. xxii. 13.

They have ${ }^{\kappa}$ contemptuously smitten my cheeks ${ }^{m}$; $\kappa \kappa$ They have gathered themselves together against me.

11 God delivereth me up to the iniquitous ", And, by the hands of the wicked, overthroweth me.

12 I was at ${ }^{\circ}$ ease, and He brake me in pieces $^{p}$;

Yea, He took hold of my neck, and dashed me to atoms ${ }^{q}$,

And set me up ${ }^{\lambda}$ for This mark ${ }^{r}$.

13 His $^{s}$ archers compass me round about;

$\mu$ One cleaveth my reins, and spareth not;

${ }^{\nu}$ Another poureth out my ${ }^{t}$ gall upon the earth.

1 Or, Minc Adversary sharpencth His eyes against me. Or, Mine Adrersary-He sharpeneth, \&e.-Editor, 1862.

* Would express my sympathy for you by a nod. But see Append.

$\kappa$ with contempt.

m 1 Kings xxii. 24; Luke ri. 29 , die.

$\kappa \kappa$ they gather themselves.

$n$ infra xxx. 2-16.

$\dagger$ i.e., My grief would be so great as to choke my utterance.

$\ddagger$ i.e., Grod.

\$i.e., against me.

|| The present emaciated state of my body is regarded by my friends as a proof of my guilt.

sırpa iii. 26 ; infra xxix. 2-25.

p supra ix. 17, 18 ; infir $t$ xix. $20 ; \mathrm{xxx}$. $17-19,30 ;$ Ps. 1. 22 ; Lam. iii. 11.

q Exod. xv. 6; Ps. ii. 9.

$\lambda$ for a mark to him. $r$ supra vii. 20; Lam. iii. 12, 13.

s supra ri. $4 ; \mathrm{Ps}$. xxтii. 2.

$\mu$ he cleaveth.

$\nu$ he poureth out.

$t$ Pror. vii. 23 ; Lam. ii. 11 . 
to be breacheth.

$\beta$ breach upon [the] face of breacli.

a infia xus. 14.

i he rumneth.

6 Gen. sxarii. 34, de.

iscab.

c supra rer. 10 ; is. 31; infira xix. 13-19; xxx. 1, 9-14, sc.; Ps. rii. 5; xxii. 15.

\& from, through. ce inf'rasrii. 7 ; Lam. ․ 17.

d supra si. 14 , fe.

e supra ri. 30 ; is. 21; xi. 4; xxiii. 10-12; xธтіi. $4-6$.

$f$ Gen. ir. 11 ; Isa. xxri. 21.

$\because$ not place.

$g$ infia xxxir. 2S; Gen. ir. 10; 1 Sam. г. 12; ix. 16, Se. hespra $\mathbf{x} .7$.

$\eta$ in the heights.

i supra r. 2; riii. 2 ; xi. 2,3 ; xii. 4 ; infra srii. 2 , se.

$\theta$ hath......dropped.

k Ps.ri. 6-8; xxxis. 12; Lam. i. 16; iii. 48,49 .

$l$ supra ix. 19, $32-35$; xiii. 3 , 15, 16, 1S-2; xir. 13 ; infira sis. 26,27; xxiii. 3-7; xxxi. 35-37.

$\kappa$ rears of number. m supra rii. 9, 10; x. 21 ; хіг. 12; xx. 9, \&c.

$\lambda$ spoiled, destrosed. $n$ infra xix. $1 \bar{r}$.

o supra rii. 6 ; is. 25,26 ; infrasss. 16,27 .
$14 \omega$ This one breacheth me with $\beta$ breach upon breach ; ${ }^{a}$

$\gamma$ That one runneth upon me like a mighty man.

15 I have sewed ${ }^{b}$ sackcloth upon $m y^{\delta}$ sores, And defiled $m y^{\circ}$ horn $*$ in the dust.

$16 \mathrm{M} y$ face is red $\epsilon$ with weeping, And on my eyelids is the shadow-of-death ; ${ }^{c} \dagger$

17 Not for any violence in mine hands; ${ }^{d}$

My prayer also hath been pure. ${ }^{e} \ddagger$

is $O$ earth, corer not my blood, ${ }^{f}$

And let there be $₫$ no space for my cry $!^{g}$ j

19 Even now, behold, in heaven is my witness, And my testimony $\eta$ on high.

$20 \mathrm{My}{ }^{i}$ mockers-my friends !

To God $\theta$ doth mine eye drop tears, ${ }^{k}$

21 That one might 'plead for a man with God, As every son of man should plead for his fellow.

$2:$ For $\kappa$ a few years will come,

And I shall go the way, whence I shall not return. ${ }^{m}$

\section{CHAPTER XVII.}

1 Mr breath is become ${ }^{\lambda}$ corrupt;

$M y^{\circ}$ days are extinct;

* i.e., my dignity and glory.

t The expression, shadow of death, which occurs so frequently in this book (e.g., iii. 5 ; x. 21 ; xii. 22 ; xxiv. 17; xxviii. 3 ; xxxir. 22, \&c.), of course means deep darkness, darkness like that of the under-world. According to our present usage of the rords shadow and shade, death-shade would, I think, be more correct, but it has a less agreeable sound. In the Auth. Vers., however, shadow, which is now generally taken to mean "the image of a body produced by its interception of light," is commonly used in the sense of shade, the formless obscurity produced by the same cause.-Comp. supra rii. 2 ; Isa. iv. 6 ; $\mathrm{xxr} .4,8$ c.-Editor, 1862.

$\ddagger$ i.e, was ever made with sincerity of heart.

$\S$ i.e., let my cry extend beyond the limits of space. 
They are grares to me.*

2 Are there not ${ }^{\omega}$ mockers ${ }^{a}$ with me?

Yea, $\beta$ on their ${ }^{b}$ provocation mine eye dwelleth continually.

$3 \gamma^{1}$ Order it thus, I pray Thee; be Thou surety for me with Thyself;

$\delta$ Who is there else, that will ${ }^{c}$ strike hands for me?

4 (For THEIR heart $\dagger$ hast Thou hid from understanding, ${ }^{d}$

Seeing that Thou wouldest not exalt them. ${ }^{e}+$ )

[But if one did come forward and offer himself as my bail]

5 e "Friends," $f$ he would say, "should bear their part;"

But for this even the eyes of his children would $\zeta$ look in vain. ${ }^{g}$

6 Then would he set me up $\eta$ as an ${ }^{g g}$ example to nations,

And I should be as a tabret in former times. $\S$

7 Seeing that mine eye hath become $\operatorname{dim},{ }^{h}$ by reason of vexation,

And my limbs are all of them as $\theta$ a shadow. ${ }^{i}$

8 The upright would be amazed at this,

And the innocent bestir himself against the hypocrite.

9 Yea, the just would ${ }^{k}$ hold fast his way, ${ }^{k}$

And the pure of hands $\lambda$ increase in strength.

10 But, despite them all, ye would $\mu$ come on again; || nay, come ye even now,

1 Perhaps, Put forth now Thine hand; or, Give now heed unto me. See

(1) mockeries.

a supra xii. 4 ; xri.

$20, \& c$.

$\beta$ on their provoking.

b supra viii. 2 ; xi. 2 ,

3 ; xv. 2-13; in-

fra xix. 2, \&c.

y put.

$\delta$ who [is] he [that]

will be struck (i.e., strike hands) for my hand?

c Prov. vi. 1, \&c.

d supra vi. 6,7 ;

xii. 3 ; xiii. 4,5 ;

infra xxxii. 3,12 , 13.

e supra vi. 15-27;

xii. 4,5 ; xvi. 20 ;

xvii. 2 ; xix. 14 ,

$19,21,22,28,29$;

xxvi. $2-4$.

$\epsilon$ friends...... for a share.

$f$ supra vi. 14, 15, 21 ; xiii. 4 ; $\mathbf{x}$ i. 2 ; infia xix. 14, 19, 21 ; xxvi. 2; Jer. ix. 4,5 ; Mic. vii. 5 .

$\zeta$ fail, be consumed [with longing].

$g$ supraxi. 20 ; infra xix. 27 ; xxxi. 16 ; Ps. Ixix. 3, \&c.

$\eta$ for [the] comparing of nations.

$q g 2$ Pet. ii. 6.

$h$ Lam. v. 17.

$\theta$ the shadow.

i supra xvi. 8 ; infra xix. 20 ; xxxiii. 21.

$\kappa$ take hold of, seize, grasp.

$k$ supra ii. 9 ; infra xxvii. 6.

$\lambda$ add, increase, strength, firmness. $\mu$ return.

l supra vi. 29. Appendix.-Editor, 1S62.

* They are as joyless, yen, as loathsome as the grare.

$\dagger$ The heart of these my friends.

$\ddagger$ Inspire them with the exalted and gracious feelings of true friendship.

\$ I should give the alarm to men, and render them more chary of bestowing their confidence upon their friends.

$\|$ In spite of the amazement of the upright at your conduct, \&c., ye, my friends, would again bring forward your worthless, yet insulting, arguments. 
For I shall not find among you one wise-man! a supra vii. 6 ; ix. 11 My days have ${ }^{a}$ passed away, my plans have been broken off-

$\omega$ possessions.

$\beta$ or, before.

b supra $\nabla .19-26$; viii. $16-22$; xi. 15-19; Isa. $\nabla$. 20.

c supra iii. 20-22; vi. 9 ; vii. 15,16 ; ix. 21 ; x. 1,18 ; xiv. 13.

$\gamma$ wait.

$\delta$ my conches.

$\varepsilon$ I have called, I call, I would call, cry.

d infra xxxiv. 1S; 1 Kings xiii. 30 ; Prov. vii. 4 ; Jer. ii. 27 ; iii. 4,19 ; xxii. 18.

e supra vi. 11; xiii. 15 ; xiv. 19 ; infra xix. 10.

$\zeta$ limbs of [the] grave.

$f$ infra xviii. 13.

$\eta$ on [the] dust.

$\theta$ rest, quiet.

$g$ supra iii. 13, 14, 17-19; 2 Sam. vii. 12, \&c.

$\kappa$ till when.

$h$ supra viii. 2.

$\lambda$ put ends to words.

i supra xiii. 5, 13 ; xvi. 3 ; xvii. 4; infra xix. 2 ; xxi. 2,3 .

$k$ infra xxxiv. 4 .

$\mu$ as the beast.

$l$ Ps. lxxiii. 22 ; xxxii. 9 ; xlix. 12 , 20 ; Eccles. iii. 18, 19.

m supra xvii. 2, 4$8,9,10,12$; supra vi. 15-25; xii. 4 , 5 ; xiii. 4, 7-12; xvi. 20 ; xix. 13 , $14,19,22,2 \mathrm{~S}, 29$; xxi. $5,6,27,34$; xxvi. 2-4. Comp. also supra xvi. 10 , 11.
The w treasures of mine heart.

12 Night would they* make day,

Light to be at hand, $\beta$ in the face of darkness. ${ }^{b}$

13 Truly, $I^{c} \gamma$ long for the grave to be mine house, Even for the time, when in the darkness I shall have spread my $\delta$ couch.

14 To corruption I would $\epsilon$ cry, "Thou art my father!"

"O my mother!" and "O my sister!" to the worm. ${ }^{d}$

15 For where is now my ${ }^{e}$ hope?

Yea, my hope, who will see it fulfilled?

$16^{1}$ These Slimbs, destined to the grave ${ }^{f}$-let them go down!

Verily, altogether $\eta$ in the dust is ${ }^{\theta}$ peace $^{g}$.

\section{CHAPTER XVIII.}

1 Then answered Bildad the Shuhite, and said:

$2^{2}$ kHow long will ye speak such things ${ }^{h}$ ?

Ye should $\lambda$ make an end of words ${ }^{i}$;

Ye should consider ${ }^{k}$ __ and after, let us speak.

3 Wherefore are we counted $\mu$ as beasts ${ }^{l}$ ?

And why are we unclean in your eyes ${ }^{m}$ ? $\ddagger$

1 Or, ye limbs, destined to the grave, may ye go down, or, perhaps, go down; for the fut. is sometimes nearly equivalent to an imper. See note in

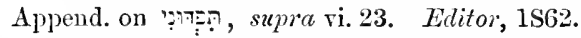

2 Or, perhaps, How long will it be ere ye make an end of words? or, till ye have (lit., shall have) made an end of words? See Append. Editor, 1862.

* These pretended friends of mine endeavour to persuade me that light (happiness) is about to shine upon me, although they clearly see that the dirkness (calamity) which envelopes me is constantly becoming deeper and deeper. Editor, 1862.

$\uparrow$ Comp. Chap. viii. 2.

+ In thine eyes, Job, and those of the philosophers thou representest. 
4. $\mathrm{O}$ thou, that art as one tearing himself in his anger ${ }^{a}$,

Because of thee must the earth be $\psi$ forsaken, And the ${ }^{b}$ Rock remove out of His place ${ }^{c}$ ? *

5 Yes, the light of the wicked sHaLL be put out ${ }^{d}$; And the $\omega$ blaze of his fire shall Noт shine ${ }^{e}+\dagger$

6 Daylight ${ }^{\beta}$ shall become darkness ${ }^{f}$ in his tent, Yea, his ${ }^{g}$ lamp over him shall be put out.

$7 \gamma$ His mighty strides shall be straitened ${ }^{k}$, And his own counsel cast him keadlong .

8 For he was let loose with a net upon his feet; $\ddagger$ Yea, he walketh upon network ${ }^{k}$.

9 The ${ }^{l}$ snare shall take hold upon his heel,

1 The trap shall prevail against him.

$10 \delta$ The noose lieth hid for him on the ground,

$\epsilon$ And the gin upon the path ${ }^{m}$.

$11 \zeta$ On every side " terrors $\eta$ shall affright him ; Yea, ${ }^{\theta}$ at his heels, shall they ${ }^{*}$ chase him all about.

$12{ }^{\lambda} \mathrm{His}^{*}$ first-born shall be famished ${ }^{p}$, And destruction shall be ready at his side;

13 He shall $\mu$ gnaw his body's limbs ${ }^{2}-$

$Y e a$, he shall $\mu$ gnaw his limbs - that $\nu$ first-born, doomed to death ${ }^{r}$.

14. His ${ }^{s}$ confidence $\$$ shall be $\pi$ uprooted from his tent ;

Yea, it shall $\rho$ bring him to the king of terrors '.

1 Or, The trap shall seize upon him. Scc Append. Editor, 1862.

* Must we, to please thee, in accordance with thy fancy that thou art very hardly treated, regard the world as deserted by its supreme Ruler? See infra xxii. 11-14, and comp. supr $\ell$ xiv. 18.

+ He repeats here with emphasis what he had before asserted (in Chap. viii).

a supra xvi. 9.

$\psi$ left.

6 Deut. xxxii. 4, 15, $18,30,31,37$; Ps. xviii. 2, 31,46; xix. 14 ; xxviii. 1 ; xxxi. 2, 3 ; xlii. 9 ; lxii. 2 , \&c., \&c.

c supra vi. $24,29,30$; vii. 12 ; ix. $15-$ 26 ; x. $2,3-7,15$; xii. 6 ; xvi. 17. Comp. supraxr.4, 12 ; infra xxii. 11 -14 ; alsoxiv. 18. d sitpra v. 14; xr. 22, 23,30 ; xx. 26; Prov. xiii. 9 ; xxiv. 20 ; supra xi. 17. $\omega$ or, flame.

e supra iv. 8-11; v. $3-5,12-14$; viii. $11-15$; $x i$. 20 ; xv. 20-35; xx. 4-29; xxii. 19,20 ; xxvii. 13 -23. Comp. also ix. 23,24 ; xii. 6 ; xxi. $7-15,17,18$, 23, 24.

$\beta$ hath become dark. $f \sec (d)$ and $(e)$. $g$ infia xxix. 3 , and see $(d)$ and $(e)$.

$\gamma$ [the] steps of his niglit.

$h$ sup $)^{\circ} a$ iii. 23 ; xiii. 27 ; Ps. xviii. 36 ; l'rov. ir.12; Lam. iii. 7,9 .

i supra v. 13; Ps. vii. 15 ; is. 15 , \&c.

k. supra viii. 14, 15; infia $\mathrm{xx}$ 5, 8 ; xxrii. 18, 21, \&e.; 1's. xxxvii. 10; Prov. ri. 15, \&e.

l supra v. 5.

$\hat{c}$ his noose [is] hid on (or, in) the ground. $\varepsilon$ and his gin, fe. m Ps.cxl. 5; ix. 15; Gen. xlix. 17, \&c.

$\zeta$ round about.

$n$ ver. 14 ; supra $\mathrm{xv}$. 21,24 ; infraxxvii. 20 ; xxx. 15.

$\ddagger$ i.e., though he was a free agent, yet there was a net about $\eta$ hare atlighted. his feet ready to entangle him, if he chose to leave the path of $\theta$ at his feet. rectitude.

$\S$ i.e., the wicked man's confidence.

$\lambda$ [the beginning] of his might.

o Exod. ir. $23 ;$ xi. 5 ; xii. 12, 29; Josh. vi. 26; 1 Kings xvi. 34 ; Mic. vi. 7. p supra xv. 23; Iam. ii. 11, 12, 19, 20, \&c. $\quad \mu$ eat, devour. $\quad q$ Isa. xlix. 26; 2 Kings ri. 28, 29. $\quad v$ firstborn of death. $r$ supra xvii. 16 ; comp. Isa. xir. $30 . \quad s$ supra riii. $11 . \quad \pi$ broken away. $\rho$ make him to step. $\quad t$ supra xv. 21 ; infra xx. 25; xxrii. 20; xxx. 15; 1's. lxxiii. 19, Se.

F $\quad \mathrm{F} \stackrel{2}{2}$ 
$a$ it (i.e., every one of the terrors).

$\beta$ without [its being] to him.

a infra xx. 19.

$b$ Gen. xix. 24 ; Ps. xi. 6.

c Amos ii. 9.

d supra $\mathrm{x} \nabla .30,32,33$.

e infra $\times x .9$; Deut. xxxii. $26 ; 2 \mathrm{Sam}$. xviii. 18; Ps.xxxiv. 16 ; cix. 15 ; Isa. xxvi.14; Jer.xi.19. $\gamma$ hath perished.

$f^{\prime}$ infra xxx. 8 ; 2 Sam. xiv. 7 ; Ps. ix. 5, \&c.

$\delta$ [shall be] to him. $\varepsilon$ on the faee of.

$\zeta$ they shall thrust him.

$g$ supra vers. 5,6 and references there.

$\eta$ they shall remove him, or cause him to wander, flee.

$\theta$ [shall there be] to him.

h supra v. 4; Isa. xiv. 22 ; Ps.exxvii. $3-5$; cxxviii. 3,6 . i infra xx. 26 ; Jer. xi. $22,23$.

$\kappa$ [the] posterior, later, ones.

$\lambda$ have been amazed. $\mu$ [last]day, end, fate.

$k$ supra xiv. 6 ; $\mathbf{x v}$. 32 , \&c.

$\nu$ [the] anterior, earlier, ones.

$\pi$ took hold of horror.

$l$ infra xxi. 6 ; Ps. exix. 53.

$\rho$ or, knoweth not.

m supra viii.22; infra xx. 29, \&c. See $s u$ pra ver. 5 note $(e)$. $\sigma$ till when.

n supra vi. 26 ; гii. 3 ; xiii. $4,5,7$; xvi. $2,3,20$; xvii. 2 ; infira xxi. 3, 34; xxvi.2-4. Comp. also supra viii. 2 ; xi. 2 ; $x \nabla .2,3$.

$\tau$ This.

o Gen. xxxi. 7, 41 ; Numb. xiv. 22 ; Zech. viii. 23.

$\phi$ do ye put me to the blush.

$\chi$ ye should behave.

p supra xriii. 5-21; xv. 2-13, \&c. Comp. supra xii. 4 ; xvi. 20 ; xrii. $2 . \psi \psi$ have I indeed erred. $\omega$ my error. aa i.e., the truth, fact, is, ye, \&e. $\beta \beta$ over me. $\gamma \gamma$ would plead my reproaeh, de. gradation, disgrace, against me. $q$ supra iv. 6-8; x. 17; xi. 14, 15 ; xvi. 8; infra xxii. 23 , \&c.

\section{CHAPTER XIX.}

1 Then Job answered, and said:

$2 \sigma$ How long will ye vex my soul, And crush me with words ${ }^{n}$ ?

$3 \tau{ }^{\tau}$ These $^{\circ}$ ten times $\phi$ have ye put me to the blush; Are ye not ashamed $x$ to behave thus impudently to $\mathrm{me}^{p}$ ?

4 And yet, $\psi$ if indeed I have erred, With myself will abide $\omega$ the penalty of mine error.

5 But aa truly ye would magnify yourselves $\beta \beta$ above me,

And $\gamma \gamma$ would bring my disgrace as an argument against me ${ }^{q}$.

* i.e., terrors.

† but taken away by violence from its rightful owner. 
6 Know then, that God hath $\omega^{\omega}$ wronged me ${ }^{a}$,

And $\beta$ cast His net around me.
7 Behold! I I ${ }^{b}$ cry out, "Wro ix. 17, 22;
xxvii. 2 , \&c. $\gamma$ heard ;

I cry aloud, but there is no justice ${ }^{c}$. to go arouud upon me. $b$ infra $\mathrm{xxx} .20$; Lam. iii. 8 , \&c.

c supra vi. 10, 29,30;

$8 \mathrm{My}$ way hath $\mathrm{He}^{d}$ hedged up, that I cannot pass,

And upon my paths He setteth darkness ${ }^{e}$.

$9 \mathrm{My}$ glory He hath stripped from off me, And $\delta$ removed the ${ }^{\epsilon}$ crown $^{f}$ from mine head ${ }^{g}$.

10 He breaketh me down on every side, so that I $\zeta$ pass away ;

And mine ${ }^{h}$ hope hath He removed $\eta$ like a tree ${ }^{i}$.

11 For, He hath kindled His wrath against me, And counterl me unto $\mathrm{Him}$ as one of His adversaries ${ }^{k}$.

$12 \mathrm{His}^{\prime}$ troops come on together, And $\theta$ raise up their way against $\mathrm{me}^{m}$, And encamp round about my tent.

$13 \mathrm{My}{ }^{n}$ brethren hath $\mathrm{He}^{o}$ put far ${ }^{\kappa}$ from me,

$\lambda$ And they, that know me, verily are estranged

from me.

$14 \mu \mathrm{My}$ kinsfolk $\nu$ have failed me, And $\pi$ mine ${ }^{p}$ acquaintance have forgotten me.

15 The $\rho$ dwellers in mine house, yea, mine own maids, account me for a stranger ${ }^{q}$;

I am become an ${ }^{q q}$ alien in their eyes.

$16 \sigma$ I call to my servant, but he will not answer;

With my own mouth must I entreat him.

$17 \mathrm{My}{ }^{r}$ breath is become $\tau$ offensive to my wife, And so were $\phi \mathrm{my}$ caresses to $x \mathrm{my}$ children.*

18 Yea, $\psi^{s}$ little-children ${ }^{\omega}$ despise me ;

* If I had any. See Comment.

ix. $17,21,22,28$,
$30,31: x .3,6,7$

15 ; xii. 6 ; xiii. 15 ;

xiv. 16,17 ; xvi.17;

infra ver. 29 ; xxiii.

$10,12,13$; xxvii. 2 ,

$4-6$; хxx. 0, 21;

xxxi. 5,6 ; xxxiv. 5.

$\gamma$ answered.

$d$ supra iii. 23 ; xii. 14 ; xiii. 27 ; infra xxxiii. 11 ; Ps. lxxxviii. 8; Lam. iii. 7,9 ; Hos. ii. 6 . e infra xxii. 28; xxix. 3 ; xxx. 26 ; and Comp. supra xriii. 5,6 .

$\delta$ caused to turnaway. $\varepsilon$ erown (diadem) of my head.

$f$ Lam. v. 16.

g supra ix. 30, 31 ; xri. 15; infraxxx. 19 ; xxxi. 36 ; Ps. viii. 5; Heb. ii. 9. Comp. also infra xxix. 2-25.

c go, am gone.

h supra vi. 11; xiv. 19 ; xrii. 15.

$\eta$ like the trce.

$i$ infra xxiv. 20; supra viii. 18, 19 ; xiv. $7-9$; Isa. xxx. 17 : 1xv. 22 ; Ps. xcii. 12, \&c.

ksupra xiii. 24; xvi. $9 ; x .3,16$, fe. l supra x. 17; xvi. 13 ; vi. 4.

$\theta$ have raised.

minfra $x x x .12$; Isa. lvï. 14 ; lxii. 10 ; 2 Sam. xx. 15; 2 Kings xix. 32; Ezek. ir. ¿, \&c.

$n$ supra vi. 15; Ps. lxix. S; John vii.5. o Ps. Ixxxriii. 8, 18. $\kappa$ from near me, with me.

$\lambda$ and my knowers. $\mu$ my near-ones, those near to me. $y$ have ceased.

$\pi$ my known-ones, those known by me. $\quad p$ Ps. xxxi. 11 ; Ixxxriii. 8, 18; Luke xxii. 5.-62, \&c. $\quad \rho$ dwellers of mine honse. $q$ Comp. infraxxx. 1, 9, 10. $q q$ Ps. lxix. $8 . \quad \sigma$ I ealled. $r$ supra $x$ rii. $1 . \quad \tau$ strange. $\phi$ my being affeetionate, my affection, i.e., the marks of $m y$ affection, my endearments. $\chi$ [the] ehildren of my belly, body. $\psi$ lit., nanglity, wieked, litthe children. sinfia $\leq x i .11 ; \leq x \leq .1,12$; Lev. xix. $3:$. w despised. 
$a$ I rise up.

$\beta$ and they spake.

$\gamma$ men of my counscl.

$\delta$ have abhorred.

a Ps. xxxviii. 11;

lxxxviii. 18, \&e.

$\varepsilon$ hath cleaved.

b supra vii.5; xvii.7; infra xxx. 17, 18, 30 ; Ps. cii. 5 ; Lam. iv. 8.

$\zeta$ pity me.

c supra i. 11,12; ii. 5,6 ; vi. 4 ; x ri. 12 -14,\&c.; 1 Sam. จ. 11.

d supra vii. 14, 18, 20 ; ix. 17 ; x. 3 ; xiii. 27 ; xix. $6-$ 13 , \&c.

$\eta$ se will not be glutted.

e supra vi. 27; infra xxxi. 31; Ps.xxrii. 2.

$\theta$ the book.

$f$ Exod. xrii. 14; Ps. xl. 7 ; Jer. xxx. ?, \&c.

$g$ Jer. xrii. 1.

h Exod.xxviii. 9, 11;

xxxii. 16 ; xxxix. 6 .

$i$ Ps. xix. 14; lxxriii.

35 ; ciii. 4 ; Isa. xli.

14; xliii. 14; xliv. $6,23,24$; xlvii. 4 ; xlriii. 17 ; xlix. 7 , 26 ; liv. 5,8 ; $l x$.

16 ; lxiii. 16 ; Jer. 1 . 31.

$\kappa[$ is] living.

$\lambda$ stand, endure.

$k$ Isa. xli. 4 ; xliv. 6 ; xlviii. 12.

$\mu$ they have thus pierced.

$l$ supra ii. 7 ; rii. 5 ; xiii. 28 ; xvi. 14 .
${ }^{1}$ Even, a when I stand $b y, \beta$ they speak against me.

19 All $\gamma$ my familiar friends $\delta$ abhor me, And such as I loved are turned against me ${ }^{a}$.

20 To my skin, and to my flesh, my bone $\epsilon^{\epsilon}$ cleaveth $^{b}$, And I am escaped only with the skin of my teeth.* $21 \zeta$ Have pity upon me, have pity upon me, O ye my friends,

For the hand of God hath smitten me ${ }^{c}$ !

22 Why should ye persecute me like God ${ }^{d}$ ?

${ }^{2}$ Yea, $\eta$ ye seem never to be glutted with my flesh $!^{e} \dagger$

23 Oh that now my words were written down!

Oh that they were engraved in $\theta$ a book ${ }^{f}$ !

24 That, with a ${ }^{g}$ style of iron, and with lead, $\ddagger$ For ever, they were ${ }^{h}$ graven in the rock!

(These words namely)

25 That I know that $m y^{i}$ Redeemer $\$ \kappa$ liveth, And that $\mathrm{He}$ will $\lambda$ remain the ${ }^{k}$ last upon the earth. 26 Yea, even after my skin ${ }^{\mu}$ is thus pierced ${ }^{l}$,

1 Or, possibly, Even when I rise up; i.e., when I rise up to speak. Comp. infra xxix. 9, 10, 21, 22, where we see that, in the days of Job's prosperity, even nobles and princes laad not ventured to speak in his presence, far less to interrupt him. That it was not unusnal in those days to rise up to speak may, I think, be inferred from infra xxx. 20; xxxiii. 5 . See Appendix. Editor, 1862 .

2 Or, And why will ye not be satisfied with my flesh? Editor, 1862.

* My gums, alone of my whole body, do not cleave to their bones, my teeth, because I no longer have any. [This is, perhaps, somewhat far-fetched, but I can suggest nothing better. See Appendix. Editor, 1862.]

† Comp. Ps. xxvii. 2, "When evil-doers approach me to eat my flesh" (i.e., to glut their hate upon me).

$\ddagger$ i.e., engraved with an iron style, and the letters afterwards filled up with lead.

§ i.e., God. Comp. Ps. xix. 15 (A. V. 14), "O Jehovah,

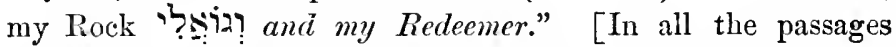
quoted in the margin the word Redeemer (or the verb redeem) indubitably refers to God alone, as in every one of them, but Ps. lxxviii. 35, He is mentioned by His own peculiar name Jehovah (A. V. the Lord). In Ps. lxxviii. $35 \mathrm{He}$ is called Most High God. In Isaiah there is one passage, viz., lix. 20, in which the expression the Redeemer is generally taken to refer to the Messialı. Editor, 1862. 
${ }^{1} \omega$ Still from my flesh, can I see $\operatorname{God}^{a}$ : *

27 Whom I, for myself, can see,

Yea, mine eyes behold, $+\beta$ and not another ${ }^{b}$;

For Him are my reins ${ }^{c}$ consumed $\gamma$ within me ${ }^{d}{ }^{\ddagger} \ddagger$

28 But ye say: "What is a persecuted-man to $\operatorname{Him}^{e}$ ? $\$$ "

And, $\delta$ therefore, the root of the matter $\epsilon$ must be found in me ${ }^{e f}$.

$29 \zeta$ Be ye afraid of the sword ${ }^{g}$,

For $\eta$ furious ${ }^{h}$ are the punishments of the sword; $\theta$ 'Therefore, should ye know, that there is a judgment $^{i}$.

\section{CHAPTER XX.}

1 Then answered Zophar the Naamathite and said:

2 For this, do my thoughts impel me to answer,

$1 \mathrm{Or}$

Still from my flesh shall I see God:

Whom I for myself shall see, \&c.

i.e., Notwithstanding the deplorable condition to whieh I am redueed by my disease, I feel confident that I shall yet live to see God, yea, behold Him face to face, and then I shall learn from His own mouth, and not through you, wherefore He contendeth with me. Comp. supra vii. 21; ix. $11,32-35$; x. 2 ; xiii. $3,17-21$; xiv. 11,15 ; infra xix. 29 ; xxiii. $3-9$; xxxi. 35 ; xxxiii. 6 : and see $\Lambda_{\text {ppendix. Editor, } 1862 .}$

* Even the flesh, which is visible through the holes in my skin-disgusting as it is, is so wonderfully wrought, that $I$ see it must be God, who made it. [Or, Notwithstanding this tattered and, as it were, motll-eaten skin (supra xiii. 28), my body is still so fearfully and wonderfully made (Ps. cxxxix. 14), that I cannot help recognising therein the handiwork of God. Editor, 1862.]

$\dagger$ Without needing the eyes of another to see Him for me, without having Him preached to me by others.

$\ddagger$ I intensely long for Him. [The reins are here supposed to be the seat of intense feeling. With equal inexactness the heart is still described as the abode of violent emotions and passions. See marg. ref. Editor, 1862.]

§ i.e., what pleasure can God have in seeing a man persecuted?

$\|$ i.e., that ye will be called to account for imputing to a fellow creature crimes, of which he is imnocent.
() Yet.

a Ps.exxxix.14-16; supi $a$ x. 10, 11.

$\beta$ and not a stranger.

6 Prov. xxvii. 2.

c Psa. xvi. 7 ; lxxiii. 21 ; Jer. xi. 20 ; xii. 2, \&c. ; supra xi. 20 ; xvii. 5 ; xxxi. 16.

$\gamma$ in my bosom.

d supra ix. 34,35 ; xiii. $3,17-24$; xxiii. $3-10$.

e supra iv. 7-11, 17 ; viii. 3,20 ; xi. 6 ; xv. $14-16$; infra xxii. 2, 3 ; xxv. 4-6 ; xxxiv. $10-12$.

$\delta$ So [the] root of [the] matter, \&c. $\varepsilon$ was found.

finfra xxxii. $3,13$.

$\zeta$ Be ye afraid for yourselves from [the] face of (from before) [the] sword. g supra xiii. 10, 11 ; Deut. xxxii. 41 ; 1 Chron. xxi. 12; Isa. lxvi. 16 ; Jer. xlvii. 6 ; Ezek. xxi. $3-5$.

$\eta$ fury.

$h$ Isa. lix. 18

$\theta \mathrm{Or}$, so that ye should know, bear in mind.

i infraxx xii. 3 ; xlii. 7 ; Ps. cxix. 120; Ezek. xi. 8, 9. 
(1) $\mathrm{m} y$ hasting.

$\beta$ correction of $\mathrm{my}$ shame.

a supra xii. 2-6; xiii. 2-4, 7-13; xvi. 2, 4, 5, 11, 20; xvii. $2-10$; xix. $2-5,13,14,19$, $21,22,29,29$.

$\gamma$ spirit from my understanding.

$\delta$ from eternity.

$\varepsilon$ from [the] placing of man.

$\zeta$ triumphant-shout of.

$\eta$ from near.

$\theta$ till a moment.

b supra viii. 11-15; xг. 29-33; infra xxi. 18 ; хxทіi. 18 -21 .

$\kappa$ touch, attain unto. $\lambda$ cloud.

$c$ Obad. vers. 3,4 .

$d$ Ps. Ixxxiii. 10 ; Jer. xvi. 4, \&c.

e Isa. xiv. 11-17.

$\mu$ those seeing him, his seers.

$f$ Ps. Ixxiii. 20; Isa. xxix. 7,8 .

$\nu$ and they shall not find him.

$\pi$ shall be made to wander.

$g$ supra ix. 23 ; rer. 5 ; infra xxi. 13, 18; Ps.xxxvii. 36; xlix. 11, 12 .

$\rho$ shall not add [to see him]; or [the] eye hath seen him, and shall see him no more.

$h$ supra rii. 8.

$\sigma$ not still, again.

$i$ supra rii, 10 ; riii. 18; Ps. ciii. 16.

$\tau$ conciliate.

$v$ cause to return.

$\phi$ his substance.

$k$ infra vers. $15,18$.

$\chi$ bones (see supra vii. 15).

$k k$ infia $a$ xxi. 26.

$\psi$ upon.

$l$ infra xxi. 23 ; Ps. 1 xxxiii. 16.

in Prov. ix. 17.

$n$ Ps. x. 7 ; Cant. iv. 11.

$\alpha$ and leave it not.

$\beta$ in [the] midst of his palate.
And, on this account, is ${ }^{\omega}$ mine haste in me;

3 I must hear $\beta$ rebuke intended for my shame ${ }^{a}$; Therefore, doth the $\gamma$ spirit of mine understanding cause me to answer.

4 Knowest thou not this $\delta$ from of old,*

$\epsilon$ From the time that man was placed upon the earth,*

5 That the $\zeta$ triumphing of the wicked is $\eta$ of recent date,

And the joy of the hypocrite $b u t^{\theta}$ for a moment ${ }^{b}$ ?

6 Though his excellency mount up unto the heavens,

And his head ${ }^{\kappa}$ reach up unto the ${ }^{\lambda}$ clouds ${ }^{c}$,

7 Yet, like his own dung, for ever shall he perish $^{e}$;

$\mu$ They, that saw him, shall say: "Where is he?"

8 Like a ${ }^{f}$ dream shall he fly away, ${ }^{\nu}$ and not be found ;

Yea, he ${ }^{*}$ shall be chased away, as a vision of the night ${ }^{g}$.

9 The eye, which saw him, $\rho$ shall see him no more ${ }^{h}$, And $\sigma$ no more shall his place behold him ${ }^{i}$.

10 His children shall $\tau$ pay court unto the poor,

Or his own hands must $v$ restore $\phi$ their substance $^{k}$.

11 Though his $x$ limbs are full-of his youthful-vigour, Yet with him shall it ${ }^{k k}$ lie down $\psi$ in the dust ${ }^{l}$.

12 Though wickedness be $s{ }^{m}$ sweet in his mouth, That he hideth it under his tongue ${ }^{n} ; \dagger$

13 Though he spare it, ${ }^{a}$ and let it not go, But keep it back $\beta$ within his palate;

14 Yet, his meat, $\ddagger$ in his bowels, is changed;

* i.e., from the history of olden times ; from the history of man since his creation.

$\dagger$ As though it were some dainty morsel.

$\ddagger$ i.e., this meat of his, his wickedness, which is to him as meat, yea, as dainty meat. 
${ }^{\omega}$ Gall of asps it becometh $\beta$ within him ${ }^{a}$.

15 He swallowed down wealth, $\gamma$ but shall ${ }^{b}$ vomit it

\section{up again ;}

From his belly $\delta$ shall God drive it out.

$16 \in$ It was ${ }^{c}$ gall of asps he was sucking;

As the viper's tongue shall it slay him.

$17 \zeta \mathrm{He}$ shall look upon no floods, no rivers, nor brooks, of ${ }^{d}$ honey and milk ${ }^{e}$.

$18 \eta \mathrm{He}$ shall restore that, for which he laboured, and shall not swallow it down ${ }^{f}$;

As the wealth that he robbed, so shall be $\eta$ its restitution $^{g}$, and he shall not rejoice therein.

19 Because he crushed, he abandoned the poor ${ }^{h}$, And violently-took away an house, $\theta$ which he did not build ${ }^{i}$;

20 Because he kknew no quiet in his $\lambda$ inward parts ${ }^{i i}$; -

Therefore, shall he not $\mu$ escape ${ }^{\nu}$ with that which he delighted in.

21 No remnant was there $\pi$ from his meal ${ }^{k}$, Therefore his prosperity shall not endure ${ }^{l}$.

22 In the fulness of his $\rho$ abundance $\sigma$ shall he be put to straits;

$\tau$ Every plague of the wretched $\uparrow$ shall come - upon him.

$23 \mathrm{He}$ will be about to fill his belly ${ }^{m}$, When $v$ God shall send $\phi$ His burning wrath upon $\operatorname{him}^{n}$;

Yea, He will ${ }^{\circ}$ rain it down $\chi$ upon him at his $\psi$ meal $^{p}$.

24 He may flee from the iron weapon,

$B$ ut the bow of brass will a strike him through. +

25 This $\beta$ may be drawn, and come out of his body,

* i.e., for the poor. Comp. Chap. xxxi. 17.

$\dagger$ i.e., every plague that can make man wretched, or from which a wretched man can suffer.

$\ddagger$ i.e., with its arrow.

$\omega$ bitterness.

$\beta$ in his inward. parts.

a Rer. x. 9, 10; Ezek. ii. 10 ; iii. 3 .

$\gamma$ and hath vomited it up, but romiteth it up.

$b$ Pror. xxiii. 8; xxт. 16

ò or, God drireth it out.

$\varepsilon$ lit., he sucketh (sucked) gall of asps ; [the] viper's tongue shall slay him.

c Jer. viii. 14 ; ix. 15.

$\zeta$ he shall not look upon floods of rivers of - brooks of-honey and milk. $d 2$ Sam. xrii. 29.

e infra xxi. 24; xxix. 6 ; Exod. iii. S, \&c. $\eta$ causing to return. $f$ rer. 20 ; infra xxix. $1 \%$.

$\eta \eta$ or, his restitution.

$g$ Exod. xxii. 4; Ler. ri. 4, \&c.; Prov. vi. 31.

h infra xxii. 5-7,9 ; xxir. $3-12$; xxxi. 16, 19, \&e.

$\theta$ and doth not build it.

$i$ Deut. xxriii. 30 ; Isa. $1 x r .21,22$.

$\kappa$ knew not.

$\lambda$ belly.

supra iii. 17 ; xr. 20 ; Pror. iv. 16.

$\mu$ deliver [himself].

$v$ with his delight.

$\pi$ to his food.

$k$ infra xxxi. 17 ; xxir. 10, 11; Luke xri. 21.

$l$ Vers. 5, 9; xxrii. $18,20,21, \mathrm{se}$.

$\rho$ sufficiency.

$\sigma$ shall it be narrow to him.

- Every blow, stroke, plague, of a miserable, wretehed,man.

$m$ Numb. xi. 33 .

$v$ He.

$\phi$ [the] burning of His wrath.

$n$ Ezek. xxii. 31 ; Mal. iv. 1.

- Ps. xi. 6; Ezek. xxrriii. 22.

$\chi$ upon them. $\psi$ food. $p$ Ps. Ixxriii. 30,31. a pass through, trarerse, him. $\beta$ hath one drawn, (i.c. if one liath drawn [it], so that it is gone out of [his] body = if it (this) be drawu and come out, \&c. 
$\psi$ lightning.

a supra Xv. 21; xviii. 11, 14; xxrii. 20 ; Ps. lxxiii. 19, \&c.

$\omega$ all darkness, i.e., calamity.

$b$ supra xviii. 5, 6, and references there.

c supra $\mathrm{\nabla .} 5$; xv. 29 ; infraxxvii. 16, 17; Jer. xv. 13 ; xvii. 3, \&.c.

$\beta$ [which] was not blown, fanned.

d Ezek. xxii. 20, 21.

$e$ Ps. xxi. 9 ; Isa. xxvi. 11.

$\gamma$ [the] one remaining.

$f$ supra $\mathrm{x}$ riii. $19 ; \mathrm{xx}$. 26; infraxxvii. 15; Jer. viii. 3, \&c.

$g$ Isa. xiv. 7.

$\delta$ [is] raising itself up, rising up.

$\varepsilon$ [the] heritage of his sentence from God.

h infra xxvii. 13.

i supra xiii. $6,17, \& c$.

$k$ supra xiii. 4,5 ; xvi. 2,3 ; xix. 2,3 , \&c. ; infra rer. 34 .

$\zeta$ atter my speaking. $\eta$ mayest thou mock.

$l$ supra xii. 4 ; xvi. 10,20 ; xrii. 2.

$\theta$ [was] my complaint in respect to.

m supra ix. 22-24; xii. 6.

$\kappa$ or', and if [so] why may I not, \&c.?

$\lambda$ may not my spirit be short.

nsupra xvii. 2 ; xix. $2,3, \&$ e.
Yea, the $\psi$ glittering-arrow-from his gall ;

Then, other terrors ${ }^{a}$ will come on him.

$26 \omega^{\omega}$ Every kind of darkness ${ }^{b}$ is laid up for his hidden-treasures ${ }^{c}$;

A fire ${ }^{\beta}$ not fanned ${ }^{a}{ }^{*}$ shall devour him ${ }^{e}$; $H e$ shall fare ill $\gamma$ that is left in his tent ${ }^{f}$.

27 The heavens shall reveal his iniquity, Yea, the ${ }^{g}$ earth $\delta$ riseth up against him.

28 The increase of his house shall depart, Flowing-away in the day of His wrath.

29 Such is the portion of the wicked-man from God, And $\epsilon$ the heritage appointed unto him by God ${ }^{h}$.

\section{CHAPTER XXI.}

1 But Job answered, and said:

2 Hear ye attentively my speech ${ }^{i}$, And let this be your consolations ${ }^{k} ! \dagger$

3 Bear with me, and let me speak; And, $\zeta$ after that I have spoken, $\eta$ may ye ${ }^{l}$ mock on.

$4{ }^{1}$ As for me, ${ }^{\theta}$ was my complaint of any other man ${ }^{m} ?+$

$\kappa$ Why, then, $\lambda$ may I not well lose patience ${ }^{n}$ ?

1 Or (as formerly explained by Dr. Bernard),

As for me, was my complaint of man?

i.e, of a being weak and ignorant, who might do me injustice-no, I complained of an all-perfect Being, God, who knoweth me to be innocent, yet treateth me as though I were gnilty. See note on supra xii. 7, p. 421, and see infra ver. 34. Appendix. Editor, 1862.

* i.e., a fire that requires no fanning; a fire sent from heaven.

+ Ye have so entirely failed to console me, ye have proved such miserable comforters, ye so vex and crush me with your words, that I implore you to grant me the consolation of your silence, and to suffer me to find ease in giving vent to my grief. See infra ver. 34. Editor, 1862.

$\ddagger$ Did I broach the subject of the fate of the wicked man? No, I have complained only of my own fate. May I not then well lose patience, when I hear you continually harping on a subject which you liave ouly introduced for my annoyance? 
$5 \omega$ Look on me, and be amazed ${ }^{a}$ !

Yea, lay your hand upon your mouth ${ }^{b}$ !

$6 \beta$ Verily, when I think on $i t,{ }^{c}{ }^{*} \gamma$ I founded,

$\delta$ And shuddering taketh hold upon my flesh ${ }^{d}$.

7 Wherefore do the wicked live ${ }^{e}$ ?

They $\epsilon$ become old, yea, $\zeta$ wax mighty in power $^{f}$;

8 Their seed is established before them, yea, with them,

And their offspring $\eta$ before their eyes ${ }^{g}$.

9 Their houses are in peace ${ }^{h}$, without fear,

Neither is the rod of God upon them.

$10 \theta$ Their bull gendereth, and $\kappa$ faileth not;

$\lambda$ Their cow ${ }^{\mu}$ calveth, and ${ }^{\nu}$ casteth-not-her-calf ${ }^{i}$.

11 They send forth their $\pi$ little-children $\rho$ like a flock;

Yea, their children frisk-about ${ }^{k}$;

12 They take-up the tabret and harp'

And rejoice at the sound of the lute.

13 'They ${ }^{\sigma}$ spend their days in prosperity,

And in a moment are crushed down into the

$$
\text { grave }^{m} \cdot \dagger
$$

14 $\tau$ Therefore they say unto God: "Depart from us $^{n}$,

" $v$ For we desire not to know Thy ways;

15 "What is the Almighty, that we should serve $\mathrm{Him}^{\circ}$ ?

"And $\phi$ what profit ${ }^{p}$ could we have, if we should $\chi$ pray unto Him?

(To this ye will say)

16 "Lo, their prosperity is not in their oun hand ${ }^{q} . "$

* When I think of, recall, your eruel and perfidious behaviour, and the manner in which $I$, an innocent man, am treated by God.

$\dagger$ i.e., without illness or pain. See Comment., note, on Chap. ix. 23.

p infraxxii. 2, 3 ; хxxiv. 9 ; хxхr. 3 ; xxxi. 2 ; ix. 22, \&c. $\chi$ cntreat Him. $q$ supra viii. $11-15$; xv. 29,30 ; xavii. $15-20$, dc. $\omega$ turn to.

a supra xvii. 8 .

$b$ infra xxix. $9 ; x \mathbf{x}$. 4 ; Mic. vii. 16.

$\beta$ so, if (when) I have remembered, remember.

c Ps.xlii.4; cxxavii. 1.

$\gamma$ then I am confounded.

$\delta$ and my tlesh taketh hold on shuddering.

d supra xviii. 20 ; Ps. cxix. 53.

$e$ Jer. xii. 1, 2.

$\varepsilon$ have become old.

$\zeta$ have waxed mighty.

f supra ix. 22-21; xii. 6 ; Chap. xxiv.

$\eta$ at their eyes.

g supra xx. 26; xviii. $12,13,19$; v. 4; infra xxvii. 14.

la supra xriii. 15; viii. 15 ; Г. 24 ; infra xxvii. 18.

$\theta$ his bull; i.e., the bull of ercry one of them.

$\kappa$ eauseth not to reject.

$\lambda$ his cow ; i.e., the cow of erery one of them.

$\mu$ eauseth to eseape, releaseth, delirereth herself, or her young.

$v$ aborteth not.

$i$ Gen. xxxi. S, 9 ; Deut. xxriii. 18.

$\pi$ lit., wicked little children.

0 like the floek.

h Ps. xxix. 6 ; cxiv.4.

7 Gen. xxxi. 27 ; Ps. lxxxi. 2 ; Isa. v. 12; infra xxx. 31; Ps. cxxxrii. 2, \&e. $\sigma$ wear away, consume.

m supra ix. 23 ; viii. $11-15$; xv. $29-$ 33; xx. 5-8; xxir. 19; xxvii. 15-21. $\tau$ So they hare said. $n$ infra xxii. 17.

$v$ Since, seeing that. o supra xi. 11 ; infra xxii. 11-14; Exod. v. 2; Ps.x. 11 ; lxxiii. 11, \&e. $\phi$ what could we profit? 
a infra $\mathrm{xxii} .18$.

b supra xviii. 5, 6 ; xx. 26, and references there.

Indeed, the counsel of the wicked is far from me. ${ }^{a *}$

17 How oft is it, I ask, that the ${ }^{b}$ lamp of the wicked is put out,

And that their calamity cometh upon them,

Even the sorrows $\mathrm{He} \dagger$ distributeth in $\mathrm{His}$ anger?

c Exod. xv. 7; Ps. lxxxiii. 13; Isa. xl. 24.

$\alpha$ wind.

$\beta$ [the] whirlwind hath stolen, stealeth, it [away].

d Ps. i. 4 ; xxxv. 5 ; Hos. xiii. 3.

e supra v. 4 ; xriii. $12,13,16,17,19$; xx. 26 ; xxvii. 14 , 15 ; Exod. xx. 5 ; comp. supra xxi. 8,11 .

ee infra xxxiv. 11. $\gamma \gamma$ or $i$.

$\gamma$ what [is] his concern?

f supra ix. 23 ; xxi. 13 ; xiv. 10-12 \& references there.

$g$ supra xiv. 5.

$\delta$ are cut off.

$\varepsilon$ to God.

h supra iv. 17 ; viii. 3 ; xi. $6-9$; xv. 8,14 ; xxv.4-6; xxxiii. 12 ; xxxiv. 12 ; Is. xl. 13, 14; Rom. xi. 34 .

$\zeta$ high-ones.

$i$ supra iv. 18 ; $\mathrm{x}$. 15 ; infra xxv. 5. $\eta$ this.

$\theta$ substancc, essence, of his [bodily] perfection, his very perfection.

$\kappa$ all of him.

li supra ver. 13 ; ix. 23 ; infra xxiv. 19.

\section{That they are as ${ }^{c}$ stubble before the a blast,} And as chaff, that $\beta$ the whirlwind snatcheth away $^{d}$ ?

$19 \ddagger "$ But God layeth up His affliction for his children ${ }^{e . "}$

$\S$ Him himself should $\mathrm{He}{ }^{e e}$ requite, that he might know $\gamma \gamma$ Him. $\|$

20 His own eyes should see his calamity, And of the wrath of the Almighty HE should drink.

21 For $\gamma$ what concern hath he in his house after $\operatorname{him}^{f}$,

And when the ${ }^{g}$ number of his months $\delta$ is cut off?

22 If "Shall one teach $\epsilon$ God knowledge ${ }^{h}$,

"Seeing He judgeth $\zeta$ those that are on high ${ }^{i}$ ?"

$23 * * \eta$ The one $\dagger \dagger$ dieth in $\theta$ the very perfection of his strength,

Being ${ }^{k}$ wholly at ease and quiet ${ }^{k}$;

* I only tell you what they really do say, I do not pretend to explain why they say so.

ti.e., God.

$\neq$ A second objection made by the friends.

$\S$ But this does not satisfy me. The wicked-man should himself reap the fruits of his wickedness.

II Know Him, i.e., acknowledge, recognise Him, know that there is a Grod who punishes the wicked, and recognise in his own sufferings the hand of God. Editor, 1862.

T A third objection on the part of Job's friends.

** But here are facts, which confute your argument.

t十 i.e., the· wicked-man. 
24 His vessels $\psi$ are-full-of milk ${ }^{a}$, And the marrow of his bones $\omega$ is moistened ${ }^{b}$. 25 But a the other $*$ dieth $\beta$ in bitterness of soul ${ }^{c}$, $\gamma$ For never had he tasted pleasure ${ }^{d}$.

26 Yet alike they lie down $\delta$ in the dust, And the worm ${ }^{e}$ covereth them.

27 Lo! I know your thoughts,

And the devices $\epsilon$ ye wrongfully-imagine against me.

28 For ye say: "Where is the house of the noble. minded $^{f}$ ?

"And where the tent, the habitations, of the wicked ${ }^{g}$ ?" $†$

$29 B u t$, have ye $\epsilon \epsilon$ never asked of $\zeta$ them that pass by the way ${ }^{h}$ ? +

( $\eta$ Only that, which they have noted, ye must not $\theta$ deny);

'They will tell you

30 That, in the day of calamity, the wicked is $\kappa$ spared,

Even $\lambda$ in the day, when wrath is brought-on ${ }^{i}$.

* i.e., the good man.

+ i.e., a man can never affirm with certainty of any house, that it harbours a good or a wicked man, whereby Job of course means, that his friends would insinuate, that with respect to his own dwelling, no one could say to which class its proprietor belonged. [But surely we may interpret these words both somewluat more and somewhat less literally, and understand them to refer to what has been constantly asserted by Job's three friends, that, namely, the house of the righteous is built upon a rock, whilst the tent of the wicked stands upon the sand. Comp. supra iv. 7 ; v. 24 ; viii. 15,22 ; xviii. 15 ; xxvii. 18 ; Prov. xii. 7 ; xiv. 11. IIouse and tent will then be used fig. (as they very frequently are) for their respective owners, with all that belongs and appertains to them (comp. 2 Sam. iii. 1); whilst the "thoughts" and "devices" of Job's friends will refer to the inference which they wished to be drawn from their assertions, that, namely, as Job's house had not stood, he must be a wicked man. Editor, 1862.]

$\ddagger$ i.e, men of much travel, great travellers.

$\psi$ have been full of.

$a$ Gen. xlix. 12.

$\omega$ is made to drink, is watered.

$b$ Prov. iii. 8 ; infra $\mathrm{xxx} .30$; Prov. xiv. 30 ; xvii. 22 ; Ps. xxxii. 3,4 .

$a$ this.

$\beta$ with bitter soul.

c supra iii. 20 ; ix. 18, 23.

$\gamma$ Seeing lie had not eaten of good.

d supra ix. 25; Ps. xxxiv. 12.

$\delta$ on [the] dust.

$e$ infra xxiv. 20 ; Isa. xiv. 11 ; $\mathrm{cf}$. supra vii. 5.

$\varepsilon$ ye wrongfullyurge.

f supra iv. 7 ; v. 21 , sc.

$g$ supra viii. 15, 22 ; xviii. 15; xxvii. 18 , de.

$\varepsilon \varepsilon$ not.

$\zeta$ passers-on [the] way.

$h$ Ps. lxxx. 12 ; 1xxxix. 41 ; Lam. i. 12 ; ii. 15 , \&c.

$\eta$ but their marks.

$\theta$ ignore.

$\kappa$ withlolden.

$\lambda$ at [the] day of wraths are brought on.

i supra ix. 22-24; sii. 6; Chap. sxir. 
a supra i. 11 ; ii. 5. $\omega$ And hath he done, if he hath done. $\beta$ repay to him. $\gamma$ to [the] graves.

$\delta$ brought.

$\varepsilon$ shock.

$\zeta$ sweet...have been. $b$ infra xxiv. 20; supra x vii. 14.

$\eta$ every man.

$\theta$ draw.

$\kappa$ no number.

c supra xiii. 4 ; xvi. 2 ; ver. 2, \&e.

$\lambda$ remained a fallacy, deceit, treachery.

d sipra vi. $6,7,25$; xii. 4,5 ; xiii. 2,4 , 5 ; xvi. 2,3 ; xix. 2 , 28, 29 ; xxxii. 11,12 ; xlii. 7 .

e supra xxi. 15; infra xxxiv. 9 ; xxxv. $3,6,7$; Ps. xvi. 2 ; supra vii. 20 ; ix. 22 ; x. 3 , 7 , \&c.

$\mu$ to themselves.

infra xxxv. 8 .

v understanding man.

$\pi$ [Is any] concern, interest, to [the] Almighty, that thou art, \&e.? $g$ infra xxxv. $6,7$. $\rho$ from thy fear.

$h$ supra ix. 32 .

$i$ infra xxiv. 3, 9; Hxod. xxii. 26, 27; Deut. xxiv. 12, 13, 17.

$k$ infra xxxi. 19, 20.
31 Who will declare his way ${ }^{*}{ }^{a}$ before his face? $\omega$ And when he hath done amiss, who will $\beta$ requite him?

32 Yea, even $\gamma$ to the burying-place will he be $\delta$ borne

Honoured, as when he watched over his corn$\epsilon$ shocks. $\dagger$

33 SSweet unto him are the clods of the valley, ${ }^{b} \neq$ Seeing that, after him, $\S \eta$ all men will ${ }^{\theta}$ move-on, And before him, men $\kappa$ without number.

34 How then can ye ${ }^{c}$ comfort me with that, which $i s$ vain,

Seeing that your answers all prove ${ }^{\lambda}$ deceitful $^{d}$ ?

\section{CIIAPTER XXII.}

1 Then Eliphaz the Temanite answered, and said :

2 Can a man be profitable unto $\operatorname{God}^{e}$ ?

${ }^{\mu}$ Himself $^{f}$, surely, doth the ${ }^{\nu}$ wise-man profit.

$3 \pi$ Hath the Almighty any advantage, if thou art righteous,

Or amy gain, if thou makest thy ways perfect $^{g}$ ?

$4 \rho$ 'Through awe of thee, will $\mathrm{He}$ reason with thee ${ }^{h}$;

And enter with thee into judgment? saying,

"Is not thy wickedness great?

"Yea, there is no end to thine iniquities.

6

"For thou didst take pledges ${ }^{i}$ of thy brethren for nought,

"And didst strip off the garments of the naked ${ }^{k} . \|$

* i.e., his course of life. Who dares reproach him with it?

+ i.e., When he thinks of his death, he will revel, by anticipation, in the honours which will then be paid to him.

$\ddagger$ i.e., in order, namely, that no poor man should glean.

$\$$ i.e., after his coffin or bier ; i.e., will follow him to the grave.

|| i.e., thou strippedst off men's garments, so as to leave them naked. 
" $\psi$ Thou gavest no water to the weary to $\psi$ thou didst not drink $^{a}$,

"And from the hungry thou withheldest bread $^{b}$. make [the] weary to drink water.

a Prov. xxv. 21 ; Matt. xxr. 42.

$b$ infra xxiv. 5, 6,10 , 11 ; xxxi. 17 .

8 " $\omega$ (As though the $\beta$ mighty man alone $\begin{gathered}\omega \text { or, Seeing that [in } \\ \text { thy thoughts the] }\end{gathered}$ $\gamma$ possessed the earth ${ }^{c}$,

"And the $\delta$ man of authority should alone divell $\epsilon$ therein).

$9 \quad$ " $d$ Widows thou didst send empty away, mighty man, \&c.

$\beta$ man of arm.

$\gamma$ to him [was, belonged].

c supra ix. 24.

$\delta$ elerated of conn. tenanee. "That the arms of the ${ }^{d}$ fatherless $\zeta$ might $\varepsilon$ in it. be crushed ${ }^{e}$.

d infra xxiv. 3,9 ; xxxi. 16-18, 21, 22, se.

"Therefore were there round about thee suares $^{f}$,

"And $\eta$ sudden ${ }^{g}$ terror ${ }^{h}$ confounded thee."

$11^{1}$ Or, canst thon not see ${ }^{*}$ for the darkness, And abundance of water, which $\theta$ are above thee? *

12 Is not God in the height of heaven?

Yea, behold the ${ }^{k}$ summit of the stars, $\lambda$ how high they are ${ }^{i}$ !

13 And so, perchance, thou sayest: "How $\mu$ can God know" ?

"Can Ile judge through the thick-darkness?

$\zeta$ might [every one] be crushed.

e supra iv. 3 ; infra xxxriii. 15 ; Ps. $x$. 15 ; xxxrii. 17 ; Ezek. xxx. 21, 22, 24, 25; Comp. Hos. vii. 15 .

$f$ supra v. 5 ; xriii. $8-10$, se.

$\eta$ fear of suddenly, coming on suddenly.

$g$ Prov. iii. 25; ri. 15; 1 Thess. v. 3.

h supra xv. 21; xriii. 11-14; xxvii. 20 ; 1's. 1xxiii. 19, \&c.

$\theta$ eorereth thee.

$\kappa$ head.

14 "Thick ' clouds are a $v$ covering to IFim, that He cannot see;

$\lambda$ that they are high. infra xxxr. 5 ; Isa. xl. 26.

$\mu$ hath God known. "Yea, in the circuit of heaven only doth IIe $k$ supra ix. 11, 22, walk." †

15 What! Dost thou keep-to that track of old, Which ${ }^{\pi}$ wicked men ${ }^{m}$ have trodden, 16 Who $\rho^{\rho}$ withered in death $\sigma$ before their time ${ }^{n}$ ?

1 Or (as formerly explained by Dr. Bernard),

Or is there dirkness that thou canst not see, And dotli the abundance of water corer thee?

See Appendix. Editor, 186?.

* Canst thou not see that there is a God, canst thou not believe in God's Providence, on account of the dark and rainfraught clouds, which intervene between thee and heaven?

$\dagger$ i.e., He confines Ilis attention to heavenly Beings only, as alone worthy of His care. 4 ; infra xxiii. 8, 9 ; xxir. 1 ; Ps. $x$. 11 ; lxxiii. 11 ; xiv. 7 ; Isa. xl. 26,27 ; Ezek. viii. 12 ; ix. 9.

linfira xxvi. $9 ; 1$ Kings viii. 12; Ps. xevii. 2.

$v$ eoneealment, hiding, covert.

$\pi$ men of wicked. ness.

$m$ Gen. vi. 5, 1113.

$\rho$ beeame wrinkled, shrirelled (eorpses).

$\sigma$ when [it is] not time.

$n$ Gen. rii. 21-23. 
(1) [like] a river, [which] should be poured out.

$\beta$ foundation, principle.

$\gamma$ who [were] saying.

a supra $\mathrm{xxi} .14$.

6 supra xii. 6 ; xxi. 7-13.

c supra xxi. 16.

$\delta$ that they may rejoice.

$d$ Ps. xxxiv. 2 ; crii.

42 ; Zech. $x .7$.

Comp. Ps. Iriii. 10.

$\varepsilon$ mock at them.

$e$ Pв. lii. 6; ii. 4 . Comp. supra xii. 4.

$\zeta$ eaten up, devoured.

$f$ Exod. xi. 5-7; xii. 29,30 ; viii. 21-23, \&c.

$\eta$ and prosper.

$g$ supra ix. 4.

$\theta$ now.

$\kappa$ put.

h supra vi. 10 ; infra xxiii. 12 ; Ps. cxix. 11.

$\lambda$ up to, close up to, right up to.

$i$ supra v. 8,17 ; viii. 5 ; xi. 13.

k supra xii. 14.

$\mu$ lit. their principle [was].
${ }^{1}$ Indeed, wlike an overflowing river were their $\beta$ principles.*

$17 \gamma$ Which said unto God: " $a$ Depart from us!" "But," thou wilt ask, "What doeth the Almighty unto them, $\dagger$

18 "Seeing $\mathrm{He}$ hath filled their houses with good things ${ }^{b}$ ?"

Indeed, the counsel of the wicked is far from $\mathrm{me}^{c}$.

$19^{2}$ But the righteous shall see $\delta$ they have reason to rejoice ${ }^{d}, \S$

And the inmocent shall $\epsilon$ laugh them to scorn ${ }^{e}$, saying,

20 "Surely our substance hath not been destroyed, "Whereas fire hath $\zeta$ consumed their abundance ${ }^{f}$."

21 Acquaint now thyself with Him; $\eta$ so shalt thou prosper $^{g}$;

Yea, by these things $\$$ shall good come unto thee:

22 Receive, ${ }^{\theta}$ I pray thee, the law from His mouth, And ${ }^{k}$ lay up His ${ }^{h}$ words in thine heart.

23 If thou wilt return $\lambda$ altogether unto the Almighty ${ }^{i}$, thou shalt be built up ${ }^{k}$, -

1 Or, $\mu$ Whose principles were like an overflowing river; or, Seeing their foundation was as a rushing stream;

So that it bore them away with it to destruction, and will bear away all who tread in their footsteps. Editor, 1862.

2 Or, But the rightcous shall see it, and rejoice. Editor, 1862.

* There is something so irresistible, so entratnant in their doctrines, that they very likely have hurried thee away. [See supra xv. 12. Editor, 1862.]

+ i.e., What doth $\mathrm{He}$ do to them, that they should rebel against Him.

+ I cannot account for their rebellion, for I hold no communion with them; all that $I$ know is, that they do rebel.

$\S$ i.e., that they were not drawn into the vortex of their (i.e., these wicked men's) principles.

II i.e., the abundance of the wicked.

T By the things which I am about to recommend to thee, by the course of conduct which I am about to lay down for thee. Editor, 1862. 
TRANSLATION. CHAPS. XXiI. $24-30$; xxiII. $1-2$.

If thou wilt but ${ }^{\omega}$ remove iniquity far from thy tents ${ }^{a}$.

24. Yea, ${ }^{\beta}$ regard gold $\beta \beta$ as dust ${ }^{b}$, Even fine gold of ${ }^{\circ}$ Ophir, as the $\gamma$ pebbles of the brooks $^{b}$;

25 And let the Almighty be $\delta$ thy gold ${ }^{d}$, And His might, $\epsilon$ thy silver.

$26{ }^{e}$ Then, surely, shalt thou delight thyself $\zeta$ in the Almighty ${ }^{f}$,

And shalt ${ }^{g}$ lift up thy face unto God. 27 Thou wilt pray unto Him, and He shall hear $d$ Isares). xxxiii. 6 ; thee ${ }^{h}$;

And so thou wilt perform thy vows ${ }^{i}{ }^{*}$

28 And when thou shalt decree a thing, then it shall be established unto thee ${ }^{k}$,

Yea, light $\eta$ shall shine ${ }^{l}$ upon thy ways.

$29 \eta \eta$ When men are abaséd, $\eta \eta$ thou wilt say : "It

is pride ${ }^{m}$ !" $†$

"Seeing that one $\theta$ of humble ${ }^{n}$ spirit could have saved them all. $\ddagger$

30 "Yea he $\S$ could have delivered even lim, that was not "guiltless ${ }^{\circ}$;"

And so shall he be delivered also by the purity of thine hands. ${ }^{p} \|$

\section{CHAPTER XXIII.}

1 Then Job answered, and said :

2 Will to-day too $\mathrm{my}^{q}$ complaint be rebellion ${ }^{r}$ ? My stroke $\lambda$ is heavier than my groaning ${ }^{s}$. I

* i.e., All thy wishes will be aceomplished.

$\dagger$ i.e., It is their pride has eaused their ruin.

$\ddagger$ i.e., by praying and intereeding for them.

$\S$ i.e., the humble-minded man.

II i.e., the one, who is not guiltless, shall be delivered by thy merit.

I Will my complaints be considered by my friends as rebellion against God? But, I groan fur less than my sufferings would warrant me in doing.

$\omega$ mike....... to be far. a supra viii.6; xi. 1. $\beta$ put.

$\beta \beta$ on a level with dust.

binfra xxxi. 21, 25; xxxvi. 19 ; Isa. xiii. 17 ; Ps. lii. 7 ; Prov. xxiii. 4, 5; 1 Tim. vi. $9,10,17$, \&c.

c infica xxviii. 16 ; 1 Kings ix. 2S ; 1 Chron. xxix. 4; Ps. xlr. 9; Isa. xiii. 12 .

$\gamma$ rock, stone, pebble.

of thy golds (trea-

Matt. vi. 19, 20, \&c.

$\varepsilon$ silver to thee.

e supra v. 19-26; viii. $6,7,21,22$; xi. $15-19$.

$\zeta$ on, on account of, or, witl.

finfore xxrii. 10; xxxir. 9 ; Ps.cxix. 16.

$g$ supra x. 15; xi.

15; Gen.ir. 5, 6, \&c.

ll infia xrxiii. 26 ;

supra vi. 8 ; ix. 16 ;

x. 20 ; xiv. 13 ; xri.

21 ; xix. 7 ; infora

xxiii. 3 ; xlii. 8 ;

Isa. Ixr. 24; Mark

xi. $23, \geq 4$.

$i$ P's xxii. 25; Prov. rii. 14 , \&

ksupra xrii. 11; infia xlii. 8.

$\eta$ hath shined.

l supra xix. 8; infra xxix. 3 ; supra $\mathrm{x}$. 3 , ke.

$\eta \eta$ when they have lowered [themselves].

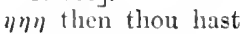
said, sayest.

m Pror. xri. 1s; xxix. 23 ; Ps. 1xxiii. 6 , \&e.

$\theta$ low of exes, of humble looks.

$n$ infora 5 . 4; xlii. 4, 6, $8 ; 2$ Chron. xxxir. $27 ; P^{\prime}=x$. 17 ; exxxi. 1; l'rov. xxx.13; Isia.ii. 11 . $\kappa$ innocent.

o i, fi $\leftrightarrow$ x xxiii. 23,24

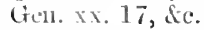

i) infraxh. 8. q supra vï. 11 ; x. 1 ; xiii. $13-15$, \&e. $r$ supra xxii. 2-1, 13-17; xix. 7 ; ix. $17,22,21$; infraxvir. 1 ; xxvii. 2 ; xxxii. 2, Sc. $\lambda$ hath been heavy orer, beyond, my groaning. $s$ suprevi. 3 ; iii. 21 , \& 
a supra ix. 11, 19 ; x. 16 ; xiii. 3,19 ; xix. 26 ; xxxi. 35 -37 , se.

b supraxiii. 18 ; infra xxxiii. 5.

c supra ix. 3, 32; xiii. 22 , \&c.

d suprax. 2; xiii. 23; comp. vi. 21.

e supra ix. 4, 19 ; xii. 13,16 ; xxxvi. 5 ; Dan. ii. 20.

$a$ would set $[\mathrm{Hi}$ is heart] upon me.

$\beta$ [might the] upright [be] arguing.

$f$ supra xiii. 16 .

$\gamma 1$ should escape.

g supra vi. 21, 29, 30 ; ix. $20,21,35$; x. 7 ; xi. 4 ; xiii. 15 ; xvi. 17 ; xix. 6,7 ; infora vers. $10-12$; xxvii. 5 , 6 ; ehap. xxxi. passim.

$\delta$ forwards.

$\varepsilon$ backwards.

$\zeta$ on $\mathrm{His}$ working.

$\eta$ left.

$\theta$ then I cannot.

$\kappa$ right.

h supra ix. 11 ; xxii.

13, 14; Ps. cxxxix.

$5-12$.

$i$ suprax. 7 .

$\lambda$ [the] way with me.

$\mu$ as the gold.

$k$ see references ver. $7(g)$.

$\nu$ seized hold on.

$\pi$ step.

$l$ supra ix. 35 ; xiii. 15 ; xxvii. 5,$6 ; \mathrm{Ps}$. exix. 4, and passim.

$\rho$ by reason of $\mathrm{my}$ law.

mPs.xxxix. 1 ; cxix. 106 , sc.

n supra xxii. 22 ; vi. 10 ; Ps.cxix. 11.
3 Ol that I knew, where I might find Him ${ }^{a}$ ! That I might come even to His seat! ${ }^{a}$

4 I would ${ }^{b}$ order $m y$ cause before Him, And fill my mouth with arguments ${ }^{c}$.

5 Then, should I know the words He would answer me,

And understand what $\mathrm{He}$ would say unto me ${ }^{d}$.

6 Would He contend with me with the greatness of His power ${ }^{e}$ ?

No! but $\mathrm{He}^{a}$ would give heed unto me.

$7{ }^{1}$ There $\beta$ might the $e^{\hat{f}}$ upright argue with Him; So should $\gamma$ I free myself for ever from my judge ${ }^{g}$.

8 Behold, I go $\delta$ Eastward, and $\mathrm{He} i s$ not there; And $\epsilon$ Westward, but I cannot perceive Him;

$9^{2} \zeta$ When He worketh in the $\eta$ North, $\theta$ I cannot behold Him ;

He veileth Himself in the ${ }^{*}$ South, and I cannot see $\mathrm{Him}^{h}$.

10 Surely, had $\mathrm{He} b u t^{i}{ }^{*}$ known $\lambda$ the way, which was mine,

Had He but tried me, I should have come forth $\mu$ as gold ${ }^{k}$.

11 My foot hath $\nu$ held fast His $\pi$ steps,

His way have I kept, and not declined $\dagger$;

12 The commandment of His lips also, and have not gone back fiom it ${ }^{l}$;

$\rho$ By reason of the law I made $\mathrm{me}^{m}$, laid I up the ${ }^{n}$ words of His mouth.

1 Or, There doth the upright argue with Him ; i.e., the upright (but the upright only) are allowed to eome before Him (see supra xiii. 16), and plead their causes; I am upright, and, therefore, if I could but find my way to His judgment seat, He could not refuse to hear me, although He now hideth himself from me. Editor, 1862.

$2 \mathrm{Or}$, Northward, when He worketh, but I cannot behold IIim.

* i.e., turned his attention to, considered, noticed, examined. -Editor, 1862.

+ I have put and not dcclined, because I find it in the Auth. Vers., and because it sounds well ; else and I have not declined from it would certainly be more correct, as we do not say to decline a'way.-Editor, 1862. 
TRANSLATION. CHAPS. XXIII. $13-17$; xxIV. $1-4$.

13 But He is $\psi$ without His like ${ }^{x}$ - who then can $\psi$ one, uniqne.

$\omega$ hinder $\mathrm{Him}^{y}$ ?

So what His soul $a$ willed He hath done ${ }^{z}$ *

$x$ Deut. iv. 35,39 ;

xxxii. $39 ; 1$ Sam.

ii. 2 ; Isa. xliv. 6 ; xlv. 22.

14 Surely, $\mathrm{He}$ will $\beta$ accomplish $\gamma$ that, which is $\omega$ cause him to turn decreed for me ; ${ }^{a}$

Yea, $\delta$ many such things ${ }^{b}$ may there be with $\mathrm{Him} . \dagger$

15 Therefore, am I confounded before Him; back.

y supra ix. 12; xi. 10 ; xii. $14 ;$ Isa. xliii. 13 ; Dan. iv. 35 , \&e.

$a$ so His soul desired and He did.

$\delta \delta$ When I consider this, $\ddagger \mathrm{I}$ am in dread of $\approx$.

Him $^{b}$.

Ps. $\operatorname{cxv} .3$; $\operatorname{exxx}$.

$\beta$ make eomplete.

$\gamma$ my decree.

16 But it is God who hath made $\epsilon$ faint my heart ${ }^{c}$, $\delta$ supra ix. 28 . Yea, the Almighty hath confounded me;

these.

8 suprax. 13 ; ix. 28.

17 Because I was not cut off $\zeta$ before this darkness ${ }^{d}$ io eonsider I (i.e., if came,

When I consider), then I am, Se.; or, I eonE soft. gloom ${ }^{d}$.

$c$ Jer. viii. 18 ; Lam. i. $22 ;$ v. 17, \&c.

$\zeta$ from before.

\section{CHAPTER XXIV.}

$\eta$ had covered up from $m y$ face, from before me.

d supra xviii. 5, 6, and referenees; iii. the Almighty ${ }^{e}$,

Yet $\kappa$ they, that love Him, $\lambda$ do not see His days $^{f} . \$$

2 Here, $\lambda \lambda$ men $\|$ remove landmarks ${ }^{g}$;

There, ${ }^{\mu}$ seize upon an herd, and ${ }^{\nu}$ feed $i t$;

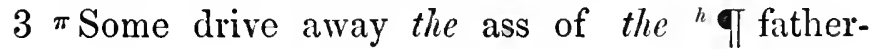

less ;

And talie the ${ }^{h}$ ovidow's ox for a pledge;

$4 \rho$ Others turn the needy out of the way;

Yea, the poor of the earth are ${ }^{\sigma}$ altogether hid .

1 Or, perhaps :

Why, if events are not hidden from the Almighty,

Yet, do they that love Him, not see His days?

See Appendix. Editor, 1862.

11-16; Jer. xx.

17,18

$\theta$ times.

e supraxi. 11 ; infra xxviii. 24; xxxiv. 21,22 ; хxхті. 4 ; xxxyii. 16 ; Prov. xv. 3 ; Jer. xri. 17 ; xxxii. 19, \&e.

$\kappa$ His knowers, lo. vers.

$\lambda$ hare not seen.

$f$ supra iii. 23; xi. 11 ; xxi. 19 ; xxii. 13,14 ; xxiii. 8, 9 ; ix. 22-21; xii. 6 ; xxi. $7-13$; Ps. x. $1,6,11$; Eecles. vii. 15; riii, $11-14$, \&e.

$\lambda \lambda$ they remore.

$g$ Deut. xix. 14; xxvii. 17 ; Prop, xxii. 28.

* Unto me.

$\uparrow$ Laid up for me.

‡ That still greater calamitics may befall mo.

$\S$ i.e., His days of retribution.

|| i.e., the wicked.

T i.e., the defenceless and destitute.

$\mu$ have seizcd.

$\nu$ fed.

$\pi$ they lead, drive.

linfia rel. y, and references; Deut. xxiv, 17; xxrii. 19 , \&c.

$\rho$ thoy turn. $\quad \sigma$ were, have been, hidden.

$i$ infia xxix. 8; $\operatorname{xxx} .5,6$; Judg. ix. 5, \&c.

G G 2 
a supraxi. 12 ; infra $\mathrm{xxx} .7$; Isa. xxxii. 14 ; Jer. xiv. 6.

$\psi$ have they gone forth, do they go forth.

$b$ infra xxx. 3, 4; Matt. iii. 4.

$\omega[$ the] wilderness[is] bread to him for the ehildren.

$\beta$ fodder.

c supraxxi. $32 ;$ Lev. xix. 9,10 ; xxiii. 22. $\gamma$ vineyard.

$d$ Lev. xix. 10 ; Dent. xx. $6 ; \mathrm{xxv} .4 ; 1$ Cor. ix. 7, 9, 10.

$e$ vers. 9, 10 .

finfra xxxi. 19, 20.

$\delta$ from, through.

$\varepsilon$ shower.

g Dan. iv. 15, 23, 25, 33.

$\zeta$ have embraced.

h infraxxx. 6 ; Isa. ii. $10,19,21$; Jer. xvi. 16; Lam.iv. 5.

$i$ supra ver. 3 ; vi. 27 ; xxii. 9 ; infra xxix. 12 ; xxxi.17, 21 , se.

k Exod. xxii. 26, 27 ; Deut. xxiv. 12, 13, 17 , \&e.

$l$ ver. 7 .

$m$ supra v. 5 .

$\eta$ sheaf.

$\theta$ between.

$\kappa$ have trod.

$n$ Isa. 1xiii. 3 ; Lam. i. 15 ; Neh, xiii. 15 , se.

$\lambda$ were thirsty.

$\mu$ mortals.

nn infra xxxiv. 28; xxxv. 9, \&e.

$v$ putteth not, layeth not up, wrong.

o ver. 1 ; supra ix. 22,$21 ;$ xii. 6 ; xxi. $7-13$; Ps. x. 1, 6, 11 ; Eecles. vii. 15 ; viii. $11-$ 14

$\pi$ they.

$\rho$ were, have been.

$\sigma$ among rebellers of light.

$\tau$ they know not.

o its ways.

$x$ and have not abode.

p infraxsxriii.13,15; J thn ii. 19-21.

$\psi$ at the light.
5 Behold, as ${ }^{a}$ wild-asses, $\psi$ must they go forth in the ${ }^{b}$ desert to their work,

Seeking diligently for food ${ }^{b}$;

$\omega$ The wilderness ${ }^{b}$ must yield them bread for their children.

6 In the field, they must reap his $\beta$ grain $^{c}, *$ And gather the $\gamma$ vintage ${ }^{d}$ of the wicked.

i Naked, they pass the night, without clothing ${ }^{e}$,

And have no covering in the cold ${ }^{f}$.

$8 \delta$ With the ${ }^{\epsilon}$ showers of the mountains, are they ${ }^{g}$ wet,

And, for want of shelter, $\zeta$ embrace the rock $^{h}$.

9 They (the wicked) pluck the ${ }^{i}$ fatherless from the breast,

And that, which is upon the poor, they take to pledge ${ }^{k}$.

10 Naked go they (the poor), without clothing , And, ${ }^{m}$ hung'ring, bear the $\eta$ sheaves. $\dagger$

$11 \theta$ Within their $\ddagger$ walls they press out oil; They ${ }^{\kappa}$ tread their wine-presses ${ }^{n}$, yet $\lambda$ suffer thirst.

12 From out the city too, $\mu$ men groall, And the soul of the slain ${ }^{m}$ crieth out; Yet, God vimputeth no wrong to the oppressors $^{\circ}$.

$13 \pi$ Some of them $\rho$ are $\sigma$ of those, that rebel against the light; $\S$

$\tau$ Others know not $\phi$ the ways thereof,

$\chi$ Nor abide in its paths ${ }^{p}$.

$14 *$ With the light, the murderer riseth;

* i.e., the grain of the wicked man mentioned in the second henistich.

+ i.e., Their tyrannical master allows them to starve in the midst of plenty, like the ox, which is muzzled while treading out the corn. Comp. Deut. xxv. 4.

\$ i.e., the wicked men's walls.

$\$$ i.e., they set light, as it were, at defiance, by commisting their crimes in broad day. 
He killeth the poor and needy ${ }^{a}$; And, in the night, is $\omega$ as a thief.

15 The ${ }^{b}$ eye also of the ${ }^{c}$ adulterer $\beta$ watcheth for the twilight ${ }^{d}$,

" $\gamma$ No eye, ${ }^{*}$ " $\delta$ saith he, "must see me ;"

So he putteth on $\epsilon$ a mask ${ }^{e}$.

16 In the dark, $\epsilon \epsilon$ they ${ }^{f}$ dig-through houses;

By day, they $\zeta$ shut themselves up;

They $\eta$ love not the light ${ }^{g}$.

17 For $\theta$ to all of them is the morning as the $\varepsilon$ a hiding, corering, shadow-of-death ;

a supra v. 15, 16 ; xx. 19 ; xxiv. 4,9 ; xxx. 25 ; xxxi. 16, 19 ; xxxiv. 19,28 ;

Ezek. sriii. 12;

xxii. 29, \&e.

$\omega$ as the thief.

$b$ infra xxxi. 1; 2 Pet. ii. 14; Matt. จ. 28.

c infra xxxi. 9.

$\beta$ hath watched.

d Prov. vii. 9.

$\gamma$ saying, [there]must not see me an eye.

$\delta$ saying.

of face.

e Exod. xxxiv. 33.

For then, $\mathrm{k}$ they feel the terrors of the shadowof-death.

$\varepsilon \varepsilon$ he (i.e., every one of the class of burglars) hath digged.

$18 \lambda$ They are light upon the face of the waters ${ }^{h} ; \dagger f$ Exod.xxii. 2; Matt. ${ }^{i}$ Accursed is their ${ }^{k}$ portion $\neq$ in the land; $\mu$ They turn not $b y$ the ${ }^{l}$ way of the vineyards.

19 Yet, as ${ }^{m}$ drought and heat ${ }^{\nu}$ steal away snowwaters ${ }^{n}$,

So they glide down into the grave ${ }^{\circ}$.

20 Whereas, $\pi$ she, that bare him, ought to forget him ;

The worm should be sweet unto him ${ }^{p}$;

$\rho$ He should be remembered no more ${ }^{q}$;

So iniquity ${ }^{\sigma}$ would be broken as a stick ${ }^{r}$. vi. 19, 20; sxiv. 43 ; Luke xii. 39 ; comp. Ezek, riii. 8 ; xii. $5,7,12$.

$\zeta$ have sealed.

$\eta$ know not, frequent not, are not intimate with, love not.

g John iii. 19-2l ; Jer. xlix. 9 ; Obad. 5 ; Matt. xxvii. 64. $\theta$ to them together.

$n$ he becometh acquainted with, recogniseth.

$\lambda$ lie [is].

lits sxvii, 42 ; xxriii. 4.

$21 \tau$ For he ${ }^{s}$ crusheth the barren, that beareth not ${ }^{t}$, And doeth not good to the widow"

$22 \mathrm{He}$ attracteth, moreover, other mighty men by his power; 9

* We have translated -ias? here, saith he, instead of saying, which would refer to the eye, and not to the adulterer.

i 1) at. xxviii.16, \&e.

$k$ Gen. xxxiii. 19; Futh ii. 3; 2 Sam. xiv. 30,31 ; xxiii. 12; 2 Kings ix. 21.

$\mu$ he turneth.

$l$ Numb. xxii. 2.1; xx. 17 ; xxi. 22.

$m$ Jer. 1. 38.

y snatch away, spoil. n supravi. 17, 18.

† i.e., they are expert swimmers; when pursued, they will swim across a river.

$\ddagger$ portion, i.e., a parcel of ground, as 2 Kings ix. 21 .

$\S$ i.e., quickly, smoothly, without suffering or pain.

$\|$ i.e., his last illness ought to be of such a loathsome nature, and so protracted, as to make even his own mother leave him to his fate, and him himself long for the grave.

T i.e., to imitate him in his acts of oppression and cruelty.

o supra ix. 23 ; xxi. 13 ; comp. supre riii. $11-15 ; \mathrm{xv}$ 29, 33 ; хx. 5,8 ; xxvii. 18-21.

$\pi$ [the] womb should forget him.

p) supia xrii. 14; xxi. $33,26$.

$\rho$ he should not be remembered again.

$q$ sugravii. 8 ; xriii 17 ; xx.9; Ps. xxxiv. 16, \&c. $\sigma$ was, hath been, broken as the stick, or tree. $\quad r$ supra v. 16; xix. 10 ; xiv. 7 ; Ps. xxix. 5 ; Isa. lxv. 22 . $\tau$ crushing. $s$ l Sam. i. $6 . \quad t$ Cren. xi. 30 ; Judg. xiii. 2. usuproxii.9; xxiv. 3 ; infra xxxi. 16, de. 
$\omega$ riseth he up (i.e., if he riseth up), then he hath no confidence in ; or, he riseth up, and he hath, de.

$\beta$ he must give to him.

a 1 Kings ix. 21; 2

Kings xvii. 3; xxiii. 33.

$\gamma$ and he may be stajed.

$b$ Isa. iii. 1, \&c.

c infra xxxiv. 21.

o have they become exalted.

$\varepsilon$ and (or, then) he [is] not.

$\checkmark$ head of.

$\eta$ ear-of-corn.

d Isa. xrii. 5 ; Jer. li. 33 ; Joel iii. 13.

$\theta$ make me to lie.

e supra xi. 3 ; Prov. xxx. $6 ; 1$ John v. 10.

$\kappa$ make my speech [to] nothing.

$f$ supra xv. 2,3 ; infora xxxiv. 35 ; xxxv. 16; comp. supra xii. 2 ; xix. 2 , \&e.

$g$ supra ix. 4, 10,12 ; xii. $13-25$, \&c. ; Ps. ciii. 19 ; lxvi. $3,4,7$; Dan. iv. 34 ; vii. 14 ; Rev. i. $6, \& c$.

h supra xiii. 21 ; ix. 34 ; xxxvii. 22.

$\lambda$ making.

$i$ comp. supra xxi. 22 ; Ps. cxxxv. 6 ; Dan. iv. 35.

$\mu$ troops.

$k$ Gen. xv. 5 ; Deut. i. $10 ;$ x. 22 ; Heb. xi. 12.

$l$ Ps. xix. 6 ; Míatt. v. 45 .

m supra iv. 17 ; ix. 2 ; xv. $14-16$.

n supra xv. 14; xir. 1, 4; Ps. li. 5; Matt. xi. 11.

o Isa. xiii. 10; Ezek. xxxii. 7 ; Amos v. 20; Eccles. xii. 2; Matt. xxiv. 29; Mark xiii. 24; Luke xxiii. 44, 45.

$v$ or, so that she no longer, \&e.

$p$ Ps. xix. 4. $\pi$ have $\omega$ When he riseth up, not one of them is sure of his life.

$23^{\beta}$ They must ${ }^{a}$ pay him, that they may be in security, $\gamma$ and ${ }^{b}$ stay themselves upon him;

Still, his eyes are upon their ways ${ }^{c}$.*

$24{ }^{\delta}$ If they have become exalted but a little, ${ }^{\epsilon}$ they are undone,

Or humbled, brought to silence, as all others, Or cut off even, as the $\xi$ tops of $\eta$ ears-of-corn ${ }^{d}$. 25 Now, if this be not so, who can ${ }^{\theta}$ prove me a liar ${ }^{e}$,

Or ${ }^{\kappa}$ make my speech nothing worth ${ }^{f}$ ?

\section{CHAPTER XXV.}

1 Then answered Bildad the Shuhite, and said:

$2^{g}$ Dominion and ${ }^{h}$ dread are with Him; $\dagger$

$\lambda$ He maketh peace in His high places. ${ }^{i} \ddagger$

3 Is there any number to His ${ }^{\mu}$ hosts $^{k}$ ?

Yet, upon which of them ariseth not His sun ${ }^{\text {}}$ ?

4. How then can frail-man be just with God ${ }^{m}$ ?

Or, how he be pure, that is born of woman ${ }^{n}$ ?

5 Behold, the despoiling of the moon, ${ }^{\circ} \nu$ how she no longer pitcheth-her-tent ${ }^{p} ! \S$

Yea, the stars $\pi$ are not pure in His eyes!

6 How much less frail-man-a worm ${ }^{q}$ !

And the son of man-an insect!

\section{CHAPTER XXVI.}

1 Then Job answered and said:

$2 \rho^{r}$ What help hast thou given him, that hath no power?

* i.e., he keeps his eye upon them, lest they should become too powerful.

$\uparrow$ i.e., the dread which God inspires is in proportion to His power and dominion.

廿i.e., He maintains harmony among the heavenly bodies.

\$ i.e., how, when eclipsed, she seems no longer to have her pavilion in the heavens. Comp. Ps. xix. 4.

$r$ supra xiii. 4 ; xvi. 2. 
What w succour to the arm, that hath no strength ${ }^{a}$ ?

3 What $\beta$ counsel a" to him, that hath no wisdom ${ }^{b}$, Or what sound-knowledge hast thou $\gamma$ imparted in abundance ${ }^{c}$ ?

4 To whom hast thou uttered these words?

Yea, whose breath hath come forth from thee ${ }^{d}$ ?*

5 The place, where the giant-monsters of the deep are formed-

That, which is beneath the waters $\delta$ and the inhabitants thereof ${ }^{e}$

$6 \in$ The grave-_all these lie naked before $\mathrm{Him}^{f}$,

${ }^{*}$ Nor is there any covering to destruction ${ }^{f} . \dagger$ $7 \eta \mathrm{He}^{g}$ stretcheth out the north o'er the void;

* Hast thou told me anything I did not know before? Hast thou not rather re-echoed my own sentiments? Have not I myself proclaimed the boundless wisdom and might of God?

+ i.e., His eye diveth down to the bottom of the sea, nay it penetrateth even the grave, and witnesseth the decomposition and decay which there go on, in all their stages. Comp. Prov. xv. 11 . [Although it would seem from supra xiv. 11, 12, \&ce, that Job believed man to be altogether annihilated at death, yet it is evident from supra $\times 21,22$, where he speaks of the grave (Sheōl,) as "a land of darkness," \&rc., that, giving the reins to his imagination, he pictured to himself (although no doubt but in dim and shadowy outline) the Bonies of the dend not as lying in their individual graves, but as congregated in some common receptacle, some deep (supre xi. 8) and gloomy realm beneath the earth. Now such a realm seems to me to be better expressed by the word grare (which, when used as a general term (the grave), has, if I mistake not, a very similar meaning), or pit, than by hell, which is used in the A. V., as by hell, like IIcedes and Orcus, we commonly understand a place tenanted by the spinits of the dcad. I hardly agree, however, with Dr. Bernard in thinking that $J_{0 b}$ here intended to allude to the decomposition and decay which take place after death, for, though this meaning may no donbt be extracted from ivị: yet it can scarcely be said to afford a very striking or grand example of the piercing-ken of God, and I therefore prefer to

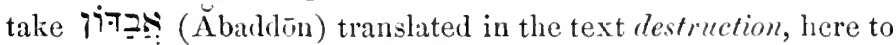
be used concretely of the place to which Job supposed the death-destroyed bodies of mankind to descend, so that it would be nearly equivalent to Sisiv' (Shenl) in the first hem., translated grave. See $A_{1}$ pendix._Editor, 1862.] hast thou succoured.

a supra ri. 11,12 ; xii. 7.

$\beta$ hast thou counselled?

aa supra $\nabla .8$; xi. 13,14 ; xxii. $21-$ 23.

b supra v. 2 ; vi. 13 ; xi. 6 ; xii. 3 ; xiii. 2 ; infra xxviii. 39 [28]; xxxiv. 35 ; $\operatorname{xxx} .16$.

$\gamma$ made to know.

c supra vi. $6,7,25$; xii. 2 ; xiji. $2,4,5$, $7-10$; xvi. 2,3 ; infra xsxii. $3,13$.

d supra ix. 4-12; xii. $13-25$; infra xxvii. 11 ; supra xir. 1-4; ix. 32.

$\delta$ and their inhabitants.

infira xxxriii. 16; Ps. exxrix. 9.

$\varepsilon$ or $[$ the] pit (A.T. hell) ; comp. Prov. ix. 18 and supra x. 21,22 .

$f$ Ps.cxxxix.8; Prov. xг. 11; Heb. iv. 13 ; comp. Prov. viii. 28 .

and [there is] no corering.

$\eta$ stretching out.

y Isa. xlii. 5 ; xliv. 21 ; xlv. 12; 1 's. civ. 2 . 
(1) hanging.

$\beta$ not anything.

$\gamma$ binding up.

$a$ Gen. i. 6, 7 ; Prov. xxx. 4 ; comp. in.

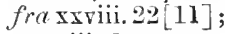
xxxriii, 9.

6 Prov, viii. 28 ; infra xxxviii. 22,37.

c infra xxxvi. 29; xxхrii. 16.

o shutting up.

$\varepsilon$ He hath spread.

d supra xxii. 13,1 i 1 Kings viii. 12 Ps. xevii. 2; Dan. vii. 13; Matt.xxiv. 30 ; xxvi. 64; Rev. xiv. 14

$\zeta$ IIe hath circled a bound.

$e$ Prov. viii. 27.

$f$ infra xxxviii. 10, 11 ; Prov. viii. 29; Jer. v. 22 ; comp. supera rii. 12.

$\eta$ till[the] end of light with darkness.

$g$ comp. supra ix. 6 ; 1 Sam. ii. 8; Ps. lxsv. 3.

$\theta$ from, through.

h P. xviii. 15 ; cri. 9.

$i$ Exod. xiv. 21; Josh. iii. 16 ; Ps. cri. 9.

k infra xxsviii. 11; Jer. v. 22; Ps. lxxxix. 9; Prov. viii. 29.

$\lambda$ hath beautified.

$l$ infir xxxvii. 21,22. $\mu$ fleeing.

$\nu$ ends, extremities, extreme lines.

$\pi$ wlat a trille of a thing.

$\rho$ in it; i.e., in this discourse.

$\sigma$ [the] thinder of His might.

$m$ infio xxviii. 26; xxxrii. $2-5$; xxxviii. 25 ; xl. 9 ; Ps. xxix. 3-9.

$n$ infra xxxri. 29.

$\tau$ added to take up.

$\phi$ impressive-discourse.

o infica xxix. 1; Numb. xxiii. 7, 18 ; xxiv. $3,15,20$, 21, 23 ; Mic. ii. 4 ; Hab. ii. 6. $\omega$ He hangeth the earth upon $\beta$ nothing.

$8 \gamma \mathrm{He}^{a}$ bindeth up the waters in His thick-clouds ${ }^{b}$, Yet the cloud is not rent under them ${ }^{\circ}$.

$9 \delta$ He shutteth up the face of His throne; $\epsilon$ He spreadeth over it His cloud ${ }^{d}$.

$10 \zeta \mathrm{A}{ }^{e}$ circling bound hath He drawn upon the face of the waters ${ }^{f}$,

To endure $\eta$ till day and night have their end.

11 The ${ }^{g}$ pillars of heaven are shaken, And are amazed ${ }^{\theta}$ at His rebuke ${ }^{h}$.

1: By His power, He clove $*$ the sea ${ }^{i}$, And by His understanding, smote He its pride ${ }^{k}$ -

13 With His blast, which $\lambda$ beautifieth the heavens" ${ }^{\prime}$; $†$ With His hand, which formed the $\ddagger^{\mu}$ swift serpent. 14 Lo, these are but ${ }^{\nu}$ outlines of His ways, $\$$ And $\pi$ how small a matter hath $\rho$ here been heard of Him!

${ }^{\sigma}$ His mighty ${ }^{m}$ thunder, also, who can ${ }^{n}$ understand?

\section{CHAPTER XXVII.}

\section{Ani Job $\tau$ again took up his $\| \phi$ parable $^{\circ}$, and said :}

* My friend, Mr. Randolph, suggests that allusion is here made to the Creation as described in Gen. i., where we read in ver. 9, that the dry land appeared in consequence of the gathering of the waters into one place, i.e., in consequence of the division or cleavage of the sea into different portions. This explanation seems to accord very well with the second hemistich, for through this uprising of the land, those bounds, limits or shores were given to the sea, by which its pride is frequently described as being smitten or checked. Comp. infra xxxviii. 10, 11 ; Prov. viii. 29 ; Jer. v. 22, \&c.-Editor, 1862.

$\dagger$ i.e., by chasing away the clouds which at any time disfigure it. t i.e., lightning.

$\$$ i.e., His works.

|| Parable here, as supra xiii. 12, infra xxix. 1, is not used, as in the New Test., in the sense of similitude, but rather in that of a sententious, or weighty and impressive discourse. See Corn. -Editor, 1862 . 
$2 A s$ God $\omega$ liveth, who hath $\beta$ rejected my just-cause ${ }^{a}, \omega[i s]$ living. And the Almighty, who hath ${ }^{b}$ embittered my $a$ infra away. 5 ; soul,

$3 \gamma$ All the while my ${ }^{c}$ breath is in me, And the spirit of God is in my ${ }^{\delta}$ nostrils ${ }^{d}$,

$4 \in$ My lips shall not speak iniquity ${ }^{e}$,

$\zeta$ Nor my tongue utter deceit ${ }^{e}$.

5 Far be it from me, $\eta$ that I should pronounce you right;

Till I ${ }^{\theta}$ die, will I not ${ }^{*}$ put away mine integrity from me ${ }^{f}$.

6 On my righteousness have I laid fast hold, and will not let it $\mathrm{go}^{g}$;

My heart cannot reproach any of my days ".*

7 Let mine enemy be as the wicked,

And he that $\lambda$ riseth up against me, as the iniquitous ${ }^{i} . \dagger$

8 For what is the ${ }^{k}$ hope of the hypocrite, though he get him gain ${ }^{l}$,

Though God ${ }^{\mu}$ grant him to be at ease?

9 Will God hear his cry ${ }^{m}$,

When distress cometh upon him?

10 Can he ${ }^{\nu}$ take pleasure in the Almighty ${ }^{*}$ ?

Can he call upon God $\pi$ at any time ${ }^{\circ}$ ?

11 I will $\rho$ teach you what is in the power of God ${ }^{p}$, For that, which is with the Almighty, I do not conceal ${ }^{q}$ ‡

12 Behold ye, all of you, have seen $i t^{r}$; supra xix. 7 and references there.

$b$ supra iii. 20 ; rii. 11 ; ix. 18 ; xxi. 25.

$\gamma$ that all the while (see Comm.).

c supra xii. 10; Isa. ii. 22 ; xlii. 5 .

$\delta$ nose, nostril.

dinfia sxxiii. 4; xxxiv. 14; Gen. ii. 7 ; vii. 22.

$\epsilon$ if my lips speak.

supra vi. $30 ; \mathrm{xV}$ 5,6 ; xi. $3,4,6$.

$\zeta$ if my tongue uttereth.

$\eta$ if.

$\theta$ gire up the ghost, expire.

$\kappa$ turn away.

$f$ supra ii. 3,9 ; $i n$. fira xxxi. 6.

$g$ supra ii. 3,9 ; xrii. 9; Prov. iv. 13 ; Jer. viii. 5.

h supra vi. 10, 30; ix. 17,$21 ; x .7,15$; xi. 4 ; xiii. 15 ; xri. 17 ; xix. 6,7 ; xxiii. $7,10-12$; infra chap.xxxi.passim; xxxiii. 9 ; xxxiv. 5 ; comp. also vii. 20,21 ; xir. 4; inf'raxl.4; slii. 6.

$\lambda$ [is] raising himself up.

$i$ Ps. xxxrii. 1; lxxiii. 3 ; Prov. xxir. 1,19 , \&c.

lo supra riii. 13,14 ; xi. 20 ; comp. xix. 10.

$l$ Matt. xvi. 26.

$\mu$ ease his soul.

m Ps. xviii. 41 ; lxvi. 18 ; Prov. i. 28 ;

* i.e., there is not a single day in my whole life, on which $I$ Isa. i. 15 ; Jer. xi. 11 ; xiv. 12 ; Ezek. riii. 18 ; Mic. iii. 4 ; comp. supra riii. 20 ; xix. 7 ; infra xxx. 20.

v delight himself upon, on account of. mind, and complain unto God, which he dares not do.

$¥$ So that it is not for you to preach the omnipotence of God to me, but rather for me to preach it to you.

o supra xiii. 16 ; xxiii. 7 ; comp. Ps. xxxiv. 1.

$\rho$ instruct. ix. 4-12. $q$ supra ri. 10 ; comp. xiii. 7-10; infia xlii. 7 . ix. $4-12$.

n supra xxii. 26 ; infra xxxiv. 9; 1's. xxxrii. 4 ; Isa. lviii. 14.

$\pi$ at all time[s].

p supra xii. $13-25$; $r$ supia xii. $13-25$; 
$a$ are re rain [with] ranity.

d supra xiii. 4, 12; xri. 2,3 ; хxi. 34 ; Ixxii. $5,9,12, \mathrm{se}$.

e suprasx. 29; хriii. 21 ; r. $3-5$; riii. $11-15$; si. 20 ; รт. 20-35; xriii. $5-21 ; \mathrm{xx} .5-29$; хxii. 19, 20; хxхіт. $21-27,8 \mathrm{c}$.

f supia xxi. 8, 11; รx. 10 ; гriii. 12, 13, 16, 17, 19; ร下. $30,32,33$; 4 ; i. $18,19$.

$g$ supra r. 20 ; хr. 22 ; xix. 29; infia Ixxiii. 1S; Ixxri. 12; comp. supra Г. 4 ; riii. 4.

h supra xriii. 12, 13;

Lam. ii. 11, 12, 19; comp. supra T. 5 xr. 23.

$\beta$ his remainers, rem. nants, relicts, surrirors.

supra sriii. $19 ; \mathrm{x} \mathbf{.}$. 26.

y his widows.

$k$ Ps. Ixxriii. 6t; Jer. xri. 4-7; xxii. 18, 19.

$l$ Zech. ix. 3 ; comp. supra $\mathrm{x}$ sii. 24,25 ; infra xxix. 18; Gen. xsii. 17, \&e.

$m$ Gen. xlv. 22; Josh. Ixii. S ; 2 Kings $5.5 ; 2$ Chron. ix. 24.

n supra r. 5 ; $x r$. 29 ; хх. 15, 18, 25; Jer. x下. 13; $\mathrm{x}$ rii. 3.

o hath builded.

o supra riii. 14, 15; xт. $3 t$; sтiii. 15, Sc.

$p$ Isa. i. 8 ; Lam. ii. 6 ; comp. Isa. $\mathrm{r}$. 2 ; $x \times$ riii. 12.
Why, then, a do ye behave so altogether vainly" ?*

\section{CHAPTER XXVIII. $\dagger$}

['Thes answered Zophar, the Namathite and said :]

$1[13]$ \& Such is the portion of the wicked man with $\mathrm{God}^{e}$,

And the heritage of oppressors, which they shall receive from the Almighty ${ }^{e}$.

2 [14] If his ${ }^{f}$ children are multiplied, it is for the sword $^{g}$;

And his offspring shall not be satisfied-with bread ${ }^{h}$. $3[15]^{\beta}$ They that ${ }^{i}$ remain of him shall be buried at their death,

But $\gamma$ their widows shall not weep ${ }^{k}$.

4 [16] Though he heap up silver as the dust ${ }^{l}$, And, as the ${ }^{l}$ mire, prepare lim raiment ${ }^{m}$;

5 [17] He may prepare, but the just shall put it on, And the silver shall the innocent divide".

6 [1S] He $\delta$ buildeth his house like the moth ${ }^{\circ}$, Or like the booth which the watchman maketh ${ }^{p} \cdot{ }^{j}$

* i.e., ye have seen and heard me proclaim the Divine omnipotence; why, then, do je indulge in such vain attempts to teach it to me?

+ Our reasons for making Zophar the speaker of our Chap. xxriii., which comprises the last eleven verses of Chap. xxvii.. and the whole of Chap. xxviii., in the text, will be found given at length in the Commentary.

$\ddagger$ The numbers in square brackets indicate the corresponding verses of Chap. xxvii. in the Hebrew text.

§ The booths, lodges, or huts (תְ) which were placed in vineyards and gardens, and were inhabited by the watchmen who guarded the crops, were probably intended to last only one season, and would therefore naturally be constructed of frail and perishable materials. See Isa. i. 8 ; Jon. iv. 5 ; Lev. xxiii. 40-42. From the last of these passages it would appear that booths, or huts (כְכ) were sometimes made of the branches and boughs of trees.-Editor, 1862. 


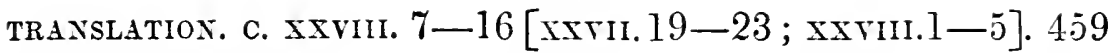

7 [19] He may lie down rich, whis wealth not $\omega$ and it is not gauholly ${ }^{a}$ gathered in ${ }^{b} *$

$\beta$ He openeth his eyes-and ${ }^{c}$ it is not. ${ }^{d}$

$8[20]^{e}$ Terrors $\gamma$ overtake him $\delta$ as waters ${ }^{f}$;

In the ${ }^{f f}$ night, a whirlwind $\epsilon$ stealeth him away ${ }^{g}$. c supra rii. 21 ; riii.

$9[21]$ The ${ }^{h}$ east wind $\zeta$ catcheth him up, $\eta$ and he is gone;

$\theta$ Yea, as a ${ }^{i}$ storm, doth it hurl him from his place.

$10[22]$ Then will he ${ }^{k}$ cast himself upon him, and not ${ }^{l}$ spare,

Who from his ${ }^{k}$ power used hastily to flee ${ }^{m} ; \dagger$

11 [23] He will ${ }^{n}$ clap $^{\lambda}$ his hands at him, And ${ }^{o}$ hiss ${ }^{\mu}$ him out of his place.

(Here begins Chapter xxriii. in the text.)

$12[1] \mp$ Truly, there is an outlet $\nu$ for silver,

And a place $\pi$ for gold, where they refine $i^{p}$.

13 [2] Iron may be taken from the $\rho$ earth,

And stone $\sigma$ be molten into copper ${ }^{q}$.

$14[3] \tau$ Man putteth an end to darkness;

Yea, $\phi$ everything finite $\chi$ searcheth he out ${ }^{r}$,

Even the stone of deep-darliness and the shadow-of-death.

$15[4] \psi \mathrm{He}^{t}$ breaketh away aa rivers from him that dwelleth by them.

$\beta \beta$ So that they are forgotten of the foot ${ }^{\prime} ; \S$ They are emptied, they are $\gamma$ removed by frail-man.

$16[5]$ As for the earth, out of it cometh bread r,

* i.e., he has great riches at home, and also much property in other places.

$\dagger$ i.e., the man, who used to flee from before the wicked $\mu$ upon (or, at) him. tyrant, will take rengeance upon him when he is brought low.

$\ddagger$ The numbers in square brackets now indicate the corresponding rerses of Chapter xxviii. in the text.

$\S$ i.e., by the foot of him who passes over what was their bed.

a Eccles. xi. 1; 1

Kings x. 22.

$b 2$ Kings xix. 35;

Dan. T. 30.

$\beta$ he hath opened.

d supra 5.5 and rer.

5 [1]], note $(n)$.

e supraxr.21 ; Iriii.

11, 14; xx. 25;

infra Ixx. 15 ;

Deut. xxriii. 66,

67; Ps. Ixxiii. 19.

$\gamma$ reacheth,attaineth.

$c$ as the waters, or water.

$f$ supra iii 21 ; Ps. xlii. 7 ; Jon. ii. 3,5 .

ff infra xxir. 20, 25 ; supia si. 1s, 19; Exod. xii. 29, 30 ; 2 Kings xix. 35.

$\varepsilon$ hath stolen.

g supra xxi. 1S; Ps. lriii. 9; Pror. $x$. 25 ; Isa. xl. 24.

$\hbar$ Jer.sriii.17; comp. Ps. xlriii. 7.

$\%$ lifteth him.

$\eta$ and he will go, goeth.

$\theta$ rea, it will storm (or, stormetl) him ont of his place.

i Isa. xxriii. 2; xxis. $6, \& \mathrm{e}$.

$k$ supra ri. $2 \overline{-}$.

lsupra vi. 10; sri. 13.

$\kappa$ or, his hand.

m comp. chap. xrix. with chap. xxx. ; supra xx. 19; 2 Kivgs xix. 21.

$n$ Lam. if. 15 : comp. Pror. xi. 10.

$\lambda$ their hands upon (or, at) them.

Lan. ii. 15, 16 ; Jer. six. 8; xlix. 17 , se.

' for the silver.

$\pi$ for the gold.
$p$ IChron.xxriii. 18 ;

Pror. xrii.3; xxrii.

21: comp. 1 Kings

s. 11,22, se.

$\rho$ or, dust. $\quad \sigma[$ is] molten [or, one melteth stone [into] copler. Ed., 1562.] $q$ Deut. riii. 9. $\tau$ he (or, one) lath put. $\phi$ every end, limit, finite thing. $\chi$ be is starching out. $r$ Eccles. i. 13; rii. 25. s supra rer. 13 [2]. I he (or, one) hath broken. $t$ la. xix. 6 . a a river. $\beta 3$ which [are] forgotten. u comp. Ezek. axis. 11; ssxii. 13.

$v$ infra xxiv. 5 ; Ps. cir. 14. ry hare morel, wore, pass, away. 
$\omega$ as fire [ hich] is stirred up. See Commentary and Append.

a Ezek. xxriii. 14.

$\beta$ its stones.

$\gamma$ sapphire.

b infia rer. $27[16]$ and references there.

$c$ and to it [a e] dusts.

$\varepsilon$ [the] bird-of-pres Enoweth it not.

$\%$ and [the] rulture's ere hath not seen it. c infica xrsix. 29.

d supra sii. 7 ; infra ver. 32 [21]; xsIr. 11.

$\theta$ [the] sons of pride. $\kappa$ he hath put forth. e supra ix. 5 .

$\lambda$ hath orerturned. $\mu$ root.

$v$ hath cleared.

$\pi$ hath seen.

$\rho$ all preciousness, or, evers rarity.

$f$ Pror xxir. 4. g supra sxri. 8.

$\sigma$ hath bound.

$\tau$ from weeping.

h lidden-thing.

$h$ supra xii. 22 ; 1 Cor. ir. 5 ; comp. Isa. xlr. 3 .

$i$ Pror. i. 20-23; iii. $13-20$; ir. 5 13 ; riii. $1-36$; ix. $1-6$; sri. 16 ; comp. supra sxri. 3 ; xr, $2,3, \mathrm{~S}$ : xiii. $2, \overline{0}$; xii. 2,3 ; xi. 6 ; and also supra is. 1 ; xii. 13,16 ; infra xxxri. 4, 5; Ixxrii. 16; Dan. ii. $20,8 \mathrm{c}$.

$k$ Pror.iii.13; ir.5, 7 ; Eccles. rii. 23,24. l infra rer. 31 [?0]. $\chi$ estimation.

$m$ infra $a x x i i .13$.

$a$ infi $a$ rers. $32[21]$, 33 [22] ; Rom.xi. 33 : Pror. riii. 22 -31 .

o Pror. iii. 14; riii. 10,19 ; xri. 16 ; Ps. xix. 9, 10; cxix. 72 .

$\downarrow$ in her stead.

(1) Or, be weighed down bs, outweighed by.

1 Chron. sxix. 4 : Ps. xlr. 9; Isa. siii. 12. $q$ Esod. xxriii.
$r$ supra rer. 17 [6]; Exod. xxir. 10; xxriii. 18; Lam. ir. 7 , fe.

iii. 15 ; riii. 11 ; xx. 15 ; xxxi. $10.2 t$ Ezek. i. $2.2 . \quad \beta$ one

Comment.) [Or, one cannot estcem her [a] gold. Ed. 186?.] $\gamma$ sapphires ${ }^{b}$, not, hand; light ${ }^{h}$. of the living ${ }^{n}$. Ophir ${ }^{p}$; with her ; wishes to form. rocks which he cuts away.
Yet under it, it is $\omega_{\text {as stirred up fire }}^{a}$. $^{*}$

17 [6] He findeth a place, $\beta$ whose stones are

$\delta$ And which hath dust of gold.

$\zeta$ Nor the vulture's ${ }^{c}$ eye hath seen ${ }^{d}$.

19 [8] $\theta$ The proud wild beasts have not trodden it, Nor the fierce-lion passed over it.

20 [9] Upon the flinty-rock * he putteth forth his

$\mathrm{He}^{e \lambda}$ upturneth mountains from their $\mu$ roots. $\dagger$

21 [10] In the rocks he $\nu$ cutteth out rivers, And his eye ${ }^{\pi}$ seeth $\rho$ every precious-thing ${ }^{f}{ }_{+}^{+}$

$2: 2$ [11] $\mathrm{He}^{g} \sigma$ bindeth uprivers, that they trickle not, And so bringeth forth $\phi$ hidden-things to

$23[1: 2]$ But $^{i} \mathrm{Wisdom}$ - whence can she be gotten ${ }^{k}$ ? And where is the place of understanding ${ }^{l}$ ?

24 [13] Frail-man knoweth not her $\chi$ value, Seeing she is not to be ${ }^{m}$ found in the land

25 [14] The deep saith: "She is not in me!" And the sea suith: "Slee is not with me!"

26 [15] ${ }^{\circ}$ Choice-gold cannot be given $\psi$ for her; Nor ${ }^{\circ}$ silver be weighed as her price.

27 [16] She cannot $\omega$ be ralued a with fine-gold of

With the precious ${ }^{q}$ onyx, or the ${ }^{r}$ sapphire ${ }^{s}$. 28 [17] Gold and ${ }^{t}$ crystal $\beta$ cannot be compared

* i.e., there are under it natural, or volcanic, fires, and also artificial fires constantly maintained by the miners.

$\dagger$ i.e., when they interfere with the line of road which he

$\ddagger$ i.e., every precious thing contained in those parts of the

$a$ at. $\quad p$ supra xxii. 24: 1 Kings. ix. 28; $q$ Esod. xxriii. 20 ; sxxix. 13; Ezek. xxriii. 13 . s infra rer. 29 [18]; Pror. 3 one cannot compare to her (See 
TRANSLATION. CHAP. XxNIII. 29-39 [18-2S].

Nor ${ }^{a}$ vessels $^{z}$ of pure-gold be given in ex- $a$ [is] a vesselof finechange for her.

29 [1S] $\beta$ Jewels ${ }^{a}$ of high price, yea $\gamma$ diamonds, $\approx$ Exxrii. 16,29 , 23; shall not be mentioned with her ;-

$\delta$ For the attraction of Wisdom is $\epsilon$ above rubies ${ }^{b}$.

30 [19] The ${ }^{c}$ topaz of Ethiopia cannot be $\zeta$ compared with her;

Neither shall she be $\eta$ valued with pure ${ }^{\theta}$ gold.

31 [20] $\times$ Whence, then, this Wisdom, doth she come? And where is the place of understanding ${ }^{d}$ ?

$32[21]$ Seeing she $\lambda$ is hid from the eyes of all living $^{e}$,

Yea, and from the forls of hearen $\mu$ is concealed ${ }^{g}$.

33 [22] Destruction and Death $v$ say:

"With our ears have we heard her $\pi$ fame.

$34[23]$ "God $\rho$ understandeth her way,

"And He knoweth her place;

$35[24]$ "For HE can look unto the ends of the earth $^{h}$,

"Can see what is inder $\sigma$ the whole heaven;

36 [25] $\tau$ "So that He can make eren a weight for the wind ${ }^{i i}$; ${ }^{*}$

"The waters also $\mathrm{He} \phi$ meteth with a measure ${ }^{k}$. 37 [26] $x^{l}$ "When He made a $\psi$ law for the rain ", $i$ infra xxrrii. 3 ; "And a way for the $\omega$ thunder-flash" ${ }^{m}$;

38 [27] "Then did He see her, and declare her;

"He established her, a yea, and searched her out ;

39 [28] "But unto man He said:

" Behold! the "fear of the Lord-that is wisdom ${ }^{\circ}$,

" And $\beta$ to depart from evil-that is understanding ${ }^{p}$.' "

* i.e., determine the weight of the wind, air. gold her exchange, equiralent. xxxrii. 16, 23 Jer. lii. 19; Ezra i. $6,7,9-11 ;$ r. 14 , \&c.

$\beta$ high-things (Ezek. xxrii. 16; Prov. xхir. 7).

Pror. 5x. 15; supra ter. 27 [16]. $\gamma$ diamond.

$\hat{c}$ seeing that, since.

$\varepsilon$ more than.

6 Pror. iii. 15; riii. 11 ; xx. 15 ; xxxi. 10 ; comp. supra rer. 27 16].

c Esod. Ixriii. 17; Ezek. xxriii. 13; Rer. sxi. 20.

- See rer. $2 S$ [1T].

i) or, weighed dorn br, out weighed br.

$\theta$ fine-gold.

* So wisdom whence doth she come?

d supra ver. 23 [12].

$\lambda$ hath been hidden.

e supra rer. 24 [13].

$f$ supra rer. $18[\bar{\tau}]$.

$\mu$ hath been concealed.

g supra rer. 1s [7]; xii. 7 ; infraxest. 11.

2' hare said.

\# or, report.

$\rho$ hath understood.

h supra xi. 7 : xхri. 6: infra Ixxir. 21, 22 ; Ps. cxxxix. 7-12; Pror. xT. 3 ; Zech. ir. 10; xli. 11; Dan. ix.12.

$\sigma$ all the hesren.

$\tau$ 'so as to make.

ii Pror. x.s. 4.

$\phi$ hath meted.

k Isa. Il. 12; comp. infra sxxriii. 5.

$\chi$ on His making.

l Pror. riii. $27-30$.

$\downarrow$ decree, statute.

Il infra xxsriii. 25, $26,25,37$.

$\omega$ tlash of [the] roices, thunders.

$m$ infra xxsriii. 25. $a$ and also, likewise. n supra ir. 6 ; sr. 4 ; Ps. xix. 9, 10; cxis. 72.

o Ps. cxi. 10; Pror.i. 7 ; ix. 10 ; Eccles. xii. 13. $\beta$ to turn. $p$ Pror. iii. 7 ; riii. 13 ; xri. 6, 17. 


\section{CHAPTER XXIX.}

$\omega$ added to take up. $\beta$ impressive discourse. See Comm. a supra xxrii. 1; Numb. xxiii. 7, 18 ; xxiv. 3,15 , $20,21,23$; Mie. ii. 4 ; Hab. ii. 6 .

$\gamma$ months of formertime, of old.

8 supra i. $1-5$.

$\gamma \gamma$ days God used to keep me.

c suprai. 10.

$\delta$ on its shining, His lamp.

d Comp. supra xviii. 6 ; xxi.17; Ps.xviii. 2S; $\operatorname{cxx} x i i .17$.

e supra x. 3 ; xxii. 28; Numb. ri. 25; Ps. xxxi. 16, \&e. Comp. supra xriii. 5,$6 ; \mathrm{xxi}, 17$, \&e.

$f$ supra v. 14 ; xii. 25 ; Deut. xxviii. 29 ; Isa. lix. 10. $g$ infra xxxiii. 25; Ps. lxxxix. 45; Eceles. xii. 1, \&e.

$\varepsilon$ lit. autumn. See Comm.

$\zeta$ on [the] sccretblessing of God [being], \&e.

h supra i. 10.

$\eta$ On [the] Almighty's yet [being].

i supra i. 2, 4, 5, \&ce; xxi. 8, 11 ; xix. 17 ; Ps. exxvii. $3-5$; exxviii. 3 ; Pror. xvii. 6.

$\theta$ in [the] bathing of my steps.

$\theta \theta$ perhaps eream. (SeeCommentary.)

$k$ Comp. supra xx. 17 ; xxi. 24 ; Cant. v. 12; Geu. slix. 11,12 , \&e.

2 Deut. xxxii. 13, 14; Ps. lxxxi. 16.

$\kappa$ used to pour. going forth to [the] with me. going forth to [the] gate over. supra xix. 1S; infia xxx. 1.
iv. $2 . \quad \pi$ used to lay. $\rho$ to. Mic. vii. 16. $\rho \rho$ they were hid. 26. $r$ infra $x$ lii. $5 . \tau$ esteem 5 , $\sigma$ to

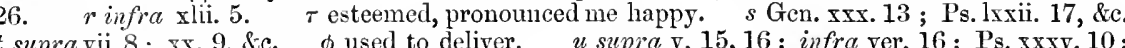
t supra vii. 8; xx. 9, \&c. $\phi$ used to deliver. $u$ supra v. 15, 16 ; infra ver. 16 ; Ps. sxxv. 10; lxxxii. 3,4 ; Prov. xxii. 22, $23 . \quad \chi$ erying. $v$ infra xxx. 20; xxxiv. 28; xxxv. 9, 12; supra xxiv. 12 ; xxvii. 9 ; xix. 7 , \&c. $\quad$ ev supra vi. 27 ; xxii. 9 ; xxiv. 3,9 ; infia xxxi. 17,21 ; Exod. xxii. 22, \&c.

1 And Job ${ }^{\omega}$ again took up his ${ }^{*} \beta$ parable, ${ }^{a}$ and said :

2 Oh that I were as in $\gamma$ months past, ${ }^{b}$ As in the $\gamma \gamma$ days, when God ${ }^{\circ}$ preserved me! $3 \delta$ When His ${ }^{d}$ lamp $s 0^{e}$ shined upon my head, That by its light I could walk in darkness! ${ }^{f}$

4. As I was in the ${ }^{g}$ days of my $\epsilon$ youth, $\zeta$ When the ${ }^{b}$ secret-blessing of God was upon my tent!

$5 \eta$ When the Almighty was yet with me, $\mathrm{My}^{i}$ children round about me!

$6{ }^{\theta}$ When my steps were bathed in ${ }^{\theta \theta}$ milk, ${ }^{k}$ And the ${ }^{l}$ rock ${ }^{k}$ poured $\lambda$ me out rivers of oil $!^{m}$ $7 \lambda \lambda$ When I went forth to the gate, through the city, And in the broad-place ${ }^{\mu}$ prepared my seat!

8 The $e^{n}$ young-men saw me, ${ }^{\nu}$ and hid themselves; Yea, the very-aged ${ }^{\circ}$ rose up, and stood.

9 Princes ${ }^{p}$ restrained their words, And $\pi$ laid their hand $\rho$ upon their mouth. ${ }^{p p}$

10 As to the voice of the nobles_ $\rho \rho$ they hid themselves,

And their tongue cleaved $\sigma$ to the roof of their mouth. ${ }^{q}$

$11{ }^{1}$ For the ear, which ${ }^{r}$ heard of me, rblessed $^{s}$ me; And the ${ }^{t}$ eye, which saw me, bare me witness,

12 That I $\phi$ delivered the poor, ${ }^{,} x$ that cried, ${ }^{\circ}$ And the ${ }^{w}$ fatherless, $\psi$ that had none to help him..$^{x}$

1 Or, For the ear heard and blessed me,

And the eye saw and bare me witness, \&c.-Editor, 1862.

$$
\text { * See note (\|) p. } 456 .
$$

$m$ Ezek. xxxii. 14; Mic. vi. 7 ; Deut. xxxiii. $24 . \quad \lambda \lambda$ on my $\mu$ used to prepare. n supra xxxii. 4, 6, 7; Lev. xix. 32 ; Comp. $\nu$ and were hid, used to be hid. o Lev. xix. 32. p supra pp supra xxi. 5 ; infra xl. 4 ; Judg. xviii. 19; Prov. xxx. 32 ;

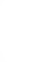



13 The blessing of $\omega$ him, that was ${ }^{z}$ ready to perish, $\underset{z i n f r a}{\omega}$ [one] perishing. a came upon me,

Isa. xxvii. 13.

And I $\beta$ caused the ${ }^{b}$ widow's heart to $\gamma$ sing for joy $a$ used to come.

14 I put on righteousness, and it $\delta$ decked me ${ }^{c}$, My justice-as a robe or a turban ${ }^{d}$.

15 I was ${ }^{e}$ eyes to the blind, And feet was I to the lame ${ }^{f}$.

16 I was a ${ }^{g}$ father to the needy,

$\epsilon$ And the ${ }^{h}$ cause of them I knew not, searched I out.*

17 And $\mathrm{I}^{i}$ brake the grinders of the wicked;

Yea, from his very teeth, did I $\zeta$ pluck the $\eta$ spoil ${ }^{k}$.

$\beta$ used to cause.

b supra $\mathrm{x} \times \mathrm{ii} .9$; $\mathrm{x} \times \mathrm{i}$. 3,21 ; infraxxxi.

16 ; Exod. xxii. 22, \&c.

$\gamma$ utter a joyful, triumphant, shout.

$\delta$ clothed.

$c$ Ps. exxxii. 9 ; Isa. lix. 17; lxi. 10; Ephes. vi. 14-17.

d infra xxxi. 36.

$e$ Numb. x. 31.

f supra iv. 4 .

$g$ infra xxxi. 18 ; Ps. lxviii. 5; Judg. xrii. 10 ; xviii. 19.

$\varepsilon$ And [as for the] cause ...... I used to search it out.

$h$ infia xxxi. 13; supra xxvii. 2; xiii. 18; Exod. xxiii. 3,6 ; Pror. xxix. 7 , de.

$i$ supra ir. 10 ; $\mathrm{Ps}$. iii. 7 ; lriii. 6 ; Lam. iii. 16.

19 "My ${ }^{n}$ root is ${ }^{\mu}$ open to the waters", "And the ${ }^{p}$ dew lieth all night on my $\pi$ branches ${ }^{q}$;

20 " $\mathrm{My}{ }^{r}$ glory will be ever $\rho$ fresh with me, "And my ${ }^{s}$ bow in mine hand ${ }^{t}$ renew its strength. $\ddagger "$

$\zeta$ used I to cast.

$\eta$ or, prey.

k supra xx. 23; Numb. xi. 33 ; 1 Sam. xrii. $35 ;$ Ps. lxxviii. 30,31 ; exxiv. 6.

$\theta$ said [in my heart]; comp. supra i. 5 (note 3).

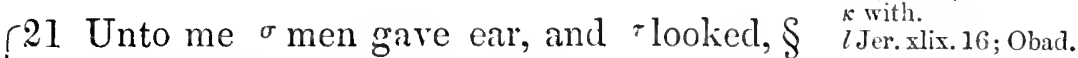
And $\phi$ kept silence ${ }^{u}$ at my counsel.

$A \dagger\{22$ After $x$ my words, $\psi$ they spake not again, ver. 4 ; Ilab. ii. 9 ; comp. Ps. xxx. 6,$7 ;$ supra iii. 25,26 .

I That my speech might still ${ }^{v}$ drop on them.

* i.e., I saw justice done even to perfect strangers.

expe up the ghost, expire.

$m$ Gen. xxii. 17 ; xxxii. 12, \&c.

+ See Commentary, note page 257. The verses n supra riii. 17 ; marked $B$ would seem to come more appropriately after those marked A.

$\ddagger$ See note on bowastring, infra xxx. 11 .

$\S$ i.e., looked, waited, for my advice.

xriii. 16, \&c.

$\mu$ opened.

o supra riii. 17 ; xiv. 9 ; I's. i. 3 ; Jer. xvii. 8 ; Ezek. xxxi. 4, 5, 7, 14, Se.

$p$ Gen. xxvii. 28 ; Deut. xxxiii. 13 ; Prov. xix. 12; IIos. xiv. $5 . \quad \pi$ branch. $q$ supra viii. 16 ; xv. 30, 32; xviii. 16, \&c. . r supra xix. 9 ; ix. 31 ; xvi. 15, \&c. $\rho$ new. $s$ infra xxx. 11; Gen. xlix. 24; 1 Sam. ii. 4; Jer. li. $56 . \quad t$ supraxir. 7 ; Ps. ciii. 5 ; Isa. xl. 31. $\sigma$ they hearkened. $\quad \tau$ waited, hoped, looked for. $\phi$ used to be silent. $\quad$ supra rers.ix. 10 ; infra xxxii. 4, 6. $\chi \mathrm{my}$ word. $\psi$ they used not to repeat [their speceh.] $v$ Deut. xзxii. 2; Prov. v. 3; Cant. iv. 11; Ezck. $x x .16$; xxi. 2, \&c. 
CHAPS. xxIx. $23-25 ;$ xxx. $1-3$.

$\omega$ used to look, wait, hope.

$a$ Deut. xxxii. 2 ; Ps. lxxii. 6; 2 Sam. xxiii. 4 ; Hos. vi. 3.

b supra ver. 19 ; Ezek. ii. 8 ; iii. 2 ; Deut. xi. 11.

$c$ Deut. xi. 14; Prov. xvi. 15; Joel ii. 23 , \&c.

$\beta$ used to laugh, smile.

d Ps. iv. 6 ; xliv. 3 ; lxxxix. 15 ; xe. 8 ; Prov. xvi. 15 ; comp. Neh. ii. 2, 3 ; Eccles. vii. 3. $\gamma$ they used not to make to fall.

e supra x. 15; xi. 15; xxii. 26 ; Gen. iv. 5,6 , \&c.

¿ I used to choose.

$\varepsilon$ used to sit.

$f 1$ Sam. ix. 22.

$\zeta$ used to dwell.

$\eta$ in (or, among) the troop.

$g$ Isa. lvii. 18 ; Ixi. 2,3 .

$\theta$ less than I witl regard to days.

h supra xix. 18 ; comp. xxix. 8; infra xxxii. 6, 7 ; Lev. xix. 32.

$\kappa$ have laughed at me.

$i 1$ Sam. xvii. 43; 2 Sam. iii. 8; 2 Kings viii. 13; comp. 1 Sam. xxiv. 14 ; 2 Sam. ix. 8; xvi. 9 , \&c.

$k$ infra ver. 21.

$\lambda$ [be] to me. $\mu$ had perished.

l Comp. supia xxiv. 10,11 ; Lam. ii. 12,19 .
23 Yea, they $\omega$ looked for me, as for the early rain $^{a}$,

And ${ }^{b}$ opened-wide their mouth, as for the ${ }^{c}$ latter-rain.

24 I $\beta$ smiled at them-they would not believe me; $*$

Yet, the ${ }^{d}$ light of my countenance $\gamma$ they cast not down ${ }^{e}$.

25 I $\delta$ chose out their way, and $\epsilon$ sat at their head $^{f}$;

Yea, I $\zeta$ abode as a king in the midst of his $\eta$ army,

And as one that ${ }^{g}$ comforteth mourners. $\ddagger$

\section{CIIAPTER XXX.}

1 But now, those ${ }^{\theta}$ younger ${ }^{h}$ than myself $\kappa$ hold me in derision,

Whose fathers I disdained to set with the ${ }^{i}$ dogs of my flock.

2 (For whereto, indeed, could the ${ }^{k}$ strength of their hands ${ }^{\lambda}$ profit me?

With them, mature-age ${ }^{\mu}$ was lost ! $\$$ )

3 || Who, cheerless through want and famine ${ }^{\text {, }}$

* When by a smile I endeavoured to make them understand that I had nothing more to say, they would not believe me.

$\dagger$ Impatient though they were to hear me speak, they yet said nothing of a nature to disturb the cheerfulness of my countenance.

\pm It is the custom among the Jews of our day for mourners to sit on the ground, whilst he, who would comfort them, occupies a seat, and this appears from the present verse to have been the custom also in the time of Job.

$\S$ i.e., they passed their time unprofitably, they altogether misspent their life.

II This who (which is transposed from the second hemistich) refers to the young men mentioned in the first hemistich of the first verse.-Editor, 1862. 
${ }^{\omega}$ Flee into a ${ }^{a}$ wilderness, $\beta$ dark, waste and desolate;

4 Who $\gamma$ pluck up salt-wort by the $\delta$ bushes $^{b}$, And $\epsilon$ broom-roots are their bread ${ }^{c}$.

5 They have been driven from the midst of the city ${ }^{\prime}$; $\zeta$ Men cried after them $\eta$ as after a thief ${ }^{e}$. $6{ }^{\theta}$ So that they must dwell in the ${ }^{\kappa}$ clefts $^{f}$ of the valleys, In $\lambda$ holes in the earth and rocks ${ }^{g}$.

7 Among the bushes they ${ }^{\mu}$ groan $^{h}$; Under $\nu$ thorns they are huddled together.*

$8{ }^{i}$ Sons of the $\pi$ impious, yea, sons of men without name ${ }^{k}$,

They have been ${ }^{l}$ beaten out of the land.

9 And now $\rho$ am I become their song ${ }^{m}$; Yea, $\sigma$ I am to them $\tau$ a by-word ${ }^{m}$.

10 They $\phi$ abhor me, they $x$ stand aloof from me ${ }^{\circ}$, And $\psi$ refiain not to ${ }^{p}$ spit before my face ${ }^{q}$.

11 Because $\mathrm{He}+$ hath loosed my bow-string ${ }^{r}$, $\ddagger$ and afflicted me,

Therefore $\psi \psi$ do they let loose their ${ }^{s}$ bridle ${ }^{\omega}$ before me.

12 a Onmyright hand they rise up, the young-brood! They ${ }^{\beta}$ push away my feet ${ }^{u}$, And $\gamma$ raise up against me $\delta$ their $\$$ destructive ways ${ }^{v}$.

\section{They 6 break up my path ";}

* So as to shelter themselves from the inclemency of the weather. $\dagger$ IIe, i.e., God.

$\ddagger$ My bow-string, fig. for my authority, dignity. [See Append.]

$\S$ i.e., the ways by which they bring, or hope to bring, calamity or destruction upon Job. The metaphor is taken from the causeways which used in those times to be thrown up against besieged cities. See note in Comm. on supra xix. 12, p. 166.-Editor, 1862.

|| Do all they can to impede my movements.

$\omega$ who [are] fleeing. a supra $\mathbf{x i v .} 5$; Ps. eix. 10.

$\beta$ darkness, wasteness and desolation. $\gamma$ [are] plucking.

$\delta$ bush.

$b$ Comp. 2 Kings iv. 38,39 .

$\varepsilon$ root of brooms.

$c$ Comp. Exod. xri. 14; Matt. iii. 4.

$a$ Comp. supra xxiv. 4, 5 ; Danl. iv. 25, 32,33 .

$\zeta$ they used to ery upon them, at them.

\section{$\eta$ as the thief.}

$e$ supra xxiv. 14, 16 .

$\theta$ [so as] to dwell.

$\kappa$ cleft.

$f$ Exad. xxxiii. 22; Isa. ii. 21 ; lvii. 5 ; Cant. ii. 14, \&e.

$\lambda$ holes of.

$g$ supra xxiv. 8; Isa.ii. 19; Jer. xiii. 4 ; xri. 16.

$\mu$ lit. bray.

a supra xxir. 12.

$v$ thorn.

$i$ Judg. xix. 22 ;

1 Sam. ii. 12; 2 Sam. xxiii. 6; 1 Kings xxi. 10.

$\pi$ impious-one.

$k$ Comp. supra xriii. 17 ; Ps. cix. 13. Prov. x.7; Eccles. viii. 10; Gen. xii. 2 ; 2 Sam. rii. 9.

$l$ supra ver. 5.

$\rho$ liare I been.

$m$ Ps. lxix. 11, 12; Lan1. iii. 14, 63 ; supra xvii. 6 ; Deut. xxriii. 37; 1 Kings ix. 7 ; P's. xliv. 1t; 2 Chron. vii. 21.

$\sigma$ I have been.

$\tau$ for a word.

$\phi$ have abliorred.

$\chi$ have been far.

o supra xix. 13-15, 19, \&c.

$\psi$ have not withleld spittle.

$p$ Comp. Dent. xxv.

9; Matt. xxvi.67; xxrii. 30, se. $\quad$ q supra xxix. 8, 10. $\quad$ r supra xxix. 20; 1 Sam. ii. 4; Ps. xxxvii. 15; Jer. Ii. 56; Hos.i. 5, ke. $4 \psi$ have they let loose. $s$ Isa. xxxrii. 29; Ps.xxxii.9; xxxix. 1, Se. $\quad \omega$ from my face. a On [the] right. $t$ supra ver. 1 ; xix. 18 ; comp. xxix. 8 ; infra xxxii. 6,7 ; Lev. xix. 32. $\beta$ they have pushed. u supra r. 23 ; Pror. iii. $23 . \quad \gamma$ and have raised. $\delta$ [the] ways of their destruction, calamity. $v$ supra xix. 12; Isa. lrii. 14 ; lxii. $10 ; 2$ Sam. xx. 15; 2 Kings xix. 32; Jer. xviii. 15; Ezek. iv. ㄹ, \&e. $\varepsilon$ have broken up. w supra xix. 8; Isa. iii. 12; Lam. iii. 9; comp. supra iii. 23; Lam. iii. 7; Hos. ii. 6, \&e. 
$\omega$ (it is] not helping.

$a$ Isa. Xxx. 5.

$\beta$ have rolled themselves.

$b$ Isa. lix. 19; xxriii. 2; Ezek. xiii. 11, 13.

c supraxr. 21; xriii. 11,14 ; xx. 25; xxvii. 20 ; Ps. lxxiii. 19, se.

$\gamma$ hath been turned.

$\delta$ it (every one of the terrors) pursueth.

os lit., my noble-one.

$\varepsilon$ thick-cloud.

d supra vii. 9; Isa. 1s. 8; 2 Pet. ii. 17 ; comp. supra xi. 20.

$\zeta$ poureth itself out. y) upon, with, me.

e Ps. xlii. 4, 5 .

$f$ supra xxi. 6 ; xriii. 20 ; Ps. cxix. 53. $g$ supra rii. 4, 13, 14 ; Ps. vi. 6; Deut. xxviii. 67.

hinfra ver. 30 ; xxxiii. 19.

$\theta$ one hath pierced.

$\kappa$ from upon me.

$\lambda$ lie not down.

$\mu$ with greatness of strength.

$\nu$ [the] mouth of, opening of.

i supra ii. 7 ; vii. 5 ; xix. 26.

$\pi$ to the mire (or (elay).

k supra ix. 31 ; infra xl. 13; Ps. xl. 2; lxix. 2, 14; Jer. xxxriii. 22, \&e. $\rho$ so that I compared myself.

linfi $a$ xlii. 6 ; Gen. $\mathrm{x}$ riii. 27.

$m$ supra vii. 5.

n supra xix. 7 ; xri. 18 ; vi. 8 ; vii. 7,20 ; x. 2-22, \&e; comp. infra xxxriii. 2, \&e. o comp. supra ix. 3 ; infraxxxi.35, noten.

p 1 Sam. i. 26 ; Mark xi. 25 ; comp. supra xix. 18, note 1 ; infru ver. 28 ; xxxiii.5; Jer.xviii. 20.
They help on my calamity,

Though $\omega$ it is no ${ }^{a}$ help to them.

14 As through a wide breach they come upon me; In the tempest's stead they $\beta$ roll themselves $i n^{b}$.

$15^{c}$ 'Terrors $\gamma$ are turned upon me;

As the wind $\delta$ they pursue $\delta \delta$ my soul, So that my safety hath passed like $\epsilon$ a cloud ${ }^{d}$.

16 And now is my soul $\zeta$ poured out $\eta$ within me ${ }^{e}$; Days of affliction take hold upon me ${ }^{f}$.

17 By ${ }^{g}$ night my ${ }^{h}$ bones ${ }^{\theta}$ are pierced through $\kappa$ in me,

And my sinews $\lambda$ take no rest ${ }^{?}$.

$18 \mu$ With great effort only can my garment be changed;

It girdeth me like ${ }^{\nu}$ the collar of my tunic ${ }^{i} .^{*}$

$19 \mathrm{HE} \dagger$ hath cast me ${ }^{\pi}$ into the mire ${ }^{k}$,

$\rho$ So that I am become like ${ }^{l}$ dust and ashes ${ }^{m}$. $\ddagger$

20 "I cry aloud unto Thee, but Thou dost not hear me ${ }^{\circ}$;

$\mathrm{I}^{p}$ stand up in prayer, but Thou regardest me not ${ }^{\circ}$.

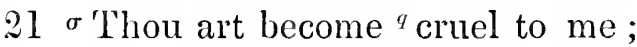

By the ${ }^{r}$ might of Thine hand $\tau$ dost Thou shew Thine ${ }^{s}$ hate towards me.

22 Thou $\phi$ didst lift me up, on the ${ }^{t}$ wind didst make me ride, " $\$$

And now Thy wisdom dissolveth me avay ${ }^{v}$.

23 Of a truth I know, that Thou wilt $x$ bring me back unto death ",

Even to the ${ }^{x}$ house of assembly for all living;

* i.e., owing to the number of the sores, with which he is covered, his garment sticks to, and girds, his body as tightly as its collar does his neck.

+ i.e., God.

$\ddagger$ Alluding to the state of his skin, which in Elephantiasis is said to have very much the appearance of dried and cracked mud. Com. supra vii. 5.

$\S$ Thou didst raise me to the highest pitch of glory and dignity.

$\sigma$ Thou art turned into a cruel-one. $q$ supr $\alpha$ xri. $9,11-14$; ix. $17,30,31$; rii. 14, \&e. $r$ comp. supre xvi. 14 ; xxiii. 6 , \&c. $T$ Thou hatest me. s supre xix.11; xvi. 9; xiii. $24 . \phi$ usedst to lift me up, to make me ride. $t 2$ Sam. xxii. 11 ; Ps. xriii. 10 ; comp. Isa.xl. 31 u Deut. xxxii. 13 ; Isa. lriii. 14; Ps. lxri. 12 . v supra xix. 10 ; xvi.8; xix. 20 ; vii.7; comp. vi. 12 , \&c. $\chi$ eause me to return. $\quad w$ supra $\times$. 9 ; comp. vii. 1,16 ; Eccles. ix. $5 . \quad x$ supra $x$ rii. 13 ; x. 21, 22 ; comp. infia xxxviii. 17 ; Lan. iii. 6 ; Isa. lix. 10 ; Ps. exliii. 3, \&e. 
24. Howbeit, when there is prayer for them a, * $\mathrm{He}$ will not ${ }^{b}$ put forth His hand,

Nor ${ }^{\omega}$ when His calamity $\dagger$ cometh and there is a loud-cry for them ${ }^{a}{ }^{*}$.

25 Did I not weep ${ }^{\beta}$ for him, whose lot was hard ${ }^{c}$ ? Was not my soul grieved for the $\gamma$ needy ${ }^{d}$ ?

26 Verily, I looked for $\operatorname{good}^{e}$, but evil came ${ }^{e e}$; Yea, I hoped for $\operatorname{light}^{f}$, but there came deepdarkness ${ }^{g}$.

$27 \mathrm{My}{ }^{h}$ bowels $\gamma \gamma$ boil, and $\delta$ are not quiet, $\epsilon S o^{i}$ suddenlyare days of affliction come upon me. 28 I $\epsilon \in$ go-about blackened, but $\zeta$ not by the sun ${ }^{k}$; $\dagger$ I $\zeta \zeta$ rise up, I cry aloud in the assembly ${ }^{l}$.

$29 \mathrm{~A}{ }^{m}$ brother am I become to ${ }^{n}$ dragons, And a companion to $\eta$ young owls ${ }^{\circ}$.

30 My skin $\eta \eta$ is black ${ }^{p} \theta$ upon me, And ${ }^{\kappa}$ my ${ }^{q}$ bones are burned with heat.

31 So that my harp $k \kappa$ is turned to mourning ${ }^{r}$, And my lute into the voice ${ }^{\lambda}$ of them that weep ${ }^{r}$.

\section{CHAPTER XXXI.}

1 I $\mu$ made a covenant with mine eyes ${ }^{s}$; How then could I look upon a ${ }^{\nu}$ maid ${ }^{\prime}$ ?

2 Yet what $\pi$ portion "hath been allotted me by God from above?

Or what $\rho$ inheritance ${ }^{\text {w }}$ by the Almighty, $\sigma$ from on high?

3 Should not calamity be for the $\tau$ wicked ",

* i.e., for death and the grave.

+ It is not the sun, which hath given this dark hue to my skin, it is my misery and the force of my disease. a supra xvii. 13,14; xiv. 13 ; comp. vi. 9 ; vii. 15,16 ; xxiii. 17.

$l$ comp. supra vi. 9. $\omega$ when (or, if) in His calamity, i.c., in calamity inflicted by IIim, [there is] a loud ery, \&c. $\beta$ for [the] hard of day.

c supra xxix. 12, 13, $15-17$; infica xxxi. 16-20; Ps. xxxv. 13; Jer. x riii. 20; Rom.xii. 15; Heb. xiii. 3.

$\gamma$ needy-one.

a supra xxix. 16; infice xxsi. 16, 19, 20 ; Ps. xli. 1; Pror. xir. 21, \&le; comp. supra xxii. $6,7,9$.

e suprexxix. 18; Ps. xxx. 6.

ee supra iii. 26 ; iv. 5 , \&c.

$f$ suppo xxir. 3 , notes $d, e, f$.

g supre xriii. 5, notes $d$ and $e$; xxiii. 17.

$h 1$ Kings iii. 26 ; Isa. xri. 11; Jer. ir. 19 ; Lam. i. 20 ; ii. 11 ; Cint. $\mathrm{x} .4$, Se.

$\gamma \gamma$ have been made to boil.

i have not been silent.

$\varepsilon$ days of afliction prevented, antici. pated, me, came upon me before [I expected them].

i supra i. 13-19; ii. 7 ; xx. 23; xxrii. $19-21$; infice xxxir. 20, 205.

$\varepsilon \varepsilon$ have gone about.

$\zeta$ without sun.

linfice ver. 80 ; Cunt. i. 5, 6; Lam. iv. 8 ; 1 . 10 .

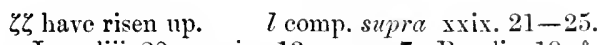
$n$ Isa. xliii. 20 ; xxxiv. 13 ; xxxv. 7 ; Ps. xlir. 19, Sc. Ps. cii. 6 ; Mic. i. $8 . \quad \eta \eta$ hath become black. Ps. eii. 6 ; Mic. i. $8 . \quad \eta \eta$ hath become black. p supra ver. 28 , note $k$.
$\kappa$ my bone. $q$ supra ver. 17 ; Ps. xxxi. 10 ; cii. 3 ; Jer. xx. 9; Lam. xxi. 24. $\quad \kappa \kappa$ hath become. $\quad r$ supra xxi. 12 ; Isa. xxir. S. In of ejes. $s$ Matt. v. 28 ; 2 Pet. ii. $14 ; 1 \mathrm{Joh}$ ii. 16.2, strictly speaking, a young woman whether married or unmarried. $t$ Prov. vi. $25 . \quad \pi$ portion of God. $u$ suprax. $2 y$; xxil. 13 ; Ps. xi. 6 ; Isa. xrii. 14, \&c. $\rho$ inheritance of [the] Almights. $\tau$ iniquitous-man. $\sigma$ from high-pla es. 
TRANSLATION. CHAP. XXXi. 4-10.

$x$ Ps. lviii. 3 ; Isa. i. 4 ; Ezek. xiv. 5.

a supra xiii. 27 ; vii. 12; xvi. 9 ; xxiii. 10; infraxxxiv.21; Jer. xxxii. 19, \&c.

b supra xiv. 16 ; infra xxxiii. 11, \&c.

c Jer. ii. 5; Ephes. iv. 17 ; Prov. xii. 11 ; xxviii. 19.

$d$ Prov. i. 16; Isa. lix. 7.

e supra $\mathrm{xxvii.4;} \times \mathrm{xv}$. 5 ; xi. 3 ; ix. 21 ; xvi. 17, \&c.

$f$ Lev. xix. 36; Dent. xxv.13-15; Prov. xi. 1 ; Hos. xii. 7 ; Amos viii. 5 .

$\psi$ balances of righteonsness, justice.

$g$ Dan. v. 27; Ps.

lxii. 9; Isa. xxvi. 7.

he supraxiii.18; xxiii. 7,10 ; ix. 21 ; x. 7 ; xiii. 15 ; xxiii. 11,12 ; xxvii. 6.

$\omega$ used to turn, or, should have turned. $i$ Ps.xxv. 8.

k supra xxiii. 11; Gen. xviii. 19; Ps. xviii. 21 ; Isa.Xxx. $11, \& c$.

$l$ infra vers. 9, 27; supra ver. 1 ; xi. 13; xxii. 22 .

m supra $\times \mathrm{xv} 12$; хxiv. 15; 2 Pet. ii. 14; 1 Joln ii. 16.

$n$ Dent. xiii. 17.

o supra xi. 14; xvi. 17; 1 Sam. xxiv. 11 ; Ps. vii. 3 ; Jonah iii. 8.

$\alpha$ I should have sown and another should \&e.

$p$ Lev. xxvi. 16 , Jeut. xxriii. 18, 30 , $33,38-40,42$; ef. supra $\mathrm{V} .5$.

$\beta$ my offsprings.

$q$ ver. 12.

$r$ infra ver.27; Deut. xi. 16.

$\gamma$ on account of, or, to.

$s$ Prov. vi. 24, 25 ; vii. 8-23; Jer. v. 8; Matt. v. 28.

$t$ supra xxiv. 15; Gen. xii. 15-18; xx. 3 ; xxvi. 10 ; Exod. Xx. 14; Numb.v.12-27;
And ${ }^{x}$ estrangement ${ }^{*}$ for the workers of iniquity?

4. Doth not He see my ways ${ }^{a}$, And number all my steps $^{b}$ ?

$5{ }^{1}$ Have I walked with vanity ${ }^{c}$ ?

Or hath my foot ${ }^{d}$ hasted to deceit ${ }^{e}$ ?

6 Let Him weigh me in ${ }^{f} \psi$ just balances ${ }^{g}$, And then will God know mine integrity ${ }^{h}$.

7 If my step ${ }^{\omega}$ had turned from ${ }^{i}$ THE way ${ }^{k}, \dagger$ And mine ${ }^{l}$ heart walked after mine eyes ${ }^{m}$, Or any blot had ${ }^{n}$ cleaved to mine hands ${ }^{\circ}$;

8 Then, ${ }^{a}$ when Isowed, another should have eaten ${ }^{p}$, And ${ }^{\beta}$ my produce should have been ${ }^{q}$ rooted up ${ }^{p} ! \ddagger$

9 If mine heart had been enticed ${ }^{r} \gamma$ by a woman ${ }^{s}$, So that I had laid wait at my neighbour's door $^{t} ; \S$

10 Then should my wife have "ground for another, $\|$ 1 Or,

5. If I had walked with ranity, Or my foot had hasted to deceit,

6. (Let Him weigh me in just balances And then will God know mine integrity,)

7. If my step had turned from the way, And \&e., \&e.

8. Then, when I sowed, \&e., \&c.

Ver. 6. is thus parenthetical, and ver. 8 forms the apodosis to ver. 5, as well as to ver.7. This interpretation was suggested to me by Mr. Randolph, and is, I find, also given by Wolfssohn, thongh this Commentator translates somewhat differently. See Appendix. Editor, 1862.

* i.e., estrangement from God, which ought to be the lot of profligate and not of chaste men. [Estrangement is here taken rather in the sense of the alienation of God from man, i.e., the disfavour of God; whereas in the passages quoted in the margin it is the alienation of man from God; i.e., the impiety of man, which is spoken of. Editor, 1862].

+ i.e., from the right way. See Comment.

$\ddagger$ How then was it that I was blessed with such abundant harvests year after year?

$\S$ To watch when he should be from home.

If i.e., should have ground corn, should have had to perform the most menial offices. [Comp. Judg. xvi. 21 ; Lam. v. 13. Editor, 1862].

2 Sam. xii. 9,.11, 13, 14, \&c., \&c. u Judg. xvi. 21 ; Lam. v. 13. 
And upon her others have bowed down ${ }^{a}$ !

11 For this is a ${ }^{\omega}$ heinous crime ${ }^{b}$;

Yea, it is an "iniquity to be punished by the judges ${ }^{d}$. $^{*}$

12 For it is a ${ }^{e}$ fire, which consumeth even to destruction ${ }^{f}$,

And so should have uprooted all mine increase $^{g}$ !

13 If I ${ }^{\beta}$ had slighted the just-cause of my ${ }^{h}$ manservant,

Or my ${ }^{h}$ maid-servant, $\gamma$ when they contended with $\mathrm{me}^{i}$,

14. What then could I have done, if God $\delta$ had arisen?

And if $\mathrm{He} \epsilon$ had visited me, what could I have answered $\mathrm{Him}^{k}$ ?

15 Did not $\zeta$ He that made me in the belly ${ }^{l}$, make him,

And $\eta$ fashion him in $\theta$ a like womb ${ }^{m}$ ?

16 Did I ${ }^{*}$ withhold the poor from their desire " ?

Or cause the eyes of the ${ }^{\circ}$ widow to fail ?

17 Or eat my morsel myself alone ${ }^{p}$, And the ${ }^{q}$ fatherless did not eat thereof?

18 Surely, from my youth, he $\uparrow$ grew up with me, as with a father ${ }^{r}$,

And, as though she had come out from my mother's belly, ${ }^{s}$ so guided I her. +

19 Could I endure to see one perishing without clothing?

$\lambda$ Or the needy, without covering ${ }^{t}$ ?

* If I had been guilty of such a heinous crime as adultery, even mortal judges would have sentenced me to the severest punishments; how then could God have suffered me to remain unpunished?

$\uparrow$ the fatherless.

\$ the widow.

a Deut. xxviii. 30 ; 2Sam.xii.11; xvi. 21,22 ; Jer. viii. 10, \&c.

$\omega$ or, a flagitious crime.

$b$ Gen. xxxix. 9; 2 Sam. xii. 9, 13 ; Ps. li. 1-4, \&c.

c infra ver. 28.

$d$ Lev. xx. 10 ; Deut. xxii. 22 ; Numb. T. 15-27.

e Prov. vi. 27-29.

$f$ Prov. vi. 32.

$g$ supra ver. 8

$\beta$ used to slight, reject ; or, should have slighted.

$h$ Exod. xxi. 26, 27, 32 ; Deut. xxiv. 14; Jer. xxxiv. 8 $-11,14-17$, \&c. $\gamma$ on their contending.

i supra xxix. 16, 17 ; Exod. xxiii. 3,6 ; Prov. xxix. 7 ; supra xiii. 10 ; infra xxxii. 21 ; xxxir. 19 , \&e.

$\delta$ should have arisen. $\varepsilon$ should have visited.

$k$ infra xl. 4,5 ; xlii. 6 ; supra xxv. 4; xxii. $11-17,21$ -23, \&c. ; Nah.i. 6 ; comp. supra xxiii. 4,5 ; xiii. 3 , 22 , \&e.

$\zeta$ my Maker in the belly.

$l$ supra x. 8-11; 1's. exxxix. 1316.

$\eta$ cstablish, found, create.

$\theta$ one womb.

$m$ infra xxxiii. 6 ; xxxiv. 19.

$\kappa$ use to withhold.

n supra xxii. 6, 7,9; xxix. 12, 16, 17 ; infi*a vers. $19,20$.

o supra xxii. 9; xxix. 13 ; infia ver. 18 ; supra xxiv. 3,21 ; Exod. xxii. 2224.

p sipra xx. 21.

$q$ supra xxii.9; $\mathrm{xxix}$. 1.) ; infra ver. 21 ; supra vi. 27 ; xxiv. 3,9 , Ee.; Exod. xxii. 22-24; Matt. xxr. 35, 4.2 ; Tuke xvi. $21 . \quad r$ supra xxix. 16; Jer. iii. 4; 1sa. xxii. 21.
$s$ Prov. ii. 17 ; Ps. xxxv. 14. $\quad \lambda$ or no covering to the needy. $t$ supra xxii. 6 ; infra sxiv. 7, 10; Matt. xxs. 36, 43; Exod xxii. 26, 27; Deut. xxiv. 13 . 
(o) used to keep himself warm.

$\beta$ by means of.

a Isa. x. 32; xi. 15; Zech. ii. 9.

$b$ supra rer. 17 , and references there.

$\gamma$ beeause, or, when,

I nised to see.

c supra r. 4; Prov. xxii. 22; Amos r. 12.

dinfia xxxriii. 15 ;

Ps. x. 15; Ezek. xxx. $21 ;$ comp. supra xxii. 9 ; iv. 10 ; xxix. 17.

$e$ comp. Numb. r. 22,27 ; Acts. xii. 23 ; xxriii. $4-6$.

c [the] calamity of God.

$f$ sima iii. 26; Ps. стіх. 120.

$g$ suma xiii. 11.

$\epsilon$ should not have been able.

h. sipraxxii. 11-17, $21-23 ;$ xr. 4.

i supra xxii. 24, 25; comp.infraxxxri. 18, 19 ; xxriii. 15 $-17,19$; Pror. sri. 16.

$k$ supra viii. 14.

$\zeta$ to the fine-gold.

$l$ comp. supra xrii.

14 , note $d$.

$\eta$ used I to rejoice?

$\theta$ found, attained, acquired.

m supra xv. 29; xx. 15,28 ; xxvii. 16 , 17.

$\kappa$ used I to see?

2 Deut. iv. 19 ; xvii. 3; 2 Kings xvii. 16 ; xxiii. 5 ; Jer. viii. 2.

$\lambda$ used to shine.

$\mu$ going.

o supra ver. 9

$y$ and my hand kissed my mouth.

$p$ Ps. ii. 12; 1 Kings xix. 18; Hos. xiii. 2.

$q$ superxy.12; xriii. 4 ; xxii. 11-14.

$\rho$ a judicial iniquity. $r$ super rer. 11.

$s$ Fxod. xxii. 20; Deut. xiii. 1-11; xrii.e-5; 2 Kings xxii. $] 7,8$

$\sigma$ from above. c) my hater. $\psi$ foumd, reached, him.
20 Did not rather his loins bless me, Seeing he $\omega$ kept himself warm $\beta$ with the fleece of my lambs?

21 If I had " shaken mine hand against the fatherless ${ }^{b}$,

$\gamma$ Because I saw mine help in the ${ }^{c}$ gate ${ }^{*}$

22 Then should my shoulder have fallen from the blade,

Or mine ${ }^{d}$ arm $\dagger$ have been broken from its bone $^{e} !+$

$23 \$$ But $\delta$ calamity from God was a terror to $\mathrm{me}^{f}$,

And, by reason of $\mathrm{His}^{g}$ Majesty, $\epsilon \mathrm{I}$ could not do this thing ${ }^{\text {h. }}$

24 Did I ever make ${ }^{i}$ gold my confidence ${ }^{k}$ ?

$\mathrm{Or} \zeta$ to ${ }^{i}$ fine-gold say: " "Thou art my trust ${ }^{k} "$ ?

$25 \eta$ Did I rejoice, because my wealth was great, And because mine hand had ${ }^{\theta}$ gotten much ${ }^{m}$ ? $26 \kappa$ Did I consider the "sun, when he ${ }^{\lambda}$ shined, Or the glorious ${ }^{n}$ moon, $\mu$ as she moved along;

27 So that my heart was secretly enticed ${ }^{\circ}$, $\nu$ And my mouth ${ }^{p}$ kissed my hand ${ }^{q}$ ?

28 This too had been $\rho^{r}$ an iniquity for the judge ${ }^{s}$,

For I should have denied God $\sigma$ that is above ${ }^{t}$.

29 Did I $\tau$ rejoice at the calamity $\phi$ of him, that hated me ${ }^{u}$ ?

Or $\chi$ exult, when evil $\psi$ befell him?

* If I had even threatened the fatherless with a blow, because I knew the Judge would side with me, if a charge were brought against me.

$t$ i.e., the fore-arm.

\pm i.e., the bone of the upper arm, the humerus.

$\S$ i.e., But I never acted so cruelly, for calamity, \&c. Editor, 1562 .

$t$ supra xxii. 11-14, 23 ; xriii. 4 ; vi. 10 ; xix. 25. $\tau$ use to rejoice. Sam. x xiv. 9-11, 17-19; 2 Sam. i. 12 ; Matt. v. 44, \&c. $\chi$ bestir myself. 
30 Nay, I suffered not even ${ }^{\omega}$ my mouth to $\sin ^{a}$, So as to demand his life with a curse ${ }^{b}$ ?

31 Did not the ${ }^{c}$ men of my tent say, "Oh, that we had of his flesh, we could not $\beta$ glut ourselves therewith " !" *

$32-N o$ ! in the street the stranger $\gamma$ lodged not ${ }^{e}$, My doors I $\delta$ opened to the ${ }^{f}$ wayfarer.

33 Could I, $\epsilon$ after the manner of man, have covered my transgressions ${ }^{g}, \dagger$

So as to ${ }^{h}$ hide mine iniquity through my self-love ${ }^{i}$;

$34 \zeta$ Because I dreaded the great multitude ${ }^{k}$, And the ${ }^{l}$ contempt of families $\eta$ terrified me, $\theta$ So that I stayed within, $\kappa$ and went not out of the door ${ }^{m}$ ?

$\S\left\{\begin{array}{c}35-{ }^{\lambda} \text { Oh that I had one, who would hear } \\ \text { me }{ }^{n} \text { ! } \\ \text { Behold } \mu \text { what I have marked down }{ }^{\circ} \text { ! Let } \\ \text { the Almighty answer me }{ }^{n} \text { ! } \\ \text { Or the book, which }{ }^{\nu} \text { mine "Adversary } \\ \text { hath written }{ }^{r} ! \|\end{array}\right.$

* They found fault with me on account of the lukewarmness of my latred towards my enemy, whilst their hatred of him was so great that they could, as it were, have eaten him up.

† i.e., Was I capable of covering my transoressions? [i.e., transgressions, or sins, such as those which Job has just been enumerating. The Heb. עִ which is eommonly translated in the A.V. transgression, or trespass, is certainly not a milder

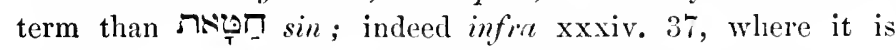
translated rebeilion, it would seem to designate a still graver offence. I make this remark because in Eng. transgression and trespass are commonly used of milder offences thin those designated by the word sin. Editor, 1862.]

$\$$ Job does not mean to say here that he had acturlly committed transgressions, and liad actually made a public confession of them, he merely assures his hearers that, if he had committed sin, he would have confessed it publicly. See Comm. pp. 286, 287. Editor, 1862.

$\S$ See Commentary, note page 28s, where it is argued that the vers. marked $A$ and $B$ miglit, very appropriately, elange places.

$\omega$ my palate.

a supra ii. 10 ; Ps. xrii. 3 ; xxxix. 1 ; Pror. xiii. 3.

$b$ Matt. v. 44; Rom. xii. 14 .

c 1 Sam. xxiv. 4.

$\beta$ be glutted.

d supra vi. 27 ; xix.

22 ; Ps. xxvii. 2.

$\gamma$ used not to lodge.

$e$ Gen. xix. 2 ; Judg.

xix. 15, 17-21;

Heb. xiii. 2.

$\delta$ used to open.

$f$ Judg. xix. 17 .

$\varepsilon$ as a man.

I supia xr. 5, 12; vi. 30 ; xxrii. 4 ; ver. 5 ; Ps. lxxriii. 36,37 .

h. Ps. xxxii. 5; Isa. xxix. 15.

$i$ supra vi. 10 ; x. 7 , 15; xi. 4; xvi. 17; xxiii. $10-12$; xxrii. $2,5,6$; xxxiii. 9,27 ; xxxy. 2.

$\zeta$ or, beeanse [if I had committed sin] I should have dreaded.

k supraxii. 2 ; infira xxxii. 9; Ps. lvi. 11 ; cxriii. 6 ; Heb. xiii. 6

$l$ supia xii. 4 ; Ps. xxii. 7,8 ; xlii. 10 ; Matt. x. 22, 28,32 .

$\eta$ would have terrified me.

$\theta$ so that I kept still, i.e., so that I should, must, have kept still, stayed within.

$\kappa$ [ind] should not liase gone out.

$m$ supra xr. 23; Exod. xii. 므.

$\lambda$ Oh that to me [there were] one histening to me!

$n$ sepre $\mathrm{xxx} .20$; xix. 7 ; comp.ri. S; vii. 7; ix. 3 : x.9; siii. 3,19-21: xir. 11, 15 ; xri. 21 ; sxiii. $3,5,9$.

le my mark; i.e., whint I have marked down, my written defence.

o supre xiii. 18; xinit. 4. p supra xiii. 22 ; ix. 32 ; xxxiii. 5 ; xxxriii. 3 ; xl. $2,4,7 . \quad v$ [the] man of my strife. q supra xri. 9 ; xiii. 24 ; $\mathrm{x} \times x .21$. $r$ supra xxiii. 5 ; xiii. 23 . 
$\approx$ Isa. ix. 6; xxii. 22 ; Ezek. xii. 7, 12 , \&e.

$\omega$ crowns to me.

a supra xxix. 14; Prov. xii. 4 ; xri. 31 ; Matt. xxrii. 29.

b supra xxiii. 10.

c supra ver. 4 ; xiv. 16; xiii. 27 ; xxxiii. 11.

d supra xiii. 15; sxiii. 11, 12 ; xxrii, 6.

e supra хxix. 8-10, $21-25$.

$\beta$ used to cry out.

$\gamma$ together used to weep.

$f$ Isa. xxiv. 4; xxxiii. 9 ; Jer. xii. 4,11 ; Joel i. 10 ; Ps.lxv. 12, 13 ; Isa. lv. 12 ; Gen. iv. 12.

$\delta$ strength withont silver.

$\varepsilon$ caused [the] soul of its owners to breathe (be breatlied) out.

$g \operatorname{supr} \alpha \mathbf{x x} .19$; xxii. $5-9 ; 1$ Kings xxi. $2,6,13,15$.

$\zeta$ gone forth.

$\eta$ thorn.

$h$ Gen. iii. 17, 18 ; Jer. xii. 13 ; supra ver. 8 ; Lev. xxvi. 16 ; Deut. xxviii. 18, \&c.; Mic. ri. 15; Isa. lv. 13.

$\theta$ noisome-weed.

$i$ comp. Isa. v. 2,4 .

$k 2$ Sam. xxiii. 1.

$\kappa$ from answering.

l supra vi. 10,24,29, 30 ; ix. 17, 21-21, 30,31 ; x. 7,15 ; xi. 4 ; xiii. 15,16 , 18, 23, 26; xvi.17; xix. $6,7,28,29$; xxiii. $7,10-12$; xxvii.2-6; $\mathrm{xxx} .20$ -22 ; xxxi. $35-$ 37 , and passim; infra xxxiii. 9 ; xxxiv. 5 ; хxxv. 2. $m$ Gen. xxii. 21 ; 1 Chron. $\nabla .14$; Jer. $x \times v .23$.

$n$ Ruth iv. 19 ; 1 Chron. ii. 9, 10 , 25,27 . $36^{\mathrm{l}}$ Would I not bear it upon my shoulder ${ }^{z}$ ?

I would bind it $\omega$ round me as a ${ }^{a}$ diadem. ${ }^{b}$ *

37 The number of my steps ${ }^{c}$ would I declare unto $\mathrm{Him}^{d}$;

As to a prince, draw near to $\mathrm{Him}^{e}$. $\dagger$

38 If my land $\beta$ had cried out against me, And its furrows $\gamma$ all had wept ${ }^{f}$,

39 If I had eaten its $\delta$ produce without payment,

Or $\epsilon$ caused the owners thereof to breathe out their life $^{g}$;

40 Then, instead of wheat, should have $\zeta$ sprung up $\eta$ thorns $^{h}$,

And ${ }^{\theta}$ noisome-weeds, instead of barley ${ }^{i}$ !

TIIE WORDS OF JOB ARE ENDED ${ }^{k}$.

\section{CHAPTER XXXII.}

1 So these three men ceased $\kappa$ answering Job, because he was righteous in his own eyes ${ }^{l}$.

2 Then was kindled the anger of Elihu, the son of Barachel, the ${ }^{m}$ Buzite, of the family of ${ }^{n}$ Ram;

1 Or, Surely, I would bear it, \&c. Editor, 1862.

* The accusations brought against me by my Adversary (i.e., Grod) would, I know, so clearly establish my innocence, that, far from marking me with a brand of infamy, they would be unto me a badge of honour.

+ To my Adversary. So far from approaching IIim in an attitude of arrogant defiance, I would draw near unto Him with the greatest deference and respect.

$\ddagger$ Sec Commentary, note 288 . 
against Job was his anger kindled, w because he considered himself more righteous than God $^{a}$.

3 And against his three friends was his anger kindled, because they had $\beta$ found no. answer, and so pronounced Job wicked ${ }^{b}$. ${ }^{*}$

4 Now Elihu $\gamma$ had delayed to speak concerning $\mathrm{Job}$, because they $\dagger$ were older than himself $\delta$ in days.

5 But, when Elihu saw, that there was no answer in the mouth of the three men, then was his anger kindled,

6 Then Elihu, the son of Barachel, the Buzite, took up his discourse, and said:

Young am $\mathrm{I} \delta$ in days, and ye are very old ${ }^{c}$,

Therefore $\epsilon$ held I back, and was afraid ${ }^{d}$

$\zeta$ To ${ }^{e}$ shew you mine'opinion.

7 I thought: Days $\ddagger$ should speak,

Seeing that a multitude of years $\eta$ teach wisdom ${ }^{f}$.

8 But, verily, it is the ${ }^{g}$ spirit uhich is in frail-man, And the breath of the Almighty, which ${ }^{\theta}$ giveth him understanding ${ }^{h}$.

9 Multitudes are not always wise ${ }^{\text {, }}$

Neither do the aged always * perceive that which is right ${ }^{k}$.

10 Therefore $I^{\lambda}$ say: ${ }^{l}$ " $m$ I Icarken unto me;

"I, yea I also, will shew mine opinion "."

11 Behold! I ${ }^{\circ}$ waited for your words;

I $\mu$ gave ear to your reasonings, until ye should have searched out the ${ }^{\nu}$ matter.

$12 \rho$ But, though I attended unto you,

* Because finding no other answer (i.e., seeing no other means), by which they could establish the justice of God, they pronounced Job guilty.

+ i.e., the three friends of Job.

† Days, i.e., many days, old age, or those whose days are many, old men. Editor, 1862.

because of his making, considering, himself righteous more than God.

$a$ See ver. 1, note $a$; infra xxxiii. 9; xxxiv. 5 ; xxxv. 2.

$\beta$ had not found an answer.

$b$ iv. $17-19$; v. 17 ; viii. $3,5,6,13-$ 15 ; si. $2-4,6$, $13-15$; xง. $4-6$, $12-16,20-35$; $x$ viii. 5-21; $x x$. 5-29; rxii. 5$17,21-23$; xxv. 4-6; xxvii. $13-$ 23 ; eomp. six. 3 , 28,29 ; xiii. 4 , se.

$\gamma$ had been waiting with [his] words eoncerning Job.

$\delta$ as to, with respect to, days.

c supra $\times \mathrm{xr} .10$.

$\varepsilon$ I erept.

d supra xxix. 8, 21, 22 ; Lev. xix. 32.

$\zeta$ from, of, showing. e supra xv. 17; infia vers. 10,17 ; xxxvi. 2.

$\eta$ make to know.

f supra xii. 12,20 ; xv. $7-10$.

g supra $\mathbf{x x .} 3$; infra xxxiv. 14; Prov. x. 27.

$\theta$ maketh them to understand, to luave understand. ing, rendereth them intelligent.

$h 1$ Kings iii. 9, 11, 12.

$i$ Exod. xxiii. 2; 1 hings xix. 10 , sc.

$\kappa$ perecire justice.

i. 1 Sam. iii. 13 ; iv. 15.

$\lambda$ said.

l. supra xiii. 4, 17, xxi 2 ; infiraxxiii. 1 , 31 ; xxxiv. 2, 16 ; slii. 4.

$m$ infra xxxiii. 1, note $g$.

$n$ supra ver. 6 ; infia ver. 17 ; xxxvi. 2 . o supra rer. 4.

$\mu$ I kept giving ear. $\nu$ matters.

$\rho$ but I kept attending unto you, and behold, \&c. 
$\omega$ conrineing.

a supra xxxi. 3537 , and passim.

$\beta$ answering.

b supra rer. 3 ; xxi. 34 ; xvi. 2,3 ; xiii. 4,5 ; xii. 3 , sc. ; infra xlii. 7 .

c supre xлviii. 12, 20,$21 ; x \vee .2,3$, 8 ; xiii. 2 ; xii. 2 ; xi. 6 ; Jer. viii. 8 .

d supra $\mathrm{x} \times \mathrm{r} .4-6$; xv. 14-16; iv. $17-19$; xix. 5 ; riii. 3 ; v. 17 , \&c. ; infia xxxiii. 12 ; xxxiv. $10-12$; xxxv. 2 ; xxxvi. 3,4 ; comp. ri. 4 ; x. 2 ; x ri. $11-14$, \&c.

$\gamma$ set in order, arrange, dispose, set, direct.

e supra $x$ xiii.4; infra xxxiii. วे; xxxvii. 19 ; Ps. v. 3.

f supra xvi. 4, 5 .

$\delta$ broken.

$\varepsilon$ words, matters.

g supra xix. 2-5; xvi. 2,3 ; xiii. 2 , 4 ; xii. $2,3$.

h supra vers. 4, 6, 11.

$\zeta$ kept waiting.

$\eta$ that they should not speak.

$\theta$.that they stood, stopped.

$i$ supra vers. 6,10 ; xv.17; infia xxxvi. 2.

$\kappa$ have been full.

$\lambda$ [the] spirit of $\mathrm{my}$ belly, body.

$k$ supra ver. 8 ; $x \mathbf{x}$. 3.

$\mu$ hath constrained me.

$l$ Ps. xxxix. 3 ; Jer. xx.9.

m supra xv. 2, 35; Ps. xliv. 25, \&c. $\nu$ is not opened.
Yet behold! there was not one of you, w that convinced $\mathrm{J}_{\mathrm{ob}}{ }^{a}$,

Not one of you, $\beta$ that answered his speeches ${ }^{b}$. 13 Peradventure ye will say: "We have found out wisdom ${ }^{c}$

"It is God that thrusteth him down, not man ${ }^{d} . " *$

14 But why did he not $\gamma^{e}$ direct his words unto me?

I indeed should not have answered him with your speeches ${ }^{f} \cdot \dagger$

$15 \ddagger$ They were $\delta$ confounded; they answered no more ;

'They put away the $\epsilon$ matter from them ${ }^{g}$.

16 So I ${ }^{h} \zeta$ waited $\eta$ until they spake no longer,

Until they ${ }^{\theta}$ ceased, and answered no more.

17 I, yea I also, will speak my part, I, yea I also, will shew mine opinion ${ }^{i}$.

18 For I $\kappa$ am full of words;

$\lambda$ The ${ }^{k}$ spirit within me ${ }^{\mu}$ constraineth me ${ }^{l}$.

19 Lo! my ${ }^{m}$ belly $\|$ is as wine, which $\nu$ hath no vent;

* Peradventure ye will say: The wisest answer we could have given Job was the one we did give him, namely, that since his aftlictions came upon him from God he must needs have richly deserved them.

† I should not, like you, have adopted a line of argument, which, far from being calculated to convince a man conscious of his innocence, could only tend to exasperate him.

* It will be observed that in this and the next verse there is a change of person, and that Elihu no longer addresses himself to Job's three friends, but speaks of them. See Comm. p. 301, note; and comp. supra xxx. 19-24, where He, His, Thou, Thine, \&c., all refer to God. Editor, 1862.

$\$$ Instead of bringing forward arguments against him, they thought it quite sufficient to declare, that he was punished because be deserved punishment, and therewith dismissed the matter.

II i.e., my inward parts, my mind. See supra xv. 2, 35, \&c. -Edilor, 1862. 
TRANSlation. ChaPs. Xxxit. $20-22 ;$ xxxili $1-5$.

Like ${ }^{a}$ new $\psi$ bottles, ${ }^{\omega}$ it is ready to burst.** 20 I will speak, $\beta$ that I may be eased ${ }^{b}$;

I will ${ }^{c}$ open my lips, and take up my dis- $\omega$ it will be cloven, course.

21 I will not now accept $\gamma$ any man's person ${ }^{d}$, Nor will I to $\gamma \gamma$ any man use flattering words.

22 For I know not how to use flattering words ${ }^{e}$; Nay for this almost must my ${ }^{f}$ Maker forgive me.†

\section{CHAPTER XXXII.}

1 So ${ }^{g}$ hear then, O Job, my words, And to all my speeches give ear.

2 Behold now! I have ${ }^{h}$ opened my mouth, My tongue hath spoken in my palate ${ }^{i}$.

3 The uprightness of my heart shall be $\delta$ mine eloquence ${ }^{k}$,

And my knowledge, that my lips $\epsilon$ speak clearly. $\$$

4 The ${ }^{l}$ Spirit of God hath made me, And the breath of the Almighty preserveth me alive. $\|$

5. If thou art able, $\zeta$ return me answer ${ }^{m}$;

${ }^{n}$ Set thy words in order before me, $\eta$ stand $^{\circ}$ up.

* New bottles (wine-skins) were more likely to burst than old ones, because as we learn from Matt. ix. 17, new and fermenting wine only was put into them.-Editor, 1862.

$\dagger$ I shall certainly never be called upon to repent for haring applied flattering epithets to any man, on the contrary, I may hare to seek forgiveness from my Maker for having, whenever I thought people required correction, arministered it to them in terms calculated perhaps to hurt their feelings.

+ I refrained from speaking as long as I was able, but now that I have once begun, I must be suffered to go on.

$\$$ I lay no claim to eloquence; all that I can promise is, to speak witl sincerity and clearness.

II I am a man like thyself, and so thou neckest not fear to contend with me, if thou thinkest I am wrong. 
()) to thy mouth.

$\beta$ for God.

a supra $\mathrm{xxxi}, 35-$ 37 ; xxx. 20 ; xxiii. $3-9$; xvi. 21 ; xiii.3, 18-21, \&c.

b supra iv. 19; xiii. 12 ; 2 Cor. $v .1$

c comp. supra ix. 34 ; xiii. 21 .

$\gamma$ my pressure, urging.

$d$ comp. supra $\mathrm{xxx}$. 21, 22; xxiii. 16 ; xix. 22 ; xvi. 9 ; xiii. 24-27; vii. 17-19, \&e.; infra vers. 10,11 .

$\gamma \gamma$ be heary.

$e$ supra xiii. 17.

$\delta$ I kept hearing.

is to me.

f supra vi. 30 ; ix. 21 ; x. 7,15 ; xi. 4 ; xri. 17 ; хxiii. $10-12$; xxvii. 2 -6 .

g supra ix. 30,31 ; x. 6 ; xiv. 16,17 , \&c.

$\varepsilon$ foratenemy to him. h supra xiii. 24 ; xvi. 9 ; xix. $11 ; \mathrm{xxx}$. 21.

i supra xiii. 27.

$k$ supra xiii. 27 ; xiv. 16 ; xxxi.4; comp. supra vii. 12, 17 -19 ; x. 20 ; xiv. 6.

$\zeta$ hast not been right.

l supra iv. 17-21;

xv. 14-16; xxv. $4-6$; cf. ix. 32 ; infra xxxr. 2.

$\eta$ to, against, Him.

m supra vii. 20 ; $\mathbf{x}$. 2 , et passim.

$\theta$ answer, declare all His matters.

n supra ix. 3, 12 ; xi. 10 ; xii. 14 ; Dan. ir. 35, \&c.

o infra xl. 5.

$\theta \theta$ one do not, \&c.

p supra iv. 13-21; Gen. xx. 3, 6; xxxi. 24; Numb. xii. 6; Dan. ii. 28.

$\kappa$ on [the] falling of dcep-sleep.

$q$ supra iv. 13.

$\lambda$ openeth [the] ear of men.

$\mu$ seal.

$r$ Gen. xx. 3 ; xxxi. $24 ; 2$ Kings xx. 1 .
6 Behold! I am, according $\omega$ to thy words, $\beta$ in the stead of $\operatorname{God}^{a}$; *

Of ${ }^{b}$ clay have I also been cut out.

7 Behold! ${ }^{c}$ my terror $\dagger$ need not dismay thee, Nor $\gamma$ mine importunity ${ }^{d} \gamma \gamma$ bear heavily upon thee.

8 But, thou didst say in mine ${ }^{e}$ ears, Yea, I $\delta$ heard the sound of words like these:

9 "I am pure, without transgression;

"I am clean, neither is there iniquity $\delta \delta$ in $\mathrm{me}^{f}$.

10 "Behold! He findeth occasions $\ddagger$ against me ${ }^{g}$ ! "He counteth me ${ }^{\varepsilon}$ for His enemy ${ }^{h}$ !

11 " He putteth my feet in the stocks"

" He watcheth all my ways ${ }^{k}$ ""

12 Behold! in this (I will answer thee) thou $\zeta$ art not right,

For God is greater than frail-man ${ }^{2} . \$$

13 Why didst thou contend $\eta$ with Him $^{m}$ ?

For He will not ${ }^{\theta}$ give account for any of $\mathrm{His}$ doings ${ }^{n}$.

14 But, surely, in ${ }^{\circ}$ one way God speaketh, Yea in ${ }^{\circ}$ two, if $\theta \theta$ man do not regard it. $\|$

15 In a dream, a vision of the night ${ }^{p}$, $\kappa$ When deep sleep falleth upon men ${ }^{q}$, In slumberings upon the couch.

16 Then $\mathrm{He}{ }^{\lambda}$ discloseth unto men, That He will ${ }^{\mu}$ decree their chastisement ${ }^{r}$;

* Thou hast expressed the wish, that thou mightest plead before God; this wish of thine is granted, for, see, here am $I$ in the stead of Grod, a substitution of persons which offereth thee this great advantage, that thou needest not stand in awe of thy opponent.

+ i.e., the terror which I can inspire.

$\ddagger$ Occasions for doing me hurt.

$\S \mathrm{He}$ is so great and exalted a Being, that we cannot but conclude that His object in inflicting sufferings upon frail men, the work of His hands, is their good, not His pleasure.

$\|$ i.e., do not regard the first way, in which He speaketh to him. 
$1 \tau \times$ So that He may remove from man his evil $x$ in order to turn doings,

$\omega$ From man the pride, which he concealeth ${ }^{b}$.

18 That He may keep back his soul from the pit ${ }^{c}$, And his life from ${ }^{\beta}$ perishing by the ${ }^{d}$ sword.*

$19 \mathrm{Or}$ he is chastened with pain upon his couch ${ }^{e}$, So that the ${ }^{f}$ strife of his limbs is vehement,

20 And his appetite $\beta \beta$ abhorreth bread ${ }^{g}$,

Yea, his soul his $\gamma$ favourite food.

21 His flesh $\delta$ wasteth $^{h}$ away out of sight,

So that his bones, which $\epsilon$ were not seen, $\zeta$ stick out ${ }^{i}$.

22 And his soul $\eta$ draweth near unto the pit ${ }^{k}$, And his life to ${ }^{\theta}$ the ${ }^{l}$ destroyers. $†$

$23 Y$ et, if there be in his behalf an interceding angel $^{m}$,

$B u t^{n}$ one ${ }^{\theta \theta}$ among a thousand,

To declare concerning that man his uprightness ;

24 Then HE $\S{ }^{k}$ hath ${ }^{\circ}$ compassion upon him, and $\lambda$ saith :

"Deliver him from going down to the pit ${ }^{p}$;

"I have found a "ransom." $\|$

25 Then ${ }^{\mu}$ his flesh becometh fresher than in childhood $^{r}$;

He returneth to the days of his youth ${ }^{s}$.

26 He prayeth unto God, and He ${ }^{\nu}$ accepteth him ${ }^{t}$, So that he $\pi$ seeth His face with $\rho$ shouts-of-joy ",

* i.e., by a violent and untimely death.

+ i.e., to the angels whom God chargeth to remove man from this world. Comp. 2 Sam. xxiv. 16.

$\ddagger$ Though among a thousand angels, who bear record to Heaven of the deeds of man on earth below, but one be found who can declare, that the man who is suffering from Heavensent disease, has done a single good action.

$\S$ i.e., that is God.

II That one good action of his I accept as redeeming his iniquities, and grant him My pardon.

$r 2$ Kings v. 14. $s$ Ps. ciii. 5 ; Isa. xl. 31. v He hath accepted him. (w) and from.

6 l Kings xxi. 1824,27-29; Deut. viii. $2,3,16$; Jas. i. 12,13 .

c infra vers. 22, 24, 28, 30 ; Jonah ii. 6 , de.

$\beta$ passing over, awas, crossing [to death].

a supra r. $20 ; x \mathrm{x}$. 22 ; xix. 29 ; xxvii. 14.

e supra $\mathrm{xxx} .17$; vii. 4, 13; 2 Kings xx. $1,3,5$; 2 Cliron. xxxii. $24-26 ; 2$ Kings i. 2, 6, 16; comp.also 2 Kings xx. 12-19 with 2 Chron. xxxii. 31.

f supraxxx. 17, 30. $\beta \beta$ abhorreth it, [namely] bread.

g supra vi. 7 ; Ps. eii. 4.

$\gamma$ food of desire.

i wasteth from sight.

h supra xvi. 8; xvii. 7.

$\varepsilon$ were not seen.

$\zeta$ are (lit., have been) made high.

$i$ supra xix. 20.

$\eta$ hath drawn near.

k supra ri. 11, 12; vii. 21 ; xri. 7 ; xvii.15, 16 ; xix.10. $\theta$ the making to die. $l 2$ Sam.xxiv. $16,17$. m supra xxii. 29,30 ; infira xlii. S; Gen. xriii. $2+-322 ; x x$. 7 ; Isa. lix. 16 ; eomp. Gen. xxxix. 5, Sc.; Dent. v. 5 ; Gal. iii. 19, 20, Sce.

n supra ix. 3.

$\theta \theta$ from, out of.

$\kappa$ had compassion.

o 2 Sam. xxiv. 16; Ps.xe. 13; exxxr. 14.

$\lambda$ said.

p supra rers. 18, 22, infra vers. 28, 30.

$q$ infia xxxri. 18; Ps.xlix. 7, 8; Hos. xiii. 14 .

$\mu$ hath . . . becomo fresh more than [in] childhood.

infra xlii, 8,$9 ; 2$ Tins cili $5 ;$ Ta 19 ; Hos. v. 15. $\pi$ hath seen. $\rho$ shout-of-joy. u P's. xlii. 4; xev. 2 ; c. 2,4 , de. 
478 TRANSLATION. CHAPs. xxxili. $27-33 ;$ xxxiv. $1,2$.

$z 1$ Sam. xxvi. 23 ; Ps.vii.8; xviii. 20; comp. Lev. xxiv. 19 ; Judg. i. 7 ; Ps. lxii. 12; Isa. xxxiii. 1, \&e.

a supra xxxi. 33,34 . $\psi$ said.

$b$ Acts xxri. 9-12; Jas. v. $16, \&$ e.

c comp. supra ri. $10,24,29,30$; ix. 17, 21-24, 35 ; x. $3,7,15$; xiii. 15, 18, 23 ; xvi. 17 ; xix. 7 ; xxiii. 7 , $10-12$; xxvii. 2 , 4-6 ; and especially chap. xxxi., throughout which Job most empha. tically declares his innocence.

d supra $\mathbf{x \times x} .13$; Ps. xxx. 9 ; Jer. ii. 8 , 11 ; vii. 8, \&e.; comp. Ps. li. 5; Ephes. ii. 3.

e supra vers. 18, 22, 24 ; infra rer. 30 . Jonah ii. 6, \&e.

$\omega$ look upon.

f supra iii. 16; infra ver. 30; Ps. Iri. 13.

$a$ twice, thrice.

$g$ supra ver. 14 ; in. frasl. 5; 2 Kings vi. 10 ; Neh. xiii. 20 ; Ps. lxii. 11.

$\beta$ cause to return.

h supra vers. 1S, 22, $24,28$.

$\gamma$ to be enlightened.

i supra ver. 28 ; iii. 16 ; Ps. xlix. 19 ; lvi. 13.

k supra xxxii. 10; xxxiii. 1 ; infia ver. 33 ; xxxiv. 2, $10,16,34$; хxхтіi. 14 ; comp. supra xiii. 6,17 ; xxi. 2 .

l supra xiii. 5, 13 ; xriii. 2 ; xxi. 3 , \&c.; comp. supra xxix. 21

$\delta$ If [there] are words [with thee]. $m$ supra xxiii. 4.

$n$ supra ver. 5 ; xiii. 22 ; infra xxxviii. $3 ; \mathrm{xl} .7$. $\varepsilon$ I have delighted, life. desired.

o comp. supra xxxii. 3 ; ix. $28,30,31$.

31 note $t . \quad q$ supra ver. 31 note $l$.

s infra rer. 31 ; supra xxxii. 7,9 ; infra ver. 35 ; xxxv. 16 ; xasviii. 2, \&e. perverted ${ }^{\circ}$, to the pit ${ }^{e}$, with man; the living ${ }^{i}$. answer ${ }^{n}$; righteous ${ }^{\circ} . \$$

33 ऽIf not, hearken thou to me ${ }^{p}$; me.

* i.e., the pardoned sinner. mere depravity, from actual love of sin.
Because that He hath requited unto frail-man according to his righteousness ${ }^{2}$.

$27{ }^{a} \mathrm{He}$ * looketh upon men $\dagger$, and $\psi$ saith $^{b}$ :

"I had sinned; yea, that which was right had I

"Although it profited me not ${ }^{d} \ddagger$.

28 " Yet He delivered my soul from passing over

So that my life should $\omega^{\omega}$ see the light ${ }^{f}$."

29 Lo! all these things God worketh ${ }^{a}$ oftentimes ${ }^{g}$

30 To $\beta$ bring back his soul from the pit ${ }^{h}$,

$\gamma$ That it may be enlightened with the light of

31 Attend, O Job, hearken unto $\mathrm{me}^{k}$;

Keep silence, and let ME speak .

$32 \delta$ If thou hast ${ }^{m}$ ought to say, return me

Speak, for $\epsilon$ I delight to pronounce thee

${ }^{q}$ Keep silence, and I will teach thee wisdom.

\section{CHAPTER XXXIV.}

1 And Elihu took up his discourse, and said:

$2^{r}$ Hear, O ye ${ }^{s}$ wise-men, my words; And, ${ }^{*}$ sye that have lnowledge, give ear unto

+ He maketh his confession publicly before men.

末 I had sometimes sinned, not from temptation, but from

$\S$ i.e., to have been righteous. I am far from wishing to tax thee with crimes, which thou mayest never have committed ; on the contrary, it is my delight to think that until the time thy anlictions came upon thee, thou didst lead a perfectly virtuous

¿ If [there are] not [words with thee]. p supra ver. $r$ supra xiii. 6,17 ; xxi. 2 ; xxxiii. 1,31 ; xlii. 4 . $\kappa$ knowing $\cdot$ men. 
3 For the ${ }^{a}$ ear should prove words, Even as the palate tasteth ${ }^{\omega}$ meat $^{b}$.

4 Let us ${ }^{c}$ choose for ourselves a manner reasoning;

Let us $\beta^{d}$ consider among ourselves. what is good.

5 Surely, Job did say: "I $\beta \beta$ am righteous ${ }^{e}$, "But God $\gamma$ hath rejected my just-cause ${ }^{f}$.

6 "Against my just-cause shall I lie ${ }^{g}$ ?

" $\delta \mathrm{My}{ }^{h}$ wound is grievous without transgression ${ }^{i} . " *$

7 Who is the man, that, like Job, Drinketh up scoffing like water ${ }^{k}$ ? 8 And goeth to $\epsilon$ consort with workers of iniquity ${ }^{l}$,

And to walk with $\zeta$ wicked men ${ }^{\text {? }}$ ?

9 For he said: " $\zeta$ Nought doth a man profit", " $\eta$ When he delighteth himself with God "."

10 Therefore, $\mathrm{O}$ ye men of $\theta$ understanding, ${ }^{\circ}$ hearken unto me:

$\kappa$ Far be wickedness from God ${ }^{n}$ !

$\lambda$ And iniquity from the Almighty ${ }^{p}$ !

11 Surely, the work of a man will Ile repay him ${ }^{q}$,

And according to a man's way, will He ${ }^{\mu}$ requite $\operatorname{him}^{q}$.

12 Yea, verily, God cannot do wicliedly, Neither can the Almighty pervert justice ${ }^{r}$.

$13 \nu$ Who hath entrusted unto Ilim earth?

* i.e., without any transgression on my part. See note + , p. 471 .

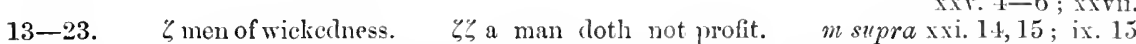
-22; xii. 6 ; but comp. xxvii. 9, 10. $\eta$ in (on) his delighting himself. $n$ supra sxii. 26 ; xxvii. 10 ; Ps. cxix. 16. $\quad$ o supra ver. 2 , notes $(s)$ and $(r) . \quad \theta$ heart. $\quad \kappa$ profune (i.e., far [be it]), to God from wickedness. See note in Append. p infia ver. 12 ; xxxvi. 23 ; supraver. 5 ; riii. 3 ; iv. 17-21; xง. 14-16; xxv.4-6; Gen. xviti. 22; Deut. xxxii.4; Iab. i. 13, \&e. $\lambda$ and [to the] Almighty from iniquity. Isuprexxi. 19; xxxiii. 26 ; Ler. xxiv. 19 ; Judg. i. 7 ; Prov. i. 31 ; Isa. ini. 10 ; Jer. xxv. 14; Fzek. xxii. 221; Ios. xii. 2, \&c. $\mu$ cause him to lind. $r$ supra vers. 10, 5, ; viii. 3, \&e.; infra ver. 17, \&e. $\nu$ who charged [the] earth upon Him? $\omega$ [what one is] to eat, or, so as to eat. See Comm. 30 ; Heb. r. 14 .

c comp. supra xxix. 6 know.

d supra xviii. 2.

$\beta \beta$ have been righteous.

e supra xxxii. 1 ; ix. $21-24 ;$ x. 15 ; xxrii. 6 ; vi. 10 , , 30 ; ix 35 18, 23 ; xvi. 17 xix. $7,28,29$; xxiii. $7,10-12$; xxrii. 5 ; chap. 31.

f supra xxvii. 2 ; ix. 17 ; xix, 6,7, 22; $\mathrm{xxx} .20,21$; comp. viii. 3 ; infra vers. $10,12, \& \mathrm{c}$.

g supra. xx Nili. 15, \&c wounded me.

h supra vi. 4 ; xri. 12-14; xiii. 28 ; vii. 5, \&c.; Ps. xxxriii. :-

$i$ supra xvi. 17.

$k$ supra xv. 16; Ps. cix.1s; l'rov xix. 28 ; comlp. supra

$\varepsilon$ join, associate with.

Pror iv 11,15 Jer. xr. 17, \&c; comp. infra vers. 36,37 ; supra xxii. $15,5-9$; iv. 7 $11,17-21 ;$ v.3; viii, $3,6,11$ 15,$20 ;$ хі. 3,6,
$14 ;$ хт. 4-6, 12 $-16, \quad 20-35$; xтiii. 5-21; $x$. $5-09$; xii 23 x.

(a)

a Isa. 1. 4. 
$\psi$ hath laid [upon him] the whole, \&c.?

$\omega$ [the] universe all of it.

a infra xxxviii. 4, 5, 12-41; xxxix. $1-13,19,26,27$, sc.; supra x. 3 , 8-13; comp. infia xxxit. 23 ; Isa. sl. 12-14, \&e.

$\beta$ to Himself.

b supra xxii. 3 ; infra $\mathrm{xxx} .6-8$.

c supra xii. 10 ; Gen. ii. 7 ; Dan. v. 23 ; Acts xrii. 28.

d supra хї. 10 ; Iва. lvii. 16; Eccles. xii. 7.

e supra x. 9 ; s rii. 16 ; Gen. ï. 7 ; iii. 19 ; Eccles. xï. 7, \&c.

f supra vers. 2,10 , and refercnces there.

$g$ supra ver 2 , and references therc.

$\gamma$ hating.

$h$ Gen. xriii. 25; supra iv. 17 ; riii. 3 ; xxv. 4, \&c. 2 Sam. xxiii. 3 ; comp. also supra ix. $17,20-21$; x. 3 ; xix. 7 ; xxiv. 1 ; sxvii. 2 ; xxx. 20,21 , \&e.

i infra sl. S; references in note (h) and comp. supra vi. 10, 29, 30; ix. 21 ; x. 15 ; xiii. 15, 18 ; xvi. 17; xxiii. $10-12$; хxгіi. 3-6; chap. xxxi.

k supra iv. 17 ; $\mathrm{xv}$. $14-16$; $\mathrm{xxv} 4-$ 6 ; viii. 3 ; хxxir. 12, \&c.; Deut. xxxii. 4; Is. slv. 21 , \&c.

$\delta$ whether [should there be a] saying?
Or who $\psi$ hath given IIim $\omega$ the whole universe in charge ${ }^{a}$ ? $*$

14 If He should set His heart $\beta$ upon Himself alone $^{b}$,

Then would He gather unto Himself His ${ }^{c}$ breath and $\mathrm{His}{ }^{d}$ spirit; $\dagger$

15 And all flesh would expire together, And man unto dust return ${ }^{e}$.

16 Now, if thou hast ${ }^{f}$ understanding, ${ }^{g}$ hear this ; ${ }^{g}$ Give ear unto the sound of my words.

17 Can indeed one, $\gamma$ who hateth justice ${ }^{h}$, rule? How then dost thou ${ }^{i}$ condemn Him that is most ${ }^{k}$ just? +

$18 \delta$ Is it meet to say unto a king: "O thou worthless-man '?"

"Thou wicked man!" $\epsilon$ unto a prince "? \$

19 IIow much less to Him, that $\zeta^{m}$ accepteth not the persons of princes,

$\eta$ Nor ${ }^{m}$ regardeth the rich before the poor,

Because they all are the work of His hands ${ }^{n}$ !

20 In a moment they die ${ }^{\circ}$ !

* One who holds a trust is liable to the suspicion, that he may abuse the confidence reposed in him, but nobody can reasonably be expected to injure that which is his own. [God made the earth and all that therein is, what advantage therefore would He have, if He vexed or destroyed the work of His hands? Comp. supra x. 3, 8-13, \&c. Editor, 1862.]

$\uparrow$ If He were to consult IHis own interest alone, He would take back unto Himself the spirit, and breath of life-His own -which IIe has bestowed upon man.

† But God does rule ; therefore He must be most just. How then canst thou charge Ilim with injustice?

$\$$ Seeing that it is one of the first rules in politics, that a Sovereign can do no wrong, and consequently is beyond the pale of all suspicion.

$l 2$ Sam. x vi. $5,7,8$,

13; Eccles. x. 20; Exod, xxii. 28; Acts xxiii. 3-5. $\quad \varepsilon$ to princes. $\quad \zeta$ hath not accepted. $m$ Dent. x. 17 ; 2 Chron. xix. 7 ; Luke xx. 21; Acts x. 34; Rom. ï. 11 ; Gal. ii. 6; Ephes. vi. 9; 1 Pet. i. 17; supra xiii. 10; sxxii 21, 22; but comp. infra xlii. 8, 9; Gen. ir. 4, 5; Mal. i. 2, 3; Rom. ix. 13-18, \&c. $\eta$ and hath not recognized, acknowledged. $n$ supra x. 3 ; xiv. 15; xxxi. 15; infra xxxrii. 7 ; Isa. xxix. 16; xlv. 9, 11, 12; Roin. ix. 20.

19 ; Isa. Xxx. 13. o supra ir. xix. 20; ix. 23; xxi. 13; infra xxxvi. 20 ; Ps. lsxiii. 18, 
Yea, at ${ }^{a} \psi$ midnight a people $\omega$ is troubled and $a$ Exod. xii. 29, 30; passeth away,

And the mighty $\beta$ is removed $\gamma$ without $\begin{aligned} & \psi \text { lalf of, middle of } \\ & \text { night. } \\ & \omega \text { are troubled [or, }\end{aligned}$ supra xxrii. 20 ; infra rer. 25. hand ${ }^{b}$ !

21 For His eyes are upon the ways of $\operatorname{man}^{c}$; Yea, He observeth all his ${ }^{d}$ steps.

22 There is no darkness, and no ${ }^{e}$ shadow of death, $\delta$ Where the ${ }^{f}$ workers of iniquity may hide themselves ${ }^{g}$.

23 Surely, He doth not lay upon man so much ${ }^{h}$, $\epsilon$ That he can enter into judgment $\epsilon \epsilon$ with God $^{i}$ !*

24 $\mathrm{He}^{k}$ breaketh the mighty in pieces $\zeta$ unsearchably $^{l}, \dot{\uparrow}$

And $\eta$ setteth up others in their stead.

25 \& Thus then He doth regard their works ${ }^{m}$, Seeing He overturneth them in the night ${ }^{n}$, so that they are ${ }^{\circ}$ crushed.

$26{ }^{\theta}$ In their very place ${ }^{p}$ He striketh the wicked; "In the place" where men " beheld them: made to tremble, shake] and pass.

$\beta$ they cause to turn away.

$\gamma$ without a (or, not by) hand.

6 infra rer. 24 ; 1 Sam. xxvi. 10 ; 2 Sam. xxir. 16; Dan. ii. 34,45 .

c supra xi. 11; xiii. 27 ; хxiv.23; xxxi. 4 ; 2 Chron. xvi. 9 ; Ps. exxxix. 2, 3 ; Jer. xxxii. 19 ; Heb. iv. 13.

a supra xiv. 16 ; xxxi. 4 ; xxxiii. 11. e supra iii. 5 ; x. 21. xii. 22 ; xri. 16 ; xxiv. 17 ; xxviii. 3 ; infra xxxriii. 17.

o to be hid, or, for to be hid (i.c., that there should be hid) there [the] worker's, \&e.

f supraxxxi.3; Ps.r. 5 ; Prov, x. 29, \&c.

$27 \lambda$ Because they ${ }^{r}$ turned away from following Him, $g$ Ps cxxix. 11, 12; Neither considered $\mu$ any of ILis ways ${ }^{s}$ :

28 So as to bring before Him the ${ }^{t}$ cry of the poor; Isa. xxix. 15 ; Jer. xxiii. 2t; Amos ix. 2,3 ; comp. supra xxvi. 6 , and referenees there.

* What God requires of man is not so diflicult, as to justify $h$ supra xi. 6 ; Ps. him in saying it is impossible he should do so much.

$\uparrow$ Unsearchably, i.e., so that none can discorer the means He employs to despatch them.

* Or, in familiar language, which here seems best to convey ciii. $8,10,14$; infra xxriii. 39 [28]; Kreles. xii. 13 ; Deut. x. 12; Mie. vi. 8 , se.

the sense, "So then, you see, He does regard, \&c."-Editor, 1862.

\$ Committing their wickedness, so that erery one may perceive in the destruction of the wicked the finger of God. Comp. Numb. xvi. 30-33.

for [him] to go.

$\varepsilon \varepsilon$ to, aguinst.

supra ix. 17, 20$2.3,32$; х. 3,7 ; xiii. 15 ; xvi. 17 , 21 ; xix. 7 ; xxiii. $10-12$; xxvii. '2 -6, se.

kupra $\mathrm{xx} .8,9$; xii. 19, 21 ; v. 15; ir. 10; Ps. ii. 9; 1xxii. 4; J (r. li. 21-23. \% [with] not (= without) search. l supra ver. 20 ; ix. 5 ; xi. $7-9$; r.9; ix. 10; 2 Kinga xix. 35 , א. . ग hath made (maketh) to stand. $m$ supra vers. 21,22 ; xi. 11 ; and ibid. ver. 7 , note $(m)$. $n$ supra ver. 20 , note $(a)$; xxrii. 20 ; xi. 19 ; 2 Kings xix. 35 . o supraxxi. 13 ; xxir. 19 ; ix. 23 ; iv. $19 . \quad \theta$ in the [rery] place of [the] wicked, he bath struck (striktth) them. p Numb. xvi. $30-33$; xi. 33 ; Ps. Ixxviii. 29-31; Acts r. 5 ; xii. 23 , sc. $\kappa$ in [the] place of men-beholding, seers. $q$ comp. supra rii. $8 ; \mathrm{xx} .9 . \quad \lambda$ for this [reason] that they turned away from after Him. $r$ supra xxiii. 11, 12; Ps. xliv. 18 ; lxxriii. 41 ; 1sa. i. 4; comp. supra xxvii. 5, 6 ; xiii. 15 ; ix. 35 anul xxii. $21-23$; xi. 13,14 ; viii. 5 ; r. 8 , se $\mu$ all His ways. $s$ note $(r)$; Ps. xxriii. 5 ; cxix. 3 ; cxxviii. 1, comp. supra ver. 21 , notes $c$ and $d, \&$. tinfia xxxr. 9, 12; supra xxix. 12 ; xxir. 12 ; xxvii.9; comp. xxx. 20 ; xix. 7 ; Gen. iv. 10 ; Exoù. ii. $23,21, \delta c$. 
$z$ Pя. ix. 12 ; xii. 5 ; хххіг. 6, \&c.

a 1 Chron. xxii. 9 ; Judg. viii. 28 ; Lev. xxvi. 6.

$\psi$ maketh to be quiet.

$b$ comp. supra ix. 12 ; xi. 10 ; xii. 14 ; xxiii. 13 ; Isa. xliii. 13 ; Dan. iv. 35.

c supra xiii. 24 ; iii. 23 ; xxıii. 3,8 , 9 ; ix. 11 ; xxix. 3 ; Ps. xiii. 1; xxvii. 9 , \&c.

d Isa. ii. 6 ; Jer. xxจ. 12, \&c.

a a man.

e 2 Sam. xii. $10 ; 1$ Kings xi. 11, \&c.

$\omega$ [it is] alike, i.e., all one.

$\beta$ an hypocritical, or,impure, defiled, profane, mall. Ed., 1862.

$f 2$ Kings xxi. 11, 12 , \&e.

g 2 Kings xxii. 16, $17, \& c$.

$\gamma$ [it is] to be said $=$ it is meet to be said.

$h$ comp. supra $\mathrm{x} \times \mathrm{xili}$. 27,28; Prov. xxviii. 13 ; 2 Kings xxii. 19, \&e.

i supra v. 17 ; Prov. iii. 11,12 ; Heb. xii. $5-8$.

$\delta$ I will not act corruptly.

$k$ infra xl. 4; slii. 6 ; comp. supra chap. xxxi.; xxvii. 2-6 ; xxiii. $4,7,10$ -12 ; xvi. 17, \&e.

$\delta \delta$ besides [that which] I can see.

$l$ supra xi. 6 ; $\mathrm{Ps}$. xix. 12.

$\varepsilon$ instruct me.

m supra xiii. 23 ; $\mathbf{x}$. 2 ; comp. vi. 21. n supra vii. 20 ; $\mathbf{x i}$. 14 ; xxii. $23,8 c$.

$\zeta$ I will not add [to do it.]

$o$ see ver. 31 , notes $h$ and $k ; 2$ Sam. xii. 13 ; xxiv. 17, Sc.;
For the cry of the afflicted He heareth ${ }^{z}$.

29 When $\mathrm{He}^{a} \psi$ giveth quietness, who then can cause trouble ${ }^{b}$ ?

And when $\mathrm{He}^{c}$ hideth $H i$ s face, who then can behold Him ? *

(Whether He doeth it because of a ${ }^{d}$ nation, or because of ${ }^{a}$ one man ${ }^{e}, \omega$ it maketh no matter ;

30 Whether because of the reigning of an $\beta$ hypocrite ${ }^{f}$, $O r$ because of the snares $\dagger$ of a people ${ }^{g}$.)

31 Surely, $\gamma$ what is meet to be said unto $\operatorname{God}^{h}$ is : "I have borne my ${ }^{i}$ chastisement; $\delta$ I will deal corruptly no more ${ }^{k}$.

32 " $\delta \delta$ More than I can see ${ }^{l}$, do Thou $\epsilon$ teach me ${ }^{m} ; \ddagger$ "If I have done iniquity", $\zeta$ I will do it no more ${ }^{\circ} . "$

33 Shall He $\eta$ requite $\theta$ according to thy mind ${ }^{p}$, Because thou ${ }^{\kappa}$ rejectest ${ }^{q}$, because thou choosest ${ }^{r}$ ? And $\lambda$ why not according to my mind ${ }^{s}$ ? $\${ }^{1}$ Now, what $\mu$ canst thou say? Speak $^{t}$ !

$3 \pm$ Men of understanding will $\mu \mu$ speak for me ${ }^{u}$, Yea,every wise man $\nu$ that heareth me will say ${ }^{u} \|$

1 Or, Now, What thou knowest, speak! See Append.-Editor, 1862.

* When in His indignation He averteth His face, who can hope for a look of favour from Him?

$\dagger$ i.e., the snares in which they entangle others and themselves, their corruption. See Comm.-Editor, 1862.

+ Point Thou out to me any offences I may have unconsciously committed, also such as I may be likely to commit unconsciously, that I may repent me of the former, and guard against the latter.

$\S$ Shall He consult thee as to how He must requite the conduct of mankind? Before He doeth aught, shall He first ask thee, whether thou approvest or disapprovest of His purpose? And why thee, and not me, or any other man?

II They will spare me the trouble of telling thee; they themselves will say respecting thee: "Job speaketh," \&c.

Ps. li. 4, \&c. $\quad \eta$ requite it. $\theta$ from with thee. p supra xxxiii. 12 ; xxi 22 ; infra $x \leq x v i$. 23 ; comp. supra iv. 17 ; xv. $14-16$; хxт. $4-6$; ix. $17,21,22 ; x .3,7$; xvi. 17 ; xix. 7 ; xxvii. 2 , Sc. ; Isa. xl. 13 ; Rom. xi. 31, 35 . $\quad \kappa$ hast rejected.

$q$ Exod. xxxii.11-14; Jer. xxvi. 19, se. $\quad r$ Numb. xvi. 30,31 ; 2 Kings i. 10,12 , \&e. $\lambda$ and [why] not I. s supra xxxii. 4,6 ; $x x i .15$; xv. 9 ; comp. xii. 3 ; xiii. 2 , \&c. $\mu$ knowest thou to say, i.e., canst thou say.

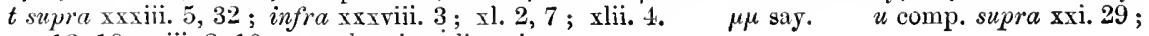
xv. 18,19 ; viii. 8,10 . $\nu$ hearing, listening. 
TRANSLATION. CHAPS. XxxIV. $35-37 ; \mathrm{xxxv.} 1-6$.

35 "Job speaketh $\psi$ without knowledge ${ }^{a}$, "And his words are $\omega$ without wisdom ${ }^{a}$."

$36 \mathrm{O}$ my Father! let Job be ${ }^{b}$ proved $\beta$ for ever, $\gamma$ That there may be answers against $\delta$ iniquitous men ${ }^{c}$.*

37 For else he will add ${ }^{d} \epsilon$ rebellion $\zeta$ to his $\sin ^{e}$; He will ${ }^{f}$ clap his hands among us, $\dagger$ And ${ }^{g}$ multiply his words against God.

$\psi$ not with know. ledge.

a infra xxxv. 16 ; xxxviii. 2 ; xlii. 3 ; supra viii. 2 ; xi. 2,$3 ; x v .2,3$; eomp, xii. 3 ; xiii. 2 , \&c.

$\omega$ not with intelli. gence, wisdom.

b comp. supra i. 11, 12 ; ii. $3-6$; $x$. $4-6$.

$\beta$ even to eternity.

$\gamma$ on account of answers, \&c.

\section{CHAPTER XXXV.}

1 And Elihu took up his discourse and said:

$2 \eta$ Thinkest thou this ${ }^{\theta}$ to be just,

That thou saidst: "My righteousness k greater than God's "."

3 That thou $\lambda$ saidst "What will it profit thee ${ }^{i}$ ?" " $\mu$-What advantage shall I have therefrom more than from my $\sin ^{k}$ ?" $\ddagger$

4 I_ I will ${ }^{b} \nu$ answer thee,

And thy friends with thee.

$5{ }^{m}$ Look-unto the heavens, and ${ }^{\pi}$ consider;

And behold the clouds, pwhich are so high above thec".

6 If thou $\sigma$ sinnest ${ }^{n}, \tau$ wherein canst thou affect $\operatorname{Him}^{p}$ ?

$\delta$ men of iniquity.

$c$ comp. Ps. exl. 8.

d supra xxiii. $2 ; 1$ Sam. xv. 23.

$\varepsilon$ see note $t$, p. 471 .

$\zeta$ upon,over, beyond. is e supra iv. 17-19; viii. 3 ; xi. $3,4,14$; xv. 14-16; xxii. 23 ; хxr. 4-6; comp. supra ix. 17 ; x. 3,7 ; xi. 4 ; xri. 17 ; xix. 7 ; xxrii. 2 ; chap. xxxi., fic.

$f$ supra xxrii. 23; Ps. xlvii.1; xeriii. 8 ; Isa. lo. 12; Lam. ii. 15, \&e.

ginfia xхxч. 16; supra viii. 2; xi. 2 ; $x v .3,13$; Eeeles. x. 14 .

$\eta$ hast thou thought, considered.

$\theta$ for justice, i.e., just, right.

$x$ more than God's.

h supra ix. 17, 21,

* That, if iniquitous men, imitating the example of Job, murmur and complain on receiving ehastisement from above, they may be told that their murmurings and grumblings will as little avail them, as those of $\mathrm{J}_{\mathrm{ob}}$ did him.

$+\mathrm{He}$ will exult and say, that it was owing to his finding fault with the Divine dispensations that God released him from his sufferings.

\$ Obserre the change of persons in this verse, and see Append.-Editor, 1862 .

35 ; x. 7,15 ; xi. 4 ; xiii. $15,1 \mathrm{~s}$; xri. 17 ; xix. 7 ; xxili. $10-12$; xxrii. 2-6; chap. xxxi.; comp. supra vi. $10,21,29,30$, \&e. ; supra xxxiii. $9-12 ;$ xxxir. 5 , 11,12 .

$\lambda$ shouldst have said. or sayest, art wont to say, keepest saring.

i supra xxi. 15 ; xxxiv. 9 ; xxxi. 2, \&e. $\mu$ what shall I profit, be benefitted. k note $i$, supre ix. 22, $21 ;$ x. 3 ; xii. 6 ; xxi.7-13, \&c.; but comp. $x \times$ rii. $7-10$. l supra xxxii. $3,5,12,17,20$; $x \times x$ iii. $33 . \quad \nu$ return thee words. $\quad m$ supra xxii. 12; infra xxxvii. 14; xxxvi. 24; Isa. xl. 26 ; Ps. viii. $3 . \quad \pi$ see. $\rho$ [which] have been, are, higher than thou. $n \operatorname{supr} a \times x i i .13-14$; xriii. $4 . \sigma$ hast (hadst) sinned, didst sin. o supra xi. 1.1; xxii. 23 , \& . $\tau$ what eanst thou work, do (or, eanst (couldst, wouldst) thou have worked, done), against Him. $p$ supra vii. 20 ; xxii. 13, 14, and ref. there; Prov. ix. 12 ; Jer. vii. 19 ; comp. Gen. vi. 5, 6 ; Lukexr. 7 , \&e. 
$\omega$ have been many. $\beta$ or, have done.

$\gamma$ last been right. eolis.

$\delta$ or, canst thou give, or have given.

a supra xxii. 2, 3; Ps. xri. 2 (?) ; comp. supra ix. $22 ; x, 3,7$.

$\varepsilon$ or, have receired.

$b$ supra xv. 20,35; xx. 12-16; Ps. vii. 15,16 ; ii. 4 ; Pror. xxri. 27 ; Eccles. x. 8.

c supra xxii. 3; xxi. 15 ; xxxiv. 9.

$\zeta$ cry they [or, make they [men] to cry] by reason, dc. $\dot{E} d, 1862$.

d infra rer. 12; supra xxir. 12; xxxir. 28; xxrii. 9 ; Ps. ix. 12, de. $\eta$ cry they out, or aloud.

e supra $\mathbf{x}$ ii. 9; xxri. 2 ; xxxi. 22 ; infra xxxriii. 15 ; Ps.x. 15, \&c.

f supra ix.24; xxii.8.

$\theta$ giving, uttering.

g supra iii. 7 ; Dau. chap. r.; Isa. $\mathrm{r}$. 11, 12 .

$\kappa$ hath not said.

h infra xxxri. 3; xxxrii. 7 ; supra xxxiii. 4; xxxii. 22 ; x. 8-11.

$i$ Ps. xlii. 10; Isa. v.12; Ps. xxriii.ś; comp. supra xxii. $12-14$ (note $k$ ).

$\lambda$ teaching us, caus. ing us to learn, more than, sc.

k supraiv. 21 ; comp. xriii.3; Ps.lxxiii.22; supra xii. 7 ; Eccles. iii. 18,19 , \&c.

$\mu$ maketh us wise more than, abore.

l supra $\mathrm{xxriii.} 7,21$; infra xxxix. 29; comp. supra xii. 7.

$y$ there, in that case, ther.

m supra rer. 9.

$\pi$ He answer.

$\rho$ or, surely [it is] in vain.

n supra xxx. 20 ; xxxi. 35 ; xix. 7 ; ix. 16 ; comp. xii. 4 ; xxiv. 1 ; Ps. xxii. 7 , 8 ; xlii. 10 , \&c. $\sigma$ regard it. o Ps. cri. 44. p supra xxir. 1; xxii. 13, 14; xriii. 4; xr. 12; ix. 22; x. 3 ; xxiii. 8,9 ; Ps. x. 11 ; lxsiii. 11 ; xcir. 7 ; stpra rer. 5 ; Isa. xl. 26,27 ; Ezek. viii. 12 ; ix. 9, \&e.
Or, if thy transgressions $\omega$ are numerous, what canst thou $\beta$ do unto Him?

7 If thou $\gamma$ art righteous, what $\delta$ givest thou $\mathrm{Him}^{a}$ ? Or what can $\mathrm{He}{ }^{\epsilon}$ receive of thine hand?

8 For a man like thyself $i$ s thy wickedness $^{b}$, And for a son of man, thy righteousness ${ }^{c}$.

$9 \zeta$ When by reason of the multitude of oppressions men cry ${ }^{d}$,

$\eta$ When they ${ }^{d} \mathrm{cry}$ out by reason of the ${ }^{e}$ arm of the mighty ${ }^{f}$,

10 And he, $\theta$ that uttereth songs in the night ${ }^{g}$,

${ }^{\kappa}$ Doth not say: "Where $i s$ God, my ${ }^{h}$ Maker ${ }^{i}$ ?

$11 \lambda$ "Who teacheth us to be more than the ${ }^{k}$ beasts of the earth,

" And ${ }^{\mu}$ maketh us more wise than the fowl of heaven ${ }^{l} ; "+$

$1: \nu$ Then, they ${ }^{m}$ cry (if $\pi$ God answer them not)

Because of the arrogancy of the evil-doers, saying:

13 " $\rho$ In vain, surely, do we call, God will not hear", "Neither will the Almighty $\sigma$ regard our affliction ${ }^{\circ} . "+$

14 But canst THou indeed also say, that thou seest Him not ${ }^{p}$ ?

* i.e., when the oppressor, who spends the night in boisterous merriment, does not say: "Where is God?" [i.e., when he does not acknowledge the power of God, and so gives no heed unto His commandment, "Thou shalt love thy neighbour as thyself."-Editor, 1862.]

+ Who gave us intellect and reason, that we might know we ought not to degrade ourselves to a level with brute beasts by taking advantage of our strength and power.

+ Such words, sinful as they are, and deserving severe punishment, are at least not altogether destitute of some shew of reason.

$\S$ But canst thou-thou who hast admitted over and over again, that thy afflictions proceed from God-canst thou say

that thou dost not recognize His finger in them? 
Translation. chaps. xxxv. 15,$16 ;$ xxxvi. $1-6$.

Thy cause is before Him "; * therefore must thou wait for $\mathrm{Him}^{b}$.

15 But now that, with which His anger hath visited thee, is as nothing ${ }^{c}$; $\dagger$

Yea, $\mathrm{He}{ }^{\omega}$ hath not regarded the great ${ }^{d}$ multitude of thy sins ${ }^{e}+$

16 Wherefore Job $\beta$ hath ${ }^{f}$ opened his mouth with ${ }^{g}$ vanity,

And ${ }^{h}$ without knowledge $\gamma$ hath ${ }^{i}$ multiplied his words.

\section{CHAPTER XXXVI.}

1 And Elihu $\delta$ proceeded, and said:

$2^{k} \in$ Bear with me yet a little, and I will shew thee,

That $\zeta$ I have still words ${ }^{l} \zeta \zeta$ on behalf of God.

3 I will take up my $\eta$ reasoning from afar, And will $\theta$ ascribe righteousness to my ${ }^{m}$ Maker ${ }^{n}$.

4 For truly $\mathrm{my}^{\circ}$ words are not $\times$ false:

He that is ${ }^{p \lambda}$ perfect in knowledge is with thee. $\S$

5 Behold! God is ${ }^{q}$ mighty, yet ${ }^{r}$ despiseth not any -

Mighty $\mu$ in strength and wisdom ${ }^{q}$.

6 He will not preserve the wicked alives,

* Having admitted that thy cause is before Him, for thee to deny His interference in the things of this world would be a palpable contradiction.

+ Compared with the exceeding sinfulness of thy speeches, the punishment God hath inflicted upon thee is as nothing. [See Append.-Editor, 1862.]

$\ddagger$ In the abundance of His mercy, He hath overlooked, to a great extent, thy sins.

\$ God hath His eye upon thee, and dealeth with thee.

supraxi. 7-9. $\lambda$ perfect of knowledges, i.e., all sorts of knowledge.

supra xiii. 18, 19

$-28 ; x .2-22$, \&c. ; comp. vi. 4 ; ix. 17,18 ; xri. 11 -14 , \&c. ; and xix. $7,6-13$; xxiii. 4; xxrii. 2 ; xxxi. 35, \&c.

b supra xiii. 15 ; Ps. xl. 1 ; Isa. xxr. 9; comp. vi. 11,12 ; vii. $6,7,21$; $x$. 20 , \&c. ; ix. 18, \&c., \&c.

c supra xi. 6; Ps. ciii. 8-12; Ezra ix. 13 ; comp. ix. 17 ; xri. 17, \&c.

$\omega$ hath not known, or knoweth not, about the great multitude, Sc., ror, noticeth not at all the multitude, \&c. Ed.

1S6:.]

d Ps. . 10.

$e$ note $c$.

$\beta$ openeth.

$f$ supra iii. 1 ; xi. 5 ; xxxii. 20 ; Ps. lixviii. 2 ; Prov. хxхi. 8, 9, \&c.

g suprexr.2; xi.:2; viii. '2, \&c.

h supra xxxir. 35 , note $a$.

$\gamma$ multiplieth.

i supra xxxir. 37 ; Pror. x. 19 ; Ec. cles. v. 3.

o adcled.

k supraxxi.3; xxxiii. 33.

$\varepsilon$ wait for me.

$\zeta$ [there are] still words.

l supra xiii. 7,8 .

š for.

$\eta$ knowledge, opinion.

$\theta$ gire, attribute.

m supra xxxr. 10, note $h$.

n supra xxxiii. 12; xxxit. 10-12, 19, 23 ; xxxvii. 23, \&c. Comp. suprá iv. 17 ; $\mathrm{xr} .11-$ 16 ; xxr. $1-6$. o supra $\mathbf{x x x}$. 1.1. $\kappa$ falsehood.

p infra xxxrii. 16 ; $q$ supra ix. 4, 19 ; xii. 13,16 ; infra rer. 22 , xxxrii. 23 ; Jer. xxxii. 19 ; Dan. ii. 20 ; Isa. xxviii. 29; Ps. xcii. 5 , \&e. $r$ supra x. 3 ; xxxir. 19 ; Deut. xxxii. 19 ; Ps. hii. 5, \&e. $\quad \mu$ of. $s$ supra vii. 20 ; ir. 9-11; v. 4,5 ; viii. $11-15$; xr. $20-35$; xviii. 5-21; xx. 5-29; xxrii. $13-23$; хxхіг. $24-27$; xxxri. $12-14$; but comp. is. $22-24$; xï. 6 ; xxi. $7-13$; xxrii. $7-10$. 
$\omega$ give, set, set up, establish; or, make, do, execute;

a supra viii. 20 ; iv. 7 ; จ. 11, 15, 16 ; viii. $16-19$; x xii. 19,$20 ; x x$ vii. $7-$ 10 ; xxxiv. 11, 28.

6 supra xxxiv. 21, notes $c, d$; xri. 9 . c comp. iii. 23 ; xiii. 24 ; xxix. 3 ; Ps. i. 6 ; Isa. $x 1.27, \&$ c. d 1 Sam. xvi. 1, sc. e sispra r. 11; 1 Sam. ii. 8 ; Ps. cxiii. 7, 8 ; crii. 41 , \&c.

$\beta \mathrm{He}$ hath caused them to sit. See Append.

f suprav. 11 ; Luke i. 52 ; Ps. crii. 41. $g$ supra xiii. 27 ; xxxiii.11; Ps. cvii. 14,16 ; Jer. ii. 20 , \&e.

$h$ Ps. crii. 10.

$\delta$ then (or, so) $\mathrm{He}$ hath declared $(=$ $\mathrm{He}$ declareth) to them.

i supra xxxiii. 1418 ; Gen. xx. 3 6 ; Dan. iv. 5,25 -27, \&c.; comp. supra v. 17 ; Ps. xciv. 12 ; Prov. iii. 11 ; Heb. xii. 511 ; 1 Cor. xi. 32 ; also 2 Kings $\mathrm{xx}$. (Isa. xxxriii.) 1 3,5 .

$\varepsilon$ make themselres mighty, prerail.

$k$ Ps. xix. 13 ; cxix. 133 ; Rom. vi. 14. $\zeta$ and $\mathrm{He}_{e}$ lith un. covered, opened.

7 infra ver. 15 ; supra xxxiii. 16; 1 Sam. ix. 15; 1 Chron. xvii. 25, \&c.

$\eta$ hath said.

$\theta$ turn, or, turn back. $m$ infra xl. 4 ; xlii. 5 , 6 ; supra viii. 5 , -23; Gen. $x x .7$. $n$ infra xlii. 10 ; suor, grant.

$\gamma$ have been high. 6 ; xi. 14 ; xxii. 21

But will ${ }^{\omega}$ establish the right of the afflicted ${ }^{*}$.

$7 \mathrm{He}{ }^{b}$ withdraweth not His eyes from the righteous ${ }^{c}$,

But, with ${ }^{d}$ kings ${ }^{e} \beta$ setteth He them up upon the throne

For ever, so that they $\gamma$ are ${ }^{f}$ exalted.

8 And if they are somelimes bound in fetters ${ }^{g}$, Sometimes caught in the cords of affliction ${ }^{h}$, $9^{1 \delta^{i}}$ It is that He may shew them what their work would be,

If their transgressions should $\epsilon$ gain the master $y^{k}$.* $10 \zeta$ So that $\mathrm{He}^{l}$ openeth their ear to instruction, And $\eta$ telleth them, that they should $\theta$ shrink $\dagger$ from evil.

11 If they hearken, and serve Him ${ }^{m}$,

${ }^{n}$ Then they will ${ }^{\circ}{ }^{\kappa}$ spend their ${ }^{p}$ days in $\lambda$ prosperity,

And their ${ }^{p}$ years in pleasures. +

12 But, if they ${ }^{q}$ hearken not, they will $\mu$ perish by the "sword,

And ${ }^{\nu}$ die, for ${ }^{r}$ want of knowledge.

13 So that the ${ }^{s} \pi$ hypocrites $\rho$ in heart lay up anger,

$1 \mathrm{Or}$, Thus He sheweth ( $=$ it is that He may shew) them their work,

And their transgressions, that they are about to gain the mastery. See Append. Editor, 1862.

* i.e., He sends afflictions upon them for the purpose of pointing out to them, that, if sin should once get the mastery over them, they would abandon the virtuous life they had hitherto led for a course of licentiousness and corruption.

$\dagger$ I have here used shrink instead of the more lit. turn, because the latter would I think generally be understood to imply that evil had already been reached, i.e., committed, whereas Dr. Bernard understands the meaning of the Heb. verb to be, to turn back, when on the road to evil. Comp. infra xxxix. 22, where שיוּ is used much in the same sense.-Editor, 1862.

$\ddagger$ If, in spite of the aflictions that are sent upon them, they continue devoted to God, they will have a speedy deliverance from their sufferings, and be restored to their former prosperity. 5-19; xxii. $21,23-30$; comp. ix. 24 ; xii. 6 ; xxi. $7-13$. o supra xxi. 13. $k$ consume. $p$ Ps. xc. 9; supia x. $5 . \lambda$ good. $q$ Gen. xx. 7 ; Lev. xxvi. 14-33, \&c. ; Deut. xviii. 19. $\mu$ pass over, away. $\quad u$ supia xxxiii. 18; xr. 22; xix. 29 ; xxvii. 14. v expire. $r$ supra $\mathrm{xxx}$. 16 ; xxxir. 35 ; iv. 21 . $s$ supra xiii. 4 ; Matt. vi. 5, $16 . \quad \pi$ or, impure, defiled, profane. $\rho$ of heart. 
Because they ${ }^{a}$ cry not out unto Him, ${ }^{*}$ when $\mathrm{He}$ a supra xxxiii. 9${ }^{b} \omega$ bindeth them.

14 Wherefore their soul ${ }^{c}$ dieth in youth ${ }^{d}$, $\beta$ And their life $i s$ among the $\gamma$ unclean ${ }^{e}$.

15 So then He delivereth the afflicted by his afflic$\operatorname{tion}^{f}$,

And ${ }^{g} \delta$ openeth $\epsilon$ his ear by chastisement ${ }^{h}$.

16 Yea, thee also hath $\mathrm{He}$ removed from the adversary's mouth ${ }^{i}$,

From ${ }^{k} \zeta$ ease, in whose place there was no straitness,

$\eta$ And from that which was set upon thy table, full of fatness ${ }^{k i}$. $†$

17 But thou hast been full of the ${ }^{\theta}$ pleadings of the wicked ${ }^{l}$;

Therefore judgment and justice ${ }^{m}$ lay hold upon thee ${ }^{n}+$

18 For now there is ${ }^{\circ}$ wrath; take heed, therefore, lest $\mathrm{He}$ remove thee with a blow ${ }^{p}, \S$

* i.e., unto God, for help, or mercy, but, on the contrary, indulge, as Job had done, in loud and bitter complaints against their Maker. See Comm.-Editor, 1862.

+ That comfort and ease, unbroken until lately by trouble or distress, were the most dangerous enemies thou couldst have had; yea they were ready to devour thee, when God in IIis mercy snatehed thee from their jaws, by sending upon thee these afflictions, of which thou so bitterly complainest.

$\$$ Hadst thou resigned thyself to the decrees of God, these sufferings of thine would have lasted but a moment; but, far from evincing resignation, thou liast indulged in hasty murmurings against God and His Providence, and therefore do thy aflictions still press heavily upon thee.

$\S$ For now, owing to thy rebellion against Him, God is really wroth with thee; so that these aftlictions, which had their origin in the love He bore thee, now abide with thee as a token of His indignation.

12, xxxiv. 9-12, \&c. ; comp. v. 8 ; viii. 5,6 ; xxii. 21-23, \&c.; ix. 17 ; x. 3,15 ; xvi. 17 ; xix. 7 ; xxvii. 2 ; $x \times x .21$, \&c.

b supra ver. 8; i. $14-19$; ii. 7 ; iii. 23 ; xiii. $27, \& \mathrm{c}$.

$\omega$ Jath bound.

c Ps. xxxiii. 19 ; Ixxviii. 50, \&c.

d supra ver. 6 ; comp. supra $\mathrm{xxi} .21,23$, 13 ; ix. 23 ; $\mathrm{xr}$. 32,33 ; viii. 12 , 13; xxrii. 19-21, \&c.; Ps. Jv. 23 ; Dent.iv. 26 ; хxx. 18, 19, \&c.; comp. also supra xxi. 7, \&.c.

$\beta$ or, while their lifo \&c.

$\gamma$ or, sodomites.

$e$ Geu. xiii. 12, 13 ; xir. 12, \&c.

$f$ supra vers. 9, 10; xxxiii. 16,17 ; Ps. cxix. 67,71 ; Jer. xxxi. 18, 19; Heb. xii. 11, \&e.

$g$ suprax ver. 10 ; xxxiii. 16, \&c.

o mneovereth.

$\varepsilon$ their ear.

$h$ supra ver. S; v.17; P'ror. iii. 11, 12; Heb.xii.5-11,ke. i supra r. 15; Gen. iv. 7 ; 1 Pet. v. 8 .

$k$ Prov. xxx. 8, 9; Neh. ix. 25, 26; Deut. xxxii. 15 ; Lukexii.15; comp. supra iii. 26 ; ir. 6 .

¿ width, roominess, not anything-compressed, - strait ened (i.e., straitness) under it.

$\eta$ and [the] coming down of (ou) thy table, i.e., that which came down upon thy table, was placed upon it.

kk Lnke xii. 1921 ; Isa. xxii. 13 ;

lvi. 11, 12 ; comp. Ps. lxix. 22; Rom. xi. 9; Pror. xxx. 8, 9 ; Dent. xxxi. 20; xxxii. 15. $\theta$ strife, contention, contending[s]. lsupra xxxiii. $9-12$; xxxiv. $5-9$; xi. 4 ; ix. 17,22 ; x. 3 ; хіii. 27 ; xvi. 17 ; xix. 7 ; xxvii. 2 ; xxx. 20,21 , \&e. m supra xxi. 6 ; xriii. 20 ; 1's. cxix. 53. n supra xxxiv. 11; xix. 29; Ps. lxii. 12; Judg. i. 7, \&e. o infra xxxriii. 2; xl. 2,8 ; xlii. $3,7, \&$ c. $\quad p$ comp. supra viii. 12 ; xv. 29,30 ; xxvii. $18-21$; Numb. xri. 35 ; also ix. 23 ; xxi. 13. 
$\beta$ when multitude, or greatness, of ransom will not make thee turn away [from it].

a supra xxxiii. 24; Ps. xlix. 7 ; Prov. xiii. 8 ; comp. vi. 23.

b supra xxxiv. 19; Ps.xlix. 6, 7 ; Pror. xi. 4 ; Ezek.vii.19; Zeph. i. 18.

c Ps. xxxiii. 16, 17 ; xliv. 3 ; Prov. xxi. 31 ; comp.supraix. 12,13 ; xi. 10 ; xii. 14; xxiii. 13, \&e. $\gamma$ the night.

d supra vii. 15 ; ix. 21 ; x. 1.

$\delta$ [which is] to cut off ; [or, for, or, at [the] going up of nations, i.e., when nations go np, perish. Ed. 1862.]

e supra xxxiv. 20, 25,26 ; iv. 19 , 20 ; 2 Kings xix. 35 , \&c.

$\varepsilon$ be guarded, guard thyself, beware.

$\zeta$ lit., didst choose.

$f$ supra vii. 15 ; Jer. viii. 3.

$\eta$ this.

$\theta$ lit. exalteth [Himself].

$g$ infra ver. 26 ; xxxvii. 23 ; supra ver. 5 ; ix. 4,19 ; xii. 13,16 ; 1 Chron xxix. 11; Dan. ii. 20, \&c.

$\kappa$ one instructing, teaching.

$h$ supra xxxiv. 32 ; Ps. xxv. 4; xxvii. 11, \&c.; supra xxi. 22 ; хxxiv. $13, \& c$; comp. supra vers. 4,5 ; infra xxxvii. 16, \&c.

$\lambda$ eharged upon Him.

i supra xxxiv. 13; xxi. 22; Isa. xl. 13, 14; Rom. xi. 34 ; Jer. xxiii. 18. $k$ supraix. 12 ; Dan. iv. 35 ; Isa. xlv.

9 ; comp. supra xxxiv. 12,17 ; viii. 3 ; iv. 17 ; infra xl. 8, \&c. ; comp. also supra ix. 2,3 ; xiv. 3, 4. $\quad \mu$ His work. l supra v. 9-16; xi. 7-10; xxv. 2, 3 ; infra xxxrii. 14, 16, \&c.; and comp. supra ix. $4-13,19$; xii. $13-25$; xxvi. 5-14; Ps. xxxiv. 3 ; lxxxvi. 8-10, \&c. $m$ Ps. viii. 3 ; lxxvii. 11 ; cxliii. 5 ; xix. 1 ; infra xxxvii. 14. $\nu$ have contemplated. $n$ Ps. xlvi. 8 , se. $\quad \pi$ looked upon it, have beheld it. $\rho[$ it $]$.

$\beta$ When no ${ }^{a}$ ransom, however great, will turn it away fiom thee;

19 Will He esteem thy ${ }^{b}$ riches? No, not ${ }^{b}$ gold, ${ }^{1}$ Nor all the efforts of strength ${ }^{c}$ !

20 Pant not for $\gamma$ that night ${ }^{d}$, *

$\delta$ Which cutteth off whole ${ }^{e}$ nations in their place.

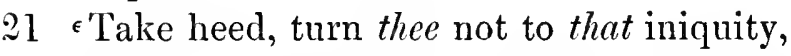
For thou ${ }^{2} \zeta$ seemest to ${ }^{f}$ choose $\eta$ it rather than affliction.

22 Behold! God ${ }^{\theta}$ is ${ }^{g}$ exalted in His power;

Who $i s^{\kappa} a^{h}$ teacher like Him?

23 Who hath ${ }^{\lambda}$ enjoined on Him His way ${ }^{i}$ ?

Or who hath ever said unto Him: "Thou hast wrought iniquity ${ }^{k} "$ ?

24 Remember that thou oughtest rather to exalt $\mu$ His works ${ }^{l}$,

Which men ${ }^{m} \nu$ do contemplate

$25 Y e a$, all men ${ }^{n} \pi$ behold them ;

Even frail-man regardeth $\rho$ them from afar. $\dagger$

1 Or, "Nor all the might of thy wealth," as I believe Dr. Bernard used translate it.-Editor, 1862.

2 Or, "didst choose it," for Job actually did choose it, though he immediately repented.-Editor, 1862 .

* Job having repeatedly declared his great longing for death and the grave, and even confessed the temptation he sometimes felt to commit suicide (chap. vii. 15), Elihu warns him against the commission of such a rash and atrocious act, reminding him that death, which unsought comes and sweeps away whole nations, will assuredly one day come and carry him away; so that there can be no occasion for him to hurry to meet it half way.

+ Instead of busying thyself with scrutinizing the dispensations of Providence, which are altogether beyond the reach of man, thou shouldest rather contemplate the visible works of God, and admire His wonderful power as displayed in them. 
26 Behold! God is ${ }^{a} \omega$ so great that we cannot know $\mathrm{Him}^{b}$;

The ${ }^{c}$ number of His years $\beta$ is unsearchable.

$27 *$ When He $\gamma$ draweth up drops of water ${ }^{d}, \dagger$

They distil rain $\delta$ into His mist ${ }^{e}$.

28 Which the ${ }^{f}$ clouds do edrop $^{g}$, And ${ }^{h} \zeta$ pour down upon man abundantly.

29 Yea, can $\eta$ any understand the spreadings of the ${ }^{\theta}$ clouds $^{i}$,

Or. the k rumblings $^{k}$ of His ${ }^{l}$ pavilion? +

$30 \S$ Lo! He hath spread over it His ${ }^{m} \lambda$ lightning, And hath covered the ${ }^{\mu}$ offspring of the sea ${ }^{n} . \|$

31 For by them He ${ }^{\nu}$ executeth judgment upon nations ${ }^{\circ}$,

By them also He giveth food in abundance ${ }^{n}$. 9 $32 \pi$ With His hands He $\rho$ covereth up the ${ }^{\sigma}$ lightning ${ }^{4}$,

But on ${ }^{\tau}$ hurling it He $\phi$ giveth it a charge ${ }^{r}$.***

33 Its ${ }^{s}$ crash telleth concerning it that it is jealousanger,

* Elihu here draws the attention of his unfortunate friend to the rain, thunder, and lightning, which were now, probably, beginning to be seen or heard as the commencement of the tempest out of which we shall soon hear God address Himself to Job.

+ i.e., by evaporation from the sea, rivers, \&c.

$\ddagger$ The elouds are termed the pavilion of God in Ps. xviii. 11

$\S$ At this moment it would seem it lightened. [The Heb. word translated over it properly refers to clouds (in Heb. a sing. collective) and not to pravilion, as over it does. The sense is, however, the same, as pavilion = clouds. - Editor, 1862.]

\| i.e., the cloud, termed the offspring of the sea, as being composed of drops of water derived by evaporation in great measure from the sea.

If Sometimes He sends rain as a punishment, sometimes as a blessing.

*** He tosses the lightning about in His hands like a ball, yet He does not throw it at randon, but points out to it the precise spot it is to strike.

Isa. xxx. 23; $\rho$ hath corered. $\sigma$ light. $q$ supra ver. it, charged it. $\quad r$ infra xxxvii. 3 ; xxxiii. $25,35,36$. s supraver. 29 , uote $k$. $\omega$ great, so that we cannot know.

b supra v. 9 ; ix. 10 ; xi. $7-9$.

c supia x. 5 ; xix. 25 ; Ps. xc. 2,4 ; cii. $25-27$; Isa. xli. 4; xliii. 13 ; xliv. $6, \& c$.

$\beta$ that [there is] no search, or, and no search $=$ without search. See Append.

$\gamma$ taketh away.

$d$ infra ver. 30 ; $\mathbf{P a}$. cxxxv. 7 ; Jel. x. 13 ; li. 16 ; comp. Eccles. i. 7.

$\delta$ or, for His mist, so as to make $\mathrm{His}$ mist. Edit., 186:2.

$e$ Gen. ii. 6.

$f$ infra $\mathbf{x x}$ iii. $11-$ $13,16,21$; xxxงiï. 9,37 .

$\varepsilon$ flow.

gsupra xхvi. 8 ; Judg. v. 4.

h. Prov. iii. 20 .

5 distil.

$\eta$ one.

$\theta$ thick-clond.

i infia xxxrii. 16; supra xxvi. 8.

$\kappa$ noises.

$k$ infia vel. 33 ; xxxrii. 4 ; Ps. lxxvii. 18 ; civ. 7.

$l 2$ Sam. xxii. 12; Ps.xviii. 11 ; xcrii. 2; xxrii. 5; 1 Kings viii. $10-12$.

m infra xxxrii. 3 ; xxxriii. 25, 35, 36 ;

Luke xvii. 24, \&c.

$\lambda$ light.

$\mu$ roots (sec Comm.). n supra ver. 27 ; comp. Eccles. i. 7.

$v$ judgeth nations.

- infiu xxxrii. 13; Gren. vii. 11, 1:2; Exod. ix. 18, 33, $3 \pm$; Ezra x. 9; comp. Ler, xxvi. 19 ; Deut. xxriii. $23 ; 1$ Kings riii. 35,36 ; xrii. 1, \&c. $p$ infra xxxrii. 13 ; lev. xxri. 3, 4; Isa. $\begin{aligned} & \text { xxx. } 23 \text {; } \\ & \text { supra ver. }\end{aligned}$ hatli enjoined upon 
a supra i. 16 ; 2 Kings i. 10, 12; 2 Sam. xxii. 14, 15; Ps. xriii. 13, 14 ; xevii. 3 , \&c.; comp. Ezek, xxi. 31 ; xxii. 31 ; xxxviii. 19 ; $P$ s. lxxix. 46.

b supra xxiii. 16; Ps. xxii. 14; хxxriii. 10; 1v. 4, \&c.

c suprair. 14; xxi. 6.

$d$ Exod. xix. 16; xx. 18.

$\beta$ hearge attentirely. $\gamma$ commotion (frémissement), raging, roaring.

e supra xxxvi. 33.

$f$ infra rers. 4,5 ; xl. 9 ; Ps. xviii. 13 ; xxix. $3-5$, $7-9$; 1xviii. 33 . $g$ infia ver. 4 ; Hos. xi. 10; Isa. xlii.13; Jer. xxv. 30, \&c.

h supra xxviii. 24; infra xli. 11.

i supra xxxri. 32 ; infra xxxviii. 35, 36 ; comp. supra j. $16 ; 2$ Sam. xxii. 15 ; Ps. xviii. 14; cxliv. 6.

$\delta$ liath directed it.

$k$ supra xxxvi. 30, 32 ; xxviii. 26 ; infra xxxviii. 25, 35,36 .

$\varepsilon$ light.

$\zeta$ upon, orer.

$\eta$ wings, skirts.

$\theta$ [the] roice [of God].

l supra ver. $\mathbf{2}$; хxxvi. 29, 33 ; xxvi. 14; infra xxxriii. 25 ; xl. 9 , \&c.

m supra ver. 2 , note $f$.

$n$ supra ver. 2, note $k$.

$\kappa$ one cannot trace them.

o supra xxvi. 14; comp.infraxxxviii. 25.

p supra xxri. 14.

$\lambda$ doing.

$\mu$ and we know not, or, that we cannot know.

q supra V. 9; ix. 10. 28 ; Lev. xxvi. $4 . \quad t$ Gen. vii. 11, 12 ; Ezra x. 9, 13 ; Exod. ix. 18, 33, 34, \&c. $\pi$ shower of rains.

That it is wrath, because of iniquity ${ }^{a}$. *

\section{CHAP'TER XXXVII. †}

1 Yea, mine ${ }^{b}$ heart ${ }^{c}$ trembleth at this ${ }^{d}$, And leapeth from its place.

$2 \beta$ Hear; oh, hear ye the $\gamma$ tumult $^{e}$ of His ${ }^{f}$ voice!

And the ${ }^{g}$ roaring that goeth out from His mouth!

$3{ }^{h}$ Under the whole heaven $\mathrm{He}^{i} \delta$ directeth it, His ${ }^{k}$ elightning also $\zeta$ unto the $\eta$ ends of the earth.

4 After it, $\theta$ the ${ }^{l}$ thunder ${ }^{m}$ roareth;

He thundereth with the ${ }^{n}$ voice of His majesty;

Yet though His ${ }^{n}$ voice is heard, ${ }^{k}$ none can ${ }^{\circ}$ trace $\ddagger$ them out.

5 God thundereth with His voice ${ }^{p}$ marvellously; Great-things $\lambda$ doeth $\mathrm{He}, \mu$ which we cannot comprehend ${ }^{q}$.

6 For to the ${ }^{r}$ snow He saith: Be thou upon the earth,

To the ${ }^{\nu}$ gentle rains also, and to the ${ }^{t} \pi$ heavy rains of His strength.

* That God somctimes gives vent to His indignation in thunder and lightning, we see from 1 Sam. xii. 17, 18.

Dr. Bernard inclines to the opinion that this verse should rather be translated as follows :

Its crash telleth concerning it that it is jealous-anger,

That it is on account of rising wrath. (See Comm.Note of Editor.)

$\dagger$ A storm (the same probably as that from which God in the next chapter addresses Job) had apparently been gathering during the delivery of the last few chapters (see notes * and $\S$ in the preceding page) and may very well be supposed to have burst forth just at this time; and, if so, Elihu will conclude his speech amidst thunder, lightning, and heavy rain.-See Comm. Editor, 1862.

$\$$ i.e., the thunder and the lightning.

$r$ infra xxxviii. 22 ; supra ix. 30. y shower of rain. s supra xxxvi. 27, 
$7 \omega^{\omega}$ And so $\mathrm{He}^{b}$ shutteth up every man ${ }^{c}$ in his place, $\beta$ That all men whom $\mathrm{He}$ hath ${ }^{d}$ made may ${ }^{e}$ know Him.

8 Then $\gamma$ must the wild-beast enter into its $\delta \operatorname{covert}^{f}$, And in its $\epsilon \operatorname{den}^{f} \zeta$ abide.

9 From the $\eta$ store-house ${ }^{g *}$ cometh the ${ }^{h}$ whirlwind, And from the ${ }^{i}$ constellations, cold.

$10 \eta \eta$ By the +breath of God $\theta$ is ${ }^{k}$ ice produced, $\theta \theta$ And the ${ }^{\kappa}$ waters' breadth $\lambda i{ }^{1}{ }^{1}$ straitened ${ }^{l}$. 11 Yea, ${ }^{\mu}$ the bright-sun weareth away the thickcloud $^{m}$,

It scattereth $\nu$ His $\ddagger$ lightning-cloud ${ }^{n}$;

$\omega$ in [the] place of every man $\mathrm{He}$ sealeth [him] up.

6 supra xxiv. 16 ; Gen. vii. 14-16, \&c. ; comp. supra xii. 14 ; ix. 7.

c supra xxxiv. 26.

$\beta$ forall [the] men of His make to know.

d supra xxxiv. 19; xxxiii. 4,6 ; x. 3 , 8-11; Isa. xlv. $9,12, \& c$

e supra xxi. 19.

$\gamma$ hath..........come, cometh.

$\delta$ lurking-place.

$f$ infra xxxriii. 40 ; xl. $21 ;$ Ps. civ. $22,8 \mathrm{c}$.

$\varepsilon$ dwellings, dens.

12 And it $\$$ turneth itself ${ }^{\circ} \pi$ round about according to His plans,

$\rho$ That it may do whatsoever $\mathrm{He}{ }^{\sigma}$ commandeth it upon the face of the world, on earth ${ }^{p}$.

13 Either for ${ }^{q} \tau$ chastisement, or for $\mathrm{His}^{r}$ land, Or for ${ }^{s}$ kindness, He causeth it $\phi$ to come.

$14{ }^{t}$ Give ear unto this, O Job! ${ }^{u}$ Stand still and ${ }^{v}$ consider the ${ }^{x}$ wondrous-works of God!

$15 \times$ Knowest thou when God ${ }^{y}$ setteth the $\psi$ sun upon His cloud,

1 Or, "hardened, congealed."-Editor, 1862.

* In which, as some of the ancients thought, the winds were confined.

$\uparrow$ As supra, vers. 2, 4, 5, thunder is represented as the voice of God, so here wind is termed His breath.-Editor, 1862.

$\ddagger$ Or, as we say, thunder-cloud.-Editor, 1862.

$\S$ i.e., the lightning-cloud. And this, if less elegant, would perhaps be more clear. See Append.-Editor, 1862.

II He sends rain, sometimes as a general chastisement, sometimes as a mark of His favour upon one particular land only, sometimes, again, as a general blessing. Comp. Amos iv. 7.

$\pi[$ in] circuits, circuitously.

$\rho$ for their doing, that they may do.

$\zeta$ dwell.

$\eta$ store-room.

$g$ Jer. x. $13 ;$ Ps. cxxxr. 7 ; comp. infra xxxviii. 22 .

h supra $x \times 1 . \quad 18$; xxrii. 20.

$i 2$ Kings xxiii. 5 ; infra xxxriii. 31 , 32 ; supra ix. 9.

$\eta \eta$ from, by means of.

$\theta$ one giveth, maketh, produceth, ice.

k infra xxxriii. 29 ; Ps.cxlvii. 17, 18 .

$\theta \theta$ or, when.

$\kappa$ width of waters.

$\lambda$ [is] in a compressed-, or firm-, mass-, or, in a narrowed-place ; or, in narrowness, straitness.

l. infra xxxriii. 30. $\mu$ serenity, brightness $m$ comp. infi" $a$ vers. $15,18,21,22$; Ezek. xxxii. 7.

$\nu$ [the] clond of $\mathrm{His}$ light, lightning.

$n$ comp.supra xхxri. 30. p supra xxxvi. 31,32 ; хxxrii. 3 ; infra xxxviii. $23,35-37 . \quad$ q supra xxxri. 31 ; infra xxxriii. 23 ; Gen. rii. 4, 11, 12; Ezra x. 9, $13 . \quad \tau$ a rod. $r$ Exod. riii. 22, 23 ; ix. 4; x. 23; xi. 6, 7; xii. 13; Amos iv. 7; Rom. ix. 18, \&c. s 1 Kings xriii. 44, 45 ; Ler. xxri. 4; Dent. xxviii. 12 ; Joel ii. 23 , \&c. $\phi$ to befall, happen to, [mell]. $\quad t$ supra xxxir. 16 ; xxxiii. 33, 31, 1 ; comp. xxxiv. 2,16 ; xiii. 6,17 , \&c. $u$ Exod. xiv. $13 . \quad v$ supra xxxr. 5 ; xxii. 12; Ps. viii. 3 ; Eccles. vii. 13 , \&c. $\quad x$ infra ver. 16 ; Ps. xxvi. 7 ; er. 2 ; exix. 27 , \&c. $\chi$ lit., knowest thou when God setteth orer them (i.e., the clouds), and maketh to shine [upon] His cloud, [the] sun. $\quad y$ vers. 11,18 ; comp. supre ix. $7 . \quad \psi$ light. 
(w) upon them.

z supra ver. 11.

$\beta$ concerning.

a comp. supra rer.

12 ; хxхvi. 29.

$\beta \beta$ or, oscillations.

$\gamma$ thick-cloud.

b supre ver. 14, $(x)$.

c supra xsxit. 4; xi. 7.

$\delta$ of knowledges, i.e., every kind of knowledge.

co [are] warm.

$\varepsilon$ on [his] making still.

$\zeta$ by means of.

$d$ Luke xii. 55.

e supra rer. 11.

f supra ver. 11 ; xxxri. $28-32$; xxxv. 5, \&c.

$\zeta \zeta$ strong.

$\eta$ poured out.

$\theta$ make us to know.

$g$ supra $\mathrm{xxxiii.} \mathrm{5;}$ xxiii. 4 ; xiii. 18.

$h$ supra $\mathrm{xxii} .11-14$.

$\kappa$ related, recounted with regard to him.

$\lambda$ speak.

$\mu$ hath a man said, saith a man.

$i$ comp. supra $\mathrm{xx}$. 5.

$v$ swallowed up.

$\pi$ have they not seen $=$ if, though, they have not seen.

$\rho$ lit. light.

$\sigma$ hath a wind passed.

$k$ supra $\mathrm{xx} \times \mathrm{i} .13$.

$l$ Zech. iv. 12.

$\tau$ with God awful (or, fearful, terrible) $[$ is the glory.

$m$ infra xl. 10 ; Ps. lxvi. 5 ; xeiii. 1 ; xevi. 4,$6 ; 1$ Chron. xxix. 11, \&c.
And maketh it to shine $\omega$ thereon $\approx$ ?

16 Knowest thou ought $\beta$ of ${ }^{a}$ the $\beta \beta$ balancings of the $\gamma$ clouds?

(Oh, the ${ }^{b}$ wondrous-works of Him that is ${ }^{c}$ perfect $\delta$ in knowledge!)

$17 \mathrm{Or}$, how thy garments $\delta \delta$ grow warm,

$\epsilon$ When $h e^{*}$ maketh still the earth $\zeta$ with a ${ }^{d}$ south-wind?

18 Dost thou with him ${ }^{*}{ }^{e}$ beat thin the ${ }^{f}$ clouds, Which are $\zeta \zeta$ firm as a $\eta$ molten mirror?

$19 \theta$ Teach us what we shall say concerning him*; For we cannot ${ }^{g}$ order our speech ${ }^{h}$ by reason of darkness. $†$

20 Shall it be $\kappa$ told of him-shall I indeed $\lambda$ declare-

Or $\mu$ any say, that he is ${ }^{i} \nu$ destroyed ? $\ddagger$

21 But now, $\pi$ though men see not the $\rho$ sun,

Yet he is bright among the clouds;

And, $\sigma$ when a wind hath passed and cleansed them away ${ }^{k}$

$22 Y e a$, by means of a north-wind-he * will come forth- ${ }^{l}$ gold. \$

But, $\tau$ the ${ }^{m}$ glory which is with God is awful.\|

* i.e., the sun.

+ We are at a loss to say what hath become of the sun on account of the darkness of the intervening clouds. [In Chap. xxii. 11-14, Job is represented by Eliphaz as adducing the very same reason for calling in doubt the existence of God, so here Elihu, by showing that the sun, when hidden from the eyes of men by thick clouds, still shines in all his brightness behind them, endearours to prove that God, though unseen by men (it may be through His being enveloped in thick clouds, see 1 Kings viii. 12 ; Ps. xviii. 11, \&cc.), does not the less exist, a Being awful in His glory.-Editor, 1862.]

* Could any one be simple enough to say, that the sun had fallen from his seat, and was destroyed, because he did not see him ?

$\$$ He will emerge from the clouds dazzling as a globe of gold, yet as nothing is his splendour when compared with the glory of his creator, God.

II His (God's) glory dazzles not the eye alone, it dazzles the mind also, and impresses it with deep awe. 
23 The Almighty!

$H e$ is $x$ great in power ${ }^{\prime}$ and ${ }^{z}$ justice,

And in the "multitude of His righteousness

He will not afflict ${ }^{b}$.

24 Men, therefore, can only fear $\operatorname{Him}^{c}$;

$B u{ }^{d}$ none even of the ${ }^{\omega}$ wise in heart can see Itim. +

\section{CHAPTER XXXVIII.}

1 Then Jehovah answered Job from out the e storm, and said:

2 Who is this a that ${ }^{f}$ darkeneth $M_{y}$ counsel, $\mathrm{By}{ }^{g}$ words without knowledge?

$3{ }^{h}$ Gird up now thy loins like a man, ${ }^{\beta}$ For ${ }^{i}$ I will ask of thee, and do thou $\gamma$ declare unto Me!

4. Where wast thou $\delta$ when I founded the earth ${ }^{k}$ ? ${ }^{l}$ Declare, if thou $\mathrm{\epsilon}$ hast ${ }^{m}$ understanding.

5 Who $\zeta$ determined her measures ${ }^{n}$, if thou knowest?

Or who ${ }^{\circ}$ stretched over her the line?

$6^{p} \eta$ Whereupon were her ${ }^{q}$ foundations $\theta$ settled? Or who ${ }^{k}$ laid her ${ }^{r \lambda}$ corner-stone,

7 ( $\mu$ When the ${ }^{s}$ morning-stars sang together ${ }^{t}$, And all the sons of God shouted for joy ${ }^{t} \$$ )

* We cannot say of Him, when, how, and to whom, He will reveal Himself.

+ He will not afflict the sons of men willingly. Comp. Lam. iii. 33.

+ All that men can do is to worship Him with reverence and with awe, inasmuch as their wisdom cannot enable them to see Him.

$\S$ That it was the custom among the Jews to celebrate the foundation of stately edifices with songs and shouts of joy and music, we learn from Ezra iii. 10-13. $\phi$ have not found Him.

x supra $\mathrm{xxiii} .3,8,9$; ix. $11 ; x i .7-9$; comp. Ps. cxxxix. $7-12$.

$\chi$ great of power.

$y$ supra ix. 4, 19; xii. 13,16 ; хxxvi. 5 ; Jer, xxxii. 19 ; Dan. ii. 20.

z supra xxxiv. 10$12,17,19$; riii. 3 ; iv. 17 ; $\mathrm{x} \times \mathrm{r}, 4$ 6 ; comp. supra ix. $17,22,24$; x. 3,7 ; xi. 4 ; xri. 17 ; xix. 7 ; xxvii. 2; xxxiii. 9-11; xxxiv. 5, do.

a Ps. ․ 7 ; li. 1 ; lxix. 13.

b Lam.iil. 33 ; Ezek. xxxiii. 11 ; supre xxxiv. 11; Judg. i. $7, \& c$.

c supra xxviii. 39 [28]; Ps. xix. 9, 10 ; cxi. 10; exix. 72 ; Prov. i. 7 ; ix. 10 ; Eccles. xii. 13 ; comp. supra iv. $6 ; x \mathrm{x} .4$.

d supra xxiii. 8, 9; ix. $11 ;$ x. 16 ; comp. supra ххх 10 ; xxii. 13, 14; 1 Kings riii. 12 ; Ps. xerii. 2, \&e.

$\omega$ wise of heart.

$e$ infraxl. 6 ; comp. 1 Kings xix. 1113; Exod. xix.16, 18, 19; xx. 18, 19 . a causing to be dark, darkening.

finfra xlii. 3.

g supra $\mathrm{xxxv}, 16$; xxxir. 35 ; xxxiii. 33 ; xv. 2, 3,79 ; xi. 6 ; viii. 2 ; г. 2 ; comp. xii. 2 , 3 ; xiii. 2 , Sce.

$h$ infra xl. 7 ; Jer. i.

17; 2 Kings ir. 29. $\beta$ and, seeing that, \&c. $i$ irfia xl. 7 ; xlii. 4 ; supra xxxiii. 32 ; xiii. 22.

$\gamma$ make me to know. $\delta$ on $\mathrm{Mr}$ founding. $\quad k$ comp. supra $x$ r. 7 ; xxriii. 26.27 ; Prov. viii. 22-31; iii. 19 ; Ps. cii. 25, \&e. linfra ver. 18 . \& knowest understanding. m supra

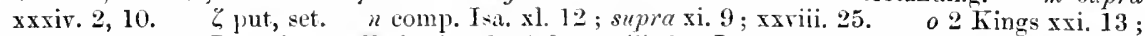
Isa. xxxir. 11 ; Lam. il. 8 ; Zech. i. 16 ; 2 Sam. viii. 2 ; Jer. xxxi. 39 , \&e. $p 1$ Sam. ii. 8 ; Ps. xxiv. 2 ; comp. supra ix. $6 . \quad \eta$ upon what. $q$ Ps. civ. 5 ; Prov. viii. 29 ; Isa. li. 13, \&c. $\theta$ caused to sink. $\quad \kappa$ cast (cf. the Fr. jeter les fondements). $\quad r$ Psa. exriii. 22 ; exliv. 12. $\lambda$ [the] stone of her corner. $\mu$ on [i he] morning-stars singing together. $s$ Rev. ii. 28 ; xxii. 16. $t$ comp. Ezra iii. $10-13$; Neh. xii. 27 . 
$\phi$ hedged.

$x$ infra ver. 10 ; supra vii.12; xxri. 12; Gen. i. 9; Ps. хxхіii. 7 ; cir. 9 ; Prov, viii.29; Jer. r. 22, \&c.

$\psi$ on its bursting forth.

$\omega$ issueth.

$y$ infra rers. 9, 29.

$a$ on my putting [the] cloud.

$z$ comp. Pror. xxx. 4 ; Ps. civ. 6; supra xxri. 8; infra ver. 14.

$b$ Gen. i. 2.

$\beta$ when (or, and) $I$ broke, decreed, determined, for it my bound.

c supra xxvi. 12; Gen. i. 9 ; Prov. viii. 29; Jer. v. 22 , de.

d supra ver.8; comp. vii. 12.

$\gamma$ unto here.

$\delta$ but thou shalt not add [to come].

$\varepsilon$ shall one lay [his hand] upon [the] pride of thy waves.

e supra xxri. 12 ; ix. 8 ; Jer. v. 22 ; Ps. 1xจ. 7 ; 1xxxix. 9 , \&c.

$\zeta$ since, of, thy days (de tes jours).

$f$ supra ix. 7 ; Gen. i. 3 ; Ps. Ixxiv. 16.

$\eta$ [so as] to seize.

$g$ supra $\mathrm{x} \times \mathrm{x}$ ii. 3 ; xxviii. $24 ; 1 \mathrm{Sam}$. ii. 10 ; Ps. xix. 6, \&c.

$\theta$ skirts.

h supra sxiv. 13, 15 -17 .

$\kappa$ turnetl, changeth, herself.

i supra x. 9; Isa. xli. 25 ; xlv. 9, \&c.

$\lambda$ set themselres up, stand.

$k$ Ps. civ. 2 ; comp. supra ver. 9.

l supia xxiv. 13,15 -17 ; v. 14 ; John iii. 19-21; Jer. xlix. 9 ; Obad. 5, \&c.

$m$ Ps. x. 15 ; xxxvii. 17; Ezek. xxx. 21 ; comp. supra sxii. 9.
8 And $\phi$ fenced in the sea with doors ${ }^{x}$, $\psi$ When it burst forth, - ${ }^{\omega}$ issued from the ${ }^{y}$ womb?

9 a When I made the clouds its garment *, And ${ }^{b}$ thick-darkness its swaddling-band;

$10 \beta$ When I assigned unto it $\mathrm{My}$ bound ${ }^{c}$, And set a bar thereon and doors ${ }^{d}$,

11 And said: " $\gamma$ Thus far shalt thou come, $\delta$ but no farther,

" $\epsilon$ And here shall thy ${ }^{e}$ proud waves be stayed"?

12 Hast thou $\zeta$ ever commanded the morning ${ }^{f}$ ? $*$ Hast thou caused the dawn to know its place, $13 \eta$ That it should seize upon the ${ }^{g \theta}$ far-corners of the earth,

And the wicked should be shaken out from her ${ }^{h}$ ? $†$ $14+$ She $\kappa$ is changed as the ${ }^{i}$ clay of a seal ; And they $\$ \lambda$ stand forth, as though clothed with $a^{k}$ garment.\|

15 But from the wicked their light 9 is withholden ${ }^{l}$, So that the high arm is broken ${ }^{m}$.

* That is, to appear.

$\dagger$ Inasmuch as wicked men, such as thieves, adulterers, and the like, are terribly afraid of day-light, as we were told in chap. xxiv. 15-17, and skulk away into their retreats on perceiving the very first glimmer thereof, the light is here described as seizing upon the earth by its corners, and shaking the wicked, like so many crumbs, out of it, as though it were a table-cloth.

\$ She, i.e., the earth.

$\$$ They, i.e., the corners of the earth, mentioned in ver. 13.

|| The earth, which in the darkness of night appears a sliapeless mass, receives a form from light, just as clay (or as we should say, wax) does from the impression of a seal. In like manner, all the objects on the surface of the earth, which, while the darkness lasts, cannot be distinguished from one another, are decked by light with various colours, constituting for them, so to say, a dress, by which they are as easily distinguished as human beings are by theirs.

I Their light, i.e., the light of the morning and the dawn (mentioned in ver. 12), and this is said to be withholden from the wicked, seeing that they shun it, and, greatly alarmed at its approach, take refuge in their lurking-places. Comp. chap. xxiv. 13. 
16 Hast thou come unto the mazes of the sea ${ }^{a}$ ? Or $\psi_{\text {walked in the }}{ }^{\omega}$ recesses of the deep ${ }^{a}$ ?

17 Have the ${ }^{b}$ gates of death been disclosed unto thee? Or canst thou see the gates of the ${ }^{c}$ shadow-ofdeath?

a Ps. Ixxrii. 19 ; cxxxix. 9; comp. supraxxvi.5; Jon. ii. 5,6 .

$\psi$ t'es-tn promené?

$\omega$ searching of.

b Ps. ix. 13; crii. 18 ; comp. Isa. xxxviii. 10.

18 Hast thou understood even the $\beta$ breadth of the e supraiii. 5 ; x. 21; earth ${ }^{d}$ ?

${ }^{e}$ Declare, if thou knowest it all!

$19{ }^{1} \gamma$ Which $i s$ the way to where light dwelleth ${ }^{f}$ ? And darkness-where $i s$ its $\delta$ abode? xii. 22 ; xvi. 16 ; xxiv. 17 ; xxviii. $3 ; \operatorname{xxxiv.~} 22$.

$\beta$ breadths, wide-expanses, of.

d supra rer. 5 .

e supra ver. 4.

$20 \in$ Doubtless thou canst take $\zeta$ them to $\eta$ their bound! $f$ where. And doubtless thou perceivest the ${ }^{\theta}$ pathways to $\delta$ place.

$\kappa$ their house !

$\varepsilon$ surely.

$\zeta$ it.

$\eta$ its bound.

$21 Y e s$, this thou knowest ${ }^{g}$, for ${ }^{\lambda}$ long since ${ }^{\mu}$ wast $\theta$ pathways of. thou born ${ }^{n}$ !

And the number of thy days is very great ${ }^{i}$ !)

$\kappa$ its.

g supra xxxii. 4,6 7,9 ; xii. 12,20 .

$\lambda$ lit. then.

22 Hast thou come unto the ${ }^{k}$ treasuries of the snow, $\mu$ art thou born. (tu And the ${ }^{k}$ treasuries of the hail canst thou $\mu \mu$ behold, $h$ supra rer. $5 ; x$. xr.

23) Which I have $\nu$ reserved against the time of $i$ comp. suprasiv. 1 ; trouble ${ }^{l}$,

$\pi$ Against the day of battle and of war $^{l}$ ?*

$24 \pi \pi$ By what way is the ${ }^{m}$ lighi distributed?

$\rho$ The east-wind spread abroad upon the earth?

$25^{n}$ Who hath ${ }^{\sigma}$ cut out a channel for the torrent ${ }^{\circ}$ ? $\dagger$ And a way for the flash of the $\tau$ thunder ${ }^{p}$ ?

26 क To cause it to rain ${ }^{q}$ upon a land, where ${ }^{r}$ no man $i s$ !

Upon a wilderness ${ }^{s} \chi$ where there is no man ${ }^{t}$;

27 'lo $\psi$ water to its "fill the desert and the waste,

$\omega$ To cause the grass-germ to spring up $"$.

$28 \beta$ Hath the rain a father ${ }^{x}$ ?

1 Or less literally, Which is the way to the dwelling-place of light.-Ed., 1862.

* Comp. Josh. x. 11, where we read that the armies of the Amorites, who had taken the field against the will of God, were destroyed by hailstones.

$\dagger$ i.e., for rain, falling in torrents.

$\ddagger$ Other than Myself. x. 5, \&e.

$k$ comp. Ps. ' $\operatorname{xxv}$. 7 ; Jer. x. 13 ; li. 16.

$\mu \mu$ see.

$\nu$ withheld, kept back, spared, for.

$l$ comp. supra xxxvii. 12,13 ; xxsvi. 31 ; Exod. ix. 18, 23, dc. ; Josh. x. 11; Ps. xriii. 12; Ixxviii. 47, 4S; cxlviii. S, Sce.

$\pi$ for.

$\pi \pi$ where [is] the way [by whicn the] light is distributed?

on supra vers. 19, $12,13$.

$\rho$ doth [the] eastwind scatter, spread [itself].

$n$ infra ver. 28.

$\sigma$ divided, cleaved.

o supra xxviii. 37 [־6]; Ps. cxlvii.8.

$\tau$ voices, thunders.

p supra xxviii. 37 [26]. $\phi$ to cause to rain. $q$ supra v. 10 ; Ps. cir. 13,14 ; cxlrii. 8 ; Jer. xir. 22. r Jer. xlir. 22 ; xlvi. 19, \&c. $s$ supra vi. 15,19 ; Ps. evii. 35 ; 1sa. xli. 18; comp. Gen. xxi. 14, $19 . \quad \chi$ not man in it. $t$ comp. supra xii. 24 ; 1's. cvii. $40 . \quad \psi$ satiate, saturate. $\quad$ Prov. $x x x .16$; comp. Ps. civ. 13. $\omega$ and to cullse, \&e. $v$ l's. cir. 14 ; exlrii.8. $\beta$ is [there] to the rain? $x$ supra vers. 25, 26; хxxvi. 27, 28; v. 10 ; xxviii. 26; Ps. Ixv. 2, 10; lxviii. 9; Jer. v. 24, \&c. 
a supra хxxri. 27; Judg. vi. $37-40$;

1 hings x vii. 1.

(1) out of [the womb of whom?

$b$ comp. supra rer. 8.

c Ps. exlvii. 17 ; comp. supra xxxvii. $9,10$.

d Ps. cxlvii. 16; comp. supra xxxrii. 10.

$\beta$ taketh, eatcheth hold of, itself, setteth fast, congealeth.

e comp.supra $\mathrm{x} \times \mathrm{xii}$. 10.

$\gamma$ bind, constrict.

f supra ix. 9; Amos v. 8.

$g$ comp. supra xxxvii. 9 ; ix. 7 .

$\delta$ open, undo.

c cause to go forth.

h supra xxxrii. 9; 2 Kings xxiii. 5 ; Isa. xiii. 10.

$\zeta$ [every one] in its season.

$i$ supra ix. 9 ;

$\eta$ her sons.

$k$ Jer. xxxi. 35, 36 ; xxxiii. 25.

$\theta$ set.

$\iota$ Matt. xvi. 2, 3.

$\kappa$ the thick-cloud.

m comp. supra vers. 12,13 ; ix. 7 ; $i n$ fra ver. $37 ; 1$ Kings xviii. 41, 44,45 ; supra xxxri. 28, note $f$.

n. supra xxii. 11 ; Jer. x. 13 ; li. 16 .

$\lambda$ cover thee.

o supra ver. 25 ; xxxvi. 30,32 ; xxxrii. 3 ; i. 16 ; xxviii. $26 ; 2$ Sam. xxii. 15 ; Ps. xviii. 14 ; cxliv. 6.

$\lambda \lambda$ behold us !

p comp. Ps. civ. 4; exlviii. 8.

$q$ comp. infra xxxix. 17 ; supra $\mathrm{xxx}$. 11.

$\mu$ the inward-parts.

$v$ hath given, gare.

$\pi$ to the imagination, mind.

$r$ comp. Gen.xiii.16; xv. 5 ; infr $\alpha x x x i x$. 2.

$\rho$ can cause to lie.
Or who hath begotten the drops of dew ${ }^{a}$ ?

29 w Out of whose ${ }^{b}$ womb came forth the ice ${ }^{c}$ ?

And the hoar-frost ${ }^{d}$ of heaven-who brought it forth?

30 - The waters hide themselves

When the face of the deep $\beta$ congealeth ${ }^{e}$ like a stone- -

31 Canst thou $\gamma$ tighten the bands of the ${ }^{f}$ Pleiades ${ }^{g}$ ? $\mathrm{Or}^{\delta} \delta$ loose the fetters of ${ }^{f}$ Orion ${ }^{g}$ ?

32 Canst thon $\epsilon$ bring forth the ${ }^{h}$ constellations $\zeta$ in their season?

Even ${ }^{i}$ Arcturus with $\eta$ his sons-canst thou guide them?

33 Knowest thou the ${ }^{k}$ ordinances of heaven?

Canst thou ${ }^{\theta}$ determine its ${ }^{l}$ dominion over the earth?

34. Canst thou lift up thy voice unto $k$ the clouds ${ }^{m}$, ${ }^{n}$ So that an abundance of water shall $\lambda$ overhang thee?

35 Canst thou send forth the lightnings ${ }^{\circ}$, so that they shall go? *

Or will they say unto thee: " $\lambda \lambda$ Here we are ${ }^{p}$ ?"

36 Who hath ${ }^{q}$ put wisdom in $\mu$ their inward-parts?

Or who ${ }^{q} \nu$ imparted understanding $\pi$ to their mind? $†$

37 Who can ${ }^{r}$ number the clouds by wisdom? Or who $\rho$ in ${ }^{s}$ layers range the ${ }^{t}$ bottles of heaven $"+\neq$ $38 \sigma$ When the dust floweth into a molten-mass, And the clods ${ }^{\tau}$ cleave fast together?

* Whither thou directest them.

t Having, in the preceding verse, so far personified the lightnings as to represent them as capable of receiving commands, and of expressing their readiness to execute them, God now asks who it is that has inparted to them wisdom and intelligence sufficient to justify ITis so representing them.

$\ddagger$ The bottles of heaven, i.e., the clouds.

$\S$ Rosenmüller makes, and perhaps justly, the following verses commence the next chapter.

s supra xxxvi. 29; хxxvii. $16 . \quad t$ comp. supraxxvi. 8. $u$ Gen. rii. 11. $\sigma$ on [the] pouring out, melting, fusing, flowing of [the] dust. $\tau$ are madi to stick together. 
TRANSLATION. CHAPS. xxxviII. $39-41 ; \mathbf{x x x i x . ~} 1-10$.

39 Dost ${ }^{a}$ thou hunt down prey for the ${ }^{b}$ lion? Or $x$ satisfy the appetite of the ${ }^{b}$ young lions, 40 When they ${ }^{c} \psi$ crouch $\omega$ in their dens, When they $\beta$ lie in the covert, $\gamma$ in $\operatorname{ambush}^{\alpha}$ ? 41 Who ${ }^{\delta}$ provideth for the ${ }^{e}$ raven his food, When his young-ones ${ }^{f}$ cry aloud unto God, When they wander for lack of meat? *

\section{CHAPTER XXXIX.}

$1{ }^{g}$ KNowest thou $\epsilon$ the time when the ${ }^{h}$ wild-goats of the rock bring forth?

Watchest thou $\zeta$ the pangs of the ${ }^{i}$ hinds in travail?

2 Canst thou ${ }^{k}$ number the ${ }^{l}$ months that they fulfil? $\mathrm{Or}^{m}$ knowest thou $\eta$ the time when they bring forth? 3 They ${ }^{n}$ bow themselves - they $\theta$ cast out $\dagger$ their

$$
\text { young- }
$$

They dismiss their " pangs.

4 Their ${ }^{k}$ young ones wax strong;

They ${ }^{\lambda}$ grow up $\mu$ in the ${ }^{p}$ plains;

They ${ }^{\nu}$ go forth, and $\pi^{\pi}$ return no more ${ }^{q}$.

5 Who hath sent forth the ${ }^{r}$ wild-ass free?

And the wild-mule's bands who hath $\rho$ loosed?

6 Whose house I have $\sigma$ made the ${ }^{s}$ wilderness,

And $\tau$ his divelling the ${ }^{t}$ salt-waste.

7 He mocketh at the tumult of the city,

And the ${ }^{\tau \tau}$ cries of the "driver he $\phi$ heedeth not.

$8 \times$ What he findeth on the " mountains is his

$$
\text { pasture; }
$$

Yea, he searcheth after every green-thing.

9 Will the "wild-bull be willing to serve thee?

Will he ${ }^{2}$ abide by thy ${ }^{x}$ crib ?

10 Canst thon whold the "wild-bull by his rope ${ }^{y}$ to

$$
\text { the furrow? }
$$

$$
\text { * Comp. Ps. cxlvii. } 9 . \quad \dagger \text { i.e., gire birth to. }
$$

a Ps. exxxvi. 25; exlv. 15,16 ; cxlvi. 7 ; cxlvii. 9.

b supra iv. 10, 11; comp. Ps. xxxiv. 10 ; civ. 21.

$\chi$ fill.

c Ps. cir. 22; supra xxxrii. 8 ; comp. Amos iii. 4.

$\psi$ bend down, bow (themselves).

$\omega$ in the dwellings, dens.

$\beta$ sit.

$\gamma$ for ambush.

d Ps. x. 9.

$\delta$ prepareth.

e PE. cxlvii. 9 ; Luke xii $2 t$; M:ttt. ri. 26 ; comp. exxxvi. 25 ; cxlv. 15,16 ; cxlvi. 7 .

$f$ Ps. exlvii. 9.

$g$ infra ver. 2.

$\varepsilon$ [the] time of [the] bringing-forth of

[the] wild-goats, \&e.

hl Sam. xxiv. 2; 1'. civ. 18.

$\zeta[$ the $]$ being in pains of labour, [the] travailing, of [the] hinds.

$i$ Ps. xxix. 9; Jer. xiv. 5.

$k$ comp. supra xxxviii. 37 ; Gen. xiii. 16 ; xr. 5 .

l. supra $\times \mathrm{i}$. 21; xiv. 5; iii. 6 ; vii. 3 ; $x \mathrm{xix} .2$. $m$ supra ver. 1.

$\eta$ [the] time of their bringing fortl.

$n 1$ Sann. iv. 19.

$\theta$ milke their young to cleare[the womb]. Comp. Exod. xiii. 2 ; xxxir. 19, \&e.

$o$ Isa. xiii. 8 ; Jer. xiii. 21 ; xxii. 23 . $\kappa$ children.

$\lambda$ become great (Fr. grandir).

$\mu$ in the open-fiel t.

$p$ Cant.ii. 7; iii. 5, \&c. $\nu$ have gone forth.

$\pi$ have not returned them (lit., tor them-

selves). $\quad q$ comp. Gen. viii. $12 . \quad r$ supra xxir. 5 ; xi. 12 ; ri. 5 ; Gen. xvi. 12; Jer. ii. 21 ; Hos. viii. 9 ; Ps. crv. 11, \&e. ; comp. supraxxx.7. $\rho$ opened, undune. $\sigma$ set, appointed. s supra xxiv. 5; Jer. ii. 24; xir.6; Dan. r. 21, \&c. $\tau$ his dwelling places. $t$ Jer. xvii. 6 ; Deut. xxix. 23; Judg. ix. 45; Ezek. xlrii. 11. $\tau \tau$ noises. u supra iii. 18, where transl. tash-master; cf. Lat. urgeo $=$ to drive and to oppress; and also agere and exigere. $\phi$ heareth not, liearkeneth not to. $\chi$ [the] searching of mountains; i.c., what is obtained by searehing the mountains. $v$ infrax $\mathbf{x} 20$. $w$ Numb. xxiii. 22 ; Deut. xxxiii. 17 ; Ps. xxii. 21 ; xxix. 6 ; xeii. 10, \&c. $\psi$ dwell at. $x$ Isa. i.3; Prov. xiv. 4. $\omega$ bind. $y$ comp. infra xli. 1-4; Isa. xxxvii. 29. 
Or will he harrow the valleys after thee?

11 Wilt thou trust in him, because his strength is great?

Or wilt thou leave unto him thy toil ? *

$\omega$ bulieve, have confidence, in him.

$\beta$ that he will bring back.

z Matt. vi. 26; xiii. 30.

$\gamma$ ostriches.

$\delta$ has been exulted, delighted, in ; has been, is, delightful.

c [is it the] wing [of the] stork, or [its] feather?

a Zech. Г. 9 ; Ps. cir. 17 ; Jer. viii. 7.

$\zeta$ leave.

$\eta$ by means of.

$\theta$ And, but, or seeing that, she hath forgotten.

$b$ Lam. iii. 34.

$\kappa$ it ; i.e., every one of the eggs.

c supra v. 23 ; infra xl. 20.

$\lambda$ One hath harden. ed [her heart.]

d Lam. ir. 3.

$\mu$ [are] for (i.e., as) not to her. See Append.

e comp. supra ix. 29; Isa. xlix. 4 ; $1 \times \mathrm{v}$. 23 ; Hab. ii. 13.

$\nu$ for vanity, emptiness.

$f$ infra ver. 22 .

$\pi$ made her to forget.

$g$ supra xvii. 4; comp. xxxriii. 36 .

$\rho$ not imparted to her in (or, of) understanding.

$\sigma$ at the time.

$h$ supra vers. 7, 22; infia xli. 29 ; 2 Kings xix. 21 ; Ps. ii. 4 , \&c.

$i$ Gen. xlix. 17 ; Exod. xr. 1 ; Jer. li. 21 ; Hag. ii. 22.
12 Canst thou $\omega$ rely on him $\beta$ to bring thee back thy seed,

And ${ }^{z}$ gather it into thy barn?

13 The wing of the $\gamma$ ostrich $\delta$ is goodly;

$B u t \epsilon$ is it the pinion, or the plumage, of the stork ${ }^{a}$ ?

14 No! for she must $\zeta$ commit her eggs unto the earth,

And must warm them $\eta$ with the dust.

$15{ }^{\theta}$ Yet she forgetteth that the ${ }^{b}$ foot may crush $\kappa$ them,

And that the ${ }^{c}$ wild-beast of the field may trample on $\mathrm{kthem.}$

$\mathrm{B}+16{ }^{\lambda}$ She hath been hardened ${ }^{d}$; her young are ${ }^{\mu}$ as though they were not hers. $\$$

${ }^{e} \nu$ In vain may be her labour $\|$, yet is she without fear ${ }^{f}$.

17 For God hath ${ }^{\pi}$ withholden from her wisdom ${ }^{g}$,

And hath $\rho$ given her no part in understanding ${ }^{g}$.

18 Could she $\sigma$ in due time but raise herself on high,

She might ${ }^{h}$ mock at the ${ }^{i}$ horse and his rider!

* Wilt thou entrust unto him the tillage of thy ground ?

+ For a Rabbinical note upon these six verses, see the end of the Chapter.

+ She might therefore be expected to be very anxious about the fate of her eggs, but is this so? Notwithstanding the risk her eggs run, she is so far from being anxious, that she even forgets they are in danger. See ver. 16._Editor, 1862.

\$ Having denied her wings, by which she would have been enabled to build her nest on high, God, in His mercy, made her callous and indifferent to her young.

$\|$ Her labour in arranging and concealing her eggs in the dust. 
19 Dost thou give ${ }^{a}$ might unto the horse?

a Ps. xxxiii. 17 ; ex! vii. 10.

Dost thou $\psi$ clothe his neck with the ${ }^{\omega}$ rust- $\psi$ make his neck to ling-mane?

20 Makest thou him $\beta$ to leap like the $\beta$ tond.

${ }^{b}$ locust?

The glory of his ${ }^{c}$ snorting is $\gamma$ terrible!

$21 \delta \mathrm{He}^{d}$ paweth in the valley, and ${ }^{e}$ exulteth

in his ${ }^{f}$ strength;

He e rusheth on $^{g}$ to meet the $\zeta$ weapons!

b Joel ii. 4, 5 ; Rev.

ix. 7 ; comp. Jer.

li. 27.

c Jer. viii. 16.

$\gamma$ terrol.

$\delta$ they dig.

d Juidg. v. 22 ; Jer. xlvii. 3 ; Nali.iii. 2.

$22 \mathrm{He}{ }^{h}$ mocketh at fear, and is not dis- $f$ supra ver. 19, mayed $^{h h}$;

note $\alpha$.

$\varepsilon$ goeth forth.

Neither turneth he back $\eta$ from the ${ }^{i}$ sword! $g$ Jer. viii. 6

23 Upon him rattleth the quiver,

$\theta$ The flaming spear-head and the javelin!

24 With clatter and with fury he $\kappa$ devoureth

the ground ${ }^{k}$,

$\zeta$ weapon.

$h$ supra vers. $7,18$.

hh infra xl. 23 ; xli. $24[16], 33[25]$.

$\eta$ from [tbe] face of, from before.

$i$ supra xix. 29.

$\theta$ [the] flame of

And $\lambda$ cannot stand still $\mu$ at the sound of $\begin{gathered}{[\text { the }] \text { spear, i.e., }} \\ \text { the spear-head. }\end{gathered}$ the trumpet!

$25 \nu$ When the trumpet soundeth amain, he saith, "Aha!"

And ${ }^{m}$ from afar he scenteth the ${ }^{n}$ battle, The ${ }^{\circ}$ thunder* of the ${ }^{*}$ chieftains, and the

${ }^{p}$ shouting!

$\kappa$ drinketh up.

$k$ Jer. ir. 13 ; Hab.

i. 8,9 .

$\lambda$ caunot be steady,

i.e., contaiu timself.

$\mu$ when [there is the] sound of [the] trumpet.

2 ' in [the] abundance of [the]

26 Is it $\rho$ by $q$ thy $\sigma$ wisdom that the hawk flieth, $\quad$ trumpet. Ps. And ${ }^{r}$ spreadeth out hiswings $\tau$ towards the south? Isa. xliv. 16, \&c.

27 Is it $\phi$ at thy command that the seagle $\chi$ soareth, And that he $\psi$ maketh his nest on high ${ }^{t}$ ?

28 On the "rock he dwelleth and abideth, On the " ${ }^{\prime} \omega$ crag of the rock, and the fastness. $\dagger$

29 Thence $\beta$ looketh he out for his ${ }^{\prime \prime} \gamma$ prey;

${ }^{x}$ Afar off his eyes behold $i t$.

30 Even his young ones "suck up blood;

And where the slain are, there is he ${ }^{*}+\neq$

* i.e., the stentorian voices.

$\dagger$ i.e., one of nature's fastnesses, a lofty and inaccessible cliff.

$\ddagger$ Comp. Matt. xxiv. 28.

$m$ infra ver. 29 ; $s u$ pra xxxri. 25.

$n$ Jer. viii. 6 ; Zech. x. 3 ; Rev. ix. 7, 9.

$o$ comp. infra xl. 9 ; Ps. xxix. 3, 4, \&c. $\pi$ or, princes.

$p 1$ Sam. xvii. 20; Amos ii. 2, \&c.

$\rho$ from, by reasoll of. $q$ comp. Jer. viii. 7 .

$\sigma$ lit., understanding, intelligence.

$r$ Jer. xlriii. 40 ; xlix. 22, \&e.

$\tau$ to [the] south.

$\phi$ in accordanec with, or becausc of, thy mouth.

s supra ix. 26; Prov. xxiii. 5 ; Isa. xl. 31 ; Obad. ver. 4 ; comp. supra г. $7 . \quad \chi$ maketh high [his tlight, or, to fly]. $\psi$ raiseth up his nest. $t$ Jer. xlix. $16 . \quad u$ comp. Obad. vers. $3,4 . \quad v$ Comp. 1 Sam. xir. 4. $\omega$ tooth. $\beta$ he hath searched, searcheth. $\quad w$ supra ix. 26 ; Hab. i. $8 . \quad \gamma$ food. $\quad x$ supra xxxvi. $25 ; 2$ Kings iv. 25, \&c. $\quad y$ comp. Numb. xxiii. 24. $\quad z$ Matt. xxiv. 28 ; Luke xvii. 37. 
* Upon this, and the five succeeding verses (rers.13-18), Dr. Bernard has the following manuscript note(from his own pen), which he has kindly allowed me to transcribe. It is accompanied by a literal translation, which is intended for the benefit of the Rabbinical student, and which I have had the more pleasure in making, as I feel assured that he will seldom or ever meet with a comment in this dialect offering fewer difficulties of construction. For my own part, however, I must say that I am disposed to think, with Rosenmüller, that the description of the horse, contained in vers. 19-25, is a mere episode, to which the use of the word כרים horse in ver. 18 gave rise. Dr. Bernard's note runs thus :-

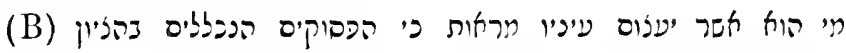

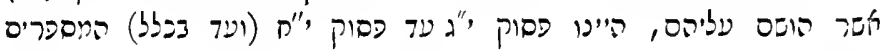

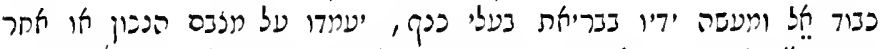

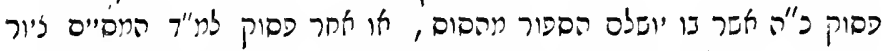

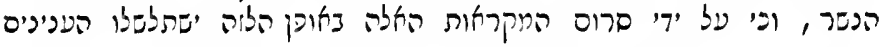

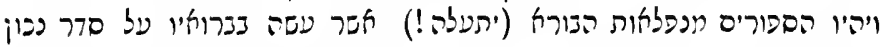

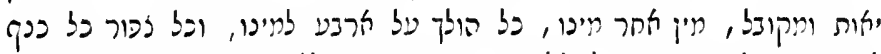

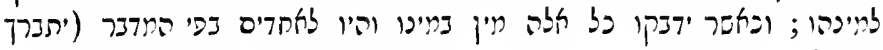

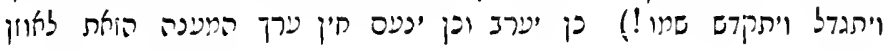

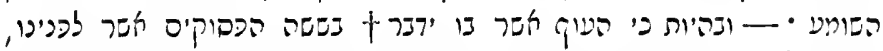

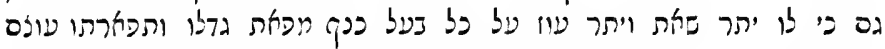

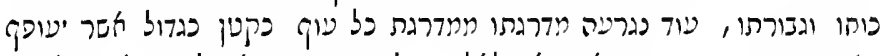

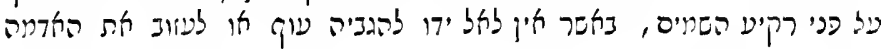

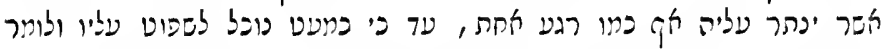

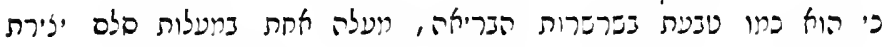

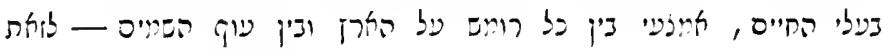

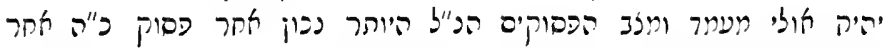

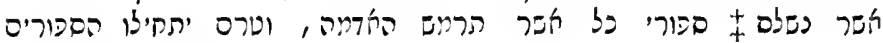

* See p. 498, note + .

$+7 \underline{=} \div$ ?

+ It will be observed that בשלם is in the sing., whereas ירתזילו is in the plur., though they both refer to a plur. noun. Still, I believe that Dr. Bernard intentionally wrote בשל בל, as it is found also in the copy which Mr. Randolph made from the original for himself. Rabbinical writers are not very particular in observing gramnatical rules, and Dr. Bernard no doubt considered that he should be writing a more idiomatical Rabhinic, if he followed in their footsteps, especially as passages are not wanting in the Bible in which a similar construction is found. Comp. infraxlii. 15, where the writer goes farther still, and not content with using a sing. verb with a plur. noun, also puts the verb, as well as three pron. affixes which occur in 


\section{מהעופות אשר יערשו כנפיהם לדאות ולעלות על במתי עבי - כן נראה \\ - 7"}

Who is he, that can shut his eyes from seeing, that the verses, which are comprehended under the mark (B) that has been placed over them, namely ver. 13 to ver. 18 (inclusively), and which declare the glory of God, and the work of His hands, in the creation of winged things, will stand in their proper place, either after ver. 25, by which the description of the lonse is completed, or after ver. 30 , which concludes the picture of the eagle, - and that, by means of the transposition of these verses after this manner, the subjects will be linked together, so that the narrations of the wonders of the Creator,-may He be exalted! -which He has wrought in His creatures, will be in a proper, beautiful, and acceptable order, kind after its kind, everything which goes on all fours, according to its kind, and every fowl, every winged thing, according to its kind; and, in proportion as all these are joined, kind to its kind, and are made a whole in the mouth of the Speaker,-may His name be blessed, exalted, and sanctified!-so will the graceful arrangement of this discourse be sweet and pleasant to the ear of the hearer. But, seeing that, with regard to the bird spoken of in the six verses before us, although it has more dignity and more strength than any other winged thing, by reason of its size and its beauty, and the might of its power and strength, its station is still lower than the station of any bird, small or great, which can fly in the open firmament of heaven, inasmuch as it has not the power of taking a high flight, nor of leaving the ground, upon which it hops, even for one moment, so that we might almost pronounce and say respecting it, that it is as a link in the chain of creation, one step of the steps of the ladder of the creation of living things, midway between everything that moves on the earth and the fowls of heaven,_therefore, the place and station of the six verses mentioned above would, perhaps, be most appropriate after ver. 25, after that the descriptions of everything that moves upon the ground have been completed, and before the descriptions of the birds, which can spread out their wings to hover and mount abore the heights of the clouds, begin._- So it seems in my humble opinion.-Note of Editor.

the verse, in the masc. gend., aithough the persons spoken of are women. See also note in Comm. on supra $\mathrm{xx} .10$. Editor, 1862.

* Abbreviated for '? lit., according to [the] poorness, or wretchedncss, or humility, of my opinion.-Ed., 1862 . 
a supra xxx riii. 1.

$b$ comp. Exod. xix. 16,18 ; $\mathrm{xx} .18$; 1 Kings xix. 11, \&c. ; Ps. 1.3 ; Nah. i. 3 , \&c.

$\psi$ or, tempest.

c supra $\mathrm{x} \times \mathrm{x}$ viii. 3 ; comp. supra xii. 18 ; 2 Kings iv. 29 ; ix. 1 ; Jer. i. 17.

d supra xxxviii. 3 ; infraxlii.4; $\mathrm{xxxiii.}$ 5,32 ; xxiii. 4 ; xiv. 15 ; xiii. 3 , 18, 19, 22 ; ix. 35, \&c.

$\omega$ make Me to know.

$\beta$ break, destroy, annul.

e supra $\mathrm{xxx} .20,21$; xxrii. 2 ; xxiv. 1 , and whole chap.; xxiii, 2, $10-17$; xxi. $7-13,23,24$, $30-34$; xix. 6,7 , 22 ; xvi. 7-16, 17 ; x. 3,15 ; ix. $22-24$, \&c.

$\gamma$ be just, be justified, comeont, forth,just. $f$ supra chap. xxxi. passim; xxrii. 3 -6 ; xxiii. $10-$ 12 ; xvi. 17 ; xiii. 15 ; x. 15 ; ix. 21 , 30,35 ; vi. 10,29 , 30 ; iii. 26 ; comp. ix. 2 ; xiv. 3,4 ; infia xl. 4 [xlii. $10]$; xlii. 6.

$\delta$ [is] then an arm to thee as [to] God.

g 1 Cor. x. 22.

$h$ supra xxxviii. 25 ; xxvi. 14.

$\varepsilon$ make to thunder.

$i$ supra $\mathrm{xxx}$ vii. 2, 4, 5 ; Ps. xxix. 3-5, $7-9, \& c$.

$\zeta$ height, highness, loftiness,exaltation, elevation.

$k$ Ps. xciii. 1 ; comp. supra xxix. 14.

$\eta$ thou mayest put on.

$l$ Ps. cir. 1 ; supra xxix. 20 ; xix. 9, \&c.

$\theta$ scarter.

$\kappa$ furies of. $\quad m$ supra $\times x .23 . \quad \quad \quad \kappa \kappa$ look, discern, look out for. $\quad n$ supra ix. 13 ; Isa. ii. 11 -17 ; v. 15 ; x. 33 , \&c. ; comp. supra ix. 31 ; xvi. 15 . o comp. supra xx. $6-10$; xxii. 29. $\lambda$ make him to be low, humble. $\quad p 1$ Sam. ii. 7, 8; Ps.lxxv.7; comp. suprav. $11 . \quad \mu$ cause him to bow. $\quad \nu$ in their place.

\section{CHAPTER XL.}

$\left.\begin{array}{l}{[\text { Ver. 1.] }} \\ {[\text { Ver. 2.] }} \\ {[\text { Ver. 3.] }} \\ {[\text { Ver. } 4 .]} \\ {[\text { Ver. 5. }]}\end{array}\right\}$

These numbers in square brackets indicate the corresponding verses in the Hebrew text. In the present translation they form Vers. 7-11 in Chap. xlii. $1[6]^{a}$ Then Jehovah answered Job from out . the ${ }^{b} \psi$ storm, and said:

$2[7]^{c}$ Gird up now thy loins like a man!

${ }^{d}$ I will ask of thee, and do thou $\omega$ declare unto Me!

$3[$ [ $]$ Wilt thou indeed $\beta$ deny* My ${ }^{e}$ justice? Wilt thou condemn Me, that thou mayest $\gamma$ seem just ${ }^{f}$ ?

$4 \quad[9] \delta$ Hast thou then an arm like God ${ }^{g}$ ?

Or canst thou ${ }^{h} \epsilon$ thunder with a ${ }^{i}$ voice like Him?

5 [10] Deck thyself now with pride and $\zeta$ majesty ${ }^{k}$; Yea, $\eta$ array thyself with ${ }^{l}$ glory and splendour!

6 [11] ${ }^{\theta}$ Pour out around thee the ${ }^{\kappa}$ fury of thine anger $^{m}$;

And ${ }^{k}$ search out every ${ }^{n}$ proud man, and ${ }^{\circ} \lambda$ bring him low!

7 [12] ${ }^{\kappa}$ Search out every ${ }^{n}$ proud man, and ${ }^{p} \mu$ humble him! $†$

Yea, crush thou the wicked $\nu$ where they stand ${ }^{q}$ !

* See note in Comment. and Appendix, on supra xv. 4.Editor, 1862.

+ i.e., Shew the keenness of thy glance by singling out straightway the proud man, though his pride be hidden in his heart (supra xxxiii. 17), and shew thy power by laying him at once prostrate. See Comm. p. 37\%.-Editor, 1862. 
TRANSLATION. CHAP. XL. $8-16$ [13-21].

8 [13] ${ }^{a}$ Hide them altogether in the ${ }^{b}$ dust! Bind $\omega$ them $\beta$ in some ${ }^{c}$ secret-place!

9 [14] Then will I, even $I, \gamma$ confess unto thee, That thine own right hand ${ }^{d}$ can $\delta$ help thee.

10 [15] * Behold now the ${ }^{e}$ beasts which I have made to be with thee!- -

$\epsilon$ 'The one $\dagger$ eateth grass like the ox ${ }^{f}$.

11 [16] Behold now his strength $i s$ in his loins ${ }^{g}$, And his might in the $\zeta$ muscles ${ }^{h}$ of his belly!

12 [17] $\eta$ When he lusteth, his tail is as a ${ }^{i}$ cedar; The ${ }^{k}$ sinews of his stones $\theta$ are entwined!

13 [18] His limbs are strong-pieces of ${ }^{l}$ brass $^{m}$, His bones, as $\kappa$ bars of ${ }^{n}$ iron!

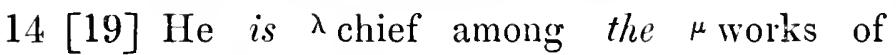
God $^{\circ}+-$

Let ${ }^{\nu}$ him that would ${ }^{p}$ dress him, $\pi$ approach him with his knife! \$

15 [20] For the mountains $\rho$ bring forth their produce for him ${ }^{q}$,

And all the ${ }^{r} \sigma$ beasts of the field ${ }^{s}$ sport $\tau$ around him. $\|$

a comp. supra xiv. 13.

$b$ comp. infra xlii. 6 ; supra xvi. 15 ; ix. 31 ; ii. 8 ; Ps. xxii. 15 ; vii. 5 ; Mic. i. 10.

$\omega$ their faces, persons.

$\beta$ in the hiddenplace.

c comp. supra xiv. 13; 1 Sam. ii. 9.

$\gamma$ or, praise thee.

See Append.

d comp. Ps. xliv. 3 ; xvii. 7 ; lx, 5, \&c.; also $\mathrm{xx}$ xiii. 16,17; supra v. 12-14.

$\delta$ or, save.

$e$ Gen. i. 24, 25.

$\varepsilon$ he eateth.

finfia rer. $15[20]$;

supra vi. 5; Numb.

xxii. 4; Ps. cvi. 20; Jer. 1. 11;

Dan. iv. 25 ; comp. supra xxxix. 8.

$g$ Prov. xxxi. 17 ; Nah. ii. 1; Dan. v. 6 .

$\zeta$ firm-things, parts, of.

$h$ comp. infra xli. 23.

$\eta$ desireth, lusteth he $=$ if, when, he desireth, lusteth.

$i$ Cant. v. 15 .

k suprax. 11.

$\theta$ are made (i.e., become, grow) entwined.

$l$ supra vi. 12; xxriii. 2 ; infraxli. 27 ; Isa. xlviii. 4.

* Not only hast thou not unlimited power over men, thou hast it not even over the brute creation.

$\dagger$ The elephant.

$m$ comp. infia xli. 23 ; supra vi. 12 .

r: bar.

$¥ \mathrm{He}$ is a wonderful creature, not only on account of his size, but also on account of his sagacity and intelligence, which surpass those of all other animals, and are inferior only to the intellect of man.

\$ Let him that has a mind to slaughter and dress him for food, let him try and approach him with his butcher's knife.

\| As he is a graminivorous, gentle, and inoffensive animal, why should not man come and butcher him, as he would do an ox, a calf, or a lamb?

I The hippopotamus.

" infraxli. 27; Dan. ii. 40 ; vii. 19 ; supra $\mathrm{x} \times \mathrm{riii} .2$; comp. Isa. xlviii. 4; Deut. xxviii. 23 .

$\lambda$ beginuing, ehief, of. $\mu$ ways of.

o comp. infra xli. 33. $y$ the dressing him, i.e., the one wishing to dress him.

$p$ Gen. xviii. 7 ; 2 Sam. xii. 4 ; xiii. 5,$7 ; 1$ Kings xrii $12 ;$ x viii. $23,25$.

$\pi$ cause to approach his knife [to him]. $\rho$ bear. $q$ supra rer. 10 ; xxxix. 8 ; Ps. exlvii. 8 ; 1. 10, 11 ; Prov, xxvii. 25 . r supra r. 22,23 ; Ps. riii. 7 ; Isa. lvi. 9, \&e. $\sigma$ wild-beast of. $s$ comp. supra xxi. 11; Ps. xxix. 6 . $\tau$ there [where he is]. $\phi$ shades. $t$ Dan. iv. 12; Mark iv. 32 ; Ilos. iv. 13 ; Jon. iv. 5, 6, \&c. $x$ he lietb. 
(1) reed.

a comp. Isa. xix. 6 , 7 ; xxxv. 7; supra viii. 11.

b infira xli. 30.

$\beta$ [each with] its shade.

$c$ Dan. iv. 12; Mark iv. 32 ; ilos. iv. 13 ; Jon. iv. 5, 6, \&c.

$\gamma$ sliades.

$\delta$ hedge, fence, him in.

$d$ Lev. xxiii. 40 ; Isa. xliv. 4; Ezek. xrii. 5 .

$\varepsilon$ be [the] river violent [lit. oppress].

$e$ Jer. т. 22; Ps. slvi. 3 ; Jude 13, \&c.

$\zeta$ he is, or would be, confident.

finfra xl. 33,24 ; Ps. xlvi. 2, 3 .

$\eta$ should break forth, burst.

$g$ comp. Ps. cxxiv. 4,5; Lam.iii.54, \&c.

$h$ comp. supra xxxi. 1 ; 1 John ii. 16 ; Matt. v: 28.

$\theta$ can (or, must) he (i.e., one) talie him.

$\kappa$ nostril.

i infra ver. 21.

$\lambda$ can (or, must) he (i.e., one), bore.

k infra ver. 21 ; 2

Kings xix. 28; Isa. xxxvii. 29.

$l$ infia ver. 24; comp. supra $\mathrm{xxxix.}$ 10.

$\mu$ cause to sink.

$m$ supra vers. $19,20$.

$v$ lit. a thorn, perliaps, a barbed hook, a barb. Sce Comm. Ed. 1862.

$\pi$ or, pierce.

$n$ comp. supra xxxis. 37 ; $\mathrm{x \times x}$ t. 16.

o supra viii. 5 ; ix. $15, \& \mathrm{c}$.

p Ps. lv. 21; Isa. xxx. 10 ; comp. supra ix. 4.

$\rho$ cut.

$q$ supra V. 23 ; xxxi. $1, \& \mathrm{c}$.

$\sigma$ slave of perpetuity, eternity, $=$ a perpetual slave.

$r$ supra $\mathrm{xx \times ix} .9,10$;

Jer. xx vii. 6 ; Exod. xxi. 6 ; Deut. xy. 17.
In the covert of the ${ }^{\omega}$ reeds ${ }^{a}$, and in the ${ }^{b}$ mire.

17 [2.2] $\beta$ With their ${ }^{c}$ shade the $\gamma$ shady-trees $*$ do $\delta$ cover him ;

The "willows of the brook encompass him about.

18 [2:5] Lo! though the river rage ${ }^{e}$, he hasteth not ;

$\zeta$ Unmoved $^{f}$ were he, though Jordan $\eta$ rushed up to his mouth ${ }^{g}$ !

$19[24]$ By his ${ }^{h}$ eyes alone ${ }^{\theta}$ can he be taken, $\dagger$ By snares, his ${ }^{\kappa}$ nostrils ${ }^{i} \lambda$ bored.

20 [25] XLI. $\mp$ Canst thou draw out the crocodile with an hook ${ }^{k}$

${ }^{1}$ And with a ${ }^{l}$ rope, $\$$ which thou mightest $\mu$ sink into his tongue?

$21\left[20^{2}{ }^{2}\right.$ Canst thou put an hook ${ }^{m}$ in his nose?

Or with a ${ }^{\nu}$ ring ${ }^{m} \pi$ bore through his cheek?

$22[27]$

${ }^{3}$ Will he ${ }^{n}$ multiply ${ }^{o}$ supplications un to thee?

Will he speak unto thee ${ }^{p}$ soft. things? $\|$

23 [28] ${ }^{4}$ Will he $\rho$ make a ${ }^{q}$ covenant with thee?

Canst thou take him for a $\sigma$ slave for ever ${ }^{r}$ ?

1 Or, perhaps, - Or canst thou with a rope sink down his tongne? i.e., depress it, keep it down, as with the curb of a bridle.-Editor, 1862.

* A corresponding and somewhat stronger jingle is found in the original.-Editor, 1862.

+ It is only by placing before his eyes something enticing and alluring that he can be subdued and mastered.

$\ddagger$ Here Chap. xli. begins in the Auth. Ver. Its corresponding verses will be indicated by the small figures which follow the square brackets.

$\S$ The rope being fastened to the hook.-Editor, 1862.

II Will he shew his attachment to thee by fawning upon thee like a dog? 
TRANSLATION. CHAPS. xL. $24-26[\because 9-31]$; xli. $1-5[4-8] .505$

24 [29] 5 Canst thou ${ }^{a}$ play with him as with a comp. Isa. xi. 6$\omega$ a bird ${ }^{b}$ ?

8.

$\omega$ the bird.

Or canst thou ${ }^{c}$ bind him for thy ${ }^{b}$ comp. Jer. r. 27 ; maidens? *

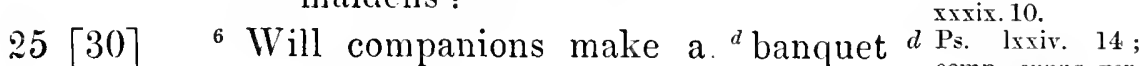
$\beta$ of him?

Will they ${ }^{e}$ divide him among the $\begin{aligned} & \beta \\ & e \text { on him }\end{aligned}$ merchants? $†$

26 [31] 7 Canst thou fill his ${ }^{f}$ skin with darts ? $f$ infra xli. 15-17; Or his head with $\gamma$ fish-spears ${ }^{f}$ ? $\gamma$ spear of fishes.

\section{CHAPTER XLI.}

$1[\ddagger 4]^{12} \delta \mathrm{I}$ will not be silent concelning his ò je ne tairai point. $\epsilon$ parts, $\varepsilon$ limbs.

Nor the matter of his $\zeta$ might, nor the $\zeta$ mights. gracefulness of his $\eta$ proportions ${ }^{g}$. $\quad \eta$ arrangement, sym-

$2[5]^{13}$ Tho hath $\theta$ stripped off the surface of metry,proportion. his garment?

Into $k$ his jaws, who would enter ? $\|$

$3[6]^{14}$ Who hath opened the ${ }^{h}$ doors of his face? 9

Round about his teeth is terror ${ }^{i}$.

$4 \quad[7]^{15}$ His ${ }^{\lambda}$ strong shields are his pride, $\mu$ Locked together as with a close ${ }^{k}$ seal.

5 [8] ${ }^{16}$ 'They $\nu$ are so near, $\pi$ one to another,

* Fasten or encage him for the amusement of thy children.

+ Will companies feast upon his flesh, or traffic with it as they do with the flesh of fish?

$\ddagger$ The numbers in square brackets indicate the corresponding verses in the Hebrew text. The small figures following the square brackets indicate, as before, the corresponding verses in the A.V. The first three verses of this chap. according to the Heb. text, form the last three of our chap. xli.

$\S$ The surface of his garment - i.e., his scales, which form the uppermost layer of that close-fitting garnent of his, his skin; who has ever been able to lift up any of them?

$\|$ Who would trust a limb within his jaws?

T i.e., his mouth. [Comp. supra iii. 10, "the doors of my [mother's] womb" = the mouth of the womb; and also Mic. vii. 5, "the doors of thy mouth."-Editor, 1562.] 
$\omega$ that air cannot come.

$\beta$ made to eleave.

$\gamma$ man to his brother.

$\delta$ cannot separate themselves.

$\varepsilon$ [every one of them] maketh light to shine.

$a$ see rer. 9, note $d$, and comp. ver. 10 .

$b$ supra iii. 9.

$c$ infia ver. 10.

$\zeta$ save themselres, disengage themselves, escape.

$d$ Ps. xviii. 8, 15; supra $\mathrm{x} \times \mathrm{xix} .20$.

e Jer. i. 13 ; infra ver. 20.

$\eta$ a blown pot.

$f 1$ Sam. ii. 14; Ezek. xi. 3, 7, 11.

$\theta$ live-, burning, coals.

g Ps.xviii. 8, 13 ; Isa. xxx. 33 ; comp. Hab. iii. 5.

$h$ supra ver. 8.

$i$ comp. supra xxxix. 19 ; xl. 16.

klodgeth,sojourneth, dwelleth.

$k$ Hab. iii. 5.

$\lambda$ fallings of, i.e., the pendulous parts of.

$l$ supra ver. 6 .

$\mu$ have eleaved.

$\nu$ [erery one of them is ] firm; it eannot be moved.

$m$ Ps. x. 6 ; cxii. 6 ; Prov. xii. 3, \&e.

$n$ Zech.vii. 12 ; eomp. supra xxxiii. 30 ; xxxix. 22 ; xl. 23 ; infra rer. 22.

$o$ Deut. xxiv. 6.

$\pi$ by reason of his raising [himself]

up. $\omega$ That no air can come between them.

$6[9]^{17}$ They are $\beta$ fast joined $\gamma$ every one to its fellow;

They take hold on one another, so that they $\delta$ cannot be sundered.

7 [10] ${ }^{18}$ His neesings * $\epsilon$ give forth $\operatorname{light}^{a}$, And his eyes are as the ${ }^{b}$ eyelids of the dawn.

$8[11]^{19}$ Out of his moutl go ${ }^{c}$ firebrands; Sparks of fire $\zeta$ leap out.

9 [12] ${ }^{20}$ From his nostrils goeth forth smoke ${ }^{d}$, As from ${ }^{e} \eta$ a bubbling pot, or ${ }^{f}$ caldron. $\dagger$

$10[13]^{21}$ His breath would ${ }^{1}$ kindle ${ }^{\theta}$ coals $^{g}$; Yea, a ${ }^{h}$ flame goeth forth from his mouth.

11 [14] ${ }^{22}$ In his ${ }^{i}$ neck ${ }^{*}$ abideth strength ; And ${ }^{k}$ before him exulteth sorrow. +

$12[15]^{23}$ The $\lambda$ folds of his flesh ${ }^{l} \mu$ stick fast together;

$\nu$ They are firm upon him; they carnot be ${ }^{m}$ moved.

$13[16]^{24}$ His heart is as firm as a ${ }^{n}$ stone; Yea, firm as the ${ }^{\circ}$ nether millstone.

14. $[17]^{25} \pi$ At his rising the mighty are afraid ${ }^{p}$;

1 Or, kindleth coals.-See Append. Editor, 1862.

* An old word=sncezings. When the crocodile sneezes, or snorts, a volume of breath issues from lis nostrils in the form of steam. This was regarded as smoke, for it seems that in former times, as well as in our days, steam and smoke were frequently confounded. Thus we commonly say of a horse when reeking with sweat, that it is smoking; and, indeed, to reek primarily means to smoke (Fries. riecke, A.-S. recan, Swed. rökı, Germ. rauchen). But where smoke is, there there must be fire, and commonly is flame; and hence, I think, we may understand what is said in vers. 7-10.-Editor, 1862.

$\dagger$ i.e., as steam from boiling water. [IIere again steam is called smoke._Ed., 1862.]

+ The sorrow, or anguish, which his approach excites in every beast, is here personified and represented as triumphantly preceding him. See Comm.-Editor, 1862. 
$\omega$ At the ${ }^{a}$ waves, ${ }^{*} \beta$ they are beside $\omega$ by reason of [the] themselves.

$15[18]^{26} \gamma \mathrm{He}$ that cometh up to $\operatorname{him}^{6}$ - his sword shall not stand,

Nor his spear, dart, nor coat-of-mail.

$16[19]^{27} \mathrm{He}$ accounteth ${ }^{c}$ iron $\delta$ as straw, ${ }^{d}$ Brass $-\epsilon$ as ${ }^{e}$ rotten wood.

$17[20]^{28} \zeta$ The ${ }^{f}$ arrow will not make him flee; Into ${ }^{g}$ stubble $\eta$ are ${ }^{h}$ sling-stones turned $\theta$ with him. $\dagger$

$18[21]^{29} \mathrm{As}^{g}$ stubble $\kappa$ are accounted $\lambda$ clubs; And he laugheth at the ${ }^{\mu}$ whiz of the javelin.

$19[22]^{30}$ Under him are ${ }^{\nu}$ sharp-pointed sherds; Nay, he spreadeth $\pi$ sharp-things upon the mire. $\neq$

$20[23]^{31}{ }^{1}$ He would make the deep to ${ }^{i}$ boil $\rho$ like a pot;

${ }^{2}$ Would make the sea $\sigma$ like a jar-ofointment. \$

$21[24]^{32}$ After him $\tau$ would he cause a path to shine ; $\|$

a Ps. evii. 26, 27; Jon. i. 5.

$\beta$ they miss themselves.

$\gamma$ [as for the] one reaching, attaining, overtaking him.

$b$ infra vers. 24-26.

c supra $\mathrm{xl} .18$; xxviii. 2; Dan. ii. 40; vii. 19 ; Isa. xlviii. 4 ; Deut. xxviii. 23.

$\delta$ for.

$d$ note $c$ and supra vi. 12.

$\varepsilon$ for wood of rottenness.

e supra xiii. 28.

$\zeta$ [the] son of a bow. $f$ Ps. xci. 5.

$g$ supra xiii. 25 ; xxi. 18; Ps. 1xxxiii. 13. $\eta$ were, have been .....turned.

$h$ 2 Chron. xxri. 14.

$\theta$ for him.

$\kappa$ were, have been ......accounted.

$\lambda$ club.

$\nu$ pointect-things, or pointednesses, of a slierd.

$\pi$ a sharpened-thing.

$i$ supra ver. 9 ; Jer.

One would $\phi$ think the deep were hoary. $\rho$ like the pot.

$\sigma$ like the jar of oint. ment.

$\tau$ would make a path light, bright.

1 Or, He maketh the deep to boil, \&c. Editor, 1862.

$\phi$ count [the] deep for hoariness.

2 Or, Maketh the sea, \&c.

After him he causeth, \&c.-Editor, 1862.

* At the waves, which are produced by his rising out of the water.

$\dagger$ Stones from a sling produce as little effect upon him, as stubble would, if thrown at him.

$\ddagger$ How can he be afraidsof the javelin, when he likes to lie upon sharp-pointed things?

$\S$ He would stir the sea about (if he came into it), with the same ease that an apothecary stirs ointment in a jar.

$\|$ He leaves a foamy and glistening wake behind him.

T We consider it so imperatively necessary to state to the reader the reasons which induced us to transfer the following verses to another place than that which they occupy in the text, 
508 Traxslation. Chap. Xli. $22-25[25,26 ;$ xL. $32 ;$ xli. 1$]$.

$\omega$ [he who] not his $\beta$ dust.

a supra sl. 19 ; xxiii.

13.

b supraxl.23; $\mathrm{xxxix.}$ 22 ; comp. ver. 13.

c supra $\mathrm{x \times x}$. 5; xxii. 12; Isa. xl. 26 ; Ps. viii. 3, \&c. $\gamma$ he [who is] king, \&c.

$d$ Gen. i. 26, 28.

e supra xxviii. 8.

$\delta$ sons of pride.

$f$ comp. supra ver. 15 ; xl. 19.

$\varepsilon$ remember.

$\zeta$ thou wilt not add. $g$ comp. Nah. i. 9

1 Sam. xxvi. 8.

h supra xvii. 15; xix. 10 ; xiv. 19 , \&c.

$\eta$ hath been belied.
$22[25]^{33} \omega H e^{*}$ whose like there $i s$ not upon $\beta$ earth ${ }^{a}$

He, that $i s$ made without dread ${ }^{b} \dagger-$

$23[26]^{34}$ He who seeth every thing high ${ }^{c}, \ddagger$ $\gamma$ Who is ${ }^{d} \mathrm{king}$ over all the ${ }^{e} \delta$ proud beasts

(On him I call, and say)

24 [Chap. xl. 32] $\S^{8}$ "Put thine hand upon him? " $\epsilon$ Think on the battle

$\zeta$ thou wilt do so no more. " $\|$

25 [Chap. xli. 1] ${ }^{9}$ Lo! ${ }^{h}$ his hope $\eta$ is deceived;

that we hope to be excused for quoting here our own words from the Commentary, p. 387.

"We have already stated the reasons which induced Wolfssohn to assign to these six verses another place than that which they occupy in the text. To every one indeed, who reads the last four of them in the connection in which they there stand, it must, we should think, seem very extraordinary, that God should first challenge man to engage with the crocodile, and then proceed to enter upon a minute description of its structure, nor is Wolfssohn the only Commentator who saw the necessity for altering their position, since Bouillier did so likewise. There is, however, another point, which seems to us still more extraordinary than this, namely, that an animal, which is in reality nothing more than a monstrous reptile, should (in the second verse of the group), be styled the king of all the proud beasts, and be said to see every thing high; and it is therefore our firm belief, that the subject of the whole of the verses under our consideration is not the crocodile, but man generally, Job of course being more particularly had in view. God says : He (man) \&c."

* i.e., man.

$\dagger$ Who braves all dangers.

\$ Who does not hang down his head and look towards the earth, but walks erect and regards the heavens and the heavenly bodies.

\$ The small figures indicate as before the corresponding verses of chap. xli. in the A.V.

\| Observe the change to the 2nd pers. in this verse, and the resumption of the $3 \mathrm{rd}$ in the next. Comp. supra pp. 474, 483, note + .. Editor, 1862 .

T His hope of conquering him. 
TRANSLATION. CHAPS. xli. $26,27[2,3]$; xlit.

Is he indeed cast down $\omega$ at w evenat his appearances.

26 [Chap. xli. 2] ${ }^{10}$ To himself he is not $s o$ cruel $^{b}, \quad$ xx. 18. that he should arouse 20 ; Prov. xi. 17 . $\beta$ set himself up.

c supra $\mathrm{xxxiii.} 13$ Who then is he, that can xxiii. 3, 5; Isa. $\beta$ stand before $\mathrm{Me}^{c}$ ? 20; Ps.lxxi. 7; Nah. i. 6 ; comp.

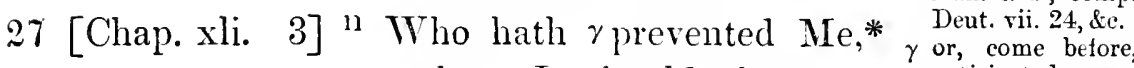
that I should have to anticipated, me. repay $\mathrm{him}^{\alpha}$ ?

That $w h i c h$ is under the whole $e$ it Gen. sis. 19 ; heavens $\delta$ is mine ${ }^{e}$ !

\section{CHAPTER XLII.}

\section{DIALOGUE. $\dagger$}

WE must again offer our apologies to the reader for quoting from our Commentary. The passage to which we would call his atteution will be found p. 390, and runs as follows:-

"Of these eleven verses (i.e., the first eleven of this chapter), which form a dialogue between Jehovah and Job, five (7-l1) we have transposed from the beginning of chap. $x l$, for the

* i.e., prevented (anticipated) Me with a service, or to use Paul's words in Rom. xi. 35, "Who hath first given unto Me ?"-Editor, 186:.

$\dagger$ In some parts of this dialngue, the names of the speakers must be supplied, as they must be also, and to a much greater extent, in the first six verses of the $63 \mathrm{~d}$ chapter of Isaiah, where, in a dialogue between Jehovah and the Prophet, it is everywhere left to the common sense of the reader to determine what is said by each. Of the first three verses of this chapter the following is a translation:-

\section{(The PropheT:)}

1. Who is this $\mathrm{e}$ that cometh from Edom, $\zeta$ With dyed garments from Buzrah? $\varepsilon$ coming.

¿े dyed of garments. 
simple, but very forcible, reason, that, as they stand in the text, they render utterly unintelligible the verses which immediately follow them. For, how could Jehovah, immediately after Job had (in ver. 4) expressed his great contrition and sincere repentance for his rash and inconsiderate language, by any possibility say (ver. 8), "Wilt thou indeed deny My justice? Wilt thou condemn Me, that thou mayest appear just?' and again, chap. xlii. 3, "Who is this, that veileth $\mathrm{My}$ counsel for want of knowledge?' Surely, so full a confession on the part of Job, instead of calling forth such a severe rebuke, would (as is actually the case according to our arrangement) be much more fittingly followed by a declaration of forgiveness and acceptance from the lips of Jehovah."

1 Then Job answered Jehovah, and said:

a Gen. xviii. 14;

Isa. xliii. 13 ; Jer. xxxii. 17, 27 ; Matt. xix. 26 ; Mark x. 27 ; xiv. 36 ; Luke xriii. 27.

$b$ comp. supra ix.12; xi. 10 ; xii. 14 ; xxiii. 13; Jer. li. 29 ; Ps. crv. 3 ; cxxxv. 6; xxxiii. 9-11; Dan. iv. 35.

c supra xxxviii. 2.

$\psi$ [is] hiding.

$d$ see note $d$, p. 511 ; Ps. xxxiii. 11; Prov. iii. 19 ; viii. 22 ; Jer. li. 15, \&c.

$\omega$ without knowledge.

e supra $\mathrm{xxx} .16$; xxxiv. $35 ; \mathrm{xv} .2$, 3 ; xi. 2 ; viii. 2 ; comp. xxvi. 3.

$\beta$ honoured, made glorious, glorified.

$\gamma$ speaking.

ot to.

$\varepsilon$ like one treading.

$\zeta$ not a man with Me.

$\eta$ tread, or, kept treading.

$\theta$ trample, or, kept trampling.

$\kappa$ is sprinkled, or, kept sprinkling, spurtling.

$\lambda$ My clothes, garments.

$\mu$ or, have stained.
2 I know that 'Thou canst do everything ${ }^{a}$, And that no purpose of Thine can be withholden from Thee $^{b}$.

\section{(JeHovah.)}

$3^{\mathrm{c}} \mathrm{Who}$ is this that $\psi$ veileth $M y{ }^{d}$ counsel $\omega$ for want of knowledge ${ }^{e}$ ? $*$

This, that is $\beta$ glorious in his apparel, Striding in the greatness of his might?

(Jihovari.)

I, $\gamma$ that speak in righteousness, Mighty to save.

\section{(The Prophet.)}

2. Why is there redness $\delta$ in Thine apparel ?

For Thy garments are $\varepsilon$ as of one that treadeth in the wine-fat.

\section{(Jehovah.)}

3. I have trodden the wine-press alone, And of the peoples there was $\zeta$ none with Me; So I $\eta$ trod them down in Mine anger, And $\theta$ trampled upon them in My wrath, That their blood $\kappa$ was sprinkled upon My garments,

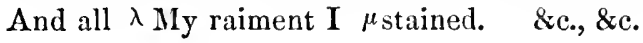

* i.e., who is it denies that everything is done by My counsel (wisdom), and attributes all to chance? 
(Jов.)

For this reason did I ${ }^{\omega}$ speak $s o, \beta$ because I did not understand;

It was $\gamma$ too wonderful for me ${ }^{d}$, so that I could not know it.

\section{(JEhova H.)}

$4^{e}$ Hear now, and I will speak;

${ }^{f} \mathrm{I}$ will ask of thee, and do thou $\delta$ declare unto Me.

$$
\text { (Јов.) }
$$

$5 \in$ By the ${ }^{g}$ hearing of the ear had I heard of Thee"

But now mine eye hath seen Thee.*

6 Wherefore I do reject my words ${ }^{i}$, And repent $\epsilon$ in dust and ashes ${ }^{k}$.

\section{$7[\dagger 1]$ 'Then Jehovah answered Job, and said :}

$8[2] \zeta$ Doth he that ${ }^{l}$ contended with the Almighty stand ${ }^{m}$ corrected?

Let $\eta$ him, that did 'dispute with God, $\theta$ give answer ${ }^{n}$ !

9 [3] Then Job answered Jehovah, and said:

[4] Behold, I $\mathrm{kam}^{o}$ vile! What can $\mathrm{I}^{p} \lambda$ answer Thee?

* Hitherto I had only lieard of Thy power and glory, and was ignorant of the dignity of my own nature; but now, after Thou hast condescenderl to reveal Thyself to me, I am convinced that my existence will not end with this life, and that therefore the afflictions that have come upon me may be as a mere nothing compared with the blessings which Thou mayest have in store for me, when 'Thou shalt have brouglit me to my eternal lome. [I do not think that Dr. Bernard is waranted in drawing this conclusion. See Append.-Editor, 1862].

$\dagger$ The numbers in square brackets indicate the corresponding verses in chap. xl. aceording to the Ifebrew text, and Auth. Vers.

$\kappa$ have been vile.

o supra ver. 6 . $35-37$; but comp. ix. $3,14,15,32,34,35$; xiii. 21 ; xir. 3 , \&c. $\omega$ declare.

$\beta$ seeing I could not understand.

$\gamma$ wonderful-things more than $I$; i.e., above, beyond, me.

d Ps. exxxix. 6; Prov. xxx. 18; supra xi. 6-9; comp. xv. 8 ; xxviii. $23-28$; xxxvi. 4; $x \times x v i i$. 16 ; Isa. xxriii. 29 ; xl. 13, 14; Jer.хxхіi. 19, \&c.; but comp. also supra ix. 4-10; xii. 12-25; xxvi. $5-14$

e comp. supra xxxiii. 31 , note $k$.

$f$ supra xxxviii. 3 ; xl. 7 , note $d$.

$\delta$ make Me to know.

$\varepsilon$ according to, at, [the] hearing of.

$g$ Ps. xviii. 44; Isa. xi. $3, \& c$. ; comp. supra xiii. 17.

$h$ comp.supraxxrii. 22.

$i$ comp. infra ver. 10 [xl. 4] ; supra vii. $16 ; 1$ Thess. iv. 8.

$\varepsilon \varepsilon$ upon.

$k$ comp. Matt. xi. 21 ; Luke x. 13 ; Dan. ix. 3 ; Jon. iii. 6 ; comp. 2 Sam. xii. $16 ; 2$ Chron. xxxiii. 12 ; xxxiv. 19, 27; comp. also supra ii. 8,12 ; ix. 31 ; xri. 15 ; xxx. 19.

$\zeta$ [is] one-contending with [the] Almighty a correctedman?

$l$ supra x. 2; xiii. 24 ; xvi. 9 ; xix. 11 ; $\mathrm{xxx} 21$; xxxi. 35, et passion.

m supra vers. 3,6 ; infra vers. $10,11$.

$\eta$ [the] one-arguing with God, or, God's arguer, disputer.

$\theta$ answer it (i.c, this question).

n suprarer. 4 , note $f$. 
$\chi$ I have put.

$\psi$ to my mouth.

z supra xхіх. 9; xxi. 5 ; Juclg. xviii. 19 ;

Prov. хxx. 32 ; Mic. vii. 16.

a supra хxxiii. 14; comp. xxxiii. 29 ; v. 19; Prov. xxx. $15,18,21,24,29$, \&e.

$\omega$ will not speak.

$\beta$ I will not add [to speak].

$b$ comp. supra xli. 8. $\gamma$ and it was.

c comp. supra xxxii. 2,3 ; vii. 22 ; $x$ i. 20.

$\delta$ hath been kindled. $\varepsilon$ an establislied-, a firm-, i.e., a true-, sincere-, thing; or trutl, sincerity.

$d$ comp. supra xiii. $4,7-12$; xix. 5 , 28,29 ; and also iv. $17-21 ; x$. $14-16$; xxv. 4 6.

e comp. ix. 22-24; x. $3 ; x$ ri. $9,11-$ 17 ; xix. 7 ; xxvii. 2 ; $\mathrm{xxx} .20,21$; supra vers. $6,10$.

$\zeta$ so now, take, \&e.

$f$ Numb. xxiii. 1, 4, 14, 29; 1 Chron. xv. $26 ; 2$ Chron. xxix. 21 ; Ezek. xlv. 23, \&c.

$\eta$ and ye shall make to go up, offer up.

g supra i. 5; Ler. iv. 12,21 ; 1 Sam. vii. 6,9 .

$h$ comp. supra $\mathrm{xxii}$. 29,30; xxxiii. 23 ; Gen. xx. 7 ; xriii. 23-25; 1 Sam. vii. $5,8,9$.

i supra xiii. 8, 10; xxxii. 21, 22; xxxiv. 19; Ps. xii. 3, se.

$\theta$ to do with you disgrace.

$k$ supra ver. 12, note d.

$l$ supra ver. 12, note $e$; comp. supra i. 8 ; ii. 3.

m supra rer. 13 , note $i$; also supra xxii. 27 ; xxxiii. 26.

o supra vers. $13,14$. $x$ I lay mine hand $\psi$ upon my mouth ${ }^{z}$.

$11[5]{ }^{a}$ Once have I spoken, but I $\omega$ will speak no more ;

Yea, ${ }^{a}$ twice—-but ${ }^{\beta} \mathrm{I}^{b}$ will not again.

$12(* \gamma) \gamma$ And it came to pass after Jehovah had spoken these words unto Job, that Jehovah said unto Eliphaz the Temanite: My ${ }^{c}$ wrath $\delta$ is kindled against thee, and against thy two friends, because ye have not spoken concerning Me $\epsilon$ sincerely ${ }^{d}, \dagger$ as hath My servant ${ }^{e}$ Job.

13 (8) $\zeta$ Therefore, take now unto you ${ }^{f}$ seven bullocks, and seven rams, and go ye unto My servant Job, $\eta$ and offer up a ${ }^{g}$ burntoffering for yourselves, and Job, My servant, shall ${ }^{h}$ pray for you; for his person will I surely ${ }^{i}$ accept, so as not $\theta$ to deal out disgrace unto you, because ye did not speak concerning $\mathrm{Me}^{k}$ sincerely, as did My servant ${ }^{l}$ Job. $†$

14 (9) So they went, Eliphaz the Temanite, and Bildad the Shuhite, and Zophar the Naamathite, and did according as Jehovah had spoken unto them; and Jehovah ${ }^{m}$ accepted the person of Job.

15 (10) And Jehovah " turned the captivity of Job, ${ }^{*}$ after that he had ${ }^{\circ}$ prayed $\lambda$ for his friends;

* The numbers in round brackets indicate the corresponding verses of chap. xlii. according to the Hebrew text and $A . V$.

+ Rash and sinful as were the words of $\mathrm{J}_{\mathrm{ob}}$, they were at least sincere; but not so yours, since it was rather from a desire to please Me that you imputed so many atrocious crimes to your unfortunate friend, than from a conviction that your assertions were true.

$n$ Dent. xxx. 3 ; Ps. exxri. 1, 4; Jer. xxix. 14, \&e. $\lambda$ for his friend, i.e., for every one of them. $\kappa$ on his praying. 
and Jehovah increased $\phi$ all that Job had $\phi$ all that [there had had ${ }^{x}$ twofold.

been] to Job to double.

16 (11) Then came there unto him all his ${ }^{y}$ brethren, and all his sisters, $\psi$ and all they that had ${ }^{z}$ known him before; and they did ${ }^{a}$ eat bread with him in his house, and ${ }^{b} \omega$ mourned with him, and comforted him for all the ${ }^{c}$ evil, that Jehovah had $\beta$ brought upon him; and they gave unto him every one $\gamma$ a piece of money, and every one $\delta$ an ${ }^{d}$ ear-ring * of gold.

17 (12) So Jehovah blessed the ${ }^{e}$ latter-end of Job more than his ${ }^{e}$ beginning; ${ }^{\epsilon}$ for he had ${ }^{f}$ fourteen thousand sheep, and six thousand camels, and a thousand yoke of oxen, and a thousand she-asses.

18 (13) $\zeta$ He had also' ${ }^{g}$ seven sons, and three daughters.

19 (14) And he called the name of $\eta$ the first, $\theta$ Jemimah; and the name of the second, $\kappa$ Keziah; and the name of the third, $\lambda$ Keren-happuch.

20 (15) And $\mu$ there were no women found in all the land so fair as the daughters of Job; and their father gave them ${ }^{h}$ inheritance $\nu$ among their brethren.

$x$ supra viii. $6,7,21$; xxii. 24,25 ; comp. Isa. xl. 2 ; lxi. 7 ; Jer. xvi. 18; Zech. ix. 12.

y supra xix. 13 ; ri. 15.

$\psi$ and all his know. ers.

z supra xix. 13, 14, 19 ; Ps. $\mathrm{x} \times x$ viii. 11 ; lxxxviii. 8, 18. a 1 Kings sxi. 7 ; Eccles.ix. 7 ; riii. 15, \&c. ; comp. suprai. 4, 18.

b supra ii. 11 ; xvi. 2,5 ; comp. Rom. xii. 15.

$\omega$ shook [their heads] at him.

c supra i. 13-19; ii. 7, \&c.

$\beta$ caused to come.

$\gamma$ one piece.

$\delta$ one ear-ring.

$d$ Ezek.xvi. 12; Gen. xxxv. 4, \&c.

e supra viii. 7 ; v. $17-26$; viii. 21 , 22 ; xi. 15-19; xxii. 23-28.

$\varepsilon$ sceing that there was to him.

$f$ supra i. 3.

$\zeta$ and there was to him.

g supra i. 2 ; comp. 1 Chron. xxv. 5.

$\eta$ the one.

$\theta$ i.e., perhaps, beautiful as the day.

$\kappa$ i.e., cassia.

21 (16) And Job lived after this an hundred and $\lambda$ i.e., horn of paint,

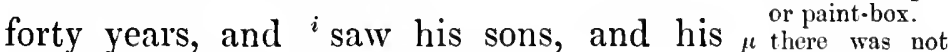
sons' sons, even ${ }^{k}$ four generations.

22 (17) So Job died, ${ }^{l}$ old and ${ }^{m} \pi$ full of days. found........women fair (beautiful) as, \&c.

$h$ Numb. xxrii. 4,7 ; xxxvi. 8; Josh. xr. $1 \mathrm{~S}, 19$.

$v$ in [the] midst of

* In Ezek. xvi. 12, the word apparently means nose-ring.-

i comp supra $\mathbf{2} 25$ xiv. 21 ; xxi. 8 ; Ps. exxii. $3-5$; exxiii. 6, 3, 4 .

$k$ comp. Gen. 1. 23; Prov, xvii. 6.

l supra v. 26 ; $\mathbf{x i}$. 17 ; and comp. ri. 11,12 ; vii. 7,16 ; x. 20 ; хri. 22, \&c. $\quad m$ Gen. xxr. 8 ; хxxr. 29 ; 1 Chron. xxiii. 1; 2 Chron. xxiv. 15 ; comp. Gen. xxiv. 1 ; Josh. xxiii. 1 ; supra xiv. 1; xxxii. 6,7. $\pi$ sated of (with) days. 



\section{IN PREFACES.}

Page $\mathrm{xxxi}$, line 2 from bottom (of notes) for "L'Shon" read "L'shon".

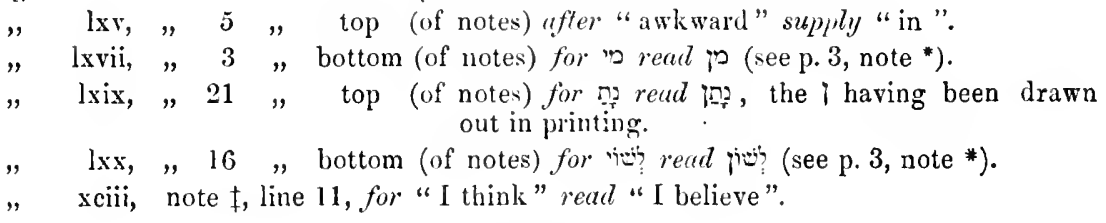

\section{IN COMLIENTARY.}

Page 7, line 3 from bottom, for "דi⿱

\begin{tabular}{|c|c|c|c|c|c|}
\hline & 12 & $"$ & 9 & " & $"$ \\
\hline & 25 & & 10 & ", & top \\
\hline & 32 , & , 3, & & $"$ & $"$ \\
\hline & 35 & $"$ & 1 & $"$ & $"$ \\
\hline & $"$ & $"$ & 6 & $"$ & $"$ \\
\hline & 36, & $"$ & 16 & " & bottom \\
\hline & $"$ & $"$ & 8 & ", & $"$ \\
\hline & 40 & $"$ & 9 & $"$ & " \\
\hline & 41, & $"$ & 4 & $"$ & , \\
\hline & 43, & $"$ & 14 & $"$ & $"$ \\
\hline
\end{tabular}
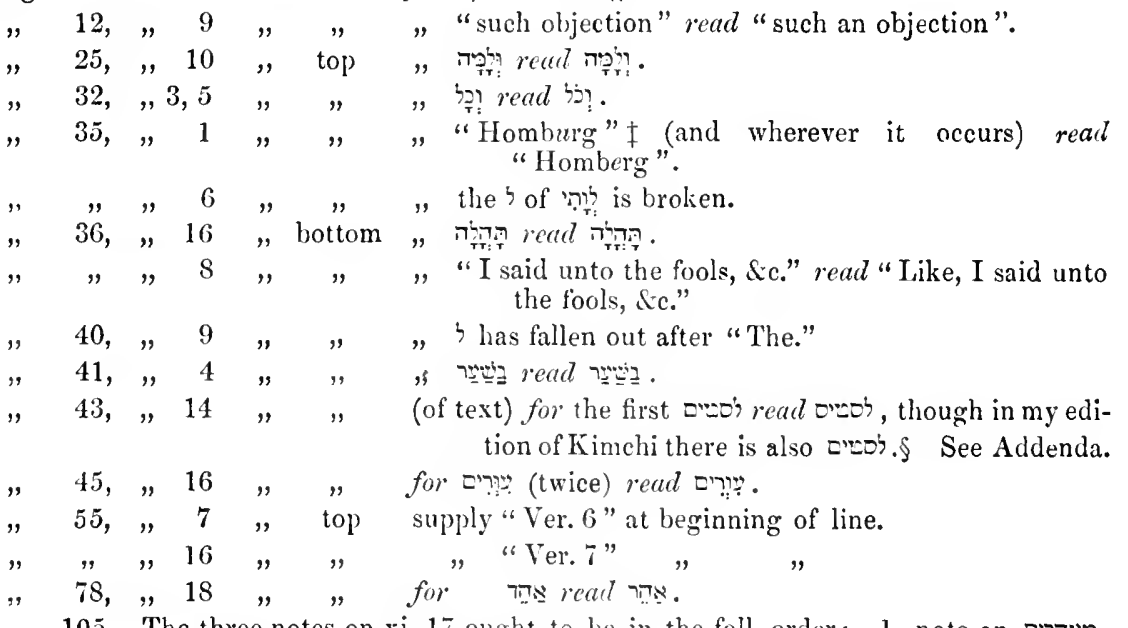

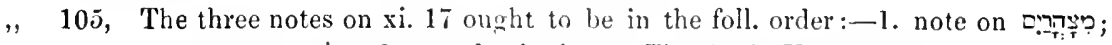

2. note on Trit 3 . note beginning, "The Auth. Vers, \&c."

$114,, 11$, top for רEw" Van der Hooght has isw".

$116,12,11$ ", bottom " "say" , "speuls".

118, " 9 , top the point of the Cherik under the $ב$ in ị is broken off.

, " $13 \quad, \quad$ in, ing the Sh'vah under the second $\pi$ has nearly disappeared.

\begin{tabular}{|c|c|c|c|c|}
\hline 119, & $" 7$ & $"$ & bottom & for" "IIe" reul "Iles". \\
\hline$"$ & $, 3,2$ & ", & " & the Segol under the second $מ$ in \\
\hline 132, & , 6 & ", & $"$ & ler the $*$ in \\
\hline 136, & 13 & , & top & 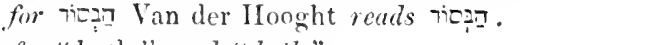 \\
\hline$"$ & 11 & , & bottom & for " both" recul "both". \\
\hline 137, & , & " & top & the Segol in the vis is broken off. \\
\hline 143, & 18 & , & bottom & the word if should be enclosed in square brackets. \\
\hline $14 t$ & , & $"$ & " & for \\
\hline 148, & 17 & , & , & 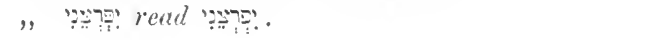 \\
\hline
\end{tabular}

* I have not, of course, included the letters which have leen lireken, or the points whieh have disappeared, during the process of striking ofl" the sherts-exceptins, indeed, in extreme cases. I must, however, do my printers the justice to say, that I have rarely, if ever, seen Hebrew, when mixed with English, more correctly and letter printed. 'The two types lo not work well togrether, as Helrew should be printed mom bleck r than winlish.

* This. was not in the sheet which was sent by me to fress, so that neither I nor my printers can account for its insertion.

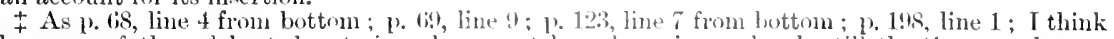
the name of the celebrated watering-place nust have been in my head, still the Germans have a Denschenname, Homburg.

$\$$ Mr. Randolph, however, tells me that in his edition of Kimchi, there is 
Page 162, line 15 from bottom the in has dropped out.

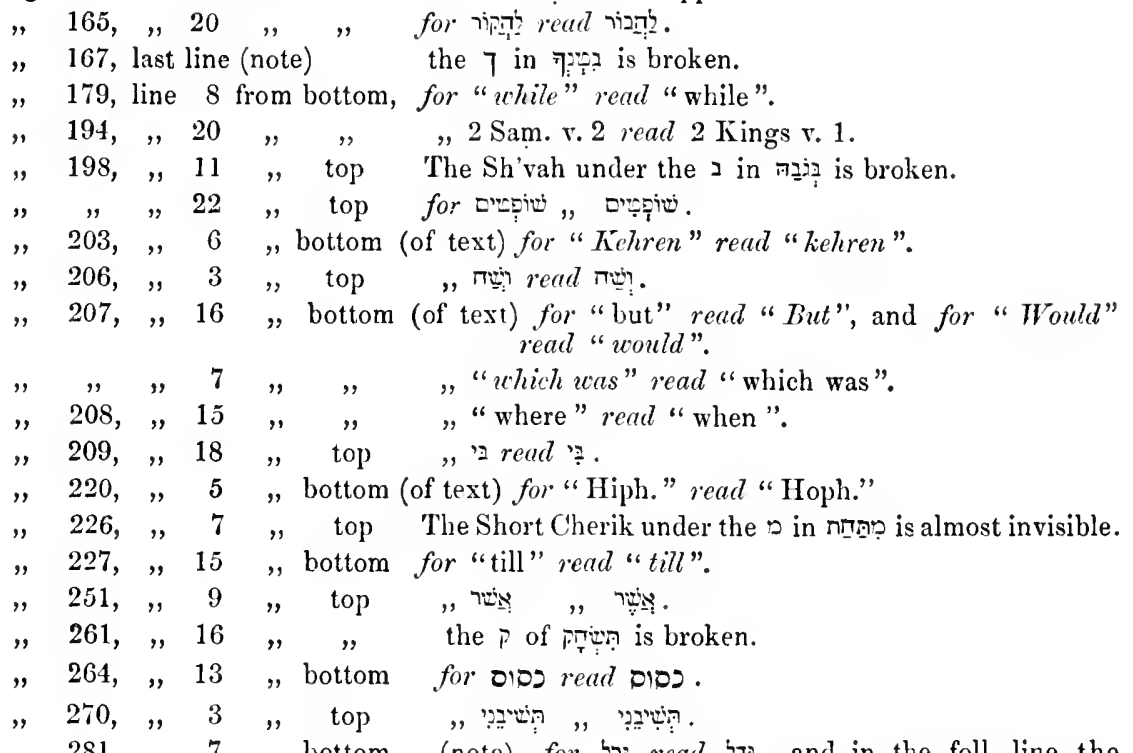

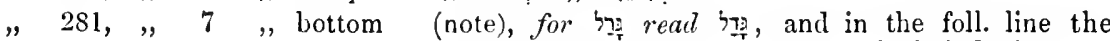
Tsayreh under the 7 in

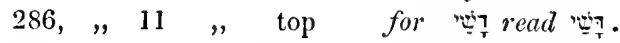

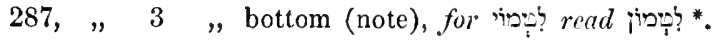

299, line 10 from bottom (note), for מנתה read, the 1 having fallen out.

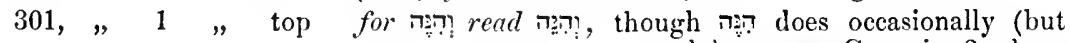
rarely) occur, as Gen. xix. 2, where it has a conjunctive accent, and is rery closely connected with the following word.

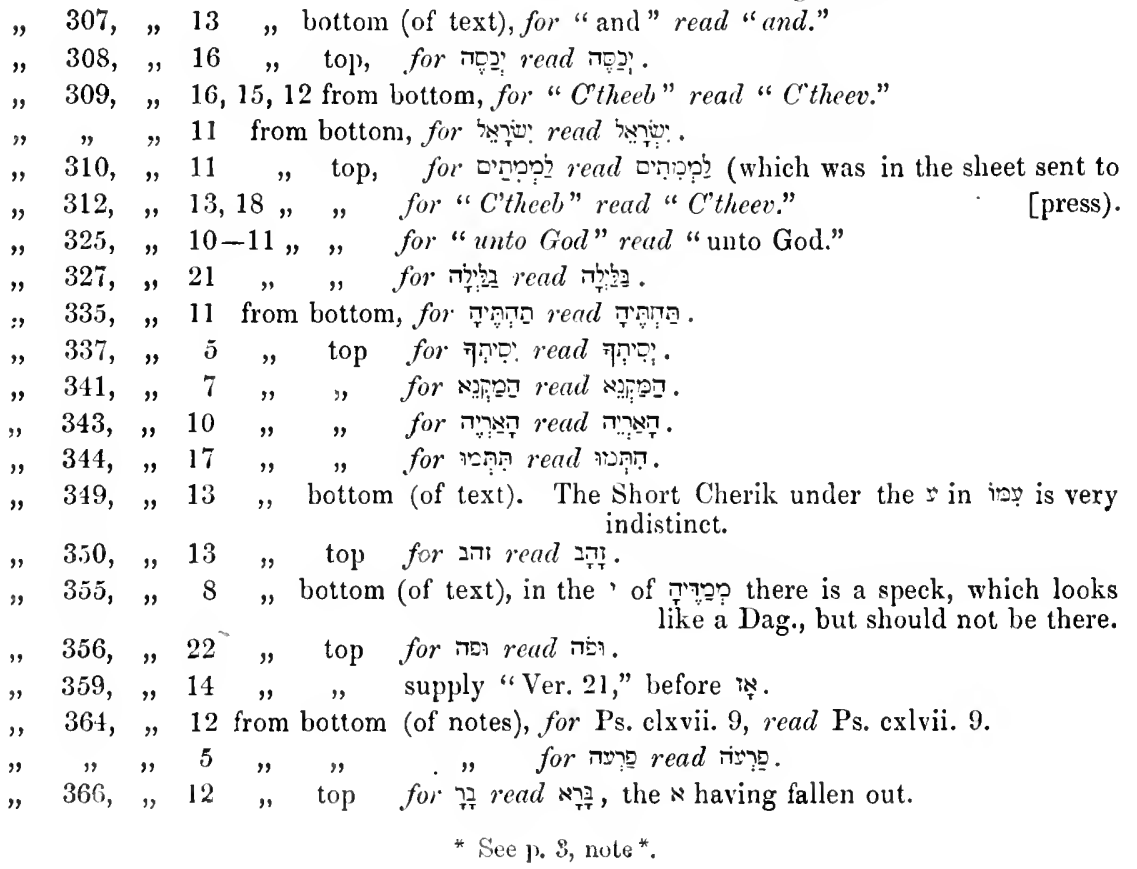




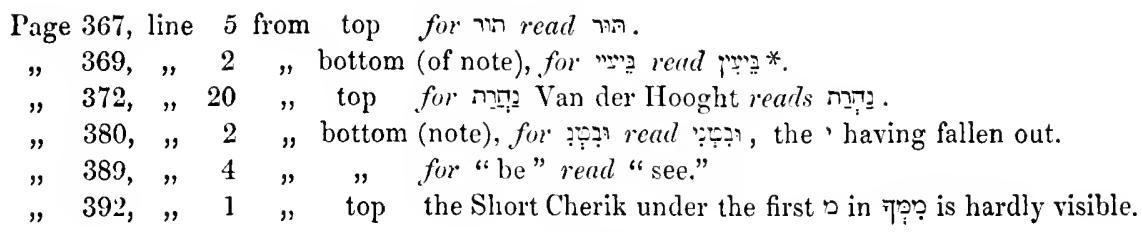

\section{ADDENDA.}

" 43, "14 " bottom

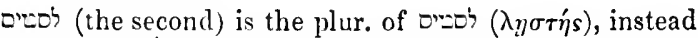
of into $\square$, instead of the addition of $\square-$, as in the plur. of Heb. words - the reason, no doubt, being that in this way an apparently plur. ending $\square-$ is obtained, whilst a cumbersome word is avoided. We do, however, find ?or in the Targ. of Job v. 5.

" 53, note on y $_{\text {. }}$. It must be allowed, however, that in Ps. xxxrii. 20 we find first 将 (with the accent on the ult. syll.), and then in pause : accent on the penult.), as though the pause caused a withdrawal of the accent (but see Hitzig on the pass.). Still, this example, even if it shews that

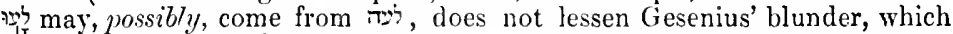
lies in comparing : $:$ with : $:$ :

80 , " 6 from bottom. It should be noticed that the name is really Numb. xxri. 20), for which

" 289, , 9, 9, must, I think, be pointed ריק:, for the expression is, no doubt,

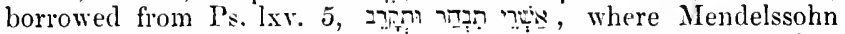
and Ben-Zev give קרe the meaning of aufnetmen, to admit, receive, adopt. In the Psalm, however, sin comes last-as it should, if it $=$ to adopl, seeing that one chooses first and adopts afterwardswhilst here קיב comes first. But Wolfssohn very likely regarded them as pretty nearly synonymous, like select and choose; or else he may, possibly, have used rere here in the sense of bringing near for the sake of examination, comparison, and then it would rightly precede the verb denoting choice; or, lastly, his memory may have failed hin, and he may have thought he was using the words in the same order as in the Psalm. Comp. Ben-Zer's Pref., p.xlvii, note 26 , where $I$ call attention to a similar transposition.

290 , note *. In the pass. quoted from the A. V., her was, no doubt, used, because, its being at that time either unknown f, or but recently introduced, the choice of the 'Translators was limited to it (chiefly familiar), his, her, or thereof (all of which were used where we use its), and of these her (earth being regarded either as a fem. or a nent.) naturally appeared the most suitable, nay, perhaps, was dermed the only one adimissible. Still, if the Translators thought it well, or found themselres constrained, to use her in the latter part of the passage in question, surely they would have done better to retrace their steps and substitute she for it, in the former part. At all events, when its came into common use, there was no longer the slightest excuse for allowing the incongruity to remain. See Narsh's Lect. on the Eng. Lang. by Smith (1 S62), p. 278 et seqq.

* Here the dot of the Long Cherik has fallen ont from under the $\$$, and the tail of the $;$ has been loroken. ; without a tail, looks very much like' .

+ Dr. Bernard should seareely have quoted penultima, for-as the aceent aetually stumds on the ultima, though it has very probably (i.e., if the root be sh) been only transforred there, either on account of the , cont. (see Nason and Bernarl's Gramm., Lett. xxxv., P.S. ( $($ ), ant comp. (for the sake of euphony perhans), as it not unfrequently is in the ease of verbs $1^{\prime \prime}:$ (e.g., 翟, Isa.

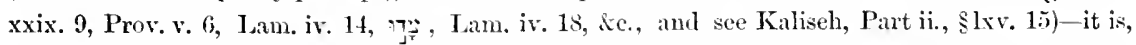
of course, impossible to ascertain precisely whether the root is wh or ospecially as 1 cons. in the case of the verhs I"צ, as well as in that of other verbs, ly no means always drives the accent

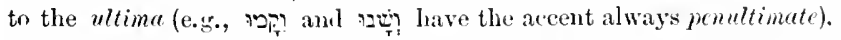

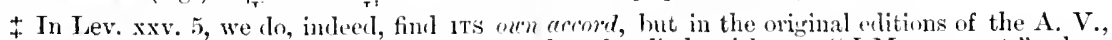
it seems there was it and not its. I have just heard a little girl say, "I Miumma pet," where the 8 of the genitive is sinilarly left out. 
Page 375, line 2 from bottom, "why did He conclude with this verse?" is literally "why did He make to cease (or stay) His hand?"

, 386, , 14 from bottom (of text). We have a very good example here of that disregard for genders, which distinguishes Rabbinical writers (for numerous examples see Ben-Zev's Preface, esp. p. xxviii., note 11), and which foreshadows, in some sort, our almost total abandonment of them, as applied to inanimate objects. But here it is easy to see why Ben-Zev wrote first (masc.), then סוב2 (masc.). It is because he sometimes uses the word (fem.) stone $=$ millstune, and sometimes, the more special word, חל (masc.). Thus הוא refers to המליונה refers to האבן אבן , for just before he had been speaking

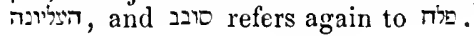

\section{ERRATA, ETC., IN TRANSLATION.}

Page 402, ver. 7, 2nd hem., for "which," read "which."

404 , ver. 8, 1st hem. Great emphasis should be laid on the "I", but this it was not easy to mark by the type (see, however, infra ch. xiii. 13,1st hem., p. 424).

407 , ver. 13, 2nd hem., for " mine," read "mine."

415 , ver. 29 , 1st hem., for "that," read " that."

426, ver. 12, line 2, for "Yea" read " Iea."

" last line (of text), "(But will this be so)" should come before the Ist hem. of ver. $14 *$.

429, ver. 26, 2nd hem., for "shield," read "shields."

446 , note $\dagger$, should be $\ddagger$, and note $\ddagger$, $\dagger$; i.e., notes $\dagger$ and $\ddagger$ should change places.

448 , ver. 19, 1st hem., for "shall see they have reason," read "shall see that they have reason".

450, ver. 7, 2nd hem., for "judge" read "Judge".

462 , ver. 7. The note of admiration at the end of this verse connects it with "Oh that I were," \&c., in ver. 2 ; but, as the verse evidently belongs rather to what follows, a semi-colon should be substituted for the note of admiration.

46 , ver. 11, 2nd hem., for "me," real "me."

467 , ver. 24,2 nd hem., dele $\dagger$.

480 , ver. 17, 2nd hem., for "How" read "How."

\section{ADDENDA.}

Page 455, line 5 from bottom (note), "Abaddon" would be more correctly written "Avaddon," but I have left the $b$, as I find the word is generally spelled with it.

" 459, ver. 13 [2] for "may be taken" and "be molten" we might very well substitute "is taken" and "is molten," the is being equivalent to the Germ. wird.

474 , line 2, "convicted" or "confuted" would perhaps express the meaning more accurately than "convinced," but "to convince" is frequently used in the A. V. = "to convict," than which it is much more common.

510 , marginal note $\delta$ (the reference to which should stand before "Why"), for "to," read "Why [art Thou] red as to Thy clothing?" Cf. Ps.

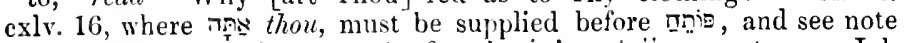
in App. on chap. xiv. 20 As for the $\rightarrow$ in Fing $=a s$ to see Job xxx. 1, xxxii. 4, 6 . I translated, "why is there redness, \&r."? because we cannot well say in Eng. "why art 'l hou red as to \&c.?"

* This transposition was accidentally made by the compositor in correcting the proof-shect. 






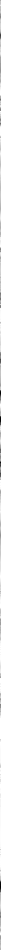
a m. พ้า

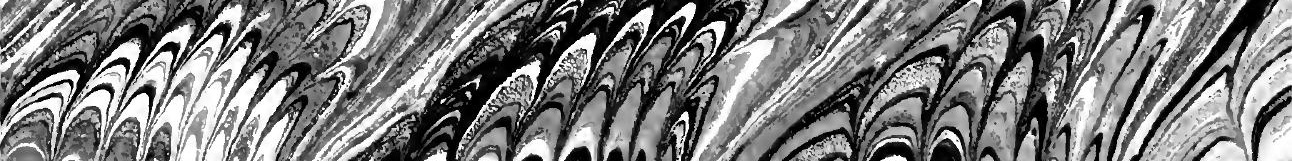

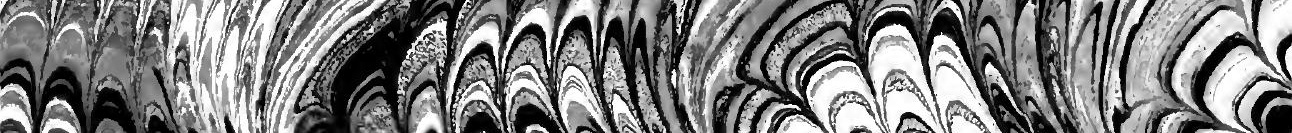
7) man man ma ) 


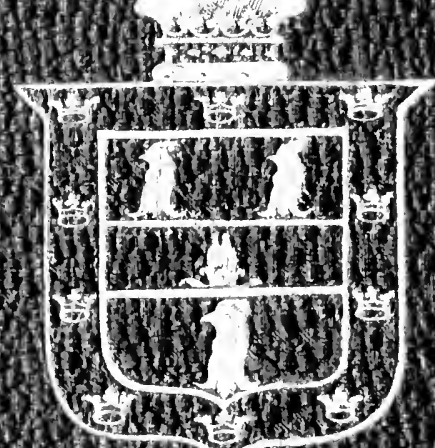

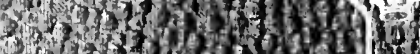

